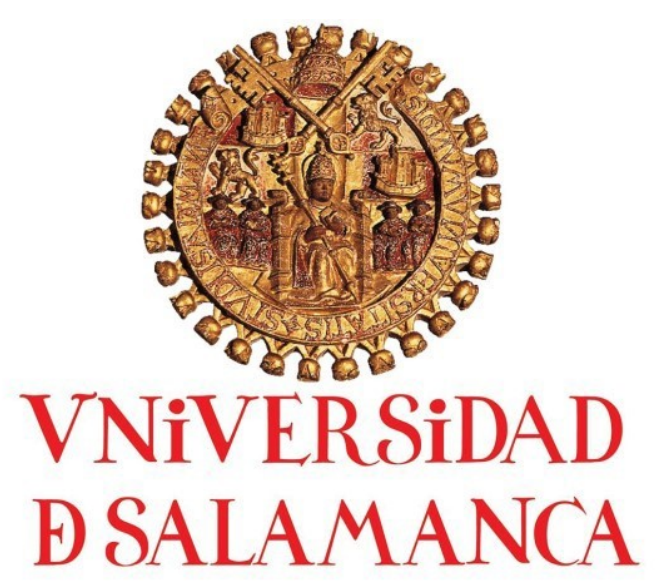

FACULTAD DE GEOGRAFÍA E HISTORIA

Departamento de Historia del Arte - Bellas Artes

TESIS DOCTORAL

\title{
A ESCULTURA DA ORDEM FRANCISCANA DA DIOCESE DE BRAGANÇA-MIRANDA
}

(Tomo I)

Maria Emília Pires Nogueiro

Diretora: Dra. Dña. Margarita Ruiz Maldonado 
Em memória de Maria Inês Pires (minha Mãe) e Carolina Vitória Pires (minha Tia) 
AGRADECIMENTOS 
O presente estudo sobre a escultura da Ordem de São Francisco nos territórios submetidos à jurisdição eclesiástica da diocese de Bragança-Miranda, representa o resultado de um caminho de investigação e estudo.

O desenvolvimento desta dissertação foi possível por contar com o apoio e incentivo de várias pessoas e entidades a quem pretendemos renovar o nosso agradecimento e homenagem.

A primeira palavra queremos dirigi-la à Professora-Doutora Margarita Ruiz Maldonado pelo incentivo ao aprofundamento do tema proposto. Disponibilizou o seu empenho e interesse em acompanhar a evolução do estudo, do qual aceitou a responsabilidade científica. As suas orientações reforçaram a consistência interna deste trabalho e o seu estímulo facilitou a sua conclusão. Também ao Departamento de História del Arte e Bellas Artes da Faculdade de Geografia e História da Universidade de Salamanca estamos gratos por terem consentido o presente tema de estudo.

Distingui-nos com a sua disponibilidade, Dom António Montes Moreira, bispo emérito da Diocese de Bragança-Miranda, na fraterna partilha de ensinamentos e interesse pelo desenvolvimento dos trabalhos.

Devemos também uma palavra de reconhecimento à docente Dolores Fraga Sampedro e José Manuel López Vásquez do Departamento de História de Arte da Universidade de Santiago de Compostela onde nos receberam ao abrigo do programa Iacobus, pelas sugestões iconográficas e bibliográficas.

Agradecemos ao colega e amigo Carlos Prada de Oliveira pela ajuda nas transcrições das fontes documentais bem como na inestimável partilha bibliográfica.

A nossa gratidão a José Navarro Talegón que desde Toro nos favoreceu com a sua atenção e ajuda nas propostas cronológicas e proximidades formais das esculturas.

O trabalho de pesquisa evidenciou a vontade de muitas pessoas e instituições de serem úteis aos nossos intentos. A todas agradecemos. Aos responsáveis da diocese de Bragança-Miranda, o bispo D. José Cordeiro e, de um modo particular ao Cónego Adelino Fernando Paes, agradecemos a recomendação que nos facultou a autorização para registarmos as esculturas da diocese. Neste sentido, manifestamos também a nossa gratidão aos párocos e demais responsáveis das cinco igrejas em estudo que com recetividade nos facilitaram a recolha de elementos, a $\mathrm{Sr}^{\mathrm{a}}$. $\mathrm{D}^{\mathrm{a}}$. Augusta na igreja de São Francisco em Bragança ao Sr. Cónego Dino Parra na igreja de São Francisco em Mogadouro. Gratos também à Câmara Municipal de Vinhais, na pessoa do vereador da 
cultura Dr. Roberto Afonso por nos facilitar a recolha de elementos nas igrejas e Museu de Arte Sacra de Vinhais.

A todos quantos esculpiram, talharam, imaginaram e criaram as esculturas e a todos quantos as encomendaram e que devotamente as preservaram para que ainda hoje as possamos fruir estamos de sobremaneira gratos. É o coletivo anónimo que consolida a memória que nos forma e que pretendemos com este trabalho homenagear.

Por último, um agradecimento muito especial a minha família, pela ajuda, pelas leituras e correções, e também aos amigos que alentaram o meu caminho, ao João, o meu companheiro, pelo permanente apoio à realização deste trabalho e por tudo! 


\section{RESUMO DA TESE DE DOUTORAMENTO \\ "A Escultura da Ordem Franciscana da \\ Diocese De Bragança-Miranda" \\ Maria Emília Pires Nogueiro}

$\mathrm{Na}$ História da Arte Portuguesa permanecem vários capítulos pouco estudados. A escultura constitui, inquestionavelmente, um dos núcleos menos abordado. As contingências que provocam esta limitação são diversas, de entre elas destaca-se a ausência documental relativa à escultura ou o escasso prestígio da produção escultórica relativamente a outras práticas artísticas. No território periférico em estudo - a Diocese de Bragança-Miranda; esta carência é ainda mais profundamente sentida. A inexistência de estudos relativos à escultura local é acrescida pela escassez documental que às esculturas se refere. A escassez documental contrasta com a abundante presença e continuada preservação das esculturas. Entre as diversas categorias artísticas é a escultura que mais se destaca nos espaços em estudo. A limitação do estudo aos espaços franciscanos prende-se com facto de se tratar da ordem religiosa com mais presença no território.

A Ordem de São Francisco chegou a Portugal pouco tempo após a sua fundação, em Itália, em 1209. No território em estudo, os Frades Menores chegaram a Bragança onde se fundou a primeira casa ainda durante o século XIII, documentalmente registada pela primeira vez em 1271. As Clarissas fundaram casa, também em Bragança, na segunda metade do século XVI, após bênção episcopal do local em 1569 o convento foi ocupado em 1598. Durante o conflituoso século XVII foi fundado o convento da Ordem Terceira Regular na vila de Mogadouro em 1618 mas as obras prolongaram-se até 1689. Na segunda metade do século XVIII, após licença obtida em 1740, em 1752 foi fundado o Seminário Apostólico, em Vinhais. Entre 1762 e 1780 a Ordem Terceira Secular fabricaria o seu próprio templo, também na vila de Vinhais. Outros espaços franciscanos existiram no território da diocese porém não resistiram até à contemporaneidade. A intensa presença da ordem franciscana na Diocese de Bragança-Miranda enquanto agentes socializadores constitui uma das linhas definidoras do âmbito de estudo. As esculturas, assim como as restantes representações figurativas, ilustravam os princípios 
doutrinários e constituíam, numa sociedade maioritariamente iletrada, um poderoso veículo de transmissão de conceitos. A par das emanações eclesiásticas gerais e as particulares da ordem de São Francisco, também a devoção popular foi definindo as devoções e as invocações taumatúrgicas que envolvem as esculturas em estudo. Muitas das identificações das figuras representadas nas esculturas estavam já esquecidas, os quase duzentos anos que nos separam da extinção das ordens religiosas criaram uma rutura na memória dos coletivos que as esculturas refletem. O reavivar da memória coletiva que se pretende com este estudo sugere um conjunto de abordagens diversas cuja relação permita perceber a importância que a escultura teve. Quem foram os seus destinatários? Que oficinas as realizavam? Em que materiais se produziam? Quais as principais caraterísticas formais e técnicas? Que modelos artísticos tiverem mais aceitação? Que cultos e devoções foram mais amplificados? Que tipologias iconográficas se privilegiaram? Que princípios doutrinários se valorizavam? Que relação existia entre a produção escultórica dos diferentes espaços franciscanos da Diocese? Que relevância tinham as esculturas no espaço sagrado? Que papel desempenhavam nos rituais? Qual a sua função nas intercessões sociais em que participavam? A estas e outras questões tentamos responder neste trabalho. Propusemonos para isso a inventariar todos os objetos escultóricos ao culto e em guarda nos espaços franciscano da Diocese de Bragança-Miranda. De modo a podermos analisar formalmente as situações de originalidade, o peso dos tradicionalismos e as influências exteriores com importância na caracterização das esculturas. A posterior análise iconográfica das figuras permitiu-nos perceber as narrativas e avaliar as intenções e os testemunhos ideológicos expressos nos objetos artísticos. Neste sentido, acompanhamos um tempo pautado pela espiritualidade que definiu os comportamentos sociais e as narrativas doutrinárias que ainda hoje as obras artísticas ilustram. O estudo da escultura da Ordem Franciscana na Diocese de Bragança-Miranda propiciou um caminho essencial para entender a arte sacra transmontana nas suas aproximações aos valores difundidos pelo território português e, simultaneamente, nas suas peculiaridades de espaço interior de fronteira. 


\section{RESUMEN DE LA TESIS DOCTORAL \\ "La Escultura de la Orden Franciscana en la diócesis de Bragança-Miranda " \\ María Emilia Pires Nogueiro}

En la historia del arte portugués sigue habiendo capítulos poco estudiados. La escultura es, sin duda, uno de los núcleos menos abordados. Las contingencias que provocan esta limitación son varias, entre ellas se destaca la ausencia documental sobre la escultura o el limitado prestígio de la producción escultórica en relación con otras prácticas artísticas. En la zona periférica de estudio - la diócesis de Bragança-Miranda esta limitación es aún más profunda. La falta de estudios sobre la escultura local se ve reforzada por la escasez documental en lo que a las esculturas se refiere. La falta de documentos contrasta con la abundante presencia de las esculturas. Entre las distintas categorías artísticas es la escultura la que más destaca en los espacios de estudio. La limitación a los espacios franciscanos se debe al hecho de que es la orden religiosa con más presencia en el territorio.

La Orden Franciscana llegó a Portugal poco después de su fundación en Italia en 1209. En el área de estudio los Frailes Menores llegarón a Bragança, donde se fundó la primera casa durante el siglo XIII cuyo primer registro documental es de 1271. Las Clarisas fundarón el convento, también en Bragança, en la segunda mitad del siglo XVI después de la bendición del obispo en 1569. Posteriormente fue ocupado en 1598. Durante el conflictivo siglo XVII se fundó el convento de la Tercera Orden Regular en Mogadouro en 1618, pero las obras se prolongaron hasta 1689. En la segunda mitad del siglo XVIII, después de la licencia obtenida en 1740, se fundó el Seminario Apostólico en Vinhais en 1752. Entre 1762 y 1780 la Tercera Orden Seglar fabricó su propio templo, también en Vinhais. Otros espacios franciscanos existíeron en la diócesis, pero no sobrevivieron hasta nuestros días. Tuvo mucha presencia la orden religiosa franciscana en la diócesis de Bragança-Miranda. Una de las líneas que definen el campo de estudio es la funcion de los franciscanos como como agentes de socialización. Las esculturas, así como todas las representaciones figurativas, ilustran los principios doctrinales que en una sociedad mayoritariamente analfabeta constituia un poderoso 
vehículo de transmisión de conceptos. Además de los principios eclesiásticos generales y del orden de San Francisco en particular, también la devoción popular definió las devociones y las invocaciones taumatúrgicas implicadas en las esculturas ahora estudiadas. Muchas de las identificaciones de las figuras representadas estaban ya olvidadas. Los casi doscientos años que nos separan de la extinción de las órdenes religiosas en 1834 crearon una ruptura en la memoria colectiva que refejan las esculturas. La reactivación de la memoria colectiva que se pretende con este estudio sugiere un conjunto de diferentes enfoques cuya relación permite la aproximación a la importancia que tuvo la escultura. ¿Quiénes fueron los beneficiarios? ¿Qué talleres las realizaron? ¿Com qué materiales se produjeron? ¿Cuáles son sus principales características formales y técnicas? ¿Qué modelos artísticos tuvieron más aceptación? ¿Qué cultos y devociónes fueron más extendidos? ¿Qué tipos iconográficos favorecieron? ¿Qué principios doctrinales valoraron? ¿Qué relación existía entre la producción escultórica de los distintos espácios franciscanos de la diócesis? ¿Qué relevancia tenian las esculturas en el espacio sagrado? ¿Qué papel jugaron en los rituales? ¿Qué función tenian en las intercesiones sociales en las que participaban? A estas y otras preguntas tratamos de responder en este trabajo. Nos propusimos para ello hacer un inventario de todos los objetos escultóricos de culto y guardados en los espácios franciscanos de la Diócesis Bragança-Miranda, para posteriormente poder analizar en las formas las situaciones de originalidad, el peso del tradicionalismo y las influencias externas más importantes en la caracterización de las esculturas. El análisis iconográfico posterior permitió percibir las narrativas y evaluar las intenciones y declaraciones ideológicas expresadas en las esculturas. En este sentido, seguimos un tiempo marcado por la espiritualidad que definió el comportamiento social y las narrativas doctrinales que las obras artísticas ilustran. El estudio de la escultura de la Orden Franciscana en la Diócesis de Bragança-Miranda propició un camino para entender el arte sacro de Trás-os-Montes en su aproximacion a los valores artísticos nacionales y en sus particularidades de territorio interior fronterizo. 


\section{SUMMARY OF THE DOCTORATE THESIS \\ "The Sculpture of the Franciscan Order in the \\ Diocese of Bragança-Miranda" \\ Maria Emilia Pires Nogueiro}

In Portuguese art history various chapters remain poorly studied. Sculpture is unquestionably one of them. The contingencies that cause this limitation are several, among them stands out the absence of documents on sculpture or the limited prestige of sculptural production in relation to other artistic practices. In the peripheral area under study - the Diocese of Bragança-Miranda - this absence is even more deeply felt. The lack of studies on local sculpture is enhanced by the lack of documents that refer to sculptures. The lack of documents contrasts with the abundant presence and continued preservation of sculptures. Among the various artistic categories, sculpture is the category that stands out most in the Franciscan spaces under study. The present study is limited to the Franciscan spaces because of the fact that it is the religious order with more presence in this territory.

The Franciscan Order arrived in Portugal shortly after it was founded in Italy in 1209. In the area under study, the Friars of S. Francis arrived in Bragança, where they founded the first institution during the thirteenth century, first recorded in documents from 1271. The Sisters of Saint Clair founded their convent, also in Bragança, in the second half of the sixteenth century, after the local bishop's blessed the place in 1569. The convent was occupied in 1598. During the conflictual seventeenth century the convent of the Third Regular Order was founded in Mogadouro in 1618 but the works on the building lasted until 1689. In the second half of the eighteenth century, after their license was obtained in 1740, the Apostolic Seminary was founded in Vinhais in 1752. Between 1762 and 1780 the Third Secular Order made their own temple, also in Vinhais. Other Franciscan spaces existed in the diocese but they did not survive to the present day. The presence of the Franciscan religious order was strong in the Diocese of Bragança-Miranda. This intense presence of Franciscan friars and sisters as socializing agents is one of the defining lines of this field of study. The sculptures, as well as other figurative representations, illustrate the doctrinal principles and in a largely illiterate society, these 
images constituted a powerful vehicle for the transmission of concepts. In addition to the general ecclesiastical principles and the particular guide lines of the Franciscan order, also popular devotion shaped the cults and thaumaturgic invocations involving the sculptures. Many of the identifications of the represented figures wave now been forgotten. The almost two hundred years that separate us from the extinction of the religious orders in 1834 have created a rupture in the collective memory of what the sculptures signify. The revival of collective memory that is intended with this study suggests a set of different approaches whose relationship allows us to realize the importance that the sculptures once had. For whom were they made? Who made them? In what materials were they produced? What are the main formal and technical characteristics? What are the artistic models that have more acceptance? What cults and devotions were more disseminated? Which iconographic types were preferred? What doctrinal principles did they valued most? What relationship existed in sculptural production between the different Franciscan spaces in the diocese? What relevance did the sculptures have in the sacred space? What role did they played in rituals? What function did they have in the social intercessions that they participated in? To these and other questions we try to formulate an answer in this work. For this reason we elaborate an inventory of all sculptural objects in worship stored in Franciscan spaces of the Bragança-Miranda Diocese. There for we can formally analyse the situations of originality, the weight of traditionalism and the external factors that influenced and are important in the characterization of the sculptures. Further we present the iconographic analysis of the figures that allowed us to analyse the narratives and the intentions and ideological statements expressed in art objects. In this regard, we follow a time guided by spirituality that defined the social behavior and doctrinal narratives that today the artistic works illustrate. The study of the sculpture of the Franciscan Order in the Bragança-Miranda Diocese has provided an essential way to understand the sacred art of Trás-os-Montes in its approaches to the values of the Portuguese territory and simultaneously its peculiarities as an inland border territory. 


\section{LISTA DE ABREVIATURAS E SINAIS}


A.N.T.T./A.H.M.F./.S.C.B. Arquivo Nacional da Torre do Tombo / Arquivo Histórico do Ministério das Finanças / Convento de Santa Clara Bragança

A.N.T.T./A.H.M.F./.S.C.B. Arquivo Nacional da Torre do Tombo / Arquivo Histórico do Ministério das Finanças / Convento de Santa Clara Vinhais

A.N.T.T./A.H.M.F./S.F.B Arquivo Nacional da Torre do Tombo / Arquivo Histórico do Ministério das Finanças / Convento de São Francisco Bragança

A.N.T.T./A.H.M.F./S.F.M. Arquivo Nacional da Torre do Tombo / Arquivo Histórico do Ministério das Finanças / Convento de São Francisco Mogadouro

A.N.T.T./A.H.M.F./S.N.S.E.V. Arquivo Nacional da Torre do Tombo / Arquivo Histórico do Ministério das Finanças / Seminário de Nossa Senhora da Encarnação Vinhais

Cx. Caixa

COHV Capela da Oração no Horto, Vinhais (Via Sacra)

Coord. Coordenação

CSDV Capela da Senhora das Dores, Vinhais

CSMV Capela do Senhor do Monte, Vinhais (Via Sacra)

DGPC Direção Geral do Património Cultural 
Dir.

fl.

Edit.

IEV

MASV

M.F.

$\mathrm{n}^{\mathrm{o}}$

OFM

Org.

p.

pp.

S

SCB

SFB

$\mathrm{s} / \mathrm{fl}$.
Direção

Fólio

Edição

Igreja da Encarnação, Vinhais (Seminário

Apostólico)

Museu de Arte Sacra, Vinhais

Micro Filme

Número

Ordem dos Frades Menores

Organização

Página

Páginas

São

Santa Clara, Bragança (igreja do convento das

Clarissas)

São Francisco, Bragança (igreja dos Frades

Menores)

Sem fólio 

Secular)

$\mathrm{Na}$ transcrição documental para destacar o erro no texto transcrito

Secretariado Nacional dos Bens da Igreja

Arquitetónico

TOR

Terceira Ordem Regular

v.

Verso

$(?)$

Os elementos duvidosos vão seguidos do sinal de interrogação entre parêntesis

Os elementos ilegíveis são identificados pela sequência de pontos 


\section{PLANO DE TRABALHO E METODOLOGIAS}


A ampla existência de esculturas, enquanto elemento patrimonial histórico é comum ainda em muitos espaços religiosos. Mas, a profunda escassez de informação, quer arquivística, quer académica, relativa à escultura religiosa da Diocese de BragançaMiranda supôs a estruturação de um plano de trabalho capaz de produzir conteúdos que permitissem uma abordagem analítica do processo artístico em questão.

$\mathrm{Na}$ pesquisa da documentação arquivística relativa à escultura destacamos a documentação produzida para o inventário dos bens móveis de 1834 . No âmbito da "Reforma geral eclesiástica" empreendida pelo Ministro e Secretário de Estado, Joaquim António de Aguiar, executada pela Comissão da Reforma Geral do Clero (1833-1837), pelo Decreto de 30 de Maio, foram extintos todos os conventos, mosteiros, colégios, hospícios e casas de religiosos de todas as ordens religiosas, ficando as de religiosas, sujeitas aos respetivos bispos, até à morte da última freira, data do encerramento definitivo. Nesta documentação do Ministério das Finanças relativa ao inventário dos conventos após a extinção das ordens masculinas constam os bens dos conventos e a avaliação que é feita dos mesmos. Guardados no arquivo da Torre do Tombo em Lisboa são documentos muito irregulares no que respeita ao registo dos elementos que o compõem. Nos diversos documentos pesquisados, relativos às casas de religiosos da Ordem de São Francisco do distrito de Bragança, escritos por diversas mãos fica exposta a dependência dos elementos registados ao maior ou menor zelo da equipa de inventariantes que elaboravam os documentos. A discrepância de elementos recolhidos é evidente, entre outros, na comparação entre o inventário do convento de Bragança (que é o mais antigo do território em estudo) e o inventário do seminário apostólico de Vinhais (que é a última casa a ser fundada escassos 80 anos antes da extinção das ordens religiosas). No primeiro é sucintamente avaliado todo o património com um registo dos bens móveis que pouco mais que os objetos de ourivesaria destaca. Enquanto o registo de Vinhais nos fornece um olhar atento a todos os detalhes móveis e imóveis que o seminário possuía no momento da chegada dos inventariantes. Este facto ilustra bem a disparidade de dados acessíveis sobre o património em estudo.

A ausência de um inventário geral dos bens móveis, mais especificamente da escultura na Diocese de Bragança-Miranda constituiu, face à forte presença de esculturas no interior dos templos, um dos problemas que consideramos relevante aprofundar.

O inventário e documentação dos objetos é fundamental para permitir o estudo, a conservação e segurança, bem como a educação e a fruição do património. O inventário 
reveste-se de vários procedimentos de modo a uniformizar medidas tendentes à integração num circuito de rápida transmissão de dados, consequentemente a uma maior divulgação da informação potenciadora de uma mais vasta rede de educação ${ }^{1}$.

Neste sentido, a par da elaboração de uma bibliografia ampla de consulta para o tema a tratar e da seleção da informação arquivística: Arquivo Distrital de Bragança; Arquivo Diocesano de Bragança; Arquivo Nacional da Torre do Tombo, foi efetuado o estudo das obras in situ para a elaboração de um inventário exaustivo.

Na medida em que o presente estudo aborda uma das categorias de património cultural móvel assumiram-se os textos editados pelas instituições de tutela do património cultural para definir as normas e procedimento relativamente ao inventário.

Na lei-quadro dos Museus; Secção IV, Artigo 16². Lei n. ${ }^{\circ}$ 47/2004 de 19 de Agosto está estipulado que:

«O inventário museológico estrutura-se de forma a assegurar a compatibilização com o inventário geral do património cultural, do inventário de bens particulares e do inventário de bens públicos, previstos nos artigos $61 .^{\circ}$ a $63 .^{\circ}$ da Lei n. ${ }^{\circ} 107 / 2001$, de 8 de Setembro.»

O inventário, contemporaneamente, compreende diversos campos, ultrapassando largamente o simples registo de um objeto. A Lei-quadro dos museus propõe:

«Ficha de inventário (...)

2 - A ficha de inventário museológico integra necessariamente os seguintes elementos:

a) Número de inventário;

b) Nome da instituição;

c) Denominação ou título;

d) Autoria, quando aplicável;

e) Datação;

f) Material, meio e suporte, quando aplicável;

g) Dimensões;

h) Descrição;

i) Localização;

j) Historial;

\footnotetext{
${ }^{1}$ Nogueiro, Maria Emília Pires, Práticas museologicas. Museu Militar de Bragança: Fundação; Práticas Museologicas, Dissertação de Mestrado em Museologia apresentado à Faculdade de Letras da Universidade do Porto, Porto, (texto policopiado), 2009, pp. 58, 59.
} 
1) Modalidade de incorporação;

m) Data de incorporação.

3 - A ficha de inventário pode ser preenchida de forma manual ou informatizada.

4 - O museu dotar-se-á dos equipamentos e das condições necessárias para o preenchimento informatizado das fichas de inventário.

5 - A normalização das fichas de inventário museológico dos diversos tipos de bens culturais será promovida pelo Instituto Português de Museus através da aprovação de normas técnicas e da divulgação de directrizes.»» ${ }^{2}$

Atendendo às medidas propostas pela Lei-quadro e às normas propostas pelo Instituto de Conservação e Museus $^{3}$ (atualmente inserido na Direcção-Geral do Património Cultural), elaboramos um modelo de ficha de inventário ${ }^{4}$ adaptado às esculturas da Ordem de São Francisco na Diocese de Bragança-Miranda, que até à atualidade carecia de um inventário geral. Os elementos que optamos incluir no inventário constituíram a base de procedimentos para os cinco templos estudados. Aplicamos o inventário para cada objeto escultórico partindo sempre da perspetiva do visitante da igreja, assim, o inventário inicia-se sempre com a primeira escultura no lado da Epistola e termina com a última escultura do lado do Evangelho.

A base de dados do inventário compreende os seguintes campos:

1. Número de inventário: Equivale a uma informação alfanumérica com número sequencial e único atribuído a cada escultura.

Optou-se por preceder a numeração com a sigla que identifica cada um dos cinco espaços franciscanos abordados no presente estudo.

\footnotetext{
${ }^{2}$ (Lei-Quadro dos museus portugueses) Artigo 19. Lei n. ${ }^{\circ}$ 47/2004 de 19 de Agosto; disponível na página da Direção Geral do Património Cultural em: http://www.patrimoniocultural.pt/pt/museus-emonumentos/rede-portuguesa/lei-quadro-dos-museus-portugueses/ acedido a 21/07/2015

${ }^{3}$ Pinho, Elsa Garrett e Freitas, Inês da Cunha, Normas de Inventário - Normas Gerais Artes Plásticas e Decorativas, Lisboa, I.P.M. (Instituto Português de Museus), 2000; Carvalho, Maria João Vilhena de, Normas de Inventário - Artes Plásticas e Artes Decorativas - Escultura, Lisboa, I.P.M. (Instituto Português de Museus), 2004.

${ }^{4}$ Nogueiro, Maria Emília Pires, Práticas museologicas. Museu Militar de Bragança: Fundação; Práticas Museologicas, Dissertação de Mestrado em Museologia apresentado à Faculdade de Letras da Universidade do Porto, Porto, (texto policopiado), 2009, pp. 60-75.
} 
Assim criamos as siglas de SFB (São Francisco Bragança); SCB (Santa Clara Bragança); SFM (São Francisco Mogadouro); o número sequencial e único precede a sigla que identifica a igreja em estudo. Relativamente ao complexo conjunto edificado de Vinhais criamos as siglas IEV (Igreja da Encarnação Vinhais); SIEV (Sacristia da Igreja da Encarnação Vinhais); CSDV (Capela da Senhora das Dores Vinhais); CSMV (Capela do Senhor do Monte Vinhais); COHV (Capela da Oração no Horto Vinhais); SFV (São Francisco Vinhais); MASV (Museu de Arte Sacra Vinhais).

Uma vez que não existe até à presente data um registo de inventário que contemple a totalidade das obras em estudo a numeração de inventário começa no algarismo: 1, e reinicia-se em cada novo espaço inventariado.

As peças que constituem elementos de um conjunto são inventariadas individualmente com um número por peça, sendo a relação entre elas salvaguardada também no campo de «Outras designações» onde se estabelece a parte do conjunto a que se reporta a ficha. Consideram-se elementos de um conjunto, todas as obras formadas por peças que embora tenham existências autónomas, só quando agrupadas permitem uma leitura formal ou funcional. Assim, optou-se por registar no campo o número de inventário da peça seguido pela posição que o objeto ocupa face aos restantes elementos, por exemplo SFB $17\left(2^{\circ} 1 \backslash 4\right)$, que refere a segunda escultura de um conjunto de quatro elementos. O número de inventário não foi marcado sobre as peças inventariados pois a sua função não constituía a de demarcar a propriedade da obra estudada mas apenas se pretendia criar um elemento operacional de identificação e quantificação das esculturas.

2. Título \Denominação - Nome atribuído ao objeto, designação inequívoca que identifica uma obra. Como já não se conhecia a devoção que muitas das esculturas representam, apenas após o estudo arquivístico e iconográfico pudemos preencher este campo para todas as obras em estudo.

3. Outras Designações - mantivemos este campo, apesar de escassas vezes preenchido, para referir outras designações que por esquecimento da devoção inicial foram sendo atribuídas às esculturas. 
4. Registo Fotográfico - em formato JPEG o registo fotográfico compreende, sempre que as condições de exposição da escultura o permitiram, a perspetiva frontal e lateral da obra, bem como os detalhes do rosto, mãos, pés e atributos iconográficos.

5. Proprietário: Nome da instituição a quem pertence o objeto: Quando a documentação nos permite destacamos os proprietários iniciais e os proprietários atuais.

6. Categoria - primeira forma de catalogação ou classificação que define uma área temática; para o presente conjunto de esculturas foram consideradas as seguintes categorias, que têm em conta o tamanho das obras, as características formais, bem como a relação de conjunto:
a. Conjunto Escultórico;
b. Conjunto Escultórico de Figurinhas;
c. Escultura de vulto completo;
d. Escultura de vulto completo de roca ou de vestir;
e. Escultura a 3/4;
f. Estatueta: quando as dimensões são cerca de metade das dimensões naturais do corpo humano;
g. Figurinha: quando as dimensões da figura são inferiores a 25 $\mathrm{cm}$;
h. Fragmentos de escultura.
i. Imagem Colossal: quando as dimensões da imagem ultrapassam as dimensões naturais do corpo humano.

7. Descrição - A descrição é feita em termos discursivos, em texto livre, o que implica a redação de dados muito diversos. Os primeiros dados a ser registados referem-se às características físicas gerais distintivas de cada obra em inventariação. Deve referir-se a categoria de cada objeto bem como o aspeto geral da peça. Após esta pequena introdução é feita uma descrição mais pormenorizada dos diversos elementos que a constituem, como os aspetos formais da posição, dos gestos, da expressão e também os elementos decorativos 
e os atributos que a acompanham. Quando se observa alguma questão relevante relativamente à conservação da obra é também descrita neste campo.

8. Técnicas (de suporte) - informação relativa à caracterização da forma ou processo que levou ao fabrico do objeto.

9. Técnicas (de acabamento) - registo dos processos utilizados na decoração e acabamento do objeto.

10. Materiais (de suporte) - registo da matéria-prima utilizada na elaboração do objeto.

11. Materiais (de acabamento) - registo dos materiais utilizada na decoração e acabamento do objeto.

12. Estado de conservação - caracterização do estado atual do objeto quanto à sua conservação. Foram consideradas as seguintes categorias:

a. Muito Bom; peça em perfeito estado de conservação.

b. Bom; Peça sem problemas de conservação (materiais estabilizados) pode porém apresentar algumas lacunas ou falhas.

c. Regular; Peça que apresenta lacunas ou falhas e que necessita de intervenções de conservação e restauro.

d. Deficiente; Peça em que é urgente intervir.

e. Mau; Peça muito mutilada que apresenta graves problemas de conservação.

13. Dimensões - levantamento das dimensões do objeto em centímetros, atendendo, sempre à dimensão máxima. Para as esculturas que se compõem a partir de um eixo vertical foi registada a:
a. Altura;
b. Largura;
c. Profundidade. 
Para as esculturas que estão colocadas de acordo com um eixo horizontal (jacentes) foi registado o:
a. Comprimento (a maior dimensão horizontal);
b. Largura (a menor dimensão horizontal);
c. Altura (dimensão do eixo vertical).

14. Restauro - Registo das intervenções e repintes que aparentemente tenham sido executados sobre a obra.

15. Datas - A datação em séculos das esculturas foi feita no momento do registo e com base nos aspetos formais da obra. Posteriormente, e com base na análise comparativa com a escultura coeva foi apurada a datação em períodos mais pequenos de tempo, dividindo as centúrias em metades ou em quartéis.

16. Proveniência - entidade ou indivíduo que originalmente detinha a posse do objeto. Quanto à proveniência da execução do objeto esta é registada no campo da Autoria ou Oficina.

17. Autoria - A ausência documental sugere, mesmo quando existe alguma referência bibliográfica relativa à autoria das esculturas, a presença da interrogação (?), na medida em que nenhuma obra está assinada, nem tão pouco se conhece à data nenhum documento que nos permita com segurança afirmar uma autoria individualizada.

18. Oficina - A ausência documental sugere, mesmo quando existem paralelismos formais com outras oficinas já estudadas, a presença da interrogação (?), na medida em que nenhuma obra está assinada, nem tão pouco se conhece à data nenhum documento que nos permita com segurança afirmar a oficina de origem das esculturas.

19. Localização - Registo do local dentro da igreja, ou de outras dependências edificadas onde se encontra a escultura exposta ou guardada. Quando existe na documentação alguma referência à localização inicial regista-se também esta informação. 
20. Histórico - Registam-se neste campo as informações recolhidas oralmente relativas ao historial do objeto. Bem como outros elementos que não sendo escultóricos se relacionam com o culto ou a devoção da escultura (ex-votos).

21. Iconografia - Registam-se neste campo os atributos iconográficos que acompanham a escultura.

22. Irmandade $\backslash$ Fraternidade $\backslash$ Confraria - Com base na documentação estudada regista-se neste campo a filiação da escultura com os coletivos sedeados no interior dos templos franciscanos em estudo.

23. Procissões - Com base na documentação estudada regista-se neste campo a presença da escultura nas procissões e cerimónias públicas dos templos franciscanos em estudo. É também registado o uso cerimonial público contemporâneo.

Os diversos itens supracitados foram pensados de modo a cobrir o máximo de informação passível de ser recolhida no momento do inventário. Outros campos foram inicialmente contemplados, no entanto, pela escassez de elementos para os preencher optou-se finalmente por exclui-los da ficha de inventário, este procedimento abrangeu os seguintes campos: Escola; Modo de Incorporação; Heráldica; Assinatura; Marcas e Punções; Devoções Populares e Lendas; Bibliografia e Exposições. Alguns deles são no entanto abordados na análise formal ou na análise iconográfica mas a ausência de elementos documentais permite-nos apenas observar hipóteses que julgamos desajustadas da sistematização da informação que uma ficha de inventário supõe.

Após o inventário da escultura dos cinco templos em estudo foi possível começar a perceber as analogias e diferenças entre as obras das várias igrejas selecionadas. Mas, o inventário constitui também a base visual que permite a análise comparativa dos aspetos estilísticos e formais de um contexto mais amplo.

Relativamente a organização da estrutura interna do trabalho optamos pela divisão do centeúdo em três capítulos. 
O Primeiro Capítulo, com base na bibliografia publicada, relativamente à organização da Ordem de São Francisco nos seus ramos mais representativos no território, foi feita a síntese da:
a. Ordem dos Frades Menores (Ordem Primeira);
b. Clarissas (Segunda Ordem);
c. Ordem Terceira (Ordem Franciscana Secular e Terceira Ordem Regular).

O Segundo Capítulo compreende o enquadramento dos cinco espaços franciscanos em estudo (Igreja dos Frades Menores de Bragança; Igreja das Clarissas em Bragança; Igreja da Terceira Ordem Regular em Mogadouro; Igreja do Seminário Apostólico de Vinhais; Igreja da Ordem Terceira Secular de Vinhais) tendo em conta:
a. A Fundação;
b. O Edificado;
c. O Interior da Igreja;
d. Fichas de Inventário da escultura.

Relativamente à fundação e ao edificado das diversas Casas Franciscanas foram recolhidos os elementos publicados. $\mathrm{O}$ interior das igrejas foi comparado com o registo de inventário feito aquando da extinção das Ordens Religiosas em 1834. Esta documentação, apesar de escassa em elementos relativos às esculturas, permitiu identificar a totalidade das devoções ilustradas nas esculturas, muitas delas já esquecidas. Foram consultadas outras fontes publicadas produzidas na sua maioria no decurso do século XVIII.

O Terceiro Capitulo compreende a análise formal e a análise iconográfica, bem como uma breve descrição das esculturas dos templos após a extinção das Ordens Religiosas: os principais cultos contemporâneos.

A produção das esculturas nas igrejas franciscanas da Diocese de Bragança-Miranda foi analisada em relação ao contexto da produção de escultura nacional. O capítulo da análise formal pretende assim apurar as datações, bem como as filiações ou autorias das esculturas. Dentro do contexto da produção de escultura nacional foram privilegiadas as esculturas já inventariadas nos territórios limítrofes (Macedo de Cavaleiros; Braga; Porto; Lamego). Dada a situação fronteiriça do território em estudo foram também comparadas com as esculturas já estudadas de Zamora e Valladolid. 
A análise formal tem como linha estruturante a perspetiva diacrónica que favorece a leitura das alterações das formas, e das influências, e simultaneamente permite identificar o ritmo de produção e encomendas.

A análise iconográfica parte da comparação ampla dos modelos iconográficos criados para ilustrar as diferentes devoções identificadas. Tem como linha estruturante a perspetiva temática. Agrupamos as várias esculturas que representam cada invocação, de modo diacrónico relativamente ao aparecimento dos cultos. A análise iconográfica favorece a interpretação das narrativas enquanto exercícios de crença. Assim, valorizamos a hermenêutica da interpretação dos objetos como representações de uma expressão ideológica e social.

Para melhor articular os diversos capítulos, optamos por iniciar nova numeração nas imagens assim como nas notas de fim de página em cada subcapítulo.

Relativamente às normas de citação bibliográfica foi utilizada a norma disponibilizada pela orientadora da tese, Prof. Dña Margarita Maldonado. As referências bibliográficas estão sempre colocadas nas notas de pé de página. No final do trabalho consta a lista geral de obras, documentos e plataformas de inventário virtuais consultadas e citadas. 
ÍNDICE 


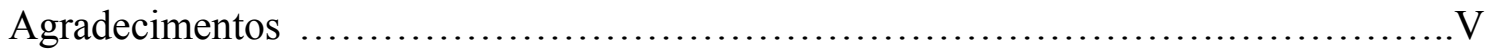

Resumo da tese de doutoramento.................................................

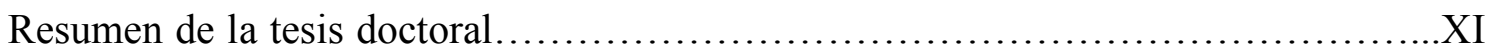

Summary of the doctorate thesis ...............................................

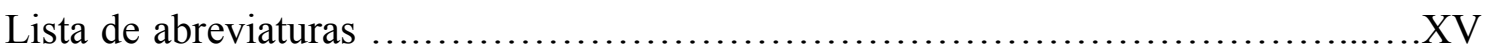

Plano de trabalho e metodologias.............................................

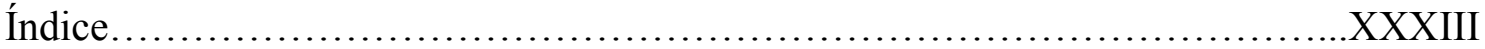

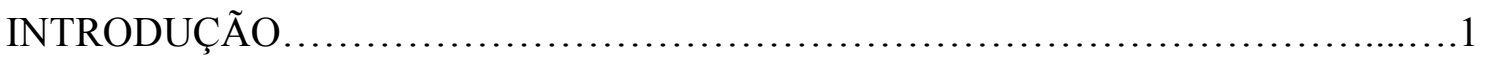

\section{CAPITULO 1}

1. A Família Franciscana em Portugal e na diocese de Bragança-Miranda:

1.1. Ordem dos Frades Menores (Primeira Ordem) ...........................11

1.2. Clarissas (Segunda Ordem) ........................................27

1.3. Ordem Terceira (Ordem Franciscana Secular e Terceira Ordem Regular)...... 33

\section{CAPITULO 2}

1. Os espaços Franciscanos no território da Diocese de Bragança-Miranda.

1.1. Convento de São Francisco em Bragança; .................................43

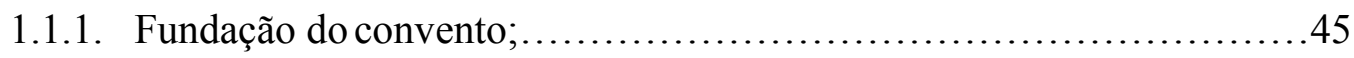

1.1.2. Edificado da igreja e convento; .................................51

1.1.3. Interior da igreja........................................... 55 
1.1.4. Fichas de inventário das esculturas atualmente a culto e em guardana igreja do Convento de São Francisco em Bragança

1.2.Convento de Santa Clara (atual igreja de Nossa Senhora das Graças) em Bragança;

1.2.1. Fundação do convento; .......................................201

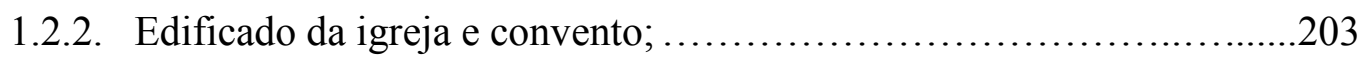

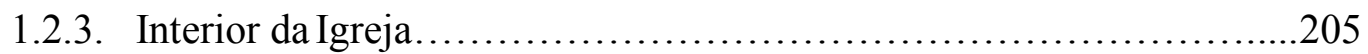

1.2.4. Fichas de inventário das esculturas atualmente a culto e em guardana igreja do convento de Santa Clara (atual igreja de Nossa Senhora das Graças) em Bragança;

1.3.Convento de São Francisco em Mogadouro;...............................249

1.3.1. Fundação do convento ..........................................251

1.3.2. Edificado da igreja ............................................253

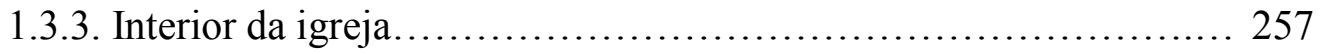

1.3.4. Fichas de inventário das esculturas atualmente a culto e em guarda na igreja do convento de São Francisco em Mogadouro

1.4. Seminário Apostólico de Nossa Senhora da Encarnação em Vinhais;

1.4.1. Fundação do convento

1.4.2. Edificado da igreja.

1.4.3. O interior da igreja.

1.4.4. Fichas de inventário das esculturas atualmente a culto e em guarda na igreja do Seminário Apostólico de Nossa Senhora da Encarnação.........375

-Capela de Nossa Senhora das Dores................................417

-Sacristia da igreja de Nossa Senhora da Encarnação....................441

-Capelas da Via Sacra “Oração no Horto”..............................461

-Capela da Via Sacra "Senhor do Monte"..............................477

-Museu de Arte Sacra............................................489

1.5.Igreja de São Francisco da Venerável Ordem Terceira, em Vinhais;...........515

1.5.1. Fundação....................................................517

1.5.2. Edificado da igreja...................................... 519 
1.5.3. O interior da igreja.

1.5.4. Fichas de inventário das esculturas atualmente a culto e em guarda na igreja de São Francisco da Venerável Ordem Terceira e no Museu de Arte Sacra de Vinhais .525

\section{TOMO II}

\section{CAPITULO 3}

1. Análise formal: Datações e Autorias; produção das esculturas no território de Bragança no contexto da produção de escultura nacional.........................565

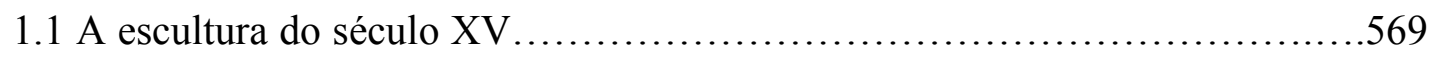

1.2 A escultura do século XVI..............................................5 575

1.3 A escultura do século XVII..........................................583

1.4 A escultura do século XVIII..........................................611

2. Análise iconográfica: $\mathrm{O}$ sentido narrativo das formas...........................707

2.1 Iconografia de Deus Pai................................................ 713

2.2 Iconografia de Cristo............................................... 716

2.3 Iconografia de Nossa Senhora.........................................744

2.4 Iconografia dos Santos Fundadores.................................... 772

2.5 Iconografia dos Santos da Ordem de São Francisco..........................790

2.6 Iconografia das Santas da Ordem de São Francisco..........................813

2.7 Iconografia dos Santos desafetos à Ordem de São Francisco.................820

2.8 Iconografia das Santas desafetos à Ordem de São Francisco..................838

3. As esculturas dos templos depois da extinção das Ordens Religiosas: Os principais cultos contemporâneos ..................................................... 841

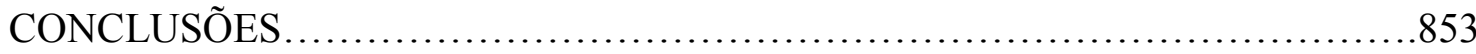


Fontes e bibliografia.

Anexos

- Consentimentos informados e comprovativo de idoneidade da Diocese de BragançaMiranda 
INTRODUÇÃO 
$\mathrm{Na}$ História da Arte Portuguesa permanecem vários capítulos pouco estudados. A escultura constitui, inquestionavelmente, um dos núcleos menos abordado. As contingências que provocam esta limitação são diversas, de entre elas destaca-se a ausência documental relativa à escultura ou o escasso prestígio da produção escultórica relativamente a outras práticas artísticas. No território periférico em estudo - a Diocese de Bragança-Miranda; esta carência é ainda mais profundamente sentida. A inexistência de estudos relativos à escultura local é acrescida pela escassez documental que às esculturas se refere. Este aspeto consubstanciou um dos caminhos que percorremos na produção deste trabalho. Neste sentido procedemos ao levantamento documental de modo a tratar de algumas das questões que as obras escultóricas nos suscitam. Nos arquivos locais, sobretudo no Arquivo Distrital de Bragança, guarda-se o núcleo notarial onde a partir do século XVIII se multiplicam as escrituras, os contratos e as notas de tabeliães. Nesta documentação encontra-se a referência a alguns nomes de entalhadores retabulares. Mais raramente surgem referidos os imaginários ou escultores que participaram nas obras retabulares e as obras registadas localizam-se sobretudo no âmbito paroquial. O núcleo documental da Mitra (dividido entre o Arquivo Distrital de Bragança e o Arquivo da Mitra) guarda registos relativos aos bens episcopais e de administração da Diocese, referindo, pontualmente também, algum nome de entalhador retabular, e, sempre colateralmente, algum imaginário ou escultor. Mas, o presente âmbito de estudo circunscreve-se à escultura a culto e em guarda nas igrejas da Ordem de São Francisco. Tratando-se de bens afetos a institutos religiosos a preservação do património documental que às esculturas se refere foi afetada pelo processo de desamortização. A partir de 1834 o decreto de extinção das Ordens Religiosas do governo liberal provocou a perda de inúmeros documentos que estavam nos conventos. Face a este cenário, as fontes que se revelaram mais profícuas em informação sobre as esculturas foram os inventários dos bens dos conventos, em guarda na Torre do Tombo em Lisboa, produzidos aquando da extinção das ordens para a imediata incorporação dos bens dos institutos religiosos na fazenda real. Apesar de parca em informação, a documentação consultada permitiu esclarecer a identificação das devoções e perceber a mobilidade das obras dentro do espaço sacro, bem como, o valor que era atribuído aos diferentes bens cultuais.

A exposta escassez documental contrasta com a abundante presença e continuada preservação das esculturas. Entre as diversas categorias artísticas é a escultura que mais 
se destaca nos espaços em estudo. A limitação do estudo aos espaços franciscanos prende-se com facto de se tratar da ordem religiosa com mais presença no território.

A Ordem de São Francisco chegou a Portugal pouco tempo após a sua fundação, em Itália, em 1209. No território em estudo, os Frades Menores chegaram a Bragança onde se fundou a primeira casa ainda durante o século XIII, documentalmente registada pela primeira vez em 1271. As Clarissas fundaram casa, também em Bragança, na segunda metade do século XVI, após bênção episcopal do local em 1569 o convento foi ocupado em 1598. Durante o conflituoso século XVII foi fundado o convento da Ordem Terceira Regular na vila de Mogadouro em 1618 mas as obras prolongaram-se até 1689. Na segunda metade do século XVIII, após licença obtida em 1740, em 1752 foi fundado o Seminário Apostólico, em Vinhais. Entre 1762 e 1780 a Ordem Terceira Secular fabricaria o seu próprio templo, também na vila de Vinhais. Outros espaços franciscanos existiram no território da diocese porém não resistiram até à contemporaneidade.

Não podemos deixar de referir que no território deste estudo que dista pouco mais de $100 \mathrm{~km}$ entre as localidades mais afastadas é evidente a pluralidade de reformas e ramos que foram formando a Família Franciscana. É manifesta esta pluralidade, pois não existe coincidência entre nenhuma das entidades a que pertenciam os conventos em estudo, todos diferem nos ramos a que se associam. Perante este complexo cenário institucional, sentimos a necessidade de rever a literatura relativa à organização da Ordem Franciscana em Portugal, centrando-nos sobretudo nos institutos locais. Assim, em capítulo próprio, aproximamo-nos dos Frades menores (Primeira Ordem), das Clarissas (Segunda Ordem) e da Ordem Terceira (Secular e Regular), na medida em que todos se estabeleceram no território. Vincularam-se os diferentes conventos a diferentes ramos apesar da proximidade e dos vários aspetos comuns entre os três territórios vizinhos que se incluem atualmente todos na Diocese de Bragança-Miranda. A região da Diocese de Bragança-Miranda está situada no nordeste montanhoso com altitude superior a $400 \mathrm{~m}$ e pluviosidade média superior a $1000 \mathrm{~mm}$, solo rochoso, acidentado e escavado pela erosão. A área interior e fronteiriça do nordeste transmontano é caracterizado, entre outros aspetos, pela ocorrência de núcleos populacionais de pequena dimensão, que, com várias debilidades, se sustentavam na agricultura e na criação de gado, e pela posição periférica relativamente aos principais centros urbanos.

Pese embora estas limitações foi forte a presença da ordem religiosa franciscana na Diocese de Bragança-Miranda. Esta intensa presença dos franciscanos enquanto agentes socializadores constitui uma das linhas definidoras do âmbito de estudo. A pregação 
constitui o principal encargo dos franciscanos. Apesar de centrados na itinerância evangélica, os franciscanos mantiveram também escolas, hospitais, enfermarias e recolhimentos para dar assistência aos pobres e marginalizados, dedicando-se igualmente ao trabalho manual e aos estudos teológicos. A profunda ligação com os leigos, mesmo o fundador da Ordem só tardiamente se ordenou diácono, justifica a posterior organização da Ordem Terceira Secular. A espiritualidade pregada pelos discípulos de $\mathrm{S}$. Francisco propunha normas de vida individual e o estímulo à prática da caridade.

As esculturas, assim como as restantes representações figurativas, ilustravam os princípios doutrinários e constituíam, numa sociedade maioritariamente iletrada, um poderoso veículo de transmissão de conceitos. A par das emanações eclesiásticas gerais e as particulares da ordem de São Francisco, também a devoção popular foi definindo as devoções e as invocações taumatúrgicas que envolvem as esculturas em estudo. Muitas das identificações das figuras representadas nas esculturas estavam já esquecidas, os quase duzentos anos que nos separam da extinção das ordens religiosas criaram uma rutura na memória dos coletivos que as esculturas refletem. O reavivar da memória coletiva que se pretende com este estudo sugere um conjunto de abordagens diversas cuja relação permita perceber a importância que a escultura teve. Quem foram os seus destinatários? Que oficinas as realizavam? Em que materiais se produziam? Quais as principais caraterísticas formais e técnicas? Que modelos artísticos tiverem mais aceitação? Que cultos e devoções foram mais amplificados? Que tipologias iconográficas se privilegiaram? Que princípios doutrinários se valorizavam? Que relação existia entre a produção escultórica dos diferentes espaços franciscanos da Diocese? Que relevância tinham as esculturas no espaço sagrado? Que papel desempenhavam nos rituais? Qual a sua função nas intercessões sociais em que participavam? A estas e outras questões tentamos responder neste trabalho. O estudo da escultura da Ordem Franciscana na Diocese de Bragança-Miranda propicia um caminho essencial para entender a arte sacra transmontana nas suas aproximações aos valores difundidos pelo território português e, simultaneamente, nas suas peculiaridades de espaço interior de fronteira.

Antecedendo o inventário das esculturas houve ainda a necessidade de uma aproximação ao contexto social e espacial que as envolve. Neste sentido, foi brevemente descrita a fundação dos conventos, os seus patronos iniciais e os diversos vínculos que com a comunidade local foram estabelecendo. Foi também sucintamente descrito o 
edificado das igrejas, bem como o interior dos templos e das estruturas retabulares que ainda expõem as esculturas.

O estudo da escultura dos franciscanos na Diocese de Bragança-Miranda, excetuando algumas obras isoladas, carecia de elementos que permitissem a sua compreensão como manifestação das práticas cultuais levadas a cabo localmente. Para atenuar esta lacuna foram recolhidos os elementos para produzir um inventário exaustivo do património escultórico da Diocese de Bragança-Miranda nas igrejas afetas à Ordem de São Francisco.

O inventário exaustivo tem como objetivos definir as principais técnicas e materiais usados na produção escultórica; reconhecer oficinas de produção artística; descrever as principais influências estilísticas; facilitar uma cronologia de cada peça de modo a contornar a ausência documental, e quantificar o número de obras de cada espaço inventariado.

A amostra em estudo recolhe as esculturas de todas as igrejas afetas à Ordem Franciscana que chegaram aos nossos dias e permite comparar divergências e aproximações entre estas várias tipologias de espaços de culto e conhecimento.

Ao assumir um campo amplo em termos temporais podemos igualmente comparar diacronicamente a prática escultórica dos franciscanos na Diocese de BragançaMiranda.

Percorremos um longo espaço de tempo que tem como limites a primeira referência à primeira casa franciscana na diocese, o Convento de São Francisco em Bragança, em 1271, e o ano de 1834 em que as Ordens Religiosas foram extintas em Portugal. Por ser um marco instaurador, a data de início do período de estudo é relativamente fácil de definir. Já a data extrema que marca o fim do âmbito de estudo poderá não ser tão restrita.

Todos os templos em estudo permanecem afetos ao culto e tiveram por isso novas aportações escultóricas, sentimos necessidade de registar em inventário também a produção contemporânea. As obras contemporâneas apesar de se tratarem já de reproduções de modelos em série foram incluídas no inventário detalhado e sucintamente analisadas em subcapítulo próprio.

A preocupação em ordenar formalmente as obras, atendendo ao seu aspeto, constitui um dos subcapítulos de análise. $\mathrm{Na}$ análise formal privilegiamos as técnicas escultóricas e decorativas, os gestos, as proximidades com outras obras, a filiação e as influências, de modo a perceber o tempo de produção das obras. A definição de cronologias permite 
estabelecer as relações com o ambiente histórico, económico e político do território em que as obras se inserem.

A escultura que ainda hoje podemos encontrar nos espaços outrora ocupados pela família franciscana na diocese de Bragança-Miranda data, na sua esmagadora maioria, do século XVIII. No entanto, encontramos alguns exemplares que podemos datar ainda dos finais do século XV, bem como, e também em número reduzido do século XVI, e uma crescente produção passível de ser identificada com o século XVII.

Após a organização formal das esculturas, definimos as narrativas comunicadas nas formas a partir do estudo iconográfico. No capítulo da análise iconográfica destacamos a comunicação que as esculturas traduzem e que resultam do espaço social e ideológico que formam a rede de significados e motivos que definiram as obras e por elas são definidos.

A ampla presença de esculturas nos espaços em estudo contrasta com a escassez de documentos que às esculturas se refiram. Este aspeto impossibilitou sobretudo que, até agora, não tenha sido possível reunir elementos bastantes para se compreender as autorias exatas das obras. A individualidade artística é, na escultura, mais até que outras categorias das artes plásticas, muito difícil de definir. A autoria das obras é, na maioria dos casos desconhecida, e não apenas pelo baixo nível de importância social dos mestres escultores, mas porque, da conceção à execução a obra escultórica, era entendida como obra coletiva. Acresce, neste âmbito, referir a comum presença dentro da própria Ordem de mestres escultores ou entalhadores. A existência de frades escultores aprofunda a ausência documental por se tratar de encomendas que careciam de registo formal. A implicação de São Francisco na reparação das igrejas e nas práticas manuais de cuidado com os lugares sagrados é também relevante, pois reforça a mesma implicação por parte dos frades da ordem franciscana relativamente aos seus conventos. Este facto pode justificar a ausência documental referente às obras efetuadas nos imóveis conventuais, bem como à encomenda de obras móveis em particular das esculturas. A corroborar este aspeto podemos destacar na documentação consultada que, em Vinhais, aquando do registo dos bens do convento, em 1834, foram várias as imagens assinaladas ainda em fase de produção, sugerindo que a mesma produção das esculturas decorria dentro do espaço conventual do seminário apostólico, possivelmente, a cargo de membros da ordem. No mesmo seminário apostólico de Vinhais, encontramos a referência a Frei Domingos relativamente à autoria de uma das 
esculturas catalogadas no presente estudo constituindo o único autor referido individualmente na produção das obras estudadas.

As igrejas franciscanas em estudo foram fundadas sob a protecção da nobreza local, mas rapidamente foram acrescentadas com o reforço do apoio real. Neste contexto, não podemos deixar de referir a persistência das mesmas familias no âmbito da edilidade do poder local. A família Morais, que no século XIII foi quem duou o terreno para que nele se fundasse o convento franciscano de Bragança, entroncará mais tarde na familia Morais Sarmento, que no século XVIII, será uma das familias responsáveis pela fundação do Seminário Apostólico e, posteriormente, da Ordem Terceira em Vinhais. O convento de Mogadouro relaciona-se com a poderosa familia Távora.

A ordem assume, no nordeste transmontano, um forte vínculo com o poder local, constituindo inquestionavelmente, a partir da evangelização dos princípios que preconizava, uma ferramenta de controlo social. As esculturas ilustravam a prática doutrinária franciscana, mas simultaneamente consubstanciam as expressões dos medos, dos temores e desejos invocados pelos restantes encomendadores. Neste amplo grupo, identificamos as confrarias e as irmandades que na sociedade do Antigo Regime constituíam uma força social que, não raras vezes, escapava às orientações das classes dominantes.

A escolha do tema de tese de doutoramento advém de todos estes factores, a necessidade de melhor entender a realidade artística na Diocese de Bragança-Miranda e, simultaneamente, a pertinência de um estudo sistematizado de recolha e análise de dados acerca das esculturas que na sua imensa maioria, nunca foram alvo de qualquer estudo.

Iniciámos este trabalho com a expectativa de contribuirmos para o entendimento das manifestações artísticas em Portugal, mais especificamente, no território da Diocese de Bragança-Miranda. Propusemo-nos analisar as situações de originalidade, o peso dos tradicionalismos e as influências exteriores com importância na caracterização das esculturas, bem como a avaliar as intenções e os testemunhos ideológicos expressos nos objetos artísticos. Neste sentido, acompanhamos um tempo pautado pela espiritualidade que definiu os comportamentos sociais e as narrativas doutrinárias que ainda hoje as obras artísticas ilustram. 


\section{A FAMÍLIA FRANCISCANA EM PORTUGAL \\ E NA DIOCESE DE BRAGANÇA-MIRANDA}


ORDEM DOS FRADES MENORES - (PRIMEIRA ORDEM) 
A simplicidade do gesto e da palavra de São Francisco contrasta profundamente com a complexidade da história da Ordem religiosa por ele iniciada.

Desde a entrada da Ordem de São Francisco em Portugal, pouco tempo após a sua fundação em Itália em 1209, até à extinção das ordens religiosas decretada pelo governo liberal no século XIX, a Família Franciscana constituiu inquestionavelmente uma poderosa e dinâmica força social com fortes vínculos com as comunidades onde intervinha.

As diversas reformas e ramos que foram formando a ampla Família Franciscana, ao longo destes seis séculos de contínua expansão, tiveram o seu reflexo no território português. Assim como, no território da Diocese de Bragança-Miranda, assumido como espaço geográfico para o presente estudo.

O território da Diocese de Bragança-Miranda ${ }^{1}$ está atualmente dividido em quatro Arciprestados: Bragança, Miranda, Mirandela e Moncorvo. Assim, contemporaneamente o território da diocese de Bragança-Miranda corresponde ao território do distrito de Bragança ${ }^{2}$.

Sem nos determos na questão, não podemos deixar de referir que neste território, que dista pouco mais de $100 \mathrm{~km}$ entre as localidades mais afastadas, é também evidente a pluralidade de reformas e ramos que foram formando a Família Franciscana. É manifesta esta pluralidade pois não existe coincidência entre nenhuma das entidades a que pertenciam os conventos em estudo, todos diferem nos ramos a que se associam, apesar da proximidade e dos vários aspetos comuns entre os três territórios vizinhos. Assim, para contextualizar no espaço e no tempo esta complexa malha institucional, bem como, para melhor definir as relações que se estabeleciam entre os conventos e as

†O tẹrritório đa Diocese de Bragança-Miranda de acordo com o Decreto $n^{\circ}$ 13/2012 de Dom José Manuel Garcia Cordeiro Bispo de Bragança-Miranda relativo à reorganizacão territorial dos Arciprestados, está atualmente dividido em quatro Arcıprestados: Arciprestado de Bragança inclui os concelhos de Bragança e de Vinhais; o Arciprestado de Miranda engloba os concelhos de Miranda do Douro, Mogadouro e Vimioso; o Arciprestado de Mirandela abrange os concelhos de Mirandela e de Macedo de Cavaleiros, com a Paróquia de Castro Vicente do concelho de Mogadouro e o Arciprestado de Moncorvo compreende os concelhos de Alfândega da Fé, Carrazeda de Ansiães, Freixo de Espada à Cinta, Torre de Moncorvo e Vila Flor. Disponível na página da Diocese de Bragança-Miranda: http://www.diocesebm.pt/ (acedido em 22 de Junho de 2015).

${ }^{2}$ O território da Diocese coincide com o do Distrito de Bragança - O Distrito de Bragança corresponde atualmente ao espaço de doze concelhos (Alfandega da Fé, Bragança, Carrazeda de Ansiães, Freixo de Espada a Cinta, Macedo de Cavaleiros, Miranda do Douro, Mirandela, Mogadouro, Torre de Moncorvo, Vila Flor, Vimioso, Vinhais). O território em estudo é constituído apenas pelos concelhos de Bragança, Mogadouro e Vinhais, referenciados segundo a ordem cronológica de fundação dos conventos franciscanos. Estes concelhos constituem parte da região fronteiriça da Terra Fria do Nordeste Transmontano limitado a norte e a este por Espanha. Adaptado de Enciclopédia das Localidades Portuguesas, http://www.mapadeportugal.net, acedido em 10 de Setembro de 2014. 
comunidades onde os conventos se fundavam, houve necessidade de elaborar uma concisa revisão da literatura publicada sobre a presença da Ordem Franciscana em Portugal, com especial atenção para o território do Nordeste Transmontano.

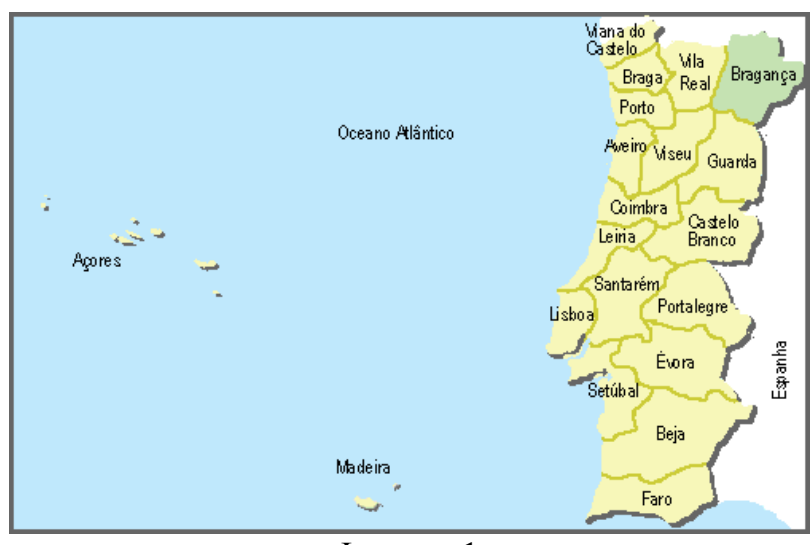

Imagem 1

Mapa de Portugal com localização do distrito de Bragança, (que coincide com o território da diocese) adaptado de http://www.mapadeportugal.net (acedido em 10 de Setembro de 2014)

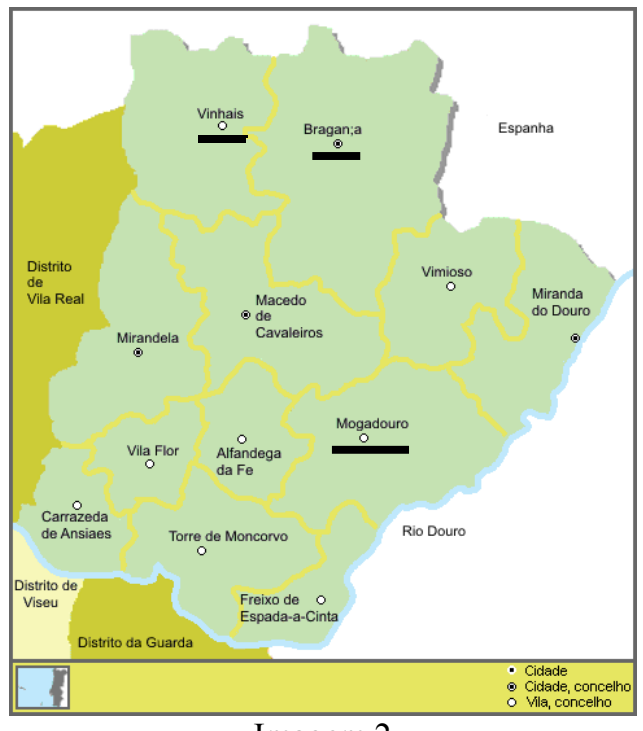

Imagem 2

Mapa da diocese que coincide com o distrito de Bragança, com destaque sublinhado das localidades em estudo adaptado de http://www.mapadeportugal.net (acedido em 10 de Setembro de 2014)

Começamos esta aproximação com uma breve exposição sobre a figura que originou a Ordem e o contexto histórico que permitiu a sua expansão.

Francisco de Assis nasceu no período de grande desenvolvimento do Ocidente medieval, que após o ano mil e de uma maneira desigual mas contínua foi palco de um significativo crescimento demográfico e económico. Ampliou-se o uso do espaço rural e tornou-se mais produtivo, mas a consequência maior foi um poderoso movimento de urbanização ${ }^{3}$.

Francisco de Assis fazia parte de uma família abastada, segundo os padrões comunais da Itália medieval. As fontes medievais revelam a data da sua conversão, em

\footnotetext{
${ }^{3}$ Le Goff, Jacques, S. Francisco de Assis, Lisboa, Teorema, 2000, pp. 15-17. Que refere ainda que a cidade facilitou o aumento e especialização do artesanato, destacando-se neste sector a construção, os têxteis e os curtumes, com importante impacto social permitindo aos mercadores um maior peso na sociedade assim como o aparecimento dos cambistas, que rapidamente se transformaram em banqueiros substituindo mosteiros e judeus no estabelecimento de crédito. A cidade passou a ser não apenas o centro económico mas também o centro de poder, sobretudo em Itália onde a institucionalização quer das corporações de artesãos e mercadores, quer das comunas das organizações politicas começou mais cedo que na restante Europa.
} 
1205 e a data da morte ocorrida a 03.10.1226. A data do nascimento de São Francisco terá sido entre 1181 e $1182^{4}$.

Integrado no movimento de reforma interna da igreja ${ }^{5}$ São Francisco na companhia de 11 jovens em 1208, retirou-se para um local ermo junto da capela de Nossa Senhora dos Anjos na Porciúncula nos arredores de Assis. Na Porciúncula terá redigido a Formula Vitae, constituída por um conjunto de normas de vida comunitária e citações do Evangelho, aprovada oralmente em 1209. À exigência da pobreza individual, comum a todas as ordens religiosas, São Francisco acrescentou o da pobreza coletiva. Algumas divergências e a necessidade de estruturação interna levaram Francisco em colaboração com o Cardeal Hugolino a redigir nova Regra em 12 capítulos, que foi aprovada em 1223 pelo Papa Honório III. O capítulo geral de 1239 elaborou as primeiras constituições que foram remodeladas e acrescentadas por São Boaventura, oitavo ministro geral da Ordem, em 1260. Os Franciscanos tornavam-se então uma organização bem estruturada e capaz de um efetivo apoio à evangelização na Europa ${ }^{6}$.

Após a morte do fundador a Ordem clericalizou-se. As comunidades estavam estruturadas de forma piramidal e centralizada. Cada comunidade ou fraternidade de irmãos era presidida por um Guardião, eleito pelo Ministro Provincial e o seu Conselho de Definidores ou Definitório. As províncias eram formadas por um conjunto mínimo de conventos ou fraternidades cujos guardiães se reuniam periodicamente em capítulo ou assembleia provincial. A designação de "custódia" aplicava-se a duas situações:

\footnotetext{
${ }^{4}$ Após a irreverência da adolescência e o serviço na milícia comunal referem os cronistas o momento de conversão de São Francisco que terá ocorrido na igreja de São Damião. Nesta igreja assumiu residência como penitente independente em finais de 1205. Enquanto irmão penitente, leigo e não religioso, Francisco dedicava-se à reparação de igrejas, prática manual que muito valorizava e que em conjunto com o cuidado com os lugares sagrados será determinante na consolidação do seu percurso. Thompson, Augustine, São Francisco de Assis, uma nova biografia, Alfragide, Casa das Letras, 2012, pp. 23-66.

${ }^{5}$ A reforma interna da igreja ou a reforma Gregoriana ultrapassa no tempo largamente o pontificado de Gregório VII (1073-1085) e potenciou vários movimentos que aspiravam retomar as origens da Igreja na sua primitiva forma. Neste sentido, surgem novas ordens religiosas (Cartuxos, fundada por Bruno em 1084 e a Ordem de Cister, iniciada por Robert de Molesmes em 1098 e muito desenvolvida por São Bernardo de Claraval), de origem espanhola inicia a família dos mendicantes São Domingos de Gusmão quando fundou em 1214 em Toulouse a Ordem Dominicana confirmada pelo Papa Honório III em 1216; multiplicaram-se os grupos de leigos religiosos e as ordens militares que associavam a atividade guerreira à dimensão religiosa. A doutrina do pecado e os sacramentos ganharam importância nos estudos dos teólogos que estruturam a alteração da confissão pública e reforçaram a confissão individual, fomentando o exame de consciência. Le Goff, Jacques, S. Francisco de Assis, Lisboa, Teorema, 2000, p. 21.

${ }^{6}$ Montes Moreira, António, "Franciscanos", in Carlos Moreira Azevedo (Dir.), Dicionário de História Religiosa de Portugal, Lisboa, Círculo de Leitores, 2000, pp. 273-280; Vasconcelos e Sousa, Bernardo (Dir.). Ordens religiosas em Portugal: das origens a Trento, Guia Histórico, Lisboa, Livros Horizonte, 2005, p. 255; Andrade, Maria Filomena Pimentel de Carvalho, "Franciscanos" in José Augusto Mourão e Ana Cristina da Costa Gomes, José Eduardo Franco (Dir.), Dicionário Histórico das Ordens e Instituições Afins em Portugal, Lisboa, Gradiva Publicações, 2010, pp.158-169.
} 
agrupamentos com menor número de conventos e, mais frequentemente, regiões de províncias com alguma autonomia interna, mas, dependentes do ministro provincial. As províncias e custódias do primeiro tipo estavam sujeitas ao ministro geral da Ordem e ao seu conselho ou definitório geral, que residiam em Roma e estavam subordinados ao Papa. Desta organização estava ausente a sujeição à autoridade diocesana, por privilégio papal, o que nos primeiros tempos da Ordem, suscitou problemas com alguns Bispos sobretudo quando estes exerciam igualmente o senhorio civil no seu território, como aconteceu em Braga e no Porto ${ }^{7}$.

Os Franciscanos estabeleceram-se em Portugal em 1217, depois do Capitulo Geral desse ano ter enviado frades para diversos países da Europa. Os primeiros conventos, simples ermitérios, foram os de Alenquer, depois Guimarães, Lisboa, todos de 1217 e Coimbra já existente em 1220. O Capítulo Geral de 1219 reforçou a organização da Ordem em províncias. Nessa data foi criada a de Espanha (Hispânia) que abrangia todos os reinos cristãos da Península Ibérica. Em 1232 e 1233 a província de Espanha desdobrou-se em três: Aragão, Castela e Santiago ou Portugal, como também aparece designada em alguns documentos contemporâneos ${ }^{8}$.

Os conventos portugueses formavam uma custódia chamada de Portugal ou de Lisboa, com alguma autonomia no âmbito da província de Santiago. O capítulo provincial de 1272 desmembrou a custódia portuguesa em duas: uma sediada em Lisboa e com sete conventos e outra em Coimbra com seis conventos. O convento de Bragança, cuja existência está documentada desde 1271, foi incorporado na custódia de Ourense por motivos de proximidade geográfica.

Durante o Cisma do Ocidente (1378-1417) a província de Santiago dividiu-se praticamente em duas do mesmo nome e com dois ministros provinciais, um em Santiago ligado ao Papa de Avinhão, e outro em Lisboa, fiel ao Papa de Roma. A

\footnotetext{
${ }^{7}$ Montes Moreira, António, "Franciscanos", in Carlos Moreira Azevedo (Dir.), Dicionário de História Religiosa de Portugal, Lisboa, Círculo de Leitores, 2000, pp. 273-280; Vasconcelos e Sousa, Bernardo (Dir.). Ordens religiosas em Portugal: das origens a Trento, Guia Histórico, Lisboa, Livros Horizonte, 2005, p. 255; Andrade, Maria Filomena Pimentel de Carvalho, "Franciscanos" in José Augusto Mourão e Ana Cristina da Costa Gomes, José Eduardo Franco (Dir.), Dicionário Histórico das Ordens e Instituições Afins em Portugal, Lisboa, Gradiva Publicações, 2010, pp.158-169.

${ }^{8}$ Dos primeiros conventos ficaram na história os nomes de dois fundadores: em Alenquer, Frei Zacarias de Roma, e, em Guimarães, Frei Gualter, que a tradição popular vimaranense ainda hoje celebra nas Festas Gualterianas. Montes Moreira, António, "Franciscanos", in Carlos Moreira Azevedo (Dir.), Dicionário de História Religiosa de Portugal, Lisboa, Círculo de Leitores, 2000, pp. 273-280; Vasconcelos e Sousa, Bernardo (Dir.). Ordens religiosas em Portugal: das origens a Trento, Guia Histórico, Lisboa, Livros Horizonte, 2005, p. 257.
} 
legalização canónica da separação ocorreu, o mais tardar, em 1421. O país contava então com 27 conventos.

As primeiras fundações de 1217 ocorrem em simultâneo aos conflitos que opunham os territórios cristãos aos territórios muçulmanos. José Mattoso menciona que no conjunto, mais de dois terços dos conventos franciscanos se situavam a sul do Mondego, isto é nas cidades de origem muçulmana. Eram cidades mais concentradas com atividades económicas mais modernas que as do Norte, com uma economia produtiva e de trocas mais intensas. Havia menos instituições religiosas e afluía mais gente deslocada, expulsa pela rigidez senhorial. A Ordem franciscana teve várias dificuldades para se implantar onde o poder eclesiástico estava mais consolidado, como Porto, Guimarães, Leiria, Estremoz e Braga. A mobilidade e o dinamismo franciscano, o facto de as suas propriedades pertencerem juridicamente à Santa Sé e, portanto, serem isentas de imposições fiscais civis e eclesiásticas, a sua organização supranacional, tudo isto criava obstáculos graves ao monopólio do poder que aquelas instituições exerciam a nível local ${ }^{9}$.

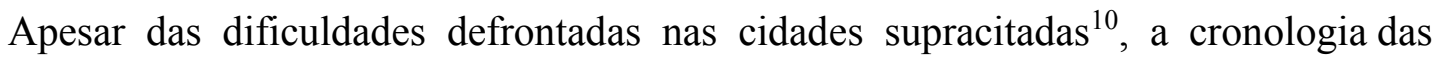
fundações dos franciscanos revela claramente os objectivos da Ordem que iniciando o apostolado em pequenos eremitérios, a curto prazo e com o apoio da realeza penetram

\footnotetext{
${ }^{9}$ As primeiras fundações dos conventos franciscanos em Portugal datam do mesmo ano da conquista de Alcácer do Sal, que libertou Lisboa da pressão muçulmana. Em 1224 quando se funda o convento em Évora esta cidade ainda se encontrava na zona de combate com os almóadas. Esta aproximação dos franciscanos ao limite entre o país cristão e o muçulmano deve relacionar-se com Marrocos e o martírio dos cinco mártires que suscitaram a vocação de Santo António, bem como o entusiasmo da cristandade ainda fortemente polarizada pela sua confrontação com o mundo islâmico. Mattoso, José, "O enquadramento social e económico das primeiras fundações franciscanas", Portugal medieval: novas interpretações, Vol. 8. Lisboa, Circulo de Leitores, 2002, pp. 243-251.

${ }^{10}$ Ao contrário das ordens monásticas que se incrustavam no meio rural, o ideal franciscano, que no plano pessoal visava a mais perfeita identificação com Cristo, na sua dimensão social caracterizava-se pelo testemunho de pobreza evangélica e pelo amor aos irmãos, especialmente traduzido no zelo pela salvação eterna de cada um. Aqui radica a preferência dos frades menores pelos espaços urbanos, onde mais fácil e intensamente poderiam difundir a sua mensagem e garantir o indispensável à própria subsistência. Desta implantação nos meios urbanos temos notícia pelo testamento de D. Afonso III que nele contemplou os Frades Menores de Lisboa, Santarém, Coimbra, Porto, Alenquer, Leiria, Guimarães, Bragança, Lamego, Guarda, Covilhã, Portalegre, Évora, Beja. A implantação das ordens mendicantes em Portugal se intensifica quando as ordens monásticas que os precederam entravam já numa fase crítica. Marques, José, "Os franciscanos no norte de Portugal nos finais da Idade Média", Boletim do Arquivo Distrital do Porto, 1982, pp. 149-189; Rema, Henrique (Frei), "A Ordem Franciscana em Tras-os-Montes" in Boletim do Arquivo Distrital de Vila Real - Revista de Cultura, Estudos Transmontanos e Durienses n ${ }^{\circ}$, Vila Real, Arquivo Distrital de Vila Real, 1995, pp. 299-332.
} 
nos centros mais populosos do reino, atraindo um grande número de fíeis pelo dinamismo pastoral da sua presença ${ }^{11}$.

O território em estudo encontra-se no Norte interior do país. No Norte do território nacional a concentração de mosteiros era muito mais intensa entre Douro e Minho do que em Trás-os-Montes ${ }^{12}$.

Montes Moreira destaca entre as atividades dos franciscanos neste período, a sua presença no ensino, sobretudo nos conventos da corrente do Conventualismo, que se instalam nos espaços urbanos com presença de escolas públicas em muitos dos seus conventos $^{13}$. As escolas conventuais multiplicam-se pelo país à medida que se aproxima o final da Idade Média, bem distintas das escolas monásticas. Mattoso refere que os Franciscanos, Dominicanos e Lóios constituem institutos religiosos vocacionados com especial empenho na pastoral, na pregação e defesa da ortodoxia católica. Os clérigos ilustres do final da Idade Média eram além dos prelados seculares os religiosos de $\mathrm{S}$. Francisco e S. Domingos. Em muitas cidades os Franciscanos competiam no ensino com os tradicionais mosteiros vinculados com o poder senhorial ${ }^{14}$.

Contudo, Franciscanos e Dominicanos sobressaiam menos no ensino do que na pregação. De forte ação popular, sobretudo os Franciscanos, o que lhes permitiu

\footnotetext{
${ }^{11}$ Andrade, Maria Filomena Pimentel de Carvalho, "Franciscanos" in José Augusto Mourão e Ana Cristina da Costa Gomes, José Eduardo Franco (Dir.), Dicionário Histórico das Ordens e Instituições Afins em Portugal, Lisboa, Gradiva Publicações, 2010, pp.158-169.
}

12 A região entre Douro e Minho era onde se acumulava maior número de famílias diferentes e também aquela onde a rede paroquial era mais densa, os mosteiros mais numerosos e a terra mais fecunda. A partir da segunda metade do século XII a maioria de fundações de novos mosteiros privilegiaram as zonas menos densas de população como o Alto Minho, Trás-os-Montes e Beira, é neste contexto de superação de problemas de fraca consolidação dos centros urbanos que surge a fundação do convento em Bragança. Mattoso, José e Armindo de Sousa in José Mattoso (Dir.), História de Portugal, volume 2, Lisboa, Círculo de Leitores, 1993, 186; Na segunda metade do século XIII os conventos do Porto e Guimarães eram os únicos centros irradiadores do espírito franciscano Entre Douro e Minho, para não dizer do todo o Além Douro, uma vez que do convento de Bragança nada se sabe para além da sua existência. Marques, José, "Os franciscanos no norte de Portugal nos finais da Idade Média", Boletim do Arquivo Distrital do Porto, 1982, pp. 149-189; Afonso, Belarmino, "Os Franciscanos no Distrito de Bragança" in Boletim do Arquivo Distrital de Vila Real - Revista de Cultura, Estudos Transmontanos e Durienses $n^{\circ} 7$, Vila Real, Arquivo Distrital de Vila Real, 1995, pp. 333-351.

\footnotetext{
${ }^{13}$ Montes Moreira, António, "Franciscanos", in Carlos Moreira Azevedo (Dir.), Dicionário de História Religiosa de Portugal, Lisboa, Círculo de Leitores, 2000, pp. 273-280.

${ }^{14}$ Mattoso, José e Armindo de Sousa in José Mattoso (Dir.), História de Portugal, volume 2, Lisboa, Círculo de Leitores, 1993, p. 235.
} 
imprimir uma profunda influência cultural com amplas consequências na transformação da mentalidade dominante ${ }^{15}$.

\section{A divisão da Ordem}

Entretanto, desde o tempo do santo fundador da Ordem que a tensão se fazia sentir. O motivo de tensão prendia-se com a questão da busca de um rigor extremo na vivência do ideal de pobreza, o anseio por uma vida autêntica de observância mais fiel e rigorosa ao Evangelho ${ }^{16}$.

No século XIV defrontam-se duas correntes dentro da Ordem: Conventualismo (ou a Claustra, como se dizia habitualmente em Portugal) e a Observância.

Os conventos da Claustra eram geralmente edificados com amplidão, seguiam um estilo de vida monacal, beneficiavam de dispensas pontifícias em matéria de pobreza, estavam geralmente localizados em centros urbanos e bastantes mantinham escolas abertas ao público. O movimento da Observância, nascido em Itália, introduziu-se em Portugal em 1392, a partir do Norte, por iniciativa de alguns frades espanhóis da província de Santiago. Ao longo do século XV fundam-se cerca de dez conventos observantes sendo o mais destacável o de Varatojo nas cercanias de Torres Vedras. Estas casas defendiam a observância integral da Regra (daí o nome do movimento), praticavam um estilo de vida austero e pobre, privilegiavam a oração mental e a

\footnotetext{
${ }^{15}$ Mattoso, José e Armindo de Sousa in José Mattoso (Dir.), História de Portugal, volume 2, Lisboa, Círculo de Leitores, 1993. O apostolado franciscano muito contribuiu para minorar as dificuldades sociais de um território ainda indefinido, ajudando a consolidar as estruturas urbanas. Também as mais espinhosas missões internacionais eram muitas vezes postas à guarda de frades franciscanos, devido à sua independência e autoridade espiritual. $\mathrm{O}$ facto de eles terem procurado as populações desprotegidas e carenciadas dos deslocados que afluíam às cidades e de desenvolverem um apostolado desinteressado deu-lhes um papel de relevo em muitas situações de conflito. Mattoso, José, "O enquadramento social e económico das primeiras fundações franciscanas", Portugal medieval: novas interpretações, Vol. 8. Lisboa, Circulo de Leitores, 2002, p. 253.

${ }^{16}$ Marques, José, "Os franciscanos no norte de Portugal nos finais da Idade Média", Boletim do Arquivo Distrital do Porto, 1982, pp. 149-189; Rema, Henrique (Frei), "A Ordem Franciscana em Tras-osMontes" in Boletim do Arquivo Distrital de Vila Real - Revista de Cultura, Estudos Transmontanos e Durienses $n^{\circ}$, Vila Real, Arquivo Distrital de Vila Real, 1995, pp. 299-332; Montes Moreira, António, "Franciscanos", in Carlos Moreira Azevedo (Dir.), Dicionário de História Religiosa de Portugal, Lisboa, Círculo de Leitores, 2000, pp. 273-280; Andrade, Maria Filomena Pimentel de Carvalho, "Franciscanos" in José Augusto Mourão e Ana Cristina da Costa Gomes, José Eduardo Franco (Dir.), Dicionário Histórico das Ordens e Instituições Afins em Portugal, Lisboa, Gradiva Publicações, 2010, pp.158-169.
} 
pregação e estavam instalados, por norma, em locais ermos ou rurais. Os Observantes constituíam vigariaria autónoma no seio da mesma província e dependiam da respetiva vigariaria geral observante: a Cismontana para Itália e Ultramontana, fora de Itália.

Em 1517 o Papa Leão X dividiu a Ordem dos frades menores em duas Ordens juridicamente distintas: a dos Frades Menores da Regular Observância e os Frades Menores Conventuais. Na sequência desta decisão os Franciscanos portugueses organizaram-se também em duas províncias nesse mesmo ano: a Província de Portugal da Regular Observância (com 27 casas e sede no convento de São Francisco em Lisboa) e a Província de Portugal dos Claustrais ou Conventuais (com 22 casas e sede no convento de São Francisco no Porto). As três casas da Madeira ficaram para a Observância e as cinco casas dos Açores para os Claustrais. Em 1568, a pedido do Cardeal D. Henrique, então regente do Reino, os conventuais foram suprimidos e integrados nos Observantes. Esse ramo franciscano só regressou a Portugal em $1967^{17}$.

Os tempos do Portugal Moderno, sobretudo o século XVI, assinalaram um período de extraordinário desenvolvimento da Ordem dos Frades menores no Reino e no Ultramar. $\mathrm{Na}$ esteira da atividade desenvolvida por São Francisco o dinamismo franciscano levou os frades a participarem na evangelização decorrente dos descobrimentos portugueses. Os franciscanos mantêm-se como os únicos evangelizadores em quase todos os territórios no ultramar até à chegada da Companhia de Jesus.

Durante o período moderno os Franciscanos estiveram organizados em três grupos, (como se pode ver no quadro 1). O primeiro grupo, chamado da Regular Observância, descendia da corrente principal da observância iniciada no século XIV, e estruturava-se em quatro províncias (Portugal e Algarves no Reino, São Tomé na India e São João Evangelista nos Açores) e duas custódias (S. Tiago Menor na Madeira e Conceição nas ilhas açorianas de S. Miguel e Santa Maria).

\footnotetext{
${ }^{17}$ Montes Moreira, António, "Franciscanos", in Carlos Moreira Azevedo (Dir.), Dicionário de História Religiosa de Portugal, Lisboa, Círculo de Leitores, 2000, pp. 273-280; Vasconcelos e Sousa, Bernardo (Dir.). Ordens religiosas em Portugal: das origens a Trento, Guia Histórico, Lisboa, Livros Horizonte, 2005, p. 258.
} 


\begin{tabular}{|c|c|c|}
\hline & Fundação* & Frades em $1739 * *$ \\
\hline \multicolumn{3}{|c|}{ Regular Observância } \\
\hline \multicolumn{3}{|l|}{ Províncias } \\
\hline Portugal & 1517 & 868 \\
\hline Algarves & $1532 / 1533$ & 922 \\
\hline S. Tomé (India) & $1583 / 1619$ & 270 \\
\hline S. João Evangelista (Açores) & $1639 / 1641$ & 309 \\
\hline \multicolumn{3}{|l|}{ Custódias } \\
\hline S. Tiago Menor (Madeira) & $1683 / 1702$ & 100 \\
\hline Conceição (Açores) & 1717 & 173 \\
\hline \multicolumn{3}{|c|}{$\begin{array}{c}\text { Estreita Observância } \\
\text { (Mais Estreita e Regular Observância } \\
\text { Instituto Capucho-Capuchos) }\end{array}$} \\
\hline \multicolumn{3}{|l|}{ Províncias } \\
\hline Piedade & 1517 & 285 \\
\hline Arrábida & 1560 & 613 \\
\hline Santo António & 1568 & 378 \\
\hline Soledade & 1673 & 435 \\
\hline Conceição & 1705/1706 & 343 \\
\hline Madre de Deus (India) & $1622 / 1629$ & 220 \\
\hline Santo António (Brasil) & $1657 / 1659$ & 420 \\
\hline Imaculada Conceição (Brasil) & $1675 / 1677$ & 379 \\
\hline \multicolumn{3}{|l|}{ Custódia } \\
\hline Malaca (Extremo Oriente) & 1584 & - \\
\hline \multicolumn{3}{|c|}{ Comissariados de Províncias do Reino no Estado do Maranhão e Grão-Pará } \\
\hline Santo António & Custódia)/1655 & 30 \\
\hline Piedade & 1693 & 36 \\
\hline Conceição & 1707 & 36 \\
\hline \multicolumn{3}{|c|}{ Missão das Províncias da Piedade (1656) e da Soledade (1673) } \\
\hline Cabo Verde e Guiné (África) & 1656 & 30 \\
\hline \multicolumn{3}{|c|}{ Seminários de Missionários Apostólicos } \\
\hline Varatojo & $1679 / 1680$ & 41 \\
\hline Brancanes (Setúbal) & 1708/1711 & 32 \\
\hline Vinhais & 1753 & - \\
\hline Mesão Frio & 1790 & - \\
\hline Falperra (Braga) & $1825 / 1828$ & - \\
\hline
\end{tabular}

Quadro 1 - síntese da organização dos franciscanos no Portugal moderno, facultado por Dom António Montes Moreira, 2015.

*Nas datas duplas a primeira indica o ano do decreto (ou da decisão) de fundação e a segunda, o da sua execução ou implementação definitiva, exceto no Seminário da Falperra que obteve beneplácito real em 1825 e confirmação pontifícia em 1828.

**Fr. Apolinário da Conceição, OFM, Claustro Franciscano erecto no domínio da Coroa Portuguesa, Lisboa, 1740. 
As entidades do segundo grupo - as províncias da Piedade, da Arrábida, de Santo António, da Soledade e da Conceição no Reino, a da Madre de Deus na India e as de Santo António e da Imaculada Conceição no Brasil, a custódia de Malaca no Extremo Oriente, três comissariados no Maranhão e a missão de Cabo Verde e Guiné - seguiam o regime mais austero da Estreita Observância ou da mais estreita e regular observância, que em Portugal tomam o nome de Capuchos ou membros do instituto Capucho, devido ao feitio pontiagudo do capelo. Não deve ser confundido com os Capuchinhos, Ordem Franciscana independente fundada em Itália em 1525 e que só se estabeleceu em Portugal em 1934. O ramo capucho desenvolveu uma atividade notável na sua missionação ultramarina.

O terceiro grupo de Franciscanos era constituído por cinco Seminários Autónomos de Missionação Apostólica: Varatojo, Brancanes, Vinhais, Mesão Frio e Falperra. Estas casas uniam uma austera disciplina conventual e intensa prática exterior de missões populares $^{18}$.

Neste ímpeto reformador dos costumes são destacáveis as restrições impostas à comunidade judaica ou de cristãos novos. A presença desta comunidade no território em estudo $^{19}$, associada às práticas comerciais e industriais, não deve ser descurada na relação com o crescimento de instituições religiosas. As casas dos religiosos durante o período moderno vão servir para a colocação de filhos e filhas dos grandes e fidalgos, mas também nas famílias de nação de cristãos-novos era corrente faze-1o ${ }^{20}$.

\footnotetext{
${ }^{18}$ Montes Moreira, António, "Franciscanos", in Carlos Moreira Azevedo (Dir.), Dicionário de História Religiosa de Portugal, Lisboa, Círculo de Leitores, 2000, pp. 273-280; Vasconcelos e Sousa, Bernardo (Dir.). Ordens religiosas em Portugal: das origens a Trento, Guia Histórico, Lisboa, Livros Horizonte, 2005, p. 258; Andrade, Maria Filomena Pimentel de Carvalho, "Franciscanos" in José Augusto Mourão e Ana Cristina da Costa Gomes, José Eduardo Franco (Dir.), Dicionário Histórico das Ordens e Instituições Afins em Portugal, Lisboa, Gradiva Publicações, 2010, pp.158-169.
}

\footnotetext{
${ }^{19}$ Francisco Manuel Alves, o Abade de Baçal dedica integralmente todo o tomo V da sua obra aos judeus no distrito de Bragança, onde refere a importância da indústria em especial das sedas nos séculos XVI e XVII em Bragança. Chacim, Miranda, Mogadouro, Santavalha, Sendim, Vila Flor, Vimioso e Vinhais. No mesmo tomo publica as diversas listas que o tribunal da Inquisição elaborou com inúmeros indivíduos provenientes dos locais em estudo. Alves, Francisco Manuel, Bragança Memórias arqueológicohistóricas do distrito de Bragança, Tomo V, Bragança, Câmara Municipal de Bragança e Instituto Português de Museus, 2000, (original publicado em 1910-1947), p XCVII.

${ }^{20}$ Apesar dos esforços de reforma, os conventos multiplicam-se e sobretudo aumentam os frades e freiras que neles viviam, muitas vezes por imposição social, para promoção do estatuto, ou no caso das famílias de nação - os cristãos novos, para melhor se integrarem num sistema onde a perseguição se intensificava. Magalhães, Joaquim Romero, "A sociedade" in José Mattoso, História de Portugal volume 3, Lisboa, Círculo de Leitores, 1993, pp. 469-509; O elevado número de religiosos tornou-se quase incomportável para a boa gestão do reino. Durante todo o século XVII o crescimento do número de religiosos foi contínuo mantendo-se até ao terceiro quartel do século XVIII comprometendo a lavoura, as receitas
} 
Além da evangelização o aumento da presença da Ordem Franciscana colmataria também o fraco acesso à educação e ao ensino da doutrina cristã que ocupava transversalmente a sociedade do espaço rural e urbano. No território de Trás-os-Montes a pregação moral relacionar-se-ia com a persistência das práticas criptojudaicas. Neste contexto social, a galanteria da corte e o humanismo de Erasmo eram realidades longínquas ao espaço do nordeste transmontano. A vigilância apertada e os instrumentos da ortodoxia impunham-se sobretudo com o inimigo mais próximo que era o praticante e conhecedor da Lei Velha ${ }^{21}$.

Perante este cenário difundem-se também no território da Diocese de BragançaMiranda as missões evangélicas. Portugal, tal como o restante espaço europeu, recebeu inúmeras missões durante o período moderno, com intenção de minorar a ignorância da população sobretudo no que concernia à doutrina cristã. Na diocese de BragançaMiranda o labor missionário não tinha sido muito intenso devido à inexistência de pregadores.

O empenho das reformas na formação académica, moral e espiritual teve os seus frutos e entre os franciscanos tornaram-se exemplo de humildade, pobreza, desprendimento do mundo e espiritualidade os membros do seminário do Varatojo de Torres Vedras, após a ação de frei António das Chagas. Frei António da Chagas foi a figura central dos dois seminários que serviram para a formação de missionários: Varatojo, em 1680, e Brancanes, em 1695, de onde viriam a sair muitos pregadores populares que irradiavam para todo o país e também para o Ultramar. O seminário de Vinhais, fundado em 1753, teve como primeiro guardião o missionário de Brancanes Fr. António de Nossa Senhora das Neves ${ }^{22}$.

fiscais e o exército. Este processo provocou várias situações de indisciplina, sobretudo antes do Concílio de Trento com faltas elementares de formação escolar, cultural e até religiosa. Paiva, José Pedro, "Os mentores" in Carlos Moreira Azevedo, História Religiosa de Portugal, volume 2, Lisboa, Círculo de Leitores, 2000, pp. 201-237.

${ }^{21}$ Em especial os povos serranos de pastores e cultivadores onde a subsistência se arranca a uma natureza hostil eram percebidos como povos rústicos e mal cristianizados, com dificuldade de entendimento da complexa doutrina cristã e perante os quais a presença dos agentes da igreja constituíam os únicos vínculos com a educação. Magalhães, Joaquim Romero, "O pano de fundo" in José Mattoso, História de Portugal volume 3, Lisboa, Círculo de Leitores, 1993, pp. 575-607.

${ }^{22}$ A missionação franciscana ganhou novo fôlego devido à incansável acão de Frei António das Chagas que entre 1672 e 1681, por ordem do seu superior, andou por todos os bispados do reino, desde o Algarve até à diocese de Miranda sobre a qual refere que tudo «he hum bosque de peccados, e huma mata de ignorancias e malícias». Paiva, José Pedro, "As missões internas" in Carlos Moreira Azevedo, História Religiosa de Portugal, volume 2, Lisboa, Círculo de Leitores, 2000, pp. 239-250; Rodrigues, Luís Alexandre, "A ação dos padres de Brancanes em Vinhais. O Seminário da Senhora da Encarnação e constituição da Venerável Ordem Terceira da Penitência” in Natália Marinho Ferreira-Alves, Os 
Durante este período os conventos da Ordem dos Frades Menores existentes no território da atual Diocese de Bragança-Miranda pertenciam às seguintes entidades ${ }^{23}$ : Bragança - pertencia à Província de Portugal, com existência documentada desde 1271; Torre de Moncorvo - fundado em 1569 na Província de Santo António, passou para a Província da Conceição em 1706; Vinhais - Seminário Apostólico, fundado em 1753.

Dos conventos dos frades menores da Diocese de Bragança-Miranda não se inclui no presente estudo o convento de Torre de Moncorvo pois apenas chegou aos nossos dias parte de uma dependência periférica do convento (atualmente usada como oficina para automóveis) como se pode observar na imagem que reproduzimos (Imagem 1). Todo o conjunto conventual e igreja foram destruídos ${ }^{24}$.

Imagem 1

Parte da estrutura arquitectónica que resta do desaparecido convento de São Francisco de Torre de Moncorvo

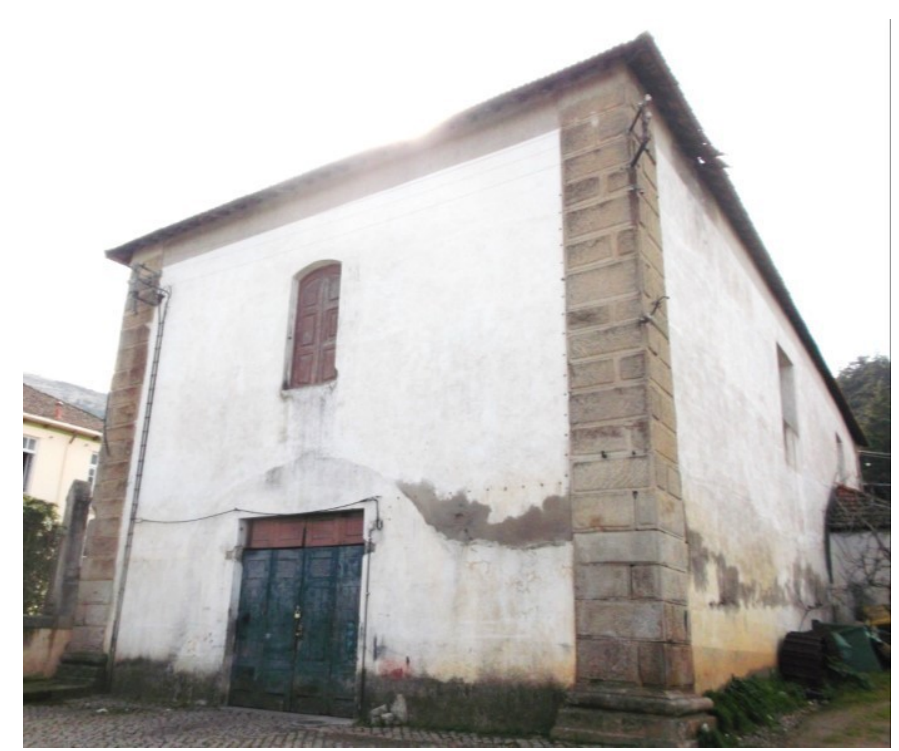

A crise interna dos institutos religiosos vinha já de meados do século XVII e agravou-se na segunda metade do século XVIII. Em primeiro lugar, a população conventual do país era excessiva. Daí resultaram dificuldades de subsistência, acumulação de dívidas dos conventos, reclamações dos credores e conflitos entre as províncias e casas por causa dos peditórios. O recrutamento vocacional era deficiente.

Franciscanos no Mundo Português II. As Veneráveis Ordens Terceiras de São Francisco, Porto, CEPESE, 2012, pp. 163-193.

${ }^{23}$ Segundo informação gentilmente cedida por Dom António Montes Moreira em Novembro de 2014 e que se transcreve na íntegra.

${ }^{24}$ Conforme consta na plataforma digital SIPA (Sistema de Informação para o Património Arquitetónico) da Direção Geral dos Edifícios e Monumentos Nacionais:

http://www.monumentos.pt/Site/APP_PagesUser/SIPA.aspx?id=27424, acedida a 28 de Outubro de 2014. 
Registavam-se infrações à disciplina regular, ociosidade, estagnação intelectual e quebra do ideal missionário.

Sem dúvida, a decadência interna não era geral. Mas atingiu uma percentagem de religiosos e situações suficientes para se repercutir com gravidade no conjunto, sobretudo neste período em que a mentalidade regalista e iluminista manifestava pouca consideração, e até mesmo hostilidade para com a vida religiosa.

No século XIX o declínio acentuou-se, também por influência de factores externos como as invasões francesas (1807-1811), a animosidade anticongreganista de vários sectores da população incluindo o clero secular, a orientação anticlerical e anticongreganista da maçonaria, a oposição do liberalismo por motivos ideológicos e de politica económica atendendo às vastas propriedades de muitos mosteiros e finalmente as necessidades do erário publico fortemente desgastado pela Guerra Civil entre absolutistas e liberais (1832-1834).

As primeiras medidas contra as Ordens Religiosas foram tomadas pelo Marquês de Pombal, em 1759 a supressão e a expulsão da Companhia de Jesus e em 1773 a obrigação de os institutos religiosos passarem a viver na obediência imediata do Núncio Apostólico sem dependência dos respetivos superiores gerais sedeados em Roma. Em 1789 a Rainha D. Maria I instituiu a Junta do Exame do Estado Actual e Melhoramento Temporal das Ordens Regulares. Uma das providências indicadas pela Junta em 1791 foi a proibição de os institutos religiosos receberam noviços. A medida foi apoiada pelo Arcebispo de Braga, o terceiro franciscano regular D. Fr. Caetano Brandão.

Em 1832, já com o liberalismo, D. Pedro IV, ainda nos Açores, extinguiu numerosos conventos neste arquipélago. Em Agosto de 1833, depois da conquista de Lisboa pelas tropas liberais a 24 de Julho, D. Pedro IV decreta a supressão de todos os conventos e mosteiros que estivessem abandonados, ou que tivessem recebido eclesiásticos hostis ao governo liberal e proíbe a admissão de noviços e noviças em todo o país. Finalmente em 1834 D. Pedro IV determinou a extinção imediata de "todos os conventos, mosteiros, colégios, hospícios e quaisquer casas de religiosos de todas as ordens regulares, seja qual for a sua denominação, instituto ou regra", e a incorporação dos seus bens na fazenda nacional, exceto paramentos e vasos sagrados que foram "postos à disposição dos Ordinários respetivos para serem distribuídos pelas igrejas mais necessitadas da Dioceses"25.

\footnotetext{
${ }^{25}$ No mesmo decreto era concedido um subsídio anual aos egressos enquanto não tivessem rendimento, benefício ou emprego público. Mas, por diversas imposições, muitas vezes foram renegados estes
} 
Os religiosos expulsos dos conventos receberam o nome de "egressos" e dedicavamse à ação pastoral nas paróquias, ao ensino. Alguns egressos de Varatojo restauraram a vida conventual nesta casa em 1861. Depois criaram-se novos conventos em S. Bernardino (Peniche), Montariol (Braga) e Torre de Giesteira (Évora) e em 1891 restaurava-se a atual província da Ordem dos Frades Menores ${ }^{26}$.

A extinção das Ordens Regulares provocou alterações profundas nos espaços conventuais em estudo. Sem exceção, todos os espaços conventuais foram adaptados a novos usos. No entanto, as igrejas dos conventos de Bragança, e Vinhais estão ainda ao culto, apesar de terem sido alvo de diversas mudanças ao longo dos séculos XIX, XX até aos nossos dias.

compromissos. Almeida, Fortunato de, História da Igreja em Portugal, Ed. pre. e dir. por Damião Peres, Livraria Civilização, Porto; Lisboa, 1967-1971, p. 146.

${ }^{26}$ Montes Moreira, António, "Franciscanos", in Carlos Moreira Azevedo (Dir.), Dicionário de História Religiosa de Portugal, Lisboa, Círculo de Leitores, 2000, pp. 273-280; Andrade, Maria Filomena Pimentel de Carvalho, "Franciscanos" in José Augusto Mourão e Ana Cristina da Costa Gomes, José Eduardo Franco (Dir.), Dicionário Histórico das Ordens e Instituições Afins em Portugal, Lisboa, Gradiva Publicações, 2010, pp.158-169. 


\section{CLARISSAS (SEGUNDA ORDEM)}


Clara de Favarone, de Assis, sentiu-se interpelada pela experiência religiosa de Francisco de Assis e em 1212 seguiu o mesmo ideal de vida sob a sua inspiração e direção. Após uma breve estadia junto das beneditinas nos mosteiros de São Paulo de Bastia e de Santo Ângelo, estabeleceu-se na igreja rural de São Damião, que se tornou o primeiro convento franciscano feminino. Santa Clara elaborou a regra que entroncava na Formula Vitae e no Privilégio da Pobreza e receberia promulgação canónica do papa Inocêncio IV em 1253. Esta primeira regra foi em 1263 reformada por Urbano IV, por ser considerada demasiado austera, criando a Regra Urbanista. Urbanista ou segunda Regra, a qual permitia a aceitação de rendas e doações.

As comunidades de Santa Clara, inicialmente denominadas damainitas, sorores ou irmãs pobres, entre outras designações, difundiram-se rapidamente e por disposição do Papa Urbano IV, passaram a designar-se Ordem de Santa Clara. Ainda hoje as Clarissas seguem duas Regras: a de Santa Clara a maioria dos mosteiros, e a de Urbano IV, os restantes ${ }^{1}$.

Todas as comunidades tinham uma abadessa que governava com um conselho de discretas, eleitas em capítulo por todas as irmãs. Os mosteiros, obrigados à clausura, eram em geral autónomos e isentos da jurisdição episcopal. Dependentes da Santa Sé, as clarissas estavam unidas aos franciscanos pela comunhão no mesmo espirito e pela autoridade comum do Cardeal Protetor e do Visitador Geral. Posteriormente começaram também a formar-se comunidades dependentes da autoridade diocesana. Assim, todas as casas de clarissas estavam dependentes de autoridades eclesiásticas masculinas: ou de um cenóbio franciscano ou do bispo local.

Segundo a mentalidade e a prática do tempo em relação à vida consagrada feminina, as Clarissas, além dos votos tradicionais de pobreza, castidade e obediência, viviam em

\footnotetext{
${ }^{1}$ Clara di Favorone di Offreduccio pertencia à aristocracia rural e seria onze anos mais nova que Francisco. Quando decidiu "deixar o mundo" dirigiu-se com sua irmã à Porciúncula onde professou obediência religiosa a Francisco. Porém, não estava a Porciúncula preparada para receber uma discípula feminina e Francisco encaminhou Clara para o vizinho convento beneditino. Thompson, Augustine, São Francisco de Assis, uma nova biografia, Alfragide, Casa das Letras, 2012, pp. 91-94; Começaram por receber das mãos do cardeal protetor da Ordem (c. 1219) a Regra de São Bento, por ser proibido pelo concílio de Latrão de 1215 elaborar novas regras. Vasconcelos e Sousa, Bernardo (Dir.). Ordens religiosas em Portugal: das origens a Trento, Guia Histórico, Lisboa, Livros Horizonte, 2005, pp. 255, 256; A "Forma de Vida" foi transmitida oralmente e por escrito por São Francisco a Santa Clara e às suas primeiras companheiras e definia os princípios espirituais e comportamentais destas novas religiosas. Em 1216 Santa Clara solicitou e obteve do Papa a concessão do direito, inédito em casas femininas, de nada possuírem nem serem obrigadas a aceitar doações ou rendas, o denominado "privilégio de pobreza", dado por Inocêncio III e confirmado por Gregório IX em 1228. Lalanda, Maria Margarida S. N. "Clarissas (Ordem de Santa Clara)" in Carlos Moreira Azevedo, Dicionário de história religiosa de Portugal, Lisboa, Circulo de Leitores, 2000, pp. 353-355.
} 
regime de clausura com separação física do mundo exterior. Mas foi a questão da pobreza que mais cisões provocou no século XIV com uma corrente conventual ou claustral. A corrente conventual ou claustral mitigada pelas dispensas papais quanto à relação com os bens materiais e a «reforma de Santa Coleta» (1381-1447) que concretizou a proibição de rendas e dotes na corrente de observância mais estrita e rigorosa quanto à pobreza e austeridade de vida. Após algumas alterações a esta reforma criaram-se em 1538 as chamadas clarissas "capuchinhas"2.

A Ordem entrou em Portugal em 1258, dois anos após a canonização de Santa Clara, quando um grupo de leigas devotas de Lamego fundaram o primeiro convento. No mesmo ano foi outorgada outra bula para fundar outro convento em Entre-os-Rios onde desde 1256 viviam três clarissas vindas de Zamora. As clarissas de Lamego foram iniciadas na observância regular por irmãs estrangeiras e por estarem demasiado distantes de outras casas masculinas da ordem foram transferidas para Santarém no ano seguinte, para o mosteiro acabado de edificar por D. Afonso III, enquanto o convento de Entre-os-Rios foi transferido para o Porto em 1416, em ambos se seguia a regra urbanista.

Os conventos de clarissas, com dependência canónica dos bispos ou dos provinciais franciscanos, chegaram a atingir em 1739 o número de 65. Na clausura era possível as monjas dedicarem-se à educação e ao ensino, não apenas das irmãs que iriam professar os votos, mas também de meninas e jovens que eram confiadas ao mosteiro para serem instruídas nos valores cristãos, leitura, escrita, canto e artes domésticas ${ }^{3}$.

No território em estudo edificaram-se apenas dois mosteiros de Clarissas: o de Santa Clara de Bragança fundado em 1569, e o de Santa Clara de Vinhais algum tempo antes de 1659. Ambos seguiam a mesma Regra, a do Papa Urbano IV e dependiam ambos da

\footnotetext{
${ }^{2}$ Havia também mulheres piedosas que se juntavam aos mosteiros quer vivendo em recolhimento como "manteladas" (terceiras franciscanas seculares) ou mesmo integrando-se num mosteiro como freiras ou leigas com estatuto especial, como aconteceu com algumas rainhas e infantas portuguesas. Lalanda, Maria Margarida S. N. "Clarissas (Ordem de Santa Clara)" in Carlos Moreira Azevedo, Dicionário de história religiosa de Portugal, Lisboa, Circulo de Leitores, 2000, pp. 353-355; Vasconcelos e Sousa, Bernardo (Dir.). Ordens religiosas em Portugal: das origens a Trento, Guia Histórico, Lisboa, Livros Horizonte, 2005, pp. 256-258.

${ }^{3}$ Sendo vedado às monjas quebrar a clausura para pedir esmola o dote tornou-se imprescindível para a subsistência individual e sobrevivência da comunidade. A gestão do património dos mosteiros estava a cargo de um síndico - procurador secular. Havia alguns conventos onde, preferencialmente, eram aceites as filhas das famílias socialmente mais abastadas. Lalanda, Maria Margarida S. N. "Clarissas (Ordem de Santa Clara)" in Carlos Moreira Azevedo, Dicionário de história religiosa de Portugal, Lisboa, Circulo de Leitores, 2000, pp. 353-355; Vasconcelos e Sousa, Bernardo (Dir.). Ordens religiosas em Portugal: das origens a Trento, Guia Histórico, Lisboa, Livros Horizonte, 2005, p. 256.
} 
jurisdição episcopal do bispo de Miranda. O de Bragança, porém, tinha começado por estar sujeito à obediência da província franciscana de Portugal.

Do mosteiro de Bragança hoje subsiste apenas a igreja. Atualmente com funções paroquiais e sob a designação oficial de Nossa Senhora das Graças, embora continue a ser chamada popularmente igreja de Santa Clara.

Quanto a Vinhais, só existe o inventário feito em meados do século XIX por ocasião da extinção do convento. O edifício do convento foi o único prédio urbano descrito, registado como estando em "ruim estado e perfeita ruína" e foi avaliado em "um conto e duzentos mil reis". A Igreja do convento não foi avaliada e, conforme consta no documento de 1858, estava "Em bom estado"4. Atualmente todo o conjunto está desaparecido.

No caso dos mosteiros femininos o decreto de extinção das ordens religiosas de 1834 permitiu que as monjas se mantivessem nas suas casas. Porém, como estavam proibidos de receber noviças desde 1833, o convento era extinto quando falecia a ultima religiosa. As candidatas que iam recebendo levavam vida comunitária, mas não existiam votos religiosos. Eram tratadas pela designação de "pupilas".

Esta diferença em relação à imediata expulsão dos religiosos das casas masculinas explica que no advento da república subsistissem ainda casas religiosas com monjas, que o regime republicano e a legislação anticongregacionista em 1910 definitivamente expulsaram. Só em 1928 recomeça a presença das Clarissas em território português, consolidando-se durante o Estado Novo. Em 1992 existiam dez mosteiros de clarissas. Todos seguindo a primeira Regra, a de Santa Clara, e dependentes da jurisdição canónica dos respetivos bispos 5 .

\footnotetext{
${ }^{4}$ No inventário dos bens do convento de Santa Clara de Vinhais não constam os objetos de culto, nem qualquer referência ao destino que lhes foi dado, apenas se refere, constantemente, o mau estado e o aspeto "velho" dos objetos avaliados, na sua maioria objetos de cozinha e roupas. No momento do registo do convento residiam nos espaços ainda passíveis de ser ocupados 8 seculares recolhidas e 5 freiras. As propriedades rurais são, inquestionavelmente, as que ocupam o maior número de registos, com destaque para lameiros, pinhal, olival, curtinhas, vinhas, castanheiros, atestando que apesar da ruína do edifício a comunidade possuía importantes recursos materiais não só em Vinhais (e Vilar d'Ossos) mas também em Mirandela (Mosteiró). No entanto, detinham também vastas dívidas e despesas sobretudo com o pagamento de ordenados (ao capelão, ao médico e aos criados) e obrigações, como era a de abastecimento de cera para as festividades em honra de São Francisco, Santa Clara, Santíssimo Coração de Jesus e Natal. A.N.T.T./A.H.M.F./C.S.C.V., Extinção das Ordens Religiosas - Convento de Santa Clara Vinhais, Arquivo Nacional da Torre do Tombo, Lisboa, Arquivo Histórico do Ministério das Finanças, Processos de Extinção das casas religiosas, Cx. 1892, 1897, s/fl.
}

${ }^{5}$ Lalanda, Maria Margarida S. N. "Clarissas (Ordem de Santa Clara)" in Carlos Moreira Azevedo, Dicionário de história religiosa de Portugal, Lisboa, Circulo de Leitores, 2000, pp. 353-355. 
ORDEM TERCEIRA DE SÃO FRANCISCO:

ORDEM FRANCISCANA SECULAR

ORDEM TERCEIRA REGULAR 


\section{Ordem Terceira Secular (Ordem Franciscana Secular)}

Já no século XI e XII havia esboços do que seriam mais tarde as ordens terceiras seculares, mas foi São Francisco de Assis que enquanto "penitente de Assis" lhes deu forma. A Ordem Terceira reunia leigos solteiros, casados ou viúvos que, após um ano de noviciado e profissão estavam aptos para o apostolado ativo. Os leigos que desejavam viver de maneira mais exigente a sua vocação cristã, dedicavam-se a cristianizar os comportamentos e as vivências das sociedades em que se inseriam. Seriam também muitas vezes os benfeitores dos conventos desempenhando um importante papel na conservação e dinamização do ideal de vida de Francisco de Assis. A Ordem Terceira Secular teve reconhecimento canónico em 1289, por Bula do Papa Nicolau IV que lhes concede também uma Regra. A substancia doutrinal da ordem já se encontrava na Carta aos fiéis redigida pelo Poverello de Assis de $1214^{1}$.

No território em estudo surgiram fraternidades de terceiros seculares em Bragança no princípio de 1600 e em Vinhais em 1762. Estas fraternidades ainda subsistem².

Em Bragança, quando em 1635, se aumentou a igreja do convento de São Francisco dos frades da Primeira Ordem, também se construiu a capela do lado da epístola para uso da Ordem Terceira. Esta fraternidade reunia terceiros em três ramos: o ramo da Lombada, o ramo de Lampaças e o ramo de Miranda. A fraternidade viveu na obediência aos guardiães do convento até 1787, ano em que as diferenças surgidas entre os terceiros e os frades levaram a que estes se opusessem às reuniões de terceiros dentro

\footnotetext{
${ }^{1}$ Montes Moreira, António, "Franciscanos", in Carlos Moreira Azevedo (Dir.), Dicionário de História Religiosa de Portugal, Lisboa, Círculo de Leitores, 2000, pp. 273-280; Araújo, António de Sousa, "Ordens Terceiras" in Carlos Moreira Azevedo (Dir.), Diccionário de História religiosa de Portugal, Lisboa, Círculo de Leitores, 2000, pp. 348-355; Vasconcelos e Sousa, Bernardo (Dir.). Ordens religiosas em Portugal: das origens a Trento, Guia Histórico, Lisboa, Livros Horizonte, 2005, p. 257; Andrade, Maria Filomena Pimentel de Carvalho, "Franciscanos" in José Augusto Mourão e Ana Cristina da Costa Gomes, José Eduardo Franco (Dir.), Dicionário Histórico das Ordens e Instituições Afins em Portugal, Lisboa, Gradiva Publicações, 2010, pp.158-169.

${ }^{2}$ Há registos de outras comunidades de Terceiros de que não resistiram vestígios artísticos nos templos próprios como em Torre de Moncorvo com estatutos desde 1699 e recolhimento de Irmãs Terceiras. Também na aldeia da Mofreita (Vinhais) se estabeleceu em 1793 o instituto das Oblatas do Menino Jesus, comunidade de Irmãs Terceiras que efemeramente estiveram na igreja de Nossa Senhora do Loreto em Bragança de onde foram transferidas pouco tempo depois para Fornos de Ledra (Macedo de Cavaleiros), as duas casas foram extintas com a República em 1910. A Recoleta de Irmãos Terceiros junto da capela de Nossa Senhora de Balsemão, próxima de Chacim (Macedo de Cavaleiros) teve aprovação do bispo em 1728, mas em 1754 professaram os Recoletos na Ordem da Imaculada Conceição (fundada na Polónia em 1686) constituindo o primeiro convento de frades conceicionistas em Portugal. Ribeiro, P. Bartolomeu, Os terceiros franciscanos portugueses; sete séculos da sua história, Braga, Tip. Missões Franciscanas, 1952, pp. 278-284; Rema, Henrique (Frei), "A Ordem Franciscana em Tras-os-Montes" in Boletim do Arquivo Distrital de Vila Real - Revista de Cultura, Estudos Transmontanos e Durienses $n^{\circ} 7$, Vila Real, Arquivo Distrital de Vila Real, 1995, pp. 299-332.
} 
da igreja do convento. Os terceiros mudaram-se para a igreja paroquial de São João Batista $^{3}$. A ordem Terceira de Bragança passou a obedecer aos superiores eclesiásticos seculares em 1788. Vigorou este regime de obediência até 1922, ano em que os terceiros de Bragança reataram relações com os superiores franciscanos ${ }^{4}$. Após a extinção das ordens religiosas D. Maria II cedeu por decreto de 1835 o templo conventual dos extintos Franciscanos da Primeira Ordem à Ordem Terceira Secular que de novo voltaram a exercer nesse espaço as suas práticas ${ }^{5}$.

Em Vinhais com a chegada dos missionários apostólicos em 1752-1755 os irmãos terceiros inscritos na fraternidade de Bragança, quiseram constituir uma fraternidade independente. Com a conclusão das obras do seminário em 1762 puderam os irmãos terceiros ocupar a capela da portaria. O fervor local e o legado do fidalgo da Casa Real José de Morais Sarmento permitiram que antes de 1779 os terceiros inaugurassem templo próprio, contíguo ao templo conventual do seminário, formando em conjunto com este, um só corpo arquitetónico de corretas linhas. Incluía a fraternidade as paróquias dos concelhos de Vinhais, Monforte e Mirandela. Após a extinção das ordens religiosas os terceiros de Vinhais passaram a obedecer a comissários pontifícios tal como sucedia com os terceiros de Bragança ${ }^{6}$. Os irmãos terceiros seculares de Vinhais foram a única fraternidade no território em estudo com templo próprio.

A Regra do Papa Nicolau IV de 1289 foi renovada por duas vezes nos tempos contemporâneos: pelo Papa Leão XIII em 1883 e pelo Papa Paulo VI em 1978. A partir

\footnotetext{
${ }^{3}$ A igreja de São João Batista era próxima do convento de Santa Escolástica e nos finais do século XVIII apresentava já várias ruinas. Rodrigues, Luís Alexandre, De Miranda a Bragança: arquitectura religiosa de função paroquial na época moderna, Bragança, Faculdade de Letras da Universidade do Porto (Tese de Doutoramento); texto policopiado, 2001, p. 6. O edifício desapareceu totalmente nos finais do século XIX e inícios do século XX.

${ }^{4}$ Ribeiro, P. Bartolomeu, Os terceiros franciscanos portugueses; sete séculos da sua história, Braga, Tip. Missões Franciscanas, 1952, pp. 278-281; Rema, Henrique (Frei), "A Ordem Franciscana em Tras-osMontes" in Boletim do Arquivo Distrital de Vila Real - Revista de Cultura, Estudos Transmontanos e Durienses n ${ }^{\circ}$, Vila Real, Arquivo Distrital de Vila Real, 1995, pp. 299-332.

${ }^{5}$ Dos atos religiosos destacam-se as festividades tradicionalmente celebradas pelos terceiros que incluíam a dos Santos Reis com armação de presépio, a de Santa Luzia, com grande romaria desde o século XVII, a Via-Sacra do Calvário nos Domingos da quaresma, na semana santa a procissão do Enterro do Senhor e da Senhora da Boa Morte, a de São Francisco, a novena e festa da Imaculada Conceição e o Oficio Geral pelos irmãos falecidos. Ribeiro, P. Bartolomeu, Os terceiros franciscanos portugueses; sete séculos da sua história, Braga, Tip. Missões Franciscanas, 1952, pp. 278-280; Castro, José de, Bragança e Miranda, (Bispado) Tomo II, Porto, Tipografia Porto Médico, Ld a , 1947, pp. 310-313.

${ }^{6}$ Ribeiro, P. Bartolomeu, Os terceiros franciscanos portugueses; sete séculos da sua história, Braga, Tip. Missões Franciscanas, 1952, p. 281.
} 
da Regra de Paulo VI a Ordem Terceira Secular passou a chamar-se Ordem Franciscana Secular ${ }^{7}$.

\section{Ordem Terceira Regular}

A Ordem Terceira Regular surgiu no século XIV, na Itália e noutros países europeus a partir de grupos de terceiros seculares que se agregavam em vida comum com os votos religiosos habituais de pobreza, castidade e obediência. De associação de fiéis seculares tornaram-se verdadeiros institutos religiosos. A Ordem Terceira Regular recebeu Regra própria em 1521 dada pelo Papa Leão $\mathrm{X}^{8}$.

A Província Portuguesa da Ordem Terceira Regular existia já em 1439. No primeiro quartel do século XVI as Províncias da Ordem Terceira Regular de Espanha e Portugal formaram congregações independentes com Ministro Geral próprio. Mas, em 1568 a Província da Ordem Terceira Regular de Portugal foi submetida à dependência da Província de Portugal da Regular Observância e pouco depois, talvez em 1586, passou à obediência imediata do Ministro Geral da Observância. Por esse motivo, nas cronicas e escritos bem como nas estatísticas da época, a Ordem Terceira Regular aparece sempre associada à Primeira Ordem. Em 1780 a Santa Sé elevou a província portuguesa da Ordem Terceira Regular a congregação autónoma, sob o nome de "Congregação Lusitana dos Regulares da Terceira Ordem da Penitência” e com Constituições próprias e faculdade de eleger o superior geral. A casa-mãe era o convento de Nossa Senhora de Jesus dos Cardais, em Lisboa, atualmente sede da Academia das Ciências de Lisboa.

A Ordem Terceira Regular teve diversos conventos em Portugal e nos territórios colonizados, entre eles o convento de São Francisco de Mogadouro (que se inclui no presente estudo) e o convento de Nossa Senhora das Flores ${ }^{9}$. Em 1739 a Ordem Terceira Regular contava 17 conventos um deles colégio universitário em Coimbra ${ }^{10}$.

\footnotetext{
${ }^{7}$ Conforme informação facilitada por Dom António Montes Moreira em Maio de 2015.

${ }^{8}$ Rema, Henrique (Frei), "A Ordem Franciscana em Tras-os-Montes" in Boletim do Arquivo Distrital de Vila Real - Revista de Cultura, Estudos Transmontanos e Durienses $n^{\circ} 7$, Vila Real, Arquivo Distrital de Vila Real, 1995, pp. 299-332.

${ }^{9}$ Félix Lopes, Frei Fernando, Colectânea de estudos de história e literatura, Volume I, Lisboa, Academia Portuguesa de História, 1997, p. 186; Afonso, Belarmino, "Os Franciscanos no Distrito de Bragança" in Boletim do Arquivo Distrital de Vila Real - Revista de Cultura, Estudos Transmontanos e Durienses $n^{\circ} 7$, Vila Real, Arquivo Distrital de Vila Real, 1995, pp. 333-351; Teixeira, Vítor Rui Gomes, "A presença franciscana na região de Bragança-Miranda até ao séc. XV", Comissão de Arte Sacra de Bragança-
} 
O convento de Mogadouro que, segundo a data gravada na cartela que se encontra sobre o nicho na fachada da igreja, a construção do edifício deve ter terminado no ano de 1689 , mas a igreja estaria pronta para servir ao culto vinte anos antes ${ }^{11}$.

O convento de Sezulfe não foi incluído no presente estudo pois o desaparecimento do templo e dos bens móveis, entre eles a escultura, que se guardavam no seu interior não o permitem. O imóvel do convento de Nossa Senhora das Flores em Sezulfe ${ }^{12}$, concelho de Macedo de Cavaleiros, encontra-se hoje quase integralmente destruído, e os bens móveis desaparecidos ou dispersos (Imagem 1).

Miranda, Páginas da História da Diocese de Bragança-Miranda, Actas do Congresso histórico 450 anos da fundação, Bragança, Comissão Executiva das Comemorações, 1997, pp. 671-683.

${ }^{10}$ Os terceiros regulares eram popularmente conhecidos em Portugal no século XVI por "Catarinos" pelo
nome do principal convento, o de Santa Catarina de Santarém, depois foram chamados de "Pedristas" e
por "Frades Borras", por causa da cor do hábito. Dentro do espirito da Ordem Terceira existiam ainda
comunidades que se consideravam "Terceiras" mas sem votos religiosos, se eram comunidades
masculinas designavam-se por "recolectas" se eram comunidades femininas eram chamadas de
"recolhimentos" Félix Lopes, Frei Fernando, Colectânea de estudos de história e literatura, Volume I,
Lisboa, Academia Portuguesa de História, 1997, p. 185; Montes Moreira, António, "Franciscanos", in
Carlos Moreira Azevedo (Dir.), Dicionário de História Religiosa de Portugal, Lisboa, Círculo de
Leitores, 2000, pp. 273-280; Araújo, António de Sousa, "Ordens Terceiras" in Carlos Moreira Azevedo
(Dir.), Diccionário de História religiosa de Portugal, Lisboa, Círculo de Leitores, 2000, pp. $348-355$;
Andrade, Maria Filomena Pimentel de Carvalho, "Franciscanos" in José Augusto Mourão e Ana Cristina
da Costa Gomes, José Eduardo Franco (Dir.), Dicionário Histórico das Ordens e Instituiçóes Afins em
Portugal, Lisboa, Gradiva Publicações, 2010, pp.158-169; Vasconcelos e Sousa, Bernardo (Dir.). Ordens
religiosas em Portugal: das origens a Trento, Guia Histórico, Lisboa, Livros Horizonte, 2005, p. 259 .

${ }^{11}$ Mourinho, António Rodrigues, Arquitectura religiosa da diocese de Miranda do Douro - Bragança, Sendim, Câmara Municipal de Miranda do Douro, 1995, p. 255.

12 Félix Lopes, Frei Fernando, Colectânea de estudos de história e literatura, Volume I, Lisboa, Academia Portuguesa de História, 1997, p. 186; Teixeira, Vítor Rui Gomes, "A presença franciscana na região de Bragança-Miranda até ao séc. XV", Comissão de Arte Sacra de Bragança-Miranda, Páginas da História da Diocese de Bragança-Miranda. Actas do Congresso histórico 450 anos da fundação, Bragança, Comissão Executiva das Comemorações, 1997, pp. 671-683; O convento de Sezulfe foi originalmente construído para a ordem do Oratório de S. Filipe Néri que apenas esteve a funcionar durante seis anos. Em 1686 a pedido do bispo D. Frei António de Santa Maria, a Ordem Terceira de S. Francisco aceitou ocupar o convento já bastante arruinado. Mas, somente, em Setembro de 1690, se lançou a primeira pedra do novo edifício conventual pelo abade de Podence, Gregório Pegas de Gouveia, contribuindo o Cabido, estando vaga a sede episcopal de Miranda, com a quantia de 150 mil réis retirados das rendas da mitra. No capítulo geral da Ordem Terceira Regular, celebrado em Lisboa a 20 de Março de 1694, é nomeado o primeiro Prelado para este convento. D. Fr João da Cruz no relatório da visita ad limina de 1754 informou que nele existiam 20 religiosos. Monsenhor José de Castro refere ainda 8 a 10 religiosos, ou 12, apenas D. Fr. João da Cruz refere 20 religiosos. Depois da extinção das ordens religiosas em 1834 parte das imagens que havia nos altares foram para Sezulfe e outra parte para as Arcas. Castro, José de, Bragança e Miranda, (Bispado) Tomo II, Porto, Tipografia Porto Médico, Lda, 1947, pp. 171-173; Afonso, Belarmino, "Os Franciscanos no Distrito de Bragança" in Boletim do Arquivo Distrital de Vila Real - Revista de Cultura, Estudos Transmontanos e Durienses $n^{\circ} 7$, Vila Real, Arquivo Distrital de Vila Real, 1995, pp. 333-351; Prada de Oliveira, Carlos, A Diocese de Miranda do Douro em meados do século XVIII, segundo as Memórias Paroquiais de 1758, Universidade do Minho, Instituto de Ciências Sociais, Braga, texto policopiado, 2006, p. 97. 


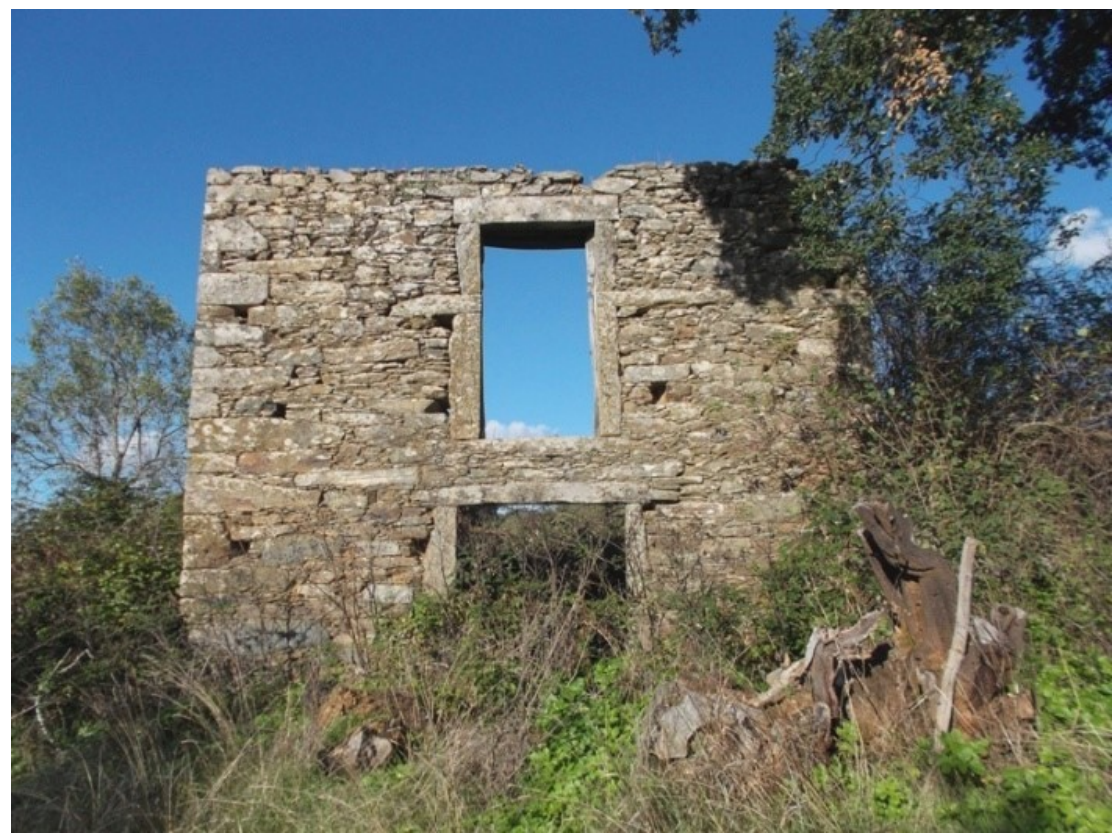

Imagem 1

Parte da parede que resta do desaparecido convento de Nossa Senhora das Flores em Sezulfe, Macedo de Cavaleiros

Depois da supressão das Ordens em 1834 a Ordem Terceira Regular não foi restaurada em Portugal ${ }^{13}$.

\footnotetext{
${ }^{13}$ Montes Moreira, António, "Franciscanos", in Carlos Moreira Azevedo (Dir.), Dicionário de História Religiosa de Portugal, Lisboa, Círculo de Leitores, 2000, pp. 273-280.
} 


\section{OS ESPAÇOS FRANCISCANOS NA DIOCESE DE BRAGANÇA-MIRANDA:}

- FUNDAÇão da CASA

- EDIFICADO DA IGREJA

- INTERIOR DA IGREJA

- FICHAS DE INVENTÁRIO DA ESCULTURA 
CONVENTO DE SÃO FRANCISCO EM BRAGANÇA 


\section{FUNDAÇÃO DO CONVENTO}

A lenda conta que foi São Francisco de Assis que fundou o convento de Bragança. No primeiro quartel do século XVIII ainda era reafirmado o mito. José Cardoso Borges na sua obra as Memórias de Bragança escrevia que ao contrário do que se declarava na Monarquia Lusitana não era o convento de Alenquer o mais antigo de Portugal, mas o convento de São Francisco em Bragança que foi:

"o primeiro convento que a religião seráfica teve em Portugal é o desta cidade nasceu nas mãos do Santo Patriarca, no de 1214, na ocasião que, voltando da romaria de Santiago, passou por esta cidade e a honrou com a sua presença. (...) A tradição nesta cidade e suas vizinhanças é tão constante que ninguém se atreveria a dizer o contrário sem nota de temeridade ${ }^{1}$, .

São vários os cronistas seráficos que indicam o Convento de Bragança como o primeiro a ser fundado no território português e pelo próprio São Francisco ${ }^{2}$. Segundo a História Seráfica de Frei Manuel da Esperança, o Convento foi desenhado por São Francisco que deixou os companheiros de peregrinação em Bragança para fundarem a comunidade ${ }^{3}$.

\footnotetext{
${ }^{1}$ Borges, José Cardoso, Memórias de Bragança, Fernando de Sousa (Coord.), Bragança, CEPESE / Câmara Municipal de Bragança, 2012 (texto original de 1721-1724), p.142.

${ }^{2}$ Esperança, Manuel da, Frei, Historia Seráfica Da ordem Dos Frades Menores de S. Francisco Na Província de Portugal, Tomo I. Lisboa : Officina Craesbeeckiana; disponível na Biblioteca Nacional online http://purl.pt/20706/4/, 1656, pp. 49, 50, e também na obra Floreto de São Francisco (Sevilha 1492) se refere a peregrinação do Santo a Compostela onde terá recebido uma visão que o impelia a fundar conventos, ideia que até esse momento o Santo recusava. Frei Marcos de Lisboa, cronista da Ordem entre 1556-1572, conta também a lenda, bem como, Frei Francisco Gonzaga em 1587, entre outros. Apesar da polémica em torno a este momento da vida do Santo, são várias as crónicas que afirmam que o Convento de Bragança foi o primeiro convento franciscano em Portugal, fundado pelo próprio São Francisco. O último historiador a mencionar a viagem de São Francisco a Portugal foi Frei Bartolomeu Ribeiro, em 1946. Teixeira, Vítor Rui Gomes, "A presença franciscana na região de Bragança-Miranda até ao séc. XV" in Comissão de Arte Sacra de Bragança-Miranda, Páginas da História da Diocese de BragançaMiranda, Actas do Congresso histórico 450 anos da fundação, Bragança, Comissão Executiva das Comemorações, 1997, pp. 671-683.
}

3 A construção do convento foi realizada sobre uma ermida dedicada a Santa Catarina, o mesmo aconteceu em Guimarães onde o convento também foi construído sobre o espaço de uma anterior capela de Santa Catarina. Teixeira, Vítor Rui Gomes, "A presença franciscana na região de Bragança-Miranda até ao séc. XV" in Comissão de Arte Sacra de Bragança-Miranda, Páginas da História da Diocese de Bragança-Miranda, Actas do Congresso histórico 450 anos da fundação, Bragança, Comissão Executiva das Comemorações, 1997, pp. 671-683; Teixeira, Vítor Gomes, O maravilhoso no mundo franciscano português da baixa idade média, Porto, Granito editores e livreiros, 1999, p. 17; Frei Manuel da Esperança na História Seráfica da Ordem dos frades de S. Francisco de 1656 descreve "Não esperou o 
A falta de documentos não permite aceitar as tradições cronísticas. $\mathrm{O}$ espaço de implementação no território português dos conventos franciscanos opera-se de Sul para Norte $^{4}$.

De 1271 data o primeiro documento conhecido relativo ao convento de São Francisco de Bragança que é o testamento de D. Afonso III (1248-1279), em que o monarca doou 50 libras ao Convento. Borges refere que a família Morais foi a principal benemérita da casa, dando o sítio para a sua instalação e a cidade favorecida com rendas públicas fez o edifício. Gonçalo Rodrigues de Morais e Constança Soares deram o terreno e várias mercês tornando-se os patronos do convento. Além das esmolas dos particulares e de rendas públicas da cidade foram vários os monarcas que protegeram o convento. Depois de D. Afonso III foi a Rainha Santa Isabel que fez uma doação ao Convento para obras no edifício da igreja. Também D. Dinis o contemplou no seu testamento. Em 1412, D. João I tomou o convento à sua proteção e, ainda no mesmo século, passou para a Casa de Bragança, que também o favoreceu ${ }^{5}$.

brio, e devoção de Bragança, que nas obras entrasse braço alheo, nem ainda da Magestade Real, encarregandose dellas à custa das rendas publicas, e esmolas particulares até ficar acabada; e se não he majestosa, não consentia então outra grandeza maior o nosso humilde estado. Posto que nunqua os reis de Portugal se izentarão de lhe fazerem mercês, e o primeiro, que repartiu em testamento esmolas pelos conventos da nossa religião, a saber D. Afonso III, no anno de 1271 a este também consignou o seu legado. A rainha Santa Isabel the teve sempre leal devoção, por ser ele o primeiro, em que entrou neste reino, quando vinha de Aragão; e ajudada de grande magnificiencia Del Rei seu marido D. Dinis, deu novo ser a igreja, reparando juntamente todos os mais edifícios. Assi o testemunhavão o forro da capela mor, a qual era obra sua, os retratos delles ambos, antes de hua ruína, com que ficarão enterrados. Mas depois o tomou à sua conta a Serenissima Caza dos Senhores Duques de Bragança". Esperança, Manuel da, Frei, Historia Seráfica Da ordem Dos Frades Menores de S. Francisco Na Província de Portugal, Tomo I, Lisboa, Officina Craesbeeckiana, disponível na Biblioteca Nacional on-line http://purl.pt/20706/4/, 1656, p. 50; Rodrigues, Luís Alexandre, Bragança no século XVIII. Urbanismo. Arquitectura, Volume I, Bragança, Junta de Freguesia da Sé, 1997, p. 416.

\footnotetext{
${ }^{4}$ Marques, José, "Os franciscanos no norte de Portugal nos finais da Idade Média", Porto, Boletim do Arquivo Distrital do Porto, 1982, pp. 149-189; Montes Moreira, António, "Franciscanos" in Carlos Moreira Azevedo, Dicionário de história religiosa de Portugal, Lisboa, Círculo de Leitores, 2000, pp. 273-280.
}

${ }^{5}$ Em 1282, a Rainha Santa Isabel passou por esta cidade quando vinha de Aragão e por ter ficado com especial devoção ao convento de São Francisco, mandou fazer a igreja que se mantém até aos nossos dias, sendo a maior igreja desta cidade. Borges, José Cardoso, Memórias de Bragança, Fernando de Sousa (Coord.), Bragança, CEPESE / Câmara Municipal de Bragança, 2012 (texto original de 1721-1724), pp. 142-147; Alves, Francisco Manuel, Bragança Memórias arqueológico-históricas do distrito de Bragança ( $2^{a}$ edição) Tomo II, Bragança, Câmara Municipal de Bragança / Instituto Português de Museus - Museu Abade de Baçal, 2000, (original publicado em 1910-1947), p. 243; Castro, José de, Bragança e Miranda, (Bispado) Tomo II, Porto, Tipografia Porto Médico, Ld ${ }^{\mathrm{a}}$, 1947, pp. 305-307; Teixeira, Vítor Rui Gomes, "A presença franciscana na região de Bragança-Miranda até ao séc. XV" in Comissão de Arte Sacra de Bragança-Miranda, Páginas da História da Diocese de Bragança-Miranda, Actas do Congresso histórico 450 anos da fundação, Bragança, Comissão Executiva das Comemorações, 1997, pp. 671-683; Rodrigues, Luís Alexandre, Bragança no século XVIII. Urbanismo. Arquitectura, Volume I, Bragança, Junta de Freguesia da Sé, 1997, p. 416; Vasconcelos e Sousa, Bernardo (Dir.), Ordens religiosas em Portugal: das origens a Trento, Guia Histórico, Lisboa, Livros horizonte, 2005, p. 279. 
Bragança, pelas garantias outorgadas no foral de D. Sancho reunia uma comunidade socialmente instável ${ }^{6}$. No início do século $\mathrm{XIII}^{7}$, havia as condições para o estabelecimento de uma Ordem Mendicante pois existia artesanato, agricultura com excedentes, comércio, famílias abastadas, bem como aspetos geográficos concretos, como a proximidade da fronteira, o afastamento dos grandes centros religiosos e a passagem de peregrinos, o que provocava animação urbana, moeda em circulação e esmolas, mas também carências de assistência espiritual, humanitária e pobreza ${ }^{8}$.

O fenómeno mendicante apesar das suas raízes e contactos com o eremitismo é um fenómeno urbano. A presença ou ausência de conventos era só por si significativa das características da cidade. Este facto justifica que, no contexto medieval, Bragança fosse o único espaço, que de forma estável e continuada, recebeu os frades menores em todo o

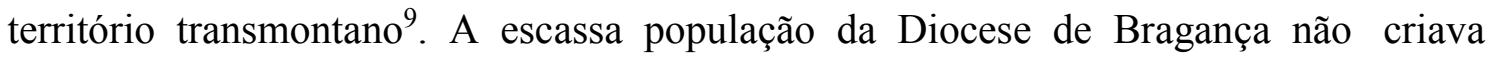
dinâmicas necessárias ao estabelecimento de casas da ordem franciscana, de forma continuada, em mais nenhum espaço.

O Convento de Bragança pertenceu à Custódia de Portugal até 1272, integrada na Província de Santiago; à Custódia da Galiza até 1330; à Custódia da Zamora até 1385, finalmente estará integrado na Custódia de Coimbra que depois integra a Província de Portugal. Ao longo do século XV o Convento aproxima-se ao ramo Conventual

\footnotetext{
${ }^{6}$ Bragança estava povoada, a modo de Roma, por escravos, judeus, adúlteros, assassinos e outros criminosos, sem dúvida atraídos pelas garantias outorgadas no foral de D. Sancho, não seria a terra melhor preparada para receber carinhosamente uma ordem religiosa. Alves, Francisco Manuel, Bragança Memórias arqueológico-históricas do distrito de Bragança (2 ${ }^{a}$ edição) Tomo II, Bragança, Câmara Municipal de Bragança / Instituto Português de Museus - Museu Abade de Baçal, 2000, (original publicado em 1910-1947), p. 242.

${ }^{7} \mathrm{O}$ contexto económico do século XIII, caracterizado pelo aumento das áreas cultivadas, o relançamento do comércio, a organização dos mesteirais e consequente desenvolvimento dos centros urbanos, propiciou o desenvolvimento e propagação da Ordem Franciscana por toda a Europa. Para este processo contribuem também as peregrinações a Santiago de Compostela e as cruzadas. Teixeira, Vítor Rui Gomes, "A presença franciscana na região de Bragança-Miranda até ao séc. XV" in Comissão de Arte Sacra de Bragança-Miranda, Páginas da História da Diocese de Bragança-Miranda, Actas do Congresso histórico 450 anos da fundação, Bragança, Comissão Executiva das Comemorações, 1997, pp. 671-683;

A peregrinação marcou fortemente a vida religiosa na Idade Média, numa sociedade compartimentada e sedentária, os peregrinos tornavam-se o sinal de uma realidade quase sagrada, por terem ousado romper com o quotidiano. Mattoso, José, História de Portugal, volume 2, Lisboa, Círculo de Leitores, 1993, pp. 206, 207.
}

${ }^{8}$ A comunidade de frades mendicantes mais próxima era de São Domingos, em Vila Real. Teixeira, Vítor Rui Gomes, "A presença franciscana na região de Bragança-Miranda até ao séc. XV" in Comissão de Arte Sacra de Bragança-Miranda, Páginas da História da Diocese de Bragança-Miranda, Actas do Congresso histórico 450 anos da fundação, Bragança, Comissão Executiva das Comemorações, 1997, pp. 671-683.

\footnotetext{
${ }^{9}$ Mattoso, José, O enquadramento social e económico das primeiras fundações franciscanas. Portugal medieval: novas interpretações, Volume 8, Lisboa, Circulo de Leitores, 2002, p. 243.
} 
(Província Portuguesa dos Frades Conventuais 1517-1568), a partir de 1568 integrou a Província Observante de Portugal ${ }^{10}$.

No período Moderno o convento da Ordem de São Francisco havia já ampliado a sua influência no território, ainda mais após a supressão do Mosteiro Beneditino do Castro de Avelãs ${ }^{11}$.

No século XVII instala-se numa capela do convento, a Ordem Terceira. No século XVIII, são comuns as referências ao estado depauperado do convento. Das rendas da Câmara despendiam-se vinte mil reis pelos sermões do Advento e da Quaresma, que se pregavam no mesmo convento, e davam uma propina de um maço de velas de seis arráteis. Para os reparos do convento a Câmara despendia ainda a provisão que de sessenta mil reis todos os anos enquanto as obras durassem, no entanto a falta de aplicação desta provisão fez com que nunca a verba fosse aplicada nos reparos ao convento ${ }^{12}$.

A presença de irmandades ${ }^{13}$, confrarias e o apoio de privados e públicos enriqueceram a história da comunidade dos franciscanos em Bragança. As irmandades e

\footnotetext{
${ }^{10}$ Castro, José de, Bragança e Miranda, (Bispado) Tomo II, Porto, Tipografia Porto Médico, Ld a ${ }^{\mathrm{a}}$ 1947, p. 307; Teixeira, Vítor Rui Gomes, "A presença franciscana na região de Bragança-Miranda até ao séc. XV" in Comissão de Arte Sacra de Bragança-Miranda, Páginas da História da Diocese de Bragança-Miranda, Actas do Congresso histórico 450 anos da fundação, Bragança, Comissão Executiva das Comemorações, 1997, pp. 671-683; Montes Moreira, António, "Franciscanos" in Carlos Moreira Azevedo, Dicionário de história religiosa de Portugal, Lisboa, Círculo de Leitores, 2000, pp. 273-280; Vasconcelos e Sousa, Bernardo (Dir.), Ordens religiosas em Portugal: das origens a Trento, Guia Histórico, Lisboa, Livros horizonte, 2005, p. 279.
}

\begin{abstract}
${ }^{11}$ Rodrigues, Luís Alexandre, Bragança no século XVIII. Urbanismo. Arquitectura, Volume I, Bragança, Junta de Freguesia da Sé, 1997, p. 416; O Mosteiro Beneditino do Castro de Avelãs foi extinto aquando da criação da Diocese de Bragança-Miranda em 1545 «O Bispado de Miranda foi ereto pelo Santo Padre Paulo III pela bula de 22 de Maio de 1545 (...) a instâncias do senhor D. João III, extinto o mosteiro de Castro de Avelãs e aplicadas as suas rendas ao Cabido da Nova Sé mirandense tudo confirmado pelo dito senhor rei por carta de 26 de Maio de 1546 (...). E o cabido tomou posse do dito mosteiro e suas rendas em 19 de Junho do mesmo ano». Alves, Francisco Manuel, Bragança Memórias arqueológico-históricas do distrito de Bragança (2 $2^{a}$ edição) Tomo III, Bragança, Câmara Municipal de Bragança / Instituto Português de Museus - Museu Abade de Baçal, 2000, (original publicado em 1910-1947), p. 14.
\end{abstract}

${ }^{12}$ Os membros da câmara tinham assento na capela-mor, e os médicos do partido tinham a obrigação de assistir ao convento de graça. Borges, José Cardoso, Memórias de Bragança, Fernando de Sousa (Coord.), Bragança, CEPESE / Câmara Municipal de Bragança, 2012 (texto original de 1721-1724), p. 142-147; Quanto ao número de frades durante o século XVIII, D. João de Sousa Carvalho informa que em 1720 viviam no convento 14 e em 1754 D. Frei João da Cruz diz que o convento era habitado, ordinariamente por $25 \mathrm{e}$, às vezes, por quase 40 em razão dos estudos, o que sugere ter havido no convento de Bragança algum tipo de escola. Castro, José de, Bragança e Miranda, (Bispado) Tomo II, Porto, Tipografia Porto Médico, Ld a 1947, pp. 304, 305; Prada de Oliveira, Carlos, A Diocese de Miranda do Douro em meados do século XVIII, segundo as Memórias Paroquiais de 1758, Universidade do Minho, Instituto de Ciências Sociais, Braga, texto policopiado, 2006, pp. 95-97.

${ }^{13}$ Em 1721-24 tinha o convento uma Irmandade das Chagas que festejava no próprio dia, a 17 de Setembro, mas sem altar particular. Além desta irmandade Borges registou a Irmandade dos militares e da 
confrarias constituíam no Antigo Regime um espaço de autonomia relativamente aos poderes civis e eclesiásticos consolidando uma forte participação social $^{14}$. A comunidade dos frades menores de Bragança, tal como no resto do país, foi extinta em 1834.

Ordem Terceira e faz referência à confraria do Santo Cristo. Borges, José Cardoso, Memórias de Bragança, Fernando de Sousa (Coord.), Bragança, CEPESE / Câmara Municipal de Bragança, 2012 (texto original de 1721-1724), p. 142-147.

As confrarias na sua maioria eram de leigos e sem estatutos o que explica a falta de documentos. Eram grupos de associados em torno de um santo, com dupla finalidade, a sua festa e o sufrágio pelos confrades. Castro, José de, Bragança e Miranda, (Bispado) Tomo II, Porto, Tipografia Porto Médico, Ld ${ }^{\text {a }}$ 1947 , pp. 311-336.

${ }^{14}$ Capela, José Viriato, et al., As freguesias do distrito de Bragança nas memórias paroquiais de 1758 , Braga, Edição José Viriato Capela / Rogério Borralheiro, 2007, p. 48. 


\section{O EDIFICADO DA IGREJA}

Se a fundação do convento remonta ao século XIII, conforme testemunha a documentação régia, o edificado é plural na sua composição que transcorre ao longo do tempo. Como também é plural o interesse e os contributos assumidos por parte da edilidade local para a fábrica, manutenção ou ampliação do edificado.

Além da família Morais, dos fundadores e respetiva descendência, várias outras famílias locais se relacionaram com capelas, padroados e sepulturas dentro da igreja, reforçando os laços entre a nobreza local e o convento.

Cardoso Borges refere que o convento foi fundado sobre a capela de Santa Catarina que corresponde ao espaço da sala do capítulo ${ }^{15}$.

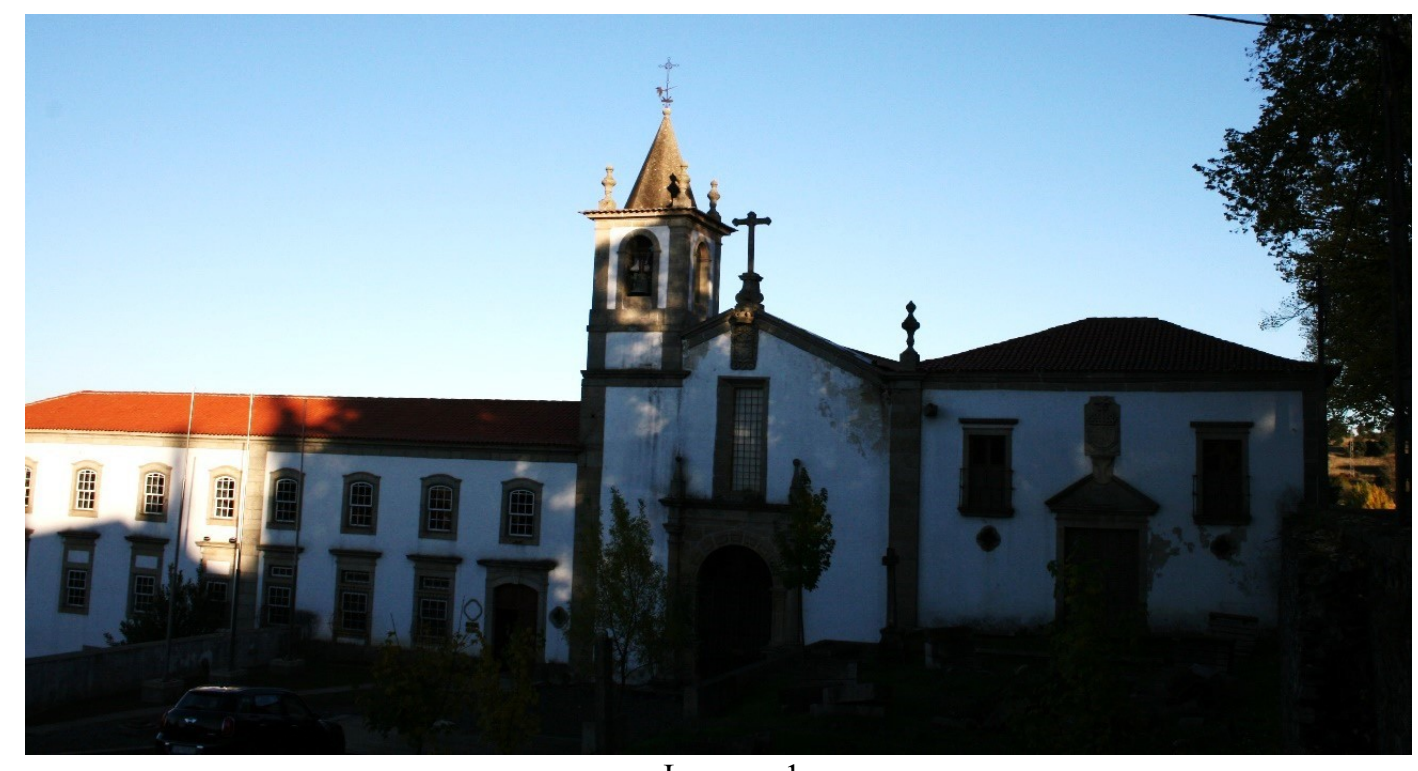

Imagem 1

Vista geral da fachada, ao centro o frontispício da igreja e adossada do lado da epístola a Casa do despacho da Ordem Terceira. Convento de São Francisco, Bragança.

O espaço conventual foi acrescentado ao longo do século XVI, XVII e XVIII (Imagem 1). A escassez documental não permite traçar o quadro construtivo do convento, apenas permite apontar alguns sucessos que o marcaram. Pelo menos três incêndios ao longo do século XVIII destruíram diversas dependências do todo o

\footnotetext{
${ }^{15} \mathrm{~A}$ capela foi privada, conforme a escritura de 1590 onde a capela e o padroado foram reclamados pelo licenciado Gaspar de Morais abade de S. Pedro de Serapicos e por Diogo Vaz Pinto, do hábito de Cristo, ambos desta cidade, que se opunham à devolução da capela e padroado por legítimos herdeiros dos instituidores. Borges, José Cardoso, Memórias de Bragança, Fernando de Sousa (Coord.), Bragança, CEPESE / Câmara Municipal de Bragança, 2012 (texto original de 1721-1724), p. 146.
} 
edificado ${ }^{16}$. As alterações a que o edifício foi sujeito após a extinção das ordens alteraram significativamente o conjunto, a que nos podemos no entanto aproximar a partir da descrição do inventário de 1834.

No inventário de 1834 foi alvo de registo todo o edificado "Havia o edifício da caza, em que estava o Convento, que continha hum claustro com trez dormitórios" No fólio 22 prossegue o inventário dos dormitórios, "d'hum so andar antigos e arruinados" com treze quatros, também em estado de ruína "pela sua antiguidade", outro dormitório de "dous andares" que tinha "dezasseis quartos" e "duas cazas maiores, que servião d'aulas, reedificado de poucos annos, e ainda por acabar em muitos quartos". O documento refere ainda as restantes dependências do edifício conventual, que tinha "nos seus baixos, caza de refeitorio, despensa, adega, cozinha, caza de deposito, cavalariças, palheiros, e caza de capitulo com sepulturas, que confrontam por hum lado com a Igreja da Ordem Terceira e que pertencia ao mesmo convento, e pelos trez lados tem a cerca do edifício". A descrição continua na cerca do convento que levava "sete a oito geiras de lavra, e vinte a vinte e seis alqueires de trigo de semeadura: tem uma fonte com algumas árvores de fruto (...) e he toda murada com muros de doze a quinza palmos, e fechada com portal de carro"17. Atualmente o muro já não existe e o espaço da cerca foi sucessivas vezes intervencionado, subsistindo apenas a fonte coberta.

Adossada à igreja do lado da epístola foi em meados do século XVIII construída a Casa do Despacho da Ordem Terceira, em 1755 estava já a obra principiada ${ }^{18}$. Atualmente a Casa do Despacho é também usada como depósito de esculturas e de fragmentos de esculturas e de retábulos resultantes das diversas alterações ocorridas no interior da igreja.

\footnotetext{
${ }^{16}$ Borges, José Cardoso, Memórias de Bragança, Fernando de Sousa (Coord.), Bragança, CEPESE / Câmara Municipal de Bragança, 2012 (texto original de 1721-1724), pp. 142-145; Rodrigues, Luís Alexandre, Bragança no século XVIII. Urbanismo. Arquitectura, Volume I, Bragança, Junta de Freguesia da Sé, 1997, p. 418.

${ }^{17}$ A cerca, o claustro e os dormitórios, as casas que serviam para as aulas, refeitório, dispensa, adega, cozinha, dispensa, cavalariça, palheiros, a casa do capítulo com sepulturas, assim como, as "capellas". No entanto nada se refere do aspeto do edificado ou bens moveis no seu interior apenas se enunciam os padroados afetos, a de Nossa Senhora da Conceição e de Santa Luzia e a "Capella de Espinhozella; Capella de Nossa Senhora da Conceição; Capella de Santo Antonio". A.N.T.T./A.H.M.F./S.F.B., Extinção das Ordens Religiosas - Convento de São Francisco em Bragança, Arquivo Nacional da Torre do Tombo, Lisboa, Arquivo Histórico do Ministério das Finanças Processos de Extinção das casas religiosas, M.F. 7580 (cota antiga Cx. 2202), 1834, fl. 21 v-22.

${ }^{18}$ Rodrigues, Luís Alexandre, Bragança no século XVIII. Urbanismo. Arquitectura, Volume I, Bragança, Junta de Freguesia da Sé, 1997, p. 431.
} 
Sobre o frontispício da igreja (Imagem 2) é Cardoso Borges que nos informa acerca da data, foi em 1635 que ameaçando ruína o frontispício foi reconstruído "de novo de obra dórica" ${ }^{19}$.

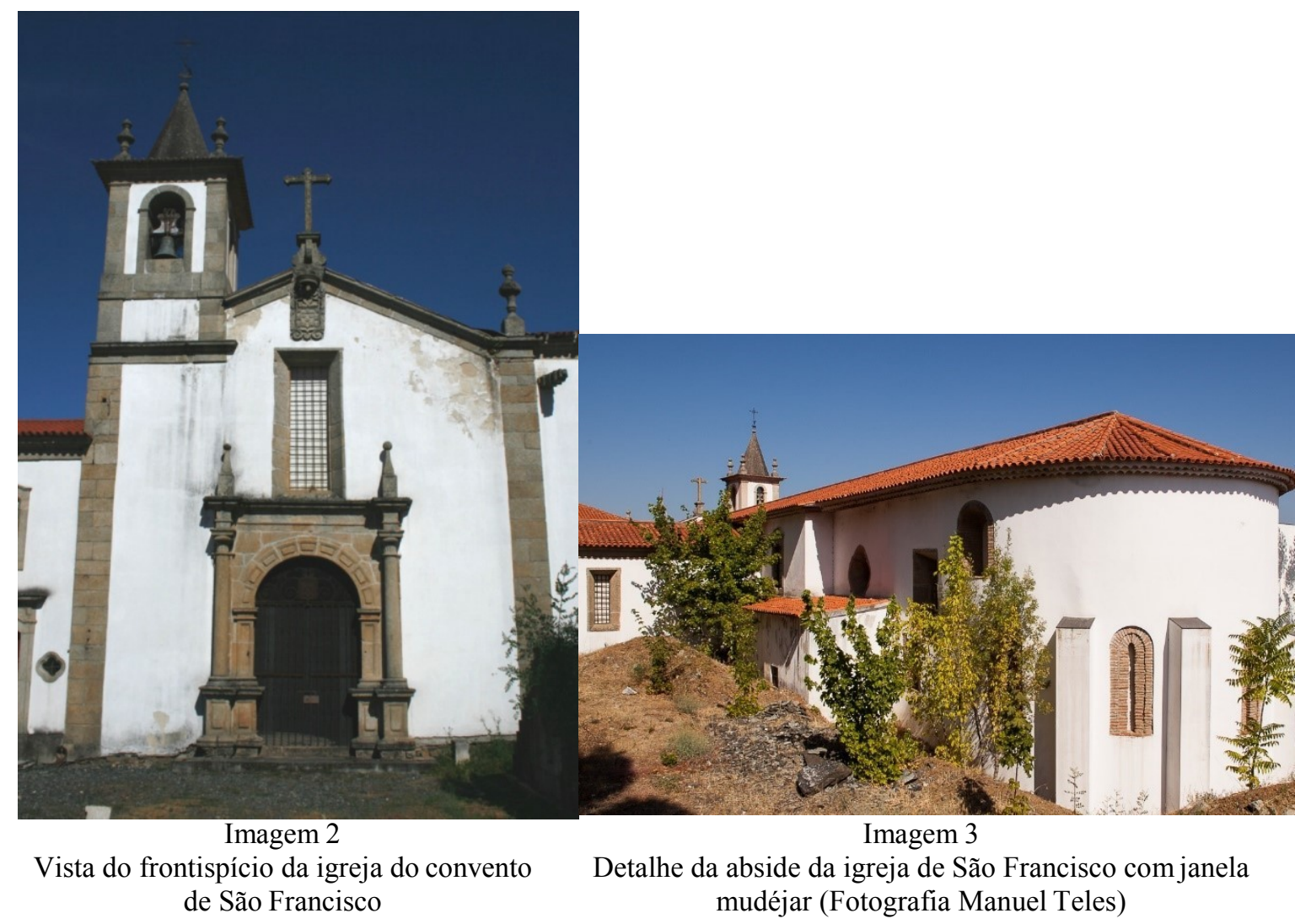

Chegou até nós o portal maneirista, com colunas dóricas e encimado pelo brasão da ordem franciscana sobre o qual está a coroa real, ilustrando a proteção que a Casa de Bragança havia tomado sobre o convento.

O edificado, sendo de uma ordem mendicante, é sóbrio e austero. A abside da igreja mantém ainda as janelas mudéjares da primitiva edificação românica (Imagem 3), que estiveram cobertas até à intervenção de restauro das últimas décadas do século XX.

Em 1834 o convento passa para o erário público. Segundo Alves Batista depois de várias alternativas propostas pelas autoridades locais para reutilizar o convento acabou este por finalmente albergar o Hospital militar em 1857, que conjuntamente com a sua farmácia privativa prestava apoio às unidades militares sediadas em Bragança. $\mathrm{O}$ hospital militar manteve-se no convento supõe-se que até 1939. Entretanto, por troca de instalações com o Asilo, ainda antes de terminar a segunda metade do século XX

\footnotetext{
${ }^{19}$ Borges, José Cardoso, Memórias de Bragança, Fernando de Sousa (Coord.), Bragança, CEPESE / Câmara Municipal de Bragança, 2012 (texto original de 1721-1724), p. 146.
} 
encontramos no Convento de S. Francisco o Asilo-Escola de S. Francisco, destinado a crianças órfãs do sexo feminino. Com as políticas de Abril a instituição a crianças órfãs do sexo feminino ganha novo estatuto e é dotada de instalações e edifício próprio, deixando o espaço do Convento devoluto. Na última década do século XX foi feita uma intervenção no edifício para o adaptar às funções de Arquivo, função que ainda se mantém em toda a área conventual ${ }^{20}$.

A igreja, bem como, a capela de Santa Catarina ou do capitulo atualmente estão ambas sob guarda de Venerável Ordem Terceira.

${ }^{20}$ Alves Batista, Maria Isabel, "O Convento de S. Francisco: Contributos para a sua história" in $A$ construção de uma identidade - Trás-os-Montes e Alto-Douro, Bragança, Arquivo Distrital de Bragança, 2002, pp. 83-87. 


\section{INTERIOR DO TEMPLO}

Relativamente ao interior do templo é escassa e difusa a informação que chegou até aos nossos dias. Para melhor entendimento do percurso dos cultos evocados e das esculturas que os registavam estabeleceu-se uma comparação entre os registos que foram feitos por Cardoso Borges em 1721-24, com o registo elaborado um século mais tarde em 1834 aquando da expulsão das Ordens Religiosas, os levantamentos do final do século XX e finalmente o inventário levado a cabo para o presente estudo em 2012.

O documento de inventário dos bens móveis lavrado em 1834 inicia-se com o auto de posse para logo prosseguir o inventário dos vasos sagrados e paramentos. A ausência de referências à escultura e pintura são de sobremaneira destacáveis num convento que estava em uso desde o século XIII, e que ainda hoje conserva um número significativo de esculturas e retábulos nos altares. Todavia, apenas nos paramentos e na ourivesaria podemos identificar a presença, se bem que velada, da escultura.

Perante a documentação existente é o testemunho de José Cardoso Borges que entre 1721-24 nos disponibiliza a descrição mais recuada do interior do templo, começando pela capela-mor refere:

"A capela-mor tem tribuna de entalhado ao moderno ${ }^{21 "}$.

Contudo, a capela-mor está atualmente despojada de qualquer retábulo, ou "tribuna entalhada ao moderno". Seguramente que para Cardoso Borges o "entalhado ao moderno" seria em talha barroca. Rodrigues acrescenta, que o retábulo entalhado "moderno" que Cardoso Borges terá visto no altar-mor, em 1715 estava já devidamente enxamblado $^{22}$. O que nos permite perceber que Cardoso Borges descrevia uma obra recentemente terminada. Alexandre Rodrigues refere ainda que posteriormente, em 1733 o bispo D. João de Sousa Carvalho terá acudido à restauração da capela-mor que havia sofrido um incêndio. Mais tarde, em 1746 foi já o bispo D. Diogo Marques Mourato que se empenhou na restauração da capela-mor após ter caído o teto ${ }^{23}$.

\footnotetext{
${ }^{21}$ Borges, José Cardoso, Memórias de Bragança, Fernando de Sousa (Coord.), Bragança, CEPESE / Câmara Municipal de Bragança, 2012 (texto original de 1721-1724), p. 142.

${ }^{22}$ Com base na análise da documentação relativa ao padroado da capela-mor. Rodrigues, Luís Alexandre, Bragança no século XVIII. Urbanismo. Arquitectura, Volume I, Bragança, Junta de Freguesia da Sé, 1997, p. 420.

${ }^{23}$ Rodrigues, Luís Alexandre, Bragança no século XVIII. Urbanismo. Arquitectura, Volume I, Bragança, Junta de Freguesia da Sé, 1997, p. 422.
} 
Todos estes infortúnios terão contribuído a que novo retábulo fosse construído. O retábulo que até à década de 90 do século XX se manteve no altar-mor era neoclássico e bastante simples, mas podia ainda ajuizar-se da talha do seu antecessor, de estilo barroco nacional, pelos restos das colunas que lhe serviam de sustento. O retábulo neoclássico ainda hoje se encontra desmontado e uma parte do retábulo está em restauro, decorrente da última intervenção feita nas últimas décadas do século XX. Neto Jacob refere ainda que, no restauro dos anos 80 do séc. XX ficaram a descoberto importantes pinturas a fresco, atribuíveis a António Leitão, formado em Roma e Antuérpia, radicado em Bragança, com datação provável de finais de quinhentos ou inícios do século seguinte. Das pinturas a fresco destaca, citando Rui Tavares (1994), duas fases, uma relacionada com a representação da Senhora do Manto (temática das Misericórdias), e outra fase geométrica mais tardia ${ }^{24}$.

Atualmente nenhum retábulo tapa a parede do altar-mor que expõe, sobre plintos, as imagens de São Francisco de Assis e São Vicente Ferrer de modo que fiquem a descoberto os restos dos painéis de pinturas a fresco que antecediam a ornamentação retabular (Imagem 4).

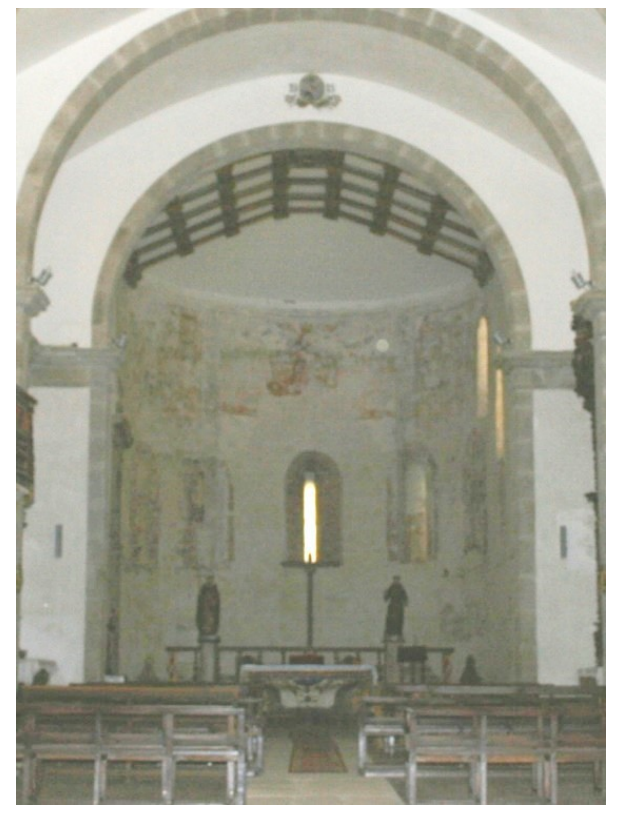

Imagem 4

Vista geral do altar-mor com as esculturas de São Francisco de Assis e São Vicente Ferrer e restos de pintura a fresco sobre a parede da abside

Após a descrição da capela-mor José Cardoso Borges enuncia os restantes espaços que preenchiam o interior da igreja que:

\footnotetext{
${ }^{24}$ Jacob, João Manuel Neto, Bragança, Lisboa, Presença, 1997, p. 102.
} 
"para a parte do Evangelho fica a capela da Imaculada Conceição que fundou o doutor Pascoal de Frias, abade de Carrazedo, com missa quotidiana, obra magnífica. E tem relíquias, a principal uma porção do Santo Lenho em uma bem curiosa cruz de ébano ${ }^{25}$ ".

Julgamos que Borges não se terá confundido nas designações de lado do evangelho e epistola quando se referia à capela da Imaculada Conceição do lado do evangelho ${ }^{26}$. Atualmente no lado do evangelho existe uma capela mas expõe um crucifixo ladeado por Santo António e São Boaventura e os Santos Mártires de Marrocos (Imagem 5).

Retábulo da capela do lado do Evangelho Capela do Doutor Pascual de Frias (original Capela da Imaculada Conceição, até 1788) Igreja de São Francisco, Bragança

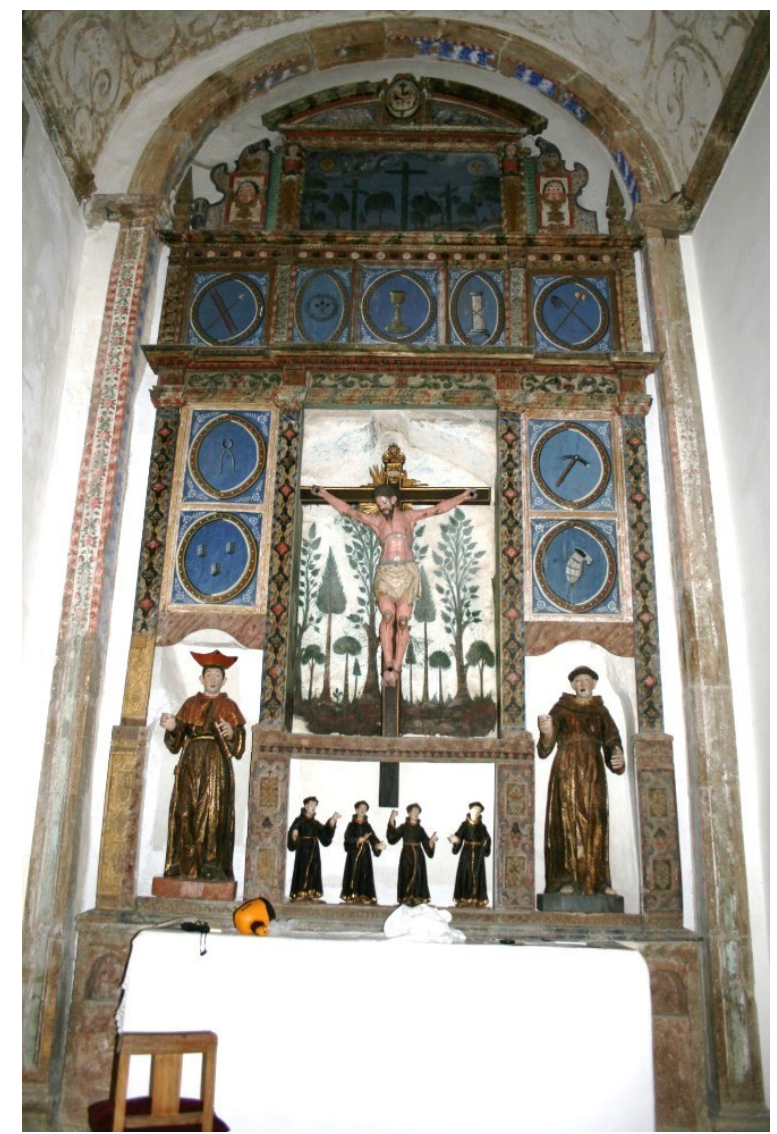

Possivelmente em data posterior ao registo de Borges, a invocação da Imaculada Conceição terá sido transferida para o lado da Epistola. Ainda hoje podemos observar na capela a pintura em perspetiva que adorna o teto em cujo centro está representada a

\footnotetext{
${ }^{25}$ Borges, José Cardoso, Memórias de Bragança, Fernando de Sousa (Coord.), Bragança, CEPESE / Câmara Municipal de Bragança, 2012 (texto original de 1721-1724), p. 142.

26 Rodrigues faz referência ao documento que descreve a capela de Nossa Senhora da Imaculada Conceição mas não refere a alteração que o altar sofreu do lado do Evangelho em que é descrita em 1721 para o lado da epístola em que se encontra desde finais do século XVIII até hoje. Rodrigues, Luís Alexandre, Bragança no século XVIII. Urbanismo. Arquitectura, Volume I, Bragança, Junta de Freguesia da Sé, 1997, pp. 424-426.
} 
imagem de nossa Senhora da Imaculada Conceição (Imagem 6), o retábulo (Imagem 7), que expõe sobre o trono a escultura da Imaculada Conceição (Imagem 8).

Quer a escultura que representa a Imaculada Conceição, quer o retábulo que a expõe, são obras do último quartel do século XVIII. O que denota a continuada transformação do espaço e da disposição das devoções no seu interior.

Possivelmente a alteração da devoção da Imaculada Conceição do lado do evangelho para o lado da epístola terá ocorrido após 1788, quando, por desavenças entre os frades e os irmãos da ordem terceira, os terceiros abandonaram o templo deixando vazia a capela funda do lado da epístola que ocupavam desde $1635^{27}$.

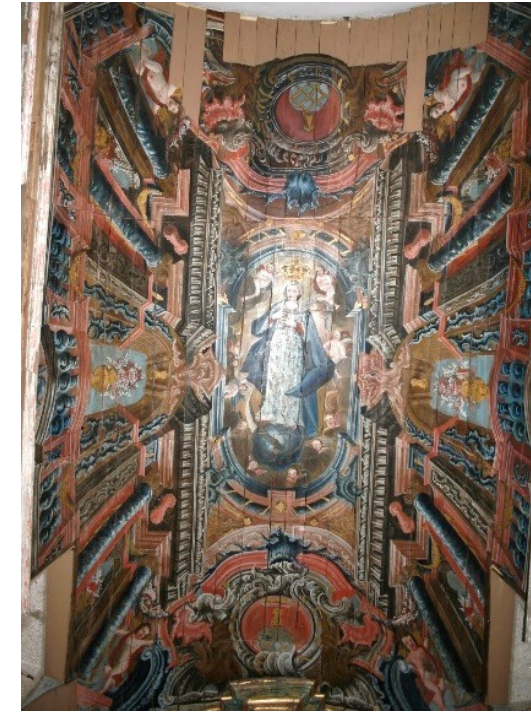

Imagem 6

Tecto pintado com a imagem de Nossa Senhora da Imaculada Conceição, na original capela da Ordem Terceira (de 1635 até 1788)

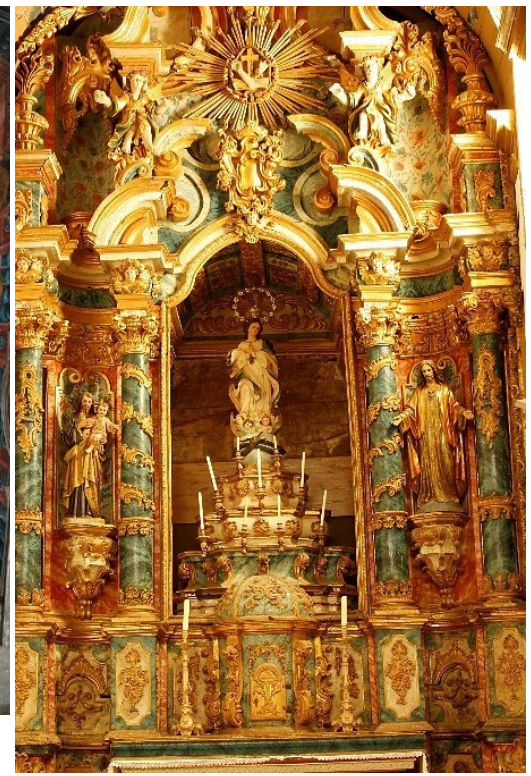

Imagem 7

Retábulo de Nossa Senhora da Imaculada Conceição, na original capela da Ordem Terceira (de 1635 até 1788 )

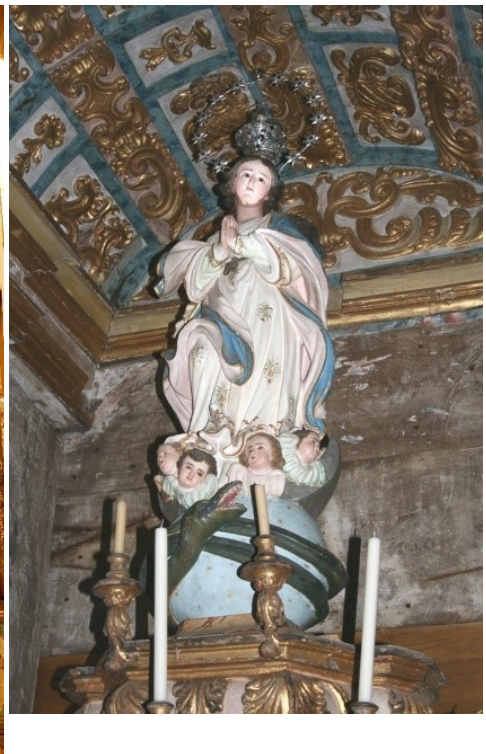

Imagem 8

Escultura de Nossa Senhora da Imaculada Conceição na original capela da Ordem Terceira (de 1635 até 1788)

A alteração dos altares e respetivas devoções, bem como dos titulares das capelas tem gerado confusão na localização das devoções até à atualidade ${ }^{28}$. As mudanças e

\footnotetext{
${ }^{27}$ Em 1635 os terceiros ocupavam uma capela funda no lado da epístola no templo conventual dos franciscanos onde se mantiveram até 1788 quando se mudaram para a desaparecida igreja de São João Batista. Ribeiro, P. Bartolomeu, Os terceiros franciscanos portugueses; sete séculos da sua história. Braga, Tip. Missões Franciscanas, 1952, pp. 278, 279.

${ }^{28}$ Rodrigues identifica a atual capela da Imaculada Conceição como Capela de Santa Catarina. Rodrigues, Luís Alexandre, Bragança no século XVIII. Urbanismo. Arquitectura, Volume I, Bragança, Junta de Freguesia da Sé, 1997, pp. 428-431. No entanto, julgamos que a atual capela da Imaculada Conceição seria a "capela funda do lado da epístola" ocupada pelos terceiros até 1788 conforme Ribeiro, P.
} 
conflitos perpetrados pelos diversos padroados alteraram a localização das capelas que continuam na sua maioria desconhecidas. Sabemos as devoções existentes mas desconhecemos a maioria dos lugares de culto.

O teto em perspetiva, assim como o retábulo rocaille são posteriores a 1788 e assumem um programa decorativo inovador dentro dos muros do convento, pois supõem uma encenação completa para espaço então deixado vazio pela ordem terceira.

O culto da Imaculada Conceição é de novo referenciado cerca de 110 anos mais tarde, porém o inventário de 1834 destaca sobretudo os vasos sagrados, a paramentaria e os objetos de ouro ou prata, o que permite perceber a presença da escultura apenas a partir dos postiços, quando se tratavam de objetos de ourivesaria ${ }^{29}$, como é possível observar na (Imagem 9), que ilustra a segunda página relativa aos vasos sagrados e paramentos. Depois de registados o turíbulo, custódias, navetas, cálices e respetivo peso do metal que os compunha, aparecem as escassas referências às imagens de culto, entre elas Nossa Senhora da Conceição.

"Havia mais huma coroa de Nossa Senhora da Conceição com suas
pedras, com o pezo de hum marco e trez oitavas"30

Bartolomeu, Os terceiros franciscanos portugueses; sete séculos da sua história. Braga, Tip. Missões Franciscanas, 1952, pp. 278, 279.

29 As referências à ourivesaria são repetidas ao longo do inventário de 1834. Destacam os já desaparecidos relicários, começando pelo de Santa Luzia que "segundo a lei vale cinco mil e setenta e cinco reis - $5075(\ldots)$ hum relicário de filigrana com santo lenho e vidro (...) vale dezoito mil novecentos e oitenta e sete meio - $18987 \frac{1}{2} \backslash$ Hua cruz de prata processional com Santo Christo (...) que segundo a lei vale sesenta e três mil tresentos e sesenta e dois reis e meio $-633621 / 2 \backslash$ A chave do sacrário da capela mor de prata (...) segundo a lei vale setecentos reis - $700 \backslash$ Hua coroa de Nossa Senhora da Conceição com suas pedras (...) que segundo a lei vale cinco mil oitocentos e sesenta e dois reis e meio - $5862 \quad \frac{1}{2} \backslash$ Hum Explendor de prata piqueno e quebrado com o peso de duas oitavas que segundo a lei vale cento e setenta e cinco reis - 175". A.N.T.T./A.H.M.F./S.F.B., Extinção das Ordens Religiosas - Convento de São Francisco em Bragança, Arquivo Nacional da Torre do Tombo, Lisboa, Arquivo Histórico do Ministério das Finanças Processos de Extinção das casas religiosas, M.F. 7580 (cota antiga Cx. 2202), 1834, fl. 44 v. Quer os relicários, quer a cruz processional e a chave já tinham sido registadas no início do documento, no entanto, no momento de lhe atribuir um valor monetário é acrescentado um resplendor "de prata piqueno e quebrado" que levanta a questão sobre uma eventual sonegação dos objetos de valor ao procurador fiscal responsável pelo inventário dos bens, que necessitou de mais tempo para registar a totalidade dos bens. Destaca-se também deste excerto o elevado valor da cruz de prata processional, que constitui o objeto mais valioso de todos os vasos e paramentos avaliados.

30 A.N.T.T./A.H.M.F./S.F.B., Extinção das Ordens Religiosas - Convento de São Francisco em Bragança, Arquivo Nacional da Torre do Tombo, Lisboa, Arquivo Histórico do Ministério das Finanças Processos de Extinção das casas religiosas, M.F. 7580 (cota antiga Cx. 2202), 1834, fl. 10 v. 


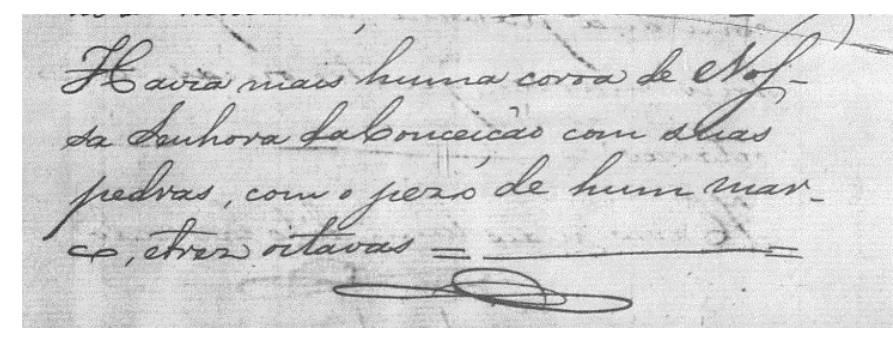

Imagem 9

Detalhe do inventário do convento de São

Francisco, Bragança, 1834

A imagem de Nossa Senhora da Imaculada Conceição ainda ostenta a coroa em prata e em volta desta uma auréola. Atualmente está ao lado direito da Virgem a figura de São José com o Menino, e à esquerda do Sagrado Coração, ambas de execução do século XX, conforme se pode observar (Imagem 7).

Há referência ao culto da Imaculada Conceição desde 1334-1342, data em que o altar de Nossa Senhora da Conceição recebeu a graça de altar privilegiado outorgada pelo Papa Bento XII ${ }^{31}$.

A antiguidade do culto e os conflitos que opuseram frades aos irmãos leigos da ordem terceira, bem como a reiterada má gestão das capelas privadas ${ }^{32}$ terão sido os responsáveis pelas alterações da localização da capela de Nossa Senhora da Imaculada Conceição do lado do evangelho para o lado da epístola.

Cardoso Borges registou ainda no interior do templo as capelas da:

"Venerável Ordem Terceira que têm sacrário e uma devota imagem de Cristo Crucificado. A de Nossa Senhora do Rosário que tem irmandade de todos os militares. A de Santo António de que é padroeiro o alcaidemor Lázaro de Figueiredo Sarmento e tem um túmulo metido na parede. A de Santa Luzia, com relíquia e, no seu dia, venerada com grande concurso. A Capela dos Borges, que por antiga e mal administrada lhe ficou só o nome. E os irmãos terceiros colocaram em ela a imagem do

\footnotetext{
${ }^{31}$ Castro, José de, Bragança e Miranda, (Bispado) Tomo II, Porto, Tipografia Porto Médico, Ld ${ }^{\mathrm{a}}$, 1947, p. 306; Teixeira, Vítor Rui Gomes, "A presença franciscana na região de Bragança-Miranda até ao séc. XV" in Comissão de Arte Sacra de Bragança-Miranda, Páginas da História da Diocese de Bragança-Miranda, Actas do Congresso histórico 450 anos da fundação, Bragança, Comissão Executiva das Comemorações, 1997, pp. 671-683.

${ }^{32}$ Sobre os processos, provisões e direitos de padroado apresentados por privados relativamente ao reconhecimento enquanto administradores das capelas ver. No entanto o autor não identifica a alteração da capela da Imaculada Conceição e as consequentes mudanças nos altares que essa alteração provocou: Rodrigues, Luís Alexandre, Bragança no século XVIII. Urbanismo. Arquitectura, Volume I, Bragança, Junta de Freguesia da Sé, 1997, pp. 424-431.
} 
Senhor dos Passos e alguns devotos na mesma festejam a S. Vicente Ferrer com novena e práticas ${ }^{33}$ ".

O registo não refere a localização das capelas, no entanto a permanência de algumas devoções permite estabelecer paralelismos com a imaginária inventariada entre 2012 e 2014 para este estudo. São vários os cultos coincidentes, entre o registo de Cardoso Borges e o que encontramos atualmente no interior da igreja, e, por exclusão, os que constituem já acrescento da época contemporânea, ou que, são posteriores a 1724.

A "devota imagem de Cristo Crucificado" que a ordem terceira expunha na sua capela poderia ser a que hoje se expõe na capela do lado do evangelho, a original capela da Imaculada Conceição (Imagem 5), assumindo a possibilidade de troca das devoções e de capelas do lado do evangelho para o lado da epístola e vice-versa. As adaptações feitas no retábulo para a adaptação da Cruz no nicho central são evidentes pois o vão é pequeno relativamente ao tamanho da figura de Cristo. A imagem de Cristo Crucificado estaria assim originalmente na capela hoje ocupada pela Imaculada Conceição e seria a devota imagem da Ordem Terceira. As restantes representações de Cristo Crucificado que ainda existem na igreja julgamos serem posteriores ao registo de Borges (Cristo Crucificado com o braço pendente SFB 03 e Cristo Alado SFB 30).

No corpo da igreja mantém-se a escultura de Nossa Senhora do Rosário num retábulo de talha barroca nacional, posterior à escultura, no lado da epístola (Imagem 10), encimado pelo brasão das armas real. A imagem tinha uma irmandade de militares. A presença dos militares é destacada na análise iconográfica a partir de pequenos fragmentos (de botas altas militares ${ }^{34}$ ) inventariados no decurso deste estudo. Mais nenhum elemento no interior da igreja nos permite identificar a presença da irmandade de militares em qualquer dos retábulos. Neste sentido desconhecemos o altar original em que a imagem de Nossa Senhora do Rosário estaria a culto.

\footnotetext{
${ }^{33}$ Borges, José Cardoso, Memórias de Bragança, Fernando de Sousa (Coord.), Bragança, CEPESE / Câmara Municipal de Bragança, 2012 (texto original de 1721-1724), p. 142.

Anos mais tarde a "Capela dos Borges, que por antiga e mal administrada lhe ficou só o nome" foi adquirida por José Cardoso Borges que enquanto síndico do convento tomou formalmente posse da capela em 1736. Rodrigues, Luís Alexandre, Bragança no século XVIII. Urbanismo. Arquitectura, Volume I, Bragança, Junta de Freguesia da Sé, 1997, p. 428.

Não temos atualmente elementos para saber qual era o espaço que dentro do templo a capela ocupava.

${ }^{34}$ Ver as fichas de inventário relativas ao $\mathrm{n}^{\circ} \mathrm{SFB} 52$ e SFB 54.
} 

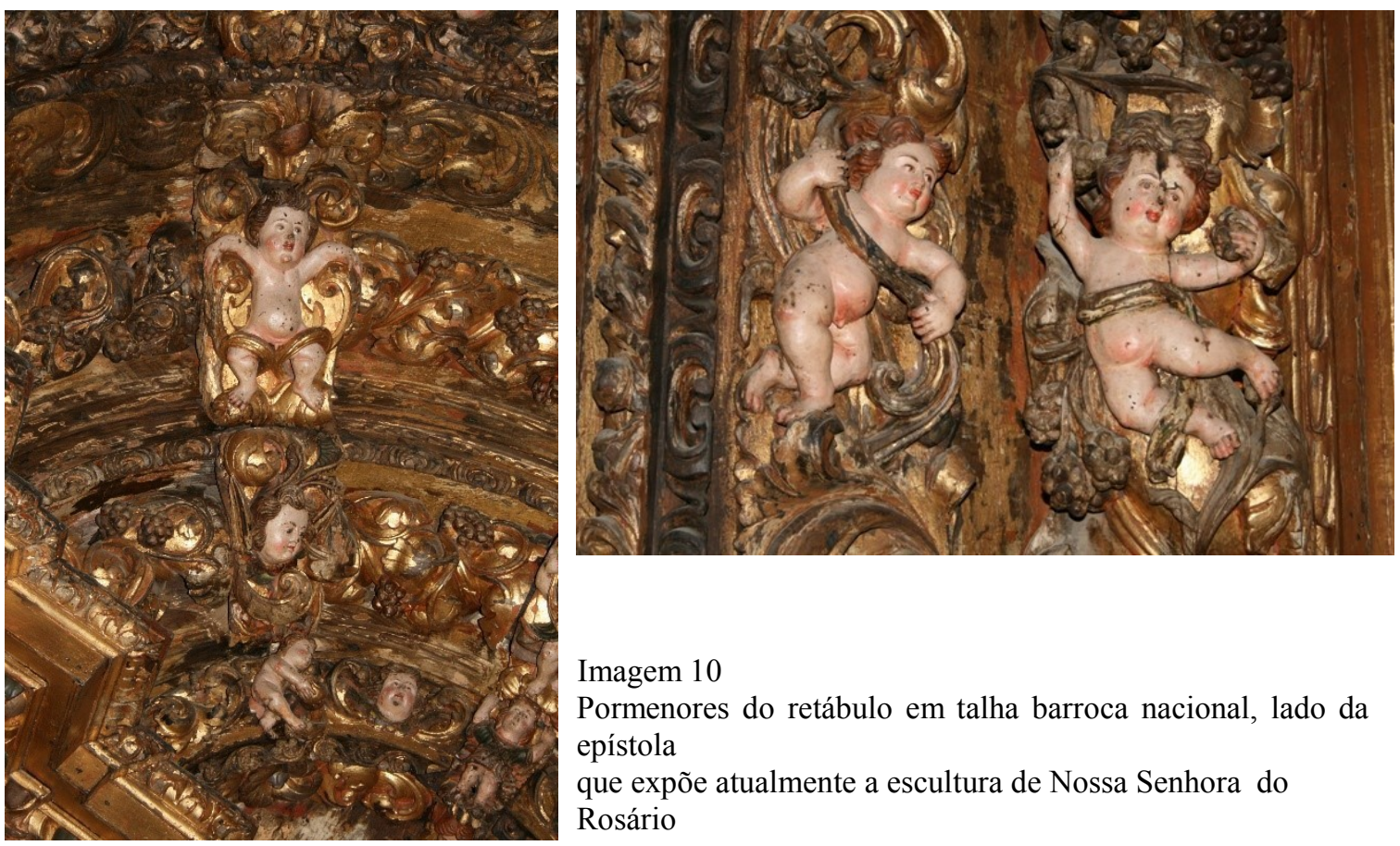

Imagem 10

Pormenores do retábulo em talha barroca nacional, lado da epístola

que expõe atualmente a escultura de Nossa Senhora do Rosário

\section{A capela de "Santo António de que é padroeiro o alcaide-mor Lázaro de Figueiredo} Sarmento e tem um túmulo metido na parede" julgamos poder ser a que está atualmente ocupada no registo superior pelo conjunto formado por Cristo Crucificado com o braço pendente para o Abraço Místico a São Francisco de Assis, acompanhado por São Benedito de Palermo, São Pascoal Bailão ${ }^{35}$, e no primeiro registo está colocado o esquife com a Senhora da Boa Morte ${ }^{36}$ (Imagem 11). A capela, no lado da epístola, é a única capela no corpo da igreja com um túmulo metido na parede sob um arco sólio.

$\mathrm{O}$ retábulo decorado com elementos barrocos do estilo nacional foi alterado. $\mathrm{O}$ cuidado na representação dos anjos é idêntico ao altar que expõe contemporaneamente a

\footnotetext{
${ }^{35}$ Rodrigues refere o processo de reconhecimento dos administradores da capela de Nossa Senhora da Conceição conforme o documento: A.N.T.T., C.S.F.B. Titollo de medição, e demarcação da capella, e inventatio dos paramentos della $\mathrm{Cx} .1$, Mç. 7 , s\fl, onde consta um inventário que descreve os diversos quadros vindos de roma que preenchiam o retábulo e as paredes cobertas de azulejo e o altar de pedra. Entre os objetos inventariados consta também uma custódia de Agnus Dei, outra custódia com a relíquia de São Pascoal Baillão, um cofre fechado com a relíquia de Santa Luzia, uma cruz de ébano em fragmentos, mas que o registo refere que ainda se podia concertar. Rodrigues, Luís Alexandre, Bragança no século XVIII. Urbanismo. Arquitectura, Volume I, Bragança, Junta de Freguesia da Sé, 1997, p. 425. Mas, não refere que a devoção ocupava então a capela do lado do evangelho e não o lado da epístola para onde foi posteriormente trasladada.

${ }^{36}$ Sobre o altar do "Senhor da Boa Morte" refere Rodrigues que estava desde 1731 na capela dos Borges que localiza no lado do evangelho. Rodrigues, Luís Alexandre, Bragança no século XVIII. Urbanismo. Arquitectura, Volume I, Bragança, Junta de Freguesia da Sé, 1997, pp. 426-428.

No entanto a escultura da Senhora (e não do Senhor) da Boa Morte está (desde as ultimas décadas) no lado da epístola, na capela que julgamos ter sido identificada por Borges (1721-1724) como a capela de Santo António. Quanto à capela dos Borges ainda não temos elementos que nos permitem identificar a sua localização dentro da igreja.
} 
imagem de Nossa Senhora do Rosário. A profusão decorativa dos anjos que brincam entre dosséis e baldaquinos anuncia as transformações da talha que o estilo joanino iriam operar. $\mathrm{O}$ amplo vão aberto no nível térreo permite atualmente a entrada no espaço interior do retábulo. Próximo do arco sólio onde esta o túmulo é possível ver uma mísula, de arranque de um arco quebrado, decorada com elementos em relevo, denunciando a anterior configuração da capela. Este aspeto mas arcaico da capela sugere que poderia também tratar-se da primitiva capela de Santa Catarina, a primeira que teve o convento. No entanto a falta de elementos apenas nos permite perceber uma anterior configuração da capela.

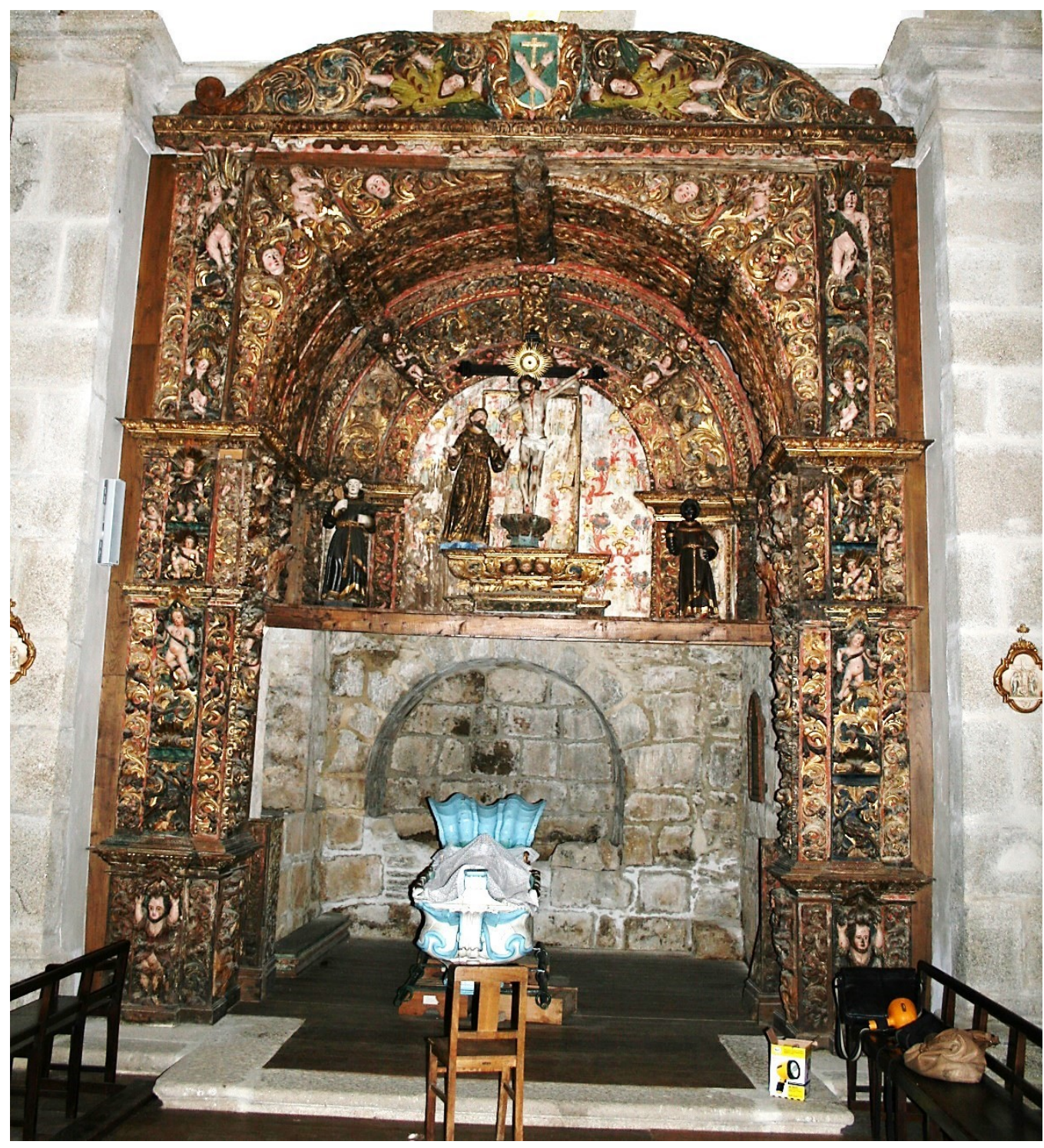

Imagem 11

Capela atualmente ocupada pela Senhora da Boa Morte, Cristo Crucificado no Abraço Místico a São Francisco de Assis, São Benedito de Palermo, São Pascoal Bailão.

No início do século XVIII seria a capela de Santo António de que era padroeiro o alcaide-mor Lázaro de Figueiredo Sarmento com um túmulo metido na parede 
Mantém-se o culto do Senhor dos Passos, referido por Borges, hoje exposto isoladamente num retábulo no lado do evangelho. E mantém-se igualmente o culto a Santa Luzia, no lado do evangelho, mas com uma escultura já do século XX. A devoção registada por Borges a São Vicente Ferrer na capela dos Borges, julgamos estar ilustrada na escultura que hoje, em conjunto com São Francisco de Assis, ocupa a capela-mor da igreja.

A imagem de São Vicente Ferrer é iconograficamente muito próxima com as imagens de São Domingos de Gusmão, o que poderá ter sugerido essa identificação, pela frequente representação dos dois santos fundadores em conjunto. Todavia não se encontra na documentação qualquer referência à devoção a São Domingos de Gusmão no interior do templo, sugerindo que a escultura identificada com essa devoção e por isso exposta em conjunto com São Francisco se trate na verdade de São Vicente Ferrer.

A relação das imagens com os retábulos que as expunham é difícil de perceber pela ausência de referências documentais mas também pelas inúmeras alterações que ocorreram no interior do templo.

Borges descreve ainda:

“Colateral, fora do arco da capela-mor e da parte do Evangelho está o altar de S.

Benedito e entre este e a porta da sacristia se guardam as relíquias daquele servo de Deus, companheiro de S. Francisco, que deixou primeiro guardião deste convento. E porque estão no interior da parede e não têm sinal para o seu conhecimento, se advirta, quando queiram trasladá-las a mais honorifico sepulcro, se hão de achar entre a porta antiga que se fechou e a nova que se abriu na sacristia, que como esta e o púlpito se mudaram haverá seis ou sete anos ficará inútil a diligencia que se fizer se atenderem à crónica do padre Esperança. Mas os veneráveis despojos ficaram no mesmo sitio e lugar, e somos muitos os que vimos as confrontações que diz o cronista, cap. $5, \mathrm{n}^{\circ} 3$, fol.53. E nesta ocasião se tiraram por um orifício alguns ossos que se dividiram, satisfazendo-se com a terra aqueles a que não chegaram, que tão radicada se acha a lembrança das suas virtudes ${ }^{37 \%}$.

\footnotetext{
${ }^{37}$ Borges descreve ainda, no interior da igreja, as sepulturas que nele se achavam e os laços genealógicos que as relacionavam, com especial detalhe nas ligações da família Morais, primeiros doadores do convento, e também da família Pimentel. Refere que o local de enterramento da família dos fundadores seria a capela de Santa Catarina do capítulo. De um dos ramos da família Morais fez o cronista descender a nobreza da vila de Vinhais, que no século XVIII esteve envolvida também na fundação do Seminário
} 
Ainda existe a escultura de São Benedito de Palermo, hoje exposta no retábulo da capela da Senhora da Boa Morte (que até ao primeiro quartel do século XVIII era a capela de Santo António).

Relativamente às relíquias do primeiro guardião ${ }^{38}$ não existe atualmente nenhum elemento na igreja que nos permite identificar o seu altar ou lugar de culto, se acaso chegou a existir.

Ecos das principais devoções percebem-se no inventário de 1834 onde ainda restavam:

"Havia mais hum relicário de Santa Luzia com vidro, com o pêso de sete onças, e duas oitavas $\backslash$ Havia mais hum relicário de filigrana com santo Lênho e vidros com o pêso de três marcos, três onças e huma oitava $\backslash$ Havia mais huma cruz processional, de prata, com Santo Christo, e por dentro da cruz com pau correspondente somente à cruz com o pêso de honze marcos trez onças, três oitavas $\backslash$ Havia mais a chave do Sacrario da Capella mor, de prata, com pezo de huma onça \Havia mais huma coroa de Nossa Senhora da Conceição com suas pedras, com o pezo de hum marco e trez oitavas 39 ",

Atualmente estão desaparecidos o relicário de Santa Luzia, o relicário em filigrana do Santo Lenho, a Cruz processional em prata e a chave do sacrário no mesmo metal.

O cronista Cardoso Borges descreve ainda a Capela de Santa Catarina:

"Da igreja passo à capela de Santa Catarina, que é a do capítulo. E sendo a primeira que este convento teve, fica hoje metida no corpo dele. Mas da fundação desta capela, na qual se venera uma milagrosa imagem de $\mathrm{S}$.

Franciscano de missionários apostólicos de Vinhais. Borges, José Cardoso, Memórias de Bragança, Fernando de Sousa (Coord.), Bragança, CEPESE / Câmara Municipal de Bragança, 2012 (texto original de 1721-1724), pp. 142-144.

${ }^{38}$ Vítor Gomes Teixeira na obra "O maravilhoso no mundo franciscano português da baixa idade média" descreve os milagres e curas operadas por intercessão das relíquias do primeiro guardião do convento de Bragança. Além do primeiro guardião, de quem se desconhece o nome, Teixeira regista também no convento de Bragança curas feitas por intercessão da santidade de D. Constança Noronha. Teixeira, Vítor Gomes, O maravilhoso no mundo franciscano português da baixa idade média, Porto, Granito editores e livreiros, 1999, p. 53. D. Constança de Noronha, primeira Duquesa de Bragança, enviuvando em 1461, e retirou-se da vida social, para se dedicar ao culto espiritual e à assistência aos mais doentes e carenciados, envergando nessa altura o hábito de franciscana. Página do Convento e Igreja de São Francisco de Guimarães: http://ordemsaofrancisco.webnode.pt/historia-da-ordem, acedida a 30 de junho de 2015.

39 A.N.T.T./A.H.M.F./S.F.B., Extinção das Ordens Religiosas - Convento de São Francisco em Bragança, Arquivo Nacional da Torre do Tombo, Lisboa, Arquivo Histórico do Ministério das Finanças Processos de Extinção das casas religiosas, M.F. 7580 (cota antiga Cx. 2202), 1834, fl. 10 v. 
Francisco ${ }^{40}$ que dizem ser cópia do original, não se acha outra notícia mais do que pertencer à família dos Morais e nele estar sita a confraria do Santo Cristo quando se deu a S. Francisco para fundar ${ }^{41}$ ".

Descreve as várias ruínas e maus-tratos que assolaram desde 1540 a capela de Santa Catarina, bem como, a incúria a que os padroeiros a tinham votado, não permitindo sequer que a confraria nela fizesse obras. Refere ainda que:

"Tudo consta de vários papéis que estão no arquivo deste convento e, tendo visto muitas vezes porque dele sou síndico há muitos anos, e daquele tempo a este cessou a razão de padroado, com que foi preciso à comunidade reedificar a capela, e já em meu tempo porque a maltratou um incêndio, a tornou a reedificar e há poucos anos lhe fez outras obras ${ }^{42}$ ".

Dos vários retábulos que ainda ocupam o interior da igreja atualmente não conseguimos identificar o local ocupado pela capela de Santa Catarina.

Mas, não poderia ser a capela que Rodrigues identifica ${ }^{43}$ pois julgamos que a capela do teto e retábulos rocailles era a capela descrita por Borges em 1721-1724 como a da Ordem Terceira, que esta abandonou em 1788, permitindo que para lá fosse trasladada a devoção da Imaculada Conceição, com novas obras retabulares e a pintura sobre o teto que ilustrava a nova devoção do espaço.

As contínuas alterações dos titulares das capelas e dos altares e consequentemente das devoções que neles se prestava culto dificultam a análise relativa às encomendas das

\footnotetext{
${ }^{40}$ Atualmente existe no Museu Abade de Baçal uma estatueta em madeira do século XVI, conforme: Santos, Rui Afonso e Soromenho, Miguel, "Escultura" in Anabela Carvalho, Isabel Cordeiro, Instituto Portugês de Museus, catálogo do Museu Abade de Baçal, Bragança, Lisboa, Instituto Português de Museus, 1994, pp. 82-92, que representa um santo franciscano. Apesar do histórico do objeto ser desconhecido, tratando-se de um museu regional onde preferencialmente foram guardadas obras do território não será de excluir esta possível hipótese. No entanto, à data desconhecemos documentos que nos permitam relacionar a escultura do Museu Abade de Baçal com o convento dos frades menores de Bragança.

${ }^{41}$ Borges, José Cardoso, Memórias de Bragança, Fernando de Sousa (Coord.), Bragança, CEPESE / Câmara Municipal de Bragança, 2012 (texto original de 1721-1724), p. 144.

${ }^{42}$ Borges, José Cardoso, Memórias de Bragança, Fernando de Sousa (Coord.), Bragança, CEPESE / Câmara Municipal de Bragança, 2012 (texto original de 1721-1724), p. 145

${ }^{43}$ Rodrigues destaca na "capela de Santa Catarina" as obras feitas no final do século XVIII que no tecto com a pintura rocaille se representa ao centro a Ascensão da Nossa Senhora. No entanto não se trata da Ascensão de Nossa Senhora, mas sim da Imaculada Conceição, conforme é possível identificar pelos atributos iconográficos que acompanham a imagem central do teto (o globo com a lua e a serpente sobre a qual está a figura da Virgem). Rodrigues, Luís Alexandre, Bragança no século XVIII. Urbanismo. Arquitectura, Volume I, Bragança, Junta de Freguesia da Sé, 1997, p. 431.

Conforme ficou exposto julgamos que a capela onde hoje se venera a imagem da Imaculada Conceição foi até 1788 a capela da Ordem Terceira, não sendo de crer que fosse a capela de Santa Catarina.
} 
obras que ilustravam os cultos. Pese embora a dificuldade acrescida à escassez documental relativa às esculturas fica, no registo dos conflitos pelos padroados das capelas, expressa a relevância do espaço do convento franciscano para a edilidade local. Este compromisso entre os privados e o templo dos Frades menores resultava em grande medida do uso tumular que era feito nas capelas, âmbito de maior destaque entre as práticas que tinham os franciscanos junto da comunidade.

Relacionada com as celebrações de exéquias fúnebres no convento encontramos na documentação de 1834 diversas referências. São sobretudo paramentos ${ }^{44}$ têxteis e demais utensílios religiosos que ocupam a maioria do inventário de avaliação dos bens após a extinção das ordens. O registo dos materiais têxteis é inquestionavelmente o mais completo de todos os bens móveis que estariam, no momento da extinção das ordens, no interior do convento e permite perceber a quantidade de estruturas que os sustinham, bem como a quantidade de usos em que lhes estavam afetos, constituindo parte integrante dos diversos cerimoniais.

Ainda no inventário de 1834 é inesperada a atitude perante a "livraria" (Imagem 12). A livraria, do convento havia sido acrescentada com 700 volumes pelo doutor Pascoal de Frias $^{45}$, (que instituiu também a capela de Nossa Senhora da Imaculada Conceição).

\footnotetext{
44 "Havia um Santo Sudario \Havia mais quatro mangas da cruz processional das quatro cores, preto, roxo, branco e encarnado $\backslash$ Havia mais um pano de damasco preto com galoens de prata das sepulturas $\backslash$ Havia outro preto de lam já velho também das sepulturas \Havia mais um frontal de seda matizado em bom uso para o sacrário \ Havia mais trez mantos de Nossa Senhor da Conceição de seda velhos". A.N.T.T./A.H.M.F./S.F.B., Extinção das Ordens Religiosas - Convento de São Francisco em Bragança, Arquivo Nacional da Torre do Tombo, Lisboa, Arquivo Histórico do Ministério das Finanças Processos de Extinção das casas religiosas, M.F. 7580 (cota antiga Cx. 2202), 1834, fl. 13. A referência aos "tres mantos de Nossa Senhor da Conceição de seda velhos" permite perceber como a original devoção à Imaculada levada a cabo na capela do lado do evangelho pelo Doutor Pascoal de Frias deixava ainda fragmentos em 1834, apesar de já velhos denotavam a importância do culto. Pois desde o último quartel do XVIII que a devoção à Imaculada contava com uma imagem de vulto redondo completo sem necessidade de "mantos" postiços. Prossegue o registo dos têxteis, (toalhas de linho e algodão) e os paramentos, (capas, dalmáticas, várias casulas, panos de estante, frontais, damasco branco bordado a oiro, véus de ombros, panos de púlpito) e já no final da lista de paramentaria surge a referência a "Hua Humbella de damasco branco que foi avaliada em preço de quatrocentos e oitenta reis - 480"; que destacamos por ainda hoje se encontrar guardada, já em estado muito deteriorado, na antiga casa do despacho da Ordem Terceira, cuidado que nenhum outro paramento inventariado em 1834 teve. Seguemse as cobertas de altar, cortinados, cortinas, panos de púlpito e "Hum arco de velludo encarnado com duas cortinas de damasco também do altar-mor". E também "sete veos de cobrir os crucifixos na Semana Santa". Além dos diversos objetos têxteis, são avaliados também alguns móveis, "Hua arca piquena (...) Hum baú piquenino de moscovia em que se goarda a prata (...) Dois caixoens piquenos (...) Hua meza com gavetas (...) Huns caixoens da sacristia com seis gavetas (...) Quatro toxeiros (..) A.N.T.T./A.H.M.F./S.F.B., Extinção das Ordens Religiosas - Convento de São Francisco em Bragança, Arquivo Nacional da Torre do Tombo, Lisboa, Arquivo Histórico do Ministério das Finanças Processos de Extinção das casas religiosas, M.F. 7580 (cota antiga Cx. 2202), 1834, fl. 47-50.
}

${ }^{45}$ O Doutor Pascoal de Frias, Abade de Carrazedo fez também a casa da livraria em que deixou mais de 700 tomos, além dos que se tiraram para o Colégio de S. Boaventura. Borges, José Cardoso, Memórias de 
Além do facto de se tratar de um convento fundado no século XIII, o que suporia a existência ainda em 1834 de documentos e livros que pudessem merecer interesse, constituiu o convento de São Francisco um raro espaço de cultura num território afastado dos grandes centros, e neste sentido torna-se ainda mais estranho o abatimento de bens tão preciosos.

O fim que foi dado aos livros antigos é representativo do escasso interesse que despertava a memória do que muitos afirmaram ser o primeiro convento franciscano de Portugal. No inventário consta:

\section{"Livraria}

Havia alguns livros d'obras antigas e troncadas, que nenhum préstimo e serventia tinhão mais do que para embrulho, que forão pesados, e achouse ter o pêzo de doze arrobas, avaliada cada arroba, com capas, a oitocentos reis ${ }^{46}$,

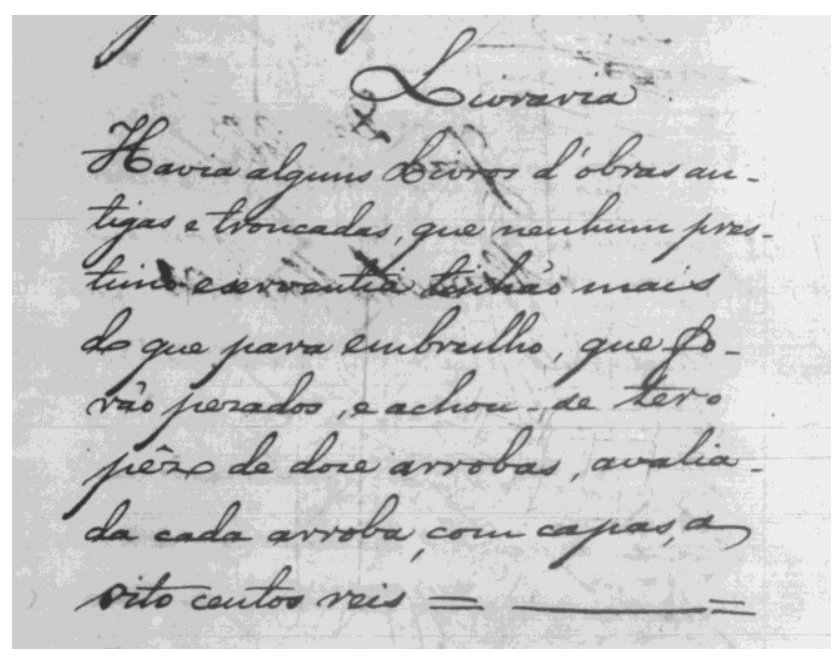

Imagem 12

Pormenor do parágrafo relativo à avaliação da livraria do convento de São Francisco, Bragança, 1834

Bragança, Fernando de Sousa (Coord.), Bragança, CEPESE / Câmara Municipal de Bragança, 2012 (texto original de 1721-1724), pp. 142, 143.

${ }^{46}$ A.N.T.T./A.H.M.F./S.F.B., Extinção das Ordens Religiosas - Convento de São Francisco em Bragança, Arquivo Nacional da Torre do Tombo, Lisboa, Arquivo Histórico do Ministério das Finanças Processos de Extinção das casas religiosas, M.F. 7580 (cota antiga Cx. 2202), 1834, fl. 21 v. 
Contrariamente ao que seria espectável face ao contexto de crise de contínuas ruinas e incêndios descrito por Borges e pela documentação posterior ${ }^{47}$ encontramos no convento de São Francisco de Bragança importantes transformações artísticas que decorreram até aos finais do século XVIII.

Apesar da carência documental sobre a escultura que se encontra hoje a culto e em guarda no convento, perfaz o seu conjunto um total de 44 obras, além de vários fragmentos também registados.

O registo dos fragmentos (sobretudo postiços de mãos e pés), conforme Imagem 13 e 14, advém de uma caixa encontrada durante o inventário na Sala do Despacho da Ordem Terceira.
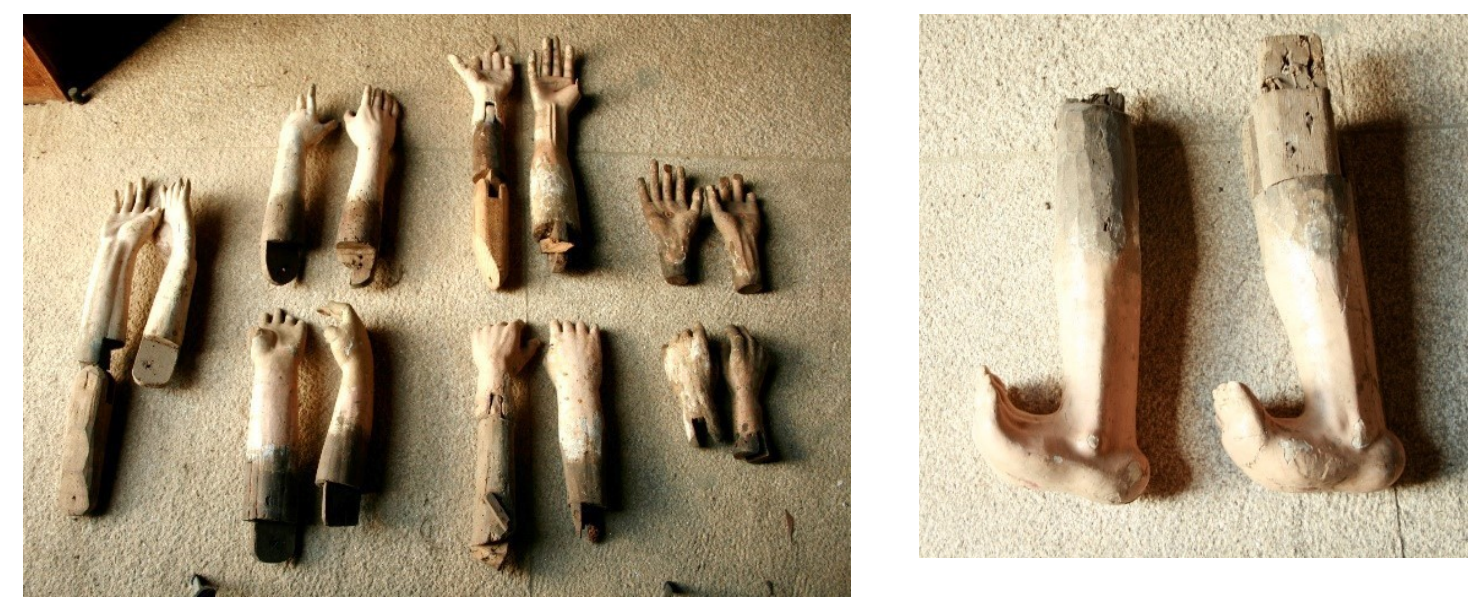

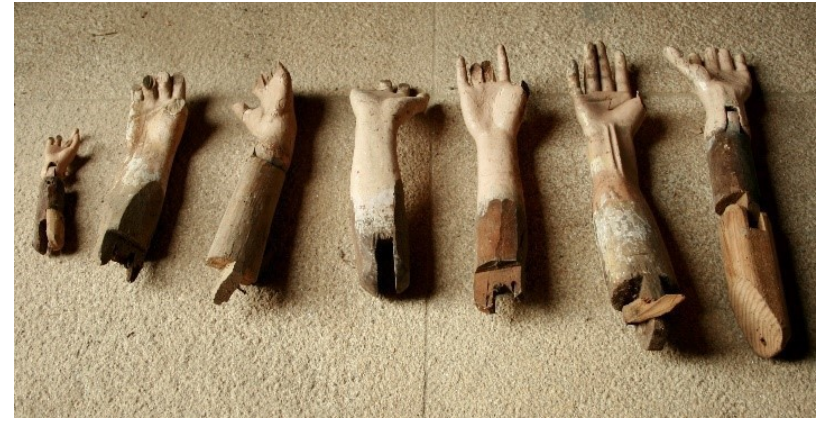

Imagem 13

Fragmentos de mãos Sala do Despacho da Ordem Terceira

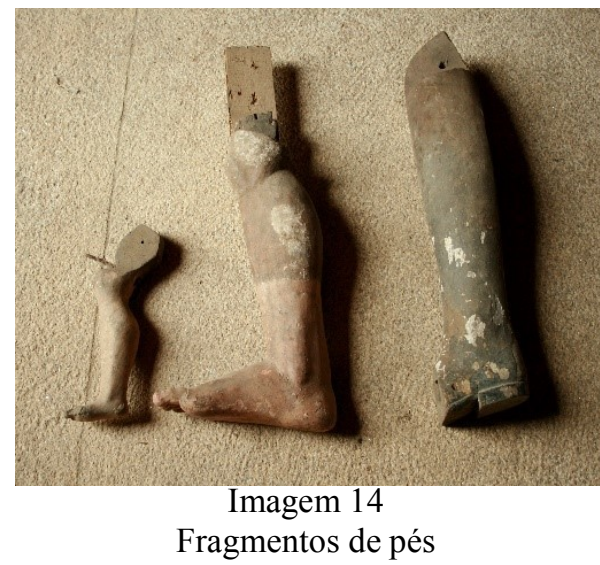

Sala do Despacho da Ordem Terceira

No decurso do inventário havíamos notado que várias esculturas apresentavam as mãos elou os pés recentemente substituídos, por peças talhadas em madeira sem policromia.

\footnotetext{
${ }^{47}$ Além dos incêndios e ruinas várias no edificado do convento os fracos recursos económicos e humanos são repetidas vezes referidos. Capela, José Viriato, et al., As freguesias do distrito de Bragança nas memórias paroquiais de 1758, Braga, Edição José Viriato Capela / Rogério Borralheiro, 2007, p. 110.
} 
Julgamos que durante as obras de restauro e adaptação do convento a arquivo, possivelmente por precaução terão retirado os postiços das esculturas de modo a que se não perdessem. Mas a demora nas obras de restauro terá provocado o esquecimento da caixa com as mãos e pés postiços (na sua maioria ainda estáveis se bem que com algumas lacunas) e houve por isso a necessidade de os substituir com peças novas de modo a permitir a sustentação das figuras. As mãos e pés originais encontram-se agora guardados na Sala do Despacho, aguardando posteriores estudos.

A escultura é claramente a categoria de artes plásticas mais representativa de todo o programa decorativo no interior do templo. $\mathrm{Na}$ sua maioria tratam-se de esculturas talhadas em madeira e cobertas com policromia, datáveis do século XVIII e atribuíveis a oficinas locais ou regionais. Das diversas oficinas destacam-se as do Porto e Braga na produção das obras mais cuidadas. 
FICHAS DE INVENTÁRIO ESCULTURA

IGREJA DE SÃO FRANCISCO, BRAGANÇA 
FICHAS DE INVENTÁRIO | ESCULTURA

Da Ordem de São Francisco na Diocese de Bragança-Miranda 


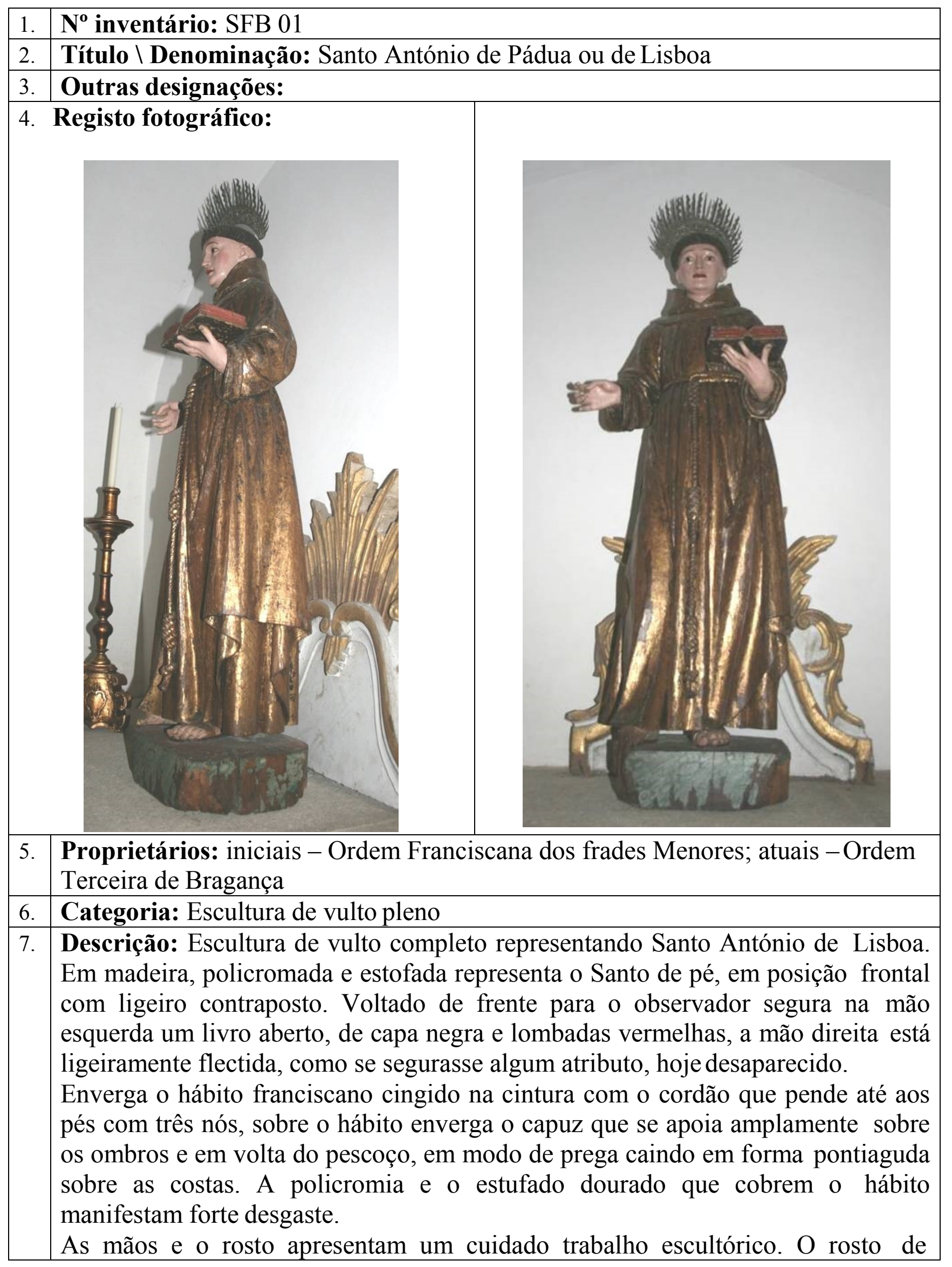




\begin{tabular}{|c|c|}
\hline & $\begin{array}{l}\text { expressão serena e traços regulares está coberto por uma brilhante carnação sem } \\
\text { sinais de repinte. A cabeça tonsurada ostenta um resplendor em forma de } \\
\text { crescente raiado em metal branco, possivelmente prata, decorado com elementos } \\
\text { vegetalistas gravados. Os pés, descalços ligeiramente afastados apenas protegidos } \\
\text { com as sandálias reforçam o ligeiro contraposto sugerido nas pregas do hábito } \\
\text { detalhadamente trabalhadas, sem no entanto quebrarem a estaticidade da figura. O } \\
\text { pé direito está parcialmente destruído bem como todo o lado direito da plataforma, } \\
\text { hexagonal decorada em verde marmoreado que serve de plinto à escultura. }\end{array}$ \\
\hline 8. & Técnicas (de suporte): Talha \\
\hline 9. & $\begin{array}{l}\text { Técnicas (de acabamento): Policromia; estufagem; fundição; cinzelagem; } \\
\text { marmoreado; }\end{array}$ \\
\hline 10. & Materiais (de suporte): Madeira; liga metálica branca, prata \\
\hline 11. & Materiais (de acabamento): Pigmentos; folha de ouro \\
\hline 12. & $\begin{array}{l}\text { Estado de Conservação: Bom; apresenta-se se estável; lacuna no pé e plataforma } \\
\text { do lado direito. }\end{array}$ \\
\hline 13. & $\begin{array}{l}\text { Dimensões: } \\
\text { Altura: } 136 \mathrm{~cm} \\
\text { Largura: } 50 \mathrm{~cm} \\
\text { Profundidade: } 31 \mathrm{~cm} \\
\end{array}$ \\
\hline 14. & Restauro: apresenta sinais de reintegração cromática \\
\hline 15. & Datas: século XVII \\
\hline 16. & Proveniência: Igreja de São Francisco de Bragança \\
\hline 17. & Autoria: desconhecida \\
\hline 18. & Oficina: Nacional \\
\hline 19. & $\begin{array}{l}\text { Localização (atual): A escultura está colocado no } 1^{\circ} \text { arco sólio do lado da } \\
\text { Epístola }\end{array}$ \\
\hline 20. & Histórico do objeto: não se conhecem registos \\
\hline 21. & Iconografia: Livro aberto; hábito franciscano; resplendor \\
\hline 22. & Irmandade: não se conhecem registos \\
\hline 23. & Procissões: não se conhecem registos \\
\hline
\end{tabular}


Retábulo em talha barroca nacional (primeira capela do lado do Epístola) que guarda no registo superior as imagens $02 \mathrm{SFB}$; $03 \mathrm{SFB}$; $04 \mathrm{SFB}$ e $05 \mathrm{SFB}$, no sobrado térreo a imagem da Senhora do Boa Morte 06 SFB. Em 1721-1724 a Capela tinha a invocação de Santo António (Borges, 2012 (texto original de 1721-1724) p.142)

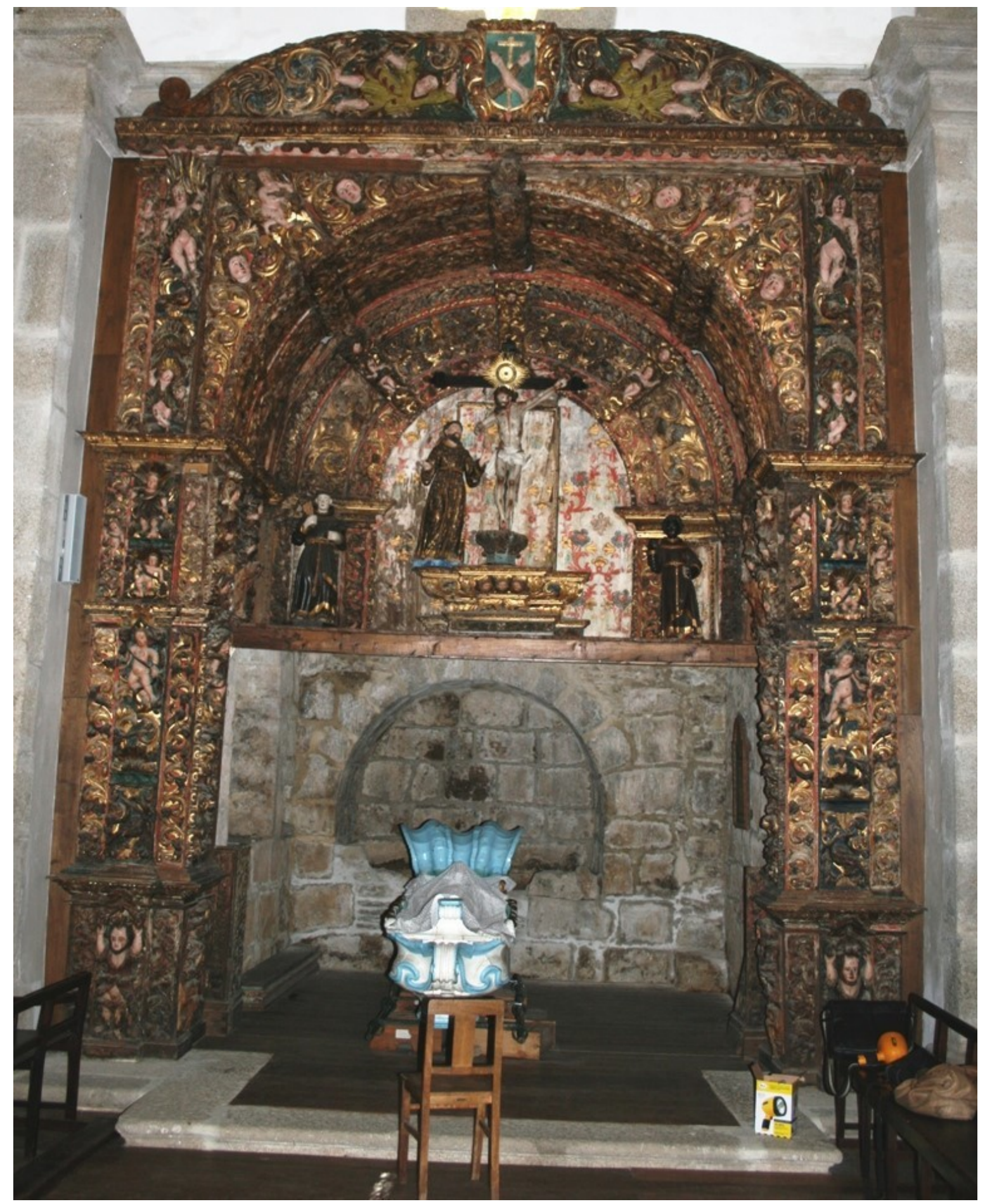


FICHAS DE INVENTÁRIO | ESCULTURA

Da Ordem de São Francisco na Diocese de Bragança-Miranda 


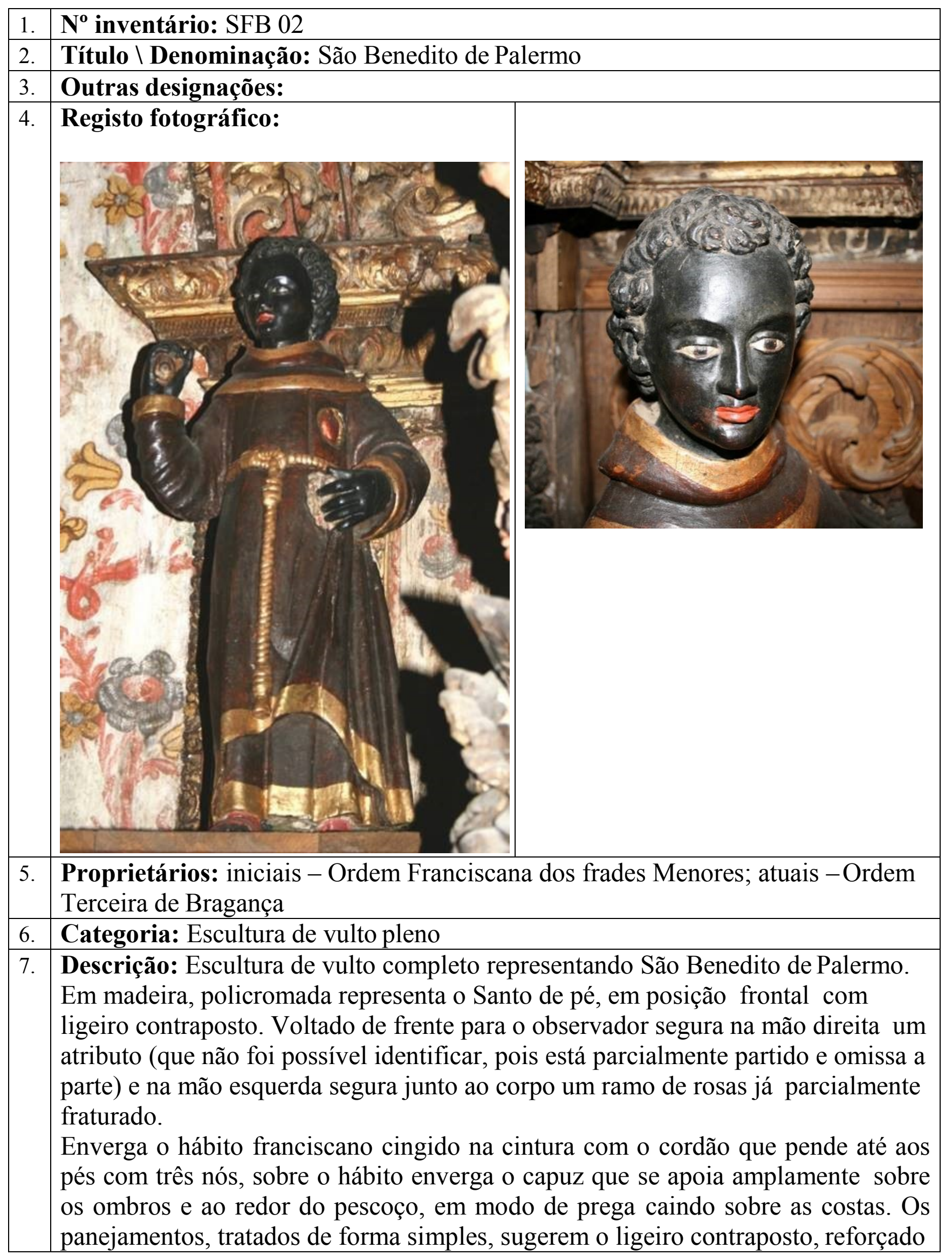




\begin{tabular}{|c|c|}
\hline & $\begin{array}{l}\text { pelo gesto da mão que recolhe, a par das rosas, parte do hábito. O hábito castanho- } \\
\text { escuro ostenta bandas douradas no bordo inferior, nos punhos e em volta do } \\
\text { capuz. Sobre o lado esquerdo do peito o santo expõe o coração escavado em } \\
\text { médio relevo policromado de vermelho. } \\
\text { O santo de pele negra, de onde destaca o rubro dos lábios fechados, apresenta } \\
\text { linhas regulares no trabalho escultórico do rosto. A cabeça tonsurada exibe um } \\
\text { farto cabelo ondulado. } \\
\text { Os pés, descalços ligeiramente afastados apenas protegidos com as sandálias } \\
\text { pintadas num tom intenso de vermelho reforçam o contraposto sugerido nas } \\
\text { pregas do hábito, sem no entanto quebrarem a estaticidade da figura. } \\
\text { A figura de São Benedito apresenta semelhanças nos detalhes escultóricos com a } \\
\text { figura de São Pascoal Bailão SFB } 05 \text {. }\end{array}$ \\
\hline 8. & Técnicas (de suporte): Talha \\
\hline 9. & abamento): Policromia \\
\hline 10. & Materiais (de suporte): Madeira \\
\hline 11. & Materiais (de acabamento): Pigmentos; folha de ouro \\
\hline 12. & Estado de Conservação: Bom; apresenta-se estável \\
\hline 13. & $\begin{array}{l}\text { Dimensões: } \\
\text { Altura: } 89 \mathrm{~cm} \\
\text { Largura: } 40 \mathrm{~cm} \\
\text { Profundidade: } 38 \mathrm{~cm}\end{array}$ \\
\hline 14. & Restauro: apresenta sinais de reintegração \\
\hline 15. & Datas: primeira metade do século XVIII \\
\hline 16. & Proveniência: Igreja de São Francisco de Bragança \\
\hline 17. & Autoria: desconhecida \\
\hline 18. & Oficina: Local $\backslash$ regional \\
\hline 19. & $\begin{array}{l}\text { Localização (inicial } \backslash \text { atual): Em 1721-24 estava num altar próprio do lado do } \\
\text { Evangelho. Hoje está na Capela da Senhora da Boa Morte, lado da Epistola. A } \\
\text { escultura está colocado no retábulo sobre um sobrado num registo elevado. }\end{array}$ \\
\hline 20. & Histórico do objeto: não se conhecem registos \\
\hline 21. & $\begin{array}{l}\text { Iconografia: Rosas; Coração; fratura com lacuna do atributo na mão direita; } \\
\text { Hábito franciscano. }\end{array}$ \\
\hline 22. & Irmandade: não se conhecem registos \\
\hline 23. & \\
\hline
\end{tabular}




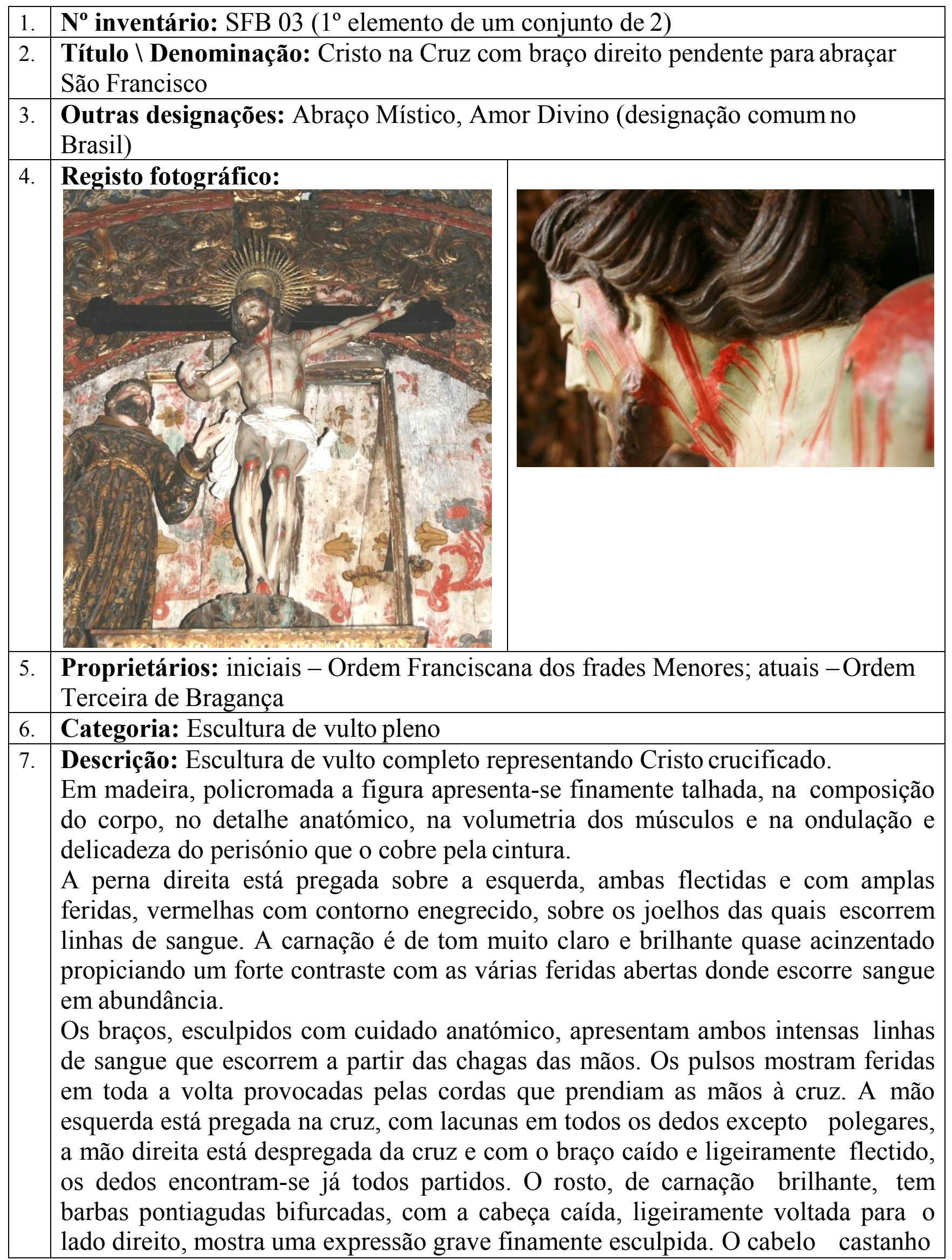




\begin{tabular}{|c|c|}
\hline & $\begin{array}{l}\text { tal como a barba é farto e ondulado com uma madeixa caída sobre o ombro direito. } \\
\text { Em volta do pescoço e sobre a testa as manchas vermelhas de sangue intensificam } \\
\text { o dramatismo da figura. O perisónio que cinge está seguro por uma corda dupla em } \\
\text { volta da cintura e as finas dobras do panejamento ondulam amplamente. } \\
\text { A cruz é de madeira negra, de secção retangular, com remates pontiagudos } \\
\text { antecedidos por três registos diferentes de formas circulares. Sobre o cruzeiro tem } \\
\text { um resplendor em metal dourado, raiado e com decorações gravadas sobre a parte } \\
\text { central representando a cruz de Malta cujo centro está ornamentado com uma } \\
\text { pedra lapidada de cor azul clara. A base cónica da cruz em madeira está totalmente } \\
\text { revestida com folhas de acanto policromadas. } \\
\text { A Escultura Cristo na Cruz com braço direito pendente é parte de um conjunto } \\
\text { com São Francisco de Assis. As semelhanças nos detalhes escultóricos e a atitude } \\
\text { de ambos sugere a mesma produção cuidada }\end{array}$ \\
\hline 8. & Técnicas (de suporte): Talha; \\
\hline 9. & Técnicas (de acabamento): Policromia; fundição, cinzelagem (do resplendor) \\
\hline 10. & Materiais (de suporte): Madeira; metal dourado \\
\hline 11. & Materiais (de acabamento): Pigmentos \\
\hline 12. & $\begin{array}{l}\text { Estado de Conservação: Bom; apresenta-se se estável; com lacunas de dedos em } \\
\text { ambas mãos. }\end{array}$ \\
\hline 13. & $\begin{array}{l}\text { Dimensões: } \\
\text { Altura: } 170 \mathrm{~cm} \\
\text { Largura: } 110 \mathrm{~cm} \\
\text { Profundidade: } 40 \mathrm{~cm}\end{array}$ \\
\hline 14. & Restauro: apresenta sinais de reintegração cromática \\
\hline 15. & Datas: segunda metade do século XVIII \\
\hline 16. & Proveniência: Igreja de São Francisco de Bragança \\
\hline 17. & Autoria: desconhecida \\
\hline 18. & Oficina: Porto $\backslash$ Braga \\
\hline 19. & $\begin{array}{l}\text { Localização (atual): Capela da Senhora da Boa Morte, lado da Epistola. A } \\
\text { escultura está colocado no retábulo sobre um sobrado num registo elevado. }\end{array}$ \\
\hline 20. & $\begin{array}{l}\text { Histórico do objeto: A Escultura Cristo na Cruz com braço direito pendente SFB } \\
03 \text { é parte de um conjunto com São Francisco SFB 04. As semelhanças nos } \\
\text { detalhes escultóricos e a atitude de ambos sugere a mesma produção. }\end{array}$ \\
\hline 21. & Iconografia: Cruz; resplendor; chagas; braço direito pendente. \\
\hline 22. & Irmandade: não se conhecem registos \\
\hline 23. & Procissões: não se conhecem registos \\
\hline
\end{tabular}


1. $\mathbf{N}^{\mathbf{0}}$ inventário: SFB $04\left(2^{\circ}\right.$ elemento de um conjunto de 2$)$

2. Título \Denominação: São Francisco de Assis a abraçar Cristo na Cruz

3. Outras designações: Abraço Místico, Amor Divino (designação comum no Brasil)

4. Registo fotográfico:
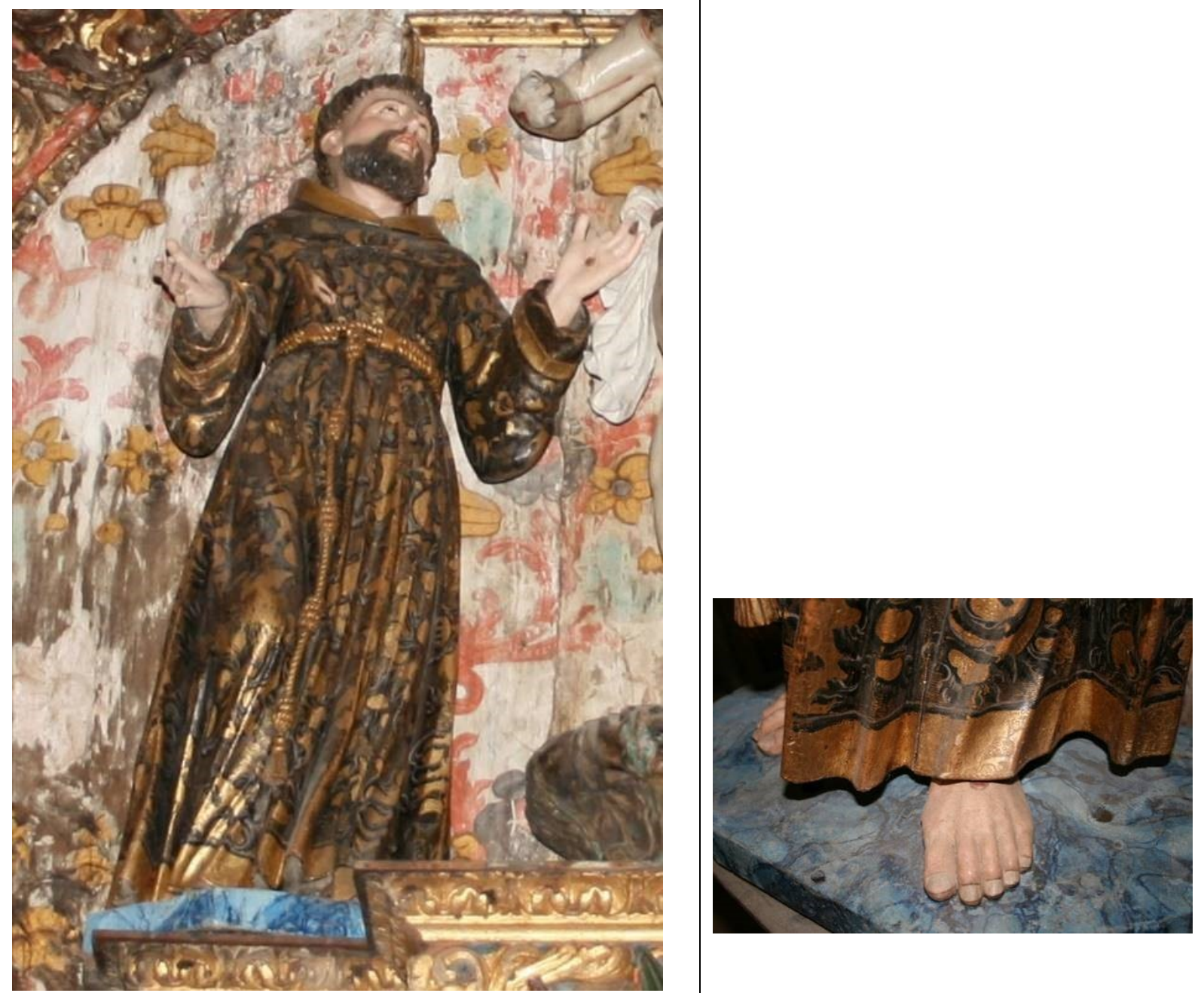

5. Proprietários: iniciais - Ordem Franciscana dos frades Menores; atuais -Ordem Terceira de Bragança

6. Categoria: Escultura de vulto pleno

7. Descrição: Escultura de vulto completo representando São Francisco de Assis.

Em madeira, policromada e estufada a figura apresenta-se finamente talhada nos detalhes anatómicos e pregueado do hábito que enverga. Está representado de pé, em posição frontal com contraposto.

O rosto, mostra uma expressão grave finamente esculpida e coberto de carnação brilhante está inclinado para a esquerda e voltado para cima, reforçando o movimento que sugere o olhar que se eleva. Tem barbas pontiagudas bifurcadas e a cabeça tonsurada apresenta o cabelo castanho e ondulado, tal como a barba.

Enverga o hábito franciscano cingido na cintura com o cordão que pende até aos pés com cinco nós, sobre o hábito enverga o capuz que se apoia amplamente sobre 


\begin{tabular}{|c|c|}
\hline & $\begin{array}{l}\text { os ombros e ao redor do pescoço, em modo de prega caindo em forma pontiaguda } \\
\text { sobre as costas. Os panejamentos em pregarias ritmadas e dobras espontâneas } \\
\text { evidenciam o contraposto sugerido pela perna direita que avança ligeiramente. } \\
\text { Todo o hábito está coberto por estufado dourado e bandas em ouro sobre os } \\
\text { punhos, bordo da túnica e capuz. } \\
\text { Os braços abertos e flectidos, esculpidos com cuidado anatómico, ligeiramente } \\
\text { elevados e com as palmas das mãos voltadas para o observador exibindo os } \\
\text { estigmas que marcam ambas. A mão esquerda apresenta lacunas dos dedos } \\
\text { (indicador e anelar). } \\
\text { A figura está assente sobre uma plataforma hexagonal em madeira decorada com } \\
\text { efeito marmoreado azul que lhe serve de plinto. } \\
\text { A Escultura São Francisco de Assis é parte de um conjunto com a imagem de } \\
\text { Cristo na Cruz com braço direito pendente. Perante as semelhanças nos detalhes } \\
\text { escultóricos e na atitude de ambos julgamos tratar-se da mesma produção oficinal. }\end{array}$ \\
\hline 8. & Técnicas (de suporte): Talha \\
\hline 9. & Técnicas (de acabamento): Policromia; estufagem; marmoreado \\
\hline 10 & Materiais (de suporte): Madeira \\
\hline 11 & Materiais (de acabamento): Pigmentos; folha de ouro \\
\hline 12 & $\begin{array}{l}\text { Estado de Conservação: Bom; apresenta-se se estável; com lacunas de dedos na } \\
\text { mão esquerda. }\end{array}$ \\
\hline & $\begin{array}{l}\text { Dimensões: } \\
\text { Altura: } 110 \mathrm{~cm} \\
\text { Largura: } 50 \mathrm{~cm} \\
\text { Profundidade: } 35 \mathrm{~cm}\end{array}$ \\
\hline 14 & Restauro: apresenta sinais de reintegração cromática \\
\hline 15 & Datas: segunda metade do século XVIII \\
\hline 16 & Proveniência: Igreja de São Francisco de Bragança \\
\hline 17 & Autoria: desconhecida \\
\hline 18 & Oficina: Porto $\backslash$ Braga \\
\hline & $\begin{array}{l}\text { Localização (atual): Capela da Senhora da Boa Morte, lado da Epistola. A } \\
\text { escultura está colocado no retábulo sobre um sobrado num registo elevado }\end{array}$ \\
\hline & $\begin{array}{l}\text { Histórico do objeto: A escultura São Francisco SFB 04 é parte de um conjunto } \\
\text { com Cristo na Cruz com braço direito pendente SFB 03. As semelhanças nos } \\
\text { detalhes escultóricos e a atitude de ambos sugere a mesma produção. }\end{array}$ \\
\hline & Iconografia: Hábito Franciscano; estigmas nas mãos. \\
\hline & Irmandade: não se conhecem registos \\
\hline & Procissões: não se conhecem registos \\
\hline
\end{tabular}




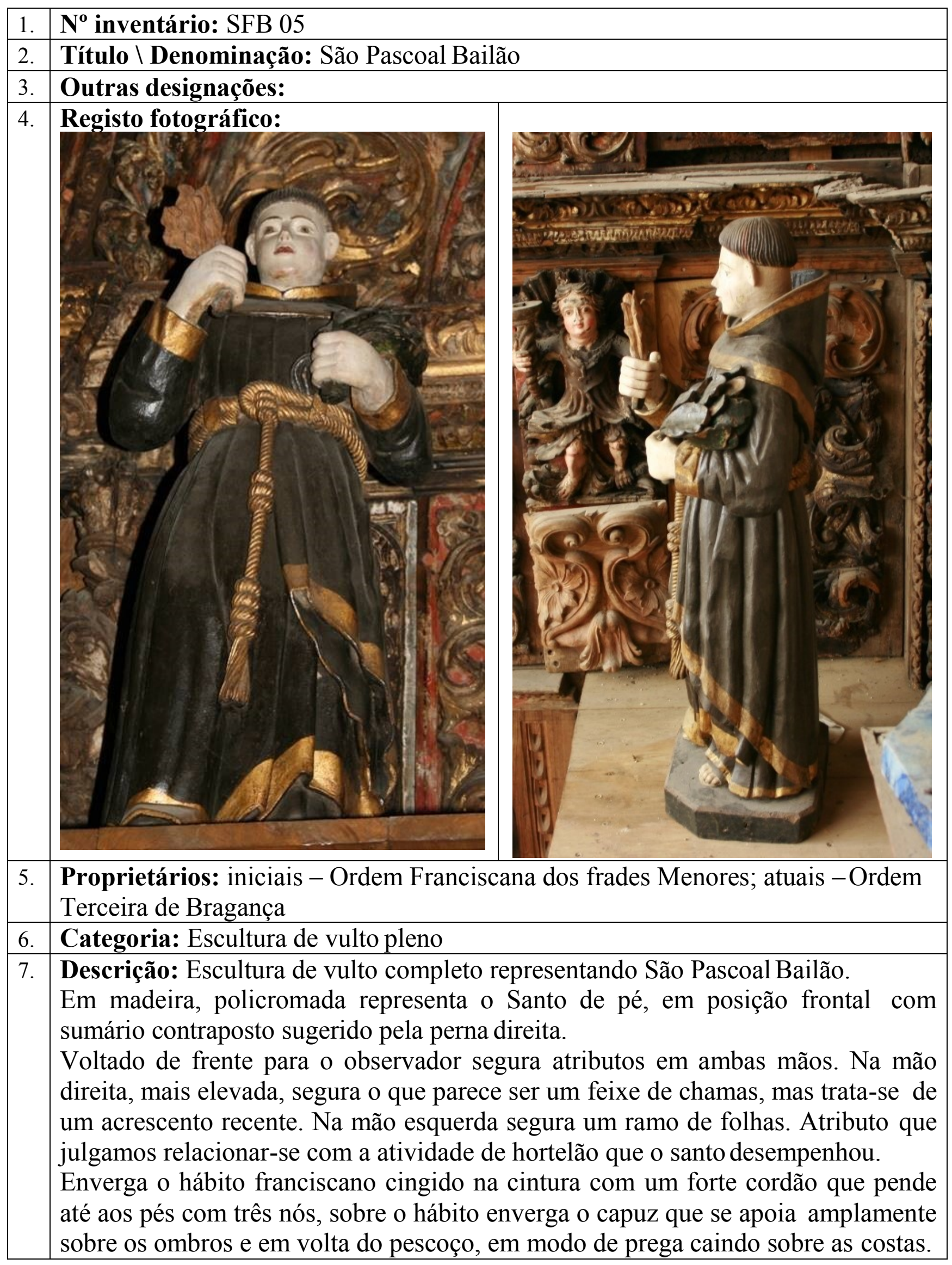




\begin{tabular}{|c|c|}
\hline & $\begin{array}{l}\text { Sob o cordão, está preso, no lado esquerdo, parte do hábito cujas pregas } \\
\text { imprimem um sumário naturalismo às vestes talhadas com alguma rigidez. Os } \\
\text { panejamentos, tratados de forma simples, sugerem o ligeiro contraposto, sem no } \\
\text { entanto quebrarem a estaticidade da figura. O hábito castanho-escuro ostenta } \\
\text { bandas douradas no bordo inferior, nos punhos e em volta do capuz. } \\
\text { A cabeça apresenta o cabelo liso e curto, sem tonsura. O rosto, de linhas regulares } \\
\text { pouco verosímeis é também sumariamente talhado na expressão. } \\
\text { Os pés, protegidos com sandálias ligeiramente afastados estão assentes sobre uma } \\
\text { base negra octogonal. } \\
\text { A figura de São Pascoal Bailão apresenta semelhanças nos detalhes escultóricos, } \\
\text { sobretudo do hábito e na estaticidade do gesto com a figura de São Benedito de } \\
\text { Palermo SFB } 02 \text {. }\end{array}$ \\
\hline 8. & Técnicas (de suporte): Talha \\
\hline 9. & Técnicas (de acabamento): Policromia \\
\hline 10. & Materiais (de suporte): Madeira \\
\hline 11. & Materiais (de acabamento): Pigmentos \\
\hline 12. & $\begin{array}{l}\text { Estado de Conservação: Bom; apresenta-se se estável; e sem lacunas } \\
\text { observáveis. }\end{array}$ \\
\hline 13. & $\begin{array}{l}\text { Dimensões: } \\
\text { Altura: } 97 \mathrm{~cm} \\
\text { Largura: } 35 \mathrm{~cm} \\
\text { Profundidade: } 27 \mathrm{~cm} \\
\end{array}$ \\
\hline 14. & Restauro: apresenta sinais de reintegração cromática \\
\hline 15. & Datas: primeira metade do século XVIII \\
\hline 16. & Proveniência: Igreja de São Francisco de Bragança \\
\hline 17. & Autoria: desconhecida \\
\hline 18. & Oficina: Local $\backslash$ regional \\
\hline 19. & $\begin{array}{l}\text { Localização (atual): Capela da Senhora da Boa Morte, lado da Epistola. A } \\
\text { escultura está colocado no retábulo sobre um sobrado num registo elevado }\end{array}$ \\
\hline 20. & $\begin{array}{l}\text { Histórico do objeto: Num documento de título e demarcação da capela da } \\
\text { Imaculada Conceição, de Pascoal de Frias, do lado do Evangelho é referida a } \\
\text { existência de uma relíquia de São Pascoal Bailão (Rodrigues, 1997, p. 425) }\end{array}$ \\
\hline 21. & $\begin{array}{l}\text { Iconografia: Hábito Franciscano; sem tonsura; ramo de folhas verdes; feixe de } \\
\text { chamas (atributo acrescentado recentemente). }\end{array}$ \\
\hline 22. & Irmandade: não se conhecem registos \\
\hline 23. & \\
\hline
\end{tabular}




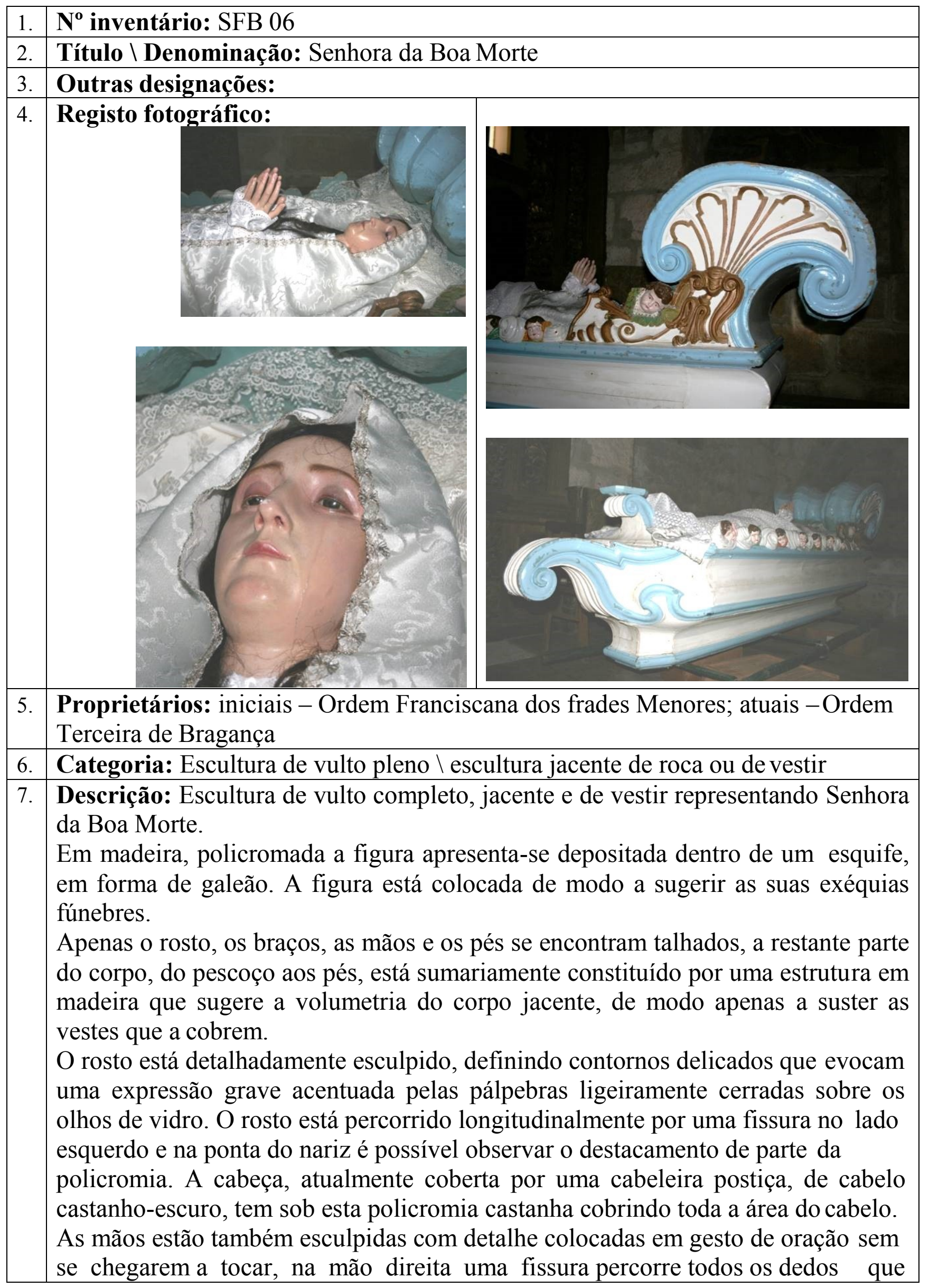




\begin{tabular}{|l|l|}
\hline & $\begin{array}{l}\text { provocou a lacuna da ponta do dedo mínimo. } \\
\text { O esquife, em madeira policromada branca e azul claro, sugere a forma de uma } \\
\text { naveta, decorado com amplos enrolamentos nos pés e na cabeceira, em talha } \\
\text { gorda, que na cabeceira está reforçada com chapas metálicas também } \\
\text { policromadas em branco e azul claro. Em ambos lados corre um friso onde } \\
\text { alternam pequenas cabeças de anjo com pequenas nuvens espiraladas. A } \\
\text { policromia que reveste o esquife parece recente. } \\
\text { A imagem está atualmente coberta com um traje de cetim branco coberta com um } \\
\text { amplo manto em renda branca. }\end{array}$ \\
\hline 8. & Técnicas (de suporte): Talha \\
\hline 9. & Técnicas (de acabamento): Policromia \\
\hline 10. & Materiais (de suporte): Madeira \\
\hline 11. & Materiais (de acabamento): Pigmentos; vidro; têxteis; cabelo \\
\hline 12. & $\begin{array}{l}\text { Estado de Conservação: Bom; apresenta-se se estável; com lacuna do dedo } \\
\text { mínimo da mão direita; fissura sobre o rosto no lado esquerdo; destacamento da } \\
\text { policromia no nariz. }\end{array}$ \\
\hline 13. & $\begin{array}{l}\text { Dimensões: (imagem jacente - plano horizontal) } \\
\text { Comprimento: } 300 \text { cm }\end{array}$ \\
\hline Largura: 96 cm \\
Altura: 83 cm
\end{tabular}


FICHAS DE INVENTÁRIO |ESCULTURA

Da Ordem de São Francisco na Diocese de Bragança-Miranda

Retábulo em talha rococó da capela de Nossa Senhora da Imaculada

Conceição do lado do Epístola com as imagens SFB 07; SFB 08 e SFB 09

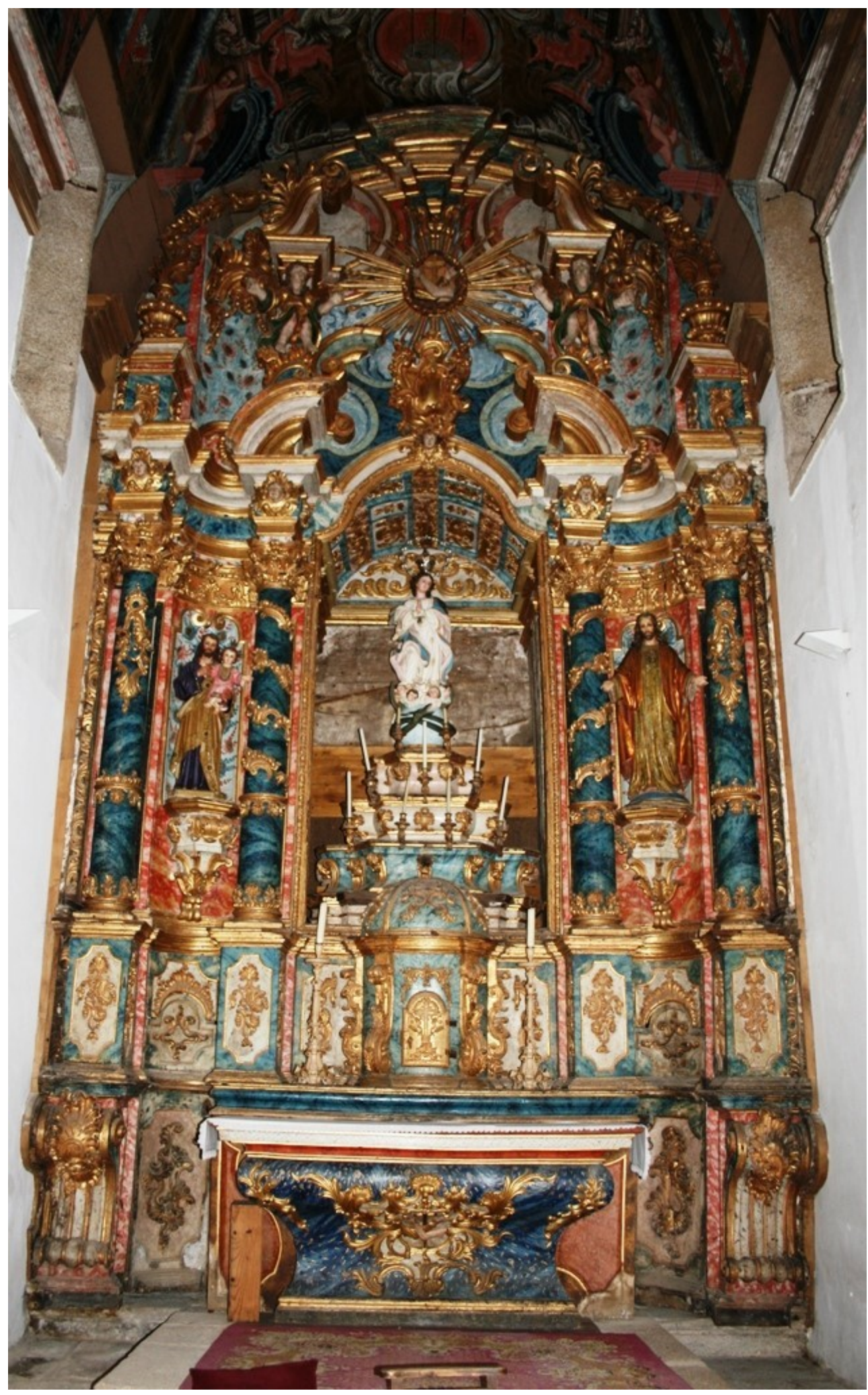


FICHAS DE INVENTÁRIO | ESCULTURA

Da Ordem de São Francisco na Diocese de Bragança-Miranda 


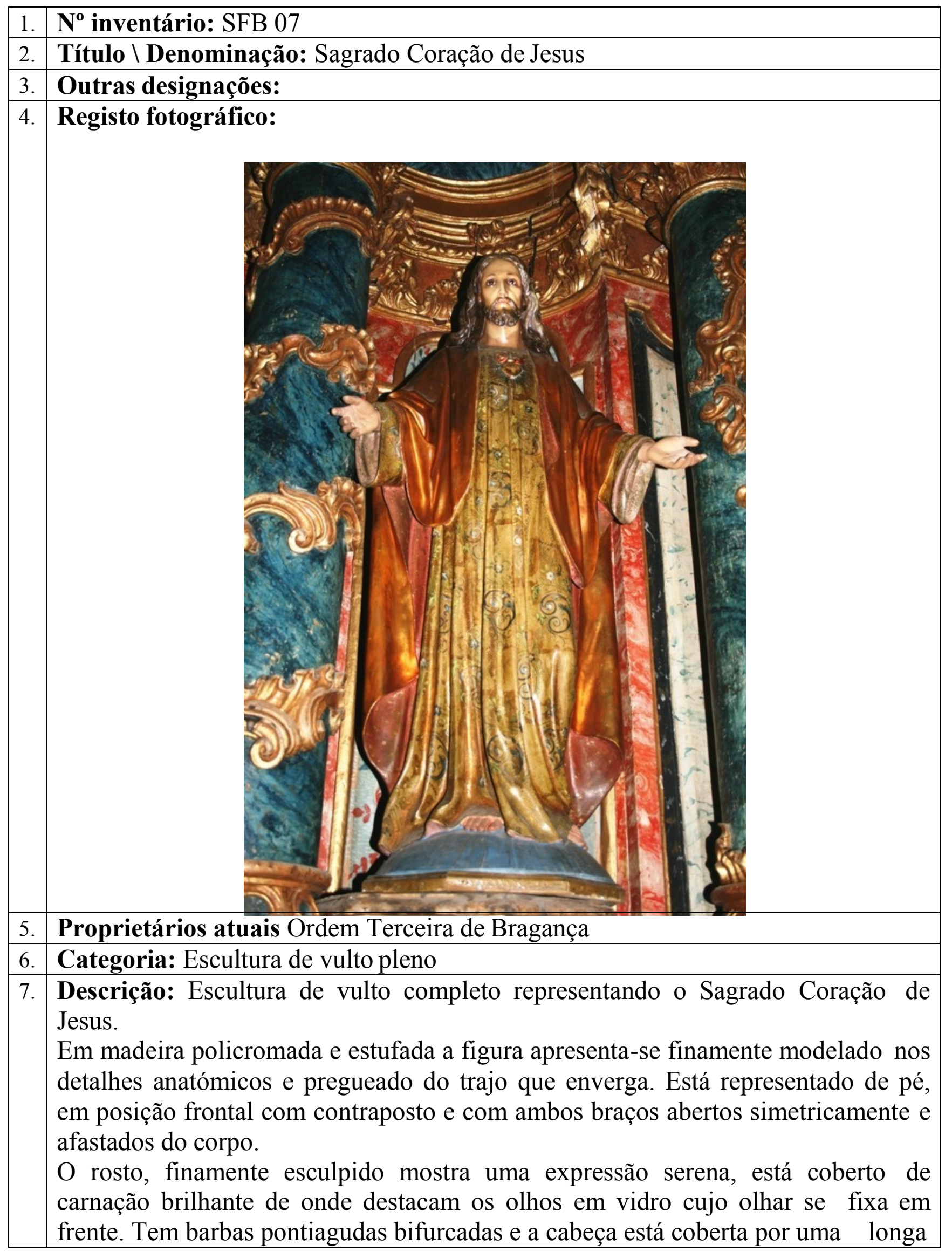




\begin{tabular}{|l|l|}
\hline cabeleira que em amplas ondas cai sobre os ombros, o cabelo é castanho e \\
ondulado, tal como a barba. \\
Enverga uma túnica amarela, profusamente decorada com estufado policromo de \\
motivos vegetalistas e enrolamentos, que o cobre até aos pés, com finas pregas \\
verticais apenas interrompidas pela quebra provocada pelo joelho esquerdo que \\
está ligeiramente flectido. Sobre a túnica amarela enverga um manto vermelho que \\
o envolve pelos ombros e cai até aos pés, o interior do manto está decorado com \\
pequenos pontos em dourado. \\
Sobre o lado esquerdo do peito sobressai o coração, em relevo e policromado num \\
brilhante tom vermelho, donde emanam linhas raiadas em toda a volta, e espessas \\
chamas vermelhas do topo \\
A figura está descalça assente sobre uma forma semiesférica pintada de azul sobre \\
uma plataforma hexagonal pintada de dourado que lhe serve de plinto. \\
A Escultura Sagrado Coração de Jesus (SFB 07) e a Escultura de São José (SFB \\
09) apresentam semelhanças nos detalhes escultóricos, modelado e policromia.
\end{tabular}




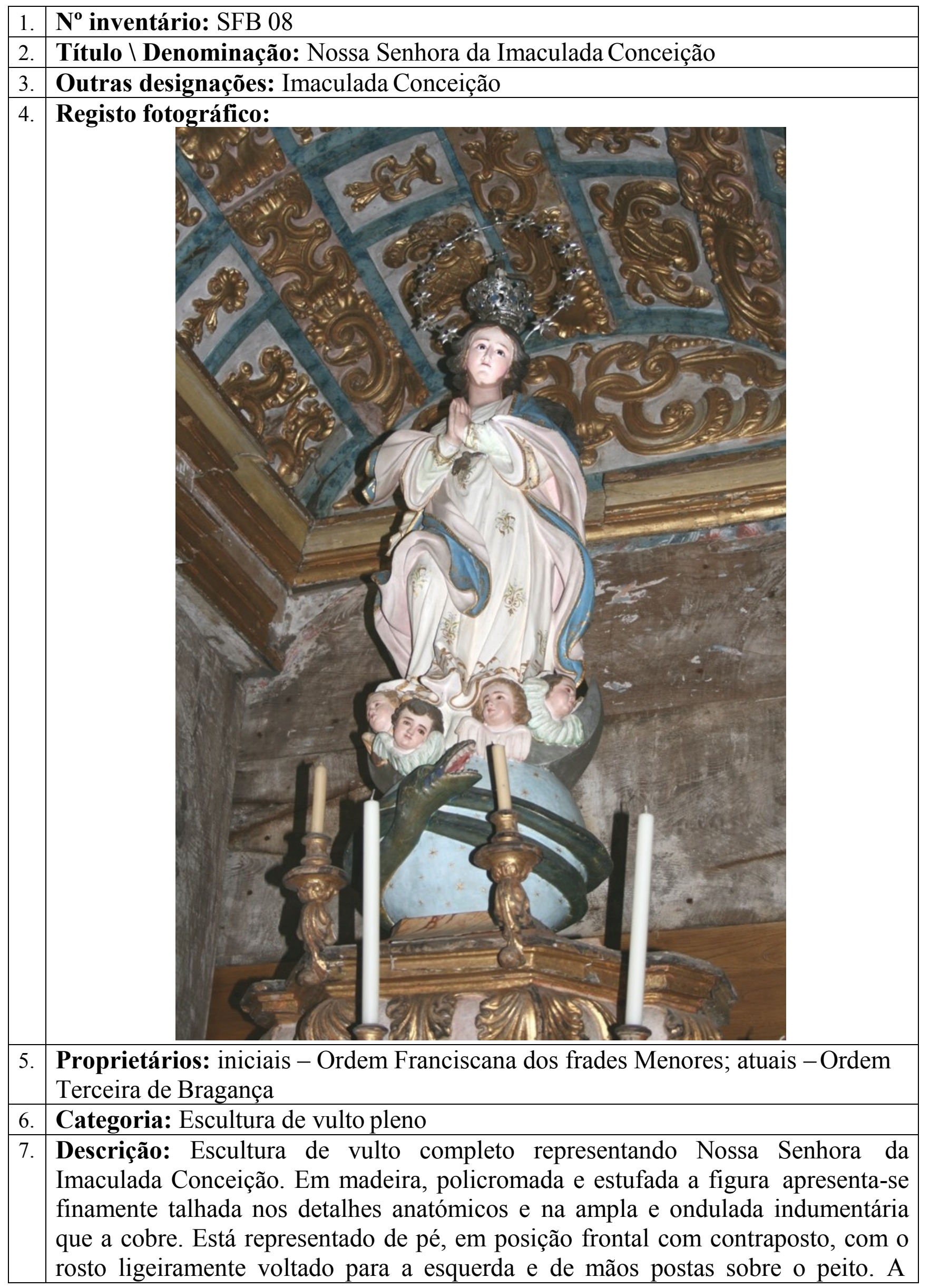




\begin{tabular}{|c|c|}
\hline & $\begin{array}{l}\text { imagem está representada com forte dinamismo, o acentuado contraposto é } \\
\text { reforçado no movimento pelo esvoaçar dos amplos panejamentos que enverga. } \\
\text { Estes são constituídos por um traje branco, cingido na cintura por um cordão } \\
\text { policromado, com aplicações estofadas douradas e policromadas dispersas por } \\
\text { toda a extensão do veste e em bandas sobre os punhos e bordo. Sobre este traje a } \\
\text { figura enverga um manto azul claro com forro num tom róseo claro, também com } \\
\text { aplicações estofadas douradas sobre os bordos do manto, que a cobre sobre os } \\
\text { ombros caindo em amplas pregas onduladas que lhe imprimem uma voluptuosa } \\
\text { sinuosidade. O rosto está finamente esculpido e coberto de carnação brilhante, } \\
\text { com traços delicados que compõem uma expressão serena. Os olhos, grandes e } \\
\text { amendoados são de vidro e fixam o olhar para a esquerda reforçando a ligeira } \\
\text { inclinação da cabeça no mesmo sentido. O cabelo, talhado em ondas largas } \\
\text { acompanha o modelado do rosto e pescoço. Aplicada sobre a cabeça tem uma } \\
\text { coroa em liga metálica branca, possivelmente prata, ornamentada com pedrarias } \\
\text { azuis, em volta da coroa está colocado um resplendor circular onde podemos } \\
\text { contar doze estrelas com centro em pedraria roxa, simetricamente colocadas, entre } \\
\text { as doze estrelas ostenta no topo do resplendor uma forma esférica sobrepujada por } \\
\text { uma ave (pomba).A escultura está colocada sobre a lua crescente que assenta sobre } \\
\text { um globo policromado azul com pequenas estrelas douradas. Em volta do globo } \\
\text { está enroscada uma serpente que o envolve com duas voltas, colorida num tom } \\
\text { verde com aplicações pontuais em azul metalizado. A cabeça da serpente, } \\
\text { apetrechada de forte dentadura, eleva-se, em atitude de ataque, em direcção à } \\
\text { imagem da Virgem. Sobre a lua está representada uma nuvem da qual emergem } \\
\text { quatro cabeças de anjos, o anjo representado do lado direito apresenta uma lacuna } \\
\text { na madeira da asa. Sobre as cabeças dos anjos paira a figura da Virgem. }\end{array}$ \\
\hline 8. & Técnicas (de suporte): Talha \\
\hline 9. & Técnicas (de acabamento): Policromia; estufagem; marmoreado; cinzelagem \\
\hline 10. & Materiais (de suporte): Madeira \\
\hline 11. & $\begin{array}{l}\text { Materiais (de acabamento): Pigmentos; folha de ouro; vidro; liga metálica } \\
\text { branca, prata }\end{array}$ \\
\hline 12. & $\begin{array}{l}\text { Estado de Conservação: Bom; apresenta-se se estável; lacunas na asa do anjo } \\
\text { representado do lado direito. }\end{array}$ \\
\hline 13. & $\begin{array}{l}\text { Dimensões: } \\
\text { Altura: } 170 \mathrm{~cm} \\
\text { Largura: } 60 \mathrm{~cm} \\
\text { Profundidade: } 60 \mathrm{~cm}\end{array}$ \\
\hline 14. & Restauro: apresenta sinais de reintegração cromática \\
\hline 15. & Datas: segunda metade do século XVIII \\
\hline 16. & Proveniência: Igreja de São Francisco de Bragança \\
\hline 17. & Autoria: desconhecida \\
\hline 18. & Oficina: Porto $\backslash$ Braga \\
\hline 19. & $\begin{array}{l}\text { Localização (inicial \atual) Inicialmente a capela da Imaculada Conceição estava } \\
\text { no lado do Evangelho. Com a desocupação da capela pela Ordem Terceira em }\end{array}$ \\
\hline
\end{tabular}


1780 a devoção foi transferida de lado. Atualmente a imagem está na tribuna do retábulo da Capela da Imaculada Conceição, lado da Epistola, onde até 1780 estava a capela da Ordem Terceira. A escultura está colocada no nicho central do retábulo num registo elevado

20. Histórico do objeto: $\mathrm{o}$ culto da Imaculada Conceição existe na igreja desde o século XIV quando o altar recebeu benefícios papais

21. Iconografia: Serpente; Lua; Coroa; Resplendor; Globo com estrelas; Querubins

22. Irmandade: não se conhecem registos

23. Procissões: não se conhecem registos 
FICHAS DE INVENTÁRIO | ESCULTURA

Da Ordem de São Francisco na Diocese de Bragança-Miranda 


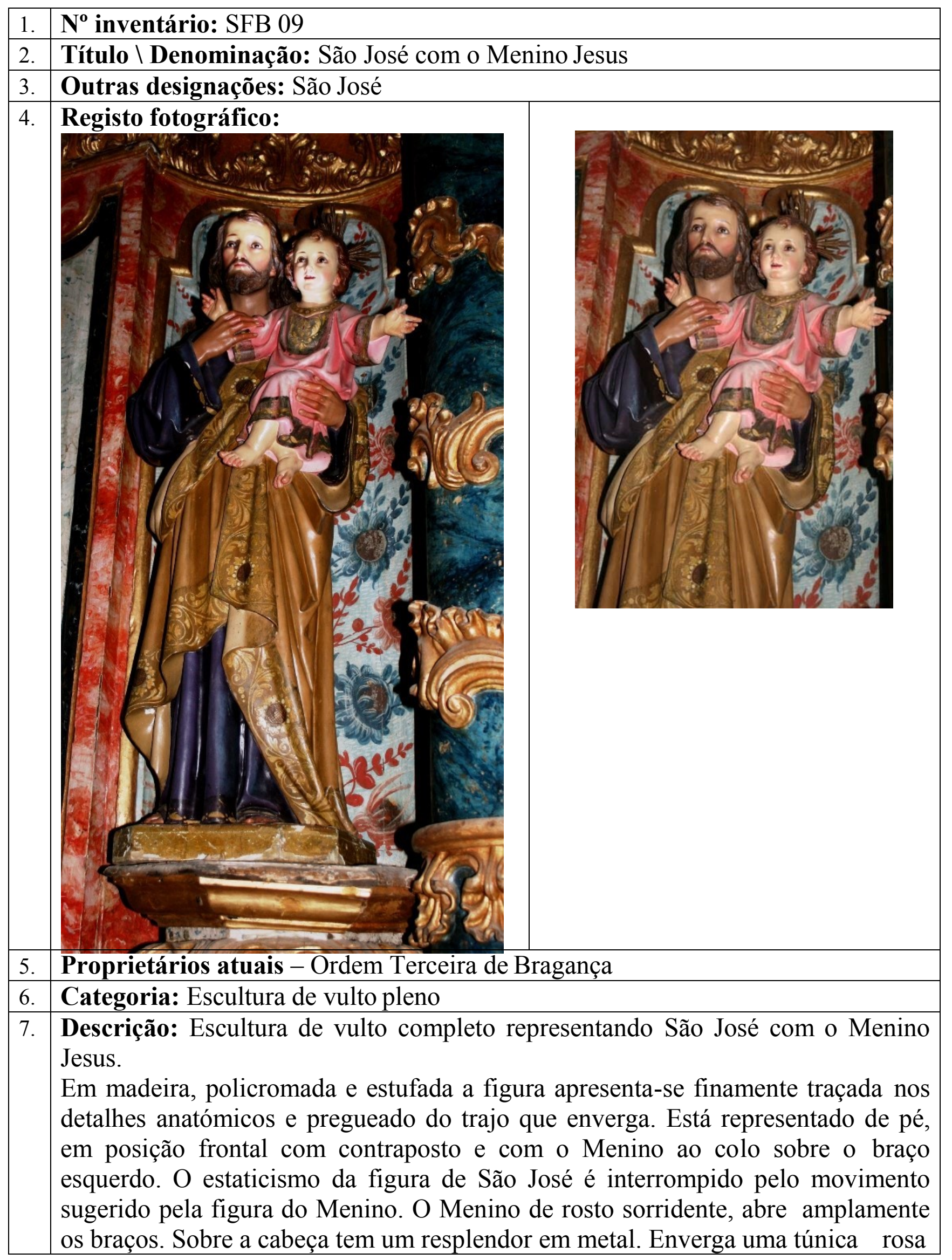




\begin{tabular}{|l|l|}
\hline & $\begin{array}{l}\text { com aplicações estufadas douradas sobre o peito, bordo inferior e punhos. As } \\
\text { mãos os pés descobertos são ternamente aconchegados pelas mãos de São José } \\
\text { que o segura em atitude protectora. A proximidade dos rostos de ambos permite } \\
\text { comparar as diferentes colorações da carnação, mais rósea a dos Menino e mais } \\
\text { morena a de São José, mas o que mais se destaca são as expressões que exprimem } \\
\text { diferentes emoções, enquanto o Menino está alegre e sorridente a expressão de } \\
\text { São José é grave e séria. São José tem os olhos de vidro, barbas curtas e a cabeça } \\
\text { coberta por uma ampla cabeleira que em amplas ondas cai sobre os ombros, o } \\
\text { cabelo é castanho e ondulado, tal como a barba. Enverga uma túnica roxa com } \\
\text { ornatos dourados sobre o bordo inferior e mangas. Sobre a túnica enverga um } \\
\text { manto amarelo que o envolve pelo ombro esquerdo preso pela figura do Menino, o } \\
\text { que provoca pregas mais dinâmicas que imprimem movimento à serena } \\
\text { estaticidade da figura de São José. Os bordos do manto estão decorados com } \\
\text { elementos vegetalistas estufados e policromados. A figura descalça está assente } \\
\text { sobre uma plataforma hexagonal pintada de dourado que lhe serve de plinto. } \\
\text { A escultura de São José com o Menino Jesus e a escultura Sagrado Coração de } \\
\text { Jesus (SFB 07) apresentam semelhanças nos detalhes escultóricos, modelado e } \\
\text { policromia. }\end{array}$ \\
\hline 8. & Técnicas (de suporte): Talha \\
\hline 9. & Técnicas (de acabamento): Policromia; estufagem; cinzelagem \\
\hline 10. & Materiais (de suporte): Madeira \\
\hline 11. & Materiais (de acabamento): Pigmentos; folha de ouro; vidro; liga metálica \\
\hline 12. & Estado de Conservação: Bom; apresenta-se se estável. \\
\hline 13. & Dimensões: \\
Altura: 104 cm \\
Largura: 48 cm \\
Profundidade: 34 cm
\end{tabular}




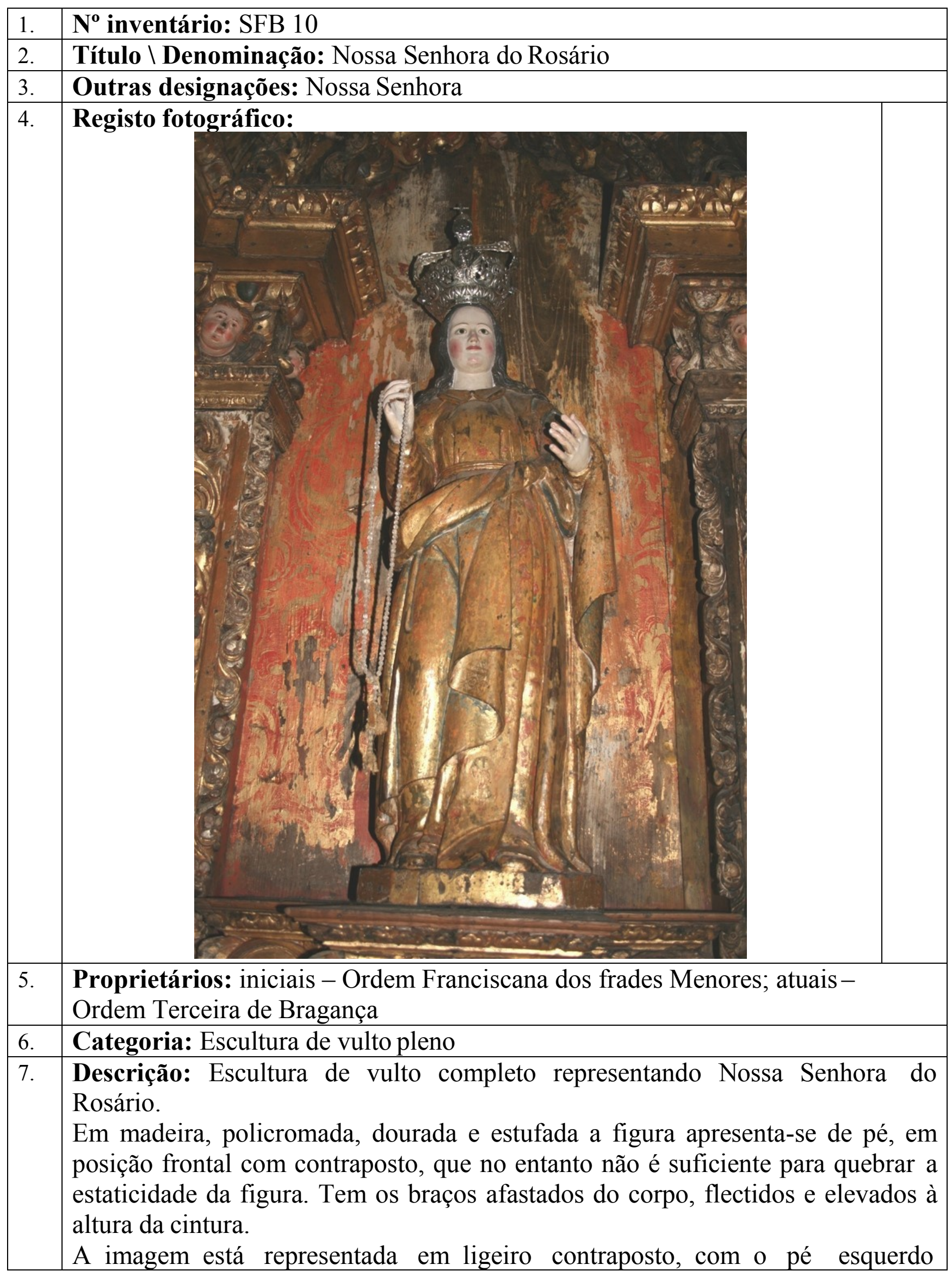




\begin{tabular}{|c|c|}
\hline & $\begin{array}{l}\text { tenuemente avançado, criando uma sumária sinuosidade reforçada pelos vincos } \\
\text { simples nos panejamentos que evocam o volume do joelho direito. } \\
\text { Enverga um trajo comprido, com gola apertada com botão em relevo, cingido na } \\
\text { cintura por um cordão talhado. A sobrepujar o trajo comprido, sobre o ombro } \\
\text { esquerdo, enverga um manto que enrosca sobre a cintura cobrindo também parte } \\
\text { do braço esquerdo de onde cai até aos pés numa ampla prega esquematicamente } \\
\text { ondulada. } \\
\text { O rosto está sumariamente esculpido e coberto de carnação clara, de onde destaca } \\
\text { o rubro dos lábios e maças do rosto } \\
\text { O cabelo castanho e talhado com ténues ondas acompanha o modelado do rosto e } \\
\text { pescoço. Aplicada sobre a cabeça tem uma opulenta e amplamente decorada } \\
\text { coroa em liga metálica branca com quatro braços que se elevam e convergem no } \\
\text { topo numa forma esférica sobrepujada por uma cruz. } \\
\text { Da mão direita ligeiramente fechada pende um longo rosário com contas } \\
\text { transparentes, tem lacuna do dedo mínimo. A mão esquerda está aberta e } \\
\text { ligeiramente flectida. } \\
\text { O douramento que cobre toda a extensão da indumentária encontra-se muito } \\
\text { desgastado bem como os motivos estufados. } \\
\text { A escultura está colocada sobre uma plataforma em madeira hexagonal dourada. }\end{array}$ \\
\hline 8. & Técnicas (de \\
\hline 9. & Técni \\
\hline 10. & Materiais (de suporte): Madeira \\
\hline 11. & $\begin{array}{l}\text { Materiais (de acabamento): Pigmentos; folha de ouro; liga metálica branca, } \\
\text { prata; vidro nas contas do rosário }\end{array}$ \\
\hline 12. & $\begin{array}{l}\text { Estado de Conservação: Bom; apresenta-se se estável; lacunas no dedo mínimo } \\
\text { da mão direita; desgaste no douramento da indumentária. }\end{array}$ \\
\hline 13. & $\begin{array}{l}\text { Dimensões: } \\
\text { Altura: } 138 \mathrm{~cm} \\
\text { Largura: } 47 \mathrm{~cm} \\
\text { Profundidade: } 35 \mathrm{~cm} \\
\end{array}$ \\
\hline 14. & Restauro: apresenta sinais de reintegração cromática \\
\hline 15. & Datas: século XVI $\backslash X V I I$ \\
\hline 16. & Prove \\
\hline 17. & Auto \\
\hline 18. & Oficina: Nacional \\
\hline 19. & $\begin{array}{l}\text { Localização (atual): Retábulo da Senhora do Rosário, lado da Epistola, junto ao } \\
\text { arco de triunfo }\end{array}$ \\
\hline 20. & Histórico do objeto: não se conhecem registos \\
\hline 21. & \\
\hline 22. & $\begin{array}{l}\text { Irmandade: Nossa Senhora do Rosário tinha irmandade de Militares em 1721- } \\
1724\end{array}$ \\
\hline 23. & Procissões: não se conhecem registos \\
\hline
\end{tabular}




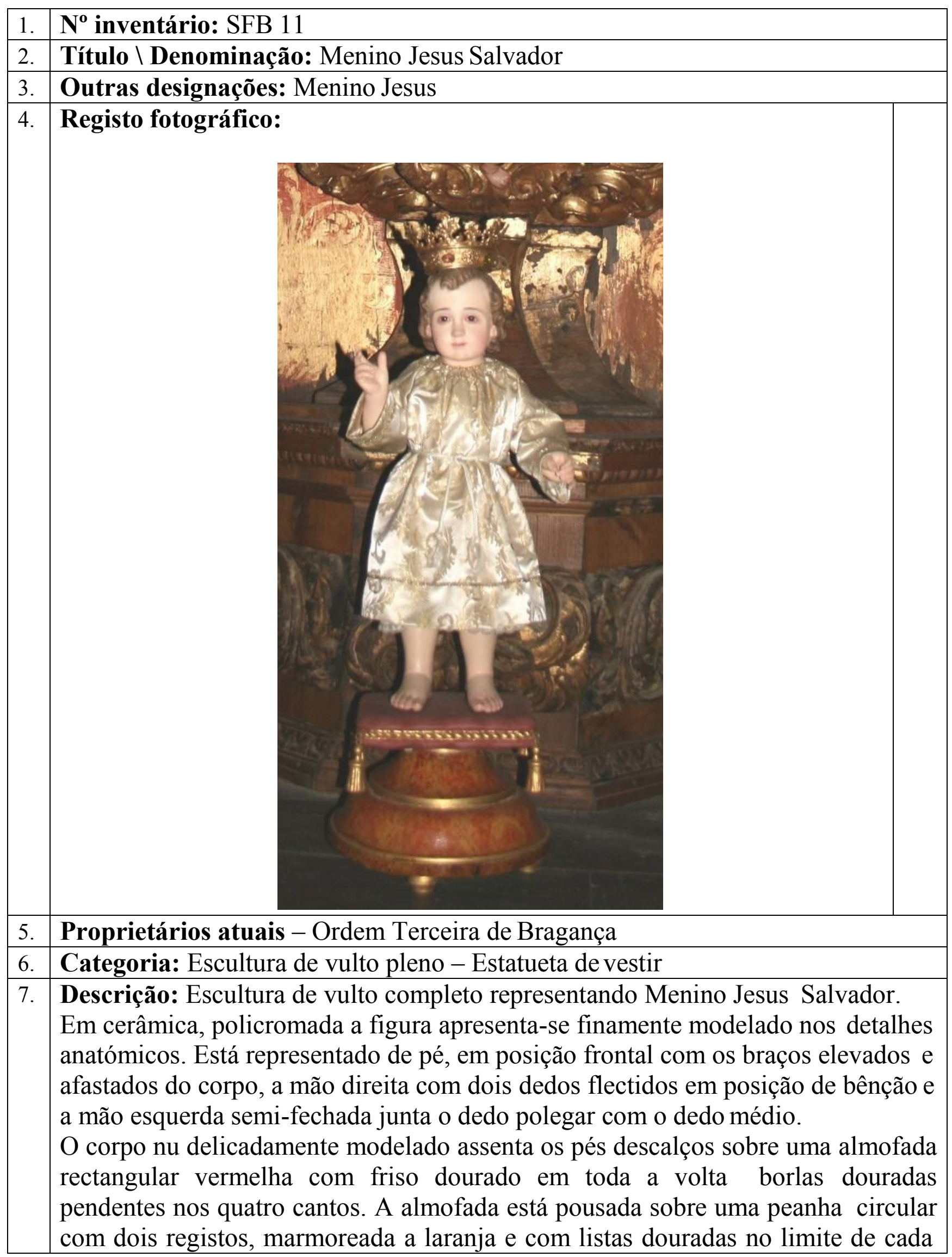




\begin{tabular}{|l|l|}
\hline & $\begin{array}{l}\text { registo. } \\
\text { O rosto róseo de expressão suave com um ligeiríssimo sorriso apresenta o olhar } \\
\text { expressivo que se eleva, tem olhos de vidro castanhos e cabelo curto ondulado } \\
\text { castanho. Sobre a cabeça tem uma coroa em metal amarelo decorada com pedras } \\
\text { lapidadas em diferentes cores. } \\
\text { Enverga uma túnica num tecido acetinado branco decorada com ornatos dourados, } \\
\text { sobre esta enverga outra túnica branca com rendas no limite inferior. }\end{array}$ \\
\hline 8. & Técnicas (de suporte): Modelagem, produção em série por molde \\
\hline 9. & Técnicas (de acabamento): Policromia; Marmoreado; cinzelagem \\
\hline 10. & Materiais (de suporte): Barro; pasta cerâmica \\
\hline 11. & Materiais (de acabamento): Pigmentos; vidro; liga metálica; têxteis \\
\hline 12. & Estado de Conservação: Bom; apresenta-se se estável. \\
\hline 13. & Dimensões: \\
Altura: 82 cm \\
Largura: 28 cm \\
Profundidade: 28 cm
\end{tabular}




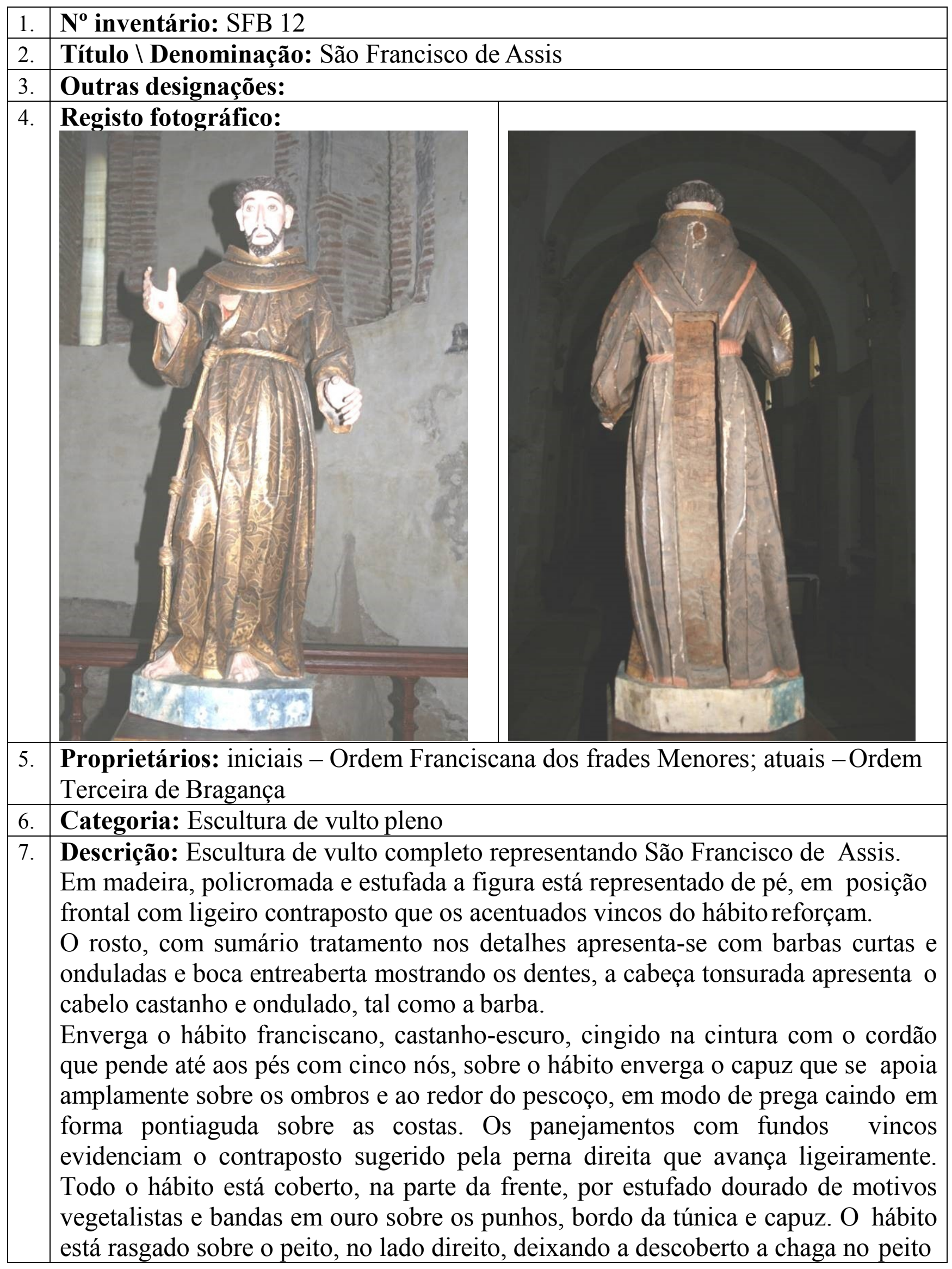




\begin{tabular}{|c|c|}
\hline & $\begin{array}{l}\text { que o Santo expõe. } \\
\text { Os braços abertos e flectidos mostram ambas mãos abertas que ostentam nas } \\
\text { palmas os estigmas que as marcam. Na mão direita apresenta lacunas nas pontas } \\
\text { de dois dedos. É evidente o cuidado na modelagem das mãos e pés descalços, bem } \\
\text { como nos panejamentos no entanto insuficientes para quebrar a estaticidade da } \\
\text { figura. } \\
\text { Nas costas é possível observar uma grande cavidade rectangular sobre toda a } \\
\text { extensão desde o capuz até aos pés, cuja cobertura está em falta, mas que permite } \\
\text { ver o interior escavado da peça (única) de madeira que constitui a imagem. } \\
\text { A figura está assente sobre uma plataforma hexagonal em madeira decorada com } \\
\text { efeito marmoreado azul que lhe serve de plinto. } \\
\text { A Escultura São Francisco de Assis (SFB 12) está atualmente colocada na capela- } \\
\text { mor em conjunto São Vicente Ferrer (SFB 13). As semelhanças nos detalhes } \\
\text { escultóricos e a atitude de ambos parecem tratar-se de obras esculpidas pelo } \\
\text { mesmo autor \oficina. }\end{array}$ \\
\hline 8. & Técnicas (de suporte): Talha \\
\hline 9. & Técnicas (de acabamento): Policromia; estufagem; marmoreado \\
\hline 10. & Materiais (de suporte): Madeira \\
\hline 11. & Materiais (de acabamento): Pig \\
\hline 12. & $\begin{array}{l}\text { Estado de Conservação: Bom; apresenta-se se estável; com lacunas nas pontas } \\
\text { dos dedos na mão direita; e na cobertura da cavidade das costas. }\end{array}$ \\
\hline 13. & $\begin{array}{l}\text { Dimensões: } \\
\text { Altura: } 130 \mathrm{~cm} \\
\text { Largura: } 51 \mathrm{~cm} \\
\text { Profundidade: } 45 \mathrm{~cm}\end{array}$ \\
\hline 14. & Restauro: apresenta sinais de reinteg \\
\hline 15. & Datas: meados do século XVIII \\
\hline 16. & Proveniência: Igreja de São Francisco de Bragança \\
\hline 17. & $\begin{array}{l}\text { Autoria É de referir as semelhanças observadas nos detalhes escultóricos do talhe } \\
\text { do rosto bem como o estufado que decora o hábito entre a presente escultura (SFB } \\
\text { 12) com a escultura de São Vicente Ferrer (SFB 13) parecendo tratar-se de obras } \\
\text { esculpidas pelo mesmo autor \oficina. }\end{array}$ \\
\hline 18. & Oficina: Local $\backslash$ regional \\
\hline 19. & Localização (atual): Capela-mor, lado da Epistola. \\
\hline 20. & Histórico do objeto: não se conhecem registos \\
\hline 21. & Iconografia: Hábito Franciscano; estigmas nas mãos e sobre o peito. \\
\hline 22. & Irmandade: não se conhecem registos \\
\hline 23. & Procissões: não se conhecem registos \\
\hline
\end{tabular}




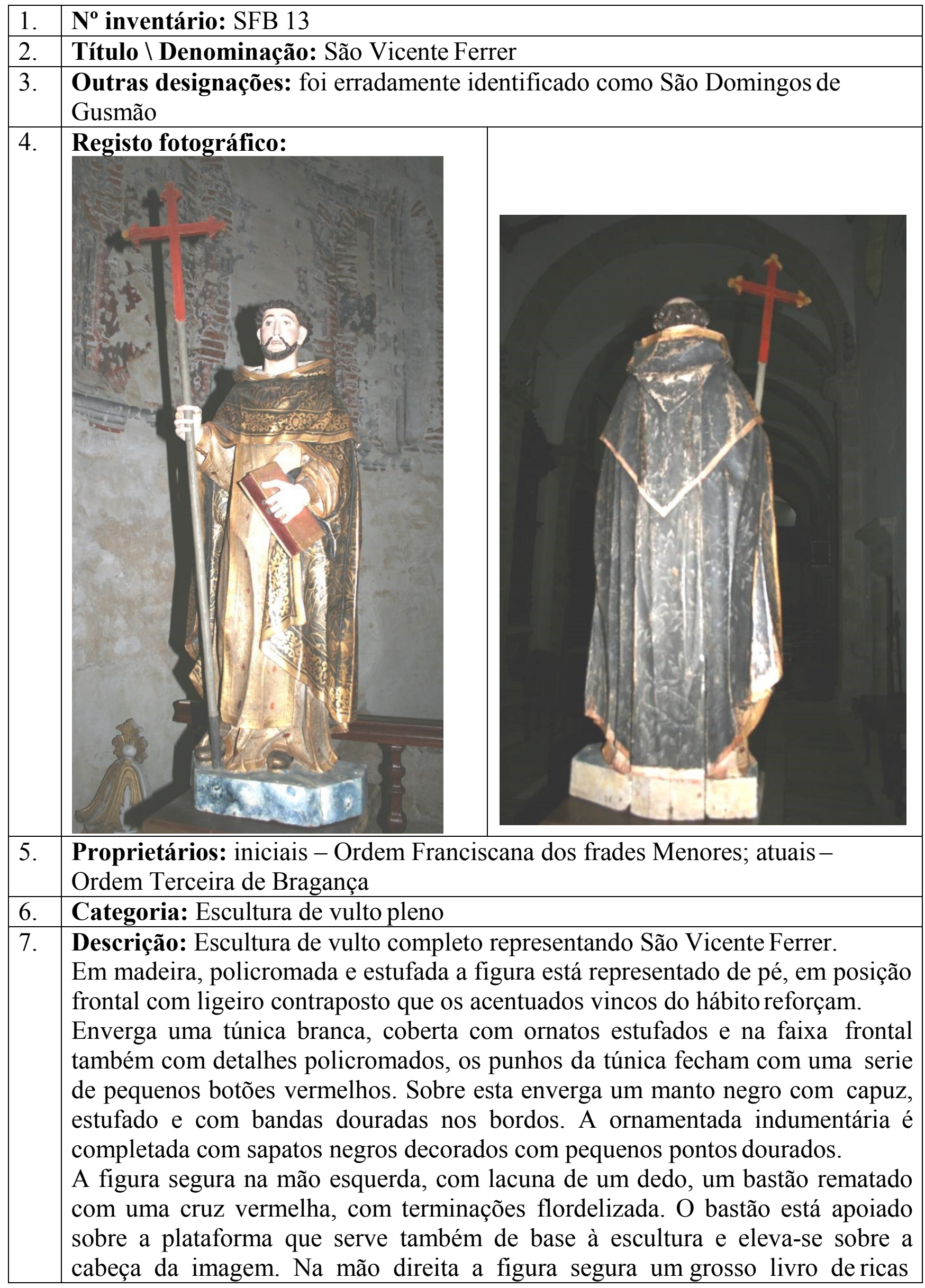




\begin{tabular}{|c|c|}
\hline & $\begin{array}{l}\text { lombadas vermelhas, excepto o dedo polegar todos os outros têm lacunas nas } \\
\text { pontas. Sobre o joelho direito há lacuna na policromia e estufagem. O rosto, com } \\
\text { sumário tratamento nos detalhes apresenta-se com barbas curtas e onduladas e } \\
\text { boca entreaberta mostrando os dentes, a cabeça tonsurada apresenta o cabelo } \\
\text { castanho e ondulado, tal como a barba. É evidente o cuidado nas mãos e pés } \\
\text { descalços, bem como nos panejamentos, no entanto, insuficiente para quebrar a } \\
\text { estaticidade da figura. Nas costas é possível observar o contorno da cavidade } \\
\text { rectangular que está escavada sobre toda a extensão da imagem desde o capuz até } \\
\text { aos pés, que se encontra ainda perfeitamente dissimulada pela pintura que a } \\
\text { cobre. A figura está assente sobre uma plataforma hexagonal em madeira } \\
\text { decorada com efeito marmoreado azul que lhe serve de plinto. } \\
\text { Está atualmente colocada na capela-mor em conjunto com uma escultura de São } \\
\text { Francisco de Assis (SFB 12), as semelhanças nos detalhes escultóricos e a atitude } \\
\text { de ambos parecem tratar-se de obras esculpidas pelo mesmo autor } \backslash \text { oficina. A } \\
\text { confusão na devoção que a imagem representa motivou a sua atual exposição, na } \\
\text { medida em que estava identificado como São Domingos de Gusmão, } \\
\text { comummente colocado em conjunto com São Francisco enquanto fundadores das } \\
\text { Ordens Mendicantes. }\end{array}$ \\
\hline 8. & Técnicas (de suporte): Talha \\
\hline 9. & Técnicas (de acabamento): Policromia; estufagem; marmoreado \\
\hline 10. & Materiais (de suporte): Madeira \\
\hline 11. & o): Pigmentos; folha de ouro \\
\hline 12. & $\begin{array}{l}\text { stado de Const } \\
\text { os dedos na mã }\end{array}$ \\
\hline 13. & $\begin{array}{l}\text { Dimensões: } \\
\text { Altura: } 160 \mathrm{~cm} \\
\text { Largura: } 58 \mathrm{~cm} \\
\text { Profundidade: } 35 \mathrm{~cm}\end{array}$ \\
\hline 14. & Restauro: apresenta sinais de reintegração cr \\
\hline 15. & \\
\hline 16. & Prov \\
\hline 17. & $\begin{array}{l}\text { Autoria Em conjunto com a escultura de São Francisco de Assis (SFB 12), as } \\
\text { semelhanças nos detalhes escultóricos e a atitude de ambos sugere tratar-se de } \\
\text { obras esculpidas pelo mesmo autor } \backslash \text { oficina. }\end{array}$ \\
\hline 18. & Oficina: Local $\backslash$ regional \\
\hline 19. & $\begin{array}{l}\text { Localização (inicial } \backslash \text { Atual Ini } \\
\text { atualmente está colocada na Car }\end{array}$ \\
\hline 20. & $\begin{array}{l}\text { Histórico do objeto: A devoção a São Vicente Ferrer foi registada no interior da } \\
\text { igreja por José Cardoso Borges, em } 1721-1724, \text { p. } 142\end{array}$ \\
\hline 21. & Iconografia: Hábito dominicano; bastão com cruz flordelizada; Livro. \\
\hline 22. & \\
\hline & em regi \\
\hline
\end{tabular}


Retábulo em pedra com detalhes maneiristas. Até aos finais do século XVIII era neste espaço que se enconrava a Capela da Imaculada Conceição, trasladada nos finais do século XVIII para o lado da epistola. Atualmente expõe as esculturas - SFB 14, SFB 15, SFB 16, SFB 17, SFB 18, SFB 19, SFB20.

Capela lateral adossada à capela mor do lado do Evangelho

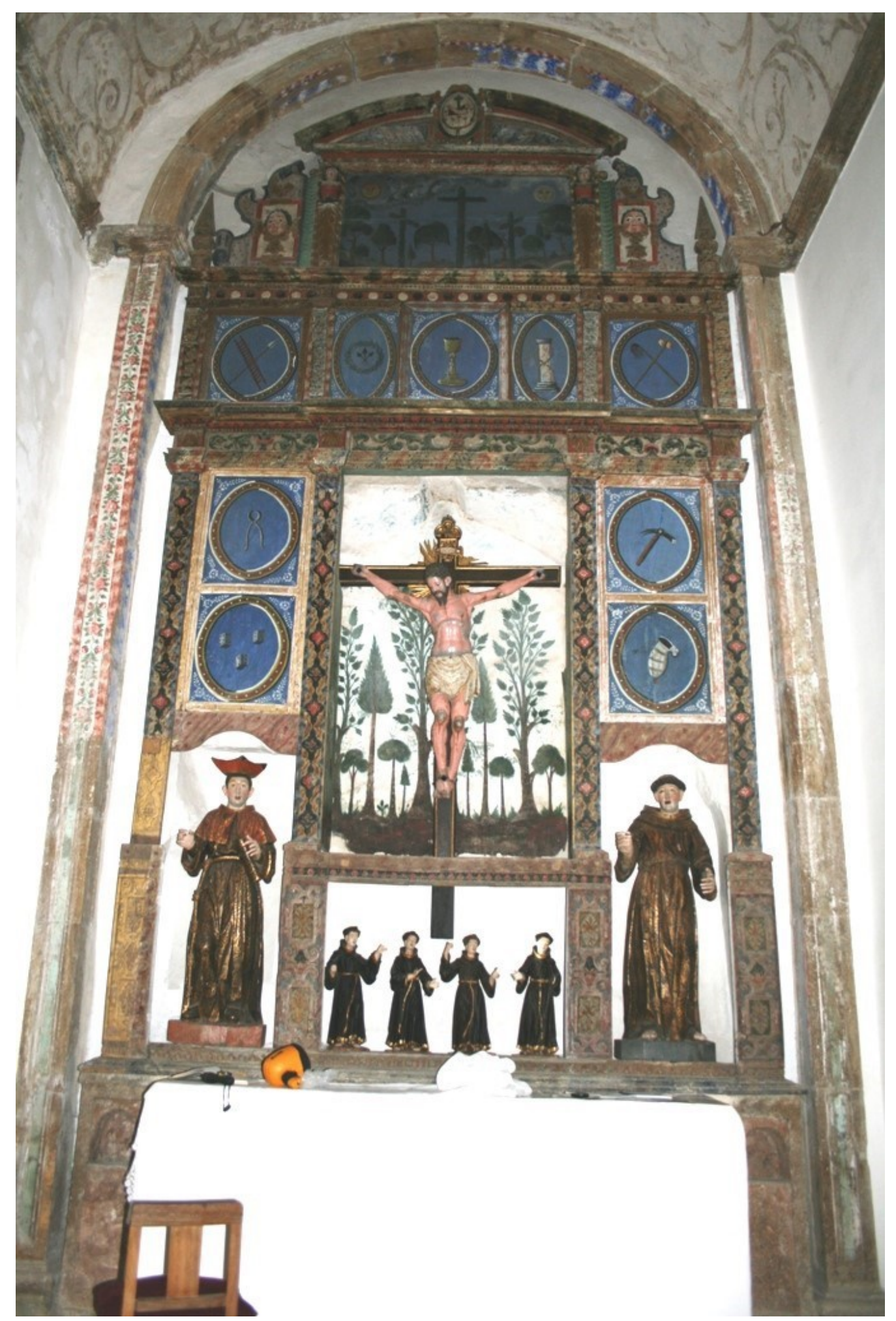


FICHAS DE INVENTÁRIO | ESCULTURA

Da Ordem de São Francisco na Diocese de Bragança-Miranda 


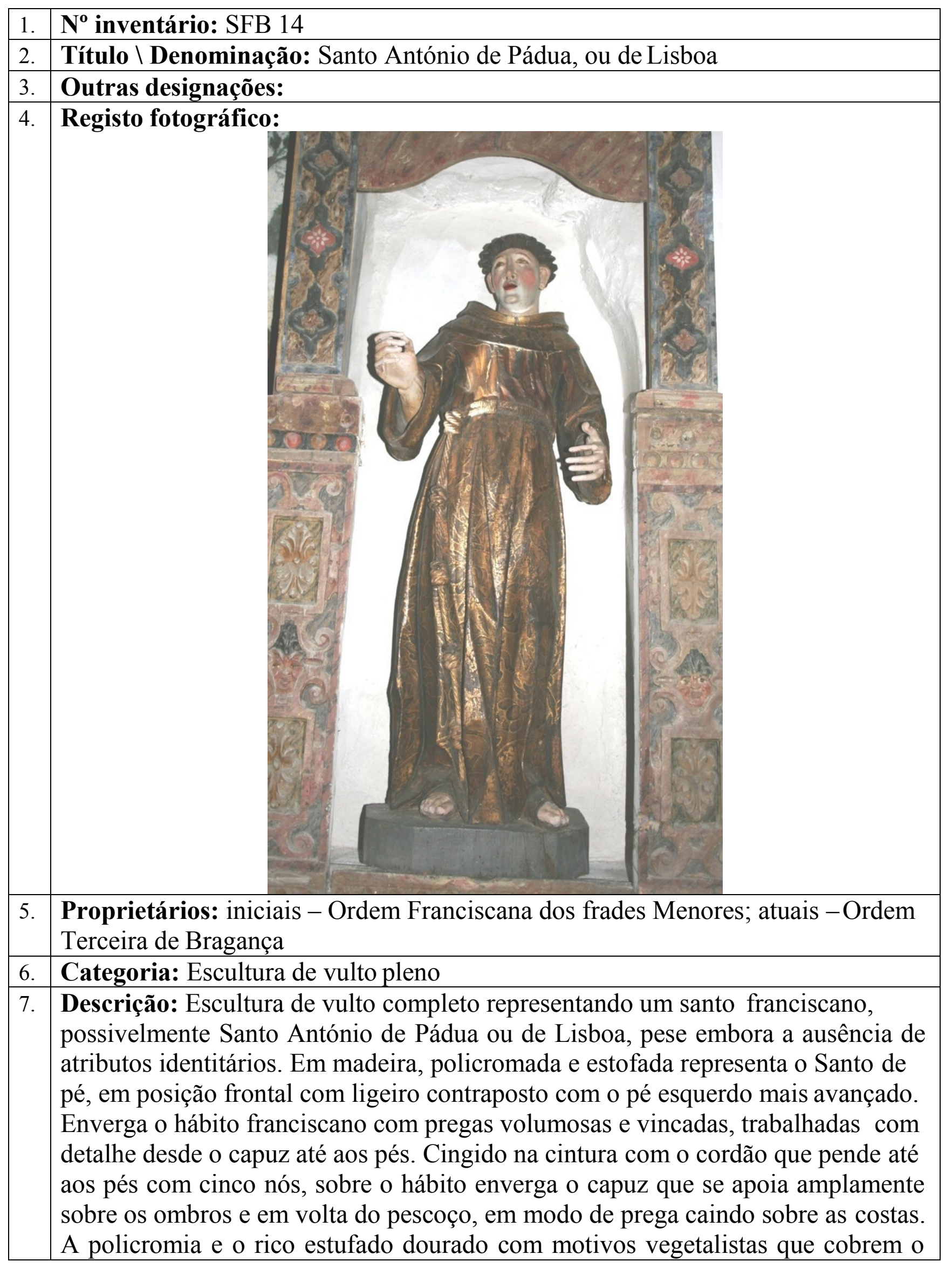




\begin{tabular}{|c|c|}
\hline & $\begin{array}{l}\text { hábito manifestam forte desgaste sobre o peito. Tem ambos braços fletidos, o } \\
\text { direito ligeiramente mais elevado. As mãos, também flectidas e trabalhadas com } \\
\text { algum detalhe denotam várias intervenções de restauro, todos os dedos, excepto o } \\
\text { polegar na mão esquerda e o mindinho o o indicador na direita, forma já repostos. } \\
\text { É evidente que na mão direita segurou algum atributo que já se perdeu. O rosto, de } \\
\text { linhas abonecadas e sumariamente talhado é na carnação que apresenta maior } \\
\text { cuidado, com lábios rubros e boca entreaberta e maças do rosto muito acentuadas } \\
\text { num tom avermelhado que contrasta fortemente com a clara carnação do rosto. Os } \\
\text { olhos, talhados na madeira sugerem que o olhar se eleva. A cabeça com cercilho } \\
\text { de largos caracóis que envolvem o rosto. Os pés, descalços ligeiramente afastados } \\
\text { apenas protegidos com as sandálias reforçam o ligeiro contraposto sugerido nas } \\
\text { pregas do hábito detalhadamente trabalhadas, sem no entanto quebrarem a } \\
\text { estaticidade da figura. A figura está assente sobre uma plataforma, hexagonal } \\
\text { decorada num tom azul. É de referir a semelhança observadas nos detalhes } \\
\text { escultóricos do talhe do rosto bem como o estufado que decora o hábito entre a } \\
\text { presente escultura (SFB 14) e a escultura de São Boaventura (SFB 15) parecendo } \\
\text { tratar-se de obras esculpidas pelo mesmo autor } \backslash \text { oficina. }\end{array}$ \\
\hline 8. & Técnicas (de suporte): Talha \\
\hline 9. & $\begin{array}{l}\text { Técnicas (de acabamento): policromia; estu } \\
\text { idêntica aos motivos dos estufados das image }\end{array}$ \\
\hline 10. & Materiais (de suporte): Madeira \\
\hline 11. & Materiais (de acabamento): Pigmentos; folha de ouro \\
\hline 12. & $\begin{array}{l}\text { Estado de Conservação: Bom; apresenta-se se estável; (não podemos observar as } \\
\text { costas) }\end{array}$ \\
\hline 13. & $\begin{array}{l}\text { Dimensões: } \\
\text { Altura: } 136 \mathrm{~cm} \\
\text { Largura: } 53 \mathrm{~cm} \\
\text { Profundidade: } 38 \mathrm{~cm}\end{array}$ \\
\hline 14. & Restauro: apresenta sinais de reintegração cromática \\
\hline 15. & Datas: século XVII \\
\hline 16. & Proveniência: Igreja de São Francisco de Bragança \\
\hline 17. & $\begin{array}{l}\text { Autoria: desconhecida; mas a semelhança observada nos detalhes escultóricos do } \\
\text { rosto e panejamentos com a escultura SFB 14. Os ornatos estufados que decoram } \\
\text { o hábito são idênticos aos das esculturas SFB } 12 \text { e SFB } 13 \text { sugerindo esse } \\
\text { acrescento decorativo posterior }\end{array}$ \\
\hline 18. & Oficina Local $\backslash$ regional \\
\hline 19. & $\begin{array}{l}\text { Localização (atual): A escultura está colocado no retábulo da capela lateral do } \\
\text { lado do Evangelho }\end{array}$ \\
\hline 20. & eto: não se conhecem registos \\
\hline 21. & \\
\hline 22. & \\
\hline 23 & es: não se conhecem registos \\
\hline
\end{tabular}




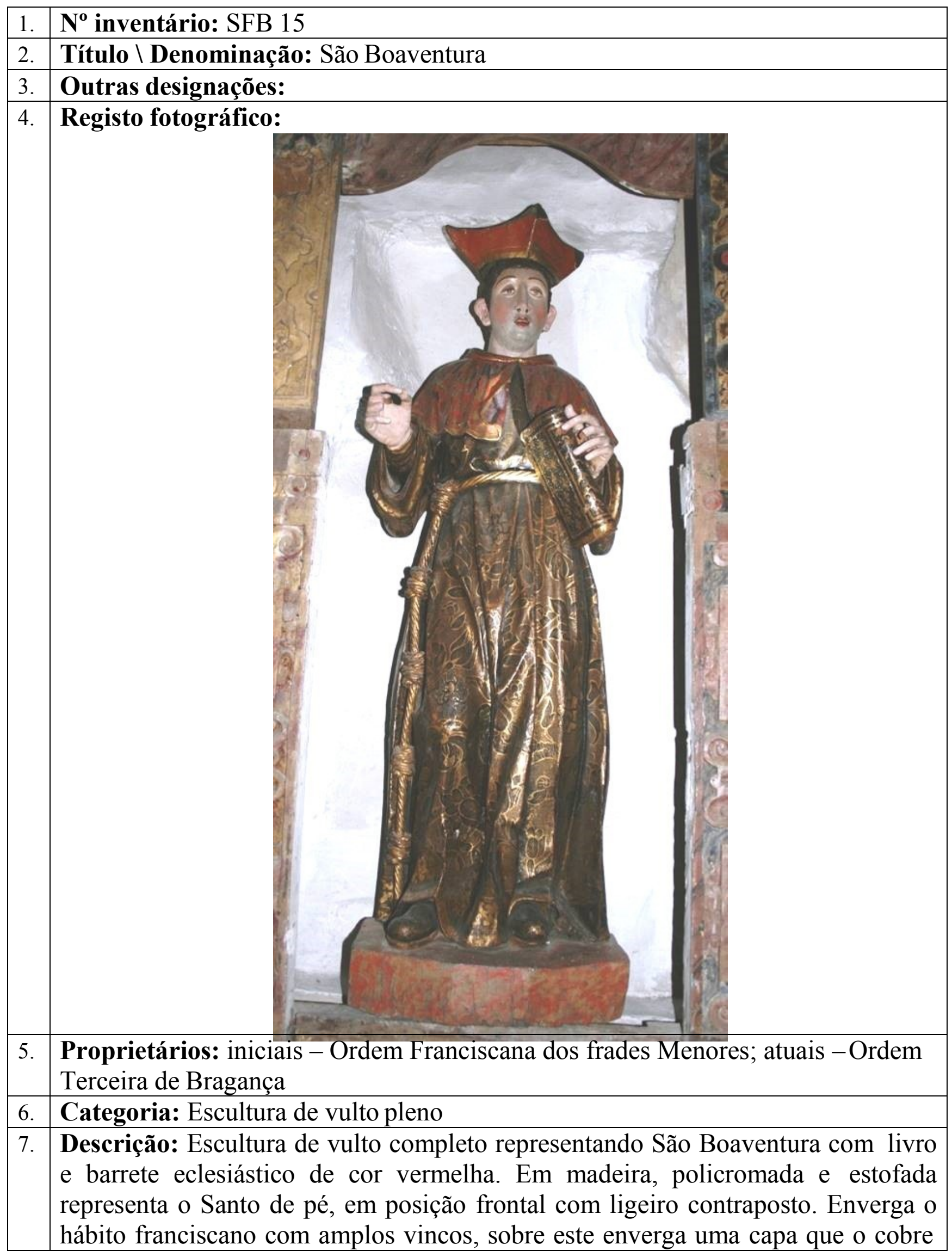




\begin{tabular}{|l|l|}
\hline & $\begin{array}{l}\text { até aos ombros, de cor vermelha com motivos vegetalistas estofado. O hábito está } \\
\text { cingido na cintura com o cordão que pende até aos pés com cinco nós. Na cabeça } \\
\text { ostenta um barrete eclesiástico de cor vermelha com quatro bicos, decorado com } \\
\text { motivos geométricos estofados. Enverga sapatos negros com pequenos pontos } \\
\text { dourados (iguais aos da imagem SFB 13), reforçando a ideia de repinte posterior } \\
\text { da obra aquando do acrescento dos motivos estufados. Tem ambos braços fletidos, } \\
\text { segura na mão esquerda um livro com capa negra ricamente estofada, a mão tem } \\
\text { lacuna de um dedo, a mão direita sugere ter também segurado algo pois apresenta } \\
\text { o dedo indicador unido ao polegar, tem lacuna de dois dedos. O rosto jovem, } \\
\text { sumariamente talhado é na carnação que apresenta maior cuidado, com os olhos } \\
\text { talhados e pintados sobre a madeira lábios rubros e boca entreaberta deixando ver } \\
\text { os dentes (quer nos contornos do rosto quer na carnação a imagem assemelha-se à } \\
\text { SFB 14). Apresenta o cabelo curto sob o barrete. A figura está assente sobre uma } \\
\text { plataforma, hexagonal decorada com marmoreado em tom laranja. É de referir a } \\
\text { semelhança observadas nos detalhes escultóricos do talhe do rosto bem como nos } \\
\text { panejamentos entre a presente escultura com a escultura de Santo António (SFB }\end{array}$ \\
\hline 14) parecendo tratar-se de obras esculpidas pelo mesmo autor $\backslash$ oficina.
\end{tabular}




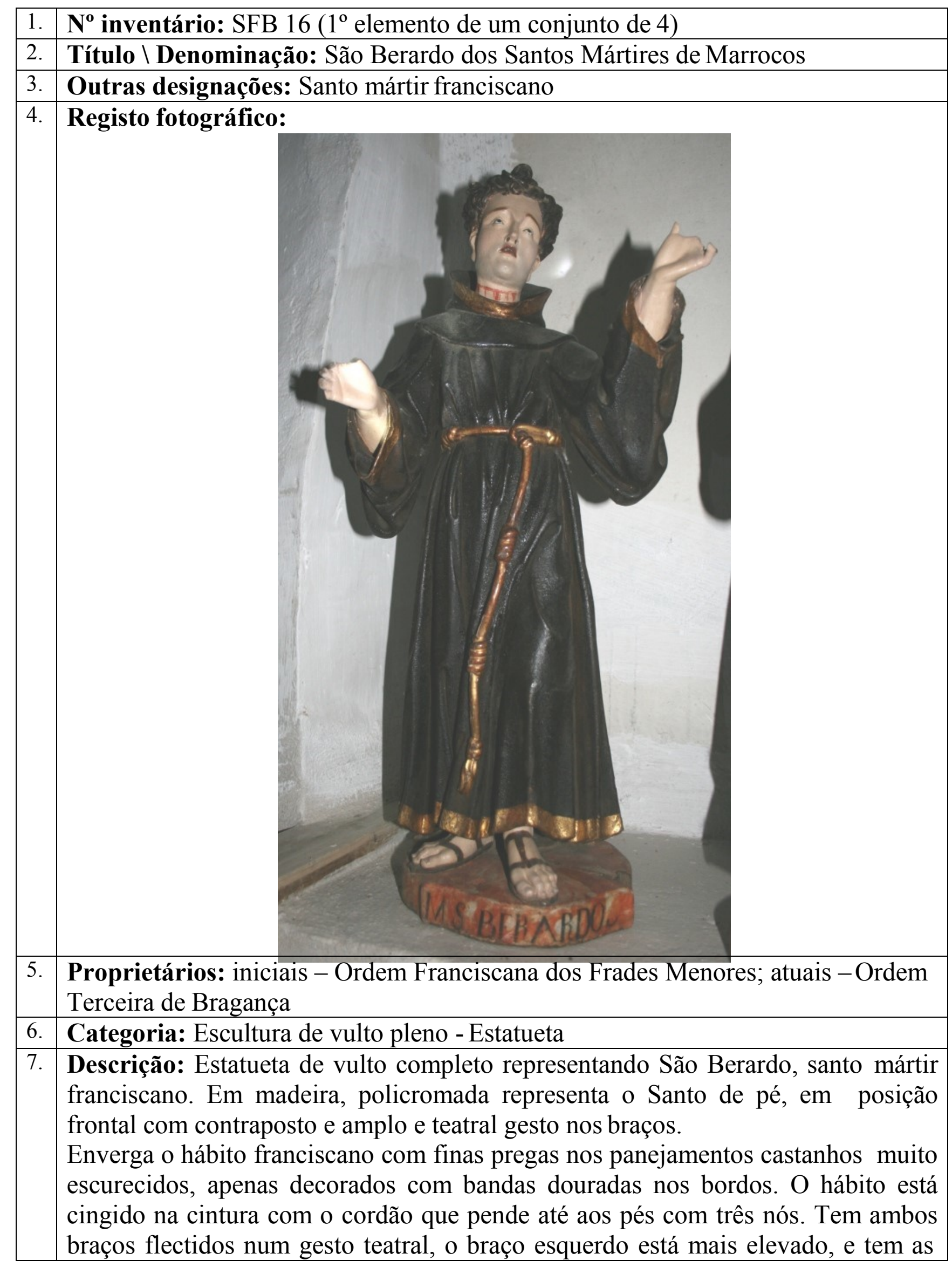




\begin{tabular}{|c|c|}
\hline & $\begin{array}{l}\text { palmas das mãos voltadas para o observador, tem lacuna de todos os dedos nas } \\
\text { duas mãos. Enverga sandálias que estão pintadas sobre os pés detalhadamente } \\
\text { esculpidos. } \\
\text { O rosto jovem de linhas suaves, ligeiramente voltado para a esquerda está } \\
\text { finamente talhado e coberto de carnação com craquele. Tem os olhos de vidro que } \\
\text { simulam o olhar que se eleva, a boca entreaberta, de lábios rubros e cantos } \\
\text { descaídos, deixando ver os dentes. } \\
\text { Apresenta a cabeça tonsurada e o cabelo castanho em vastos e assimétricos } \\
\text { caracóis em volta do rosto. Sobre o pescoço é possível ver a linha de sangue da } \\
\text { degolação que o martirizou. } \\
\text { A figura destaca-se pela teatral assimetria no gesto dos braços que lhe imprime } \\
\text { dinamismo e pelo cuidado com o talhe anatómico e com os finos vincos dos } \\
\text { panejamentos. } \\
\text { A figura está assente sobre uma plataforma, de linhas barrocas decorada com } \\
\text { marmoreado em tom laranja, na frente da plataforma pode ler-se M.S.BERARDO. } \\
\text { Faz parte de um conjunto de quatro Santos Mártires (originalmente eram cinco } \\
\text { porém o quinto elemento encontra-se de momento desaparecido). As semelhanças } \\
\text { observadas nos detalhes escultóricos do talhe de todas as esculturas que fazem } \\
\text { parte do conjunto sendo evidente tratar-se de obras esculpidas pelo mesmo autor } \\
\text { oficina. }\end{array}$ \\
\hline 8. & Técnicas (de suporte): Talha \\
\hline 9. & Técnicas (de acab: \\
\hline 10. & Materiais (de suporte): Madeira \\
\hline 11. & Materiais (de acabamento): Pigmentos; folha de ouro; vidro \\
\hline 12. & Estado de Conservação: Bom; apresenta-se se estável; lacunas c \\
\hline 13. & $\begin{array}{l}\text { Dimensões: } \\
\text { Altura: } 60 \mathrm{~cm} \\
\text { Largura: } 30 \mathrm{~cm} \\
\text { Profundidade: } 22 \mathrm{~cm}\end{array}$ \\
\hline 14. & Restauro: apresenta sinais de reintegração cromática \\
\hline 15. & Datas: primeiro quarte do século XVIII \\
\hline 16. & Proveniência: Igreja de São Francisco de Bragança \\
\hline 17. & $\begin{array}{l}\text { Autoria É de referir a semelhança observada nos detalhes escultóricos do talhe de } \\
\text { todas as esculturas que fazem parte do conjunto dos Santos Mártires de Marrocos } \\
\text { sendo evidente tratar-se de obras esculpidas pelo mesmo autor } \backslash \text { oficina. }\end{array}$ \\
\hline 18. & Oficina: Nacional \\
\hline 19. & $\begin{array}{l}\text { Localização (atual): A escultura está colocado no retábulo da capela lateral do } \\
\text { lado do Evangelho }\end{array}$ \\
\hline 20. & Histórico do objeto: não se conhecem registos \\
\hline 21. & ranciscano; marca de martírio sobre \\
\hline 22. & \\
\hline & se conhecem registos \\
\hline
\end{tabular}




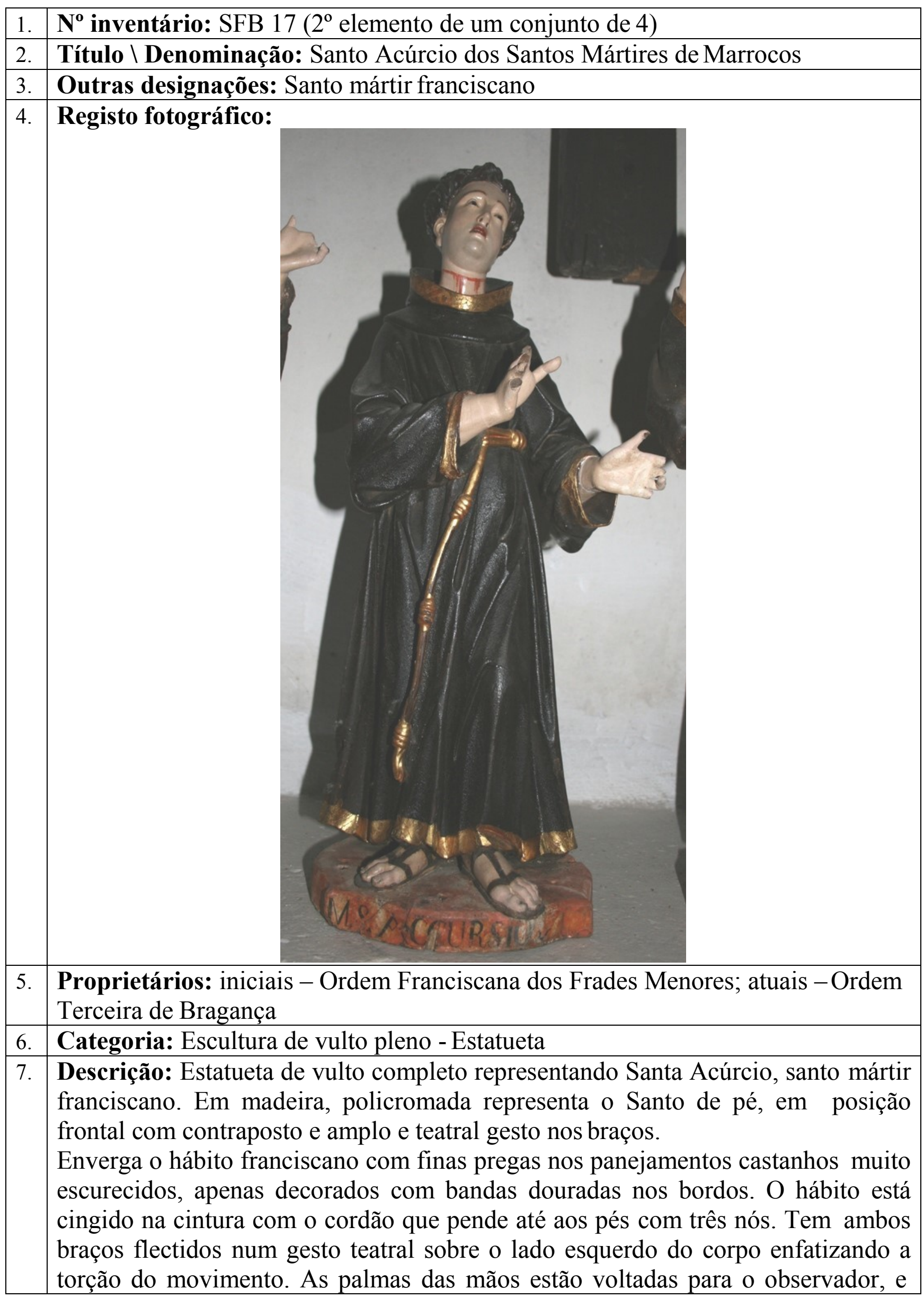




\begin{tabular}{|c|c|}
\hline & $\begin{array}{l}\text { tem lacunas de três dedos na mão esquerda e quatro na direita, o que não impede } \\
\text { ver o detalhe anatómico dos membros. Enverga sandálias que estão pintadas sobre } \\
\text { os pés cuidadosamente esculpidos. } \\
\text { O rosto jovem, finamente esculpido, apresenta linhas suaves está coberto com } \\
\text { carnação com craquele. Ligeiramente voltado para a esquerda, tem olhos de vidro } \\
\text { que simulam o olhar que se eleva, a boca está entreaberta, de lábios rubros e } \\
\text { cantos descaídos, deixando ver os dentes. Não apresenta tonsura mas sim o cabelo } \\
\text { castanho em vastos e assimétricos caracóis em volta do rosto. Sobre o pescoço é } \\
\text { possível ver a linha de sangue da degolação que o martirizou. } \\
\text { A figura destaca-se pela teatralidade dinâmica do gesto dos braços e pelo cuidado } \\
\text { com o talhe anatómico e das finas pregas dos panejamentos. } \\
\text { A figura está assente sobre uma plataforma, de linhas barrocas decorada com } \\
\text { marmoreado em tom laranja, na frente da plataforma pode ler-se } \\
\text { M.S.ACCURSIO. } \\
\text { Faz parte de um conjunto de quatro Santos Mártires (originalmente eram cinco } \\
\text { porém o quinto elemento encontra-se de momento desaparecido) É de referir as } \\
\text { semelhanças observadas nos detalhes escultóricos do talhe de todas as esculturas } \\
\text { que fazem parte do conjunto sendo evidente tratar-se de obras esculpidas pelo } \\
\text { mesmo autor } \backslash \text { oficina. }\end{array}$ \\
\hline 8. & Técnicas (de suporte): Talha \\
\hline 9. & Técnicas (de acabamento): Policromia; dourado; marmoreado \\
\hline 10. & Materiais (de suporte): Madeira \\
\hline 11. & Materiais (de acabamento): Pigmentos; folha de ouro (?); vidro \\
\hline 12. & Estado de Conservação: Bom; apresenta-se se estável; lacunas em sete dedos \\
\hline 13. & $\begin{array}{l}\text { Dimensões: } \\
\text { Altura: } 60 \mathrm{~cm} \\
\text { Largura: } 23 \mathrm{~cm} \\
\text { Profundidade: } 23 \mathrm{~cm}\end{array}$ \\
\hline 14. & Restauro: apresenta sinais de reintegração cromática \\
\hline 15. & Datas: primeiro quarte do século XVIII \\
\hline 16. & Proveniência: Igreja de São Francisco de Bragança \\
\hline 17. & $\begin{array}{l}\text { Autoria É de referir a semelhança observada nos detalhes escultóricos do talhe de } \\
\text { todas as esculturas que fazem parte do conjunto sendo evidente tratar-se de obras } \\
\text { esculpidas pelo mesmo autor } \backslash \text { oficina. }\end{array}$ \\
\hline 18. & Oficina: Nacional \\
\hline 19. & $\begin{array}{l}\text { Localização (atual): A escultura está colocado no retábulo da capela lateral do } \\
\text { lado do Evangelho }\end{array}$ \\
\hline 20. & Histórico do objeto: não se conhecem registos \\
\hline 21. & Iconografia: hábito franciscano; marca de martírio sobre o pescoço \\
\hline 22. & Irmandade: não se conhecem registos \\
\hline 23. & Procissões: não se conhecem registos \\
\hline
\end{tabular}




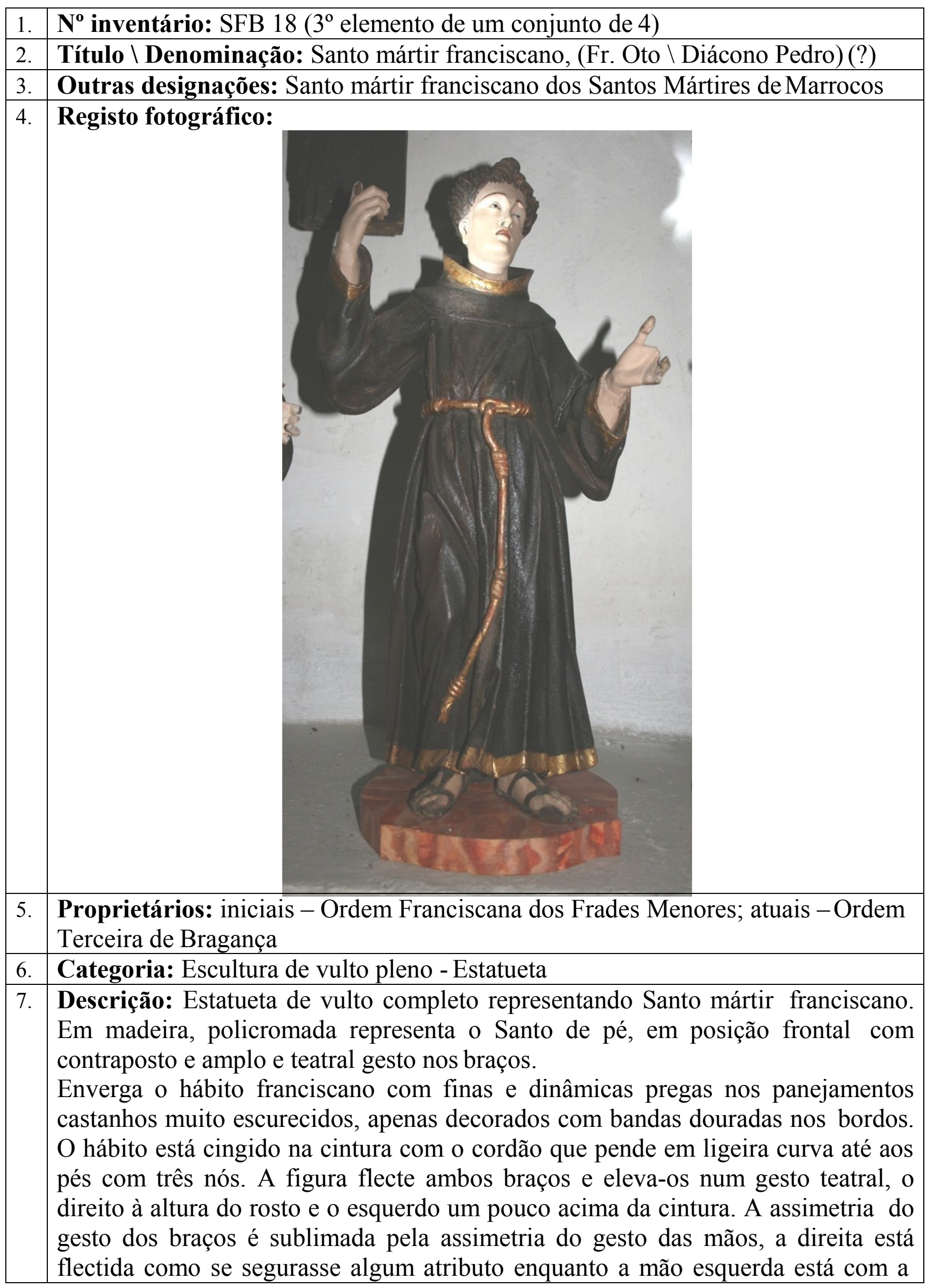




\begin{tabular}{|c|c|}
\hline & $\begin{array}{l}\text { palma voltada para a frente, têm ambas lacunas nos dedos ( } 4 \text { dedos na esquerda e } \\
\text { um na direita) o que não impede ver o detalhe anatómico dos membros. Enverga } \\
\text { sandálias que estão pintadas sobre os pés cuidadosamente esculpidos, tem lacuna } \\
\text { de um dedo no pé esquerdo. O rosto jovem, finamente esculpido está coberto com } \\
\text { carnação com craquele, apresenta linhas suaves na boca entreaberta, de lábios } \\
\text { rubros e cantos descaídos, deixando ver os dentes. Os olhos de vidro que simulam } \\
\text { o olhar que se eleva reforçam a ligeira inclinação da cabeça para a esquerda. } \\
\text { Apresenta tonsura e o cercilho castanho com vastos e assimétricos caracóis em } \\
\text { volta do rosto. Não é observável qualquer sinal de martírio. } \\
\text { Destaca-se pela teatralidade dinâmica do gesto dos braços e pelo cuidado com o } \\
\text { talhe anatómico e das finas pregas dos panejamentos. } \\
\text { A figura está assente sobre uma plataforma, de linhas barrocas em recorte } \\
\text { ondulado decorada com marmoreado em tom laranja, sem qualquer legenda que a } \\
\text { identifique. } \\
\text { Faz parte de um conjunto de quatro Santos Mártires (originalmente eram cinco } \\
\text { porém o quinto elemento encontra-se de momento desaparecido) É de referir as } \\
\text { semelhanças observadas nos detalhes escultóricos do talhe de todas as esculturas } \\
\text { que fazem parte do conjunto sendo evidente tratar-se de obras esculpidas pelo } \\
\text { mesmo autor } \backslash \text { oficina. }\end{array}$ \\
\hline 8. & Técnicas (de suporte): Talha \\
\hline 9. & Técnicas (de acabamento): Policromia; dourado; marmoreado \\
\hline 10. & Materiais (de suporte): Madeira \\
\hline 11. & Materiais (de acabamento): Pigmentos; folha de ouro; vidro \\
\hline 12. & Estado de Conservação: Bom; apresenta-se se estável; lacunas em sete dedos \\
\hline 13. & $\begin{array}{l}\text { Dimensões: } \\
\text { Altura: } 58 \mathrm{~cm} \\
\text { Largura: } 30 \mathrm{~cm} \\
\text { Profundidade: } 14 \mathrm{~cm}\end{array}$ \\
\hline 14. & Restauro: apresenta sinais de reintegração cromática \\
\hline 15. & Datas: primeiro quartel do século XVIII \\
\hline 16. & Proveniência: Igreja de São Francisco de Bragança \\
\hline 17. & $\begin{array}{l}\text { Autoria É de referir a semelhança observada nos detalhes escultóricos do talhe de } \\
\text { todas as esculturas que fazem parte do conjunto sendo evidente tratar-se de obras } \\
\text { esculpidas pelo mesmo autor } \backslash \text { oficina. }\end{array}$ \\
\hline 18. & Oficina: Nacional \\
\hline 19. & $\begin{array}{l}\text { Localização (atual): A escultura está colocado no retábulo da capela lateral do } \\
\text { lado do Evangelho }\end{array}$ \\
\hline 20. & Histórico do objeto: não se conhecem registos \\
\hline 21. & Iconografia: hábito franciscano \\
\hline 22. & Irmandade: não se conhecem registos \\
\hline 23. & Procissões: não se conhecem registos \\
\hline
\end{tabular}




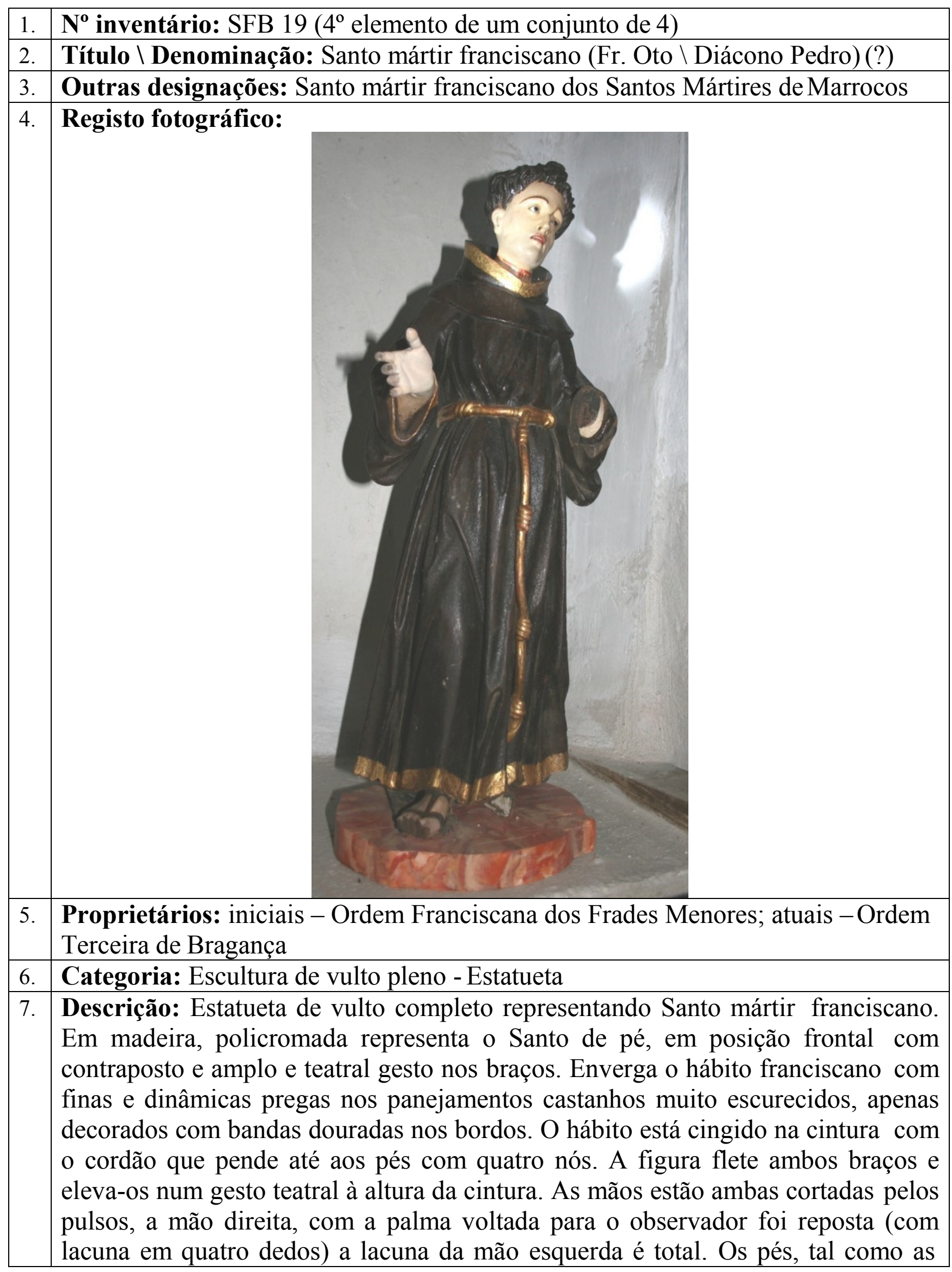




\begin{tabular}{|c|c|}
\hline & $\begin{array}{l}\text { mãos apresentam significativas lacunas, da quase totalidade do pé esquerdo e da } \\
\text { extremidade de todos os dedos do pé direito, ambos envergam sandálias que estão } \\
\text { pintadas sobre os pés cuidadosamente esculpidos. O rosto jovem, finamente } \\
\text { esculpido está coberto com carnação com craquele, com coloração mais } \\
\text { escurecida em volta da boca e queixo sugerindo a barba. Apresenta linhas suaves } \\
\text { na boca entreaberta, de lábios rubros e cantos descaídos, deixando ver os dentes. } \\
\text { Os olhos de vidro que simulam o olhar que se eleva reforçam a ligeira inclinação } \\
\text { da cabeça para a direita. Apresenta tonsura e o cabelo castanho em amplos e } \\
\text { assimétricos caracóis em volta do rosto. Em volta do pescoço apresenta a marca } \\
\text { de sangue do martírio. Destaca-se pela teatralidade dinâmica do gesto dos braços e } \\
\text { pelo cuidado com o talhe anatómico e das finas pregas dos panejamentos. A figura } \\
\text { está assente sobre uma plataforma, de linhas barrocas em recorte ondulado } \\
\text { decorada com marmoreado em tom laranja, sem qualquer legenda que a } \\
\text { identifique. Faz parte de um conjunto de quatro Santos Mártires (originalmente } \\
\text { eram cinco porém o quinto elemento encontra-se de momento desaparecido) É de } \\
\text { referir as semelhanças observadas nos detalhes escultóricos do talhe de todas as } \\
\text { esculturas que fazem parte do conjunto sendo evidente tratar-se de obras } \\
\text { esculpidas pelo mesmo autor } \backslash \text { oficina. }\end{array}$ \\
\hline 8. & Técnicas (de suporte): Talha \\
\hline 9. & Téc \\
\hline 10. & Mate \\
\hline 11. & to): Pigmentos; folha de ouro; vidro \\
\hline 12. & $\begin{array}{l}\text { 1; Significativas lacunas de } \\
\text { mentos na policromia. }\end{array}$ \\
\hline 13. & $\begin{array}{l}\text { Dime } \\
\text { Altura } \\
\text { Largu } \\
\text { Profur }\end{array}$ \\
\hline 14. & $\begin{array}{l}\text { Restauro: a mão direita parece ter sido reposta recentemente e apresenta sinais de } \\
\text { reintegração cromática }\end{array}$ \\
\hline 15. & Datas: primeiro quarte do século XVIII \\
\hline 16. & \\
\hline 17. & $\begin{array}{l}\text { Autoria É de referir a semelhança observada nos detalhes escultóricos do talhe de } \\
\text { todas as esculturas que fazem parte do conjunto sendo evidente tratar-se de obras } \\
\text { esculpidas pelo mesmo autor } \backslash \text { oficina. }\end{array}$ \\
\hline 18. & Oficina: Nacional \\
\hline 19. & $\begin{array}{l}\text { Localização (atual): A escultura está colocado no retábulo da capela lateral do } \\
\text { lado do Evangelho }\end{array}$ \\
\hline 20. & eto: não se conhecem registos \\
\hline 21. & sobre o \\
\hline 22. & \\
\hline 23 & s: não se conhecem registos \\
\hline
\end{tabular}




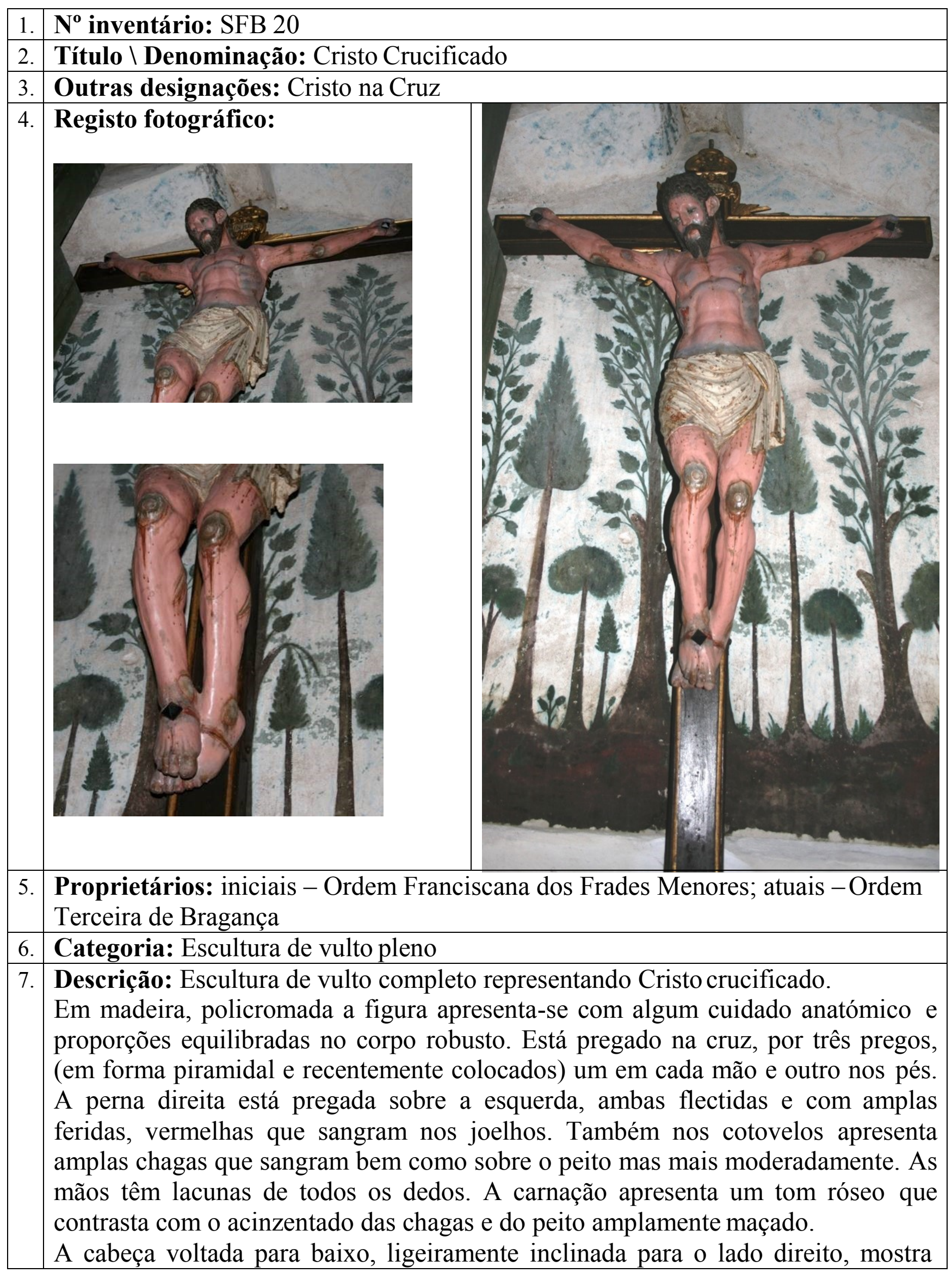




\begin{tabular}{|l|l|}
\hline & $\begin{array}{l}\text { uma expressão de sereno sofrimento. O rosto apresenta o olhar baixo, pálpebras } \\
\text { semi-cerradas lábios fechados e barbas pontiagudas bifurcadas. O cabelo é } \\
\text { castanho, tal como a barba, farto e ondulado com uma madeixa presa detrás da } \\
\text { orelha esquerda e a restante cabeleira esculpida caída sobre as costas. } \\
\text { Sobre a testa escorrem pequenas gotas de sangue e o tom acinzentado em volta das } \\
\text { barbas e dos olhos intensificam o dramatismo da figura. O perisónio que o cinge } \\
\text { está esculpido com finas pregas que o prendem sobre o lado esquerdo, acompanha } \\
\text { a volumetria do corpo e cai de forma estática. Na base podemos ainda observar } \\
\text { dois orifícios perfurados sobrepostos na vertical (sugerindo que a escultura já } \\
\text { esteve colocada sobre uma base). Sobre o cruzeiro tem um resplendor raiado em } \\
\text { talha dourada. Em talha dourada é também a cartela que encima a cruz, decorada } \\
\text { com enrolamentos e sobre a qual está incisa a legenda INRI. A cruz é rematada por } \\
\text { uma forma trilobada em talha dourada. }\end{array}$ \\
\hline 8. & Técnicas (de suporte): Talha \\
\hline 9. & Técnicas (de acabamento): Policromia \\
\hline 10 & Materiais (de suporte): Madeira \\
\hline 11 & Materiais (de acabamento): Pigmentos; folha de ouro \\
\hline 12 & $\begin{array}{l}\text { Estado de Conservação: Bom; apresenta-se se estável; com lacunas em todos os } \\
\text { dedos. }\end{array}$ \\
\hline 13 & $\begin{array}{l}\text { Dimensões: } \\
\text { Altura: } 228 \text { cm } \\
\text { Largura: } 120 \text { cm } \\
\text { Profundidade: } 38 \text { cm }\end{array}$ \\
\hline 14 & Restauro: apresenta sinais de reintegração cromática \\
\hline 15 & Datas: primeira metade do século XVII \\
\hline 16 & Proveniência: Igreja de São Francisco de Bragança \\
\hline 17 & Autoria: desconhecida \\
\hline 18 & Oficina: Nacional \\
\hline 19 & $\begin{array}{l}\text { Localização (inicial } \backslash \text { atual) A escultura estava em 1721-1724 na capela da Ordem } \\
\text { Terceira (atual Capela da Imaculada Conceição). Hoje está colocada no retábulo da } \\
\text { capela lateral do lado do Evangelho }\end{array}$ \\
\hline 20 & Histórico do objeto: não se conhecem registos \\
\hline 21 & Iconografia: Cruz; chagas \\
\hline 22 & $\begin{array}{l}\text { Irmandade: A escultura pertencia originalmente à Ordem Terceira Secular, refere } \\
\text { José Cardoso Borges, em 1721-1724, p. 142 }\end{array}$ \\
\hline 23 & Procissões: não se conhecem registos \\
\hline
\end{tabular}




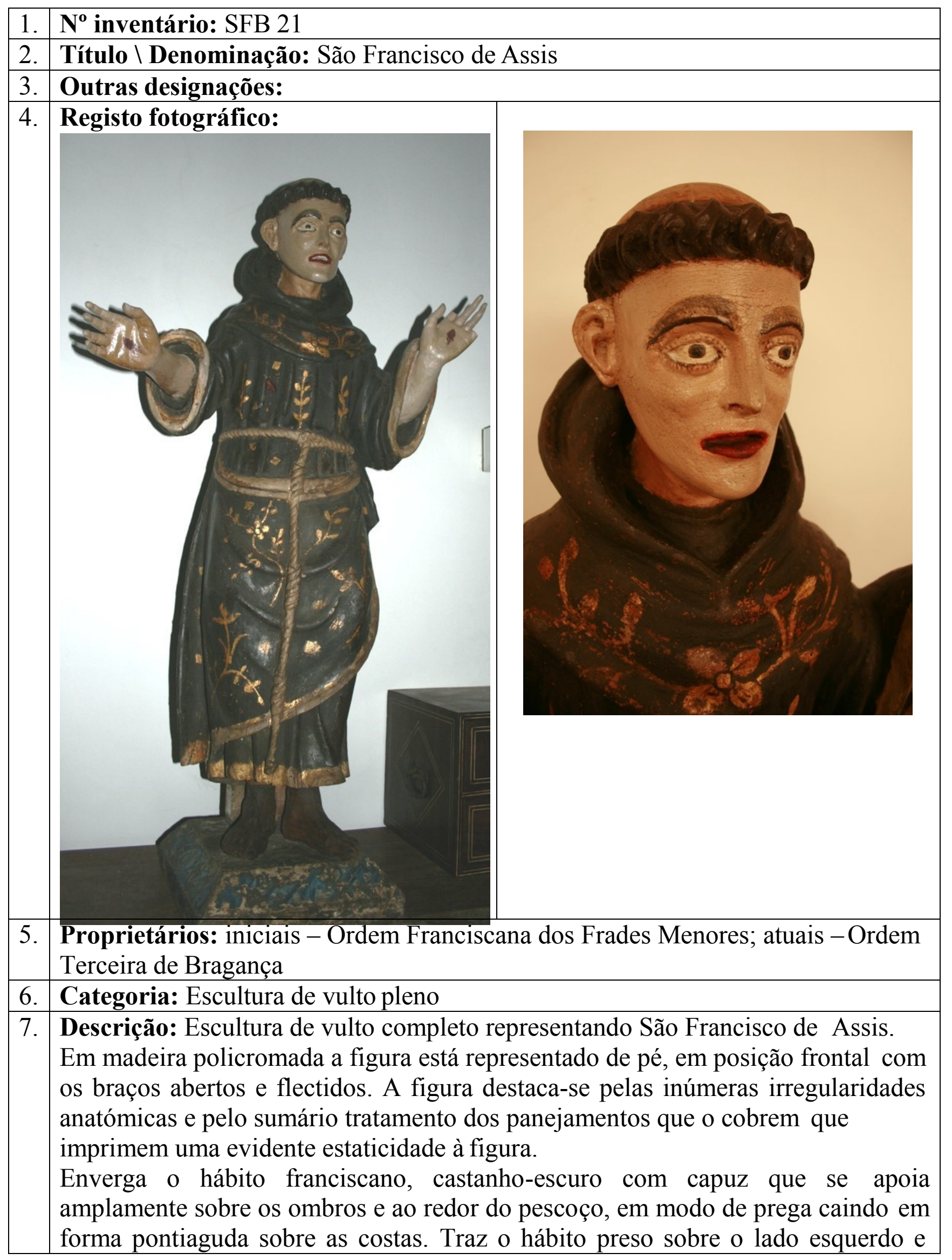




\begin{tabular}{|l|l|}
\hline cingido na cintura com o cordão que pende até aos pés com três nós, sobre o \\
hábito estão pintados motivos vegetalistas simples a dourado. Sobre o peito o \\
hábito está rasgado mostrando o estigma sofrido. As costas estão cobertas com \\
pequenos quadrados pintados a dourados e a madeira do hábito prolonga-se até à \\
base, de modo a reforçar a estabilidade da imagem. \\
Os braços abertos assimetricamente e flectidos emergem dos panejamentos \\
sumariamente tratados mostram ambas mãos abertas e voltadas para o observador \\
ostentando nas palmas os estigmas que as marcam. O braço direito é acrescento \\
posterior pois a evidente linha de junção com o corpo da peça não só evidencia \\
restos de cola como é consolidada com um parafuso. A mão esquerda apresenta \\
lacunas em dois dedos, os restantes forma colados. \\
O rosto, com sumário tratamento nos detalhes, o repinte da policromia deixou \\
enormes olhos, encimados por exageradamente espessas sobrancelhas, que fixam \\
o olhar em frente com expressão de espanto, a boca entreaberta com os cantos \\
descaídos, mostrando os dentes reforça a expressão. A cabeça tonsurada apresenta \\
o cabelo castanho com ondas regulares. Os pés, tal como o braço direito, foram \\
também intervencionados, sendo evidente que se trata de acrescentos pelas linhas \\
de junção visíveis, estão esculpidos em madeira sempolicromia. \\
A figura está assente sobre uma plataforma quadrangular em madeira decorada \\
com efeito marmoreado azul que lhe serve de plinto e apresentam inúmeras \\
marcas de infestação de insectos xilófagos.
\end{tabular}




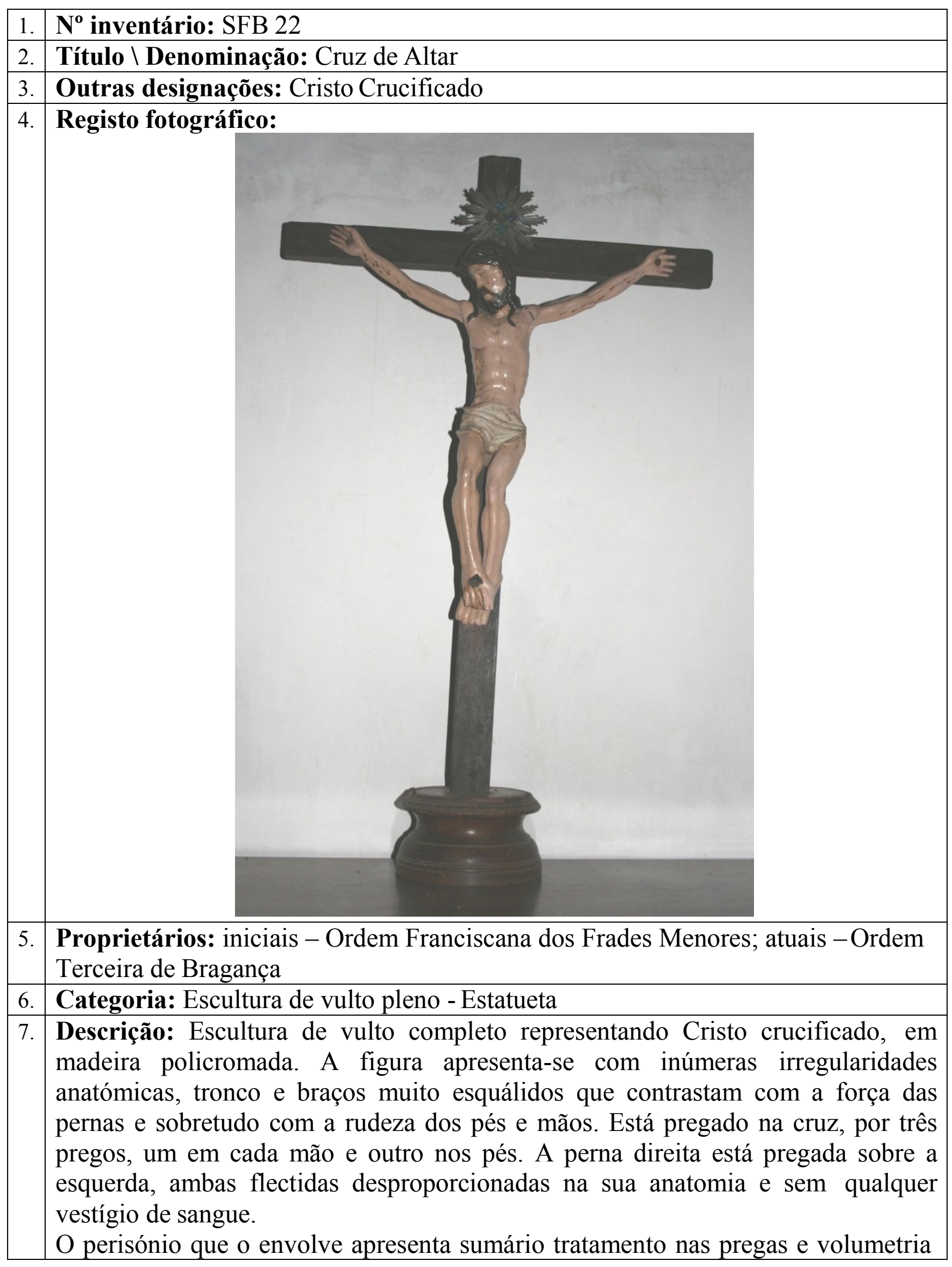




\begin{tabular}{|l|l|}
\hline & $\begin{array}{l}\text { caindo de forma estática } \\
\text { A cabeça voltada para baixo, ligeiramente inclinada para o lado direito. O rosto } \\
\text { apresenta também irregularidades nos contornos que o definem, tem a boca } \\
\text { entreaberta e os olhos quase imperceptíveis pintados sobre a carnação, e barbas } \\
\text { longas pontiagudas e bifurcadas. A carnação, seguramente posterior, é clara e } \\
\text { brilhante com craquele, apenas interrompida pelo tom vermelho acastanhado de } \\
\text { pequenas gotas a sugerir o sangue sobre a testa, mãos e pés e na chaga do peito. } \\
\text { O cabelo é castanho, tal como a barba, longo e ondulado com madeixas esculpidas } \\
\text { sobre os ombros e as costas, sobrepujado por uma coroa também em madeira. } \\
\text { A cruz é muito simples sem qualquer ornamento além do resplendor em metal } \\
\text { branco de forma circular raiada decorado ao centro com quatro pedras de cor azul } \\
\text { que envolvem o espaço central, que deveria estar preenchido com outra pedra hoje } \\
\text { desaparecida. A cruz está encaixada numa base semiesférica em madeira com } \\
\text { vários registos. }\end{array}$ \\
\hline 8. & Técnicas (de suporte): Talha \\
\hline 9. & Técnicas (de acabamento): Policromia (posterior) \\
\hline 10. & Materiais (de suporte): Madeira \\
\hline 11. & Materiais (de acabamento): Pigmentos; metal branco e pedras coloridas \\
\hline 12. & Estado de Conservação: Razoável; tem lacuna de policromia sobre o ombro \\
esquerdo na junção do braço com o corpo; apresenta sinais de infestação de insecto \\
xilófago sobre a base.
\end{tabular}


FICHAS DE INVENTÁRIO |ESCULTURA

Da Ordem de São Francisco na Diocese de Bragança-Miranda

Retábulo em talha rococo onde se expõe a escultura de Santa Clara SFB 23, e as figurinhas SFB 24 e SFB 25 do lado do Evangelho contigua ao arco triunfal, no mesmo retábulo existem ainda dois braços relicários

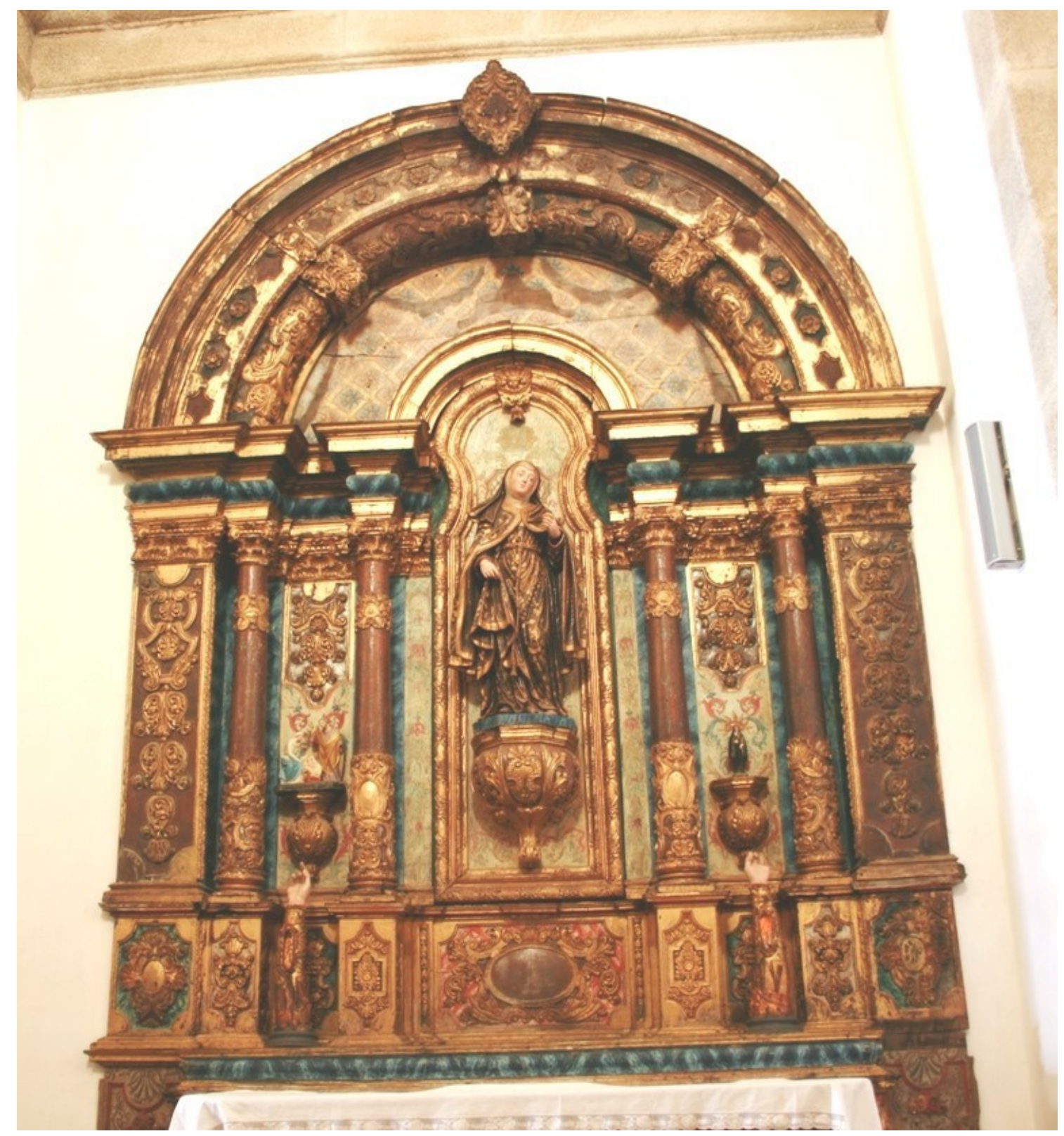


FICHAS DE INVENTÁRIO | ESCULTURA

Da Ordem de São Francisco na Diocese de Bragança-Miranda 


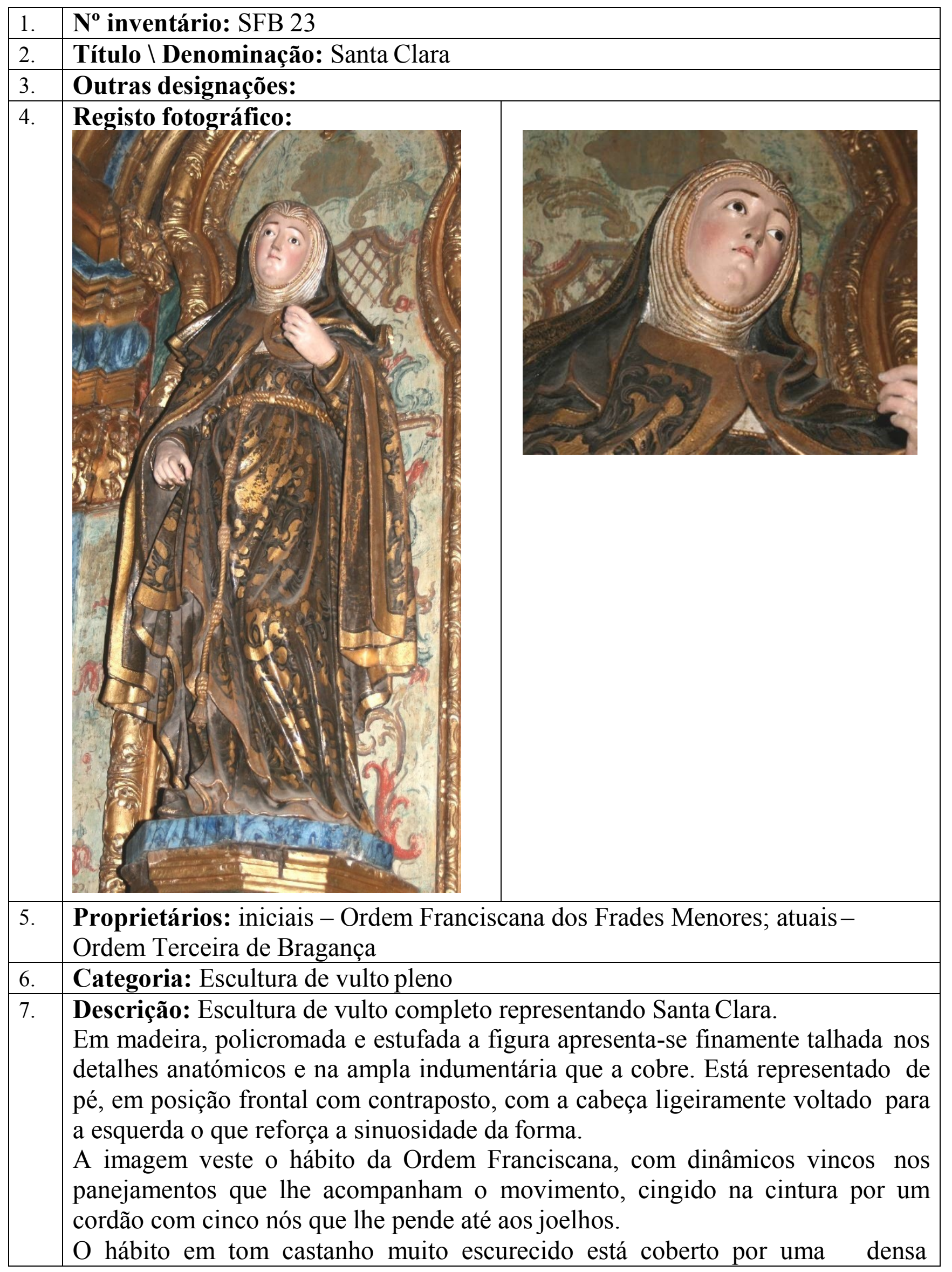




\begin{tabular}{|c|c|}
\hline & $\begin{array}{l}\text { composição de aplicações estofadas de motivos vegetalistas. Sobre este traje a } \\
\text { figura enverga um manto, também com aplicações estofadas douradas e bandas } \\
\text { no mesmo tom sobre os bordos. Apertada sobre o peito com um botão, que a } \\
\text { cobre sobre os ombros caindo em pregas largas e onduladas até aos joelhos, } \\
\text { desenhando amplos vincos que sugerem o movimento que envolve a figura. O } \\
\text { movimento sugerido pelos panejamentos permite que a ponta do pé direito fique } \\
\text { a descoberto deixando ver um sapato negro ricamente dourado. } \\
\text { A cabeça está coberta por um toucado branco justo com finas pregas que } \\
\text { rematam num bordo perlado deixando a descoberto apenas o rosto. Sobre o } \\
\text { toucado enverga um véu curto castanho muito escurecido ricamente estofado e } \\
\text { com bandas douradas em toda a volta. O rosto está finamente esculpido e coberto } \\
\text { de carnação clara e brilhante, com traços delicados que compõem uma expressão } \\
\text { serena. Os olhos, grandes e amendoados, em vidro, fixam o olhar em frente. A } \\
\text { boca entreaberta deixa a descoberto os dentes. A figura tem ambos braços } \\
\text { assimetricamente flectidos, as mãos esculpidas com detalhe anatómico de formas } \\
\text { delicadas, estão ligeiramente fechadas e sugerem no gesto segurar algum } \\
\text { atributo, hoje inexistente. Na mão esquerda é visível a linha de junção com o } \\
\text { corpo da escultura pelo destacamento da policromia. Está colocada sobre uma } \\
\text { base hexagonal marmoreada num tom azul. }\end{array}$ \\
\hline 8. & Técnicas (de suporte): Talha \\
\hline 9. & Técnicas (de acabamento): Policromia; $\mathrm{e}$ \\
\hline 10. & Materiais (de suporte): Madeira \\
\hline 11. & Materiais (de acabamento): Pigmentos; folha de ouro; vidro \\
\hline 12. & $\begin{array}{l}\text { Estado de Conservação: Bom; apresenta-se se estável; lacunas e desgaste na } \\
\text { policromia }\end{array}$ \\
\hline 13. & $\begin{array}{l}\text { Dimensões: } \\
\text { Altura: } 115 \mathrm{~cm} \\
\text { Largura: } 64 \mathrm{~cm} \\
\text { Profundidade: } 37 \mathrm{~cm}\end{array}$ \\
\hline 14. & Restauro: obra apresenta sinais de reintegração cromática \\
\hline 15. & Datas: segunda metade do século XVIII \\
\hline 16. & Proveniência: Igreja de São Francisco de Bragança \\
\hline 17. & $\begin{array}{l}\text { Autoria: desconhecida (idêntica nos detalhes escultóricos dos panejamentos com } \\
\text { a escultura de São Francisco SFB 04) }\end{array}$ \\
\hline 18. & Oficina: Porto $\backslash$ Braga \\
\hline 19. & Localização (atual): Tribuna do Retábulo, lado do Evangelho \\
\hline 20. & Histórico do objeto: não se conhecem registos \\
\hline 21. & Iconografia: Hábito de monja franciscana \\
\hline 22. & Irmandade: não se conhecem registos \\
\hline 23. & Procissões: não se conhecem registos \\
\hline
\end{tabular}




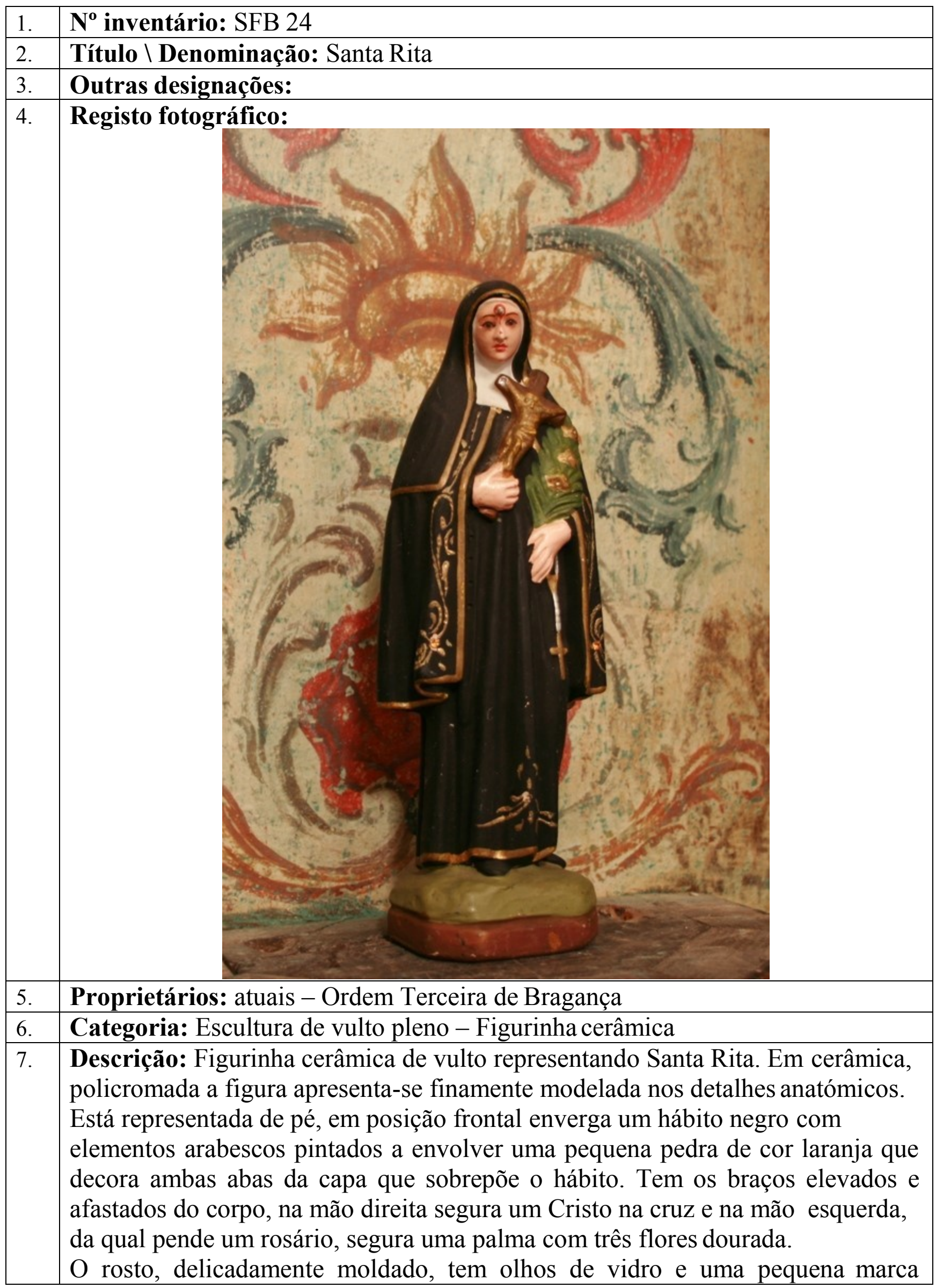




\begin{tabular}{|l|l|}
\hline & $\begin{array}{l}\text { arredondada vermelha entre as sobrancelhas. } \\
\text { Está colocada sobre uma plataforma, de base castanha e no registo superior } \\
\text { colorida a verde, também em cerâmica. }\end{array}$ \\
\hline 8. & Técnicas (de suporte): Modelagem, em série a partir de molde \\
\hline 9. & Técnicas (de acabamento): Policromia; vidro \\
\hline 10. & Materiais (de suporte): Cerâmica \\
\hline 11. & Materiais (de acabamento): Pigmentos; vidro; pequenas pedras \\
\hline 12. & Estado de Conservação: Bom; apresenta-se se estável. \\
\hline 13. & $\begin{array}{l}\text { Dimensões: } \\
\text { Altura: } 21 \text { cm } \\
\text { Largura: } 8 \text { cm } \\
\text { Profundidade: } 6 \text { cm }\end{array}$ \\
\hline 14. & Restauro: não apresenta sinais de intervenção sobre a obra \\
\hline 15. & Datas: século XX \\
\hline 16. & Proveniência: Igreja de São Francisco de Bragança \\
\hline 17. & Autoria: desconhecida \\
\hline 18. & Oficina: Porto $\backslash$ Braga (?) \\
\hline 19. & Localização (atual): Retábulo de santa Clara, lado do Evangelho \\
\hline 20. & Histórico do objeto: não se conhecem registos \\
\hline 21. & Iconografia: Palma; Cruz; Rosário \\
\hline 22. & Irmandade: não se conhecem registos \\
\hline 23. & Procissões: não se conhecem registos \\
\hline
\end{tabular}




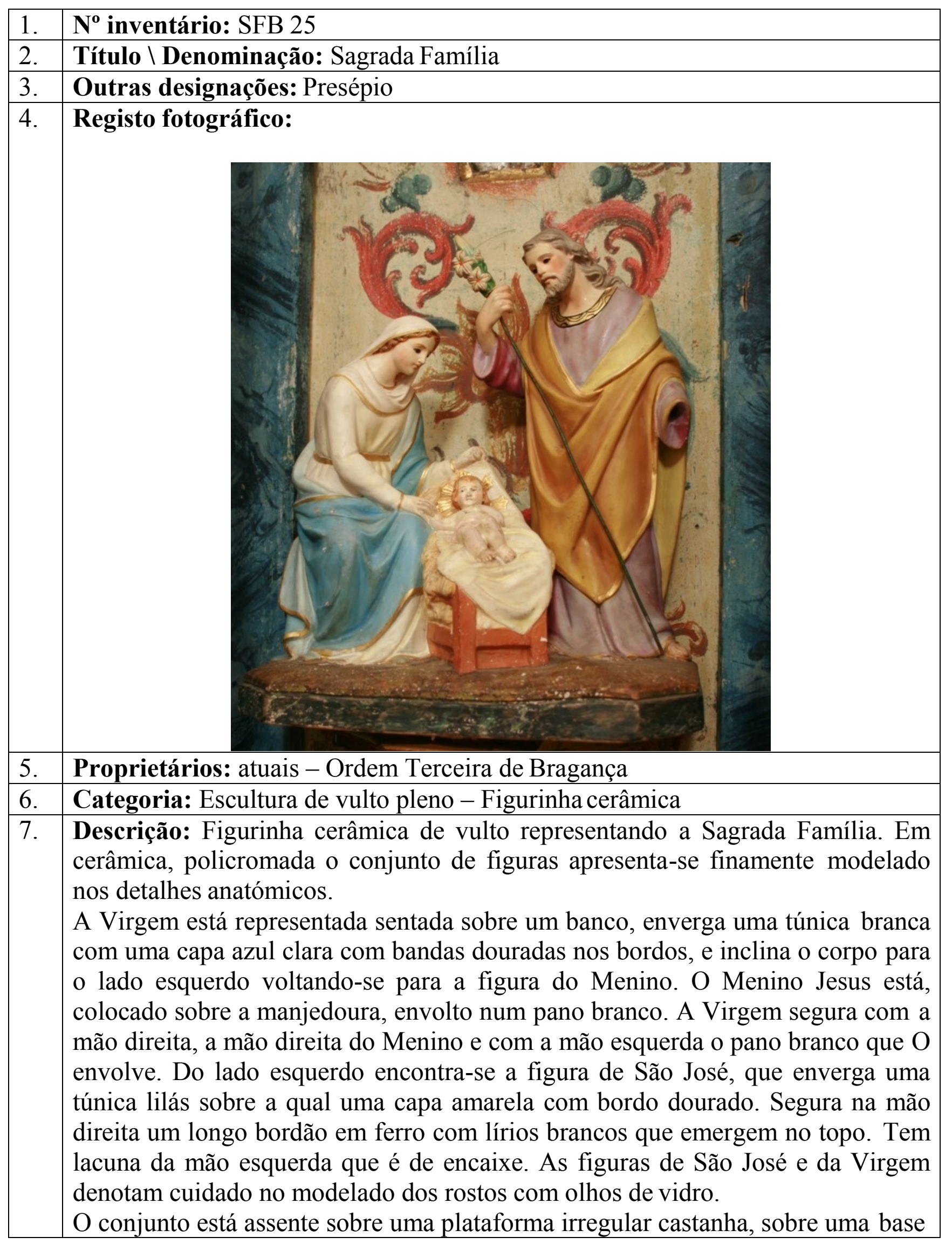




\begin{tabular}{|c|c|}
\hline & $\begin{array}{l}\text { de tom verde marmoreado também em cerâmica. } \\
\text { Sob a plataforma está colada uma etiqueta em papel com a legenda "No } 42 \text { " }\end{array}$ \\
\hline 8. & Técnicas (de suporte): Modelagem, em série a partir de molde \\
\hline 9. & Técnicas (de acabamento): Policromia; vidro \\
\hline 10. & Materiais (de suporte): Cerâmica \\
\hline 11. & Materiais (de acabamento): Pigmentos; vidro; pequenas pedras \\
\hline 12. & Estado de Conservação: Bom; apresenta-se se estável. \\
\hline 13. & $\begin{array}{l}\text { Dimensões: } \\
\text { Altura: } 30 \mathrm{~cm} \\
\text { Largura: } 27 \mathrm{~cm} \\
\text { Profundidade: } 14 \mathrm{~cm}\end{array}$ \\
\hline 14. & Restauro: não apresenta sinais de intervenção sobre a obra \\
\hline 15. & Datas: século XX \\
\hline 16. & Proveniência: Igreja de São Francisco de Bragança \\
\hline 17. & Autoria: desconhecida \\
\hline 18. & Oficina: Porto $\backslash$ Braga (?) \\
\hline 19. & Localização (atual): Retábulo de santa Clara, lado do Evangelho \\
\hline 20. & Histórico do objeto: não se conhecem registos \\
\hline 21. & Iconografia: Sagrada Família; Lírios brancos \\
\hline 22. & Irmandade: não se conhecem registos \\
\hline 23. & Procissões: não se conhecem registos \\
\hline
\end{tabular}


FICHAS DE INVENTÁRIO |ESCULTURA

Da Ordem de São Francisco na Diocese de Bragança-Miranda

Retábulo em talha rococó onde se expõe a escultura do Senhor dos Passos no nicho central SFB 26, no lado do Evangelho

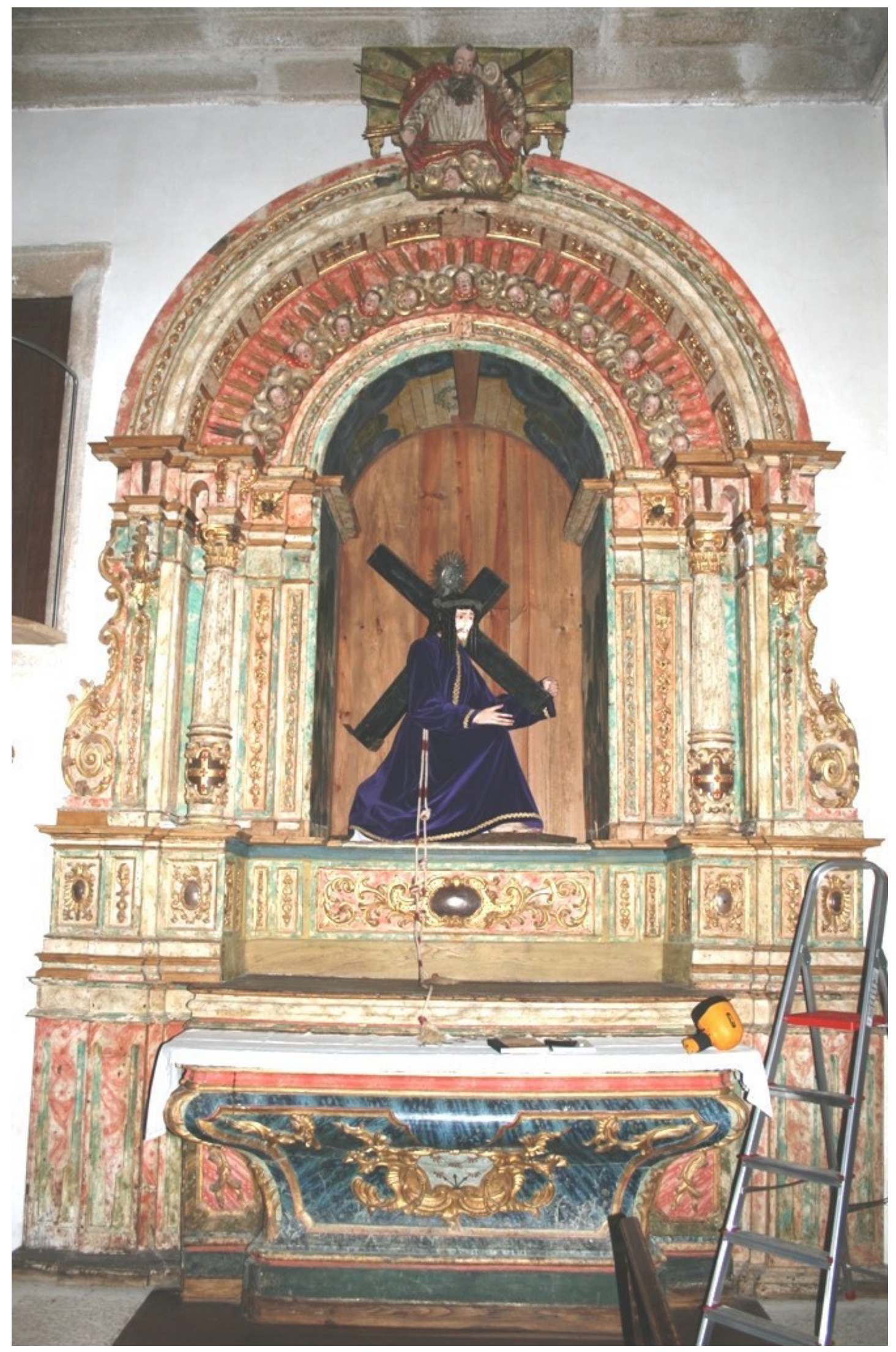


FICHAS DE INVENTÁRIO | ESCULTURA

Da Ordem de São Francisco na Diocese de Bragança-Miranda 


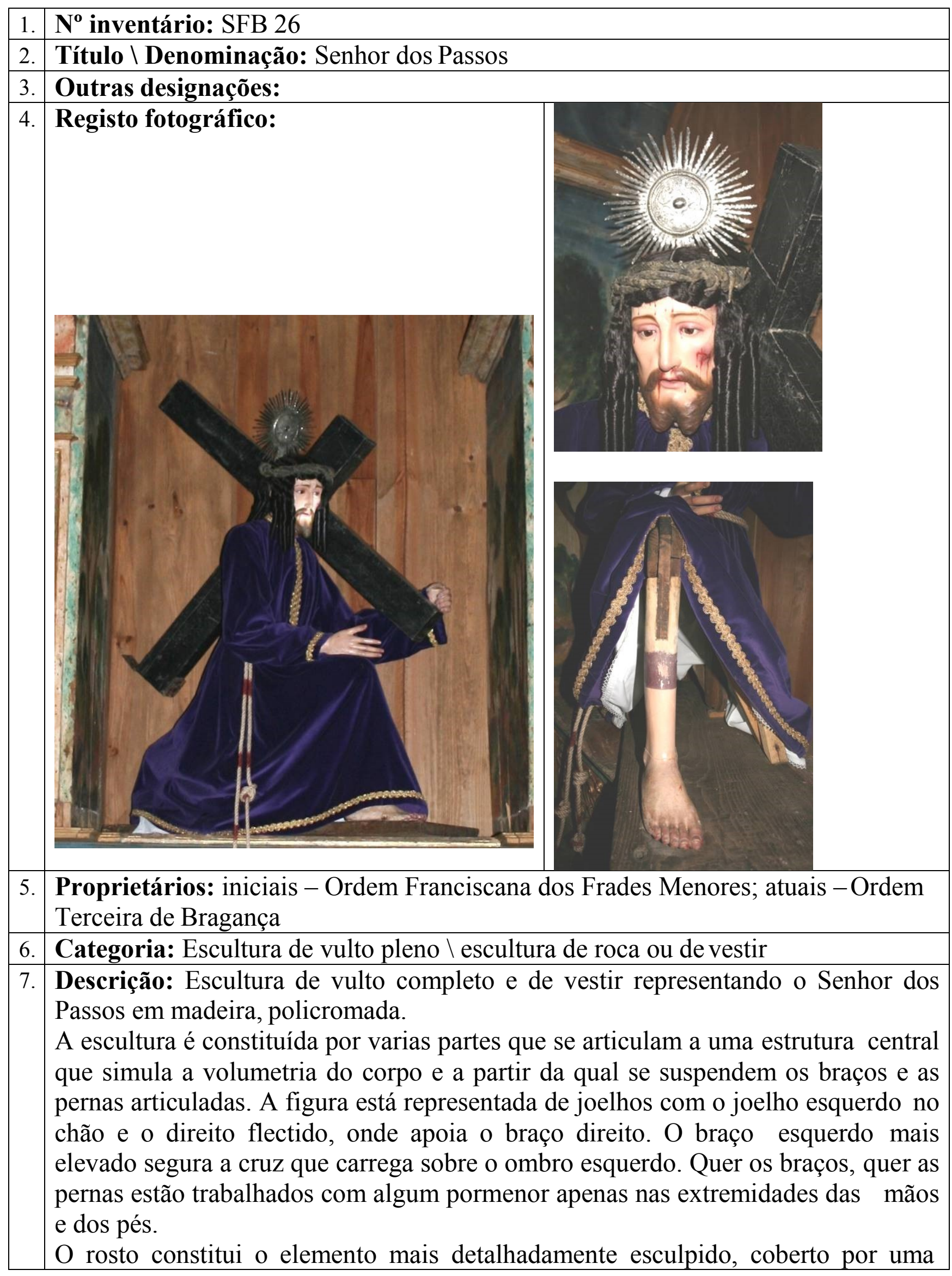




\begin{tabular}{|c|c|}
\hline & $\begin{array}{l}\text { espessa camada policroma que parece recente e suscita dúvidas quanto ao material } \\
\text { de suporte (madeira ou cerâmica?). Plasticamente reforça a expressividade do } \\
\text { rosto. Tem as sobrancelhas arqueadas e olhos de vidro semicerrados e a boca } \\
\text { entreaberta deixando os dentes levemente a descoberto. O sofrimento da expressão } \\
\text { é enfatizado com o sangue que emana do nariz e boca bem como da chaga sobre o } \\
\text { lado esquerdo do rosto e da coroa de espinho sobre a testa. As barbas pontiagudas } \\
\text { e bifurcadas estão esculpidas no mesmo suporte da cabeça. A cabeça está coberta } \\
\text { por uma farta cabeleira postiça de cabelo aparentemente natural em cachos e } \\
\text { cingida por uma coroa em corda torcida com pregos de ferro. Sobre a coroa tem } \\
\text { um resplendor em forma circular com raios ondulados e elementos vegetalistas } \\
\text { gravados no centro. A figura enverga um trajo de veludo roxo com passamanes } \\
\text { dourados sobre os punhos, bordos e gola. Sob o trajo enverga uma fina túnica } \\
\text { branca em algodão com rendas nos bordos. A cruz que a figura sustem é de } \\
\text { madeira sem qualquer decoração, com um elemento em ferro no topo inferior para } \\
\text { possivelmente permitir acrescentar o último troço da cruz, que está em falta por } \\
\text { limitação do espaço. A escultura está colocada sobre uma base em madeira de } \\
\text { forma retangular. Está inserido na tribuna de um retábulo de feição rocaille } \\
\text { encimado por uma figura de deus Pai. }\end{array}$ \\
\hline 8. & Técnicas (de suporte): Talha \\
\hline 9. & Técnicas (de acabamento): Policromia; fundição \\
\hline 10 & Materiais (de suporte): Madeira \\
\hline 11 & Materiais (de acabamento): Pigmentos; vidro; têxteis; cabelo \\
\hline 12 & Estado de Conservação: Bom; apresenta-se se estável. \\
\hline 13 & $\begin{array}{l}\text { Dimensões: } \\
\text { Altura: } 160 \mathrm{~cm} \\
\text { Largura: } 70 \mathrm{~cm} \\
\text { Profundidade: } 116 \mathrm{~cm}\end{array}$ \\
\hline 14 & Restauro: apresenta sinais de reintegração cromática \\
\hline 15 & Datas: século XVIII, a cabeça parece posterior, século XIX \\
\hline 16 & Proveniência: Igreja de São Francisco de Bragança \\
\hline 17 & Autoria: desconhecida \\
\hline 18 & Oficina: Porto $\backslash$ Braga \\
\hline 19 & $\begin{array}{l}\text { Localização (inicial } \backslash \text { atual) Inicialmente a devoção estava a culto na Capela dos } \\
\text { Borges. Atualmente está no retábulo do Senhor dos Passo ( }\left(2^{\circ} \text { a partir do altar mor), }\right. \\
\text { lado do Evangelho }\end{array}$ \\
\hline 20 & $\begin{array}{l}\text { Histórico do objeto: Em 1721-1724 Cardoso Borges refere a devoção da Ordem } \\
\text { Terceira à imagem do Senhor dos Passos, então venerado na Capela dos Borges } \\
\text { (Borges, } 2012 \text { (texto original de 1721-1724) p. 142) }\end{array}$ \\
\hline 21 & Iconografia: Cruz; Resplendor; Imagem de Roca \\
\hline 22 & Irmandade: Ordem Terceira Secular de Bragança \\
\hline & Procissões: não se conhecem registos \\
\hline
\end{tabular}


Retábulo com talha rococó com escultura de Santa Luzia no nicho central SFB 27, ladeada pelas imagens SFB 28 e SFB 29, primeiro retábulo no lado do Evangelho a partir do portal de entrada. Sobre o retábulo existem vários ex-votos votivos de Santa Luzia, em cera representando olhos.

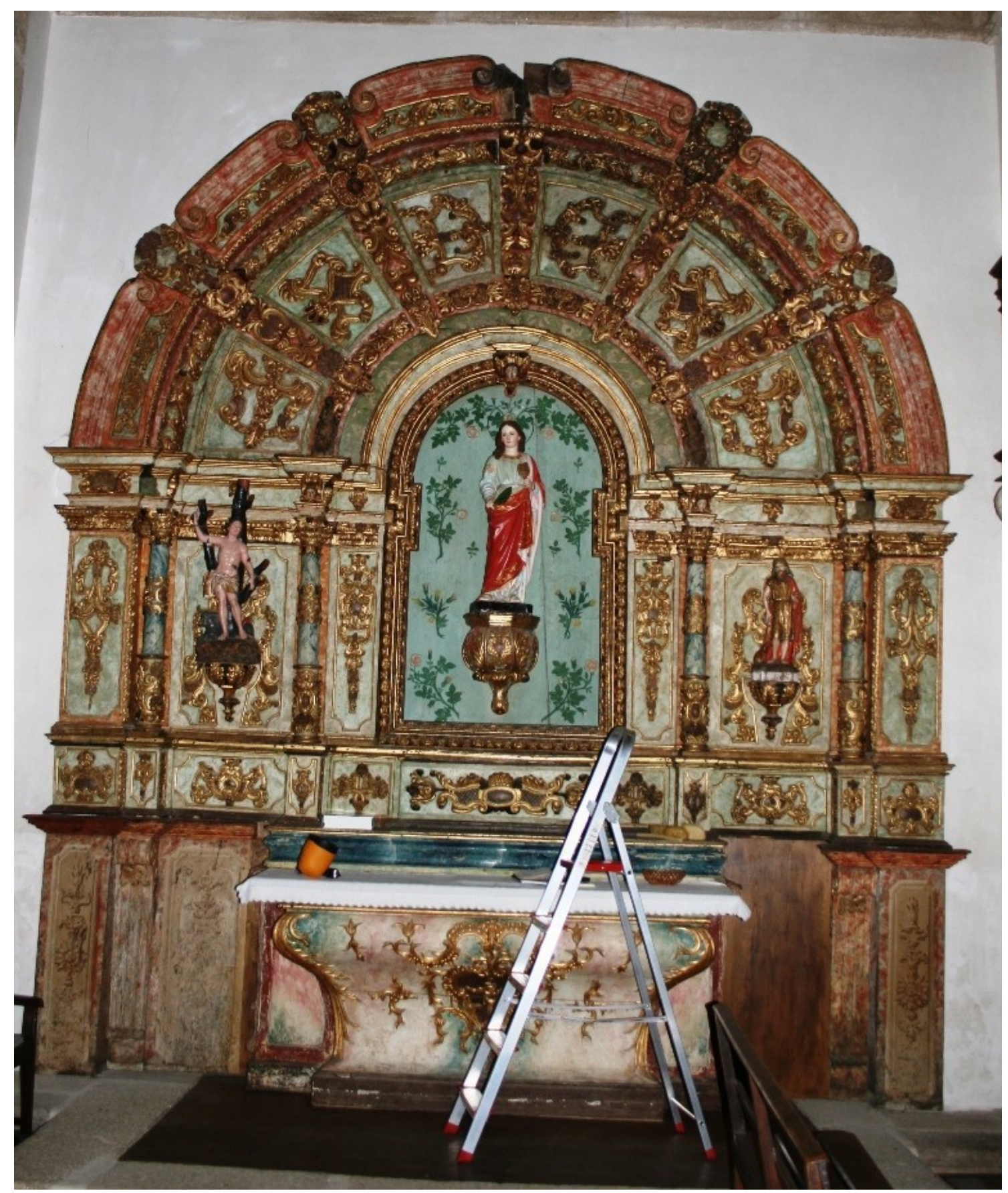


FICHAS DE INVENTÁRIO | ESCULTURA

Da Ordem de São Francisco na Diocese de Bragança-Miranda 


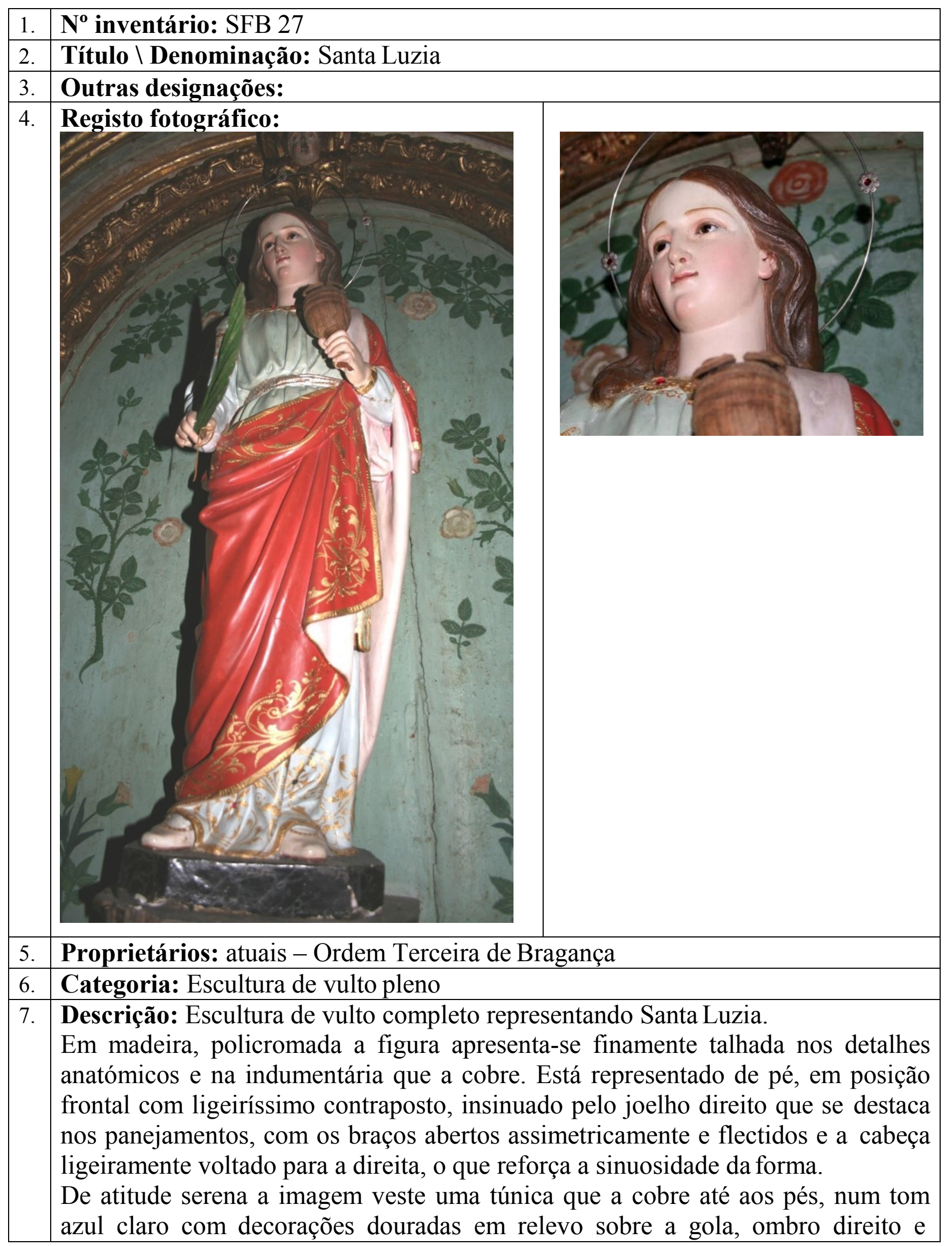




\begin{tabular}{|c|c|}
\hline & $\begin{array}{l}\text { punhas, no bordo inferior as decorações são apenas pintadas a dourado. } \\
\text { Sobre este traje a figura enverga uma capa vermelha que a cobre sobre o ombro } \\
\text { esquerdo e recolhe em drapeado no braço esquerdo. As vestes deixam a } \\
\text { descoberto a ponta dos sapatos brancos ricamente ornamentados com pequenos } \\
\text { pontos dourados. As mãos estão esculpidas com detalhe anatómico de formas } \\
\text { delicadas, na mão direita, com lacuna de três dedos, segura uma palma e na } \\
\text { esquerda, mais próxima do peito segura um cálice em madeira sem policromia, e } \\
\text { com lacuna do pé do cálice. O rosto de feições delicadas e expressão serena está } \\
\text { finamente esculpido e coberto de carnação clara e brilhante. Os olhos, } \\
\text { amendoados, são em vidro, fixam o olhar em frente. } \\
\text { O cabelo é farto e levemente ondulado em tom castanho com madeixas sobre o } \\
\text { lado direito e costas. A envolver a cabeça ostenta uma auréola composta por um } \\
\text { aro em metal branco, circular, com três pequenas flores aplicadas com uma pedra } \\
\text { vermelha ao centro. } \\
\text { A escultura está colocada sobre um plinto hexagonal marmoreado num tom negro. }\end{array}$ \\
\hline 8. & Técnicas (de suporte): Talha \\
\hline 9. & Técnic: \\
\hline 10. & s (de suporte): Madeira \\
\hline 11. & $\begin{array}{l}\text { Materiais (de acabamento): Pigmentos; folha de ouro; vidro; metal branco e } \\
\text { pedras vermelhas }\end{array}$ \\
\hline 12. & $\begin{array}{l}\text { Estado de Conservação: Bom; apresenta-se se estável; lacunas nas mãos e } \\
\text { atributos (cálice) e desgaste na policromia }\end{array}$ \\
\hline 13. & $\begin{array}{l}\text { Dimensões: } \\
\text { Altura: } 104 \mathrm{~cm} \\
\text { Largura: } 32 \mathrm{~cm} \\
\text { Profundidade: } 37 \mathrm{~cm} \\
\end{array}$ \\
\hline 14. & $\begin{array}{l}\text { Restauro: Sobre o punho esquerdo é visível uma profunda fissura que parece ter } \\
\text { sido alvo de uma intervenção de restauro para consolidar a mão e o cálice ao } \\
\text { corpo da escultura. Apresenta sinais de reintegração cromática. }\end{array}$ \\
\hline 15. & Datas: século XX \\
\hline 16. & Prov \\
\hline 17. & Autoria: \\
\hline 18. & Oficina: Braga\Porto (?) \\
\hline 19. & $\begin{array}{l}\text { Localização (atual): Retábulo, lado do Evangelho (primeiro a partir do portal de } \\
\text { entrada do templo) }\end{array}$ \\
\hline 20. & $\begin{array}{l}\text { Histórico do objeto: A devoção a Santa Luzia existia já em 1721-1724, tinha } \\
\text { altar próprio e relíquia e celebrava-se o seu dia com grande devoção (Borges, } \\
2012 \text { (texto original de } 1721-1724 \text { ) p. 142). Atualmente ainda se celebra a sua } \\
\text { festividade dia } 13 \text { de Dezembro }\end{array}$ \\
\hline 21. & Iconografia: Palma; cálice; auréola \\
\hline 22. & Irmandade: não se conhecem registos \\
\hline & lecem registos \\
\hline
\end{tabular}




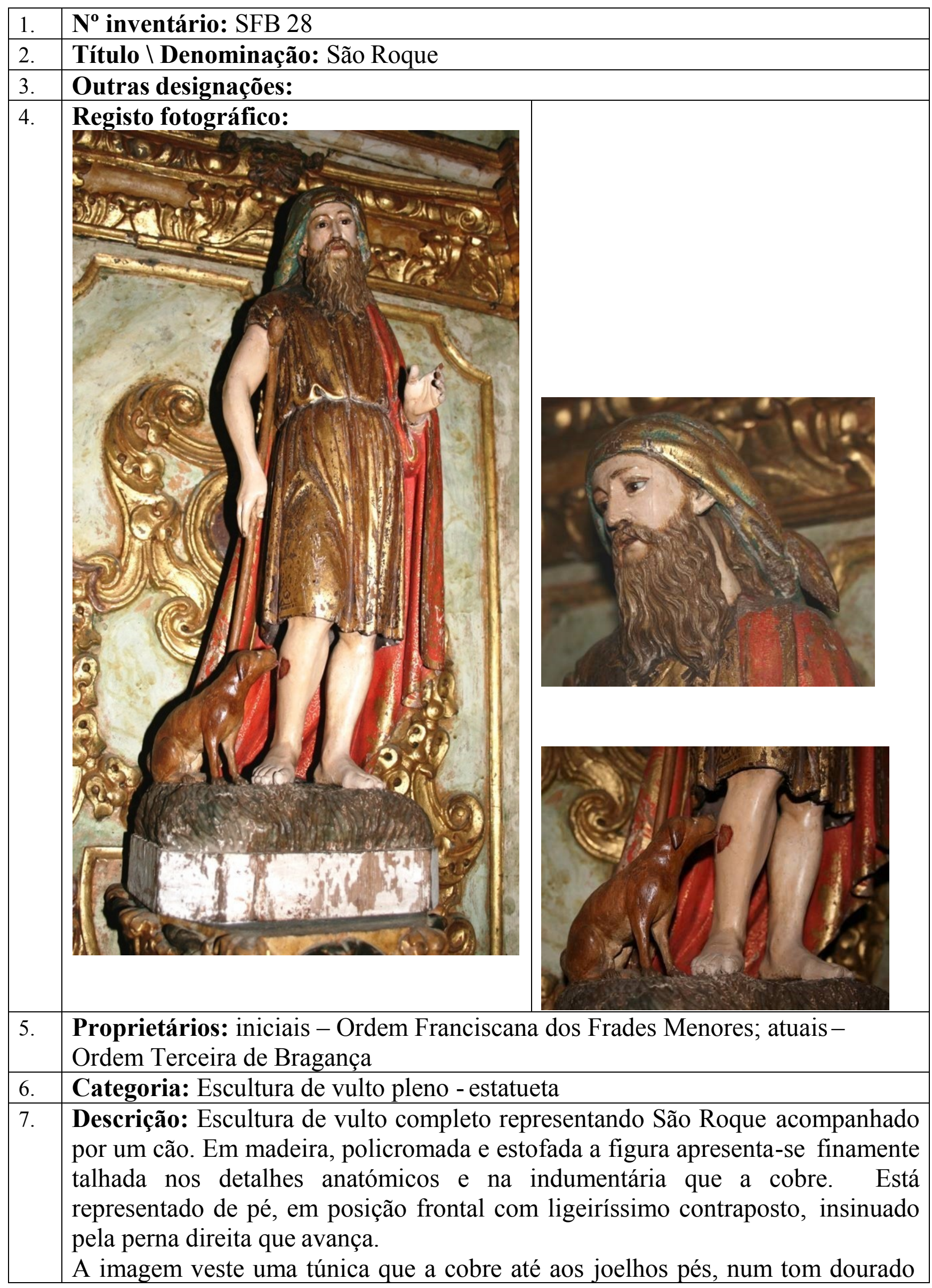




\begin{tabular}{|c|c|}
\hline & $\begin{array}{l}\text { com restos de estofagem já muito desgastada. Sobre este, traja um manto } \\
\text { vermelho com estufagem de elementos vegetalistas e na cabeça usa um pano } \\
\text { verde enroscado com decorações estufadas. } \\
\text { O rosto de feições delicadas está finamente esculpido e coberto de carnação clara } \\
\text { e brilhante. Os olhos, amendoados, são em vidro e fixam o olhar num ponto } \\
\text { baixo. A figura apresenta longas e fartas barbas castanhas onduladas que caiem } \\
\text { sobre o peito, a boca está entreaberta, mostrando ligeiramente os dentes. } \\
\text { As mãos estão esculpidas com detalhe anatómico de formas delicadas, na mão } \\
\text { direita, está apoiada na bengala que sob o ombro direito suporta o corpo, e a } \\
\text { esquerda, com lacuna de dois dedos, está mais próxima do peito sugere ter } \\
\text { segurado algum atributo. } \\
\text { Os pés estão descalços e as pernas descobertas permitem ver a chaga na perna } \\
\text { direita que está a ser lambida por um cão. O cão, sentado e de tom castanho, está } \\
\text { esculpido com detalhe anatómico, em peça autónoma, colocado ao lado do santo } \\
\text { e sobre o mesmo plinto. } \\
\text { O conjunto está colocado sobre um plinto castanho coberto de marcas de formão } \\
\text { sobre uma base branca muito desgastada hexagonal. }\end{array}$ \\
\hline 8. & Técnicas (de suporte): Talha \\
\hline 9. & Técnicas (de acabamento): Policromia; estufagem \\
\hline 10. & Materiais (de suporte): Madeira \\
\hline 11. & Materiais (de acabamento): Pigmentos; folha de ouro; vidro \\
\hline 12. & $\begin{array}{l}\text { Estado de Conservação: Bom; apresenta-se se estável; lacuna de dois dedos na } \\
\text { mão esquerda e desgaste na policromia e estufagem }\end{array}$ \\
\hline 13. & $\begin{array}{l}\text { Dimensões: } \\
\text { Altura: } 60 \mathrm{~cm} \\
\text { Largura: } 24 \mathrm{~cm} \\
\text { Profundidade: } 20 \mathrm{~cm}\end{array}$ \\
\hline 14. & Restauro: apresenta sinais de reintegração \\
\hline 15. & Datas: século XVIII $\backslash$ século XIX \\
\hline 16. & Proveniência: Igreja de São Francisco de Bragança \\
\hline 17. & Autoria: desconhecida \\
\hline 18. & Oficina: Porto $\backslash$ Braga \\
\hline 19. & $\begin{array}{l}\text { Localização (atual): Retábulo de Santa Luzia, lado do Evangelho (primeiro a } \\
\text { partir do portal de entrada do templo) }\end{array}$ \\
\hline 20. & Histórico do objeto: não se conhecem registos \\
\hline 21. & Iconografia: Chaga; Cão; Bastão \\
\hline 22. & Irmandade: não se conhecem registos \\
\hline 23. & Procissões: não se conhecem registos \\
\hline
\end{tabular}




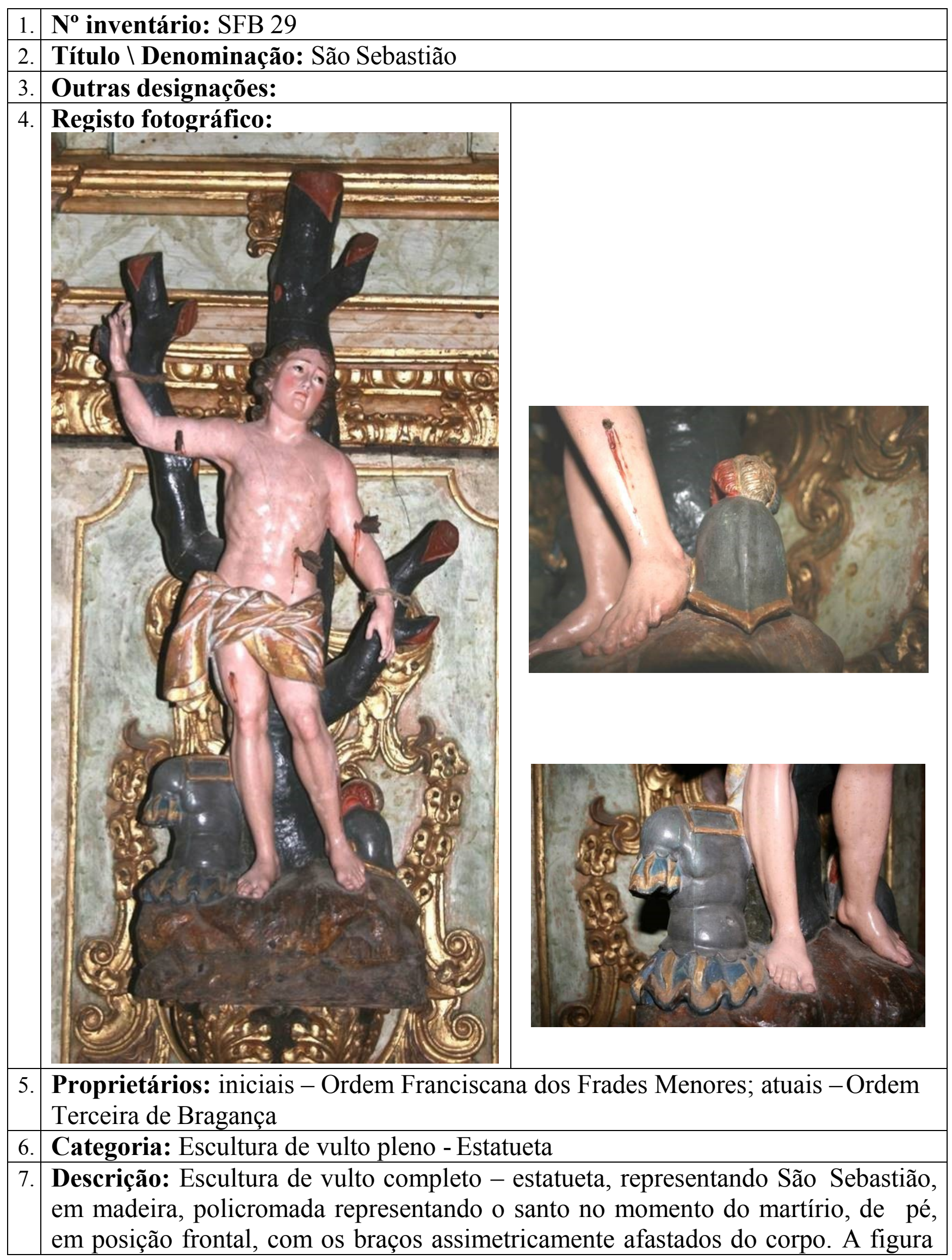




\begin{tabular}{|l|l|}
\hline & $\begin{array}{l}\text { apresenta-se apenas coberto com um ligeiro panejamento cingido na cintura cujos } \\
\text { vincos largos lhe imprimem algum dinamismo. Está preso com cordas pelos braços } \\
\text { a uma árvore parcialmente cortada, com o braço direito elevado e o esquerdo à } \\
\text { altura da cintura. Está martirizado com cinco flechas que lhe perfuram o corpo } \\
\text { donde escorre sangue no torso, braços e pernas, as duas flechas das pernas já estão } \\
\text { desaparecidas restando apenas os orifícios do martírio. O dramatismo do } \\
\text { sofrimento é enfatizado pelo contraste com a expressão doce do rosto de delicados } \\
\text { traços, com olhos de vidros que elevam o olhar. O cabelo, curto, é castanho e está } \\
\text { esculpido com largas ondas. De forte carga dramática o corpo nu, martirizado, está } \\
\text { representado com algum cuidado na anatomia e proporções. A carnação apresenta } \\
\text { um tom róseo claro e brilhante que contrasta violentamente com o vermelho do } \\
\text { sangue das chagas. } \\
\text { Aos pés do santo, do lado esquerdo, podemos ver um elmo com plumas vermelhas } \\
\text { e amarelas, no lado direito, a armadura ricamente decorada com elementos em } \\
\text { relevo. O conjunto está colocado sobre um plinto castanho que simula um chão } \\
\text { pedregoso. }\end{array}$ \\
\hline 8. & Técnicas (de suporte): Talha \\
\hline 9. & Técnicas (de acabamento): Policromia \\
\hline 10 & Materiais (de suporte): Madeira \\
\hline 11 & Materiais (de acabamento): Policromia; vidro \\
\hline 12 & $\begin{array}{l}\text { Estado de Conservação: Bom; apresenta-se se estável; com lacunas de dois dedos } \\
\text { na mão direita e dois dedos na mão esquerda }\end{array}$ \\
\hline 13 & $\begin{array}{l}\text { Dimensões: } \\
\text { Altura: } 90 \text { cm } \\
\text { Largura: } 40 \text { cm } \\
\text { Profundidade: } 28 \text { cm }\end{array}$ \\
\hline 14 & Restauro: apresenta sinais de reintegração cromática \\
\hline 15 & Datas: segunda metade do século XVIII \\
\hline 16 & Proveniência: Igreja de São Francisco de Bragança \\
\hline 17 & Autoria: desconhecida \\
\hline 18 & Oficina: Porto $\backslash$ Braga \\
\hline 19 & $\begin{array}{l}\text { Localização (atual): Retábulo de Santa Luzia, lado do Evangelho (primeiro a } \\
\text { partir do portal de entrada do templo) }\end{array}$ \\
\hline 20 & Histórico do objeto: não se conhecem registos \\
\hline 21 & Iconografia: Flechas; cordas; arvore cortada; elmo; armadura; chagas \\
\hline 22 & Irmandade: não se conhecem registos \\
\hline 23 & Procissões: não se conhecem registos \\
\hline
\end{tabular}


1. $\mathbf{N}^{\mathbf{0}}$ inventário: SFB 30

2. Título $\backslash$ Denominação: Cristo Alado

3. Outras designações: Cristo Serafim, Cristo na visão de São Francisco no monte Alverne

\section{Registo fotográfico:}
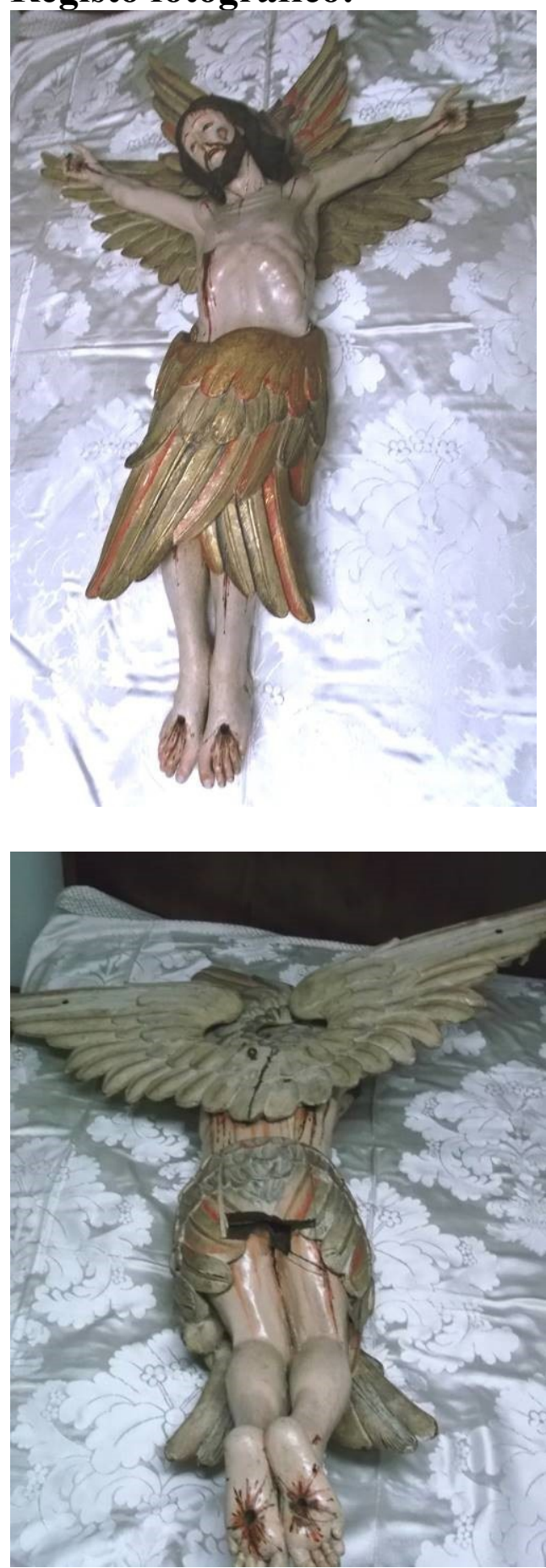
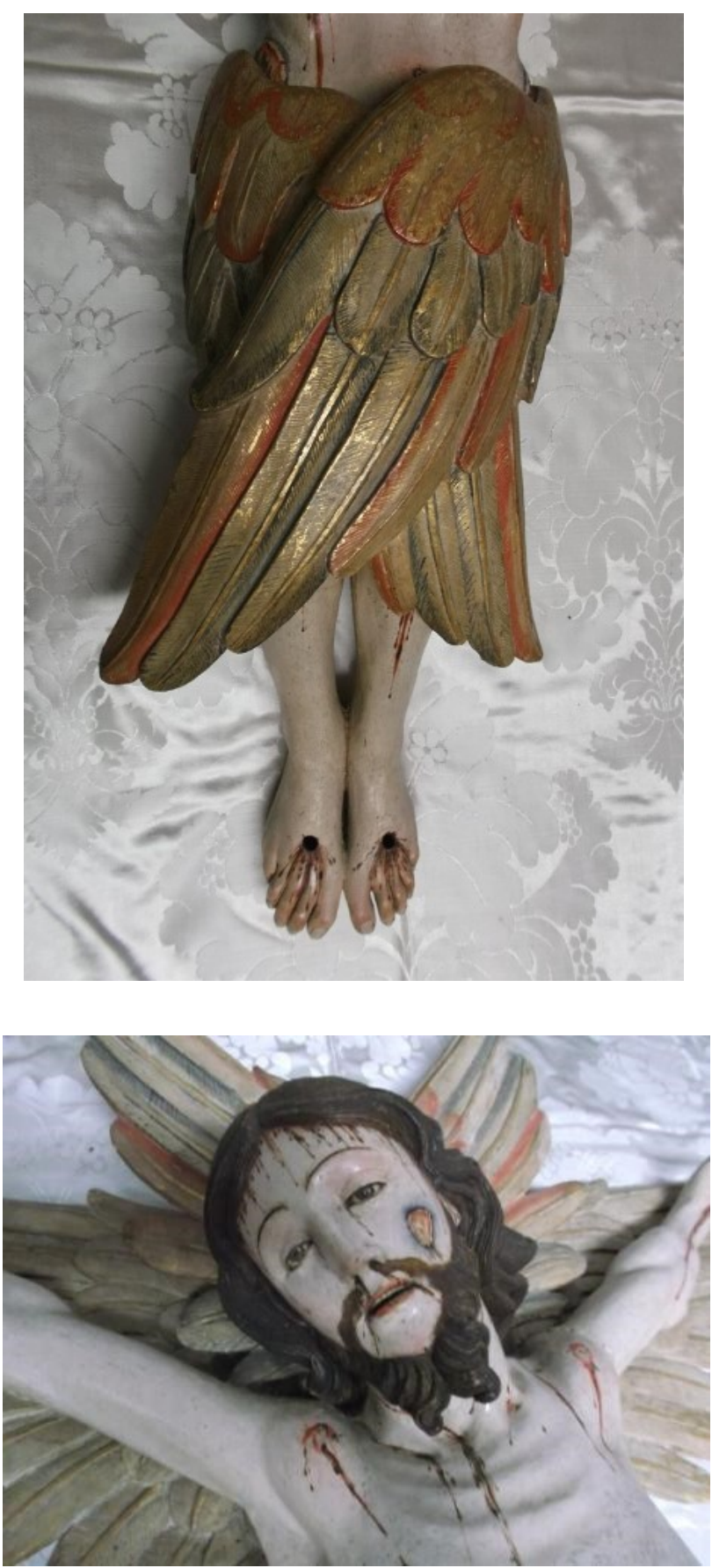

5. Proprietários: iniciais - Ordem Franciscana dos Frades Menores; atuais - Ordem Terceira de Bragança 
6. Categoria: Escultura de vulto pleno

7. Descrição: Escultura de vulto completo representando Cristo Crucificado com três pares de asas.

Em madeira, policromada e dourada a figura apresenta-se finamente talhada, na composição do corpo, no detalhe anatómico, na volumetria dos músculos e nos pormenores das seis asas que envolvem a figura.

A figura eleva ambos braços que estão pregados sobre o par de asas que se encontra mais amplamente aberto. Das costas emergem dois pares de asas, um par mais aberto e outro sobre o primeiro com asas mais pequenas e sobrepostas. Os braços são acrescentos à peça central que compõe a escultura, pois é possível ver sob a policromia a linha de junção com o corpo. Estão bem talhados mas com uma ligeira desproporção em relação à restante anatomia. Das chagas das mãos emergem gotas de sangue em amplas manchas sobre as palmas. A mão direita tem lacuna do dedo indicador e a mão esquerda tem lacuna de todos os dedos excepto o polegar.

As pernas, quase totalmente tapadas pelo terceiro par de asas que cobre a figura pela cintura, estão juntas e paralelas e não sobrepostas como costuma acontecer nas figuras de Cristo Crucificado, mostram em ambos pés as chagas do martírio de cujos orifícios dos pregos emergem gotas de sangue.

O dorso está esculpido com detalhe na anatomia e ferimentos que ostenta sobre os ombros e mais profundo sobre o peito no lado direito. Toda a carnação é branca muito clara reforçando o contrate com as marcas de martírio.

A cabeça, ligeiramente inclinada para o lado direito, mostra um rosto de contornos delicados que compõem uma expressão de sereno sofrimento. Da linha do cabelo emergem várias gotas de sangue que escorre sobre a testa, também do nariz e dos cantos da boca escorre sangue abundante. A boca, entreaberta deixa os dentes ligeiramente a descoberto. Tem cabelos longos e ondulados esculpidos que caiem sobre as costas, as barbas bifurcadas são também esculpidas, enquanto o bigode sobre os lábios é apenas pintado. Os olhos, pintados reforçam a inclinação da cabeça baixa. Sobre o lado esquerdo do rosto apresenta uma profunda e ensanguentada ferida vermelha com bordos cinzentos.

A figura, de vulto completo, tem toda a parte de traz detalhadamente trabalhada com pormenor nos três pares de asas. Também é visível a parte escavada no interior da escultura e posteriormente coberta sobre a zona lombar da figura. Os três pares de asas, com penas detalhadamente esculpidas, apresentam policromia branca, azul e vermelha com revestimento dourado em toda a extensão das asas. As asas que cobrem a figura sobre a cintura estão esculpidas na mesma madeira do tronco e pernas. Os dois pares de asas que emergem das costas são peças autónomas, posteriormente pregadas sobre as costas apresentando uma argola em ferro para suspensão e orifícios nos dois extremos.

A escultura teria originalmente uma cruz, que segundo informação da atual zeladora (D. Augusta) está hoje desaparecida pois não foi devolvida do gabinete de restauro. 


\begin{tabular}{|c|c|}
\hline & A Escultura de Cristo Crucificado Alado está atualmente guardada na sacristia \\
\hline 8. & Técnicas (de suporte): Talha \\
\hline 9. & Técnicas (de acabamento): Policromia; douramento \\
\hline 10. & Materiais (de suporte): Madeira \\
\hline 11. & Materiais (de acabamento): Pigmentos \\
\hline 12. & $\begin{array}{l}\text { Estado de Conservação: Bom; apresenta-se se estável; com lacunas de dedos em } \\
\text { ambas mãos e nas costas na peça que cobre o vão escavado no interior da } \\
\text { escultura. }\end{array}$ \\
\hline 13. & $\begin{array}{l}\text { Dimensões: } \\
\text { Altura: } 130 \mathrm{~cm} \\
\text { Largura: } 100 \mathrm{~cm} \\
\text { Profundidade: } 25 \mathrm{~cm}\end{array}$ \\
\hline 14. & Restauro: apresenta sinais de reintegração cromática \\
\hline 15. & Datas: segunda metade do século XVIII \\
\hline 16. & Proveniência: Igreja de São Francisco de Bragança \\
\hline 17. & Autoria: desconhecida \\
\hline 18. & Oficina: Porto $\backslash$ Braga \\
\hline 19. & $\begin{array}{l}\text { Localização (atual): A Escultura de Cristo Crucificado Alado está atualmente } \\
\text { guardada na sacristia }\end{array}$ \\
\hline 20. & Histórico do objeto: não se conhecem registos \\
\hline 21. & Iconografia: Chagas; Três pares de asas \\
\hline 22. & $\begin{array}{l}\text { Irmandade: existiu uma irmandade das Chagas (Borges, } 2012 \text { (texto original de } \\
1721-1724 \text { ) p. 142) }\end{array}$ \\
\hline 23. & Procissões: não se conhecem registos \\
\hline
\end{tabular}


FICHAS DE INVENTÁRIO | ESCULTURA

Da Ordem de São Francisco na Diocese de Bragança-Miranda 


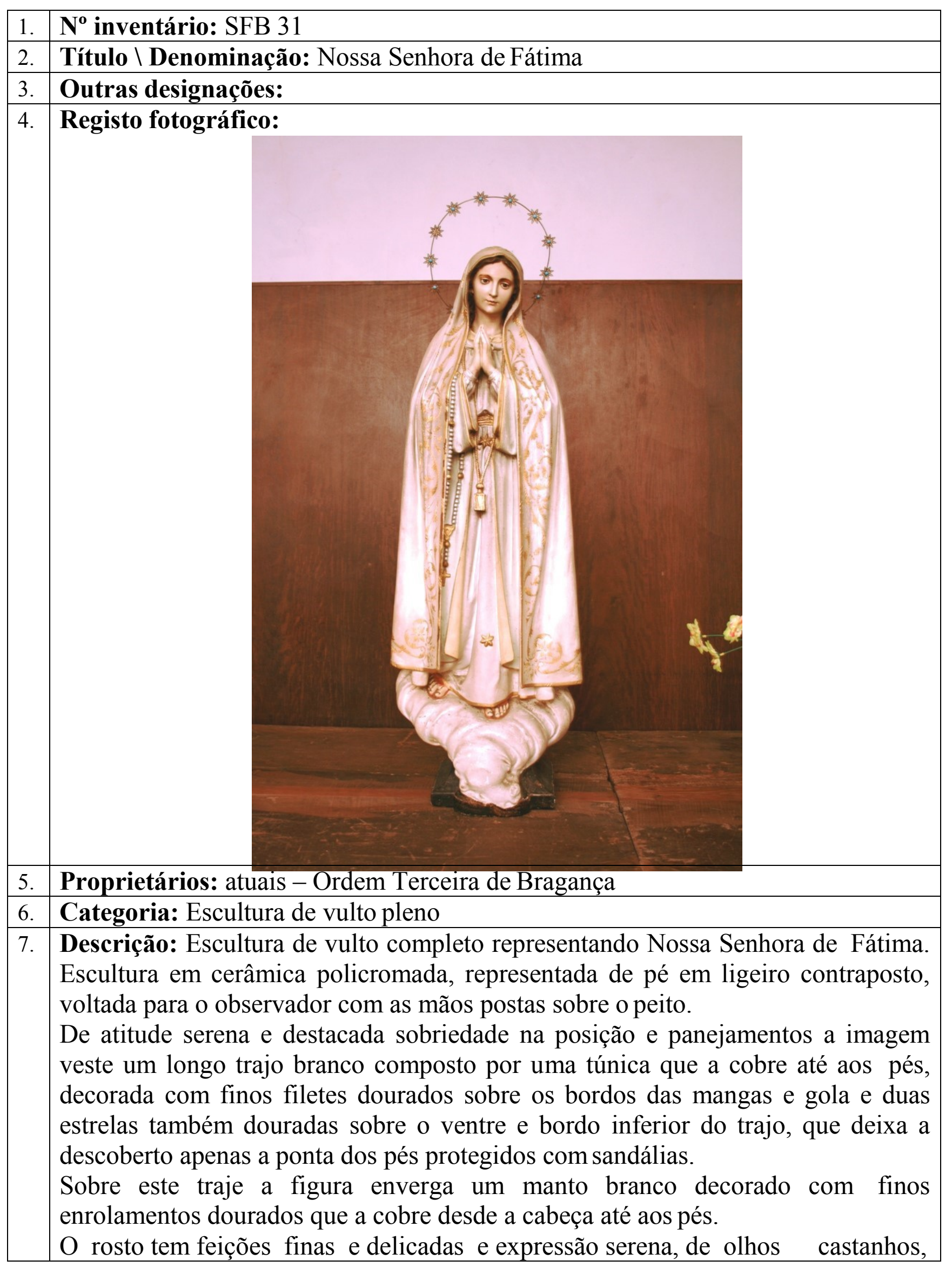




\begin{tabular}{|l|l|}
\hline & $\begin{array}{l}\text { amendoados, em vidro e cabelo castanho ligeiramente perceptível sob o manto. } \\
\text { Sobre o braço direito pende um rosário e no pescoço pende um cordão dourado } \\
\text { que suspende uma forma paralelepipédica também dourada. } \\
\text { A figura apresenta uma auréola em metal dourado de forma circular decorado com } \\
\text { doze estrelas que têm ao centro uma pequena pedra de cor azul-turquesa (lacuna } \\
\text { da pedra numa estrela) } \\
\text { Está assente sobre uma nuvem branca e de contornos arredondados irregulares, } \\
\text { assente sobre uma plataforma negra quadrangular. }\end{array}$ \\
\hline 8. & Técnicas (de suporte): Modelagem \\
\hline 9. & Técnicas (de acabamento): Policromia; dourados; fundição \\
\hline 10. & Materiais (de suporte): Madeira \\
\hline 11. & $\begin{array}{l}\text { Materiais (de acabamento): Pigmentos; douramento; vidro; metal dourado e } \\
\text { pedras azul-turquesa }\end{array}$ \\
\hline 12. & Estado de Conservação: Bom; apresenta-se se estável; lacunas na policromia; \\
lacuna de uma pedra no esplendor
\end{tabular}




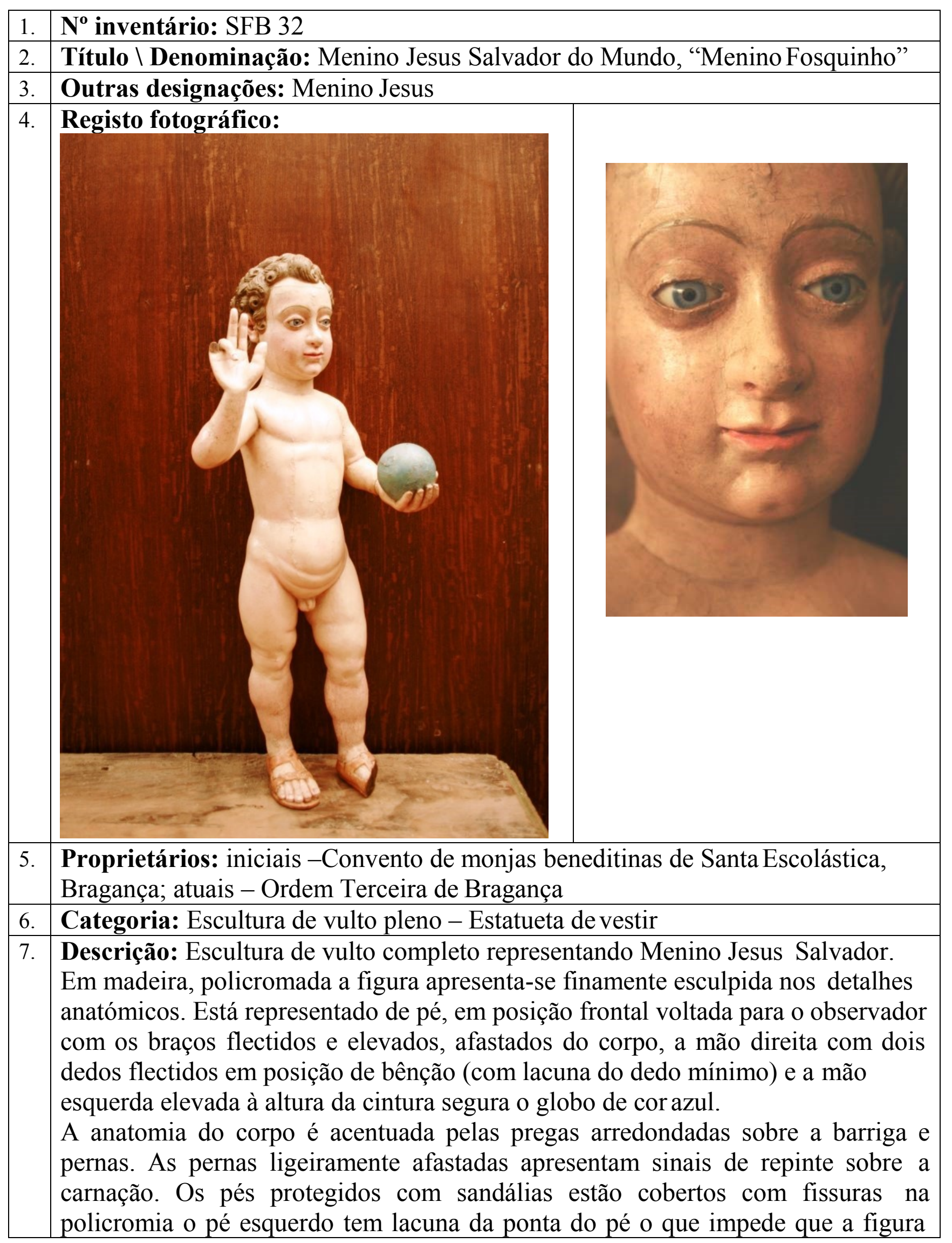




\begin{tabular}{|c|c|}
\hline & $\begin{array}{l}\text { sustenha em pé. } \\
\text { O menino está representado nu, com genitais, delicadamente esculpido sugerindo } \\
\text { as linhas arredondadas de uma anatomia infantil. O rosto de expressão serena } \\
\text { destaca-se também pelos contornos arredondados, os olhos são de vidro de cor } \\
\text { azul claro. O cabelo ondulado e curto é de cor castanha clara. } \\
\text { Atualmente a figura não enverga trajo, porém, é perceptível ao longo da cintura } \\
\text { uma marca de desgaste do cordão que o cingia sobre a policromia. } \\
\text { A escultura destaca pela cuidadosa proporção infantil e contornos suaves que a } \\
\text { compõem. }\end{array}$ \\
\hline 8. & Técnicas (de suporte): Talha \\
\hline 9. & Técnicas (de acabamento): Policromia \\
\hline 10. & Materiais (de suporte): Madeira \\
\hline 11. & Materiais (de acabamento): Pigmentos; vidro \\
\hline 12. & $\begin{array}{l}\text { Estado de Conservação: Bom; apresenta-se se estável, lacunas no pé e mão; } \\
\text { fissuras em parte importante da policromia }\end{array}$ \\
\hline 13. & $\begin{array}{l}\text { Dimensões: } \\
\text { Altura: } 68 \mathrm{~cm} \\
\text { Largura: } 28 \mathrm{~cm} \\
\text { Profundidade: } 20 \mathrm{~cm} \\
\end{array}$ \\
\hline 14. & $\begin{array}{l}\text { Restauro: apresenta sinais de reintegração cromática recente sobre as pernas; } \\
\text { reintegração do dedo colado na mão direita }\end{array}$ \\
\hline 15. & Datas: primeira metade do século XVIII \\
\hline 16. & $\begin{array}{l}\text { Proveniência: Extinto convento de monjas beneditinas de Santa Escolástica } \\
\text { Bragança }\end{array}$ \\
\hline 17. & Autoria: desconhecida \\
\hline 18. & Oficina: Castelhana (?) \\
\hline 19. & $\begin{array}{l}\text { Localização (inicial \atual) Inicialmente estava em capela própria no convento } \\
\text { das monjas beneditinas. Atualmente está guardado na sacristia dentro do arcaz. }\end{array}$ \\
\hline 20. & $\begin{array}{l}\text { Histórico do objeto: Cardoso Borges refere a grande devoção ao "Menino } \\
\text { Fosquinho" na desaparecida capela do convento de monjas beneditinas de Santa } \\
\text { Escolástica (Borges, } 2012 \text { (texto original de 1721-1724) p. 158). O convento } \\
\text { beneditino é muito próximo do convento de São Francisco, sugerindo pela } \\
\text { extinção as Ordens que a imagem pudesse ter sido resguardada pela Ordem } \\
\text { Terceira, que atualmente ainda a guarda. }\end{array}$ \\
\hline 21. & Iconografia: Menino; Globo terrestre na mão esquerda \\
\hline 22. & Irmandade: não se conhecem registos \\
\hline 23. & Procissões: não se conhecem registos \\
\hline
\end{tabular}




\begin{tabular}{|c|c|}
\hline 1. & $\mathbf{N}^{\mathbf{0}}$ inventário: SFB 33 \\
\hline 2. & Título\Denominação: Menino Jesus Salvador \\
\hline 3. & Outras designações: Menino Jesus \\
\hline 4. & Registo fotográfico: \\
\hline 5. & Proprietários: atuais - Ordem Terceira de Bragança \\
\hline 6. & Categoria: Escultura de vulto pleno - Figurinha de vestir \\
\hline 7. & $\begin{array}{l}\text { Descrição: Escultura de vulto em gesso representando Menino Jesus Salvador. } \\
\text { Está representado de pé, em posição frontal voltada para o observador em ligeiro } \\
\text { contraposto com os braços flectidos e elevados, afastados do corpo, a mão direita } \\
\text { mais elevada com dois dedos flectidos em posição de bênção e a mão esquerda } \\
\text { elevada à altura da cintura está flectida simulando suster algum atributo que já } \\
\text { não tem. } \\
\text { O corpo nu é acentuado pelas linhas arredondadas mas com pouco detalhe. O } \\
\text { rosto também de linhas arredondadas e expressão serena tem os olhos em vidro } \\
\text { castanho com o cabelo ondulado e curto. } \\
\text { As unhas das mãos e pés, bem como os lábios apresentam um tom róseo que se } \\
\text { destaca do resto da carnação. } \\
\text { O braço esquerdo foi intervencionado recentemente com cola abundante sobre a } \\
\text { fractura. Figura sumariamente modelada nos detalhes anatómicos. Não se segura } \\
\text { na posição frontal em que está representado. }\end{array}$ \\
\hline 8. & Técnicas (de suporte): Modelagem, em série a partir de molde \\
\hline 9. & Técnicas (de acabamento): Policromia \\
\hline 10. & Materiais (de suporte): Gesso \\
\hline 11. & Materiais (de acabamento): Pigmentos; vidro \\
\hline
\end{tabular}




\begin{tabular}{|l|l|}
\hline 12. & $\begin{array}{l}\text { Estado de Conservação: Bom; apresenta-se se estável, com sinais de } \\
\text { intervenção recente no braço esquerdo }\end{array}$ \\
\hline 13. & $\begin{array}{l}\text { Dimensões: } \\
\text { Altura: } 38 \mathrm{~cm} \\
\text { Largura: } 16 \mathrm{~cm} \\
\text { Profundidade: } 12 \mathrm{~cm}\end{array}$ \\
\hline 14. & Restauro: consolidação recente no braço esquerdo \\
\hline 15. & Datas: segunda metade do século XX \\
\hline 16. & Proveniência: Igreja de São Francisco de Bragança \\
\hline 17. & Autoria: desconhecida \\
\hline 18. & Oficina: Braga (?) \\
\hline 19. & Localização (atual): Sacristia dentro do arcaz. \\
\hline 20. & Histórico do objeto: não se conhecem registos \\
\hline 21. & Iconografia: Menino; Desaparecido o atributo na mão esquerda \\
\hline 22. & Irmandade: não se conhecem registos \\
\hline 23. & Procissões: não se conhecem registos \\
\hline
\end{tabular}




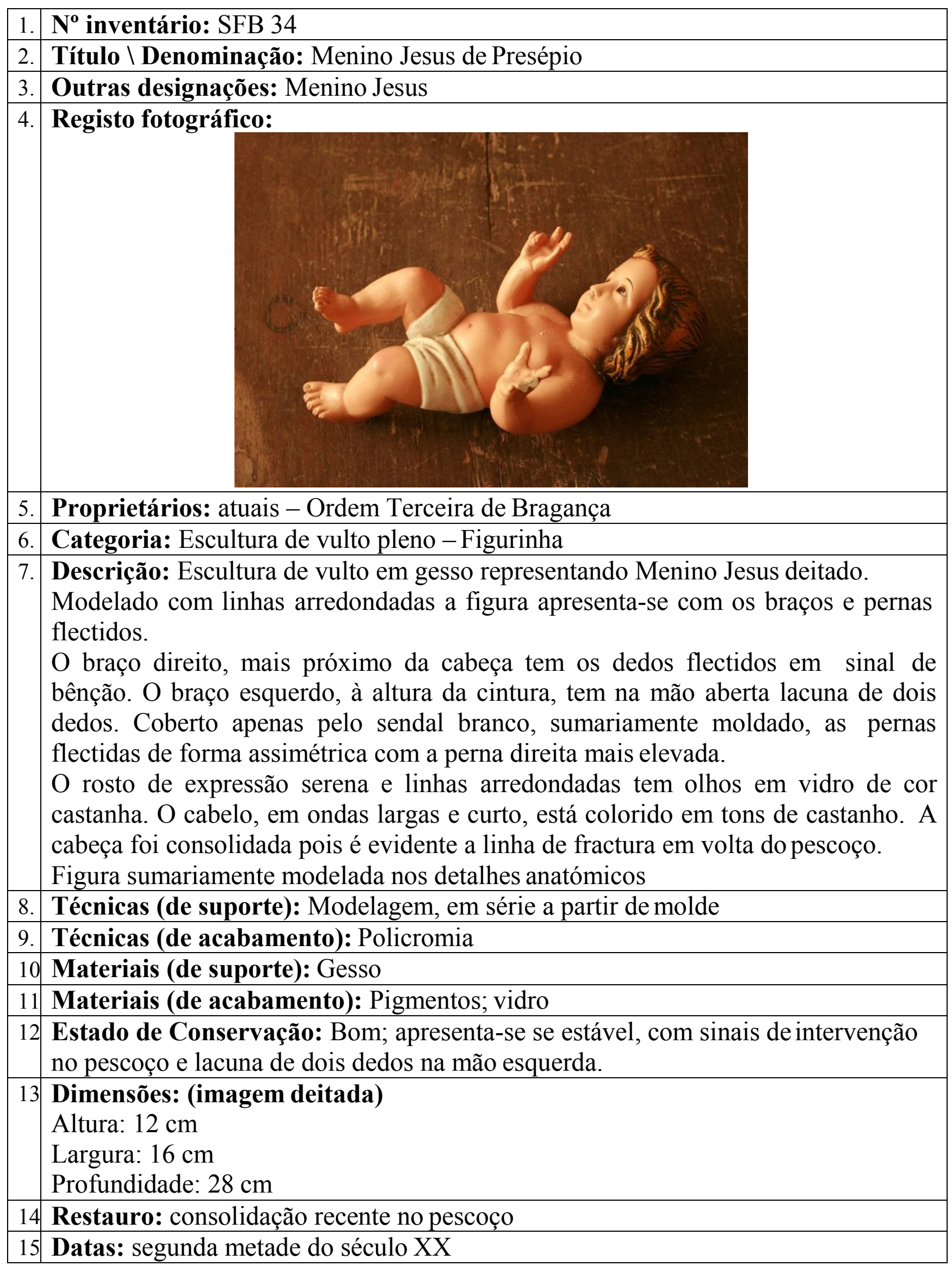


16 Proveniência: Igreja de São Francisco de Bragança

17 Autoria: desconhecida

18 Oficina: Braga (?)

19 Localização (inicial \Atual) - Sacristia dentro do arcaz.

20 Histórico do objeto: não se conhecem registos

21 Iconografia: Menino deitado; presépio.

22 Irmandade: não se conhecem registos

23 Procissões: não se conhecem registos 


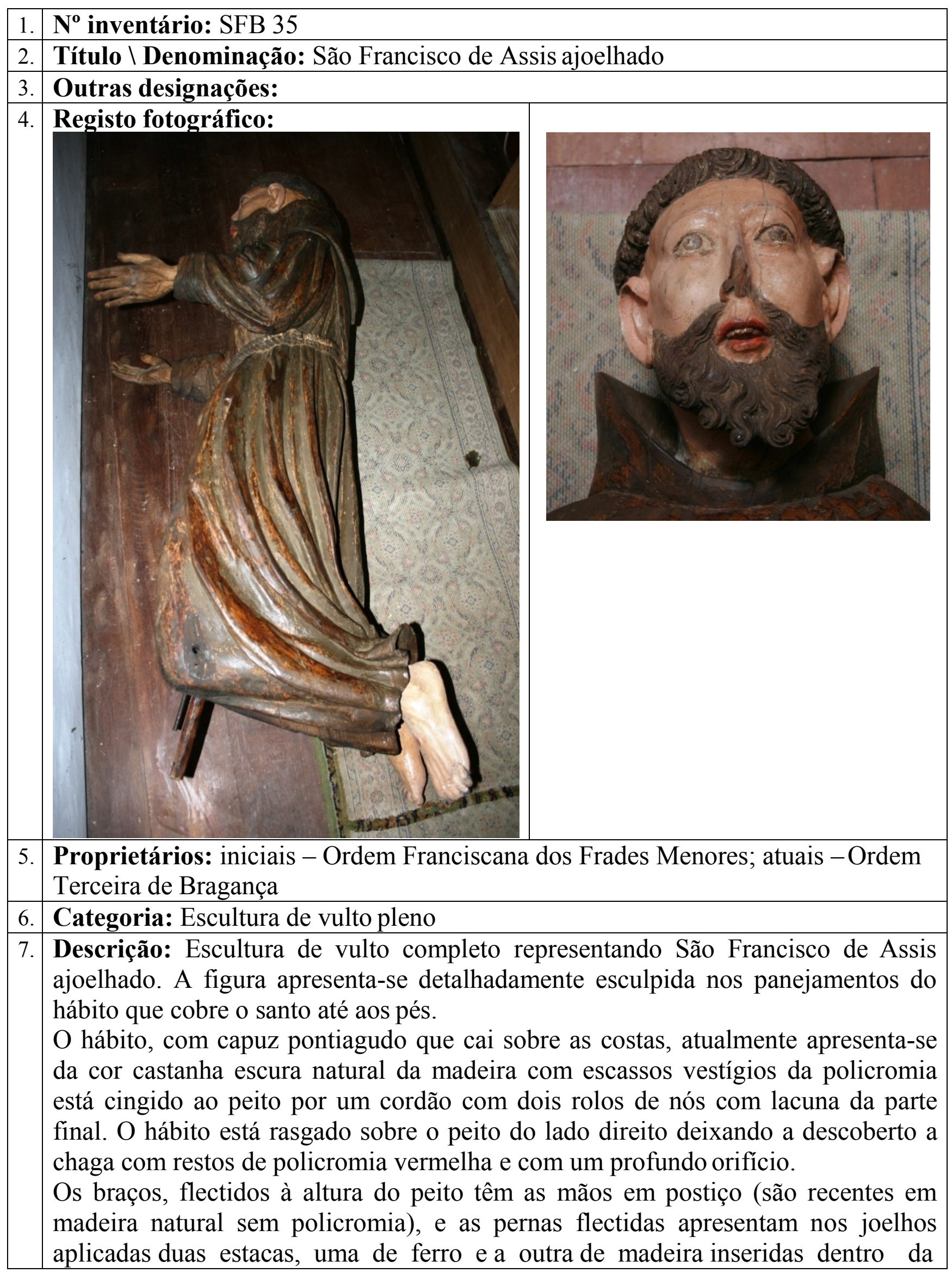




\begin{tabular}{|l|l|}
\hline & $\begin{array}{l}\text { escultura de modo a permitir a sua exposição assente numa base. Apresenta um } \\
\text { terceiro orifício de maior dimensão aparentemente com a mesma função mas que } \\
\text { atualmente já não tem nenhuma estaca. O rosto modelado sumariamente contrasta } \\
\text { com o detalhe dos enrolamentos que decoram a barba o cabelo que cobre a } \\
\text { cabeça tonsurada. A cabeça de forma anatómica irregular está coberta de } \\
\text { policromia, porém a carnação parece ser repinte. A boca vermelha está entreaberta } \\
\text { permitindo que se vejam os dentes. Tem lacuna da ponta do nariz. Os olhos muito } \\
\text { abertos reforçam a expressão de espanto sugerida pela boca entreaberta. } \\
\text { Os pés ainda estão policromados, possivelmente do mesmo momento do repinte da } \\
\text { cabeça, estão descalços e apresentam a mancha vermelha a sugerir o estigma. }\end{array}$ \\
\hline 8. & Técnicas (de suporte): Talha \\
\hline 9. & Técnicas (de acabamento): Policromia \\
\hline 10 & Materiais (de suporte): Madeira \\
\hline 11 & Materiais (de acabamento): Pigmentos; \\
\hline 12 & $\begin{array}{l}\text { Estado de Conservação: Bom; apresenta-se se estável; lacuna na ponta do nariz; } \\
\text { acrescento recente das mãos postiças; forte desgaste da policromia e estufado do } \\
\text { hábito; sinais de repinte }\end{array}$ \\
\hline 13 & $\begin{array}{l}\text { Dimensões: } \\
\text { Altura: } 154 \text { cm } \\
\text { Largura: } 57 \text { cm } \\
\text { Profundidade: } 63 \text { cm }\end{array}$ \\
\hline 14 & $\begin{array}{l}\text { Restauro: acrescento recente das mãos postiças; apresenta sinais de reintegração } \\
\text { cromática }\end{array}$ \\
\hline 15 & Datas: século XVII \\
\hline 16 & Proveniência: Igreja de São Francisco de Bragança \\
\hline 17 & Autoria: desconhecida \\
\hline 18 & Oficina: Local $\backslash$ regional \\
\hline 19 & $\begin{array}{l}\text { Localização (atual): Corredor da sacristia, (a imagem encontra-se deitadopois } \\
\text { não é possível expô-la na sua posição correta por ausência de suporte) }\end{array}$ \\
\hline 20 & $\begin{array}{l}\text { Histórico do objeto: não se conhecem registos, mas é de referir que se trata do } \\
\text { único exemplar em que S. Francisco está representado de joelhos podendo por isso } \\
\text { estar relacionado com a imagem de Cristo Serafim (SFB 30) }\end{array}$ \\
\hline 21 & Iconografia: Hábito Franciscano; estigmas nos pés e sobre opeito. \\
\hline 22 & Irmandade: não se conhecem registos \\
\hline 23 & Procissões: não se conhecem registos \\
\hline
\end{tabular}




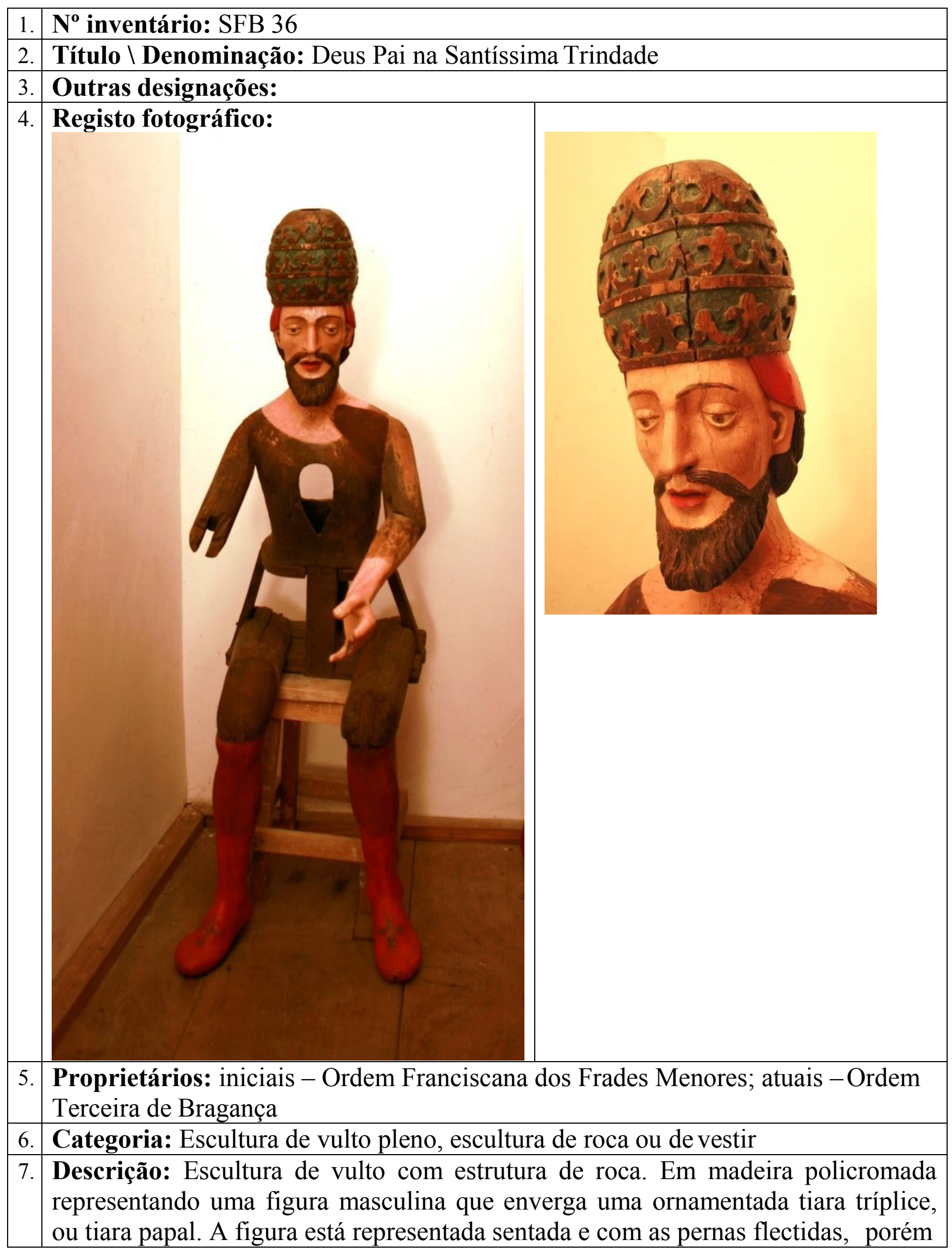




\begin{tabular}{|l|l|}
\hline & $\begin{array}{l}\text { é evidente pelos encaixes de madeira nos joelhos que as pernas já foram passíveis } \\
\text { de ser estendidas para expor a imagem de pé. Sobre o peito apresenta um orifício } \\
\text { de contornos arredondados ao qual corresponde nas costas um amplo orifício de } \\
\text { forma quadrangular. A parte correspondente ao ventre é simulada por uma } \\
\text { estrutura trapezoidal. Nos ombros estão pregados os braços, o direito tem lacuna de } \\
\text { braço e mão, o esquerdo tem lacuna de dois dedos apresentando carnação apenas a } \\
\text { partir do punho. } \\
\text { O rosto, de expressão grave, sumariamente tratado e olhar baixo tem barbas e } \\
\text { bigode castanho com ligeiras ondulações. O cabelo curto apenas visível na nuca é } \\
\text { também castanho e ondulado. A cabeça está coberta por um gorro de cor vermelha } \\
\text { sobre o qual enverga a tiara tríplice de forma abaulada nos bordos decorada num } \\
\text { tom verde com três registos horizontais sobrepostos de ornamentos vegetalistas } \\
\text { estilizados. A carnação está aplicada apenas até ao peito, reforçando a sua } \\
\text { necessidade de indumentária postiça. } \\
\text { A figura destaca pela exuberância da tiara pelas pernas pintadas de vermelho até } \\
\text { aos joelhos, simulando botas altas, sobre as quais tem uma cruz pintada. }\end{array}$ \\
\hline 8. & Técnicas (de suporte): Talha \\
\hline 9. & Técnicas (de acabamento): Policromia \\
\hline 10 & Materiais (de suporte): Madeira \\
\hline 11 & Materiais (de acabamento): Pigmentos \\
\hline 12 & $\begin{array}{l}\text { Estado de Conservação: Bom; apresenta-se se estável; lacuna do braço direito e } \\
\text { de dois dedos na mão esquerda }\end{array}$ \\
\hline 13 & $\begin{array}{l}\text { Dimensões: } \\
\text { Altura: } 150 \text { cm } \\
\text { Largura: } 53 \text { cm } \\
\text { Profundidade: } 75 \text { cm }\end{array}$ \\
\hline 14 & Restauro: apresenta sinais de reintegração cromática \\
\hline 15 & Datas: século XVII \\
\hline 16 & Proveniência: Igreja de São Francisco de Bragança \\
\hline 17 & Autoria: desconhecida \\
\hline 18 & Oficina: Nacional \\
\hline 19 & Localização (atual): Corredor ao lado do coro alto \\
\hline 20 & Histórico do objeto: não se conhecem registos \\
\hline 21 & Iconografia: Figura de roca; Tiara tríplice; botas altas vermelhas \\
\hline 22 & Irmandade: não se conhecem registos \\
\hline 23 & Procissões: não se conhecem registos \\
\hline
\end{tabular}




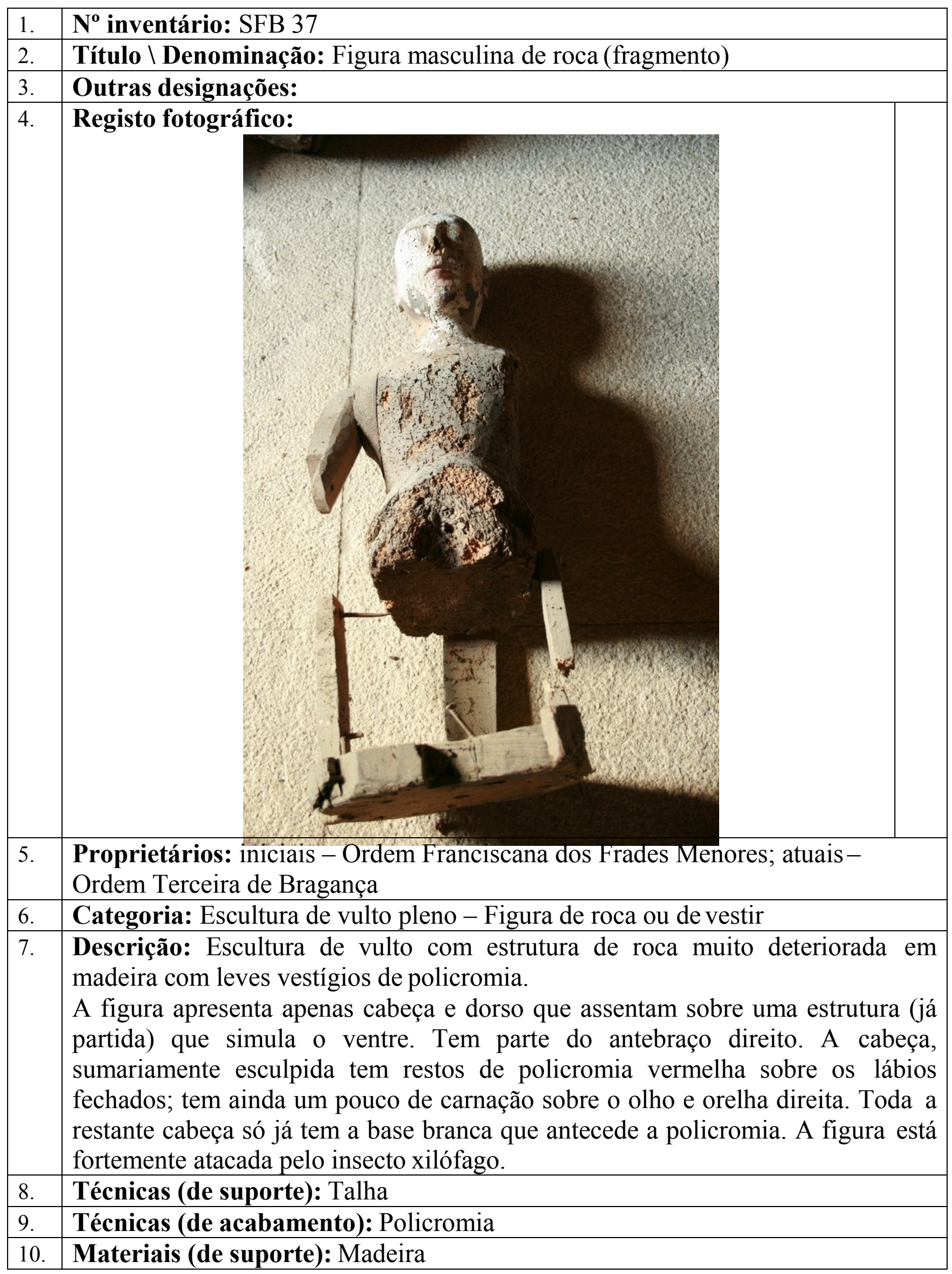




\begin{tabular}{|l|l|}
\hline 11. & Materiais (de acabamento): Pigmentos \\
\hline 12. & $\begin{array}{l}\text { Estado de Conservação: Mau; lacunas várias; degradação da policromia e } \\
\text { ataque de xilófago em toda a obra. }\end{array}$ \\
\hline 13. & $\begin{array}{l}\text { Dimensões: } \\
\text { Altura: } 78 \mathrm{~cm} \\
\text { Largura: } 32 \mathrm{~cm} \\
\text { Profundidade: } 22 \mathrm{~cm}\end{array}$ \\
\hline 14. & Restauro: não apresenta sinais de intervenção sobre a obra \\
\hline 15. & Datas: século XVII \\
\hline 16. & Proveniência: Igreja de São Francisco de Bragança \\
\hline 17. & Autoria: desconhecida \\
\hline 18. & Oficina: Local \\
\hline 19. & Localização (atual): Sala da Casa do Despacho da Ordem Terceira \\
\hline 20. & Histórico do objeto: não se conhecem registos \\
\hline 21. & Iconografia: Figura de roca \\
\hline 22. & Irmandade: não se conhecem registos \\
\hline 23. & Procissões: não se conhecem registos \\
\hline
\end{tabular}




\begin{tabular}{|c|c|}
\hline 1. & $\mathbf{N}^{\mathbf{0}}$ inventário: SFB 38 \\
\hline 2. & Título \Denominação: Santa Luzia \\
\hline 3. & Outras designações: Figura feminina sem cabeça \\
\hline 4. & Registo fotográfico: \\
\hline 5. & $\begin{array}{l}\text { Proprietários: iniciais - Ordem Franciscana dos Frades Menores; atuais- } \\
\text { Ordem Terceira de Braganca }\end{array}$ \\
\hline 6. & Categoria: Escultura de vulto pleno - estatueta \\
\hline 7. & $\begin{array}{l}\text { Descrição: Escultura de vulto com lacuna de cabeça em madeira com restos de } \\
\text { policromia representando uma figura feminina. } \\
\text { A estatueta apresenta-se muito deteriorada. A cabeça foi destacada do corpo } \\
\text { encontrando-se a madeira do pescoço com sinais de ruptura. Tem lacuna dos } \\
\text { braços, apresenta o corpo coberto de vestes que com pragueado fino a cobrem até } \\
\text { aos pés. A cintura bem demarcada apresenta sinais de policromia. A figura } \\
\text { feminina jovem está assente com pregos de ferro sobre uma plataforma } \\
\text { octogonal } \\
\text { A figura está fortemente atacada pelo insecto xilófago. }\end{array}$ \\
\hline 8. & Técnicas (de suporte): Talha \\
\hline 9. & Técnicas (de acabamento): Policromia \\
\hline 10. & Materiais (de suporte): Madeira \\
\hline 11. & Materiais (de acabamento): Pigmentos \\
\hline 12. & Estado de Conservação: Mau; lacunas várias; degradação da policromia e \\
\hline
\end{tabular}




\begin{tabular}{|l|l|}
\hline & ataque de xilófago em toda a obra. \\
\hline 13. & $\begin{array}{l}\text { Dimensões: } \\
\text { Altura: } 68 \mathrm{~cm} \\
\text { Largura: } 25 \mathrm{~cm} \\
\text { Profundidade: } 16 \mathrm{~cm}\end{array}$ \\
\hline 14. & Restauro: não apresenta sinais de intervenção sobre a obra \\
\hline 15. & Datas: século XVII \\
\hline 16. & Proveniência: Igreja de São Francisco de Bragança \\
\hline 17. & Autoria: desconhecida \\
\hline 18. & Oficina: Local \ regional \\
\hline 19. & Localização (atual): Sala da Casa do Despacho da Ordem Terceira \\
\hline 20. & Histórico do objeto: não se conhecem registos \\
\hline 21. & Iconografia: não se conhecem registos \\
\hline 22. & Irmandade: não se conhecem registos \\
\hline 23. & Procissões: não se conhecem registos \\
\hline
\end{tabular}




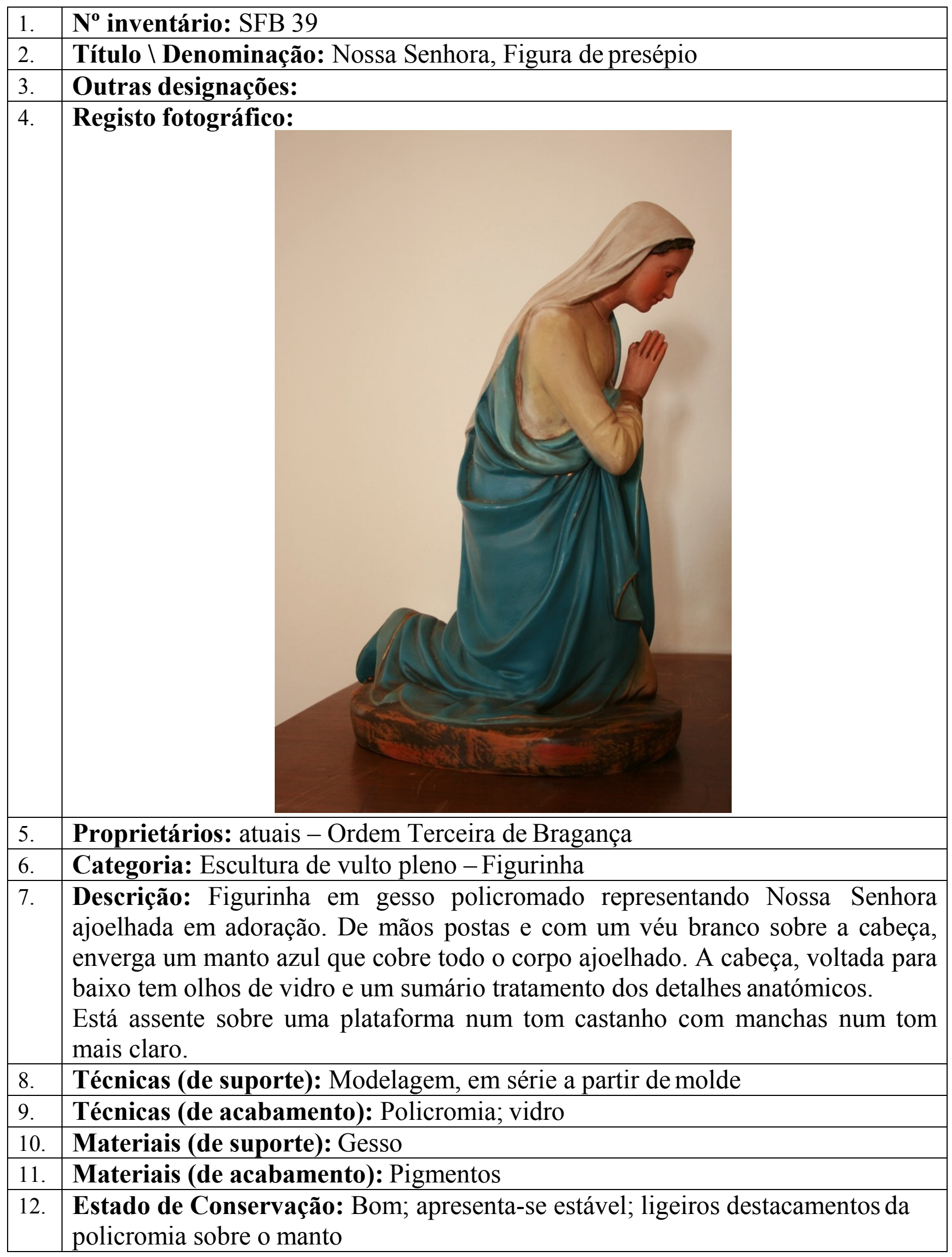




\begin{tabular}{|l|l|}
\hline 13. & $\begin{array}{l}\text { Dimensões: } \\
\text { Altura: } 36 \mathrm{~cm} \\
\text { Largura: } 15 \mathrm{~cm} \\
\text { Profundidade: } 24 \mathrm{~cm}\end{array}$ \\
\hline 14. & Restauro: não apresenta sinais de intervenção sobre a obra \\
\hline 15. & Datas: segunda metade do século XX \\
\hline 16. & Proveniência: Igreja de São Francisco de Bragança \\
\hline 17. & Autoria: desconhecida \\
\hline 18. & Oficina: Braga (?) \\
\hline 19. & Localização (atual): Sala da Casa do Despacho da Ordem Terceira \\
\hline 20. & Histórico do objeto: é elemento de um conjunto com S. José \\
\hline 21. & Iconografia: Nossa Senhora de joelhos; presépio \\
\hline 22. & Irmandade: não se conhecem registos \\
\hline 23. & Procissões: não se conhecem registos \\
\hline
\end{tabular}




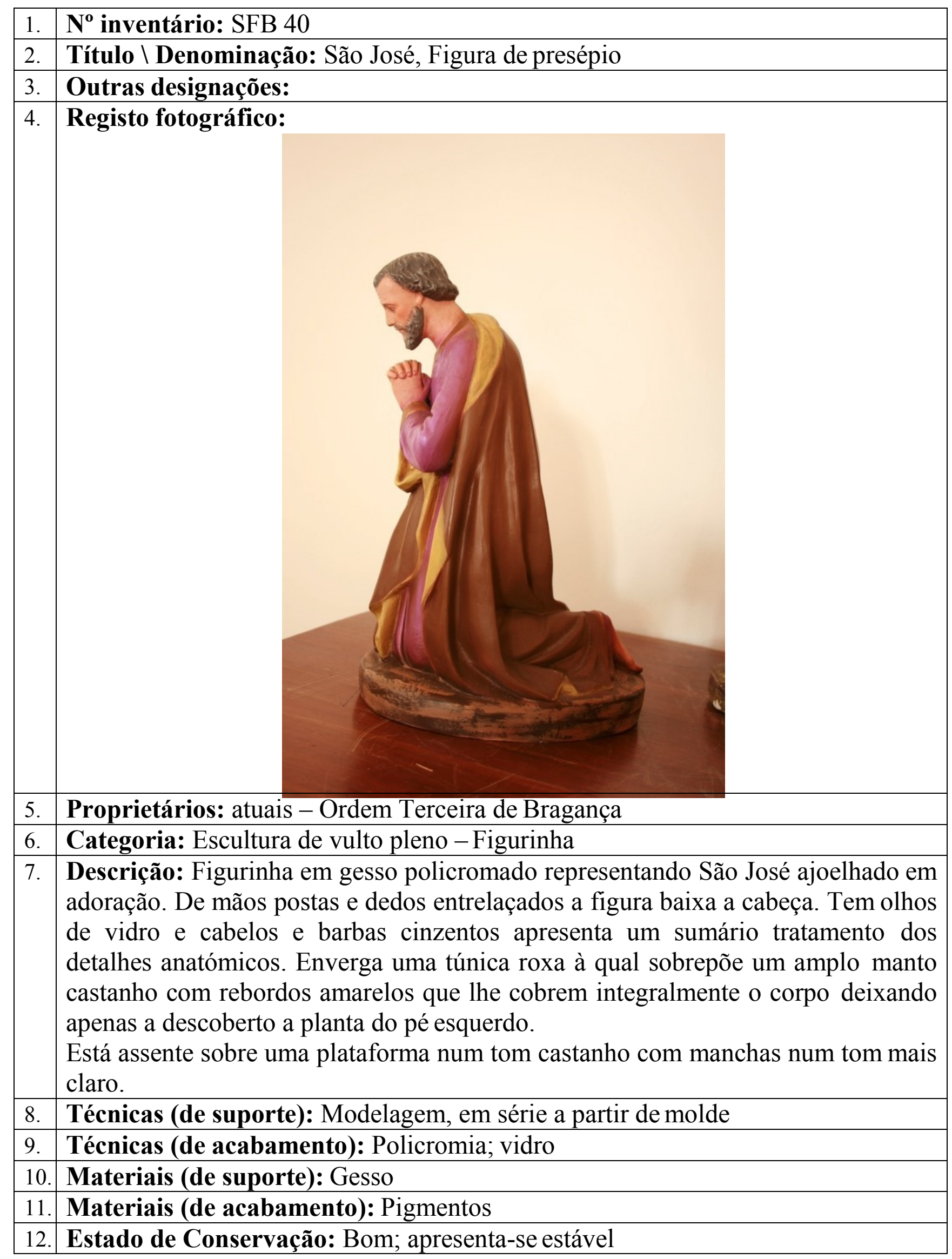




\begin{tabular}{|c|l|}
\hline 13. & $\begin{array}{l}\text { Dimensões: } \\
\text { Altura: } 35 \mathrm{~cm} \\
\text { Largura: } 16 \mathrm{~cm} \\
\text { Profundidade: } 27 \mathrm{~cm}\end{array}$ \\
\hline 14. & Restauro: não apresenta sinais de intervenção sobre a obra \\
\hline 15. & Datas: segunda metade do século XX \\
\hline 16. & Proveniência: Igreja de São Francisco de Bragança \\
\hline 17. & Autoria: desconhecida \\
\hline 18. & Oficina: Braga (?) \\
\hline 19. & Localização (atual): Sala da Casa do Despacho da Ordem Terceira $\left(1^{\circ}\right.$ andar) \\
\hline 20. & Histórico do objeto: é elemento de um conjunto com Nossa Senhora \\
\hline 21. & Iconografia: S. José ajoelhado; presépio \\
\hline 22. & Irmandade: não se conhecem registos \\
\hline 23. & Procissões: não se conhecem registos \\
\hline
\end{tabular}




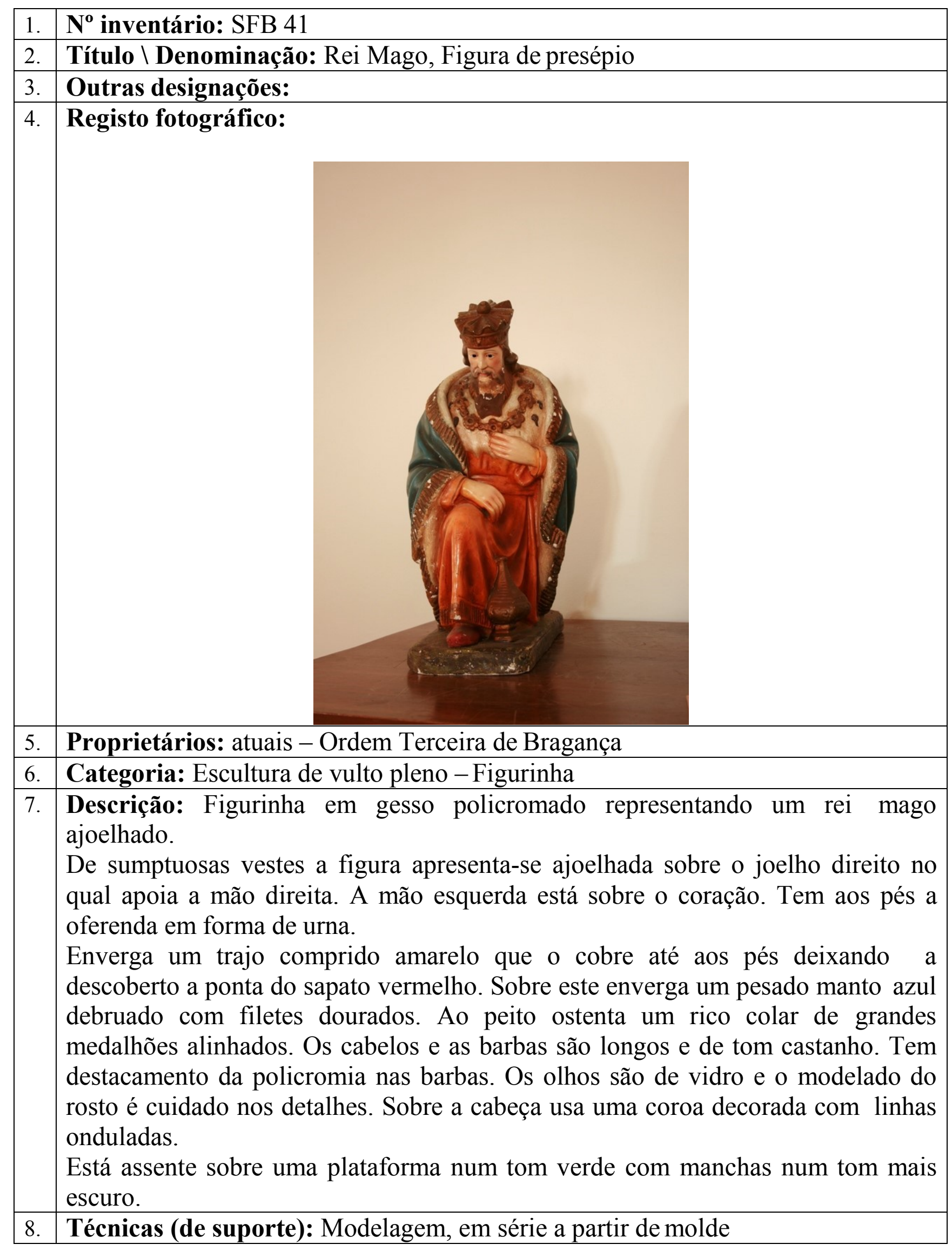




\begin{tabular}{|l|l|}
\hline 9. & Técnicas (de acabamento): Policromia; vidro \\
\hline 10. & Materiais (de suporte): Gesso \\
\hline 11. & Materiais (de acabamento): Pigmentos \\
\hline 12. & $\begin{array}{l}\text { Estado de Conservação: Bom; apresenta-se estável; destacamentos da policromia } \\
\text { nas zonas mais expostas; a degradação do gesso solta um fino pó branco que se } \\
\text { acumula em volta da figura }\end{array}$ \\
\hline 13. & $\begin{array}{l}\text { Dimensões: } \\
\text { Altura: } 47 \mathrm{~cm} \\
\text { Largura: } 24 \mathrm{~cm} \\
\text { Profundidade: } 40 \mathrm{~cm}\end{array}$ \\
\hline 14. & Restauro: não apresenta sinais de intervenção sobre a obra \\
\hline 15. & Datas: século XX \\
\hline 16. & Proveniência: Igreja de São Francisco de Bragança \\
\hline 17. & Autoria: desconhecida \\
\hline 18. & Oficina: Braga (?) \\
\hline 19. & Localização (atual): Sala da Casa do Despacho da Ordem Terceira (1 ${ }^{\circ}$ andar) \\
\hline 20. & Histórico do objeto: é elemento de um conjunto de três reis magos \\
\hline 21. & Iconografia: Rei Mago; oferenda; presépio \\
\hline 22. & Irmandade: não se conhecem registos \\
\hline 23. & Procissões: não se conhecem registos \\
\hline
\end{tabular}




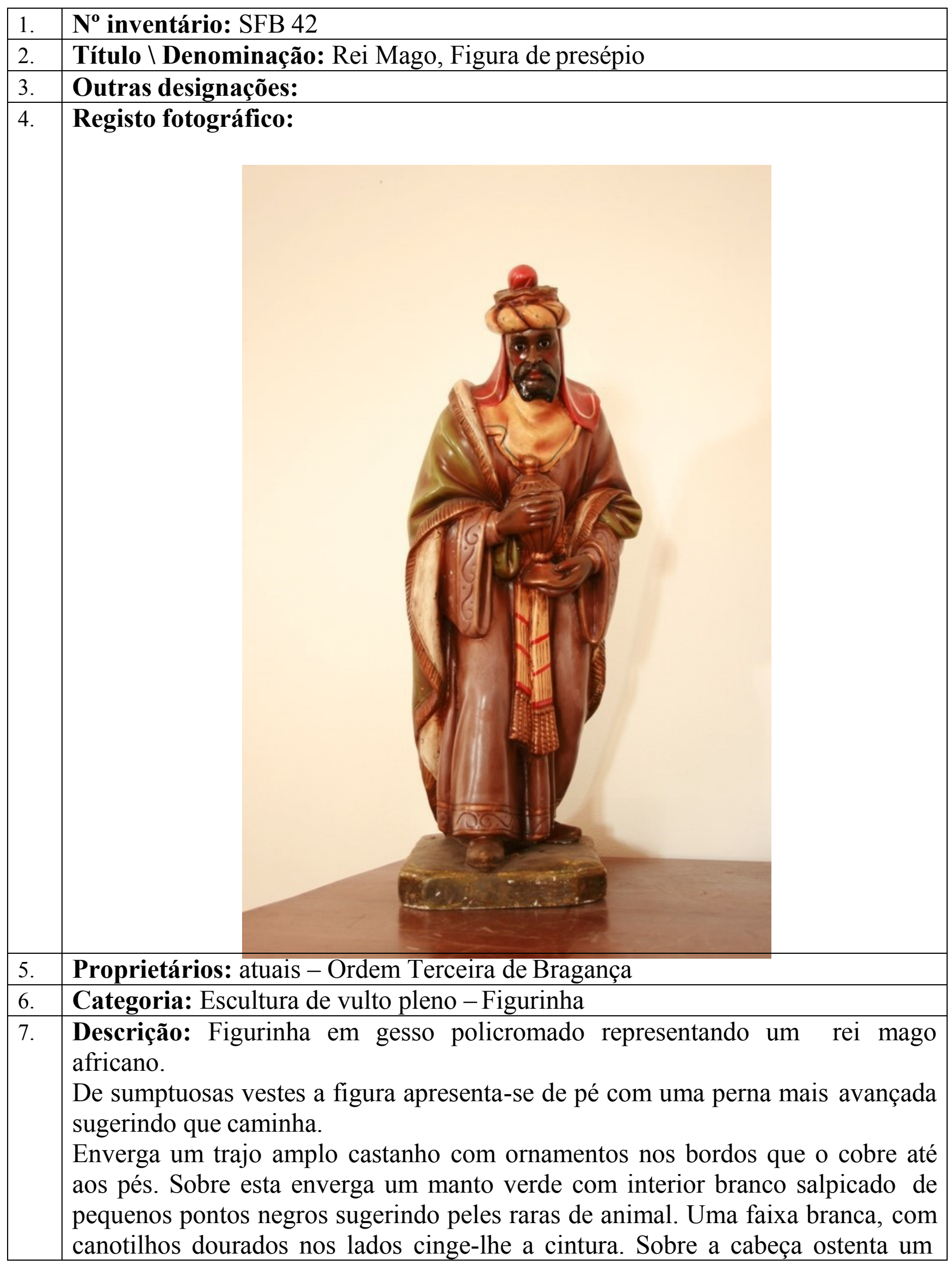




\begin{tabular}{|c|c|}
\hline & $\begin{array}{l}\text { turbante amarelo ricamente decorado que sobrepõe um véu vermelho. O rosto de } \\
\text { carnação brilhante negra com barba bifurcada negra tem os olhos de vidro e um } \\
\text { cuidado modelado do rosto nos detalhes. } \\
\text { Os braços flectidos à altura da cintura seguram com ambas mãos um recipiente } \\
\text { com tampa e pé de forma arredondada com decorações esquemáticas. } \\
\text { Está assente sobre uma plataforma num tom verde com manchas num tom mais } \\
\text { escuro. }\end{array}$ \\
\hline 8. & Técnicas (de suporte): Modelagem, em série a partir de molde \\
\hline 9. & Técnicas (de acabamento): Policromia; vidro \\
\hline 10. & Materiais (de suporte): Gesso \\
\hline 11. & Materiais (de acabamento): Pigmentos \\
\hline 12. & $\begin{array}{l}\text { Estado de Conservação: Bom; apresenta-se estável; alguns destacamentos da } \\
\text { policromia; a degradação do gesso solta um fino pó branco que se acumula em } \\
\text { volta da figura }\end{array}$ \\
\hline 13. & $\begin{array}{l}\text { Dimensões: } \\
\text { Altura: } 64 \mathrm{~cm} \\
\text { Largura: } 20 \mathrm{~cm} \\
\text { Profundidade: } 35 \mathrm{~cm}\end{array}$ \\
\hline 14. & Restauro: não apresenta sinais de intervenção sobre a obra \\
\hline 15. & Datas: século XX \\
\hline 16. & Proveniência: Igreja de São Francisco de Bragança \\
\hline 17. & Autoria: desconhecida \\
\hline 18. & Oficina: Braga (?) \\
\hline 19. & Localização (atual): Sala da Casa do Despacho da Ordem Terceira ( $1^{\circ}$ andar) \\
\hline 20. & Histórico do objeto: é elemento de um conjunto de três reis magos \\
\hline 21. & Iconografia: Rei Mago africano; oferenda; presépio \\
\hline 22. & Irmandade: não se conhecem registos \\
\hline 23. & Procissões: não se conhecem registos \\
\hline
\end{tabular}




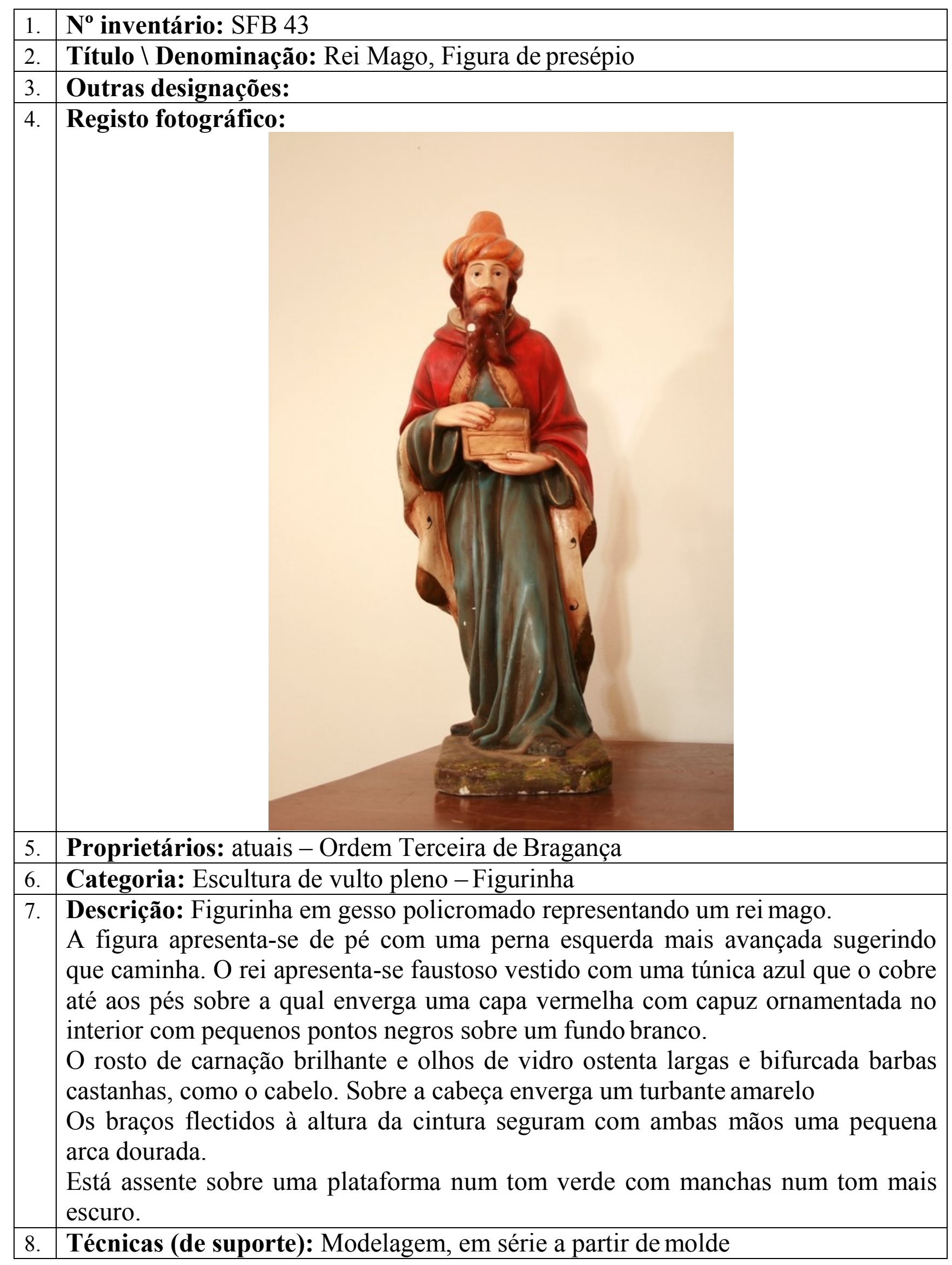




\begin{tabular}{|l|l|}
\hline 9. & Técnicas (de acabamento): Policromia; vidro \\
\hline 10. & Materiais (de suporte): Gesso \\
\hline 11. & Materiais (de acabamento): Pigmentos \\
\hline 12. & $\begin{array}{l}\text { Estado de Conservação: Bom; apresenta-se estável; pequenos destacamentos da } \\
\text { policromia; a degradação do gesso solta um fino pó branco que se acumula em } \\
\text { volta da figura }\end{array}$ \\
\hline 13. & $\begin{array}{l}\text { Dimensões: } \\
\text { Altura: } 67 \mathrm{~cm} \\
\text { Largura: } 26 \mathrm{~cm} \\
\text { Profundidade: } 30 \mathrm{~cm}\end{array}$ \\
\hline 14. & Restauro: não apresenta sinais de intervenção sobre a obra \\
\hline 15. & Datas: segunda metade do século XX \\
\hline 16. & Proveniência: Igreja de São Francisco de Bragança \\
\hline 17. & Autoria: desconhecida \\
\hline 18. & Oficina: Braga (?) \\
\hline 19. & Localização (atual): Sala da Casa do Despacho da Ordem Terceira (1 ${ }^{\circ}$ andar) \\
\hline 20. & Histórico do objeto: é elemento de um conjunto de três reis magos \\
\hline 21. & Iconografia: Rei Mago; oferenda; presépio \\
\hline 22. & Irmandade: não se conhecem registos \\
\hline 23. & Procissões: não se conhecem registos \\
\hline
\end{tabular}




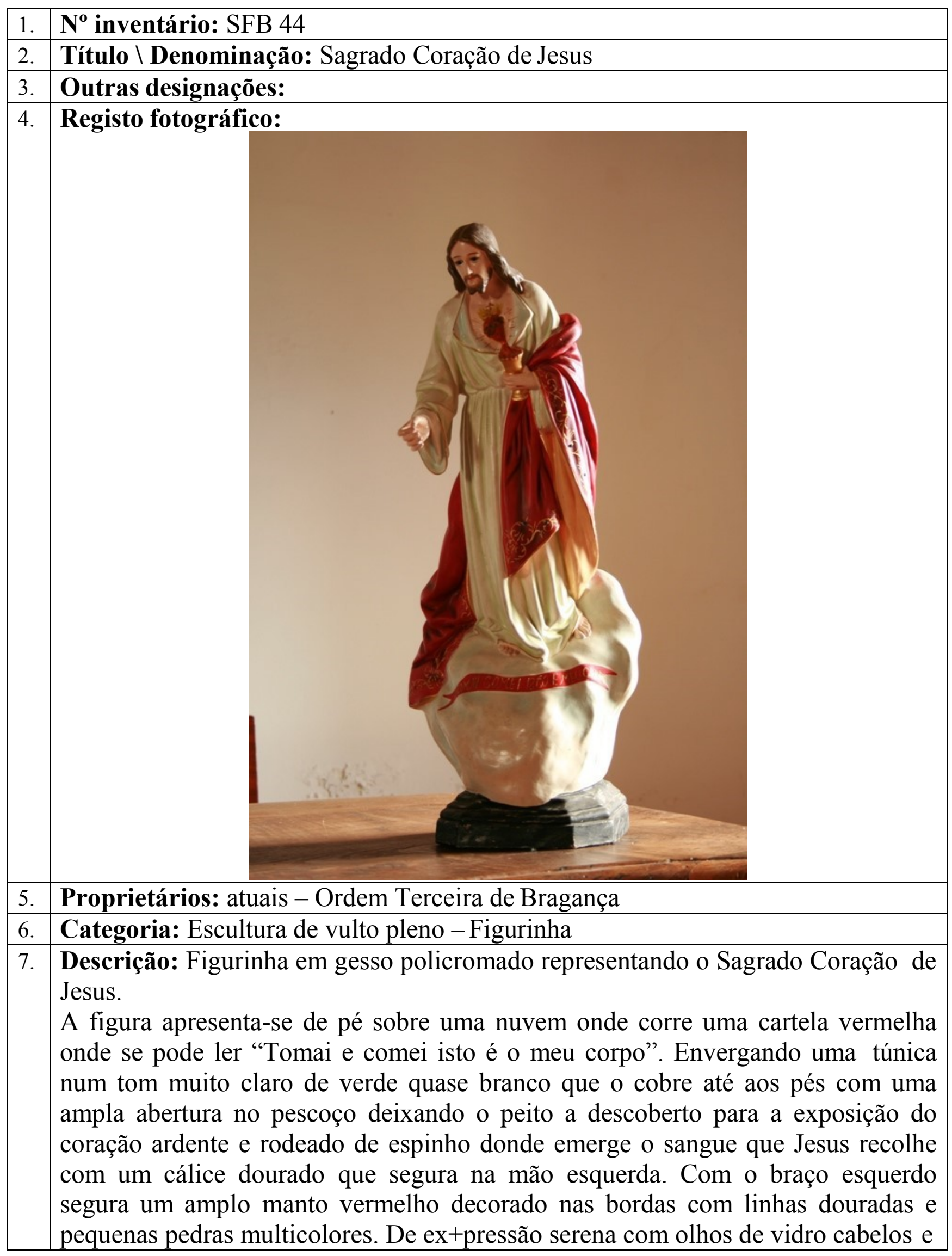




\begin{tabular}{|c|l|}
\hline & $\begin{array}{l}\text { barbas longas de cor castanha. } \\
\text { O braço direito flectido apresenta a mão vazia (porém pode já ter segurado algum } \\
\text { atributo) } \\
\text { Está assente sobre uma plataforma num tom negro e de forma octogonal. }\end{array}$ \\
\hline 8. & Técnicas (de suporte): Modelagem \\
\hline 9. & Técnicas (de acabamento): Policromia; vidro \\
\hline 10. & Materiais (de suporte): Gesso \\
\hline 11. & Materiais (de acabamento): Pigmentos \\
\hline 12. & Estado de Conservação: Bom; apresenta-se estável. \\
\hline 13. & $\begin{array}{l}\text { Dimensões: } \\
\text { Altura: } 58 \text { cm } \\
\text { Largura: } 24 \text { cm } \\
\text { Profundidade: } 22 \text { cm }\end{array}$ \\
\hline 14. & Restauro: não apresenta sinais de intervenção sobre a obra \\
\hline 15. & Datas: século XX \\
\hline 16. & Proveniência: Igreja de São Francisco de Bragança \\
\hline 17. & Autoria: desconhecida \\
\hline 18. & Oficina: Braga (?) \\
\hline 19. & Localização (atual): Sala da Casa do Despacho da Ordem Terceira (1 ${ }^{\circ}$ andar) \\
\hline 20. & Histórico do objeto: não se conhecem registos \\
\hline 21. & Iconografia: Coração ardente; espinhos; cálice \\
\hline 22. & Irmandade: não se conhecem registos \\
\hline 23. & Procissões: não se conhecem registos \\
\hline
\end{tabular}




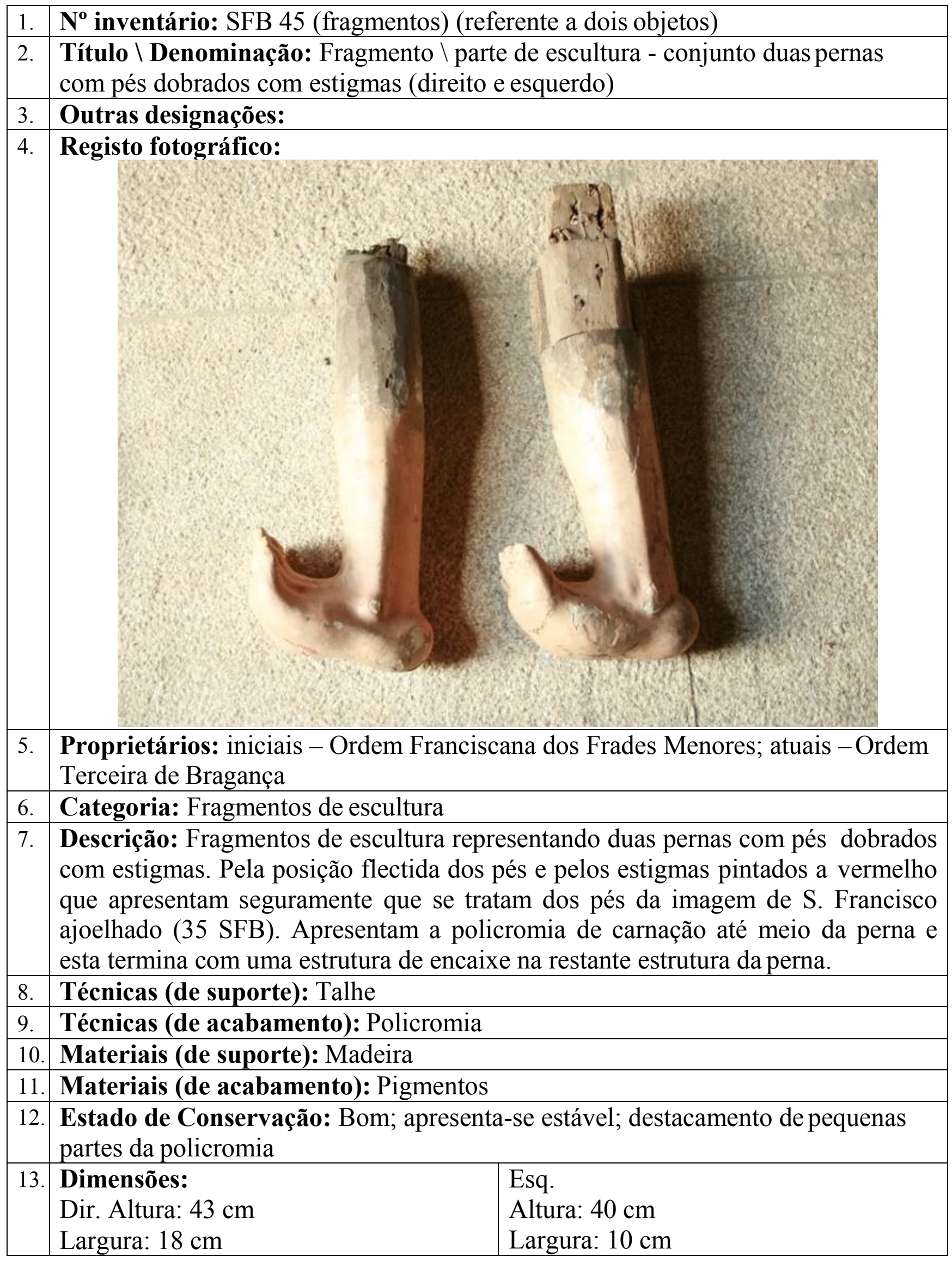




\begin{tabular}{|c|l|l|}
\hline & Profundidade: $8 \mathrm{~cm}$ & Profundidade: $9 \mathrm{~cm}$ \\
\hline 14. & Restauro: não apresenta sinais de intervenção sobre a obra \\
\hline 15. & Datas: século XVIII \\
\hline 16. & Proveniência: Igreja de São Francisco de Bragança \\
\hline 17. & Autoria: desconhecida \\
\hline 18. & Oficina: Local \\
\hline 19. & Localização (atual): Sala da Casa do Despacho da Ordem Terceira \\
\hline 20. & $\begin{array}{l}\text { Histórico do objeto: julgamos que os fragmentos de escultura, na sua maioria } \\
\text { mãos e pés, advêm das últimas obras efetuadas sobre o edificado (finais do século } \\
\text { XX). Possivelmente para não se perderem as mãos e pés das esculturas foram } \\
\text { destacadas e guardadas em conjunto. O prolongamento das obras de restauro terá } \\
\text { provocado o momentâneo desaparecimento que instigou a substituição de várias } \\
\text { mãos e pés das esculturas a culto. }\end{array}$ \\
\hline 21. & Iconografia: Pés fletidos; Estigmas \\
\hline 22. & Irmandade: não se conhecem registos \\
\hline 23. & Procissões: não se conhecem registos \\
\hline
\end{tabular}




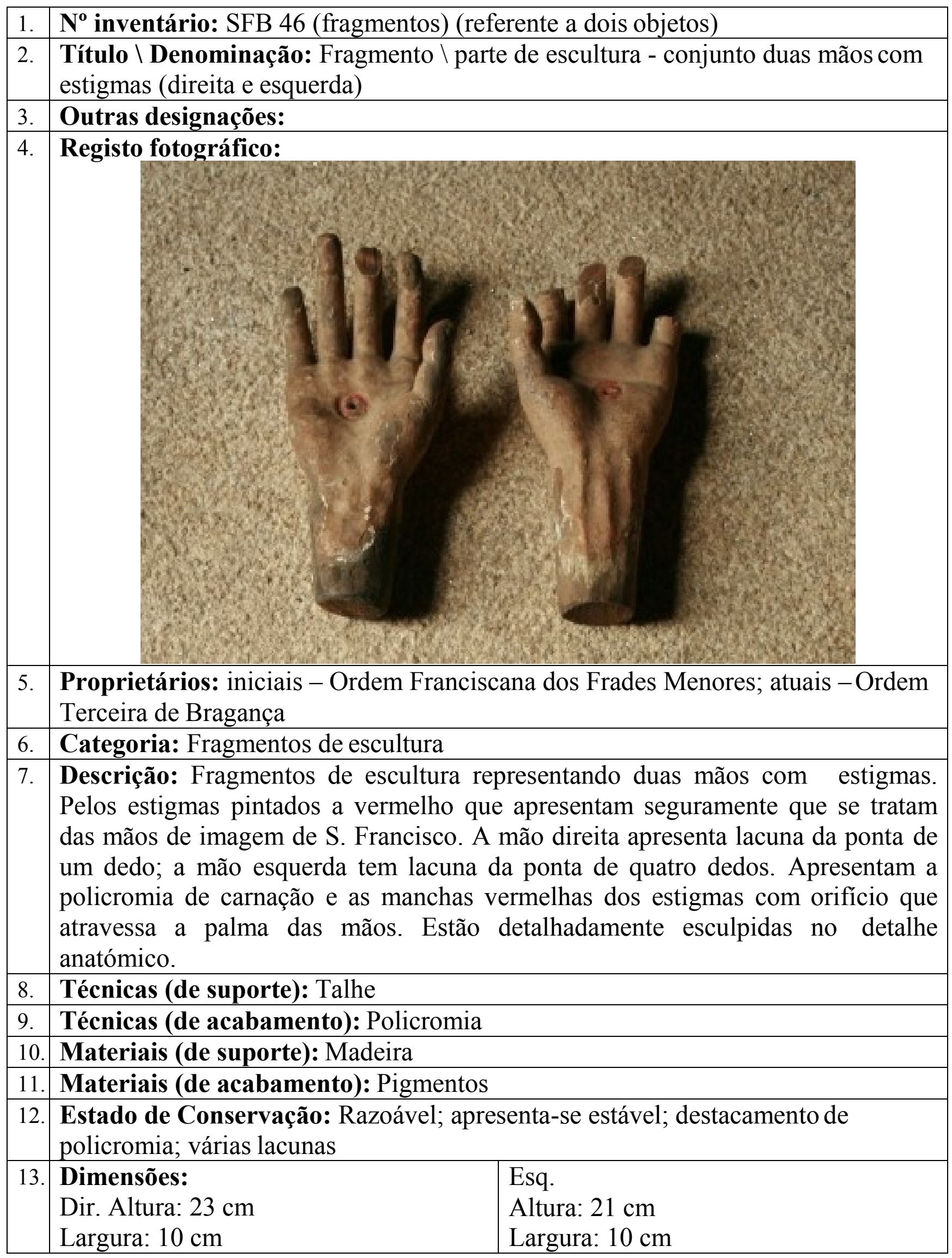




\begin{tabular}{|c|l|l|}
\hline & Profundidade: $4 \mathrm{~cm}$ & Profundidade: $5 \mathrm{~cm}$ \\
\hline 14. & Restauro: não apresenta sinais de intervenção sobre a obra \\
\hline 15. & Datas: século XVIII \\
\hline 16. & Proveniência: Igreja de São Francisco de Bragança \\
\hline 17. & Autoria: desconhecida \\
\hline 18. & Oficina: Local \regional \\
\hline 19. & Localização (atual): Sala da Casa do Despacho da Ordem Terceira \\
\hline 20. & $\begin{array}{l}\text { Histórico do objeto: julgamos que os fragmentos de escultura, na sua maioria } \\
\text { mãos e pés, advêm das últimas obras efetuadas sobre o edificado (finais do século } \\
\text { XX). Possivelmente para não se perderem as mãos e pés das esculturas foram } \\
\text { destacadas e guardadas em conjunto. O prolongamento das obras de restauro terá } \\
\text { provocado o momentâneo desaparecimento que instigou a substituição de várias } \\
\text { mãos e pés das esculturas a culto. }\end{array}$ \\
\hline 21. & Iconografia: Estigmas \\
\hline 22. & Irmandade: não se conhecem registos \\
\hline 23. & Procissões: não se conhecem registos \\
\hline
\end{tabular}




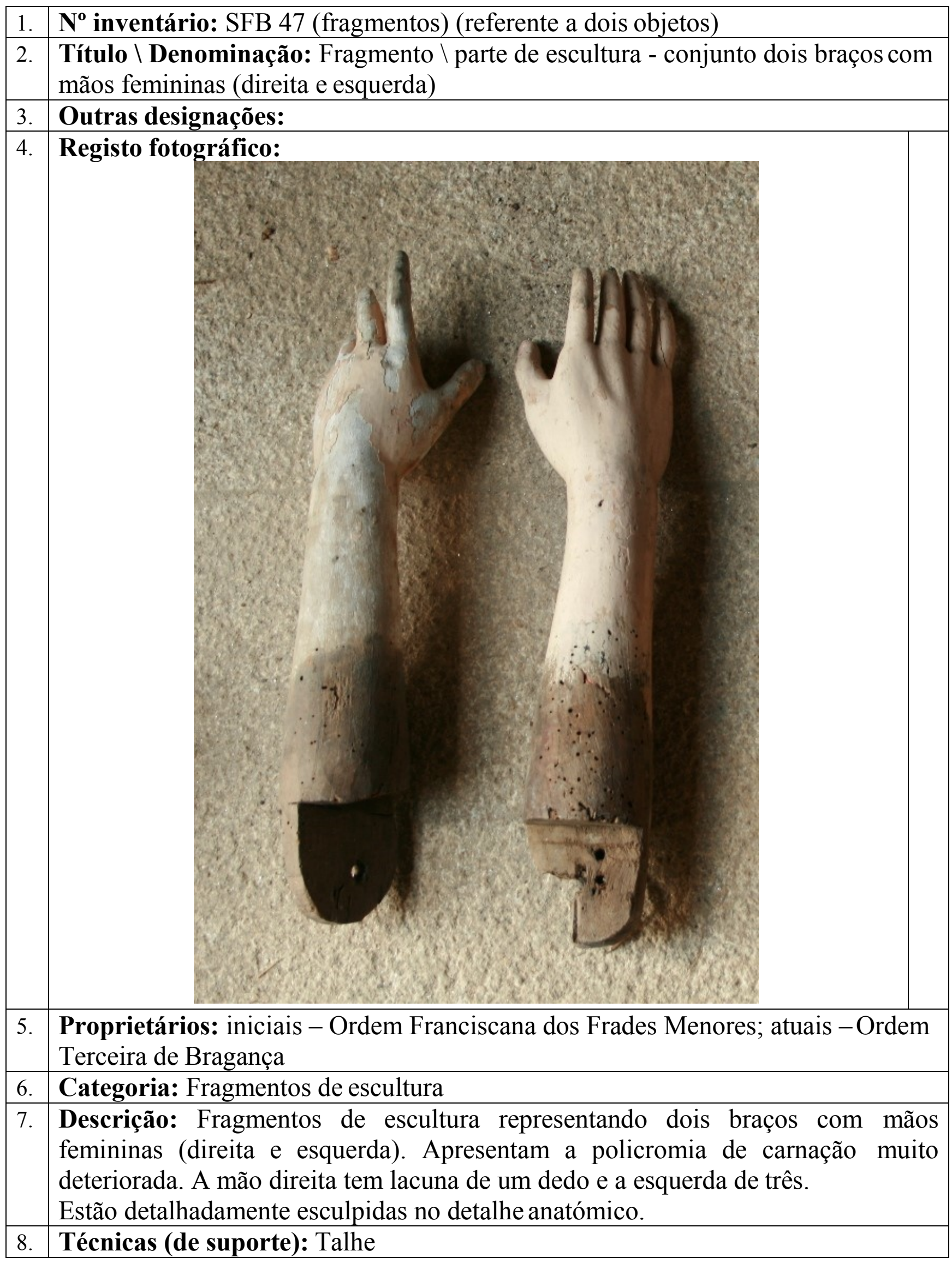




\begin{tabular}{|l|l|l|}
\hline 9. & Técnicas (de acabamento): Policromia \\
\hline 10. & Materiais (de suporte): Madeira \\
\hline 11. & Materiais (de acabamento): Pigmentos \\
\hline 12. & $\begin{array}{l}\text { Estado de Conservação: Razoável; apresenta-se estável; destacamento de } \\
\text { policromia; várias lacunas }\end{array}$ \\
\hline 13. & $\begin{array}{l}\text { Dimensões: } \\
\text { Dir. Altura: } 42 \mathrm{~cm} \\
\text { Largura: } 9 \mathrm{~cm} \\
\text { Profundidade: } 6 \mathrm{~cm}\end{array}$ & $\begin{array}{l}\text { Esq. } \\
\text { Altura: } 40 \mathrm{~cm} \\
\text { Largura: } 9 \mathrm{~cm} \\
\text { Profundidade: } 7 \mathrm{~cm}\end{array}$ \\
\hline 14. & Restauro: não apresenta sinais de intervenção sobre a obra \\
\hline 15. & Datas: século XVIII \\
\hline 16. & Proveniência: Igreja de São Francisco de Bragança \\
\hline 17. & Autoria: desconhecida \\
\hline 18. & Oficina: Nacional \\
\hline 19. & Localização (atual): Sala da Casa do Despacho da Ordem Terceira \\
\hline 20. & $\begin{array}{l}\text { Histórico do objeto: julgamos que os fragmentos de escultura, na sua maioria } \\
\text { mãos e pés, advêm das últimas obras efetuadas sobre o edificado (finais do século } \\
\text { XX). Possivelmente para não se perderem as mãos e pés das esculturas foram } \\
\text { destacadas e guardadas em conjunto. O prolongamento das obras de restauro terá } \\
\text { provocado o momentâneo desaparecimento que instigou a substituição de várias } \\
\text { mãos e pés das esculturas a culto. }\end{array}$ \\
\hline 21. & Iconografia: não se conhecem registos \\
\hline 22. & Irmandade: não se conhecem registos \\
\hline 23. & Procissões: não se conhecem registos \\
\hline
\end{tabular}




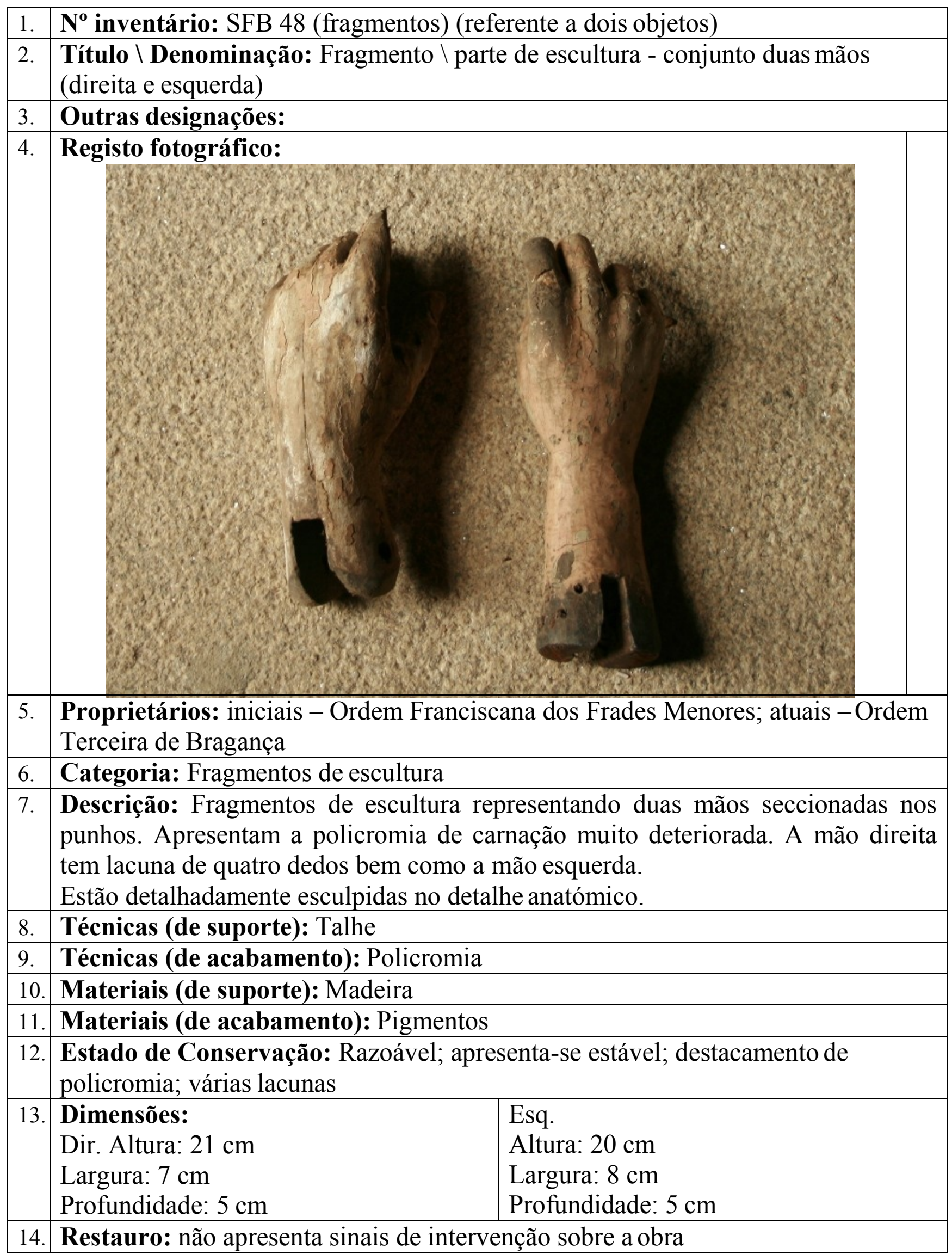




\begin{tabular}{|c|l|}
\hline 15 & Datas: século XVIII \\
\hline 16. & Proveniência: Igreja de São Francisco de Bragança \\
\hline 17. & Autoria: desconhecida \\
\hline 18. & Oficina: Local $\backslash$ regional \\
\hline 19. & Localização (atual): Sala da Casa do Despacho da Ordem Terceira \\
\hline 20. & $\begin{array}{l}\text { Histórico do objeto: julgamos que os fragmentos de escultura, na sua maioria } \\
\text { mãos e pés, advêm das últimas obras efetuadas sobre o edificado (finais do século } \\
\text { XX). Possivelmente para não se perderem as mãos e pés das esculturas foram } \\
\text { destacadas e guardadas em conjunto. O prolongamento das obras de restauro terá } \\
\text { provocado o momentâneo desaparecimento que instigou a substituição de várias } \\
\text { mãos e pés das esculturas a culto. }\end{array}$ \\
\hline 21. & Iconografia: não se conhecem registos \\
\hline 22. & Irmandade: não se conhecem registos \\
\hline 23. & Procissões: não se conhecem registos \\
\hline
\end{tabular}




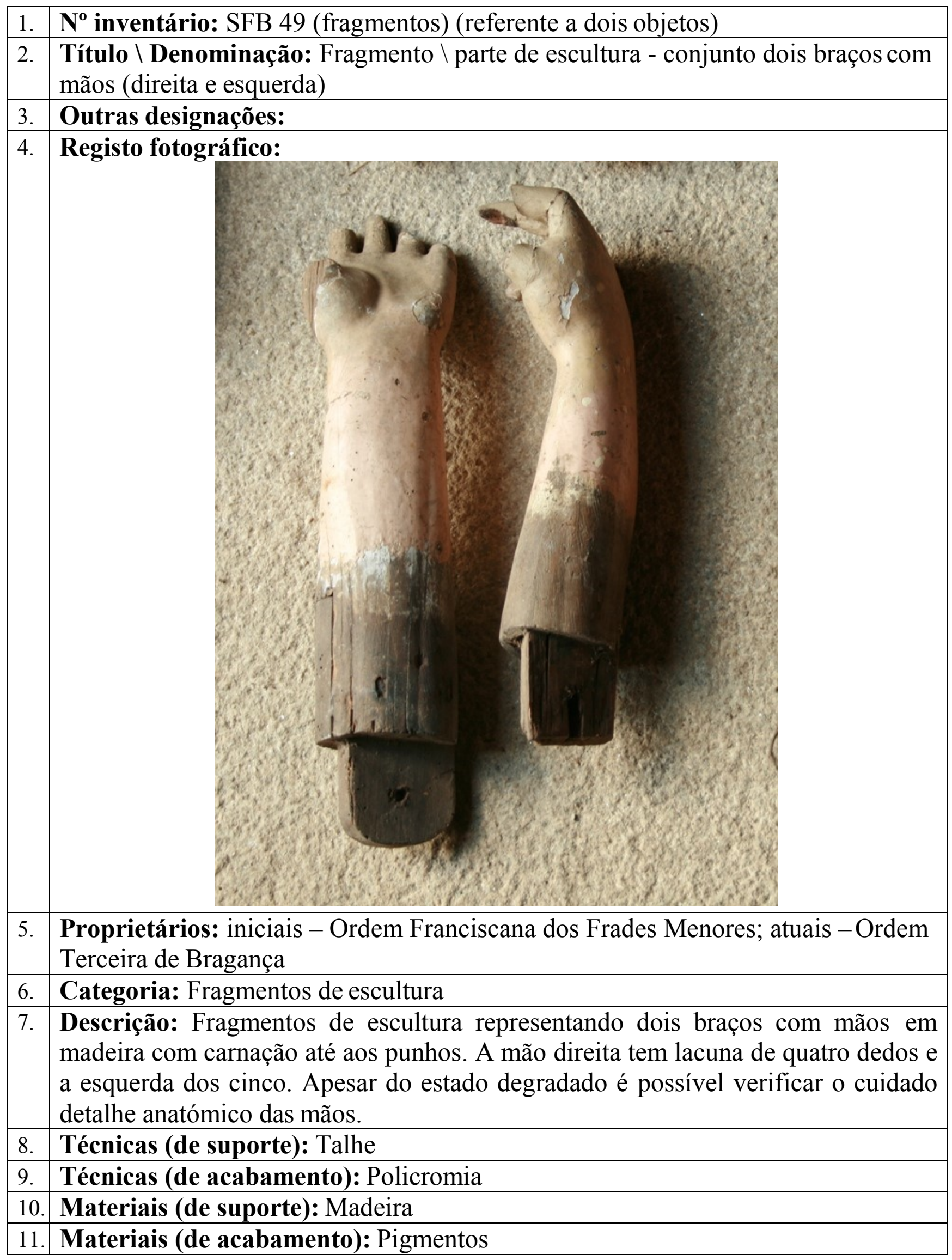


12. Estado de Conservação: Razoável; apresenta-se estável; destacamento de policromia; várias lacunas

\begin{tabular}{|r|l|l|}
\hline 13. & Dimensões: \\
Dir. Altura: $32 \mathrm{~cm}$ & $\begin{array}{l}\text { Esq. } \\
\text { Largura: } 11 \mathrm{~cm} \\
\text { Profundidade: } 9 \mathrm{~cm}\end{array}$ & $\begin{array}{l}\text { Largura: } 10 \mathrm{~cm} \\
\text { Profundidade: } 7 \mathrm{~cm}\end{array}$ \\
\hline 14. & Restauro: não apresenta sinais de intervenção sobre a obra \\
\hline 15. & Datas: século XVIII \\
\hline 16. & Proveniência: Igreja de São Francisco de Bragança \\
\hline 17. & Autoria: desconhecida \\
\hline 18. & Oficina: Nacional \\
\hline 19. & Localização (atual): Sala da Casa do Despacho da Ordem Terceira \\
\hline 20. & $\begin{array}{l}\text { Histórico do objeto: julgamos que os fragmentos de escultura, na sua maioria } \\
\text { mãos e pés, advêm das últimas obras efetuadas sobre o edificado (finais do século } \\
\text { XX). Possivelmente para não se perderem as mãos e pés das esculturas foram } \\
\text { destacadas e guardadas em conjunto. O prolongamento das obras de restauro terá } \\
\text { provocado o momentâneo desaparecimento que instigou a substituição de várias } \\
\text { mãos e pés das esculturas a culto. }\end{array}$ \\
\hline 21. & Iconografia: não se conhecem registos \\
\hline 22. & Irmandade: não se conhecem registos \\
\hline 23. & Procissões: não se conhecem registos \\
\hline
\end{tabular}




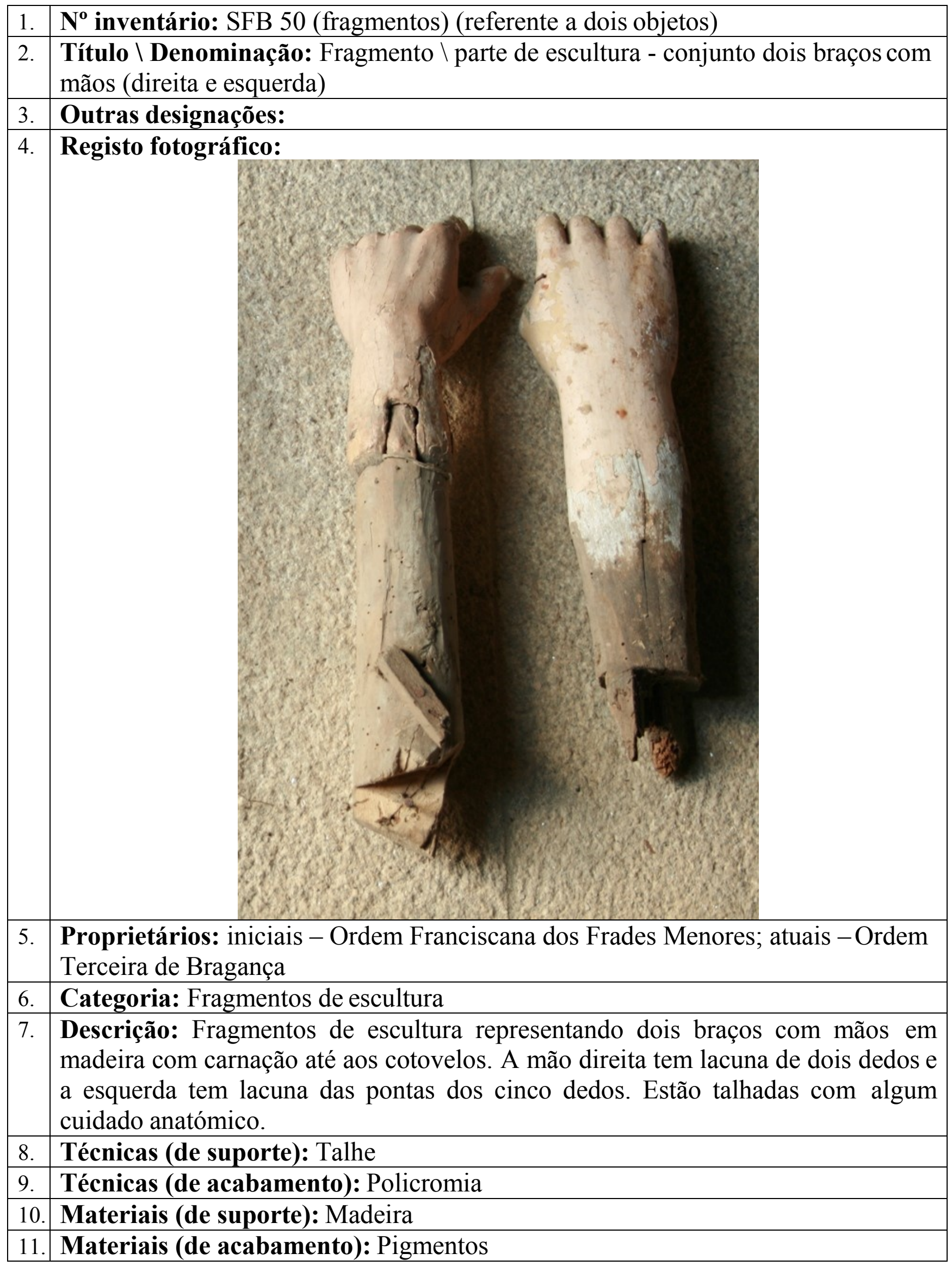


12. Estado de Conservação: Razoável; apresenta-se estável; destacamento de policromia; várias lacunas

\begin{tabular}{|r|l|l|}
\hline 13. & Dimensões: \\
Dir. Altura: $59 \mathrm{~cm}$ & $\begin{array}{l}\text { Esq. } \\
\text { Largura: } 12 \mathrm{~cm} \\
\text { Profundidade: } 6 \mathrm{~cm}\end{array}$ & $\begin{array}{l}\text { Largura: } 11 \mathrm{~cm} \\
\text { Profundidade: } 6 \mathrm{~cm}\end{array}$ \\
\hline 14. & Restauro: não apresenta sinais de intervenção sobre a obra \\
\hline 15. & Datas: século XVIII \\
\hline 16. & Proveniência: Igreja de São Francisco de Bragança \\
\hline 17. & Autoria: desconhecida \\
\hline 18. & Oficina: Local \regional \\
\hline 19. & Localização (atual): Sala da Casa do Despacho da Ordem Terceira \\
\hline 20. & $\begin{array}{l}\text { Histórico do objeto: julgamos que os fragmentos de escultura, na sua maioria } \\
\text { mãos e pés, advêm das últimas obras efetuadas sobre o edificado (finais do século } \\
\text { XX). Possivelmente para não se perderem as mãos e pés das esculturas foram } \\
\text { destacadas e guardadas em conjunto. O prolongamento das obras de restauro terá } \\
\text { provocado o momentâneo desaparecimento que instigou a substituição de várias } \\
\text { mãos e pés das esculturas a culto. }\end{array}$ \\
\hline 21. & Iconografia: não se conhecem registos \\
\hline 22. & Irmandade: não se conhecem registos \\
\hline 23. & Procissões: não se conhecem registos \\
\hline
\end{tabular}




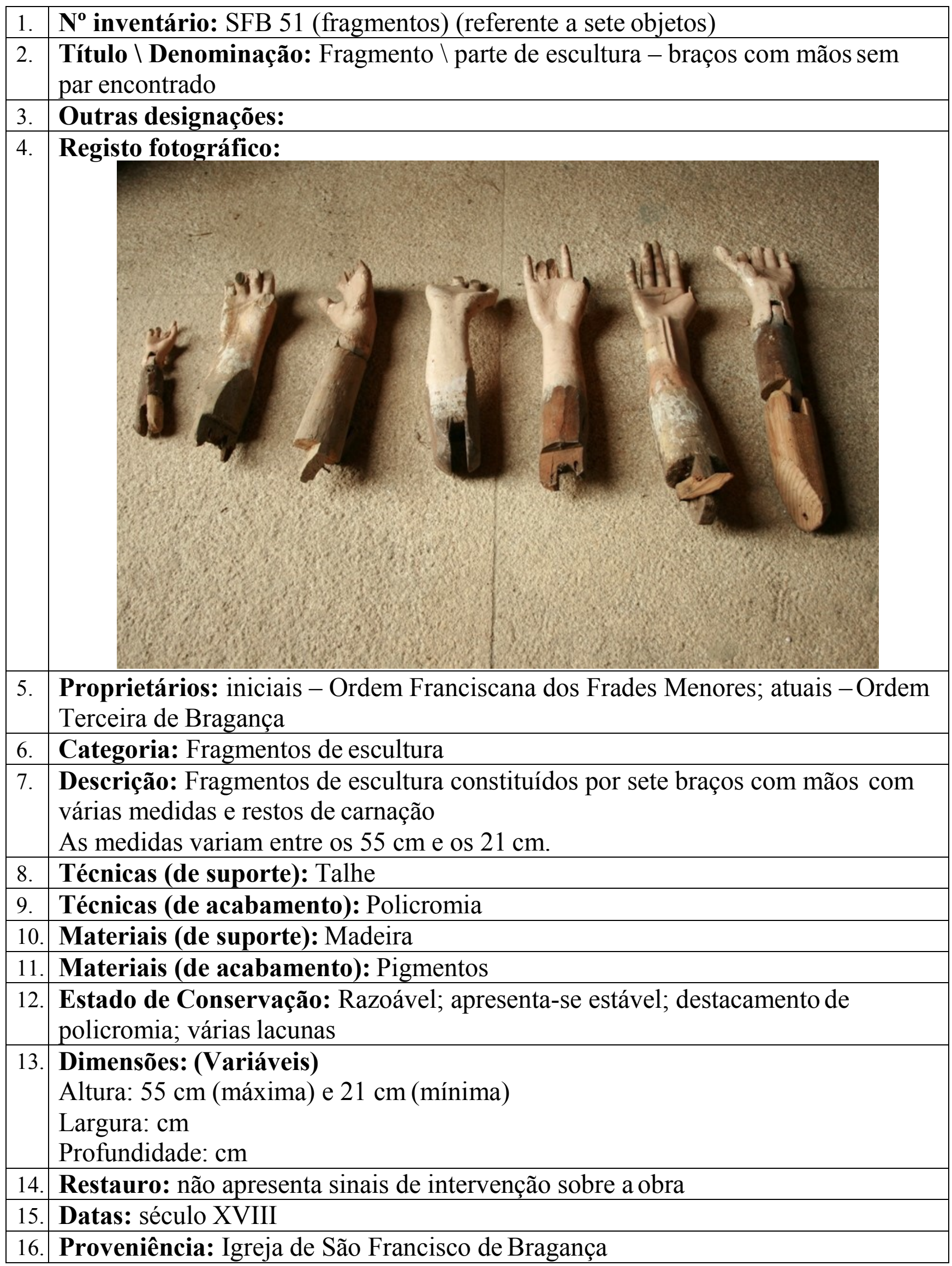




\begin{tabular}{|c|l|}
\hline 17. & Autoria: desconhecida \\
\hline 18. & Oficina: Local \regional \\
\hline 19. & Localização (atual): Sala da Casa do Despacho da Ordem Terceira \\
\hline 20. & $\begin{array}{l}\text { Histórico do objeto: julgamos que os fragmentos de escultura, na sua maioria } \\
\text { mãos e pés, advêm das últimas obras efetuadas sobre o edificado (finais do século } \\
\text { XX). Possivelmente para não se perderem as mãos e pés das esculturas foram } \\
\text { destacadas e guardadas em conjunto. O prolongamento das obras de restauro terá } \\
\text { provocado o momentâneo desaparecimento que instigou a substituição de várias } \\
\text { mãos e pés das esculturas a culto. }\end{array}$ \\
\hline 21. & Iconografia: não se conhecem registos \\
\hline 22. & Irmandade: não se conhecem registos \\
\hline 23. & Procissões: não se conhecem registos \\
\hline
\end{tabular}




\begin{tabular}{|c|c|}
\hline 1. & $\mathbf{N}^{0}$ inventário: SFB 52 (fragmentos) (referente a quatro objetos) \\
\hline 2. & $\begin{array}{l}\text { Título \Denominação: Fragmento } \backslash \text { parte de escultura } \text { - par de pernas combotas } \\
\text { de cano alto }\end{array}$ \\
\hline 3. & Outras designações: \\
\hline 4. & Registo fotográfico: \\
\hline 5. & Proprietários: iniciais - Ordem Franciscana dos Frades Menores; atuais - \\
\hline 6 & $\begin{array}{l}\text { Urdem lerceira de Bragança } \\
\text { Cateonoria: Fraomentos de escultura }\end{array}$ \\
\hline 7. & $\begin{array}{l}\text { Descrição: Fragmentos de escultura constituídos por quatro pernas com botas de } \\
\text { cano alto. Peculiar conjunto de pernas com encaixe para sustentação em madeira } \\
\text { cobertas de cabedal simulando botas de militares }\end{array}$ \\
\hline 8. & Técnicas (de suporte): Talhe \\
\hline 9. & Técnicas (de acabamento): Policromia \\
\hline 10. & Materiais (de suporte): Madeira \\
\hline 11. & Materiais (de acabamento): Pigmentos; cabedal \\
\hline 12. & $\begin{array}{l}\text { Estado de Conservação: Razoável; apresenta-se estável; destacamento de } \\
\text { policromia; várias lacunas }\end{array}$ \\
\hline 13. & $\begin{array}{l}\text { Dimensões: (Variáveis) } \\
\text { Altura: } 24 \mathrm{~cm} \text { (máxima) e } 21 \mathrm{~cm} \text { (mínima) } \\
\text { Largura: } 5 \mathrm{~cm} \text { (máxima) e } 3 \mathrm{~cm} \text { (mínima) } \\
\text { Profundidade: } 10 \mathrm{~cm} \text { (máxima) e } 8 \mathrm{~cm} \text { (mínima) }\end{array}$ \\
\hline 14. & Restauro: não apresenta sinais de intervenção sobre a obra \\
\hline 15. & Datas: século XVIII \\
\hline
\end{tabular}




\begin{tabular}{|l|l|}
\hline 16. & Proveniência: Igreja de São Francisco de Bragança \\
\hline 17. & Autoria: desconhecida \\
\hline 18. & Oficina: Local $\backslash$ regional \\
\hline 19. & Localização (atual): Sala da Casa do Despacho da Ordem Terceira \\
\hline 20. & $\begin{array}{l}\text { Histórico do objeto: julgamos que os fragmentos de escultura de botas militares } \\
\text { estaria relacionado com as celebrações levadas a cabo pela Irmandade de } \\
\text { Militares na igreja }\end{array}$ \\
\hline 21. & Iconografia: Botas altas de militar \\
\hline 22. & $\begin{array}{l}\text { Irmandade: Na Capela de Nossa Senhora do Rosário houve uma Irmandade de } \\
\text { Militares (Borges, 2012 (texto original de 1721-1724) p. 142) }\end{array}$ \\
\hline 23. & Procissões: não se conhecem registos \\
\hline
\end{tabular}




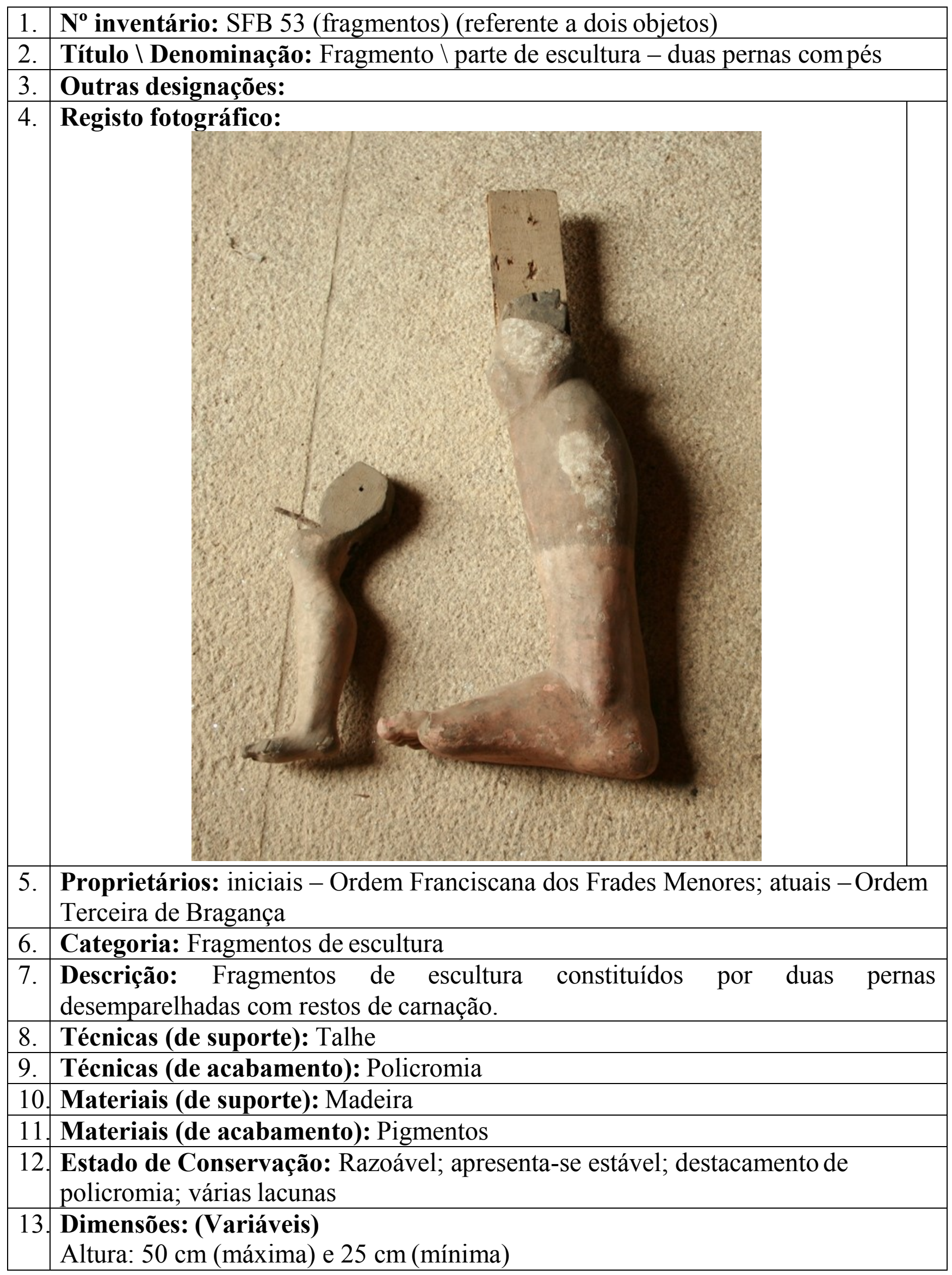




\begin{tabular}{|l|l|}
\hline & $\begin{array}{l}\text { Largura: } 8 \mathrm{~cm} \text { (máxima) e } 3 \mathrm{~cm} \text { (mínima) } \\
\text { Profundidade: } 21 \mathrm{~cm} \text { (máxima) e } 7 \mathrm{~cm} \text { (mínima) }\end{array}$ \\
\hline 14. & Restauro: não apresenta sinais de intervenção sobre a obra \\
\hline 15. & Datas: século XVIII \\
\hline 16. & Proveniência: Igreja de São Francisco de Bragança \\
\hline 17. & Autoria: desconhecida \\
\hline 18. & Oficina: Local $\backslash$ regional \\
\hline 19. & Localização (atual): Sala da Casa do Despacho da Ordem Terceira \\
\hline 20. & $\begin{array}{l}\text { Histórico do objeto: julgamos que os fragmentos de escultura, na sua maioria } \\
\text { mãos e pés, advêm das últimas obras efetuadas sobre o edificado (finais do século } \\
\text { XX). Possivelmente para não se perderem as mãos e pés das esculturas foram } \\
\text { destacadas e guardadas em conjunto. O prolongamento das obras de restauro terá } \\
\text { provocado o momentâneo desaparecimento que instigou a substituição de várias } \\
\text { mãos e pés das esculturas a culto. }\end{array}$ \\
\hline 21. & Iconografia: não se conhecem registos \\
\hline 22. & Irmandade: não se conhecem registos \\
\hline 23. & Procissões: não se conhecem registos \\
\hline
\end{tabular}




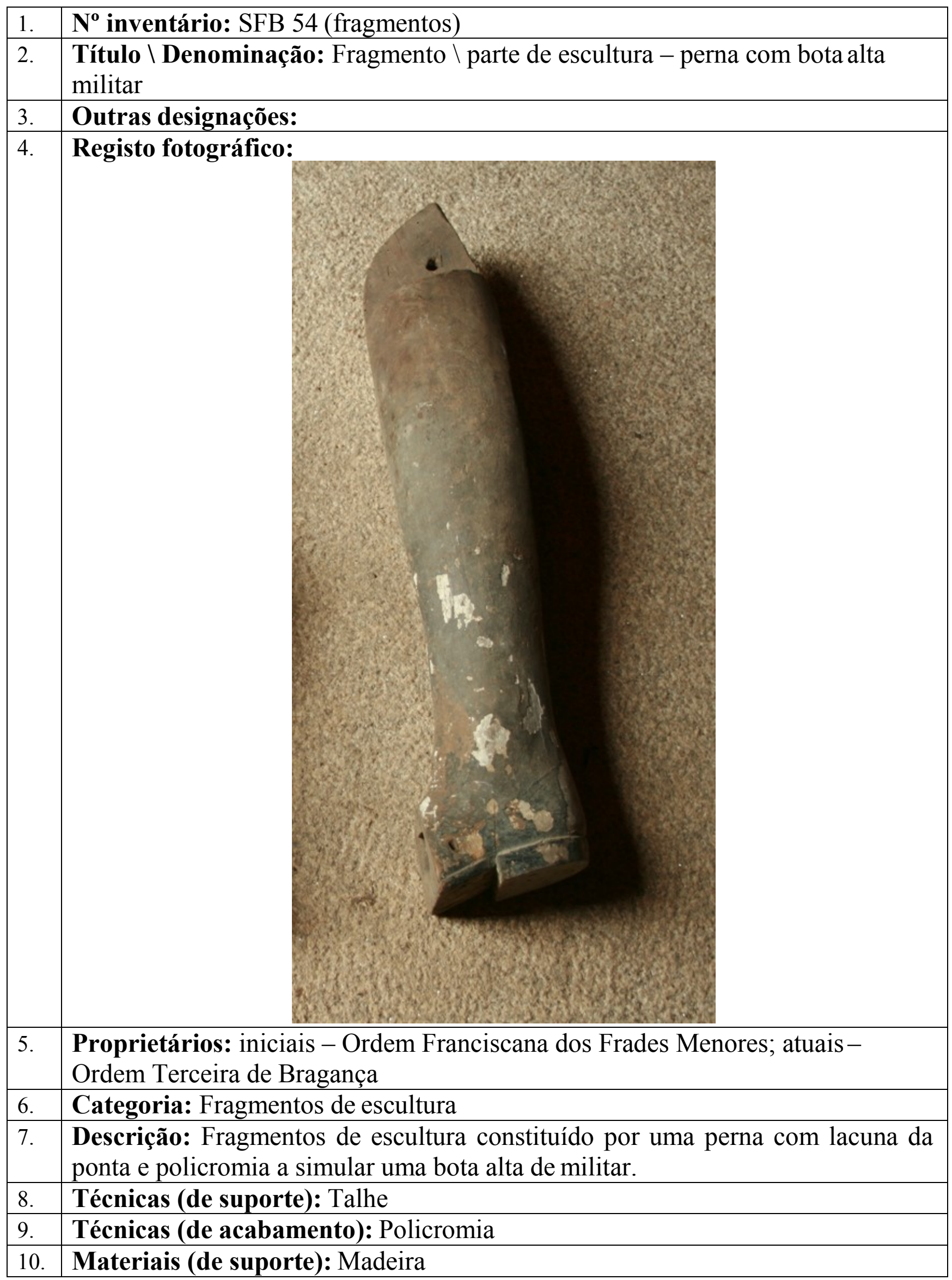




\begin{tabular}{|l|l|}
\hline 11. & Materiais (de acabamento): Pigmentos \\
\hline 12. & $\begin{array}{l}\text { Estado de Conservação: Razoável; apresenta-se estável; destacamento de } \\
\text { policromia; várias lacunas }\end{array}$ \\
\hline 13. & $\begin{array}{l}\text { Dimensões: (Variáveis) } \\
\text { Altura: } 50 \mathrm{~cm} \\
\text { Largura: } 7 \mathrm{~cm} \\
\text { Profundidade: } 11 \mathrm{~cm}\end{array}$ \\
\hline 14. & Restauro: não apresenta sinais de intervenção sobre a obra \\
\hline 15. & Datas: século XVIII $\backslash$ XIX \\
\hline 16. & Proveniência: Igreja de São Francisco de Bragança \\
\hline 17. & Autoria: desconhecida \\
\hline 18. & Oficina: Local $\backslash$ regional \\
\hline 19. & Localização (atual): Sala da Casa do Despacho da Ordem Terceira \\
\hline 20. & $\begin{array}{l}\text { Histórico do objeto: julgamos que os fragmentos de escultura de botas militares } \\
\text { estaria relacionado com as celebrações levadas a cabo pela Irmandade de } \\
\text { Militares na igreja }\end{array}$ \\
\hline 21. & Iconografia: bota alta militar \\
\hline 22. & Irmandade: não se conhecem registos \\
\hline 23. & Procissões: não se conhecem registos \\
\hline
\end{tabular}




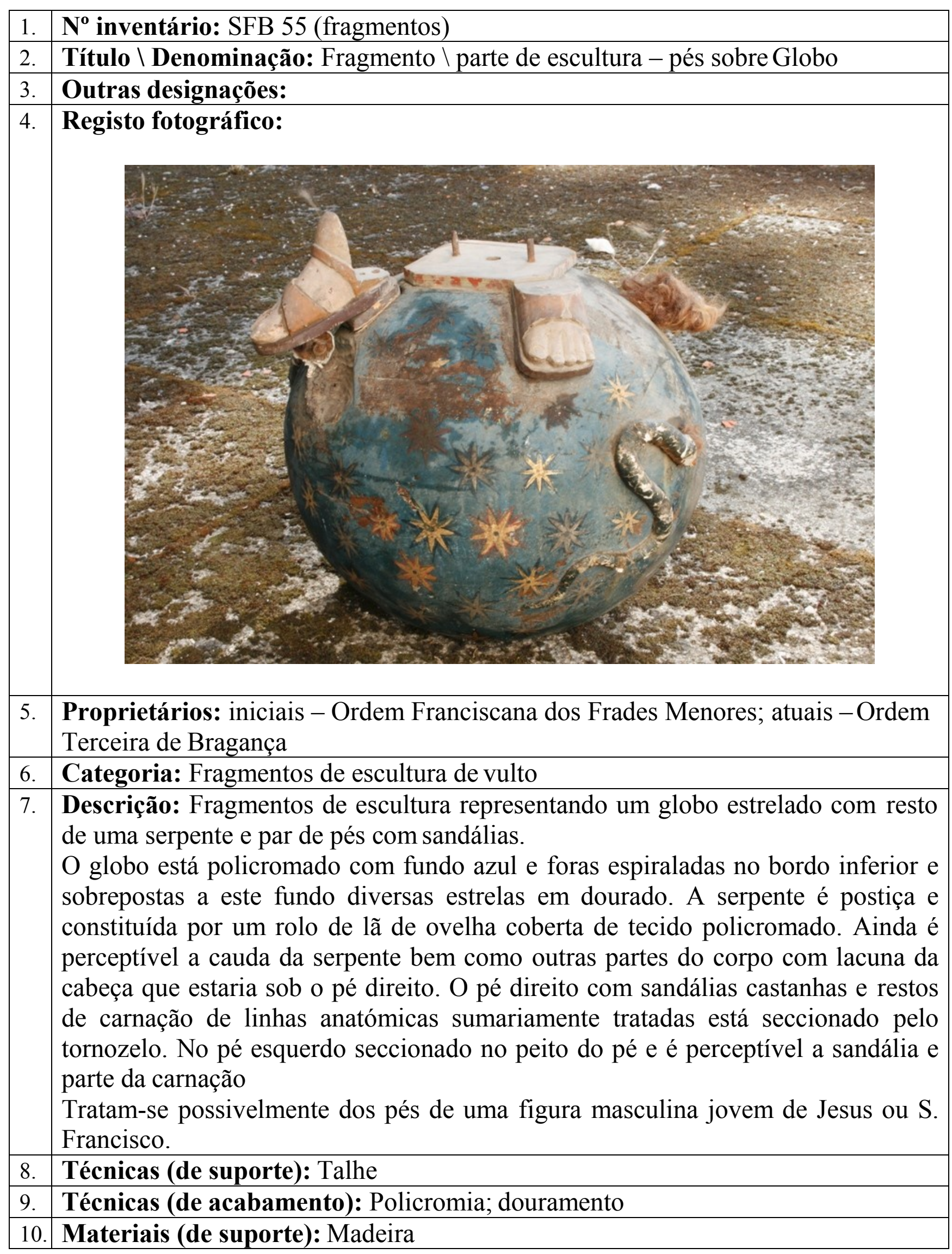




\begin{tabular}{|r|l|}
\hline 11. & Materiais (de acabamento): Pigmentos; fibras de lã \\
\hline 12. & $\begin{array}{l}\text { Estado de Conservação: Razoável; apresenta-se estável; destacamento de } \\
\text { policromia; várias lacunas }\end{array}$ \\
\hline 13. & $\begin{array}{l}\text { Dimensões: (Variáveis) } \\
\text { Altura: } 38 \mathrm{~cm} \\
\text { Largura: } 40 \mathrm{~cm} \\
\text { Profundidade: } 40 \mathrm{~cm}\end{array}$ \\
\hline 14. & Restauro: não apresenta sinais de intervenção sobre a obra \\
\hline 15. & Datas: século XVIII \\
\hline 16. & Proveniência: Igreja de São Francisco de Bragança \\
\hline 17. & Autoria: desconhecida \\
\hline 18. & Oficina: Local \regional \\
\hline 19. & Localização (atual): Sala da Casa do Despacho da Ordem Terceira \\
\hline 20. & Histórico do objeto: não se conhecem registos \\
\hline 21. & Iconografia: Globo terrestre estrelado; pés com sandálias a pisar serpente \\
\hline 22. & Irmandade: não se conhecem registos \\
\hline 23. & Procissões: não se conhecem registos \\
\hline
\end{tabular}


CONVENTO DAS CLARISSAS EM BRAGANÇA 


\section{FUNDAÇÃO}

A 8 de dezembro de 1569, o bispo de Miranda, D. António Pinheiro, benzeu solenemente o sítio para o convento de freiras de Santa Clara, debaixo do título de Nossa Senhora da Conceição ${ }^{1}$.

Destinado às filhas e netas dos cidadãos de Bragança, foi inicialmente construído na praça da Cruz de Pau (atual Praça da Sé), mas como nesse local as freiras não se adaptaram o espaço foi doado aos jesuítas e foi encetado novo projeto para as clarissas.

Em 1568, a câmara e o bispo disponibilizaram-se a iniciar um novo projeto para as monjas. A sua construção foi iniciada em 1569, entretanto as monjas ficaram instaladas em casas pertencentes à Misericórdia. Deram entrada no novo convento em 1598, ano em que ainda não estava terminada a obra, mas já era habitável. A câmara era padroeira do convento, dada a ajuda económica que disponibilizou, mas o duque de Bragança também apoiou a fábrica do edifício ${ }^{2}$.

Foi o padre frei Martinho de Melo, ministro provincial da Santa Província de Portugal que enquanto prelado do novo mosteiro mandou vir de Santa Clara no Porto quatro monjas, a abadessa, a vigária e mais duas companheiras, logo depois chegariam mais monjas de Vila Viçosa para prosseguirem na disciplina monástica do convento. A profícua disciplina imposta às monjas de Santa Clara de Bragança permitiu que em meados do século XVII fossem reformar o Mosteiro de Santa Clara de Vinhais e já no século XVIII o Mosteiro de Chaves ${ }^{3}$.

A comunidade de monjas clarissas dependia administrativamente dos frades menores, até 1693 data em que o convento passou a estar sujeito à jurisdição do

\footnotetext{
${ }^{1}$ Borges, José Cardoso, Memórias de Bragança, Fernando de Sousa (Coord.), Bragança, CEPESE / Câmara Municipal de Bragança, 2012 (texto original de 1721-1724), pp. 151, 152; Castro, José de, Bragança e Miranda, (Bispado) Tomo I, Porto, Tipografia Porto Médico, Ld a , 1946, p. 196; Alves, Francisco Manuel, Bragança Memórias arqueológico-históricas do distrito de Bragança (2a edição) Tomo III, Bragança, Câmara Municipal de Bragança / Instituto Português de Museus - Museu Abade de Baçal, 2000, (original publicado em 1910-1947), p. 215.

2 Borges, José Cardoso, Memórias de Bragança, Fernando de Sousa (Coord.), Bragança, CEPESE / Câmara Municipal de Bragança, 2012 (texto original de 1721-1724), p. 152; Castro, José de, Bragança e Miranda, (Bispado) Tomo I, Porto, Tipografia Porto Médico, Ld ${ }^{\mathrm{a}}$, 1946, p. 195; Rodrigues, Luís Alexandre, Bragança no século XVIII. Urbanismo. Arquitectura, Volume I, Bragança, Junta de Freguesia da Sé, 1997, p. 331.

${ }^{3}$ Borges, José Cardoso, Memórias de Bragança, Fernando de Sousa (Coord.), Bragança, CEPESE / Câmara Municipal de Bragança, 2012 (texto original de 1721-1724), pp. 152-155.
} 
Ordinário dependendo espiritual e temporalmente do Bispo da Diocese de BragançaMiranda ${ }^{4}$.

O convento tinha capacidade para 45 monjas mas, com a obrigação de nele entrarem as filhas e netas dos cidadãos de Bragança, o número aumentou consideravelmente. Em 1693 havia, entre monjas e criadas, 103 pessoas dentro do convento. Como para professar as freiras tinham que ter dote é de supor que todas pertenciam a famílias remediadas ou nobres, com destaque para a nobreza local. Em 1721-1724 havia 120 religiosas de véu preto, 2 religiosas de véu branco, 8 noviças e 6 educandas ${ }^{5}$.

\footnotetext{
${ }^{4}$ Castro, José de, Bragança e Miranda, (Bispado) Tomo I, Porto, Tipografia Porto Médico, Ld ${ }^{\mathrm{a}}$, 1946, pp. 215-17; Rodrigues, Luís Alexandre, Bragança no século XVIII. Urbanismo. Arquitectura, Volume I, Bragança, Junta de Freguesia da Sé, 1997, p. 331.

${ }^{5}$ Borges, José Cardoso, Memórias de Bragança, Fernando de Sousa (Coord.), Bragança, CEPESE / Câmara Municipal de Bragança, 2012 (texto original de 1721-1724), p. 155; Alves, Francisco Manuel, Bragança Memórias arqueológico-históricas do distrito de Bragança (2a edição) Tomo II, Bragança, Câmara Municipal de Bragança / Instituto Português de Museus - Museu Abade de Baçal, 2000, (original publicado em 1910-1947), p. 223-227; Castro, José de, Bragança e Miranda, (Bispado) Tomo I, Porto, Tipografia Porto Médico, Ld ${ }^{\text {a }}$ 1946, pp. 200-204.
} 


\section{EDIFICADO DA IGREJA}

A construção do edifício foi iniciada em 1569. A igreja foi entregue aos mestres pedreiros Afonso Gonçalves e irmão António Gonçalves, moradores em Bragança por contrato lavrado em 1596. As obras no convento prolongaram-se pois em 1631 ainda não estavam terminadas. A conclusão das obras, ou da maioria delas terá ocorrido cerca de $1697^{6}$. O processo de construção do convento foi lento e sofreu várias alterações de modo a adaptar o espaço às necessidades que foram emergindo ${ }^{7}$.

Do complexo conventual, e das capelas que existiam na cerca do convento já não resta nada, apenas a igreja chegou aos nossos dias.

O portal principal, aberto lateralmente como corresponde a uma igreja conventual feminina, tem entre pilastras coríntias o frontão triangular com o brasão da cidade $^{8}$ (Imagem 1).

Com a Guerra da Restauração foram destruídas várias instalações para a construção da nova muralha que passava na cerca do convento, as tropas chegaram a ocupar um dormitório. Mais tarde, o convento foi indemnizado pela coroa por esses danos. Durante o século XVII recebiam rendas de diversas fontes, ao longo do século XVIII a pobreza foi-se instalando e o Bispo D. Aleixo editou uma pastoral cativando as esmolas dos fregueses. Em 1806 o estado de ruína tornava urgente a mudança do hospital e da enfermaria 9 .

\footnotetext{
${ }^{6}$ Castro, José de, Bragança e Miranda, (Bispado) Tomo I, Porto, Tipografia Porto Médico, Ld a , 1946, p. 195; Rodrigues, Luís Alexandre, Bragança no século XVIII. Urbanismo. Arquitectura, Volume I, Bragança, Junta de Freguesia da Sé, 1997, p. 332.

${ }^{7}$ Tal como ocorreu nas obras de restauro do convento de São Francisco de Bragança, também no das monjas clarissas foram reutilizados materiais de construção provenientes do extinto mosteiro beneditino do Castro de Avelãs. A construção do convento foi sofrendo várias alterações de modo a adaptar o espaço às necessidades que emergiam. Muitas vezes estas alterações eram conduzidas por privados que custeavam a construção de celas, uns para dar mais comodidade às fillhas, outros por devoção. A existência de celas privadas constituiu um foco de perturbação na comunidade de religiosas. Rodrigues, Luís Alexandre, Bragança no século XVIII. Urbanismo. Arquitectura, Volume I, Bragança, Junta de Freguesia da Sé, 1997, pp. 333-335.

${ }^{8}$ Borges, José Cardoso, Memórias de Bragança, Fernando de Sousa (Coord.), Bragança, CEPESE / Câmara Municipal de Bragança, 2012 (texto original de 1721-1724), p. 155;

O portal é almofadado e ladeado por dois medalhões seguindo o gosto de João de Ruão, as armas da cidade estão datadas de 1597. Jacob, João Manuel Neto, Bragança, Lisboa, Presença, 1997, p. 99.

${ }^{9}$ Castro, José de, Bragança e Miranda, (Bispado) Tomo I, Porto, Tipografia Porto Médico, Ld ${ }^{\mathrm{a}}, 1946$, p. 211; em 1788 de novo o Bispo refere a "lamentável penúria a que esta reduzido o convento" Rodrigues, Luís Alexandre, Bragança no século XVIII. Urbanismo. Arquitectura, Volume I, Bragança, Junta de Freguesia da Sé, 1997, pp. 335-353.
} 


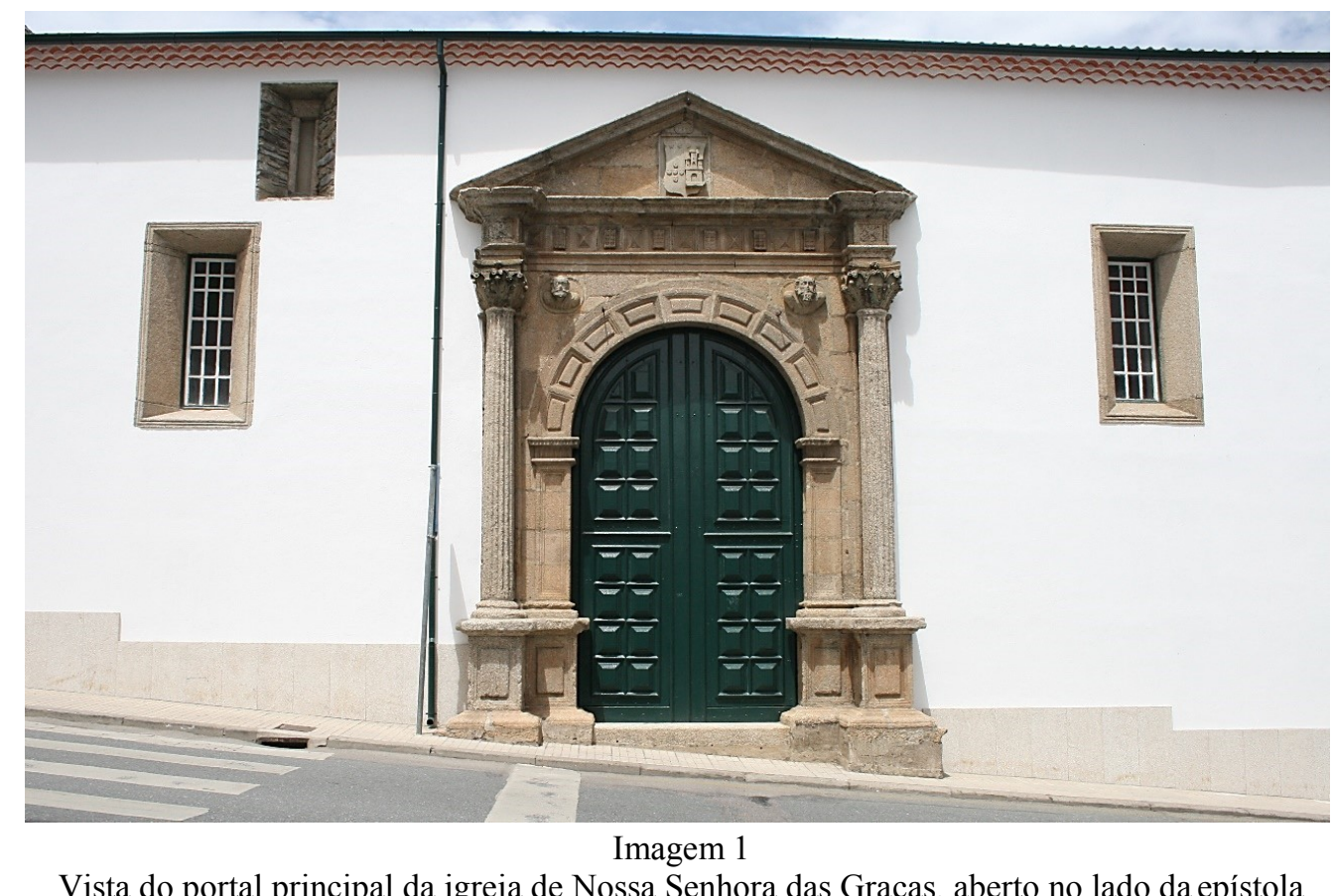

Em 1870 faleceu a última religiosa o que de imediato permitiu a distribuição dos bens do convento segundo o que o governador do bispado dispôs. O governo cedeu a igreja à Arquiconfraria de Nossa Senhora das Graças em 1870. As alfaias, vasos, paramentos sagrados e mais objetos de culto foram distribuídos pela Arquiconfraria de Nossa Senhora das Graças, igrejas da Misericórdia, a de Santa Maria e São Vicente, a catedral, a capela do Seminário e a igreja de Azinhoso ${ }^{10}$.

Após a extinção das ordens religiosas o convento teve inúmeros projetos, que não chegaram a concretizar-se. Mais tarde o espaço do convento, entretanto demolido, foi utilizado pela Santa Casa da Misericórdia para aí instalar um jardim infantil ${ }^{11}$.

\footnotetext{
${ }^{10}$ Castro, José de, Bragança e Miranda, (Bispado) Tomo I, Porto, Tipografia Porto Médico, Ld a , 1946, p. 212.

${ }^{11}$ Jacob, João Manuel Neto, Bragança, Lisboa, Presença, 1997, pp. 98, 99.
} 


\section{INTERIOR DO TEMPLO}

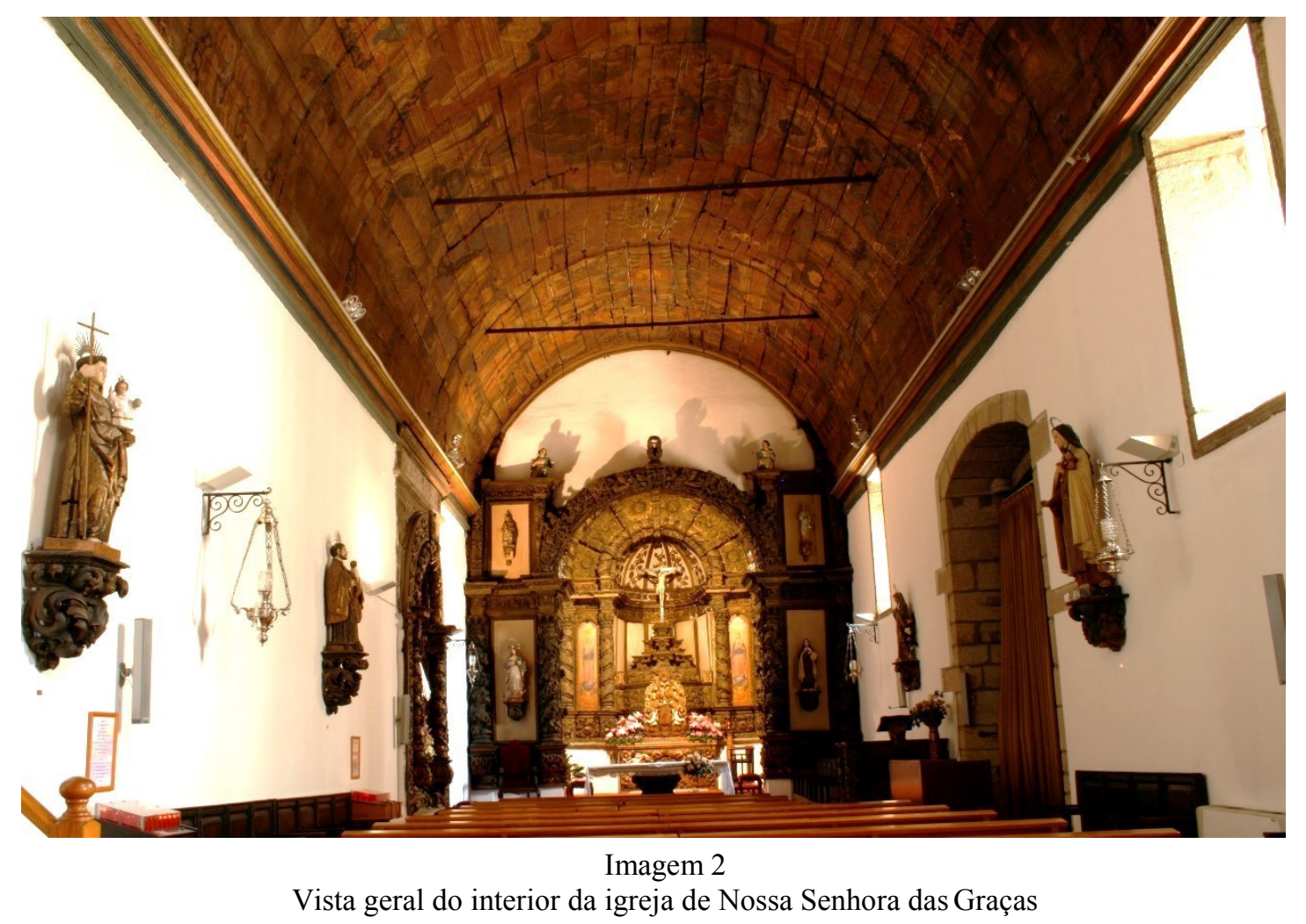

A igreja é desde o último quartel do século XIX designada de igreja de Nossa Senhora das Graças. Enquanto igreja conventual havia sido chamada de igreja de Nossa Senhora da Conceição. No entanto, localmente é referida como igreja de Santa Clara, mantendo nessa designação popular a memória das clarissas que a ocuparam.

O templo de uma única nave tem o teto abobadado e está coberto de pintura sobre madeira (Imagem 2). O escurecimento dos pigmentos não permite perceber em detalhe a composição da pintura que representa a Virgem ao centro ladeada de arquiteturas fingidas.

Entre 1721 e 1724 Borges descrevia o interior do templo com:

"a capela-mor, toda coberta de entalhado ao moderno e a frente do arco com dois altares, um de Nossa Senhora dos Remédios e outro de Santo António, nos lados da tribuna S. Francisco e Santa Clara e, em levantado trono, a imagem de Nossa Senhora da Conceição, sua padroeira ${ }^{12}$ "

\footnotetext{
12 Borges, José Cardoso, Memórias de Bragança, Fernando de Sousa (Coord.), Bragança, CEPESE / Câmara Municipal de Bragança, 2012 (texto original de 1721-1724), p. 155; Rodrigues, Luís Alexandre,
} 
O retábulo da capela-mor "entalhado ao moderno" seria para Borges de talha barroca nacional, da primeira metade do século XVIII. Apesar das alterações recentes em que se removeram as portas e escadas de acesso ao interior do retábulo, exteriormente a estrutura ainda mantém a traça "ao moderno" que Borges teria visto

Mas, quase três séculos depois de Borges ter observado o interior do templo de Santa Clara, apenas a imagem de Santo António por ele registada se mantém a culto. A imagem da padroeira Nossa Senhora da Conceição colocada "em levantado trono" já não existe no templo. A devoção mantém-se mas com uma escultura do século XX.

O mesmo ocorre com as esculturas de São Francisco e Santa Clara, que se mantêm as devoções mas com esculturas do século XX. A imagem e a devoção a Nossa Senhora dos Remédios já desapareceram.

$\mathrm{Na}$ estrutura decorativa mantém-se o arco triunfal (Imagem 3), em talha barroca nacional, que divide a capela-mor do corpo da igreja e que julgamos que é também o que Borges descreveu como "o arco com dois altares", mas hoje apenas expõe imaginária do século XX.

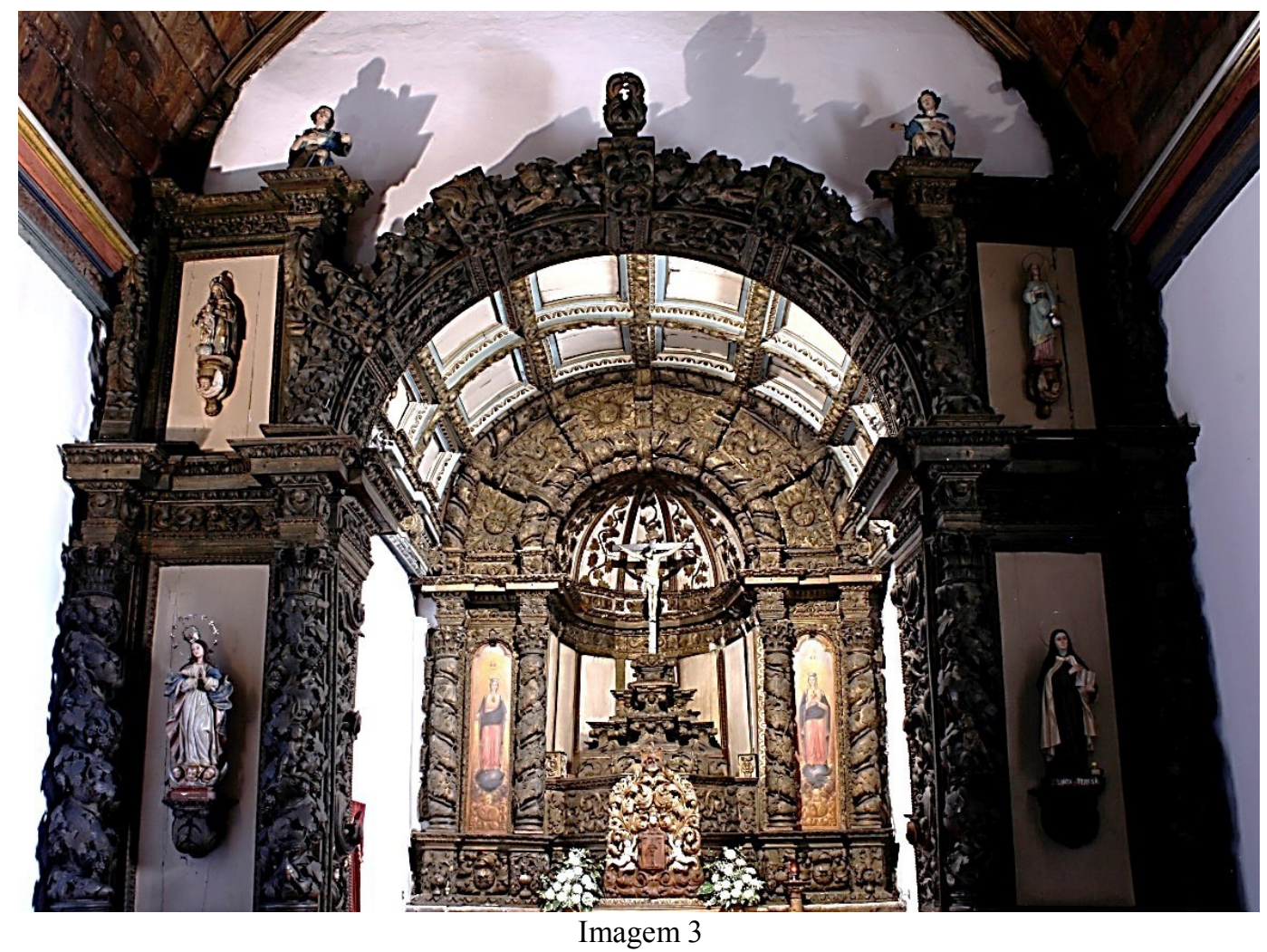

Capela-mor e arco triunfal da igreja de Nossa Senhora das Graças

Bragança no século XVIII. Urbanismo. Arquitectura, Volume I, Bragança, Junta de Freguesia da Sé, 1997, pp. 332, 333. 
A ausência de obras anteriores à extinção das ordens religiosas (1834) e a massiva presença de esculturas do século XX, sobretudo da segunda metade do século, sugere a recente substituição das obras originais por esculturas novas.

Borges descrevia ainda "uma capela de São Caetano com irmandade, muito frequentada dos fiéis, porque este santo em toda a parte é milagroso ${ }^{13}$ ".

Atualmente existe ainda a capela onde originalmente se prestava culto São Caetano. A capela tem hoje no altar a imagem da padroeira da cidade, Nossa Senhora das Graças $^{14}$ (Imagem 4).

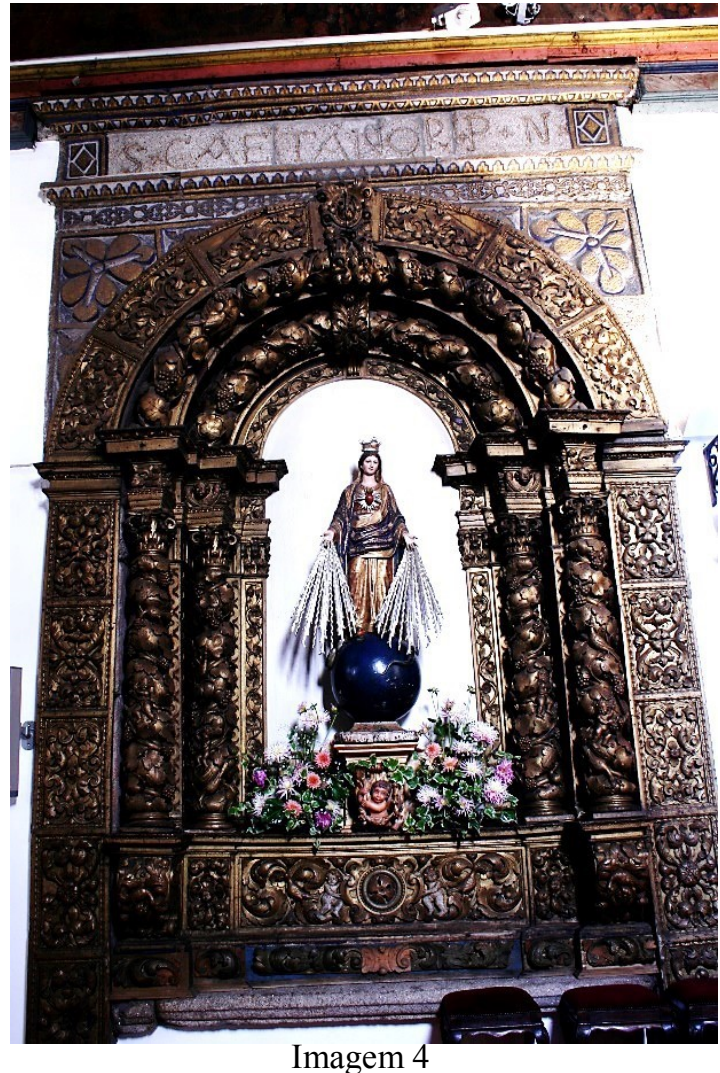

Capela de São Caetano, atualmente ocupada pela imagem de Nossa Senhora das Graças

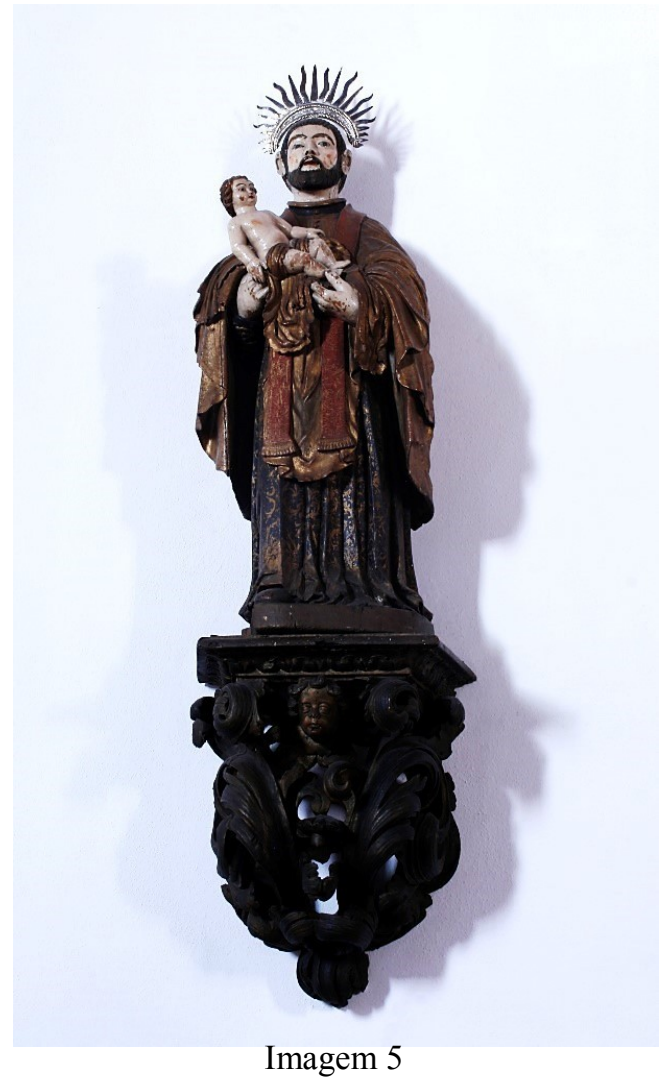

Escultura de São Caetano

Sobre uma peanha no lado do evangelho

A escultura de São Caetano está colocada sobre uma peanha do mesmo lado do evangelho onde está a capela.

\footnotetext{
${ }^{13}$ Borges, José Cardoso, Memórias de Bragança, Fernando de Sousa (Coord.), Bragança, CEPESE / Câmara Municipal de Bragança, 2012 (texto original de 1721-1724), p. 155.

${ }^{14}$ A imagem de Nossa Senhora das Graças foi adquirida em 1862, Jacob, João Manuel Neto, Bragança, Lisboa, Presença, 1997, p. 100, citando Francisco Felgueiras (1964) "Roteiro e escorço histórico da cidade de Bragança" na revista "Amigos de Bragança, $2^{\mathrm{a}}$ série, $\mathrm{n}^{\mathrm{0}} 7 \backslash 8 \mathrm{Fev}$.
} 
Borges destaca os milagres operados no século XVII pela prodigiosa imagem de São Francisco. Contemporaneamente apenas existe uma escultura de São Francisco que é do século XX. Mas o local Museu Abade de Baçal expõe uma escultura quinhentista de um santo franciscano ${ }^{15}$. Pese embora a ausência de fontes documentais que relacionem a escultura do museu com o convento não podíamos deixar de fazer esta referência.

Depois de Borges é no inventário feito após a extinção das ordens religiosas que encontramos elementos que se relacionem com as esculturas a culto e as devoções na igreja do convento das clarissas.

O Convento foi suprimido dia 29 de Dezembro de 1864. A documentação do Ministério das Finanças reúne várias referências relativas aos bens do convento. No entanto, a escultura apenas a podemos perceber quando se relaciona com algum acessório de metal precioso. O destaque foi dado aos bens móveis de ourivesaria, seguido de mobiliário.

O termo de depósito e entrega data de dia 10 de Maio de 1870 e descreve os vasos sagrados avaliados, são enumerados os cálices, copas, navetas e incensário, todos de prata e entre eles surge uma referência colateral às esculturas (Imagem 6)

“Tres resplendores e uma coroa de prata de pouco pezo pertencentes às imagens dos altares", que foram avaliadas em igual valor que o incensário que a precede, "vinte e oito mil e oito centos reis $-28.800^{16 "}$

\footnotetext{
${ }^{15}$ A escultura do museu revela um notável tratamento da fisionomia que confere ao santo uma gravidade ascética próxima aos modelos plásticos do Humanismo Cristão e ao espirito emergente da Idade Moderna. O acervo de escultura do Museu Abade de Baçal será porventura oriundo dos conventos extintos de Trás-os-Montes. Santos, Rui Afonso e Soromenho, Miguel, "Escultura" in Anabela Carvalho, Isabel Cordeiro, Instituto Português de Museus, catálogo do Museu Abade de Baçal, Bragança, Lisboa, Instituto Português de Museus, 1994, p. 83.

${ }^{16}$ A.N.T.T./A.H.M.F./C.S.C.B., Extinção das Ordens Religiosas - Convento de Santa Clara - Bragança, Arquivo Nacional da Torre do Tombo, Lisboa, Arquivo Histórico do Ministério das Finanças, Processos de Extinção das casas religiosas, Cx. 1891, 1870, s/fl. Existem várias cópias de inventários segundo o que é referido num documento sendo que o primeiro inventário data de 1858, onde no entanto, havia omissão de elementos (como um prédio rural em Bragada).
} 


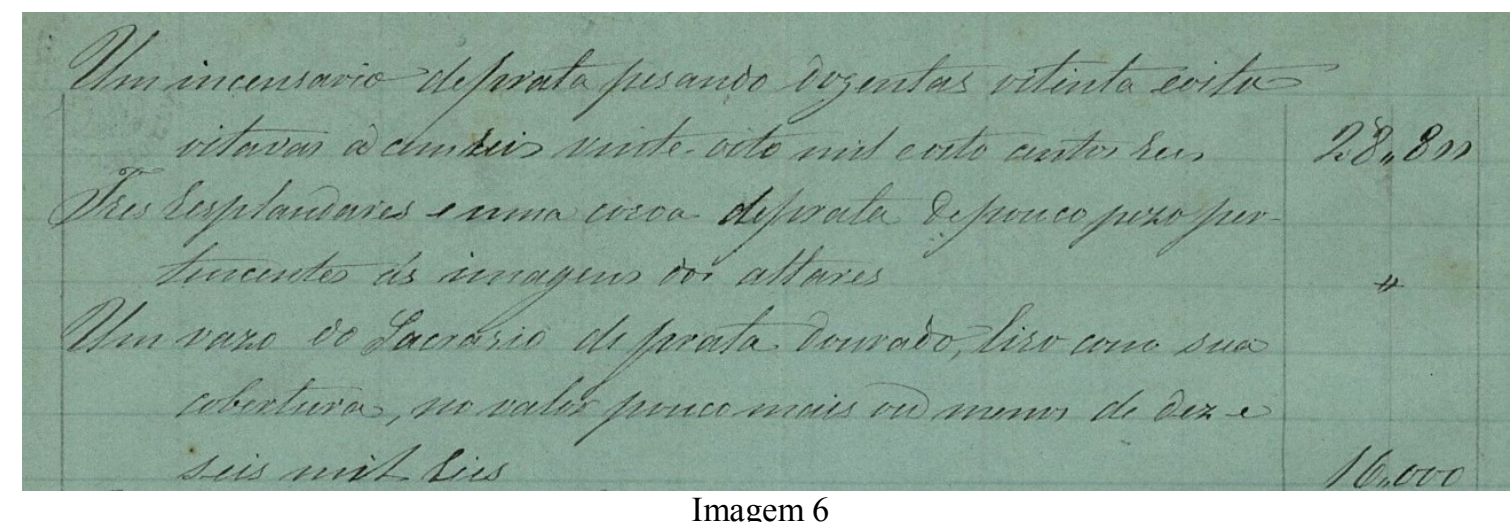

Excerto de termo de depósito e entrega data de dia 10 de Maio de 1870 dos bens móveis do convento de Santa Clara em Bragança

No final do mesmo fólio foram registados:

"Vários painéis em estado de se lhes não poder consignar valor algum Uma pequena alampada de prata que allumia o altar da $\mathrm{Sr}^{\mathrm{a}}$ das Dores que se diz ser propriedade particular destinada àquele uso com a clausula de reverter ao poder dos seus proprietários no caso da extinção do convento ${ }^{17}$,

Ainda hoje se mantém a devoção a Nossa Senhora das Dores, junto à capela-mor do lado da epistola, em madeira talhada, policromada e estufada, com espada e auréola de prata, mas, mais uma vez, trata-se de uma escultura do século XX, reforçando a permanência dos cultos mas com substituição de imagens que os ilustravam.

Os painéis, "em estado de se lhes não poder consignar valor algum" possivelmente de pintura, ter-se-ão deteriorado e estão atualmente desaparecidos.

Com o título "Objectos ultimamente inventariados" são registados vários artigos sobretudo de ourivesaria, (custódia, cálices, galhetas, âmbula, chave de sacrário, todos em prata) e relacionado com a imaginária surge:

"Um báculo de prata da imagem de Santa Clara que peza duzentas e dez gramas, a vinte e cinco reis cada uma, cinco mil duzentos e cincoenta $\mathrm{R}$ 5.250

\footnotetext{
${ }^{17}$ A.N.T.T./A.H.M.F./C.S.C.B., Extinção das Ordens Religiosas - Convento de Santa Clara - Bragança, Arquivo Nacional da Torre do Tombo, Lisboa, Arquivo Histórico do Ministério das Finanças, Processos de Extinção das casas religiosas, Cx. 1891, 1870, s/fl.
} 
Um relicário da mesma imagem, de prata que peza duzentas e cincoenta e uma gramas a vinte e cinco reis cada uma seis mil duzentos e setenta e cinco R- $6.275^{18,}$

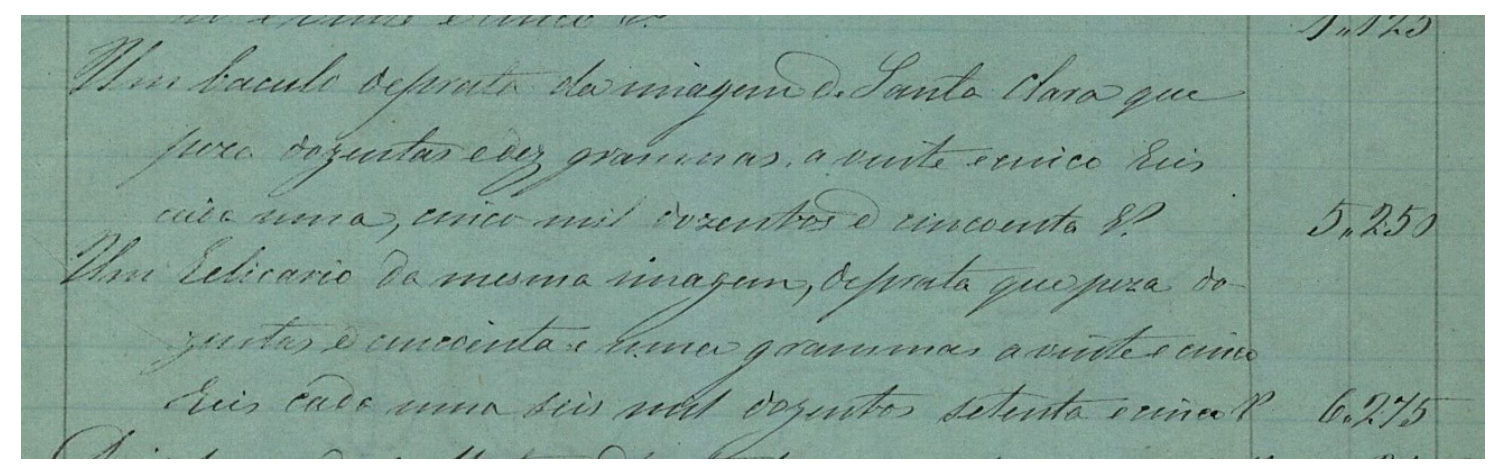

Imagem 7

Excerto do documento intitulado "Objectos ultimamente inventariados" dos bens móveis do convento das Clarissas em Bragança

Quer o báculo, quer a custódia em prata não se encontram actualmente na igreja, nem a imagem a que lhes estariam associados, pois a imagem hoje a culto de Santa Clara é uma escultura do século XX, feita em Braga pela casa Teixeira Fanzeres \& filhos.

$\mathrm{O}$ registo prossegue com os paramentos ${ }^{19}$ dos quais destacamos, por se poderem relacionar com o cerimonial de exposição pública das esculturas:

"Um paleo branco primavera com franja de seda armada, em bom estado, vinte mil reis -20.000

Um arco da capella mor de damasco vermelho com franja e galões de seda em mao estado cinco mil reis $-5.000(\ldots)$

Um baldaquino bordado a oiro, em bom estado, doze mil reis $-12.000^{20}$,

São ainda avaliadas vários têxteis, capas, toalhas de altar e por fim o inventario termina com o registo de:

\footnotetext{
${ }^{18}$ A.N.T.T./A.H.M.F./C.S.C.B., Extinção das Ordens Religiosas - Convento de Santa Clara - Bragança, Arquivo Nacional da Torre do Tombo, Lisboa, Arquivo Histórico do Ministério das Finanças, Processos de Extinção das casas religiosas, Cx. 1891, 1870, s/fl.

${ }^{19}$ Sobre o usos de têxteis para ornamentar o espaço interior da igreja recomendava o visitador no ano de 1713 que se não usassem pois danificavam a talha cuja "manuffactura e aceio (...) escuza qualquer outro ornatto". Em 1720 noutra visita se recomendava que deveriam fazer-se novas cortinas para os altares que durante a quaresma cobrissem tudo e permitissem abrir tudo ao mesmo tempo no sábado de Aleluia. Em 1741 referia o visitador o "perfeito asseio" com que a comunidade reparou os paramentos após o incêndio Rodrigues, Luís Alexandre, Bragança no século XVIII. Urbanismo. Arquitectura, Volume I, Bragança, Junta de Freguesia da Sé, 1997, pp. 345-352. A relevância dos têxteis para as cerimónias religiosas fica expressa na documentação dos visitadores, bem como na avaliação que é feita aquando da venda dos bens.
}

${ }^{20}$ A.N.T.T./A.H.M.F./C.S.C.B., Extinção das Ordens Religiosas - Convento de Santa Clara - Bragança, Arquivo Nacional da Torre do Tombo, Lisboa, Arquivo Histórico do Ministério das Finanças, Processos de Extinção das casas religiosas, Cx. 1891, 1870, s/fl. 
"Uma Umbella de damasco branco, em mao estado mil e duzentos reis 1.200

Um orgao pequeno inutilizado

Várias Imagens existentes na Igreja e coro do Convento ${ }^{21}$,

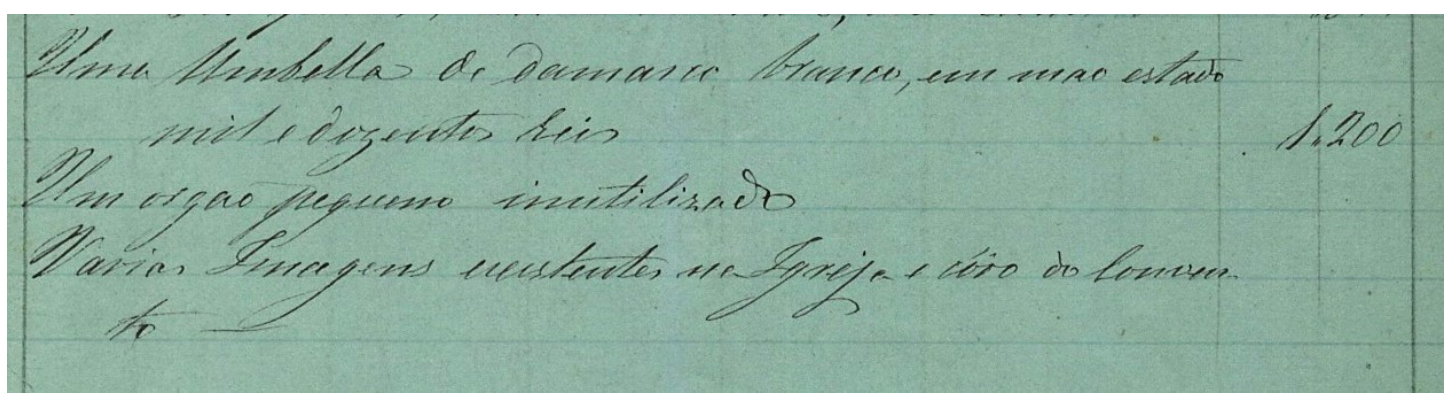

Figura 4

Excerto do documento intitulado "Objectos ultimamente inventariados" dos bens móveis do convento de Santa Clara em Bragança

Apenas no último registo as esculturas são mencionadas. Mas, sem qualquer detalhe, o documento apenas refere que são "várias" e se distribuem pela "Igreja e coro do Convento", não lhes é atribuído valor.

Das 15 esculturas que se encontram a culto no interior do templo apenas 4 nos parecem anteriores à extinção das ordens religiosas. A maioria das esculturas são obras do século XX, que possivelmente substituíram outras, hoje desaparecidas.

\footnotetext{
${ }^{21}$ A.N.T.T./A.H.M.F./C.S.C.B., Extinção das Ordens Religiosas - Convento de Santa Clara - Bragança, Arquivo Nacional da Torre do Tombo, Lisboa, Arquivo Histórico do Ministério das Finanças, Processos de Extinção das casas religiosas, Cx. 1891, 1870, s/fl.

As restantes capilhas da caixa relativa ao inventário dos bens do convento das clarissas de Bragança (da capilha 2 até à 6) contêm os documentos da doação de parte da cerca para se construir uma praça de mercado; o inventário de 1858 com a avaliação da igreja e coros na quantia de 1.000 .000 reis, onde se repetem as menções à ourivesaria e paramentaria, assim como são referidos também os títulos de crédito públicos e as propriedades rurais em Bragança e Vimioso com detalhe do nome dos arrendatários, local, e a quantidade de alqueires de trigo e centeio que se colhiam. Diversos documentos relativos ao mapa das despesas e aos bens e rendimentos, com destaque para as propriedades agrícolas e alguns prédios urbanos (casas na rua das Moreirinhas) e o algibe pertencente à mitra que tinha outra casa contígua que era também das clarissas (na rua de Fora de Portas). As propriedades rurais e a sua avaliação: os casais em Sendas, Freixedelo, França, Baçal e Rebordãos. Autos de avaliação do património urbano e da cerca do convento que passa para a Câmara Municipal de Bragança.
} 


\section{FICHAS DE INVENTÁRIO}

\section{ESCULTURA}

IGREJA DO CONVENTO DAS CLARISSAS, BRAGANÇA 
FICHAS DE INVENTÁRIO |ESCULTURA

Da Ordem de São Francisco na Diocese de Bragança-Miranda 


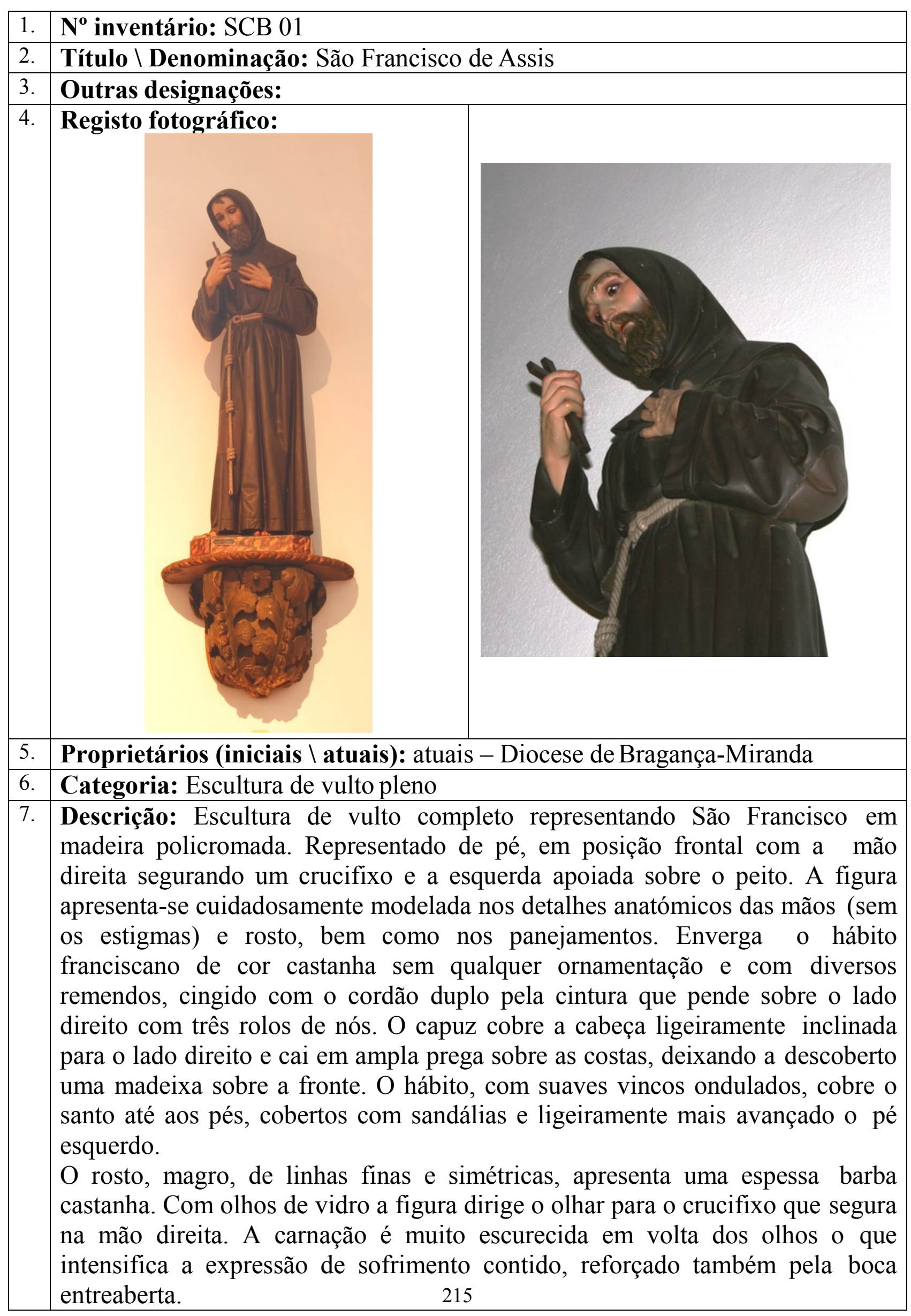




\begin{tabular}{|c|c|}
\hline & $\begin{array}{l}\text { A figura está assente sobre uma plataforma em madeira de forma octogonal } \\
\text { decorada com marmoreado castanho e beije. No lado direito da plataforma está } \\
\text { pregada uma chapa metálica onde pode ler-se: "Arte Sacra \ Casa Fanzeres } \\
\text { fundada em } 1891 \backslash \text { Domingos A. T. Fanzeres \ Braga Portugal". Ao lado da } \\
\text { chapa uma fissura percorre toda a extensão lateral da plataforma }\end{array}$ \\
\hline 8. & Técnicas (de suporte): Talhe \\
\hline 9. & Técnicas (de acabamento): Policromia \\
\hline 10. & Materiais (de suporte): Madeira \\
\hline 11. & Materiais (de acabamento): Pigmentos; vidro \\
\hline 12. & $\begin{array}{l}\text { Estado de Conservação: Bom; apresenta-se estável; fissura na plataforma com } \\
\text { destacamento da policromia; pequenos destacamentos da policromia sobre o } \\
\text { hábito e rosto }\end{array}$ \\
\hline 13. & $\begin{array}{l}\text { Dimensões: Não foi possível registar estes elementos } \\
\text { Altura: } \\
\text { Largura: } \\
\text { Profundidade: }\end{array}$ \\
\hline 14. & Restauro: não apresenta sinais de intervenção sobre a obra \\
\hline 15. & Datas: século XX \\
\hline 16. & Proveniência: igreja de Nossa Senhora das Graças \\
\hline 17. & Autoria: Domingos A. T. Fanzeres \\
\hline 18. & Oficina: Casa Fanzeres, Braga \\
\hline 19. & $\begin{array}{l}\text { Localização (atual): Lado da Epistola, depois da porta comum, sobre uma } \\
\text { peanha }\end{array}$ \\
\hline 20. & Histórico do objeto: não se conhecem registos \\
\hline 21. & Iconografia: Hábito franciscano; Crucifixo \\
\hline 22. & Irmandade: não se conhecem registos \\
\hline 23. & Procissões: não se conhecem registos \\
\hline
\end{tabular}




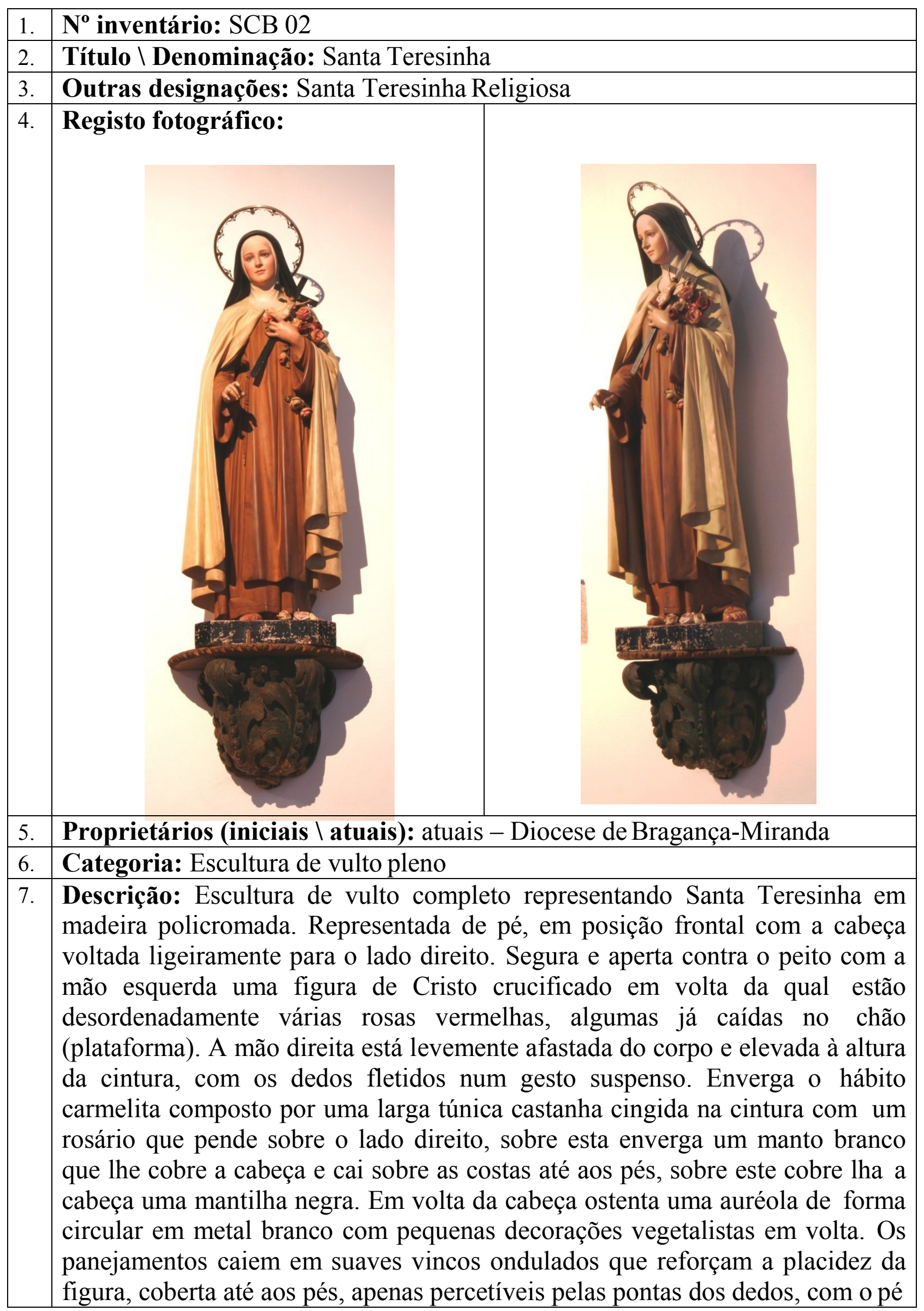




\begin{tabular}{|l|l|}
\hline & $\begin{array}{l}\text { direito ligeiramente mais avançado. De rosto jovem, fisionomia delicada e } \\
\text { expressão serena fixa o olhar num ponto longínquo, com olhos de vidro amplos } \\
\text { e amendoados num tom claro de azul. A figura está assente sobre uma } \\
\text { plataforma em madeira de forma octogonal negra com diversas fissuras e } \\
\text { destacamento da policromia. }\end{array}$ \\
\hline 8. & Técnicas (de suporte): Talhe \\
\hline 9. & Técnicas (de acabamento): Policromia \\
\hline 10. & Materiais (de suporte): Madeira \\
\hline 11. & Materiais (de acabamento): Pigmentos; vidro \\
\hline 12. & $\begin{array}{l}\text { Estado de Conservação: Bom; apresenta-se estável; fissura na plataforma } \\
\text { com destacamento da policromia; pequenos destacamentos da policromia sobre } \\
\text { o hábito e rosto }\end{array}$ \\
\hline 13. & $\begin{array}{l}\text { Dimensões: Não foi possível registar estes elementos } \\
\text { Altura: } \\
\text { Largura: } \\
\text { Prof }\end{array}$ \\
\hline 14. & $\begin{array}{l}\text { Restauro: No manto branco do lado direito é possível observar marcas de cola } \\
\text { de uma consolidação recente. }\end{array}$ \\
\hline 15. & Datas: século XX \\
\hline 16. & Proveniência: igreja de Nossa Senhora das Graças \\
\hline 17. & Autoria: desconhecida \\
\hline 18. & Oficina: Casa Fanzeres (?) \\
\hline 19. & $\begin{array}{l}\text { Localização (atual): Lado da Epistola, depois da porta comum, sobre uma } \\
\text { peanha }\end{array}$ \\
\hline 20. & $\begin{array}{l}\text { Histórico do objeto: são várias as semelhanças com a figura de São Francisco } \\
\text { (no modelado dos detalhes anatómicos e panejamentos) pode por isso ter a } \\
\text { mesma proveniência, não havendo certeza mantém-se a interrogação }\end{array}$ \\
\hline 21. & $\begin{array}{l}\text { Iconografia: Cristo Crucificado; Rosas vermelhas; Rosário; Auréola; Hábito } \\
\text { Carmelita; }\end{array}$ \\
\hline 22. & Irmandade: não se conhecem registos \\
\hline 23. & Procissões: não se conhecem registos \\
\hline
\end{tabular}




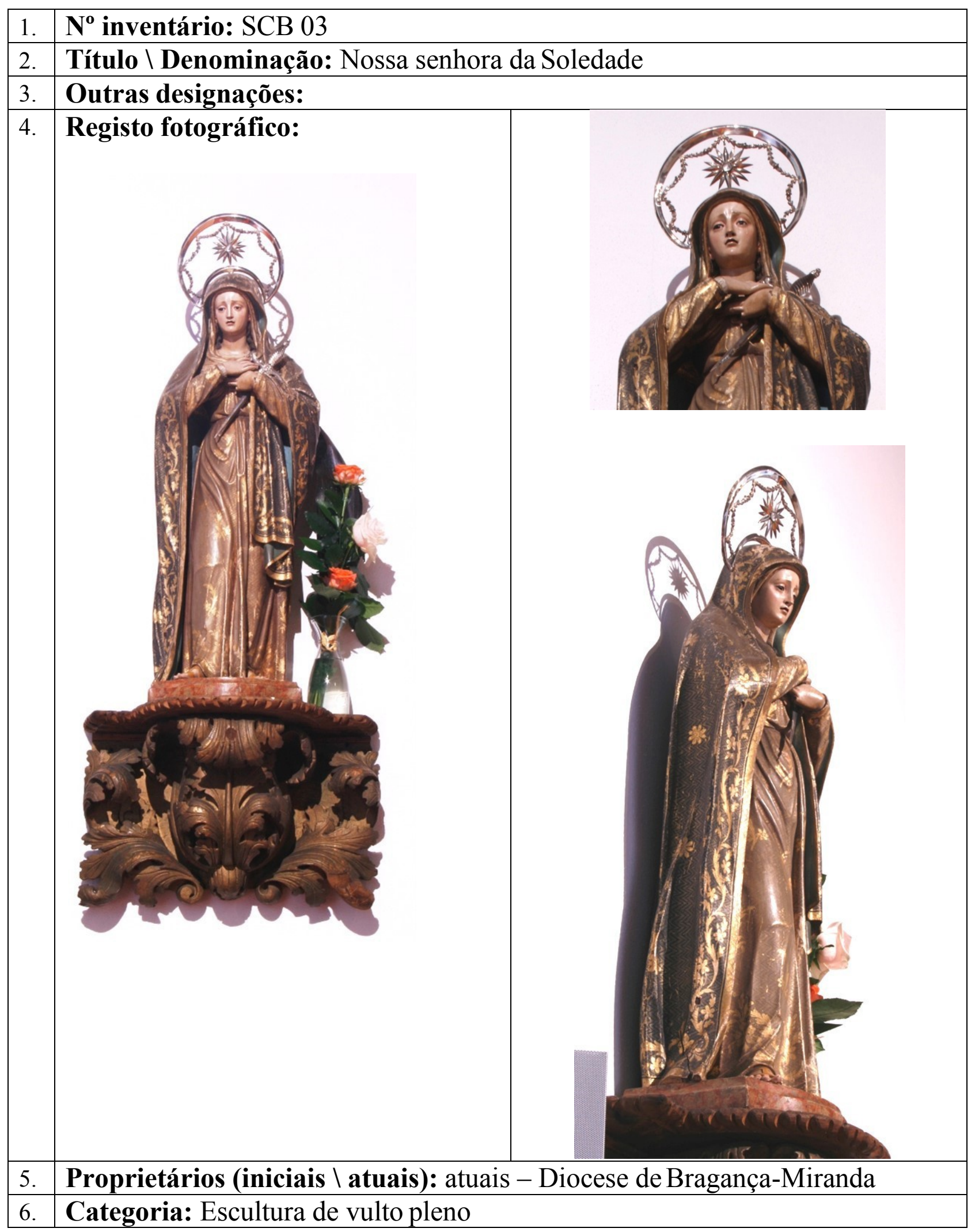


7. Descrição: Escultura de vulto completo representando Nossa Senhora da Soledade em madeira policromada e estufada. A figura destaca-se pelas formas delicadas das mãos e rosto, pela expressão contida de sofrimento, bem como pela ornamentação do traje.

De pé, com a perna direita ligeiramente avançada a figura cruza as mãos sobre uma espada que cinge junto ao peito. Enverga um traje com pregueado suave composto por uma túnica num tom beije muito desgastado coberta de motivos estufados a ouro. Sobre esta enverga uma mantilha branca que lhe cobre a cabeça deixando pequenas madeixas de cabelo castanho a descoberto. Sobre a mantilha usa um ornamentado manto negro, com interior azul, com estufado a ouro que a cobre até aos pés, cobertos com sandálias. O rosto jovem de suaves linhas e cuidados detalhes anatómicos, apresenta uma expressão de dor contida, com ligeiro franzir das sobrancelhas e olhar baixo, com os olhos em vidro. A figura segura contra o peito uma espada curta de dois gumes com punho e guarda mão ornamentados, em metal branco. Sobre a cabeça ostenta uma auréola com uma estrela ao centro que pende dos ornatos vegetalistas que cobrem o interior do círculo.

Está assente sobre uma peanha de forma quadrangular irregular, seguramente posterior.

8. Técnicas (de suporte): Talhe

9. Técnicas (de acabamento): Policromia; Estufado a ouro

10. Materiais (de suporte): Madeira

11. Materiais (de acabamento): Pigmentos; vidro; metal branco

12. Estado de Conservação: Bom; apresenta-se estável; lacuna de dedo na mão direita

13. Dimensões: Não foi possível registar estes elementos

Altura:

Largura:

Prof

14. Restauro: apresenta sinais de reintegração cromática

15. Datas: século XX

16. Proveniência: igreja de Nossa Senhora das Graças

17. Autoria: desconhecida

18. Oficina: Braga, Portugal

19. Localização (atual): Lado da Epistola, próxima ao arco de triunfo

20. Histórico do objeto: não se conhecem registos

21. Iconografia: Uma espada; auréola

22. Irmandade: não se conhecem registos

23. Procissões: não se conhecem registos 
FICHAS DE INVENTÁRIO |ESCULTURA

Da Ordem de São Francisco na Diocese de Bragança-Miranda

Arco Triunfal em talha barroca nacional com quatro nichos que acolhem as imagens SCB 04, SCB 05, SCB 07, SCB 08

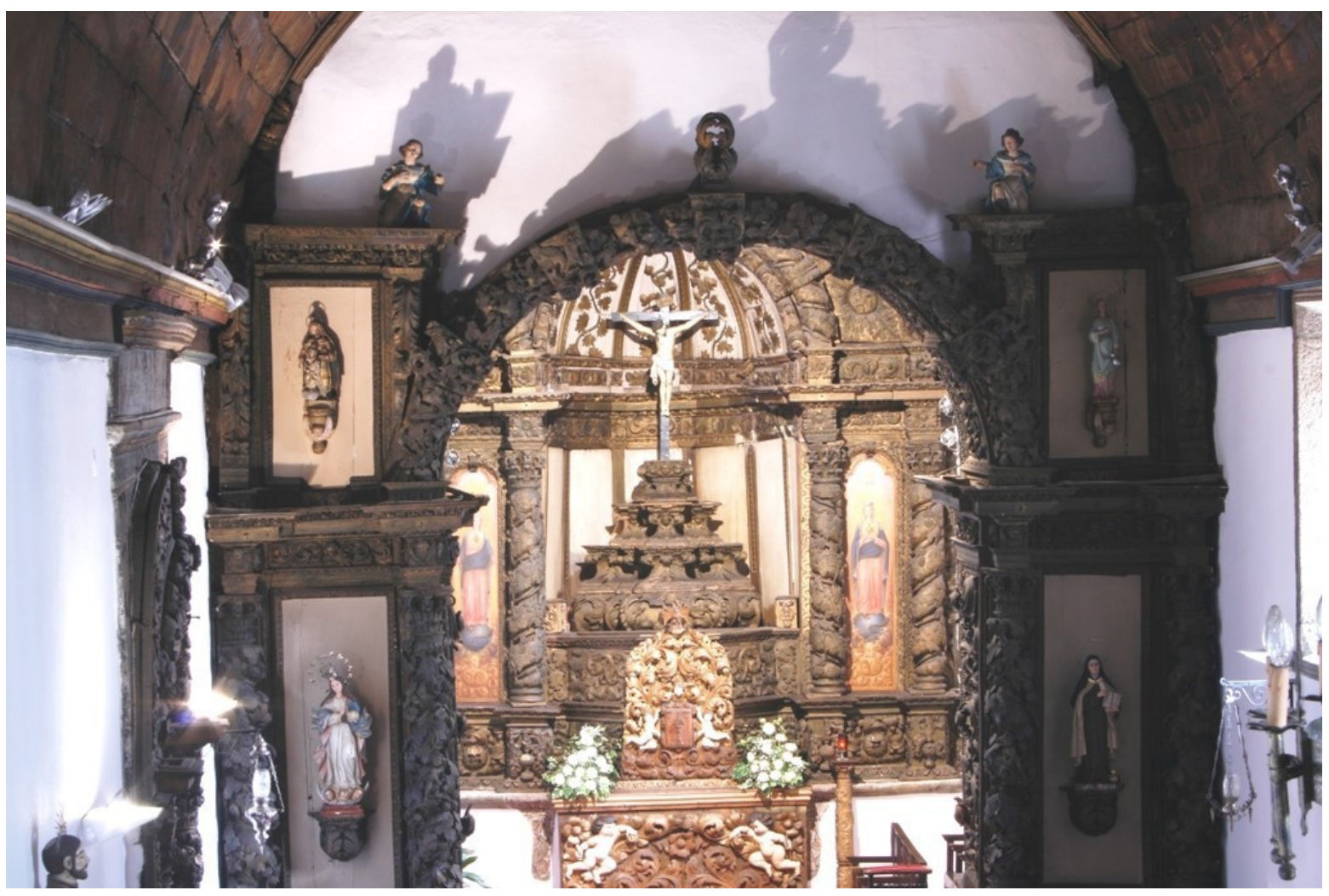


FICHAS DE INVENTÁRIO |ESCULTURA

Da Ordem de São Francisco na Diocese de Bragança-Miranda 


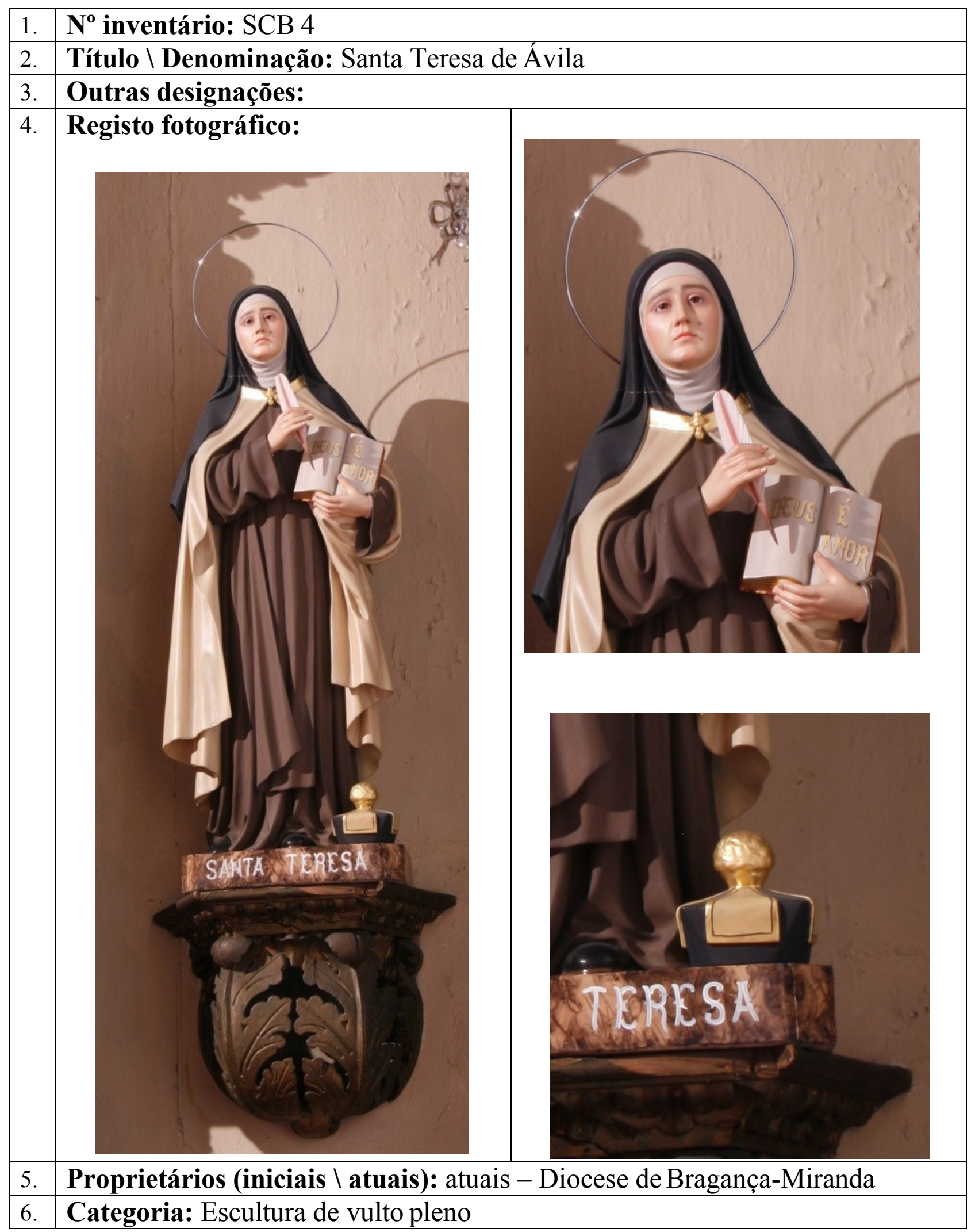


7. Descrição: Escultura de vulto completo representando Santa Teresa.

A figura está de pé em posição frontal com hábito carmelita segurando na mão direita uma pluma que apoia sobre o livro aberto que segura na mão esquerda, onde pode ler-se "Deus é Amor" em letras maiúsculas douradas.

De rosto com traços vincados e expressão grave, tem olhos de vidro e a cabeça envolta na mantilha branca sobre a qual enverga o manto negro que a cobre até meio das costas. Sob este usa um manto branco que a cobre até aos pés cingido no pescoço por uma fivela dourada. Sob os mantos usa a túnica castanha que com regular pregueado a cobre até aos pés. $\mathrm{Na}$ cabeça ostenta uma auréola simples. Junto aos pés, cobertos com sapatos negros, está pousado sobre o lado esquerdo um barrete eclesiástico negro com bordos e borla central dourados.

A figura está assente sobre uma plataforma em madeira de forma octogonal com marmoreado castanho, na face frontal pode ler-se "Santa Teresa" em letras brancas maiúsculas.

8. Técnicas (de suporte): Talhe

9. Técnicas (de acabamento): Policromia

10. Materiais (de suporte): Madeira

11. Materiais (de acabamento): Pigmentos; vidro

12. Estado de Conservação: Bom; apresenta-se estável sem sinais de degradação.

13. Dimensões: Não foi possível registar estes elementos

Altura:

Largura:

Prof

14. Restauro: não apresenta sinais de intervenção sobre a obra

15. Datas: século XX

16. Proveniência: igreja de Nossa Senhora das Graças

17. Autoria: desconhecida

18. Oficina: Casa Fanzeres (?)

19. Localização (atual): Lado da Epistola, no primeiro registo do Arco de triunfo que separa a nave da capela-mor

20. Histórico do objeto: são várias as semelhanças com a figura de São Francisco, bem como com Santa Teresinha religiosa (no modelado dos detalhes anatómicos e panejamentos) pode por isso ter a mesma proveniência, não havendo certeza mantém-se a interrogação

21. Iconografia: Hábito Carmelita; Pluma; Livro aberto Auréola; barrete eclesiástico negro com bordos e borla central dourados

22. Irmandade: não se conhecem registos

23. Procissões: não se conhecem registos 


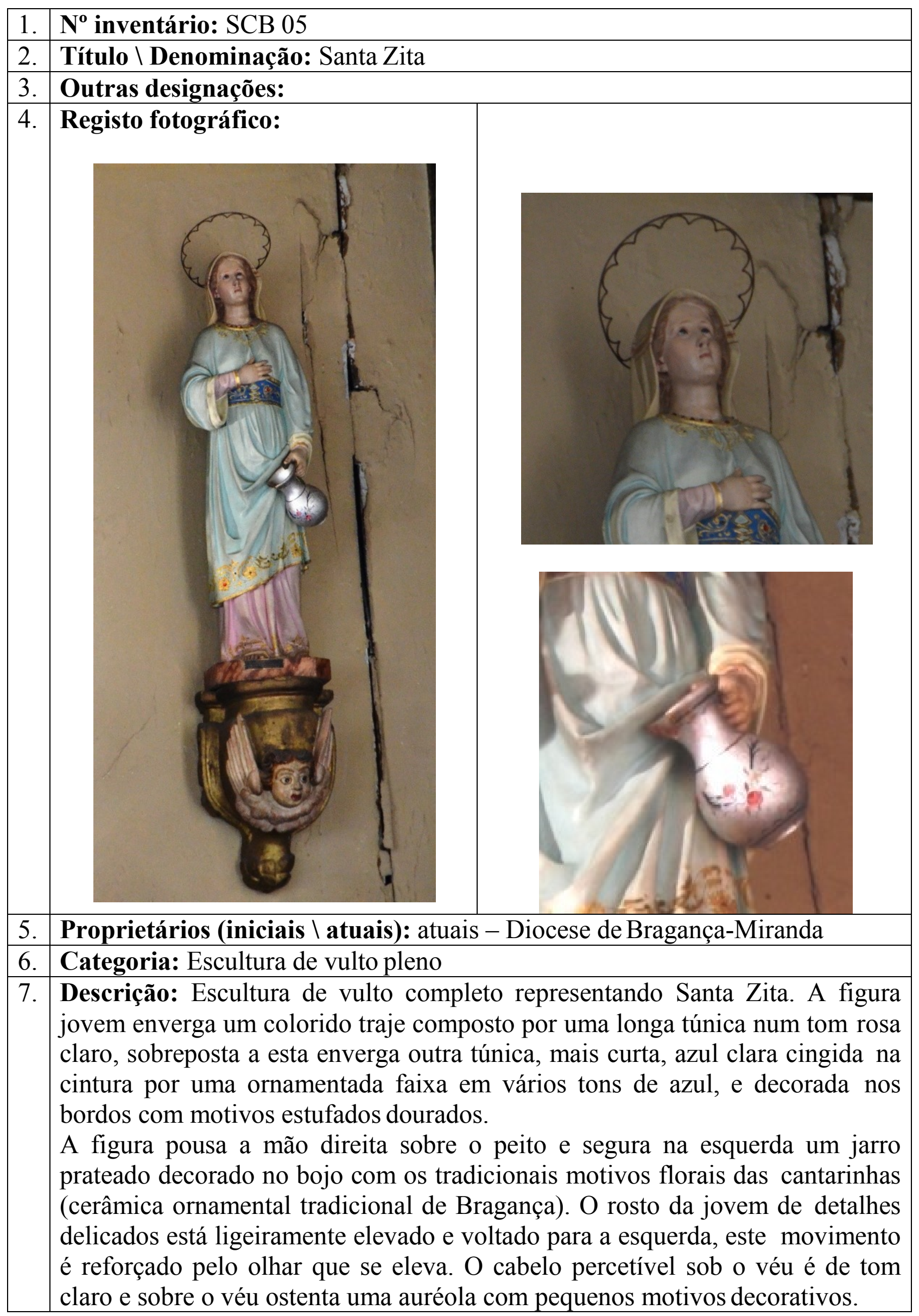




\begin{tabular}{|c|c|}
\hline & $\begin{array}{l}\text { A figura está assente sobre uma plataforma em madeira de forma octogonal } \\
\text { com marmoreado em tom castanho claro. }\end{array}$ \\
\hline 8. & Técnicas (de suporte): Talha \\
\hline 9. & Técnicas (de acabamento): Policromia \\
\hline 10. & Materiais (de suporte): Madeira \\
\hline 11. & Materiais (de acabamento): Pigmentos \\
\hline 12. & Estado de Conservação: Bom; apresenta-se estável sem sinais de degradação. \\
\hline 13. & $\begin{array}{l}\text { Dimensões: Não foi possível registar estes elementos } \\
\text { Altura: } \\
\text { Largura: } \\
\text { Prof }\end{array}$ \\
\hline 14. & Restauro: não apresenta sinais de intervenção sobre a obra \\
\hline 15. & Datas: século XX \\
\hline 16. & Proveniência: igreja de Nossa Senhora das Graças \\
\hline 17. & Autoria: desconhecida \\
\hline 18. & Oficina: Casa Fanzeres (?) \\
\hline 19. & $\begin{array}{l}\text { Localização (atual): Lado da Epistola, no registo mais alto do Arco de triunfo } \\
\text { que separa a nave da capela-mor }\end{array}$ \\
\hline 20. & $\begin{array}{l}\text { Histórico do objeto: são várias as semelhanças com a figura de São Francisco, } \\
\text { bem como com Santa Teresinha Religiosa (no modelado dos detalhes } \\
\text { anatómicos e panejamentos) pode por isso ter a mesma proveniência, não } \\
\text { havendo certeza mantém-se a interrogação. Na plataforma tem pregada uma } \\
\text { chapa de identificação da oficina idêntica à de S. Francisco, mas dada a } \\
\text { localização da escultura é difícil aceder à leitura }\end{array}$ \\
\hline 21. & Iconografia: Jarro; Auréola \\
\hline 22. & $\begin{array}{l}\text { Irmandade: Segundo informação da atual zeladora houve até tempo recente } \\
\text { uma irmandade, ou confraria das empregadas domésticas }\end{array}$ \\
\hline 23. & Procissões: não se conhecem registos \\
\hline
\end{tabular}




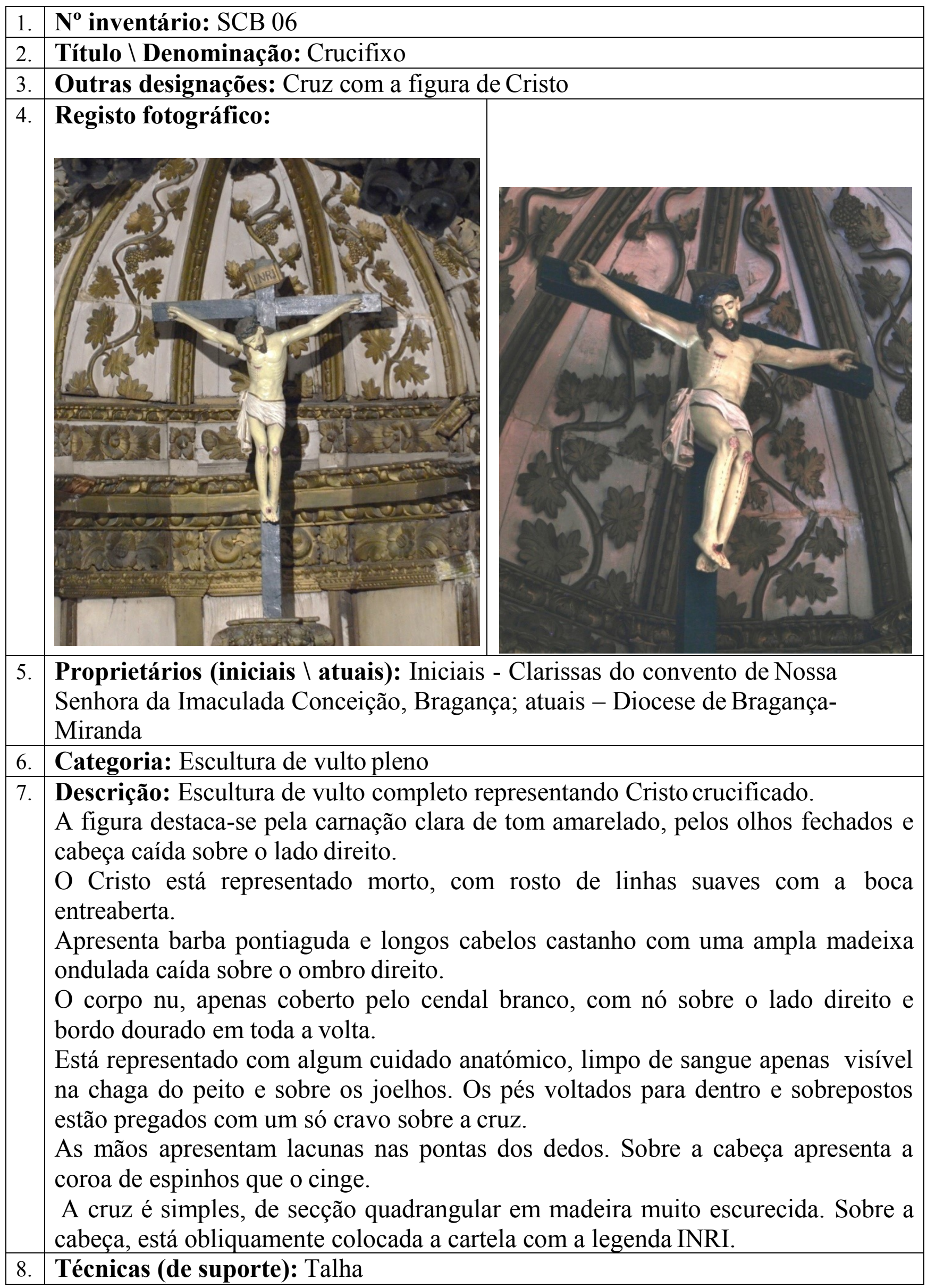




\begin{tabular}{|c|c|}
\hline 9. & Técnicas (de acabamento): Policromia \\
\hline 10. & Materiais (de suporte): Madeira \\
\hline 11. & Materiais (de acabamento): Pigmentos; folha de ouro \\
\hline 12. & $\begin{array}{l}\text { Estado de Conservação: Bom; apresenta-se se estável; com lacunas nas pontas } \\
\text { dos dedos. }\end{array}$ \\
\hline 13. & $\begin{array}{l}\text { Dimensões: Não foi possível registar estes elementos } \\
\text { Altura: } \\
\text { Largura: } \\
\text { Profundidade: }\end{array}$ \\
\hline 14. & Restauro: apresenta sinais de intervenção sobre a obra \\
\hline 15. & Datas: primeira metade do século XVII \\
\hline 16. & Proveniência: igreja de Nossa Senhora da Conceição (convento das clarissas) \\
\hline 17. & Autoria: desconhecida \\
\hline 18. & Oficina: Nacional \\
\hline 19. & $\begin{array}{l}\text { Localização (atual): A escultura está colocada na tribuna do retábulo da capela- } \\
\text { mor }\end{array}$ \\
\hline 20. & Histórico do objeto: não se conhecem registos \\
\hline 21. & Iconografia: Cruz; chagas \\
\hline 22. & Irmandade: não se conhecem registos \\
\hline 23. & Procissões: não se conhecem registos \\
\hline
\end{tabular}




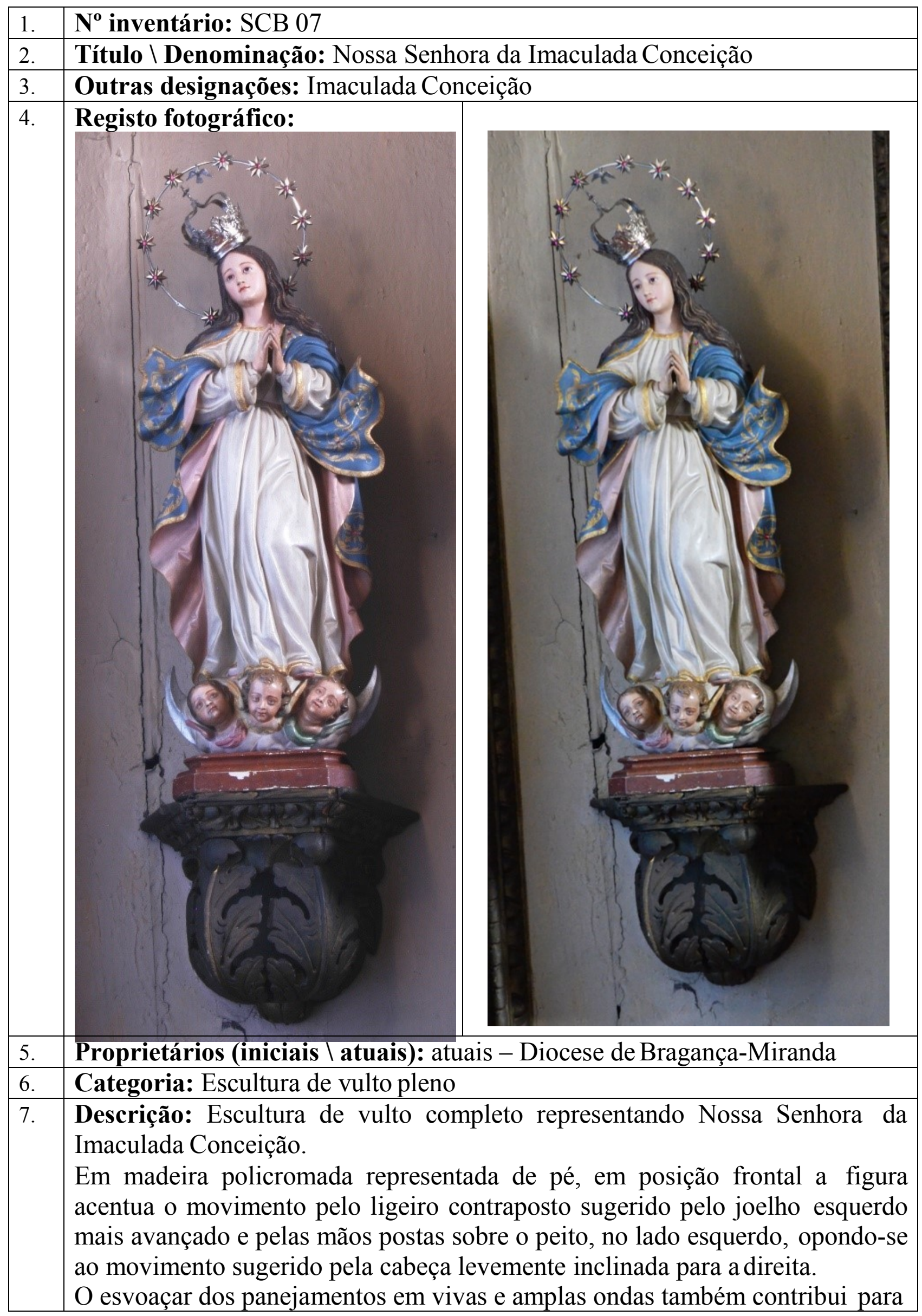




\begin{tabular}{|l|l|}
\hline & $\begin{array}{l}\text { a dinâmica plasticidade da figura. Enverga uma túnica branca, cingida na } \\
\text { cintura que a cobre até aos pés. A túnica está decorada com filete dourado } \\
\text { sobre os punhos gola e bordo. Sobre este traje a figura enverga um manto azul } \\
\text { claro com forro rosa e decorado com estofado dourado que a cobre sobre os } \\
\text { ombros caindo em amplas pregas onduladas até aos pés. } \\
\text { O rosto está finamente esculpido e coberto de carnação brilhante, com traços } \\
\text { delicados que compõem uma expressão serena. Os olhos, de vidro, elevam o } \\
\text { olhar. O cabelo longo e ondulado cai sobre os ombros. } \\
\text { Aplicada sobre a cabeça tem uma coroa em liga metálica branca ornamentada } \\
\text { com quatro braços que se unem no centro encimado por uma cruz. Em volta } \\
\text { desta uma aurela estrelada ornamentada com pedras amarelas no centro das } \\
\text { dez estrelas e uma pequena pomba também em metal branco. } \\
\text { A escultura assenta sobre uma nuvem da qual emerge transversalmente uma } \\
\text { lua crescente prateada e frontalmente três cabeças de anjo com asas. Está } \\
\text { colocada sobre uma plataforma castanha de forma octogonal com três registos, } \\
\text { tem destacamentos de policromia. }\end{array}$ \\
\hline 8. & Técnicas (de suporte): Talha \\
\hline 9. & Técnicas (de acabamento): Policromia; estufagem; cinzelagem \\
\hline 10. & Materiais (de suporte): Madeira \\
\hline 11. & $\begin{array}{l}\text { Materiais (de acabamento): Pigmentos; folha de ouro; vidro; liga metálica } \\
\text { branca }\end{array}$ \\
\hline 12. & $\begin{array}{l}\text { Estado de Conservação: Bom; apresenta-se se estável; destacamentos de } \\
\text { policromia na plataforma }\end{array}$ \\
\hline 13. & $\begin{array}{l}\text { Dimensões: Não foi possível registar estes elementos } \\
\text { Altura: } \\
\text { Largura: } \\
\text { Profundidade: }\end{array}$ \\
\hline 14. & Restauro: não apresenta sinais de intervenção sobre a obra \\
\hline 15. & Datas: século XX \\
\hline 16. & Proveniência: igreja de Nossa Senhora das Graças \\
\hline 17. & Autoria: desconhecida \\
\hline 18. & Oficina: Porto \Braga (?) \\
\hline 19. & $\begin{array}{l}\text { Localização (atual): Lado do Evangelho, no primeiro registo do Arco de } \\
\text { triunfo que separa a nave da capela-mor }\end{array}$ \\
\hline 20. & Histórico do objeto: não se conhecem registos \\
\hline 21. & Iconografia: Lua; Coroa; Auréola. \\
\hline 22. & Irmandade: não se conhecem registos \\
\hline 23. & Procissões: não se conhecem registos \\
\hline
\end{tabular}




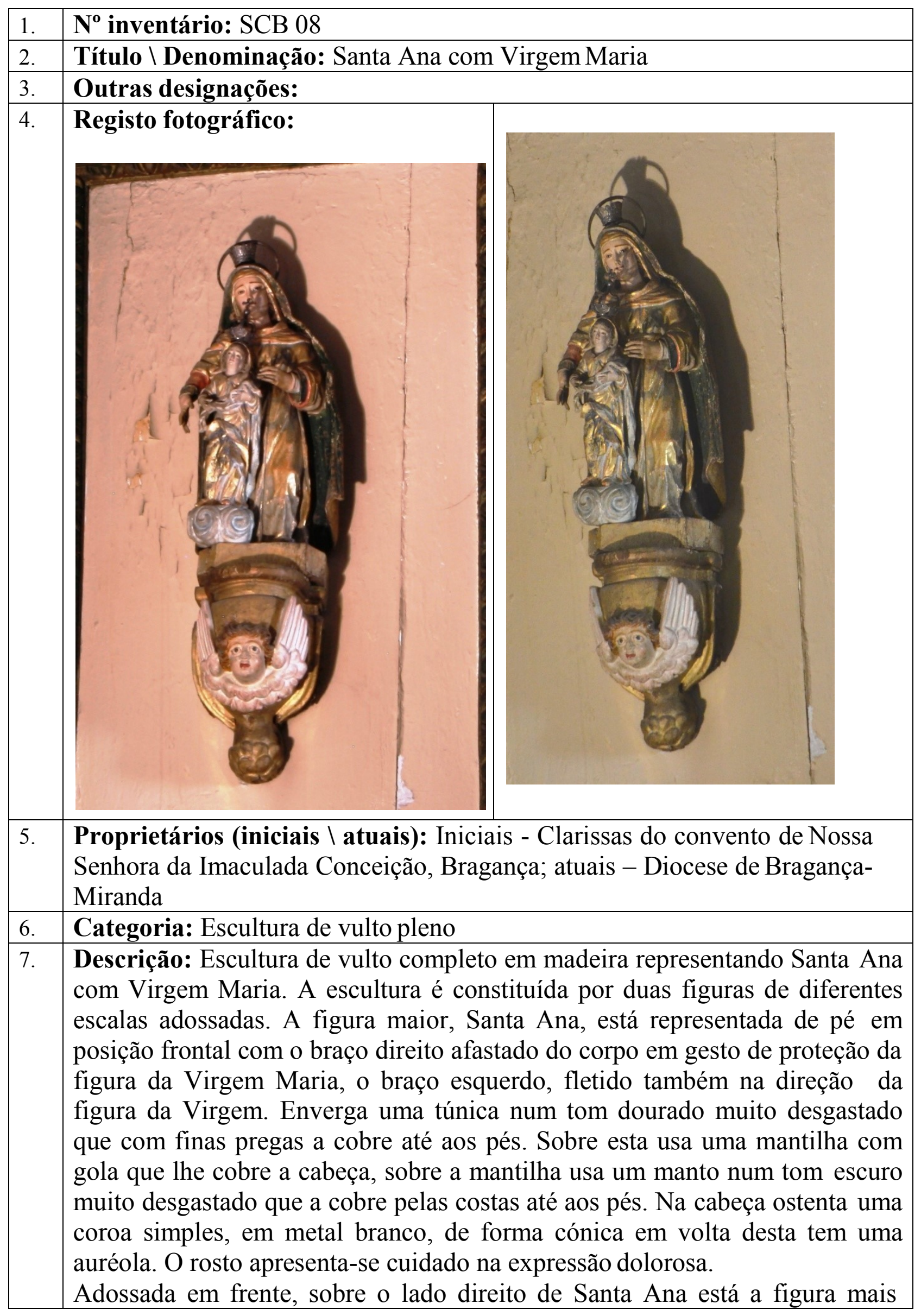




\begin{tabular}{|l|l|}
\hline & $\begin{array}{l}\text { pequena que representa a Virgem Maria. Representada de pé, em posição } \\
\text { frontal a figura flete ambos braços sobre o peito onde assenta um panejamento } \\
\text { (que poderia suster a figura do Menino) mas já não tem qualquer atributo. } \\
\text { Enverga uma túnica que a cobre até aos pés, com pregueado e detalhes } \\
\text { anatómicos sumariamente tratados. Ostenta uma coroa, em metal branco, } \\
\text { constituída por quatro elementos que se unem sob uma cruz. } \\
\text { O conjunto está colocado sobre uma plataforma octogonal de tom beije. }\end{array}$ \\
\hline 8. & Técnicas (de suporte): Talhe \\
\hline 9. & Técnicas (de acabamento): Policromia \\
\hline 10. & Materiais (de suporte): Madeira \\
\hline 11. & Materiais (de acabamento): Pigmentos; metal branco \\
\hline 12. & Estado de Conservação: Bom; apresenta-se estável; desgaste na policromia. \\
\hline 13. & $\begin{array}{l}\text { Dimensões: Não foi possível registar estes elementos } \\
\text { Altura: } \\
\text { Largura: } \\
\text { Prof }\end{array}$ \\
\hline 14. & Restauro: apresenta sinais de reintegração cromática \\
\hline 15. & Datas: século XVII \\
\hline 16. & Proveniência: igreja de Nossa Senhora da Conceição (convento das clarissas) \\
\hline 17. & Autoria: desconhecida \\
\hline 18. & Oficina: Nacional e Castelhana (?) \\
\hline 19. & $\begin{array}{l}\text { Localização (atual): Lado do Evangelho, no registo mais alto do Arco de } \\
\text { triunfo que separa a nave da capela-mor }\end{array}$ \\
\hline 20. & $\begin{array}{l}\text { Histórico do objeto: As diferenças formais observadas entre as duas figuras } \\
\text { sugere que podem ter sido adossadas posteriormente }\end{array}$ \\
\hline 21. & Iconografia: Santa Ana com Virgem; auréola \\
\hline 22. & Irmandade: não se conhecem registos \\
\hline 23. & Procissões: não se conhecem registos \\
\hline
\end{tabular}


Retábulo em talha barroca nacional, com inscrição de "S. CAETANO R.P. N." no lado do Evangelho junto ao arco triunfal no nicho central está a imagem de Nossa Senhora das Graças SCB 09

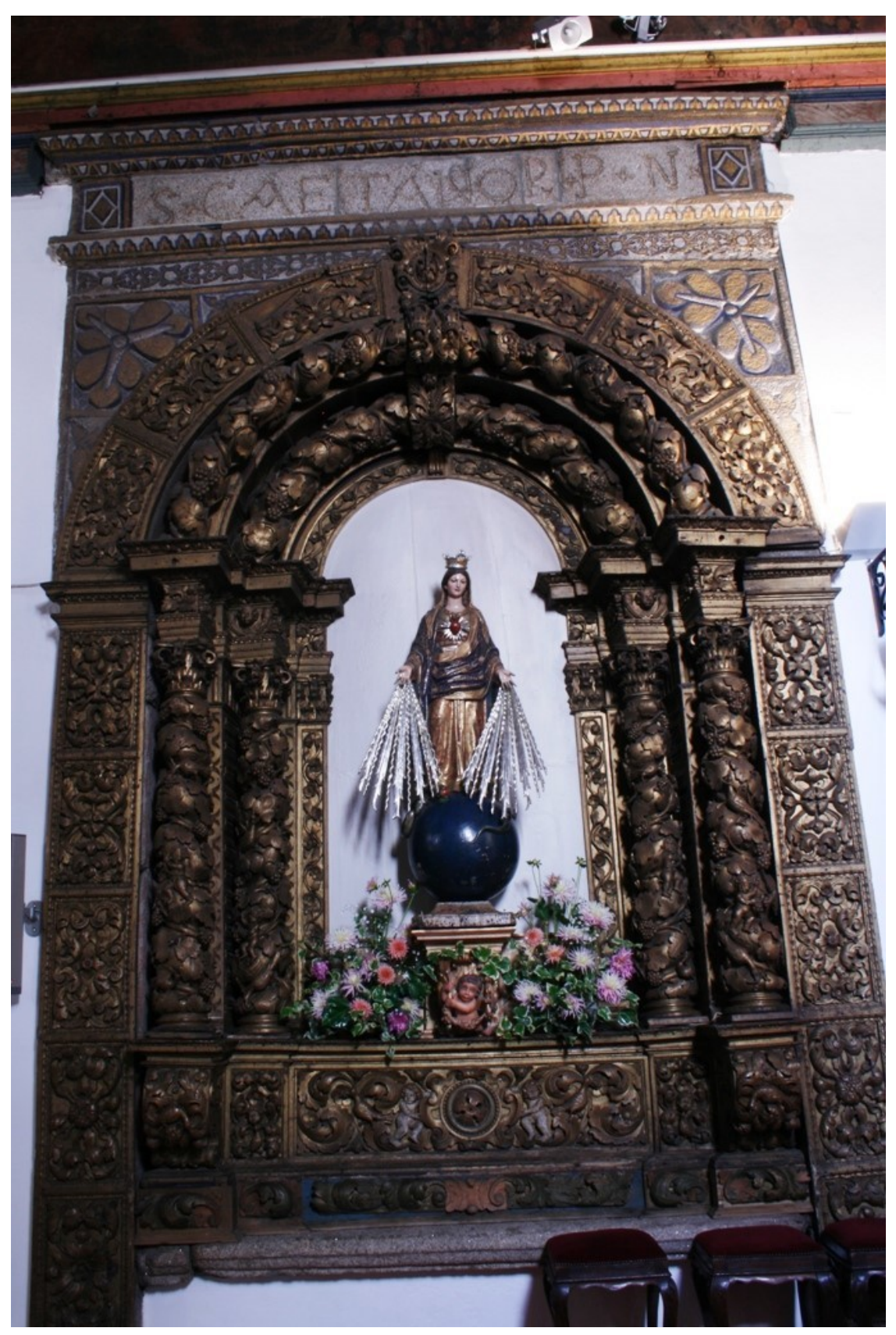


FICHAS DE INVENTÁRIO |ESCULTURA

Da Ordem de São Francisco na Diocese de Bragança-Miranda 


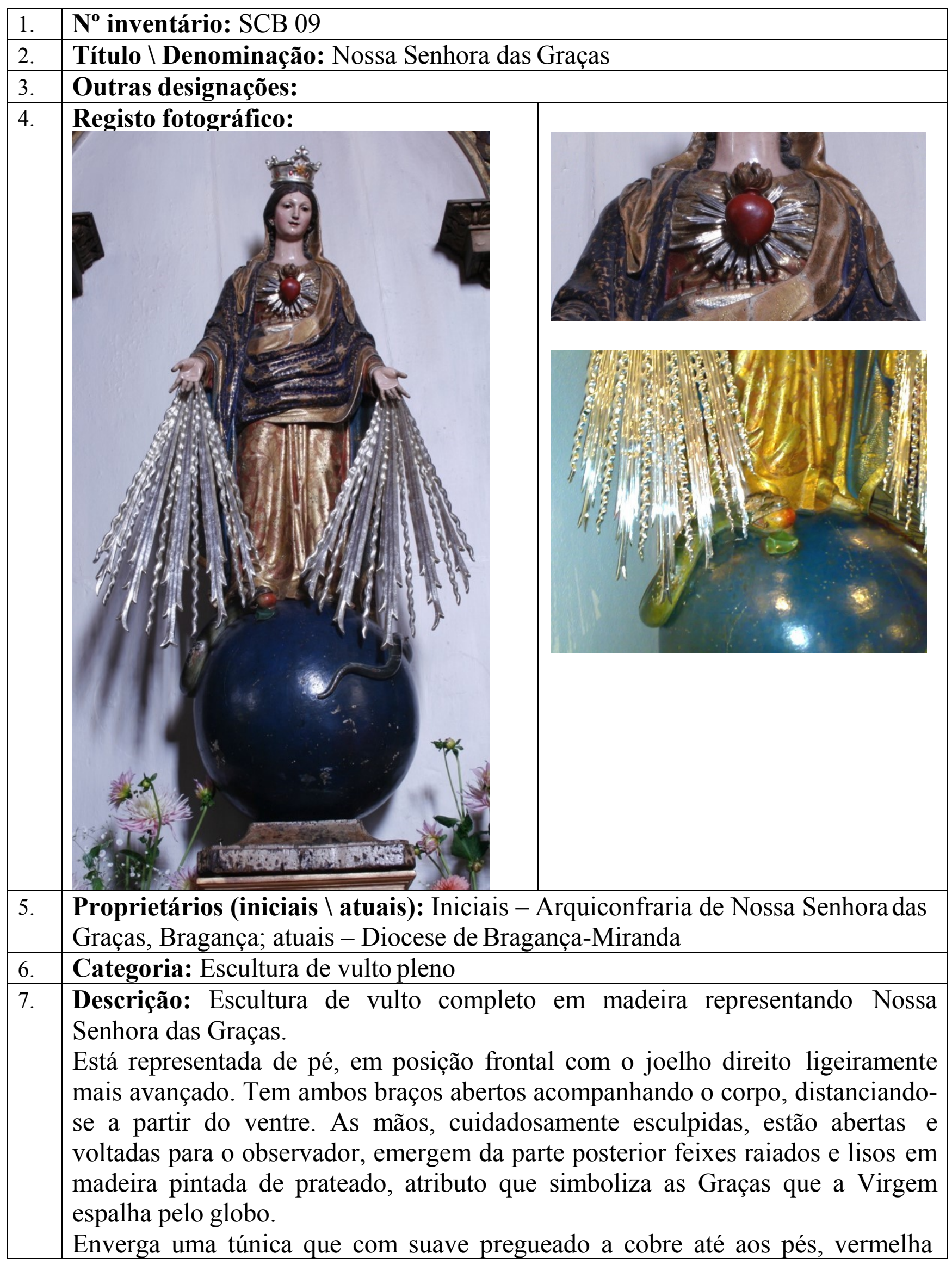




\begin{tabular}{|c|c|}
\hline & $\begin{array}{l}\text { intensamente coberta de motivos florais estofados dourados. Sobre esta enverga } \\
\text { um manto azul coberto de estrelas e ornamentos estofados que a envolve pelos } \\
\text { ombros traçada sobre o ventre caindo em suaves ondas pelas costas. Sobre a } \\
\text { cabeça usa uma mantilha de tom dourado que lhe deixa a descoberto algumas } \\
\text { madeixas que lhe envolvem o rosto. Sobre a mantilha ostenta uma coroa com } \\
\text { pontas decorada com uma estrela sobre a fronte. } \\
\text { O rosto, simétrico e de linhas finas tem uma expressão suave, com carnação } \\
\text { muito brilhante o que reforça a delicada anatomia facial. Os olhos, de vidro, } \\
\text { evocam uma expressão doce do olhar baixo. } \\
\text { Sobre o peito o coração ardente em madeira destaca-se do resplendor raiado em } \\
\text { metal prateado. } \\
\text { A figura assenta sobre um globo azul-escuro percorrido em toda a volta por uma } \\
\text { serpente que morde uma maça e que a Virgem pisa com o pé direito, protegido } \\
\text { com sandálias. O globo está colocado sobre uma plataforma quadrangular com } \\
\text { três registos de tom beije muito deteriorada. }\end{array}$ \\
\hline 8. & Técnicas (de suporte): Talha \\
\hline 9. & \\
\hline 10. & Mate \\
\hline 11. & $\begin{array}{l}\text { Materiais (de acabamento): Pigmentos; folha de ouro; vidro; liga metálica } \\
\text { branca }\end{array}$ \\
\hline 12. & $\begin{array}{l}\text { Estado de Conservação: Bom; apresenta-se se estável; destacamentos de } \\
\text { policromia na serpente, globo e pontas dos dedos. Tem vários pregos e parafusos } \\
\text { aplicados sobre o globo. }\end{array}$ \\
\hline 13. & $\begin{array}{l}\text { Dimensões: Não foi possível registar estes elementos } \\
\text { Altura: } \\
\text { Largura: } \\
\text { Profundidade: }\end{array}$ \\
\hline 14. & Restauro: não apresenta sinais de intervenção sobre a obra \\
\hline 15. & Datas: século XIX \\
\hline 16. & 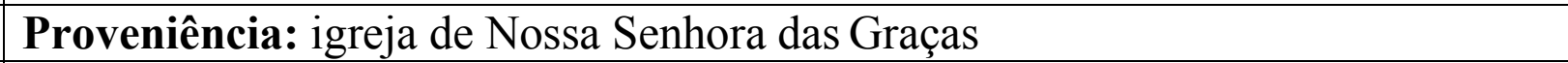 \\
\hline 17. & \\
\hline 18. & Oficina: Nacional (Porto \Braga) \\
\hline 19. & $\begin{array}{l}\text { Localização (atual - Lado do Evangelho, no retábulo de São Caetano(conforme } \\
\text { inscrição que o encima) que antecede o Arco de triunfo que separa a nave da } \\
\text { capela mor }\end{array}$ \\
\hline 20. & Histórico do objeto: não se conhecem registos \\
\hline 21. & $\begin{array}{l}\text { Iconografia: Feixes de Luz (Graças); Coroa; Coração Ardente; Serpente; Maça; } \\
\text { Globo. Aquando das festividades em sua honra em Agosto a coroa é substituída } \\
\text { por outra em metal branco com resplendor estrelado }\end{array}$ \\
\hline 22. & Irmandade: Tem arquiconfraria desde o século XIX \\
\hline 23. & $\begin{array}{l}\text { Procissões: A imagem representa a padroeira da cidade sai em procissão nas } \\
\text { festividades de Agosto }\end{array}$ \\
\hline
\end{tabular}




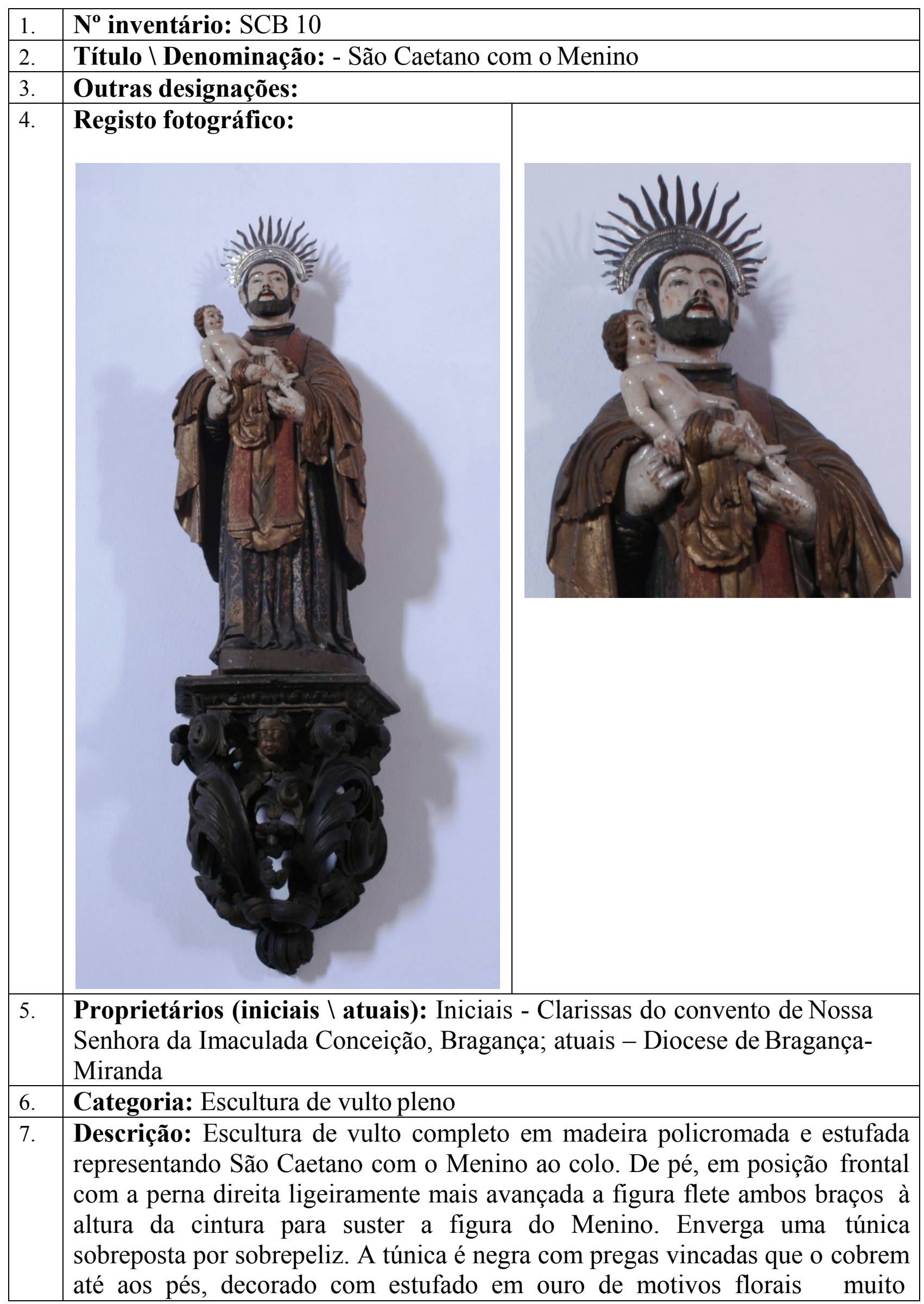




\begin{tabular}{|c|c|}
\hline & $\begin{array}{l}\text { desgastados. A sobrepeliz vincada pela flexão dos braços é de tom dourado e } \\
\text { cobre-o até aos joelhos, sobre esta enverga o escapulário em tom vermelho. } \\
\text { As mãos com carnação muito brilhante estão parcialmente envolvidas no } \\
\text { panejamento que cobre o Menino pela cintura. O rosto de São Caetano, } \\
\text { também com carnação muito brilhante da qual destaca o rubro dos lábios } \\
\text { fechados (repintados?). Com barbas e cabelos curtos de cor castanha, os olhos } \\
\text { pintados que fixam o olhar em frente reforçam a estaticidade da figura. Sobre a } \\
\text { cabeça ostenta um resplendor semicircular raiado. } \\
\text { O Menino destaca-se pelas irregularidades anatómicas e ausência de } \\
\text { proporções infantis. De corpo nu levemente reclinado apenas coberto por um } \\
\text { véu na cintura, tem os cabelos cuidadosamente decorado com enrolamentos } \\
\text { simétricos em tom castanho claro. } \\
\text { Ambas as figuras têm destacamentos na policromia da carnação. Está assente } \\
\text { sobre plataforma de contornos arredondados com lacuna no lado direito. }\end{array}$ \\
\hline 8. & Técnicas (de suporte): Talhe \\
\hline 9. & Técnicas (de acabamento): Policromia; Estufado dourado \\
\hline 10. & Materiais (de suporte): Madeira \\
\hline 11. & Materiais (de acabamento): Pigmentos; Metal branco \\
\hline 12. & $\begin{array}{l}\text { Estado de Conservação: Bom; apresenta-se estável; destacamentos da } \\
\text { policromia da carnação; desgaste na policromia e estufado. }\end{array}$ \\
\hline 13. & $\begin{array}{l}\text { Dimensões: Não foi possível registar estes elementos } \\
\text { Altura: } \\
\text { Largura: } \\
\text { Profundidade: }\end{array}$ \\
\hline 14. & Restauro: apresenta sinais de reintegração cromática no rosto \\
\hline 15. & Datas: primeira metade do século XVIII \\
\hline 16. & Proveniência: igreja de Nossa Senhora da Conceição (convento das clarissas) \\
\hline 17. & Autoria: desconhecida \\
\hline 18. & Oficina: Local $\backslash$ regional \\
\hline 19. & $\begin{array}{l}\text { Localização (inicial } \backslash \text { atual) Inicialmente a imagem deveria estar no altar } \\
\text { contíguo em cujo lintel consta a inscrição de "S. CAETANO R. P. N." } \\
\text { Actualmente está sobre uma peanha também no lado do Evangelho }\end{array}$ \\
\hline 20. & Histórico do objeto: não se conhecem registos \\
\hline 21. & Iconografia: - Menino ao colo; Batina; Sobrepeliz; Escapulário; Resplendor \\
\hline 22. & $\begin{array}{l}\text { Irmandade: Teve Irmandade com muitos fiéis (Borges, } 2012 \text { (texto original } \\
\text { de 1721-1724), p. 155) }\end{array}$ \\
\hline 23. & Procissões: não se conhecem registos \\
\hline
\end{tabular}




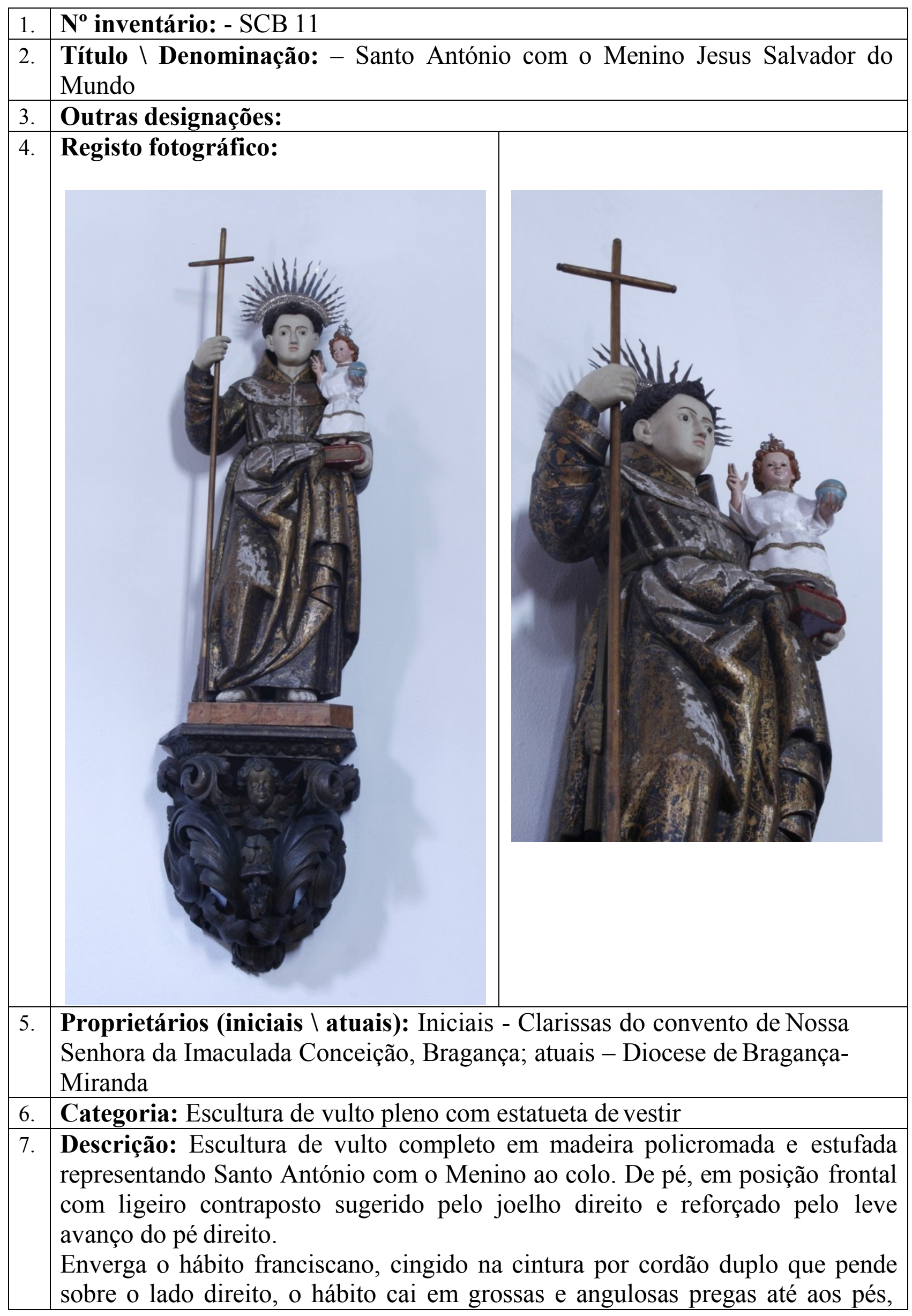




\begin{tabular}{|c|c|}
\hline & $\begin{array}{l}\text { cobertos com sandálias, deixando apenas as pontas dos dedos a descobertos. O } \\
\text { hábito num tom castanho muito escuro quase negro está coberto de motivos } \\
\text { estufados a ouro já muito desgastados. } \\
\text { O braço direito está afastado do corpo e elevado à altura do ombro, a mão } \\
\text { fletida segura uma cruz alta que assenta na plataforma e se eleva sobre o corpo } \\
\text { do Santo, a cruz é simples e de secção circular. } \\
\text { O braço esquerdo sustem, à altura da cintura, um grosso livro fechado com } \\
\text { capas vermelhas sobre o qual está colocado o Menino Jesus Salvador do } \\
\text { Mundo. } \\
\text { A carnação do rosto e mãos de santo António é mate e de tom homogeneamente } \\
\text { amarelo (repinte?). De expressão grave o rosto jovem fixa o olhar em frente } \\
\text { com modelação cuidada nos detalhes anatómicos. Sobre a cabeça tonsurada, } \\
\text { com cabelo curto em amplas ondas de cor castanha, ostenta um resplendor } \\
\text { semicircular raiado (igual ao de São Caetano SCB 10). } \\
\text { O Menino eleva os dois dedos da mão direita em sinal de bênção e na mão } \\
\text { esquerda ostenta o globo de cor azul. O rosto tem feições delicadas, os cabelos } \\
\text { são curtos de cor castanho claro. A figura encontra-se vestida e ornada com } \\
\text { uma coroa encimada por uma cruz. } \\
\text { Está assente sobre plataforma octogonal decorada com marmoreado em tom } \\
\text { castanho claro. }\end{array}$ \\
\hline 8. & Técnicas (de suporte): Talhe \\
\hline 9. & Técnicas (de acabamento): Policromia \\
\hline 10. & Materiais (de suporte): Madeira \\
\hline 11. & Materiais (de acabamento): Pigmentos; Metal branco; têxteis \\
\hline 12. & $\begin{array}{l}\text { Estado de Conservação: Bom; apresenta-se estável; destacamento integral da } \\
\text { policromia sobre o lado direito da figura, que acompanha uma fissura profunda. }\end{array}$ \\
\hline 13. & $\begin{array}{l}\text { Dimensões: Não foi possível registar estes elementos } \\
\text { Altura: } \\
\text { Largura: } \\
\text { Profundidade: }\end{array}$ \\
\hline 14. & Restauro: apresenta sinais de reintegração cromática nas mãos e rosto \\
\hline 15. & Datas: século XVII \\
\hline 16. & Proveniência: igreja de Nossa Senhora da Conceição (convento das clarissas) \\
\hline 17. & Autoria: desconhecida \\
\hline 18. & Oficina: Nacional \\
\hline 19. & Localização (atual): Lado do Evangelho sobre uma peanha \\
\hline 20. & Histórico do objeto: não se conhecem registos \\
\hline 21. & Iconografia: Menino ao colo; hábito franciscano; Livro; Cruz alta; Resplendor \\
\hline 22. & Irmandade: não se conhecem registos \\
\hline 23. & Procissões: não se conhecem registos \\
\hline
\end{tabular}




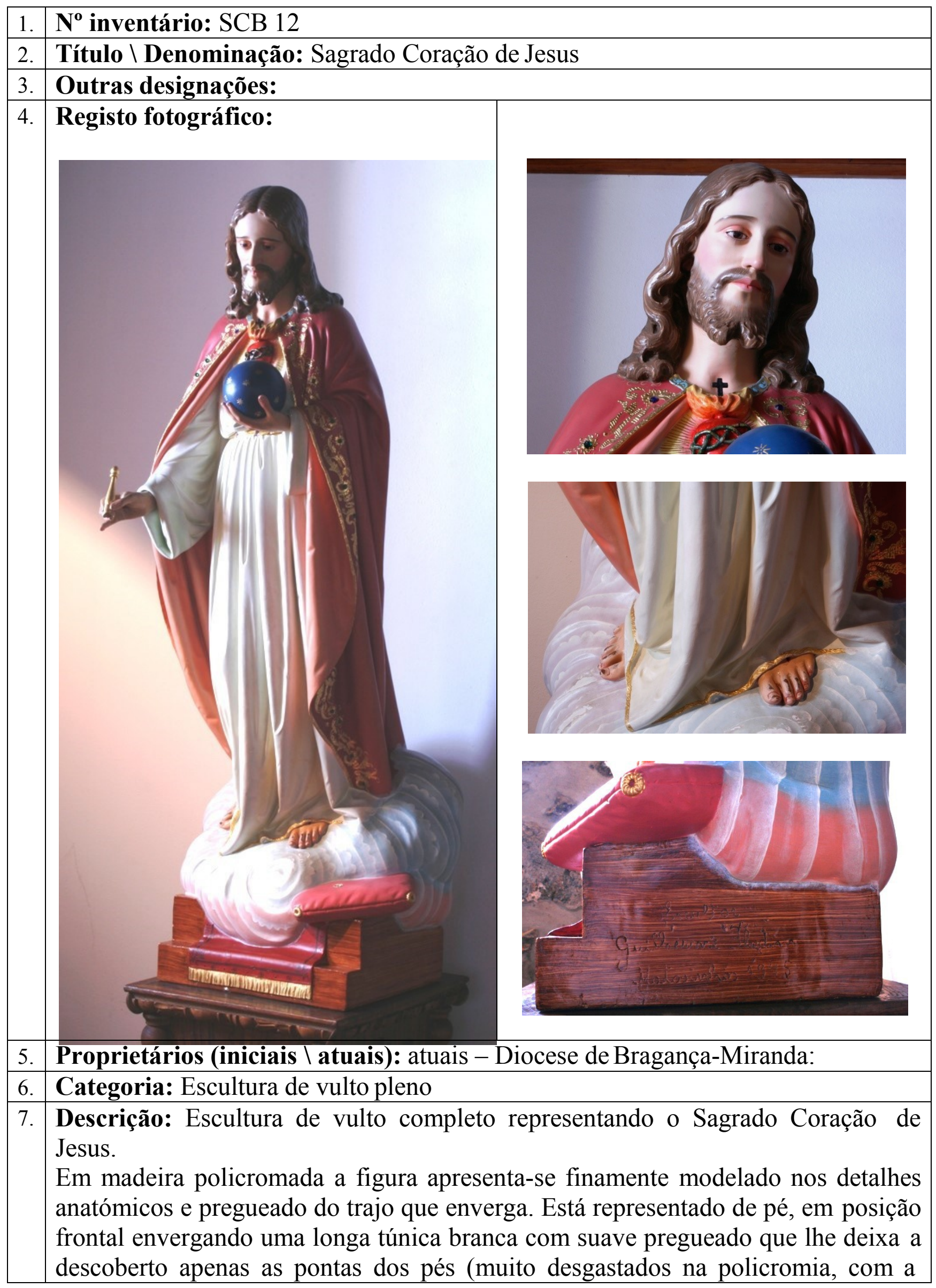




\begin{tabular}{|c|c|}
\hline & $\begin{array}{l}\text { madeira de suporte a descoberto). A túnica está cingida na cintura por um cordão } \\
\text { duplo pintado em dourado, sobre esta enverga um manto amplo vermelho, preso } \\
\text { sobre o pescoço e caindo sobre as costas cobrindo desde os ombros até aos pés, } \\
\text { decorado nos bordos por ornatos dourados com pequenas pedrasincrustadas. } \\
\text { A mão direita afastada do corpo à altura da cintura segura uma parte do que terá } \\
\text { sido um atributo entretanto partido, em madeira pintada de dourado. A mão } \\
\text { esquerda segura junto ao peito o globo azul decorado com estrelas. Ambas as } \\
\text { mãos, com as respetivas chagas, estão cuidadosamente esculpidas. } \\
\text { Sobre o peito emerge o coração ardente cingido por uma coroa de espinhos e } \\
\text { encimado por uma cruz. } \\
\text { O rosto, de expressão serena baixa ligeiramente o olhar, com olhos de vidro, e } \\
\text { cuidados detalhes anatómicos. Usa a barba bifurcada e longos cabelos cujas } \\
\text { madeixas castanhas caiem sobre os ombros. } \\
\text { A figura está descalça e assente sobre uma nuvem que simula estar suspensa sobre } \\
\text { uma bancada com degraus com tapete vermelho e um coxim rosa. Está assinada } \\
\text { sobre a bancada no lado esquerdo, onde pode ler-se "Escultor } \backslash \text { Guilherme Thedim } \\
\backslash \text { Matosinhos } 1945 \text { ". }\end{array}$ \\
\hline 8. & Técnicas (de suporte): Talha \\
\hline 9. & nto): Policromia \\
\hline 10. & Materiais (de suporte): Madeira \\
\hline 11. & Materiais (de acabamento): Pigmentos; vidro \\
\hline 12. & $\begin{array}{l}\text { Estado de Conservação: Bom; apresenta-se se estável; forte desgaste na } \\
\text { policromia decorrente da fricção que os fiéis fazem sobre os pés da escultura; } \\
\text { lacuna de parte do atributo na mão direita }\end{array}$ \\
\hline 13. & $\begin{array}{l}\text { Dimensões: } \\
\text { Altura: } 153 \mathrm{~cm} \\
\text { Largura: } 60 \mathrm{~cm} \\
\text { Profundidade: } 58 \mathrm{~cm}\end{array}$ \\
\hline 14. & Restauro: não apresenta sinais de intervenção sobre a obra \\
\hline & Datas: século XX, 1945 \\
\hline 16. & Proveniência: igreja de Nossa Senhora das Graças \\
\hline 17. & ne Thedim \\
\hline & Oficina: Matosinhos \\
\hline 19. & Localização (atual): Sob o coro alto no lado da Epistola \\
\hline 20. & Histórico do objeto: não se conhecem registos \\
\hline 21. & $\begin{array}{l}\text { Iconografia: coração ardente cingido por coroa de espinhos e encimado por cruz; } \\
\text { globo azul com estrelas }\end{array}$ \\
\hline 22. & não se conhecem registos \\
\hline & \\
\hline
\end{tabular}




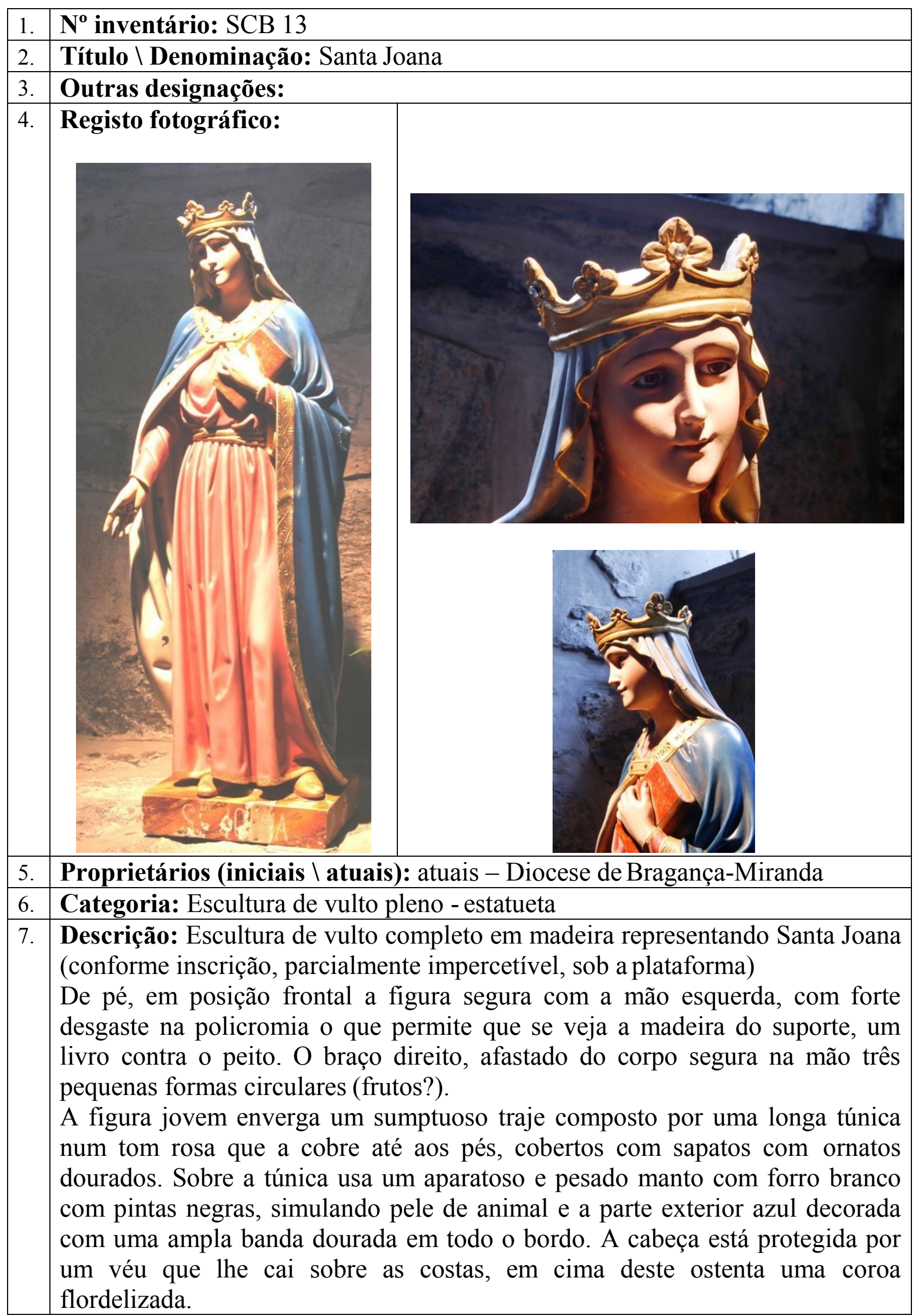




\begin{tabular}{|l|l|}
\hline & $\begin{array}{l}\text { Com olhos de vidro que reforçam o refinado modelado do rosto juvenil de } \\
\text { expressão serena. } \\
\text { A figura está assente sobre uma plataforma quadrangular em madeira com } \\
\text { marmoreado em tom castanho claro, sobre a frente pode ler-se " Sta } \\
\text { JO(SIC)A". } \\
\text { É semelhante no gesto e modelado do rosto à escultura do Sagrado Coração de } \\
\text { Jesus SCB 12 sugerindo a mesma produção oficinal. }\end{array}$ \\
\hline 8. & Técnicas (de suporte): Talha \\
\hline 9. & Técnicas (de acabamento): Policromia \\
\hline 10. & Materiais (de suporte): Madeira \\
\hline 11. & Materiais (de acabamento): Pigmentos; vidro \\
\hline 12. & Estado de Conservação: Bom; apresenta-se estável; desgaste e destacamentos \\
na policromia.
\end{tabular}




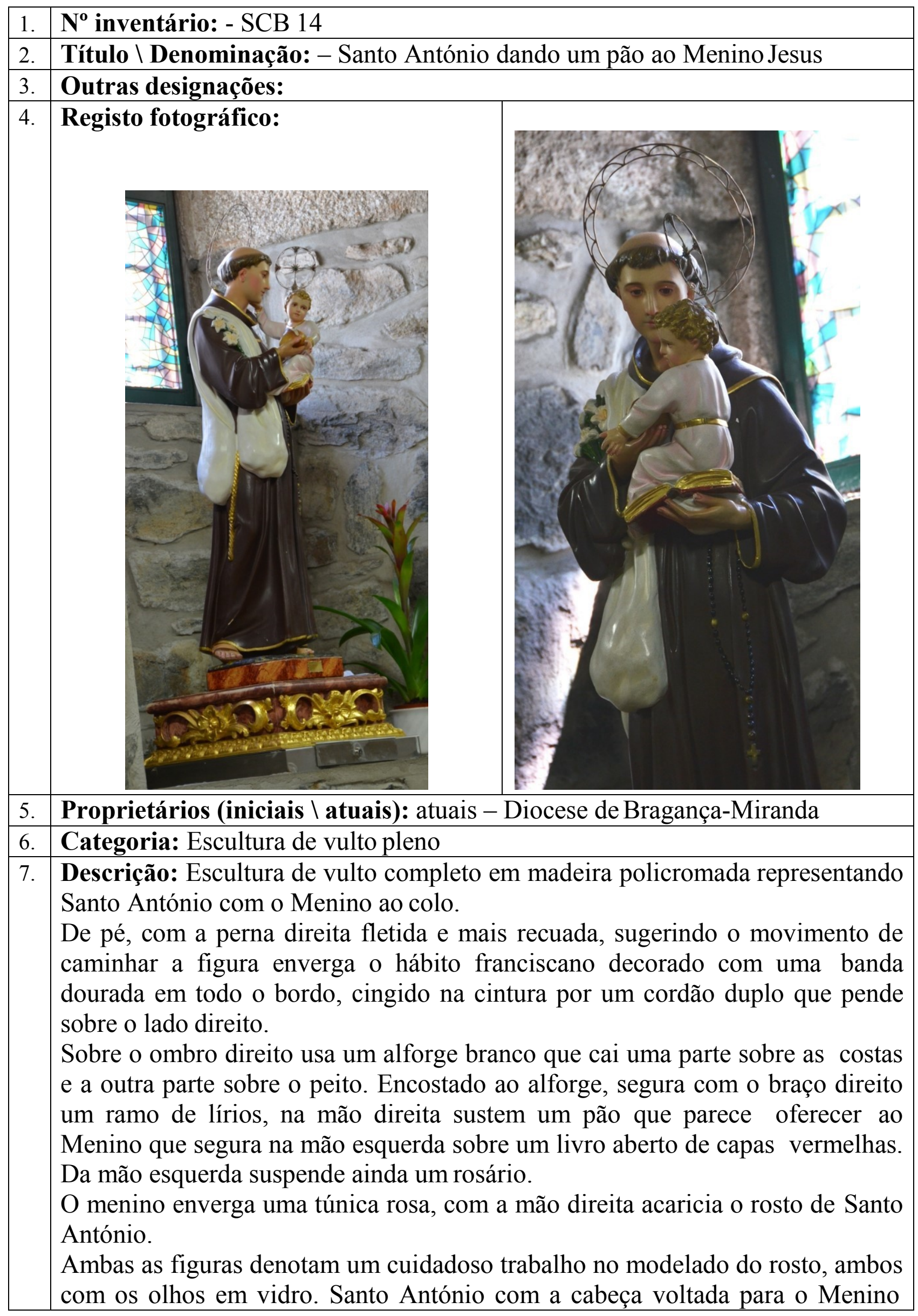




\begin{tabular}{|c|c|}
\hline & $\begin{array}{l}\text { apresenta a tonsura e uma auréola circular simples. O Menino Jesus olha em } \\
\text { frente e ostenta uma auréola decorada com uma forma cruciforme no interior da } \\
\text { circunferência. } \\
\text { A escultura está assente sobre plataforma octogonal decorada com marmoreado } \\
\text { em tom laranja. }\end{array}$ \\
\hline 8. & Técnicas (de suporte): Talha \\
\hline 9. & Técnicas (de acabamento): Policromia \\
\hline 10. & Materiais (de suporte): Madeira \\
\hline 11. & Materiais (de acabamento): Pigmentos; Metal branco \\
\hline 12. & Estado de Conservação: Bom; apresenta-se estável. \\
\hline 13. & $\begin{array}{l}\text { Dimensões: } \\
\text { Altura: } 90 \mathrm{~cm} \\
\text { Largura: } 45 \mathrm{~cm} \\
\text { Profundidade: } 49 \mathrm{~cm}\end{array}$ \\
\hline 14. & Restauro: não apresenta sinais de intervenção sobre a obra \\
\hline 15. & Datas: século XX \\
\hline 16. & Proveniência: igreja de Nossa Senhora das Graças \\
\hline 17. & Autoria: desconhecida \\
\hline 18. & Oficina: Porto $\backslash$ Braga (?) \\
\hline 19. & Localização (atual): Sob o coro alto no lado da Epistola \\
\hline 20. & Histórico do objeto: não se conhecem registos \\
\hline 21. & $\begin{array}{l}\text { Iconografia: Menino ao colo; hábito franciscano; Livro; Alforge; Pão; Lírios; } \\
\text { Auréola; Rosário }\end{array}$ \\
\hline 22. & Irmandade: não se conhecem registos \\
\hline 23. & Procissões: não se conhecem registos \\
\hline
\end{tabular}




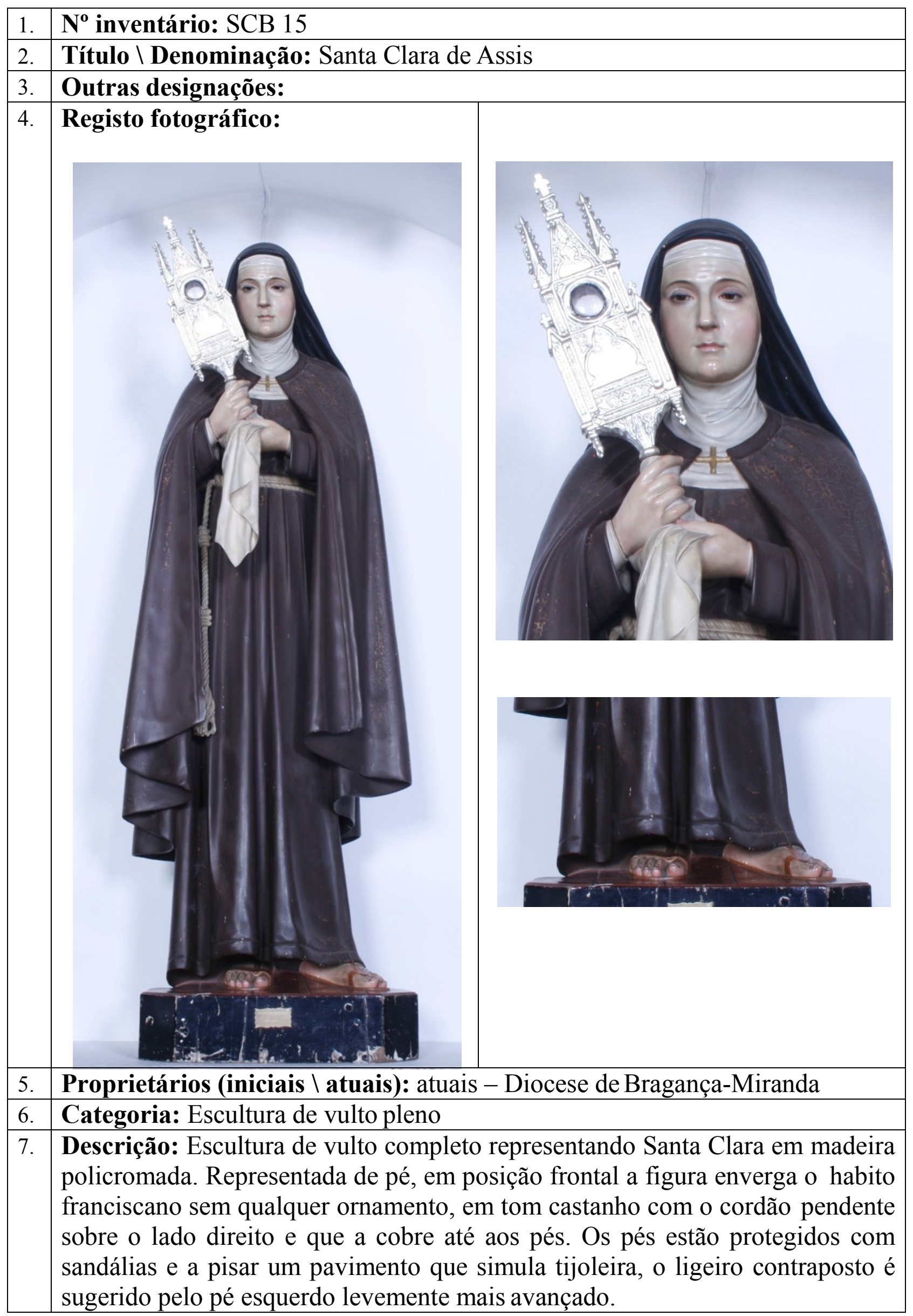




\begin{tabular}{|l|l|}
\hline & $\begin{array}{l}\text { A figura segura na mão direita uma custódia muito ornamentada com } \\
\text { elementos góticos sob uma forma paralelepipédica com um mostruário circular } \\
\text { em vidro ao centro. Na mão esquerda segura um lenço branco que pende. } \\
\text { Ambos os braços estão fletidos e elevados à altura do peito. } \\
\text { A monja de expressão grave e traços vincados baixa levemente o olhar, com os } \\
\text { olhos em vidro e a carnação muito brilhante. } \\
\text { A figura está assente sobre uma plataforma em madeira de forma octogonal } \\
\text { negra mas cujo piso é de tom laranja com quadrícula. No lado esquerdo da } \\
\text { plataforma está colada uma chapa metálica com a seguinte inscrição: “ } \\
\text { Fanzeres } \backslash \text { Oficia } \backslash \text { Teixeira Fanzeres \& filhos Lda } \backslash \text { Braga” }\end{array}$ \\
\hline 8. & Técnicas (de suporte): Talhe \\
\hline 9. & Técnicas (de acabamento): Policromia \\
\hline 10. & Materiais (de suporte): Madeira \\
\hline 11. & Materiais (de acabamento): Pigmentos; vidro \\
\hline 12. & $\begin{array}{l}\text { Estado de Conservação: Bom; apresenta-se estável; destacamentos da } \\
\text { policromia sobre o hábito }\end{array}$ \\
\hline 13. & $\begin{array}{l}\text { Dimensões: } \\
\text { Altura: } 130 \text { cm }\end{array}$ \\
\hline 14. & $\begin{array}{l}\text { Largura: } 47 \text { cm } \\
\text { Profundidade: } 38 \text { cm }\end{array}$ \\
\hline 15. & Dataura: século XX \\
\hline 16. & Proveniência: igreja de Nossa Senhora das Graças \\
\hline 17. & Autoria: Teixeira Fanzeres \& filhos \\
\hline 18. & Oficina: Casa Fanzeres, Braga, Portugal \\
\hline 19. & Localização (atual): Coro Alto no lado do Evangelho \\
\hline 20. & Histórico do objeto: não se conhecem registos \\
\hline 21. & Iconografia: Hábito franciscano; Custódia; lenço branco \\
\hline 22. & Irmandade: não se conhecem registos \\
\hline 23. & Procissões: não se conhecem registos \\
\hline
\end{tabular}


CONVENTO DE SÃO FRANCISCO EM MOGADOURO 


\section{FUNDAÇÃO DO CONVENTO}

No início do século XVII, em 1609, em plena época de domínio filipino, chegaram a Mogadouro os frades da Terceira Ordem Regular de São Francisco ${ }^{1}$. O Cabido da Sé de Miranda beneficiou com esmola os frades terceiros e também o convento. O convento foi fundado no ano de 1618, mas as obras ter-se-ão prolongado até aos finais dessa centúria $^{2}$. A data de 1689 gravada na cartela que se encontra sobre o nicho na fachada da igreja poderá celebrar o final da construção do atual edifício pois há documentos que permitem dizer que a igreja estaria pronta para servir ao culto, vinte anos antes ${ }^{3}$.

Em 1796, o convento contava com 9 religiosos, 3 irmãos leigos, 2 donatos e 2 moços ${ }^{4}$.

A tradição refere que o convento foi mandado edificar por D. Luís Álvares de Távora, $8^{\circ}$ alcaide da praça de Miranda do Douro e $7^{\circ}$ Senhor e Comendador da vila de Mogadouro, por comutação de um voto de peregrinação aos lugares santos 5 .

Apesar do concelho de Mogadouro pertencer ao arcebispado de Braga até 1882, eram os bispos de Miranda do Douro - Bragança que ordenavam os padres franciscanos do convento, atendendo à distância que os separava de Braga ${ }^{6}$.

\footnotetext{
${ }^{1}$ Mourinho (Júnior), António Rodrigues, Arquitectura religiosa da Diocese de Miranda do Douro Bragança, Sendim, Câmara Municipal de Miranda do Douro, 1995, p. 255.

${ }^{2}$ Alves, Francisco Manuel, Bragança Memórias arqueológico-históricas do distrito de Bragança $\left(2^{a}\right.$ edição) Tomo I, Bragança, Câmara Municipal de Bragança / Instituto Português de Museus - Museu Abade de Baçal, 2000, (original publicado em 1910-1947), p. 382; Mourinho (Júnior), António Rodrigues, Arquitectura religiosa da Diocese de Miranda do Douro - Bragança, Sendim, Câmara Municipal de Miranda do Douro, 1995, p. 255.

${ }^{3}$ Mourinho (Júnior), António Rodrigues, Arquitectura religiosa da Diocese de Miranda do Douro Bragança, Sendim, Câmara Municipal de Miranda do Douro, 1995, p. 255.

${ }^{4}$ Alves, Francisco Manuel, Bragança Memórias arqueológico-históricas do distrito de Bragança $\left(2^{a}\right.$ edição) Tomo I, Bragança, Câmara Municipal de Bragança / Instituto Português de Museus - Museu Abade de Baçal, 2000, (original publicado em 1910-1947), p.382.

${ }^{5}$ Mourinho (Júnior), António Rodrigues, Arquitectura religiosa da Diocese de Miranda do Douro Bragança, Sendim, Câmara Municipal de Miranda do Douro, 1995, p. 256; um dos proeminentes membros da família Távora, que senhoreava a vila de Mogadouro, perante o impedimento de se penitenciar nos lugares da Terra Santa, decidiu substituir a promessa pelo custeamento de um mosteiro para frades franciscanos naquela vila transmontana. Rodrigues, Luís Alexandre, "Caminho Doloroso: as gravuras italianas da Ordem Terceira de Vinhais" in Natália Marinho Ferreira-Alves (Coord.), Franciscanos no Mundo Português III, Porto, CEPESE - Centro de Estudos da População, Economia e Sociedade 2013, pp. 491-527.
} 
${ }^{6}$ Mourinho (Júnior), António Rodrigues, Arquitectura religiosa da Diocese de Miranda do Douro Bragança, Sendim, Câmara Municipal de Miranda do Douro, 1995, p. 256. 


\section{EDIFICADO DA IGREJA}

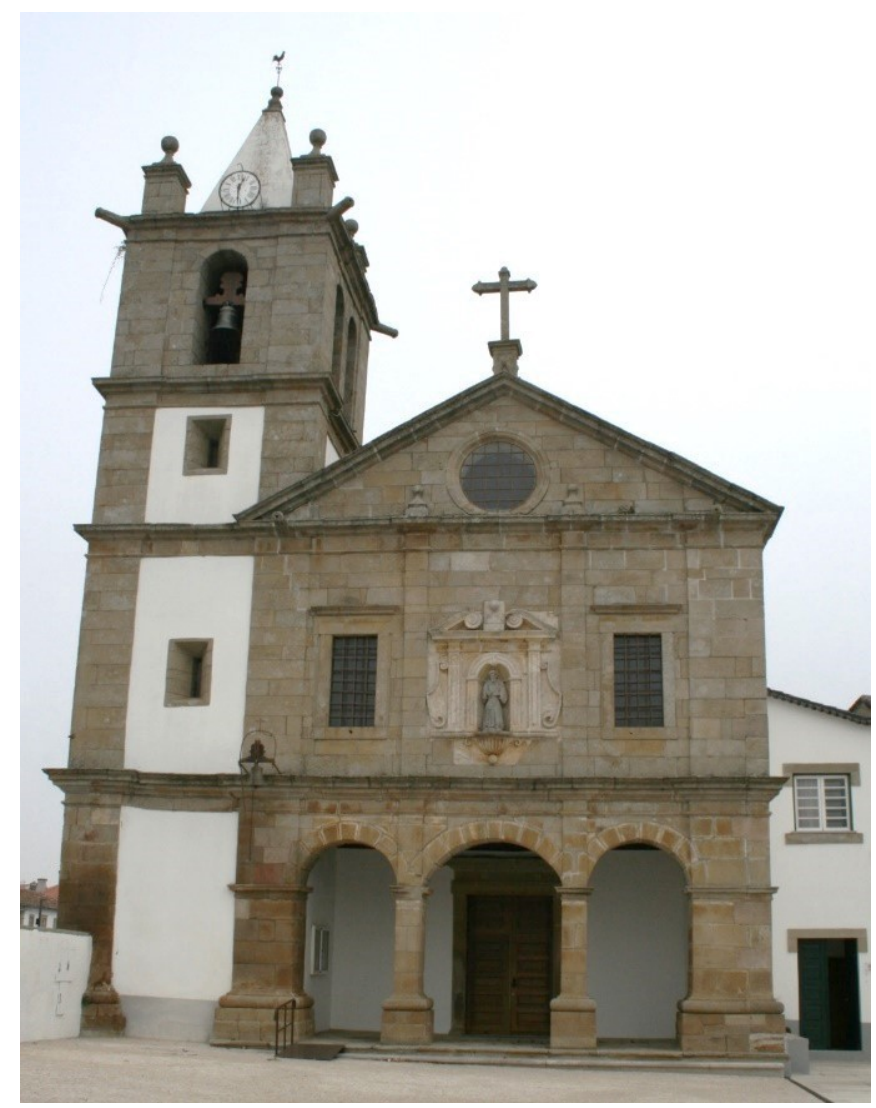

Imagem 1 - Vista do frontispício da igreja de São Francisco Mogadouro. Século XVII (1618\1689)

A deslocação da corte para Madrid em consequência da perda da independência de Portugal provocou, durante a dinastia dos Filipes, a ruralização da nobreza nacional ${ }^{7}$. Com este fenómeno da ruralização da nobreza, com uma presença continuada dos nobres nos seus territórios da província, pode relacionar-se a fundação do convento franciscano em Mogadouro e a intervenção dos Távoras.

A proteção dada às Ordens religiosas pelo poder filipino, com a confirmação de privilégios e esmolas para empreendimentos construtivos está na origem de uma intensa atividade arquitetónica, que começa logo após a chegada de D. Filipe II a Portugal. Esta arquitetura será caracterizada por uma relativa independência à normativa da renascentista de tradição italiana. Prática e conservadora a arquitetura de designado

\footnotetext{
${ }^{7}$ Ferreira, Sílvia, A talha. Esplendores de um passado ainda presente (sécs. XVI-XIX), Lisboa, Nova Terra, 2008, pp. 23-25.
} 
"estilo chão" adapta-se aos programas construtivos conventuais que impunham regras estritas de organização funcional e um relativo despojamento decorativo ${ }^{8}$.

A igreja do convento de Mogadouro tem o frontispício, em granito, com geometria simples e equilibrada, rematado por um frontão triangular que quebra a demarcada horizontalidade imposta pelas arquitraves salientes (Imagem 1).

A entrada no templo é feita a partir de uma galeria porticada com três arcos de meio ponto sustentados por fortes pilastras de cantaria granítica. Separado dos arcos, pela saliente arquitrave está colocado o nicho central entre dois janelões, que constitui o único elemento decorativo da fachada. O nicho assenta sobre uma mísula concheada, decoração que se repete na parte interior onde se guarda a imagem em granito de São Francisco. O nicho central é rematado por um frontão semicircular interrompido por um pináculo sobre o qual está inscrita a data de 1689. Está decorado com volutas e ladeado por duas aletas simplificadas. Os ornatos curvilíneos, sobressaem sobre a decoração geométrica, que envolvem o vão do nicho.

O facto dos nossos principais centros de decisão terem sido deslocados para Espanha no período compreendido entre 1580 e 1640 não pode ter deixado de incrementar relacionamentos e favorecido a circulação, entre os dois territórios, dos membros das famílias religiosas, nomeadamente dos franciscanos ${ }^{9}$.

Neste sentido Mourinho refere as semelhanças arquitetónicas da igreja de Mogadouro com a igreja da Encarnação de Madrid, obra do arquiteto carmelita Fr Alberto de la Madre de Dios (Imagem 2). Afirma dessa forma as influências espanholas, justificáveis não só pela proximidade territorial mas também porque, a partir de 1580 , com a união das duas coroas se assiste a um forte intercâmbio artístico entre Portugal e Espanha. Por outro lado os Távora eram uma nobre família de corte com relações com artistas de todos os ramos, viviam em Portugal e em Espanha, e neste movimento traziam deste país o que de mais moderno havia no campo da arte do tempo. Destas influências Mourinho destaca a de Francisco de Mora, discípulo de Juan de Herrera e que também terá trabalhado com Fr Alberto de la Madre de Dios ${ }^{10}$.

\footnotetext{
${ }^{8}$ Soromenho, Miguel, "Classicismo, italianismo e «estilo chão». O ciclo filipino." in Paulo Pereira (direção) História da Arte Portuguesa, volume II, Lisboa, Círculo de Leitores, 1995, pp. 376-403.

${ }^{9}$ Rodrigues, Luís Alexandre, "Caminho Doloroso: as gravuras italianas da Ordem Terceira de Vinhais" in Natália Marinho Ferreira-Alves (Coord.), Franciscanos no Mundo Português III, Porto, CEPESE Centro de Estudos da População, Economia e Sociedade 2013, pp. 491-527.

${ }^{10}$ Mourinho (Júnior), António Rodrigues, Arquitectura religiosa da Diocese de Miranda do Douro Bragança, Sendim, Câmara Municipal de Miranda do Douro, 1995, p. 260.
} 


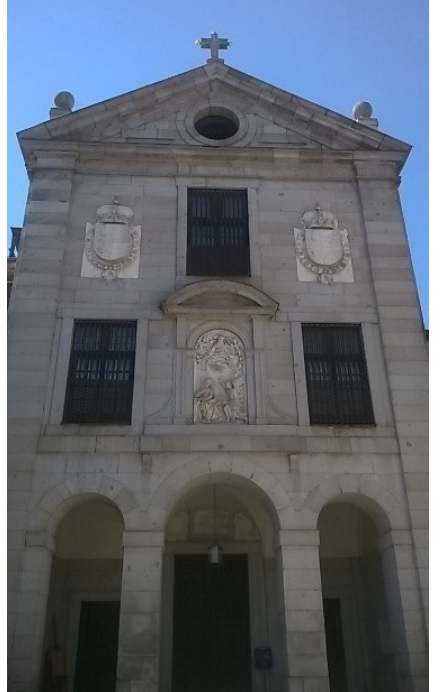

Imagem 2

Vista do frontispício da igreja da Encarnação, Madrid Século XVII $(1611 \backslash 1616)^{11}$

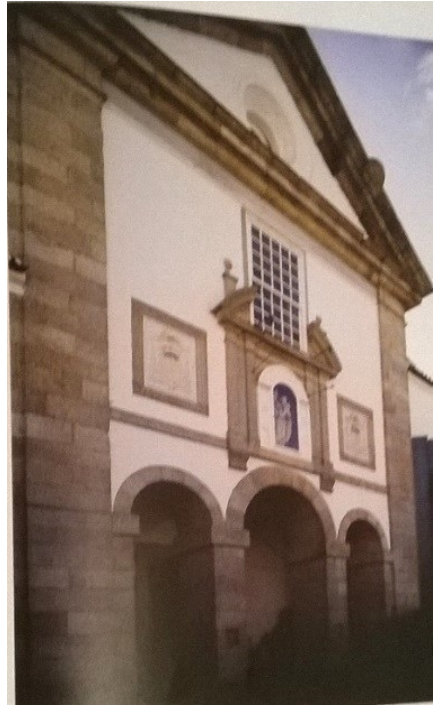

Imagem 3

Vista do frontispício Igreja de Nossa Senhora dos Remédios, Évora Século XVII (1606) ${ }^{12}$

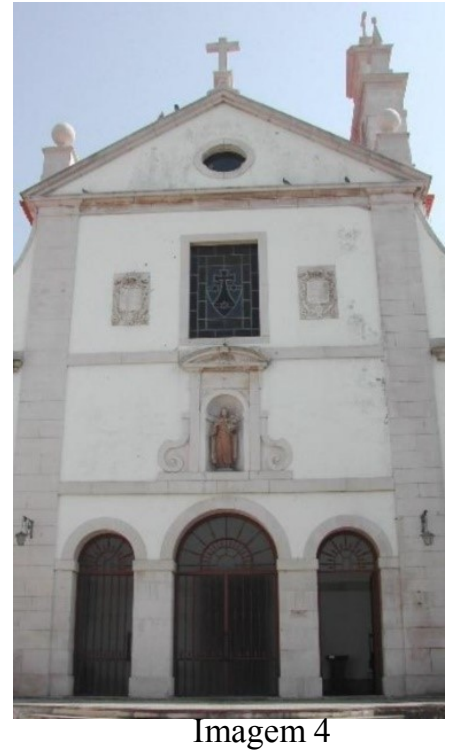

Vista do frontispício Igreja do Convento do Carmo, Aveiro Século XVII $(1628 \backslash 1643)^{13}$

Inquestionavelmente que a proximidade formal existe entre os frontispícios das igrejas. Mas, a simplicidade do esquema construtivo de fachada retangular com nártex porticado de três vãos sobrepujado com frontão triangular é comum a vários outros espaços coevos em Portugal. Destes espaços destacamos as igrejas dos Carmelitas Descalços como a igreja de Nossa Senhora dos Remédios de Francisco de Mora em Évora (Imagem 3) ou a Igreja do Convento do Carmo em Aveiro (Imagem 4). Em todos os frontispícios parece influir o desenho de Sebastiano Serlio e a tratadística transalpina ${ }^{14}$.

\footnotetext{
${ }^{11}$ Mourinho (Júnior), António Rodrigues, Arquitectura religiosa da Diocese de Miranda do Douro Bragança, Sendim, Câmara Municipal de Miranda do Douro, 1995, p. 260.

${ }^{12}$ Datação e imagem do frontispício da igreja de Nossa Senhora dos Remédios em Évora conforme consta em pp. 33, 34: Soromenho, Miguel, "A Arquitectura do ciclo filipino" in Dalila Rodrigues (Coord.) Arte Portuguesa Arte Portuguesa - Da Pré-História ao Século XX, volume 10, Lisboa, Fubu Editores, 2009, pp. 7-125.

${ }^{13}$ Datação e a imagem do frontispício da igreja do Convento do Carmo em Aveiro conforme consta no site da Direcção Geral de Património Cultural, acedido a 16 de Março de 2015.

http://www.patrimoniocultural.pt/en/patrimonio/patrimonio-imovel/pesquisa-do-patrimonio/classificadoou-em-vias-de-classificacao/geral/view/74017.

${ }^{14}$ Soromenho, Miguel, "A Arquitectura do ciclo filipino" in Dalila Rodrigues (Coord.) Arte Portuguesa Arte Portuguesa - Da Pré-História ao Século XX, volume 10, Lisboa, Fubu Editores, 2009, pp. 7-125, citando Pereira, J. F. (1999) A Cultura Arquitectónica Portuguesa (sistema clássico), Lisboa, s. ed.
} 
O claustro conventual é de planta quadrada com arcos abatidos nos vãos, a parte ocidental depois de entrar em ruínas foi destruída e o que resta de edificado foi transformado para se adaptar às funções que agora cumpre.

Após a extinção das Ordens Religiosas o convento sofreu um grave incêndio em 1885 que devastou grande parte do edifício e destruiu toda a documentação que se guardava no interior. No ano de 1927 sofreu novo incêndio do qual foi reparado no último quartel do século XX, período em que o interior do convento foi intervencionado para receber repartições públicas. A Câmara Municipal de Mogadouro, um pequeno núcleo museológico e uma repartição das Finanças ocupam atualmente o espaço conventual. A igreja mantém as funções do culto religioso ${ }^{15}$.

\footnotetext{
${ }^{15}$ Mourinho (Júnior), António Rodrigues, Arquitectura religiosa da Diocese de Miranda do Douro Bragança, Sendim, Câmara Municipal de Miranda do Douro, 1995, pp. 256, 257.
} 


\section{INTERIOR DA IGREJA}

A regularidade da fachada é transposta para o interior do templo. De nave única com três capelas laterais ou criptas abertas em cada um dos lados, com arcos de meio ponto. $\mathrm{O}$ arco do cruzeiro e o arco triunfal da capela-mor são da mesma forma e tamanho. Sobre o fecho do arco triunfal ainda podemos ver o brasão com as armas dos Távoras reforçando a relação desta família com a fundação do convento. $\mathrm{O}$ coro alto mantém o cadeiral, do século XVIII ${ }^{16}$ (Imagem 5 e 6) profusamente decorado com animais, elementos naturalistas e figuras híbridas, e uma estante decorada com os mesmos motivos.
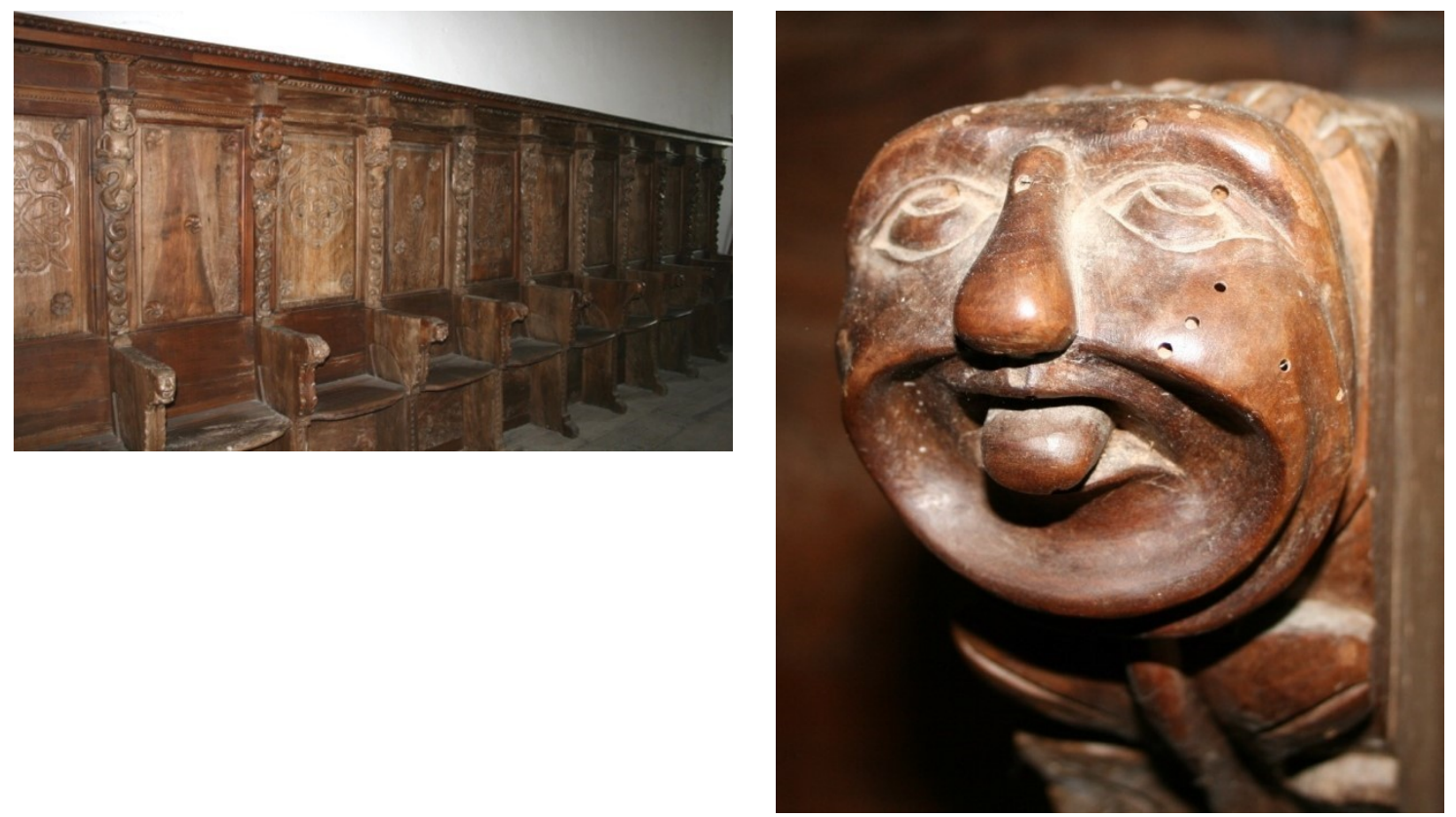

Imagem 5

Cadeiral do coro alto Igreja de São Francisco, Mogadouro
Imagem 6

Cadeiral do coro alto (pormenor) Igreja de São Francisco, Mogadouro

O altar-mor foi descrito no inventário dos bens após a extinção das ordens (1834), (Imagem 7):

"Primeiramente examinado o Templo, achou nelle Ministro que havia no mesmo um retablo com sua tribuna, sacrário, banqueta, Cruz Crucifixo e castiçais, tudo de madeira dourada, o que adorna

\footnotetext{
${ }^{16}$ Mourinho (Júnior), António Rodrigues, A talha nos concelhos de Miranda do Douro, Mogadouro e Vimioso nos séculos XVII e XVIII, Braga, Associação de Municípios do Planalto Mirandês, 1984, pp. 57, 58; Mourinho (Júnior), António Rodrigues, Arquitectura religiosa da Diocese de Miranda do Douro Bragança, Sendim, Câmara Municipal de Miranda do Douro, 1995, p. 261.
} 
o Altar môr, que tem para ornamento duas Imagens grandes, hua de São Francisco, e São Domingos.

Mais hua pedra ara, mais na mesma Capella mor, trez santos forrados de lam ${ }^{17}$,

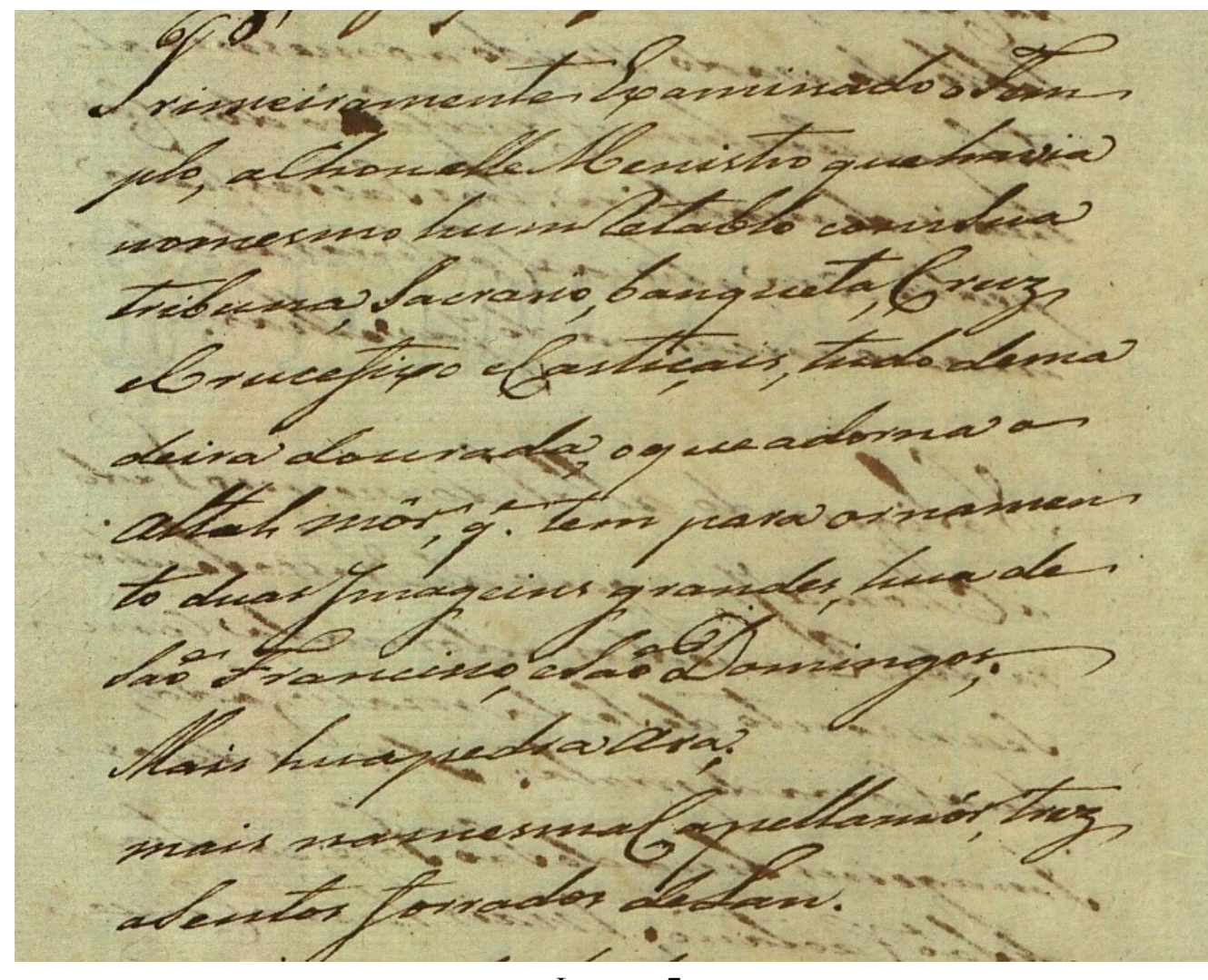

Imagem 7

Detalhe do documento de inventário dos bens: A.N.T.T./A.H.M.F./S.F.M., Extinção das Ordens Religiosas - Convento de São Francisco em Mogadouro, Arquivo Nacional da Torre do Tombo, Lisboa, Arquivo Histórico do Ministério das Finanças, Processos de Extinção das casas religiosas, Cx. 2238, 1834, fl. 4

No altar-mor ainda hoje se expõem as imagens "grandes" de São Francisco e Santo Domingos $^{18}$, (Imagem 8). O alto supedâneo em granito sobre o qual estão expostas as esculturas está decorado com ornatos maneiristas, recentemente repintados.

\footnotetext{
${ }^{17}$ No mesmo altar-mor ainda se registou "Mais quatro tocheiros de madeira grandes. $\backslash$ Mais hua banca que serve de credencia (?), \Mais dois pares de cortinas de damasco encarnado já velhas \"Mais hum docel de damasco branco emsima da Tribuna, para a exposição do Santissimo Sacramento, já velho \ Mais hua alampada de metal amarelo em bom uso.” A.N.T.T./A.H.M.F./S.F.M., Extinção das Ordens Religiosas - Convento de São Francisco em Mogadouro, Arquivo Nacional da Torre do Tombo, Lisboa, Arquivo Histórico do Ministério das Finanças, Processos de Extinção das casas religiosas, Cx. 2238, 1834, fl. 4, 4 v.

${ }^{18}$ No entanto, as imagens estão colocadas na ordem contaria ao que se registou em 1834, na medida em que, primeiro é referida a imagem de São Francisco (que estaria no lado do Evangelho) e só depois a de Santo Domingos (que estaria no lado da Epístola), pois é essa a ordem de inventario registada ao longo de todo o documento.
} 


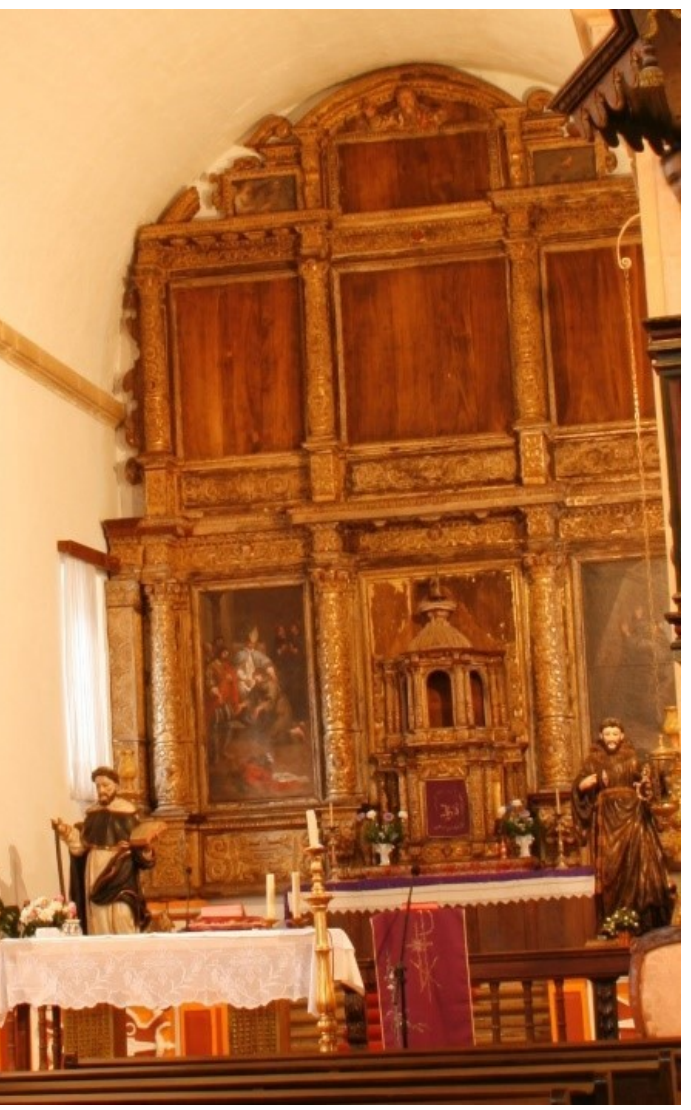

O retábulo maneirista ${ }^{19}$ é constituído por painéis, com cenas da vida de São Francisco, pintados sobre tela e apresenta lacuna de vários painéis que se perderam no processo de restauro ${ }^{20}$.

Os "trez santos forrados de lam" já não constituem hoje parte do altar-mor, que também já não expõe os "quatro tocheiros de madeira grandes" nem tão pouco existem restos dos "dois pares de cortinas de damasco encarnado já velhas". Do registo da "tribuna, sacrário, banqueta, Cruz Crucifixo" subsiste o sacrário, em forma de pequeno templo adossado ao painel pictórico central. A tribuna, entendida como lugar elevado, também ainda a podemos identificar, como o alto supedâneo em granito decorado com

\footnotetext{
${ }^{19}$ A escultura ornamental do retábulo do altar-mor é, segundo Mourinho, igual à do retábulo do Santíssimo Sacramento da Catedral de Miranda do Douro e possivelmente do mesmo autor, Francisco Lopes Matos, de Viseu. O retábulo foi construído nas últimas décadas do século XVII, o autor das pinturas iconograficamente ricas é ainda desconhecido. Mourinho (Júnior), António Rodrigues, $A$ talha nos concelhos de Miranda do Douro, Mogadouro e Vimioso nos séculos XVII e XVIII, Braga, Associação de Municípios do Planalto Mirandês, 1984, pp. 51, 52.

${ }^{20} \mathrm{Em} 1945$ as telas superiores do retábulo do altar-mor foram restauradas em Lisboa e nunca foram devolvidas (segundo moradores); O altar-mor e pinturas da igreja foram considerados Imóvel de Interesse Público, Decreto n ${ }^{\circ} 40$ 361, DG, 1. ${ }^{a}$ série, n. ${ }^{\circ} 228$ de 20 outubro 1955 / Em vias de classificação (Homologado como IIP - Imóvel de Interesse Público, Despacho de 19 julho 1974 do Secretário de Estado dos Assuntos Culturais e Investigação Científica) (igreja) conforme consta na página: http://www.monumentos.pt/Site/APP PagesUser/SIPA.aspx?id=2692, da Direcção Geral de Património Cultural, do Instituto da Habitação e da Reabilitação Urbana, acedida a 1 de julho de 2015.
} 
enrolamentos e cujas saliências a ambos lados serve de base às esculturas expostas. Relativamente à banqueta enquanto "conjunto de seis castiçais e uma cruz para decoração de um altar ${ }^{21}$ " já não consta atualmente no altar-mor. Quer o dossel quer a lâmpada estão também ambos desaparecidos. A presença do dossel de damasco em conjunto com as cortinas do mesmo material permitem perceber de que forma estaria o interior do templo vestido, sendo que os ornamentos têxteis constituíam uma parte importante da encenação cerimonial.

É estranho não haver qualquer referência no inventário de 1834 aos painéis de pintura que formavam o retábulo, hoje já parcialmente em falta, e que comporiam um importante conjunto pictórico retabular, com cenas da vida de são Francisco.

O registo prossegue com os altares laterais, descritos como:

"Altares Collaterais

Primeiramente, no do lado do Evangelho, hua imagem de Nossa Senhora da Conceição colocada no meio do retablo dourado unido ao mesmo altar que tem hum Crucifixo dois castiçais de madeira; Tres sacras, hua pedra ara, e huas cortinas de damasco encarnado já velhas ${ }^{22}$ ".

Imagem 9

Retábulo maneirista com escultura de Imaculada

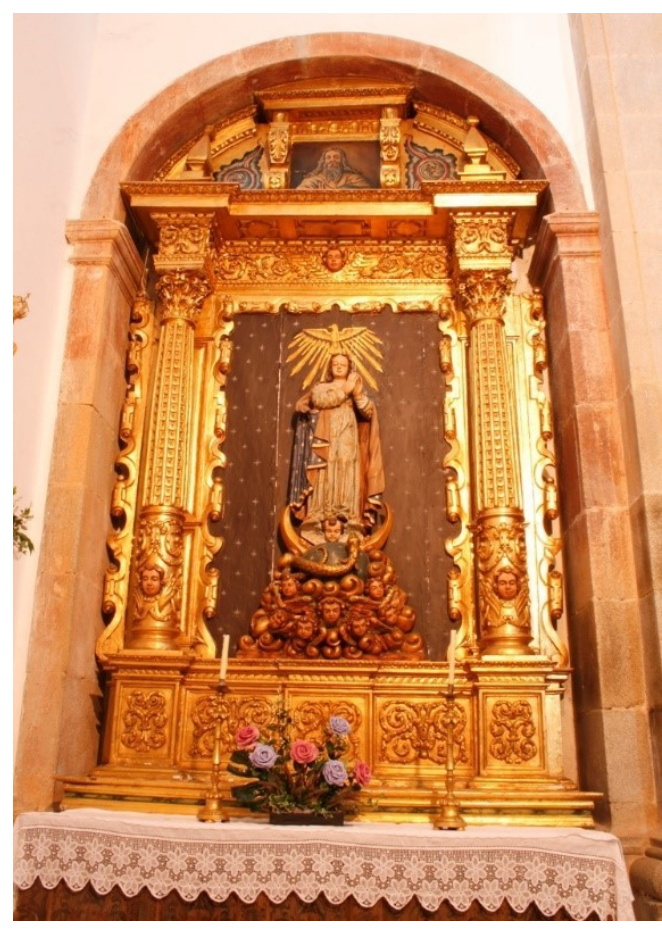

Conceição - transepto do lado do Evangelho

${ }^{21}$ Pais da Silva, Jorge Henrique e Calado, Margarida, Dicionário de termos de arte e arquitectura, Lisboa, Presença, 2005, p. 54.

22 A.N.T.T./A.H.M.F./S.F.M., Extinção das Ordens Religiosas - Convento de São Francisco em Mogadouro, Arquivo Nacional da Torre do Tombo, Lisboa, Arquivo Histórico do Ministério das Finanças, Processos de Extinção das casas religiosas, Cx. 2238, 1834, fl. 4 v. 
O templo tem o transepto ligeiramente diferenciado do corpo da igreja e colocado no lado do Evangelho ainda hoje podemos ver o retábulo com a escultura de Nossa Senhora da Imaculada Conceição, (Imagem 9) adossada ao painel central que lhe serve de fundo. A imagem de Nossa Senhora da Imaculada Conceição parece-nos posterior ao retábulo maneirista ${ }^{23}$ Mantém-se no altar a pedra ara, no entanto, o crucifixo, os castiçais e as sacras estão hoje desaparecidos. As "cortinas de damasco encarnado", que em 1834 já estavam "velhas" estão hoje desaparecidas, mas constituiriam, em conjunto com as "cortinas de damasco branco" que cobriam a oposta imagem de Cristo crucificado, um importante elemento cénico e decorativo do espaço do transepto.

A descrição dos altares continua registando todos os altares que compõem o lado do Evangelho, partindo do transepto para a entrada da igreja (Imagem 10):

"No sigundo altar do mesmo lado achou a Imagem de Nossa Senhora dos Remédios adornada com seu manto de seda matizada, e hua coroa de prata. Mais duas imagens, hua de São José, e outra de São Caetano; mais hum Crucifixo, e quatro castiçais de madeira, três sacras, hua pedra $\operatorname{ara}^{24}$,

Detalhe do documento de inventário dos bens A.N.T.T./A.H.M.F./S.F. M., Extinção das Ordens Religiosas - Convento de São Francisco em Mogadouro, Arquivo Nacional da Torre do Tombo, Lisboa, Arquivo Histórico do Ministério das Finanças, Processos de Extinção das casas religiosas, Cx. 2238, 1834, fl. 5

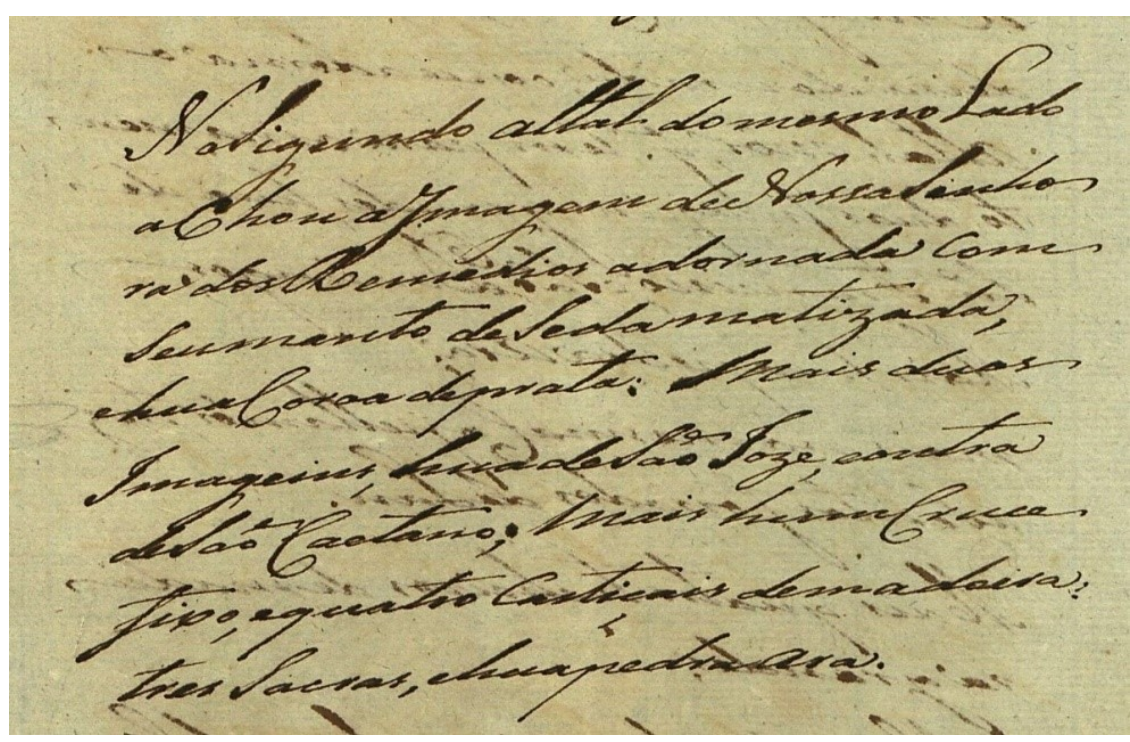

\footnotetext{
${ }^{23}$ Mourinho considera que as imagens são coevas aos retábulos que as expõem e atribui a autoria a António de Oliveira, entalhador da Torre de Moncorvo, autor dos retábulos das relíquias da catedral de Miranda do Douro. Mourinho (Júnior), António Rodrigues, A talha nos concelhos de Miranda do Douro, Mogadouro e Vimioso nos séculos XVII e XVIII, Braga, Associação de Municípios do Planalto Mirandês, 1984, pp. 54, 55.
}

24 A.N.T.T./A.H.M.F./S.F.M., Extinção das Ordens Religiosas - Convento de São Francisco em Mogadouro, Arquivo Nacional da Torre do Tombo, Lisboa, Arquivo Histórico do Ministério das Finanças, Processos de Extinção das casas religiosas, Cx. 2238, 1834, fl. 4 v., 5. 
A disposição atual das imagens, com exceção da capela-mor e dos dois altares do transepto, está bastante alterada. O segundo altar está hoje apenas ocupado por uma imagem de Nossa Senhora, (Imagem 11) é uma imagem de roca, ou de vestir, adornada com o seu manto, que julgamos ser a imagem de "Nossa Senhora dos Remédios adornada com seu manto de seda matizada, e hua coroa de prata" conforme refere o registo de 1834. Ainda hoje a escultura ostenta a "coroa de prata". Mas, a invocação da imagem estava perdida ${ }^{25}$.

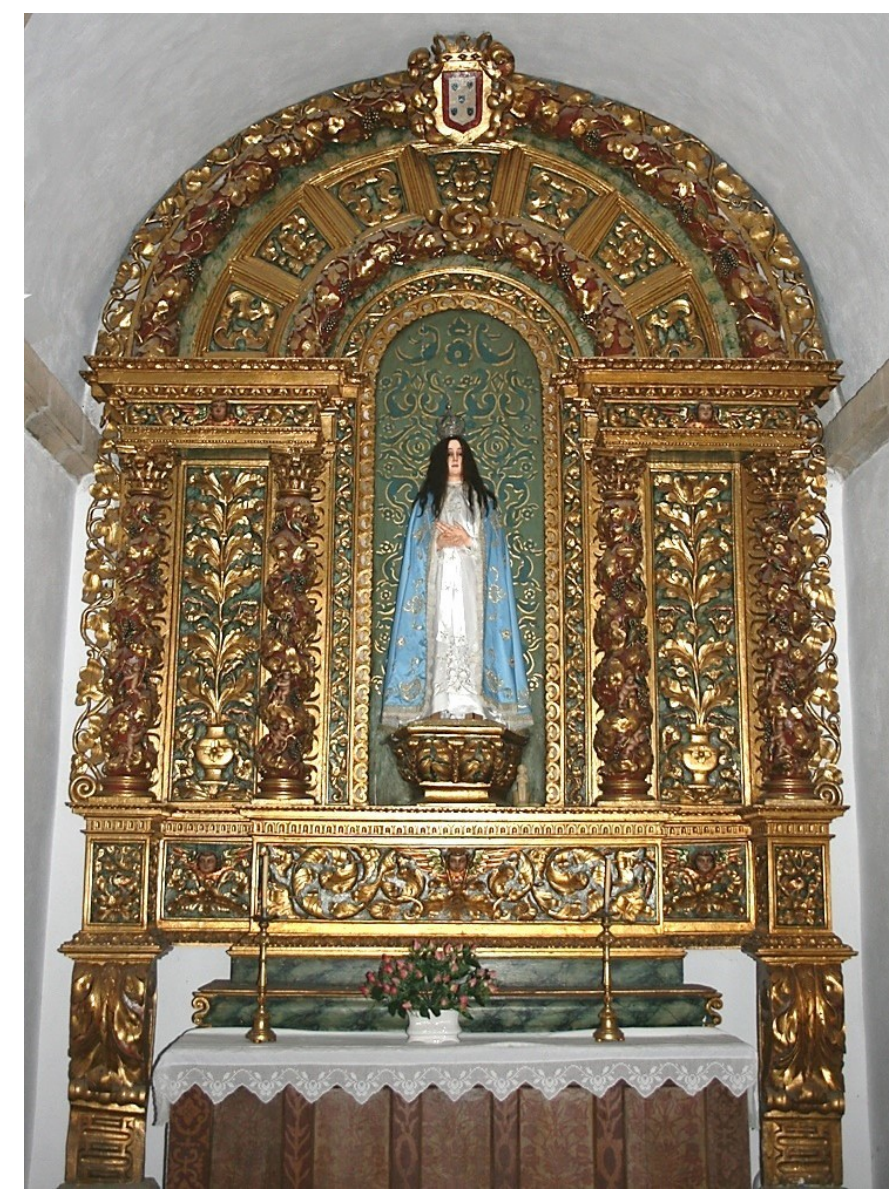

Imagem 11

Retábulo barroco nacional com escultura de roca de Nossa Senhora dos Remédios, segundo altar do lado do Evangelho

Porém, é-nos difícil perceber como seria possível, num retábulo que apenas tem um nicho central, colocar tantas imagens conforme se regista em 1834.

\footnotetext{
${ }^{25}$ O atual pároco responsável pela igreja, Cónego Dino Parra, em Dezembro de 2013, contou a lenda que refere que a imagem terá milagrosamente sustido, sem qualquer apoio, a custódia num dia em que saiu em procissão ostentando a Sagrada Forma. A lenda poderá relacionar a escultura com a invocação de Nossa Senhora dos Remédios. Mourinho refere a mesma lenda Mourinho (Júnior), António Rodrigues, A talha nos concelhos de Miranda do Douro, Mogadouro e Vimioso nos séculos XVII e XVIII, Braga, Associação de Municípios do Planalto Mirandês, 1984, pp. 54, 55, mas relaciona-a com a escultura de Nossa Senhora da Imaculada Conceição, que estando adossada ao retábulo e não sendo de roca seria difícil expô-la em procissão.
} 
A imagem de "São José, e outra de São Caetano" estão atualmente colocadas sobre peanhas em altares no lado da Epístola, são imagens de tamanho idêntico à imagem de roca que ocupa o nicho central, o que levanta questões sobre a disposição não só das imagens, mas, também da organização das estruturas retabulares que as sustinham. Relativamente ao "Crucifixo, e quatro castiçais de madeira, três sacras" já não constam na igreja, onde apenas se mantêm dois castiçais e a "pedra ara".

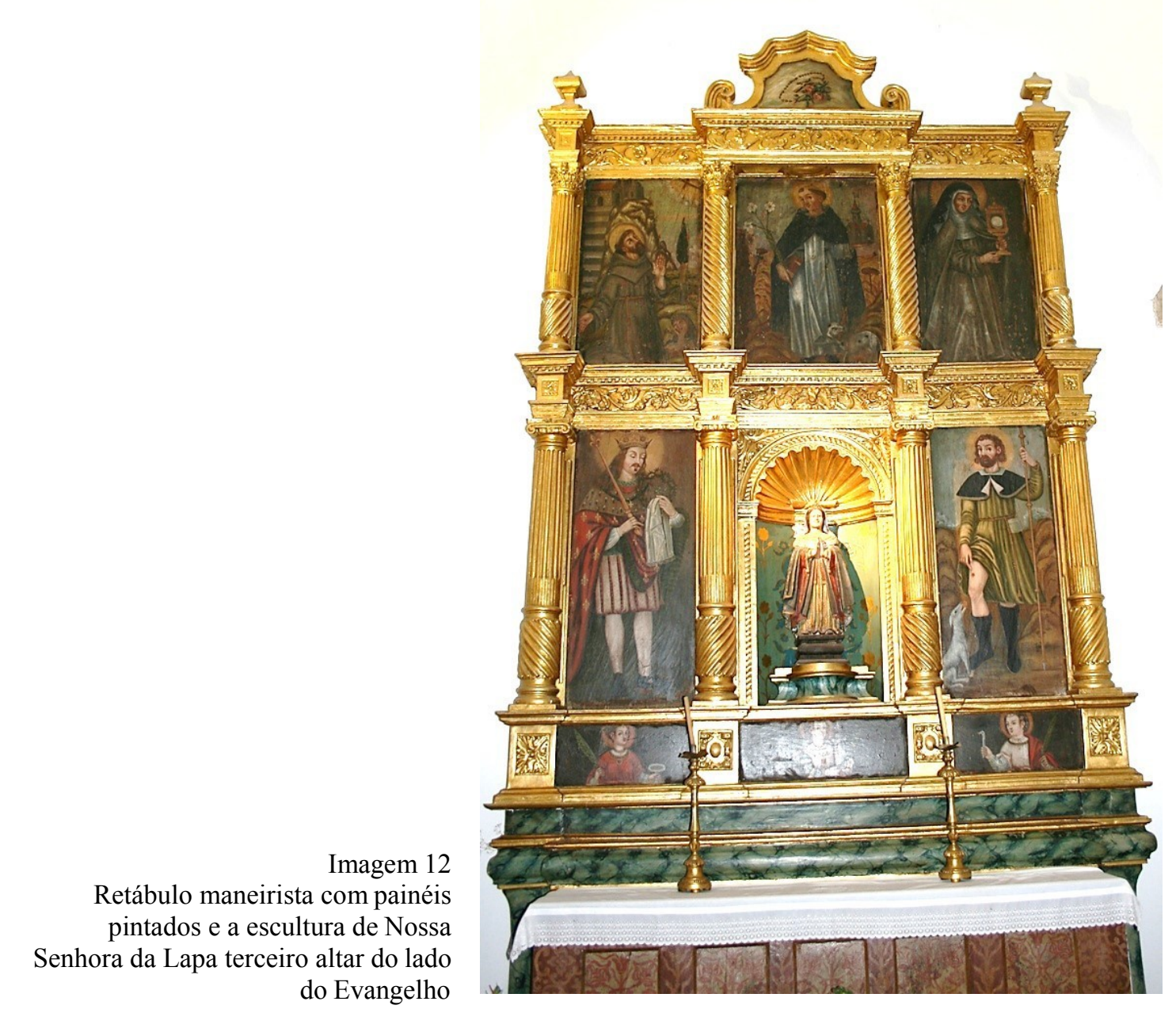

"No terceiro altar que esta unido ao retablo que tem varias imagens debuxadas achou a imagem de Santo António, a Imagem de Nosso / De nosso Senhor Jesus Christo, pedra ara, e dous castiçais de estanho ${ }^{26}$ ".

Também neste altar se recolhem várias alterações comparativamente ao que hoje podemos observar. Refere o documento de 1834 que "esta unido ao retablo que tem varias imagens debuxadas" Atualmente, (Imagem 12) o retábulo ainda está constituído por vários painéis com figuras de santos pintadas. No entanto, nem na pintura nem na

26 A.N.T.T./A.H.M.F./S.F.M., Extinção das Ordens Religiosas - Convento de São Francisco em Mogadouro, Arquivo Nacional da Torre do Tombo, Lisboa, Arquivo Histórico do Ministério das Finanças, Processos de Extinção das casas religiosas, Cx. 2238, 1834, fl. 4 v., 5. 
escultura encontramos hoje as imagens identificadas em 1834 de "Santo António, a Imagem de Nosso / De nosso Senhor Jesus Christo". A "pedra ara" ainda se mantém, bem como os "dous castiçais de estanho".

Atualmente, apenas no nicho central existe espaço para expor esculturas e está ocupado por uma escultura que representa Nossa Senhora. Julgamos que se trata da escultura que se registou em 1834 no altar seguinte como "Nossa Senhora da Lapa". Os motivos hagiológicos dos painéis são relativos a São Francisco, Santo Domingos de Gusmão e Santa Clara no registo superior e São Roque e São Luís no registo que assenta sobre o supedâneo e sob este Santa Luzia, Santa Bárbara e Santa Apolónia27.

Ainda no lado do evangelho já contíguo ao nártex é descrito o último altar desse lado:

"No quarto altar e ultimo do mesmo lado, achou a imagem de Nossa Senhora da Lapa, a de Nosso Senhor Jesus Christo crucificado, e dois castiçais de estanho. ${ }^{28,}$

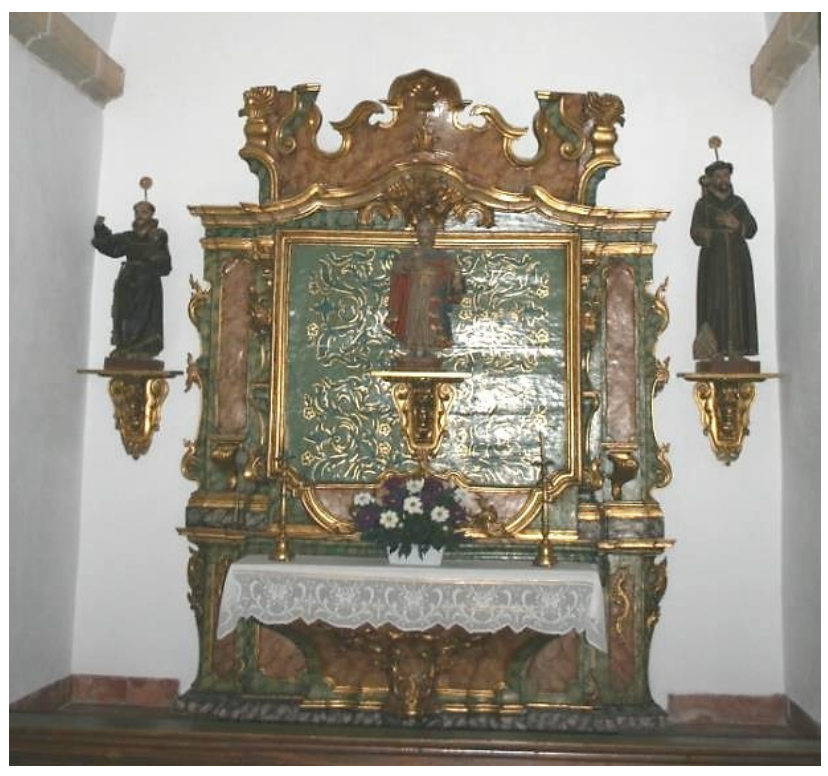

Imagem 13

Retábulo rococó, último altar do lado do Evangelho

\begin{abstract}
${ }^{27}$ Mourinho identifica as figuras no primeiro registo como Santa Luzia, Santa Bárbara e Santa Apolónia; sobre estes painéis estão representadas as figuras de São Francisco de Borja "vestido de conde" e São Roque, e no registo superior, São Francisco, São Domingos e Santa Clara. No nicho central do retábulo refere a escultura de Nossa Senhora do Rosário. Mourinho (Júnior), António Rodrigues, A talha nos concelhos de Miranda do Douro, Mogadouro e Vimioso nos séculos XVII e XVIII, Braga, Associação de Municípios do Planalto Mirandês, 1984, pp. 53, 54. O inventário de 1834 e a iconografia das imagens permitem-nos acrescentar que a imagem identificada por Mourinho como São Francisco de Borja "vestido de conde" será seguramente São Luís, e a escultura no nicho central que Mourinho identifica como Nossa Senhora do Rosário é Nossa Senhora da Lapa.
\end{abstract}

28 A.N.T.T./A.H.M.F./S.F.M., Extinção das Ordens Religiosas - Convento de São Francisco em Mogadouro, Arquivo Nacional da Torre do Tombo, Lisboa, Arquivo Histórico do Ministério das Finanças, Processos de Extinção das casas religiosas, Cx. 2238, 1834, fl. 5. 
Como se pode observar na imagem 13, atualmente o retábulo já não expõe nenhuma das imagens registadas em 1834, de Nossa Senhora da Lapa e Jesus Cristo crucificado. Hoje, no nicho central está a imagem de São Pedro, ladeado à direita por São Pedro de Alcântara e à esquerda por São Bernardino de Siena. A escultura registada como "Nossa Senhora da Lapa" poderá corresponder à imagem de Nossa Senhora exposta contemporaneamente no retábulo anterior, e cuja invocação já se havia perdido.

Se compararmos as medidas do espaço expositivo central dos retábulos são semelhantes, podendo perfeitamente a escultura de Nossa Senhora da Lapa (Imagem 12) já ter estado exposta no altar rococó (Imagem 13) conforme sugere o registo de 1834.

Também já não consta a imagem de "Nosso Senhor Jesus Christo crucificado." Porém, ainda se observam os "dois castiçais de estanho" que aparentemente mantêm a sua localização desde 1834.

O registo prossegue com os altares laterais do lado da Epístola.

"Altares do lado da Epístola

No primeiro altar achou a Imagem de Nosso Senhor Jesus Christo, hua grande, e outra piquena, dois castiçais de madeira, três sacras, hua estante piquena, hua pedra ara, huas cortinhas de damasco branco já velhas, e hum Veo de filo de seda velho que tapava o crucifixo grande ${ }^{29 "}$.

A “Imagem de Nosso Senhor Jesus Christo (...) grande” será com certeza o crucifixo grande que ainda hoje está exposto no transepto, no primeiro altar depois da capela-mor no lado da epístola (Imagem 14). Tal como acontece com o retábulo de Nossa Senhora da Imaculada Conceição, no lado oposto da igreja, também esta imagem está colocada sobre um painel central pintado que lhe serve de fundo, e também neste retábulo observamos detalhes maneiristas nos trabalhos de talha.

O registo de 1834 refere mais outra imagem de "Nosso Senhor Jesus Christo" (...) "piquena" que já não consta atualmente dos objetos de culto expostos. Também as três sacras estão hoje desaparecidas e a "estante piquena". Assim como, as cortinas de damasco branco, e o véu de seda que tapava o crucifixo grande, paramentos já desaparecidos mas que permitem perceber a encenação que era disposta em volta das esculturas, que ora se expunham, ora se resguardavam da exposição pública.

29 A.N.T.T./A.H.M.F./S.F.M., Extinção das Ordens Religiosas - Convento de São Francisco em Mogadouro, Arquivo Nacional da Torre do Tombo, Lisboa, Arquivo Histórico do Ministério das Finanças, Processos de Extinção das casas religiosas, Cx. 2238, 1834, fl. 5. 
Os castiçais de madeira ainda se expõem no retábulo sobre o supedâneo, onde subsiste também a pedra ara.

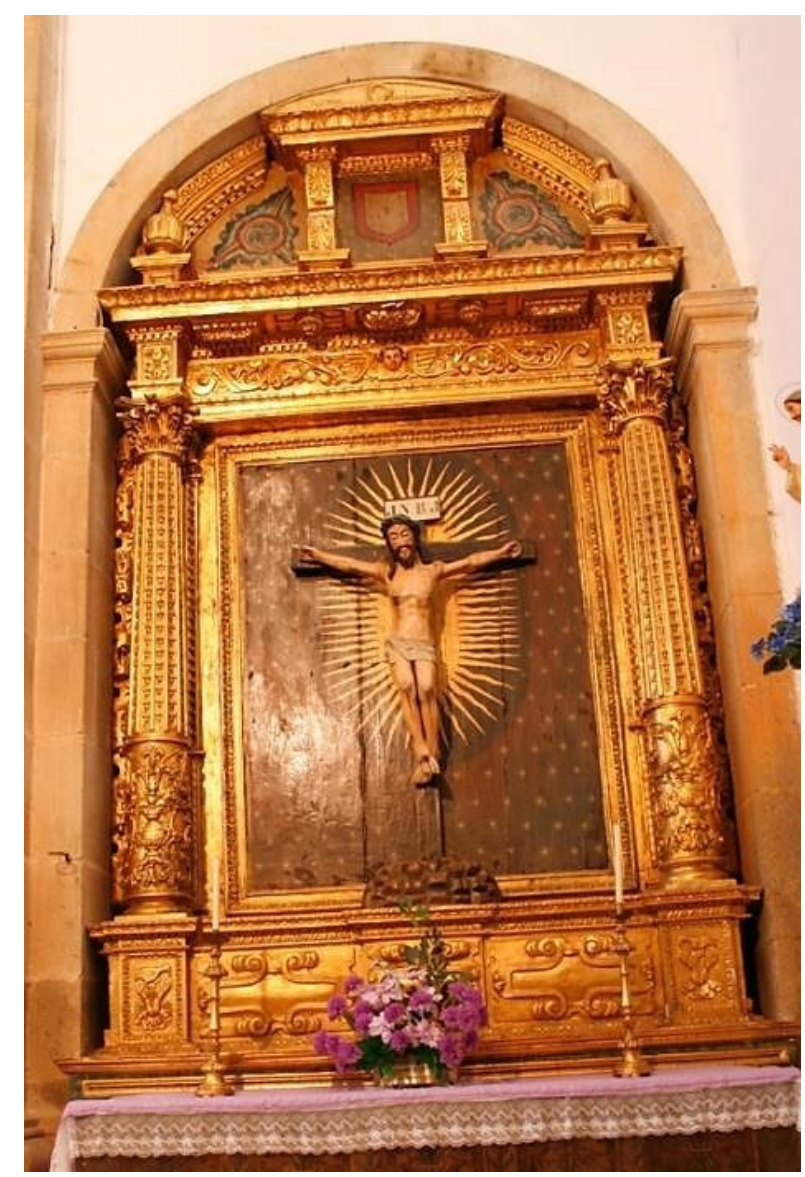

Imagem 14

Retábulo maneirista com escultura de Cristo Crucificado, transepto do lado da Epístola

Após a descrição do retábulo de Cristo, no inventário de 1834 é descrito o retábulo no lado da epístola já no corpo da igreja, que difere nos cultos e no conjunto hagiológico comparativamente ao que hoje podemos observar: "No sigundo, três Imagens, Santa Izabel, São Bernardino, e São Pedro d'Alcantara ${ }^{30}$ ".

A imagem de Santa Isabel, poderá seguramente corresponder à imagem que ainda hoje está colocada no nicho central do retábulo e cuja invocação já se havia perdido.

É uma figura de roca, que está atualmente vestida com traje negro e manto azulescuro, o que poderia levar a pensar tratar-se de Nossa Senhora da Soledade ou de uma invocação relacionada com a Paixão de Cristo, no entanto, o inventário de 1834 não

30 A.N.T.T./A.H.M.F./S.F.M., Extinção das Ordens Religiosas - Convento de São Francisco em Mogadouro, Arquivo Nacional da Torre do Tombo, Lisboa, Arquivo Histórico do Ministério das Finanças, Processos de Extinção das casas religiosas, Cx. 2238, 1834, fl. 5. 
refere nenhuma imagem neste contexto narrativo, o que permite identificar a imagem como Santa Isabel (da Hungria ou de Portugal).

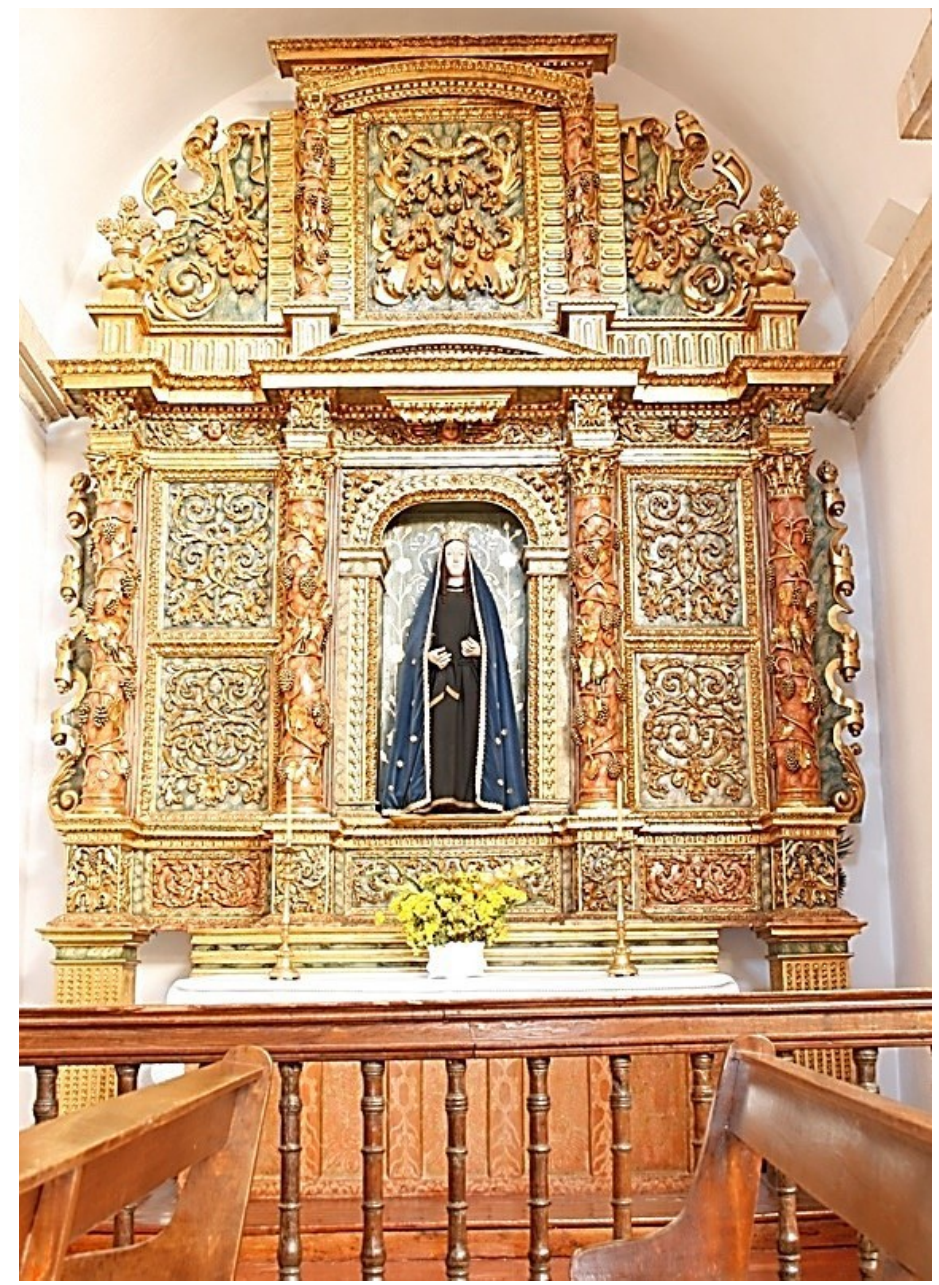

Imagem 15

Retábulo com imagem de Santa Isabel da Hungria \de Portugal (?), no lado da Epístola

Relativamente às esculturas de "São Bernardino, e São Pedro d'Alcantara" estão atualmente colocados no lado do Evangelho, no altar rocaille ladeando em conjunto a escultura de São Pedro.

O retábulo de Santa Isabel expõe apenas uma imagem no nicho central e carece de outros nichos ou suportes que permitam a exposição de duas imagem do tamanho das figuras de "São Bernardino, e São Pedro d'Alcantara" ainda a culto na igreja, o que sugere que o retábulo poderá já terá sido alterado na sua composição desde 1834 até aos nossos dias. 


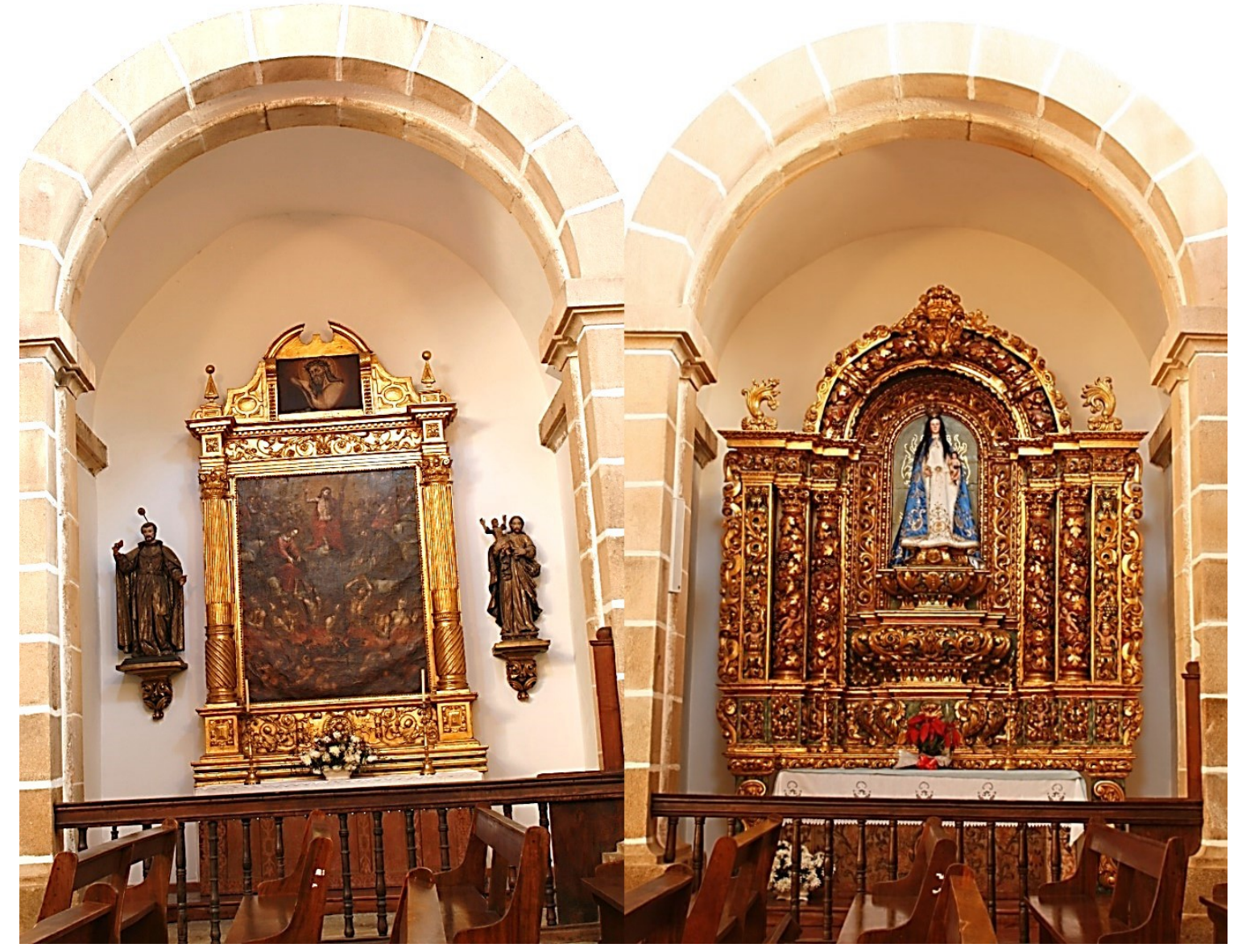

Imagem 16

Imagem 17

Retábulo maneirista com painel pintado "das almas", ladeado pelas imagens de São José com o

Menino e São Caetano, no lado da epístola

Retábulo barroco nacional com escultura de Nossa Senhora do Caminho no lado da epístola

No registo dos retábulos seguintes pode ler-se no inventário dos bens de 1834:

"No terceiro, hum retablo, com seu painel das almas, e hum crucifixo.

No quarto e ultimo; Imagem de São Pedro, e hum crucifixo.

Mais duas alampadas de metal amarello velhas, no corpo da Igreja ${ }^{31}$ ".

O "terceiro" retábulo ainda hoje mantém no painel central a pintura "das almas ${ }^{32}$ " (Imagem 16), mas acrescentaram duas peanhas laterais onde estão expostas as imagens

31 A.N.T.T./A.H.M.F./S.F.M., Extinção das Ordens Religiosas - Convento de São Francisco em Mogadouro, Arquivo Nacional da Torre do Tombo, Lisboa, Arquivo Histórico do Ministério das Finanças, Processos de Extinção das casas religiosas, Cx. 2238, 1834, fl. 5.

32 No painel das Almas está representada a figura de São Francisco de Assis como intercessor no julgamento das almas em conjunto com Nossa Senhora Mourinho (Júnior), António Rodrigues, A talha nos concelhos de Miranda do Douro, Mogadouro e Vimioso nos séculos XVII e XVIII, Braga, Associação de Municípios do Planalto Mirandês, 1984, pp. 56, 57. 
de São José com o Menino e São Caetano ${ }^{33}$ que estariam em 1834 no retábulo de Nossa Senhora dos Remédios.

O último altar estava em 1834 ocupado com a imagem de São Pedro, que atualmente está colocada no altar oposto no lado do evangelho.

A figura de roca que representa Nossa Senhora do Caminho ocupa hoje em exclusividade o último altar (Imagem 17). Trata-se de uma incorporação recente no templo. A escultura de roca sai em procissão durante as festividades de Nossa Senhora do Caminho, padroeira de Mogadouro. Contemporaneamente existe uma nova escultura que representa a mesma invocação e que assegura o culto, guardada na sua própria capela à entrada da vila.

Os crucifixos registados em 1834 quer no altar das almas quer no altar de São Pedro (atualmente de Nossa Senhora do Caminho) estão hoje desaparecidos.

Após o registo das imagens no interior do templo foi descrito o coro e a sacristia ${ }^{34}$. Relativamente ao coro surpreende a ausência de referência ao cadeiral, ainda hoje em uso, e dotado de diversos detalhes decorativos. Foram ainda descritas algumas alfaias litúrgicas, vasos e galhetas e termina a página com o registo de "Mais hum esquife dos mortos em bom uso, mais cinco quadros ${ }^{35}$ ". Os itens de paramentaria foram descritos e organizados por cores, começa o registo com a roupa branca (alvas, toalhas, sobrepelizes, casulas) e termina com a referência a: "Mais hum pallio branco com sua

\footnotetext{
${ }^{33}$ Relativamente à escultura de São Caetano a sua identificação advém do registo de 1834 assim como da análise iconográfica da imagem. Mourinho (Júnior), António Rodrigues, A talha nos concelhos de Miranda do Douro, Mogadouro e Vimioso nos séculos XVII e XVIII, Braga, Associação de Municípios do Planalto Mirandês, 1984, pp. 55, 56, identifica-o como Santo Inácio de Loiola, no entanto não nos parece que se trate dessa invocação, pese embora as semelhanças na indumentária e na iconografia não aparece na documentação qualquer referência a Santo Inácio de Loiola, no entanto São Caetano é referido, reforçando essa invocação.

34 “Coro $\backslash$ Hua estante grande, e outra piquena, com três livros competentes. $\backslash$ Sacristia $\backslash$ Primeiramente hum altar, com hum crucifixo, e pedra ara, dois castiçais de estanho, e hua sacra, \Mais hua banca de castanho em mau uso e piquena, \Mais duas cruzes processionais, hua de pao preto, e outra de metal amarello pratiado" A.N.T.T./A.H.M.F./S.F.M., Extinção das Ordens Religiosas - Convento de São Francisco em Mogadouro, Arquivo Nacional da Torre do Tombo, Lisboa, Arquivo Histórico do Ministério das Finanças, Processos de Extinção das casas religiosas, Cx. 2238, 1834, fl. 5 v.

35 A.N.T.T./A.H.M.F./S.F.M., Extinção das Ordens Religiosas - Convento de São Francisco em Mogadouro, Arquivo Nacional da Torre do Tombo, Lisboa, Arquivo Histórico do Ministério das Finanças, Processos de Extinção das casas religiosas, Cx. 2238, 1834, fl. 5 v.
} 
guarnição de prata uzado ${ }^{36}$. Depois da roupa branca foi inventariada a roupa encarnada, depois a verde, roxa e finalmente a preta, na sua maioria tratavam-se de ternos e casulas.

Após o registo da paramentaria segue-se o registo da prata ${ }^{37}$. Quer o palio branco quer o relicário que guardava o cálice e a custódia estão hoje desaparecidos, reforçando mais uma vez as alterações do cerimonial que foi lentamente abandonando as práticas cénicas que envolviam os objetos têxteis, ou mesmo as maquinetas que supunham uma alteração dinâmica do espaço. Depois da prata foram descritos os objetos em metal ${ }^{38}$.

Com o registo dos metais termina o inventário dos vasos sagrados e objetos de culto, as restantes páginas do documento recolhem os juros afetos aos créditos que o convento disponibilizava ${ }^{39}$.

O registo dos juros pelos créditos concedidos pelo convento é inquestionavelmente o registo que ocupa mais espaço em todo o inventário, preenchendo desde a página 7 até à página 21, envolvendo, pela origem dos devedores, quase todas as freguesias que compreendem ainda atualmente a municipalidade de Mogadouro, com especial incidência para a própria vila de Mogadouro. Surge ainda uma declaração do Morgado de Villadalla relativo a uma paga ao convento de 20 alqueires de trigo com obrigação de dizer, na capela do capítulo, que se acha situada no claustro, 13 missas, uma cantada no dia de Nossa Senhora da Conceição, mais 1000 reis para a fábrica da mesma capela.

36 A.N.T.T./A.H.M.F./S.F.M., Extinção das Ordens Religiosas - Convento de São Francisco em Mogadouro, Arquivo Nacional da Torre do Tombo, Lisboa, Arquivo Histórico do Ministério das Finanças, Processos de Extinção das casas religiosas, Cx. 2238, 1834, fl. 6.

${ }^{37}$ Depois da píxide, cálice foi registado "Mais hum calice que serve na custodia dourado $\backslash$ Mais a capella, ou relicário da custodia que serve no sobredito calice" A.N.T.T./A.H.M.F./S.F.M., Extinção das Ordens Religiosas - Convento de São Francisco em Mogadouro, Arquivo Nacional da Torre do Tombo, Lisboa, Arquivo Histórico do Ministério das Finanças, Processos de Extinção das casas religiosas, Cx. 2238, 1834, fl. $6 \mathrm{v}$.

${ }^{38}$ Além do turíbulo "Mais dois sinos, e hua sineta na torre, e na mesma hum engenho de relógio, velho e desconcertado.। Mais duas sinetas piquenas no interior do convento." A.N.T.T./A.H.M.F./S.F.M., Extinção das Ordens Religiosas - Convento de São Francisco em Mogadouro, Arquivo Nacional da Torre do Tombo, Lisboa, Arquivo Histórico do Ministério das Finanças, Processos de Extinção das casas religiosas, Cx. 2238, 1834, fl. 6 v., 7.

${ }^{39}$ As escrituras dos juros foram organizadas de forma alfabética tendo por referência a origem dos devedores, foi registado também o nome do devedor, o valor da escritura de juro e a data em que deveria ser paga, assim, começa por Azinhoso, Algoso, Azinhozo (de novo), Brunhozo, Figueira, Bruço, Castanheira, Castro Vicente, Figueira, Gebelim, Lagoaça, Linhares, Macedo, Mogadouro (é a origem do número maior de devedores), Miranda, Penas Roias, Pezo, Parada, Paradela, Predo de Bemposta, Quinta da Boca, Quinta das Quebradas, Remondes, S. Antão, Soutello, S. Martinho, Soutello (de novo), Thó, Valdeporco, Vilarinho, Valdemadre, Ventuzelo, Valpereiro, Viduedo, Villadalla, Valverde, Zava.

Após o registo das escrituras de juro foram ainda descritos: a livraria; os móveis de madeira e respectivas avaliações; móveis de barro, ferro e lata, mais roupa e por fim as casas e propriedades que envolviam o convento, com exceção da igreja e sacristia, (a cerca com a vinha, lameiros, palheiros, arvores de fruto, mais lameiros no sitio do Vale de Carviçais e um moinho e várias terras com castanheiros). 
Atualmente o claustro constitui o espaço central dos paços do conselho, função que ocupa hoje o espaço conventual, e já não subsiste nenhuma capela do capítulo no claustro.

Destaca-se no inventário de 1834 a permanência hoje em dia de grande parte da coleção de escultura que então era registada. Com a exceção de duas esculturas, uma que representava Santo António e outra que representava Cristo e quatro Cristos Crucificados (provavelmente cruzes de altar) as maioria imagens escultóricas ainda se encontram ao culto.

No entanto é de referir a alteração dos locais originais de culto das imagens dentro da igreja $^{40}$. Bem como, importa referir também a rutura na memória relativa à identidade de muitas das figuras representadas, que a consulta da documentação dos Processos de Extinção das Casas Religiosas de 1834 permitiu identificar.

\footnotetext{
${ }^{40}$ Neste sentido destacamos que na década de 70 do século XX o templo se encontrava vazio de esculturas, conforme se pode ver nas fotografias da página relativa ao Convento e Igreja de São Francisco / Câmara Municipal de Mogadouro, da plataforma da Direcção Geral de Património Cultural, do Instituto da Habitação e da Reabilitação Urbana, acedida em Maio de 2015: http://www.monumentos.pt/Site/APP_PagesUser/SIPA.aspx?id=2692. Este aspeto permite-nos entender que após 1834 o templo sofreu diversas reformas e alterações o que provocou a alteração dos altares e das devoções que expunham.
} 
FICHAS DE INVENTÁRIO |ESCULTURA

Da Ordem de São Francisco na Diocese de Bragança-Miranda

\section{FICHAS DE INVENTÁRIO}

ESCULTURA

IGREJA DE SÃO FRANCISCO, MOGADOURO 
FICHAS DE INVENTÁRIO | ESCULTURA

Da Ordem de São Francisco na Diocese de Bragança-Miranda 


\section{Igreja de São Francisco, Mogadouro}

Retábulo em talha barroca nacional onde atualmente está colocada a imagem de Nossa Senhora do Caminho (primeira capela, a partir da entrada, do lado do Epístola)

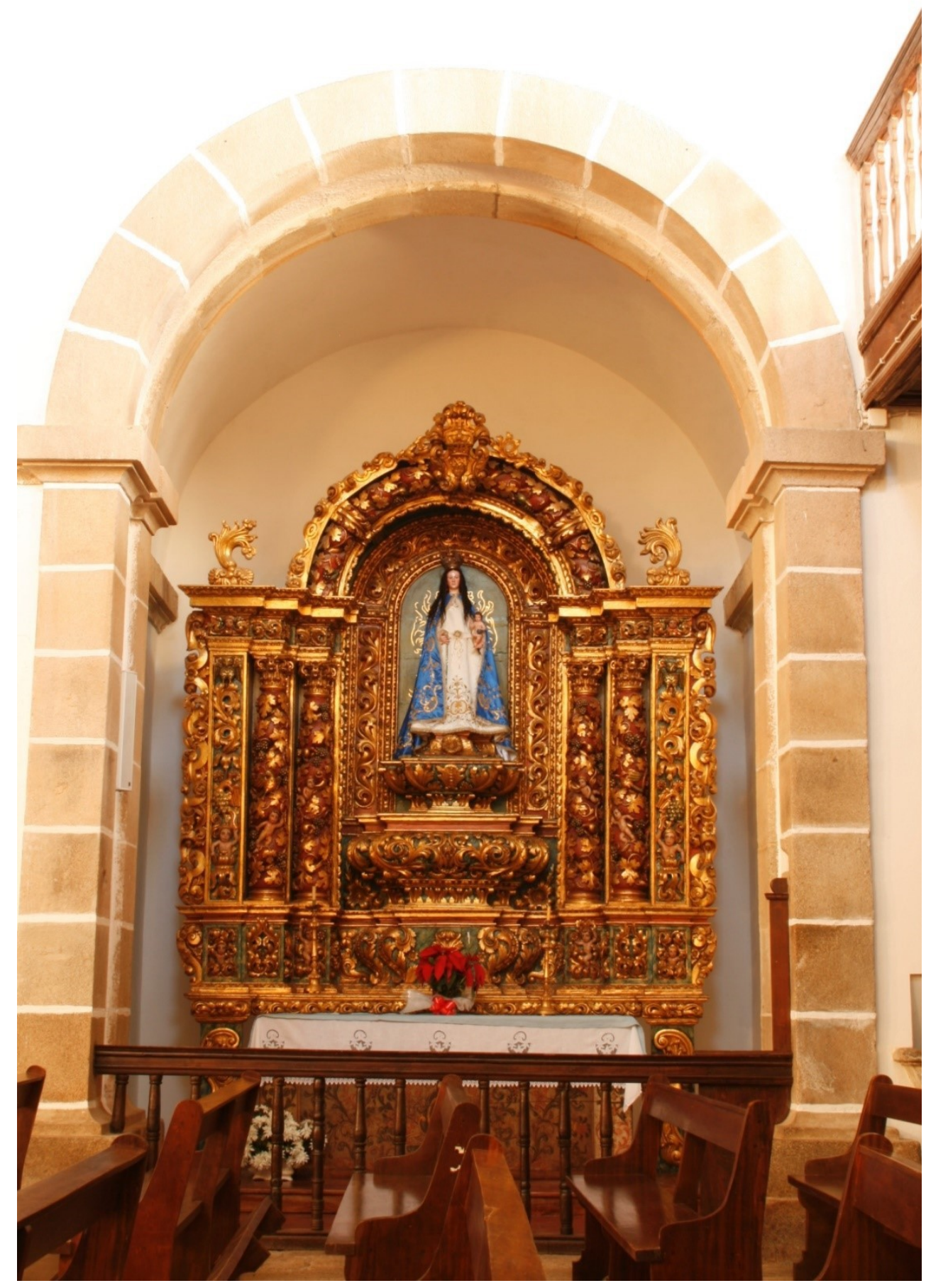


FICHAS DE INVENTÁRIO | ESCULTURA

Da Ordem de São Francisco na Diocese de Bragança-Miranda 


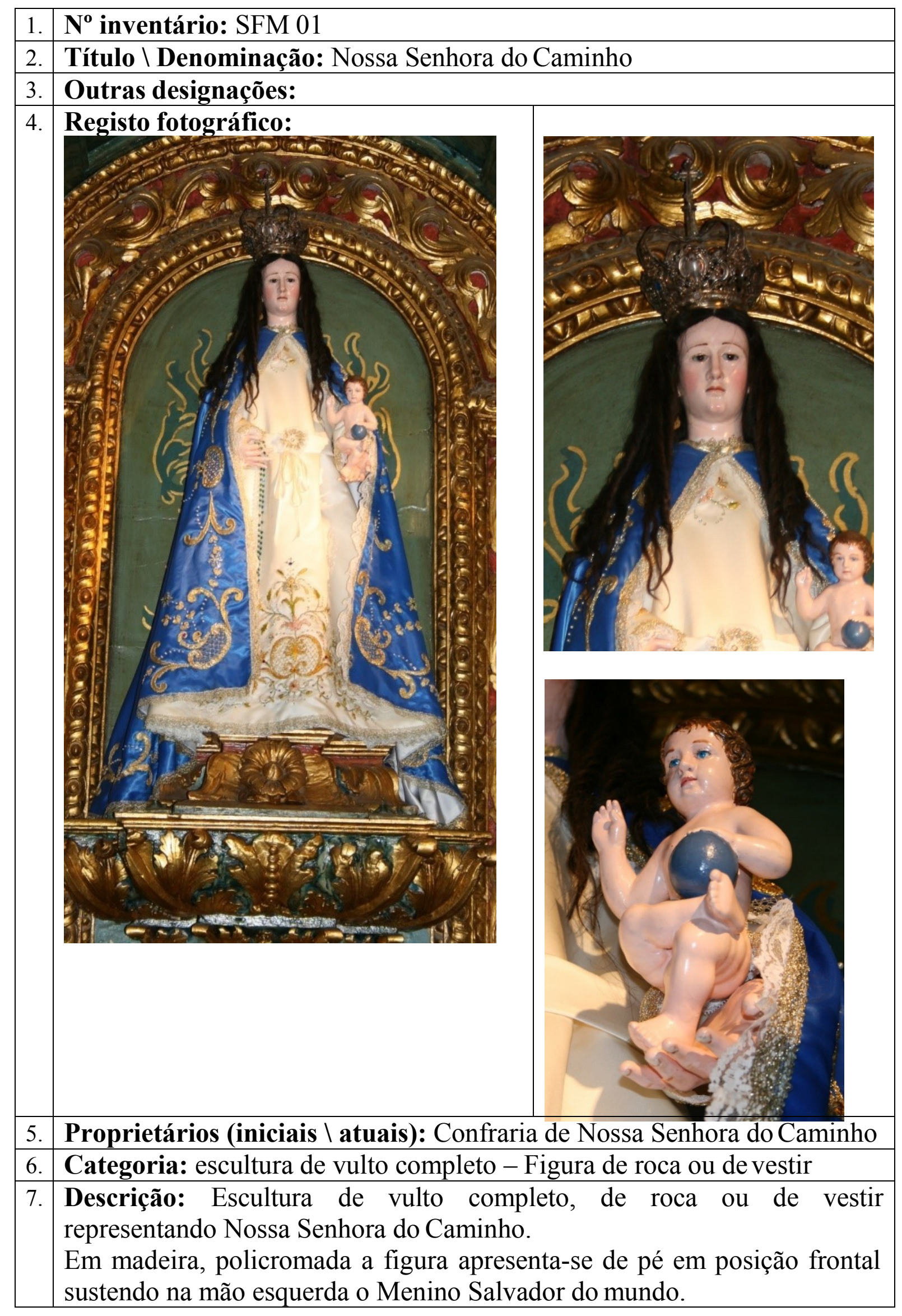




\begin{tabular}{|l|l|}
\hline Apenas a cabeça e os braços se encontram talhados, a restante parte do \\
corpo, do pescoço aos pés, está sumariamente constituído por uma \\
estrutura em madeira que sugere a volumetria do corpo da Virgem de pé, \\
de modo a suster as vestes que a cobrem. \\
O rosto está detalhadamente esculpido, definido por contornos simétricos e \\
delicados que evocam uma expressão grave acentuada pelo olhar baixo \\
com olhos de vidro. Com carnação recente muito brilhante está colorido \\
num tom róseo sobre os pómulos. A cabeça está coberta por uma cabeleira \\
postiça, de cabelo (natural) que cai sobre os ombros e costas em longos \\
cachos de cor castanho-escuro. Ostenta sobre a cabeça uma ornamentada \\
coroa em prata repuxada com quatro braços encimadas por uma cruz. As \\
mãos estão também esculpidas com detalhe, a mão direita está colocada \\
junto ao corpo sobre a cintura e atualmente pende por entre os dedos dois \\
rosários, tem lacuna da ponta de um dedo. A mão esquerda sustem entre os \\
dedos e o punho uma graciosa figura de um Menino Salvador do mundo. \\
O Menino, esculpido com cuidado nos contornos arredondados mas com \\
algumas inconsistências na anatomia, está sentado sobre o punho de Nossa \\
Senhora, com a perna direita descontraidamente cruzada sobre a esquerda, \\
cujo pé assenta entre os dedos da mãe. Segura com a mão esquerda o \\
globo azul, pousado sobre a perna. A mão direita elevada está voltada para \\
o observador em sinal de bênção. O rosto de contornos arredondados tem \\
os olhos de vidro e o cabelo curto esculpido na madeira. A figura do \\
menino apresenta-se sem vestes. \\
A imagem está atualmente coberta com uma túnica branca que a cobre até \\
aos pés cingida na cintura por uma faixa com um rosetão com apliques \\
dourados do qual pende fitas em cetim, a túnica está decorativamente \\
bordada com bordados em relevo dourado sobre o fundo e sobre o peito, o \\
traje é debruado com dourados. Sobre a túnica enverga um manto azul \\
decorativamente bordado a ouro em toda a volta e cingido sobre o \\
pescoço.
\end{tabular}


rostos

15. Datas: século XVIII

16. Proveniência: Capela de Nossa Senhora do Caminho, Mogadouro

17. Autoria: desconhecida

18. Oficina: Local \regional

19. Localização (inicial \atual): Inicialmente a imagem ocupava a capela de Nossa Senhora do Caminho. Atualmente está n

No retábulo Nacional do lado da Epístola sob o primeiro arco depois do coro alto.

20. Histórico do objeto: A imagem de roca é retirada para o Santuário da Nossa Senhora do Caminho durante as festividades; originalmente era levada em procissão.

21. Iconografia: Imagem de Roca; Coroa; Menino salvador do mundo com globo

22. Irmandade: Tem Irmandade porém atualmente pouco ativa (segundo informação do atual pároco cónego Dino Parra)

23. Procissões: Tem procissão e celebrações próprias em devoção de Nossa Senhora do Caminho 
FICHAS DE INVENTÁRIO | ESCULTURA

Da Ordem de São Francisco na Diocese de Bragança-Miranda 


\section{Igreja de São Francisco, Mogadouro}

Retábulo maneirista com pintura representando as Almas do Purgatório, ladeado pelas esculturas SFM 02 e SFM 03 (segunda capela do lado do Epístola)

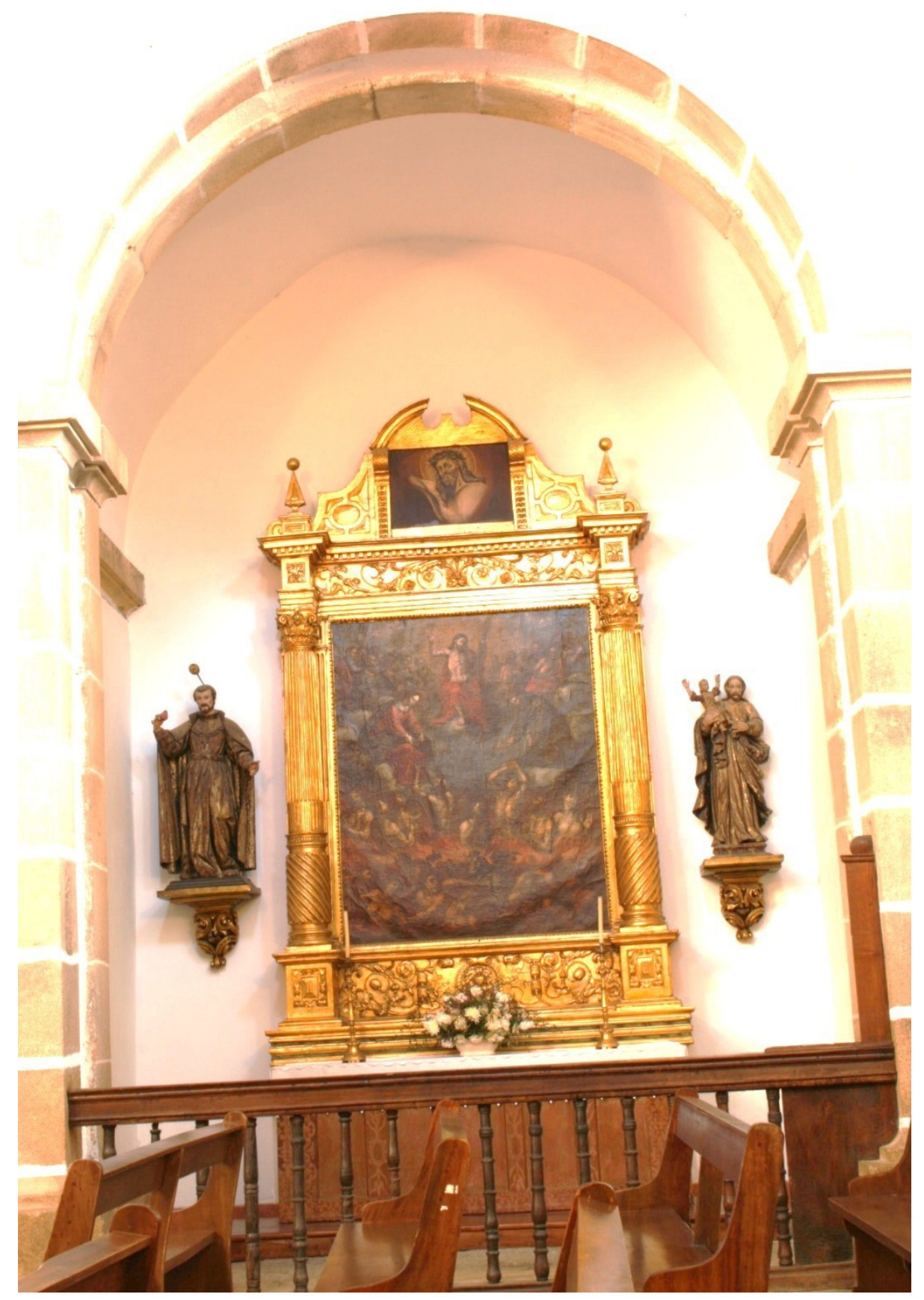


FICHAS DE INVENTÁRIO | ESCULTURA

Da Ordem de São Francisco na Diocese de Bragança-Miranda 


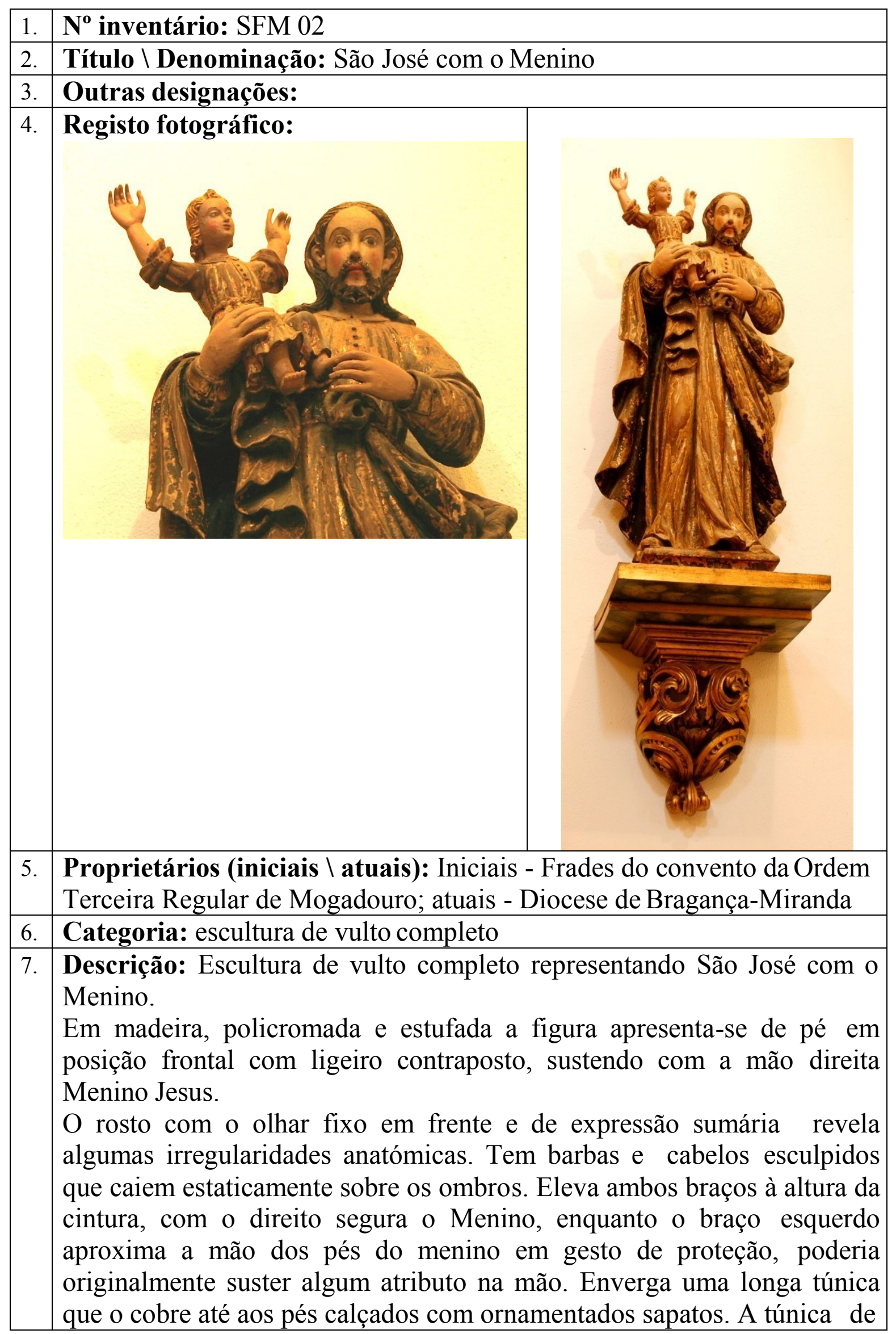




\begin{tabular}{|l|l|}
\hline & $\begin{array}{l}\text { vincos ondulados, com a estufagem dourada e clara policromia já muito } \\
\text { desgastadas, aperta com uma gola sobre o pescoço e com pequenos } \\
\text { botões sobre o peito. Sobre a túnica enverga um longo manto escuro que } \\
\text { o envolve pelas costas e que sustem pelo cordão que o cinge na cintura e } \\
\text { o outro extremo sobre o braço que segura o Menino. O manto envolve-o } \\
\text { em esvoaçantes e amplas vincos que imprimem algum dinamismo à } \\
\text { estaticidade da figura, tal como a túnica o manto também é policromado e } \\
\text { estufado porém encontra-se já muito desgastado. } \\
\text { O Menino destaca-se pela exagerada e pouco natural gestualidade, tem } \\
\text { ambos braços abertos e elevados à altura da cabeça como se sugerisse a } \\
\text { eminência de um amplo abraço. Está sentado sobre o braço de São José e } \\
\text { enverga uma túnica apertada sobre o peito com pequenos botões, as } \\
\text { mangas dobradas deixam os braços descobertos. Revela algumas } \\
\text { irregularidades anatómicas e desproporção dos braços e pernas. A cabeça } \\
\text { tem cabelos loiros esculpidos está ligeiramente voltada para a figura de } \\
\text { São José. A escultura está assente sobre uma base polilobada decorada } \\
\text { com elementos vegetalistas em marmoreado vermelho e castanho. }\end{array}$ \\
\hline 8. & Técnicas (de suporte): Talha \\
\hline 9. & Técnicas (de acabamento): policromia; estufagem \\
\hline 10. & Materiais (de suporte): Madeira \\
\hline 11. & Materiais (de acabamento): pigmentos; ouro \\
\hline 12. & Estado de Conservação: Razoável; apresenta-se estável mas com forte \\
desgaste na policromia e estufagem
\end{tabular}




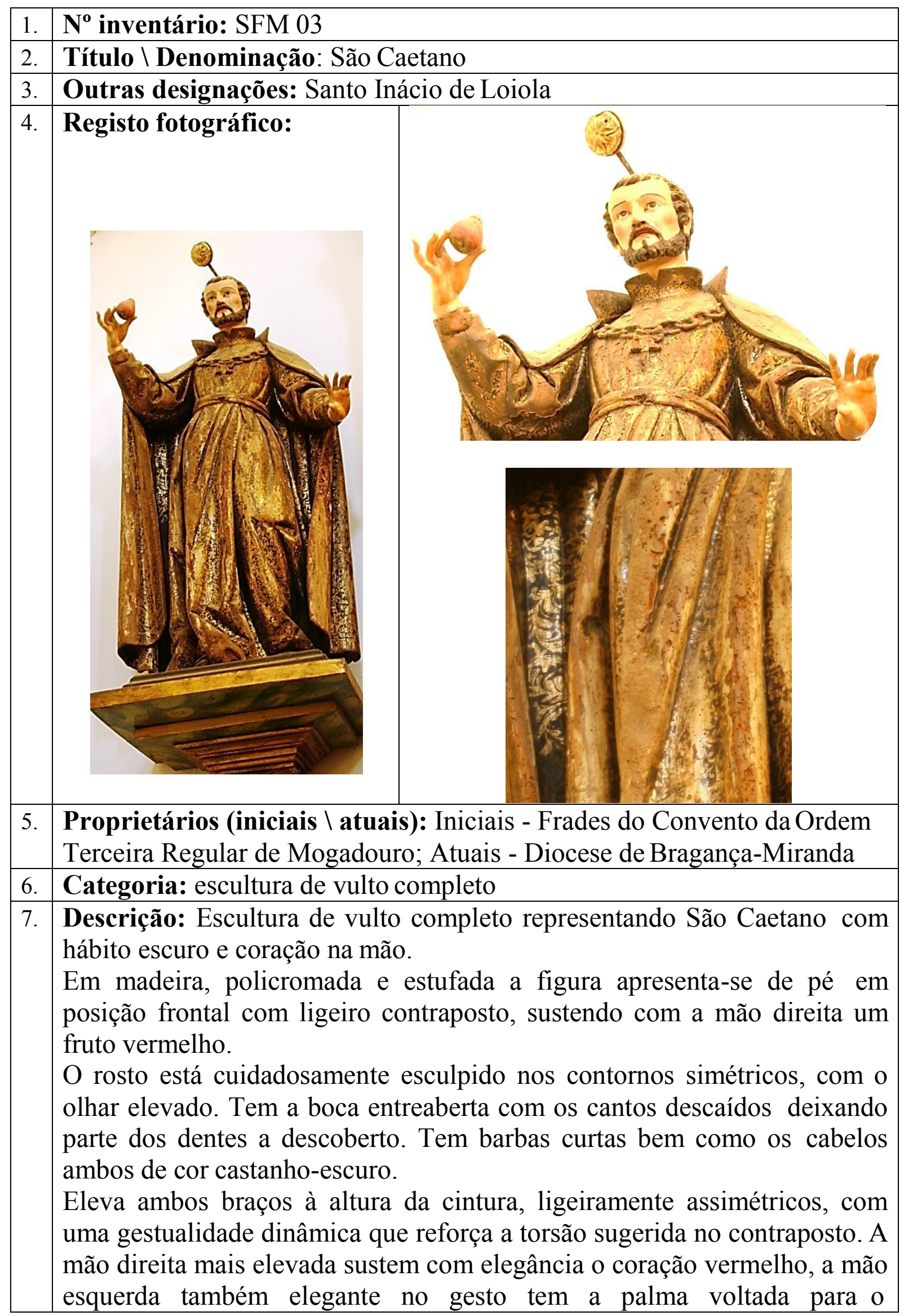




\begin{tabular}{|c|c|}
\hline & $\begin{array}{l}\text { observador. } \\
\text { Enverga uma longa túnica negra amplamente coberta com motivos } \\
\text { vegetalistas estofados que o cobre até aos pés. A túnica de panejamentos } \\
\text { com vincos profundos e ondulados, com a estufagem dourada policromia } \\
\text { já muito desgastadas, aperta com uma gola subida sobre o pescoço. Sobre } \\
\text { a túnica enverga um longo manto com golas subidas apertadas com uma } \\
\text { grossa corrente com um crucifixo esculpida também sobre a madeira. } \\
\text { Sobre a cabeça o Santo ostenta um pequeno resplendor de forma circular } \\
\text { elevado sobre a cabeça com um ornamento vegetalista ao centro em } \\
\text { madeira dourada. } \\
\text { O santo está assente sobre uma base quadrangular com vários registos } \\
\text { visivelmente posterior à data da escultura. }\end{array}$ \\
\hline 8. & Técnicas (de suporte): Talha \\
\hline 9. & Técnicas (de acabamento): policromia; estufagem \\
\hline 10. & Materiais (de suporte): Madeira \\
\hline 11. & Materiais (de acabamento): pigmentos; ouro \\
\hline 12. & $\begin{array}{l}\text { Estado de Conservação: Razoável; apresenta-se estável mas com forte } \\
\text { desgaste na policromia e estufagem; são visíveis marcas de infestação de } \\
\text { inseto xilófago }\end{array}$ \\
\hline 13. & $\begin{array}{l}\text { Dimensões: } \\
\text { Altura: } 130 \mathrm{~cm} \\
\text { Largura: } 70 \mathrm{~cm} \\
\text { Profundidade: } 57 \mathrm{~cm}\end{array}$ \\
\hline 14. & Restauro: apresenta sinais de reintegração cromática na carnação do rosto \\
\hline 15. & Datas: segunda metade do século XVII \\
\hline 16. & Proveniência: igreja de São Francisco Mogadouro \\
\hline 17. & Autoria: desconhecida \\
\hline 18. & Oficina: Castelhana \\
\hline 19. & $\begin{array}{l}\text { Localização (atual): No retábulo maneirista do lado da Epístola sob o } \\
\text { segundo arco depois do coro alto. }\end{array}$ \\
\hline 20. & Histórico do objeto: não se conhecem registos \\
\hline 21. & Iconografia: hábito religioso (Teatinos); Coração \\
\hline 22. & Irmandade: não se conhecem registos \\
\hline & Procissões: não se conhecem registos \\
\hline
\end{tabular}




\section{Igreja de São Francisco, Mogadouro}

Retábulo em talha com elementos maneiristas e barrocos com a escultura de Santa Isabel SFM 04

(Terceira capela do lado do Epístola, antecede o transepto)

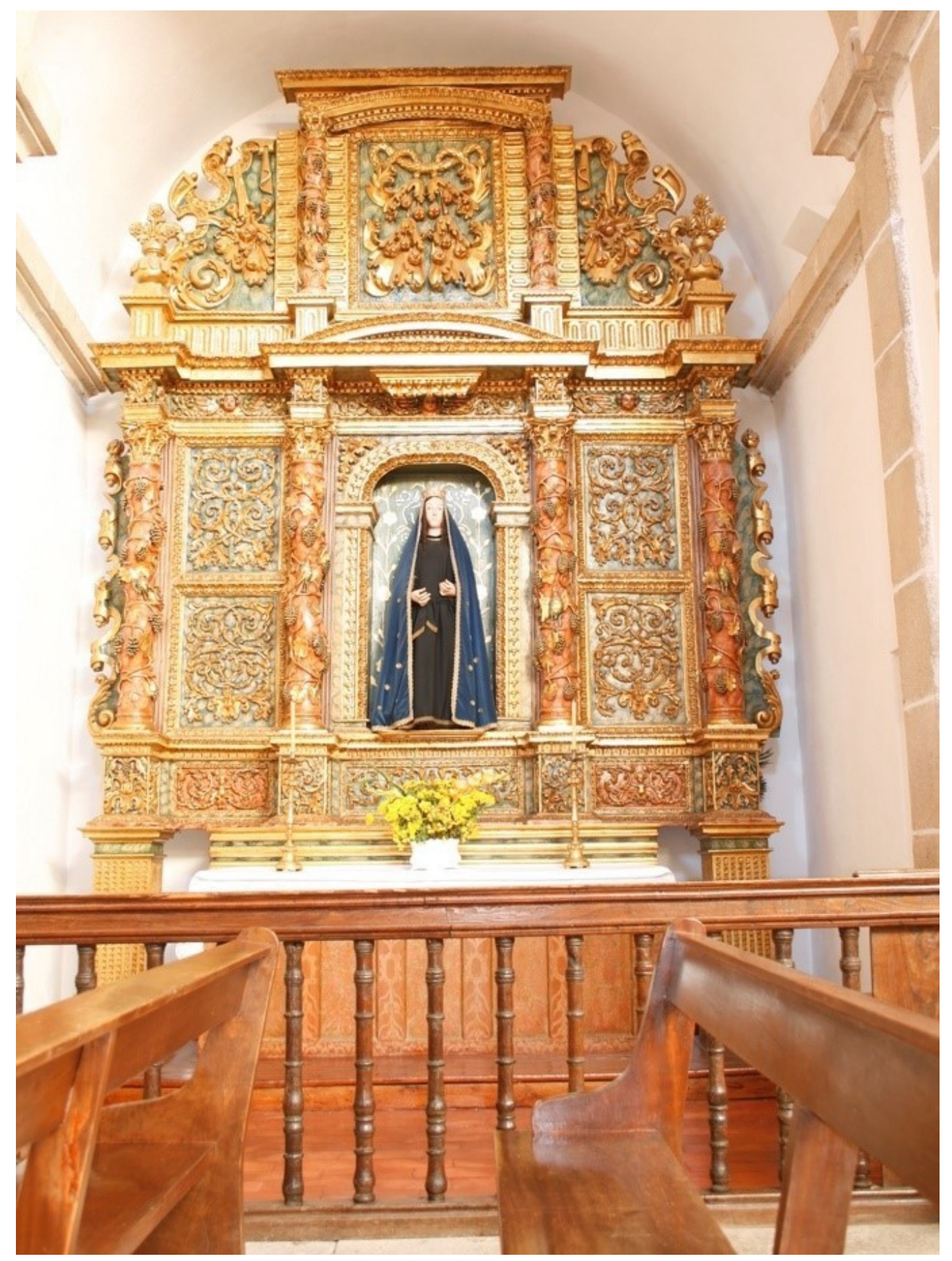


FICHAS DE INVENTÁRIO | ESCULTURA

Da Ordem de São Francisco na Diocese de Bragança-Miranda 


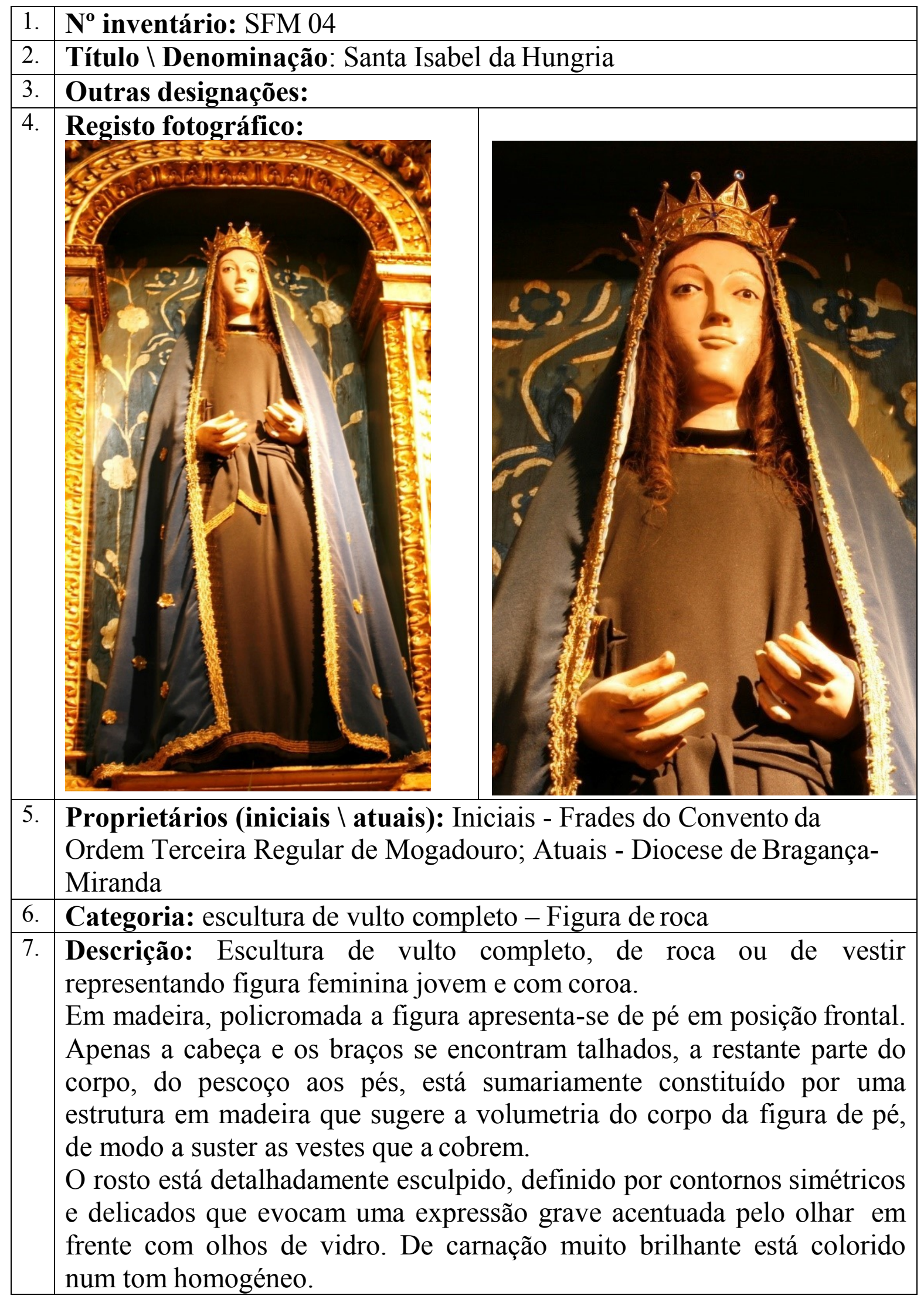




\begin{tabular}{|c|c|}
\hline & $\begin{array}{l}\text { A cabeça está coberta por uma cabeleira postiça, de cabelo (natural) que } \\
\text { cai sobre os ombros e costas em longos cachos de cor castanho-escuro, } \\
\text { parcialmente encobertos pelo manto que cobre a figura. Ostenta uma } \\
\text { coroa em metal dourado decorada com pedrarias e com ornamentos em } \\
\text { filigrana. O manto que a cobre desde a cabeça aos pés é de veludo azul } \\
\text { debruado com passamanarias douradas e com florões dourados sobre os } \\
\text { bordos. Sob o manto enverga uma túnica negra decorada nos bordos por } \\
\text { passamanarias douradas e cingida na cintura com uma faixa negra } \\
\text { decorada com dourados. } \\
\text { As mãos, esculpidas com detalhe estão ambas fletidas e elevadas à altura } \\
\text { da cintura. }\end{array}$ \\
\hline 8. & Técnicas (de suporte): Talha \\
\hline 9. & Técnicas (de acabamento): policromia; tecido; fundição e filigrana \\
\hline 10. & Materiais (de suporte): Madeira \\
\hline 11. & $\begin{array}{l}\text { Materiais (de acabamento): pigmentos; cabelos (naturais); ouro; metal } \\
\text { dourado; pedrarias; vidro }\end{array}$ \\
\hline 12. & Estado de Conservação: Bom; apresenta-se estável \\
\hline 13. & $\begin{array}{l}\text { Dimensões: } \\
\text { Altura: } 130 \mathrm{~cm} \\
\text { Largura: } 50 \mathrm{~cm} \\
\text { Profundidade: } 50 \mathrm{~cm}\end{array}$ \\
\hline 14. & $\begin{array}{l}\text { Restauro: apresenta sinais de reintegração cromática recente sobre o } \\
\text { rosto }\end{array}$ \\
\hline 15. & Datas: segunda metade do século XVIII \\
\hline 16. & Proveniência: igreja de São Francisco Mogadouro \\
\hline 17. & Autoria: desconhecida \\
\hline 18. & Oficina: Local $\backslash$ regional \\
\hline 19. & $\begin{array}{l}\text { Localização (atual): No retábulo do lado da Epístola sob o segundo arco } \\
\text { depois do coro alto. }\end{array}$ \\
\hline 20. & Histórico do objeto: não se conhecem registos \\
\hline 21. & Iconografia: Imagem de roca; coroa \\
\hline 22. & Irmandade: não se conhecem registos \\
\hline 23. & Procissões: não se conhecem registos \\
\hline
\end{tabular}




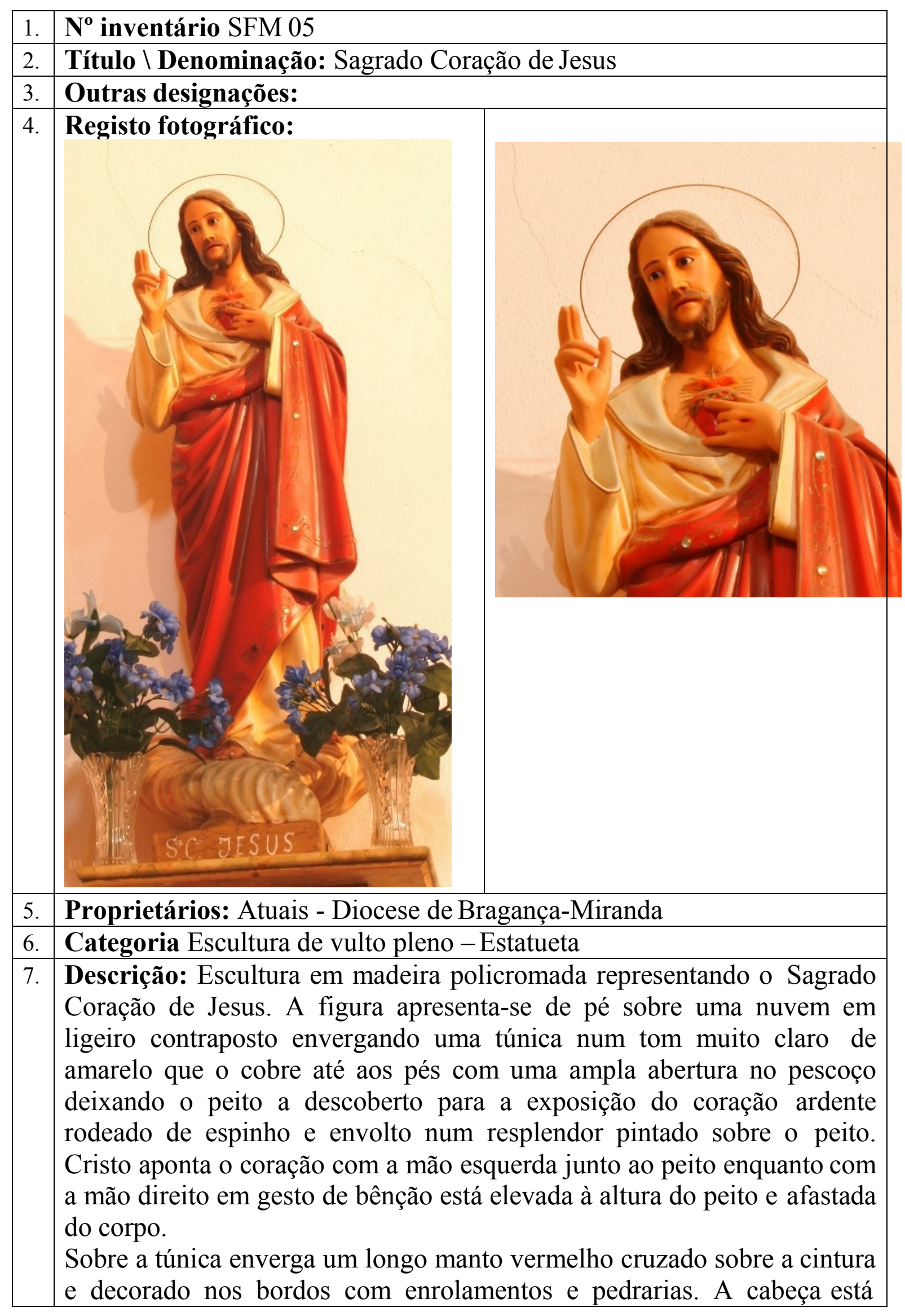




\begin{tabular}{|c|c|}
\hline & $\begin{array}{l}\text { levemente inclinada para o lado direito e o rosto de expressão serena com } \\
\text { olhos de vidro cabelos e barbas bifurcadas e cabelos longos de cor } \\
\text { castanha que caiem em amplas ondas sobre as costas. Sobre a cabeça } \\
\text { ostenta uma auréola de forma circular simples em metal. } \\
\text { A nuvem sobre a qual Cristo está pousado está assente sobre uma base } \\
\text { quadrangular marmoreada em tom amarelo em cuja frente pode ler-se em } \\
\text { letras brancas } S^{\circ} C^{o} J E S U S \text {. }\end{array}$ \\
\hline 8. & Técnicas (de suporte): Talha \\
\hline 9. & Técnicas (de acabamento): Policromia; vidro \\
\hline 10. & Materiais (de suporte): Madeira \\
\hline 11. & Materiais (de acabamento): Pigmentos \\
\hline 12. & Estado de Conservação Bom; apresenta-se estável. \\
\hline 13. & $\begin{array}{l}\text { Dimensões: } \\
\text { Altura: } 100 \mathrm{~cm} \\
\text { Largura: } 40 \mathrm{~cm} \\
\text { Profundidade: } 30 \mathrm{~cm} \\
\end{array}$ \\
\hline 14. & Restauro: não apresenta sinais de intervenção sobre a obra \\
\hline 15. & Datas: século XX \\
\hline 16. & Proveniência: igreja de São Francisco Mogadouro \\
\hline 17. & Autoria: desconhecida \\
\hline 18. & $\begin{array}{l}\text { Oficina: Casa Sagrado Coração de Jesus Porto (conforme placa metálica } \\
\text { colada na base da escultura) }\end{array}$ \\
\hline 19. & Localização (atual): Transepto no lado da Epístola \\
\hline 20. & Histórico do objeto: não se conhecem registos \\
\hline 21. & Iconografia: Coração ardente; espinhos \\
\hline 22. & Irmandade: não se conhecem registos \\
\hline 23. & Procissões: não se conhecem registos \\
\hline
\end{tabular}




\section{Igreja de São Francisco, Mogadouro}

Retábulo maneirista com Escultura de Cristo Crucificado SFM 06 Transepto do lado do Epístola

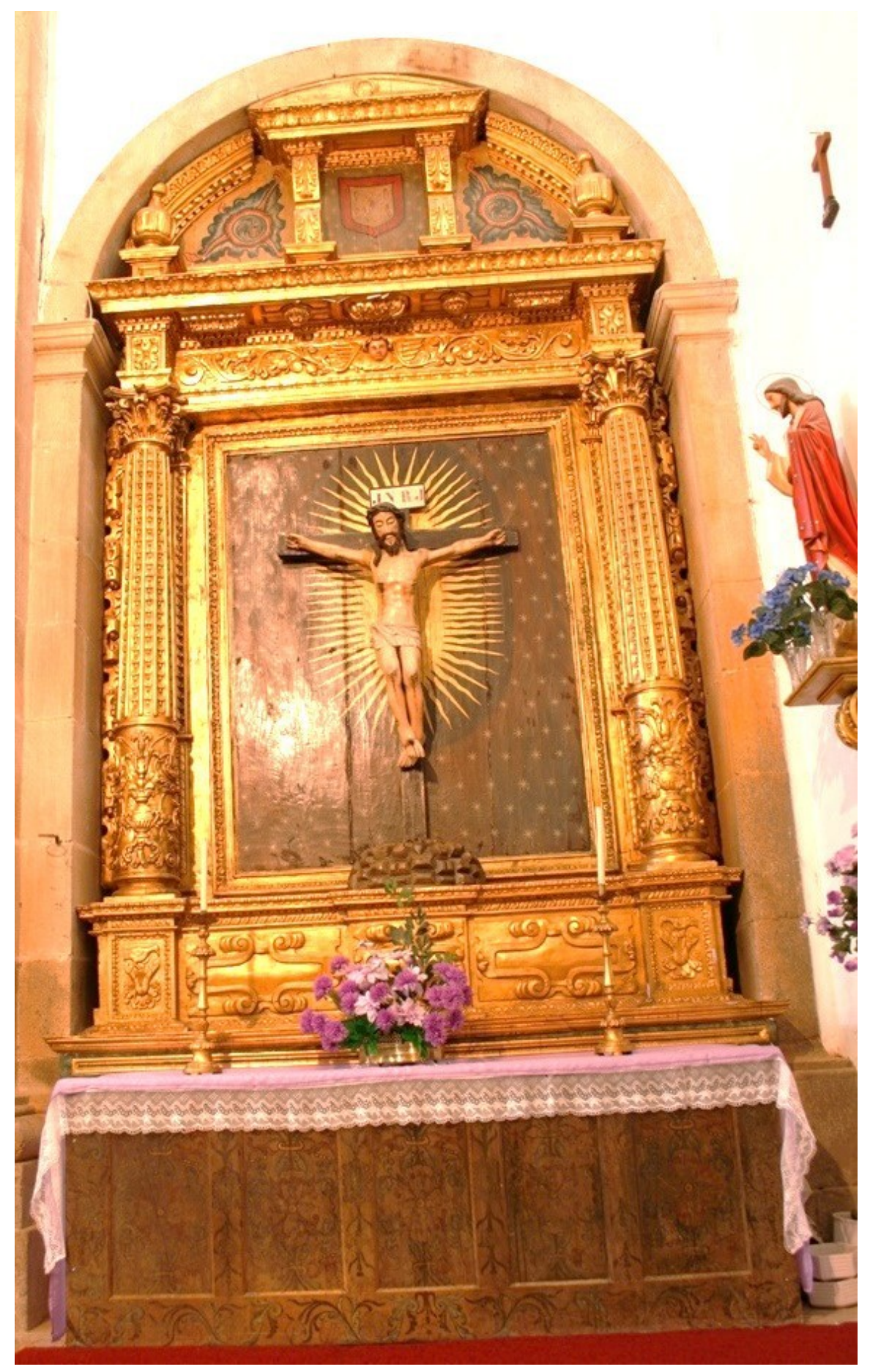


FICHAS DE INVENTÁRIO | ESCULTURA

Da Ordem de São Francisco na Diocese de Bragança-Miranda 


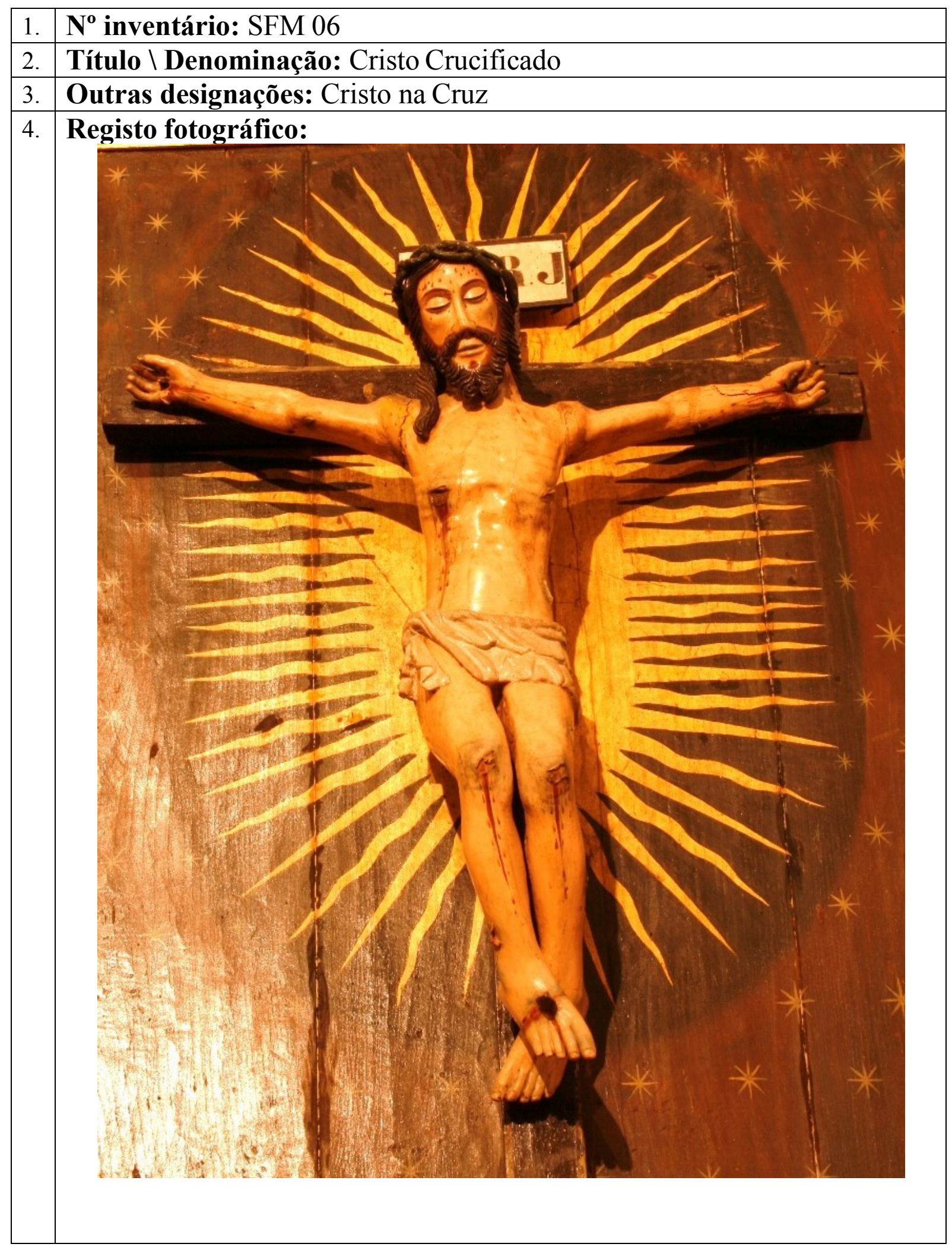




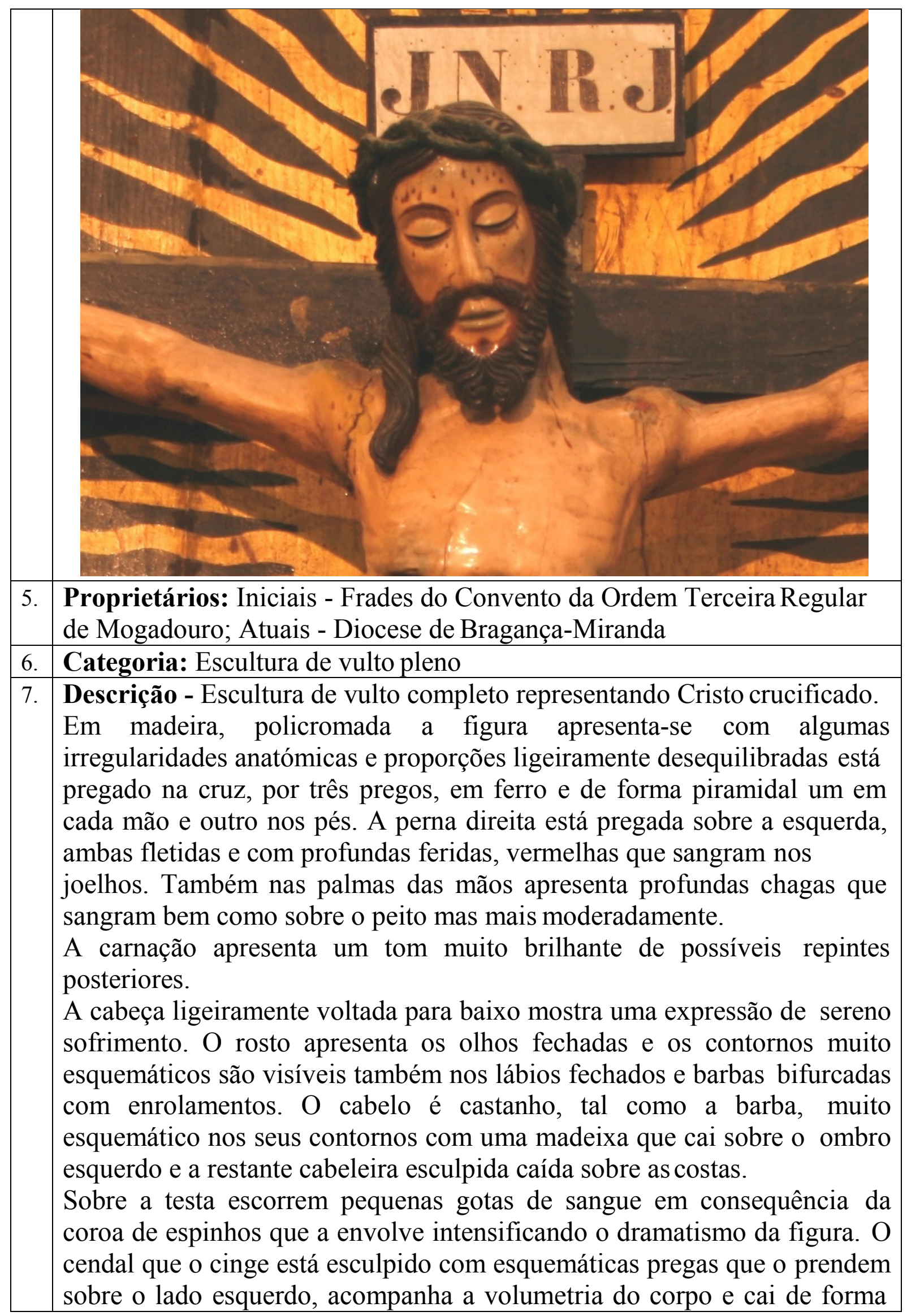




\begin{tabular}{|l|l|}
\hline & $\begin{array}{l}\text { estática. } \\
\text { Na base da cruz está representado com geométricos volumes o rochedo do } \\
\text { gólgota e junto à cruz está depositada a caveira com os dois ossos que a } \\
\text { acompanham. } \\
\text { Sobre o cruzeiro tem uma cartela que encima a cruz, debruada a negro } \\
\text { sobre a qual está incisa a legenda INRI. A cruz simples e de secção } \\
\text { retangular está envolvida num resplendor pintado na tela central do } \\
\text { retábulo que alberga a imagem. }\end{array}$ \\
\hline 8. & Técnicas (de suporte): Talha \\
\hline 9. & Técnicas (de acabamento): Policromia \\
\hline 10. & Materiais (de suporte): Madeira \\
\hline 11. & Materiais (de acabamento): Pigmentos; ferro (pregos) \\
\hline 12. & Estado de Conservação: Bom; apresenta-se se estável; mas com \\
profundas fissuras na policromia no encaixe dos braços com o dorso e \\
sobre o punho esquerdo.
\end{tabular}


FICHAS DE INVENTÁRIO | ESCULTURA

Da Ordem de São Francisco na Diocese de Bragança-Miranda 
Igreja de São Francisco - Mogadouro

Retábulo maneirista com pintura (lacuna de quatro paineis) do altar-more arco triunfal com as armas dos Távoras.

$\mathrm{Na}$ frente do retábulo estão as imagens de São Francisco SFM 07 no lado do Epístola e São Domingos com cão do lado do Evangelho SFM 08

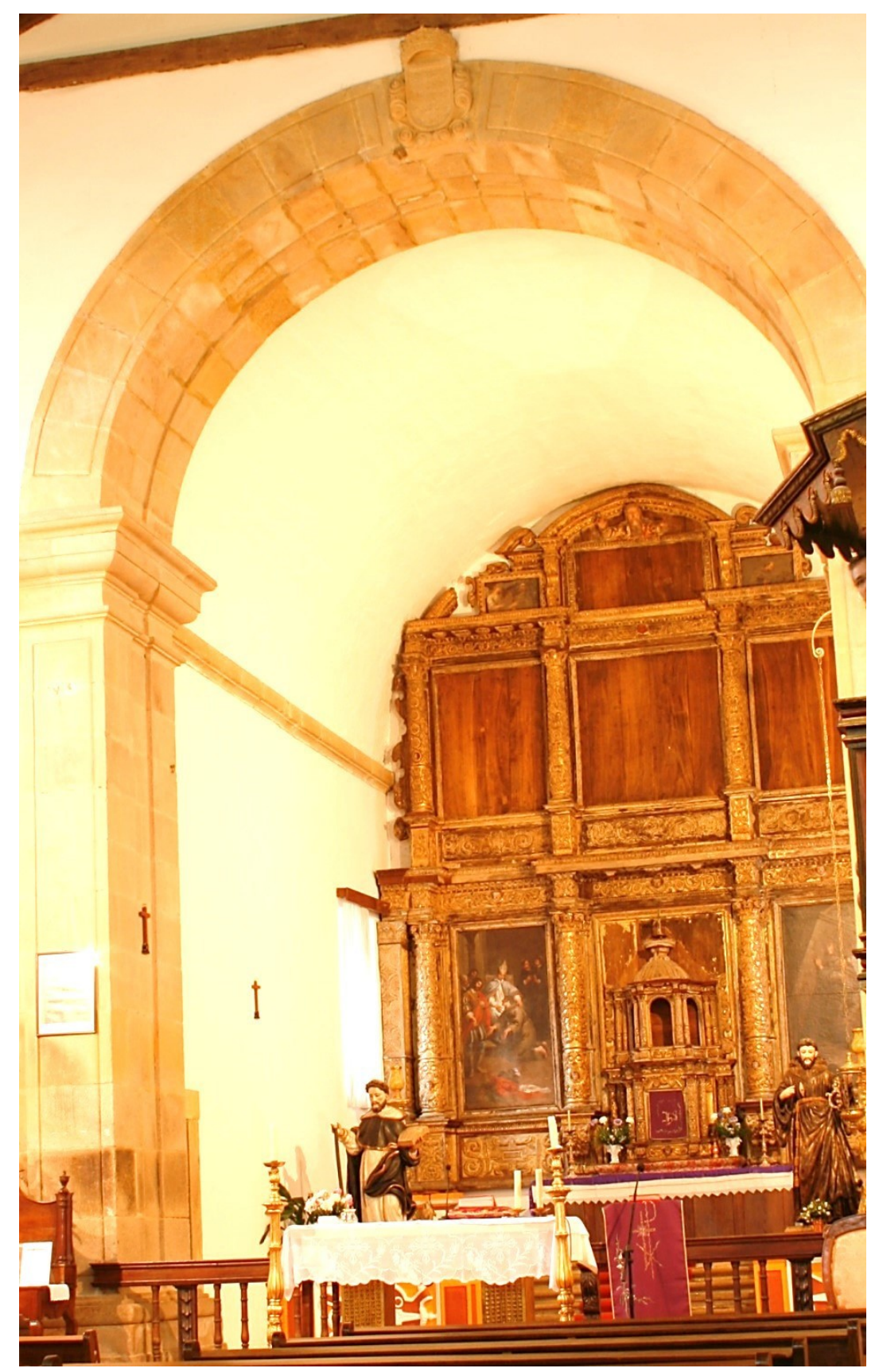


FICHAS DE INVENTÁRIO | ESCULTURA

Da Ordem de São Francisco na Diocese de Bragança-Miranda 


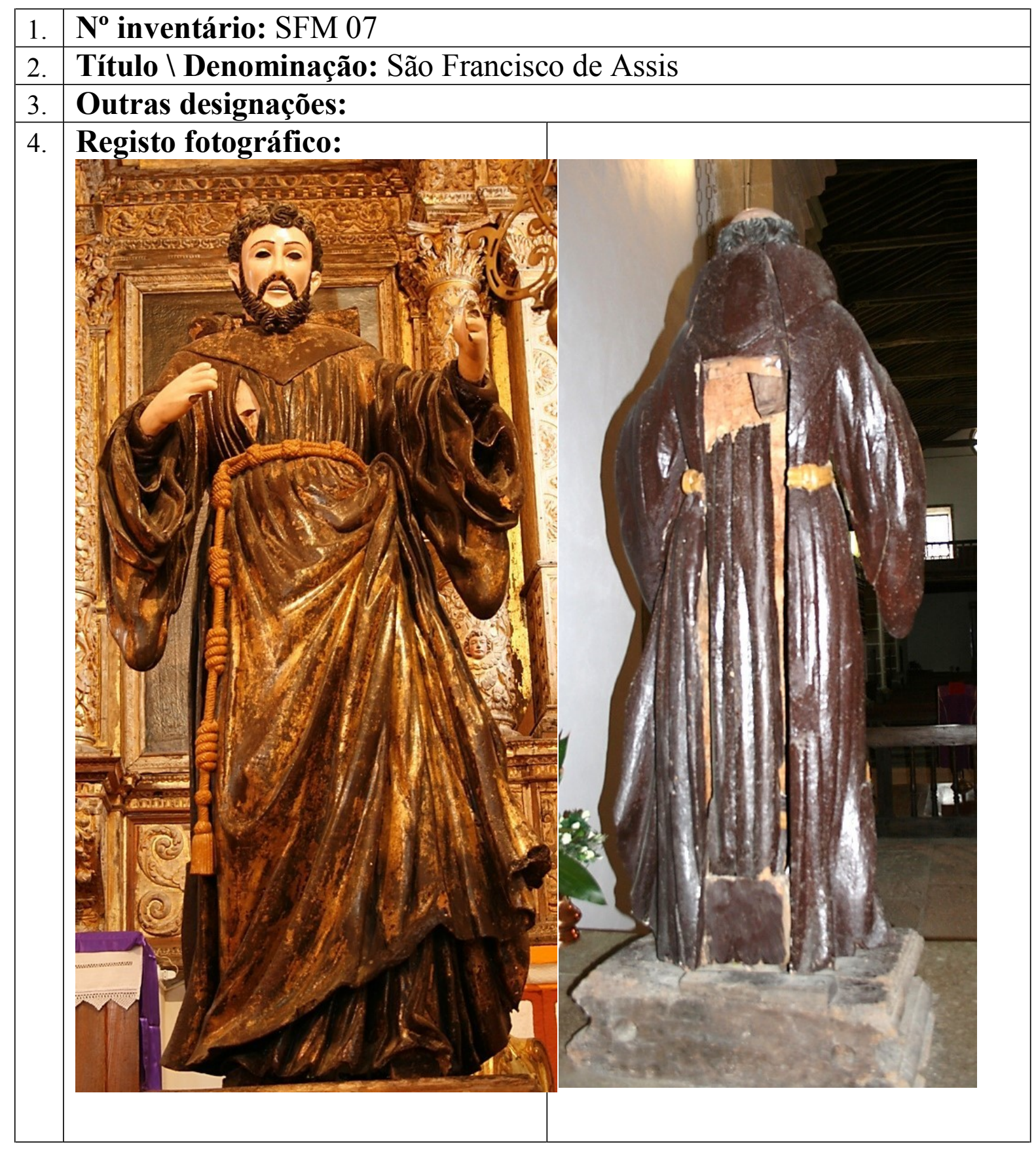




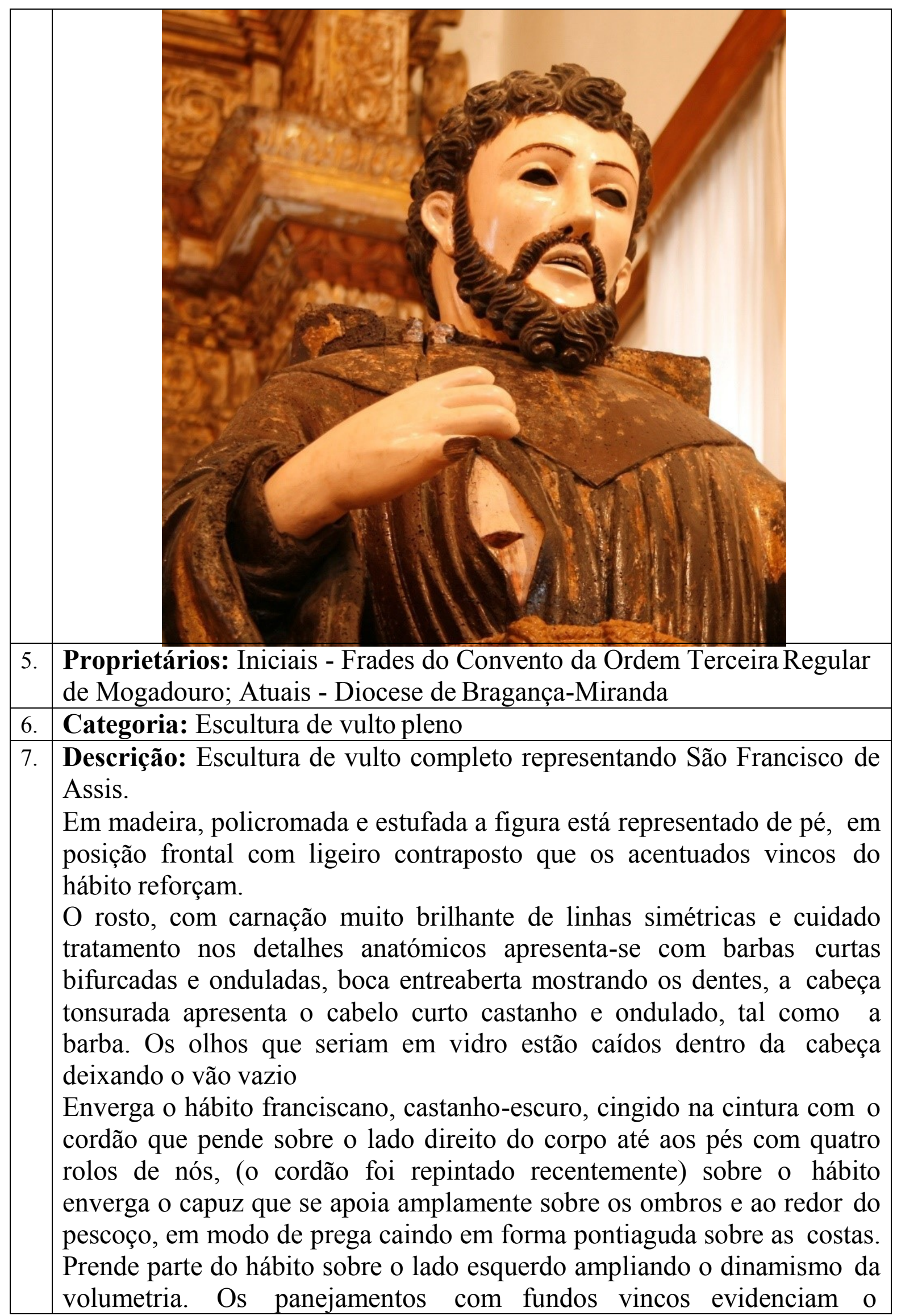




\begin{tabular}{|l|l|}
\hline & $\begin{array}{l}\text { contraposto sugerido pela perna direita que avança ligeiramente. Todo o } \\
\text { hábito está coberto, na parte da frente, por estufado dourado fortemente } \\
\text { desgastado. O hábito está rasgado sobre o peito, no lado direito, deixando } \\
\text { a descoberto a chaga no peito que o Santo expõe. } \\
\text { As mangas do hábito são mais amplas na zona dos cotovelos (como se } \\
\text { observa em várias esculturas de SFV). Os braços abertos e fletidos } \\
\text { assimetricamente mostram ambas mãos abertas com lacuna da ponta de } \\
\text { todos os dedos e pela ausência dos estigmas possivelmente não serão as } \\
\text { mãos originais. Toda a escultura sofreu já vários repintes e nas costas o } \\
\text { vão aberto apresenta parte da tampa em muito mau estado de } \\
\text { conservação. } \\
\text { A figura está assente sobre uma plataforma retangular com vários registos } \\
\text { decorados com marmoreado já muito desgastado. } \\
\text { A Escultura São Francisco de Assis está atualmente colocada na capela- } \\
\text { mor em conjunto com a imagem de Santo Domingos de Gusmão. As } \\
\text { semelhanças entre ambos são poucas, apenas a escala é semelhante. }\end{array}$ \\
\hline 8. & Técnicas (de suporte): Talha \\
\hline 9. & Técnicas (de acabamento): Policromia; estufagem; marmoreado \\
\hline 10. & Materiais (de suporte): Madeira \\
\hline 11. & Materiais (de acabamento): Pigmentos; folha de ouro \\
\hline 12. & $\begin{array}{l}\text { Estado de Conservação: Razoável; apresenta-se se estável; lacunas nas } \\
\text { pontas dos dedos e pés, na cobertura da cavidade das costas e marcas de } \\
\text { infestação de xilófago um pouco por toda a obra. }\end{array}$ \\
\hline 13. & Dimensões: \\
Altura: 195 cm \\
Largura: 86 cm \\
Profundidade: 55 cm
\end{tabular}


FICHAS DE INVENTÁRIO | ESCULTURA

Da Ordem de São Francisco na Diocese de Bragança-Miranda 


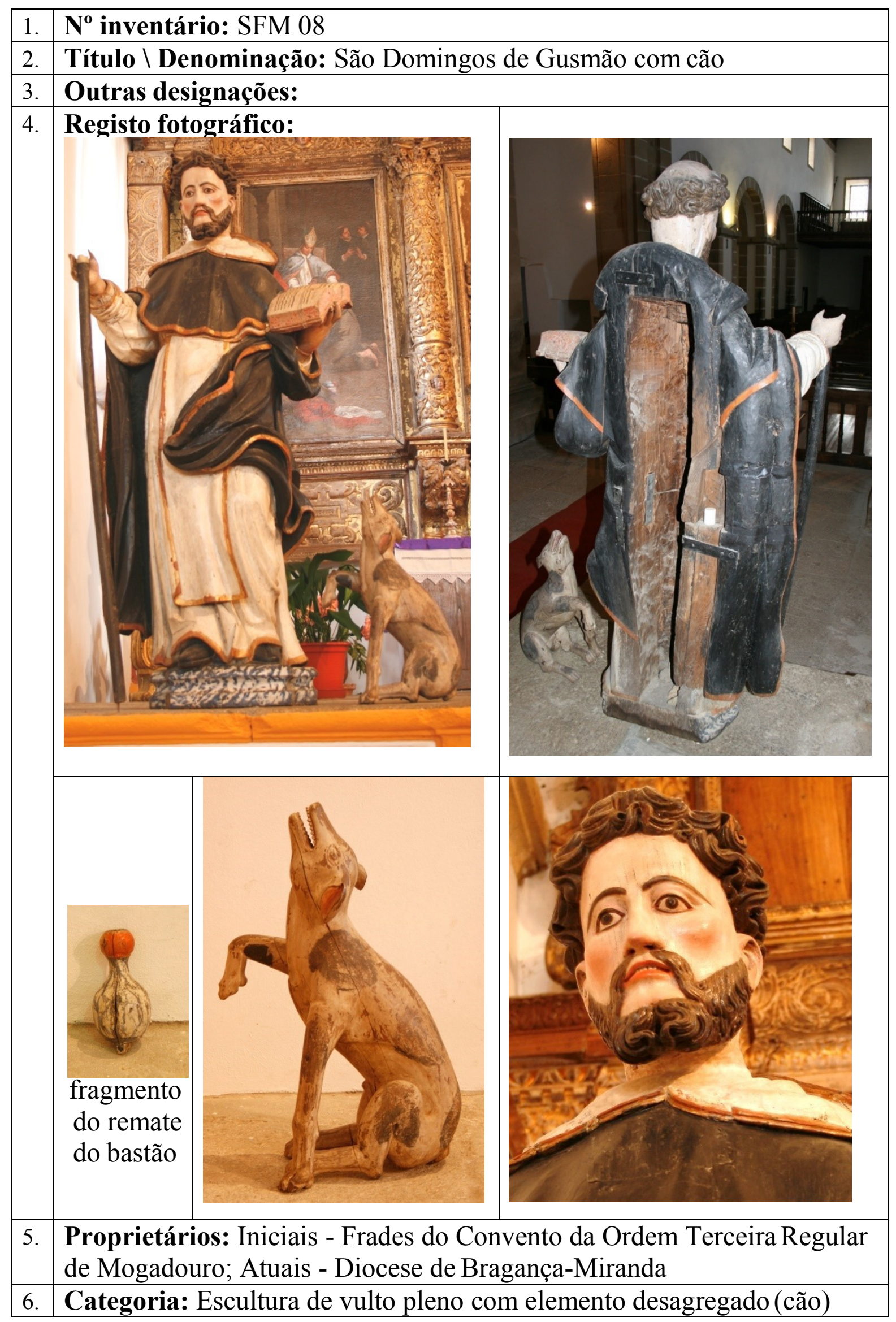


7. Descrição: Escultura de vulto em madeira policromada representando São Domingos com uma figura de um cão.

A figura está de pé, em contraposto sugerido pela perna esquerda ligeiramente mais fletida e com um cão sentado ao lado esquerdo, porém desagregado já fora da plataforma que suporta a figura do santo. Enverga o hábito dominicano com um grosso e dinâmico pregueado nos panejamentos da capa negra com capuz que o cobre sobre os ombros até aos pés com um volumoso vinco sobre o lado esquerdo. Sob a capa enverga uma túnica branca, ambas debruadas com um filete em ouro sobre os bordos.

O hábito está mais trabalhado na frente a parte posterior está mais sumariamente policromada, sendo que tem já lacuna da tampa que esconde o vão.

Flete e eleva ambos os braços à altura do peito, o braço direito tem lacuna de todos os dedos e sustém um bordão também já com lacuna do remate superior (de forma elíptica) que está guardado no interior oco da figura. A mão e o braço esquerdo, com a com várias fissuras, segura um livro aberto com decorativas manchas vermelhas nas lombadas.

$\mathrm{O}$ santo tonsurado apresenta uma expressão grave tem a boca entreaberta com os cantos descaídos deixando a descoberto parte dos dentes. $\mathrm{O}$ rosto, simétrico, com barbas encaracoladas e bifurcadas tem os olhos pintadas.

Do lado esquerdo acompanha-o um pequeno cão branco e negro que está sentado com a pata direita erguida e volta a cabeça para o santo.

A figura do santo está assente sobre uma base polilobada com marmoreado azul.

A Escultura São Domingos de Gusmão está atualmente colocada na capela-mor em conjunto com a imagem de São Francisco de Assis. As semelhanças entre ambos são poucas, apenas a escala é semelhante, o tratamento dado aos detalhes é mais sumário na escultura de $\mathrm{S}$. Domingos.

8. Técnicas (de suporte): Talha

9. Técnicas (de acabamento): Policromia; dourado; marmoreado

10. Materiais (de suporte): Madeira

11. Materiais (de acabamento): Pigmentos; folha de ouro

12. Estado de Conservação: Razoável; apresenta-se se estável; lacunas nas pontas dos dedos da mão direita e fissuras profundas na mão esquerda; lacuna da tampa do vão na parte posterior e fratura do remate do bordão.

13. Dimensões: (da figura de São Domingos)

Altura: $183 \mathrm{~cm}$

Dimensões: (do cão)

Altura: $63 \mathrm{~cm}$

Largura: $91 \mathrm{~cm}$

Largura: $25 \mathrm{~cm}$

Profundidade: $43 \mathrm{~cm}$ 


\begin{tabular}{|r|l|}
\hline & Profundidade: $55 \mathrm{~cm}$ \\
\hline 14. & $\begin{array}{l}\text { Restauro: apresenta sinais de reintegração cromática na carnação do } \\
\text { rosto }\end{array}$ \\
\hline 15. & Datas: segunda metade do século XVIII \\
\hline 16. & Proveniência: igreja de São Francisco Mogadouro \\
\hline 17. & Autoria: desconhecida \\
\hline 18. & Oficina: Local $\backslash$ regional \\
\hline 19. & Localização (atual): Capela-mor, lado do Evangelho \\
\hline 20. & Histórico do objeto: não se conhecem registos \\
\hline 21. & Iconografia: Hábito dominicano; cão; livro aberto; bordão \\
\hline 22. & Irmandade: não se conhecem registos \\
\hline 23. & Procissões: não se conhecem registos \\
\hline
\end{tabular}


FICHAS DE INVENTÁRIO | ESCULTURA

Da Ordem de São Francisco na Diocese de Bragança-Miranda 
Igreja de São Francisco, Mogadouro

Retábulo maneirista com escultura de Imaculada Conceição - SFM09 Transepto do lado do Evangelho

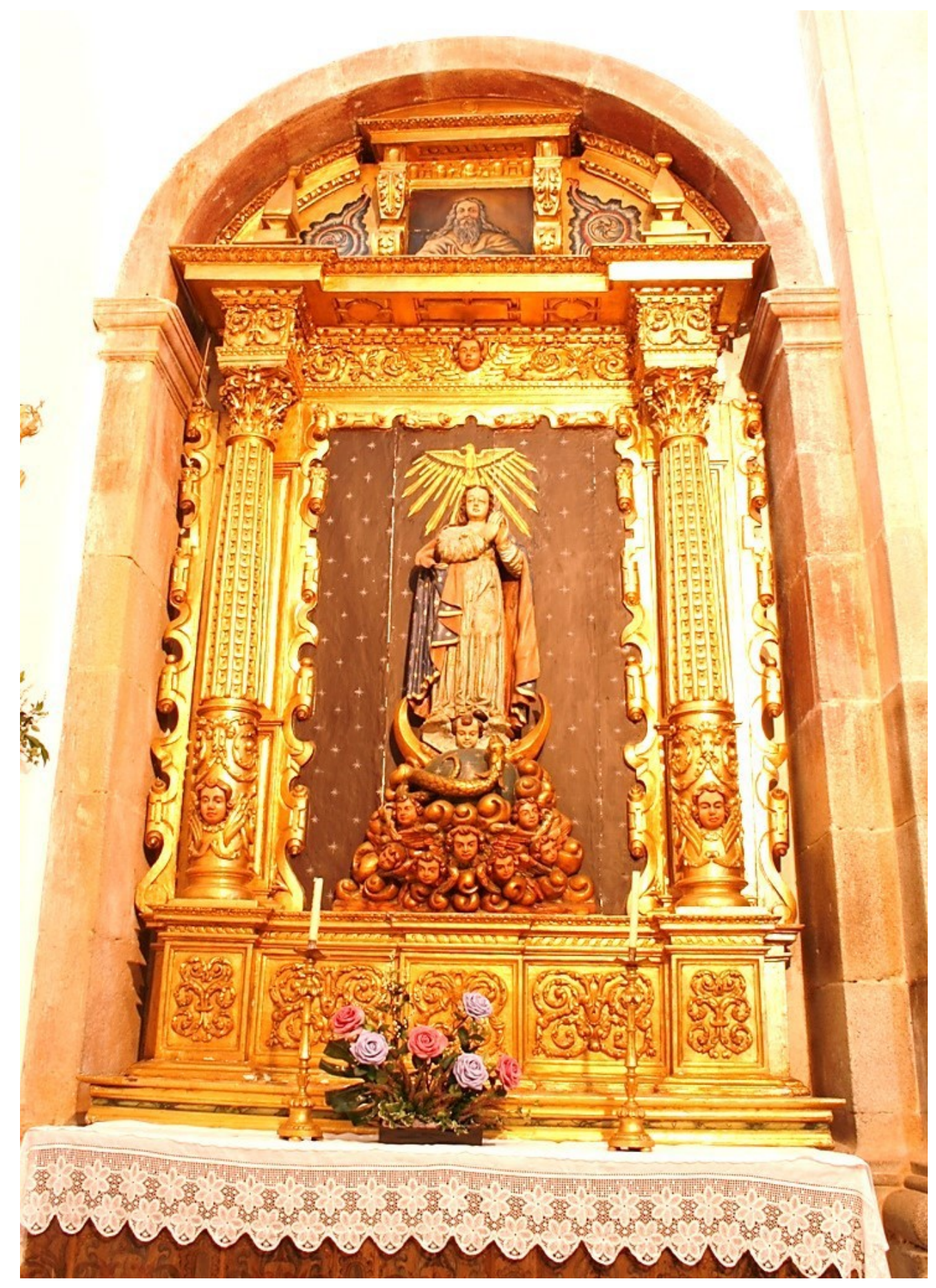


FICHAS DE INVENTÁRIO | ESCULTURA

Da Ordem de São Francisco na Diocese de Bragança-Miranda 


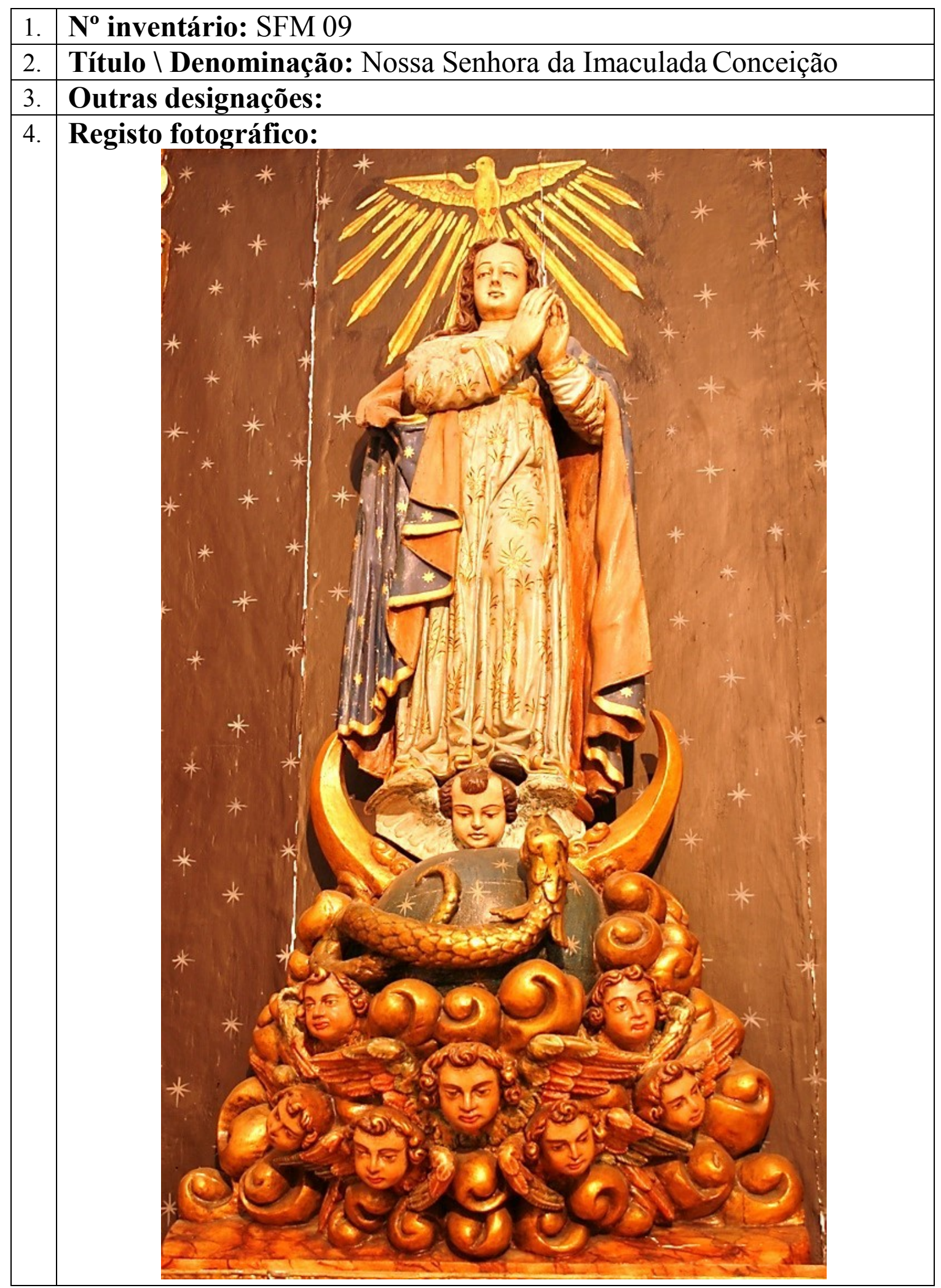




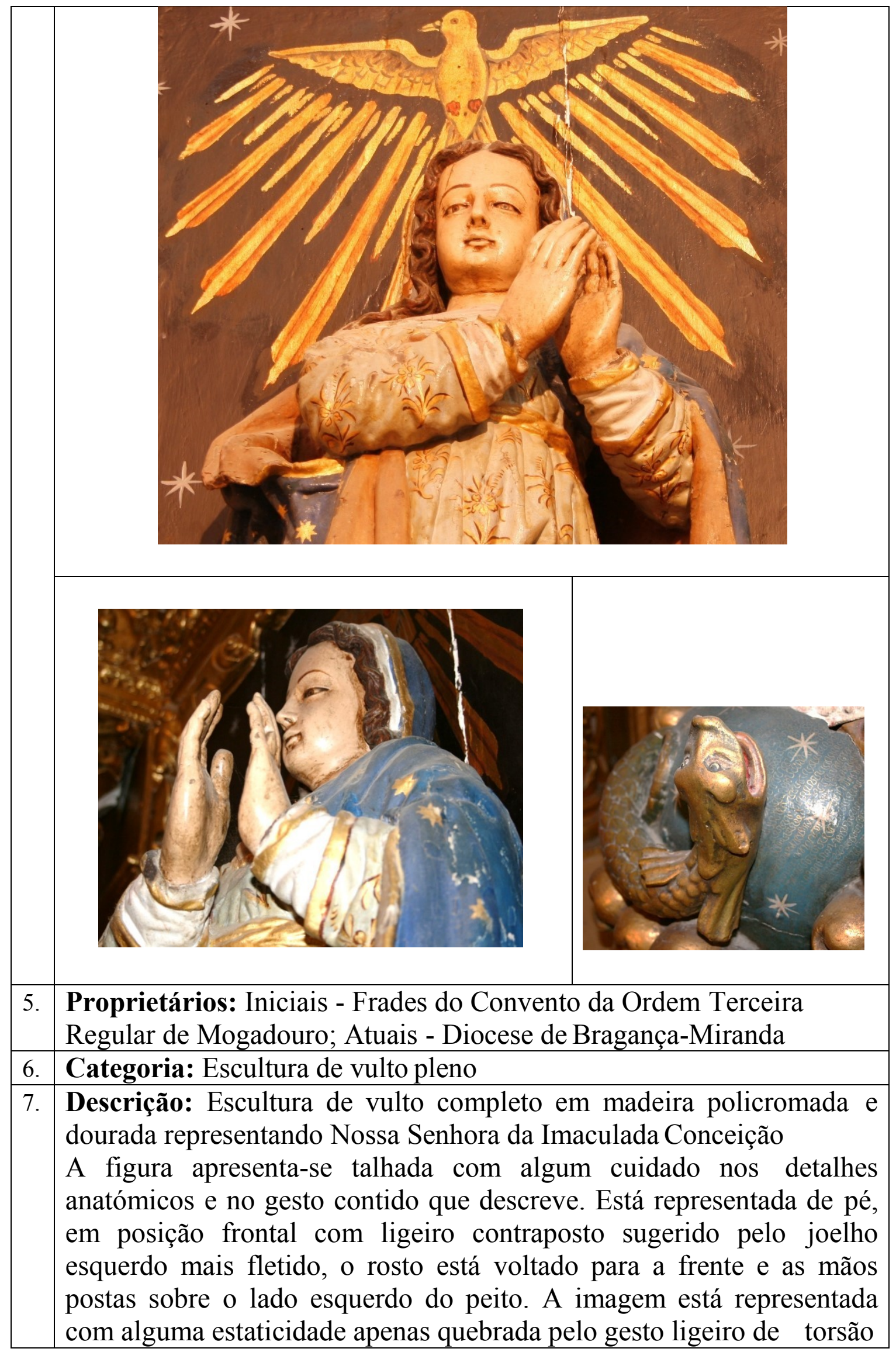




\begin{tabular}{|l|l|}
\hline do corpo de modo a permitir a colocação das mãos tão acentuadamente \\
sobre o lado esquerdo. \\
Enverga uma longa túnica azul clara decorada com ornatos vegetalistas \\
dourados em toda a extensão e que a cobre até aos pés onde o \\
pregueado se vinca em formas mais irregulares. A túnica está cingida \\
na cintura por um cordão dourado \\
Sobre este traje a figura enverga um manto azul-escuro amplamente \\
coberto por estrelas douradas que lhe cobre a cabeça envolvendo-a \\
pelas costas com um amplo vinco sobre o lado direito sustido pelo \\
braço direito. \\
O rosto está finamente esculpido e coberto de carnação homogénea e \\
suave, com traços delicados que compõem uma expressão serena. Os \\
olhos, grandes e amendoados são pintados e fixam o olhar em frente. O \\
cabelo, quase impercetível sob o manto, está talhado em ondas suaves \\
que acompanham o modelado do rosto e pescoço caindo sobre as \\
costas. \\
A escultura está colocada sobre um querubim colocado sobre a lua \\
crescente dourada que assenta sobre um globo policromado azul com \\
pequenas estrelas e ornatos dourados. Em volta do globo está \\
enroscada uma serpente dourada, com escamas e fantasiosa cabeça que \\
o envolve. A cabeça da serpente, com a boca escancarada eleva-se, em \\
atitude de ataque, em direção à imagem da Virgem. Sob o globo está \\
representada uma nuvem dourada da qual emergem sete querubins com \\
dinâmicos movimentos de asa. \\
Sobre a cabeça da virgem, já na pintura retabular do painel central do \\
retábulo que a expõe, está representada uma pomba dourada de cujas \\
asas emerge um resplendor emoldurando a cabeça da Virgem, a \\
restante superfície do painel é de tom negro com estrelas.
\end{tabular}




\begin{tabular}{|c|c|}
\hline 15. & Datas: segunda metade do século XVIII \\
\hline 16. & Proveniência: igreja de São Francisco Mogadouro \\
\hline 17. & Autoria: desconhecida \\
\hline 18. & Oficina: Local $\backslash$ regional \\
\hline 19. & $\begin{array}{l}\text { Localização (atual): Retábulo maneirista no transepto do lado do } \\
\text { Evangelho }\end{array}$ \\
\hline 20. & Histórico do objeto: não se conhecem registos \\
\hline 21. & $\begin{array}{l}\text { Iconografia: Serpente; Lua; Globo com estrelas; manto com estrelas; } \\
\text { querubins. }\end{array}$ \\
\hline 22. & Irmandade: não se conhecem registos \\
\hline 23. & Procissões: não se conhecem registos \\
\hline
\end{tabular}




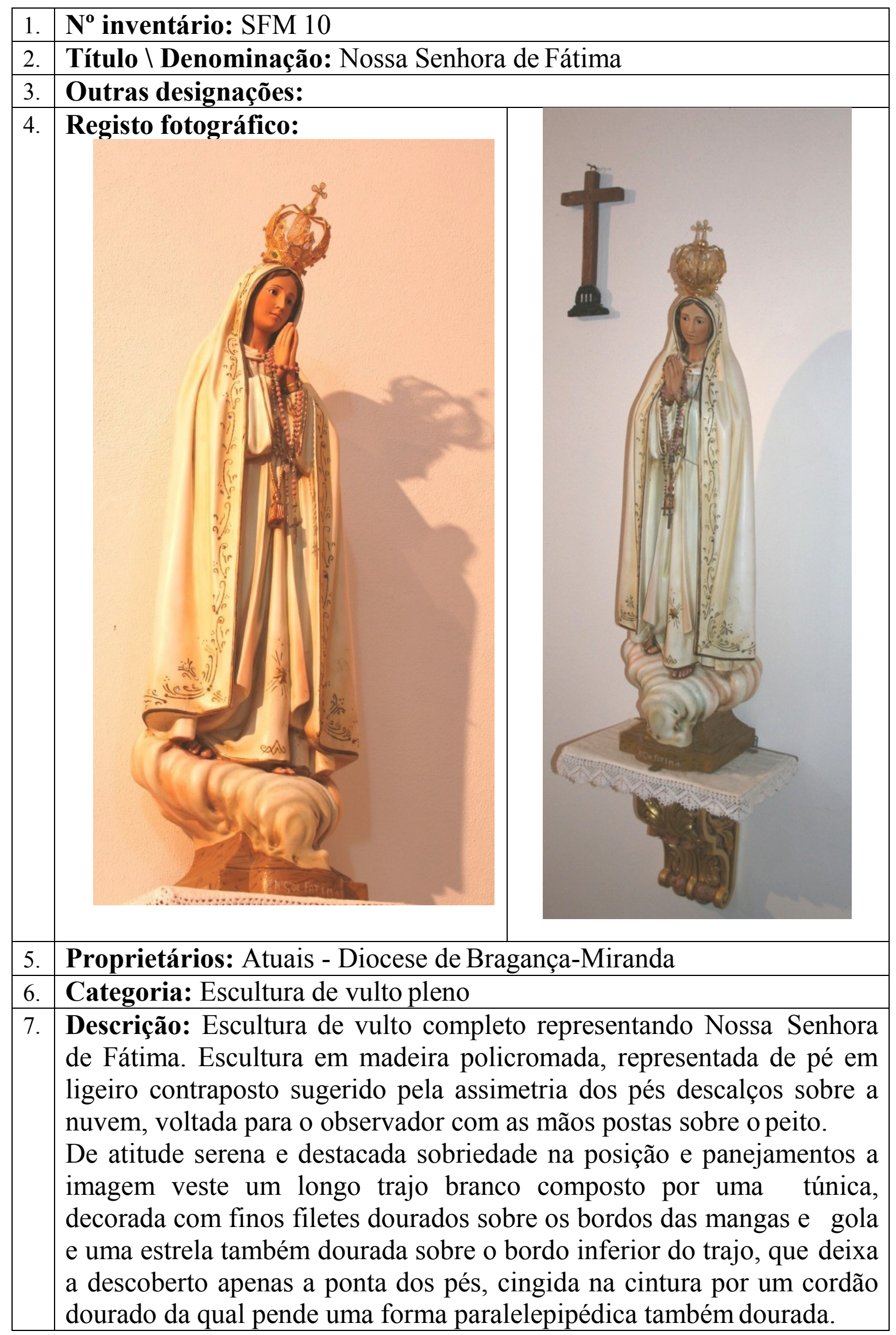




\begin{tabular}{|c|c|}
\hline & $\begin{array}{l}\text { Sobre este traje a figura enverga um manto branco decorado com finos } \\
\text { enrolamentos dourados que a cobre desde a cabeça até aos pés. } \\
\text { O rosto tem feições finas e delicadas e expressão serena, de olhos } \\
\text { castanhos, amendoados, em vidro e cabelo castanho ligeiramente } \\
\text { percetível sob o manto. } \\
\text { Das mãos postas pendem dois rosários colocados posteriormente. } \\
\text { A figura ostenta uma coroa de filigrana em metal dourado decorada com } \\
\text { pedrarias com quatro braços que se elevam rematados por um globo } \\
\text { encimado por uma cruz. } \\
\text { Está assente sobre uma nuvem branca e de contornos arredondados } \\
\text { irregulares, assente sobre uma plataforma quadrangular de tons } \\
\text { castanhos em cuja frente está inscrito com letras brancas } \mathrm{N}^{\mathrm{a}} \mathrm{S}^{\mathrm{a}} \text { de } \\
\text { FATIMA. Sobre o lado direito da plataforma esta colocada uma placa } \\
\text { metálica onde pode ler-se: "Casa Sagrado Coração de Jesus - Porto". }\end{array}$ \\
\hline 8. & Técnicas (de suporte): talha \\
\hline 9. & Técnicas (de acabamento): Policromia; dourado; fundição; filigrana \\
\hline 10. & Materiais (de suporte): madeira \\
\hline 11. & $\begin{array}{l}\text { Materiais (de acabamento): Pigmentos; folha de ouro; metal amarelo; } \\
\text { pedrarias }\end{array}$ \\
\hline 12. & Estado de Conservação: Bom; apresenta-se se estável. \\
\hline 13. & $\begin{array}{l}\text { Dimensões: } \\
\text { Altura: } 120 \mathrm{~cm} \\
\text { Largura: } 35 \mathrm{~cm} \\
\text { Profundidade: } 23 \mathrm{~cm}\end{array}$ \\
\hline 14. & Restauro: não apresenta sinais de intervenção sobre a obra \\
\hline 15. & Datas: século XX \\
\hline 16. & Proveniência: igreja de São Francisco Mogadouro \\
\hline 17. & Autoria: desconhecida \\
\hline 18. & $\begin{array}{l}\text { Oficina: Casa Sagrado Coração de Jesus Porto (conforme placa } \\
\text { metálica colada na base da escultura) }\end{array}$ \\
\hline 19. & Localização (atual): Mísula no transepto do lado do Evangelho \\
\hline 20. & Histórico do objeto: não se conhecem registos \\
\hline 21. & Iconografia: Rosário; Coroa \\
\hline 22. & Irmandade: não se conhecem registos \\
\hline 23. & Procissões: não se conhecem registos \\
\hline
\end{tabular}


Igreja de São Francisco - Mogadouro

Retábulo com talha barroca nacional com escultura de Nossa Senhora dos Remédios - SFM 11

Capela que antecede o transepto do lado do Evangelho

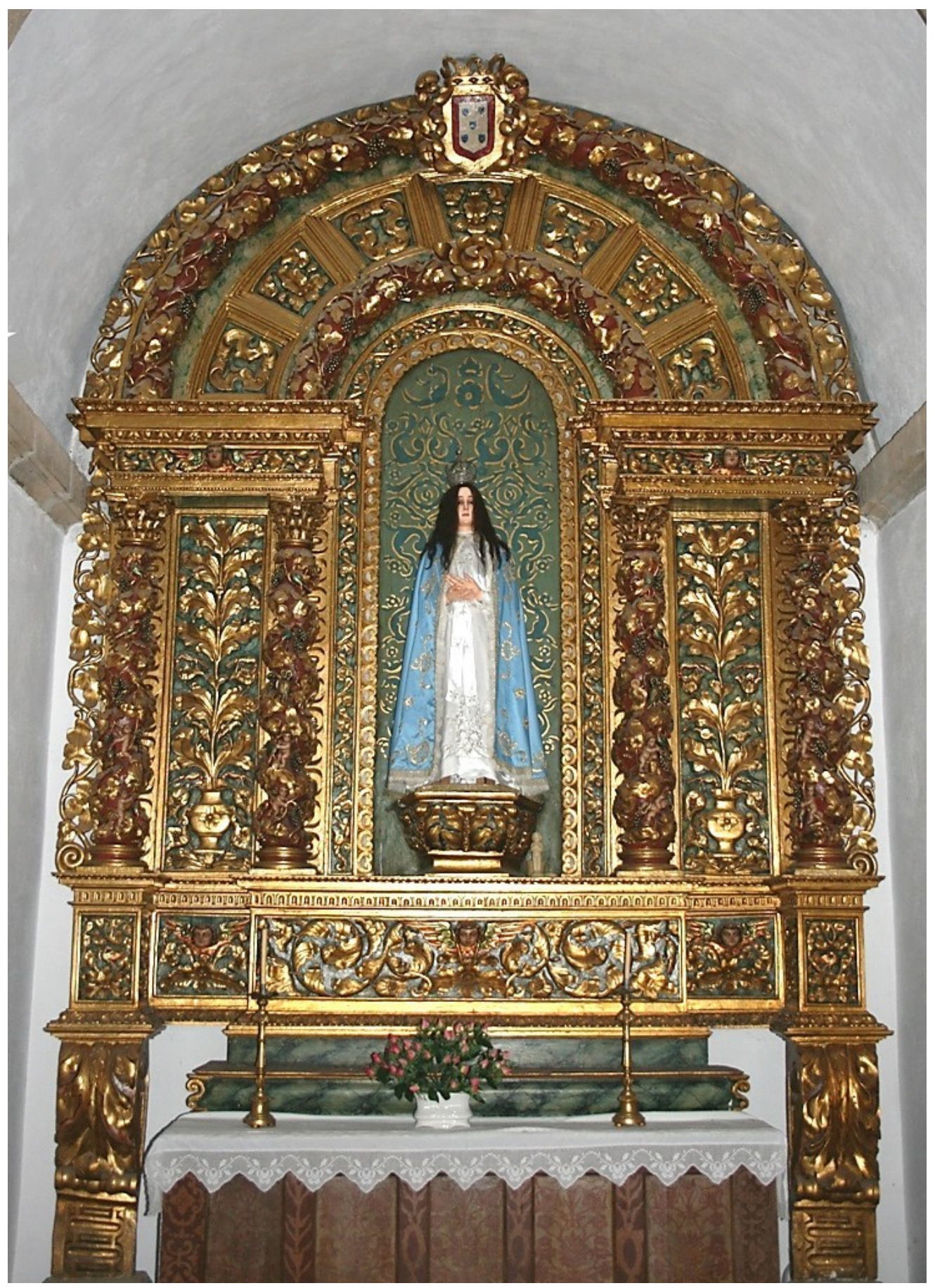


FICHAS DE INVENTÁRIO | ESCULTURA

Da Ordem de São Francisco na Diocese de Bragança-Miranda 


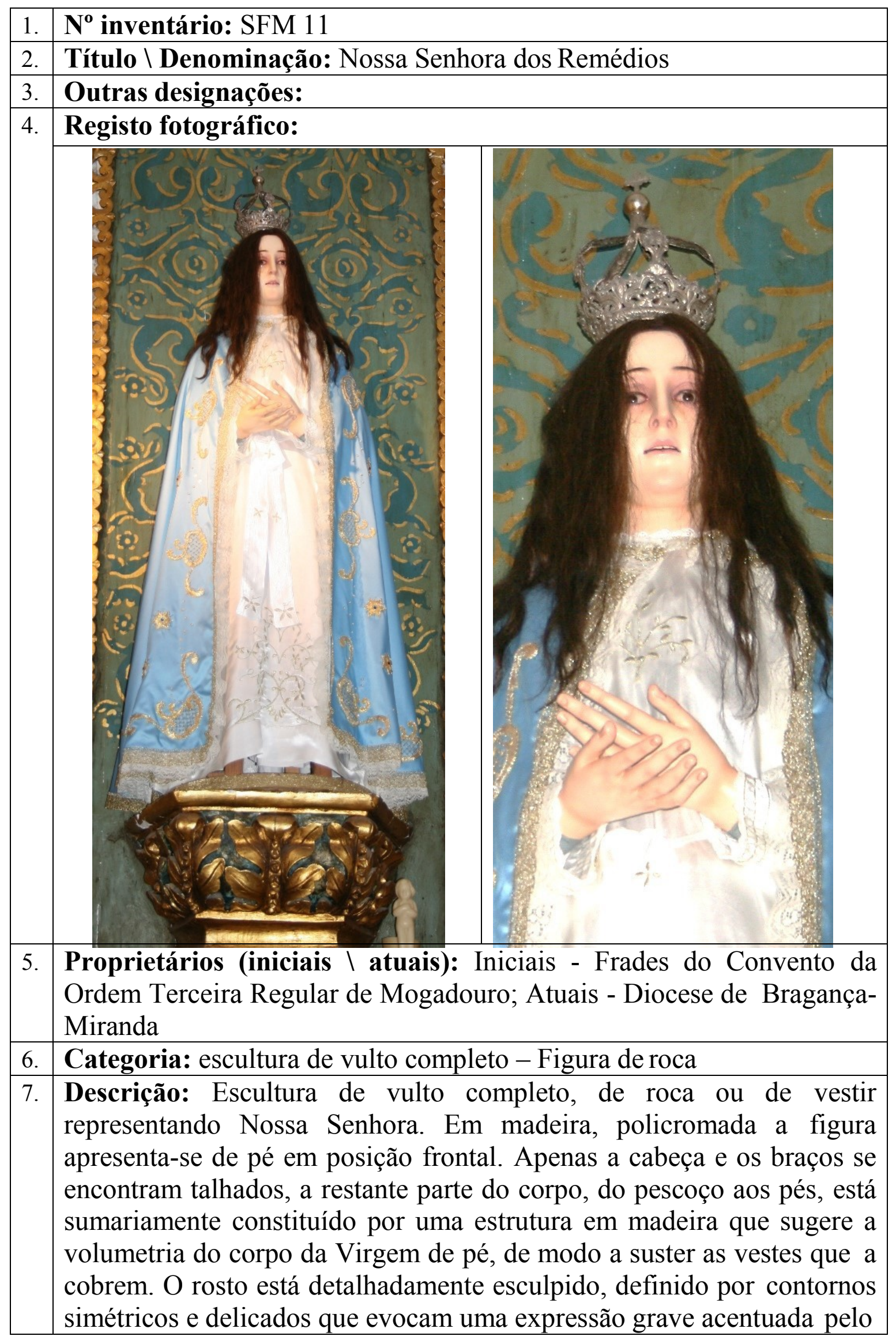




\begin{tabular}{|c|c|}
\hline & $\begin{array}{l}\text { olhar em frente com olhos de vidro. O rosto de carnação muito brilhante } \\
\text { está colorido com gradações de tom de modo a intensificar a } \\
\text { volumetrias dos rasgos anatómicos. Tem a boca entreaberta deixando } \\
\text { parte dos dentes a descoberto. A cabeça está coberta por uma cabeleira } \\
\text { postiça, de cabelo (natural?) que cai sobre os ombros e costas em longas } \\
\text { madeixas de cor castanho-escuro. Ostenta uma coroa em metal prateado } \\
\text { (prata?) repuxado com cinco braços que se elevam rematados por um } \\
\text { globo encimado por uma cruz. O manto que a cobre pelos ombros é de } \\
\text { Seda (ou cetim) azul claro debruado com passamanarias douradas e } \\
\text { com estrelas e enrolamentos bordados em dourados sobre os bordos. } \\
\text { Sob o manto a Virgem enverga uma túnica branca decorada nos bordos } \\
\text { por bordados dourados e cingida na cintura com uma faixa branca } \\
\text { decorada com dourados. As mãos esculpidas com detalhe estão ambas } \\
\text { sobrepostas sobre a cintura. Pela policromia parecem recentes ou alvo } \\
\text { de recente repinte. }\end{array}$ \\
\hline 8. & Técnicas (de suporte): Talha \\
\hline 9. & Técnicas (de acabamento): policromia; tecido; fundição; repuxado \\
\hline 10. & Materiais (de suporte): Madeira \\
\hline 11. & $\begin{array}{l}\text { Materiais (de acabamento): pigmentos; cabelos (naturais?); ouro; } \\
\text { metal prateado (prata?); pedrarias; vidro }\end{array}$ \\
\hline 12. & Estado de Conservação: Bom; apresenta-se estável \\
\hline 13. & $\begin{array}{l}\text { Dimensões: } \\
\text { Altura: } 160 \mathrm{~cm} \\
\text { Largura: } 70 \mathrm{~cm} \\
\text { Profundidade: } 48 \mathrm{~cm} \\
\end{array}$ \\
\hline 14. & Restauro: apresenta sinais de reintegração cromática nas mãos \\
\hline 15. & Datas: ultimo quartel do século XVIII \\
\hline 16. & Proveniência: igreja de São Francisco Mogadouro \\
\hline 17. & Autoria: desconhecida \\
\hline 18. & Oficina: Local $\backslash$ regional \\
\hline 19. & $\begin{array}{l}\text { Localização (atual): No retábulo barroco nacional do lado da } \\
\text { Evangelho sob o primeiro arco depois do arco de triunfo. }\end{array}$ \\
\hline 20. & $\begin{array}{l}\text { Histórico do objeto: Existe uma lenda local que refere que a imagem } \\
\text { terá, milagrosamente sustido, sem qualquer apoio, a custódia num dia } \\
\text { em que saiu em procissão. Informação do Cónego Dino Parra } \\
\text { (dezembro de 2013) }\end{array}$ \\
\hline 21. & Iconografia: Imagem de roca; coroa \\
\hline 22. & Irmandade: não se conhecem registos \\
\hline 23. & $\begin{array}{l}\text { Procissões: Sai atualmente em procissão durante as celebrações da } \\
\text { Semana Santa, segundo informação do atual pároco P. Dino Parra. }\end{array}$ \\
\hline
\end{tabular}


Igreja de São Francisco, Mogadouro

Retábulo em talha com elementos maneiristas e barrocos preenchido com pinturas e son o nicho a escultura de Nossa Senhora da Lapa - SFM 12 Segunda capela do lado do Evangelho

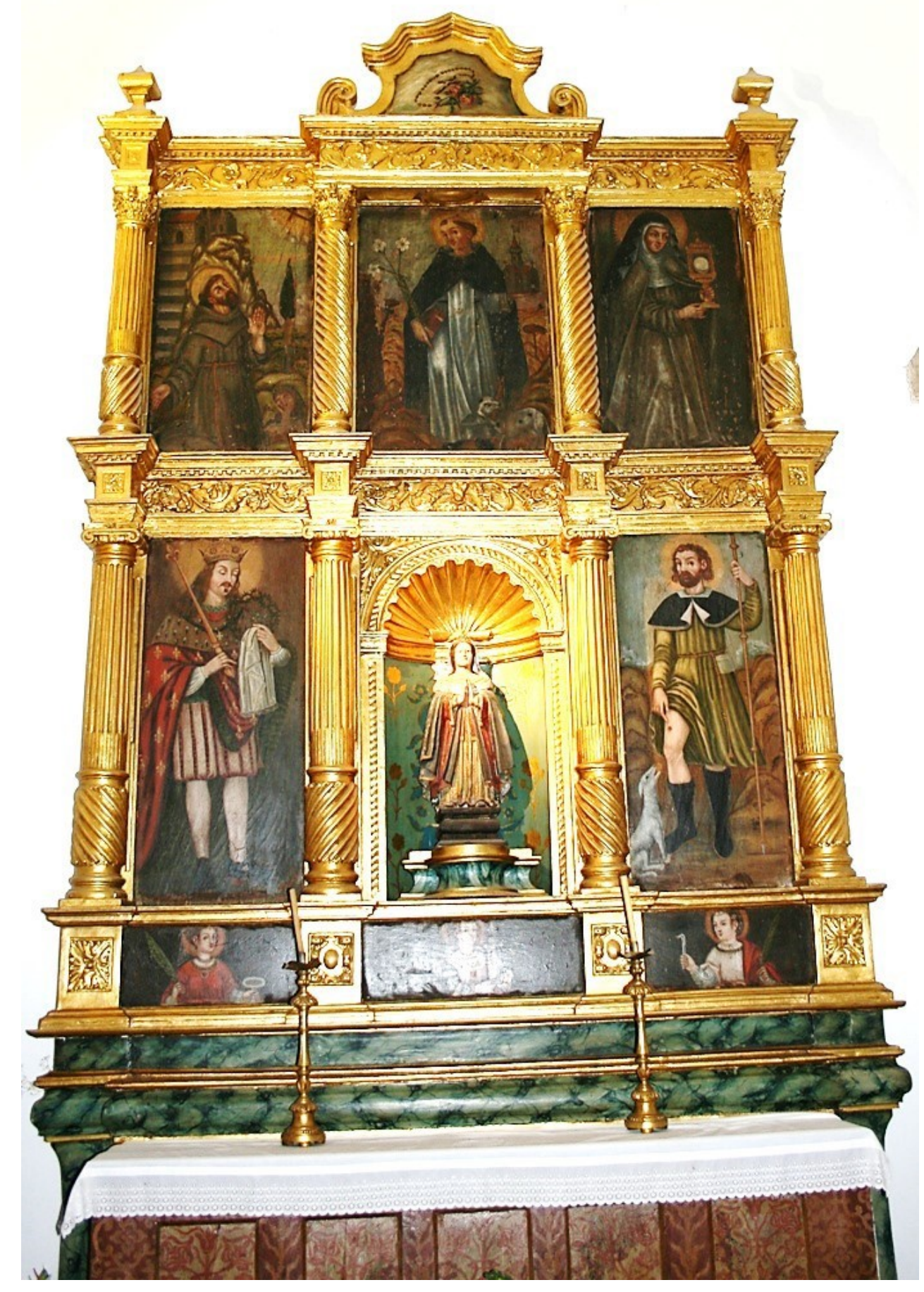


FICHAS DE INVENTÁRIO | ESCULTURA

Da Ordem de São Francisco na Diocese de Bragança-Miranda 


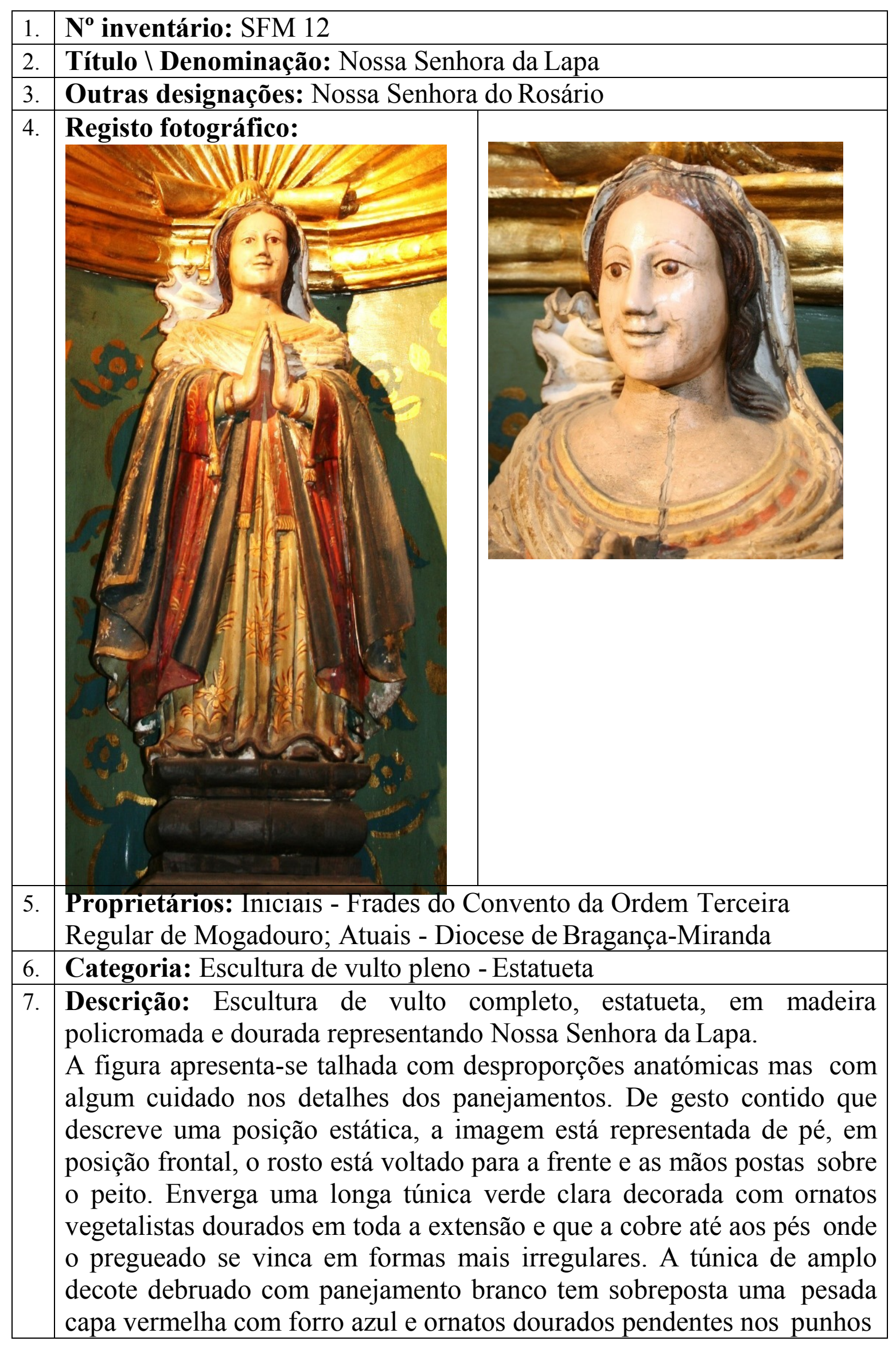




\begin{tabular}{|c|c|}
\hline & $\begin{array}{l}\text { e pintados sobre os bordos. Sobre esta enverga uma outra capa de cor } \\
\text { azul amplamente decorada com estrelas douradas. O rosto sumariamente } \\
\text { talhado está coberto por uma carnação homogénea de tom suave, com } \\
\text { olhos pintados, de olhar fixo em frente e um leve sorriso esboçado nos } \\
\text { lábios pálidos que evoca uma expressão serena. O cabelo, quase } \\
\text { impercetível sob o véu branco que com sumario tratamento evoca um } \\
\text { panejamento esvoaçante sobre o lado direito, está talhado em ondas } \\
\text { suaves que acompanham o modelado do rosto e pescoço caindo sobre as } \\
\text { costas. } \\
\text { A escultura está colocada sobre uma base polilobada em vários registos } \\
\text { de tom roxo. }\end{array}$ \\
\hline 8. & Técnicas (de suporte): Talha \\
\hline 9. & Técnicas (de acabamento): Policromia; dourado \\
\hline 10. & Materiais (de suporte): Madeira \\
\hline 11. & Materiais (de acabamento): Pigmentos; folha de ouro \\
\hline 12. & $\begin{array}{l}\text { Estado de Conservação: Bom; apresenta-se se estável; mas com vários } \\
\text { destacamentos da policromia. }\end{array}$ \\
\hline 13. & $\begin{array}{l}\text { Dimensões: } \\
\text { Altura: } 82 \mathrm{~cm} \\
\text { Largura: } 36 \mathrm{~cm} \\
\text { Profundidade: } 26 \mathrm{~cm}\end{array}$ \\
\hline 14. & Restauro: apresenta sinais de reintegração cromática \\
\hline 15. & Datas: segunda metade do século XVIII \\
\hline 16. & Proveniência: igreja de São Francisco Mogadouro \\
\hline 17. & $\begin{array}{l}\text { Autoria: desconhecida; nos detalhes anatómicos, policromia e motivos } \\
\text { estufados assemelha-se à imagem de Nossa Senhora da Imaculada } \\
\text { Conceição SFM } 08\end{array}$ \\
\hline 18. & Oficina: Local $\backslash$ regional \\
\hline 19. & $\begin{array}{l}\text { Localização (atual): Retábulo maneirista e barroco do lado do } \\
\text { Evangelho, sob o segundo arco depois do arco de triunfo }\end{array}$ \\
\hline 20. & Histórico do objeto: não se conhecem registos \\
\hline 21. & Iconografia: mãos postas sobre o peito \\
\hline 22. & Irmandade: não se conhecem registos \\
\hline 23. & Procissões: não se conhecem registos \\
\hline
\end{tabular}


Igreja de São Francisco - Mogadouro

Retábulo com talha rococo com escultura na peanha central SFM 14 ladeado pelas esculturas - SFM 13 e SFM 15

Primeira capela, apartir do portal no lado do Evangelho

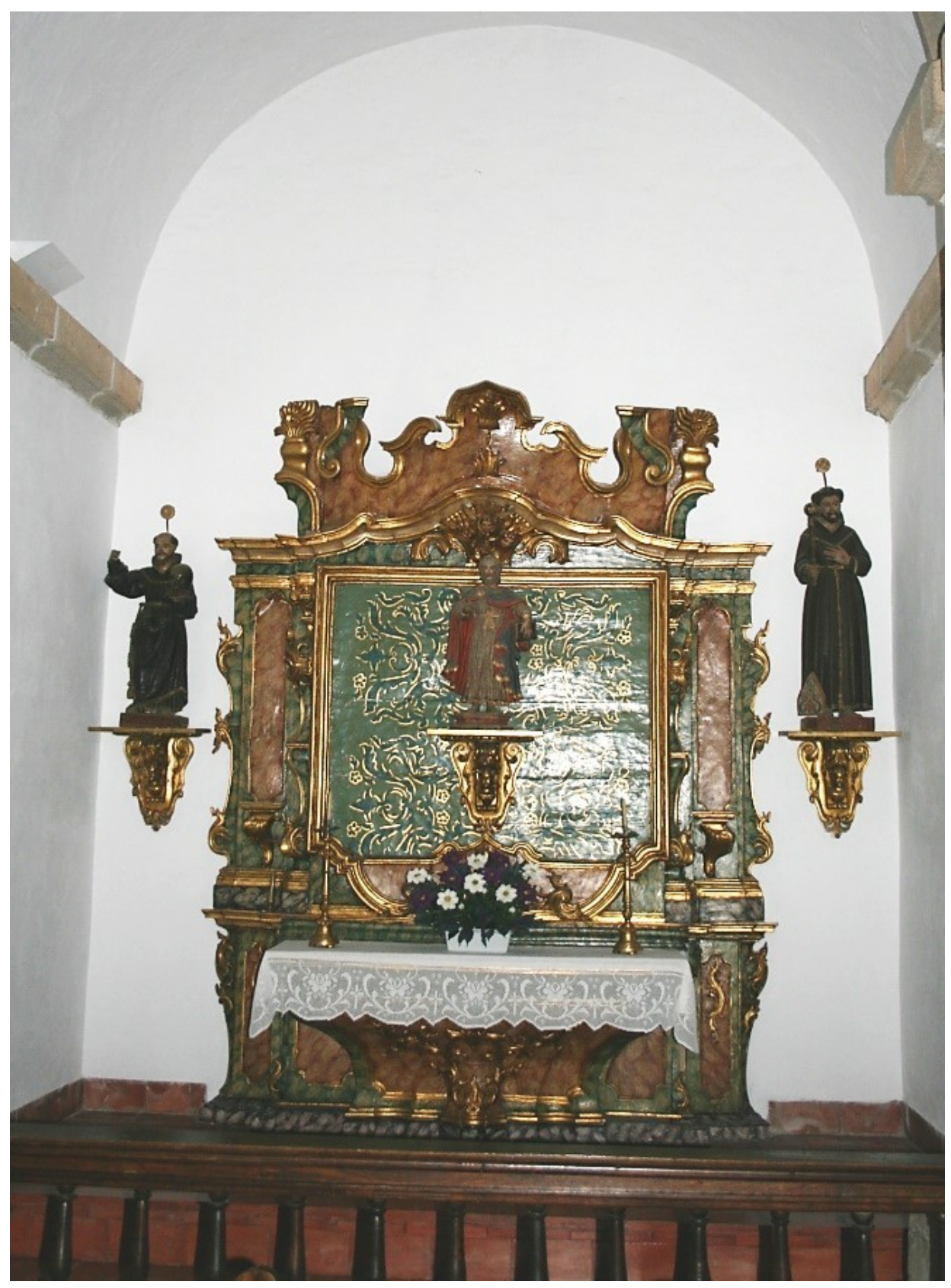


FICHAS DE INVENTÁRIO | ESCULTURA

Da Ordem de São Francisco na Diocese de Bragança-Miranda 


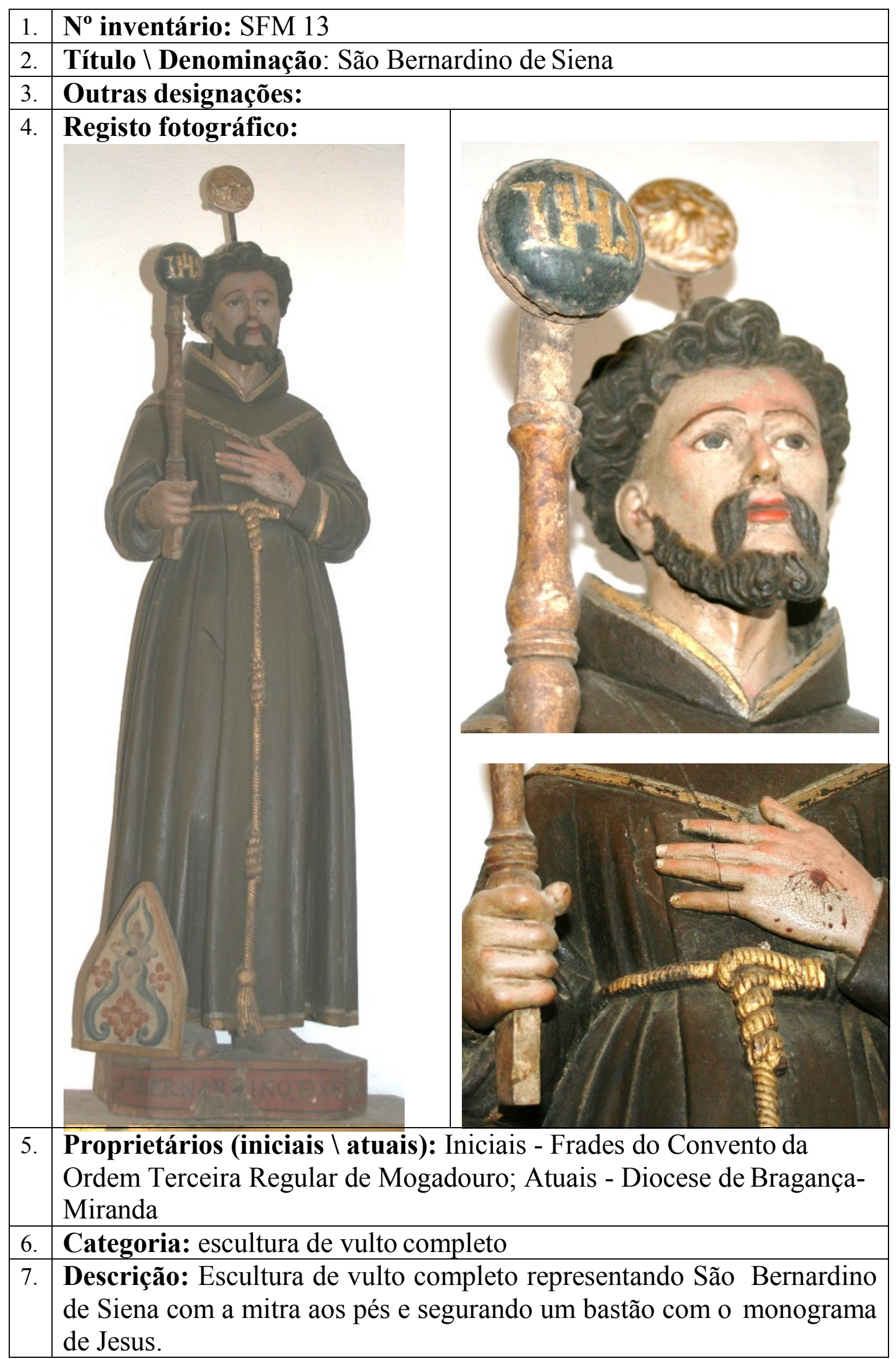




\begin{tabular}{|c|c|}
\hline & $\begin{array}{l}\text { Em madeira, policromada a figura apresenta-se de pé em posição frontal } \\
\text { sustendo com a mão direita um bastão curto encimado por uma forma } \\
\text { circular negra com o trigrama de Cristo IHS a dourado encimado por } \\
\text { uma cruz. } \\
\text { O rosto de contornos simétricos com o olhar fixo em frente e de } \\
\text { expressão grave está esculpido com algum cuidado. Tem barbas curtas e } \\
\text { farto bigode sobre os lábios rubros, os cabelos de cor castanho-escuro } \\
\text { são também esculpidos e com largas e ornamentadas ondas sobre a } \\
\text { frente. Eleva ambos braços à altura da cintura, o direito mais elevado e } \\
\text { afastado do corpo sustem o bastão curto de secção circular com vários } \\
\text { registos, a mão esquerda está junto ao corpo com a palma aberta sobre o } \\
\text { peito. Ambas as mãos apresentam os estigmas. Enverga o hábito } \\
\text { franciscano, castanho-escuro, cingido na cintura com o cordão que } \\
\text { pende sobre a frente com três rolos de nós, sobre o hábito enverga o } \\
\text { capuz que se apoia amplamente sobre os ombros e ao redor do pescoço, } \\
\text { em modo de prega caindo em forma pontiaguda sobre as costas. O } \\
\text { hábito é simples apenas decorado com uma faixa dourada, já muito } \\
\text { esbatida, sobre os bordos, cobre-o até aos pés que estão descalços. } \\
\text { Do lado direito pregado sobre o hábito junto aos pés está a mitra } \\
\text { esquematicamente representada ornamentada com elementos } \\
\text { vegetalistas. } \\
\text { Sobre a cabeça o Santo ostenta um pequeno resplendor de forma } \\
\text { circular elevado sobre a cabeça com um ornamento vegetalista ao } \\
\text { centro em madeira dourada. } \\
\text { O santo está assente sobre uma base octogonal vermelha em cuja frente } \\
\text { pode ler-se "So BERNAR(...)INO D SENA" }\end{array}$ \\
\hline 8. & Técnicas (de suporte): Talha \\
\hline 9. & Técnicas (de acabamento): policromia; dourado \\
\hline 10. & Materiais (de suporte): Madeira \\
\hline 11. & Materiais (de acabamento): pigmentos; ouro \\
\hline 12. & $\begin{array}{l}\text { Estado de Conservação: Bom; apresenta-se estável mas com forte } \\
\text { desgaste na policromia }\end{array}$ \\
\hline 13. & $\begin{array}{l}\text { Dimensões: } \\
\text { Altura: } 135 \mathrm{~cm} \\
\text { Largura: } 40 \mathrm{~cm} \\
\text { Profundidade: } 27 \mathrm{~cm}\end{array}$ \\
\hline 14. & $\begin{array}{l}\text { Restauro: apresenta sinais de reintegração cromática sobre os lábios e } \\
\text { rosto }\end{array}$ \\
\hline 15 . & Datas: primeira metade do século XVIII \\
\hline 16. & Proveniência: igreja de São Francisco Mogadouro \\
\hline
\end{tabular}




\begin{tabular}{|c|l|}
\hline 18 & Oficina: Local \regional \\
\hline 19 & $\begin{array}{l}\text { Localização (atual): Sobre uma mísula junto ao retábulo rococó do } \\
\text { lado do Evangelho sob o primeiro arco depois do coro alto. }\end{array}$ \\
\hline 20. & Histórico do objeto: não se conhecem registos \\
\hline 21. & $\begin{array}{l}\text { Iconografia: hábito franciscano; mitra; bastão com trigrama de Cristo } \\
\text { IHS; estigmas nas mãos }\end{array}$ \\
\hline 22. & Irmandade: não se conhecem registos \\
\hline 23. & Procissões: não se conhecem registos \\
\hline
\end{tabular}


FICHAS DE INVENTÁRIO | ESCULTURA

Da Ordem de São Francisco na Diocese de Bragança-Miranda 


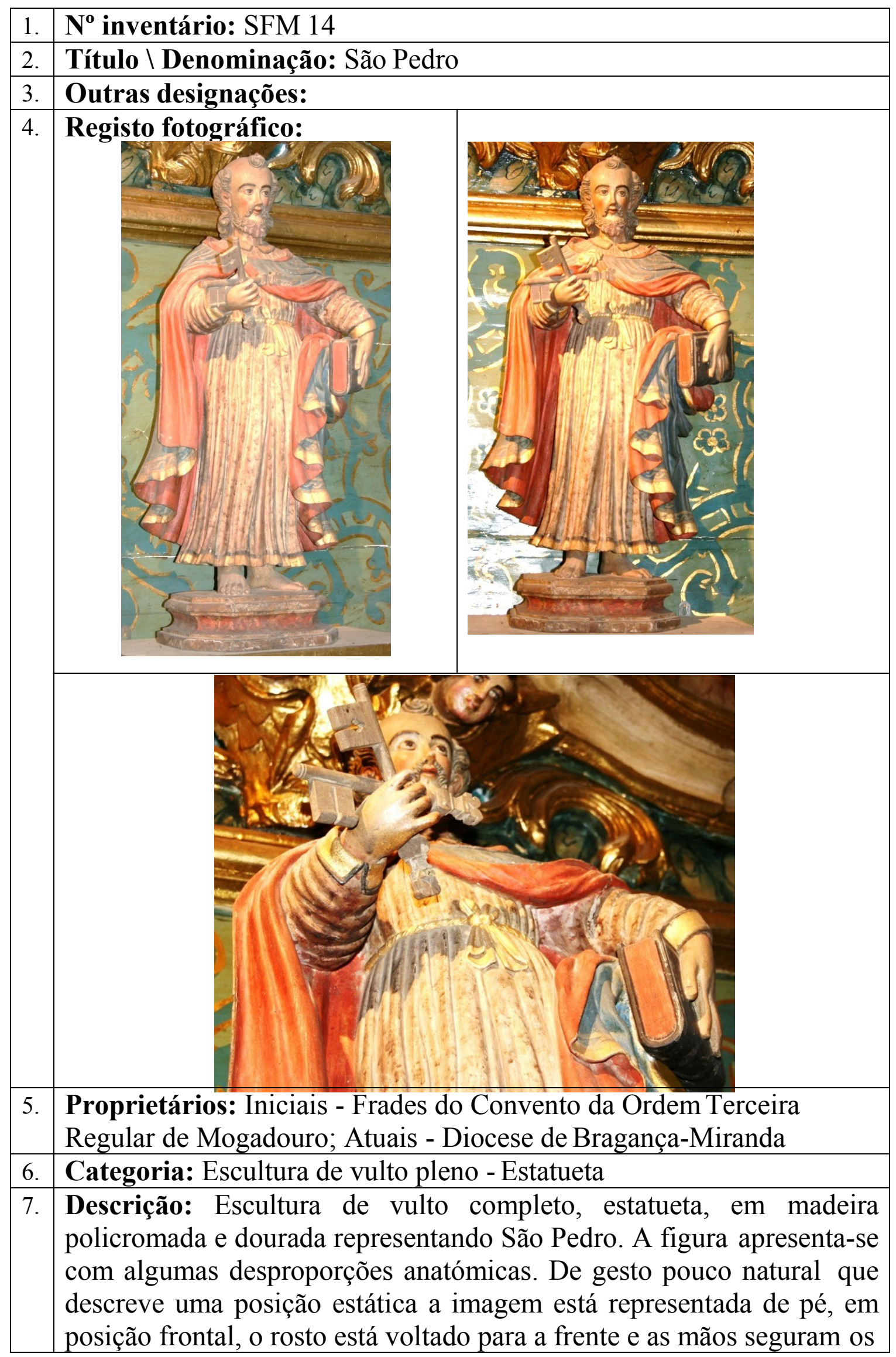




\begin{tabular}{|l|l|}
\hline & $\begin{array}{l}\text { atributos que o identificam. Enverga uma longa túnica num tom beije } \\
\text { claro decorada com bandas douradas nos bordos e punhos e cingida } \\
\text { sobre a cintura com um cordão dourados com laçada que o cobre até } \\
\text { aos pés descalços com pregueado vincado em formas regulares. A } \\
\text { quebrar a estaticidade da túnica o amplo manto que o cobre sobre os } \\
\text { ombros preso sobre o ombro direito evoca o esvoaçar dos } \\
\text { panejamentos pela ondulação impressa nos grossos vincos. O grosso } \\
\text { manto é azul com forro vermelho ornamentados com detalhes } \\
\text { dourados sobre os bordos. Flete e eleva ambos os braços à altura da } \\
\text { cintura, o braço direito ostenta duas grandes chaves cruzadas em aspas, } \\
\text { o braço esquerdo segura junto ao corpo um grosso livro fechado de } \\
\text { capas negras, que sustem em conjunto com parte da capa cujo vinco } \\
\text { esvoaça para a frente do corpo. O rosto talhado com algumas } \\
\text { irregularidades anatómicas tem coloração rósea sobre os pómulos e } \\
\text { lábios, com olhos pintados fixos em frente que compõem uma } \\
\text { expressão grave. A ondulação dos cabelos e barbas é detalhada porém } \\
\text { pouco naturalista. Está colocada sobre uma base octogonal em vários } \\
\text { registos pintada de cor vermelha. }\end{array}$ \\
\hline 8. & Técnicas (de suporte): Talha \\
\hline 9. & Técnicas (de acabamento): Policromia; dourado \\
\hline 10. & Materiais (de suporte): Madeira \\
\hline 11. & Materiais (de acabamento): Pigmentos; folha de ouro \\
\hline 12. & Estado de Conservação: Bom; apresenta-se se estável; desgaste na \\
policromia.
\end{tabular}




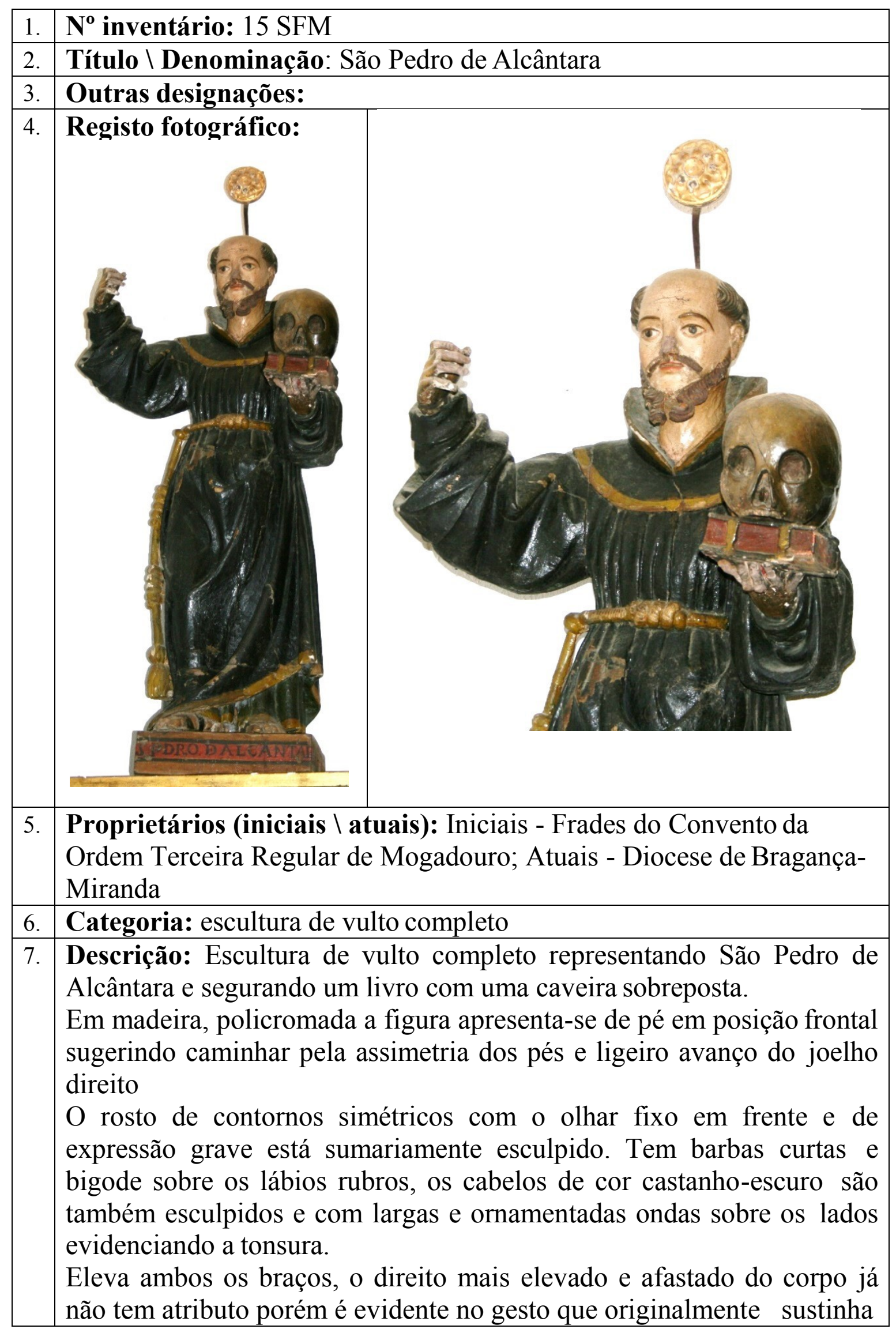




\begin{tabular}{|l|l|}
\hline & $\begin{array}{l}\text { algum objeto. Na mão esquerda sustém um livro fechado com } \\
\text { ornamentadas capas com fechos e sobre a qual está depositada uma } \\
\text { caveira. } \\
\text { Enverga o hábito franciscano, castanho-escuro quase negro, cingido por } \\
\text { um cordão que pende sobre o lado direito com dois rolos de nós, sobre o } \\
\text { hábito enverga o capuz que se apoia amplamente sobre os ombros e ao } \\
\text { redor do pescoço, em modo de prega caindo em forma pontiaguda sobre } \\
\text { as costas. O hábito é simples com pregueados grosso, apenas decorado } \\
\text { com uma faixa dourada, já muito esbatida, sobre os bordos, cobre-o até } \\
\text { aos pés protegidos com sandálias. } \\
\text { Sobre a cabeça o Santo ostenta um pequeno resplendor de forma } \\
\text { circular elevado sobre a cabeça com um ornamento vegetalista ao } \\
\text { centro em madeira dourada. } \\
\text { O santo está assente sobre uma base quadrangular vermelha em cuja } \\
\text { frente pode ler-se "S PEDRO D ALCANTARA" }\end{array}$ \\
\hline 8. & Técnicas (de suporte): Talha \\
\hline 9. & Técnicas (de acabamento): policromia; dourado \\
\hline 10. & Materiais (de suporte): Madeira \\
\hline 11. & Materiais (de acabamento): pigmentos; ouro \\
\hline 12. & Estado de Conservação: Bom; apresenta-se estável mas com forte \\
desgaste na policromia e várias fissuras
\end{tabular}




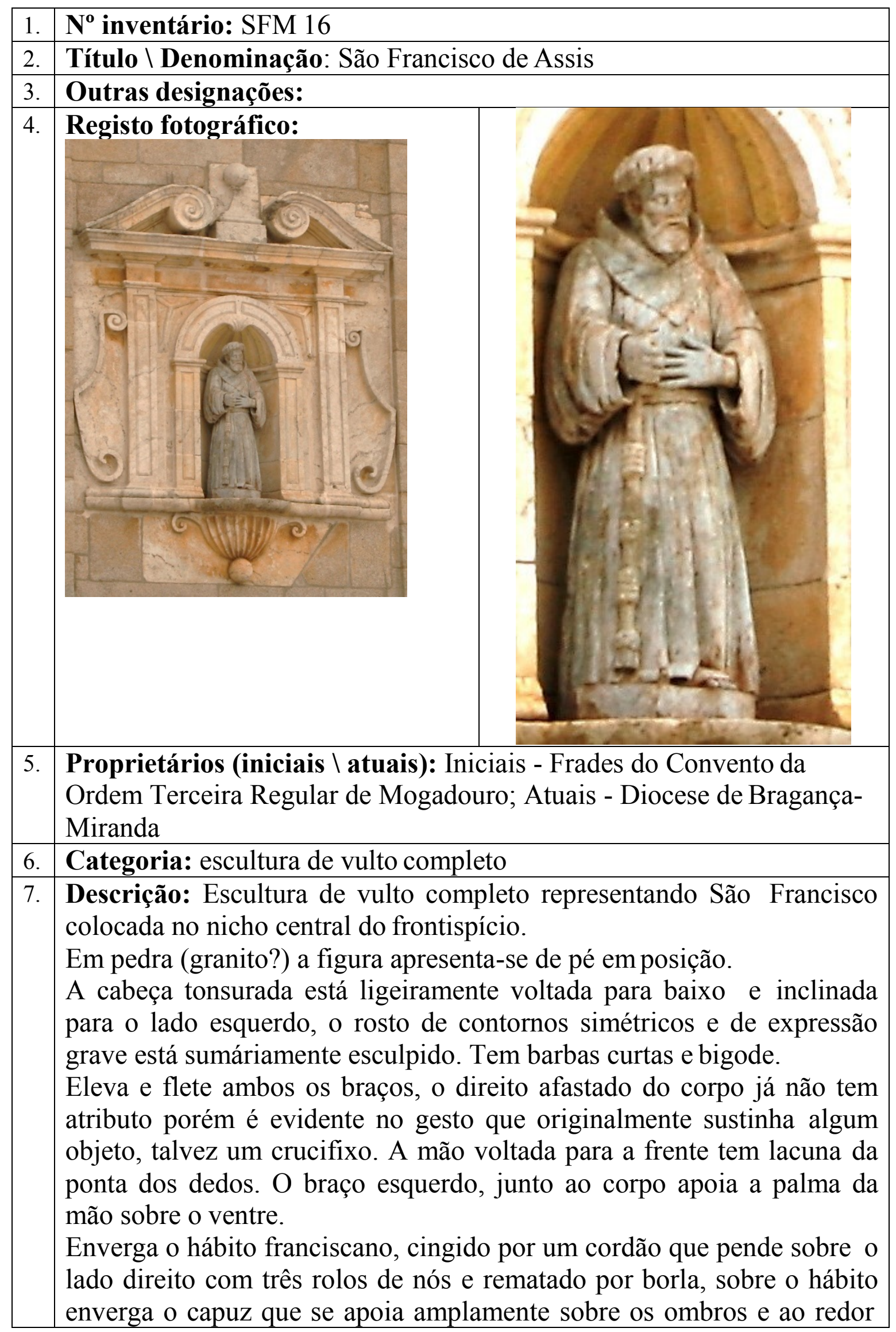




\begin{tabular}{|c|c|}
\hline & $\begin{array}{l}\text { do pescoço, em modo de prega caindo em forma pontiaguda sobre as } \\
\text { costas. O hábito roçagante é simples com pregueados grosso, deixando } \\
\text { visível apenas a ponta do pé esquerdo. } \\
\text { O santo está assente sobre uma base hexagonal no mesmo material que } \\
\text { o suporte. }\end{array}$ \\
\hline 8. & Técnicas (de suporte): Talha \\
\hline 9. & Técnicas (de acabamento): \\
\hline 10. & Materiais (de suporte): pedra (granito?) \\
\hline 11. & Materiais (de acabamento): \\
\hline 12. & $\begin{array}{l}\text { Estado de Conservação: A distância a que se encontra do observador } \\
\text { não permite um olhar detalhado mas parece estável mas com forte } \\
\text { desgaste e lacuna da ponta dos dedos na mão direita. }\end{array}$ \\
\hline 13. & $\begin{array}{l}\text { Dimensões: Não foi possível recolher estes elementos } \\
\text { Altura: } \\
\text { Largura: } \\
\text { Profundidade: }\end{array}$ \\
\hline 14. & Restauro: Não foi possível recolher estes elementos \\
\hline 15. & Datas: século XVIII \\
\hline 16. & Proveniência: igreja de São Francisco Mogadouro \\
\hline 17. & Autoria: desconhecida \\
\hline 18. & Oficina: Local $\backslash$ regional \\
\hline 19. & $\begin{array}{l}\text { Localização (atual): A escultura está colocada num nicho concheado } \\
\text { sobre o portal no frontispício da igreja }\end{array}$ \\
\hline 20. & Histórico do objeto: não se conhecem registos \\
\hline 21. & Iconografia: hábito franciscano. \\
\hline 22. & Irmandade: não se conhecem registos \\
\hline 23. & Procissões: não se conhecem registos \\
\hline
\end{tabular}


SEMINÁRIO FRANCISCANO DE MISSIONÁRIOS APOSTÓLICOS DE VINHAIS 


\section{FUNDAÇÃO DO CONVENTO}

Obtida a licença régia de D. João V em 1740, em 1752 fundaram os missionários franciscanos o Seminário de Nossa Senhora da Encarnação em Vinhais ${ }^{1}$. O seminário gozou da benemerência de José de Morais Sarmento e da real proteção da rainha D. Maria $\mathrm{I}^{2}$. O nobre local José de Morais Sarmento era fidalgo da casa real e sargento-mor de cavalaria e foi o principal impulsionador da fundação do seminário. Mas foi necessária uma forte persistência na sua demanda para logrou trazer os franciscanos para Vinhais ${ }^{3}$. O esforço para o estabelecimento da Ordem Franciscana em Vinhais

\footnotetext{
${ }^{1}$ Os seminários autónomos de missionários apostólicos uniam a uma austera disciplina conventual a intensa atividade exterior de pregação de missões populares. Quanto ao regime administrativo dependiam diretamente do governo central da ordem, sem laços jurídicos nem com as províncias nem sequer entre eles. O convento de Varatojo foi o primeiro seminário apostólico autónomo da ordem, autonomizado da Província dos Algarves com autorização papal de 1679, a este se seguiram outros quatro: Brancanes 1682; Vinhais em 1753; Mesão Frio em 1790 e Falperra em 1826. Montes Moreira, António, "Franciscanos" in Carlos Moreira Azevedo, Dicionário de história religiosa de Portugal, Lisboa, Círculo de Leitores, 2000, pp. 273-280; Castro, José de, Bragança e Miranda, (Bispado) Tomo II, Porto, Tipografia Porto Médico, Ldª , 1947, pp. 349, 350.

${ }^{2} \mathrm{Na}$ parede do pórtico da igreja do convento gravada em lápide de granita: FUNDOU ESTE SEMINÁRIO JOSE DE MORAES SARMENTO \ FIDALGO DA CASA REAL, MESTRE DE CAMPO, E NA- $\backslash$ TURAL DESTA VILLA DE VINHAES, NO ANNO DE $\backslash$ M.DCCC.LII. CEDEU O PADROADO DELLE NAS MÃOS DE \ SUA MAGESTADE, E FALECEU NO ANNO DE M.DCC.LXII. Martins, Firmino A., Subsídios para a história religiosa do distrito de Bragança: a Ordem III e a casa do Fundador do convento de S. Francisco de Vinhais, Coimbra, Imprensa da Universidade, 1929, p. 7; e do lado oposto: SUA MAJESTADE FIDELISSIMA \ ACCEITOU O PADROADO \ DESTE SEMINARIO, $\backslash$ E TOMOU PARA SEMPRE $\backslash$ O SEU REAL NOME E NO $\backslash$ DE TODOS OS SEUS SUCESSORES, \DEBAIXO DA SUA REGIA \E IMMEDIATA PROTECÇÃO, \NO ANNO DE M.DCC.LXXVII. Castro, José de, Bragança e Miranda, (Bispado) Tomo II, Porto, Tipografia Porto Médico, Ld ${ }^{\mathrm{a}}$ 1947, p. 357; Rema, Henrique (Frei), "A Ordem Franciscana em Tras-os-Montes" in Boletim do Arquivo Distrital de Vila Real - Revista de Cultura, Estudos Transmontanos e Durienses $n^{\circ} 7$, Vila Real, Arquivo Distrital de Vila Real, 1995, pp. 299-332.
}

\footnotetext{
${ }^{3}$ A tentativa de estabelecer uma casa de religiosos houvera sido já iniciada pelo pai de José de Morais Sarmento, António de Morais Ferreira, que tinha tentado estabelecer um hospício de missionários trinos. Além dos frades descalços da Santíssima Trindade a indisponibilidade para vir para Vinhais era também comum a Carmelitas Descalços, Capuchos, aos padres do Seminário do Varatojo e até aos franciscanos de Brancanes. Apesar das ofertas para fazer a obra e da insistência na fartura da côngrua que seria disponibilizada ao seminário, o guardião de Brancanes tardou em aceitar a fundação do seminário de Vinhais. Para a conclusão deste processo parece incontornável o empenho do bispo D. João da Cruz. Rodrigues, Luís Alexandre, "A ação dos padres de Brancanes em Vinhais. O Seminário da Senhora da Encarnação e constituição da Venerável Ordem Terceira da Penitência" in Natália Marinho FerreiraAlves (Coord.), Os Franciscanos no Mundo Português II. As Veneráveis Ordens Terceiras de São Francisco, Porto, CEPESE - Centro de Estudos da População, Economia e Sociedade 2012, pp. 163-193.
} 
advém não só da nobreza local mas também do prelado que então conduzia os destinos da diocese, o Bispo D. João da $\mathrm{Cruz}^{4}$.

Frei António de Nossa Senhora das Neves foi o frade fundador do Seminário de Nossa Senhora da Encarnação em Vinhais. No entanto, por oposição do guardião de Brancanes não foi Frei António de Nossa Senhora das Neves quem veio primeiro, mas os padres Frei Diogo dos Prazeres e Frei Francisco se S. Alberto também de Brancanes que se apresentaram na fundação do seminário de Vinhais ${ }^{5}$. Constata-se assim a relação que unia ambas as casas de missionários apostólicos ${ }^{6}$.

As missões insistiram prioritariamente na conversão, penitência e reforma dos comportamentos $^{7}$. Os Missionários Apostólicos andavam em grupos numerosos (três ou

\begin{abstract}
${ }^{4}$ D. João da Cruz era da Ordem dos Carmelitas, com muito apreço pelos frades Capuchinhos bem como pelos Missionários de Varatojo. Terá chegado à diocese de Miranda do Douro após ter ocupado a cátedra da diocese do Rio de Janeiro onde pela escassa população e extensão do território terá percebido o contributo positivo que poderia ser prestado pelos missionários, ver: Castro, José de, Bragança e Miranda, (Bispado) Tomo II, Porto, Tipografia Porto Médico, Ld'a 1947, pp. 317-347; D. João da Cruz redigiu e fez publicar várias pastorais, ver: Prada de Oliveira, Carlos, Pastorais dos Bispos de Miranda do Douro e Bragança, Bragança, Câmara Municipal de Bragança, 2011, pp. 95-138, onde se evidencia a sua fixação numa correta instrução religiosa de modo a combater os maus costumes, este reforço de ação sobre a comunidade deve ser relacionado com o presto apoio que o prelado dedicou ao estabelecimento e avanço da obra dos missionários em Vinhais. Além da família de Morais Sarmento outros nobres locais contribuíram para o engrandecimento do seminário Martins, Firmino A., Subsídios para a história religiosa do distrito de Bragança: a Ordem III e a casa do Fundador do convento de S. Francisco de Vinhais, Coimbra, Imprensa da Universidade, 1929, p. 7; Castro, José de, Bragança e Miranda, (Bispado) Tomo II, Porto, Tipografia Porto Médico, Ld ${ }^{\mathrm{a}}$, 1947, pp.358-360; Rema, Henrique (Frei), "A Ordem Franciscana em Tras-os-Montes" in Boletim do Arquivo Distrital de Vila Real - Revista de Cultura, Estudos Transmontanos e Durienses n ${ }^{\circ}$, Vila Real, Arquivo Distrital de Vila Real, 1995, pp. 299-332.
\end{abstract}

${ }^{5}$ Martins, Firmino A., Subsídios para a história religiosa do distrito de Bragança: a Ordem III e a casa do Fundador do convento de S. Francisco de Vinhais, Coimbra, Imprensa da Universidade, 1929, p. 7; Castro, José de, Bragança e Miranda, (Bispado) Tomo II, Porto, Tipografia Porto Médico, Ld'a 1947, pp.353-355; Rema, Henrique (Frei), "A Ordem Franciscana em Tras-os-Montes" in Boletim do Arquivo Distrital de Vila Real - Revista de Cultura, Estudos Transmontanos e Durienses $n^{\circ} 7$, Vila Real, Arquivo Distrital de Vila Real, 1995, pp. 299-332; Rodrigues, Luís Alexandre, "A ação dos padres de Brancanes em Vinhais. O Seminário da Senhora da Encarnação e constituição da Venerável Ordem Terceira da Penitência" in Natália Marinho Ferreira-Alves (Coord.), Os Franciscanos no Mundo Português II. As Veneráveis Ordens Terceiras de São Francisco, Porto, CEPESE - Centro de Estudos da População, Economia e Sociedade 2012, pp. 163-193.

${ }^{6} \mathrm{O}$ estabelecimento do seminário apostólico em Vinhais e a premência da missionação no espaço rural relaciona-se com a persistência da superstição e outros prolongamentos do paganismo ancestral que influía no comportamento religioso que os missionários pretendiam transformar. Neste sentido é possível depreender que a conjugação de fatores como a presença continuada dos missionários, o conhecimento profundo das questões locais, e o relacionamento que tinham com o poder de decisão, foi fundamental para o que os franciscanos de Nossa Senhora dos Anjos de Brancanes se fixarem em Vinhais. Rodrigues, Luís Alexandre, "A ação dos padres de Brancanes em Vinhais. O Seminário da Senhora da Encarnação e constituição da Venerável Ordem Terceira da Penitência" in Natália Marinho Ferreira-Alves (Coord.), Os Franciscanos no Mundo Português II. As Veneráveis Ordens Terceiras de São Francisco, Porto, CEPESE - Centro de Estudos da População, 2012, pp. 166-173.

${ }^{7}$ Paiva refere que a primeira metade de Setecentos é o tempo áureo das missões internas. Não eram apenas os bispos a solicitar as missões, os monarcas, os poderes municipais, os poderosos, os párocos, 
quatro) ao chegarem a uma localidade costumavam dirigir-se de imediato ao pároco para este tocar o sino congregando o povo. O sermão, o ensino do catecismo, o desfile de procissões penitenciais, a realização de confissões a difusão de devoções, diluição de discórdias e inimizades, a assistência aos presos nas cadeias e aos pobres e doentes nos hospitais constituíam as principais atividades dos missionários ${ }^{8}$. A comunicação a partir de meados do século XVII incluía a teatralização do sermão? .

A ação missionária em geral teve um papel relevante na difusão e enraizamento de devoções que, entre outros aspetos, tinham o condão de perpetuar a ação da missão após a retirada dos missionários. Os Missionários Apostólicos deram muita atenção à oração mental junto das camadas populares escrevendo manuais que ensinavam o modo de a fazer ${ }^{10}$.

devotos locais, todos eles podiam clamar pela sua presença. O período da Quaresma e o Advento eram o tempo privilegiado para efetuar missão. Por vezes, ocasiões excecionais, como um terramoto, ou uma inundação causada pelas chuvas, provocavam missões que tinham um significado assistencial evidente. Outras prolongavam-se pelo decurso de todo o ano, como sucedia regularmente com as dos missionários de Brancanes e Varatojo. Paiva, José Pedro, "As missões internas" in Carlos Moreira Azevedo, História Religiosa de Portugal, volume 2, Lisboa, Círculo de Leitores, 2000, pp. 239-250.

${ }^{8}$ Frei António das Chagas, e plausivelmente os seus discípulos do Varatojo e Brancanes, apareciam com regularidade de noite e surpreendiam as populações aos brados de «penitência, penitência...», dramatizando, desde logo, o momento da missão. Junto da autoridade religiosa local e informavam-se dos vícios concretos que mais afetavam as populações, para poderem orientar melhor as futuras predicações. Estas informações eram por vezes prestadas pelos prelados que disponibilizavam aos missionários extratos das denúncias ocorridas nas visitas pastorais As missões compunham-se da predicação de sermões, ensino do catecismo, desfile de procissões penitenciais, realização de confissões, difusão de múltiplas devoções, diluição de discórdias e inimizades, assistência aos presos nas cadeias e aos pobres e doentes nos hospitais. O sermão, normalmente debitado no interior das igrejas ou, quando o quantitativo de fiéis o exigia, em amplas praças, era um dos momentos fortes da missão. A estratégia enunciada era clara e encontrava-se não apenas no sermão, mas na globalidade do ato de missão: infligir terror, para conduzir os fiéis ao arrependimento e à reforma dos comportamentos. Paiva, José Pedro, "As missões internas" in Carlos Moreira Azevedo, História Religiosa de Portugal, volume 2, Lisboa, Círculo de Leitores, 2000, pp. 239-250.

${ }^{9}$ A entoação da voz, os gestos, o recurso a imagens eram cada vez mais trabalhados nos púlpitos e os pregadores, uns com mais sucesso do que outros, não hesitaram em se fazer acompanhar de caveiras, crucifixos, coroas de espinhos, cordas, em se bofetearem ou autoflagelarem. E o choro, os gritos, os gemidos, o arrepiar dos cabelos, eram muitas vezes os efeitos pretendidos e conseguidos. Os Missionários Apostólicos insistiram nas procissões de penitentes e a sua missão terminava habitualmente com uma. Realizavam-se durante a noite e chegavam a durar cinco horas, os missionários faziam curtas pregações. Quando havia ordens terceiras, a procissão abria com a imagem de São Francisco transportada pelos irmãos da ordem devidamente trajados, com cordas ao pescoço, silvas na cabeça e descalços, a que se seguiam em duas alas os membros do povo que as incorporavam, também descalços, com velas nas mãos e intervalando silêncios de compunção e reverência, com gemidos, soluços e brados de «Senhor Deus Misericórdia». Paiva, José Pedro, "As missões internas" in Carlos Moreira Azevedo, História Religiosa de Portugal, volume 2, Lisboa, Círculo de Leitores, 2000, pp. 239-250.

${ }^{10}$ Franciscanos e missionários apostólicos, tal como António das Chagas declara numa carta, que «em todos os povos grandes deixo a oração mental, vias-sacras, terço ou cousas de Nossa Senhora, e nos pequenos Via Sacra e terço». Os missionários promoviam a oração mental junto das camadas populares, 
Os missionários apostólicos permaneceram em Vinhais até 1834. Nesses escassos 80 anos consolidaram um importante conjunto arquitetónico, reuniram um número considerável de objetos artísticos de uso cerimonial e uma destacável biblioteca. Contribuíram também para a fundação da Venerável Ordem Terceira que mantém o legado franciscano no território.

prática que os Jesuítas sempre condenaram. Paiva, José Pedro, "As missões internas" in Carlos Moreira Azevedo, História Religiosa de Portugal, volume 2, Lisboa, Círculo de Leitores, 2000, pp. 239-250. 


\section{EDIFICADO DA IGREJA}

As obras do edifício foram sucessivas vezes proteladas. É escassa a informação relativa ao processo de construção e aos seus intervenientes, constante nas fontes conhecidas. Destaca-se a figura de Frei Constantino da Conceição, nascido em Azurara e que faleceu em Vinhais em 1767, onde chegou após ter estado no Bispado da Baía. Frei Constantino da Conceição era carpinteiro e apesar da sua mediana suficiência terá chegado a Vinhais na condição de conselheiro técnico para a edificação da igreja e alojamentos. Este aspeto explica as semelhanças entre o programa arquitetónico da frontaria da igreja do seminário de Brancanes e da igreja do seminário de Nossa Senhora da Encarnação em Vinhais (Imagem 1). De igual maneira que permite perceber como eram autossuficientes as casas religiosas na conceção, execução e direção de obras $^{11}$.

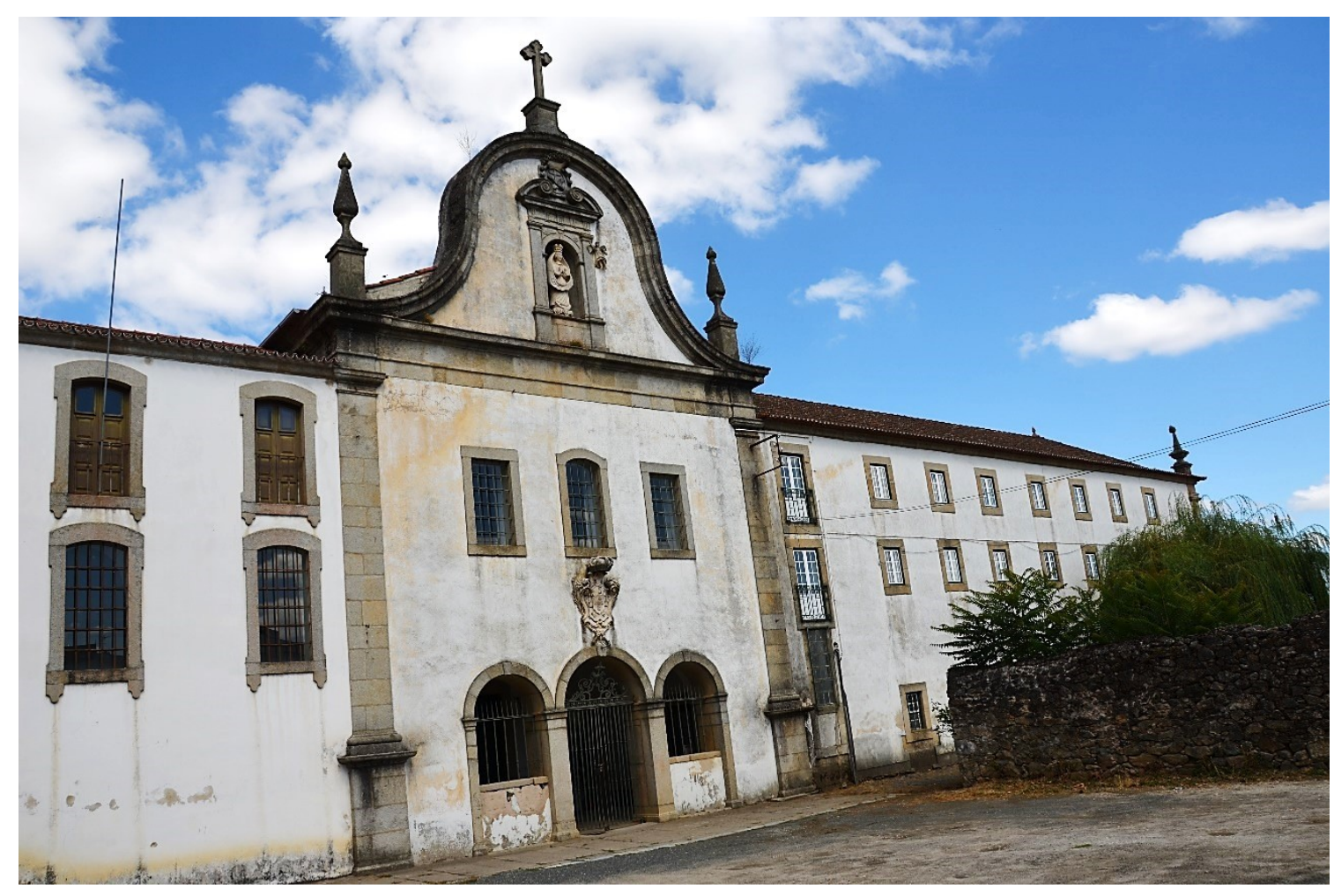

Imagem 1

Frontispício da igreja de Nossa senhora da Encarnação do Seminário Apostólico de Vinhais

\footnotetext{
${ }^{11}$ Conforme a documentação do Seminário dos Missionários Apostólicos de Nossa Senhora dos Anjos de Brancanes: Rodrigues, Luís Alexandre, "A ação dos padres de Brancanes em Vinhais. O Seminário da Senhora da Encarnação e constituição da Venerável Ordem Terceira da Penitência" in Natália Marinho Ferreira-Alves (Coord.), Os Franciscanos no Mundo Português II. As Veneráveis Ordens Terceiras de São Francisco, Porto, CEPESE - Centro de Estudos da População, Economia e Sociedade 2012, pp. 163193.
} 
A autossuficiência para a conceção, direção e execução de obras dentro dos elementos da própria Ordem justifica de alguma forma a ausência de documentação lavrada relativa a encomendas e contratos de obras, não apenas no edificado arquitetónico mas também nos programas decorativos que preenchiam o interior dos espaços.

O conjunto edificado do seminário franciscano de missionários apostólicos de Vinhais inclui a igreja da Encarnação, de uma só nave, com a capela lateral de Nossa Senhora das Dores e a sacristia, a área conventual e o claustro.

Dentro do perímetro da cerca do seminário existem duas capelas (Imagem 2 e Imagem 3) de uma via-sacra.

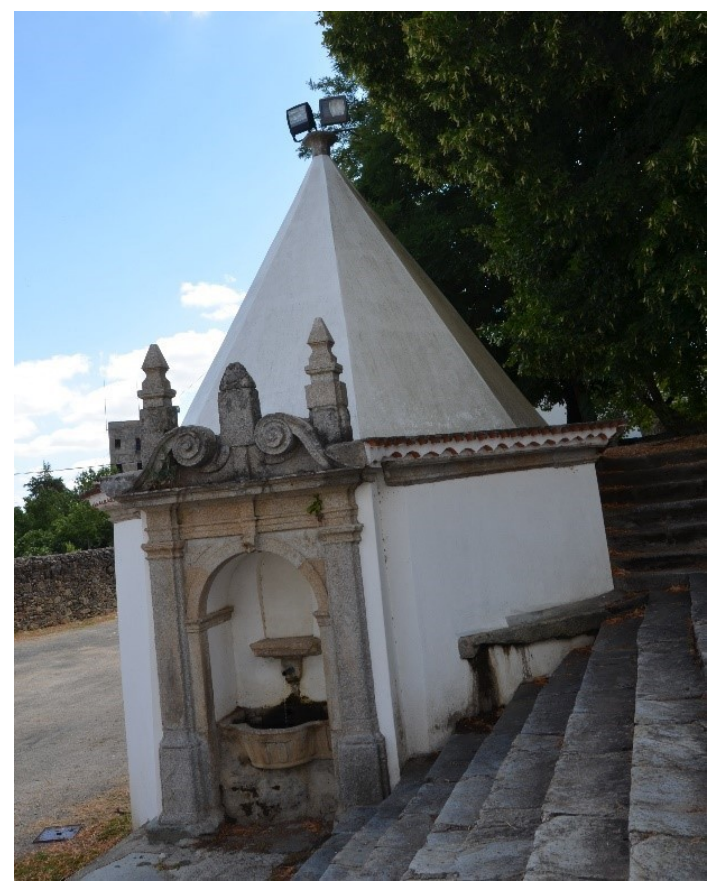

Imagem 2

Capela da Oração no Horto, na cerca do Seminário Apostólico

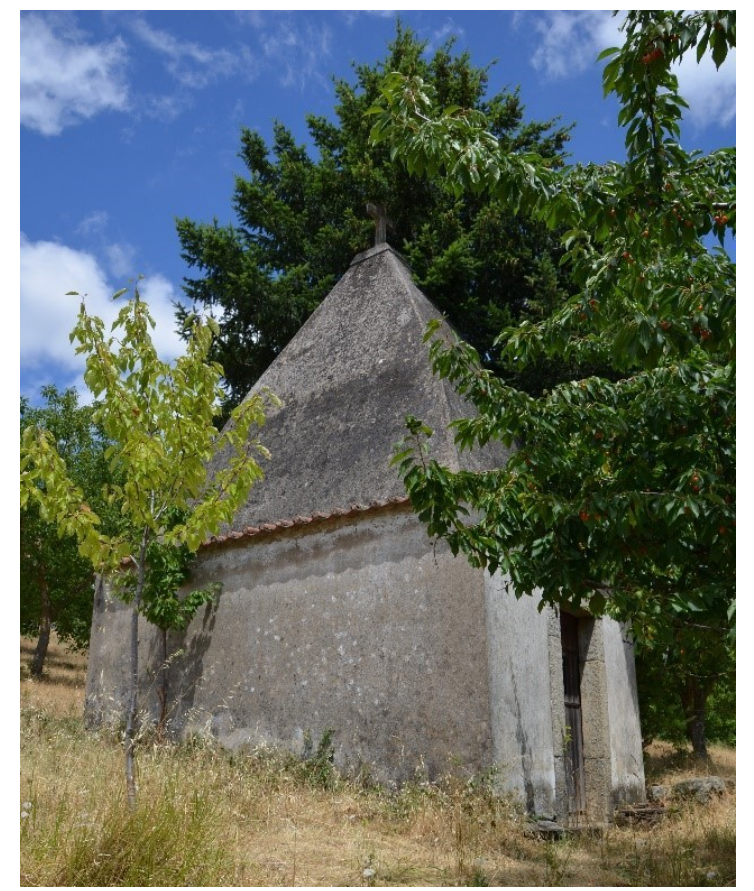

Imagem 3

Capela do Senhor do Monte, cerca do Seminário Apostólico

A Capela da Oração no Horto está próxima do Seminário e tem adossada uma fonte coberta decorada com um frontão semicircular interrompido em granito. A capela do Senhor do Monte está dentro da propriedade agrícola mais afastada do edificado conventual. No interior, guardam ambas as capelas, conjuntos escultóricos em terracota, já muito deteriorados, em risco de se perderem. Pese embora a ausência documental que o certifique, julgamos que as capelas pertenciam ao seminário. Formalmente existem relações de proximidade entre as obras escultóricas do interior da igreja e as terracotas das capelas. Além da proximidade formal, a devoção votada à via-sacra constitui uma 
das práticas devocionais preferenciais dos missionários. Estes aspetos sugerem que as capelas podem ter sido encomendadas pelos frades missionários.

A igreja e o convento sofreram várias alterações, após a expulsão das Ordens Religiosas em 1834, de modo a comportar as diversas funções que foram sendo atribuídas ao espaço. Inicialmente serviu de alojamento e mais tarde como quartel de destacamento militar e finalmente como seminário diocesano ${ }^{12}$.

A igreja mantém-se ao culto, o espaço conventual está parcialmente vazio. Em 2009 foi inaugurado o Museu de Arte Sacra da Ordem III de São Francisco Vinhais instalado numa parte do espaço conventual ${ }^{13}$.

\footnotetext{
${ }^{12}$ Quando em 1929 o padre Firmino Martins descreveu o convento o espaço ainda era usado como quartel de destacamento militar. Destacou algumas alterações que então observou como a da capela do capítulo que foi transformada em cozinha e a da capela da Senhora do Carmo (hoje desaparecida), no claustro adaptada a dispensa, desde o ano de 1865. Martins, Firmino A., Subsidios para a história religiosa do distrito de Bragança: a Ordem III e a casa do Fundador do convento de S. Francisco de Vinhais, Coimbra, Imprensa da Universidade, 1929, p. 8; José de Castro refere o documento em que se descreve o bom estado do interior do templo que se mantinha de modo a permitir o seu uso como igreja matriz. Refere também a compra do espaço conventual pelo clero da diocese, sendo bispo Dom António Luís de Almeida. Descreve ainda o ocorrido aos frades (na sua maioria naturais de povoações próximas) após a extinção das ordens. Castro, José de, Bragança e Miranda, (Bispado) Tomo II, Porto, Tipografia Porto Médico, Lda ${ }^{\mathrm{a}}$, 1947, pp. 361-363.

${ }^{13} \mathrm{O}$ Museu pertence ao município de Vinhais e compõe-se de duas salas de exposições, visita ao Coro da Igreja de Nossa Senhora da Encarnação, Coro da Igreja de São Francisco e Capela de Nossa Senhora das Dores, fazendo parte deste grupo, ainda, a Capela da Oração de Jesus no Horto, localizada no exterior do complexo. Integra uma coleção de arte sacra, ourivesaria, paramentaria, estatuária, pintura, mobiliário, gravura e arquivo documental. Conforme informação no portal da (2015) http://cmvinhais.pai.pt/ms/ms/camara-municipal-de-vinhais-turismo-5320-331-vinhais/ms-90043268-p-2/, acedida a 03 de julho de 2015 .
} 


\section{INTERIOR DO TEMPLO}

Sobre o interior do templo é o inventário dos "bens de raiz do Seminário Franciscano de missionários apostólicos em Vinhais ${ }^{14}$ " produzido após a extinção das ordens religiosas que nos dá mais elementos. Em inventário segundo a assentada de dia 5 de Junho de 1834 começa o registo das "imagens de vulto e quadros" guardados no interior dos espaços do convento.

No interior da sacristia da igreja de Nossa Senhora da Encarnação havia:

"Hum oratório com vidraças e dentro hum crucifixo sem resplendor e set [sic] santos de vulto a saber; Sam João, Nossa Senhora, Sam Sebastião, Santa Bárbara, Sam Domingos, todos com resplendores de prata avaluado tudo pelos louvados em preço e quantia de trinta mil reis - 30\$000"15.

Atualmente o interior da sacristia guarda seis imagens, sendo que apenas quatro estão colocadas nos nichos do oratório que hoje se apresenta sem vidraças.

No nicho central do oratório está colocado um crucifixo (Imagem 4). No entanto, ao contrário do que surge registado em 1834 o atual crucifixo apresenta um resplendor em metal prateado colocado sobre a cruz, conforme. A escala do crucifixo parece desajustada com a moldura interior do nicho central o que permite pensar que se trata de uma substituição da imagem entretanto acrescentada, ou possivelmente até mudada de local. No inventário de 1834 são inventariados vários crucifixos, atualmente além deste

\footnotetext{
${ }^{14}$ No inventário dos bens de raiz do Seminário Franciscano de missionários apostólicos em Vinhais, após a descrição do edificado, todo avaliado em vinte contos de reis, segue-se a descrição do modo como este foi encontrado. Encontrava-se abandonado precipitadamente pelos frades que haviam fugido com medo das tropas de D. Maria II, na altura eram 20 os frades que moravam no convento, deixando as chaves a um criado. Daí que na relação dos bens para arrematação constassem muitos bens comestíveis com destaque para o vinho (277 almudes), a farinha e legumes vários, carne de porco e aguardente. Bem como, todas as propriedades agrícolas do convento, os animais, as colmeias, e todos os bens móveis de uso do convento na cozinha, as caldeiras, potes e até chocolateiras, caixas de chá e louças de Braga. Objectos de refeitório, como garfos e facas, objectos de enfermaria, e objectos de serviço da casa, o mobiliário comum das estantes, arcas, mesas e cadeiras, e toda a roupa de uso doméstico. Foi também feito um detalhado registo da livraria. Os livros registados incluem o autor, título e número de volumes. Estão inventariados por temas, na sua maioria de teologia, direito, história, mística, cerimonias eclesiásticas, moral e filosofia perfazendo várias centenas de volumes, apresentados no total na quantidade de 326 volumes. Além da livraria existe também o registo do arquivo onde constavam os livros de benfeitores, estatutos e actas. A.N.T.T./A.H.M.F./S.N.S.E.V., Extinção das Ordens Religiosas Seminário de Nossa Senhora da Encarnação - Vinhais, Arquivo Nacional da Torre do Tombo, Lisboa, Arquivo Histórico do Ministério das Finanças, Processos de Extinção das casas religiosas, Cx. 2265, $1834, \mathrm{~s} / \mathrm{fl}$.
}

${ }^{15}$ A.N.T.T./A.H.M.F./S.N.S.E.V., Extinção das Ordens Religiosas - Seminário de Nossa Senhora da Encarnação - Vinhais, Arquivo Nacional da Torre do Tombo, Lisboa, Arquivo Histórico do Ministério das Finanças, Processos de Extinção das casas religiosas, Cx. 2265, 1834, s/fl. 
existem mais três cruzes de altar que estão expostas dentro de uma das vitrinas do contíguo Museu de Arte Sacra.

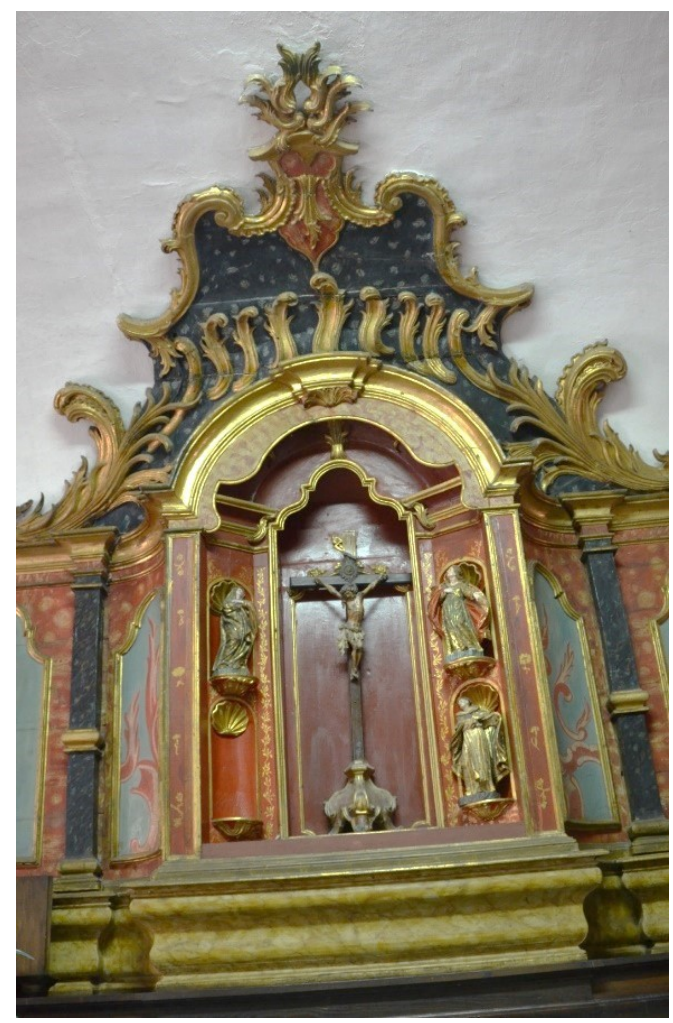

Imagem 4

Oratório da sacristia da igreja de Nossa Senhora da Encarnação, com a imagem de Cristo crucificado ao centro ladeado à direita por Nossa Senhora e à esquerda por São João e Santo Domingos de Gusmão.

À direita do crucifixo, no nicho do registo superior está colocada uma estatueta de Nossa Senhora representada no calvário, possivelmente a mesma "Nossa Senhora", que sem mais especificidade alguma da sua invocação foi registada em 1834 . O nicho que está sob esta imagem encontra-se hoje vazio ${ }^{16}$.

Os nichos do oratório que ladeiam a figura de Cristo crucificado pelo lado esquerdo estão atualmente ambos ocupados. O nicho superior pela figura de São João e o inferior pela de São Domingos de Gusmão, também estas duas esculturas podem ser as de "San João" e "San Domingos" registadas em 1834 como parte do oratório. No entanto, não existe atualmente nenhuma escultura de "San Sebastião", nem na sacristia nem na

\footnotetext{
${ }^{16}$ Segundo informação da atual zeladora da igreja de Nossa Senhora da Encarnação $\left(\mathrm{Sr}^{\mathrm{a}} \mathrm{D}\right.$. Iolanda, natural e residente em Vinhais) o nicho agora vazio estava até há poucos anos ocupado pela imagem de marfim de Nossa Senhora da Conceição. Essa imagem está atualmente exposta dentro de uma vitrina no museu de arte sacra contíguo ao convento, no entanto, na pesquisa documental não foi encontrada qualquer referência a essa organização do interior do oratório.
} 
igreja, sendo que ambos os espaços foram alvo de um inventário de toda a escultura para a elaboração do presente estudo.

Relativamente à imagem de Santa Bárbara registada em 1834 no interior do oratório também não existe, quer na sacristia quer na igreja, atualmente nenhuma imagem de Santa Bárbara cujo tamanho permita pensar tratar-se da obra que preenchia um dos nichos segundo o inventário do século XIX. A sacristia guarda hoje uma escultura de Santa Bárbara, colocada à direita do oratório conforme a imagem 5 , porém será com maior certeza a que estaria outrora no altar de Santo António no interior da igreja registada no mesmo inventário. Assim como, a imagem de São Joaquim, de tamanho idêntico à de Santa Barbara, colocado à esquerda do oratório, conforme a mesma imagem, seria seguramente a imagem que acompanhava Santa Ana no seu altar.

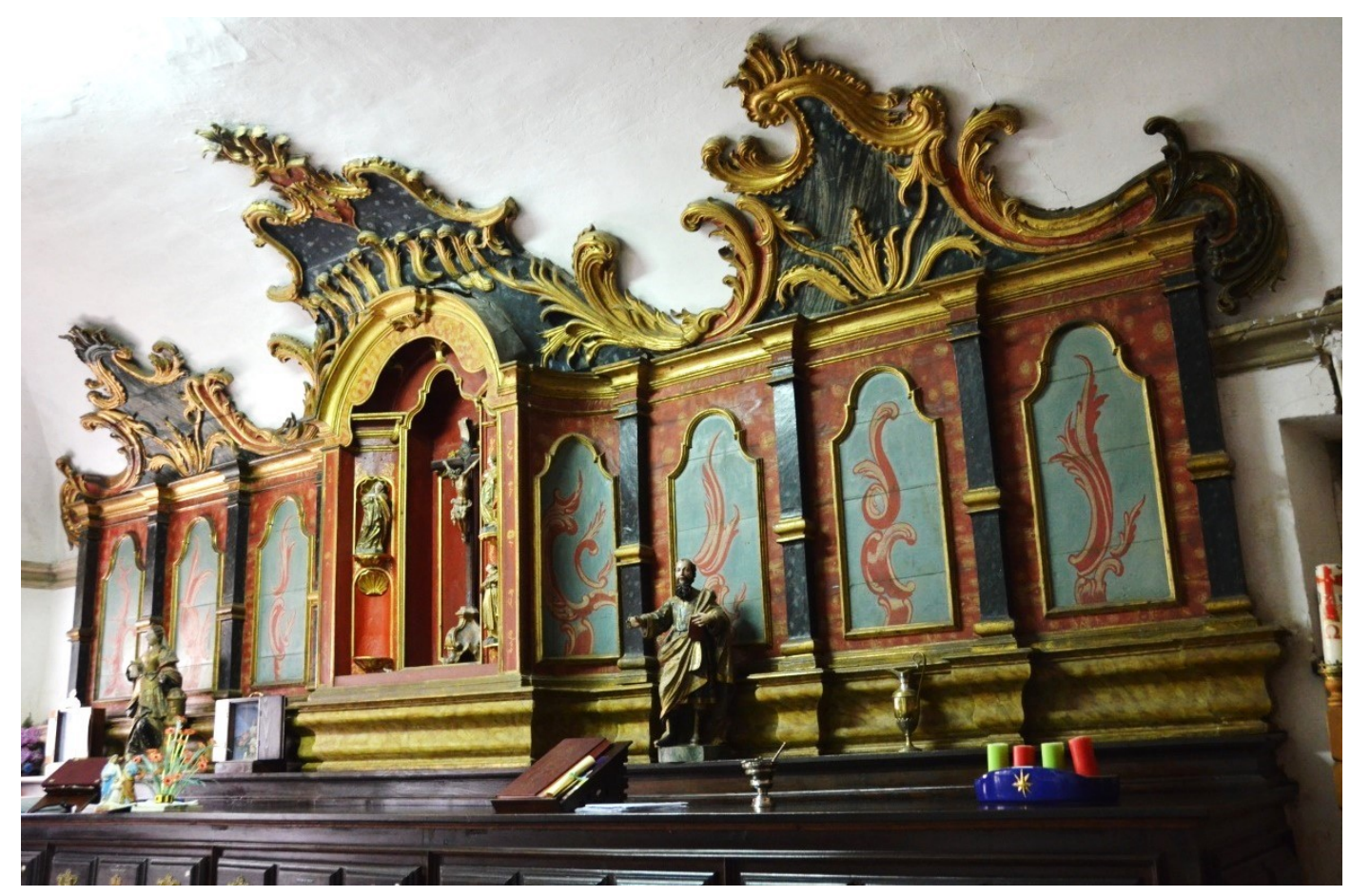

Imagem 5

Conjunto em talha que envolve o oratório sobre o arcaz da sacristia. Sobre o Arcaz estão atualmente expostas as imagens de Santa Bárbara (que estaria em 1834 no altar de Santo António da Igreja de Nossa

Senhora da Encarnação); e a imagem de São Joaquim (que estaria no altar de Santa Ana namesma igreja).

O inventário de 1834 refere ainda que "os santos de vulto" do oratório se apresentavam "todos com resplendores de prata" no entanto estão hoje desaparecidos. Assim, dos "santos de vulto a saber; Sam João, Nossa Senhora, Sam Sebastião, Santa Bárbara, Sam Domingos", que eram guardados dentro do oratório em 1834 chegaram até nós as imagens de Domingos (Imagem 6), Nossa Senhora (Imagem 7), São João, 
(Imagem 8), sendo que, apenas um dos nichos é que se encontra vazio é possível que as imagens em falta estivessem colocadas sobre o arcaz.

As alterações observadas na disposição das imagens na sacristia, tendo por base a comparação dos registos de 1834 e a observação no ano de 2013, revelam não só o desaparecimento de duas obras, mas também de todos os resplendores que à exceção do crucifixo todas as imagens ostentavam, e das vidraças que protegiam o oratório.

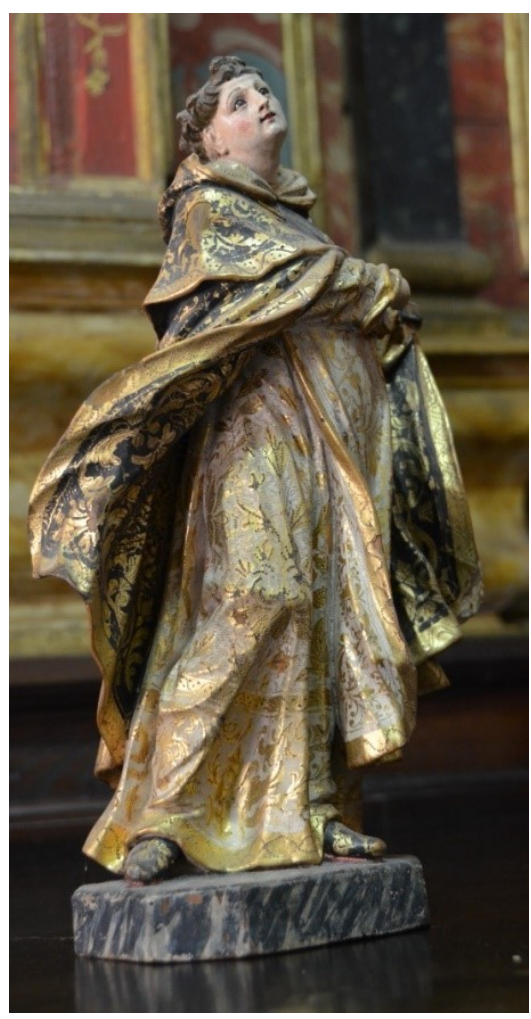

Imagem 6

São Domingos SIEV 02,

Oratório na sacristia

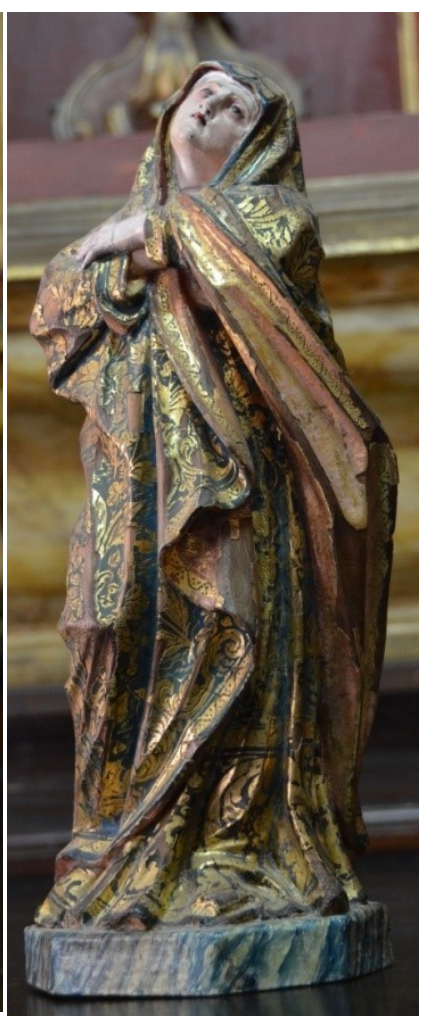

Imagem 7

Nossa Senhora SIEV 04

Oratório na sacristia

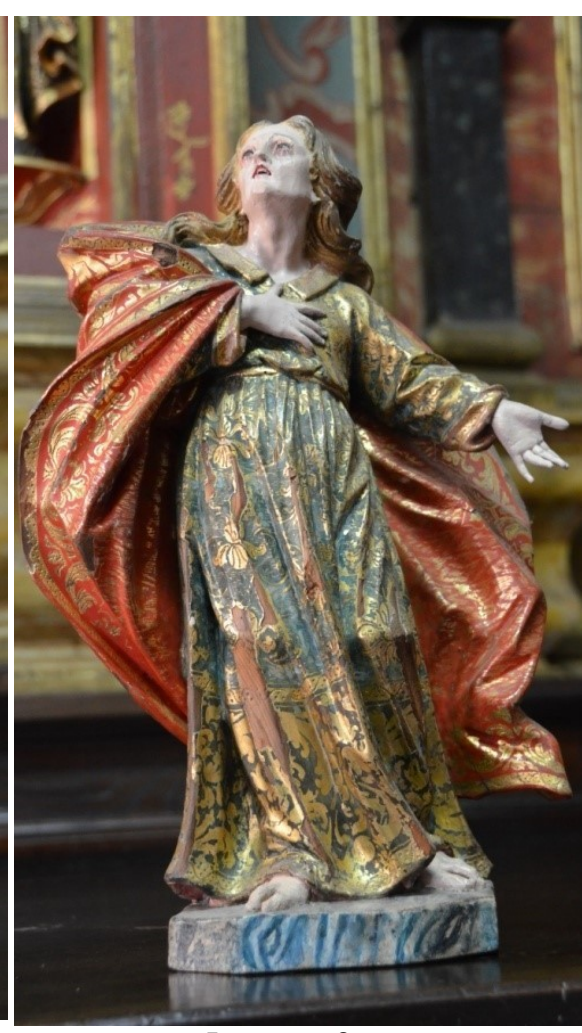

Imagem 8

São João SIEV 03

Oratório na sacristia

Após o inventário de mais cinco quadros é registado ainda no interior da sacristia:

"Hum prezepio com vidraça e dentro tem hum menino Jesus e sua

Mae e todas as mais figuras para representar o dito prezepio

avaluado no preço de quatro mil e oitocentos reis - 4\$800"17.

Atualmente existe uma maquineta com vidraça que guarda um presépio, conforme (Imagem 9). Porém já não se encontra na sacristia da igreja de Nossa Senhora da Encarnação mas está adossada ao arco triunfal da igreja de São Francisco da Venerável Ordem Terceira, construída contigua à igreja de Nossa senhora da Encarnação, podendo

17 A.N.T.T./A.H.M.F./S.N.S.E.V., Extinção das Ordens Religiosas - Seminário de Nossa Senhora da Encarnação - Vinhais, Arquivo Nacional da Torre do Tombo, Lisboa, Arquivo Histórico do Ministério das Finanças, Processos de Extinção das casas religiosas, Cx. 2265, 1834, s/fl. 
por isso tratar-se da mesma obra registada em 1834. Tal como surge no inventário de 1834 também hoje é possível observar "menino Jesus e sua Mae e todas as mais figuras" num conjunto constituído por trinta figuras, de tamanho aproximado de $15 \mathrm{~cm}$ de altura, que compõem a cena do presépio e inúmeros animais que as acompanham. A representação apresenta-se escalonada criando diversos planos narrativos. O plano central é ocupado pela choupana que abriga São José com resplendor e a Virgem Maria com coroa, ambos ajoelhados em adoração do Menino deitado entre eles sobre palhas.

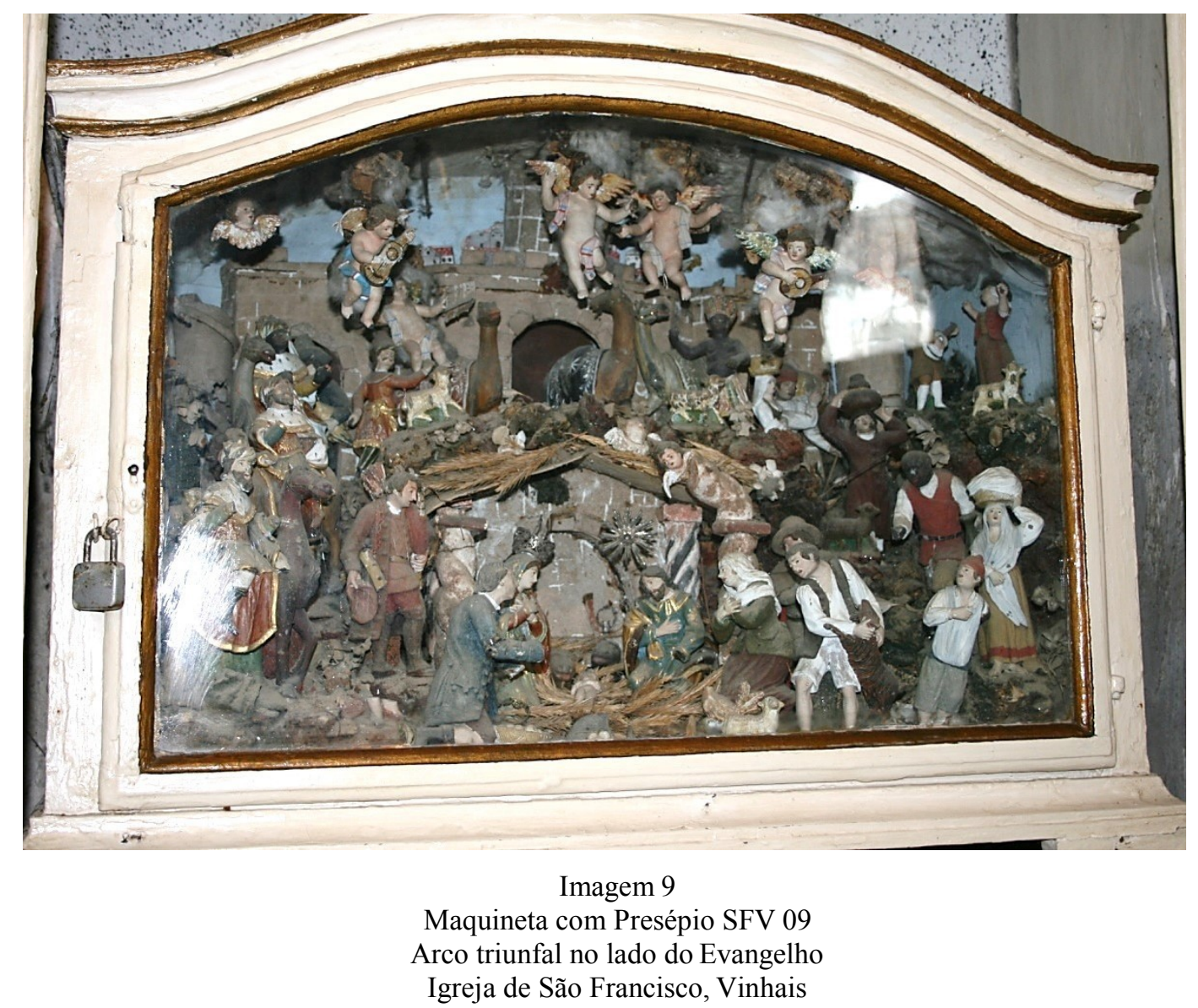

Relativamente ao inventário do interior da igreja foram primeiro registados os quadros, que constituem no total doze itens, sendo que, um dos itens tem mais que um quadro (trata-se de uma via sacra com catorze quadros no total ${ }^{18}$ ), que está atualmente

\footnotetext{
${ }^{18}$ As gravuras que representam a Via Crucis atualmente expostas no Museu de Arte Sacra de Vinhais foram registadas no inventário de 1834 como parte dos bens do Seminário Apostólico, não sendo por isso de crer que o conjunto tivesse sido encomendado pela Ordem Terceira conforme refere Rodrigues, mas antes sim pelos frades missionários. Rodrigues, Luís Alexandre, "Caminho Doloroso: as gravuras italianas da Ordem Terceira de Vinhais" in Natália Marinho Ferreira-Alves (Coord.), Franciscanos no Mundo Português III, Porto, CEPESE - Centro de Estudos da População, Economia e Sociedade 2013, pp. 491-527.
} 
em parte exposta no Museu de Arte Sacra. Após o registo dos quadros é que surge o registo das esculturas, ou imagens conforme são designadas no documento.

As imagens foram inventariadas partindo dos altares que as guardavam. Com início no altar-mor, seguido pelos restantes altares das diversas invocações lavadas a culto à época. Com a exceção da tribuna do altar-mor e do altar de Nossa Senhora da Boa Morte diferem dos cultos contemporâneos dos registados em 1834.

Imagem 10

Vista geral do altar-mor da igreja de Nossa Senhora da Encarnação. No nicho central, sobre a tribuna, está a imagem de Nossa Senhora da Encarnação IEV 06 com o Anjo da Anunciação IEV 07 suspenso. O conjunto está ladeado por São Domingos de Gusmão IEV 05 no lado da Epistola e Santo António IEV 08 do lado do Evangelho (no nicho originalmente ocupado pela imagem de São Francisco de Assis IEV 09).

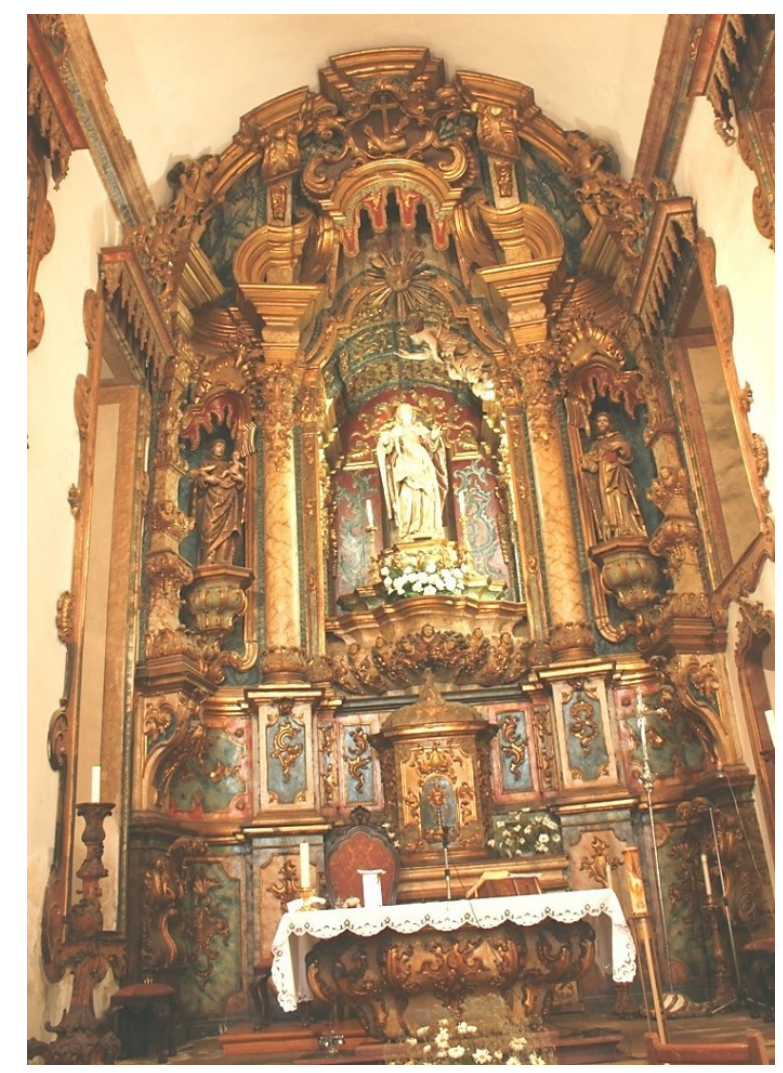

No altar-mor, comparando o registo de 1834 (Imagem 11) com a atual distribuição da imaginária regista-se a alteração das esculturas dos nichos laterais.

No inventário de 1834, o trono do altar-mor, expunha as mesmas imagens centrais do retábulo - Nossa Senhora da Encarnação e o Anjo. Mas o trono central estava ladeado pelas imagens de São Domingos de Gusmão, (Imagem 12) em conjunto com São Francisco, (Imagem 13). Atualmente o nicho do lado do Evangelho está ocupado pela escultura de Santo António, e o lado da Epistola expõe a imagem de São Domingos de Gusmão. 


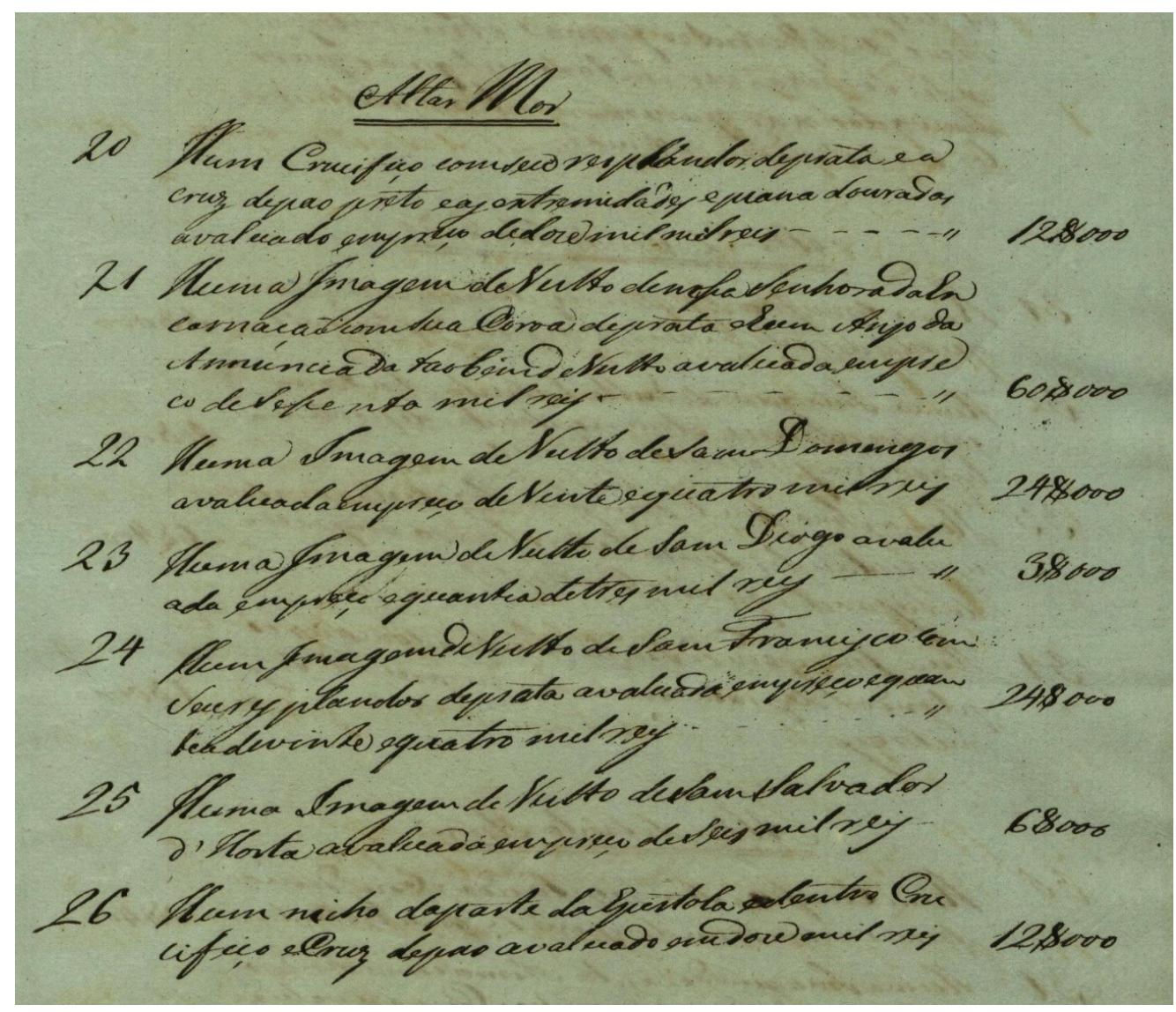

Imagem 11

Excerto do inventário dos bens de raiz do Seminário Franciscano de missionários apostólicos em Vinhais, relativo ao altar-mor

"Huma imagem de vulto de Nossa senhora da Encarnação com sua coroa de prata e seu Anjo da Anunciação também de vulto avaliada em preço de sesenta mil reis $-60 \$ 000$.

Huma imagem de vulto de Sam Francisco com seu resplendor de prata avaluado em preço e quantia de de vinte e quatro mil reis $24 \$ 000$

Huma imagem de vulto de Sam Domingos avaliada em preço de vinte e quatro mil reis $-24 \$ 000 " 19$.

${ }^{19}$ A.N.T.T./A.H.M.F./S.N.S.E.V., Extinção das Ordens Religiosas - Seminário de Nossa Senhora da Encarnação - Vinhais, Arquivo Nacional da Torre do Tombo, Lisboa, Arquivo Histórico do Ministério das Finanças, Processos de Extinção das casas religiosas, Cx. 2265, 1834, s/fl. 


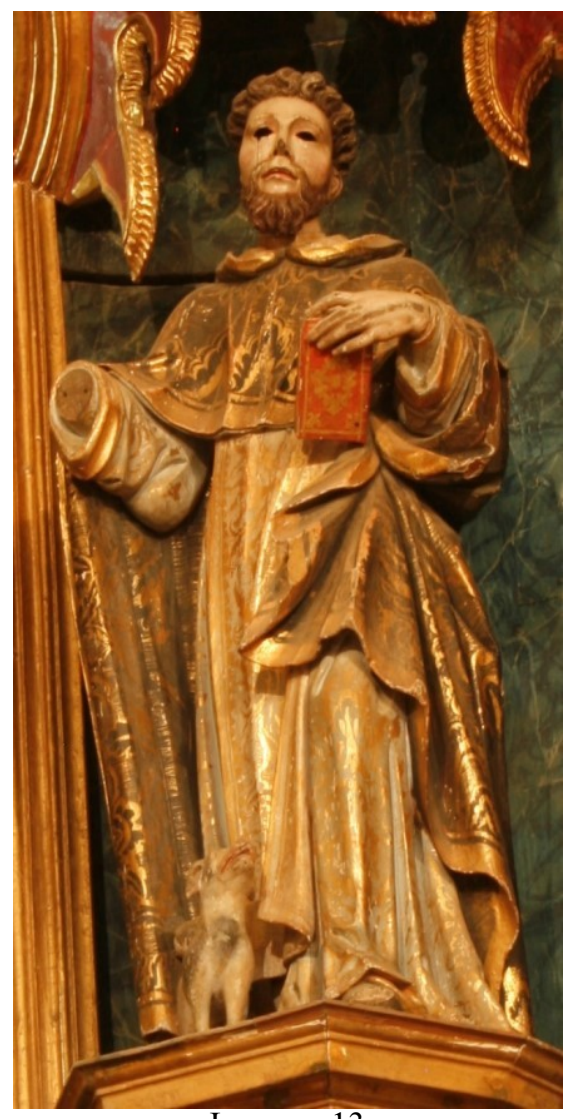

Imagem 13

Escultura de Santo Domingos de Gusmão que em conjunto com São Francisco de Assis, ladeava em 1834 o nicho central do altar-mor. Atualmente a imagem está no nicho do lado da Epistola no altarmor.

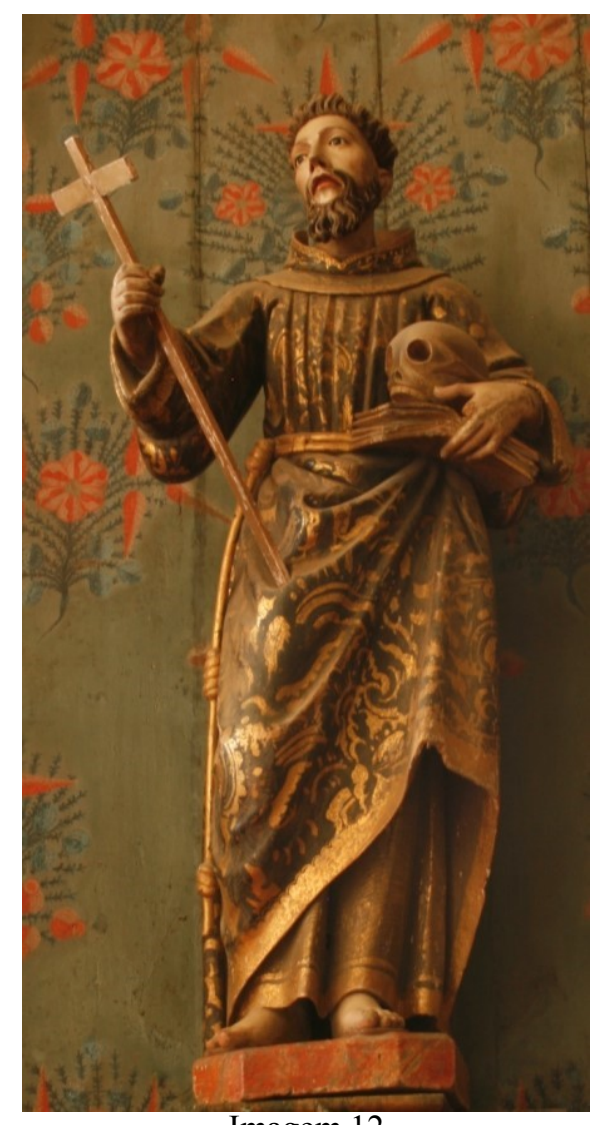

Imagem 12

Escultura de São Francisco de Assis, que em conjunto com São Domingos de Gusmão ladeava em 1834 o nicho central do altar-mor. Atualmente a imagem de São Francisco está exposta no outrora "Altar do Senhor Resuscitado".

Pela gestualidade das figuras, podemos supor que São Domingos de Gusmão estaria no lado do Evangelho, e não no lado da Epistola como está atualmente, e São Francisco estaria colocado à esquerda de Nossa Senhora, portanto no lado da Epistola. A ambas imagens é atribuído o mesmo valor de "vinte e quatro mil reis - 24\$000" apesar de na época a imagem de São Francisco ter um resplendor de prata e não haver qualquer referência ao resplendor de São Domingos. Atualmente, nenhuma das imagens ostenta resplendor. As semelhanças formais entre as imagens de São Francisco e Santo Domingos e a coerência iconográfica do conjunto que representa os dois principais impulsionadores das ordens mendicantes permite supor que terá sido originalmente pensado para acompanhar Nossa Senhora da Encarnação no altar-mor, e muito possivelmente poderão ter sido executados no mesmo momento.

Ainda no altar-mor foi registado: 
"Hum crucifixo com seu resplendor de prata e a cruz de pau preto e as extremidades e peanha douradas avaluado no preço de doze mil reis $-12 \$ 000,20$

Atualmente não está no altar-mor, mas pode tratar-se de uma das cruzes de altar exposta no contíguo Museu de Arte Sacra. Além deste crucifixo existia:

"Huma imagem de vulto de Sam Diogo avaliada em preço e quantia de três mil reis - 3\$000; Huma imagem de vulto de Sam Salvador d'Horta avaliada em preço de seis mil reis - $6 \$ 000$. Hum nicho de parte da Epistola e dentro Crucifixo e Cruz de pao avaluado em doze mil reis - 12\$000"21

Também as imagens de São Diogo e São Salvador da Horta, registados em 1834 não constam atualmente da imaginária inventariada nos espaços da igreja. Ambas as imagens seriam seguramente de menor tamanho, se atendermos ao menor valor que lhes é atribuído pelo inventariante, o que poderia permitir que estivessem colocados no supedâneo do retábulo, ou sob os nichos laterais em alguma saliência entretanto desaparecida ou nos diversos degraus que constituem o trono que serve de suporte à imagem central de Nossa Senhora da Encarnação.

No nicho lateral também já não está hoje o crucifixo de "pao", que estava então exposto dentro do nicho do lado da Epistola. Atualmente, este espaço está ocupado pela imagem de São José, que pertencia outrora ao altar de Santa Ana, conforme consta no registo efetuado em 1834.

$\mathrm{Na}$ leitura do documento depois da descrição das imagens do altar-mor, o inventariante descreve o altar do Senhor Ressuscitado. Atualmente a imagem do Senhor Ressuscitado está desaparecida"22. Mas em 1834 no "Altar do Senhor Resuscitado" existia:

\footnotetext{
${ }^{20}$ A.N.T.T./A.H.M.F./S.N.S.E.V., Extinção das Ordens Religiosas - Seminário de Nossa Senhora da Encarnação - Vinhais, Arquivo Nacional da Torre do Tombo, Lisboa, Arquivo Histórico do Ministério das Finanças, Processos de Extinção das casas religiosas, Cx. 2265, 1834, s/fl.

${ }^{21}$ A.N.T.T./A.H.M.F./S.N.S.E.V., Extinção das Ordens Religiosas - Seminário de Nossa Senhora da Encarnação - Vinhais, Arquivo Nacional da Torre do Tombo, Lisboa, Arquivo Histórico do Ministério das Finanças, Processos de Extinção das casas religiosas, Cx. 2265, 1834,s/fl.

${ }^{22}$ No catálogo Imagens e Esculturas - Comemorações Jubilares dos 450 anos da Diocese de Bragança Miranda, (Gomes, et al., 1996 p. 19) está registada com fotografia uma escultura que representa Cristo Ressuscitado da igreja de Nossa Senhora da Encarnação de Vinhais, que actualmente está em parte desconhecida.
} 
"Huma imagem de vulto de Jesus Christo avaluado em doze mil reis $-12 \$ 000$.

Hum Crucifixo de marfim e cruz de pao avaluado em preço e quantia de mil e seiscentos reis $-1 \$ 600$ "23.

O altar que ainda existe, no lado do Evangelho dentro da capela-mor, expõe hoje a imagem de São Francisco que julgamos ter estado originalmente do lado da Epistola no nicho lateral do altar-mor em conjunto com São Domingos de Gusmão.

Confrontado com o outrora denominado "Altar do Senhor Resuscitado" surge o "Altar da Senhora da Boa Morte", onde foi registado: "Hum Crucifixo e cruz e peanha de pao preto avaluado em preço e quantia de quinhentos reis - $\$ 500$ ” que já não consta da actual colecção da igreja e:

"Huma Senhora da Boa Morte hoje vestida com hum vestido cor de rosa em seu caixão com suas vidraças e tem dentro do caixão sete diferentes laminas humas com relíquias outras com pinturas de santos avaliada em preço de sessenta mil reis $-60 \$ 000^{24 \%}$.

A Senhora da Boa Morte está atualmente vestida com traje branco dentro do seu caixão com vidraças, (Imagem 13) no entanto, as lâminas com relíquias e com pinturas de santos já não estão expostas dentro do esquife que se encontra apenas ocupado pela imagem de Nossa Senhora. O registo termina com uma nota que refere:

"N.B. Tem em cima deste caixão dous portaes, dentro dos quaes se achão vinte e quatro buracos de diferentes formas e tem vidros por onde se deixão ver em todos relíquias que os Louvados não quizerão avaliar por seu valor não se poder estimar ${ }^{25}$ ".

Sobre o esquife embutido na parede, ainda hoje estão os espaços que outrora guardavam as relíquias, estão agora, na sua maioria, vazios.

\footnotetext{
${ }^{23}$ A.N.T.T./A.H.M.F./S.N.S.E.V., Extinção das Ordens Religiosas - Seminário de Nossa Senhora da Encarnação - Vinhais, Arquivo Nacional da Torre do Tombo, Lisboa, Arquivo Histórico do Ministério das Finanças, Processos de Extinção das casas religiosas, Cx. 2265, 1834, s/fl.

${ }^{24}$ A.N.T.T./A.H.M.F./S.N.S.E.V., Extinção das Ordens Religiosas - Seminário de Nossa Senhora da Encarnação - Vinhais, Arquivo Nacional da Torre do Tombo, Lisboa, Arquivo Histórico do Ministério das Finanças, Processos de Extinção das casas religiosas, Cx. 2265, 1834,s/fl.

${ }^{25}$ A.N.T.T./A.H.M.F./S.N.S.E.V., Extinção das Ordens Religiosas - Seminário de Nossa Senhora da Encarnação - Vinhais, Arquivo Nacional da Torre do Tombo, Lisboa, Arquivo Histórico do Ministério das Finanças, Processos de Extinção das casas religiosas, Cx. 2265, 1834, s/fl.
} 


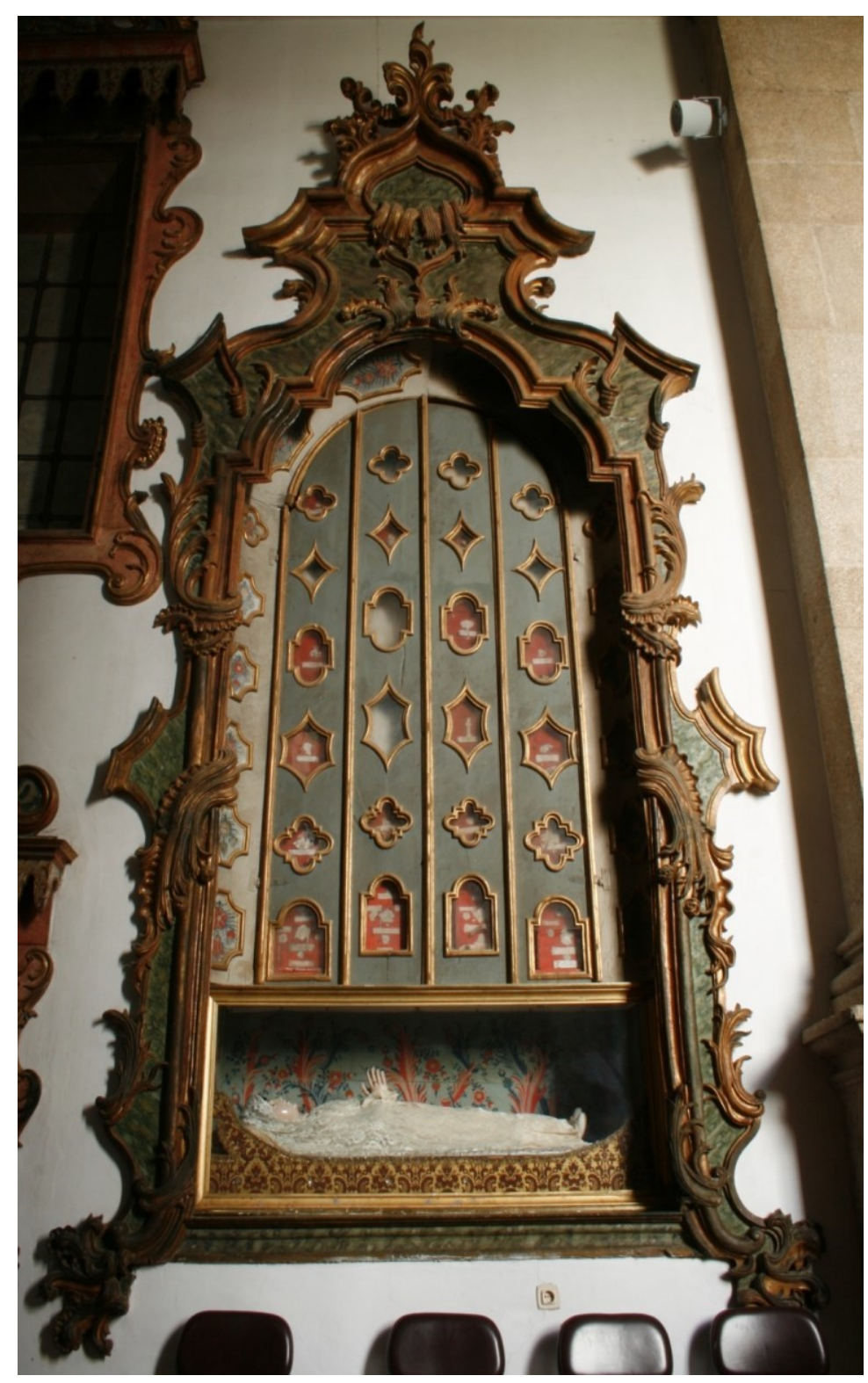

Figura 12

Retábulo rocaille da Senhora da Boa Morte IEV 03 com o armário das relíquias, dentro da capela-mor no lado da Epistola

Já no corpo da igreja foi registado o "Altar de Santo Antonio", que seria o retábulo que ainda hoje subsiste no lado do Evangelho. Atualmente o retábulo com elementos rocaille mas denunciando já as transformações neoclássicas, expõe apenas a imagem do Sagrado Coração de Jesus, obra datada de 1964 da autoria Guilherme F. Thedim (Imagem 14). 


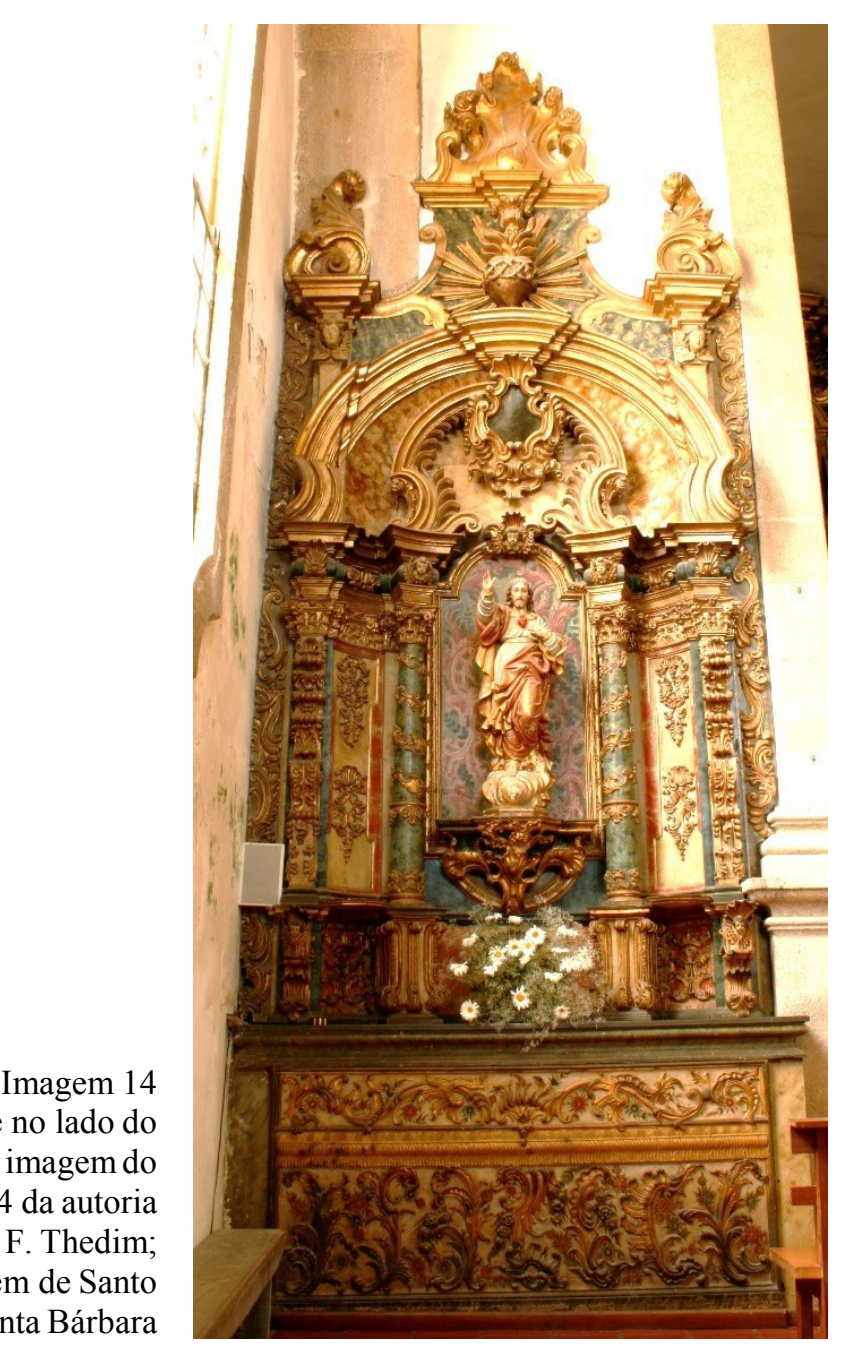

No entanto em 1834 expunha um crucifixo que atualmente já não expõe, e também uma imagem de Santo António, São João Batista e Santa Bárbara:

"Hum Crucifixo com seu resplendor e a cruz auguada de preto avaliada em preço de tres mil $3 \$ 00$

Huma imagem de vulto de Santo Antonio com seu menino e tem resplendor de prata avaluado em quarenta mil reis $-40 \$ 000$ Huma imagem de Sam João Baptista com seu resplendor de prata avaluado em preço de seis mil e quatrocentos reis $-6 \$ 400$ Hua imagem de Santa Barbara com resplendor de prata avaliada em preço de seis mil reis $-6 \$ 000^{26 "}$

\footnotetext{
${ }^{26}$ A.N.T.T./A.H.M.F./S.N.S.E.V., Extinção das Ordens Religiosas - Seminário de Nossa Senhora da Encarnação - Vinhais, Arquivo Nacional da Torre do Tombo, Lisboa, Arquivo Histórico do Ministério das Finanças, Processos de Extinção das casas religiosas, Cx. 2265, 1834,s/fl.
} 
A imagem de Santo António seguramente que se trata da imagem que atualmente está exposta no nicho do lado do Evangelho no altar-mor, hoje já sem o resplendor (Imagem 16).

A imagem de São João Batista inventariada poderá ser a que está atualmente num nicho do lado do evangelho onde outrora eram os confessionários, (Imagem 15), também sem o resplendor. Por fim, surge a referência de uma imagem de Santa Bárbara que certamente será a que está hoje na sacristia (Imagem 16), e que tal como na maioria das restantes imagens em que surge a referência ao resplendor, este encontra-se hoje ausente da escultura.

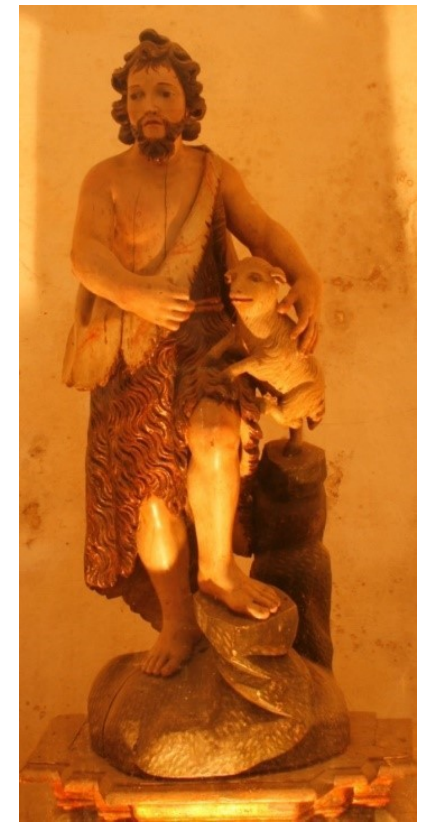

Imagem 15

São João Batista IEV 13 atualmente exposto num nicho do lado do evangelho

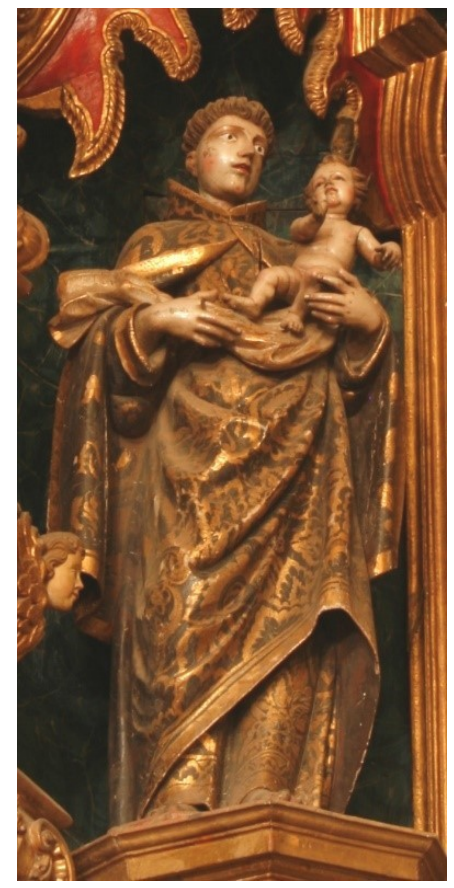

Imagem 16

Santo António com o Menino, IEV 8 atualmente exposto no altar-mor

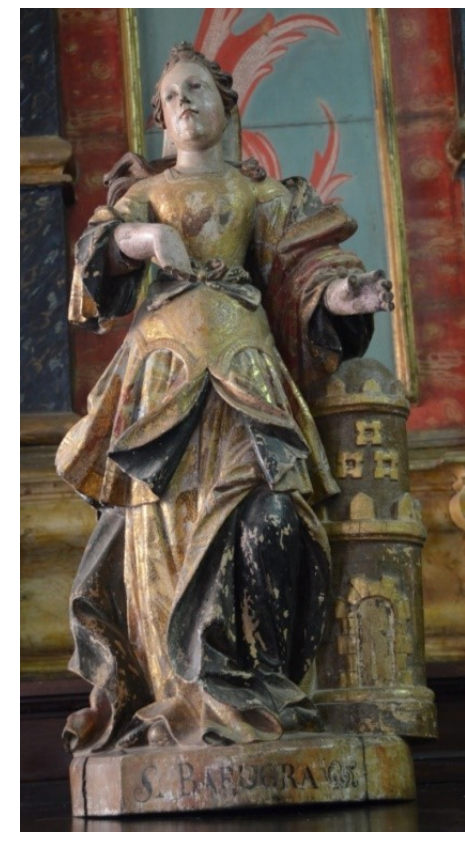

Imagem 17

Santa Bárbara, SIEV 6 atualmente exposta na sacristia

O altar de santo António está atualmente fragmentado enquanto conjunto hagiológico, no entanto, apesar de expostas em diferentes locais é-nos ainda possível entender a narrativa que constituíam.

No lado da Epistola também se mantém o retábulo, de igual feição que o retábulo no lado do evangelho. Atualmente guarda apenas a imagem de Nossa Senhora de Fátima de 1964 de Guilherme F. Thedim.

Todavia em 1834 era identificado como "Altar de Santa Ana", e expunha: 
"Hum crucifixo sem resplendor e cruz de madeira avaliada em dous mil e quatrocentos $-2 \$ 400$.

Huma imagem de Santa Ana com a Senhora ao collo cada huma com sua coroa avaliada em preço de vinte mil reis $-20 \$ 000$

Huma imagem do menino Jesus em ponto grande com seu resplendor avaluado em preço de seis mil ris $-6 \$ 000$

Duas imagens de vulto hua de Sam José outra de Sam Joaquim ambos com resplendor e avaliada cada hua em preço de catorze e quatrocentos reis somão vinte e oito mile oitocentos reis $28 \$ 800^{27}$

O crucifixo já não consta da atual coleção, assim como a "imagem do menino Jesus em ponto grande com seu resplendor" e a disposição atual das imagens que ainda existem envolve diversos espaços.

A imagem de "Santa Ana com a Senhora ao collo", que não é ao colo mas ao lado, está colocada num nicho no lado do evangelho (Imagem 19). Já nenhuma das figuras ostenta a coroa que originalmente possuíam. Relativamente às "Duas imagens de vulto hua de Sam José ${ }^{28}$ outra de Sam Joaquim ambos com resplendor" atualmente a escultura de São José (Imagem 20) está num nicho do lado da Epistola dentro da capela-mor e a imagem de São Joaquim (Imagem 18) está colocada sobre o arcaz da sacristia. Já nenhuma das esculturas apresenta o resplendor.

O altar de santa Ana está hoje em dia segmentado enquanto conjunto, e a falta da imagem do "menino Jesus em ponto grande" empobrece o que seria a narrativa completa da sagrada família. Porém, as imagens que restam e apesar de expostas em diferentes locais permitem supor o conjunto que originalmente criavam.

\footnotetext{
27 A.N.T.T./A.H.M.F./S.N.S.E.V., Extinção das Ordens Religiosas - Seminário de Nossa Senhora da Encarnação - Vinhais, Arquivo Nacional da Torre do Tombo, Lisboa, Arquivo Histórico do Ministério das Finanças, Processos de Extinção das casas religiosas, Cx. 2265, 1834, s/fl.

${ }^{28}$ Existe uma referência a outra imagem de São José, já no final do documento de inventário, na desaparecida capela de Nossa Senhora do Carmo ou do Claustro "Huma imagem de Sam Jose com o menino ambos de vulto com resplendores de prata avaluados em preço de vinte mil reis - 20\$000". No entanto o superior valor dado à imagem que estava na capela de Nossa Senhora do Carmo ou do Claustro sugere que deveria ser uma imagem de maior tamanho que a estatueta que chegou aos nossos dias ainda a culto. A.N.T.T./A.H.M.F./S.N.S.E.V., Extinção das Ordens Religiosas - Seminário de Nossa Senhora da Encarnação - Vinhais, Arquivo Nacional da Torre do Tombo, Lisboa, Arquivo Histórico do Ministério das Finanças, Processos de Extinção das casas religiosas, Cx. 2265, 1834, s/fl.
} 


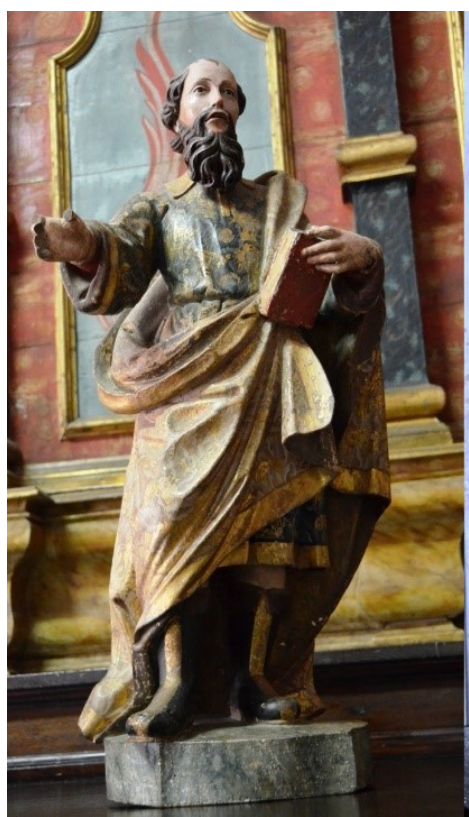

Imagem 18

São Joaquim SIEV 01 atualmente exposto na sacristia

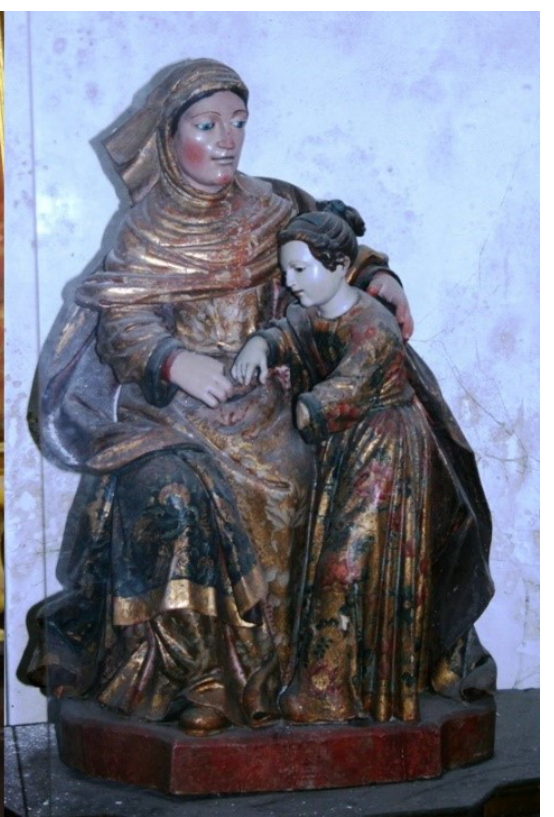

Imagem 19

Santa Ana com a Virgem IEV 12 atualmente colocada dentro de um nicho no lado do evangelho

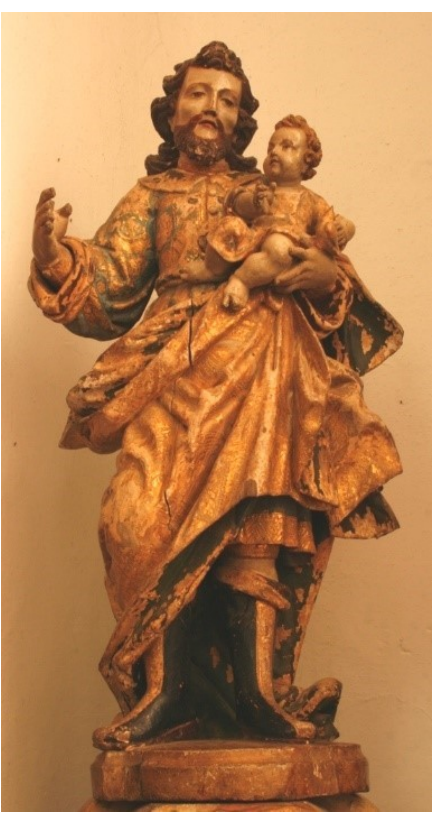

Imagem 20

São José IEV 4

atualmente exposto no nicho da capela-mor no lado da epístola

Ainda dentro da igreja, o coro constituía em 1834 mais um espaço de exposição das imagens a culto, facto que atualmente já não se observa pela restrição de entrada a partir da igreja.

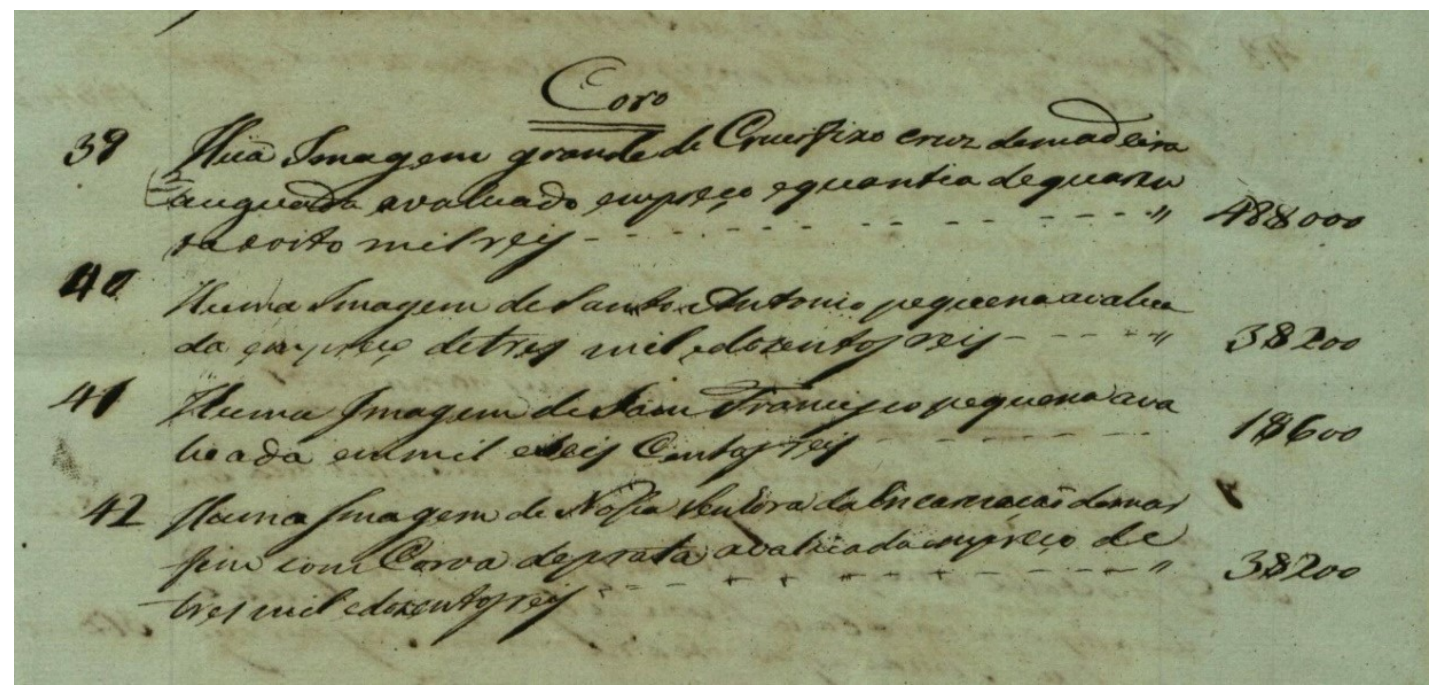

Imagem 21

Excerto do inventário dos bens de raiz do Seminário Franciscano de missionários apostólicos em Vinhais, relativo ao coro 
Hoje em dia, apenas se acede ao coro alto da igreja de nossa Senhora da Encarnação a partir do museu de Arte Sacra que ocupa o espaço outrora conventual que liga agora a igreja de Nossa Senhora da Encarnação com a contígua igreja de são Francisco da Venerável Ordem Terceira.

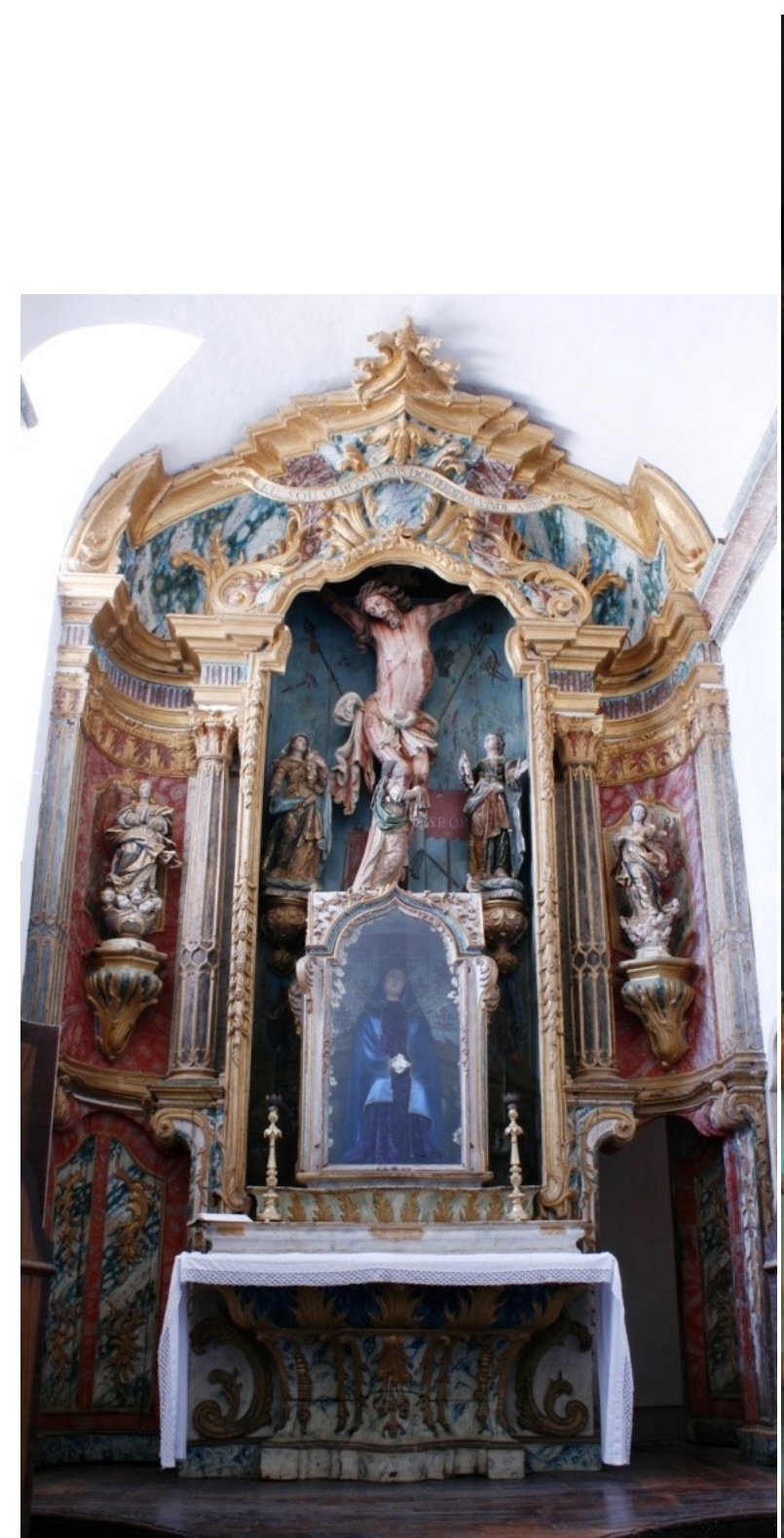

Imagem 22

Retábulo rocaille da capela de Nossa Senhora das Dores

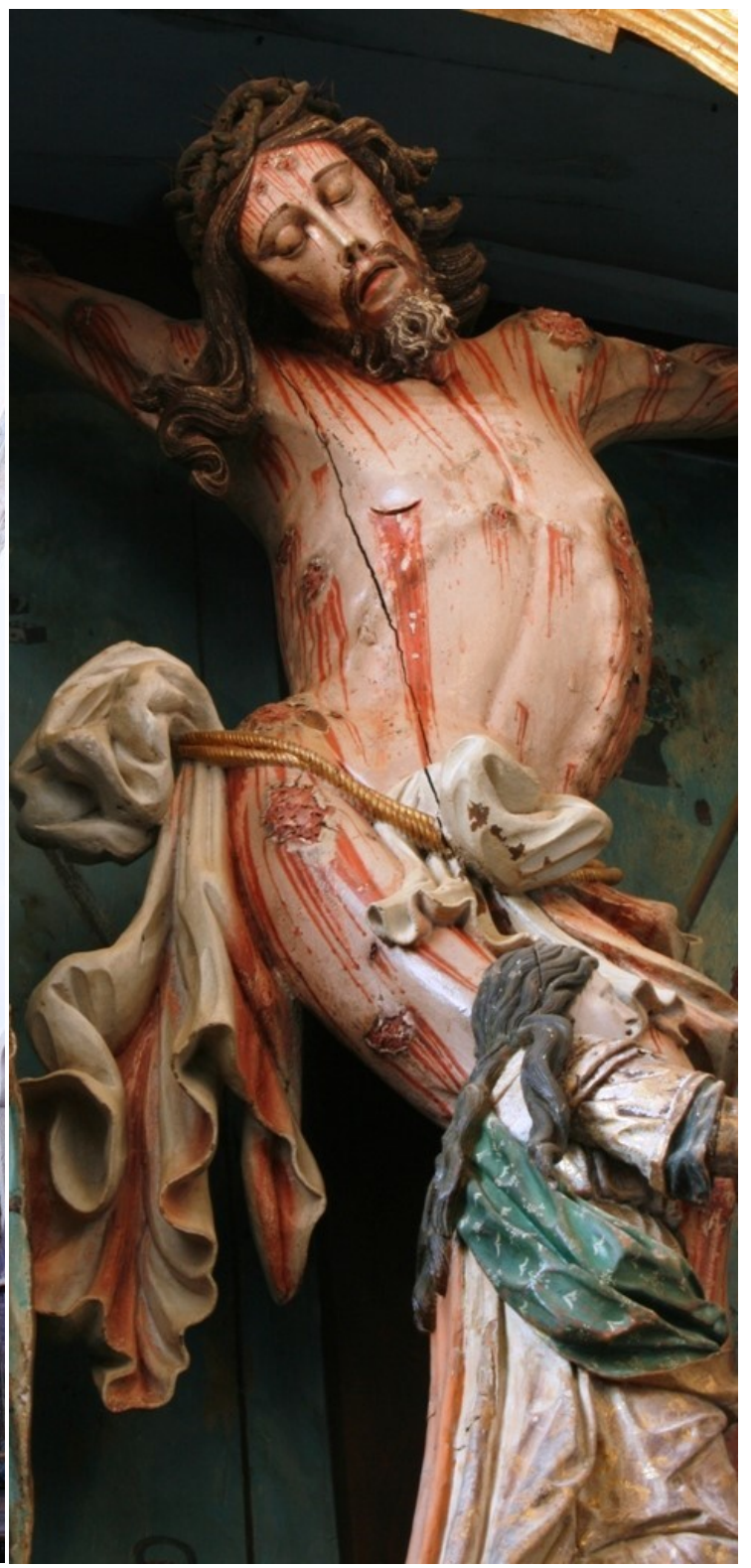

Imagem 23

Detalhe da imagem de "Cristo do Côro" exposto no retábulo da capela de Nossa Senhora das Dores

No inventário do Coro (Imagem 21) foi registada "Hua imagem grande de Crucifixo cruz de madeira auguada avaluado em preço e quantia de quarenta e oito mil reis - 


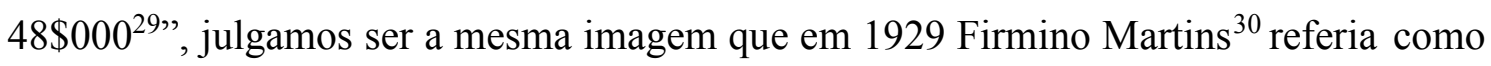
o "Senhor do Côro, (...) na capela do lado direito do pórtico da igreja". É a única imagem de um crucifixo de grande tamanho que existe ainda hoje no conjunto edificado franciscano de Vinhais, o elevado valor que lhe é atribuído no inventário (comparativamente ao valor das restantes imagens) reforça a importância da escultura, não só pela escala do tamanho mas seguramente também pela expressividade escultórica que a imagem traduz.

A imagem colossal está atualmente a culto no retábulo da capela de nossa Senhora das Dores (Imagem 22 e Imagem 23), conforme estaria já em 1929 quando Firmino Martins a atribuiu a Frei Domingos.

São evidentes os trabalhos de adaptação do nicho central do retábulo, claramente limitado de tamanho face à escala colossal da figura de Cristo, o que nos permite supor que originalmente a imagem não teria sido executada para aquele espaço. Bem como, a escala e os detalhes escultóricos da figura de Cristo permitem compará-la com a também colossal figura de Nossa Senhora da Encarnação, que lhe estaria originalmente oposta, permitindo-nos pensar que se tratam de obras executadas no mesmo momento e pela mesma autoria.

Além da "imagem grande de Crucifixo" estavam também a culto no coro alto:

$$
\begin{aligned}
& \text { "Huma imagem de Santo Antonio pequena avaliada em preço de } \\
& \text { três mil e duzentos reis }-3 \$ 000 \\
& \text { Huma imagem de Sam Francisco pequena avaliada em mil e } \\
& \text { seiscentos reis - } 1 \$ 600
\end{aligned}
$$

\footnotetext{
${ }^{29}$ A.N.T.T./A.H.M.F./S.N.S.E.V., Extinção das Ordens Religiosas - Seminário de Nossa Senhora da Encarnação - Vinhais, Arquivo Nacional da Torre do Tombo, Lisboa, Arquivo Histórico do Ministério das Finanças, Processos de Extinção das casas religiosas, Cx. 2265, 1834, s/fl.

${ }^{30}$ Obra do escultor Frei Domingos, notável artista, a quem são atribuídas algumas das esculturas que ainda hoje se observam na Igreja do convento, entre as quais, é reconhecida pelos entendidos como obraprima a imagem do Senhor do Côro, hoje na capela do lado direito do pórtico da igreja, e tantos outros, que seria fastidioso enumerar. Martins, Firmino A., Subsídios para a história religiosa do distrito de Bragança: a Ordem III e a casa do Fundador do convento de S. Francisco de Vinhais, Coimbra, Imprensa da Universidade, 1929, p. 8; Castro, José de, Bragança e Miranda, (Bispado) Tomo II, Porto, Tipografia Porto Médico, Lda, 1947 , p. 358. Ambos os autores destacam outros frades de Vinhais que se notabilizaram nas letras e em cargos eclesiásticos. Castro refere que em 1796 tinha o seminário, 17 religiosos, 6 leigos, 6 donatos e 4 moços Castro, José de, Bragança e Miranda, (Bispado) Tomo II, Porto, Tipografia Porto Médico, Lda, 1947, p. 361.
} 
Huma imagem de Nossa Senhora da Encarnação em marfim com coroa de prata avaliada em preço de três mil e duzentos reis $3 \$ 200^{31}$,

Nenhuma destas imagens se encontra atualmente no coro alto, nem em qualquer outra dependência da igreja. No inventário efetuado no decurso desta pesquisa consta no museu de Arte Sacra uma imagem de Nossa Senhora, esculpida em marfim, (Imagem 24), trata-se porém de uma Imaculada Conceição e não de "Nossa Senhora da Encarnação", conforme refere o inventário de 1834, persiste por isso a dúvida sobre se é a mesma imagem ou se de duas imagens distintas se trata. Também sobre esta pequena figura de marfim foi referido pela atual zeladora que estava originalmente no oratório da sacristia, porém, tal como referido na nota que acompanha a análise documental relativa à sacristia, tal informação não foi confirmada em nenhum registo.

Imagem 24

Imaculada Conceição MASV 05, em marfim, atualmente exposta no Museu de Arte Sacra

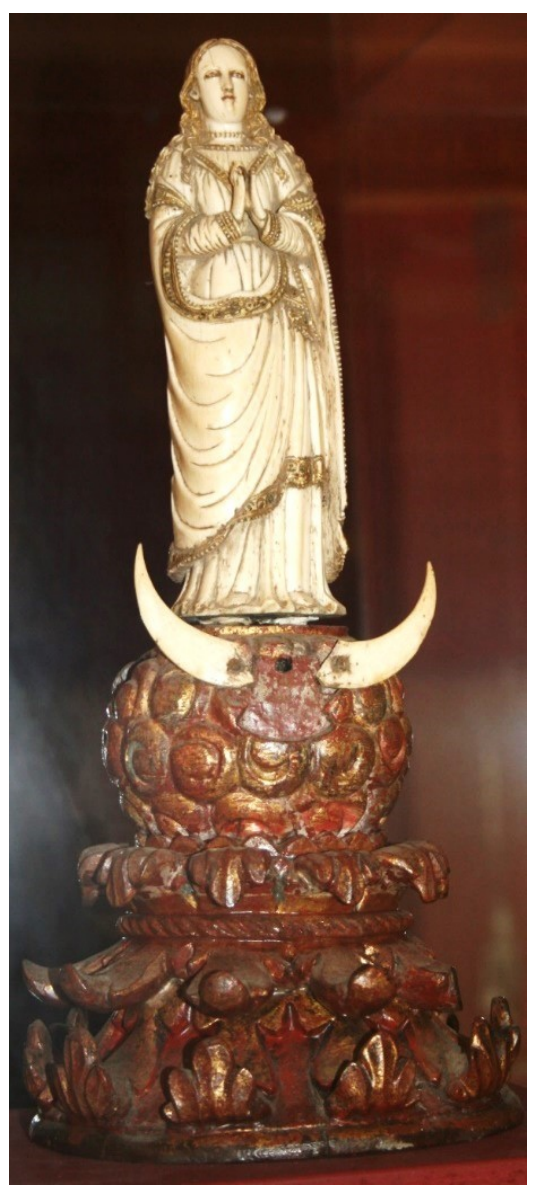

\footnotetext{
${ }^{31}$ A.N.T.T./A.H.M.F./S.N.S.E.V., Extinção das Ordens Religiosas - Seminário de Nossa Senhora da Encarnação - Vinhais, Arquivo Nacional da Torre do Tombo, Lisboa, Arquivo Histórico do Ministério das Finanças, Processos de Extinção das casas religiosas, Cx. 2265, 1834, s/fl.
} 
Com assentada datada de 7 de Junho de 1834 e lavrada na sacristia do extinto convento dos missionários apostólicos de Vinhais prossegue o inventário dos bens móveis, depois de registada a sacristia e a igreja segue-se a capela da Senhora das Dores, contigua à igreja de Nossa Senhora da Encarnação com entrada principal a partir do nártex, atualmente porém acede-se por uma porta lateral, junto ao retábulo, a partir do Museu de Arte Sacra.

\section{"Capella da Senhora das Dores}

Hum Crucifixo com resplendor de prata e cruz pequena de pau preto avaliada em preço de três mil e duzentos reis $-3 \$ 200$

Hum camarim com vidros tem dentro Nossa Senhora das Dores com sete espadas de prata e a Senhora de vestes avaliada em preço de quarenta mil - $40 \$ 000$

Hum Crucifixo sem resplendor grande e a cruz de madeira avaluado em trinta mil reis $-30 \$ 000$

Tres imagens de vulto que são Nossa Senhora Sam João e a Madalena cada huma avaliada com preço de vinte mil reis somão a quantia de sessenta mil reis $-60 \$ 000$

Huma imagem de vulto de Sam Boaventura avaliada em catorze mil e quatrocentos reis $-14 \$ 400$

Huma imagem de vulto de Sam Bernardino com resplendor avaliada em preço de catorze mil e quatrocentos reis $-14 \$ 400^{32}$,

32 A.N.T.T./A.H.M.F./S.N.S.E.V., Extinção das Ordens Religiosas - Seminário de Nossa Senhora da Encarnação - Vinhais, Arquivo Nacional da Torre do Tombo, Lisboa, Arquivo Histórico do Ministério das Finanças, Processos de Extinção das casas religiosas, Cx. 2265, 1834, s/fl. 


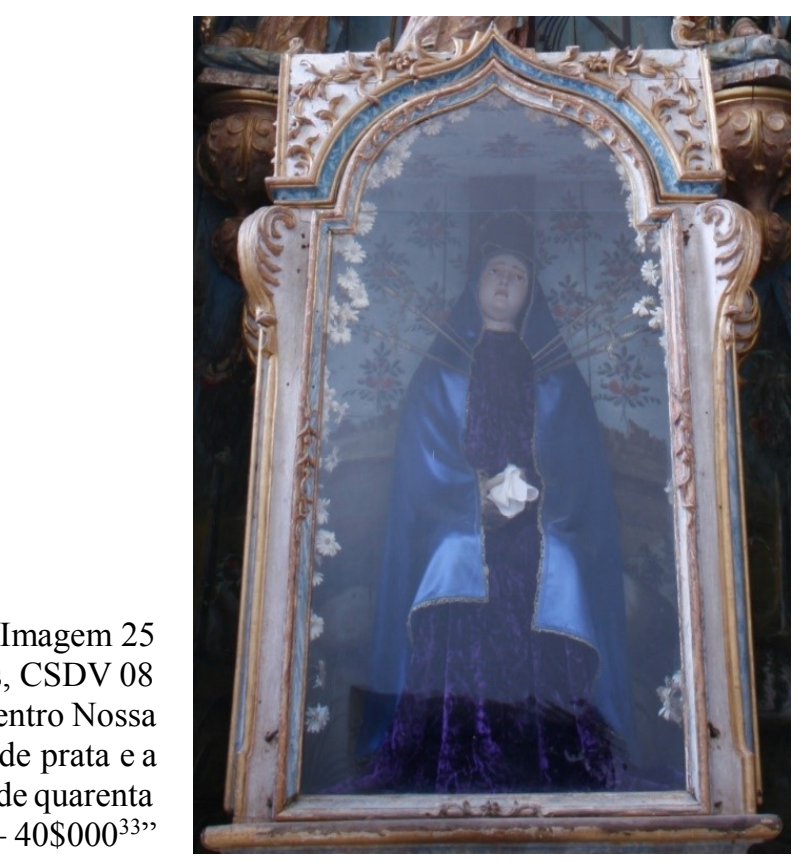

O "Crucifixo com resplendor de prata e cruz pequena de pau preto", já não consta na disposição do retábulo, poder-se-á tratar de uma das cruzes de altar atualmente expostas no Museu de arte Sacra.

O "Crucifixo sem resplendor grande e a cruz de madeira avaluado em trinta mil reis 30\$000", estará desaparecido também. Julgamos que o Cristo de tamanho colossal hoje exposto na capela é o que outrora estaria colocado no coro alto, o que permite pensar que a imagem do Crucifixo grande registada em 1834 dentro da capela terá sido retirada e substituída pela imagem que estava antes no coro.

As restantes imagens que compõem o retábulo ainda se mantêm hoje na disposição registada em 1834; Nossa Senhora das Dores estava em "Hum camarim com vidros (...) com sete espadas de prata e a Senhora de vestes" (Imagem 25), assim como as "Tres imagens de vulto que são Nossa Senhora Sam João e a Madalena" (Imagem 26, 27, 28) e que compõem o conjunto do calvário, estando enquanto conjunto, seguramente associados ao mesmo momento de produção.

\footnotetext{
${ }^{33}$ A.N.T.T./A.H.M.F./S.N.S.E.V., Extinção das Ordens Religiosas - Seminário de Nossa Senhora da Encarnação - Vinhais, Arquivo Nacional da Torre do Tombo, Lisboa, Arquivo Histórico do Ministério das Finanças, Processos de Extinção das casas religiosas, Cx. 2265, 1834, s/fl.
} 


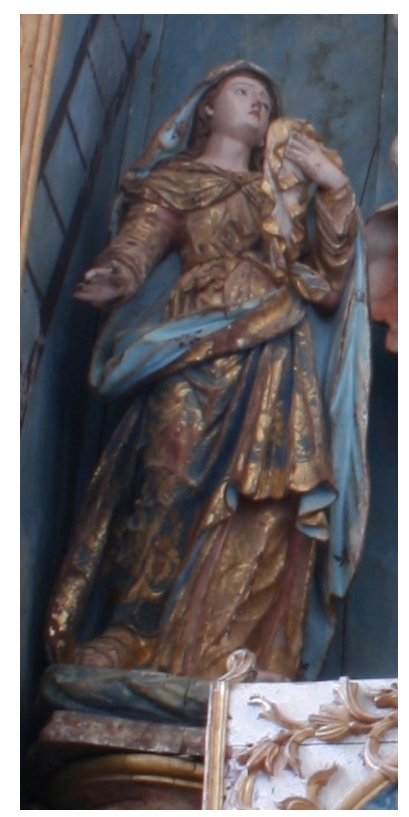

Imagem 26

Nossa Senhora, CSDV 05, Capela de Nossa Senhora das Dores

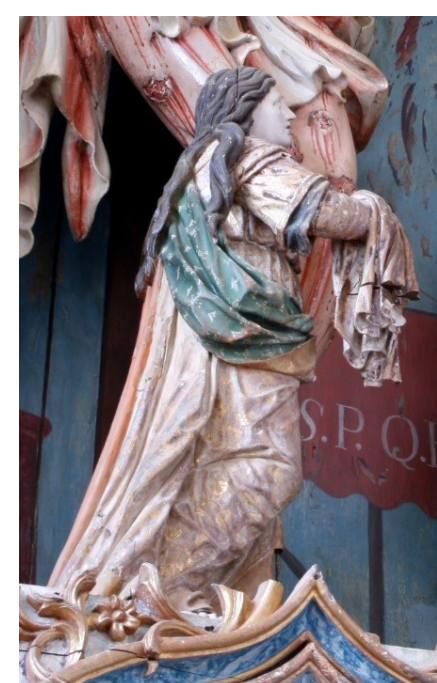

Imagem 27

Santa Maria Madalena, CSDV 04, Capela de Nossa Senhora das Dores

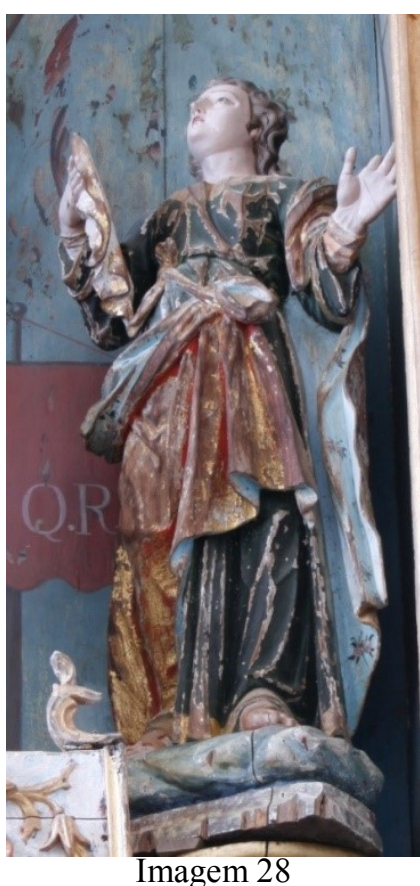

São João, CSDV 03,

Capela de Nossa Senhora das Dores

O mesmo se observa relativamente às imagens de São Bernardino e São Boaventura (Imagens 29, 30) que se mantêm ainda dentro da capela de Nossa Senhora das Dores. Atualmente estão confrontadas em nichos laterais junto ao retábulo.

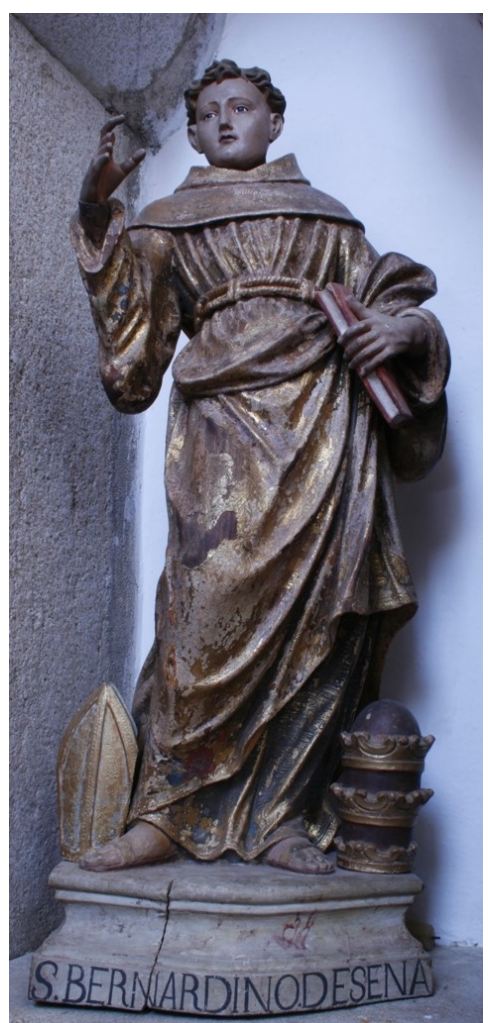

Imagem 29

São Bernardino CSDV 01 Capela de Nossa Senhora das Dores

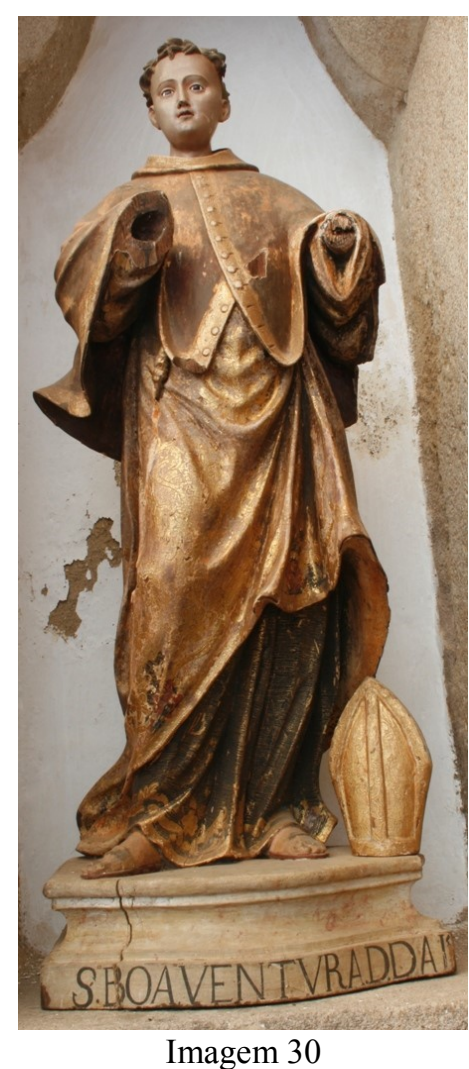

São Boaventura CSDV 09 Capela de Nossa Senhora das Dores 
Após o registo das imagens no inventário de 1834 segue-se o capítulo do registo dos "Vasos sagrados ornatos e mais paramentos", onde além dos vasos sagrados foi também registada a vasta paramentaria que existia então no convento. De entre elas destacamos um palio, pela possibilidade de se relacionar com as cerimónias públicas de exposição das imagens e também pelo elevado valor que lhe é atribuído, sendo dos bens móveis um dos que foi mais valorizado:

"Hum palio de seda vermelha bordado com paletão de ouro com seis varas de pao preto avaluado tudo em preço de trezentos mil

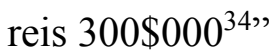

Também relacionado com a exposição pública das imagens, possivelmente com a imagem jacente da Senhora da Boa Morte, surge: "Huma urna de Semana Santa de talha dourada avaliada e preço de oito mil reis $-8 \$ 000^{35}$ ",

Após o registo de todos os bens móveis são inventariados os retábulos e outras estruturas arquitetónicas no interior da igreja, que nos permitem perceber a organização interior dos altares e dos diferentes espaços de culto:

"Finalmente nomeou a igreja que tinha sido dos Missionários Apostolicos, e estava anexa ao convento dos ditos frades a qual igreja he magnifica da invocação de Nossa Senhora da Encarnação tem hum grande retablo dourado, tribuna e altar de frontaes, tem mais quatro altares colleteraes, do Senhor Ressuscitado e de Santa Ana de hum lado, e do outro a Senhora da Boa Morte e Santo Antonio todos tem retablos bons de talha dourada: tem umas grades altas pintadas, separando o corpo da igreja tem coro, vasos no coro, cadeiras altas separadas pintadas, e douradas tem púlpitos pintados, e finalmente tem confissionários

\footnotetext{
${ }^{34}$ A.N.T.T./A.H.M.F./S.N.S.E.V., Extinção das Ordens Religiosas - Seminário de Nossa Senhora da Encarnação - Vinhais, Arquivo Nacional da Torre do Tombo, Lisboa, Arquivo Histórico do Ministério das Finanças, Processos de Extinção das casas religiosas, Cx. 2265, 1834, s/fl.

${ }^{35}$ Ainda no inventário dos têxteis há o registo de vários frontais para os altares, ao todo oito, três deles em damasco, e dois em madeira em talha dourada para os altares colaterais. Inventariaram também os tocheiros, castiçais, campainhas, alâmpadas, espevitadores e apagadores, lavatórios e até a cera branca. A.N.T.T./A.H.M.F./S.N.S.E.V., Extinção das Ordens Religiosas - Seminário de Nossa Senhora da Encarnação - Vinhais, Arquivo Nacional da Torre do Tombo, Lisboa, Arquivo Histórico do Ministério das Finanças, Processos de Extinção das casas religiosas, Cx. 2265, 1834, s/fl.
} 
metidos na parede tendo as portas para os claustros do extinto convento com quem confronta pela parte do Nascente e pela parte do Poente com a Igreja dos Terceiros, tem um pateo a entrada da igreja do dito convento extinto que fecha com grades de ferro, e para a parte de Poente tem huma capela que se domina com appelido de Nossa Senhora das Dores com sua sacristia que tudo foi avaluado pelos Louvados attendendo ao tempo prezente e estimação que agora tinha em preço de cinco contos de reis $5: 000 \$ 000^{36,}$

Depois do registo dos elementos arquitetónicos e com assentada datada de 10 de Junho de 1834, são inventariados os bens das demais capelas que existiam então dentro do convento: a Capela da Senhora do Carmo; capela do Capitulo; Altar da Enfermaria e a Capela do Noviciado.

Atualmente já nenhum destes espaços existe enquanto tal, no entanto, algumas das imagens inventariadas podem ser identificadas com imagens que ainda hoje estão a culto ou em guarda no Museu de Arte Sacra. Da desaparecida capela da Senhora do Carmo ou Claustro, constava:

"Hum crucifixo de marfim sem resplendor e a cruz de pau preto com embutidos avaluado em preço de quatro mil reis $-4 \$ 000$

Huma imagem de Nossa Senhora do Carmo com coroa de prata avaliada em preço de vinte e quatro mil reis $-24 \$ 000$

Huma imagem de Sam Jose com o menino ambos de vulto com resplendores de prata avaluados em preço de vinte mil reis $20 \$ 000$

Huma imagem de Sam Miguel o Anjo avaluado em preço de catorze mil e quatrocentos reis $-14 \$ 400$

N.B. Todos estes santos estavam na capella chamada da Senhora do Carmo no Claustro ${ }^{37,}$

\footnotetext{
${ }^{36}$ A.N.T.T./A.H.M.F./S.N.S.E.V., Extinção das Ordens Religiosas - Seminário de Nossa Senhora da Encarnação - Vinhais, Arquivo Nacional da Torre do Tombo, Lisboa, Arquivo Histórico do Ministério das Finanças, Processos de Extinção das casas religiosas, Cx. 2265, 1834, s/fl.

${ }^{37}$ A.N.T.T./A.H.M.F./S.N.S.E.V., Extinção das Ordens Religiosas - Seminário de Nossa Senhora da Encarnação - Vinhais, Arquivo Nacional da Torre do Tombo, Lisboa, Arquivo Histórico do Ministério das Finanças, Processos de Extinção das casas religiosas, Cx. 2265, 1834, s/fl.
} 


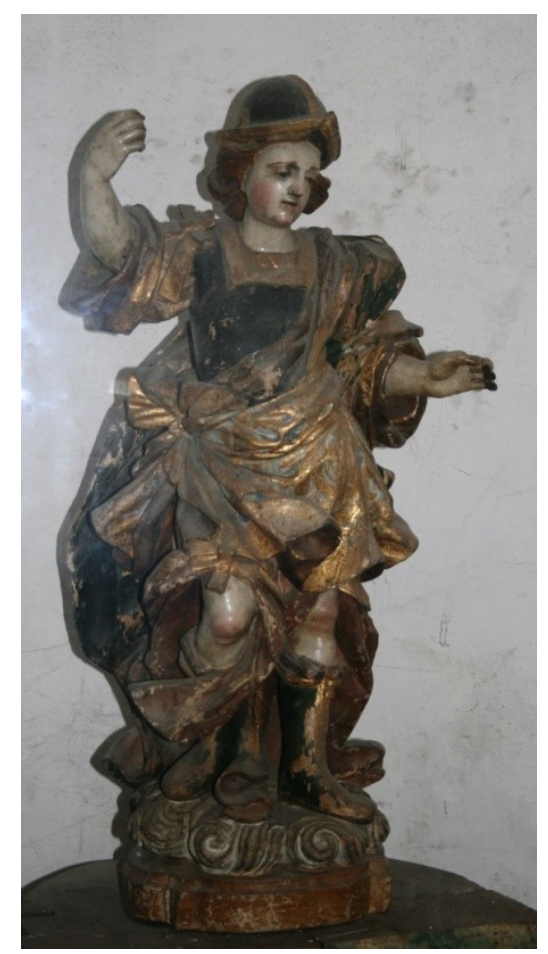

Imagem 31

São Miguel Arcanjo IEV 11

atualmente exposto lado do evangelho na igreja de Nossa Senhora da Encarnação

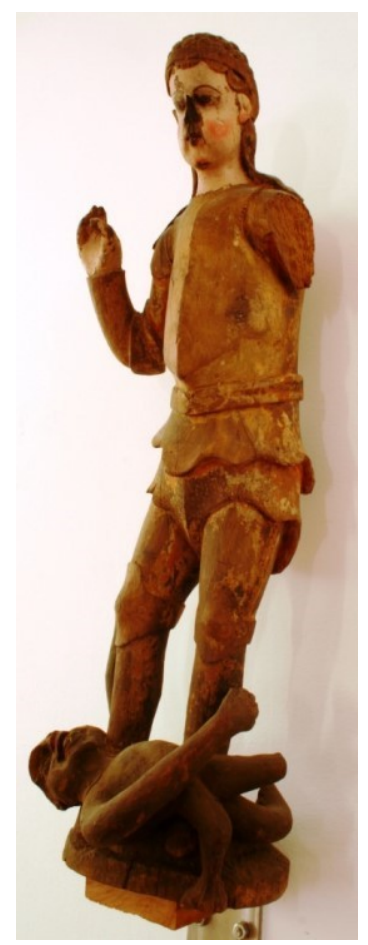

Imagem 32

São Miguel Arcanjo MASV 03 atualmente exposto no Museu de Arte Sacra

Destaca-se deste conjunto de imagens registada a imagem de São Miguel, por existirem ainda hoje duas esculturas a ilustrar essa devoção. Existe uma imagem de São Miguel a culto num dos nichos laterais do lado do Evangelho no corpo da igreja de Nossa Senhora da Encarnação (Imagem 31), seguramente terá sido esta a ser avaliada em "catorze mil e quatrocentos reis". Mas, existe uma outra imagem de São Miguel, mais arcaica, que atualmente está em exposição no museu de Arte Sacra (Imagem 32).

A imagem de "Sam Jose com o menino" levanta a dúvida sobre a identificação da anterior imagem de São José enquanto elemento do conjunto do altar de Santa Ana. No registo do altar de Santa Ana não surge qualquer referência ao Menino que o Santo sustém ao colo, sendo por isso possível que a imagem de São José registada na capela de Nossa Senhora do Carmo seja a que está ainda hoje a culto no nicho do lado da epístola na capela-mor da igreja de Nossa Senhora da Encarnação: Também a diferença nos valores que são atribuídos a cada uma das imagens aumenta a incerteza relativamente a atual identificação da imagem de São José. A imagem do altar de Santa Ana valia "catorze e quatrocentos reis" enquanto a imagem registada na capela do Carmo foi avaliada em "vinte mil reis", o que nos faz supor que seria de maior tamanho. No entanto, a imagem existente é semelhante no tamanho e forma à de São Joaquim que 
também identificamos no altar de santa Ana (mas atualmente exposto na sacristia), o que nos faz pensar que a imagem hoje desaparecida seria a de maior valor, e possivelmente maior tamanho também, portanto a imagem de São José com o menino da Capela de Nossa Senhora do Carmo.

A imagem de nossa Senhora do Carmo julgamos ser a que se encontra atualmente na capela privada de São Caetano da casa dos condes de Vinhais.

A seguinte capela que foi inventariada foi a "Capela do Capitulo" onde havia:

"Hum crucifixo de marfim e a cruz em pau preto avaluado em quatro mil reis $-4 \$ 000$

Huma imagem de vulto de Nossa Senhora da Conceição com coroa de prata avaliada em trinta mil - $30 \$ 000$

Hum crucifixo grande e a cruz de madeira em preço de dous mil reis $-2 \$ 000$

N.B. Estes Santos estavão na capela do fundo dos claustros chamada a do Capitulo 38 ".

Das três imagens registadas na Capela do Capítulo apenas chegou aos nossos dias a imagem de Nossa Senhora da Conceição.

Na capela de Nossa Senhora das Dores está atualmente no lado do Evangelho uma imagem de Nossa Senhora da Conceição (Imagem 33) que não consta no registo feito em 1834 da dita capela. Possivelmente depois de 1834 a imagem terá sido trasladada da capela do Capitulo para a Capela de Nossa Senhora das Dores.

\footnotetext{
38 A.N.T.T./A.H.M.F./S.N.S.E.V., Extinção das Ordens Religiosas - Seminário de Nossa Senhora da Encarnação - Vinhais, Arquivo Nacional da Torre do Tombo, Lisboa, Arquivo Histórico do Ministério das Finanças, Processos de Extinção das casas religiosas, Cx. 2265, 1834, s/fl.
} 


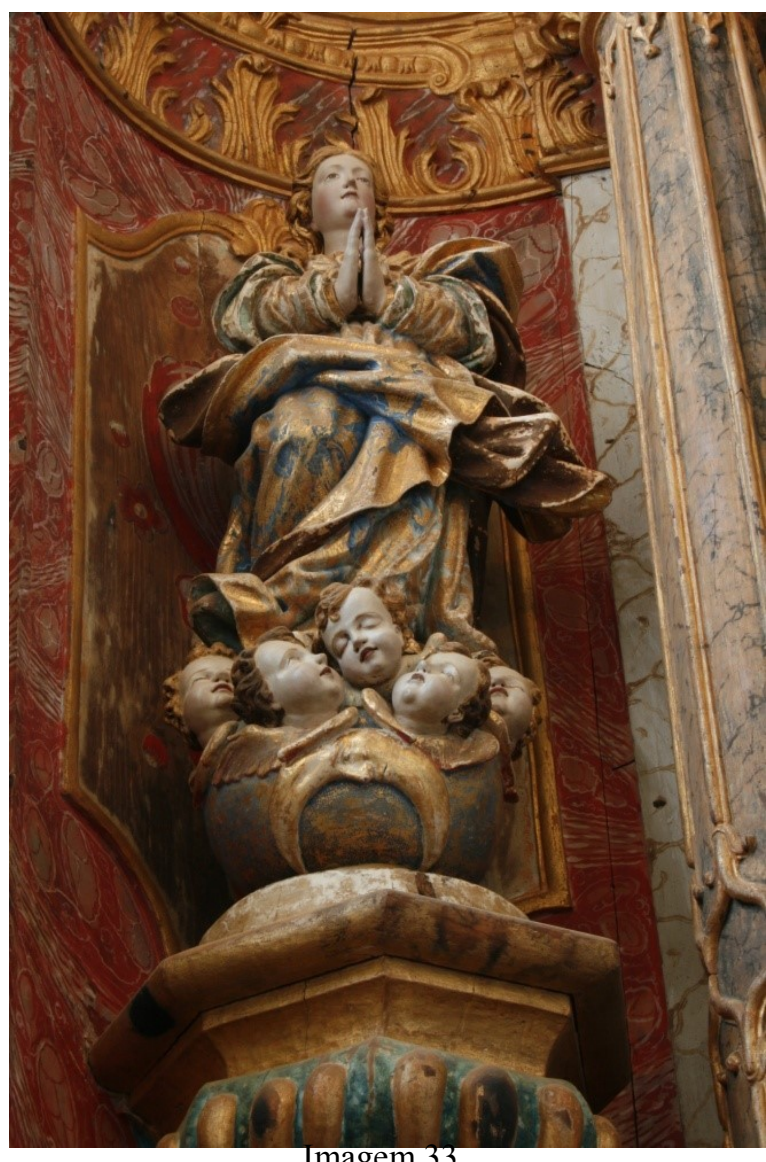

Imagem 33

Nossa Senhora da Imaculada Conceição CSDV 07 Atualmente a culto no nicho lateral do retábulo da capela de Nossa Senhora das Dores

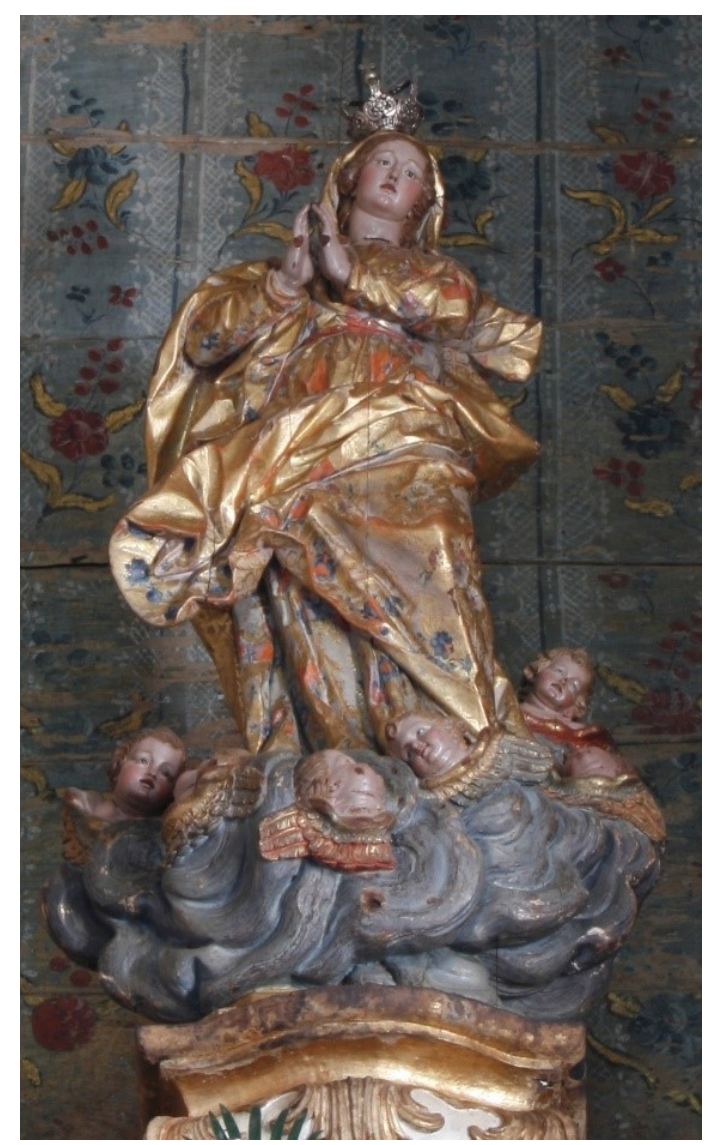

Imagem 34

Nossa Senhora da Imaculada Conceição SFV 07 Atualmente a culto no altar-mor da Igreja da São Francisco da Venerável Ordem Terceira

Também no altar da Enfermaria apenas a referência da imagem de Nossa Senhora da Conceição nos parece passível de ser relacionada com a atual coleção exposta. O inventário refere:

Hum crucifixo com resplendor e a cruz de madeira avaluado em setecentos e vinte reis - $\$ 720$

Hua imagem de vulto de Nossa Senhora da Conceição avaliada em quarenta mil reis $-40 \$ 000$

Huma imagem de vulto de Nossa Senhora pequena metida em um redondo de pao, e tem talha avaluada em preço de oitocentos reis - $\$ 8000$

N.B. Estas imagens estavão no Altar da Enfermaria ${ }^{39}$

Na contígua igreja da Ordem terceira está, sobre o trono do altar-mor, uma imagem de Nossa Senhora da Imaculada Conceição (Imagem 34). Não havendo mais elementos

39 A.N.T.T./A.H.M.F./S.N.S.E.V., Extinção das Ordens Religiosas - Seminário de Nossa Senhora da Encarnação - Vinhais, Arquivo Nacional da Torre do Tombo, Lisboa, Arquivo Histórico do Ministério das Finanças, Processos de Extinção das casas religiosas, Cx. 2265, 1834, s/fl. 
além da diferença de valor que lhes é atribuído a cada uma das esculturas; trinta e quarenta mil reis respetivamente. Não nos permite perceber qual dos anteriores espaços guardava que imagem da Imaculada Conceição atualmente expostas. Não nos parece plausível porém, que a imagem principal do trono da capela-mor da Ordem Terceira fosse trasladada da capela do capítulo ou da capela do noviciado, pois apesar da igreja da Ordem Terceira ser ligeiramente posterior à igreja e seminário de Nossa senhora da Encarnação, foram coevas, e necessariamente que o altar-mor da igreja de são Francisco teria um programa estruturado de início, não dependente das alterações sofridas mais tarde com a expulsão das ordens religiosas.

Da "Capela do Noviciado" não se encontra atualmente nenhuma das esculturas que foram inventariadas em 1834:

Hum crucifixo sem resplendor e a cruz de madeira dourada avaliada em preço de oitocentos reis - $\$ 8000$

Huma imagem de vulto de Nossa Senhora com sua coroa avaliada em preço de quatro mil reis $-4 \$ 000$

Huma imagem de vulto de Menino Jesus em ponto grande com sua coroa de prata avaluado em preço de dous mil e quatrocentos reis $-2 \$ 400$

Huma imagem de Sam João Baptista pequena avaluado em preço de mil e duzentos reis $-1 \$ 200$

Huma imagem de Jesus Christo de pao avaliada em preço de mil e duzentos reis $-1 \$ 200$

Huma imagem de vulto de Santo Ignacio avaluado em preço e quantia de mil e duzentos - $1 \$ 200$

Huma imagem de vulto de pao preto de Nossa senhora da Conceição sem ainda estar encarnada avaliada em preço de oitocentos reis - $\$ 8000$

Huma imagem do menino Jesus nova em ponto grande com seu resplendor avaliada em preço de catorze mil reis $-14 \$ 000$

N.B. Estas imagens estavão na capela que chamavão de Noviciado $^{40}$.

\footnotetext{
${ }^{40}$ A.N.T.T./A.H.M.F./S.N.S.E.V., Extinção das Ordens Religiosas - Seminário de Nossa Senhora da Encarnação - Vinhais, Arquivo Nacional da Torre do Tombo, Lisboa, Arquivo Histórico do Ministério das Finanças, Processos de Extinção das casas religiosas, Cx. 2265, 1834, s/fl.
} 
Merece atenção o facto de estar registada uma escultura que ainda não estava terminada "sem ainda estar encarnada" e uma outra escultura nova, o que denota a efervescente e continuada ação de melhoria dos objetos de culto por parte de uma congregação que estava estabelecida há pouco tempo no território de Vinhais.

Permite também pensar que a execução das esculturas se lavava a cabo, se não integralmente pelo menos em parte, no interior do convento, e portanto a cargo dos frades que o habitavam. Estes elementos reforçam a possibilidade de uma oficina de talha dentro do seminário. Acresce neste âmbito a figura de Frei Domingos, autor do "Cristo do Côro" e de outras esculturas que formalmente se aproximam.

Ao detalhado registo das esculturas segue-se o registo de mais "vasos sagrados vestimentas e ornatos". Esta lista consta sobretudo de paramentaria; vários conjuntos de casulas, dalmáticas, panos vários, frontais de altar e também os sinos, de todos os bens destacamos uma cruz processional, atualmente também desaparecida ${ }^{41}$.

Após o inventário escreveu o inventariante um texto onde afirma que estavam inventariados todos "os vasos sagrados imagens paramentos e mais vestimenta e que não tinham achado mais nada em este Convento e Igreja e nem sabia demais, mesmo sob suspeita que se constava que os Religiosos do dito Convento tinham escondido várias cousas, mas que não sabia aonde". Refere ainda as penas que incorria quem sonegasse bens no inventário.

O interior do templo e sobretudo a disposição das esculturas foi bastante alterada após o registo de 1834. No entanto, apesar das transformações, e perdas verificadas, é assinalável o número de imagens que se mantêm a culto e em guarda na igreja do seminário apostólico de Vinhais.

\footnotetext{
41 "Huma Cruz Procional [sic] de latam com seu Santo Christo de latam digo de pao com três mangas branca preta e roxa de damasco avaluada em preço de quatro mil reis $-4 \$ 000$ "

Terminado o registo dos "vasos sagrados vestimentas e ornatos" segue-se mais uma lista de inventário de missais e breviários com referência ao ano de impressão e local (na maioria em Antuérpia e Veneza), no mesmo registo referem ainda vários "Oficios" (de Semana Santa e de Nossa Senhora) bem como, paramentos "chamados Seráphicos". Termina o registo com o inventário de oito livros de procissões e "dois theatros eclesiásticos". A.N.T.T./A.H.M.F./S.N.S.E.V., Extinção das Ordens Religiosas - Seminário de Nossa Senhora da Encarnação - Vinhais, Arquivo Nacional da Torre do Tombo, Lisboa, Arquivo Histórico do Ministério das Finanças, Processos de Extinção das casas religiosas, Cx. 2265, 1834, s/fl.
} 


\section{FICHAS DE INVENTÁRIO}

ESCULTURA

\section{IGREJA DE NOSSA SENHORA DA ENCARNAÇÃO DO SEMINÁRIO APOSTÓLICO DE VINHAIS}


FICHAS DE INVENTÁRIO | ESCULTURA

Da Ordem de São Francisco na Diocese de Bragança-Miranda 


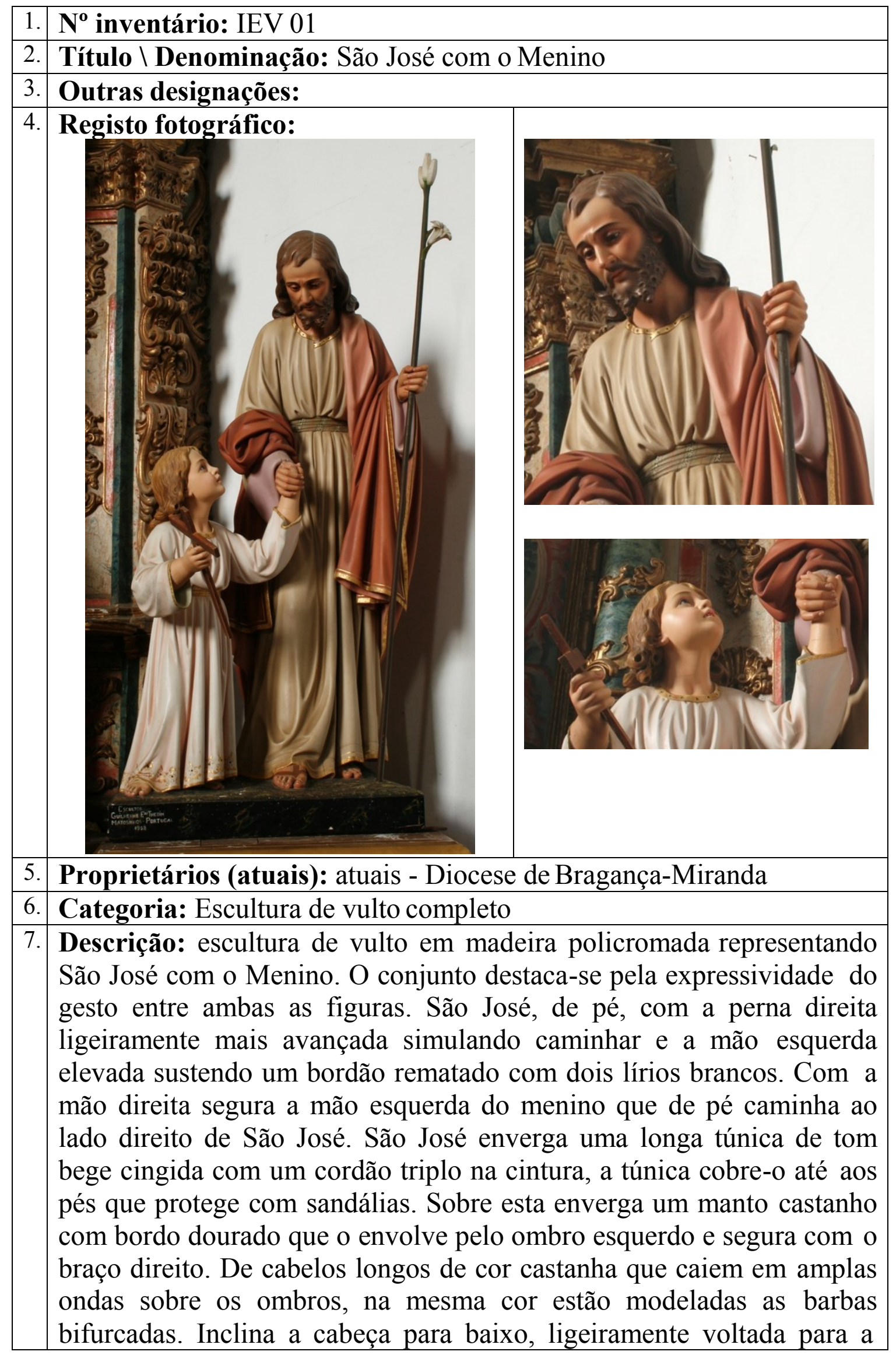




\begin{tabular}{|l|l|}
\hline & $\begin{array}{l}\text { figura do Menino, o rosto, maduro, de expressão serena tem os olhos de } \\
\text { vidro e as sobrancelhas levemente franzidas, evocam a preocupação da } \\
\text { figura madura. } \\
\text { A figura do menino, à direita de São José inclina a cabeça para cima } \\
\text { devolvendo o olhar, com expressão alegre, boca entreaberta, e suaves e } \\
\text { arredondadas linhas do rosto infantil com olhos de vidro em cor azul. } \\
\text { Enverga uma túnica rosa cingida na cintura por um cordão duplo e com } \\
\text { ornatos dourados nos bordos. Está descalço e segura na mão direita } \\
\text { uma cruz que eleva à altura do peito. Os cabelos de cor castanha clara } \\
\text { caiem sobre os ombros em suaves e amplas ondas. } \\
\text { Ambas as figuras estão assentes sobre uma plataforma negra } \\
\text { marmoreada em tom verde. Sobre a frente no lado direito é possível ler: } \\
\text { "ESCULTOR \ GUILHERME F.ra THEDIM \ MATOSINHOS - } \\
\text { PORTUGAL } \backslash 1958 ”\end{array}$ \\
\hline 8. & Técnicas (de suporte): Talha \\
\hline 9. & Técnicas (de acabamento): Policromia; marmoreado \\
\hline 10 & Materiais (de suporte): Madeira \\
\hline 11 & Materiais (de acabamento): Pigmentos; vidro \\
\hline 12 & $\begin{array}{l}\text { Estado de Conservação: Bom; estável, fissura sobre a manga direita } \\
\text { de São José (gesso) }\end{array}$ \\
\hline 13 & $\begin{array}{l}\text { Dimensões: } \\
\text { Altura: } 138 \text { cm } \\
\text { Largura: } 70 \text { cm } \\
\text { Profundidade: } 76 \text { cm }\end{array}$ \\
\hline 14 & Restauro: não apresenta sinais de intervenção sobre a obra \\
\hline 15 & Datas: século XX, 1958 \\
\hline 16 & Proveniência: igreja de Nossa Senhora da Encarnação em Vinhais \\
\hline 17 & Autoria: Guilherme F.ra Thedim \\
\hline 18 & Oficina: Matosinhos, Porto \\
\hline 19 & $\begin{array}{l}\text { Localização (atual): Sobre um plinto no lado da Epistola próximo ao } \\
\text { arco de triunfo }\end{array}$ \\
\hline 20 & Histórico do objeto: não se conhecem registos \\
\hline 21 & Iconografia: Lírios brancos; cruz \\
\hline 22 & Irmandade: não se conhecem registos \\
\hline 23 & Procissões: não se conhecem registos \\
\hline
\end{tabular}


FICHAS DE INVENTÁRIO |ESCULTURA

Da Ordem de São Francisco na Diocese de Bragança-Miranda

Retábulo rococó no transepto do lado da Epistola, no nicho central está a imagem IEV 02

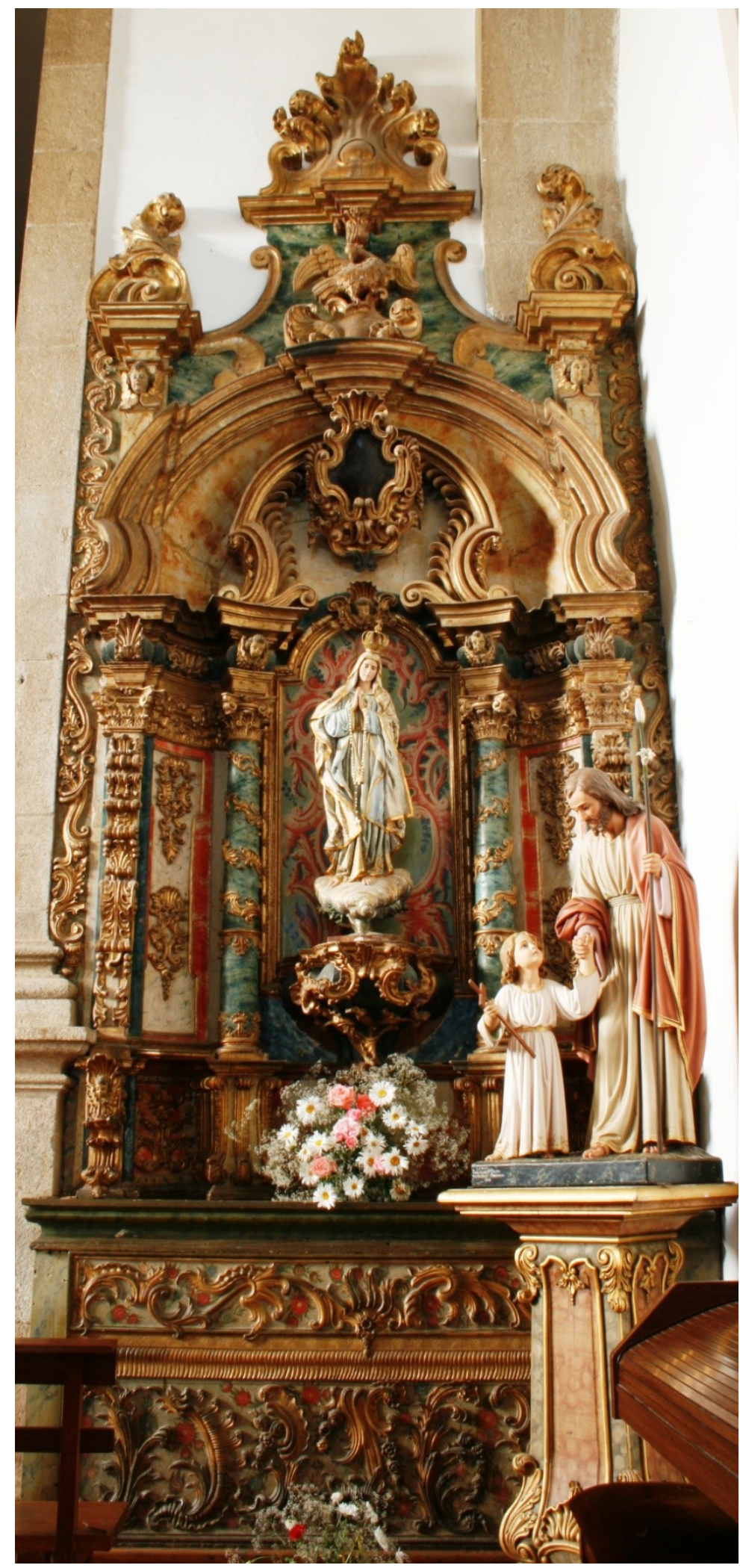


FICHAS DE INVENTÁRIO | ESCULTURA

Da Ordem de São Francisco na Diocese de Bragança-Miranda 


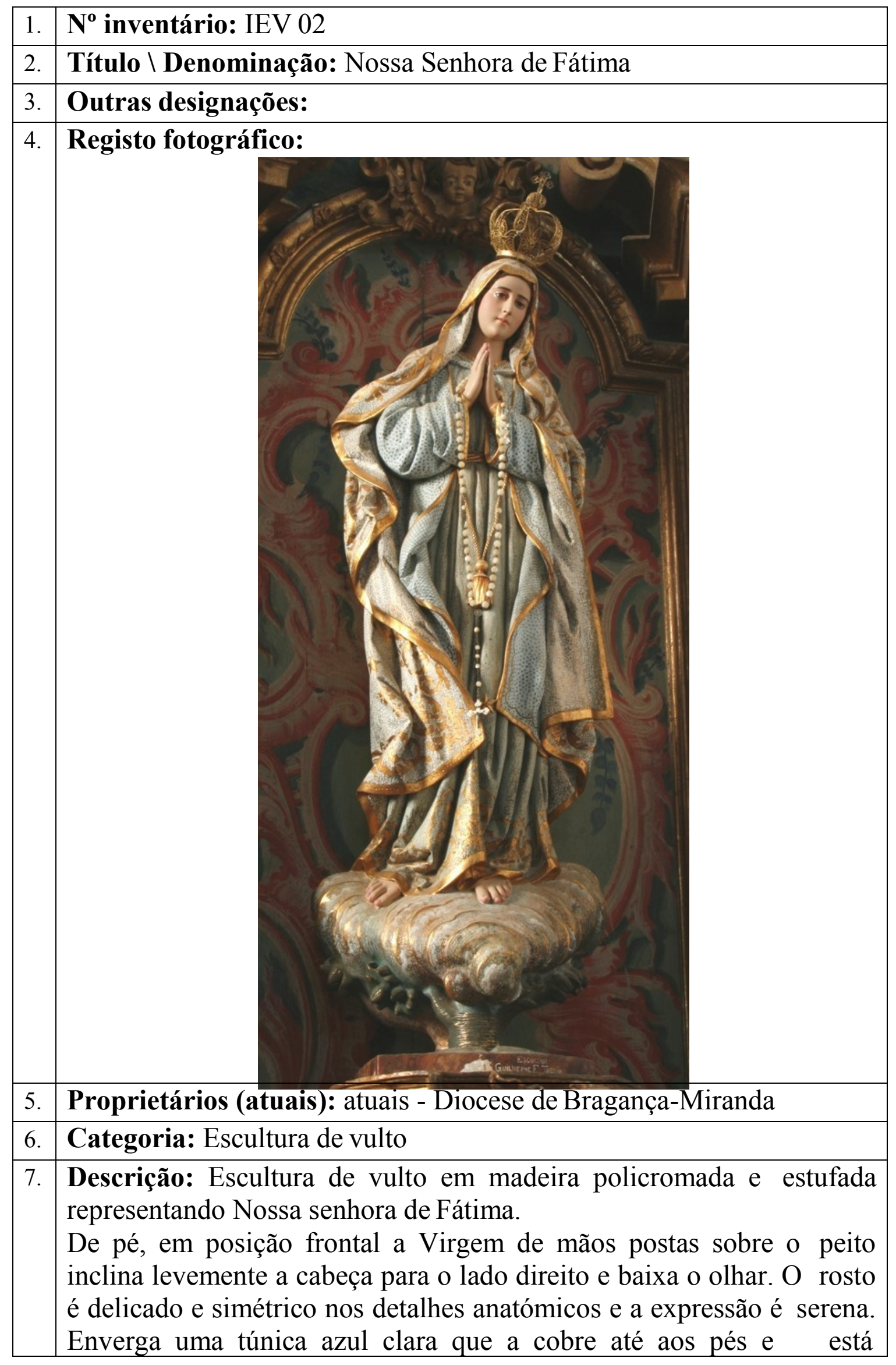




\begin{tabular}{|c|c|}
\hline & $\begin{array}{l}\text { densamente decorada com estrelas estufadas em dourado. Sobre a } \\
\text { cabeça cobre-a um manto ricamente decorado com motivos estufados } \\
\text { dourados e filetes dourados sobre os bordos. Os panejamentos } \\
\text { envolvem a figura em dinâmicos pregueados quebrando a estaticidade } \\
\text { do gesto. Sobre a cabeça ostenta uma coroa em filigrana dourada } \\
\text { (ouro?). Do cordão esculpido que a cinge na cintura pende uma forma } \\
\text { cilíndrica com franjas. Nas mãos está suspenso um rosário em } \\
\text { madrepérola. A figura está descalça e com os pés ligeiramente } \\
\text { desencontrados que assentam sobre uma nuvem, de contornos } \\
\text { arredondados e decorada com dourados, que paira sobre uma azinheira. } \\
\text { A azinheira está colocada sobre uma plataforma de tom castanho em } \\
\text { cuja frente sobre o lado direito pode ler-se: "ESCULTOR । } \\
\text { GUILHERME F. THEDIM \MATOSINHOS" }\end{array}$ \\
\hline 8. & Técnicas (de suporte): Talha \\
\hline 9. & Técnicas (de acabamento): Policromia; estufado \\
\hline 10. & Materiais (de suporte): Madeira \\
\hline 11. & $\begin{array}{l}\text { Materiais (de acabamento): Pigmentos; vidro; folha de ouro; metal } \\
\text { dourado; madrepérola }\end{array}$ \\
\hline 12. & Estado de Conservação: Bom; estável \\
\hline 13. & $\begin{array}{l}\text { Dimensões: } \\
\text { Altura: } 128 \mathrm{~cm} \\
\text { Largura: } 55 \mathrm{~cm} \\
\text { Profundidade: } 35 \mathrm{~cm} \\
\end{array}$ \\
\hline 14. & Restauro: não apresenta sinais de intervenção sobre a obra \\
\hline 15. & Datas: século XX, 1964 \\
\hline 16. & Proveniência: igreja de Nossa Senhora da Encarnação em Vinhais \\
\hline 17. & Autoria: Guilherme F. Thedim \\
\hline 18. & Oficina: Matosinhos, Porto \\
\hline 19. & $\begin{array}{l}\text { Localização (atual): No nicho central do retábulo no lado da Epistola } \\
\text { próximo ao arco de triunfo }\end{array}$ \\
\hline 20. & Histórico do objeto: não se conhecem registos \\
\hline 21. & Iconografia: Coroa; nuvem: azinheira; rosário; manto estrelado \\
\hline 22. & Irmandade: não se conhecem registos \\
\hline 23. & Procissões: não se conhecem registos \\
\hline
\end{tabular}


FICHAS DE INVENTÁRIO |ESCULTURA

Da Ordem de São Francisco na Diocese de Bragança-Miranda

Retábulo em talha rococó da capela-mor do lado da Epístola com a imagem IEV 03

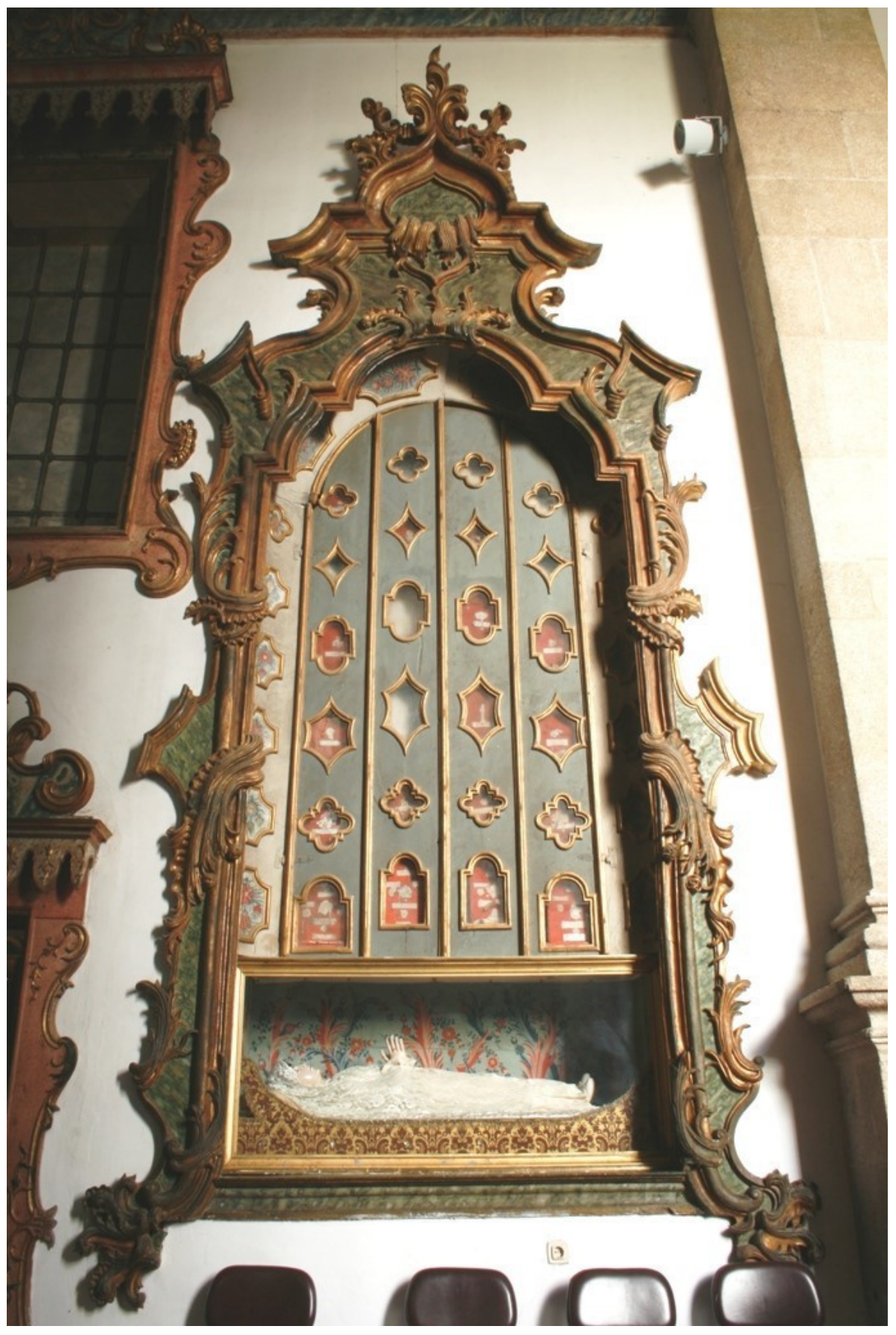


FICHAS DE INVENTÁRIO | ESCULTURA

Da Ordem de São Francisco na Diocese de Bragança-Miranda 


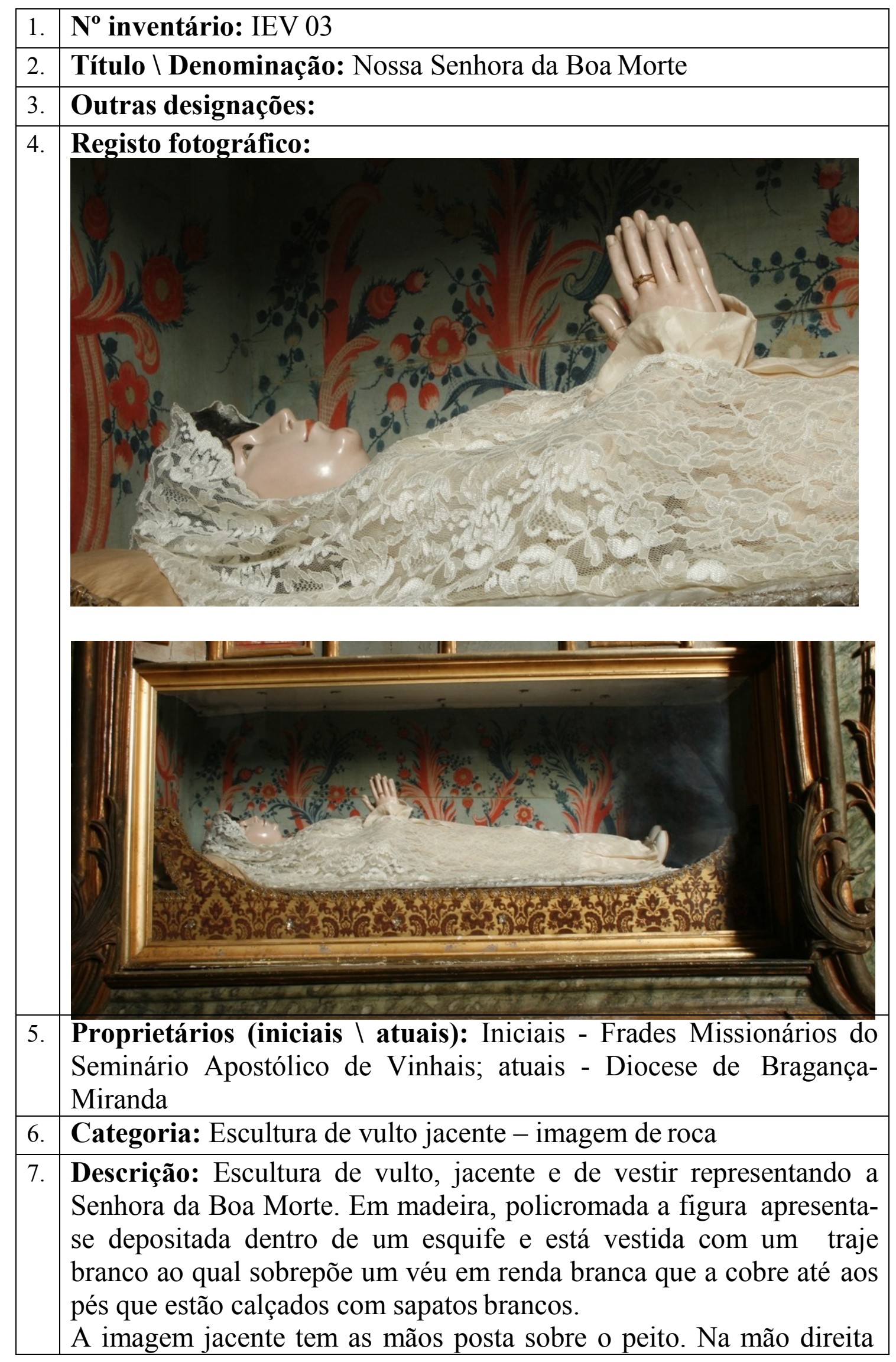




\begin{tabular}{|l|l|}
\hline & $\begin{array}{l}\text { ostenta um anel. O rosto, jovem e de contornos delicados tem a boca } \\
\text { entreaberta e os olhos de vidro em tom castanho que olham em frente, } \\
\text { a carnação é muito brilhante e a expressão serena. A cabeça com } \\
\text { cabelo natural castanho está coberta pelo véu de renda que a cinge até } \\
\text { aos pés. } \\
\text { Está depositada sobre um estrado decorado com elementos estofados } \\
\text { dourados sobre vermelho mais elevado na cabeceira e nos pés. O } \\
\text { esquife que a guarda tem a frente de vidro e os lados em madeira } \\
\text { pintada num tom azul claro com motivos vegetalistas em tons } \\
\text { brilhantes de vermelho e verde, está integrado num retábulo } \\
\text { encimado por diversos nichos que continham relíquias (na maioria } \\
\text { vazios). }\end{array}$ \\
\hline 8. & Técnicas (de suporte): Talha \\
\hline 9. & $\begin{array}{l}\text { Técnicas (de acabamento): Policromia; tecido nos panejamentos que } \\
\text { a cobrem }\end{array}$ \\
\hline 10. & Materiais (de suporte): Madeira \\
\hline 11. & Materiais (de acabamento): Pigmentos; vidro; cabelo \\
\hline 12. & Estado de Conservação: Bom; estável \\
\hline 13. & Dimensões: (figura jacente) \\
Comprimento: 134 cm \\
Largura: 35 cm \\
Altura: 35 cm
\end{tabular}




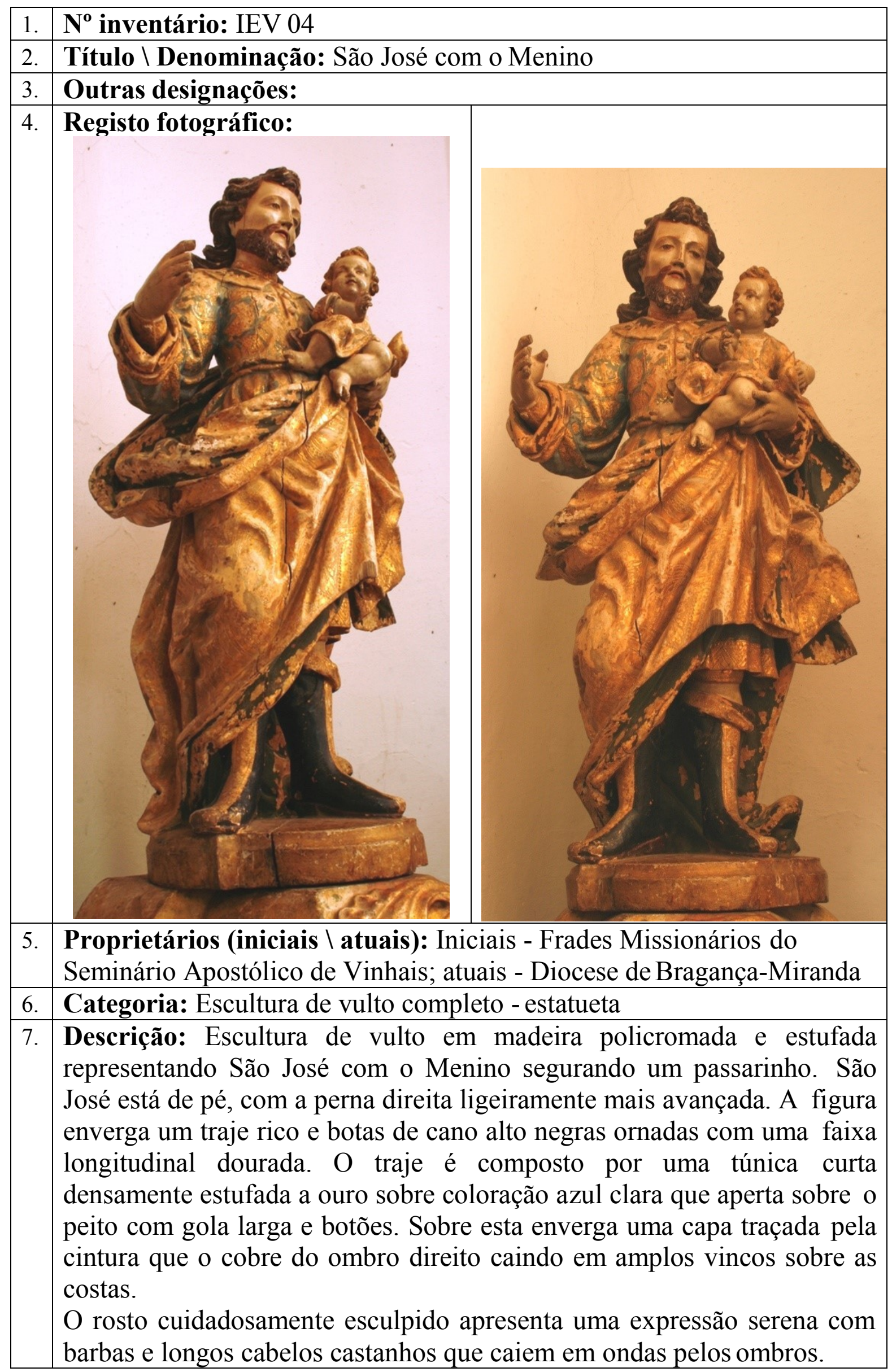




\begin{tabular}{|c|c|}
\hline & $\begin{array}{l}\text { O gesto de São José é largo com ambos braços elevados e fletidos, o } \\
\text { direito, mais afastado do corpo, tem lacuna da ponta dos cinco dedos e no } \\
\text { esquerdo sustém a figura do Menino Jesus. } \\
\text { A figura do Menino Jesus está anatomicamente cuidada nos contornos } \\
\text { arredondados e dinâmica torção do corpo. O rosto é delicado e com } \\
\text { expressão alegre e sorridente. Tem lacuna de dois dedos na mão direita e } \\
\text { na esquerda sustem uma pequena ave com lacuna da cabeça. O Menino } \\
\text { enverga uma túnica policromada. O conjunto das duas figuras destaca-se } \\
\text { pelo dinamismo do gesto e expressividade dos rostos. } \\
\text { Está assente sobre uma base circular com marmoreado vermelho. }\end{array}$ \\
\hline 8. & Técnicas (de suporte): Talhe \\
\hline 9. & Técnicas (de acabamento): Policromia; estufado; marmoreado \\
\hline 10. & Materiais (de suporte): Madeira \\
\hline 11. & Materiais (de acabamento): Pigmentos; folha de ouro \\
\hline 12. & $\begin{array}{l}\text { Estado de Conservação: Bom; estável, lacuna de dedos na mão direita } \\
\text { da figura de São José e da cabeça da ave; desgaste na policromia; fissura } \\
\text { na figura de São José }\end{array}$ \\
\hline 13. & $\begin{array}{l}\text { Dimensões: } \\
\text { Altura: } 70 \mathrm{~cm} \\
\text { Largura: } 40 \mathrm{~cm} \\
\text { Profundidade: } 35 \mathrm{~cm}\end{array}$ \\
\hline 14. & Restauro: apresenta sinais de reintegração cromática \\
\hline 15. & Datas: segunda metade do século XVIII \\
\hline 16. & Proveniência: igreja de Nossa Senhora da Encarnação em Vinhais \\
\hline 17. & Autoria: Frei Domingos \\
\hline 18. & Oficina: Local \\
\hline 19. & $\begin{array}{l}\text { Localização (inicial } \backslash \text { atual): Inicialmente estava no altar de Santa Ana; } \\
\text { atualmente está dentro de um nicho na capela-mor no lado da Epistola }\end{array}$ \\
\hline 20. & Histórico do objeto: não se conhecem registos \\
\hline 21. & Iconografia: São José jovem; traje palaciano; Menino com Ave \\
\hline 22. & Irmandade: não se conhecem registos \\
\hline 23. & Procissões: não se conhecem registos \\
\hline
\end{tabular}


FICHAS DE INVENTÁRIO | ESCULTURA

Da Ordem de São Francisco na Diocese de Bragança-Miranda

Retábulo em talha rococó com detalhes joaninos do altar-mor com as imagens IEV 05, IEV 06, IEV 07, IEV 08

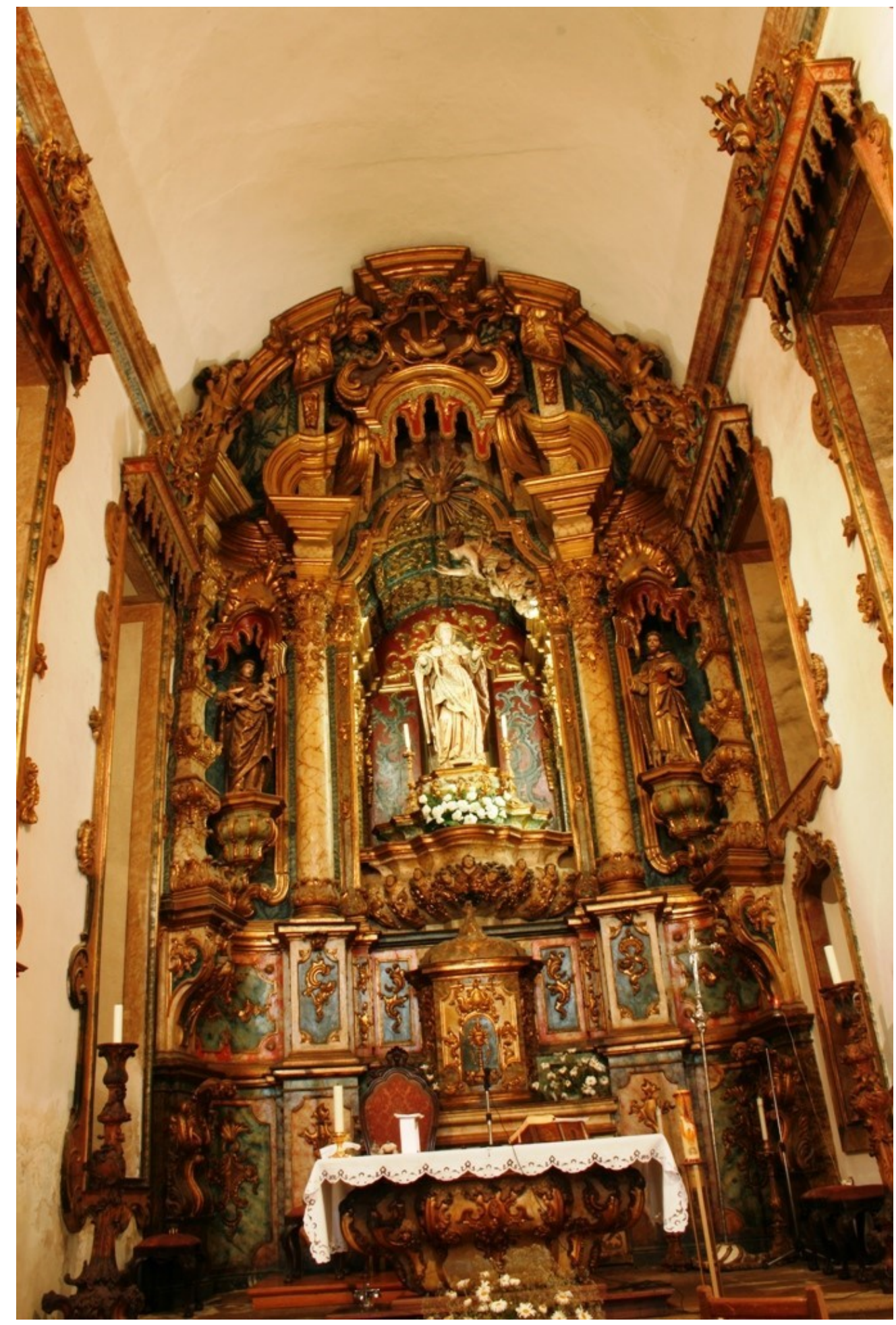


FICHAS DE INVENTÁRIO | ESCULTURA

Da Ordem de São Francisco na Diocese de Bragança-Miranda 


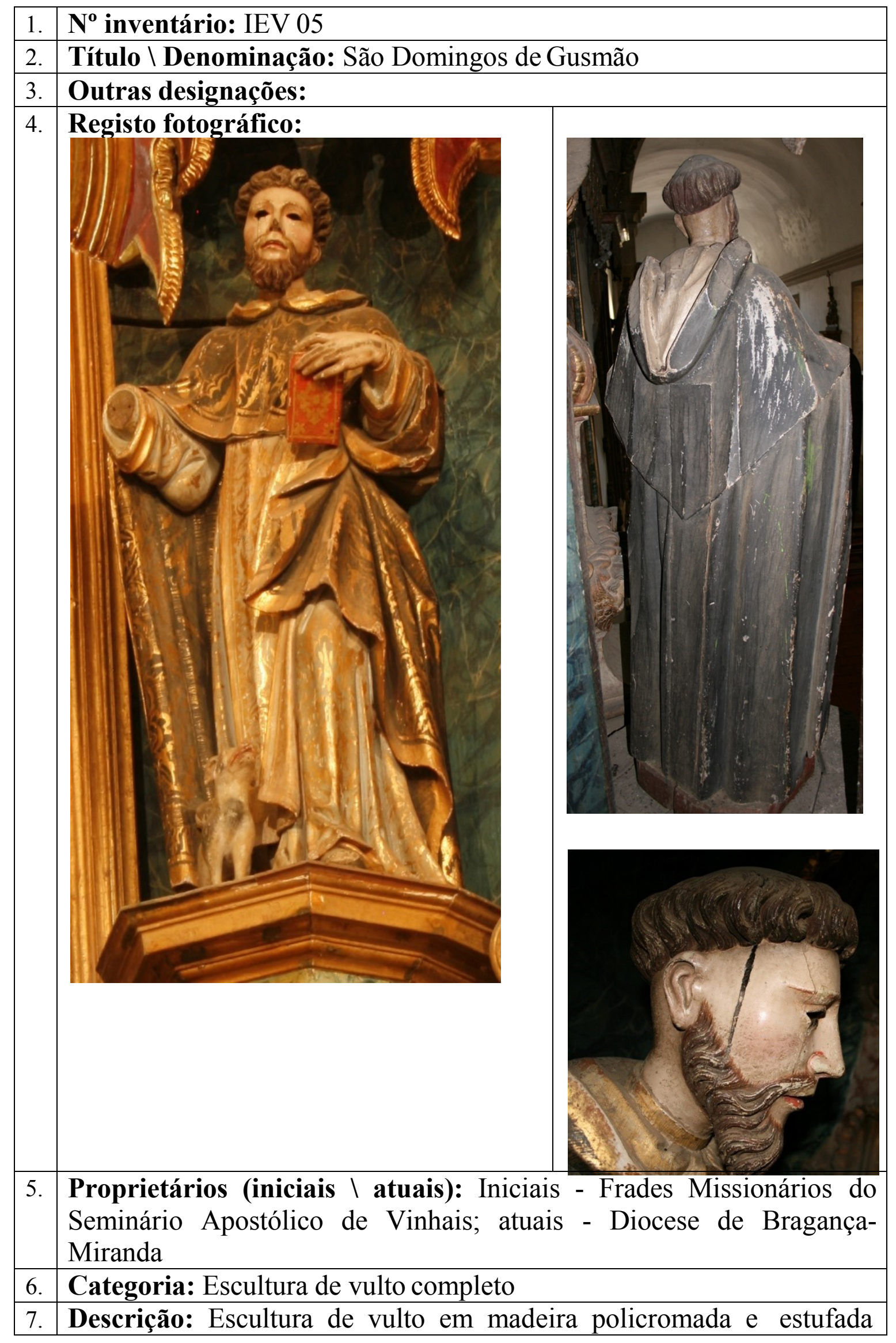




\begin{tabular}{|c|c|}
\hline & $\begin{array}{l}\text { representando São Domingos. A figura está de pé, em contraposto } \\
\text { sugerido pela perna esquerda ligeiramente mais avançada com um cão } \\
\text { sentado ao lado direito. Enverga o hábito dominicano com dinâmico } \\
\text { pregueado nos panejamentos da túnica branca sobre a qual enverga uma } \\
\text { capa negra com capuz que o cobre pelas costas até aos pés. O hábito } \\
\text { está coberto de estufado na frente a parte posterior está mais } \\
\text { sumariamente policromada. } \\
\text { Flete e eleva ambos os braços à altura do peito, o braço direito tem } \\
\text { lacuna da mão e o braço esquerdo, com a policromia muito desgastada, } \\
\text { segura um livro fechado de ricas capas vermelhas com ornatos } \\
\text { dourados. } \\
\text { O santo tonsurado apresenta uma expressão serena tem a boca } \\
\text { entreaberta deixando a descoberto parte dos dentes, o rosto com barbas, } \\
\text { está cuidadosamente esculpido mas uma fissura lateral provocou que os } \\
\text { olhos de vidro descaíssem deixando atualmente a figura semolhos. } \\
\text { Do lado direito acompanha-o um pequeno cão branco e negro que está } \\
\text { sentado e volta a cabeça para o santo. } \\
\text { Está assente sobre uma base circular com marmoreado vermelho. }\end{array}$ \\
\hline 8. & Técnicas (de suporte): Talhe \\
\hline 9. & Técnicas (de acabamento): Policromia; estufado; marmoreado \\
\hline 10. & Materiais (de suporte): Madeira \\
\hline 11. & Materiais (de acabamento): Pigmentos; folha de ouro \\
\hline 12. & $\begin{array}{l}\text { Estado de Conservação: Bom; estável, lacuna de mão direita; desgaste } \\
\text { na policromia; fissura na cabeça que provocou que descaíssem os olhos }\end{array}$ \\
\hline 13. & $\begin{array}{l}\text { Dimensões: } \\
\text { Altura: } 155 \mathrm{~cm} \\
\text { Largura: } 65 \mathrm{~cm} \\
\text { Profundidade: } 43 \mathrm{~cm} \\
\end{array}$ \\
\hline 14. & Restauro: apresenta sinais de reintegração cromática \\
\hline 15. & Datas: segunda metade do século XVIII \\
\hline 16. & Proveniência: igreja de Nossa Senhora da Encarnação em Vinhais \\
\hline 17. & Autoria: Frei Domingos \\
\hline 18. & Oficina: Local \\
\hline 19. & $\begin{array}{l}\text { Localização (inicial \atual): Inicialmente ladeava em conjunto com } \\
\text { São Francisco de Assis o nicho central do altar-mor; atualmente está } \\
\text { também no retábulo mor dentro do nicho no lado da Epistola }\end{array}$ \\
\hline 20. & Histórico do objeto: não se conhecem registos \\
\hline 21. & Iconografia: Cão; Livro fechado; hábito dominicano \\
\hline 22. & Irmandade: não se conhecem registos \\
\hline 23. & Procissões: não se conhecem registos \\
\hline
\end{tabular}




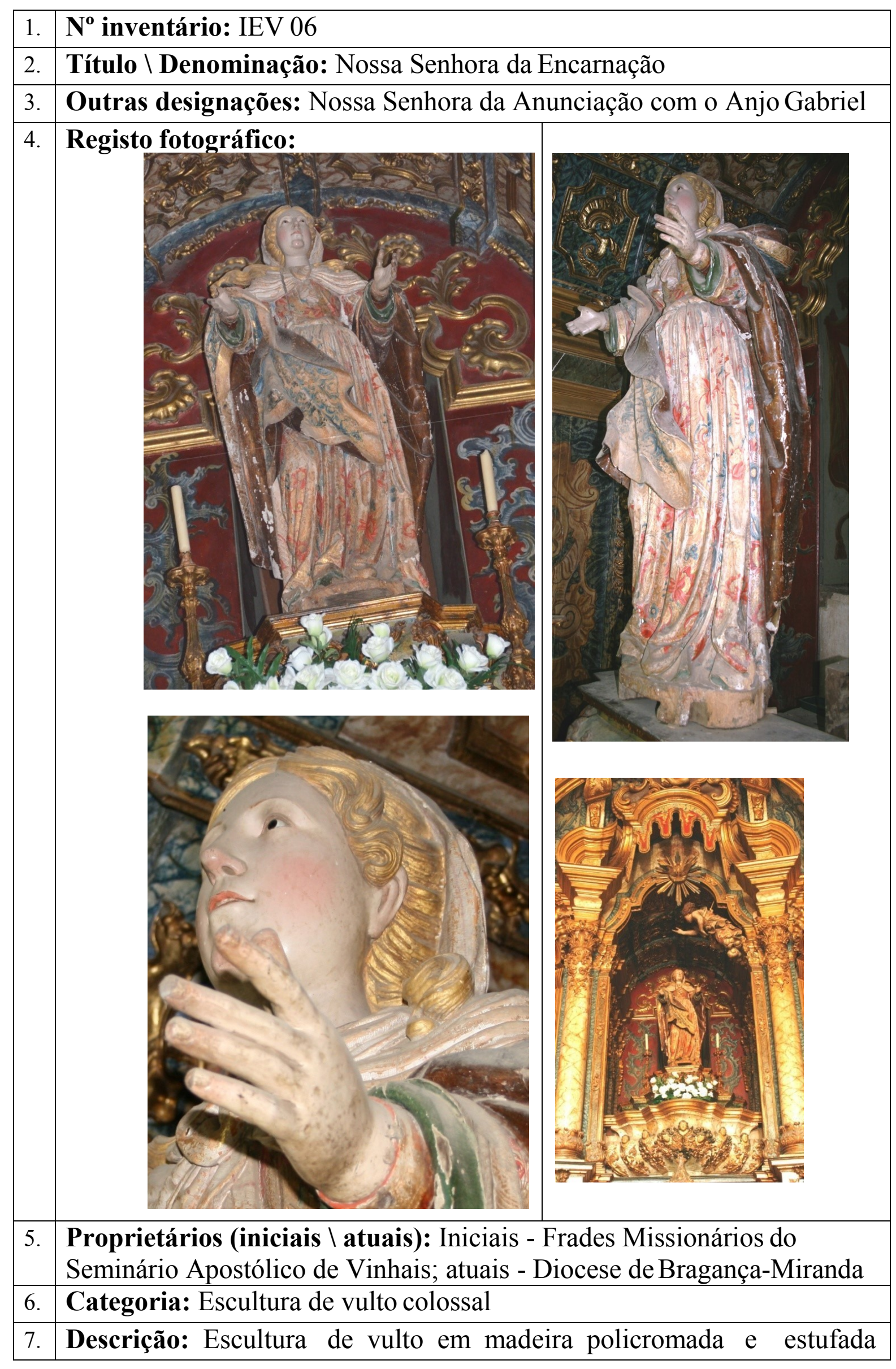




\begin{tabular}{|c|c|}
\hline & $\begin{array}{l}\text { representando Nossa senhora da Encarnação. De pé, em posição frontal } \\
\text { com ligeiro contraposto sugerido pelo joelho direito mais avançado a } \\
\text { Virgem eleva e flete os braços abertos à altura da cintura com as mãos } \\
\text { abertas (a mão direita tem lacuna de todos os dedos). Enverga um traje } \\
\text { muito decorado com elementos policromos e dourados estufados cingido } \\
\text { na cintura. Sobre este usa um véu que lhe cobre parcialmente a cabeça } \\
\text { que aperta com um nó sobre o peito. Sobre as costas enverga uma capa } \\
\text { que com dinâmicos e amplos vincos a cobre até aos pés caindo parte } \\
\text { sobre a frente sustida pelo braço direito. De rosto delicado nos } \\
\text { arredondados contornos anatómicos ergue os olhos de vidro em } \\
\text { expressão serena com a boca entreaberta deixando parte dos dentes a } \\
\text { descoberto. Tem farta cabeleira loira esculpida na madeira em largas } \\
\text { ondas que lhe envolvem o rosto e caiem dinamicamente sobre os ombros. } \\
\text { Está assente sobre uma base circular com lacunas na frente. } \\
\text { A figura faz parte de um conjunto, com o anjo Gabriel, que preenche o } \\
\text { espaço central do retábulo mor. }\end{array}$ \\
\hline 8. & Técnicas (de suporte): Talha \\
\hline 9. & Técnicas (de acabamento): Policrom \\
\hline 10. & Materiais (de suporte): Madeira \\
\hline 11. & Materiais (de acabamento): Pigmentos; vidro; folha de ouro \\
\hline 12. & $\begin{array}{l}\text { Estado de Conservação: Razoável; lacuna dos dedos na mão direita e de } \\
\text { parte do pregueado do manto no lado direito; fissura profunda sobre o } \\
\text { lado direito do peito; marcas de inseto xilófago }\end{array}$ \\
\hline 13. & $\begin{array}{l}\text { Dimensões: } \\
\text { Altura: } 200 \mathrm{~cm} \\
\text { Largura: } 90 \mathrm{~cm} \\
\text { Profundidade: } 70 \mathrm{~cm}\end{array}$ \\
\hline 14. & Restauro: apresenta sinais de reintegração cromática \\
\hline 15. & Datas: segunda metade do século XVIII \\
\hline 16. & Proveniência: igreja de Nossa Senhora da Encarnação \\
\hline 17. & Autoria: Frei Domingos \\
\hline 18. & Oficina: Local \\
\hline 19. & $\begin{array}{l}\text { Localização (inicial } \backslash \text { atual): Mantém-se no local de origem, o nicho } \\
\text { central do retábulo mor }\end{array}$ \\
\hline 20. & $\begin{array}{l}\text { Histórico do objeto: a imagem colossal de Nossa Senhora da } \\
\text { Encarnação estaria originalmente oposta à imagem colossal de Cristo, } \\
\text { colocada sobre o coro alto. }\end{array}$ \\
\hline 21. & Iconografia: Mãos abertas; olhar erguido \\
\hline 22. & Irmandade: não se conhecem registos \\
\hline 23. & Procissões: não se conhecem registos \\
\hline
\end{tabular}




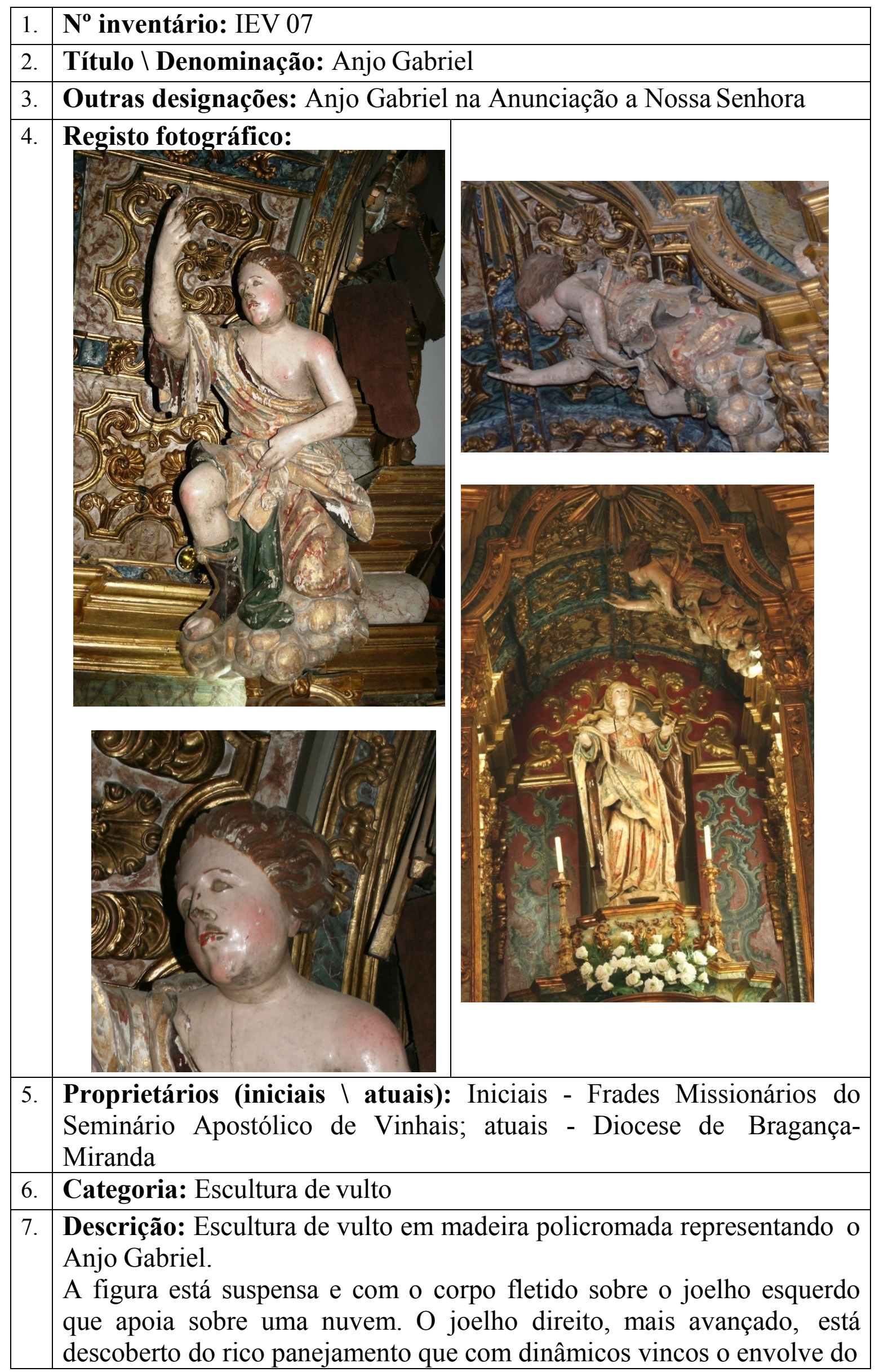




\begin{tabular}{|c|c|}
\hline & $\begin{array}{l}\text { ombro direito, a perna fletida apoiada sobre a nuvem está calçada com } \\
\text { uma original e ornamentada bota que deixa a descoberto a ponta dos } \\
\text { dedos. O anjo está voltado para a figura de Nossa senhora da } \\
\text { Encarnação para quem ergue o braço direito com o dedo indicador } \\
\text { apontado para cima, com lacuna de três dedos. O braço esquerdo fletido } \\
\text { à altura da cintura tem lacuna de dois dedos. Enverga um manto muito } \\
\text { decorado com elementos policromos e dourados estufados que o } \\
\text { envolve pela cintura, deixando a descoberto o ombro esquerdo e o } \\
\text { joelho direito. De rosto delicado nos arredondados contornos } \\
\text { anatómicos volta os olhos (com a policromia já muito desgastada) para a } \\
\text { figura da Virgem, com expressão serena com a boca entreaberta } \\
\text { deixando parte dos dentes a descoberto. Tem cabelos castanhos curtos } \\
\text { em largas ondas esculpidos na madeira. A figura está suspensa com uma } \\
\text { corda que o segura na parte superior do nicho do retábulo central e está } \\
\text { colocado obliquamente do lado esquerdo da Virgem com a qual faz } \\
\text { conjunto na representação da cena da Anunciação. }\end{array}$ \\
\hline 8. & Técnicas (de suporte): Talha \\
\hline 9. & Técnicas (de acabamento): Policromia; estufado; dourado \\
\hline 10. & Materiais (de suporte): Madeira \\
\hline 11. & Materiais (de acabamento): Pigmentos; folha de ouro \\
\hline 12. & $\begin{array}{l}\text { Estado de Conservação: Bom; estável; lacuna dos três dedos na mão } \\
\text { direita e dois na mão esquerda; forte desgaste na policromia. }\end{array}$ \\
\hline 13. & $\begin{array}{l}\text { Dimensões: } \\
\text { Altura: } 130 \mathrm{~cm} \\
\text { Largura: } 60 \mathrm{~cm} \\
\text { Profundidade: } 60 \mathrm{~cm}\end{array}$ \\
\hline 14. & Restauro: apresenta sinais de reintegração cromática \\
\hline 15. & Datas: segunda metade do século XVIII \\
\hline 16. & Proveniência: igreja de Nossa Senhora da Encarnação em Vinhais \\
\hline 17. & Autoria: Frei Domingos \\
\hline 18. & Oficina: Local \\
\hline 19. & $\begin{array}{l}\text { Localização (inicial } \backslash \text { atual): Mantém-se no local de origem, o nicho } \\
\text { central do retábulo mor }\end{array}$ \\
\hline 20. & Histórico do objeto: não se conhecem registos \\
\hline 21. & Iconografia: Nuvem; anjo Gabriel \\
\hline 22. & Irmandade: não se conhecem registos \\
\hline 23. & Procissões: não se conhecem registos \\
\hline
\end{tabular}




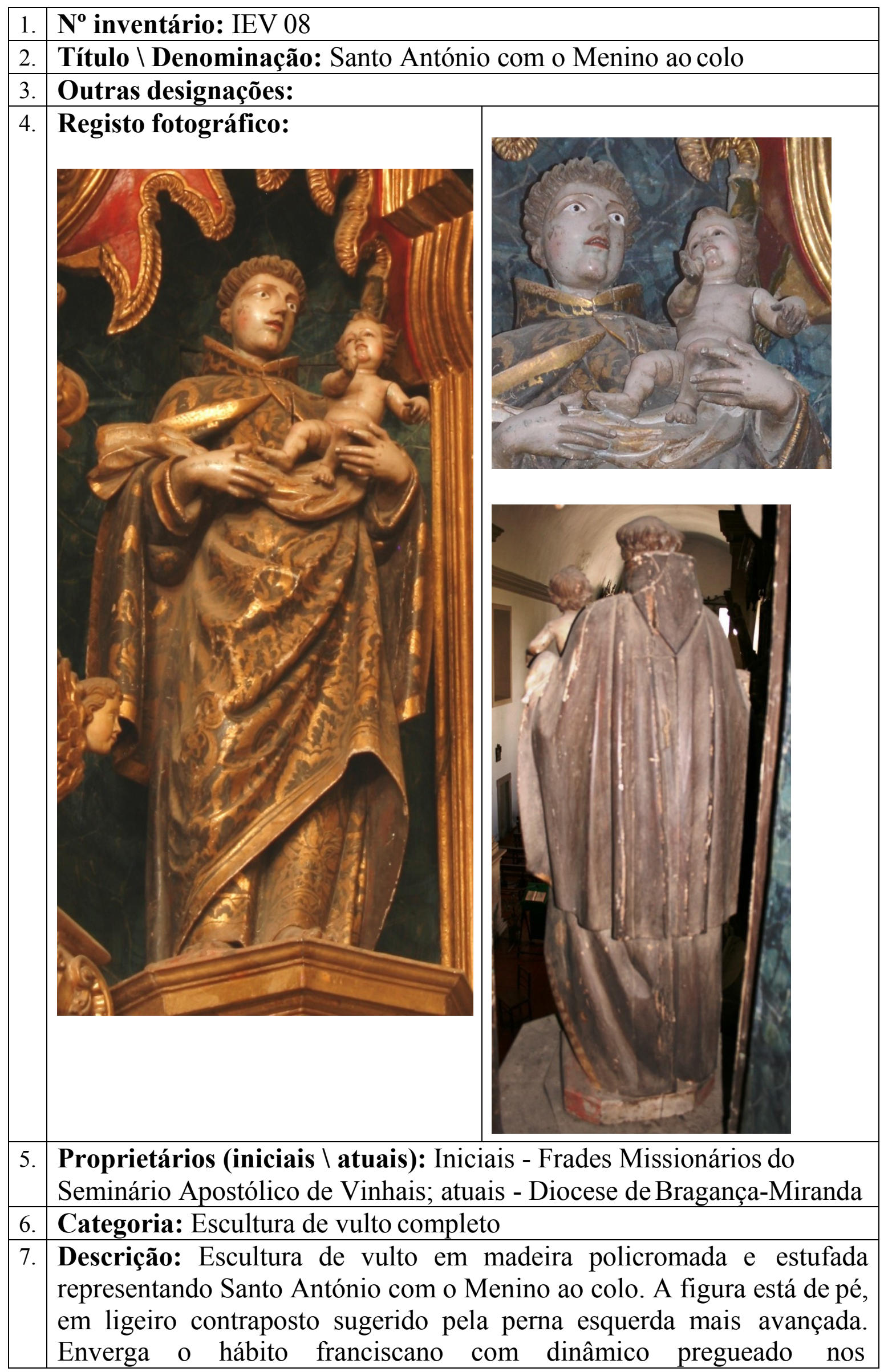




\begin{tabular}{|l|l|}
\hline & $\begin{array}{l}\text { panejamentos e densamente coberto na frente por ornatos dourados } \\
\text { estufados. A figura do Santo sustém o Menino ao colo que com cuidada } \\
\text { anatomia infantil e gesto dinâmico torce o corpo nu em atitude jovial, de } \\
\text { expressão alegre sorri deixando parte dos dentes a descoberto, os olhos } \\
\text { são apliques postiços de vidro e tem lacuna de todos os dedos na mão } \\
\text { direita. Está envolto num véu branco sustido por ambas as mãos do } \\
\text { Santo com lacuna de um dedo na mão direita. } \\
\text { O santo tonsurado apresenta uma expressão serena tem a boca } \\
\text { entreaberta deixando a descoberto parte dos dentes, o rosto da figura do } \\
\text { santo parece ter sido intervencionado, pelo menos nos apliques de vidro } \\
\text { dos olhos que estão agora excessivamente abertos. } \\
\text { Enverga sandálias e está assente sobre uma base circular com } \\
\text { marmoreado vermelho. } \\
\text { A figura destaca-se pelo cuidadoso trabalho dos pregueados nos } \\
\text { panejamentos e pelo gesto e anatomia infantil na figura do Menino. }\end{array}$ \\
\hline 8. & Técnicas (de suporte): Talhe \\
\hline 9. & Técnicas (de acabamento): Policromia; estufado; marmoreado \\
\hline 10. & Materiais (de suporte): Madeira \\
\hline 11. & Materiais (de acabamento): Pigmentos; vidro; folha de ouro \\
\hline 12. & Estado de Conservação: Bom; estável, lacuna de dedo na mão direita; \\
desgaste na policromia
\end{tabular}


FICHAS DE INVENTÁRIO |ESCULTURA

Da Ordem de São Francisco na Diocese de Bragança-Miranda

Retábulo em talha rocaille da capela-mor do lado do Evangelho coma imagem IEV 09

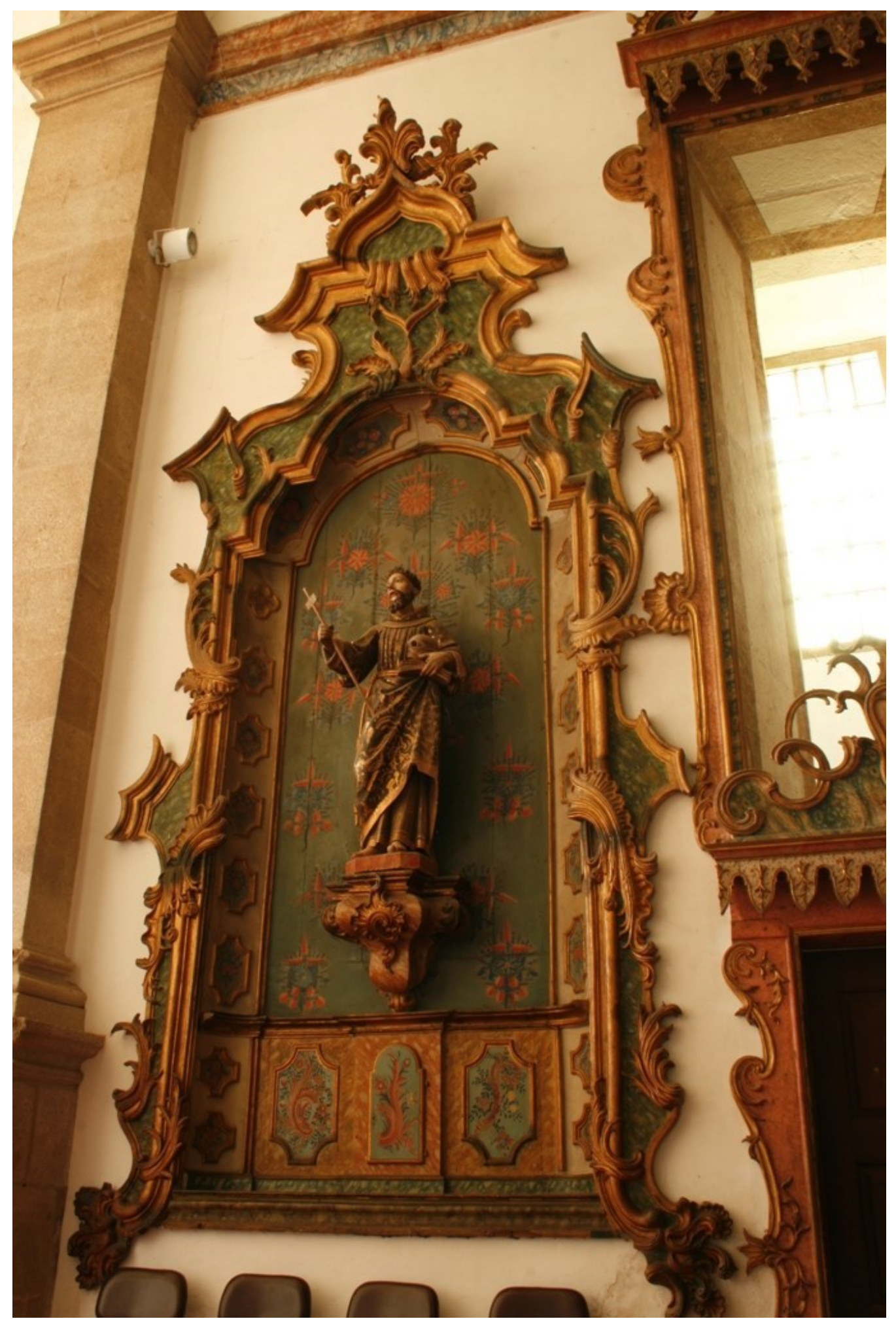


FICHAS DE INVENTÁRIO | ESCULTURA

Da Ordem de São Francisco na Diocese de Bragança-Miranda 


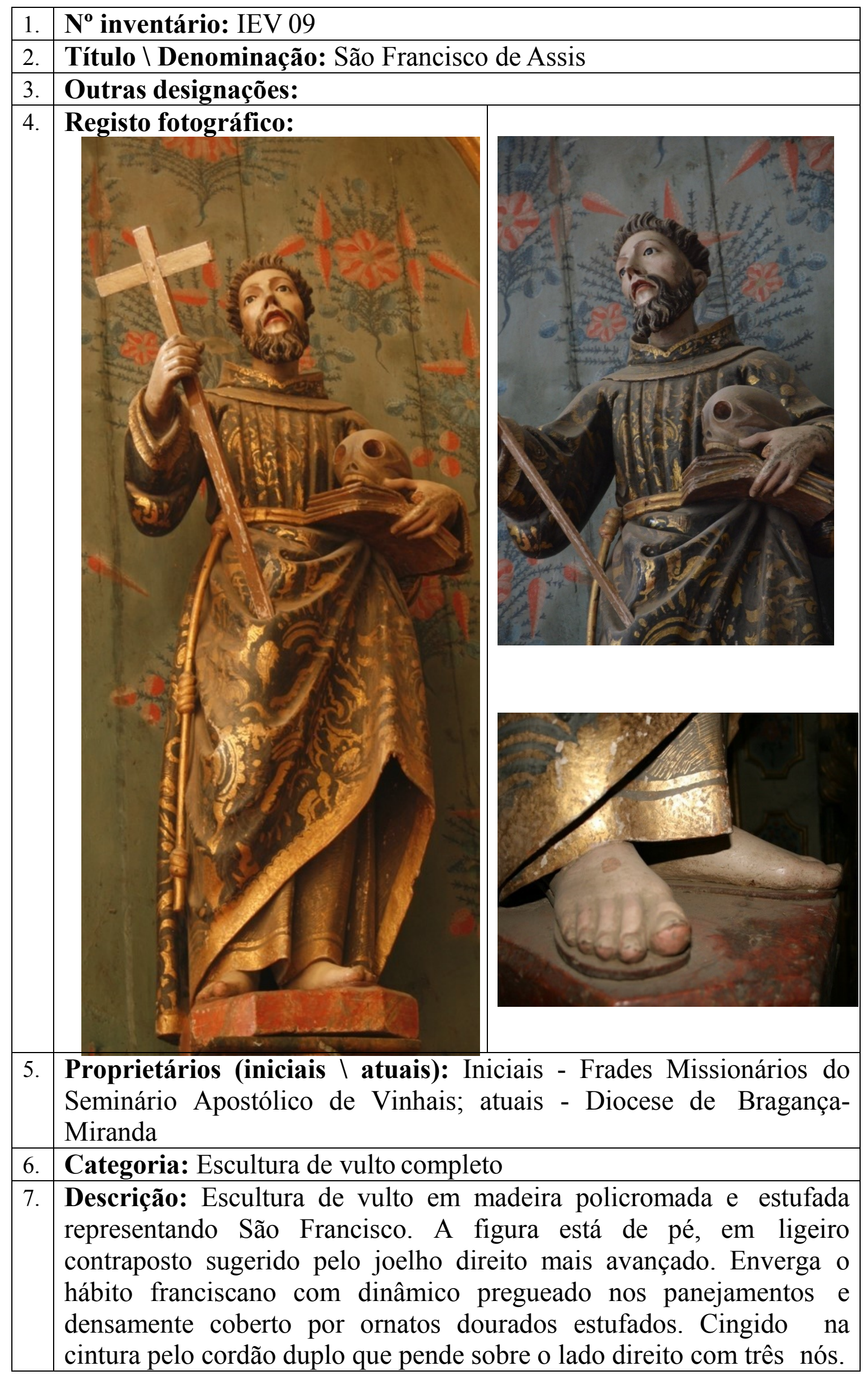




\begin{tabular}{|l|l|}
\hline & $\begin{array}{l}\text { No lado esquerdo a parte superior do hábito está repuxada pelo braço } \\
\text { esquerdo deixando a descoberto a túnica interior negra com bordo } \\
\text { dourado que o cobre até aos pés, já sem a parte superior das sandálias } \\
\text { por desgaste na policromia mas ainda com os estigmas visíveis. } \\
\text { Eleva e flete ambos braços, o braço direito mais elevado segura com a } \\
\text { mão um crucifixo, simples de secção quadrangular, a manga do hábito } \\
\text { é mais ampla sobre o cotovelo (tal como se observa nas imagens da } \\
\text { igreja de S. Francisco 08 SFV e 04SFV). Na mão esquerda, com } \\
\text { lacuna de um dedo, segura um livro aberto sobre o qual está colocada } \\
\text { uma caveira. } \\
\text { O santo tonsurado apresenta uma expressão de sofrimento com linhas } \\
\text { demarcadas a boca entreaberta com os cantos descaídos e o olhar fixo } \\
\text { em frente com olhos de vidro. } \\
\text { Terá originalmente envergado sandálias (porém apenas se percebe a } \\
\text { parte inferior das mesmas) e está assente sobre uma base octogonal } \\
\text { com marmoreado vermelho. } \\
\text { A figura destaca-se pelo cuidadoso trabalho dos pregueados nos } \\
\text { panejamentos e pela variedade dos atributos que acompanham o santo. }\end{array}$ \\
\hline 8. & Técnicas (de suporte): Talha \\
\hline 9. & Técnicas (de acabamento): Policromia; estufado; marmoreado \\
\hline 10. & Materiais (de suporte): Madeira \\
\hline 11. & Materiais (de acabamento): Pigmentos; vidro; folha de ouro \\
\hline 12. & Estado de Conservação: Bom; estável, lacuna de dedo na mão \\
esquerda; desgaste na policromia
\end{tabular}


FICHAS DE INVENTÁRIO |ESCULTURA

Da Ordem de São Francisco na Diocese de Bragança-Miranda

Retábulo em talha rocaille no transepto do lado do Evangelho com a imagem IEV 10

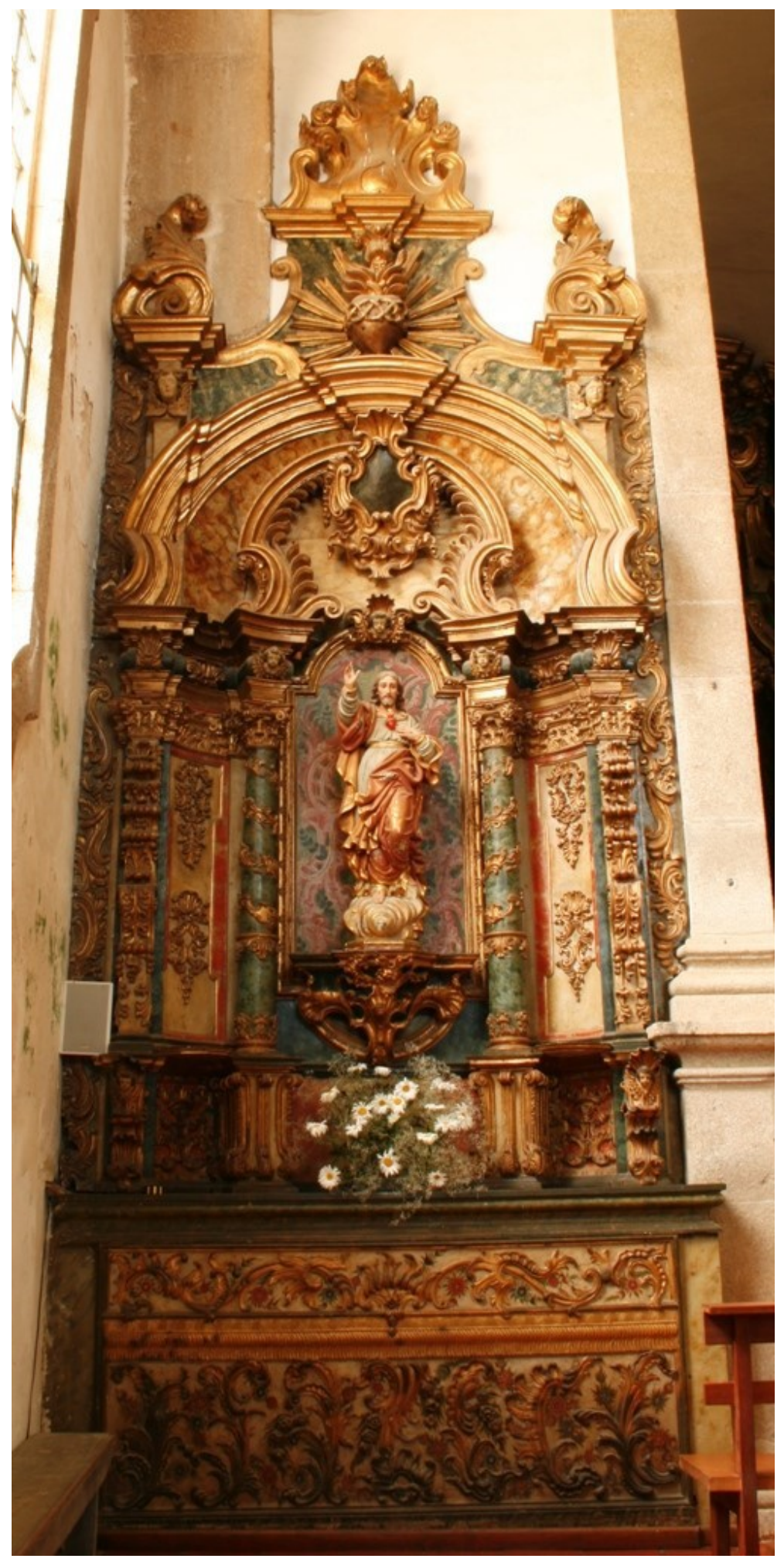


FICHAS DE INVENTÁRIO | ESCULTURA

Da Ordem de São Francisco na Diocese de Bragança-Miranda 


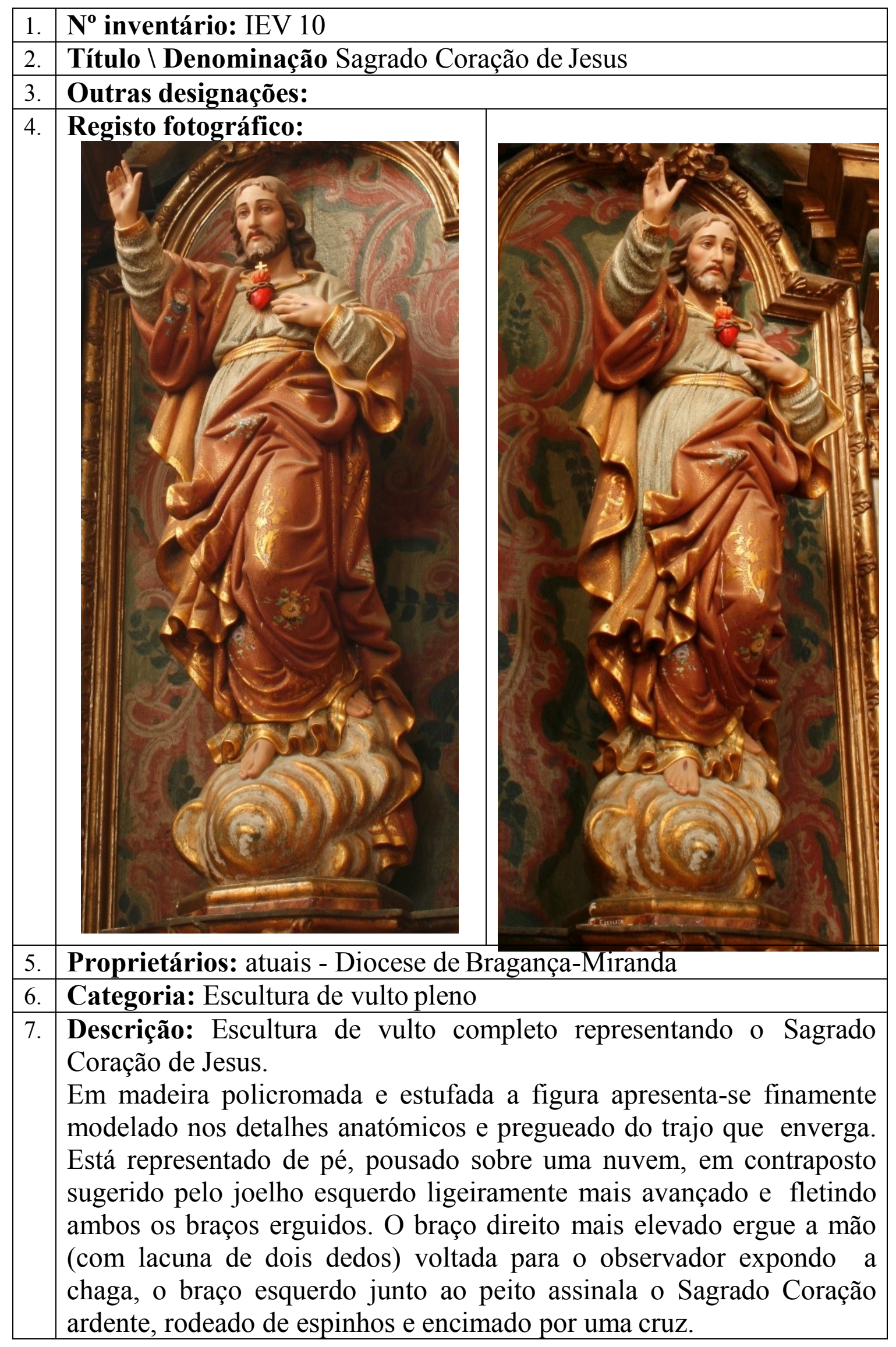




\begin{tabular}{|c|c|}
\hline & $\begin{array}{l}\text { A figura enverga uma longa túnica azul clara decorada com elementos } \\
\text { dourados cingida na cintura com um cordão. Sobre esta usa uma capa } \\
\text { vermelha, ornada de elementos estufados policromos, que lhe cobre o } \\
\text { ombro direito e em esvoaçante pregueado o envolve pelas costas } \\
\text { recolhendo-a com o braço esquerdo. } \\
\text { O rosto com carnação brilhante e cuidadosos detalhes da simétrica } \\
\text { anatomia tem expressão grave e olha em frente. } \\
\text { Usa a barba bifurcada e longos cabelos castanhos que caiem sobre as } \\
\text { costas. } \\
\text { A figura está descalça, com chagas em ambos os pés, e assente sobre } \\
\text { uma nuvem de contornos arredondados decorados com dourado. } \\
\text { Na base onde assenta a nuvem está escrito a letra branca sobre fundo } \\
\text { castanho ESCULTOR } \backslash \text { GUILHERME F. THEDIM } \backslash \text { MATOSINHOS } \\
1964\end{array}$ \\
\hline 8. & Técnicas (de suporte) Talha \\
\hline 9. & Técnicas (de acabamento): Policromia; estufado \\
\hline 10. & Materiais (de suporte) Madeira \\
\hline 11. & Materiais (de acabamento): Pigmer \\
\hline 12. & $\begin{array}{l}\text { Estado de Conservação Bom; apresenta-se se estável; lacuna de dois } \\
\text { dedos na mão direita }\end{array}$ \\
\hline 13. & $\begin{array}{l}\text { Dimensões: } \\
\text { Altura: } 113 \mathrm{~cm} \\
\text { Largura: } 52 \mathrm{~cm} \\
\text { Profundidade: } 50 \mathrm{~cm} \\
\end{array}$ \\
\hline 14. & Restauro: não apresenta sinais de intervenção sobre a obra \\
\hline 15. & Datas: século XX, 1964 \\
\hline 16. & Proveniência: igreja de Nossa Senhora da Encarnação em Vinhais \\
\hline 17. & Autoria: Guilherme Thedim \\
\hline 18. & Oficina: Matosinhos, Porto \\
\hline 19. & Localização (atual): Nicho central do Retábulo do Evangelho \\
\hline 20. & Histórico do objeto: não se conhecem registos \\
\hline 21. & $\begin{array}{l}\text { Iconografia: coração ardente cingido por coroa de espinhos e } \\
\text { encimado por uma cruz; estigmas; sinal de bênção }\end{array}$ \\
\hline 22. & Irmandade: não se conhecem registos \\
\hline 23. & Procissões: não se conhecem registos \\
\hline
\end{tabular}




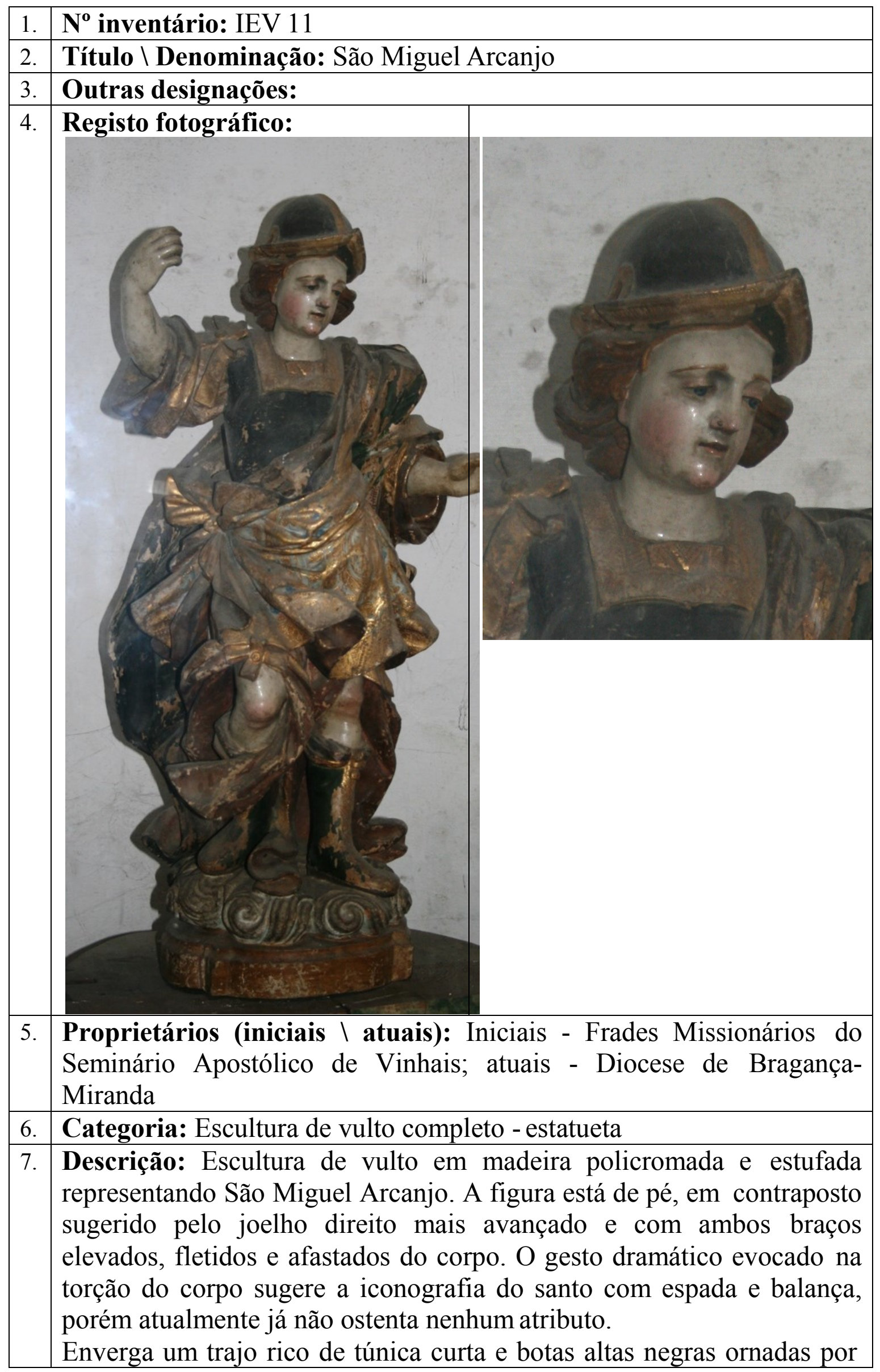




\begin{tabular}{|c|c|}
\hline & $\begin{array}{l}\text { lista dourado, sobre a túnica enverga uma capa cruzada sobre o ombro } \\
\text { esquerdo que o envolve em panejamentos esvoaçantes que reforçam o } \\
\text { movimento sugerido pela torção do corpo. } \\
\text { O rosto jovem com carnação muito brilhante baixa os olhos e apresenta } \\
\text { uma expressão grave. Os cabelos são curtos e de cor castanha, com } \\
\text { amplas ondas, percetíveis em parte sob o elmo, de cor escura com } \\
\text { ornatos dourados estufados. } \\
\text { A figura destaca-se pelo dinamismo e cuidadoso trabalho dos } \\
\text { pregueados nos volumosos panejamentos. } \\
\text { Assenta sobre uma nuvem com enrolamentos e espirais que assenta } \\
\text { sobre uma base circular com marmoreado vermelho. } \\
\text { Assemelha-se no traje, no dinamismo do gesto e na base à imagem de } \\
\text { São José com o Menino (IEV 04) }\end{array}$ \\
\hline 8. & Técnicas (de suporte): Talhe \\
\hline 9. & Técnicas (de acabamento): Policromia; estufado; marmoreado \\
\hline 10. & Materiais (de suporte): Madeira \\
\hline 11. & Pigmentos; folha de ouro \\
\hline 12. & $\begin{array}{l}\text { Estado de Conservação: Bom; estável, lacuna da ponta de todos os } \\
\text { dedos na mão esquerda; desgaste na policromia }\end{array}$ \\
\hline 13. & $\begin{array}{l}\text { Dimensões: } \\
\text { Altura: } 80 \mathrm{~cm} \\
\text { Largura: } 45 \mathrm{~cm} \\
\text { Profundidade: } 35 \mathrm{~cm}\end{array}$ \\
\hline 14. & Restauro: apresenta sinais de reintegração cromática \\
\hline 15. & Datas: segunda metade do século XVIII \\
\hline 16. & Proveniência: igreja de Nossa Senhora da Encarnação em Vinhais \\
\hline 17. & Autoria: desconhecida \\
\hline 18. & Oficina: Nacional \\
\hline 19. & $\begin{array}{l}\text { Localização (inicial \ atual): Inicialmente estaria na desaparecida } \\
\text { capela da Senhora do Carmo ou Claustro; atualmente está colocado } \\
\text { num nicho aberto na nave central do lado do Evangelho }\end{array}$ \\
\hline 20. & Histórico do objeto: não se conhecem registos \\
\hline 21. & Iconografia: elmo; botas altas \\
\hline 22. & Irmandade: não se conhecem registos \\
\hline 23. & Procissões: não se conhecem registos \\
\hline
\end{tabular}




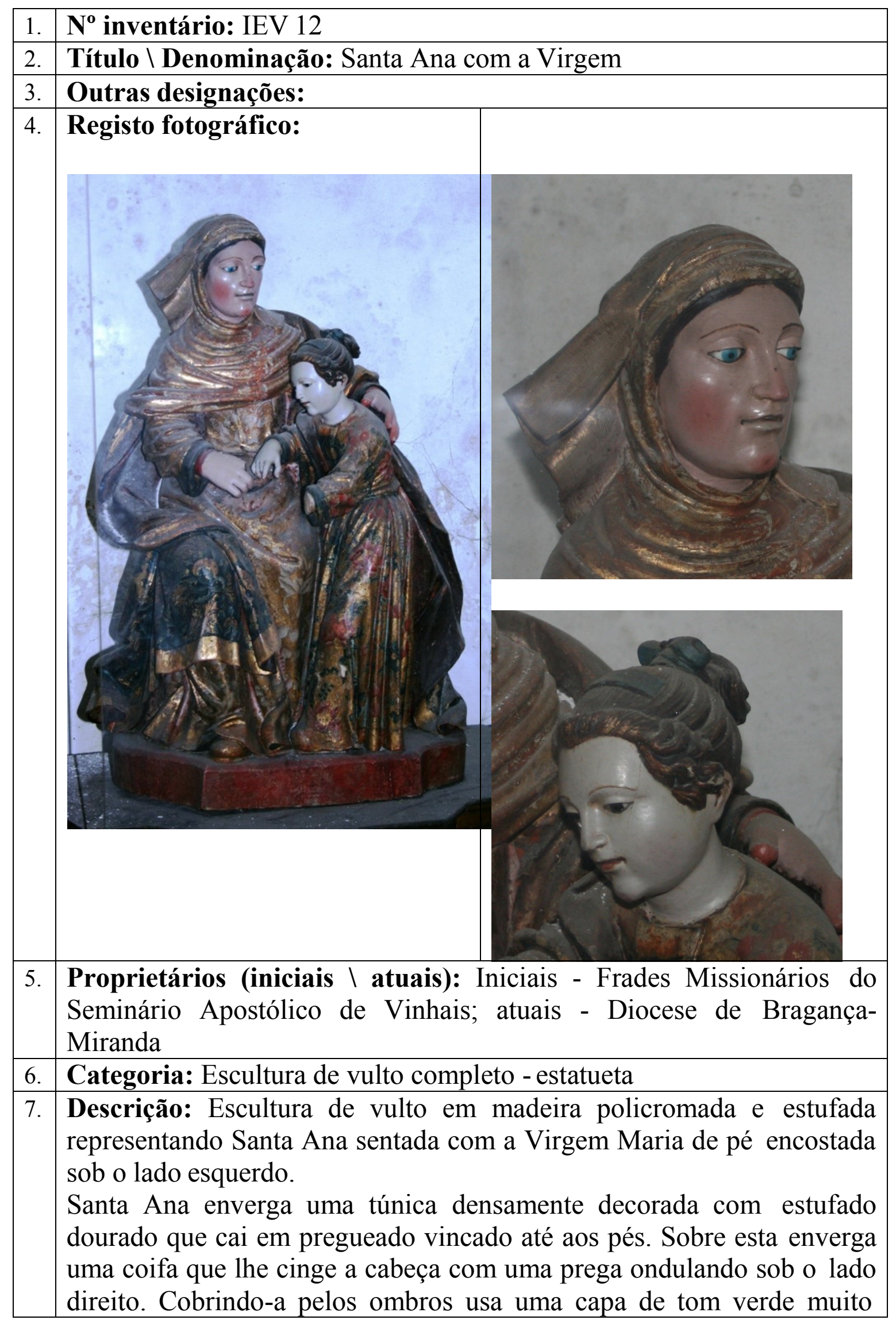




\begin{tabular}{|c|c|}
\hline & $\begin{array}{l}\text { escurecido com ornatos estufados. O rosto de linhas vincadas } \\
\text { expressão serena esboça um ligeiro sorriso, os olhos de vivo tom de } \\
\text { azul são de vidro e baixam o olhar. A mão direita, com lacuna de um } \\
\text { dedo está pousada sobre o colo enquanto a mão esquerda está colocada } \\
\text { sobre o ombro da Virgem num gesto de ternura. } \\
\text { A Virgem Maria, de pé, está ligeiramente inclinada para a frente sobre o } \\
\text { regaço de Santa Ana, onde originalmente estaria colocado o livro para } \\
\text { onde convergiriam ambos olhares (porém atualmente esse atributo esta } \\
\text { desaparecido). A jovem Virgem enverga uma túnica densamente } \\
\text { decorada com estufados dourados e policromos que a cobre até aos pés. } \\
\text { Os cabelos presos decorativamente com uma fita verde que deixa cair } \\
\text { algumas madeixas sobre o rosto. O rosto de carnação mais clara que o } \\
\text { de Santa Ana é suave nos contornos delicados, com olhos de vidro que } \\
\text { fixam o atributo desaparecido. A mão direita aponta com o indicador (o } \\
\text { livro desaparecido) e a esquerda está fraturada no pulso com lacuna } \\
\text { total da mão. } \\
\text { O conjunto destaca-se pelo gesto de relação entre ambas as figuras. } \\
\text { Assenta sobre uma base polilobada vermelha. }\end{array}$ \\
\hline 8. & Técnicas (de suporte): Talhe \\
\hline 9. & Técnicas (de acabamento): Policromia; estufado \\
\hline 10. & Materiais (de suporte): Madeira \\
\hline 11. & Materiais (de acabamento): Pigmentos; folha de ouro; vidro \\
\hline 12. & $\begin{array}{l}\text { Estado de Conservação: Razoável; estável, lacuna da mão esquerda da } \\
\text { Virgem; lacuna de dedo de Santa Ana; lacuna de atributo (livro); } \\
\text { desgaste na policromia; a pintura de cal do nicho cai sobre a figura }\end{array}$ \\
\hline 13. & $\begin{array}{l}\text { Dimensões: } \\
\text { Altura: } 70 \mathrm{~cm} \\
\text { Largura: } 55 \mathrm{~cm} \\
\text { Profundidade: } 40 \mathrm{~cm} \\
\end{array}$ \\
\hline 14. & Restauro: apresenta sinais de reintegração cromática \\
\hline 15. & Datas: segunda metade do século XVIII \\
\hline 16. & Proveniência: igreja de Nossa Senhora da Encarnação em Vinhais \\
\hline 17. & Autoria: Frei Domingos \\
\hline 18. & Oficina: Local $\backslash$ regional \\
\hline 19. & $\begin{array}{l}\text { Localização (inicial } \backslash \text { atual): Inicialmente tinha altar próprio, no lado } \\
\text { da epístola; atualmente está dentro de um nicho aberto na nave central } \\
\text { do lado do Evangelho }\end{array}$ \\
\hline 20. & Histórico do objeto: não se conhecem registos \\
\hline 21. & Iconografia: Virgem Maria menina e Santa Ana \\
\hline 22. & Irmandade: não se conhecem registos \\
\hline 23. & Procissões: não se conhecem registos \\
\hline
\end{tabular}




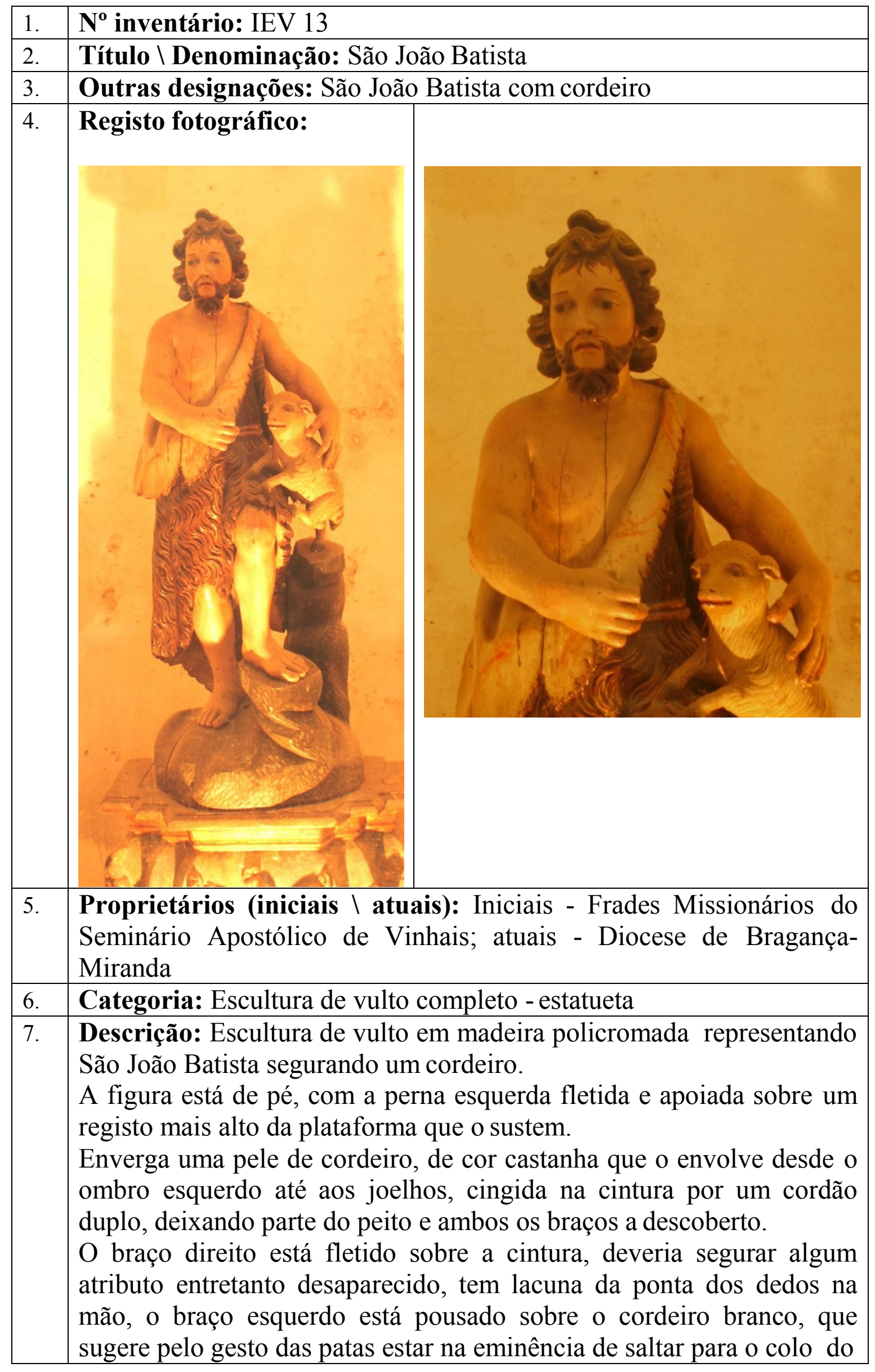




\begin{tabular}{|l|l|}
\hline & $\begin{array}{l}\text { santo. } \\
\text { A figura do santo, com irregularidades na anatomia está descalço } \\
\text { sobre uma plataforma que sugere o meio natural e que se eleva em três } \\
\text { diferentes registos que servem de apoio para a flexão da perna do } \\
\text { santo bem como para o cordeiro. } \\
\text { O rosto de expressão grave apresenta barbas e cabelos castanhos } \\
\text { curtos e ondulados esculpidos na madeira e com algumas madeixas } \\
\text { pintadas sobre o rosto. } \\
\text { A figura destaca-se pelo gesto entre São João e o cordeiro. }\end{array}$ \\
\hline 8. & Técnicas (de suporte): Talhe \\
\hline 9. & Técnicas (de acabamento): Policromia \\
\hline 10. & Materiais (de suporte): Madeira \\
\hline 11. & Materiais (de acabamento): Pigmentos \\
\hline 12. & $\begin{array}{l}\text { Estado de Conservação: Bom; estável, lacuna da ponta de todos os } \\
\text { dedos na mão direita; fissuras na policromia }\end{array}$ \\
\hline 13. & $\begin{array}{l}\text { Dimensões: } \\
\text { Altura: } 80 \text { cm } \\
\text { Largura: } 35 \text { cm } \\
\text { Profundidade: } 35 \text { cm }\end{array}$ \\
\hline 14. & Restauro: apresenta sinais de reintegração cromática \\
\hline 15. & Datas: segunda metade do século XVIII \\
\hline 16. & Proveniência: igreja de Nossa Senhora da Encarnação em Vinhais \\
\hline 17. & Autoria: Frei Domingos \\
\hline 18. & Oficina: Local \\
\hline 19. & $\begin{array}{l}\text { Localização (inicial } \backslash \text { atual): Originalmente estava no altar de Santo } \\
\text { António, no lado do evangelho; atualmente está colocado no nicho } \\
\text { aberto na nave central do lado do evangelho }\end{array}$ \\
\hline 20. & Histórico do objeto: não se conhecem registos \\
\hline 21. & Iconografia: cordeiro branco; vestes de pele de cordeiro \\
\hline 22. & Irmandade: não se conhecem registos \\
\hline 23. & Procissões: não se conhecem registos \\
\hline &
\end{tabular}




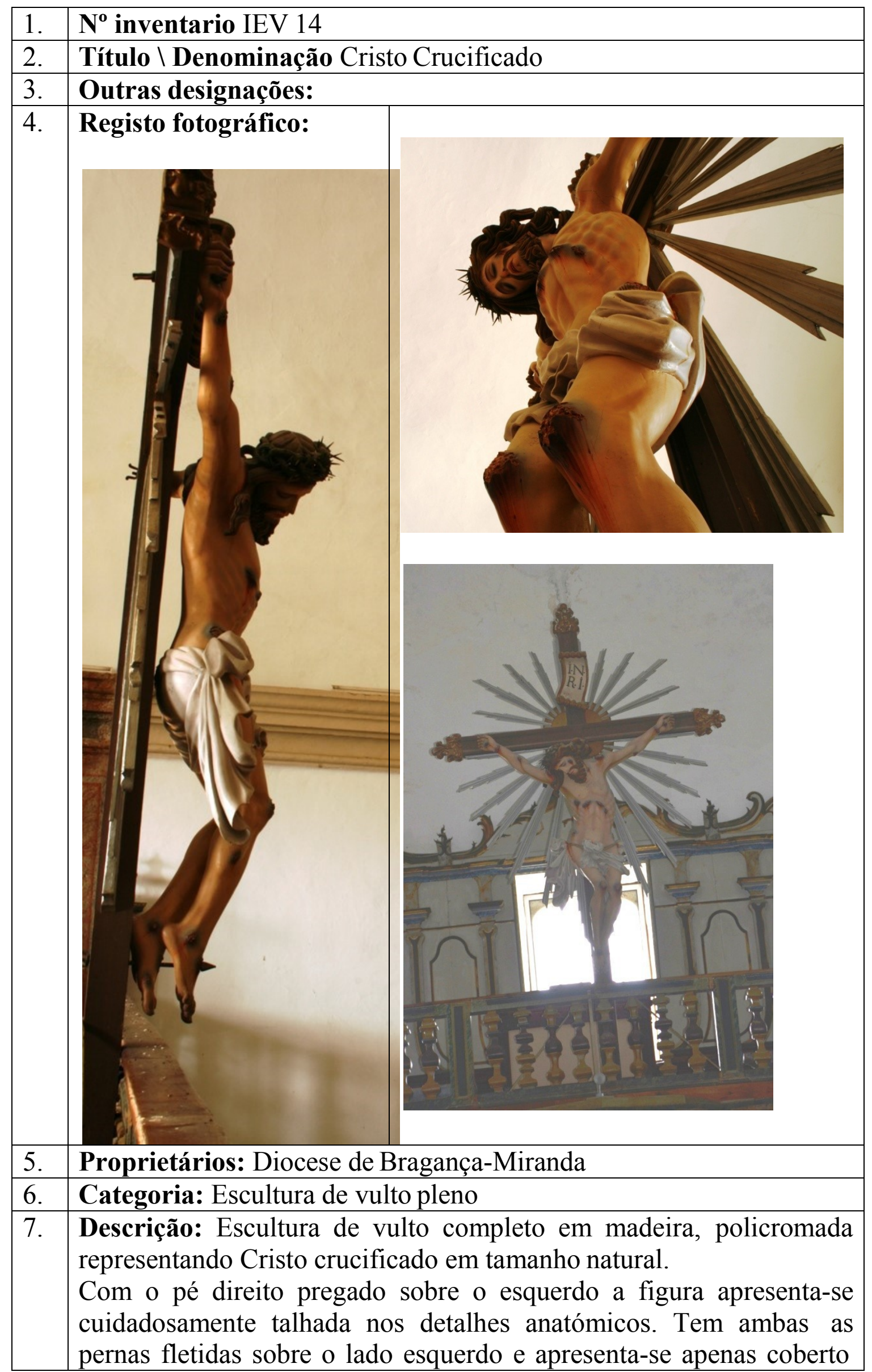




\begin{tabular}{|l|l|}
\hline & $\begin{array}{l}\text { com o cendal branco cingido por um cordão duplo. O cendal que o } \\
\text { cobre, preso com um nó sobre o lado direito, ondula amplamente em } \\
\text { dinâmicos pregas que caiem sobre a frente e o lado direito do corpo. } \\
\text { A cabeça está caída sobre o ombro direito. O rosto magro e de linhas } \\
\text { simétricas tem os olhos fechados e a boca entreaberta com os cantos } \\
\text { descaídos deixando a descoberto os dentes, enfatizando o sofrimento } \\
\text { do corpo morto e martirizado. As barbas estão talhadas em onduladas } \\
\text { formas de tom castanho-escuro, tal como os cabelos longos que caiem } \\
\text { em dinâmicas ondas sobre as costas e ombro direito. Sobre a cabeça } \\
\text { cinge-o uma coroa de espinhos com pregos pontiagudos. } \\
\text { O corpo magro está martirizado com chagas abertas nos joelhos, pés, } \\
\text { punhos e mãos e sobre todo o peito com realistas feridas profundas } \\
\text { mas que não mancham de sangue o corpo limpo. } \\
\text { O corpo está pregado sobre uma cruz de madeira decorada nos } \\
\text { remates por formas polilobadas douradas. Do centro da cruz emerge } \\
\text { um resplendor raiado que preenche o espaço entre os braços e a } \\
\text { estaca da cruz. A cruz está encimada por uma cartela onde pode ler-se } \\
\text { "J.N./R.I." }\end{array}$ \\
\hline 8. & Técnicas (de suporte): Talha \\
\hline 9. & Técnicas (de acabamento): policromia \\
\hline 10. & Materiais (de suporte) Madeira \\
\hline 11. & Materiais (de acabamento): Pigmentos \\
\hline 12. & $\begin{array}{l}\text { Estado de Conservação Bom; apresenta-se se estável; fissuras na } \\
\text { policromia } \\
\text { Dimensões: } \\
\text { Altura: } 390 \text { cm (com a cruz) } \\
\text { Largura: } 240 \text { cm } \\
\text { Profundidade: } 60 \text { cm }\end{array}$ \\
\hline 14. & Restauro: não apresenta sinais de intervenção sobre a obra \\
\hline 15. & Datas: século XX \\
\hline 16. & Proveniência: igreja de Nossa Senhora da Encarnação em Vinhais \\
\hline 17. & Autoria: desconhecida \\
\hline 18. & Oficina: Braga (?) $\backslash$ Matosinhos (?) \\
\hline 19. & $\begin{array}{l}\text { Localização (atual) A escultura está colocado no coro alto sobre a } \\
\text { balaustrada voltado para o altar-mor }\end{array}$ \\
\hline 20. & Histórico do objeto: não se conhecem registos \\
\hline 21. & Iconografia: Cruz; resplendor; cendal; coroa de espinhos \\
\hline 22. & Irmandade: não se conhecem registos \\
\hline 23. & Procissões: não se conhecem registos \\
\hline
\end{tabular}




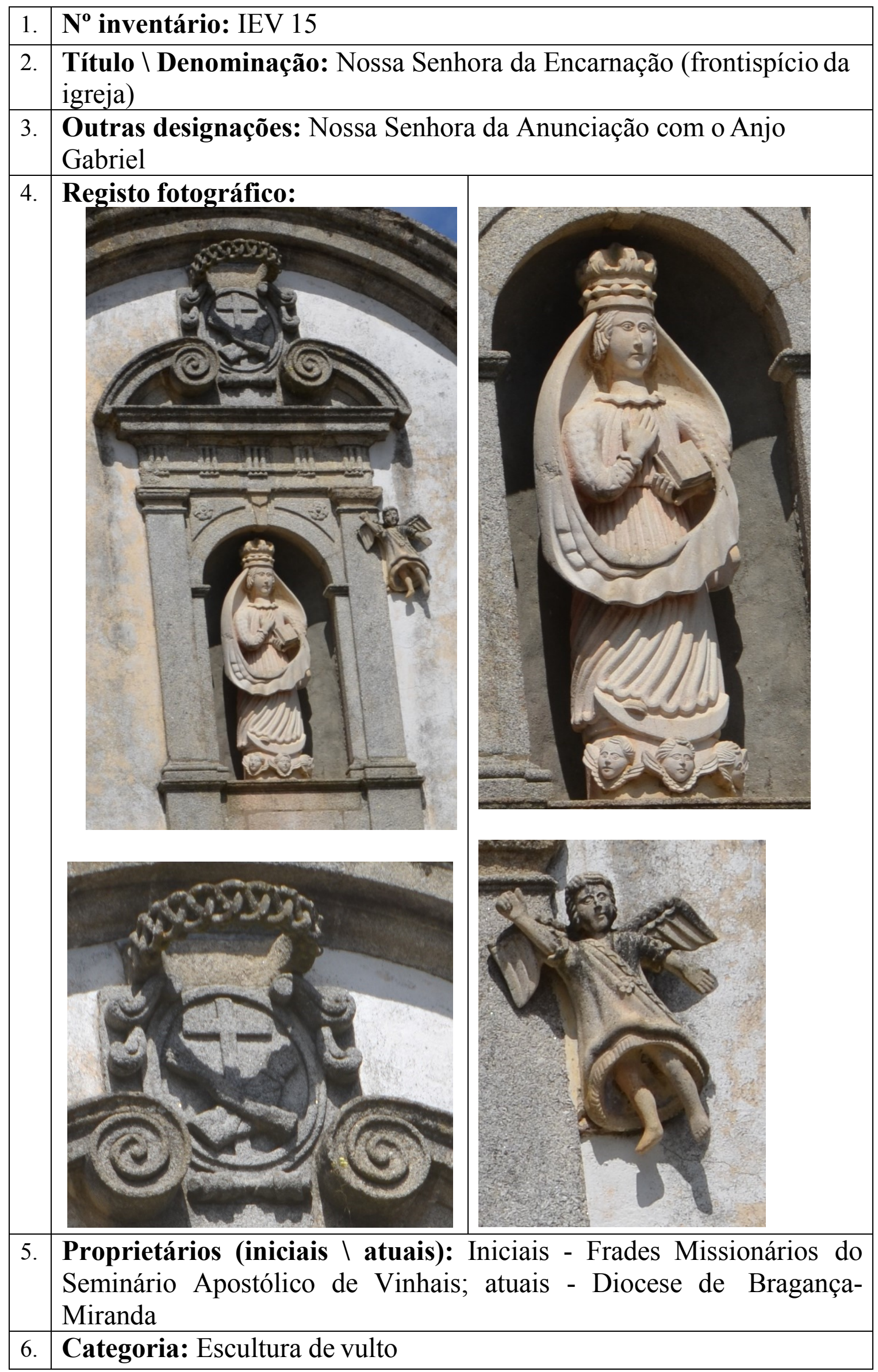




\begin{tabular}{|l|l|}
\hline 7. & $\begin{array}{l}\text { Descrição: Escultura de vulto em pedra, granito, representando Nossa } \\
\text { senhora da Encarnação. } \\
\text { De pé, em posição frontal a Virgem eleva e flete os braços. O braço } \\
\text { direito tem a mão sobre o peito enquanto o esquerdo segura um livro } \\
\text { aberto. Enverga uma túnica roçagante cingida na cintura. Sobre este } \\
\text { usa um amplo manto que lhe cobre parcialmente a cabeça e a envolve } \\
\text { sobre as costas traçada sobre a cintura. O rosto está sumariamente } \\
\text { tratado nos detalhes anatómicos e voltado para a frente. Ostenta na } \\
\text { cabeça, sobre o manto uma coroa. Na base que a suporta está } \\
\text { representada uma lua crescente sobre a qual estão três querubins. } \\
\text { Do lado esquerdo da imagem, já fora do nicho está esculpida a forma } \\
\text { de um anjo. O anjo está voltado para a frente levemente inclinado para } \\
\text { a direita, eleva o braço direito em direção à imagem de Nossa Senhora, } \\
\text { enquanto assimetricamente baixa o braço esquerdo. Enverga túnica } \\
\text { pelos joelhos com sumário tratamento dos panejamentos e detalhes } \\
\text { anatómicos. }\end{array}$ \\
\hline 8. & Técnicas (de suporte): Talha \\
\hline 9. & Técnicas (de acabamento): \\
\hline 10. & Materiais (de suporte): Pedra - granito \\
\hline 11. & Materiais (de acabamento): \\
\hline 12. & Estado de Conservação: Bom; a distância a que a imagem se encontra \\
não permite uma observação dos detalhes
\end{tabular}




\section{FICHAS DE INVENTÁRIO}

ESCULTURA

CAPELA DE NOSSA SENHORA DAS DORES

DO SEMINÁRIO APOSTÓLICO DE VINHAIS 
FICHAS DE INVENTÁRIO | ESCULTURA

Da Ordem de São Francisco na Diocese de Bragança-Miranda 
FICHAS DE INVENTÁRIO |ESCULTURA

Da Ordem de São Francisco na Diocese de Bragança-Miranda

Retábulo rococó do Senhor dos Perdidos na Capela de Nossa Senhora das Dores, Seminário Apostólico de Vinhais

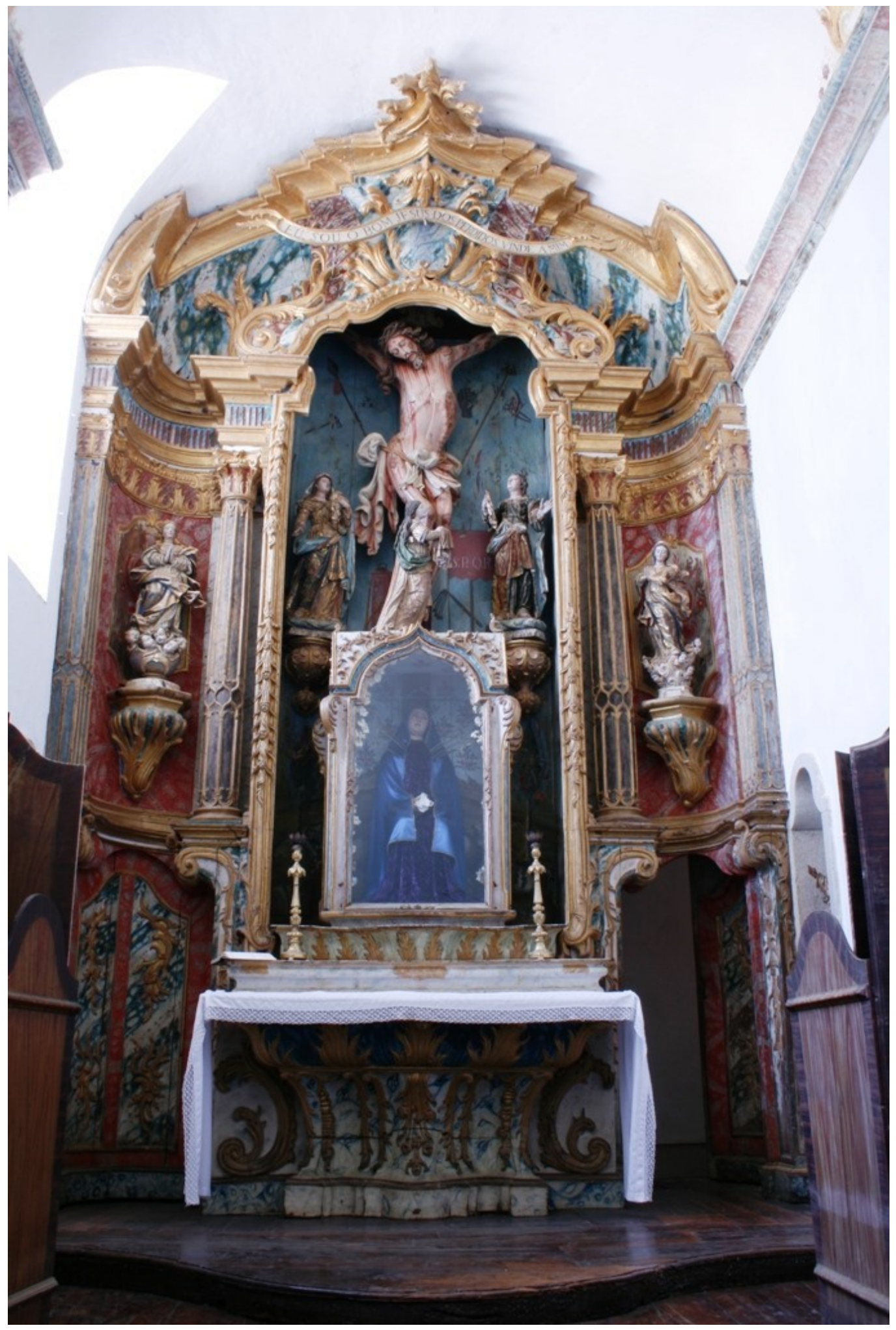


FICHAS DE INVENTÁRIO | ESCULTURA

Da Ordem de São Francisco na Diocese de Bragança-Miranda 


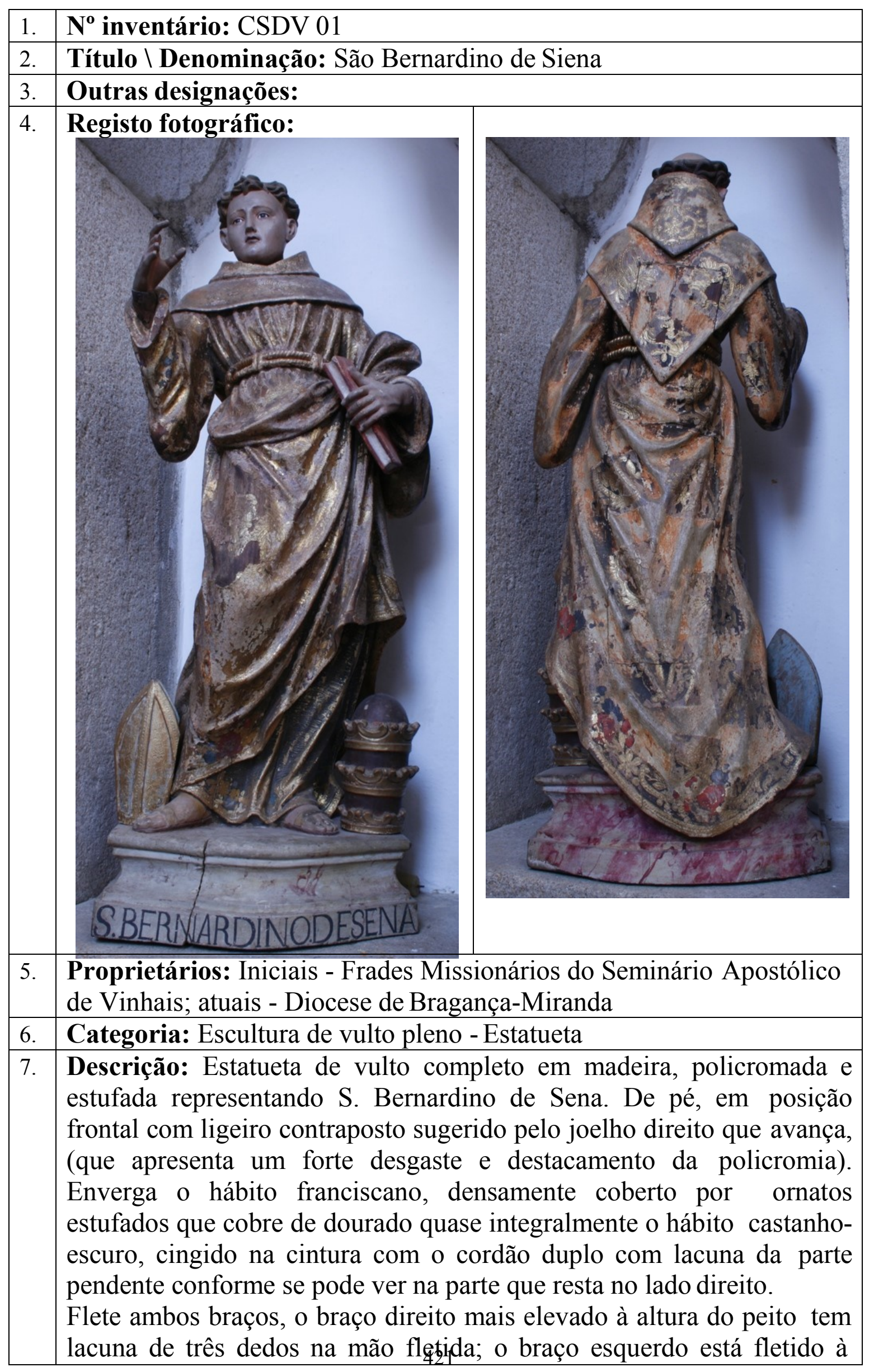




\begin{tabular}{|c|c|}
\hline & $\begin{array}{l}\text { altura da cintura e segura na mão um livro fechado de capas vermelhas } \\
\text { sustendo simultaneamente com o braço parte do hábito traçado. O } \\
\text { hábito com capuz pontiagudo caído sobre os ombros e costas apresenta } \\
\text { nas mangas, sob os cotovelos, um prolongamento mais amplo que o } \\
\text { resto da manga (tal como é observável no hábito das figuras SFV } 04 \text { e } \\
\text { SFV 08). O rosto jovem, finamente esculpido, apresenta linhas suaves } \\
\text { está coberto com carnação com craquele. Ligeiramente voltado para a } \\
\text { direita, tem olhos de vidro e expressão grave. A cabeça tonsurada } \\
\text { apresenta madeixas onduladas de cabelos em tom claro de castanho. } \\
\text { Junto aos pés cuidadosamente esculpidos, desencontrados e com } \\
\text { sandálias, e4stão colocados dois chapéus, do lado direito a mitra papal e } \\
\text { do lado esquerdo a tiara tríplice papal, ambos policromados e decorados } \\
\text { com elementos dourados. Está assente sobre um plinto polilobado } \\
\text { marmoreado em tom branco e vermelho onde pode ler-se em letras } \\
\text { maiúsculas "S. BERNARDINO DE SENA". } \\
\text { A figura destaca-se pela teatralidade dinâmica do gesto dos braços e } \\
\text { pelo cuidado com o talhe anatómico e das finas pregas dos } \\
\text { panejamentos. }\end{array}$ \\
\hline 8. & Técnicas (de suporte): Talha \\
\hline 9. & Técnicas (de acabamento): Policromia; dourado; marmoreado \\
\hline 10. & Materiais (de suporte): Madeira \\
\hline 11. & Materiais (de acabamento): Pigmentos; folha de ouro (?); vidro \\
\hline 12. & $\begin{array}{l}\text { Estado de Conservação: Bom; apresenta-se estável; lacunas desgaste } \\
\text { na policromia }\end{array}$ \\
\hline 13. & $\begin{array}{l}\text { Dimensões: } \\
\text { Altura: } 80 \mathrm{~cm} \\
\text { Largura: } 32 \mathrm{~cm} \\
\text { Profundidade: } 30 \mathrm{~cm} \\
\end{array}$ \\
\hline 14. & Restauro: apresenta sinais de reintegração cromática \\
\hline 15. & Datas: segunda metade do século XVIII \\
\hline 16. & Proveniência: igreja do Seminário Apostólico de Brancanes \\
\hline 17. & $\begin{array}{l}\text { Autoria: desconhecida, mas é de referir a semelhança observada nos } \\
\text { detalhes escultóricos do talhe desta figura com a figura CSDV 09 São } \\
\text { Boaventura, sendo evidente tratar-se de obras esculpidas pelo mesmo } \\
\text { autor } \backslash \text { oficina. }\end{array}$ \\
\hline 18. & Oficina: Nacional (Lisboa?) \\
\hline 19. & $\begin{array}{l}\text { Localização (inicial } \backslash \text { atual): Mantém-se na mesma capela; atualmente } \\
\text { está colocado dentro de um nicho no lado da epístola }\end{array}$ \\
\hline 20. & Histórico do objeto: não se conhecem registos \\
\hline 21. & Iconografia: hábito franciscano; livro; mitra papal; tiara tríplice papal \\
\hline 22. & Irmandade: não se conhecem registos \\
\hline 23. & Procissões: não se conhecem registos \\
\hline
\end{tabular}




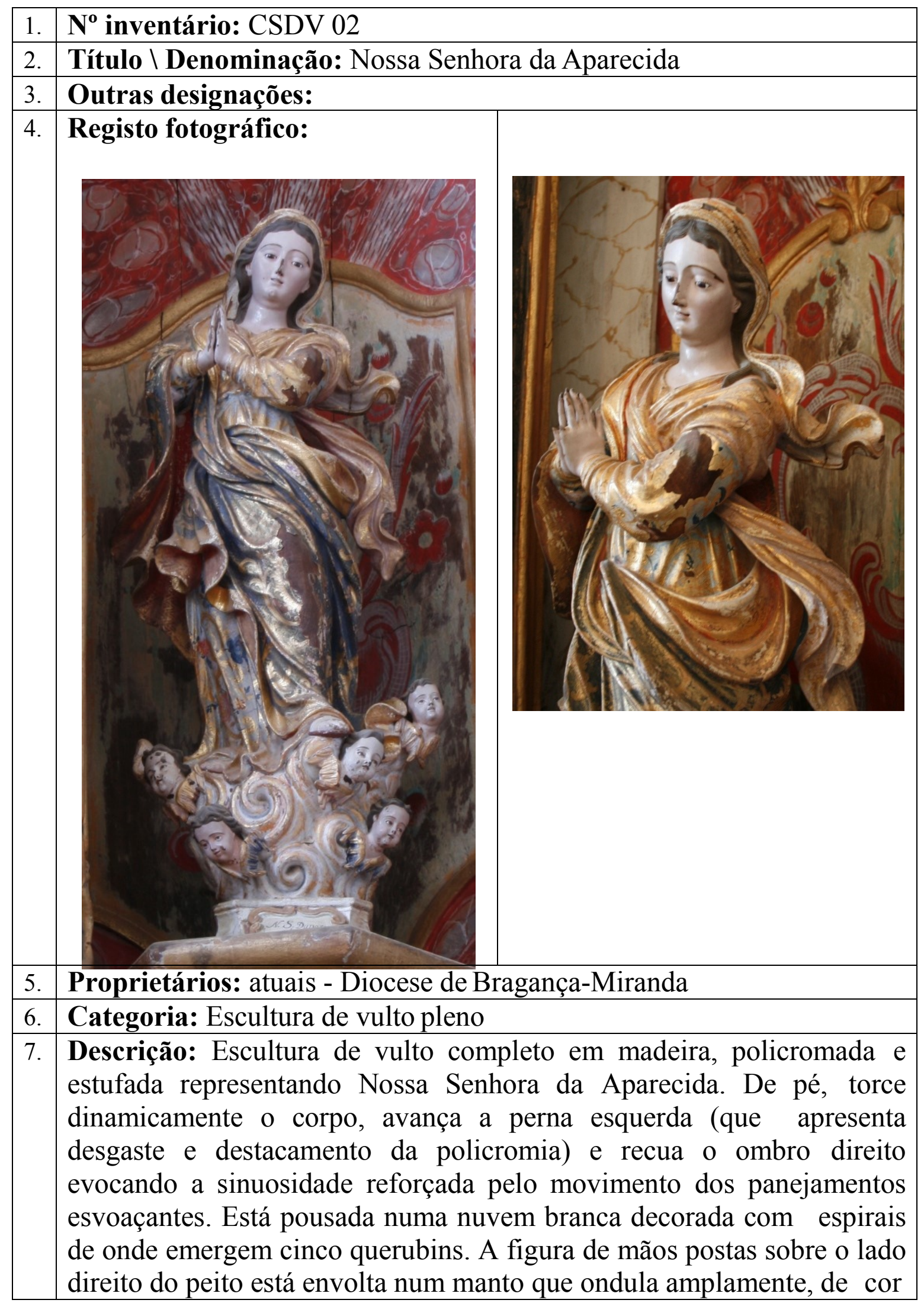




\begin{tabular}{|l|l|}
\hline & $\begin{array}{l}\text { azul e forro vermelho, intensamente decorado com motivos estufados } \\
\text { dourados. Sob este usa uma túnica azul clara com motivos dourados e } \\
\text { policromados estufados, que a cobre até aos pés protegidos com } \\
\text { sandálias. } \\
\text { O rosto jovem, finamente esculpido, apresenta linhas suaves e expressão } \\
\text { alegre, esboça um suave sorriso deixando os dentes a descoberto. De } \\
\text { olhar baixo, com olhos de vidro apresenta destacamento da policromia } \\
\text { no nariz. A cabeça, ligeiramente voltada para a esquerda, tapada com } \\
\text { um véu branco e dourado que deixa a descoberto parte dos cabelos } \\
\text { castanhos. } \\
\text { A figura está assente sobre uma base polilobada branca com ornatos } \\
\text { dourados onde se pode ler N. S. Dapare/sida. } \\
\text { A figura destaca-se pela teatralidade dinâmica do gesto dos braços e } \\
\text { pelo cuidado com o talhe anatómico e das finas pregas dos } \\
\text { panejamentos. }\end{array}$ \\
\hline 8. & Técnicas (de suporte): Talha \\
\hline 9. & $\begin{array}{l}\text { Técnicas (de acabamento): Policromia; estufado dourado e } \\
\text { policromado; marmoreado }\end{array}$ \\
\hline 10. & Materiais (de suporte): Madeira \\
\hline 11. & Materiais (de acabamento): Pigmentos; folha de ouro; vidro \\
\hline 12. & Estado de Conservação: Bom; apresenta-se se estável; lacunas em sete \\
dedos
\end{tabular}




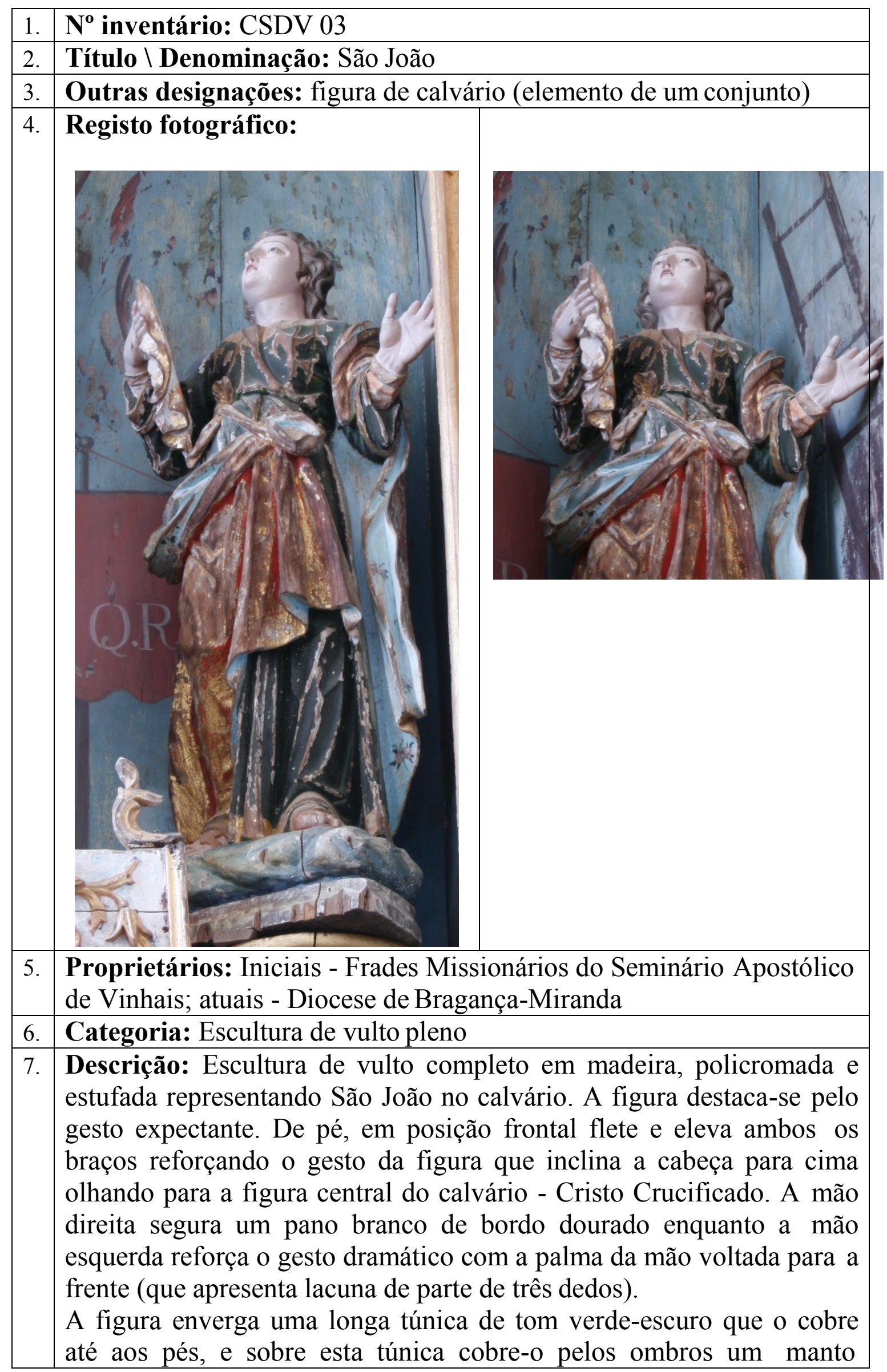




\begin{tabular}{|c|c|}
\hline & $\begin{array}{l}\text { vermelho (com forte desgaste na policromia) e restos de estufado } \\
\text { dourado, cujo forro interior é de tom azul com motivos policromos } \\
\text { estufados. O manto sustido no ombro esquerdo está traçado sobre a } \\
\text { cintura caindo em vincadas pregas até aos pés que protege com } \\
\text { sandálias. } \\
\text { A cabeça está voltada para cima com uma ligeira inclinação para o } \\
\text { lado direito. O rosto jovem e de contornos arredondados, está } \\
\text { cuidadosamente talhado na expressão de dor com as sobrancelhas } \\
\text { arqueadas e a boca entreaberta deixando os dentes parcialmente } \\
\text { descobertos. No pescoço sobressai a masculinidade do contorno do } \\
\text { jovem santo. O cabelo curto é talhado em largas ondas de tom castanho } \\
\text { claro. } \\
\text { A figura está assente sobre uma plataforma irregular que assenta sobre } \\
\text { uma base semicircular. }\end{array}$ \\
\hline 8. & Técnicas (de suporte): Talha \\
\hline 9. & $\begin{array}{l}\text { Técnicas (de acabamento): policromia; estufado dourado e } \\
\text { policromado }\end{array}$ \\
\hline 10. & Materiais (de suporte): Madeira \\
\hline 11. & Materiais (de acabamento): Pigmentos; folha de ol \\
\hline 12. & $\begin{array}{l}\text { Estado de Conservação: Bom; apresenta-se se estável; lacunas de } \\
\text { parte dos dedos na mão esquerda e desgaste na policromia. }\end{array}$ \\
\hline 13. & $\begin{array}{l}\text { Dimensões: } \\
\text { Altura: } 114 \mathrm{~cm} \\
\text { Largura: } 64 \mathrm{~cm} \\
\text { Profundidade: } 50 \mathrm{~cm}\end{array}$ \\
\hline 14. & Restauro: apresenta sinais \\
\hline 15. & Datas: segunda metade do século XVIII \\
\hline 16. & Proveniência: igreja de Nossa Senhora da Encarnação em Vinhais \\
\hline 17. & $\begin{array}{l}\text { Autoria: desconhecida, mas as semelhanças formais e no gesto das } \\
\text { figuras do conjunto do calvário (Virgem Maria, Santa Maria Madalena } \\
\text { e São João) sugerem tratar-se de obras do mesmo autor ou oficina. }\end{array}$ \\
\hline 18. & Oficina: Nacional \\
\hline 19. & $\begin{array}{l}\text { Localização (inicial \ atual): Mantém a localização original, a } \\
\text { escultura está colocado no nicho central do retábulo ao lado esquerdo } \\
\text { da figura de Cristo e em conjunto com a Virgem Maria e Santa Maria } \\
\text { Madalena }\end{array}$ \\
\hline 20. & Histórico do objeto: não se conhecem registos \\
\hline 21. & Iconog \\
\hline 22. & \\
\hline 23. & \\
\hline
\end{tabular}




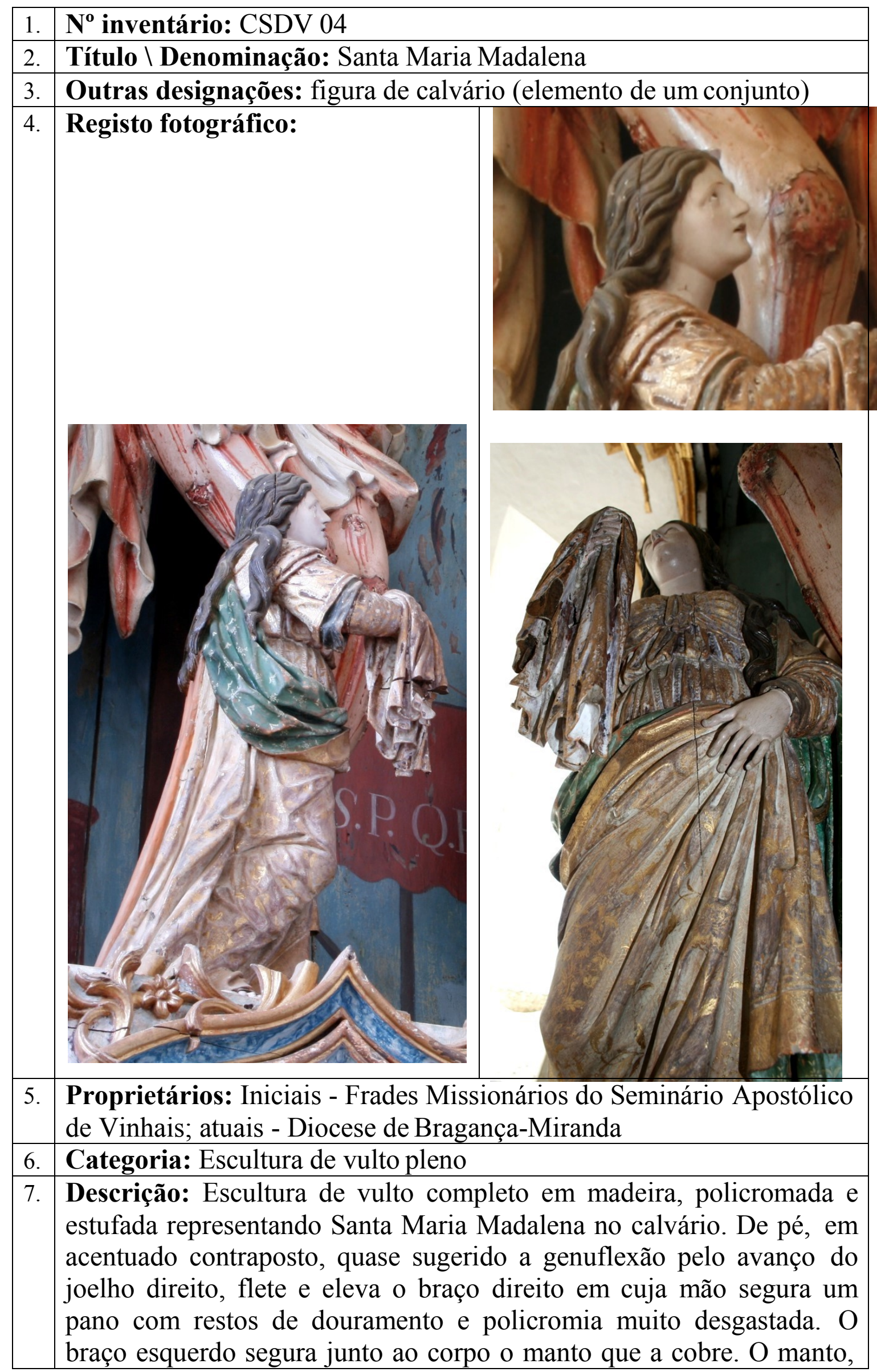




\begin{tabular}{|c|c|}
\hline & $\begin{array}{l}\text { de tom róseo claro e densamente coberto com motivos estufados } \\
\text { dourados e forro verde com motivos estufados policromados, envolve- } \\
\text { a do ombro esquerdo até aos pés, está traçado abaixo da cintura. Sob o } \\
\text { manto enverga uma túnica decorativamente cingida na cintura e sobre } \\
\text { o peito que a cobre com pregueado fino. } \\
\text { A cabeça está voltada para cima. O rosto jovem e de contornos } \\
\text { arredondados, está cuidadosamente talhado na expressão de dor com as } \\
\text { sobrancelhas arqueadas e a boca entreaberta com os cantos descaídos } \\
\text { deixando os dentes parcialmente descobertos. } \\
\text { Os longos cabelos, cuidadosamente talhados, caiem sobre os ombros } \\
\text { em amplas e onduladas madeixas de cor castanha escura. } \\
\text { A figura descalça assenta os pés sobre uma plataforma irregular. }\end{array}$ \\
\hline 8. & Técnicas (de suporte): Talha \\
\hline 9. & $\begin{array}{l}\text { Técnicas (de acabamento): Policromia; estufado dourado e } \\
\text { policromado }\end{array}$ \\
\hline 10 . & Materiais (de suporte): Madeira \\
\hline 11. & Materiais (de acabamento) \\
\hline 12. & $\begin{array}{l}\text { Estado de Conservação: Bom; apresenta-se se estável; lacunas de } \\
\text { parte dos dedos na mão esquerda e desgaste na policromia. Tem duas } \\
\text { profundas fissuras longitudinais uma na frente e outra sobre a cabeça } \\
\text { da figura. }\end{array}$ \\
\hline 13. & $\begin{array}{l}\text { Dimensões: } \\
\text { Altura: } 90 \mathrm{~cm} \\
\text { Largura: } 48 \mathrm{~cm} \\
\text { Profundidade: } 53 \mathrm{~cm}\end{array}$ \\
\hline 14. & Restauro: apresenta sinais c \\
\hline 15 . & Datas: segunda metade do século XVIII \\
\hline 16. & Proveniência: igreja de Nossa Senhora da Encarnação em Vinhais \\
\hline 17. & $\begin{array}{l}\text { Autoria: desconhecida, mas as semelhanças formais e no gesto das } \\
\text { figuras do conjunto do calvário (Virgem Maria, Santa Maria Madalena } \\
\text { e São João) sugerem tratar-se de obras do mesmo autor ou oficina. }\end{array}$ \\
\hline 18. & Oficina: Nacional \\
\hline 19. & $\begin{array}{l}\text { Localização (inicial \ atual): Mantém a localização original, a } \\
\text { escultura está colocado no nicho central do retábulo de perfil para o } \\
\text { observador em frente da figura de Cristo e em conjunto com a Virgem } \\
\text { Maria e São João. }\end{array}$ \\
\hline 20. & Histórico do objeto: não se conhecem registos \\
\hline 21. & Iconografia: Santa Maria Madalena no calvário segurando um lenço \\
\hline 22. & Irmandade: não se conhecem registos \\
\hline 23. & \\
\hline
\end{tabular}




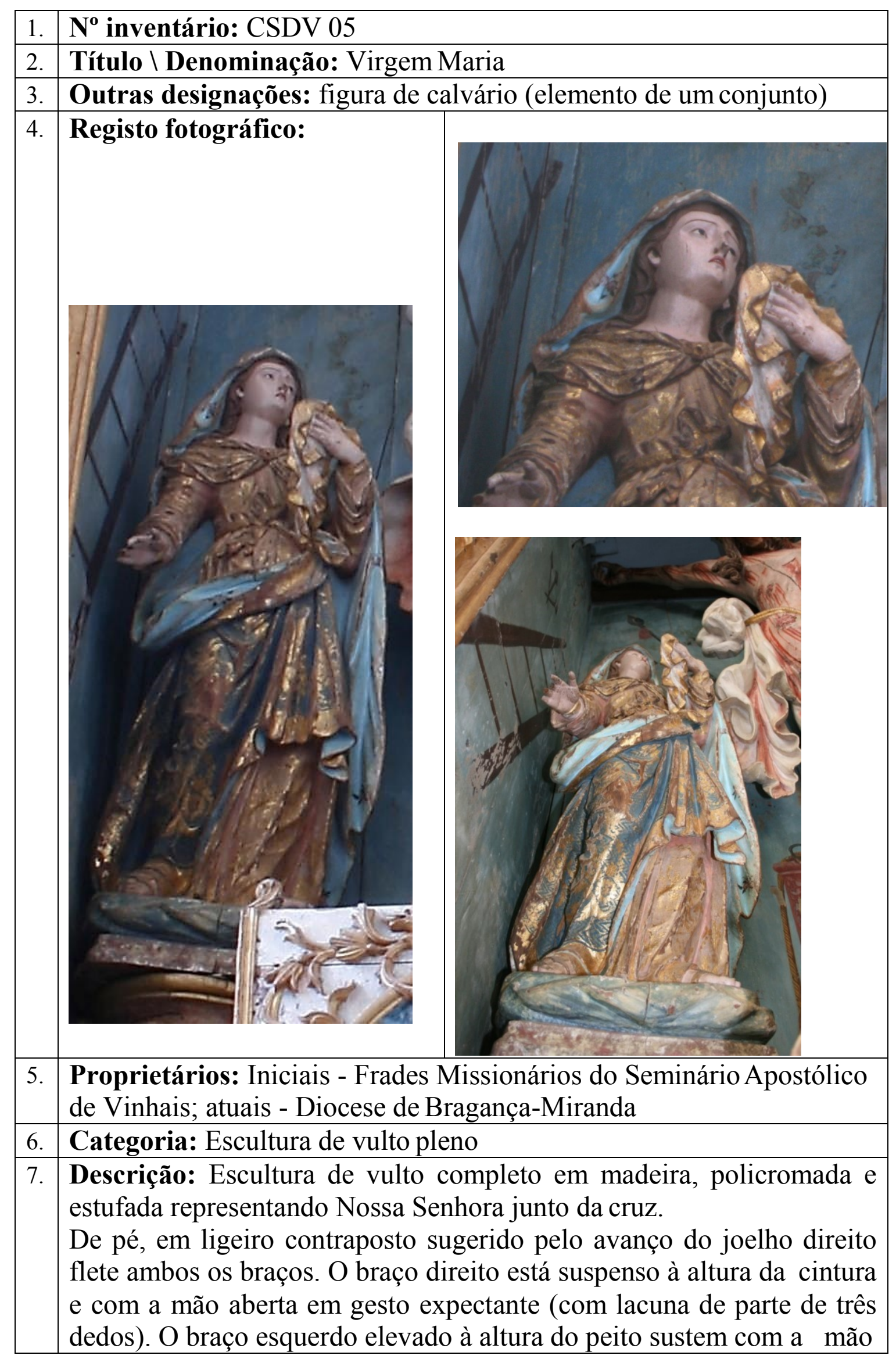




\begin{tabular}{|c|c|}
\hline & $\begin{array}{l}\text { um pano de cor branca com bordo dourado. Enverga uma larga túnica, } \\
\text { num tom róseo coberto de dourado já muito desgastado, cingida na } \\
\text { cintura com um ornamentado laço. Sobre esta cinge-a uma capa } \\
\text { abotoada sobre o peito. Um largo manto, de tom azul densamente } \\
\text { coberto por estufados dourados com forro azul claro com motivos } \\
\text { policromados estufados, cobre-a sobre a cabeça e envolve-lhe o corpo } \\
\text { está traçada sobre a cintura. O largo manto permite que se veja parte } \\
\text { dos longos cabelos de tom castanho claro. O rosto jovem da Virgem } \\
\text { está cuidadosamente talhado e voltado para a direita ligeiramente } \\
\text { inclinado para cima. Com contida expressão de dor sugerida pela boca } \\
\text { entreaberta com os cantos descaídos deixando os dentes parcialmente } \\
\text { descobertos e pelo arquear das sobrancelhas. } \\
\text { A figura enverga sandálias e está assente sobre uma plataforma } \\
\text { irregular de tom azul que está sobre uma base polilobada marmoreada } \\
\text { em tom vermelho. }\end{array}$ \\
\hline 8. & Técnicas (de suporte): Talha \\
\hline 9. & nento): Policromia; estufad \\
\hline 10. & te): Madeira \\
\hline 11. & Materiais (de ac \\
\hline 12. & $\begin{array}{l}\text { Estado de Conservação: Bom; apresenta-se se estável; lacunas de } \\
\text { parte dos dedos na mão direita e desgaste na policromia. Destacamento } \\
\text { da policromia sobre o nariz. }\end{array}$ \\
\hline 13. & $\begin{array}{l}\text { Dime } \\
\text { Alturc } \\
\text { Largu } \\
\text { Profu }\end{array}$ \\
\hline 14. & Restauro: apresenta sinais de reintegração cromática \\
\hline 15. & tade do século XVIII \\
\hline 16. & $C_{1}$ \\
\hline 17. & $\begin{array}{l}\text { Autoria: desconhecida, mas as semelhanças formais e no gesto das } \\
\text { figuras do conjunto do calvário (Virgem Maria, Santa Maria Madalena } \\
\text { e São João) sugerem tratar-se de obras do mesmo autor ou oficina. }\end{array}$ \\
\hline 18. & Oficina: Nacional \\
\hline 19. & $\begin{array}{l}\text { Localização (inicial \ atual): Mantém a localização original, a } \\
\text { escultura está colocado no nicho central do retábulo ao lado direito da } \\
\text { figura de Cristo e em conjunto com a Santa Maria Madalena e São } \\
\text { João. }\end{array}$ \\
\hline 20. & stórico do objeto: não se conhecem registos \\
\hline 21. & Icon \\
\hline 22. & \\
\hline 23. & \\
\hline
\end{tabular}




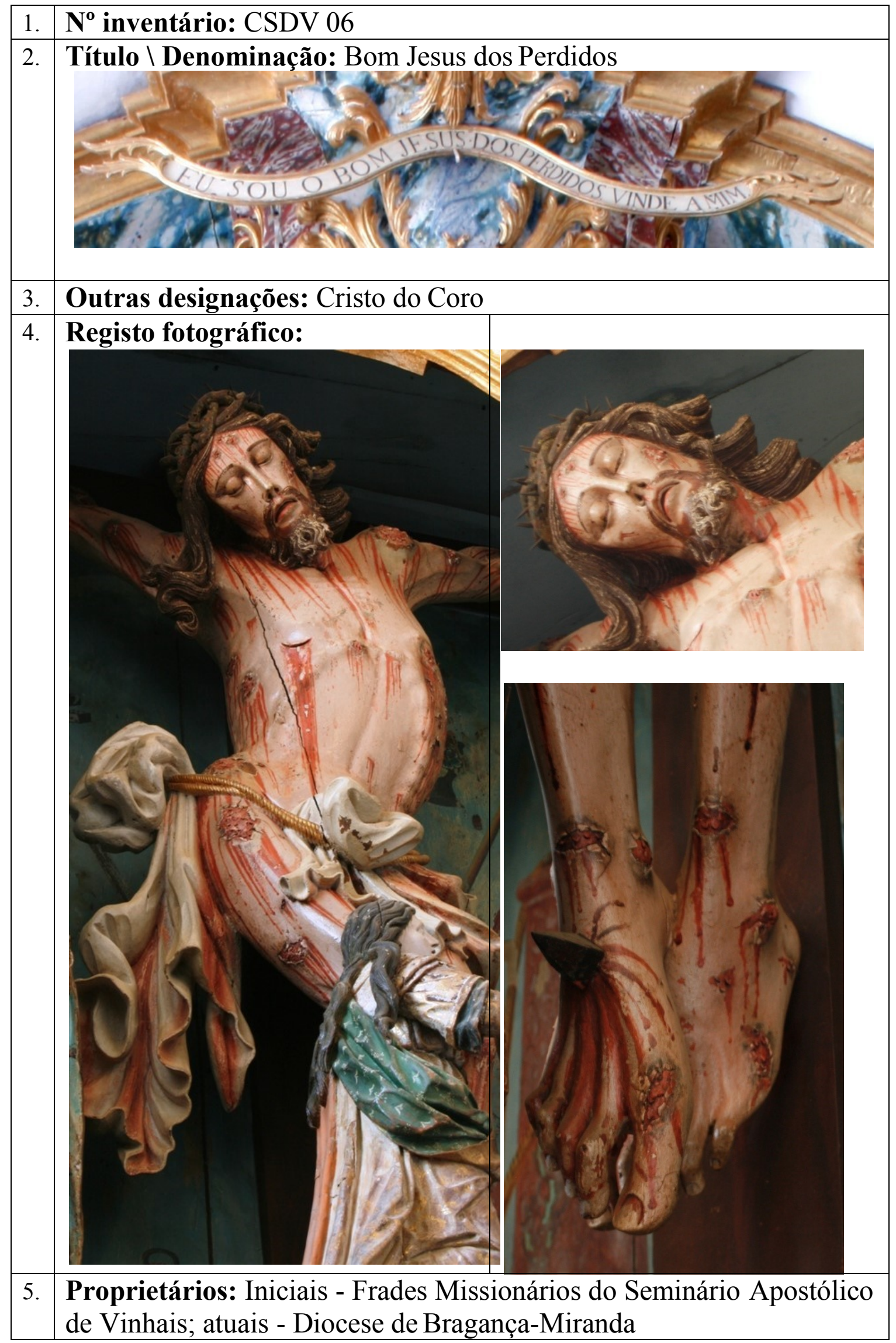




\begin{tabular}{|c|c|}
\hline 6. & ategoria: Escultura de vulto pleno - colossal \\
\hline 7. & $\begin{array}{l}\text { Descrição: Escultura de vulto completo em madeira, policromada } \\
\text { representando Cristo crucificado em tamanho colossal. A escultura } \\
\text { sobressai não apenas no tamanho mas na expressividade da torção do } \\
\text { corpo bem como na intensidade das marcas da tortura. Com o pé } \\
\text { direito pregado sobre o esquerdo tem ambas as pernas fletidas sobre o } \\
\text { lado esquerdo obrigando a proeminência do lado direito da anca que se } \\
\text { apresenta nua apenas com o cordão duplo que lhe cinge o cendal } \\
\text { branco. O cendal que o cobre, muito ensanguentado, ondula } \\
\text { amplamente em dinâmicos pregas que caiem sobre o lado direito do } \\
\text { corpo. O dorso, intensamente torcido, reforça a linha curva do lado } \\
\text { esquerdo do corpo, com evidência da estrutura óssea das costelas bem } \\
\text { como do ombro esquerdo mais saliente. O dramático gesto do corpo é } \\
\text { sublimado pelo peso da cabeça caída sobre o lado direito enfatizando } \\
\text { na sinuosidade das linhas o sofrimento do corpo morto. A figura é } \\
\text { detalhadamente trabalhada nos aspetos anatómicos executados com } \\
\text { proporção e expressividade. As marcas dos flagelos ultrapassam as } \\
\text { mãos, os pés e o peito e estendem-se por todo o corpo em feridas } \\
\text { abertas de onde escorrem abundantes gotas de sangue. } \\
\text { O rosto magro e de linhas simétricas apresenta os olhos fechados e a } \\
\text { boca entreaberta com os cantos dos lábios descaídos. As barbas estão } \\
\text { talhadas em onduladas formas de tom castanho-escuro, tal como os } \\
\text { cabelos longos que caiem em dinâmicas ondas sobre as costas e ombro } \\
\text { direito. Sobre a cabeça cinge-o uma coroa de espinhos cujos cortes } \\
\text { provocados sobre a pela cobrem a testa de sangue. } \\
\text { O corpo está pregado sobre uma cruz simples encimada por uma } \\
\text { cartela onde pode ler-se "J.N./R.I." } \\
\text { O retábulo que acolhe a escultura parece ter sido alterado para } \\
\text { comportar a escala colossal do Bom Jesus dos Perdidos, encobrindo } \\
\text { parte da figura pois não só os braços da cruz estão já nos espaços } \\
\text { reservados aos nichos laterais como a base da cruz está inserida dentro } \\
\text { da caixa oratório que alberga a imagem de Nossa Senhora das Dores. } \\
\text { No topo do retábulo corre uma cartela onde pode ler-se em letras } \\
\text { maiúsculas "EU SOU O BOM JESUS DOS PERDIDOS VINDE A } \\
\text { MIM". }\end{array}$ \\
\hline 8. & Técnicas (de suporte): Talha \\
\hline 9. & \\
\hline 10. & \\
\hline 11. & \\
\hline 12. & $\begin{array}{l}\text { Estado de Conservação: Bom; apresenta-se se estável; profunda } \\
\text { fissura sobre o lado direito do dorso. }\end{array}$ \\
\hline 13. & $\begin{array}{l}\text { Dimensões: } \\
\text { Altura: } 320 \mathrm{~cm} \text { (com a cruz) só o corpo: } 200 \mathrm{~cm}\end{array}$ \\
\hline
\end{tabular}




\begin{tabular}{|r|l|}
\hline & $\begin{array}{l}\text { Largura: } 160 \mathrm{~cm} \\
\text { Profundidade: } 68 \mathrm{~cm}\end{array}$ \\
\hline 14. & Restauro: apresenta sinais de reintegração cromática \\
\hline 15. & Datas: segunda metade do século XVIII \\
\hline 16. & Proveniência: igreja de Nossa Senhora da Encarnação em Vinhais \\
\hline 17. & $\begin{array}{l}\text { Autoria: Frei Domingos (única obra que lhe é atribuída por Firmino } \\
\text { Martins em 1929) }\end{array}$ \\
\hline 18. & Oficina: Local \\
\hline 19. & $\begin{array}{l}\text { Localização (inicial } \backslash \text { atual): Originalmente a escultura estava } \\
\text { colocada sobre o coro alto da igreja de Nossa Senhora da Encarnação; } \\
\text { atualmente a escultura está colocado no nicho central do retábulo }\end{array}$ \\
\hline 20. & $\begin{array}{l}\text { Histórico do objeto: a imagem colossal de Cristo colocada sobre o } \\
\text { coro alto estaria originalmente oposta à imagem colossal de Nossa } \\
\text { Senhora da Encarnação no altar-mor }\end{array}$ \\
\hline 21. & Iconografia: Cristo morto na cruz; intensos sinais de martírio \\
\hline 22. & Irmandade: não se conhecem registos \\
\hline 23. & Procissões: não se conhecem registos \\
\hline
\end{tabular}


FICHAS DE INVENTÁRIO | ESCULTURA

Da Ordem de São Francisco na Diocese de Bragança-Miranda 


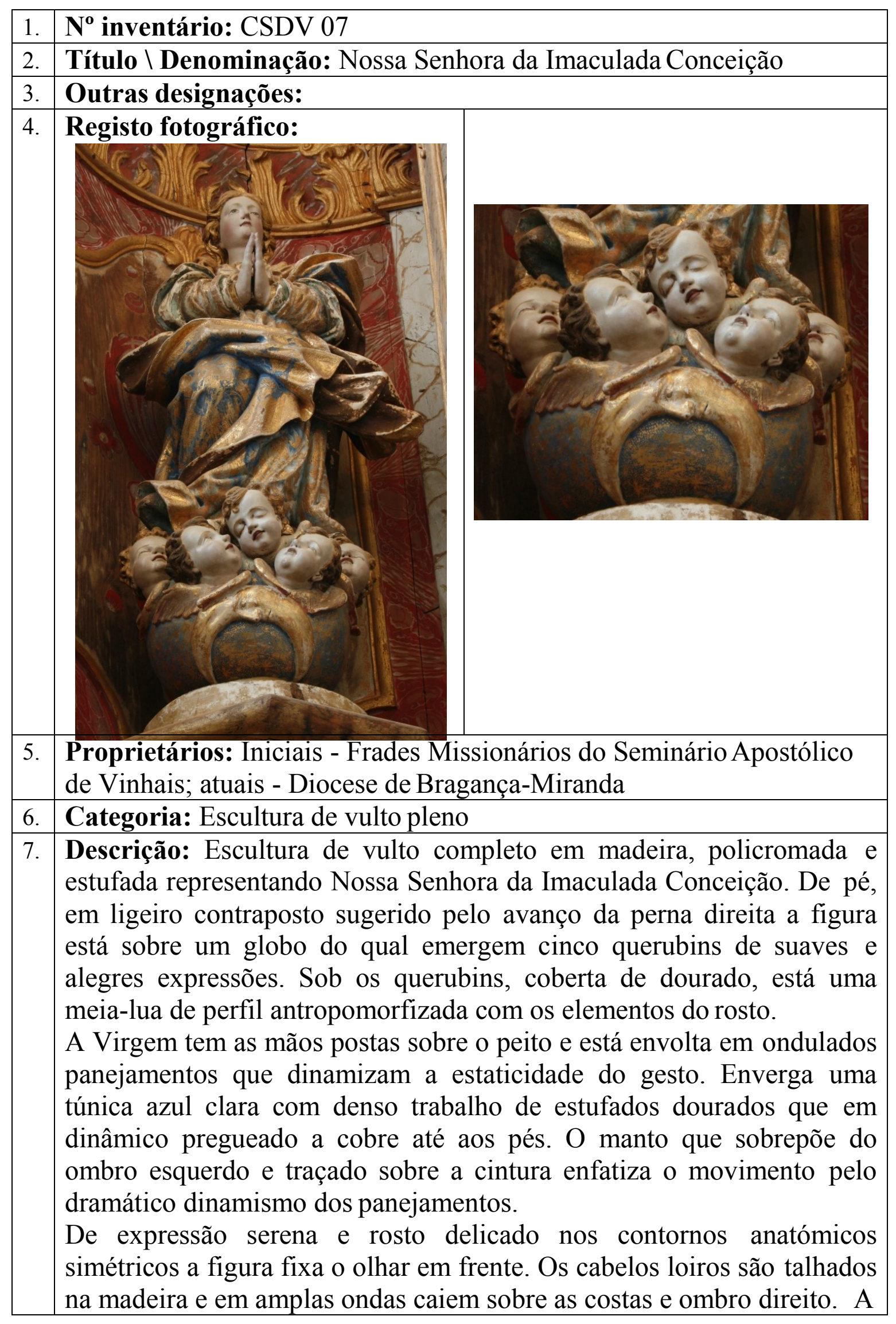




\begin{tabular}{|c|l|}
\hline & figura está assente sobre uma base circular branca. \\
\hline 8. & Técnicas (de suporte): Talha \\
\hline 9. & Técnicas (de acabamento): Policromia; estufado e douramento \\
\hline 10. & Materiais (de suporte): Madeira \\
\hline 11. & Materiais (de acabamento): Pigmentos; folha de ouro \\
\hline 12. & $\begin{array}{l}\text { Estado de Conservação: Bom; apresenta-se se estável; desgaste na } \\
\text { policromia }\end{array}$ \\
\hline 13. & $\begin{array}{l}\text { Dimensões: } \\
\text { Altura: } 110 \mathrm{~cm} \\
\text { Largura: } 50 \mathrm{~cm} \\
\text { Profundidade: } 35 \mathrm{~cm}\end{array}$ \\
\hline 14. & Restauro: apresenta sinais de reintegração cromática \\
\hline 15. & Datas: segunda metade do século XVIII \\
\hline 16. & Proveniência: igreja de Nossa Senhora da Encarnação em Vinhais \\
\hline 17. & Autoria: Frei Domingos \\
\hline 18. & Oficina: Local \\
\hline 19. & $\begin{array}{l}\text { Localização (inicial \ atual): Originalmente estava na desparecida } \\
\text { Capela do Capitulo; atualmente a escultura está colocada dentro de um } \\
\text { nicho no altar no lado do evangelho }\end{array}$ \\
\hline 20. & Histórico do objeto: não se conhecem registos \\
\hline 21. & Iconografia: Globo; Lua; Querubins; mãos postas sobre o peito \\
\hline 22. & Irmandade: não se conhecem registos \\
\hline 23. & Procissões: não se conhecem registos \\
\hline
\end{tabular}




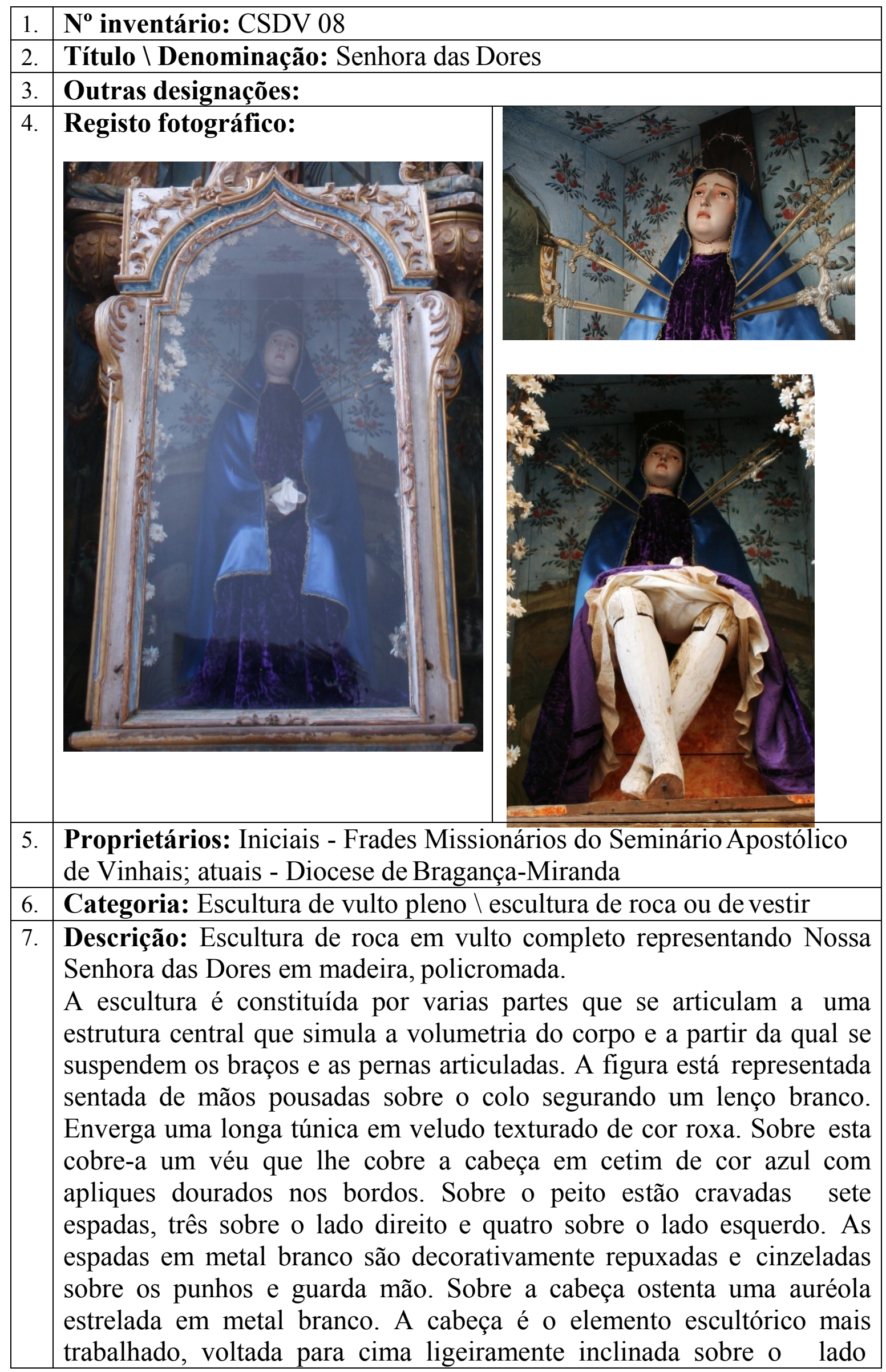




\begin{tabular}{|c|c|}
\hline & $\begin{array}{l}\text { esquerdo destaca-se pelo dramatismo da expressão de dor que transmite. } \\
\text { Com as sobrancelhas arqueadas e o olhar, com olhos de vidro, que se } \\
\text { eleva enquanto a boca entreaberta e com os cantos dos lábios descaídos } \\
\text { deixa a descoberto parte dos dentes. A expressão de dor é intensificada } \\
\text { pelas lágrimas que escorrem uma sobre o lado direito e duas sobre o } \\
\text { esquerdo. A policromia sobre o pescoço está muito desgastada, bem } \\
\text { como sobre as mãos que são cuidadosamente talhadas. A figura está } \\
\text { sentada dentro de uma caixa oratório em talha dourada rococó sobre } \\
\text { fundo branco com elementos marmoreados a azul. A caixa está } \\
\text { trespassada na parte posterior por parte da cruz que sustém a imagem do } \\
\text { Bom Jesus dos Perdidos, e aproveita a pintura do fundo do retábulo que } \\
\text { representa o gólgota ao qual acrescenta elementos vegetalistas } \\
\text { policromados repetidos. A frente e os lados são em vidro e parece que a } \\
\text { escultura teve que ser adaptada ao espaço da caixa, pois parte do pé } \\
\text { direito está cortado de modo a caber no seu interior. A caixa está } \\
\text { colocada no primeiro registo da parte central do retábulo. }\end{array}$ \\
\hline 8. & Técnicas (de suporte): Talha \\
\hline 9. & $\begin{array}{l}\text { Técnicas (de acabamento): Policromia; Têxteis; fundição; cinzelagem; } \\
\text { repuxado; marmoreado }\end{array}$ \\
\hline 10. & Materiais (de suporte): Madeira \\
\hline 11 . & Materiais (de acabamento): Pigmentos; vidro; têxteis; metal branco \\
\hline 12 . & $\begin{array}{l}\text { Estado de Conservação: Bom; apresenta-se se estável destacamento da } \\
\text { policromia no pescoço. }\end{array}$ \\
\hline 13. & $\begin{array}{l}\text { Dimensões: } \\
\text { Altura: } 128 \mathrm{~cm} \\
\text { Largura: } 60 \mathrm{~cm} \\
\text { Profundidade: } 70 \mathrm{~cm}\end{array}$ \\
\hline 14. & Restauro: apresenta sinais de reintegração cromática \\
\hline 15. & Datas: segunda metade do século XVIII \\
\hline 16. & Proveniência: igreja de Nossa Senhora da Encarnação em Vinhais \\
\hline 17. & Autoria: Frei Domingos \\
\hline 18. & Oficina: Local \\
\hline 19. & $\begin{array}{l}\text { Localização (inicial } \backslash \text { atual): Mantém-se no local de origem, o retábulo } \\
\text { da capela de Nossa Senhora das Dores, no } 1^{\circ} \text { registo, parte central }\end{array}$ \\
\hline 20. & $\begin{array}{l}\text { Histórico do objeto: Acompanham a imagem quatro ex-votos } \\
\text { dedicados aos seus milagres e representando Nossa Senhora das Dores } \\
\text { em pintura a óleo sobre madeira com as datas de } 1779 \text { e } 1873\end{array}$ \\
\hline 21. & $\begin{array}{l}\text { Iconografia: Senhora das Dores; Sete espadas; Imagem de Roca; } \\
\text { aureola; lágrimas }\end{array}$ \\
\hline 22. & Irmandade: não se conhecem registos \\
\hline 23. & Procissões: não se conhecem registos \\
\hline
\end{tabular}




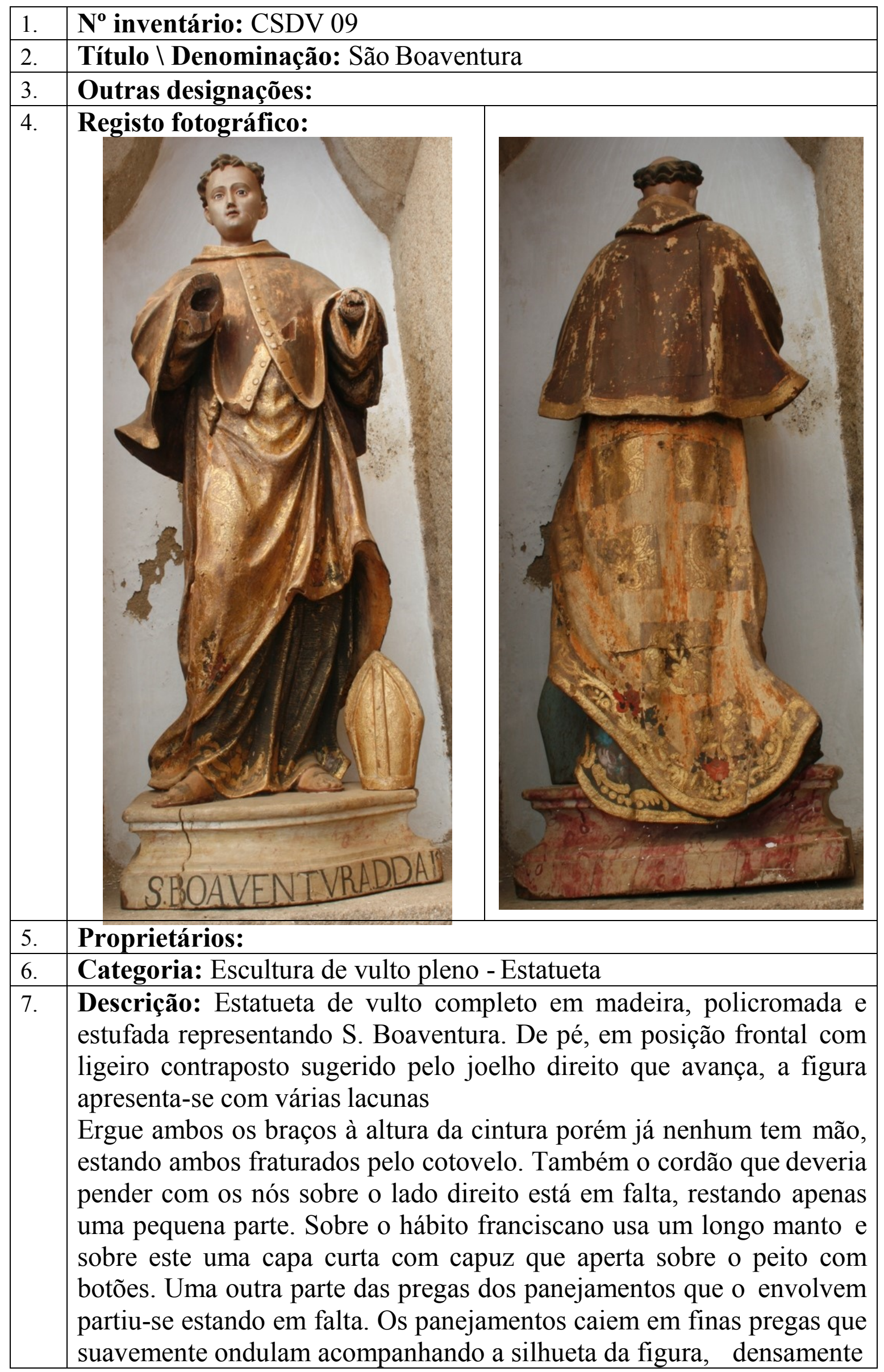




\begin{tabular}{|l|l|}
\hline & $\begin{array}{l}\text { cobertos por ornatos estufados dourados e restos de estufados } \\
\text { policromados que o cobrem até aos pés. Os pés afastados e com o pé } \\
\text { direito mais avançado estão calçado com sandálias. Ao lado do pé } \\
\text { esquerdo está no chão pousada uma mitra decorada com estufado } \\
\text { dourado. A figura assenta numa base polilobada marmoreada em cor } \\
\text { branca e vermelha em cuja frente pode ler-se "S. Boaventura } \\
\text { D.DAJ(...)". O rosto jovem cuidadosamente talhado nos detalhes } \\
\text { anatómicos, tem a boca entreaberta deixando ver parte dos dentes e } \\
\text { olhando em frente com olhos de vidro que compõem uma expressão } \\
\text { serena. A cabeça é tonsurada e coberta com madeixas de cor castanha } \\
\text { clara. } \\
\text { A figura destaca-se pela teatralidade dinâmica do gesto dos braços e } \\
\text { pelo cuidado com o talhe anatómico e das finas pregas dos } \\
\text { panejamentos. }\end{array}$ \\
\hline 8. & Técnicas (de suporte): Talha \\
\hline 9. & Técnicas (de acabamento): Policromia; dourado; marmoreado \\
\hline 10. & Materiais (de suporte): Madeira \\
\hline 11. & Materiais (de acabamento): Pigmentos; folha de ouro; vidro \\
\hline 12. & $\begin{array}{l}\text { Estado de Conservação: Razoável; apresenta-se estável mas com } \\
\text { muitas lacunas (mãos) desgaste e fissuras na policromia }\end{array}$ \\
\hline 13. & $\begin{array}{l}\text { Dimensões: } \\
\text { Altura: } 80 \text { cm } \\
\text { Largura: } 36 \text { cm } \\
\text { Profundidade: } 28 \text { cm }\end{array}$ \\
\hline 14. & Restauro: apresenta sinais de reintegração cromática \\
\hline 15. & Datas: segunda metade do século XVIII \\
\hline 16. & Proveniência: igreja do Seminário Apostólico de Brancanes \\
\hline 17. & $\begin{array}{l}\text { Autoria: desconhecida mas é de referir a semelhança observada nos } \\
\text { detalhes escultóricos do talhe desta figura com a figura CSDV 01 São } \\
\text { Bernardino de Siena, sendo evidente tratar-se de obras esculpidas pelo } \\
\text { mesmo autor } \backslash \text { oficina. }\end{array}$ \\
\hline 18. & Oficina: Nacional (Lisboa?) \\
\hline 19. & $\begin{array}{l}\text { Localização (inicial I atual): Mantém-se na mesma capela; } \\
\text { atualmente a escultura está colocado dentro de um nicho no lado do } \\
\text { evangelho }\end{array}$ \\
\hline 20. & Histórico do objeto: não se conhecem registos \\
\hline 21. & Iconografia: hábito franciscano; mitra \\
\hline 22. & Irmandade: não se conhecem registos \\
\hline 23. & Procissões: não se conhecem registos \\
\hline
\end{tabular}




\section{FICHAS DE INVENTÁRIO}

ESCULTURA

SACRISTIA DA IGREJA

\section{DE NOSSA SENHORA DA ENCARNAÇÃO DO SEMINÁRIO APOSTÓLICO DE VINHAIS}


FICHAS DE INVENTÁRIO | ESCULTURA

Da Ordem de São Francisco na Diocese de Bragança-Miranda 


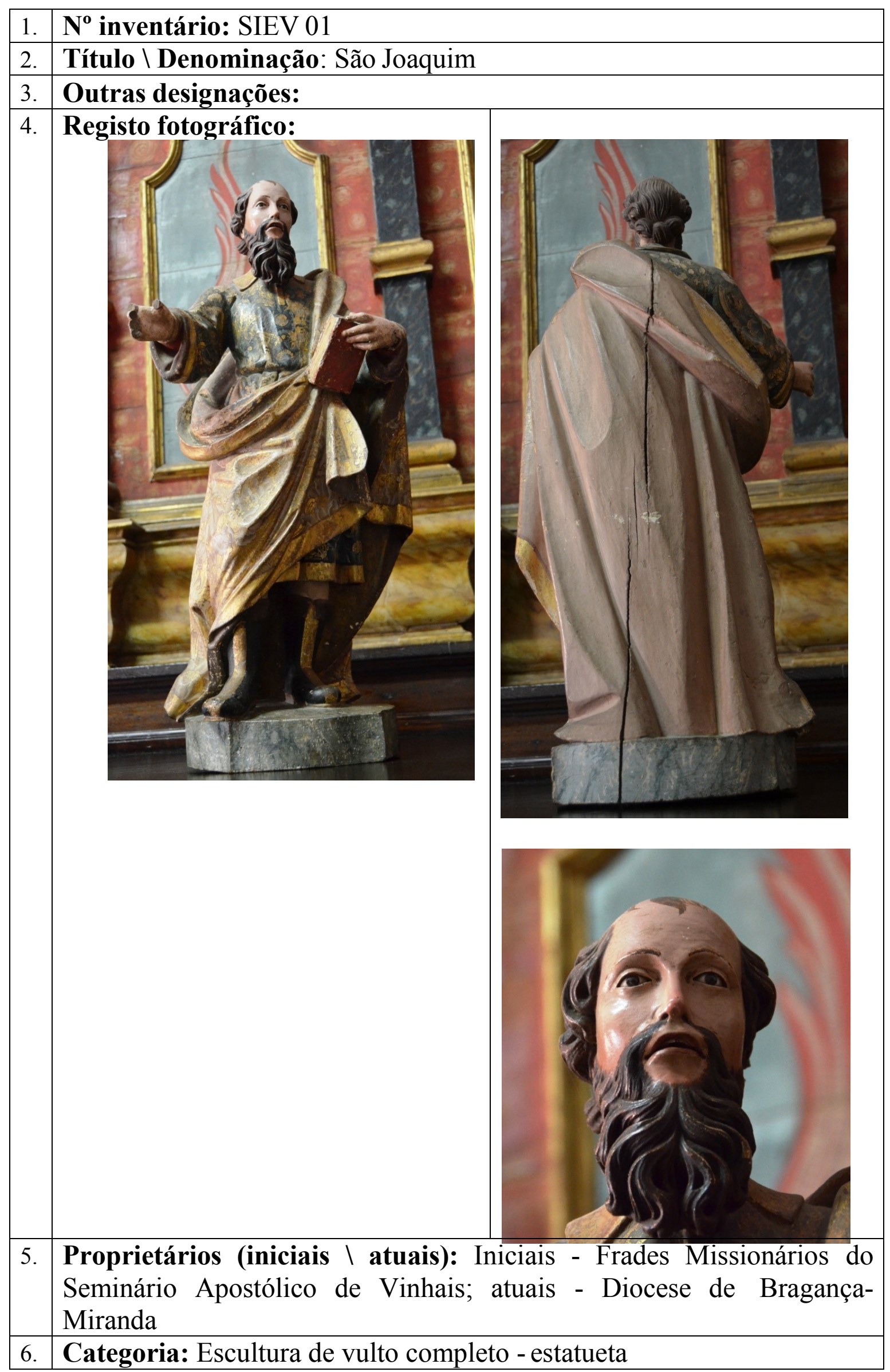




\begin{tabular}{|c|c|}
\hline 7. & $\begin{array}{l}\text { Descrição: Escultura de vulto em madeira policromada e estufada } \\
\text { representando São Joaquim com traje curto e botas altas. Está } \\
\text { representado de pé, em contraposto, com o joelho direito ligeiramente } \\
\text { mais avançado afigura eleva e flete ambos os braços à altura da cintura, } \\
\text { o braço direito tem a palma da mão voltada para o observador, com } \\
\text { lacuna da ponta de todos os dedos. O braço esquerdo com o punho } \\
\text { fletido segura com a mão um livro de capas vermelhas que apoia sobre a } \\
\text { cintura. Enverga um ornamentado traje curto até aos joelhos com ligeiro } \\
\text { pregueado de cor verde cingido na cintura e decorado nos bordos e gola } \\
\text { com douramento e motivos dourados estofados cobrem toda a extensão } \\
\text { dos panejamentos. Sobre este envolve-o pelo ombro esquerdo um manto } \\
\text { traçado sobre a cintura que cai sobre as costas em amplo e ligeiramente } \\
\text { ondulado pregueado. O rosto cuidadosamente esculpido com olhos de } \\
\text { vidro, boca entreaberta com os cantos dos lábios descaídos deixando } \\
\text { parte dos dentes a descoberto. Apresenta uma expressão serena com } \\
\text { longas e onduladas barbas, parcialmente calvo, os cabelos são curtos e } \\
\text { castanhos tal como as barbas. } \\
\text { Os pés levemente desencontrados estão protegidos por botas altas de cor } \\
\text { negra com uma lista dourada. Está assente sobre uma base circular } \\
\text { irregular com marmoreado verde. }\end{array}$ \\
\hline 8. & Técnicas (de suporte): Talha \\
\hline 9. & Técnicas (de acabamento): Policromia; estufado; marmoreado \\
\hline 10. & Materiais (de suporte): Madeira \\
\hline 11. & Materiais (de acabamento): Pigmentos; vidro; folha de ouro \\
\hline 12. & $\begin{array}{l}\text { Estado de Conservação: Bom; estável, lacuna de dedo na mão direita; } \\
\text { desgaste na policromia; fissura nas costas }\end{array}$ \\
\hline 13. & $\begin{array}{l}\text { Dimensões: } \\
\text { Altura: } 78 \mathrm{~cm} \\
\text { Largura: } 41 \mathrm{~cm} \\
\text { Profundidade: } 33 \mathrm{~cm}\end{array}$ \\
\hline 14. & Restauro: apresenta sinais de reintegração cromática \\
\hline 15. & Datas: segunda metade do século XVIII \\
\hline 16. & Proveniência: igreja de Nossa Senhora da Encarnação em Vinhais \\
\hline 17. & Autoria: Frei Domingos \\
\hline 18. & Oficina: Local \\
\hline 19. & $\begin{array}{l}\text { Localização (inicial } \backslash \text { atual): Originalmente estava no altar de Santa } \\
\text { Ana, na igreja de Nossa Senhora da Encarnação; Atualmente está na } \\
\text { sacristia sobre o arcaz. }\end{array}$ \\
\hline 20. & Histórico do objeto: não se conhecem registos \\
\hline 21. & Iconografia: Livro; traje curto com botas altas \\
\hline 22. & Irmandade: não se conhecem registos \\
\hline 23. & Procissões: não se conhecem registos \\
\hline
\end{tabular}


Calvário (Nossa Senhora, São João, Cristo) e São Domingos no armário oratório em talha rococó na Sacristia da igreja de Nossa Senhora da Encarnação

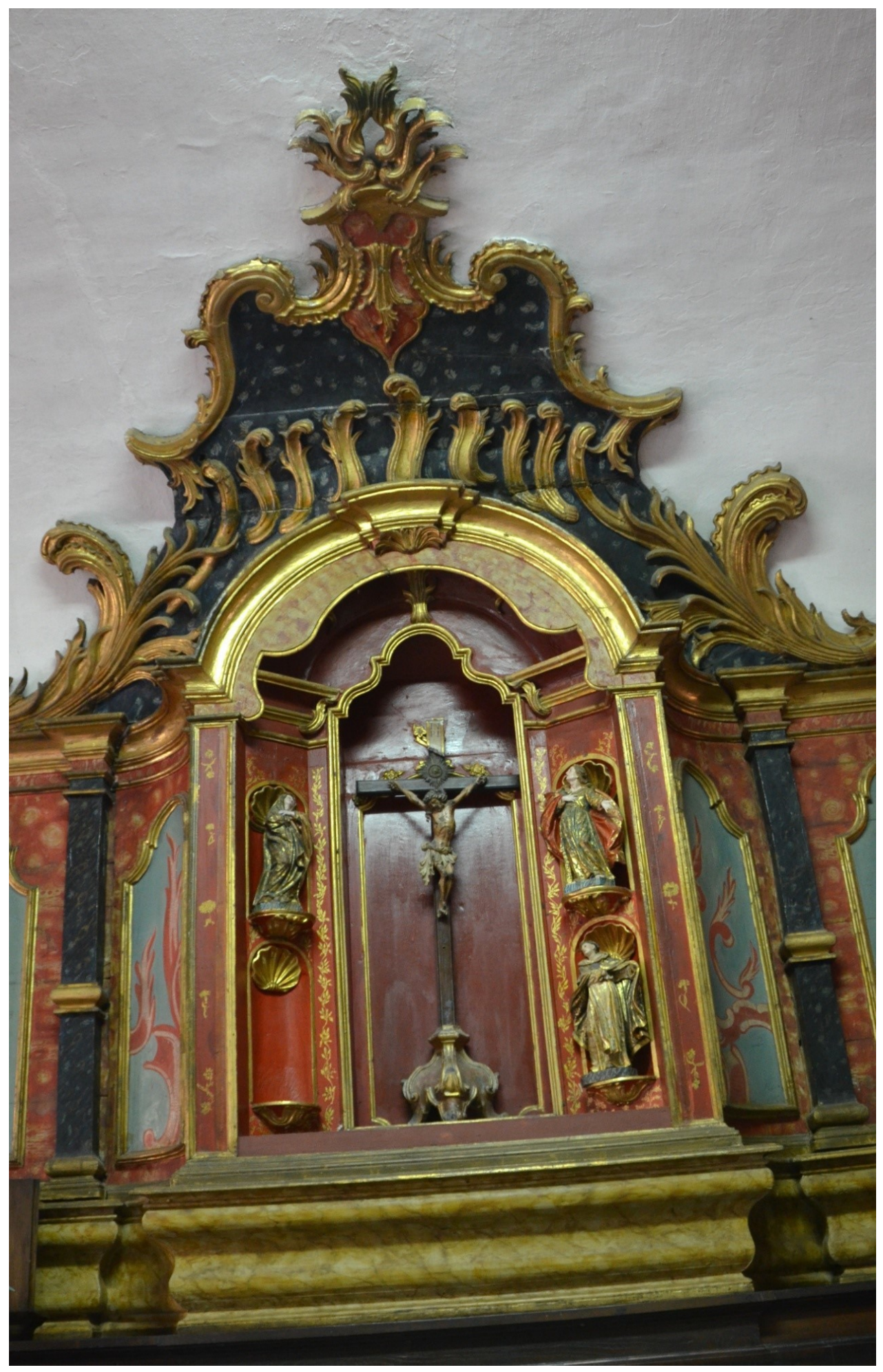


FICHAS DE INVENTÁRIO | ESCULTURA

Da Ordem de São Francisco na Diocese de Bragança-Miranda 


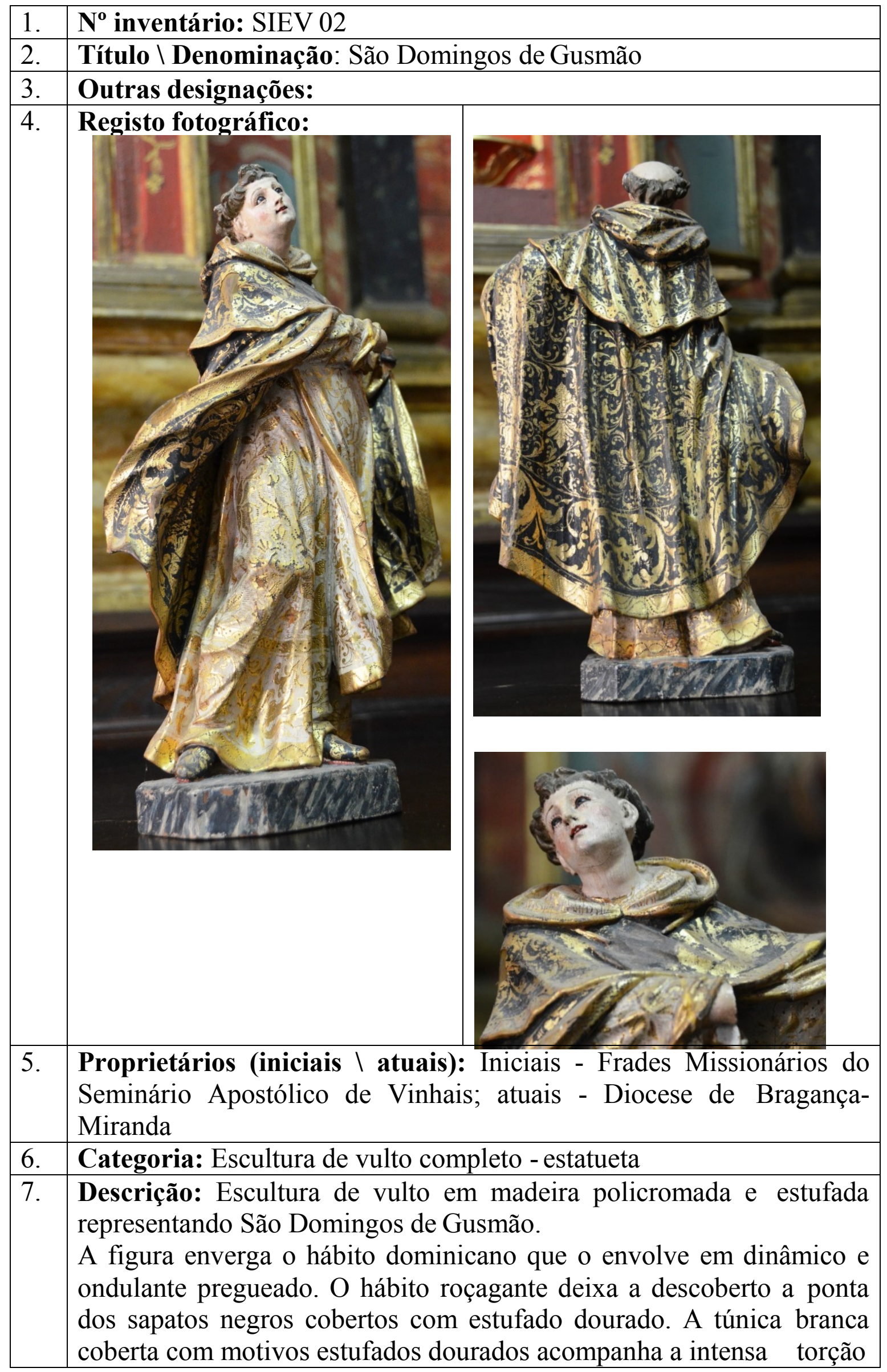




\begin{tabular}{|l|l|}
\hline & $\begin{array}{l}\text { do corpo em contraposto. Os braços, ambos com lacuna das mãos, } \\
\text { estão elevados e voltados para o lado esquerdo como se segurassem } \\
\text { algum atributo entretanto desaparecido. O manto negro com capuz que } \\
\text { o cobre ondula com movimento e está integralmente decorado com } \\
\text { estufados dourados. A cabeça tonsurada tem cabelo castanho } \\
\text { dinamicamente ondulado e está voltada para trás levemente inclinada } \\
\text { para o lado direito enfatizando o dramatismo da torção do gesto. } \\
\text { O rosto apresenta uma expressão jovial sugerida pelo leve sorriso que } \\
\text { deixa a descoberto parte dos dentes. Os olhos de vidro elevam o olhar } \\
\text { num movimento reforçado pelo arquear das sobrancelhas. A figura que } \\
\text { se destaca pelo dinamismo do esvoaçar dos panejamentos e pela torção } \\
\text { da pose está assente sobre uma base octogonal com marmoreado } \\
\text { verde. }\end{array}$ \\
\hline 8. & Técnicas (de suporte): Talha \\
\hline 9. & Técnicas (de acabamento): Policromia; estufado; marmoreado \\
\hline 10. & Materiais (de suporte): Madeira \\
\hline 11. & Materiais (de acabamento): Pigmentos; vidro; folha de ouro \\
\hline 12. & $\begin{array}{l}\text { Estado de Conservação: Bom; estável, lacuna das mãos; desgaste e } \\
\text { lacunas na policromia }\end{array}$ \\
\hline 13. & $\begin{array}{l}\text { Dimensões: } \\
\text { Altura: } 37 \text { cm } \\
\text { Largura: } 24 \text { cm } \\
\text { Profundidade: } 15 \text { cm }\end{array}$ \\
\hline 14. & $\begin{array}{l}\text { Restauro: apresenta sinais de reintegração cromática sobre o nariz e } \\
\text { lábios }\end{array}$ \\
\hline 15. & Datas: último quartel do século XVIII \\
\hline 16. & $\begin{array}{l}\text { Proveniência: sacristia da igreja de Nossa Senhora da Encarnação em } \\
\text { Vinhais }\end{array}$ \\
\hline 17. & $\begin{array}{l}\text { Autoria: desconhecida, mas nos detalhes anatómicos, gestualidade e } \\
\text { traje é muito semelhante as restantes figuras que completam a cena de } \\
\text { Calvário guardada no armário oratório (Nossa Senhora e São João } \\
\text { estando em falta a figura que representa Santa Maria Madalena, ou de } \\
\text { São Francisco, que poderia também ser parte no conjunto a par de São } \\
\text { Domingos) }\end{array}$ \\
\hline 18. & Oficina: Nacional \\
\hline 19. & $\begin{array}{l}\text { Localização (inicial } \backslash \text { atual): Mantém-se no local original na sacristia } \\
\text { dentro do oratório no nicho do primeiro registo, lado esquerdo. }\end{array}$ \\
\hline 20. & Histórico do objeto: não se conhecem registos \\
\hline 21. & Iconografia: Hábito dominicano \\
\hline 22. & Irmandade: não se conhecem registos \\
\hline 23. & Procissões: não se conhecem registos \\
\hline
\end{tabular}




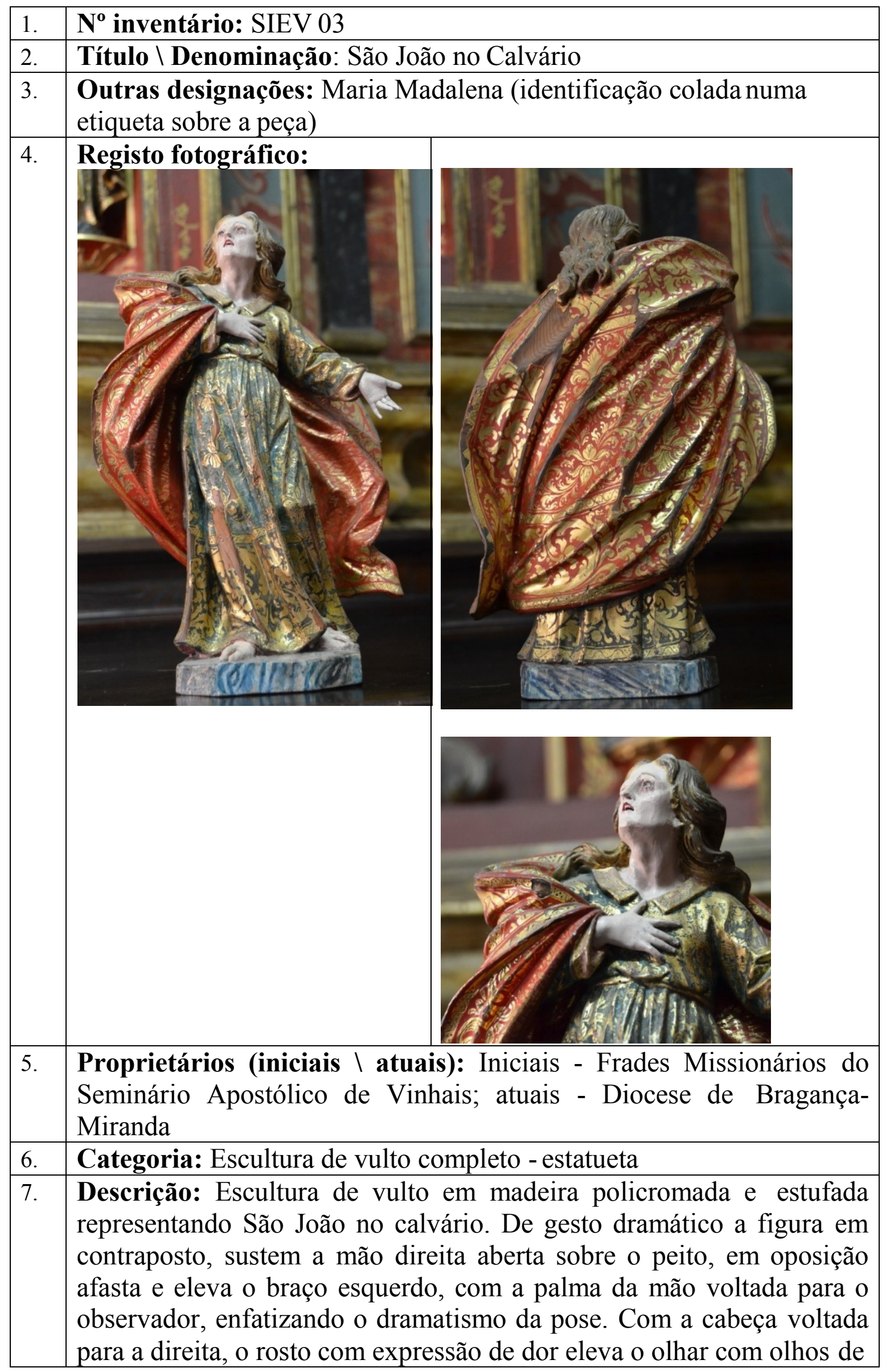




\begin{tabular}{|l|l|}
\hline & $\begin{array}{l}\text { vidro envoltos em lágrimas. A boca com os cantos dos lábios } \\
\text { descaídos deixa a descoberto parte dos dentes intensificando a } \\
\text { expressão de dor impressa também na tensão dos músculos do } \\
\text { pescoço. Tem cabelos loiros que em amplas e longas ondas cai sobre } \\
\text { as costas. A figura enverga uma longa túnica roçagante de cor verde } \\
\text { coberta por estufados dourados, cingida na cintura e com gola dourada. } \\
\text { Sobre a túnica usa um esvoaçante manto vermelho que cinge ao corpo } \\
\text { com o braço direito e envolve a figura pelas costas. Os pés descalços } \\
\text { assentam sobre uma base marmoreada em tom azul de forma } \\
\text { octogonal. }\end{array}$ \\
\hline 8. & Técnicas (de suporte): Talha \\
\hline 9. & Técnicas (de acabamento): Policromia; estufado; marmoreado \\
\hline 10. & Materiais (de suporte): Madeira \\
\hline 11. & Materiais (de acabamento): Pigmentos; vidro; folha de ouro \\
\hline 12. & $\begin{array}{l}\text { Estado de Conservação: Bom; estável; desgaste e lacunas na } \\
\text { policromia }\end{array}$ \\
\hline 13. & $\begin{array}{l}\text { Dimensões: } \\
\text { Altura: } 38 \text { cm } \\
\text { Largura: } 26 \text { cm } \\
\text { Profundidade: } 13 \text { cm }\end{array}$ \\
\hline 14. & $\begin{array}{l}\text { Restauro: apresenta sinais de reintegração cromática sobre o rosto e } \\
\text { mãos }\end{array}$ \\
\hline 15. & Datas: último quartel do século XVIII \\
\hline 16. & $\begin{array}{l}\text { Proveniência: sacristia da igreja de Nossa Senhora da Encarnação em } \\
\text { Vinhais }\end{array}$ \\
\hline 17. & $\begin{array}{l}\text { Autoria: desconhecida, mas nos detalhes anatómicos, gestualidade e } \\
\text { traje é muito semelhante as restantes figuras que completam a cena de } \\
\text { Calvário guardada no armário oratório (Nossa Senhora e São } \\
\text { Domingos estando em falta a figura que representa Santa Maria } \\
\text { Madalena ou de São Francisco, que poderia também ser parte no } \\
\text { conjunto a par de São Domingos) }\end{array}$ \\
\hline 18. & Oficina: Nacional \\
\hline 19. & $\begin{array}{l}\text { Localização (inicial } \backslash \text { atual): Mantém-se no local original na sacristia } \\
\text { dentro do oratório no nicho do segundo registo, lado esquerdo }\end{array}$ \\
\hline 20. & $\begin{array}{l}\text { Histórico do objeto: Sobre a base tem uma etiqueta em papel colada } \\
\text { onde se lê: "Sta Madalena / (...) S. José / Vinhais" }\end{array}$ \\
\hline 21. & Iconografia: São João no calvário \\
\hline 22. & Irmandade: não se conhecem registos \\
\hline 23. & Procissões: não se conhecem registos \\
\hline
\end{tabular}




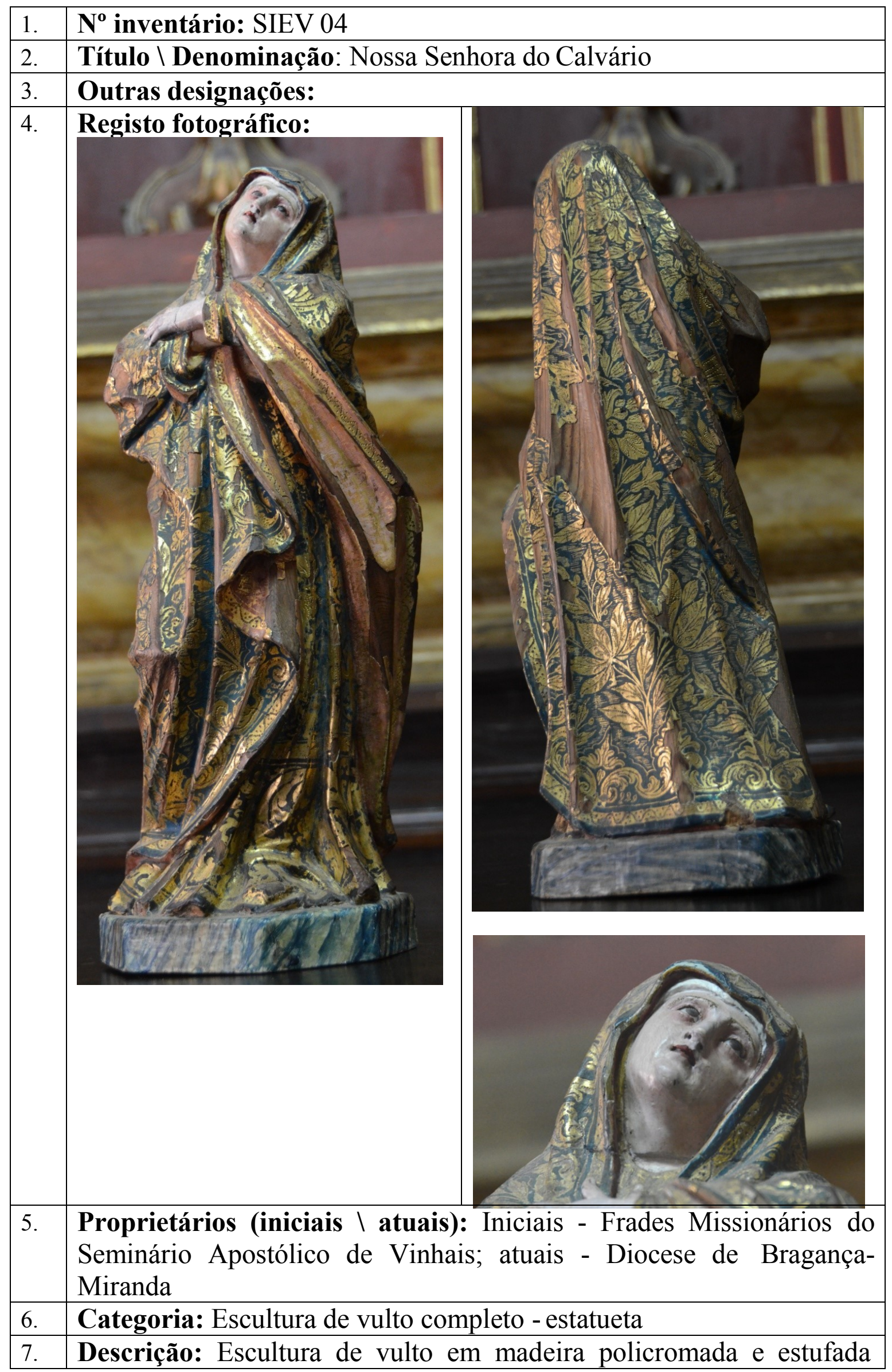




\begin{tabular}{|c|c|}
\hline & $\begin{array}{l}\text { representando Nossa Senhora no Calvário. De pé em ligeiro } \\
\text { contraposto cruza as mãos sobre o peito inclinando a cabeça para o } \\
\text { lado esquerdo reforçando a torção do corpo que em gesto pungente se } \\
\text { recolhe do sofrimento evocado na expressão do rosto. } \\
\text { O rosto delicadamente esculpido tem os olhos de vidro que elevam o } \\
\text { olhar (seguramente que o olhar estaria na direção da figura de Cristo } \\
\text { Crucificado que acompanharia o conjunto do Calvário). A boca } \\
\text { entreaberta com os cantos dos lábios descaídos deixa parte dos dentes a } \\
\text { descoberto. } \\
\text { A cabeça está envolta numa coifa branca sobre a qual enverga um } \\
\text { manto roçagante verde com motivos estufados dourados. O manto } \\
\text { ondula ligeiramente nos pregueados do lado esquerdo da figura } \\
\text { enfatizando a posse de recolhido sofrimento da Virgem. } \\
\text { Está assente sobre uma base marmoreada em tom verde de forma } \\
\text { octogonal. }\end{array}$ \\
\hline 8. & Técnicas (de suporte): Talha \\
\hline 9. & Técnicas (de acabamento): Policromia; estufado; marmoreado \\
\hline 10. & Materiais (de suporte): Madeira \\
\hline 11. & Materiais (de acabamento): Pigmentos; vidro; folha de ouro \\
\hline 12. & $\begin{array}{l}\text { Estado de Conservação: Bom; estável; desgaste e destacamento de } \\
\text { policromia }\end{array}$ \\
\hline 13. & $\begin{array}{l}\text { Dimensões: } \\
\text { Altura: } 37 \mathrm{~cm} \\
\text { Largura: } 16 \mathrm{~cm} \\
\text { Profundidade: } 14 \mathrm{~cm}\end{array}$ \\
\hline 14. & $\begin{array}{l}\text { Restauro: apresenta sinais de reintegração cromática sobre o rosto e } \\
\text { mãos }\end{array}$ \\
\hline 15. & Datas: último quartel do século XVIII \\
\hline 16. & $\begin{array}{l}\text { Proveniência: sacristia da igreja de Nossa Senhora da Encarnação em } \\
\text { Vinhais }\end{array}$ \\
\hline 17. & $\begin{array}{l}\text { Autoria: desconhecida, mas nos detalhes anatómicos, gestualidade e } \\
\text { traje é muito semelhante as restantes figuras que completam a cena de } \\
\text { Calvário guardada no armário oratório (São Domingos e São João } \\
\text { estando em falta a figura que representa Santa Maria Madalena, ou de } \\
\text { São Francisco, que poderia também ser parte no conjunto a par de São } \\
\text { Domingos) }\end{array}$ \\
\hline 18. & Oficina: Nacional \\
\hline 19. & $\begin{array}{l}\text { Localização (inicial } \backslash \text { atual): Mantém a localização original na } \\
\text { sacristia dentro do oratório no nicho do segundo registo do lado direito }\end{array}$ \\
\hline 20. & Histórico do objeto: não se conhecem registos \\
\hline 21. & Iconografia: Nossa Senhora no calvário \\
\hline 22. & Irmandade: não se conhecem registos \\
\hline
\end{tabular}


$23 . \quad$ Procissões: (?)

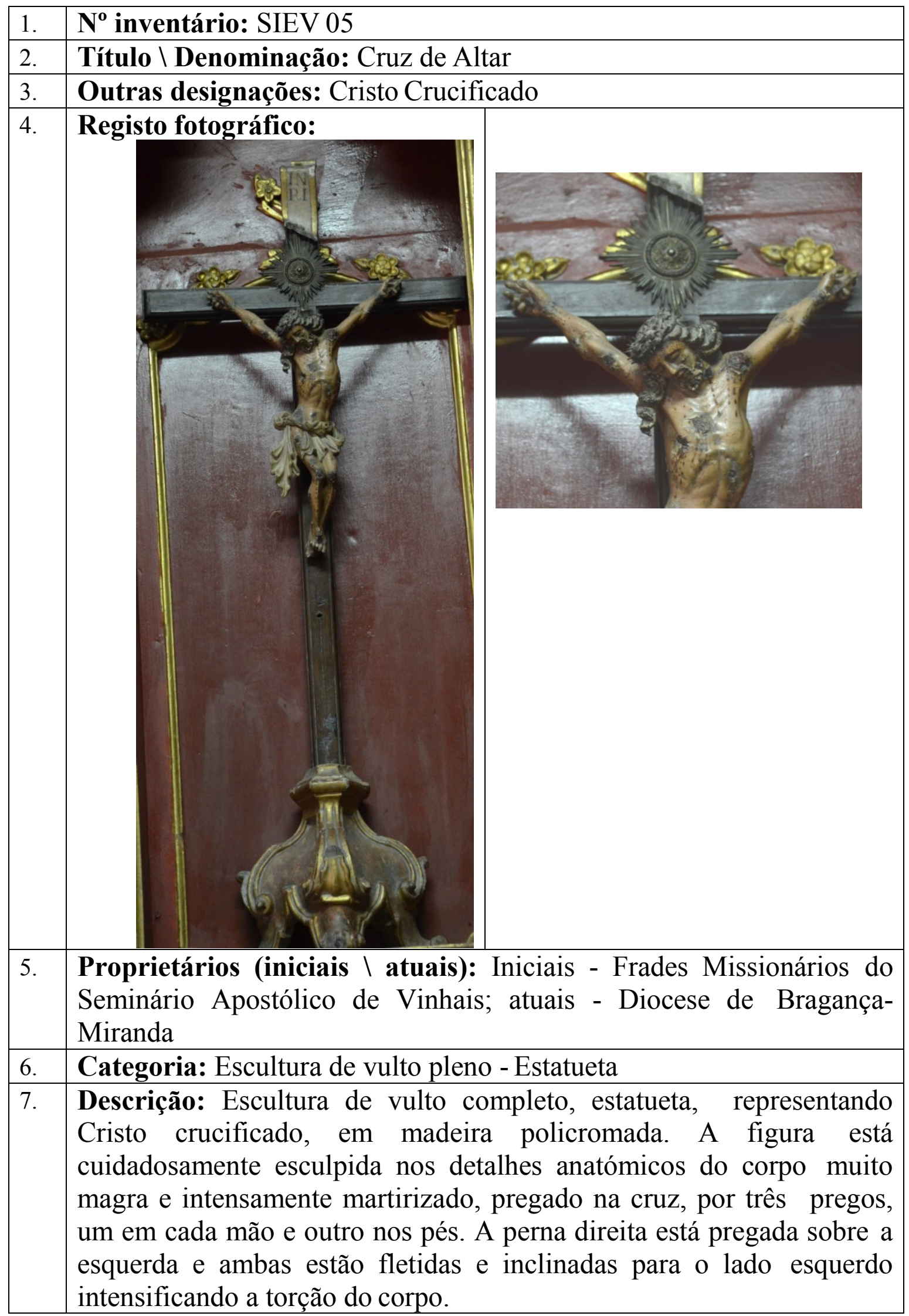




\begin{tabular}{|l|l|}
\hline & $\begin{array}{l}\text { Está coberto pelo cendal cingido na cintura por cordão duplo com as } \\
\text { pontas drapeadas em amplas e ondulante pregas finas que caiem sobre } \\
\text { o lado direito do corpo. } \\
\text { De olhos fechados tem o rosto caído sobre o lado direito com a boca } \\
\text { entreaberta, barbas e cabelo finamente talhado em volumosas ondas } \\
\text { que caiem sobre as costas e ombro direito. A cabeça está envolta pela } \\
\text { coroa de espinhos. } \\
\text { A cruz de secção retangular em madeira escura simples está decorada } \\
\text { nos bordos redondeados com vinco, ao centro, sobre a cabeça está } \\
\text { colocado um resplendor raiado em metal branco, sobre este está a } \\
\text { cartela branca com bordos dourados onde pode ler-se JN / RI. } \\
\text { A base da cruz é rococó e de forma polilobada semicircular decorada } \\
\text { com aletas douradas que se prolongam nos três pés que a sustem. }\end{array}$ \\
\hline 8. & Técnicas (de suporte): Talha \\
\hline 9. & Técnicas (de acabamento): Policromia \\
\hline 10. & Materiais (de suporte): Madeira \\
\hline 11. & Materiais (de acabamento): Pigmentos; ouro; metal branco \\
\hline 12. & $\begin{array}{l}\text { Estado de Conservação: Bom; a escultura apresenta-se estável mas } \\
\text { com lacuna em parte da base e desgaste na policromia }\end{array}$ \\
\hline 13. & $\begin{array}{l}\text { Dimensões: } \\
\text { Altura: } 118 \text { cm } \\
\text { Largura: } 44 \text { cm } \\
\text { Profundidade: } 22 \text { cm }\end{array}$ \\
\hline 14. & Restauro: apresenta sinais de reintegração cromática \\
\hline 15. & Datas: último quartel do século XVIII \\
\hline 16. & $\begin{array}{l}\text { Proveniência: sacristia da igreja de Nossa Senhora da Encarnação em } \\
\text { Vinhais }\end{array}$ \\
\hline 17. & $\begin{array}{l}\text { Autoria: desconhecida, mas Julgamos que poderá ter servido de } \\
\text { modelo para a escultura colossal de Cristo do Coro (CSDV 06) dadas } \\
\text { as semelhanças formais entre ambas as esculturas }\end{array}$ \\
\hline 18. & Oficina: Nacional \\
\hline 19. & $\begin{array}{l}\text { Localização (atual) Atualmente está colocada no centro armário } \\
\text { oratório }\end{array}$ \\
\hline 20. & Histórico do objeto: não se conhecem registos \\
\hline 21. & Iconografia: Cruz; Coroa de espinhos; Cendal; Cartela; Resplendor \\
\hline 22. & Irmandade: não se conhecem registos \\
\hline 23. & Procissões: não se conhecem registos \\
\hline
\end{tabular}




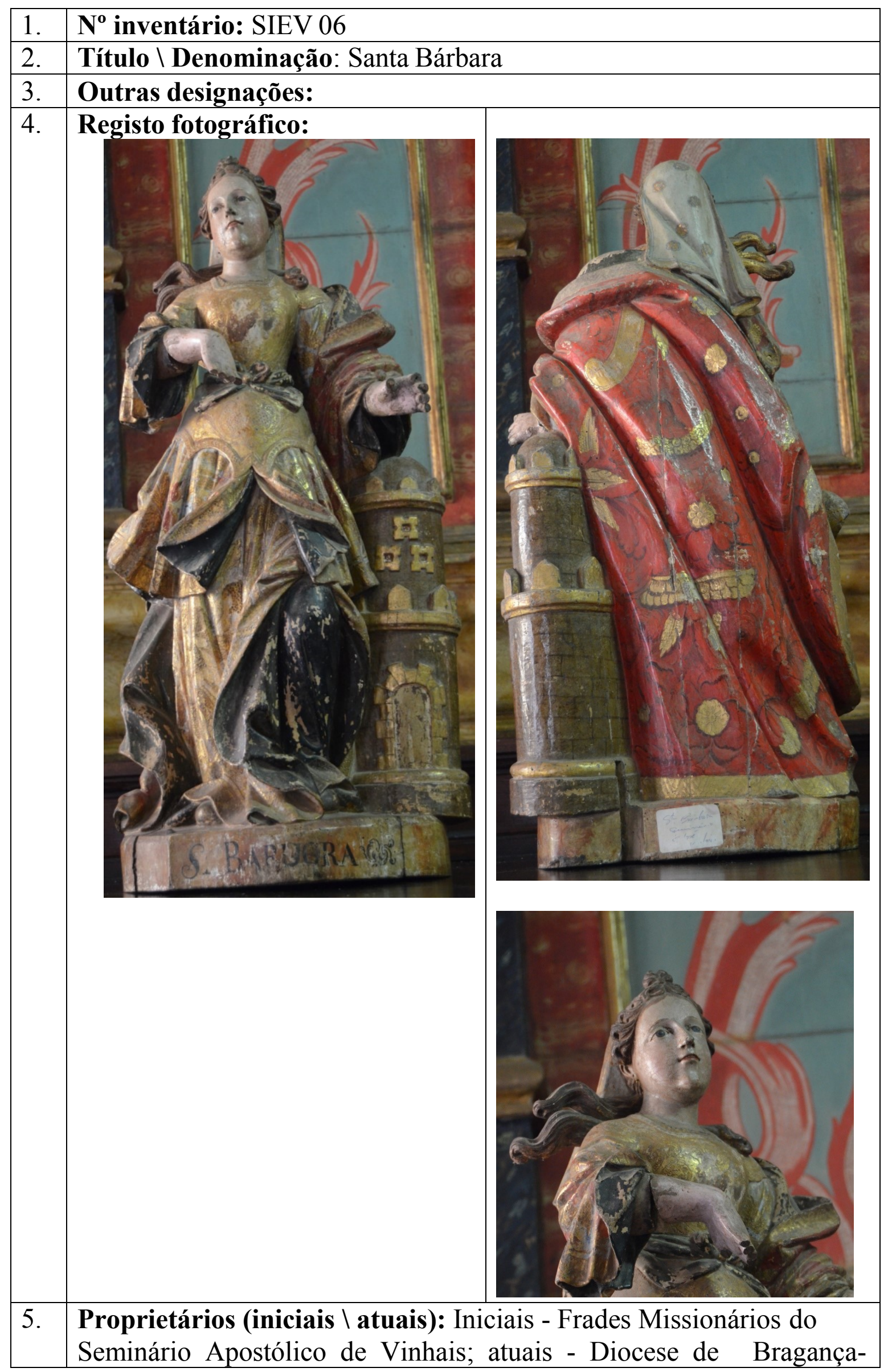




\begin{tabular}{|c|c|}
\hline & Miranda \\
\hline 6. & Categoria: Escultura de vulto completo - estatueta \\
\hline 7. & $\begin{array}{l}\text { Descrição: Escultura de vulto em madeira policromada e estufada } \\
\text { representando Santa Bárbara. Está representada de pé, em contraposto, } \\
\text { com o joelho esquerdo ligeiramente mais avançado. A figura enverga } \\
\text { um traje muito ornamentado composto por um corpete coberto por } \\
\text { motivos dourados estufados sobre o qual a cinge na cintura um } \\
\text { panejamento verde preso com um nó. Sob o corpete enverga duas } \\
\text { saias, uma roçagante que aberta sobre o joelho esquerdo deixa a } \\
\text { descoberto o forro negro e a ponta dos sapatos dourados. Sobre esta } \\
\text { enverga outra saia mais curta coberta por motivos estufados dourados e } \\
\text { policromados. As mangas também volumosas cobrem até ao } \\
\text { antebraço. Sobre o braço esquerdo sustém um amplo manto vermelho } \\
\text { decorado com motivos dourados estufados e com forro negro que a } \\
\text { cobre pelas costas até aos pés. } \\
\text { O contraposto da figura é reforçado no movimento dos braços fletidos } \\
\text { e inclinados ambos para o lado esquerdo do corpo e sugere ter } \\
\text { segurado algum atributo - a palma (entretanto desaparecido). Tem } \\
\text { lacuna de todos os dedos. } \\
\text { O rosto, de contornos arredondados, está cuidadosamente esculpido } \\
\text { com olhos pintados que elevam o olhar e a boca entreaberta deixando } \\
\text { parte dos dentes a descoberto. } \\
\text { Os cabelos presos em aparatoso penteado sob a cabeça envolvem o } \\
\text { rosto em simétricas ondas quebradas pelas madeixas que esvoaçam no } \\
\text { lado direito, ostenta sobre a cabeça um pequeno véu branco que cai } \\
\text { sobre as costas decorado com formas circulares douradas. } \\
\text { Está assente sobre uma base circular irregular com marmoreado em } \\
\text { tom laranja em cuja frente pode ler-se "S. BARVORA". Sob a mesma } \\
\text { base no lado esquerdo está colocada a torre com porta na base e três } \\
\text { janelas no segundo registo, rematados ambos registos com ameias e } \\
\text { encimados por uma cúpula. } \\
\text { Sobre a base na parte de trás está colada uma etiqueta em papel onde } \\
\text { pode ler-se "Sta Barbara } \backslash \text { Seminário S. José } \backslash \text { Vinhais" }\end{array}$ \\
\hline 8. & Técnicas (de suporte): Talha \\
\hline 9. & Técnicas (de acabamento): Policromia; estufado; marmoreado \\
\hline 10. & Materiais (de suporte): Madeira \\
\hline 11. & Materiais (de acabamento): Pigmentos; folha de ouro \\
\hline 12. & $\begin{array}{l}\text { Estado de Conservação: Bom; estável, lacuna de todos os dedos; } \\
\text { fissura sobre a base no lado direito; desgaste na policromia. }\end{array}$ \\
\hline 13. & $\begin{array}{l}\text { Dimensões: } \\
\text { Altura: } 83 \mathrm{~cm} \\
\text { Largura: } 40 \mathrm{~cm} \\
\text { Profundidade: } 32 \mathrm{~cm}\end{array}$ \\
\hline
\end{tabular}




\begin{tabular}{|c|l|}
\hline 14. & Restauro: apresenta sinais de reintegração cromática \\
\hline 15. & Datas: segunda metade do século XVIII \\
\hline 16. & Proveniência: igreja de Nossa Senhora da Encarnação em Vinhais \\
\hline 17. & Autoria: Frei Domingos \\
\hline 18. & Oficina: Local \\
\hline 19. & $\begin{array}{l}\text { Localização (inicial \atual): Originalmente estava no altar de Santo } \\
\text { António na igreja de Nossa Senhora da Encarnação; Atualmente está } \\
\text { na sacristia sobre o arcaz. }\end{array}$ \\
\hline 20. & $\begin{array}{l}\text { Histórico do objeto: as semelhanças observadas entre os rostos da } \\
\text { escultura de Santa Bárbara e de Nossa Senhora da Encarnação IEV 06 } \\
\text { denotam as mesmas técnicas escultóricas que julgamos serem de Frei } \\
\text { Domingos }\end{array}$ \\
\hline 21. & $\begin{array}{l}\text { Iconografia: Traje curto ornamentado com corpete; Torre com três } \\
\text { janelas }\end{array}$ \\
\hline 22. & Irmandade: não se conhecem registos \\
\hline 23. & Procissões: não se conhecem registos \\
\hline
\end{tabular}


FICHAS DE INVENTÁRIO | ESCULTURA

Da Ordem de São Francisco na Diocese de Bragança-Miranda 


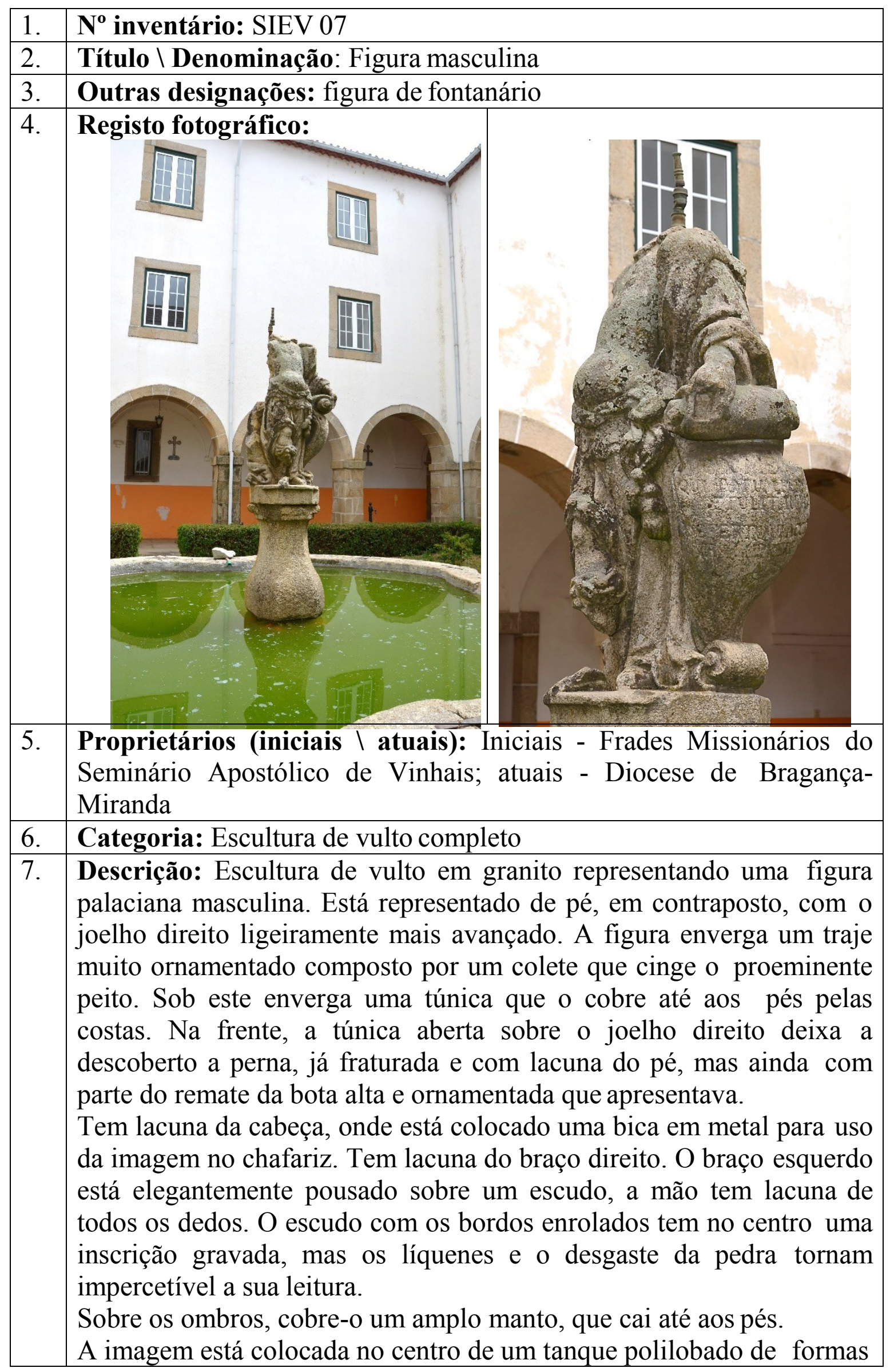




\begin{tabular}{|l|l|}
\hline & $\begin{array}{l}\text { curvilíneas em granito. O tanque está colocado no centro do claustro } \\
\text { do seminário apostólico. }\end{array}$ \\
\hline 8. & Técnicas (de suporte): Talha \\
\hline 9. & Técnicas (de acabamento): \\
\hline 10. & Materiais (de suporte): Pedra (Granito) \\
\hline 11. & Materiais (de acabamento): \\
\hline 12. & $\begin{array}{l}\text { Estado de Conservação: Razoável; lacuna da cabeça, braço direito e } \\
\text { de todos os dedos na mão esquerda, lacuna da perna; desgaste. }\end{array}$ \\
\hline 13. & $\begin{array}{l}\text { Dimensões: } \\
\text { Altura: } 90 \text { cm } \\
\text { Largura: } 50 \text { cm } \\
\text { Profundidade: } 50 \text { cm }\end{array}$ \\
\hline 14. & Restauro: não apresenta sinais de intervenção sobre a obra \\
\hline 15. & Datas: segunda metade do século XVIII \\
\hline 16. & Proveniência: igreja de Nossa Senhora da Encarnação em Vinhais \\
\hline 17. & Autoria: desconhecida \\
\hline 18. & Oficina: Braga \\
\hline 19. & $\begin{array}{l}\text { Localização (atual): Atualmente está no centro do tanque ao centro do } \\
\text { claustro }\end{array}$ \\
\hline 20. & $\begin{array}{l}\text { Histórico do objeto: existe a referência a uma inscrição gravada no } \\
\text { tanque do claustro: ESTA OBRA MANDOU FAZER JOÃO JOSÉ DE } \\
\text { MAGALHAENS MORGADO DE VLA PAÇOS CAPITAM DE } \\
\text { CAVALARIA EM CHAVES NO ANNO DE 1785 (Martins, 1929, p. } \\
\text { 8) Subsídios para a história religiosa do distrito de Bragança: a Ordem } \\
\text { III e a casa do Fundador do convento de S. Francisco de Vinhais. }\end{array}$ \\
\hline 21. & Iconografia: Traje curto palaciano; escudo \\
\hline 22. & Irmandade: não se conhecem registos \\
\hline 23. & Procissões: não se conhecem registos \\
\hline
\end{tabular}




\section{FICHAS DE INVENTÁRIO}

ESCULTURA

CAPELA DA VIA SACRA

ORAÇÃO NO HORTO

SEMINÁRIO APOSTÓLICO DE VINHAIS 
FICHAS DE INVENTÁRIO | ESCULTURA

Da Ordem de São Francisco na Diocese de Bragança-Miranda 
Capela da Via Sacra - Oração no Horto

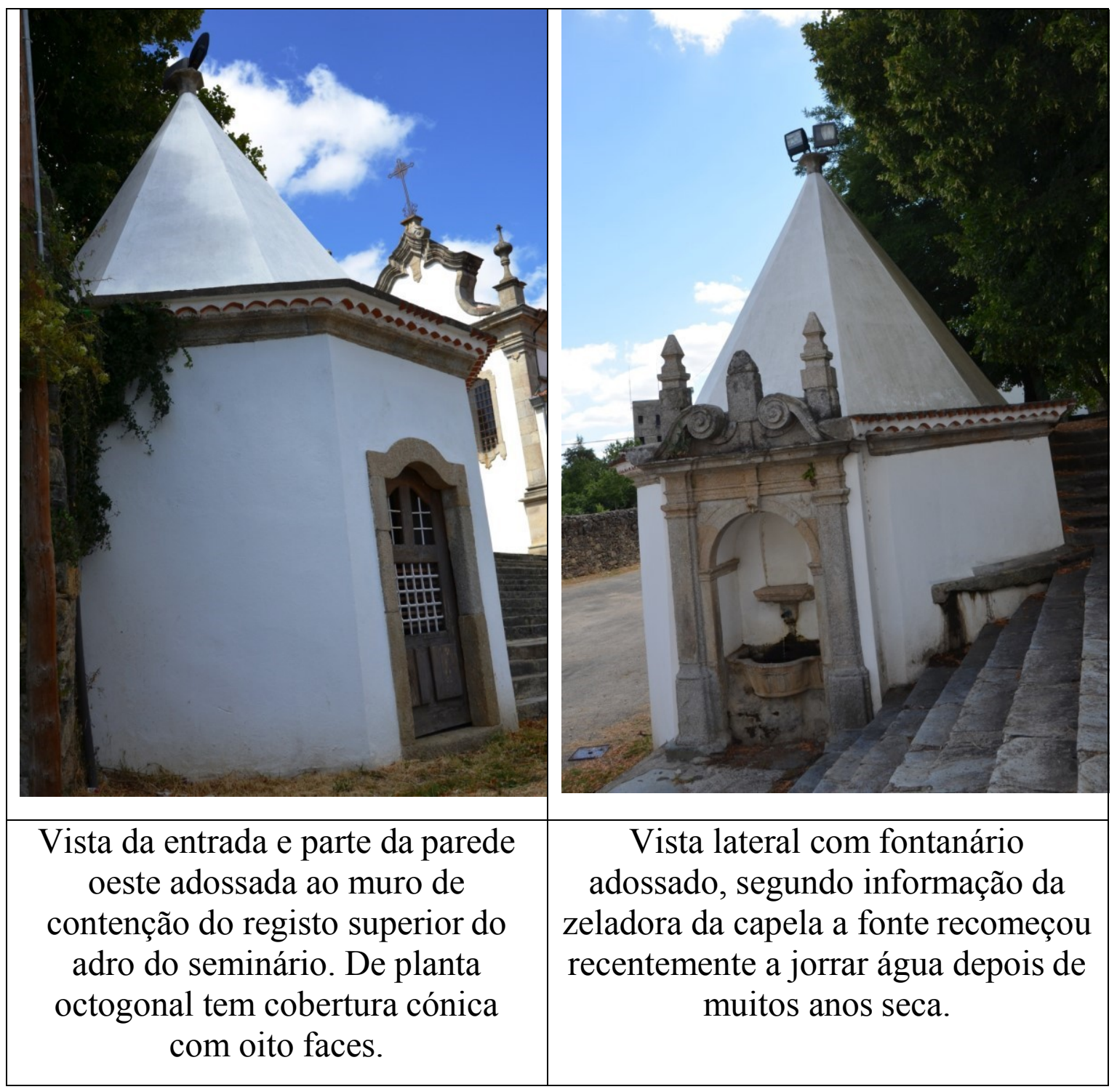


FICHAS DE INVENTÁRIO | ESCULTURA

Da Ordem de São Francisco na Diocese de Bragança-Miranda 
Capela - Oração no Horto

Vista interior com os elementos do grupo escultórico em terracota, constituído por três Apóstolos, Cristo e outra perspetiva de Cristo com o Anjo. O piso constituído por um afloramento granítico natural com irregularidades e pequenas fossas escavas. Tem várias plantas que crescem no interior sobre o suporte de terracota das esculturas, acumulando-se junto das raízes das plantas várias partes das esculturas fraturadas e intensamente deterioradas.
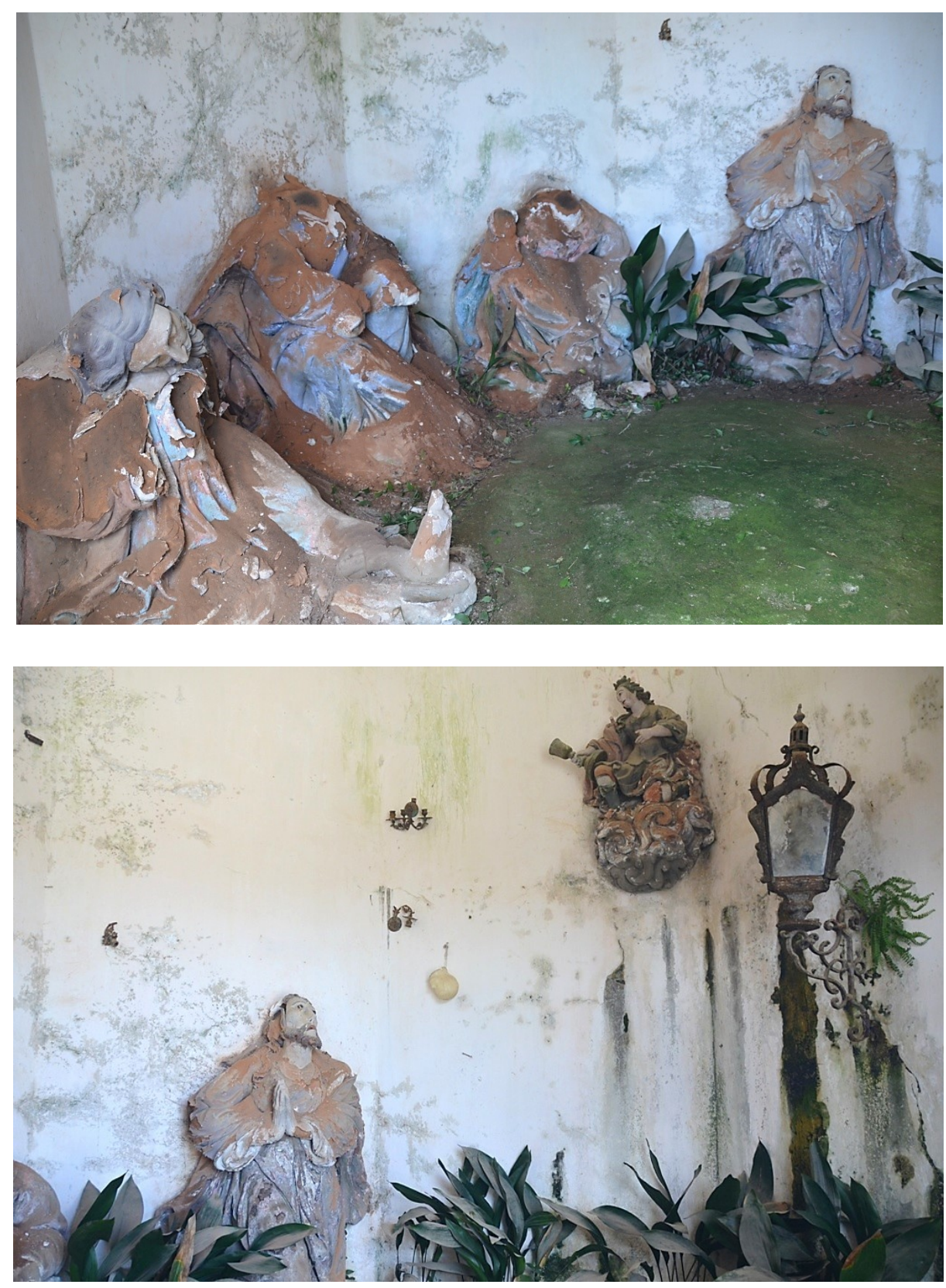
FICHAS DE INVENTÁRIO | ESCULTURA

Da Ordem de São Francisco na Diocese de Bragança-Miranda 


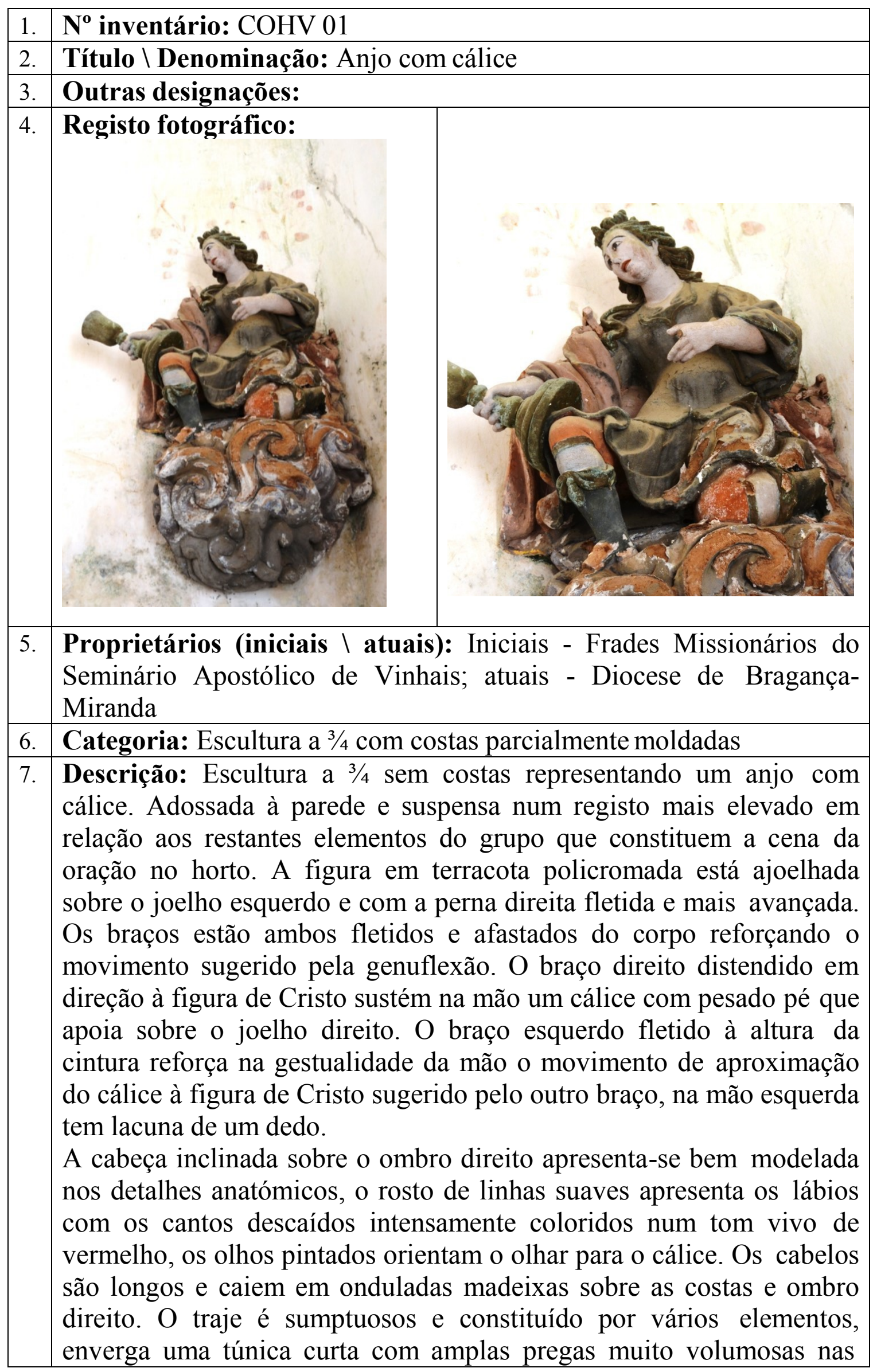




\begin{tabular}{|l|l|}
\hline 1. & mangas. Sobre esta usa um corpete ornamentado nos bordos e que lhe \\
\hline & $\begin{array}{l}\text { cinge o dorso que pela estrutura cintada evoca uma couraça militar, } \\
\text { sob este enverga calças curtas de tom vermelho decoradas nos bordos e } \\
\text { botas altas rematadas por uma ornamental laçada. A perna esquerda } \\
\text { tem lacuna da quase totalidade do pé. Envolve a figura um manto que } \\
\text { sustem no ombro direito e em amplas pregas o cobre pelas costas. A } \\
\text { figura de dinâmica gestualidade está assente sobre uma nuvem de tom } \\
\text { cinzento decorada com formas espirais sobrepostas com lacunas de } \\
\text { parte das espirais nos registos superiores. } \\
\text { A observação da figura permite perceber o jogo de anamorfose } \\
\text { (sobretudo no rosto) pois a imagem parece deformada ou confusa } \\
\text { quando observada frontalmente porém quando vista desde a entrada da } \\
\text { capela em conjunto com a figura de Cristo a posição e anatomia } \\
\text { tornam-se equilibradamente percetíveis. } \\
\text { Detrás da figura a parede tem ainda restos de policromia representando } \\
\text { elementos vegetalistas, as infiltrações de humidade serão parte do } \\
\text { problema de degradação da imagem. }\end{array}$ \\
\hline 8. & Técnicas (de suporte): Modelagem \\
\hline 9. & Técnicas (de acabamento): Policromia \\
\hline 10. & Materiais (de suporte): Terracota $\backslash$ barro cozido \\
\hline 11. & Materiais (de acabamento): pigmentos \\
\hline 12. & Estado de Conservação: Mau; lacunas várias (dedo na mão esquerda \\
e parte do pé direito) degradação ativa do material de suporte; \\
destacamento da policromia
\end{tabular}




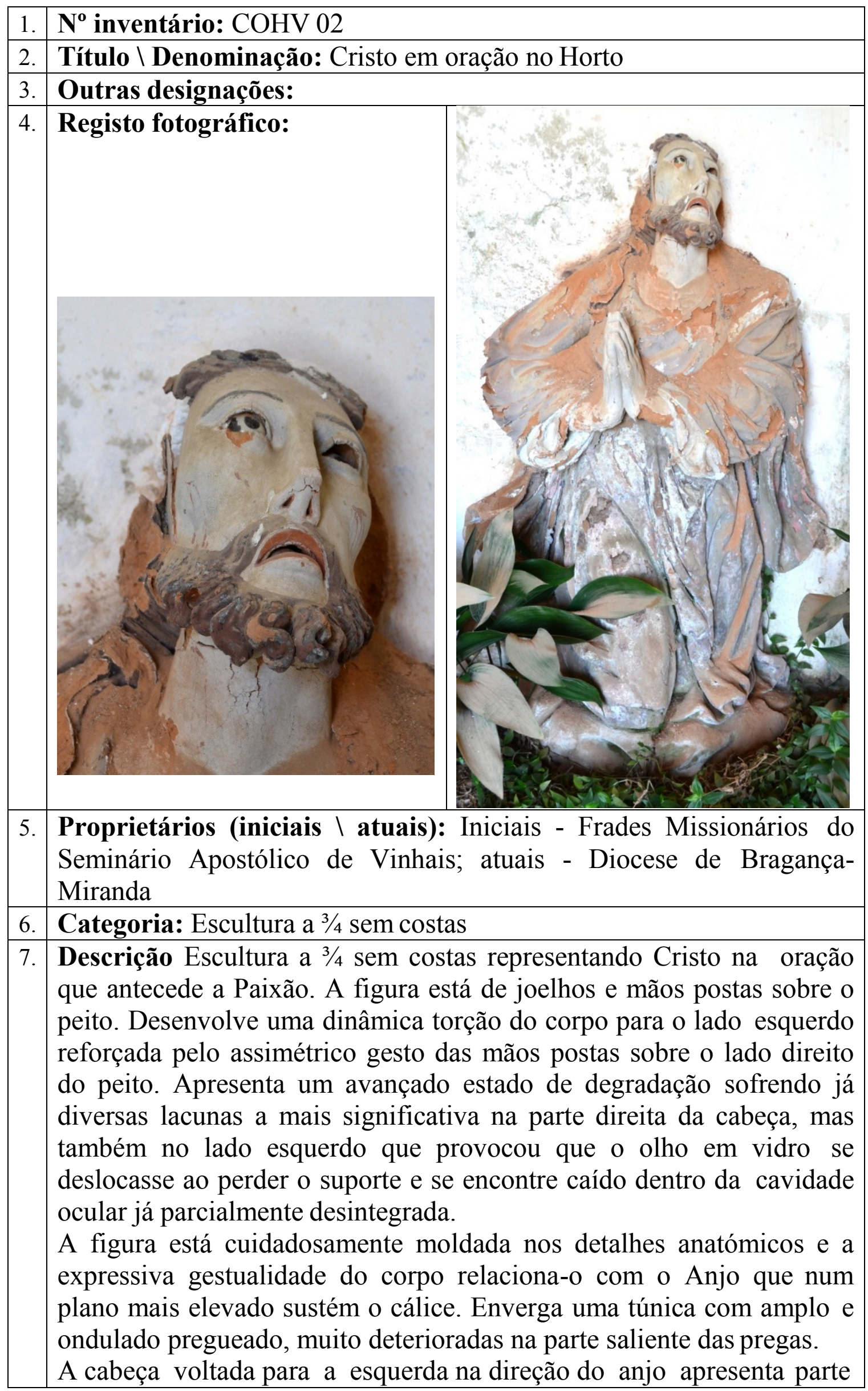




\begin{tabular}{|c|c|}
\hline & dos longos cabelos moldados em cuidadosas madeixas onduladas que \\
\hline 1 & alem sobre as costas. \\
\hline & $\begin{array}{l}\text { U rosto de carnaçao clara com expressao pungente de sotrimento eleva } \\
\text { os olhos de vidro (com lacuna de um olho) tem a boca entreaberta com } \\
\text { os cantos dos lábios descaídos deixando parte dos dentes a descoberto } \\
\text { apresenta barbas curtas modeladas em pequenas ondas. } \\
\text { Tal como as restantes figuras do conjunto apresenta sinais de } \\
\text { degradação ativa do suporte e policromia. }\end{array}$ \\
\hline 8. & Técnicas (de suporte): Modelagem \\
\hline 9. & Técnicas (de acabamento): Policromia \\
\hline 10. & Materiais (de suporte): Terracota $\backslash$ barro cozido \\
\hline 11. & Materiais (de acabamento): pigmentos; vidro \\
\hline 12. & $\begin{array}{l}\text { Estado de Conservação Mau; tem várias lacunas e degradação ativa } \\
\text { do material de suporte; destacamento da policromia }\end{array}$ \\
\hline 13. & $\begin{array}{l}\text { Dimensões: } \\
\text { Altura: } 150 \mathrm{~cm} \\
\text { Largura: } 90 \mathrm{~cm} \\
\text { Profundidade: } 44 \mathrm{~cm}\end{array}$ \\
\hline 14. & Restauro: não apresenta sinais de intervenção sobre a obra \\
\hline 15. & Datas: segunda metade do século XVIII \\
\hline 16. & Proveniência: Capela da Oração no Horto em Vinhais \\
\hline 17. & Autoria: Frei Domingos \\
\hline 18. & Oficina: Local \\
\hline 19. & $\begin{array}{l}\text { Localização (atual): A figura de Cristo a rezar no horto está adossada } \\
\text { à parede em frente da porta sobre o solo granítico. }\end{array}$ \\
\hline 20. & Histórico do objeto: não se conhecem registos \\
\hline 21. & $\begin{array}{l}\text { Iconografia: Cristo a rezar no Horto de joelhos e mãos postas sobre o } \\
\text { peito }\end{array}$ \\
\hline 22. & Irmandade: não se conhecem registos \\
\hline 23. & Procissões: não se conhecem registos \\
\hline
\end{tabular}




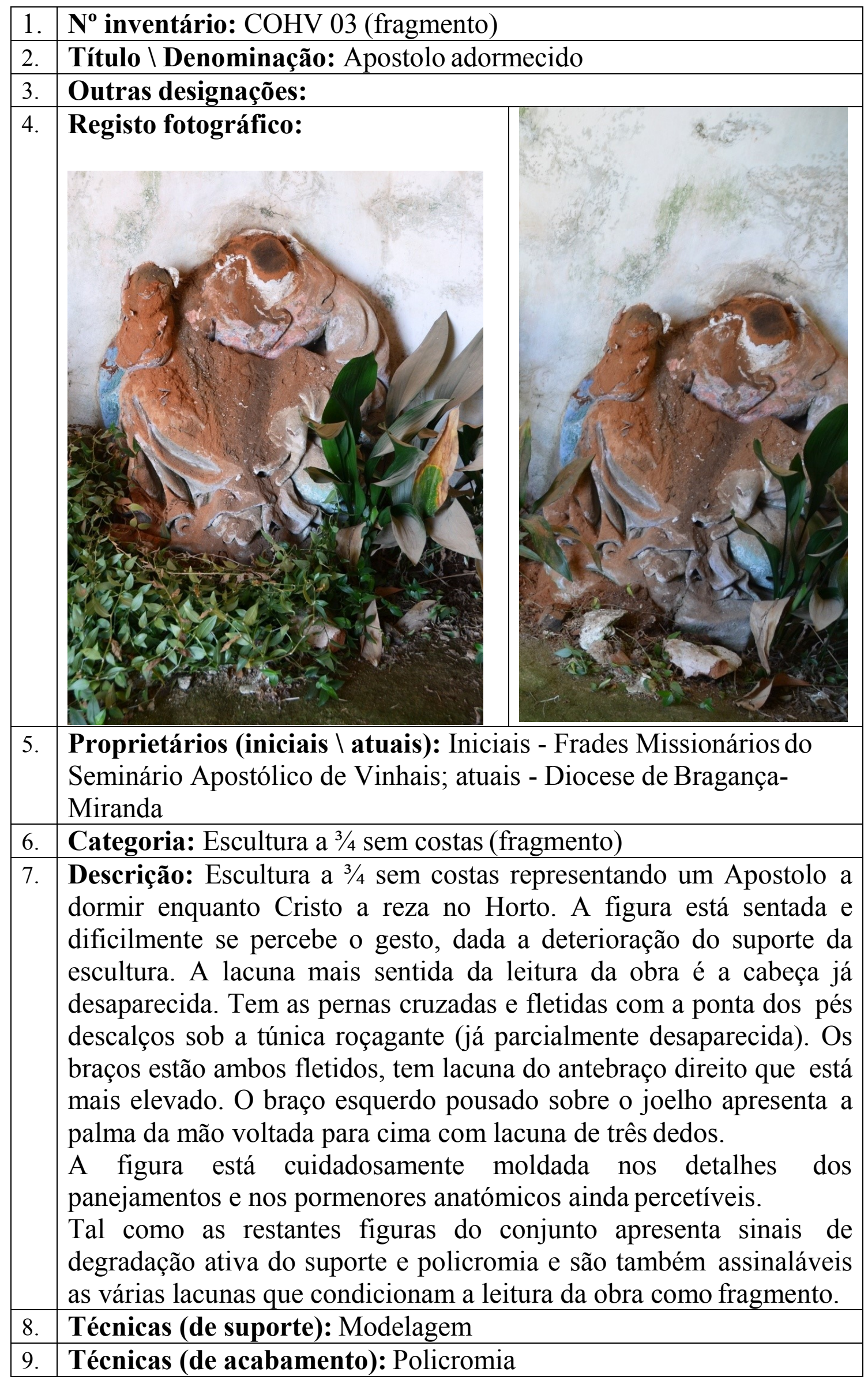




\begin{tabular}{|c|c|}
\hline 10. & Materiais (de suporte): Terracota $\backslash$ barro cozido \\
\hline 111. & Materiais (de acabamento): pigmentos \\
\hline 12. & $\begin{array}{l}\text { Estado de Conservação: Mau; lacunas várıas e degradação atıva do } \\
\text { material de suporte; destacamento da policromia }\end{array}$ \\
\hline 13. & $\begin{array}{l}\text { Dimensões: } \\
\text { Altura: } 100 \mathrm{~cm} \\
\text { Largura: } 90 \mathrm{~cm} \\
\text { Profundidade: } 70 \mathrm{~cm}\end{array}$ \\
\hline 14. & Restauro: não apresenta sinais de intervenção sobre a obra \\
\hline 15. & Datas: segunda metade do século XVIII \\
\hline 16. & Proveniência: Capela da Oração no Horto em Vinhais \\
\hline 17. & Autoria: Frei Domingos \\
\hline 18. & Oficina: Local \\
\hline 19. & $\begin{array}{l}\text { Localização (atual): A figura do Apóstolo está ao lado direito de } \\
\text { Cristo e adossada à parede em frente da porta sobre o solo granítico. }\end{array}$ \\
\hline 20. & Histórico do objeto: não se conhecem registos \\
\hline 21. & Iconografia: Apóstolo a dormir \\
\hline 22. & Irmandade: não se conhecem registos \\
\hline 23. & Procissões: não se conhecem registos \\
\hline
\end{tabular}




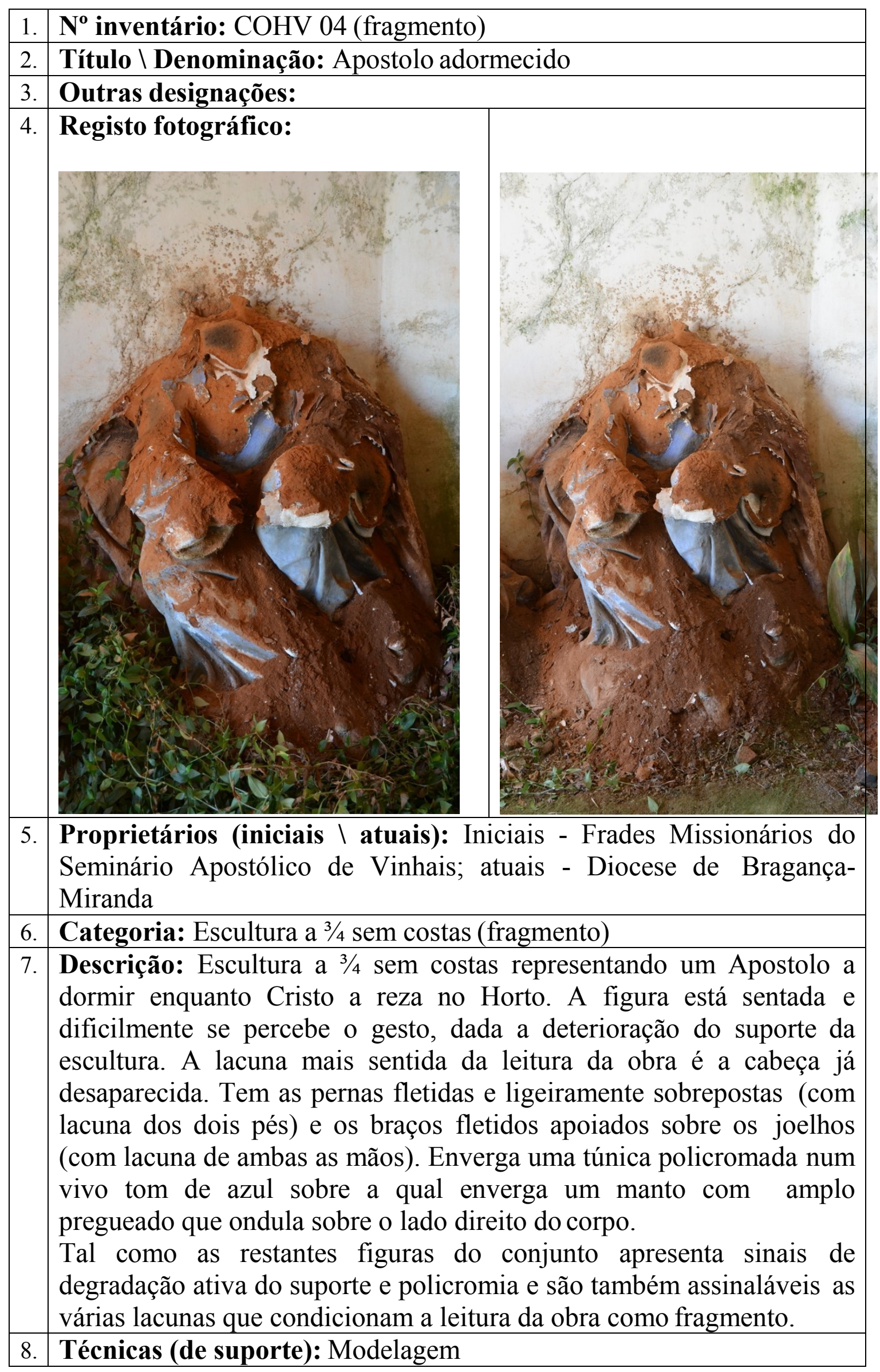




\begin{tabular}{|r|l|}
\hline 9. & Técnicas (de acabamento): Policromia \\
\hline 10 & Materiais (de suporte): Terracota $\backslash$ barro cozido \\
\hline 11 & Materiais (de acabamento): pigmentos \\
\hline 12 & $\begin{array}{l}\text { Estado de Conservação: Mau; tem várias lacunas e degradação ativa } \\
\text { do material de suporte; destacamento da policromia }\end{array}$ \\
\hline 13 & $\begin{array}{l}\text { Dimensões: } \\
\text { Altura: } 110 \mathrm{~cm} \\
\text { Largura: } 110 \mathrm{~cm} \\
\text { Profundidade: } 90 \mathrm{~cm}\end{array}$ \\
\hline 14 & Restauro: não apresenta sinais de intervenção sobre a obra \\
\hline 15 & Datas: segunda metade do século XVIII \\
\hline 16 & Proveniência: Capela da Oração no Horto em Vinhais \\
\hline 17 & Autoria: Frei Domingos \\
\hline 18 & Oficina: Local \\
\hline 19 & $\begin{array}{l}\text { Localização (inicial } \backslash \text { atual): A figura do Apóstolo está entre os outros } \\
\text { dois Apóstolos todos alinhados em semicírculo ao lado direito de } \\
\text { Cristo e adossada à parede sobre o solo granítico. }\end{array}$ \\
\hline 20 & Histórico do objeto: não se conhecem registos \\
\hline 21 & Iconografia: Apóstolo a dormir \\
\hline 22 & Irmandade: não se conhecem registos \\
\hline 23 & Procissões: não se conhecem registos \\
\hline
\end{tabular}




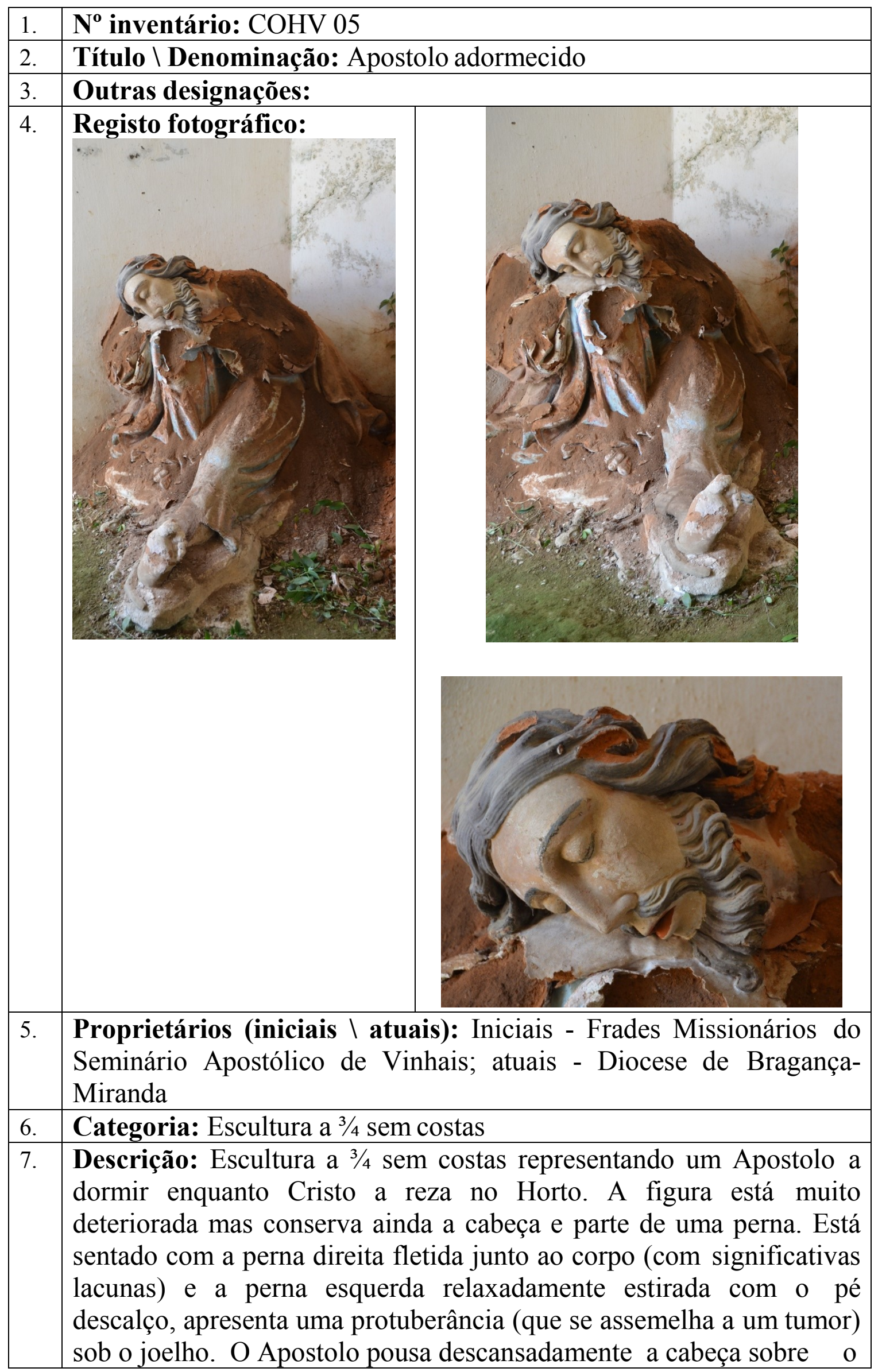




\begin{tabular}{|l|l|}
\hline & $\begin{array}{l}\text { lado direito apoiada sobre a mão. } \\
\text { O rosto de pálpebras cerradas está cuidadosamente modelado nos } \\
\text { detalhes anatómicos. Tem carnação clara e a boca policromada num } \\
\text { intenso tom vermelho, os cabelos longos e ondulados e as barbas } \\
\text { curtas em suaves ondas são moldados e policromados num tom } \\
\text { castanho. } \\
\text { Tal como as restantes figuras do conjunto apresenta sinais de } \\
\text { degradação ativa do suporte e policromia. }\end{array}$ \\
\hline 8. & Técnicas (de suporte): Modelagem \\
\hline 9. & Técnicas (de acabamento): Policromia \\
\hline 10. & Materiais (de suporte): Terracota $\backslash$ barro cozido \\
\hline 11. & Materiais (de acabamento): pigmentos \\
\hline 12. & $\begin{array}{l}\text { Estado de Conservação: Mau; tem várias lacunas e degradação ativa } \\
\text { do material de suporte; destacamento da policromia }\end{array}$ \\
\hline 13. & $\begin{array}{l}\text { Dimensões: } \\
\text { Altura: } 95 \text { cm } \\
\text { Largura: 110 cm } \\
\text { Profundidade: } 120 \text { cm }\end{array}$ \\
\hline 14. & Restauro: não apresenta sinais de intervenção sobre a obra \\
\hline 15. & Datas: segunda metade do século XVIII \\
\hline 16. & Proveniência: Capela da Oração no Horto em Vinhais \\
\hline 17. & Autoria: Frei Domingos \\
\hline 18. & Oficina: Local \\
\hline 19. & $\begin{array}{l}\text { Localização (inicial } \backslash \text { atual): A figura do Apóstolo está contigua à } \\
\text { porta da capela no lado esquerdo, sendo o último dos três Apóstolos } \\
\text { alinhados em semicírculo ao lado direito de Cristo e adossada à } \\
\text { parede sobre o solo granítico. }\end{array}$ \\
\hline 20. & Histórico do objeto: não se conhecem registos \\
\hline 21. & Iconografia: Apóstolo a dormir \\
\hline 22. & Irmandade: não se conhecem registos \\
\hline 23. & Procissões: não se conhecem registos \\
\hline
\end{tabular}




\title{
FICHAS DE INVENTÁRIO
}

ESCULTURA

\author{
CAPELA DA VIA SACRA
}

“SENHOR DO MONTE" (CRISTO MORTO)

SEMINÁRIO APOSTÓLICO DE VINHAIS 
FICHAS DE INVENTÁRIO | ESCULTURA

Da Ordem de São Francisco na Diocese de Bragança-Miranda 
Capela Da Via Sacra - "Senhor do Monte"

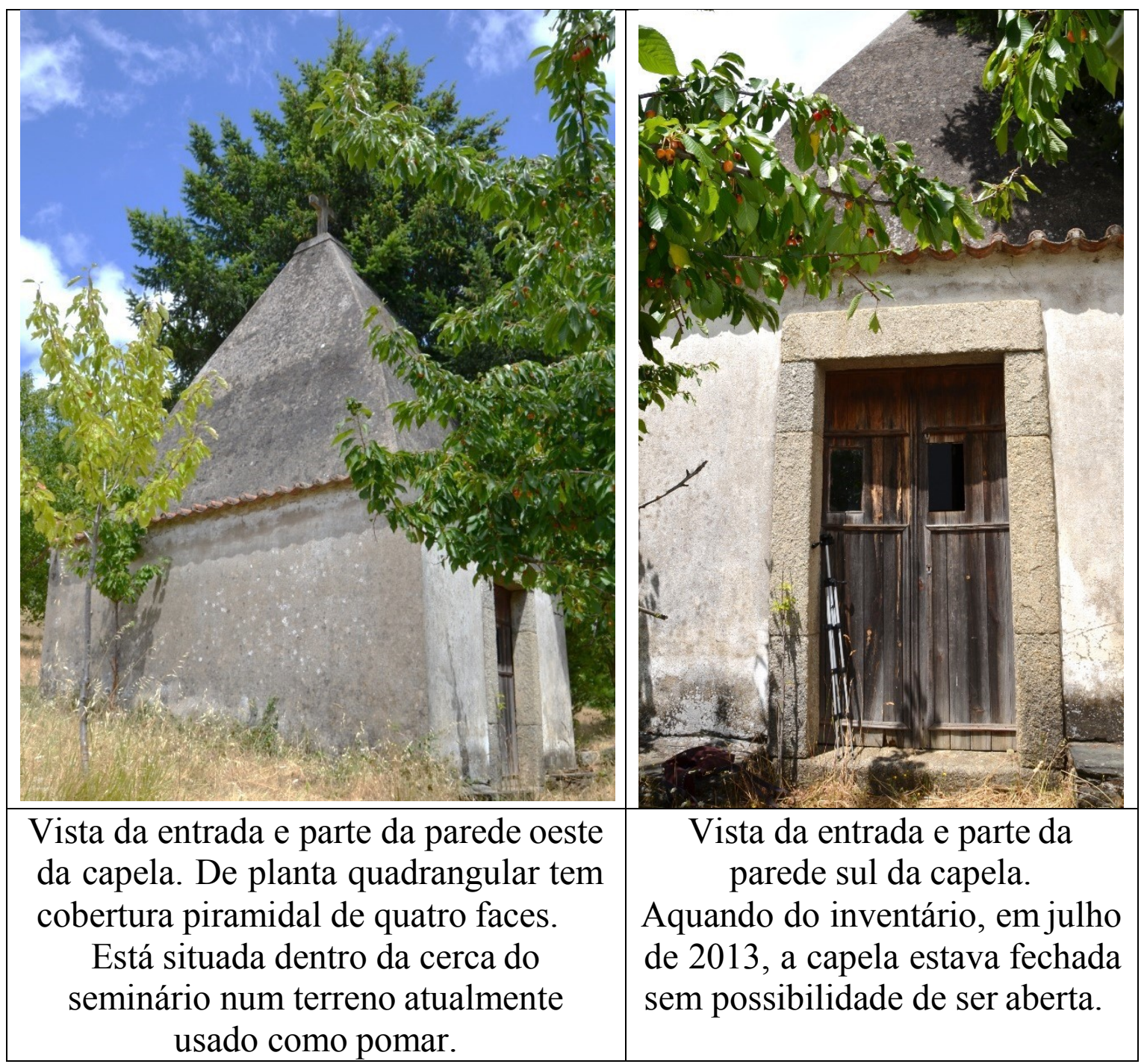


FICHAS DE INVENTÁRIO | ESCULTURA

Da Ordem de São Francisco na Diocese de Bragança-Miranda 
Capela do Senhor do Monte

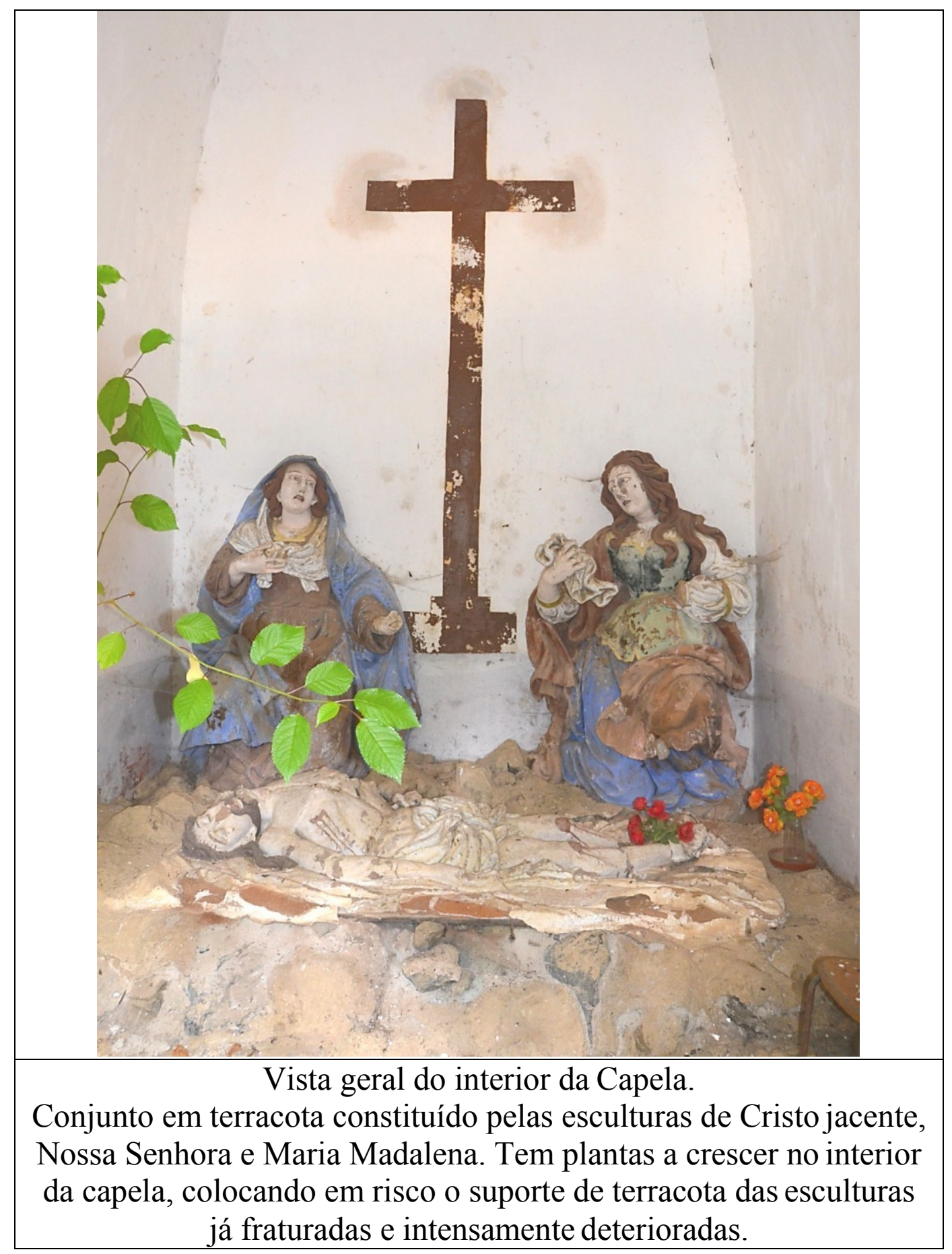


FICHAS DE INVENTÁRIO | ESCULTURA

Da Ordem de São Francisco na Diocese de Bragança-Miranda 


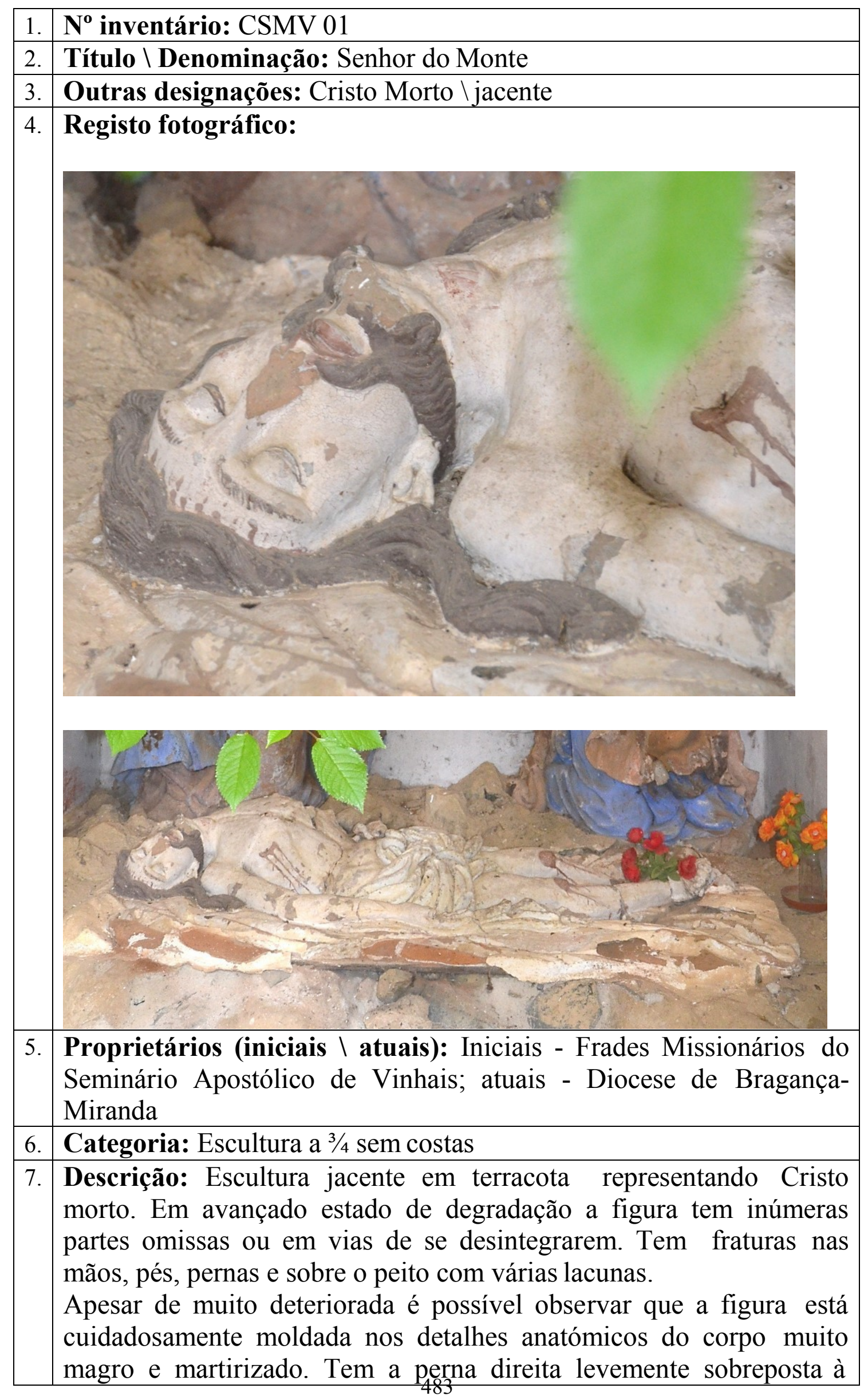


perna esquerda. O braço direito colocado junto ao corpo e o esquerdo sobre o cendal. A carnação muito clara faz destacar as manchas de sangue do martírio sobre o peito e joelhos.

A cabeça está pesadamente fincada sobre o sudário que envolve o leito sobre o qual a figura foi depositada enfatizando o peso do corpo morto. De olhos fechados e boca entreaberta, barbas e cabelo finamente modelado em ondas que lhe envolvem o rosto. Tem lacuna de parte do nariz e barbas.

8. Técnicas (de suporte): Modelagem

9. Técnicas (de acabamento): Policromia

10. Materiais (de suporte): Terracota $\backslash$ barro cozido

11. Materiais (de acabamento): pigmentos

12. Estado de Conservação: Mau; lacunas várias e degradação ativa do material de suporte

13. Dimensões: (imagem jacente $\backslash$ plano horizontal) medidas aproximadas (a capela à data do inventário estava fechada sem possibilidade de ser aberta)

Comprimento: $180 \mathrm{~cm}$

Largura: $65 \mathrm{~cm}$

Altura: $38 \mathrm{~cm}$

14. Restauro: não apresenta sinais de intervenção sobre a obra

15. Datas: segunda metade do século XVIII

16. Proveniência: Capela do Senhor do Monte em Vinhais

17. Autoria: Frei Domingos

18. Oficina: Local

19. Localização (atual): A figura de Cristo Morto está jacente no segundo registo da capela, sobre uma plataforma em terracota.

20. Histórico do objeto: não se conhecem registos

21. Iconografia Cristo Morto sobre o sudário; sinais de martírio

22. Irmandade: não se conhecem registos

23. Procissões: não se conhecem registos 


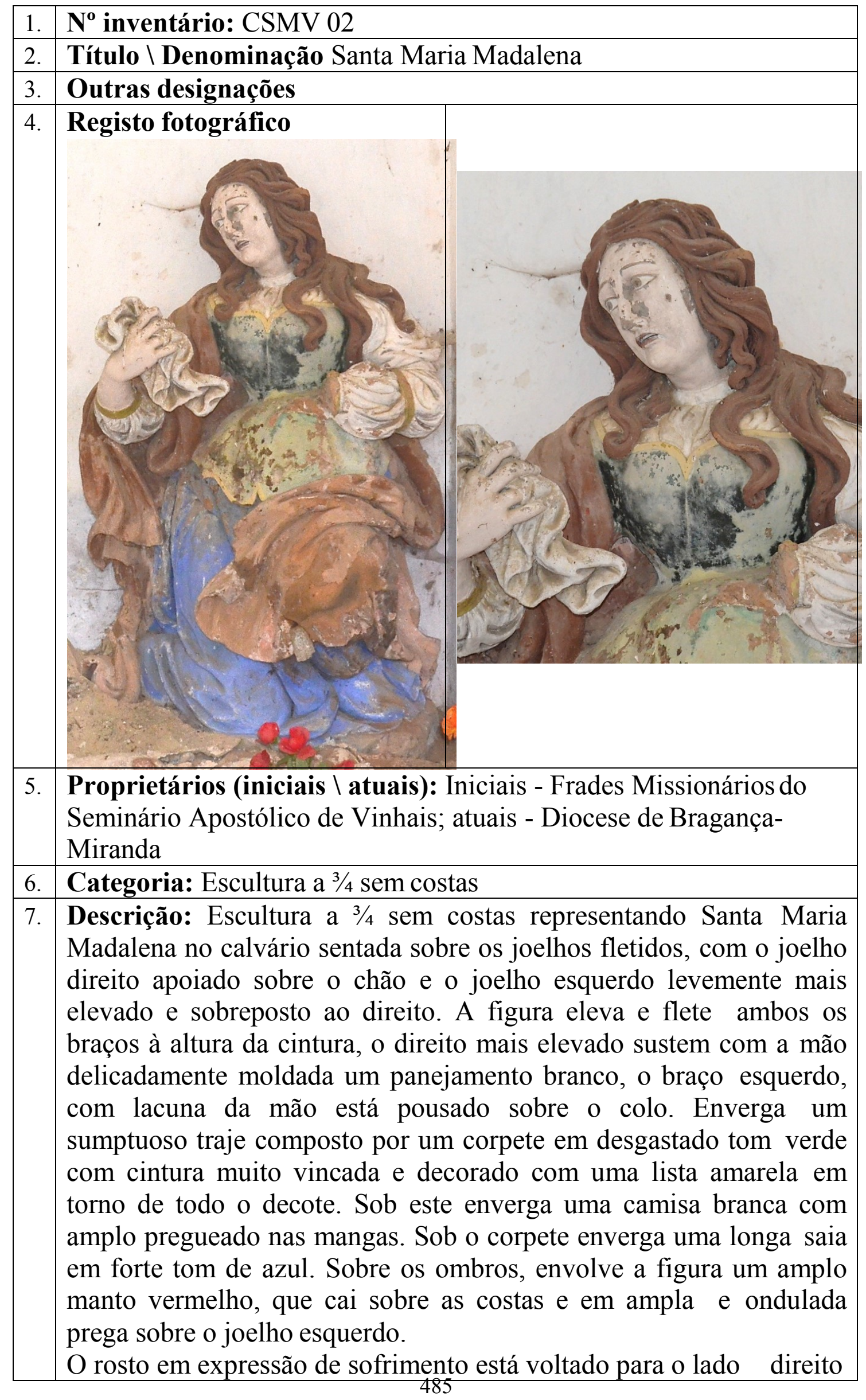




\begin{tabular}{|c|c|}
\hline & $\begin{array}{l}\text { em direção à figura da Virgem. Com carnação clara tem a boca } \\
\text { entreaberta com os cantos dos lábios descaídos e as sobrancelhas } \\
\text { arqueadas enfatizando a expressividade da figura. Os cabelos soltos } \\
\text { são longos e caiem em amplas ondas sobre os ombros. Tal como a } \\
\text { figura de Cristo jacente a figura de santa Maria Madalena apresenta } \\
\text { sinais de degradação ativa do suporte e policromia. }\end{array}$ \\
\hline 8. & Técnicas (de suporte): Modelagem \\
\hline 9. & Técnicas (de acabamento): Policromia \\
\hline 10. & Materiais (de suporte): Terracota $\backslash$ barro cozido \\
\hline 11. & Materiais (de acabamento): pigmentos \\
\hline 12. & $\begin{array}{l}\text { Estado de Conservação: Mau; lacunas várias e degradação activa do } \\
\text { material de suporte; destacamento da policromia }\end{array}$ \\
\hline 13. & $\begin{array}{l}\text { Dimensões: medidas aproximadas (a capela à data do inventário } \\
\text { estava fechada sem possibilidade de ser aberta) } \\
\text { Altura: } 137 \mathrm{~cm} \\
\text { Largura: } 98 \mathrm{~cm} \\
\text { Profundidade: } 80 \mathrm{~cm}\end{array}$ \\
\hline 14. & Restauro: não apresenta sinais de intervenção sobre a obra \\
\hline 15. & Datas: segunda metade do século XVIII \\
\hline 16. & Proveniência: Capela do Senhor do Monte em Vinhais \\
\hline 17. & Autoria: Frei Domingos \\
\hline 18. & Oficina: Local \\
\hline 19. & $\begin{array}{l}\text { Localização (atual): A figura de Santa Maria Madalena está } \\
\text { adossada à parede (lado da Epistola) no segundo registo da capela. }\end{array}$ \\
\hline 20. & Histórico do objeto: não se conhecem registos \\
\hline 21. & Iconografia: Madalena ajoelhada junto Cristo Morto \\
\hline 22. & Irmandade: não se conhecem registos \\
\hline 23. & Procissões: não se conhecem registos \\
\hline
\end{tabular}




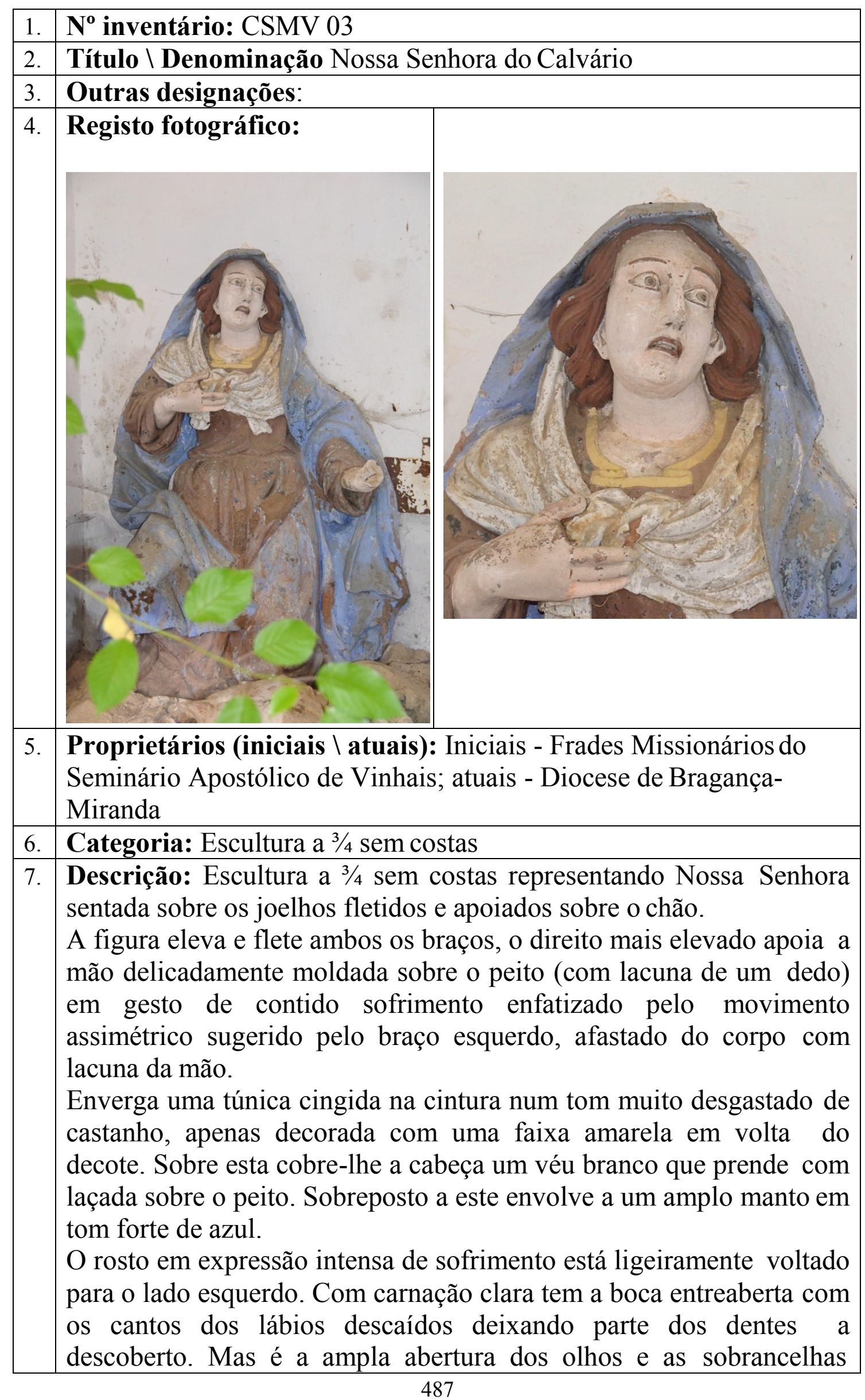




\begin{tabular}{|c|c|}
\hline & $\begin{array}{l}\text { arqueadas que mais enfatizando a dramática expressividade da figura. } \\
\text { Os cabelos quase impercetíveis sob o véu e manto são longos e } \\
\text { ondulados de cor castanha. Tal como a figura de Cristo jacente e a } \\
\text { figura de santa Maria Madalena também a figura da Virgem apresenta } \\
\text { sinais de degradação ativa do suporte e policromia. }\end{array}$ \\
\hline 8. & Técnicas (de suporte): Modelagem \\
\hline 9. & Técnicas (de acabamento): Policromia \\
\hline 10. & Materiais (de suporte): Terracota $\backslash$ barro cozido \\
\hline 11. & Materiais (de acabamento): pigmentos \\
\hline 12. & $\begin{array}{l}\text { Estado de Conservação: Mau; lacunas várias e degradação ativa do } \\
\text { material de suporte; destacamento da policromia }\end{array}$ \\
\hline 13. & $\begin{array}{l}\text { Dimensões: medidas aproximadas (a capela à data do inventário } \\
\text { estava fechada sem possibilidade de ser aberta) } \\
\text { Altura: } 137 \mathrm{~cm} \\
\text { Largura: } 110 \mathrm{~cm} \\
\text { Profundidade: } 80 \mathrm{~cm}\end{array}$ \\
\hline 14. & Restauro: não apresenta sinais de intervenção sobre a obra \\
\hline 15. & Datas: segunda metade do século XVIII \\
\hline 16. & Proveniência: Capela do Senhor do Monte em Vinhais \\
\hline 17. & Autoria: Frei Domingos \\
\hline 18. & Oficina: Local \\
\hline 19. & $\begin{array}{l}\text { Localização (inicial } \backslash \text { atual): A figura de Nossa Senhora está } \\
\text { adossada à parede (lado do Evangelho) no segundo registo da capela. }\end{array}$ \\
\hline 20. & Histórico do objeto: não se conhecem registos \\
\hline 21. & Iconografia: Nossa Senhora junto Cristo Morto \\
\hline 22. & Irmandade: não se conhecem registos \\
\hline 23. & Procissões: não se conhecem registos \\
\hline
\end{tabular}




\section{FICHAS DE INVENTÁRIO}

\section{ESCULTURA}

MUSEU DE ARTE SACRA

\section{VINHAIS}


FICHAS DE INVENTÁRIO | ESCULTURA

Da Ordem de São Francisco na Diocese de Bragança-Miranda 
Museu de Arte Sacra, Vinhais

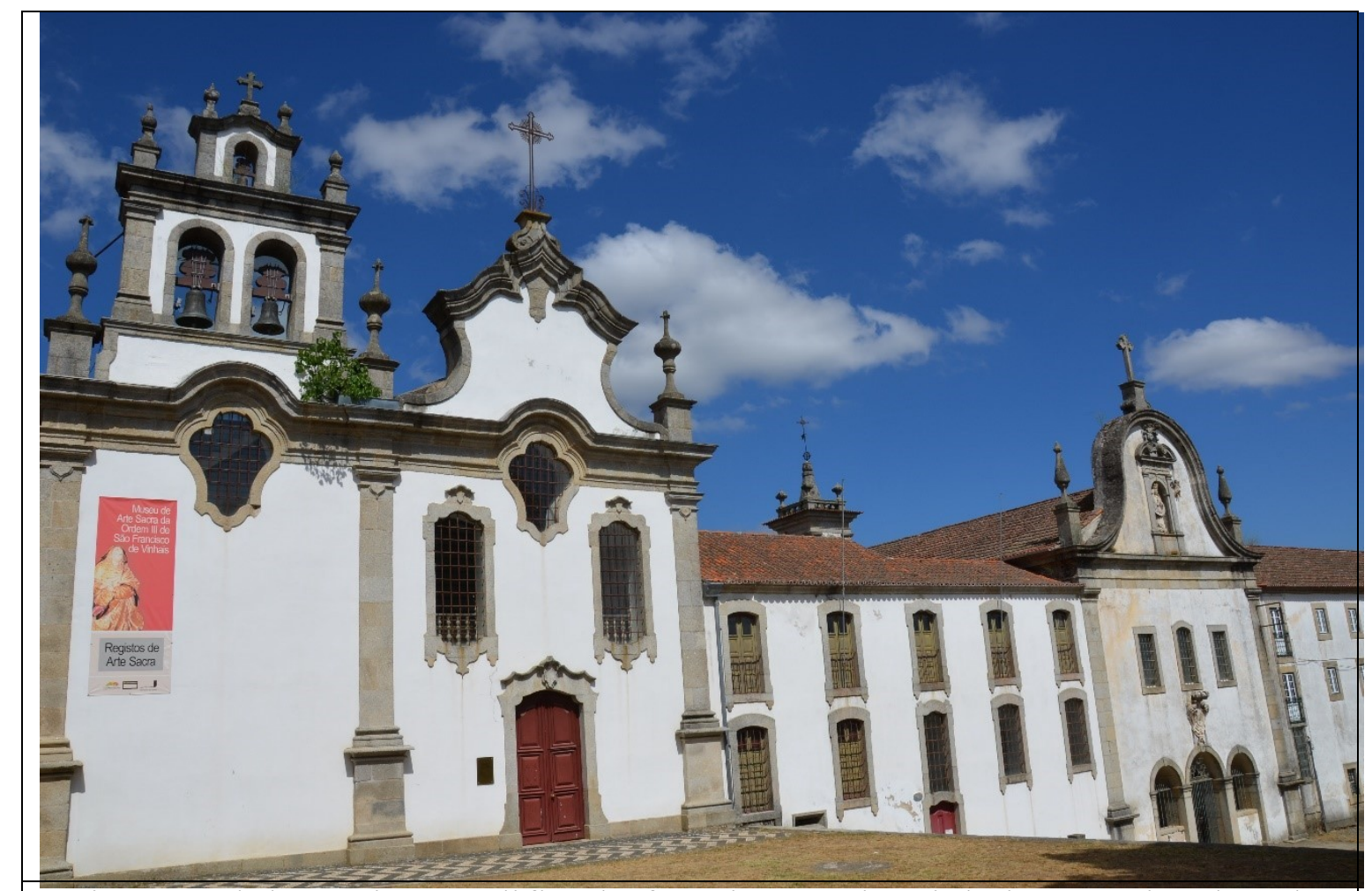

Vista geral do conjunto edificado franciscano de Vinhais, constituído pela igreja da Ordem Terceira Secular, igreja do Seminário Apostólico e espaço conventual que acolhe o Museu de Arte Sacra. 
FICHAS DE INVENTÁRIO | ESCULTURA

Da Ordem de São Francisco na Diocese de Bragança-Miranda 


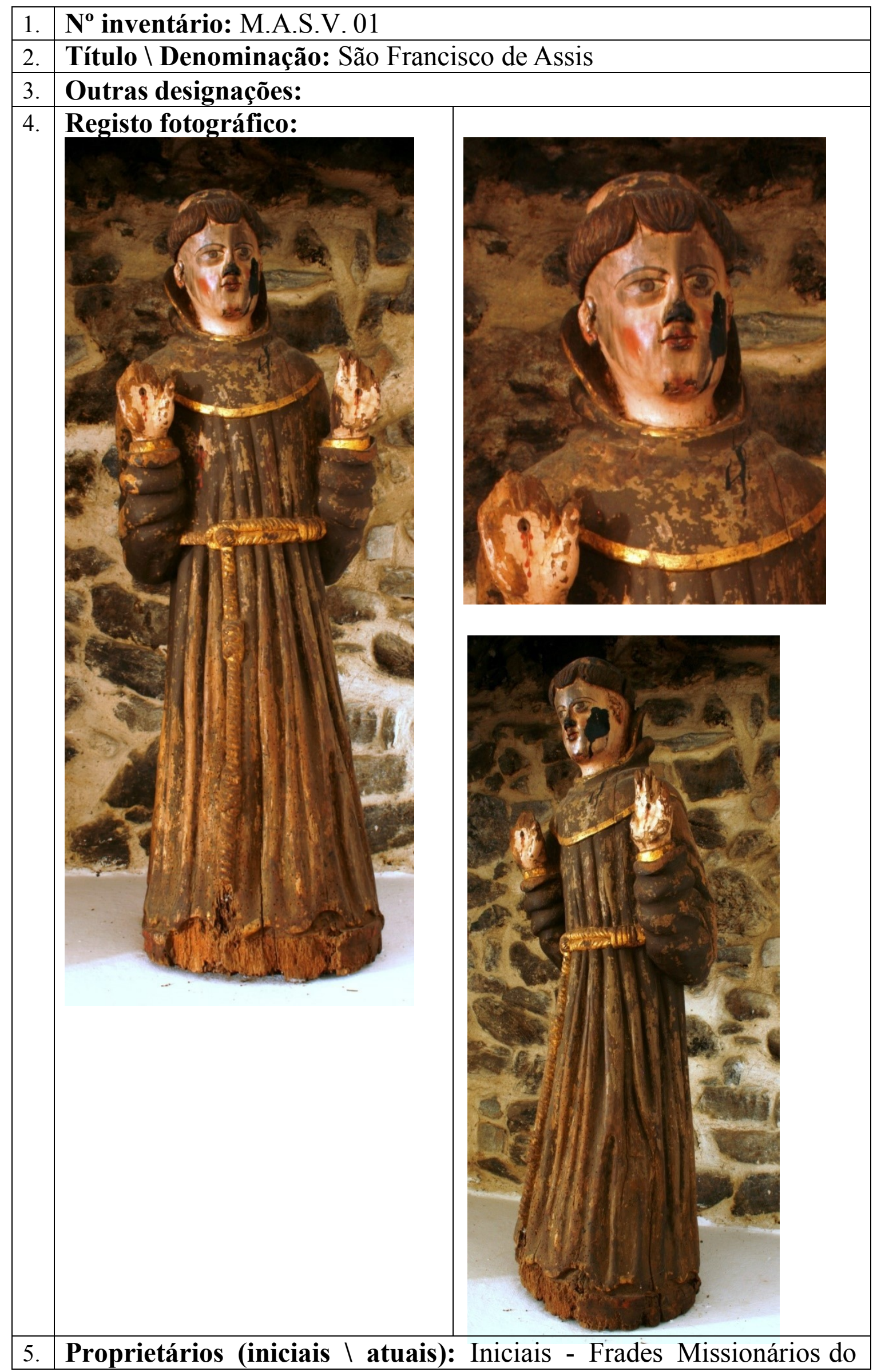




\begin{tabular}{|c|c|}
\hline & $\begin{array}{l}\text { Seminário Apostólico de Vinhais (?); atuais - Diocese de Bragança- } \\
\text { Miranda }\end{array}$ \\
\hline 6. & Categoria: Escultura de vulto completo \\
\hline 7. & $\begin{array}{l}\text { Descrição: Escultura de vulto completo em madeira policromada } \\
\text { representando São Francisco de pé, em estática posição frontal } \\
\text { elevando ambos os braços com as palmas das mãos estigmatizadas } \\
\text { voltadas para a frente, com lacuna de todos os dedos nas duas mãos. } \\
\text { O rosto, sumariamente esculpido nos detalhes anatómicos e } \\
\text { expressividade, foi posteriormente vandalizado ou por descuido } \\
\text { manchado com tinta negra sobre o lado esquerdo do rosto e hábito, são } \\
\text { também percetíveis sinais de ter sido queimado. Está tonsurado e tem } \\
\text { os olhos pintados, com olhar fixo em frente e carnação colorida de } \\
\text { vivo tom vermelho sobre as faces e sobre os lábios cerrados. } \\
\text { O hábito que enverga cingido está na cintura com cordão duplo } \\
\text { pendente sobre o lado direito com dois rolos de nós, a extremidade do } \\
\text { cordão está fraturada e assim como o bordo do hábito, encontra-se } \\
\text { muito deteriorada por infestação do inseto xilófago. O pregueado é } \\
\text { uniforme e pouco naturalista tem restos de policromia castanha com } \\
\text { bandas douradas sobre o punho e gola com capuz que cai em vinco } \\
\text { pontiagudo sobre as costas. } \\
\text { Sobre o peito, do lado direito apresenta uma chaga da qual emergem } \\
\text { pequenas gotas vermelhas. } \\
\text { A escultura encontra-se muito deteriorada mas estabilizada. Na } \\
\text { legenda que acompanha está registada a técnica de estufado porém não } \\
\text { é atualmente percetível essa técnica decorativa. }\end{array}$ \\
\hline 8. & Técnicas (de suporte): Talha \\
\hline 9. & Téc \\
\hline 10. & \\
\hline 11. & Iateriais (de a \\
\hline 12. & $\begin{array}{l}\text { Estado de Conservação: Razoável; a escultura apresenta-se estável } \\
\text { mas com fortes sinais de degradação e infestação de xilófago; tem } \\
\text { lacunas de todos os dedos e vestígios de tinta negra e sinais de ter sido } \\
\text { exposta a fogo }\end{array}$ \\
\hline 13. & $\begin{array}{l}\text { Dimensões: } \\
\text { Altura: } 103 \mathrm{~cm} \\
\text { Largura: } 38 \mathrm{~cm} \\
\text { Profundidade: } 26 \mathrm{~cm}\end{array}$ \\
\hline 14. & $\begin{array}{l}\text { Restauro: Atualmente está estabilizada na infestação deverá ter sido } \\
\text { intervencionada no momento da montagem da exposição do Museu. }\end{array}$ \\
\hline 15. & $\begin{array}{l}\text { Datas: finais do século XV, inícios do século XVI. } \\
\text { A tabela que acompanha a peça refere na legenda - século XVII }\end{array}$ \\
\hline 16. & $\begin{array}{l}\text { Proveniência: igreja de Nossa Senhora da Encarnação do Seminário } \\
\text { Apostólico de Vinhais }\end{array}$ \\
\hline
\end{tabular}




\begin{tabular}{|c|l|}
\hline 17. & Autoria: desconhecida \\
\hline 18. & Oficina: Nacional \\
\hline 19. & $\begin{array}{l}\text { Localização (inicial I atual): Foi encontrada na arrecadação da } \\
\text { sacristia da igreja de Nossa Senhora da Encarnação nos finais do } \\
\text { século XX aquando da última intervenção arquitetónica do conjunto } \\
\text { edificado. Atualmente, está colocada dentro de um nicho que servia } \\
\text { outrora de lareira, no } 1^{\text {o }} \text { piso do Museu }\end{array}$ \\
\hline 20. & $\begin{array}{l}\text { Histórico do objeto: A escultura é anterior à fundação de qualquer das } \\
\text { casas franciscanas existentes na Vila de Vinhais, o que sugere ter sido } \\
\text { trazida de outro espaço de culto. }\end{array}$ \\
\hline 21. & Iconografia: Hábito franciscano; estigmas sobre as mãos e peito \\
\hline 22. & Irmandade: não se conhecem registos \\
\hline 23. & Procissões: não se conhecem registos \\
\hline
\end{tabular}


FICHAS DE INVENTÁRIO | ESCULTURA

Da Ordem de São Francisco na Diocese de Bragança-Miranda 


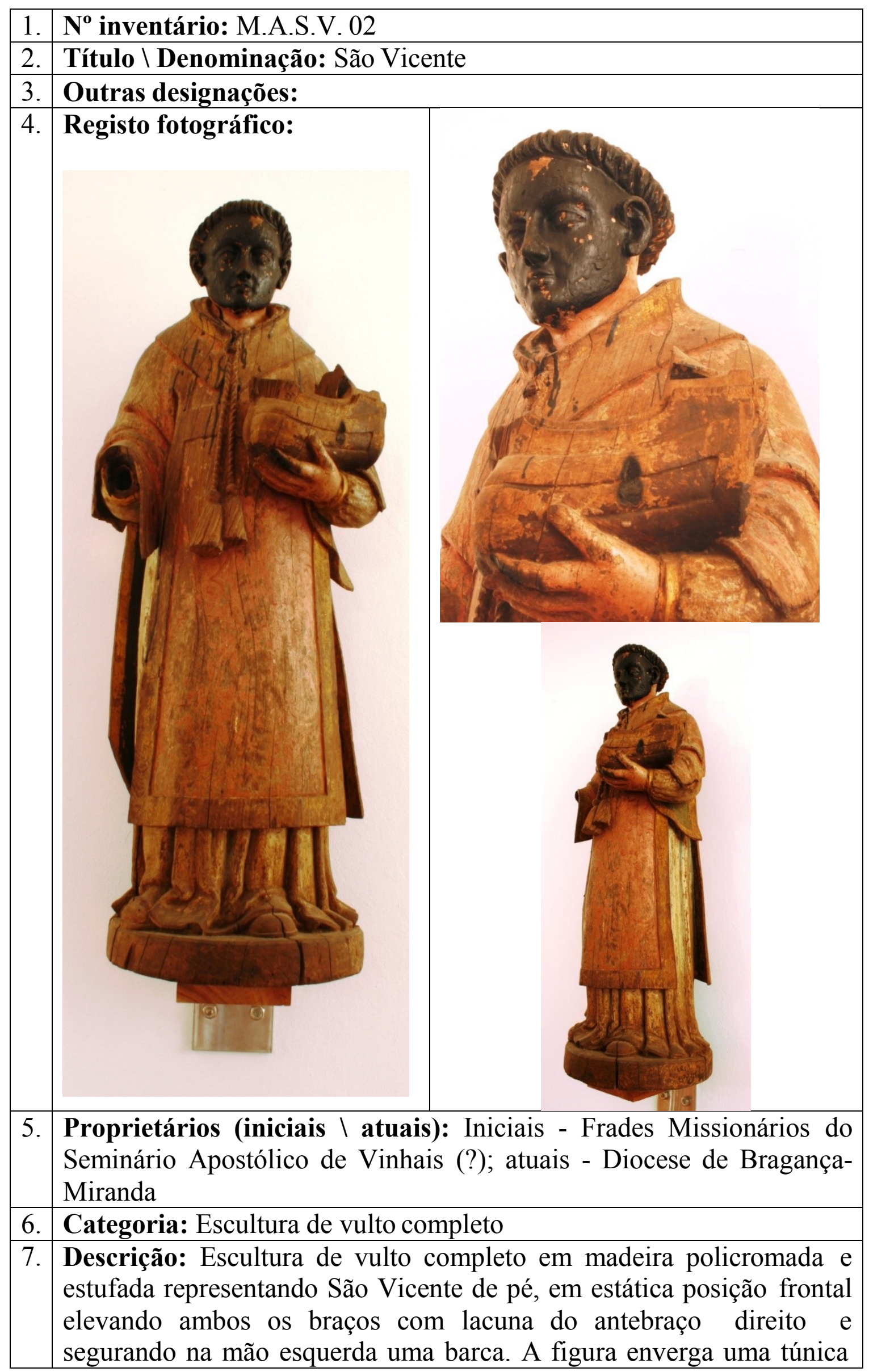




\begin{tabular}{|c|c|}
\hline & $\begin{array}{l}\text { branca que cai em vincadas pregas até aos pés, sobre esta enverga uma } \\
\text { dalmática num desgastado tom vermelho e com vestígios de } \\
\text { estufagem, policromada com bandas douradas sobre os bordos. Sobre a } \\
\text { gola pendem dois cordões rematados por borlas franjadas. A barca que } \\
\text { sustem, de forma bojuda e com castelos à proa e à popa, já muito } \\
\text { deteriorada restando apenas o casco. Sobre a popa da barca está } \\
\text { colocada uma parte de talha que se assemelha à cauda de uma ave. } \\
\text { A cabeça tonsurada está fortemente deteriorada com toda a extensão } \\
\text { do rosto pintada de negro, bem como inúmeras marcas de queimadura. } \\
\text { No entanto é ainda percetível o talhe cuidadoso do modelado } \\
\text { anatómico. Está assente sobre uma base circular. }\end{array}$ \\
\hline 8. & Técnicas (de suporte): Talha \\
\hline 9. & ento): Policromia \\
\hline 10 & Mat \\
\hline 11 & Mate \\
\hline 12 & $\begin{array}{l}\text { Estado de Conservação: Razoável; a escultura apresenta-se estável } \\
\text { mas com fortes sinais de degradação; tem lacuna do antebraço direito e } \\
\text { vestígios de tinta negra e sinais de ter sido exposta a fogo }\end{array}$ \\
\hline 13 & $\begin{array}{l}\text { Dimensões: } \\
\text { Altura: } 94 \mathrm{~cm} \\
\text { Largura: } 38 \mathrm{~cm} \\
\text { Profundidade: } 28 \mathrm{~cm}\end{array}$ \\
\hline 14 & $\begin{array}{l}\text { nta sinais de reintegração cromática, possivelmente } \\
\text { la no momento da montagem da exposição do }\end{array}$ \\
\hline 15 & $\begin{array}{l}\text { Datas: primeira metade do século XVII. } \\
\text { A tabela que acompanha a peça refere na legenda - século XVII }\end{array}$ \\
\hline 16 & $\begin{array}{l}\text { Proveniência: igreja de Nossa Senhora da Encarnação do Seminário } \\
\text { Apostólico de Vinhais }\end{array}$ \\
\hline 17 & \\
\hline 18 & Oficina: Nacional \\
\hline 19 & $\begin{array}{l}\text { Localização (inicial \ atual) Foi encontrada na arrecadação da } \\
\text { sacristia da igreja de Nossa Senhora da Encarnação nos finais do } \\
\text { século XX aquando da última intervenção arquitetónica do conjunto } \\
\text { edificado. Atualmente está colocada sobre a parede no } 1^{\circ} \text { piso do } \\
\text { Museu }\end{array}$ \\
\hline 20 & $\begin{array}{l}\text { Histórico do objeto A escultura é anterior à fundação de qualquer das } \\
\text { casas franciscanas existentes na Vila de Vinhais, o que sugere ter sido } \\
\text { trazida de outro espaço de culto. }\end{array}$ \\
\hline 21 & Iconografia: Dalmática; Barco; parte de uma ave sobre o barco \\
\hline 22 & \\
\hline & \\
\hline
\end{tabular}




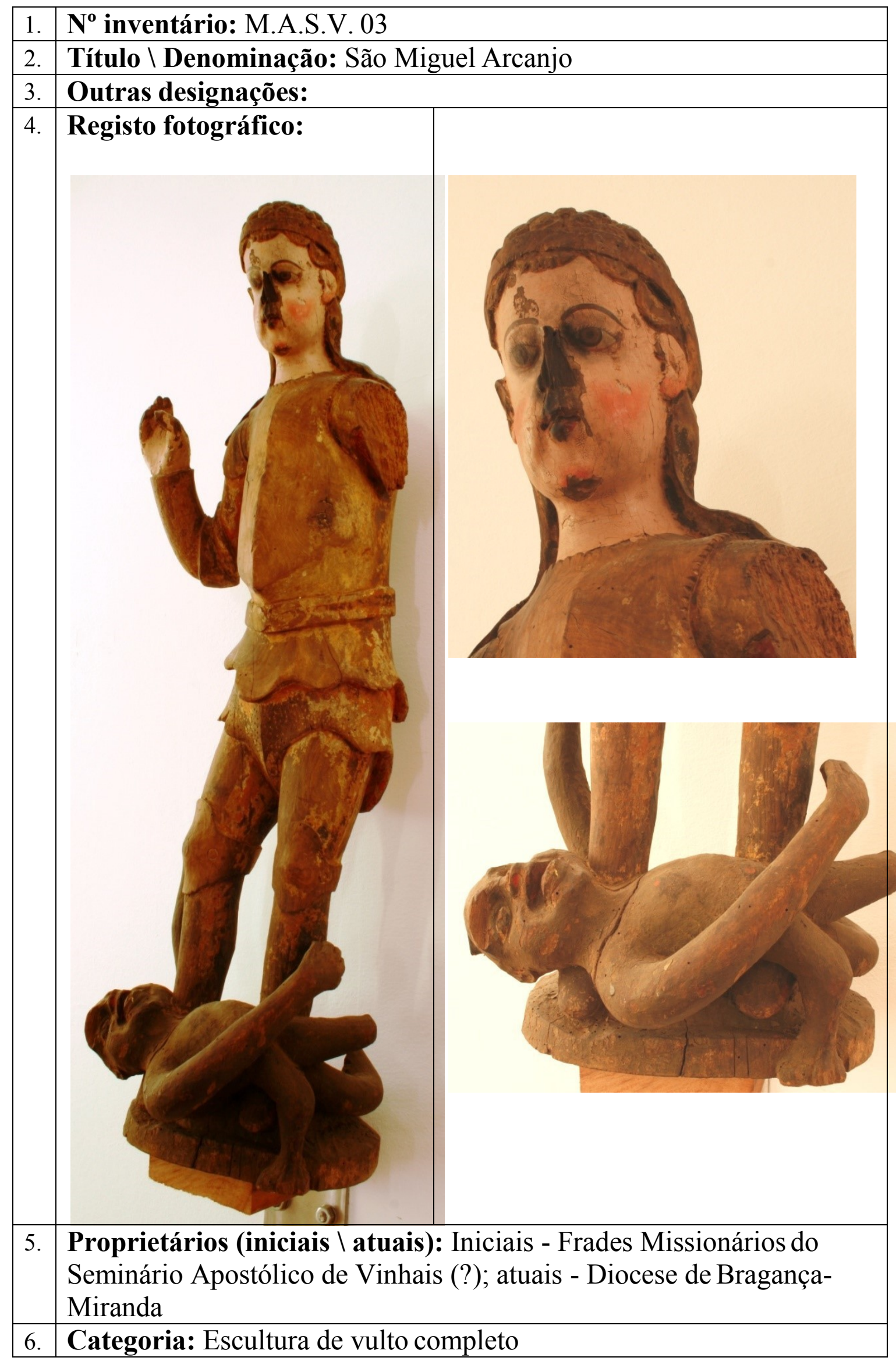




\begin{tabular}{|c|c|}
\hline & $\begin{array}{l}\text { Descrição: Escultura de vulto completo em madeira policromada } \\
\text { representando São } \\
\text { Miguel Arcanjo pisando o demónio. O Arcanjo está de pé, em posição } \\
\text { frontal com as pernas ligeiramente afastadas. Eleva e flete o braço } \\
\text { direito, já sem o atributo, com lacuna da ponta dos dedos. Tem também } \\
\text { lacuna do braço esquerdo seccionado pelo ombro. } \\
\text { Enverga um trajo militar com elmo protuberante em vinco sobre o } \\
\text { ventre e proteção sobre os joelhos. O cabelo, curto, e encaracolado } \\
\text { ostenta uma fita sobre a frente que prende detrás das orelhas. O rosto, } \\
\text { tal como nas imagens de São Francisco e São Vicente, encontra-se } \\
\text { com marcas de queimaduras. Tem lacuna da ponta do nariz e a } \\
\text { policromia dos olhos e da carnação das faces, bem como o modelado } \\
\text { anatómico do rosto é muito semelhante à da escultura de São Francisco } \\
\text { MASV 01. } \\
\text { O demónio enroscado aos pés do arcanjo está deitado sobre as costas } \\
\text { com braços e pernas elevados sugerindo movimentos de luta. Com } \\
\text { lacuna das extremidades das pernas e cauda a figura de boca } \\
\text { amplamente aberta tem ainda parte dos chifres e restos muito } \\
\text { deteriorados de pigmentação vermelha. } \\
\text { As figuras assentam sobre uma base oval em madeira. A policromia } \\
\text { que deverá ter coberto a escultura está fortemente desgastada e } \\
\text { apresenta inúmeros orifícios de infestação de xilófago. Na legenda que } \\
\text { acompanha está registada a técnica de estufado porém não é } \\
\text { atualmente percetível. }\end{array}$ \\
\hline 8. & Técnicas (de suporte): Talha \\
\hline 9. & (de acabamento): Policromia \\
\hline 10. & Matel \\
\hline 11. & Mater \\
\hline 12. & $\begin{array}{l}\text { Estado de Conservação: Razoável; a escultura apresenta-se estável } \\
\text { mas com fortes sinais de degradação e infestação de xilófago; tem } \\
\text { lacuna do braço esquerdo e das extremidades dos dedos da mão direita } \\
\text { (Arcanjo) e dos pés e cauda (Demónio). Apresenta sinais de ter sido } \\
\text { exposta a fogo }\end{array}$ \\
\hline 13. & $\begin{array}{l}\text { Dimensões: } \\
\text { Altura: } 93 \mathrm{~cm} \\
\text { Largura: } 35 \mathrm{~cm} \\
\text { Profundidade: } 27 \mathrm{~cm}\end{array}$ \\
\hline 14. & $\begin{array}{l}\text { : Atualmente está estabilizada na infestação deverá ter sido } \\
\text { ionada no momento da montagem da exposição do Museu. }\end{array}$ \\
\hline 15. & $\begin{array}{l}\text { Datas: finais do século XV, inícios do século XVI. } \\
\text { A tabela que acompanha a peça refere na legenda - século XVII }\end{array}$ \\
\hline 16. & $\begin{array}{l}\text { Proveniência: Igreja de Nossa Senhora da Encarnação do Seminário } \\
\text { Apostólico de Vinhais }\end{array}$ \\
\hline
\end{tabular}




\begin{tabular}{|l|l|}
\hline 17. & Autoria: desconhecida \\
\hline 18. & Oficina: Nacional \\
\hline 19. & $\begin{array}{l}\text { Localização (inicial I atual) Foi encontrada na arrecadação da } \\
\text { sacristia da igreja de Nossa Senhora da Encarnação nos finais do } \\
\text { século XX aquando da última intervenção arquitetónica do conjunto } \\
\text { edificado. Atualmente está colocada sobre a parede no } 1^{\circ} \text { piso do } \\
\text { Museu }\end{array}$ \\
\hline 20. & $\begin{array}{l}\text { Histórico do objeto: A escultura é anterior à fundação de qualquer das } \\
\text { casas franciscanas existentes na Vila de Vinhais, o que sugere ter sido } \\
\text { trazida de outro espaço de culto. }\end{array}$ \\
\hline 21. & Iconografia: Demónio; Elmo e proteção nos joelhos \\
\hline 22. & Irmandade: não se conhecem registos \\
\hline 23. & Procissões: não se conhecem registos \\
\hline
\end{tabular}


FICHAS DE INVENTÁRIO | ESCULTURA

Da Ordem de São Francisco na Diocese de Bragança-Miranda 


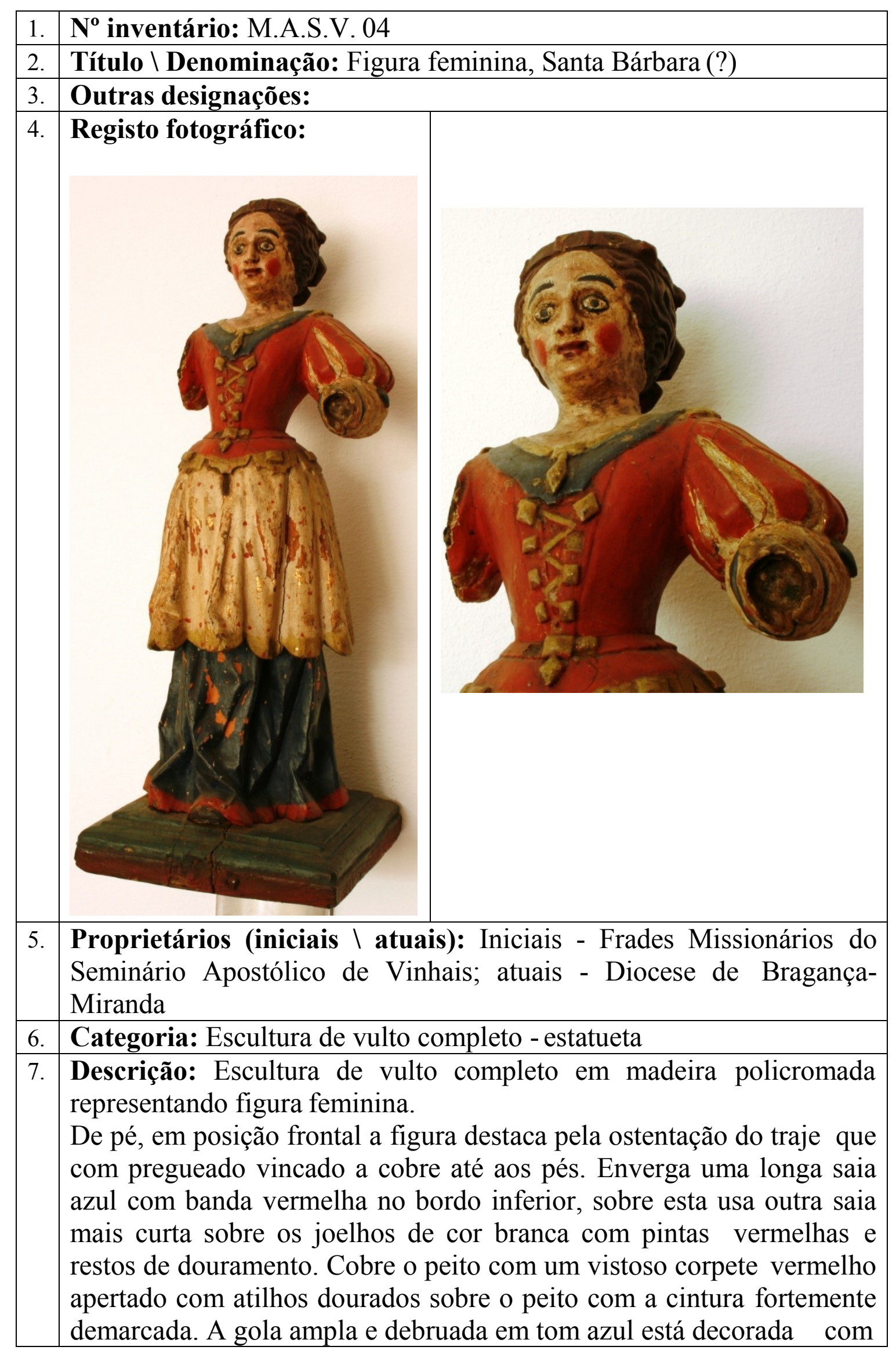




\begin{tabular}{|c|c|}
\hline & $\begin{array}{l}\text { pendentes dourados que repete no bordo do corpete. Tem lacuna do } \\
\text { braço direito, seccionado pelo ombro, o braço esquerdo está também } \\
\text { fraturado pelo cotovelo com lacuna do antebraço. A manga que o } \\
\text { cobre é ricamente ornamentada com volumosas aberturas que alternam } \\
\text { motivos decorativos dourados estufados e vermelhos. } \\
\text { A cabeça ornada com tiara sobre a fronte tem os cabelos castanhos e } \\
\text { presos sobre a nuca. O rosto sinteticamente talhado está intensamente } \\
\text { repintado, nos olhos, sobrancelhas, lábios e faces. } \\
\text { Está assente sobre uma base retangular azul em madeira. }\end{array}$ \\
\hline 8. & Técnicas (de suporte): Talha \\
\hline 9. & Técnicas (de acabamento): Policromia \\
\hline 10. & Materiais (de suporte): Madeira \\
\hline 11. & Materiais (de acabamento): Pigmentos \\
\hline 12. & $\begin{array}{l}\text { Estado de Conservação: Bom; a escultura apresenta-se estável mas } \\
\text { com fortes sinais de degradação; tem lacuna do braço direito e do } \\
\text { antebraço }\end{array}$ \\
\hline 13. & $\begin{array}{l}\text { Dimensões: } \\
\text { Altura: } 52 \mathrm{~cm} \\
\text { Largura: } 18 \mathrm{~cm} \\
\text { Profundidade: } 18 \mathrm{~cm} \\
\end{array}$ \\
\hline 14. & $\begin{array}{l}\text { Restauro: Deverá ter sido intervencionada no momento da montagem } \\
\text { da exposição do Museu. Apresenta sinais de reintegração cromática } \\
\text { sobretudo no rosto }\end{array}$ \\
\hline 15. & Datas: segunda metade do século XVIII \\
\hline 16. & $\begin{array}{l}\text { Proveniência: igreja de Nossa Senhora da Encarnação do Seminário } \\
\text { Apostólico }\end{array}$ \\
\hline 17. & Autoria: desconhecida \\
\hline 18. & Oficina: Local $\backslash$ regional \\
\hline 19. & $\begin{array}{l}\text { Localização (atual): Atualmente está colocada sobre a parede no } 1^{\circ} \\
\text { piso do Museu }\end{array}$ \\
\hline 20. & $\begin{array}{l}\text { Histórico do objeto: poderá tratar-se de uma das imagens de Santa } \\
\text { Bárbara que foram inventariadas em } 1834 \text { na igreja de Nossa senhora } \\
\text { da Encarnação do contiguo seminário apostólico }\end{array}$ \\
\hline 21. & Iconografia: traje ornado corpete; tiara \\
\hline 22. & Irmandade: não se conhecem registos \\
\hline 23. & Procissões: não se conhecem registos \\
\hline
\end{tabular}




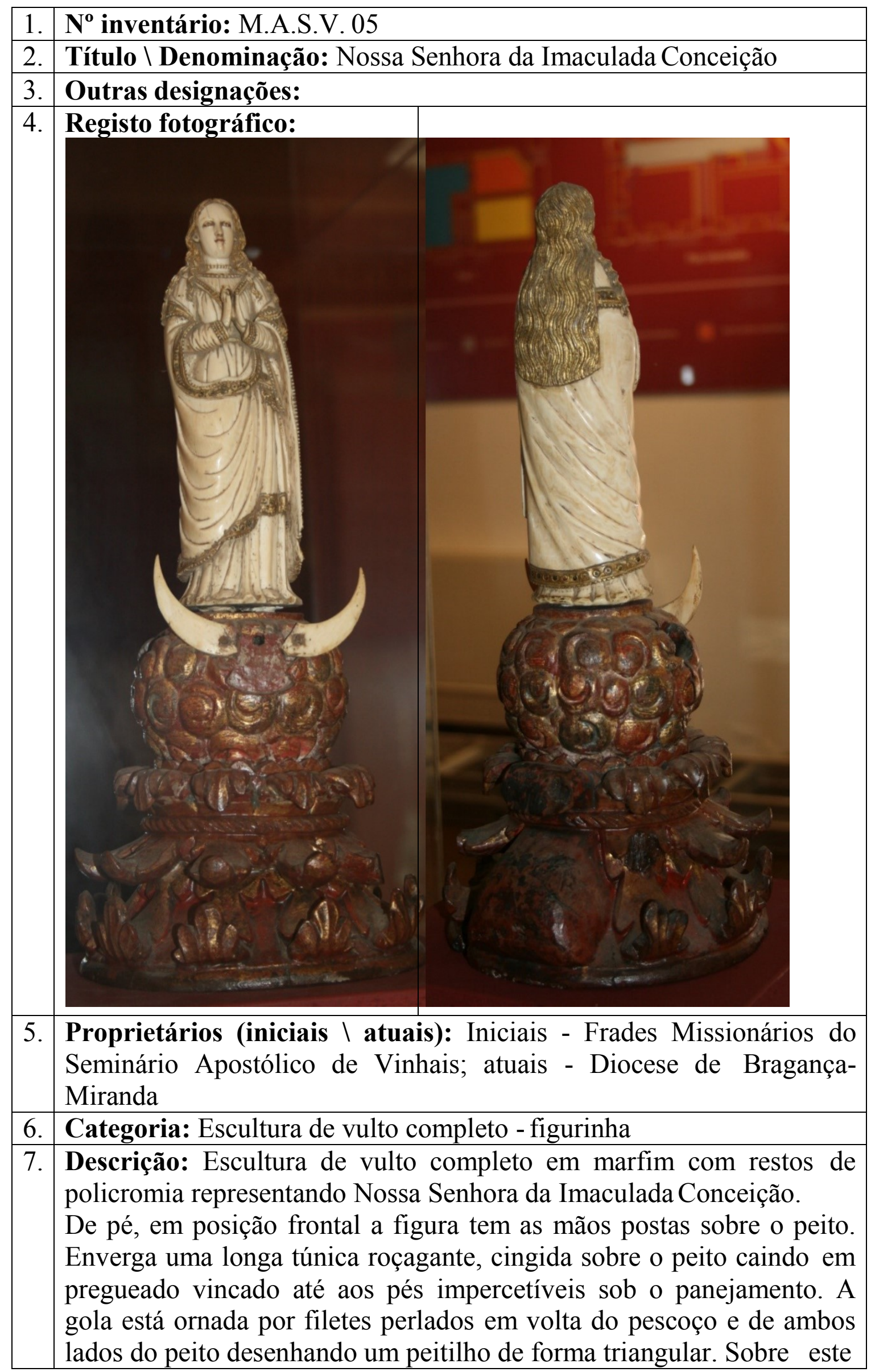




\begin{tabular}{|c|c|c|}
\hline & \multicolumn{2}{|c|}{$\begin{array}{l}\text { ornado peitilho usa uma gargantilha de pérolas junto ao pescoço. O } \\
\text { rosto, cuidadosamente esculpido de linhas simétricas que compõem a } \\
\text { expressão grave com olhar fixo em frente, apresenta vestígios de } \\
\text { policromia vermelha sobre os lábios fechados. Os cabelos são longos e } \\
\text { ondulados e caiem em amplas madeixas soltas sobre os ombros e } \\
\text { costas, coloridos num tom dourado desgastado. Sobre a túnica enverga } \\
\text { um manto ornado nos bordos por uma banda com elementos } \\
\text { geométricos coloridos num tom dourado desgastado. O manto cobre a } \\
\text { figura sobre os ombros e traçado sobre o ventre é sustido pelo braço } \\
\text { esquerdo caindo em drapeado sobre o lado esquerdo do corpo. As } \\
\text { mãos postas têm lacuna da ponta de três dedos e pela presença do } \\
\text { orifício entre as mãos sugere ter originalmente sustido algum atributo } \\
\text { entre elas. Está assente sobre uma peanha em madeira policromada e } \\
\text { dourada que representa um globo decorado com formas espiraladas, } \\
\text { sobre uma composição de folhas de acanto presas por um cordão e que } \\
\text { se sobrepõem em dois registos. Sobre o globo aos pés da imagem estão } \\
\text { pregadas duas partes de marfim que formam uma lua crescente, com } \\
\text { lacuna do elemento central. }\end{array}$} \\
\hline 8. & \multicolumn{2}{|c|}{ Técnicas (de suporte): Talha } \\
\hline 9. & \multicolumn{2}{|l|}{ Técnicas (de acabamento } \\
\hline 10 & \multicolumn{2}{|l|}{ Materiais (de suporte): $\mathrm{N}$} \\
\hline 11 & \multicolumn{2}{|c|}{ Materiais (de acabamento): Pigmentos, ouro } \\
\hline 12 & \multicolumn{2}{|c|}{$\begin{array}{l}\text { Estado de Conservação: Bom; a escultura apresenta-se estável tem } \\
\text { lacuna da ponta de três dedos e de um elemento em marfim da lua na } \\
\text { base da imagem }\end{array}$} \\
\hline 13 & $\begin{array}{l}\text { Dimensões: com peanha } \\
\text { Altura: } 33 \mathrm{~cm} \\
\text { Largura: } 17 \mathrm{~cm} \\
\text { Profundidade: } 17 \mathrm{~cm}\end{array}$ & \\
\hline 14 & \multicolumn{2}{|l|}{ Restauro: Não apresenta s } \\
\hline & \multicolumn{2}{|l|}{ Datas: século XVIII } \\
\hline & \multicolumn{2}{|c|}{ Proveniência: igreja de Nossa Senhora da Encarnação em Vinhais } \\
\hline & \multicolumn{2}{|l|}{ Autoria: desconhecida } \\
\hline & \multicolumn{2}{|l|}{ Oficina: Indo-europeia (Or } \\
\hline 19 & \multicolumn{2}{|c|}{$\begin{array}{l}\text { Localização (atual): Atualmente está colocada dentro de uma vitrina } \\
\text { no piso térreo do Museu. Segundo informação da zeladora da igreja } \\
\text { outrora a imagem estava dentro do armário } \backslash \text { oratório da sacristia da } \\
\text { igreja de Nossa Senhora da Encarnação. }\end{array}$} \\
\hline 20 & \multicolumn{2}{|c|}{ Histórico do objeto: não se conhecem registos } \\
\hline & \multicolumn{2}{|c|}{ Iconografia: Mãos postas; cabelos soltos; Lua } \\
\hline & \multicolumn{2}{|c|}{ Irmandade: não se conhecem registos } \\
\hline & \\
\hline
\end{tabular}




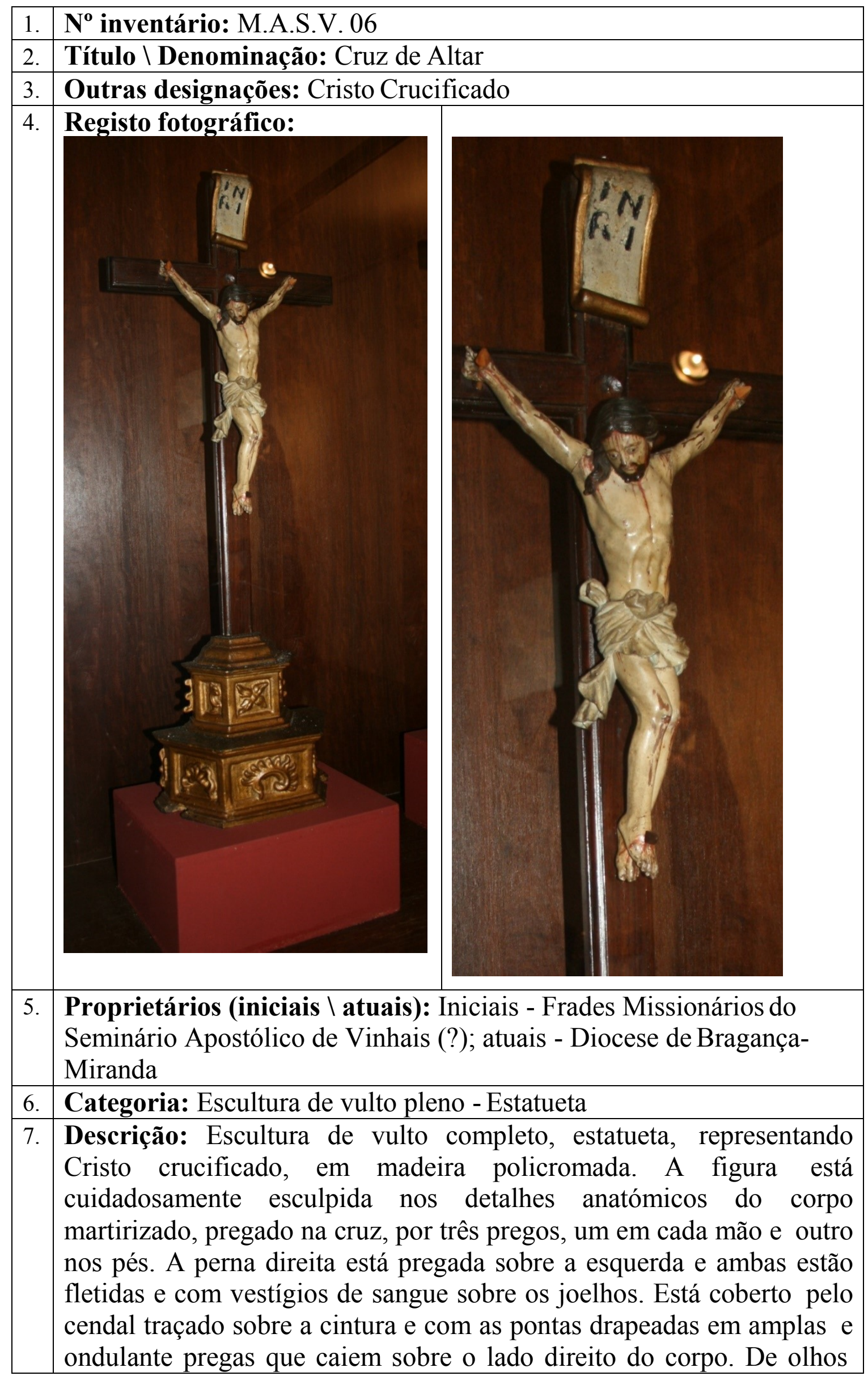




\begin{tabular}{|c|c|}
\hline & $\begin{array}{l}\text { abertos, de vidro, e rosto coberto por finas gotas de sangue volta a } \\
\text { cabeça para baixo inclinada sobre o ombro direito com barbas bífidas e } \\
\text { cabelo finamente talhado em ondas que caiem sobre as costas e ombro } \\
\text { direito. Apresenta forte desgaste na policromia da carnação das pernas } \\
\text { e braços. } \\
\text { A cruz em madeira escura tem os bordos burilados de forma } \\
\text { semicircular. Na extremidade superior da cruz está colocada a cartela } \\
\text { branca com bordos dourados onde pode ler-se JN / RI. A base da cruz } \\
\text { é dourada e decorada com elementos rococós em dois registos } \\
\text { sobrepostos de forma semi-hexagonal. }\end{array}$ \\
\hline 8. & Técnicas (de suporte): Talha \\
\hline 9. & Técnicas (de acabamento): Policromia \\
\hline 10. & Materiais (de suporte): Madeira \\
\hline 11. & Materiais (de acabamento): Pigmentos; vidro; o \\
\hline 12. & $\begin{array}{l}\text { Estado de Conservação: Bom; a escultura apresenta-se estável mas } \\
\text { com lacunas da ponta dos dedos e desgaste e lacunas na policromia }\end{array}$ \\
\hline 13. & $\begin{array}{l}\text { Dimensões: } \\
\text { Altura: } 84 \mathrm{~cm} \\
\text { Largura: } 34 \mathrm{~cm} \\
\text { Profundidade: } 13 \mathrm{~cm}\end{array}$ \\
\hline 14. & $\begin{array}{l}\text { Restauro: apresenta sinais de reintegração cromática nas letras e } \\
\text { bordo dourado da cartela }\end{array}$ \\
\hline 15. & $\begin{array}{l}\text { Datas: segunda metade do século XVIII } \\
\text { A tabela que acompanha a peça refere na legenda - século XVIII }\end{array}$ \\
\hline 16. & Proveniência: igreja de Nossa Senhora da Encarnação em Vinhais \\
\hline 17. & Autoria: desconhecida \\
\hline 18. & Oficina: Nacional \\
\hline 19. & $\begin{array}{l}\text { Localização (atual): Atualmente está colocada dentro de uma vitrina } \\
\text { em conjunto com mais duas cruzes de altar no piso térreo do Museu }\end{array}$ \\
\hline 20. & Histórico do objeto: não se conhecem registos \\
\hline 21. & Iconografia: Cruz; Cendal; Cartela \\
\hline 22. & Irmandade: não se conhecem registos \\
\hline 23. & \\
\hline
\end{tabular}




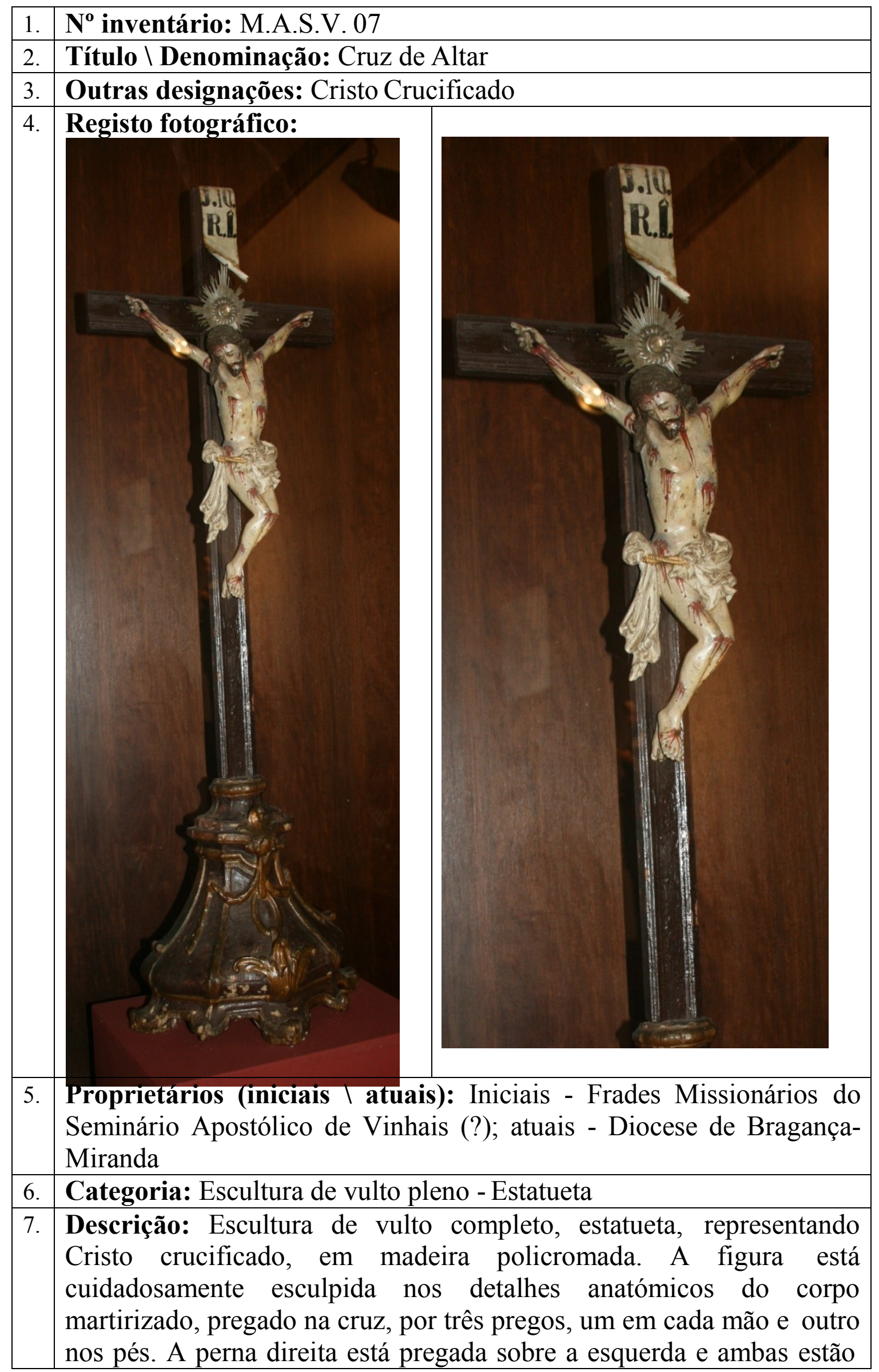




\begin{tabular}{|c|c|}
\hline & $\begin{array}{l}\text { fletidas e fortemente inclinadas para o lado esquerdo intensificando a } \\
\text { torção do corpo. } \\
\text { Está coberto pelo cendal cingido na cintura por cordão duplo dourado } \\
\text { com as pontas drapeadas em amplas e ondulante pregas que caiem } \\
\text { sobre o lado direito do corpo. De olhos fechados, e rosto coberto por } \\
\text { amplas gotas de sangue que se multiplicam sobre o peito, pernas e } \\
\text { braços. Volta a cabeça para baixo inclinada sobre o ombro direito com } \\
\text { barbas e cabelo finamente talhado em volumosas ondas que caiem } \\
\text { sobre as costas e ombro direito. } \\
\text { A cruz em madeira escura está decorada nos bordos com vinco duplo, } \\
\text { ao centro, detrás da cabeça está colocado um resplendor raiado em } \\
\text { metal branco, sobre este está a cartela branca onde pode ler-se JN / RI. } \\
\text { A base da cruz é polilobada em vários registos que se sobrepõem numa } \\
\text { forma semicircular irregular decorada com ornatos de grinaldas e } \\
\text { enrolamentos dourados. }\end{array}$ \\
\hline 8. & Técnicas (de suporte): Talha \\
\hline 9. & Técnicas (de ac \\
\hline 10. & Materiais (de suporte): Madeira \\
\hline 11. & Materiais (de acabamento): Pigmentos; ouro; metal branco \\
\hline 12. & $\begin{array}{l}\text { Estado de Conservação: Bom; a escultura apresenta-se estável mas } \\
\text { com lacunas de dedos na mão direita e desgaste na policromia do } \\
\text { cendal }\end{array}$ \\
\hline 13. & $\begin{array}{l}\text { Dimensões: } \\
\text { Altura: } 90 \mathrm{~cm} \\
\text { Largura: } 30 \mathrm{~cm} \\
\text { Profundidade: } 16 \mathrm{~cm} \\
\end{array}$ \\
\hline 14. & Restauro: apresenta sinais de reintegração cromática \\
\hline 15. & $\begin{array}{l}\text { Datas: segunda metade do século XVIII } \\
\text { A tabela que acompanha a peça refere na legenda - século XVIII }\end{array}$ \\
\hline 16. & Proveniência: igreja de Nossa Senhora da Encarnação em Vinhais \\
\hline 17. & $\begin{array}{l}\text { Autoria: desconhecida, mas julgamos que poderá ter servido de } \\
\text { modelo para a escultura colossal de Cristo do Coro (CSDV 06) dadas } \\
\text { as semelhanças formais entre ambas as esculturas }\end{array}$ \\
\hline 18. & Oficina: Nacional \\
\hline 19. & $\begin{array}{l}\text { Localização (atual): Atualmente está colocada dentro de uma vitrina } \\
\text { em conjunto com mais duas cruzes de altar no piso térreo do Museu }\end{array}$ \\
\hline 20. & Histórico do objeto: não se conhecem registos \\
\hline 21. & Iconografia: Cruz; Cendal; Cartela; Resplendor \\
\hline 22. & Irmandade: não se conhecem registos \\
\hline 23. & \\
\hline
\end{tabular}




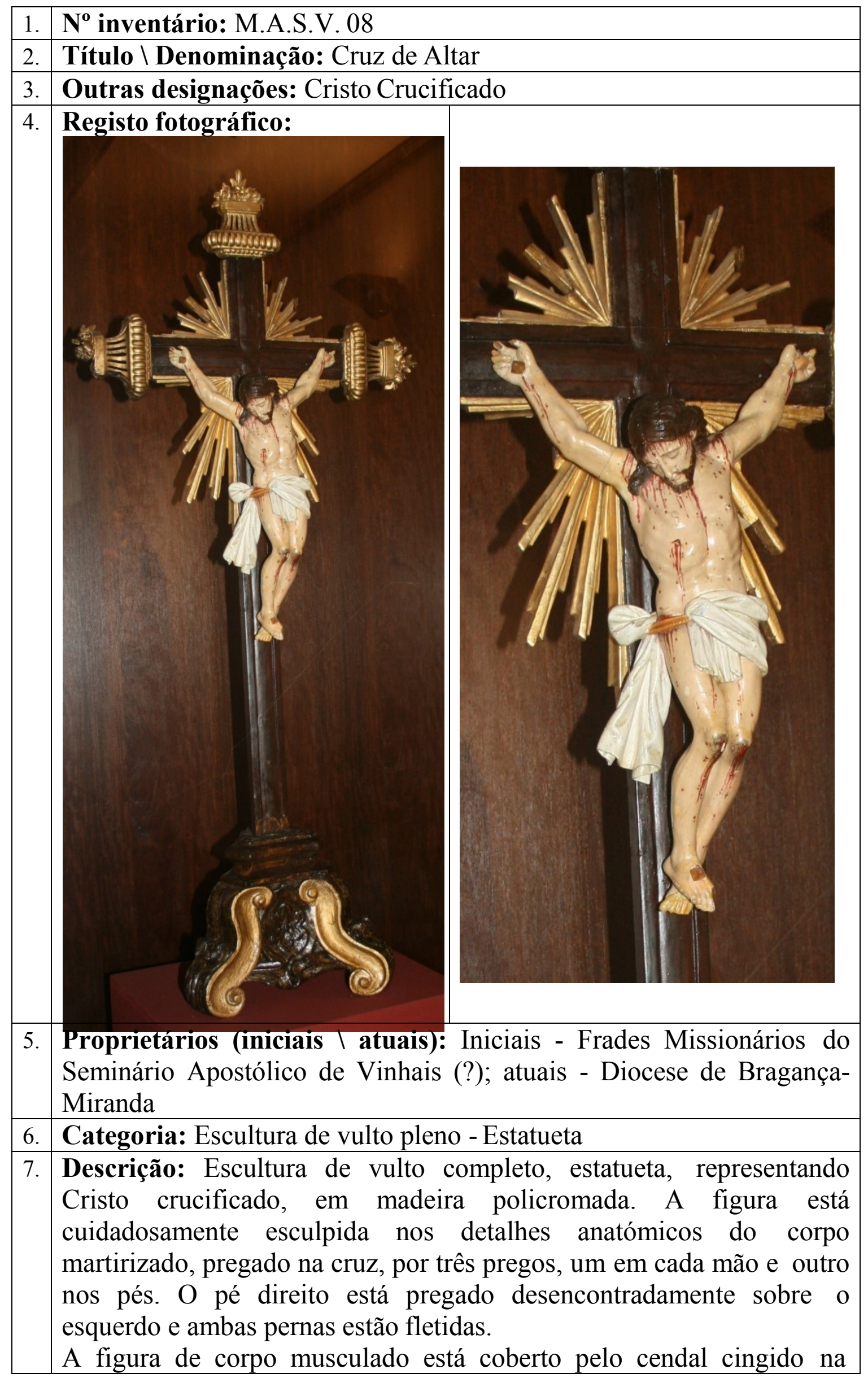




\begin{tabular}{|c|c|}
\hline & $\begin{array}{l}\text { cintura por cordão duplo com as pontas do cendal drapeadas em } \\
\text { amplas e ondulante pregas que caiem sobre o lado direito do corpo. De } \\
\text { olhos fechados, e rosto coberto por finas gotas de sangue que se } \\
\text { multiplicam sobre o peito, mãos e joelhos. Volta a cabeça para baixo } \\
\text { inclinada sobre o ombro direito com barbas e cabelo finamente talhado } \\
\text { em volumosas ondas que caiem sobre as costas e ombro direito. } \\
\text { A cruz em madeira escura está decorada nos remates com talha } \\
\text { dourada com elementos neo-clássicos que representam frutos. Da parte } \\
\text { central da cruz emerge entre os braços um resplendor raiado dourado } \\
\text { em madeira. } \\
\text { A base da cruz é em forma piramidal triangular irregular ornada com } \\
\text { aletas douradas. }\end{array}$ \\
\hline 8. & Técnicas (de suporte): Talha \\
\hline 9. & Técnicas (de acabamento): Policromia \\
\hline 10. & Materiais (de suporte): Madeira \\
\hline 11. & Materiais (de acabamento): Pigmentos; ouro \\
\hline 12. & $\begin{array}{l}\text { Estado de Conservação: Bom; a escultura apresenta-se estável mas } \\
\text { com lacunas na ponta dos dedos de ambas as mãos }\end{array}$ \\
\hline 13. & $\begin{array}{l}\text { Dimensões: } \\
\text { Altura: } 85 \mathrm{~cm} \\
\text { Largura: } 38 \mathrm{~cm} \\
\text { Profundidade: } 22 \mathrm{~cm}\end{array}$ \\
\hline 14. & Restauro: apresenta sinais de reintegração cromática \\
\hline 15. & $\begin{array}{l}\text { Datas: segunda metade do século XVIII } \\
\text { A tabela que acompanha a peça refere na legenda - século XVIII }\end{array}$ \\
\hline 16. & Proveniência: igreja de Nossa Senhora da Encarnação em Vinhais \\
\hline 17. & Autoria: desconhecida \\
\hline 18. & Oficina: Nacional \\
\hline 19. & $\begin{array}{l}\text { Localização (atual): Atualmente está colocada dentro de uma vitrina } \\
\text { em conjunto com mais duas cruzes de altar no piso térreo do Museu }\end{array}$ \\
\hline 20. & Histórico do objeto: não se conhecem registos \\
\hline 21. & Iconografia: Cruz; Cendal; Resplendor \\
\hline 22. & Irmandade: não se conhecem registos \\
\hline & Procissões: não se conhecem registos \\
\hline
\end{tabular}




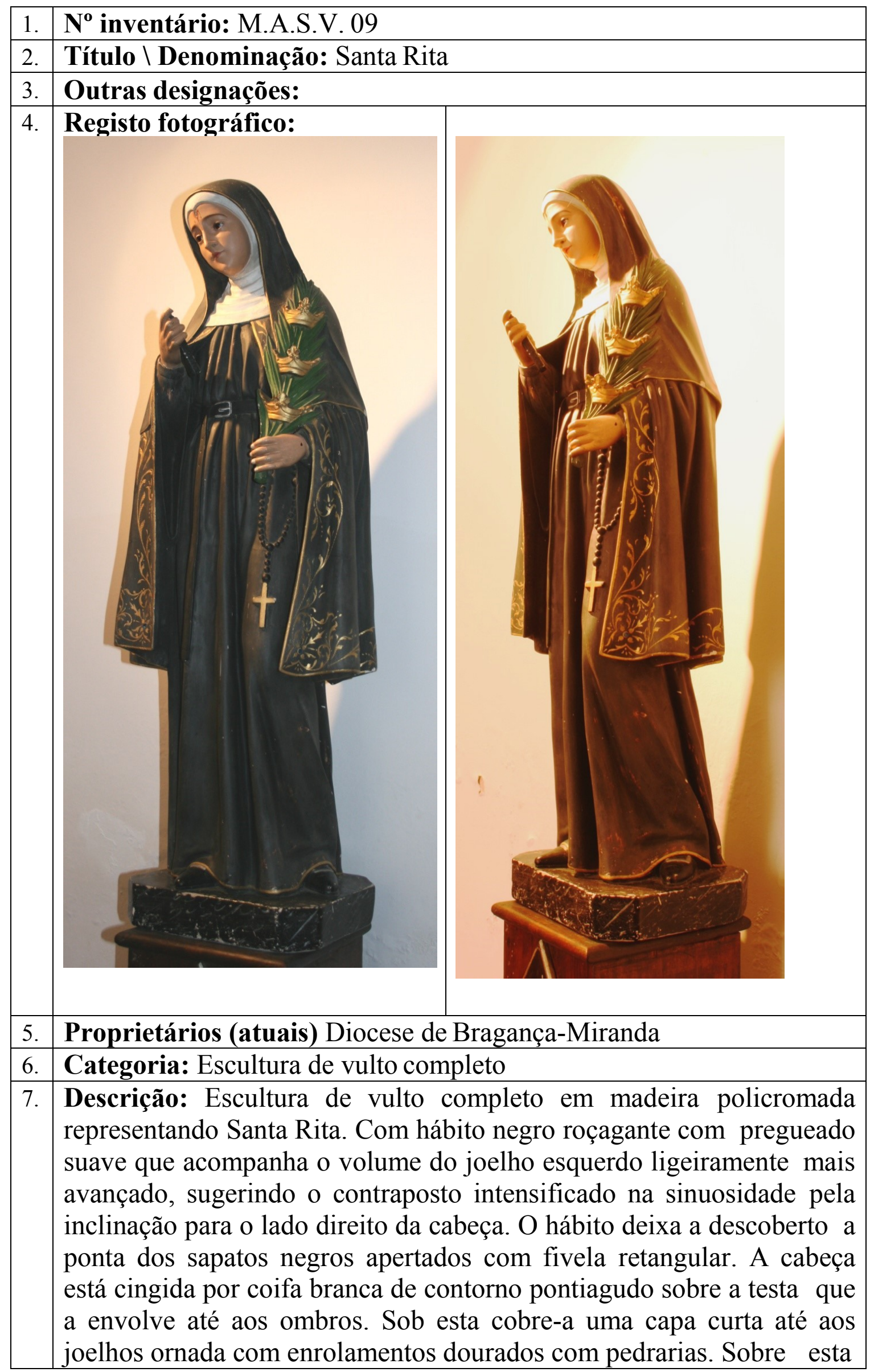




\begin{tabular}{|l|l|}
\hline & $\begin{array}{l}\text { enverga ainda outra capa negra que a envolve até à cintura. A cintura } \\
\text { está cingida por um cinto negro que aperta com fivela prateada, } \\
\text { suspenso no cinto está um rosário de contas negras que pende sobre o } \\
\text { lado esquerdo do corpo, rematado por uma cruz dourada. } \\
\text { A figura flete e eleva ambos os braços, o direito mais elevado tem a } \\
\text { mão fraturada provocando também a lacuna de parte do atributo que } \\
\text { segura, possivelmente uma cruz. A mão esquerda segura uma palma } \\
\text { verde ornada por três coroas flordelizada douradas sobrepostas } \\
\text { verticalmente. } \\
\text { O rosto jovem de expressão serena tem os olhos em vidro e uma chaga } \\
\text { com sangue sobre a testa. } \\
\text { Assenta sobre base hexagonal marmoreada a negro. Está colocada } \\
\text { sobre uma caixa de esmolas paralelepipédica que lhe serve de plinto } \\
\text { em madeira. }\end{array}$ \\
\hline 8. & Técnicas (de suporte): Talha \\
\hline 9. & Técnicas (de acabamento): Policromia, douramento \\
\hline 10. & Materiais (de suporte): Madeira \\
\hline 11. & Materiais (de acabamento): Pigmentos; vidro \\
\hline 12. & Estado de Conservação: Bom; a escultura apresenta-se estável tem \\
lacuna dos dedos da mão direita e atributo.
\end{tabular}


IGREJA DA VENERÁVEL ORDEM TERCEIRA DA PENITÊNCIA EM VINHAIS 


\section{FUNDAÇÃO}

O processo da constituição da Venerável Ordem Terceira da Penitência de Vinhais está estreitamente relacionado com a fundação do seminário apostólico de Vinhais, que emerge dos ideais da igreja militante preconizada pelos Missionários Apostólicos de Nossa Senhora dos Anjos de Brancanes ${ }^{1}$.

O fundador da Ordem Terceira de Vinhais foi José de Morais Sarmento que tinha igualmente fundado o Seminário Apostólico e deixou à Ordem Terceira em testamento todos os haveres. As casas e a igreja da Ordem Terceira foram construídas após a sua morte em $1762^{2}$.

Constituída por leigos, foi a única irmandade da ordem terceira que na diocese de Bragança-Miranda logrou construir o seu próprio templo, as restantes irmandades apenas detinham uma capela ou altar nos templos dos frades da primeira ordem, como ocorreu em Bragança e Torre de Moncorvo $^{3}$.Contigua à igreja e convento dos missionários apostólicos de Vinhais a igreja da Venerável Ordem Terceira da Penitência foi terminada em $1780^{4}$.

\footnotetext{
${ }^{1}$ Rodrigues, Luís Alexandre, "A ação dos padres de Brancanes em Vinhais. O Seminário da Senhora da Encarnação e constituição da Venerável Ordem Terceira da Penitência" in Natália Marinho FerreiraAlves (Coord.), Os Franciscanos no Mundo Português II. As Veneráveis Ordens Terceiras de São Francisco, Porto, CEPESE - Centro de Estudos da População, Economia e Sociedade 2012, pp. 163-193.

${ }^{2}$ Martins, Firmino A., Subsídios para a história religiosa do distrito de Bragança: a Ordem III e a casa do Fundador do convento de S. Francisco de Vinhais, Coimbra, Imprensa da Universidade, 1929, p. 16; Muitos outros nobres locais contribuíram para o engrandecimento da irmandade com destaque também para o Dr. José Bernardo Ferreira Sarmento. Castro, José de, Bragança e Miranda, (Bispado) Tomo II, Porto, Tipografia Porto Médico, Ld a , 1947, pp. 358, 359; Rema, Henrique (Frei), "A Ordem Franciscana em Tras-os-Montes" in Boletim do Arquivo Distrital de Vila Real - Revista de Cultura, Estudos Transmontanos e Durienses $n^{\circ}$, Vila Real, Arquivo Distrital de Vila Real, 1995, pp.299-332.

${ }^{3}$ Na segunda metade do século XVIII assiste-se a uma busca da emancipação dos espaços dos Terceiros em relação à Ordem Primeira. Esta realidade é expressa em relação ao Brasil por, Maria Berthilde Moura Filha e Ivan Cavalcanti Filho, Filha, Maria Berthilde Moura e Filho, Ivan Cavalcanti, "Ordens Terceiras Franciscanas Setecentistas: três casos de emancipação espacial na arquitetura brasileira" in Natália Marinho Ferreira-Alves (Coord.), Franciscanos no Mundo Português III, Porto, CEPESE - Centro de Estudos da População, 2013, pp. 649-672. Também em Vinhais se observa análogo procedimento, pese embora seja incomum essa emancipação em tão pequenos núcleos urbanos como é o caso de Vinhais.

${ }^{4}$ Martins, Firmino A., Subsídios para a história religiosa do distrito de Bragança: a Ordem III e a casa do Fundador do convento de S. Francisco de Vinhais, Coimbra, Imprensa da Universidade, 1929, pp. 8, 9; Castro, José de, Bragança e Miranda, (Bispado) Tomo II, Porto, Tipografia Porto Médico, Ld a , 1947, p. 359; Rema, Henrique (Frei), "A Ordem Franciscana em Tras-os-Montes" in Boletim do Arquivo Distrital de Vila Real - Revista de Cultura, Estudos Transmontanos e Durienses $n^{\circ}$, Vila Real, Arquivo Distrital de Vila Real, 1995, pp. 299-332.
} 
O aparecimento da irmandade deve também relacionar-se com a figura de Frei António de Nossa Senhora das Neves, fundador e guardião do convento da Ordem Franciscana de missionários apostólicos de Vinhais e que de acordo com os objetivos da ação apostólica terá impulsionado a criação local da Ordem Terceira da Penitência ${ }^{5}$.

\footnotetext{
${ }^{5}$ Rodrigues, Luís Alexandre, "A ação dos padres de Brancanes em Vinhais. O Seminário da Senhora da Encarnação e constituição da Venerável Ordem Terceira da Penitência" in Natália Marinho FerreiraAlves (Coord.), Os Franciscanos no Mundo Português II. As Veneráveis Ordens Terceiras de São Francisco, Porto, CEPESE - Centro de Estudos da População, Economia e Sociedade 2012, pp. 163-193; Rema, Henrique (Frei), "A Ordem Franciscana em Tras-os-Montes" in Boletim do Arquivo Distrital de Vila Real - Revista de Cultura, Estudos Transmontanos e Durienses ${ }^{\circ} 7$, Vila Real, Arquivo Distrital de Vila Real, 1995, pp. 299-332.
} 


\section{EDIFICADO DA IGREJA}

Tal como para a fundação e construção do Seminário Apostólico de Vinhais, também para a construção da igreja e constituição da Ordem Terceira foram determinantes as ações da família Morais Sarmento.

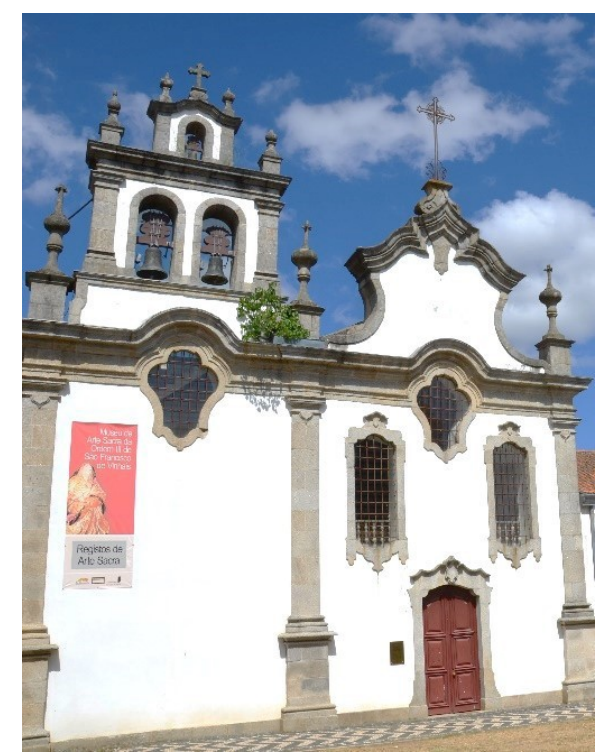

Imagem 1

Frontispício da igreja da Venerável Ordem Terceira de São Francisco

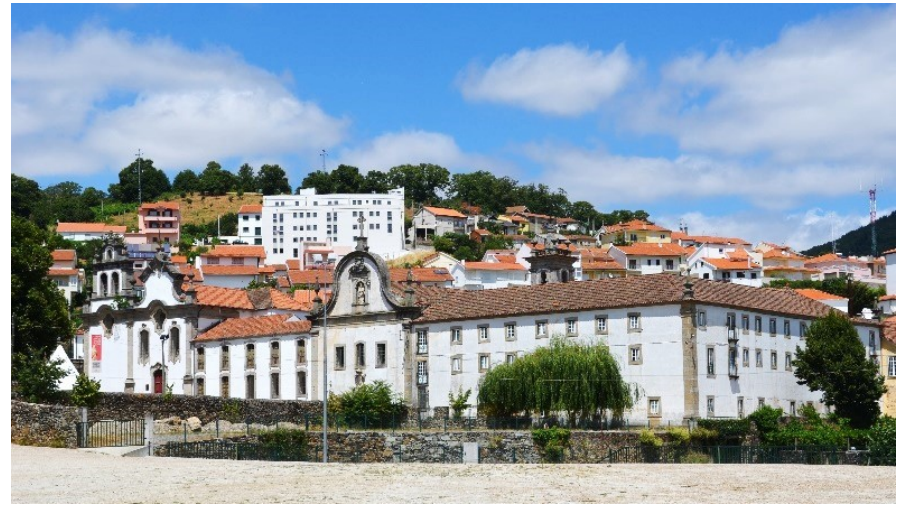

Imagem 2

Vista geral do conjunto franciscano de Vinhais, igreja da Ordem Terceira, igreja do Seminário Apostólico e espaço conventual, (no lado esquerdo da imagem parte da capela da Oração no Horto)

Do Arquivo da Câmara Municipal de Vinhais, destaca-se o documento de "Treslado da escriptura de nomeação de vincullo que fas Joze de Morais Sarmento desta villa de Vinhaes a Veneravel Ordem Terceira da Penitencia da mesma villa”, onde são evidentes as contibuições oferecidas assim como o fim a que se destinavam. As doações de José de morais Sarmento incluíram também os materiais para a edificação da igreja da Ordem e que seriam reaproveitados da sua capela e da casa fidalga que foram demolidas "para se aproveitarem dos seus materaes de pedra, madeira e telha por lhes ficar assim mais suave e menos custoza a nova obra". Iniciativa que assinalava o princípio de um empreendimento arquitetónico de algum fôlego e que demonstra como nos seus começos a irmandade não contava com casa ou capela própria onde os assuntos pudessem ser despachados e os ofícios religiosos realizados" ${ }^{6}$. Inicialmente a Ordem

\footnotetext{
${ }^{6}$ Uma parte respeitava a missas rezadas anualmente, "em seos propios dias", em honra de Nossa Senhora da Purificação, Nossa Senhora da Encarnação, Ressurreição de Cristo, Nossa Senhora dos Prazeres, Crucificação, Santa Cruz de Maio, Santo António, Santa Ana, Nossa Senhora da Assunção, Nossa
} 
Terceira servia-se dos espaços do seminário para as suas sessões e funções religiosas, denotando a ligação estreita que unia o seminário à comunidade laica franciscana. $\mathrm{O}$ empenho e as doações da família Morais Sarmento: "incluindo uma cortinha e o terreno onde se implantou a casa com seu pateo curral ou despejo das mesmas e ainda uma capela com o título das Chagas de S. Francisco", criaram as condições para que em 1780 surgisse a primeira notícia a referir a sessão da venerável ordem da penitência na sua casa e igreja $^{7}$. Além da família Morais Sarmento outros nobres de Vinhais acrescentaram doações à irmandade ${ }^{8}$. O templo dos Terceiros (Imagem 1), contíguo ao edifício do Seminário, consolida um amplo e coeso conjunto edificado (Imagem 2).

Com a construção do edifício, Rodrigues relaciona Domingos Álvares e Mateus Fernandes, mestres pedreiros minhotos, dada a cuidada continuidade espacial entre a igreja da ordem terceira e o edificado conventual pré-existente ${ }^{9}$.

O dinâmico traçado do coroamento final da frontaria supos seguramente um trabalho especializado que a mão-de-obra local dificilmente assumiria.

Senhora da Natividade, S. Francisco, Todos os Santos, Nossa Senhora da Conceição e ao Menino Deus; a outra parte onerava perpetuamente a Venerável Ordem com uma contribuição anual de 60000 réis, "de simples e pura esmola", que devia ser entregue ao síndico do seminário de Nossa Senhora da Encarnação para "as despezas da sãochristia hornatos e cultos devinos obras do mesmo seminario e sua reedificação ou para aquellas nessessidades que no mesmo seminario ocorrerem". Do mesmo arquivo se extrai um quadro de 1743 onde consta a relação de bens do oratório administrado por José de Morais Sarmento ORATÓRIO DE JOSÉ DE MORAIS SARMENTO (1743) "item lhe foi apartado primeiramente hum oratório que consta de hum Corsefissio e huma Senhora da Conceiçam pintada duas de bulto e huma emcarnada e outra nam e hum Senhor atado a coluna com espinho de Christo emcastrado em prata [...] e huma imagem de Sam Bento que esta no oratório. Rodrigues, Luís Alexandre, "A ação dos padres de Brancanes em Vinhais. O Seminário da Senhora da Encarnação e constituição da Venerável Ordem Terceira da Penitência" in Natália Marinho Ferreira-Alves (Coord.), Os Franciscanos no Mundo Português II. As Veneráveis Ordens Terceiras de São Francisco, Porto, CEPESE - Centro de Estudos da População, Economia e Sociedade 2012, pp. 163-193.

${ }^{7}$ Martins, Firmino A., Subsídios para a história religiosa do distrito de Bragança: a Ordem III e a casa do Fundador do convento de S. Francisco de Vinhais, Coimbra, Imprensa da Universidade, 1929, p. 13; Rodrigues, Luís Alexandre, "A ação dos padres de Brancanes em Vinhais. O Seminário da Senhora da Encarnação e constituição da Venerável Ordem Terceira da Penitência" in Natália Marinho FerreiraAlves (Coord.), Os Franciscanos no Mundo Português II. As Veneráveis Ordens Terceiras de São Francisco, Porto, CEPESE - Centro de Estudos da População, Economia e Sociedade 2012, pp. 163-193.

${ }^{8}$ Rodrigues, Luís Alexandre, "A ação dos padres de Brancanes em Vinhais. O Seminário da Senhora da Encarnação e constituição da Venerável Ordem Terceira da Penitência" in Natália Marinho FerreiraAlves (Coord.), Os Franciscanos no Mundo Português II. As Veneráveis Ordens Terceiras de São Francisco, Porto, CEPESE - Centro de Estudos da População, Economia e Sociedade 2012, pp. 163-193.

${ }^{9} \mathrm{Na}$ documentação notarial surgem os nomes dos dois pedreiros como testemunhas o que sugere que poderiam estar em Vinhais exercendo o ofício, ver: Rodrigues, Luís Alexandre, "A ação dos padres de Brancanes em Vinhais. O Seminário da Senhora da Encarnação e constituição da Venerável Ordem Terceira da Penitência" in Natália Marinho Ferreira-Alves (Coord.), Os Franciscanos no Mundo Português II. As Veneráveis Ordens Terceiras de São Francisco, Porto, CEPESE - Centro de Estudos da População, Economia e Sociedade 2012, pp. 163-193. 


\section{INTERIOR DO TEMPLO}

O interior do templo tem uma só nave com transepto ligeiramente diferenciado. Está decorado com três retábulos rocailles com elementos neoclássicos, dois púlpitos em talha análoga à retabular e pinturas sobre os tetos.

A capela-mor expõe os dois santos fundadores da ordem franciscana, São Francisco e Santa Clara a ladear a imagem de Nossa Senhora da Imaculada Conceição. No teto entre arquiteturas fingidas está pintada a estigmatização de São Francisco (Imagem 3).

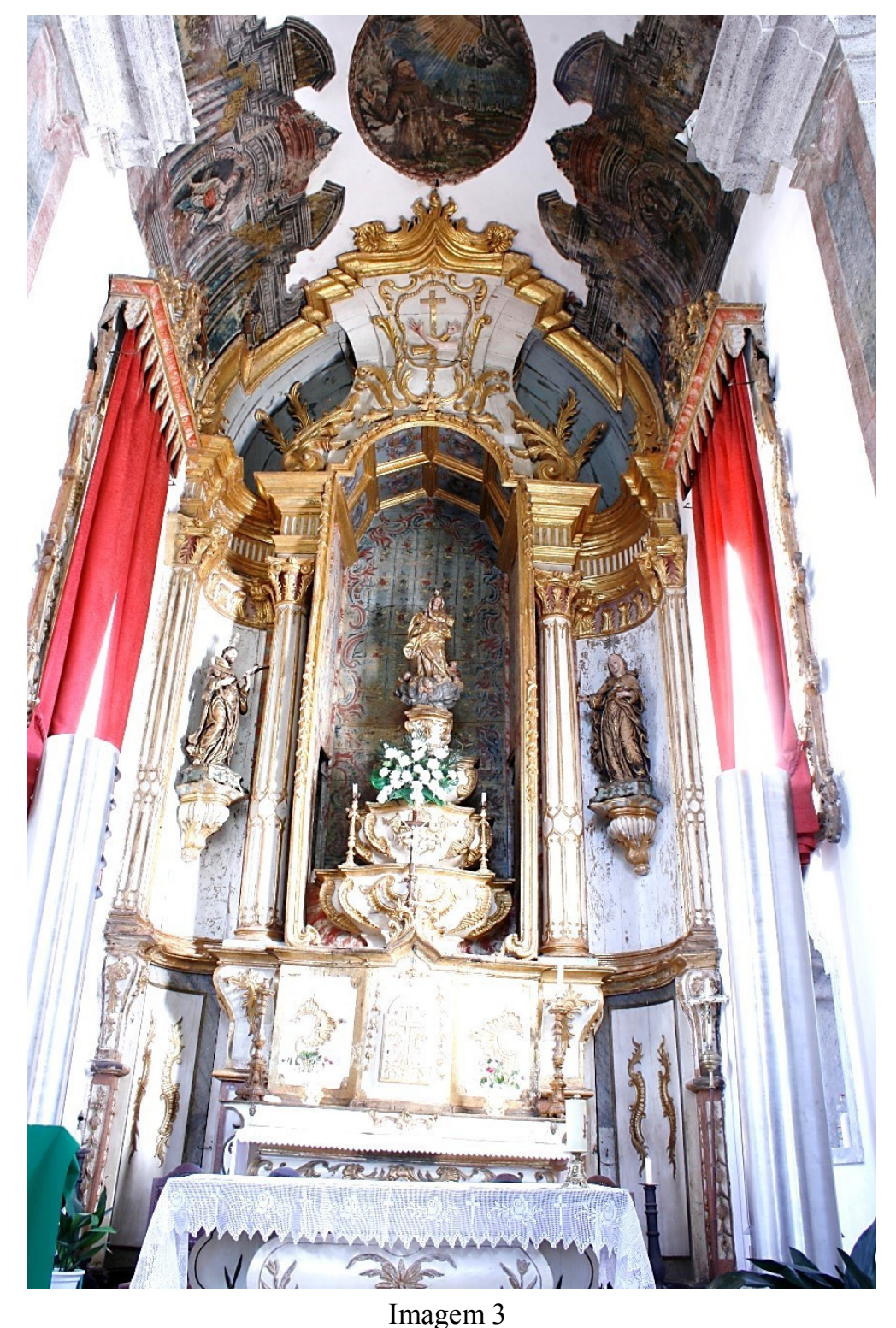

Vista geral da capela-mor da igreja de São Francisco da Venerável ordem terceira de Vinhais 
Destaca-se do conjunto interior a uniformidade conceptual do programa narrativo que ilustravam os elementos decorativos. As narrativas relativas à ordem franciscana desenvolvem-se na escultura e na pintura que apenas retrata membros que com a ordem de São Francisco se relacionam.

Excetuando as devoções contemporâneas (de Nossa Senhora de Fátima e do Sagrado Coração de Jesus), todas as devoções que foram ilustradas antes da extinção das ordens religiosas são votadas a figuras franciscanas ou devoções defendidas pela ordem de São Francisco, como era Nossa Senhora da Imaculada Conceição.
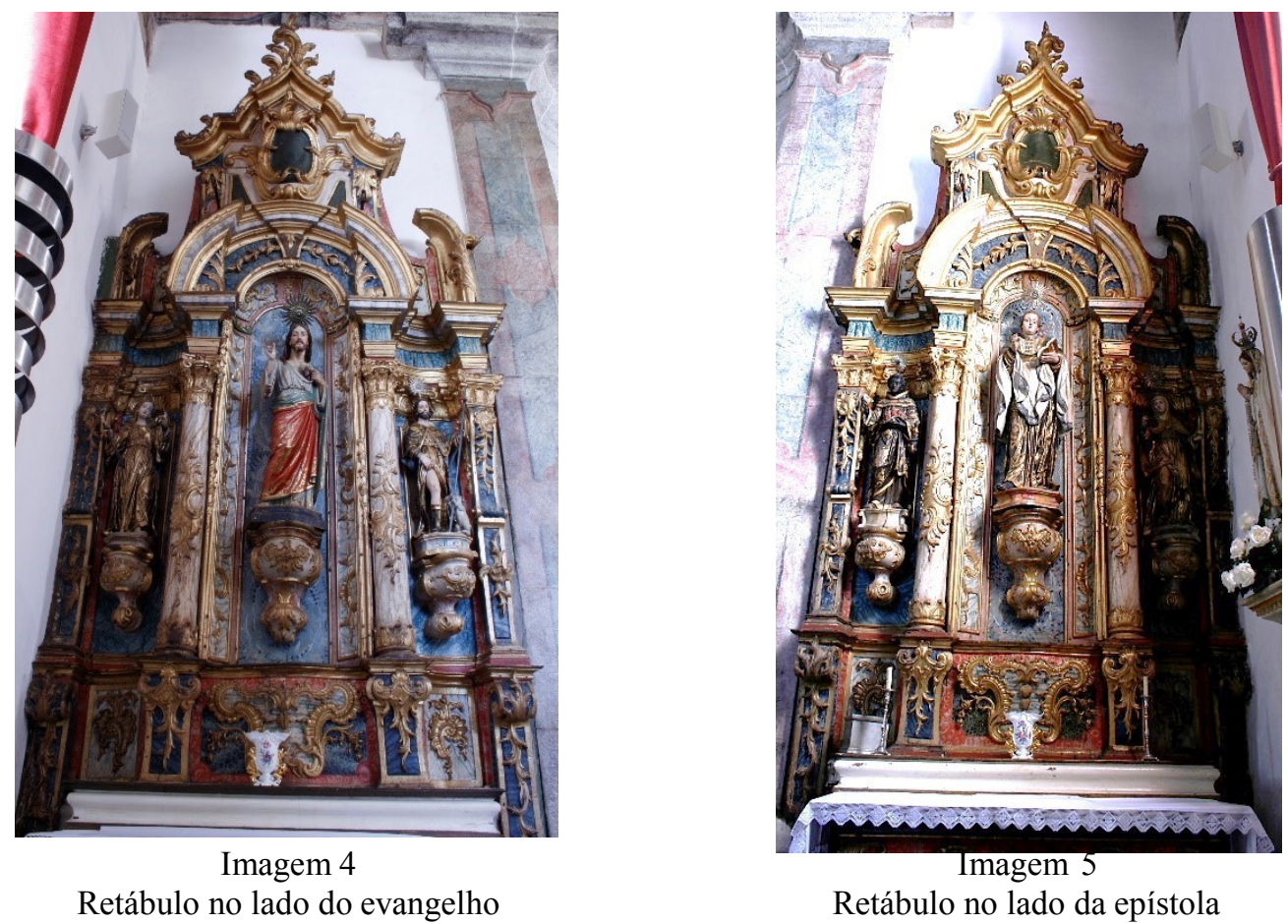

Os retábulos laterais, próximos na estrutura e nos ornatos ao retábulo-mor, apresentam um formulário rocaille já com elementos neoclássicos. A semelhança entre as estruturas retabulares e os púlpitos do templo sugerem a mesma produção oficinal e o mesmo período de execução.

Com exceção da escultura do Sagrado Coração de Jesus no retábulo do lado do evangelho, supomos que as restantes imagens ocupam o espaço para o qual originalmente foram encomendadas.

O desconhecimento de documentos relativos às esculturas que ainda estão a culto no interior do templo limita o conhecimento do processo de encomendas e dos encomendadores. No entanto, destacamos a quantidade de imagens de vulto de grande tamanho que ocupam os retábulos e sobretudo a amplificação das devoções introduzidas 
a partir de modelos iconográficos assaz incomuns. A ausência de produções locais de cariz mais popular na escultura denota a encomenda preferencial a oficinas bem apetrechadas.

Estes aspetos evidenciam uma irmandade dinâmica, com importantes recursos económicos e acesso aos principais centros artísticos nacionais.

A igreja dos terceiros de Vinhais evidencia um ímpeto construtivo e decorativo que consubstancia um programa total. As estruturas retabulares, os púlpitos e a pintura dos tetos e paredes conjugam-se numa narrativa de encenação do espaço ausente nos restantes templos em estudo.

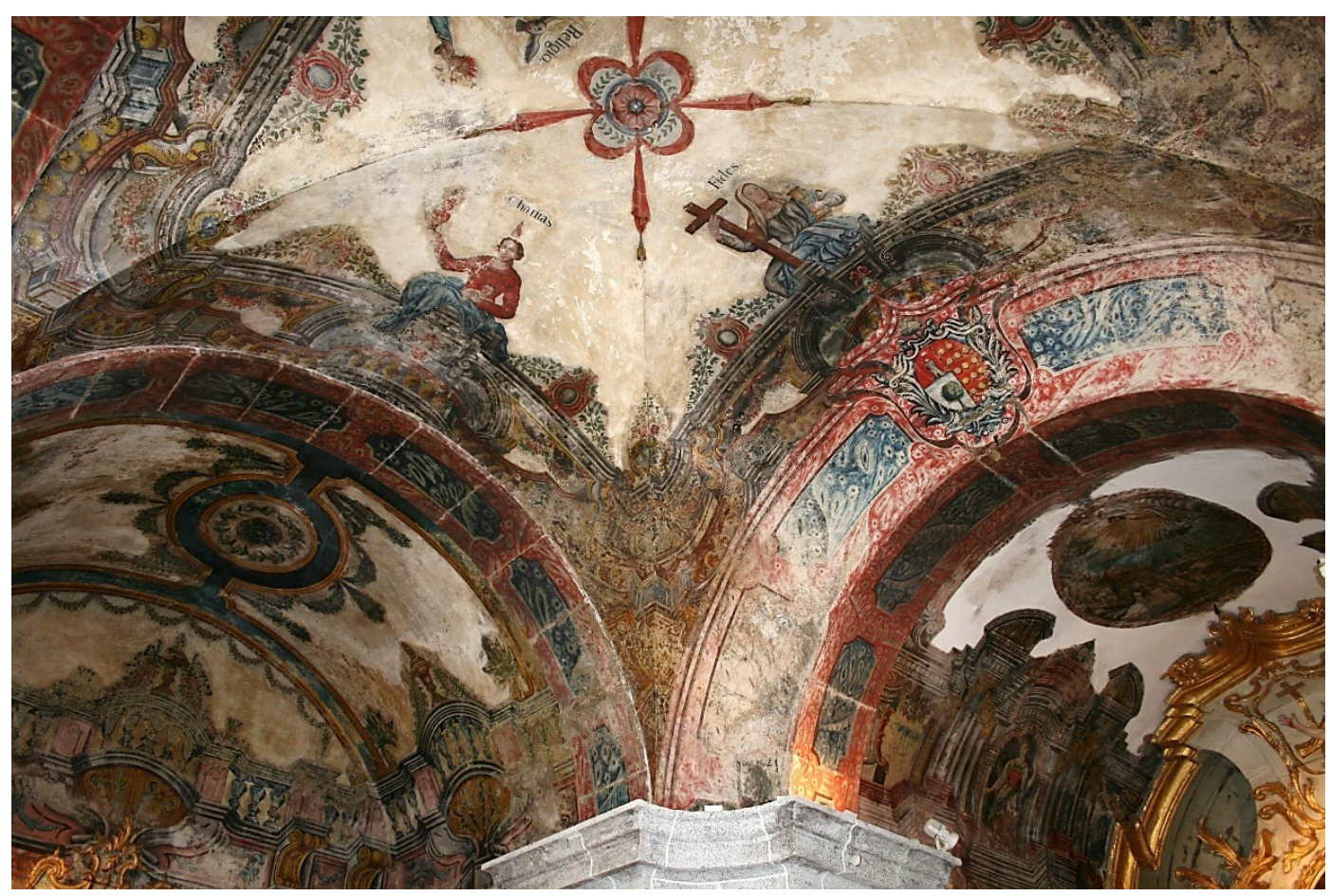

Imagem 6

Detalhe do teto pintado com arquiteturas fingidas, figuras alegóricas e o brasão da família Morais Sarmento

No território periférico em que está implementada a vila de Vinhais a presença franciscana foi determinante na catequização, na prestação assistencial promovida junto da comunidade mais carenciada e na divulgação de modelos artísticos. 


\title{
FICHAS DE INVENTÁRIO
}

\author{
ESCULTURA
}

IGREJA DE SÃO FRANCISCO DA

ORDEM FRANCISCANA SECULAR

VINHAIS 
FICHAS DE INVENTÁRIO | ESCULTURA

Da Ordem de São Francisco na Diocese de Bragança-Miranda 
FICHAS DE INVENTÁRIO |ESCULTURA

Da Ordem de São Francisco na Diocese de Bragança-Miranda

Igreja de São Francisco, Vinhais

Vista do frontispicio

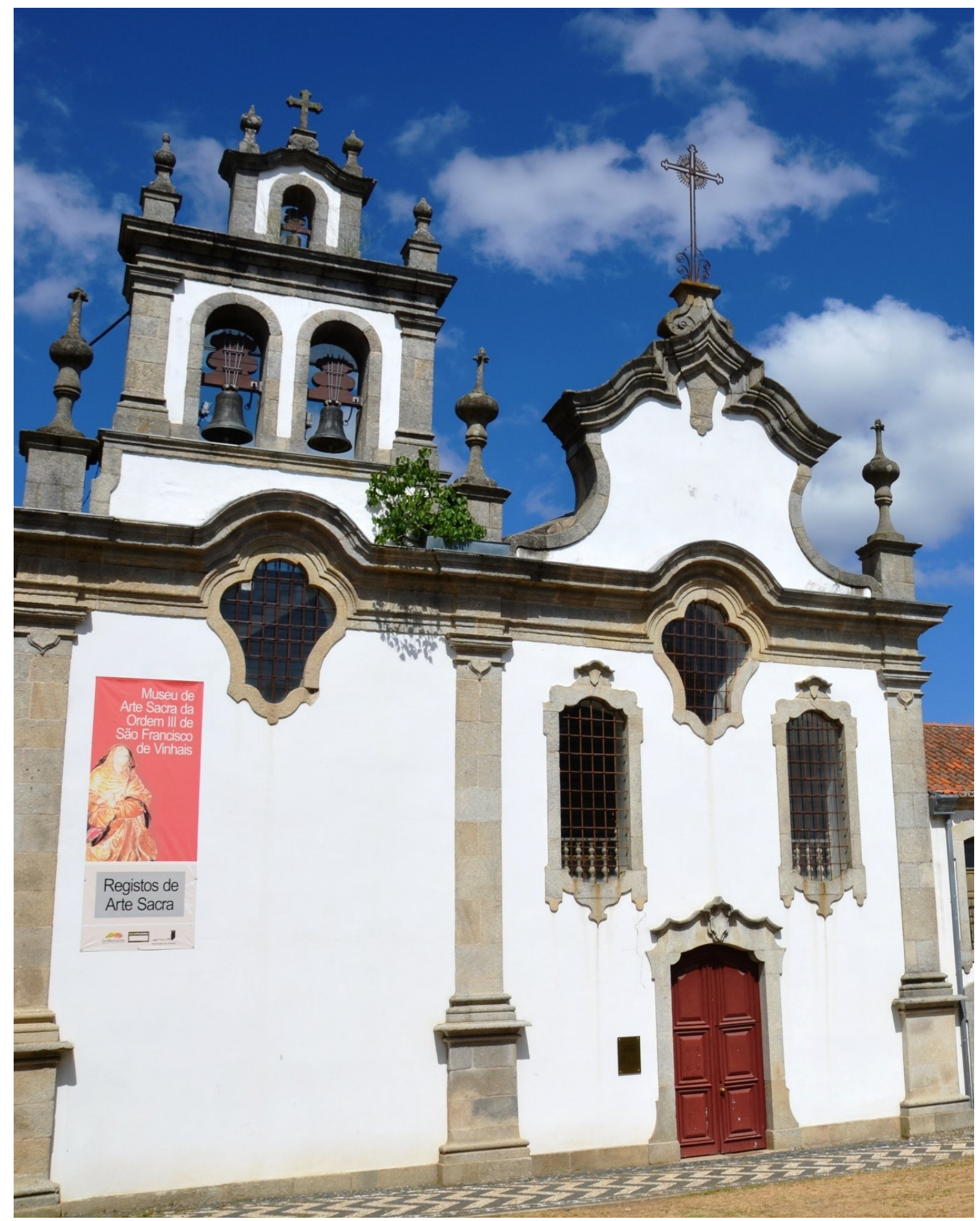


FICHAS DE INVENTÁRIO | ESCULTURA

Da Ordem de São Francisco na Diocese de Bragança-Miranda 


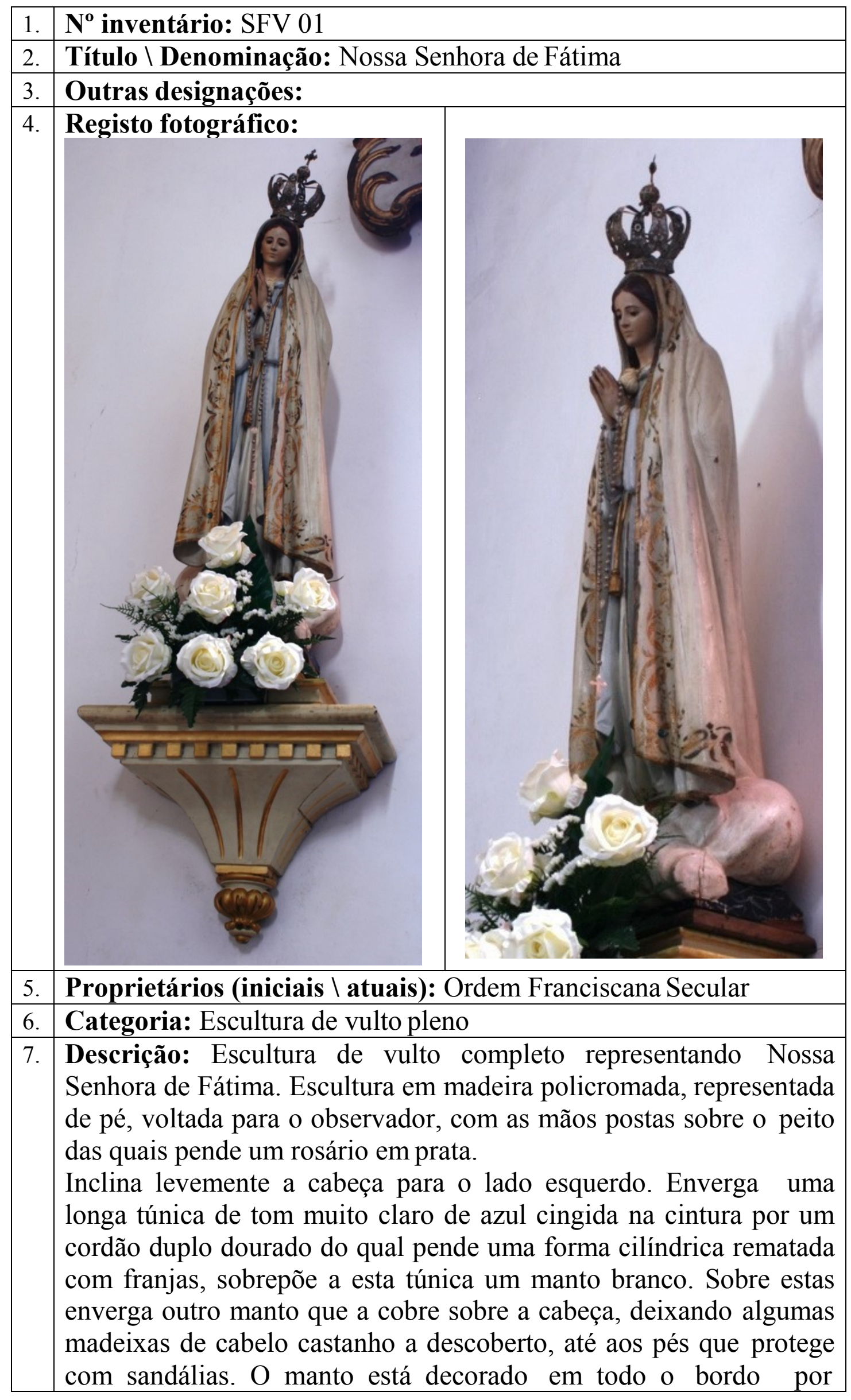




\begin{tabular}{|l|l|}
\hline & $\begin{array}{l}\text { estilizações vegetalistas douradas com pedras coloridas aplicadas. } \\
\text { Sobre a cabeça ostenta uma coroa em filigrana prateada rematada } \\
\text { por um globo, encimado por uma cruz. } \\
\text { O rosto de linhas finas e delicadas reforça a inclinação da cabeça } \\
\text { com o olhar baixo, com olhos de vidro e expressão serena. } \\
\text { A figura está cuidadosamente esculpida nos detalhes anatómicos, } \\
\text { bem como no suave pregueado nos panejamentos. } \\
\text { Está assente sobre uma nuvem pousada sobre um plinto } \\
\text { quadrangular com marmoreado negro e branco. }\end{array}$ \\
\hline 8. & Técnicas (de suporte): Talha \\
\hline 9. & $\begin{array}{l}\text { Técnicas (de acabamento): Policromia; dourados; filigrana; } \\
\text { fundição }\end{array}$ \\
\hline 10. & Materiais (de suporte): Madeira \\
\hline 11. & $\begin{array}{l}\text { Materiais (de acabamento): Pigmentos; douramento; vidro; metal } \\
\text { prateado e pedras }\end{array}$ \\
\hline 12. & $\begin{array}{l}\text { Estado de Conservação: Bom; apresenta-se se estável; desgaste na } \\
\text { policromia sobre o peito; fissuras na base }\end{array}$ \\
\hline 13. & Dimensões: \\
Altura: 130 cm \\
Largura: 45 cm \\
Profundidade: 35 cm
\end{tabular}


FICHAS DE INVENTÁRIO |ESCULTURA

Da Ordem de São Francisco na Diocese de Bragança-Miranda

Retábulo em talha rococó no transepto do lado da Epístola que guarda as imagens SFV 02, SFV 03, SFV 04

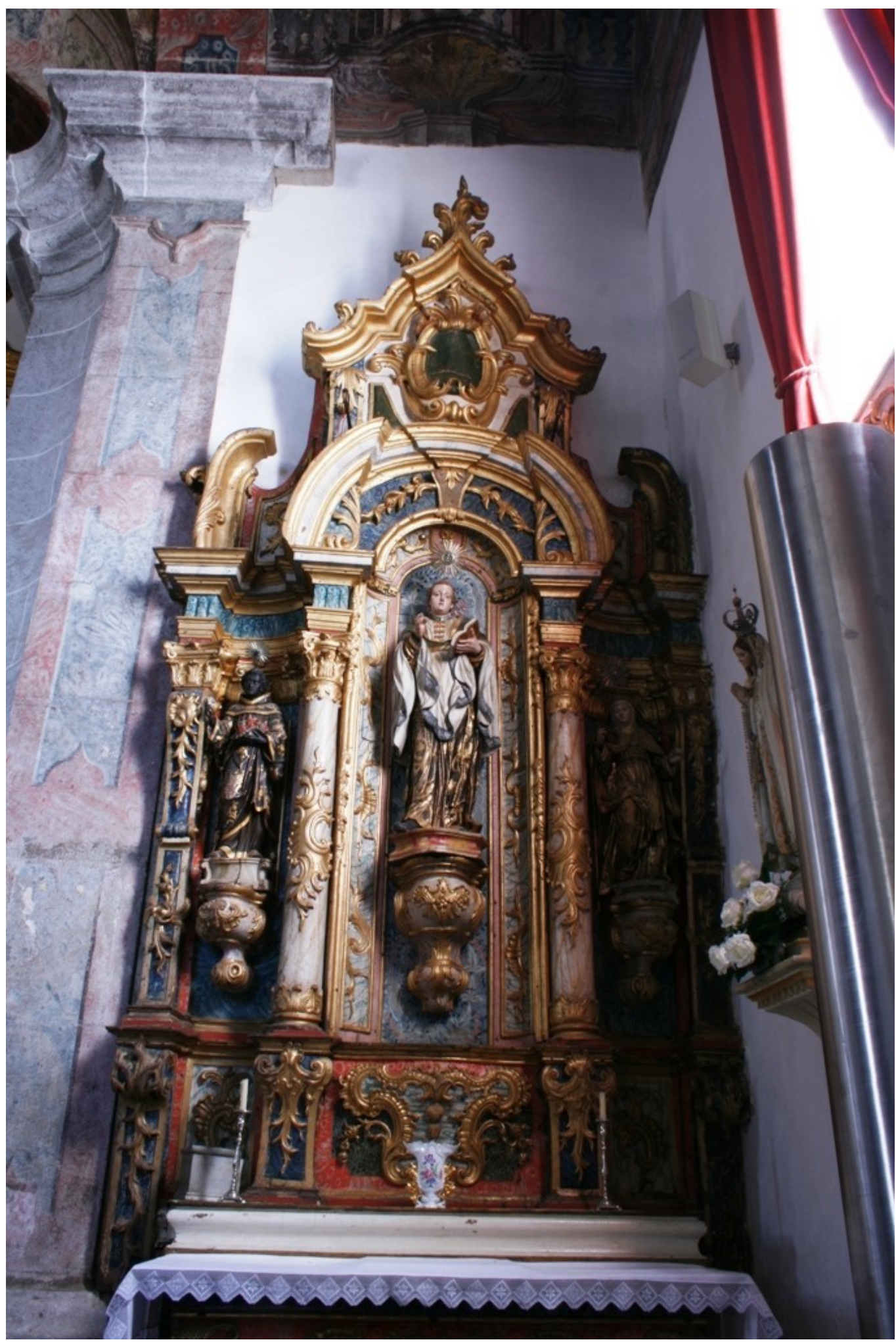


FICHAS DE INVENTÁRIO | ESCULTURA

Da Ordem de São Francisco na Diocese de Bragança-Miranda 


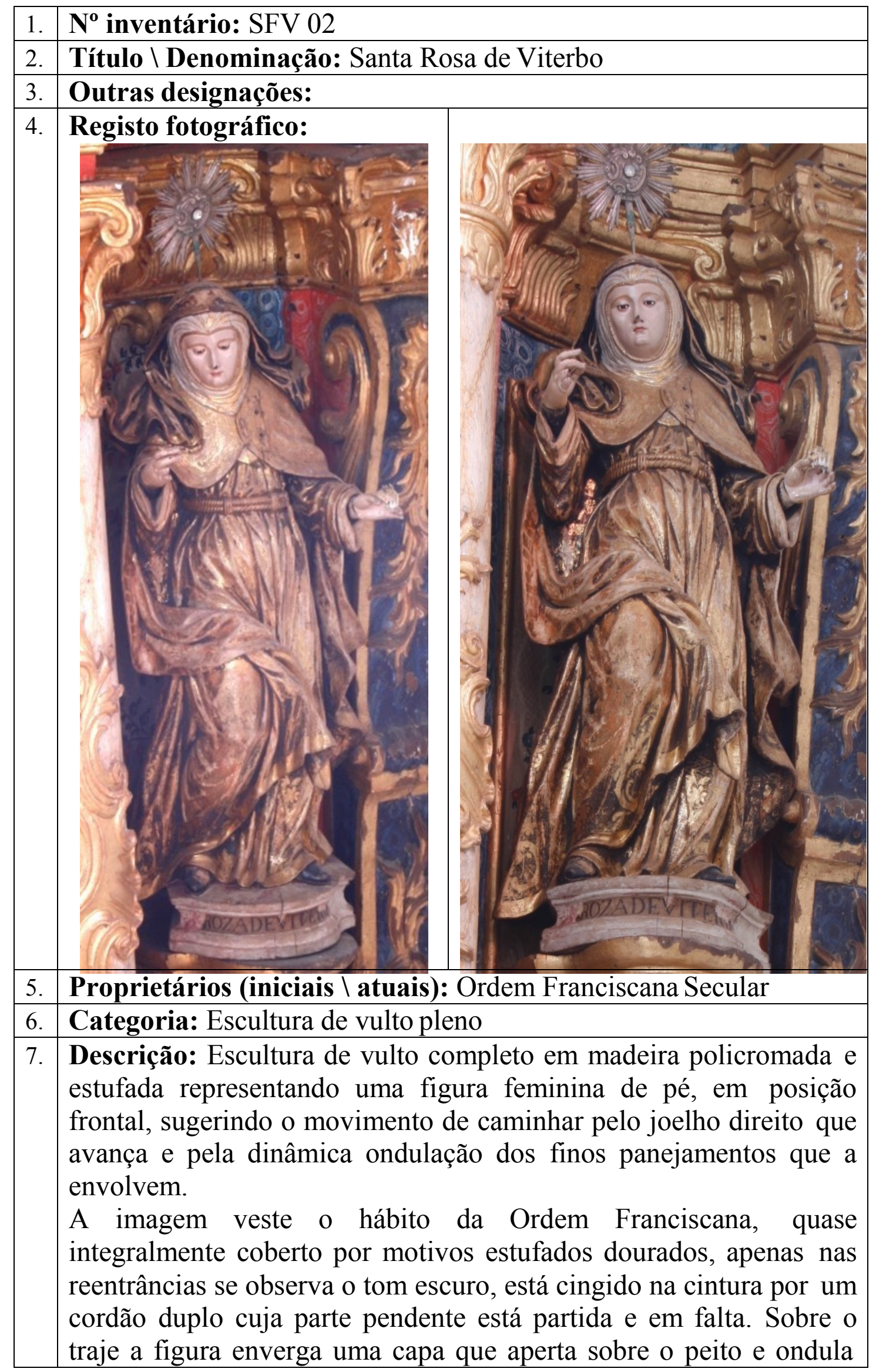




\begin{tabular}{|l|l|}
\hline & $\begin{array}{l}\text { dinamicamente envolta da figura. A santa flete ambos os braços que } \\
\text { afastados assimetricamente do corpo se elevam à altura da cintura. A } \\
\text { mão direita, com os dedos fletidos, tem lacuna de dois dedos; a mão } \\
\text { esquerda segura um atributo já partido, estão ambas cuidadosamente } \\
\text { esculpidas com contornos arredondados e brilhante carnação. O } \\
\text { rosto, também de carnação brilhante, tem os olhos de vidro e está } \\
\text { detalhadamente esculpido nos contornos anatómicos que são } \\
\text { arredondados e delicados. Está rodeado por uma coifa branca que } \\
\text { lhe cinge a cabeça com pregueado fino e sobre este usa uma } \\
\text { mantilha negra que em dinâmico pregueado lhe cai sobre os ombros. } \\
\text { Sobre a cabeça ostenta um resplendor raiado com aplique de } \\
\text { pedraria ao centro. } \\
\text { O pé esquerdo está mais avançado, sugerindo estar a caminhar e } \\
\text { assenta sobre uma base em madeira polilobada cuja pintura muito } \\
\text { desgastada permite ler, em letras maiúsculas: "ROZA DE } \\
\text { VITERB(...)" }\end{array}$ \\
\hline 8. & Técnicas (de suporte): Talha \\
\hline 9. & $\begin{array}{l}\text { Técnicas (de acabamento): Policromia; estufagem; marmoreado; } \\
\text { fundição }\end{array}$ \\
\hline 10. & Materiais (de suporte): Madeira \\
\hline 11. & $\begin{array}{l}\text { Materiais (de acabamento): Pigmentos; folha de ouro; vidro; metal } \\
\text { branco }\end{array}$ \\
\hline 12. & $\begin{array}{l}\text { Estado de Conservação: Bom; apresenta-se se estável; lacuna de } \\
\text { dedos da mão direita e do atributo na mão esquerda; desgaste na } \\
\text { policromia }\end{array}$ \\
\hline 13. & $\begin{array}{l}\text { Dimensões: } \\
\text { Altura: } 118 \text { cm } \\
\text { Largura: } 50 \text { cm } \\
\text { Profundidade: } 35 \text { cm }\end{array}$ \\
\hline 14. & Restauro: apresenta sinais de reintegração cromática \\
\hline 15. & Datas: último quartel do século XVIII \\
\hline 16. & Proveniência: igreja de São Francisco em Vinhais \\
\hline 17. & $\begin{array}{l}\text { Autoria: desconhecida, mas é semelhante no gesto e no pregueado } \\
\text { dos panejamentos, bem como na policromia (estufagem e carnação) } \\
\text { com a imagem de Santa Clara SFV 06 e de São Francisco SFV 08 }\end{array}$ \\
\hline 18. & Oficina: Porto $\backslash$ Braga \\
\hline 19. & Localização (atual): Retábulo do transepto no lado da Epistola \\
\hline 20. & Histórico do objeto: não se conhecem registos \\
\hline 21. & $\begin{array}{l}\text { Iconografia: Hábito de monja franciscana; resplendor; atributo } \\
\text { partido }\end{array}$ \\
\hline 23. & Procissões: não se conhecem registos \\
\hline
\end{tabular}




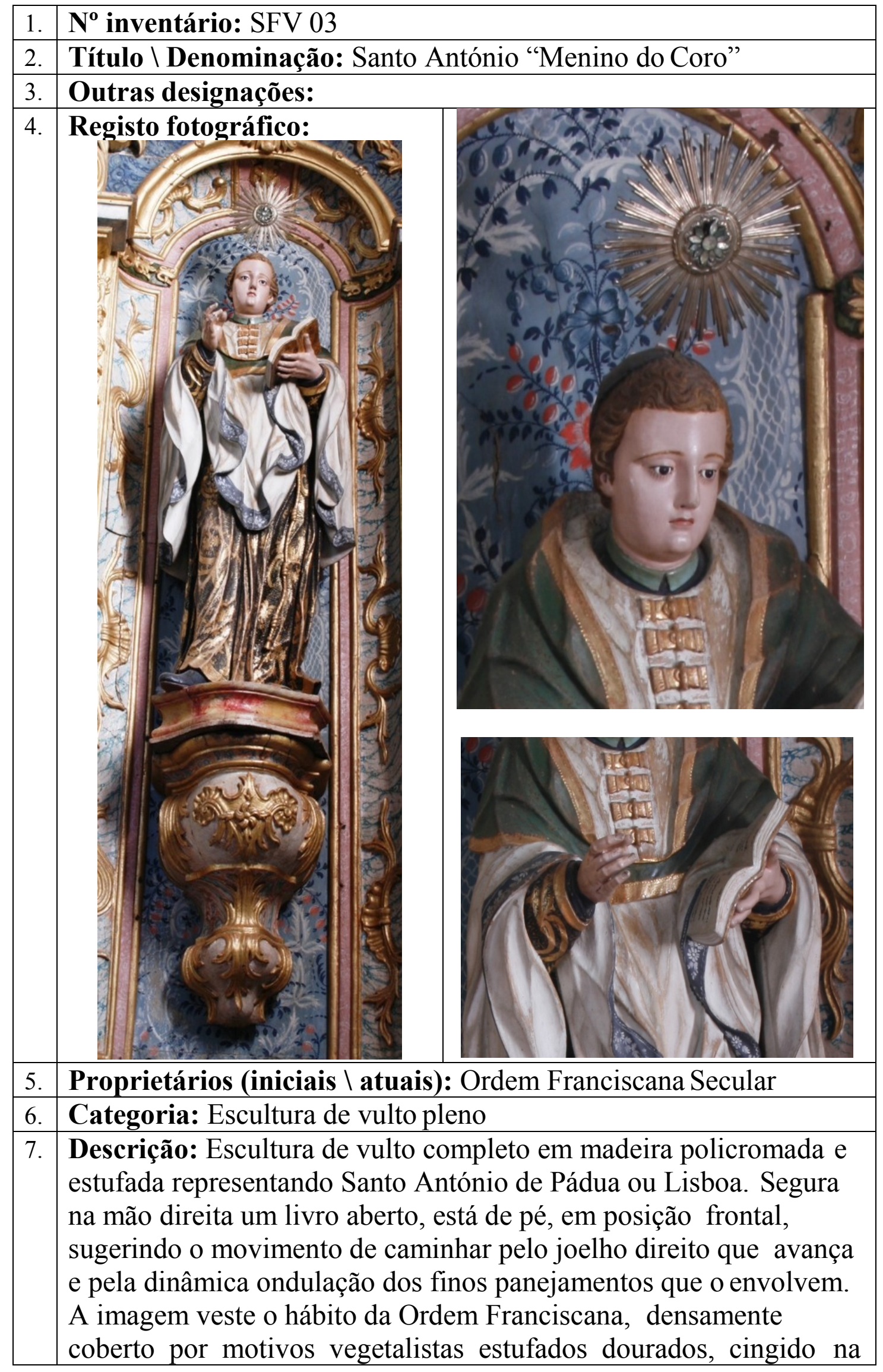




\begin{tabular}{|l|l|}
\hline & $\begin{array}{l}\text { cintura por um cordão duplo com três rolos de nós na parte } \\
\text { pendente. Sobre o hábito, enverga uma sobrepeliz branca, com } \\
\text { bordo azul decorado com elementos vegetalistas, com ampla gola } \\
\text { verde que cai sobre os ombros com bordos dourados e pregadeiras } \\
\text { quadrangulares sobre o peito, que identifica iconograficamente a } \\
\text { narrativa do "Menino do Coro". Os braços estão ambos fletidos e } \\
\text { elevados assimetricamente à altura da cintura, a mão direita, mais } \\
\text { elevada, tem os dedos fletidos e a mão esquerda está aberta para } \\
\text { suster um livro aberto com ricas capas douradas. O rosto jovem de } \\
\text { carnação brilhante e expressão grave tem os olhos de vidro, está } \\
\text { detalhadamente esculpido nos contornos anatómicos que são } \\
\text { arredondados e delicados. Os cabelos são curtos loiros e ondulados, } \\
\text { sobre a cabeça usa um solidéu e ostenta um resplendor raiado com } \\
\text { aplique de pedraria ao centro. } \\
\text { Usa sapatos negros e o pé direito mais avançado reforça a sugestão } \\
\text { de caminhar, está assente sobre uma base em madeira polilobada } \\
\text { marmoreada em tom vermelho e amarelo com pintura muito } \\
\text { desgastada e uma profunda fissura no lado direito. }\end{array}$ \\
\hline 8. & Técnicas (de suporte): Talha \\
\hline 9. & $\begin{array}{l}\text { Técnicas (de acabamento): Policromia; estufagem; marmoreado; } \\
\text { fundição }\end{array}$ \\
\hline 10. & Materiais (de suporte): Madeira \\
\hline 11. & $\begin{array}{l}\text { Materiais (de acabamento): Pigmentos; folha de ouro; vidro; metal } \\
\text { branco }\end{array}$ \\
\hline 12. & $\begin{array}{l}\text { Estado de Conservação: Bom; apresenta-se se estável; desgaste na } \\
\text { policromia; fissura na base }\end{array}$ \\
\hline 13. & $\begin{array}{l}\text { Dimensões: } \\
\text { Altura: } 160 \text { cm } \\
\text { Largura: } 60 \text { cm } \\
\text { Profundidade: } 46 \text { cm }\end{array}$ \\
\hline 14. & Restauro: apresenta sinais de reintegração cromática \\
\hline 15. & Datas: último quartel do século XVIII \\
\hline 16. & Proveniência: igreja de São Francisco em Vinhais \\
\hline 17. & Autoria: desconhecida \\
\hline 18. & Oficina: Porto \Braga \\
\hline 19. & $\begin{array}{l}\text { Localização (atual): Nicho central do Retábulo do transepto no } \\
\text { lado da Epistola }\end{array}$ \\
\hline 20. & Histórico do objeto: não se conhecem registos \\
\hline 21. & Iconografia: Hábito franciscano; Sobrepeliz; Solidéu; resplendor; \\
Livro aberto
\end{tabular}




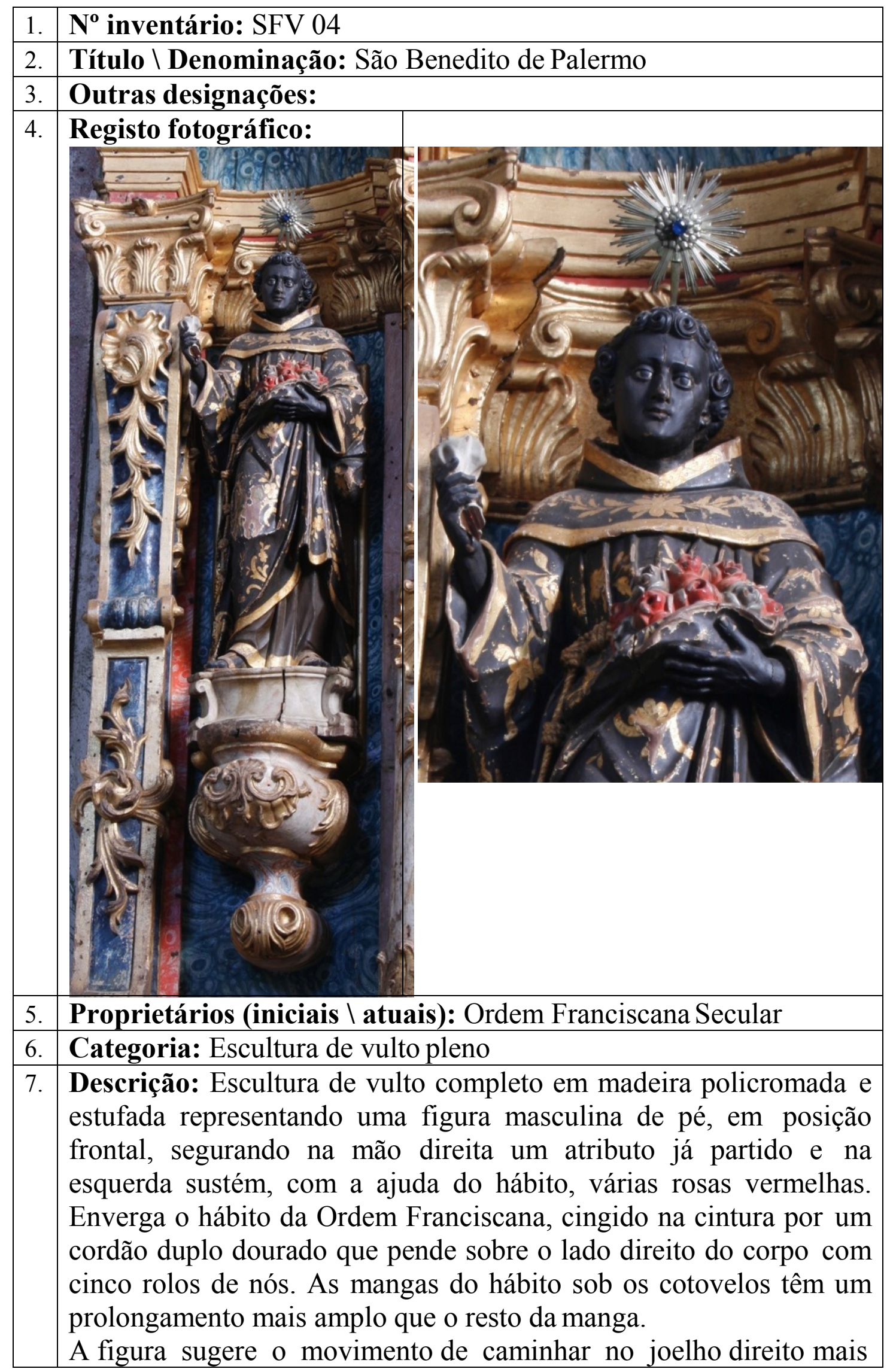




\begin{tabular}{|l|l|}
\hline & $\begin{array}{l}\text { avançado, (com desgaste total da policromia), e na posição } \\
\text { assimétrica dos pés, protegidos com sandálias. } \\
\text { O pregueado dos panejamentos com vincos fundos está decorado } \\
\text { com elementos vegetalistas estufados dourados. } \\
\text { O rosto jovem de carnação negra tem expressão grave e está } \\
\text { detalhadamente esculpido nos contornos anatómicos. Os cabelos } \\
\text { negros são curtos e ondulados. Sobre a cabeça ostenta um resplendor } \\
\text { circular raiado com aplique de pedraria azul ao centro. } \\
\text { Sobre o peito, e aconchegadas pelo hábito que o santo sustém na } \\
\text { mão esquerda destacam-se as rosas num tom vivo de vermelho. } \\
\text { Está assente sobre uma base em madeira polilobada decorada com } \\
\text { aletas entre cada registo e policromada em tom claro marmoreado, } \\
\text { apresenta uma profunda fissura no lado esquerdo. }\end{array}$ \\
\hline 8. & Técnicas (de suporte): Talha \\
\hline 9. & $\begin{array}{l}\text { Técnicas (de acabamento): Policromia; estufagem; marmoreado; } \\
\text { fundição }\end{array}$ \\
\hline 10. & Materiais (de suporte): Madeira \\
\hline 11. & $\begin{array}{l}\text { Materiais (de acabamento): Pigmentos; folha de ouro; metal } \\
\text { branco }\end{array}$ \\
\hline 12. & $\begin{array}{l}\text { Estado de Conservação: Bom; apresenta-se se estável; desgaste na } \\
\text { policromia; fissura na base }\end{array}$ \\
\hline 13. & $\begin{array}{l}\text { Dimensões: } \\
\text { Altura: } 107 \text { cm } \\
\text { Largura: } 43 \text { cm } \\
\text { Profundidade: } 35 \text { cm }\end{array}$ \\
\hline 14. & Restauro: apresenta sinais de reintegração cromática \\
\hline 15. & Datas: último quartel do século XVIII \\
\hline 16. & Proveniência: igreja de São Francisco em Vinhais \\
\hline 17. & Autoria: desconhecida \\
\hline 18. & Oficina: Porto $\backslash$ Braga \\
\hline 19. & $\begin{array}{l}\text { Localização (atual): Nicho central do Retábulo do transepto no } \\
\text { lado da Epistola }\end{array}$ \\
\hline 20. & Histórico do objeto: não se conhecem registos \\
\hline 21. & $\begin{array}{l}\text { Iconografia: - Hábito franciscano; Rosas vermelhas; (atributo } \\
\text { partido na mão direita); resplendor; figura masculina de etnia negra }\end{array}$ \\
\hline 22. & Irmandade: Ordem Franciscana Secular \\
\hline 23. & Procissões: não se conhecem registos \\
\hline
\end{tabular}




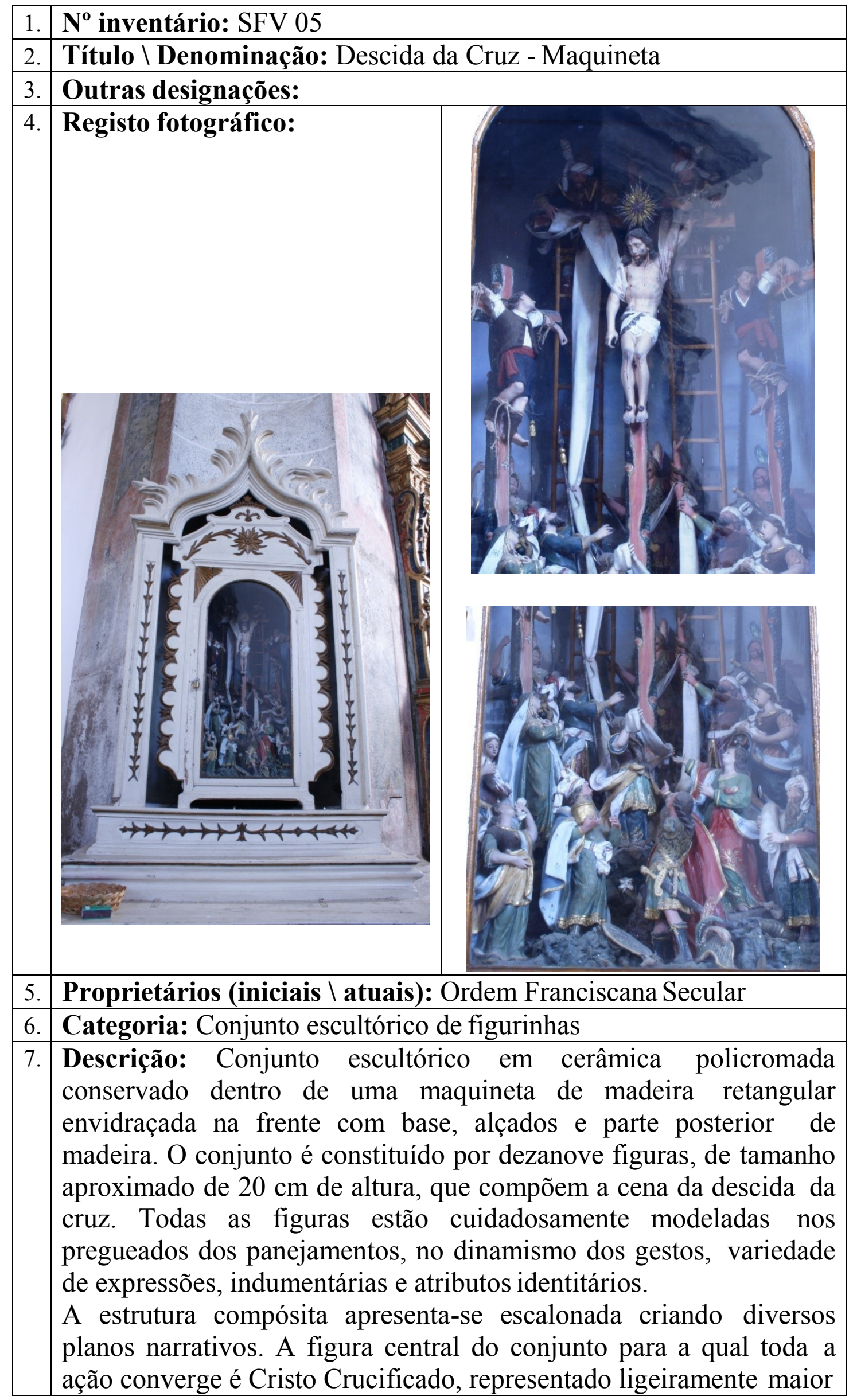


que as restantes figuras. Está sustido por uma faixa de tecido manobrada por vários indivíduos que $\mathrm{O}$ descem da cruz. $\mathrm{O}$ corpo morto de Cristo, anatomicamente cuidado nos detalhes, tem já o braço direito despregado da cruz caído junto ao corpo, enquanto o braço esquerdo está ainda a ser despregado. De todo o conjunto é a única figura com olhos fechados, as restantes têm todas os olhos de vidro. Detrás da figura de Cristo estão duas figuras ataviadas com turbantes e sumptuosas indumentárias, cada uma sobre sua escada, pousadas ambas detrás da cruz, uma de cada lado.

Em plano ligeiramente oblíquo em relação à cruz de Cristo estão mais duas cruzes, uma de cada lado de Cristo onde estão suspensos os ladrões que $\mathrm{O}$ acompanharam no suplício. A figura do ladrão colocado à direita volta a cabeça para a figura de Cristo, enquanto a figura da esquerda volta a cabeça para o lado inverso. Estão ambos vestidos com tecidos grosseiros com calças curtas e faixa vermelha em torno da cintura e com os braços e pernas sustidos por cordas na cruz.

No registo mais recuado, detrás do conjunto das cruzes estão três soldados com elmos emplumados e empunhando escudos, gesticulam e elevam a cabeça para o centro da ação da descida do corpo de Cristo. De cada lado da cruz, duas figuras com turbante e sumptuosas vestes preparam-se para receber o corpo morto suspenso na faixa de tecido branco.

Entre estas figuras está colocada a figura de Maria Madalena, com auréola sobre os longos cabelos soltos e sustendo nos braços que leva um tecido branco. Ao lado e assinalando-a com o braço direito está a outra figura aureolada do conjunto (provavelmente S. João). A acompanhar as duas figuras aureoladas estão mais quatro figuras femininas (uma delas e apesar da ausência de aureola será provavelmente a Virgem Maria, pelo gesto recolhido e longo véu que a cobre sobre a cabeça) as restantes três têm gestos arrebatados e intensas expressões de dor.

No primeiro registo estão duas figuras com turbante e largas e ornamentadas túnicas com capa. A figura colocada no lado direito segura uma arca dourada com tampa, possivelmente Nicodemos. Enquanto a figura da esquerda segura um rolo de tecido branco, seguramente preparatórios do ritual fúnebre que se iria iniciar, sugerindo tratar-se de José de Arimateia. Entre estas duas figuras está colocado o centurião romano de cabelos longos delicadamente entrançados, com o elmo emplumado e o escudo pousados no chão e arrebatado gesto do braço direito com que sinaliza a figura de Cristo morto.

Todo o conjunto está assente sobre uma base irregular pintada em 


\begin{tabular}{|c|c|}
\hline & $\begin{array}{l}\text { tons verdes simulando pedra que se eleva em diferentes registos. } \\
\text { Colocado dentro de uma maquineta em madeira policromada com } \\
\text { porta de vidro. A madeira está ornamentada com motivos } \\
\text { vegetalistas dourados nos lados e parte superior. }\end{array}$ \\
\hline 8. & Técnicas (de suporte): Modelagem \\
\hline 9. & Técnicas (de acabamento): Policromia; douramento; fundição \\
\hline 10. & Materiais (de suporte): Cerâmica $\backslash$ barro \\
\hline 11. & $\begin{array}{l}\text { Materiais (de acabamento): Pigmentos; vidro; têxteis; Corda; } \\
\text { metal branco }\end{array}$ \\
\hline 12. & $\begin{array}{l}\text { Estado de Conservação: Bom; apresenta-se se estável; lacunas nos } \\
\text { dedos nas figuras dos sacerdotes, de S. João e do soldado em } \\
\text { primeiro plano }\end{array}$ \\
\hline 13. & $\begin{array}{l}\text { Dimensões: (com oratório) } \\
\text { Altura: } 145 \mathrm{~cm} \\
\text { Largura: } 73 \mathrm{~cm} \\
\text { Profundidade: } 45 \mathrm{~cm}\end{array}$ \\
\hline 14. & Restauro: apresenta sinais de reintegração cromática \\
\hline 15. & Datas: último quartel do século XVIII \\
\hline 16. & Proveniência: igreja de São Francisco em Vinhais \\
\hline 17. & Autoria: desconhecida \\
\hline 18. & Oficina: Lisboa \\
\hline 19. & $\begin{array}{l}\text { Localização (atual): Arco de triunfo entre a capela-mor e o } \\
\text { transepto no lado da Epistola }\end{array}$ \\
\hline 20. & Histórico do objeto: não se conhecem registos \\
\hline 21. & $\begin{array}{l}\text { Iconografia: Soldados; ladrões; Cristo Morto; Virgem Maria, Maria } \\
\text { Madalena, S. João, José de Arimateia }\end{array}$ \\
\hline 22. & Irmandade: Ordem Franciscana Secular \\
\hline 23. & Procissões: não se conhecem registos \\
\hline
\end{tabular}


FICHAS DE INVENTÁRIO | ESCULTURA

Da Ordem de São Francisco na Diocese de Bragança-Miranda 
Retábulo do altar-mor em talha rococó com as imagens SFV 06, SFV 07 , SFV 08, nos cunhais da capela mor estã as maquinetas SFV 05 no lado da Epístola e SFV 09 no lado do Evangelho

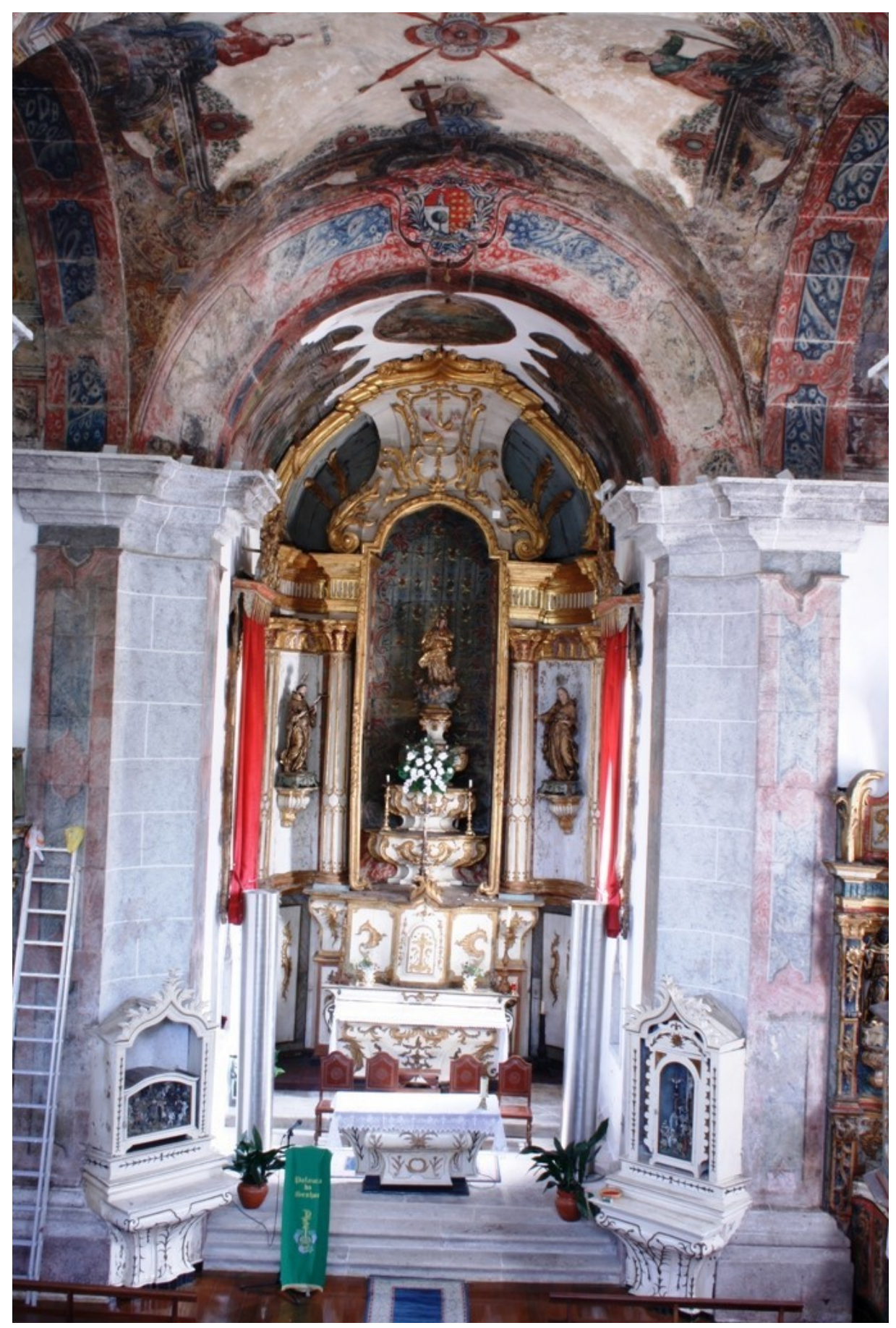


FICHAS DE INVENTÁRIO | ESCULTURA

Da Ordem de São Francisco na Diocese de Bragança-Miranda 


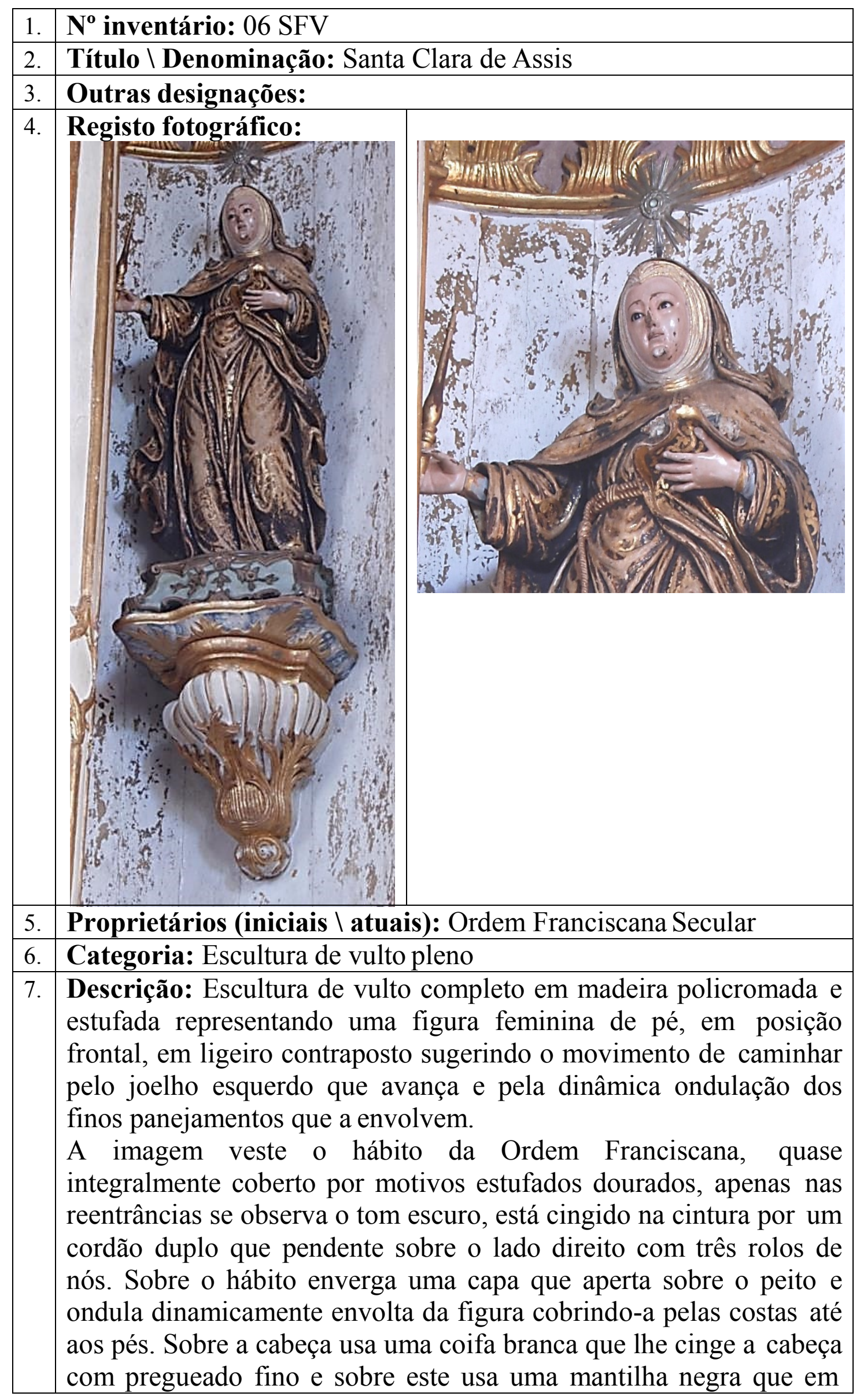




\begin{tabular}{|c|c|}
\hline & $\begin{array}{l}\text { dinâmico pregueado lhe cai sobre os ombros. } \\
\text { A figura flete e ergue ambos os braços à altura da cintura. Na mão } \\
\text { direita, com os dedos fletidos, segura um atributo, já partido, longo e } \\
\text { de secção circular; com a mão esquerda sustém, com parte do manto } \\
\text { junto ao corpo, um conjunto de flores brancas, estão ambas as mãos } \\
\text { cuidadosamente esculpidas com contornos arredondados e brilhante } \\
\text { carnação. O rosto, com expressão de sofrimento contido, também de } \\
\text { carnação brilhante, tem os olhos de vidro e está detalhadamente } \\
\text { esculpido nos contornos anatómicos que são arredondados e } \\
\text { delicados, apresenta um forte desgaste na policromia sobre o nariz. } \\
\text { Sobre a cabeça ostenta um resplendor circular raiado em metal } \\
\text { branco com aplique de pedraria ao centro. } \\
\text { Os pés com sapatos negros assentam sobre uma base em madeira } \\
\text { polilobada marmoreada em tom verde com ornamentos em talha } \\
\text { dourada sobre os bordos e bojo central. }\end{array}$ \\
\hline 8. & Técnicas (de suporte): Talha \\
\hline 9. & $\begin{array}{l}\text { Técnicas (de acabamento): Policromia; Douramento; estufagem; } \\
\text { marmoreado; fundição }\end{array}$ \\
\hline 10. & Materiais (de suporte): Madeira \\
\hline 11. & $\begin{array}{l}\text { Materiais (de acabamento): Pigmentos; folha de ouro; vidro; metal } \\
\text { branco }\end{array}$ \\
\hline 12. & $\begin{array}{l}\text { Estado de Conservação: Bom; apresenta-se se estável; lacunas e } \\
\text { desgaste na policromia; lacuna do atributo na mão direita }\end{array}$ \\
\hline 13. & $\begin{array}{l}\text { Dimensões: } \\
\text { Altura: } 160 \mathrm{~cm} \\
\text { Largura: } 75 \mathrm{~cm} \\
\text { Profundidade: } 45 \mathrm{~cm}\end{array}$ \\
\hline 14. & Restauro: apresenta sinais de reintegração cromática \\
\hline 15. & Datas: último quartel do século XVIII \\
\hline 16. & Proveniência: igreja de São Francisco em Vinhais \\
\hline 17. & $\begin{array}{l}\text { Autoria: desconhecida, mas possivelmente a mesma que a figura de } \\
\text { São Francisco 08 SFV 08; ambas semelhantes no gesto e no } \\
\text { pregueado dos panejamentos, bem como na policromia (estufagem e } \\
\text { carnação) com a imagem SFV Santa Rosa de Viterbo } 02\end{array}$ \\
\hline 18. & Oficina: Porto $\backslash$ Braga \\
\hline 19. & Localização (atual): Retábulo do Altar-mor no lado da Epistola \\
\hline 20. & Histórico do objeto: não se conhecem registos \\
\hline 21. & $\begin{array}{l}\text { Iconografia: Hábito de monja franciscana; resplendor; flores } \\
\text { brancas; atributo partido }\end{array}$ \\
\hline 22. & Irmandade: Ordem Franciscana Secular \\
\hline 23. & Procissões: não se conhecem registos \\
\hline
\end{tabular}




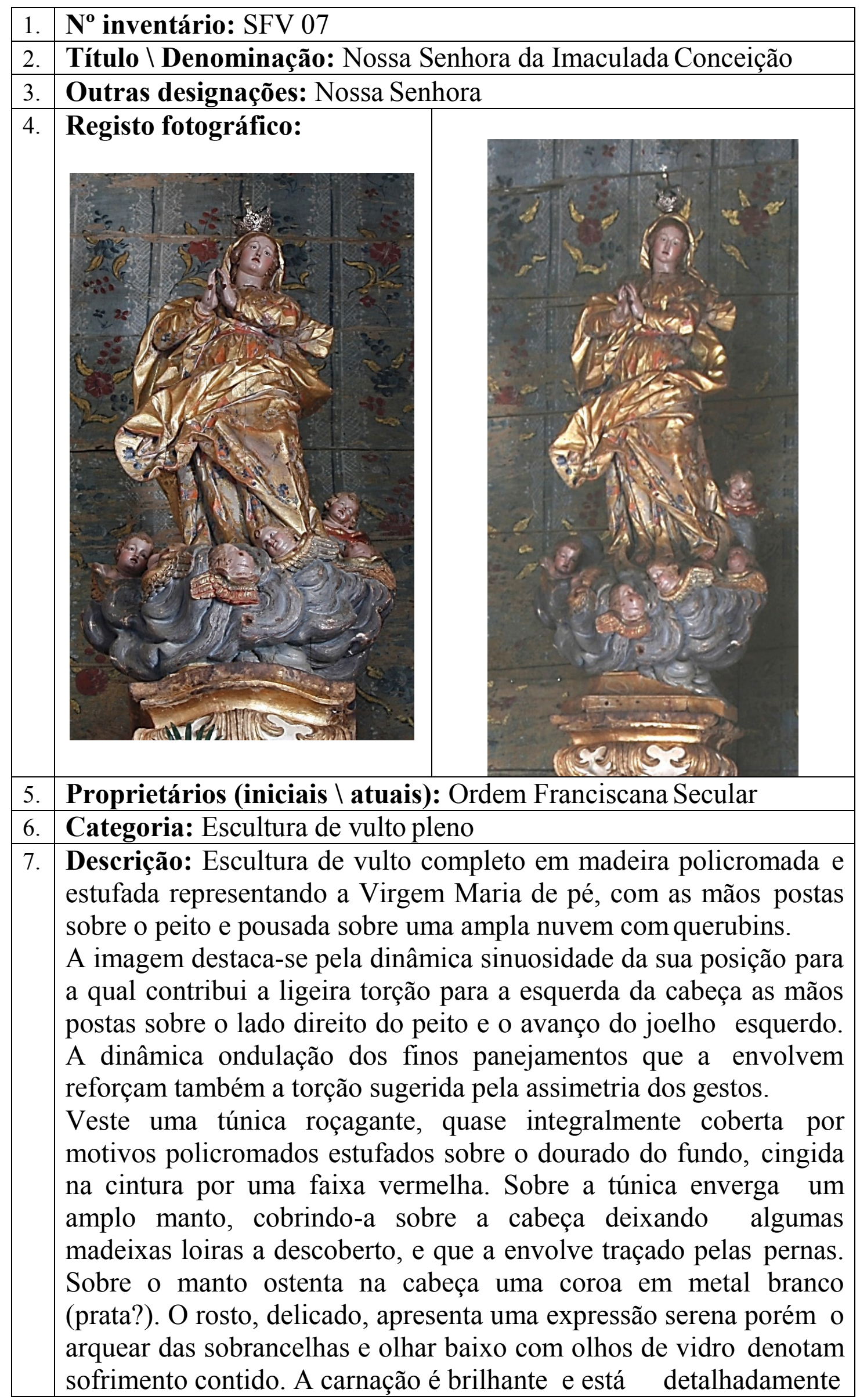




\begin{tabular}{|c|c|}
\hline & $\begin{array}{l}\text { esculpido nos contornos anatómicos que são arredondados e } \\
\text { delicados, tem lacuna de dedos em ambas mãos. } \\
\text { Assenta sobre uma volumosa e ondulada nuvem da qual emergem } \\
\text { seis querubins. }\end{array}$ \\
\hline 8. & Técnicas (de suporte): Talha \\
\hline 9. & $\begin{array}{l}\text { Técnicas (de acabamento): Policromia; Douramento; estufagem; } \\
\text { fundição }\end{array}$ \\
\hline 10. & Materiais (de suporte): Madeira \\
\hline 11. & $\begin{array}{l}\text { Materiais (de acabamento): Pigmentos; folha de ouro; vidro; metal } \\
\text { branco }\end{array}$ \\
\hline 12. & $\begin{array}{l}\text { Estado de Conservação: Bom; apresenta-se se estável; desgaste na } \\
\text { policromia; lacunas de dedos em ambas mãos; fissura vertical ao } \\
\text { longo de toda a frente da imagem e em volta do pescoço }\end{array}$ \\
\hline 13. & $\begin{array}{l}\text { Dimensões: } \\
\text { Altura: } 150 \mathrm{~cm} \\
\text { Largura: } 67 \mathrm{~cm} \\
\text { Profundidade: } 47 \mathrm{~cm}\end{array}$ \\
\hline 14. & Restauro: apresenta sinais de reintegração cromática \\
\hline 15. & Datas: último quartel do século XVIII \\
\hline 16. & Proveniência: igreja de São Francisco em Vinhais \\
\hline 17. & Autoria: desconhecida \\
\hline 18. & Oficina: Porto $\backslash$ Braga \\
\hline 19. & Localização (atual): Tribuna do retábulo do Altar-mor \\
\hline 20. & Histórico do objeto: não se conhecem registos \\
\hline 21. & $\begin{array}{l}\text { Iconografia: Virgem com as mãos postas sobre o peito; nuvem com } \\
\text { querubins; Lua; coroa }\end{array}$ \\
\hline 22. & Irmandade: Ordem Franciscana Secular \\
\hline 23. & Procissões: não se conhecem registos \\
\hline
\end{tabular}




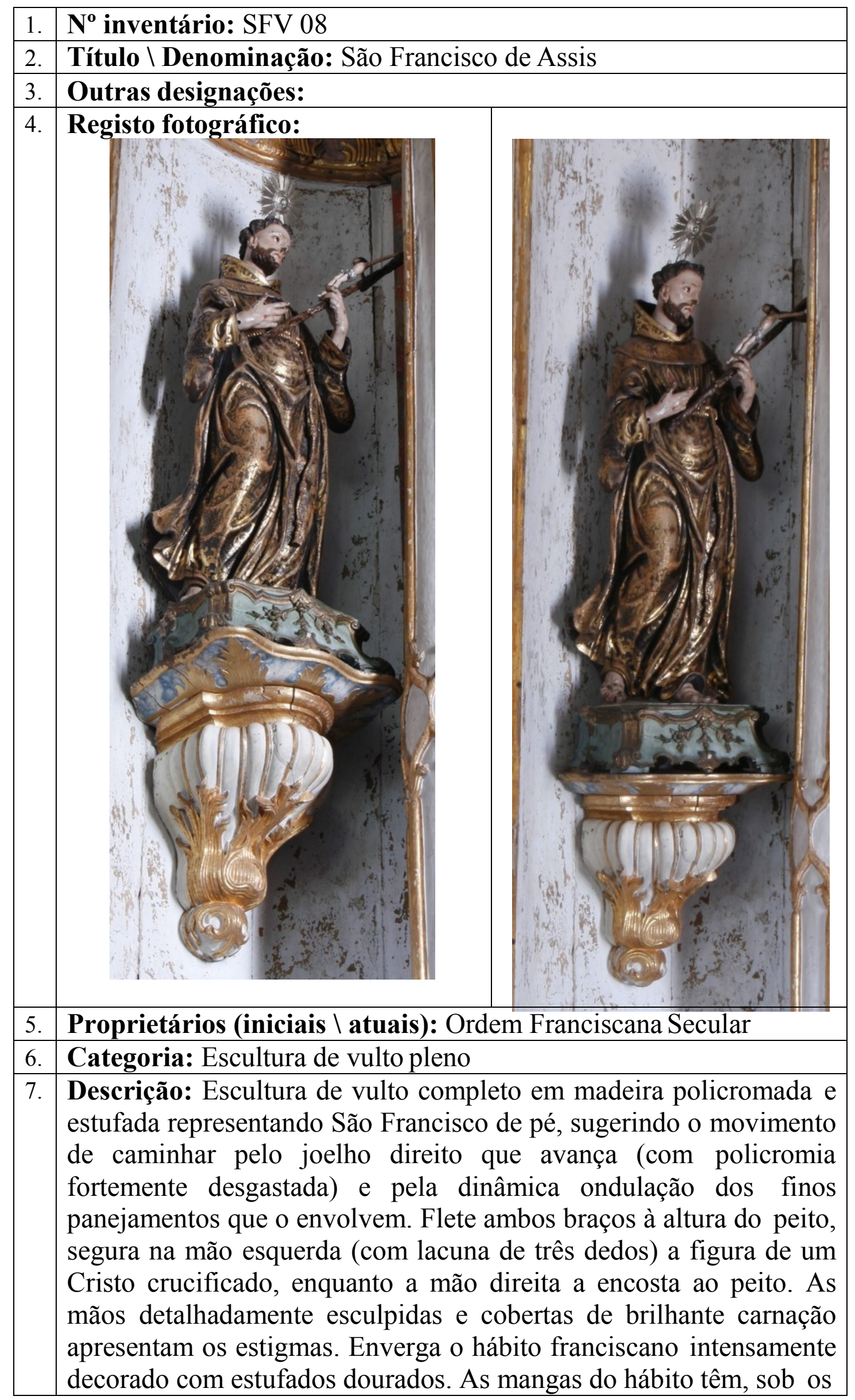




\begin{tabular}{|c|c|}
\hline & $\begin{array}{l}\text { cotovelos, um prolongamento mais amplo que o resto da manga (tal } \\
\text { como é observável no hábito de São Benedito 04 SFV) e está } \\
\text { cingido na cintura por um cordão duplo dourado que pende sobre o } \\
\text { lado esquerdo do corpo com três rolos de nós. O rosto com barbas e } \\
\text { cabelos castanhos tem olhos de vidro e um cuidadoso modelado dos } \\
\text { aspetos anatómicos (forte desgaste na policromia sobre o nariz), o } \\
\text { arqueado das sobrancelhas reforça a emotividade da expressão de } \\
\text { sofrimento contido. Inclina a cabeça para o lado esquerdo olhando a } \\
\text { figura de Cristo crucificado que sustem na mão esquerda. Sobre a } \\
\text { cabeça ostenta um resplendor circular raiado em metal branco com } \\
\text { aplique de pedraria ao centro (igual ao da figura de Santa Clara } 06 \\
\text { SFV, com a qual partilha várias semelhanças, no gesto e volumetria) } \\
\text { Ambas as figuras estão colocadas respetivamente de cada lado da } \\
\text { tribuna do altar-mor. Descalço, com estigmas nos pés fletidos de } \\
\text { caminhar e assenta sobre uma base em madeira polilobada decorada } \\
\text { com aletas entre cada registo e policromada em tom claro } \\
\text { marmoreado, apresenta uma profunda fissura no lado esquerdo. }\end{array}$ \\
\hline 8. & Técnicas (de suporte): Talha \\
\hline 9. & Técnicas (de acabamento): Policromia; estufagem; fundição \\
\hline 10. & Materiais (de suporte): Madeira \\
\hline 11. & $\begin{array}{l}\text { Materiais (de acabamento): Pigmentos; folha de ouro; metal } \\
\text { branco }\end{array}$ \\
\hline 12. & $\begin{array}{l}\text { Estado de Conservação: Bom; apresenta-se se estável; desgaste na } \\
\text { policromia, sobre o hábito e nariz; lacunas de dedos na mão } \\
\text { esquerda }\end{array}$ \\
\hline 13. & $\begin{array}{l}\text { Dimensões: } \\
\text { Altura: } 147 \mathrm{~cm} \\
\text { Largura: } 70 \mathrm{~cm} \\
\text { Profundidade: } 50 \mathrm{~cm}\end{array}$ \\
\hline 14. & Restauro: apresenta sinais de reintegração cromática \\
\hline 15. & Datas: último quartel do século XVIII \\
\hline 16. & Proveniência: igreja de São Francisco em Vinhais \\
\hline 17. & $\begin{array}{l}\text { Autoria: desconhecida, mas possivelmente a mesma que a figura de } \\
\text { Clara SFV 06; ambas semelhantes no gesto e no pregueado dos } \\
\text { panejamentos, bem como na policromia (estufagem e carnação) com } \\
\text { a imagem SFV Santa Rosa de Viterbo } 02\end{array}$ \\
\hline 18. & Oficina: Porto $\backslash$ Braga \\
\hline 19. & Localização (atual): Altar-mor no lado do Evangelho \\
\hline 20. & Histórico do objeto: não se conhecem registos \\
\hline 21. & $\begin{array}{l}\text { Iconografia: Hábito franciscano; estigmas; figura de Cristo } \\
\text { Crucificado; resplendor }\end{array}$ \\
\hline 22. & Irmandade: Ordem Franciscana Secular \\
\hline
\end{tabular}




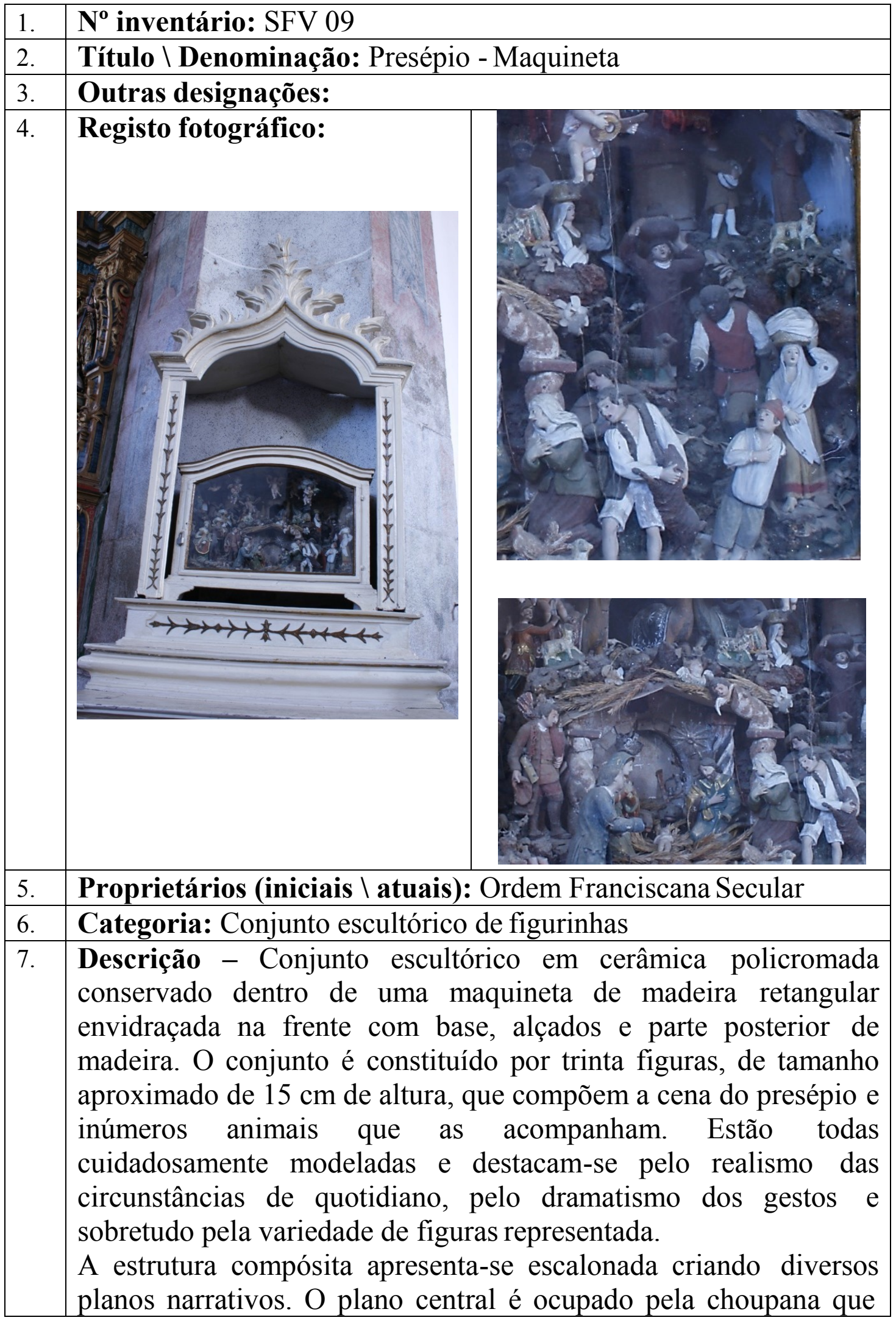




\begin{tabular}{|c|c|}
\hline & 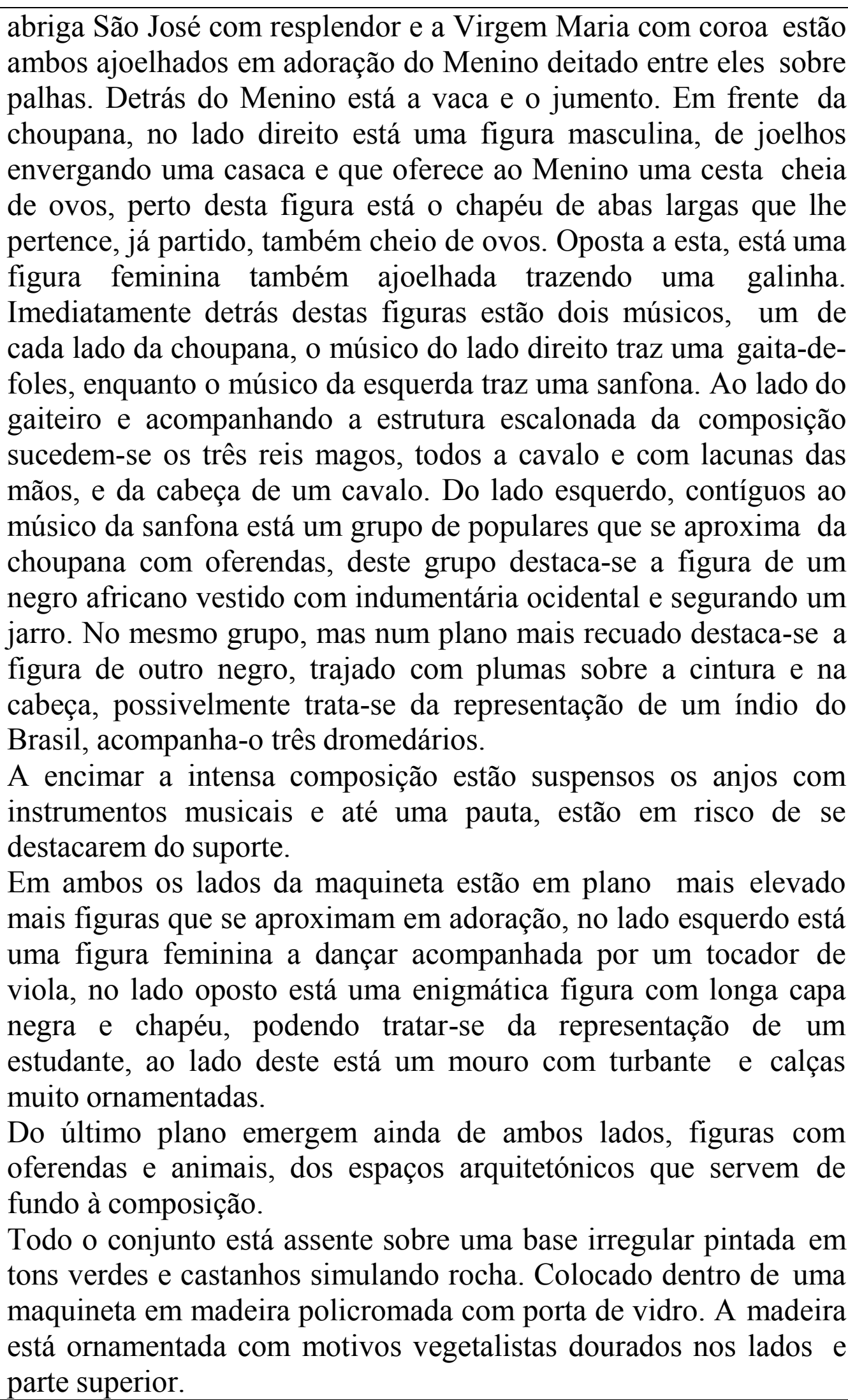 \\
\hline 8. & Técnicas (de suporte): Modelagem \\
\hline 9. & Técnicas (de acabamento): Policromia; douramento; fundição \\
\hline 10. & Materiais (de suporte): Cerâmica \barro \\
\hline 11. & Materiais (de acabamento): Pigmentos; vidro; têxteis; Corda; \\
\hline
\end{tabular}




\begin{tabular}{|l|l|}
\hline & metal branco \\
\hline 12. & $\begin{array}{l}\text { Estado de Conservação: Razoável: apresenta-se com muitas } \\
\text { lacunas e fraturas que põem em risco a estabilidade das figuras (os } \\
\text { anjos suspensos do teto da maquineta correm risco de se } \\
\text { destacarem) }\end{array}$ \\
\hline 13. & $\begin{array}{l}\text { Dimensões: (aproximadas e com oratório) } \\
\text { Altura: } 55 \mathrm{~cm} \\
\text { Largura: } 73 \mathrm{~cm} \\
\text { Profundidade: } 45 \mathrm{~cm}\end{array}$ \\
\hline 14. & Restauro: não apresenta sinais de intervenção sobre a obra \\
\hline 15. & Datas: último quartel do século XVIII \\
\hline 16. & $\begin{array}{l}\text { Proveniência: Seminário Apostólico dos frades Missionários } \\
\text { (conforme inventário de 1834) }\end{array}$ \\
\hline 17. & Autoria: desconhecida \\
\hline 18. & Oficina: Lisboa \\
\hline 19. & $\begin{array}{l}\text { Localização (inicial I atual) Em 1834 estava na sacristia da da } \\
\text { contígua igreja de Nossa Senhora da Encarnação do Seminário } \\
\text { Apostólico; Atualmente está adossada ao arco de triunfo entre a } \\
\text { capela-mor e o transepto no lado da Evangelho }\end{array}$ \\
\hline 20. & $\begin{array}{l}\text { Histórico do objeto: a maquineta do presépio foi trasladada, após } \\
\text { 1834, da sacristia da contígua igreja de Nossa Senhora da } \\
\text { Encarnação do Seminário Apostólico }\end{array}$ \\
\hline 21. & $\begin{array}{l}\text { Iconografia: Presépio; sagrada família; pastores; músicos; escavo } \\
\text { negro; índio do Brasil; anjos }\end{array}$ \\
\hline 22. & Irmandade: não se conhecem registos \\
\hline 23. & Procissões: não se conhecem registos \\
\hline
\end{tabular}


FICHAS DE INVENTÁRIO | ESCULTURA

Da Ordem de São Francisco na Diocese de Bragança-Miranda 
FICHAS DE INVENTÁRIO |ESCULTURA

Da Ordem de São Francisco na Diocese de Bragança-Miranda

Retábulo em talha rococó com as imagens SFV 10, SFV 11, SFV 12, no lado do Evangelho

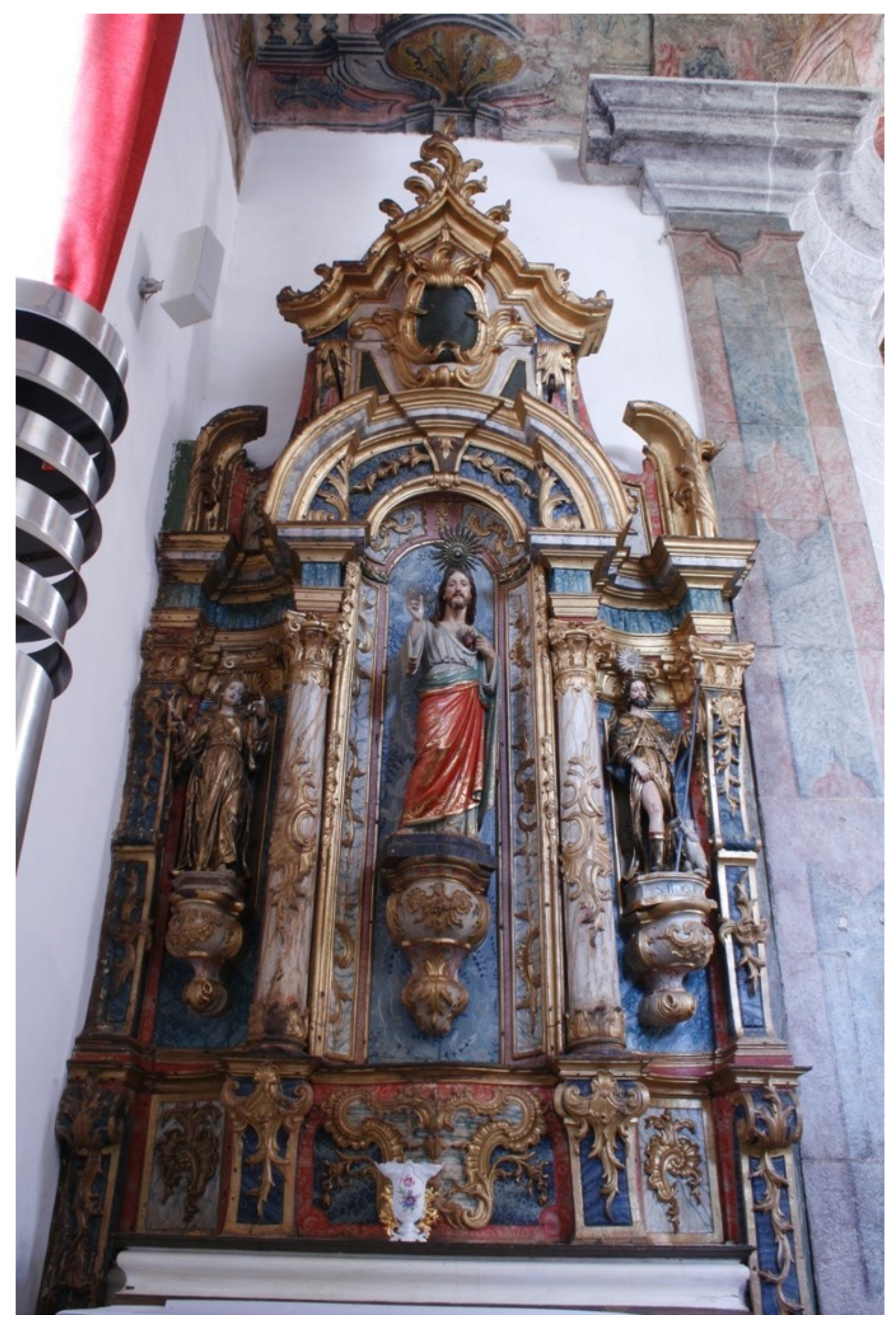


FICHAS DE INVENTÁRIO | ESCULTURA

Da Ordem de São Francisco na Diocese de Bragança-Miranda 


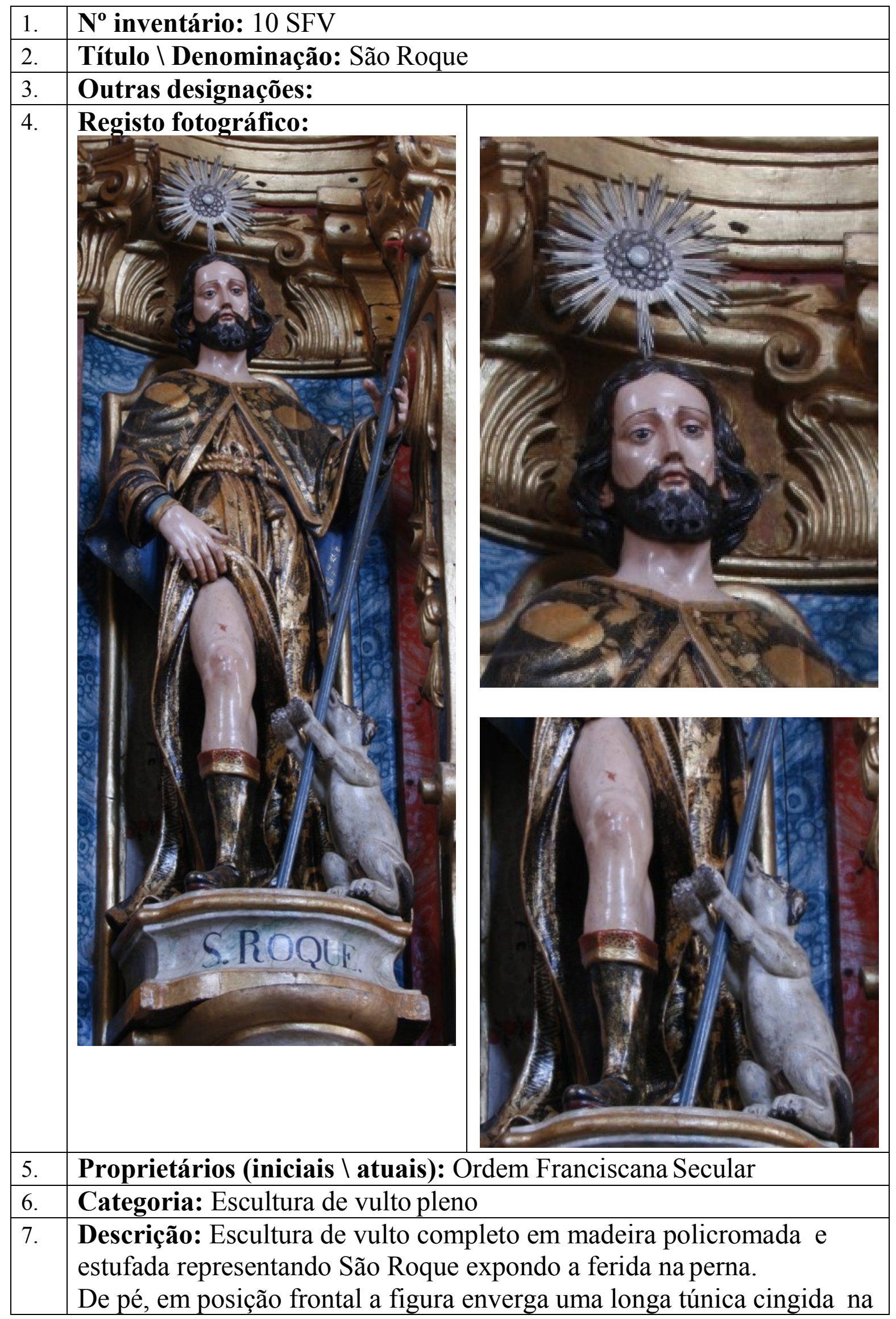




\begin{tabular}{|c|c|}
\hline & $\begin{array}{l}\text { cintura por um cordão duplo que pende sobre o lado esquerdo com três } \\
\text { nós, a indumentária é semelhante ao hábito franciscano, porém sem o } \\
\text { capuz, e sobre este usa uma capa que o cobre pelos ombros } \\
\text { Flete ambos os braços, com a mão direita a figura sustém o hábito } \\
\text { descobrindo quase toda a perna direita que tem sobre o joelho uma } \\
\text { chaga, enverga uma ornamentada bota que lhe cobre meia perna. A mão } \\
\text { esquerda com lacuna dos dedos segura um bordão do qual pende na } \\
\text { extremidade uma pequena cabaça. Encostado ao bordão está sentado o } \\
\text { cão, sobre as patas traseiras e com as patas dianteiras elevadas, é de tom } \\
\text { branco com manchas negras. } \\
\text { O rosto, de expressão grave e carnação brilhante, tem um cuidadoso } \\
\text { modelado nos aspetos anatómicos, apresenta-se com barbas e cabelos } \\
\text { castanhos curtos e ondulados. Sobre a cabeça ostenta um resplendor } \\
\text { circular raiado em metal branco com aplique de pedraria ao centro. } \\
\text { Está assente sobre uma base em madeira polilobada decorada com um } \\
\text { filete dourado entre cada registo e policromada em tom claro } \\
\text { marmoreado, na frente pode ler-se em letras maiúsculas S:ROQUE. }\end{array}$ \\
\hline 8. & Técnicas (de suporte): Talha \\
\hline 9. & Técnicas (de acabamento): Policromia; estufagem; fundição \\
\hline 10. & Materiais (de suporte): Madeira \\
\hline 11. & Materiais (de acabamento): Pigmentos; folha de ouro; metal branco \\
\hline 12. & $\begin{array}{l}\text { Estado de Conservação: Bom; apresenta-se se estável; lacunas de } \\
\text { dedos na mão esquerda }\end{array}$ \\
\hline 13. & $\begin{array}{l}\text { Dimensões: } \\
\text { Altura: } 115 \mathrm{~cm} \\
\text { Largura: } 45 \mathrm{~cm} \\
\text { Profundidade: } 35 \mathrm{~cm}\end{array}$ \\
\hline 14. & Restauro: apresenta sinais de reintegração cromática \\
\hline 15. & Datas: último quartel do século XVIII \\
\hline 16. & Proveniência: igreja de São Francisco em Vinhais \\
\hline 17. & Autoria: desconhecida \\
\hline 18. & Oficina: Porto $\backslash$ Braga \\
\hline 19. & Localização (atual): Retábulo do Transepto no lado do Evangelho \\
\hline 20. & Histórico do objeto: não se conhecem registos \\
\hline 21. & $\begin{array}{l}\text { Iconografia: Hábito franciscano curto; bordão com cabaça; cão; } \\
\text { resplendor }\end{array}$ \\
\hline 22. & Irmandade: Ordem Franciscana Secular \\
\hline 23. & Procissões: não se conhecem registos \\
\hline
\end{tabular}




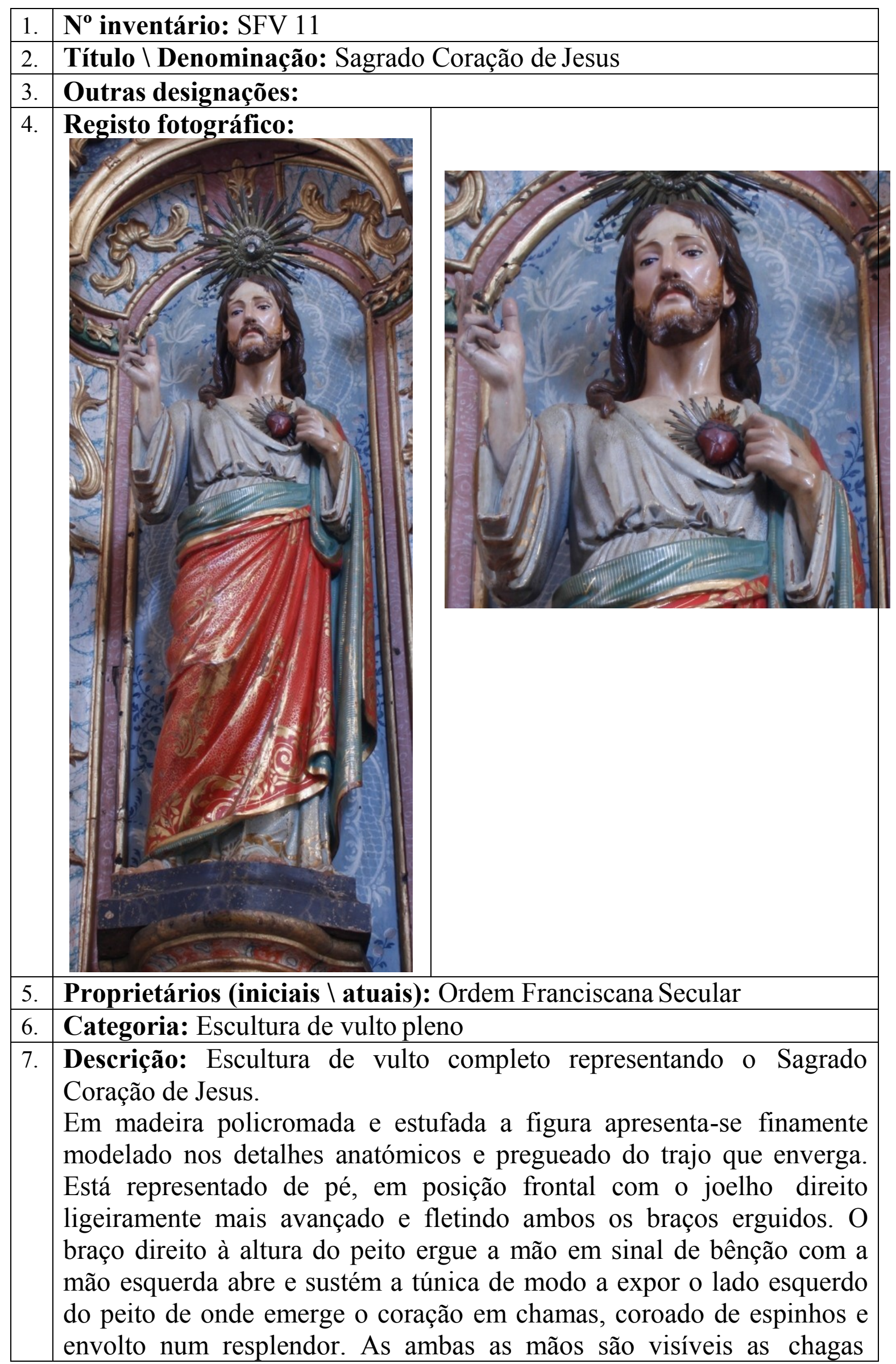




\begin{tabular}{|l|l|}
\hline & $\begin{array}{l}\text { ensanguentadas do martírio superado. } \\
\text { A figura enverga uma longa túnica azul clara branca com suave } \\
\text { pregueado que lhe deixa a descoberto apenas as pontas dos pés. A túnica } \\
\text { está cingida na cintura por um cordão, sobre esta enverga um amplo } \\
\text { manto vermelho desde o ombro esquerdo e traçado sobre a cintura } \\
\text { cobrindo desde o ombro até aos pés, decorado nos bordos por ornatos } \\
\text { arabescos dourados e com forro de tom azul. } \\
\text { O rosto, com carnação brilhante e expressão contida de tristeza } \\
\text { enfatizada pelo olhar baixo, com olhos de vidro, e cuidados detalhes } \\
\text { anatómicos. Usa a barba bifurcada e longos cabelos castanhos com uma } \\
\text { madeixa caída sobre o ombro direito. } \\
\text { Sobre a cabeça ostenta um resplendor circular raiado em metal branco } \\
\text { com aplique de pedraria ao centro. } \\
\text { A figura está descalça, com chagas em ambos os pés, e assente sobre } \\
\text { uma base em madeira polilobada em dois registos de cor negra. } \\
\text { Destaca-se pela ligeira sinuosidade da postura e pelo delicado trabalho } \\
\text { escultórico do gesto e expressão. }\end{array}$ \\
\hline 8. & Técnicas (de suporte): Talha \\
\hline 9. & Técnicas (de acabamento): Policromia; estufado; fundição \\
\hline 10. & Materiais (de suporte): Madeira \\
\hline 11. & $\begin{array}{l}\text { Materiais (de acabamento): Pigmentos; vidro; folha de ouro; metal } \\
\text { branco }\end{array}$ \\
\hline 12. & $\begin{array}{l}\text { Estado de Conservação: Bom; apresenta-se se estável; forte desgaste } \\
\text { na policromia decorrente da fricção que os fiéis fazem sobre o joelho }\end{array}$ \\
\hline 13. & $\begin{array}{l}\text { Dimensões: } \\
\text { Altura: } 148 \text { cm } \\
\text { Largura: } 55 \text { cm } \\
\text { Profundidade: } 55 \text { cm }\end{array}$ \\
\hline 14. & Restauro: não apresenta sinais de intervenção sobre a obra \\
\hline 15. & Datas: século XX \\
\hline 16. & Proveniência: igreja de São Francisco em Vinhais \\
\hline 17. & Autoria: Guilherme Thedim (?) \\
\hline 18. & Oficina: Matosinhos $\backslash$ Porto \\
\hline 19. & $\begin{array}{l}\text { Localização (atual): Nicho central do Retábulo do Transepto no lado } \\
\text { do Evangelho }\end{array}$ \\
\hline 20. & Histórico do objeto: não se conhecem registos \\
\hline 21. & $\begin{array}{l}\text { Iconografia: coração ardente cingido por coroa de espinhos e } \\
\text { resplendor; estigmas; sinal de bênção; resplendor }\end{array}$ \\
\hline 23. & Irmandade: Ordem Franciscana Secular \\
Procissões: não se conhecem registos \\
\hline
\end{tabular}




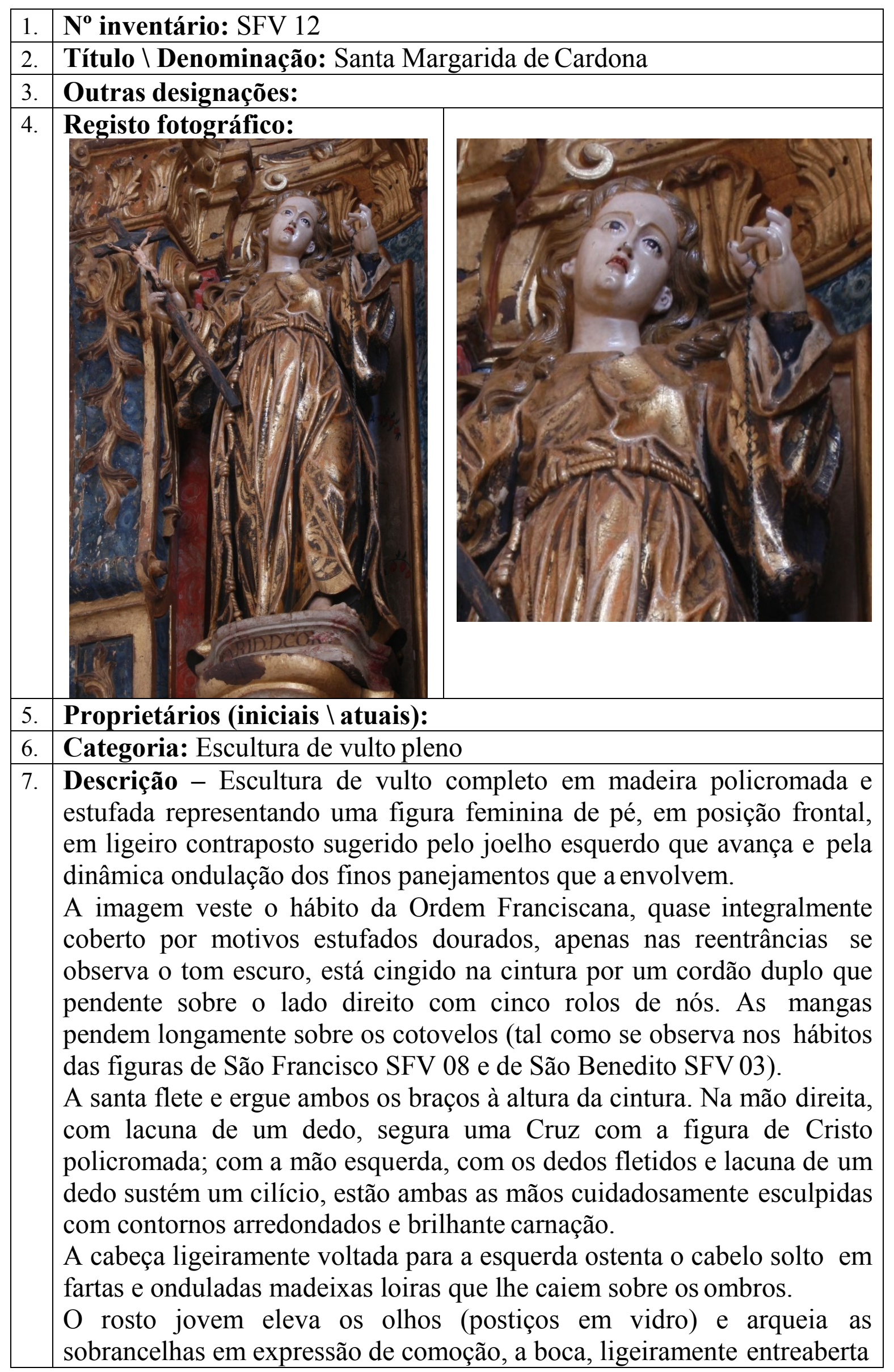




\begin{tabular}{|l|l|}
\hline & $\begin{array}{l}\text { e com os cantos dos lábios descaídos deixa a descoberto os dentes. De } \\
\text { carnação brilhante está detalhadamente esculpido nos contornos } \\
\text { anatómicos que são arredondados e delicados, observa-se destaque da } \\
\text { policromia sobre o nariz. } \\
\text { A figura está descalça e assenta sobre uma base em madeira polilobada } \\
\text { marmoreada em tom branco e vermelho em cuja superfície frontal pode } \\
\text { ler-se em letras maiúsculas S. MARGARID.D.COR(...). }\end{array}$ \\
\hline 8. & Técnicas (de suporte): Talha \\
\hline 9. & $\begin{array}{l}\text { Técnicas (de acabamento): Policromia; Douramento; estufagem; } \\
\text { marmoreado; fundição }\end{array}$ \\
\hline 10. & Materiais (de suporte): Madeira \\
\hline 11. & $\begin{array}{l}\text { Materiais (de acabamento): Pigmentos; folha de ouro; vidro; metal } \\
\text { escuro }\end{array}$ \\
\hline 12. & $\begin{array}{l}\text { Estado de Conservação: Bom; apresenta-se se estável; lacunas de um } \\
\text { dedo em cada mão; destacamento da policromia sobre o nariz; desgaste } \\
\text { da policromia }\end{array}$ \\
\hline 13. & $\begin{array}{l}\text { Dimensões: } \\
\text { Altura: } 104 \text { cm } \\
\text { Largura: } 50 \text { cm } \\
\text { Profundidade: } 35 \text { cm }\end{array}$ \\
\hline 14. & Restauro: apresenta sinais de reintegração cromática \\
\hline 15. & Datas: último quartel do século XVIII \\
\hline 16. & Proveniência: igreja de São Francisco em Vinhais \\
\hline 17. & $\begin{array}{l}\text { Autoria: desconhecida, mas é semelhante no pormenor das magas do } \\
\text { hábito a São Francisco SFV 08 e São Benedito SFV 03; no gesto e no } \\
\text { pregueado dos panejamentos, bem como na policromia (estufagem e } \\
\text { carnação) é parecida com a imagem 02 SFV Santa Rosa de Viterbo e 06 } \\
\text { SFV Santa Clara. Possivelmente a autoria é a mesma que as figuras: } \\
\text { SFV 02; 03; 06; 08; }\end{array}$ \\
\hline 18. & Oficina: Porto \Braga \\
\hline 19. & Localização (atual): Retábulo do transepto do lado do Evangelho \\
\hline 20. & Histórico do objeto: não se conhecem registos \\
\hline 21. & $\begin{array}{l}\text { Iconografia: Hábito franciscano sem o capuz; cilício; Cruz com a figura } \\
\text { de Cristo }\end{array}$ \\
\hline 22. & Irmandade: Ordem Franciscana Secular \\
\hline 23. & Procissões: não se conhecem registos \\
\hline
\end{tabular}




\begin{tabular}{|l|l|}
\hline 1. & $\mathbf{N}^{\mathbf{0}}$ inventário: SFV 13 \\
\hline 2. & Título $\backslash$ Denominação: Cruz de Altar \\
\hline 3. & Outras designações: Cristo Crucificado \\
\hline 4. & Registo fotográfico: \\
&
\end{tabular}




\begin{tabular}{|c|c|}
\hline & $\begin{array}{l}\text { remates, assenta sobre uma base polilobada em vários registos, também } \\
\text { decorada com detalhes em talha dourada. }\end{array}$ \\
\hline 8. & Técnicas (de suporte): Talha \\
\hline 9. & Técnicas (de acabamento): Policromia \\
\hline 10. & Materiais (de suporte): Madeira \\
\hline 11. & Materiais (de acabamento): Pigmentos; folha de ouro \\
\hline 12. & Estado de Conservação: Bom; apresenta-se se estável \\
\hline 13. & $\begin{array}{l}\text { Dimensões: } \\
\text { Altura: } 120 \mathrm{~cm} \\
\text { Largura: } 35 \mathrm{~cm} \\
\text { Profundidade: } 25 \mathrm{~cm} \\
\end{array}$ \\
\hline 14. & Restauro: apresenta sinais de reintegração cromática \\
\hline 15. & Datas: último quartel do século XVIII \\
\hline 16. & Proveniência: igreja de São Francisco em Vinhais \\
\hline 17. & Autoria: desconhecida \\
\hline 18. & Oficina: Porto $\backslash$ Braga \\
\hline 19. & $\begin{array}{l}\text { Localização (atual): - A escultura está colocada no altar-mor sobre o } \\
\text { sacrário }\end{array}$ \\
\hline 20. & Histórico do objeto: não se conhecem registos \\
\hline 21. & Iconografia: Cruz; chagas; \\
\hline 22. & Irmandade: Ordem Franciscana Secular \\
\hline 23. & Procissões: não se conhecem registos \\
\hline
\end{tabular}




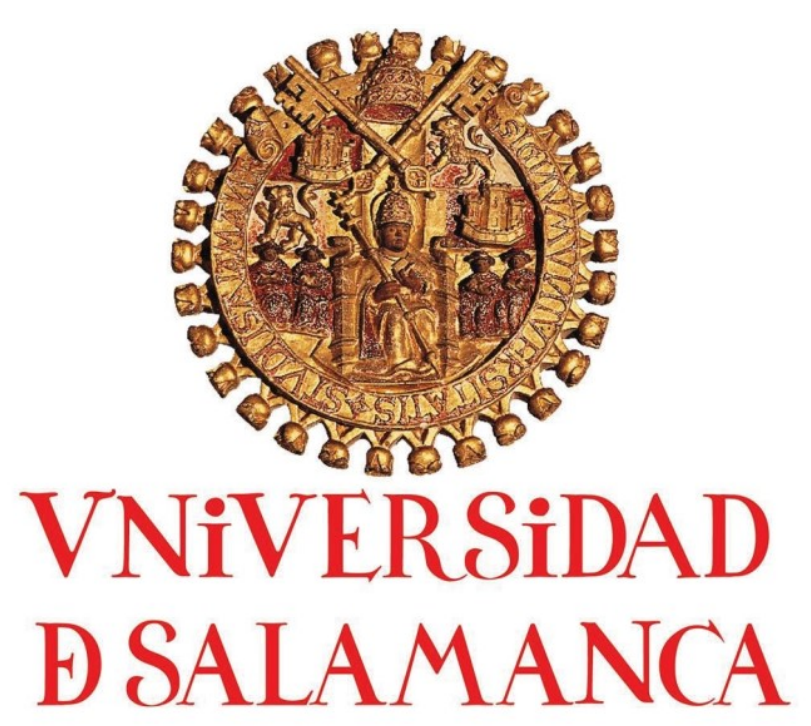

FACULTAD DE GEOGRAFÍA E HISTORIA

Departamento de Historia del Arte - Bellas Artes

TESIS DOCTORAL

\section{A ESCULTURA DA ORDEMFRANCISCANA DA DIOCESE DE BRAGANÇA-MIRANDA}

Tomo II

Maria Emília Pires Nogueiro

Diretora: Dra. Dña. Margarita Ruiz Maldonado 



\section{ANÁLISE FORMAL:}

DATAÇÕES E AUTORIAS; AS ESCULTURAS DA ORDEM DE SÃO FRANCISCO NA DIOCESE DE BRAGANÇA-MIRANDA NO CONTEXTO DA PRODUÇÃO DE ESCULTURA NACIONAL

- SÉCULO XV

- SÉCULO XVI

- SÉCULO XVII

- SÉCULO XVIII 
A escultura que ainda hoje podemos encontrar nos espaços outrora ocupados pela família franciscana na diocese de Bragança-Miranda data, na sua esmagadora maioria do século XVIII. No entanto, encontramos alguns exemplares que podemos datar ainda dos finais do século XV, bem como, e também em número reduzido do século XVI, e com uma crescente produção passível de ser identificada com o século XVII.

A escassez documental relativa à autoria das obras no interior dos espaços monásticos e conventuais é comumente conotada com a presença de monges ou frades escultores, entalhadores ou carpinteiros dentro das próprias ordens ${ }^{1}$, que estavam por isso desvinculados a contratos ou outro tipo de registo escrito. Esta prática é entendida no presente âmbito de estudo como um fator relevante para a ausência documental sobre as esculturas. Mas, a extinção das Ordens Religiosas, a consequente desamortização e o passo do tempo também contribuíram para a perda de documentos. Lamentavelmente verificamos que este fenómeno é transversal a vários outros territórios, tal como acontece, entre outros locais com as esculturas do mosteiro de Alcobaça, apesar da sua relevância no contexto da produção escultórica nacional. Quando existe alguma documentação é muito escassa em elementos. Os nomes e em alguns casos a naturalidade e a profissão são os dados registados, o que não nos permite perceber a escola ou oficina de origem dos autores nem as obras que produziram. Este aspeto é comum à maioria da documentação de registo de escultura e da talha relativa aos séculos XVII e XVIII. Outro elemento condicionante da segura afirmação da autoria das esculturas relaciona-se com o contexto de uma oficina local (ou regional) onde se confundem as obras retabulares com a imaginária, sendo a segunda claramente menos valorizada que a primeira. Este procedimento promove nos registos dos contratos de obra, que a partir do século XVIII se tornam mais frequentes, a referência aos entalhadores e a ausência dos nomes dos imaginários ou escultores, o que gera a dúvida se seriam os mesmos profissionais a assumir ambas as produções.

A individualidade artística é na escultura, mais até que outras categorias das artes plásticas, muito difícil de definir. A autoria das obras é na maioria dos casos

\footnotetext{
${ }^{1}$ Pereira, José Fernandes, "O barroco do século XVII: transição e mudança" in Paulo Pereira (direção), História da Arte Portuguesa, Volume III, Lisboa, Círculo de Leitores, 1995, pp. 11-49; Pereira, José Fernandes, "Estética barroca I: arquitectura e escultura", in Dalila Rodrigues (Coord.), Arte Portuguesa Da Pré-História ao Século XX, volume 12, Lisboa, Fubu Editores, 2009, pp. 7-136; Carvalho, Maria João Vilhena de, "A Escultura portuguesa entre a pedra, a madeira e o barro (1450-1580)" in Dalila Rodrigues (Coord.), Arte Portuguesa - Da Pré-História ao Século XX, volume 7, Lisboa, Fubu Editores, 2009, pp. 11-65; Folgar De La Calle, Maria Carmen, "La influencia portuguesa en los retablos barrocos de Galicia", Actas do II Congresso Internacional, Porto, Universidade do Porto, Faculdade de Letras. Departamento de Ciências e Técnicas do Património, 2003, pag. 475-490.
} 
desconhecida, e não apenas pelo baixo nível de importância social dos mestres escultores, mas porque, da conceção à execução a obra escultórica era entendida como obra coletiva ${ }^{2}$. Neste contexto, a ausência documental que registe as autorias e os encomendadores das obras em estudo sugere a constância da dúvida e promove uma cautelosa abordagem à datação, filiação e influências que apenas podemos deduzir a

partir da comparação com obras coevas. Na aproximação à produção local é imprescindível a reflexão sobre os condicionalismos geográficos e históricos que moldaram as formas que a escultura veio a assumir ao longo do período abordado. A periferia do território estudado, face aos diversos centros de produção artística que foram emergindo no território nacional, constitui um parâmetro significativo para esta aproximação. Neste sentido, a permanência dos arcaísmos e a pouca mestria técnica de alguma produção local intensificam as nossas dúvidas. Mas, a ampla produção escultórica, relativamente à produção das restantes artes plásticas que preenchem os interiores, propicia-nos o questionamento acerca da superação desses condicionalismos.

O estudo da arte portuguesa reflete ainda hoje o desequilíbrio entre a cultura rural e a cultura urbana. No entanto, as duas matrizes são constantes e nunca se separam exceto no seu limite extremo. Como características definidoras podemos apontar: a notável longanimidade no predomínio da conjuntura da ingenuidade popular de sobrecarga emocional; e a descontinuidade no predomínio de elementos exógenos relativamente às estruturas cultas e racionalizantes ${ }^{3}$. O âmbito cronológico deste estudo inicia-se no momento da fundação da primeira casa franciscana no distrito de Bragança - o convento de São Francisco de Bragança, em finais do século XIII e termina com o Decreto de 30 de Maio de 1834 segundo o qual foram extintos todos os conventos, mosteiros, colégios, hospícios e casas de religiosos de todas as ordens religiosas. Não chegaram aos nossos dias esculturas do século XIII ou do século XIV. Mas é no convento de São Francisco de Bragança que se regista maior constância diacrónica na encomenda das esculturas.

\footnotetext{
${ }^{2}$ de Sousa, Ernesto, Para o estudo da escultura portuguesa, Lisboa, Livros Horizonte, 1973 (2ª edição), pp. 31, 32 .

${ }^{3}$ Ernesto de Sousa refere a preferência pela designação de arte "ingénua" em vez de "popular". de Sousa,
Ernesto, Para o estudo da escultura portuguesa, Lisboa, Livros Horizonte, 1973 ( $2^{\mathrm{a}}$ edição), p. 11. Para o
estudo da escultura portuguesa; dada a constância da "ingenuidade" e a descontinuidade da erudição, bem
como, a intrincada teia que se estabelece entre ambas as linguagens optamos também pela designação de
"ingénua" para caracterizar as obras de gosto menos submetido às formas teóricas e ao sentido crítico das
mesmas. No entanto, mantemos a reserva quanto à categorização entre arte popular e erudita, e apenas
enquanto facilitadora na aproximação ao entendimento das obras se usa.
} 


\section{SÉCULO XV}

A escultura do século XV em Portugal ficou marcada pelo vigor do estaleiro de Coimbra e do Mosteiro de Santa Maria da Vitória na Batalha nos trabalhos de pedra calcária branda.

Desconhece-se a produção escultórica de vulto em pedra no território de Bragança durante o século XV. E a tradicional persistência de valores arcaizantes no gosto da encomenda local não deve ser esquecida na atribuição de datas às obras que atualmente podemos contemplar. Mas a presença de esculturas com elementos anteriores à introdução dos valores transalpinos parece bastante notória. As imagens que formalmente se identificam com a estatuária produzida durante o século XV estão atualmente expostas no Museu de Arte Sacra de Vinhais. Tratam-se de duas imagens em madeira que representam São Francisco de Assis (Imagem 1) e São Miguel Arcanjo (Imagem 2).

A informação que consta na legenda que acompanha a escultura de São Francisco de Assis coloca a imagem no século XVII, bem como o catálogo de Imagens e Escultura da Diocese ${ }^{4}$.

No entanto, pela estaticidade da posição frontal da figura que eleva junto ao corpo ambos os braços com as palmas das mãos estigmatizadas voltadas para a frente; pelo rosto oval sumariamente esculpido nos detalhes anatómicos e pelo pregueado uniforme e pouco naturalista parece mais próxima da produção escultórica do século XV que do século XVII. As mangas do hábito em fole de harmónio são uma convenção vulgar da estatuária portuguesa da segunda metade de quatrocentos ${ }^{5}$.

A conjugação destes elementos sugere tratar-se de uma obra ainda próxima aos valores estéticos do gótico.

A escultura, alterada por vandalismo ou por descuido apresenta-se manchada com tinta negra sobre o lado esquerdo do rosto abrangendo ainda parte do hábito. São também percetíveis sinais de ter sido queimada (Imagem 3).

\footnotetext{
${ }^{4}$ Gomes, José Manuel (Coord.), Imagens e escultura. 1545-1995 Comemorações Jubilares dos 450 Anos da Diocese de Bragança - Miranda, Bragança, Departamento de Liturgia e Património Cultural da Diocese de Bragança - Miranda e Comissão de Arte Sacra, 1996, p. 15.

${ }^{5}$ Gonçalves, Flávio., História da arte; Iconografia e Crítica., Lisboa, Imprensa Nacional Casa da Moeda, 1990 , p. 66.
} 


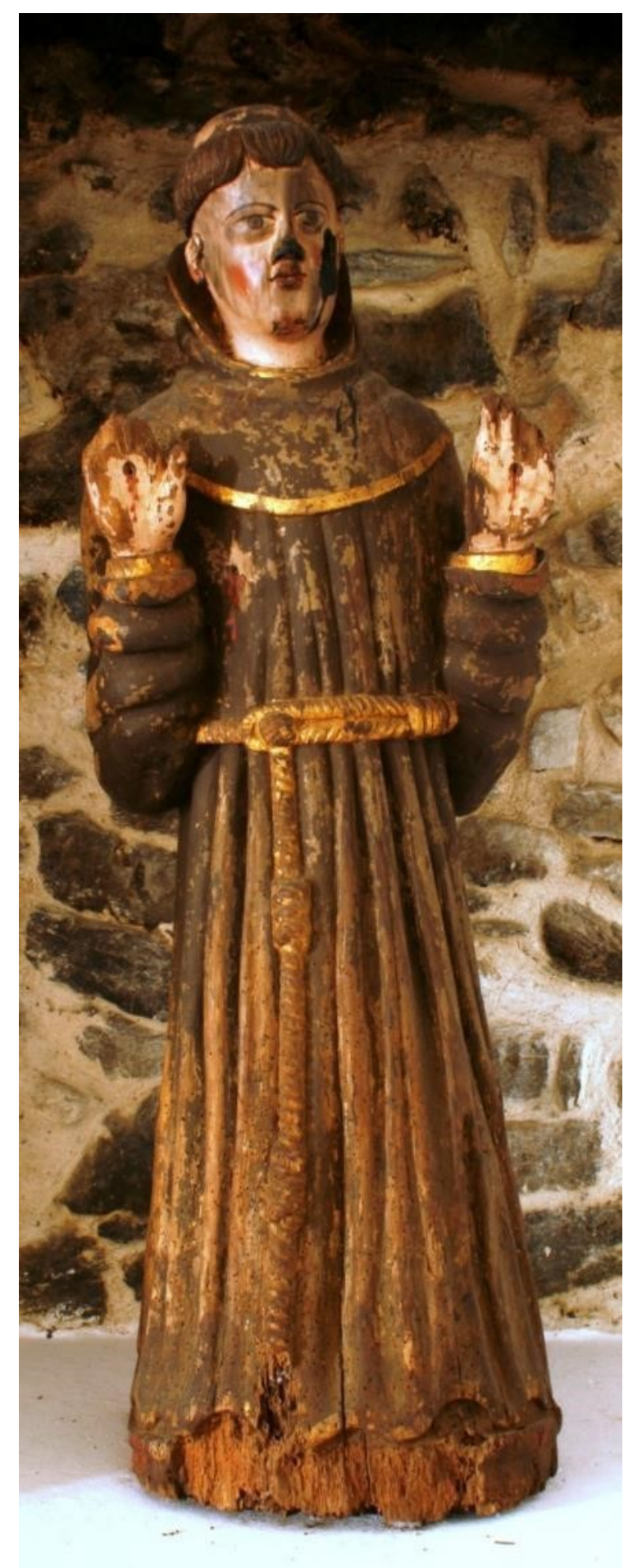

Imagem 1

São Francisco de Assis - MASV 01 Museu de Arte Sacra, Vinhais

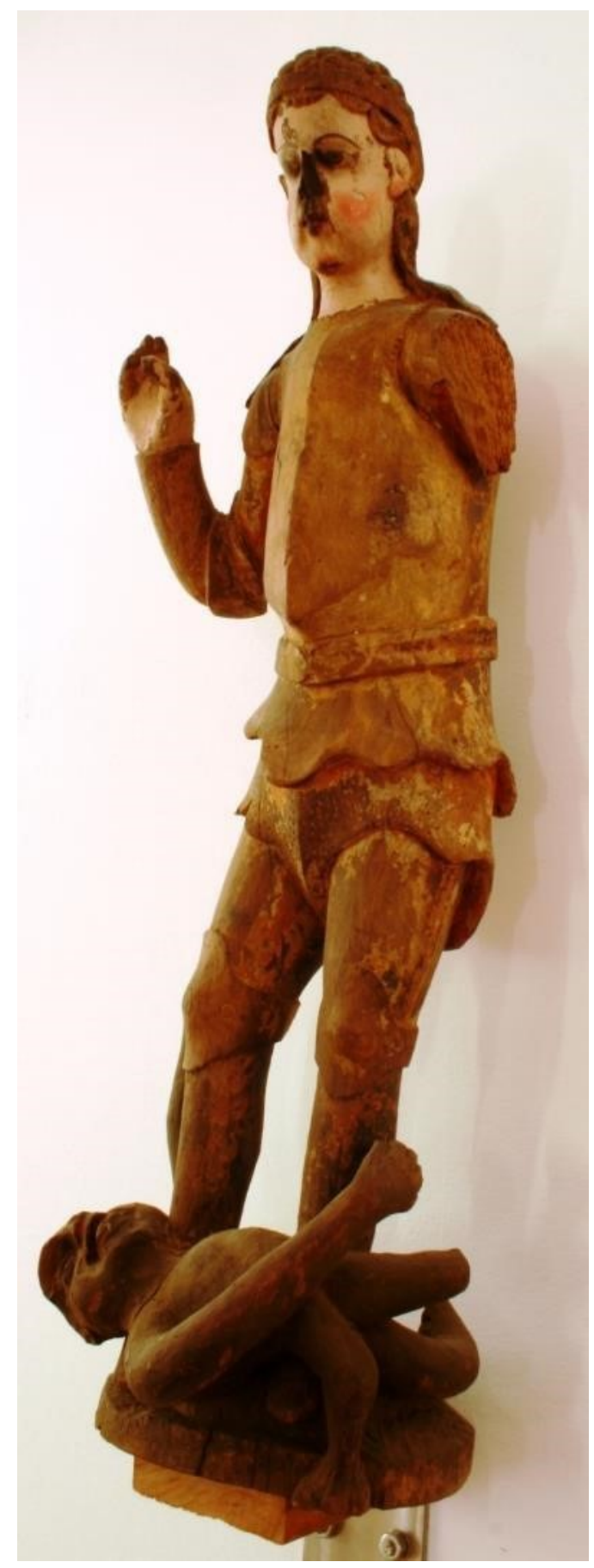

Imagem 2

São Miguel Arcanjo - MASV 03

Museu de Arte Sacra, Vinhais

Com um processo histórico idêntico à escultura de São Francisco está também no Museu de Arte Sacra de Vinhais a imagem do São Miguel Arcanjo (Imagem 2). Tratase de uma representação formalmente semelhante. Tal como a imagem de São Francisco 
a escultura de São Miguel Arcanjo está no catálogo de $1996^{6}$ datada do século XVII, bem como na legenda que acompanha a escultura. Mas, a estaticidade da representação do corpo apenas levemente dobrado pela anca, a falta de naturalismo no gesto, muito preso ao volume do corpo, e o couraçado liso que enverga com ombreiras e joelheiras, remetem formalmente a imagem para os finais do século XV, princípios do século XVI.

Atualmente estão já perdidos os atributos da lança e a balança que susteria originalmente, assim como as assas, o que constitui uma perda significativa na leitura da obra. O rosto é oval, modelado sumariamente com amenos volumes arredondados. Os contornos juvenis da boca são idênticos em ambas as esculturas. Nos olhos também se assemelham, muito abertos e inexpressivos, fixos axialmente e pintados sobre a carnação do rosto. Repintes executados posteriormente sobre a boca e pómulos do rosto parecem ter poupado os olhos que mantêm os contornos arcaizantes (Imagem 4). O cabelo, curto e encaracolado com modelado sumário ostenta uma fita sobre a frente que prende detrás das orelhas e cai sobre os ombros.

As dúvidas formais levantadas pelo arcaísmo das formas de ambas as esculturas e que nos impelem cronologicamente para os finais do século XV ou inícios do XVI são reforçadas pelo facto de se encontrarem no Museu de Arte Sacra de Vinhais. O Museu expõe obras encontradas nos espaços franciscanos de Vinhais que constitui aquele cuja ocupação é mais tardia no território em estudo, pois apenas em finais do século XVI se instalam as Clarissas em Vinhais e o Seminário Apostólico é fundado em meados do século XVIII. A origem destas duas esculturas é desconhecida apenas se sabe que até 1996 estavam guardadas na sacristia da Igreja do Seminário Apostólico de Vinhais. A descontextualização acresce dificuldade no estudo das obras, na medida em que, nas cronologias que nos parecem sugerir os contornos formais das esculturas não existia ainda qualquer espaço em Vinhais da família franciscana, apenas Bragança contava já havia dois séculos com a presença dos frades menores. Mas, formalmente são as esculturas que mais se assemelham aos modelos escultóricos do seculo $\mathrm{XV}^{7}$ de todo o conjunto de imaginária franciscana estudada.

\footnotetext{
${ }^{6}$ Ambas as imagens em conjunto com uma terceira figura que representa São Vicente foram encontradas na sacristia da igreja de Nossa Senhora da Encarnação do Seminário Apostólico de Vinhais, conforme informação no catálogo Imagens e escultura das Comemorações Jubilares dos 450 anos da Diocese de Bragança - Miranda. Gomes, José Manuel (Coord.), Imagens e escultura. 1545-1995 Comemorações Jubilares dos 450 Anos da Diocese de Bragança - Miranda, Bragança, Departamento de Liturgia e Património Cultural da Diocese de Bragança - Miranda e Comissão de Arte Sacra, 1996,p.15.

${ }^{7}$ Durante o século XV em Portugal destaca-se estatuário Gil Eanes que terá sido o principal escultor do mosteiro da Batalha e o seu auxiliar Afonso Martins. Assim como João Afonso ativo nos meados do
} 

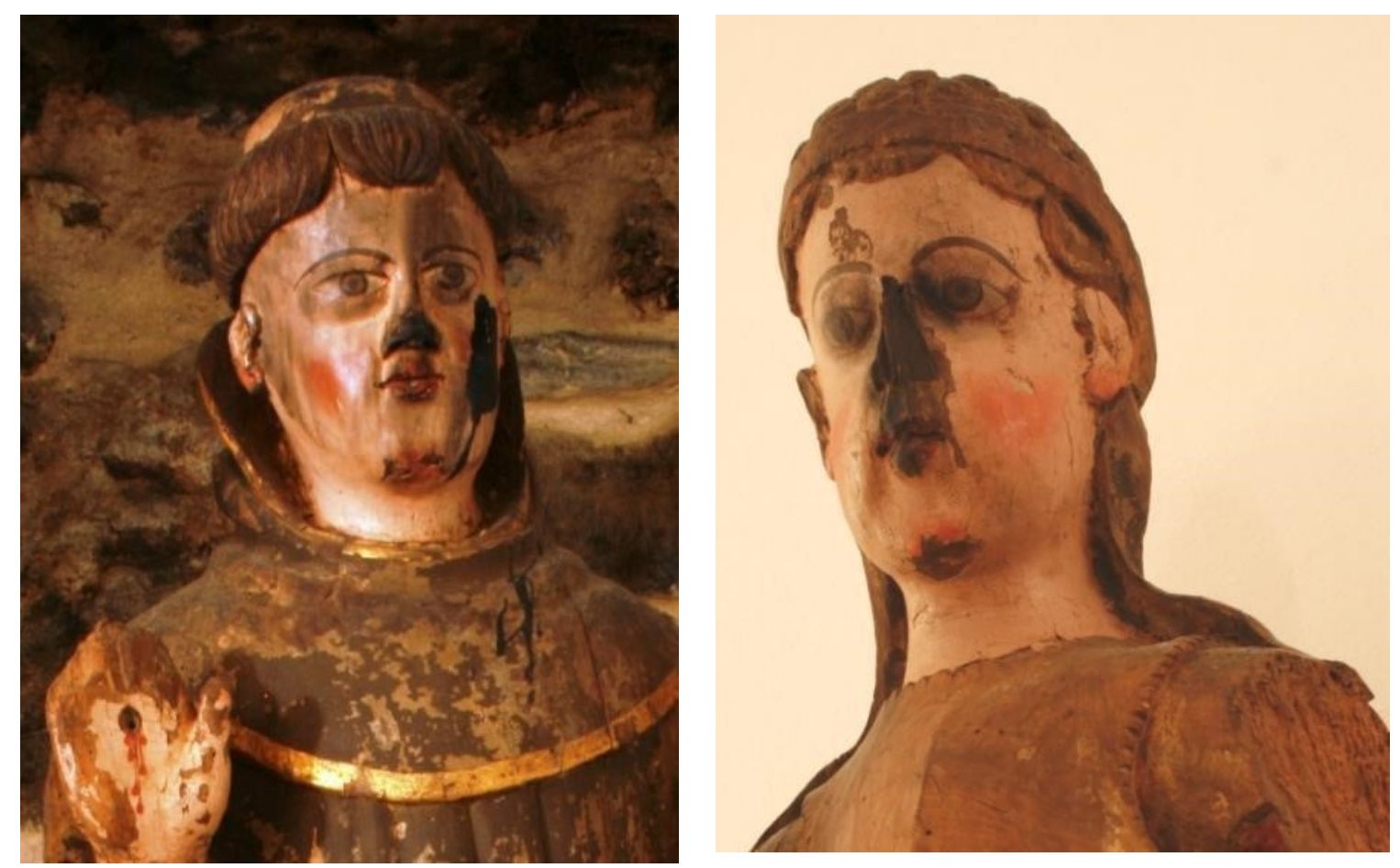

Imagem 3

Pormenor do rosto São Francisco - MASV 01 Museu de Arte Sacra, Vinhais

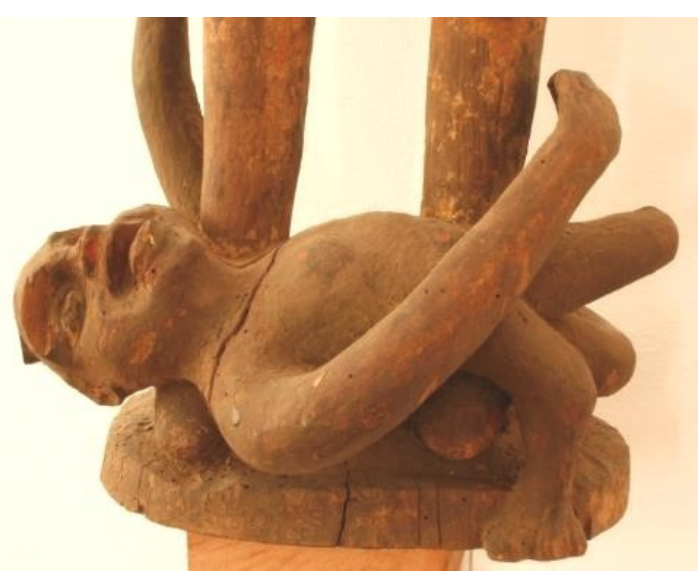

Imagem 4 e 5

Pormenor do rosto de São Miguel Arcanjo e do demónio - MASV 03

Museu de Arte Sacra, Vinhais

século XV e que se distingue pelo: ritmo sinuoso descrito pelos corpos, as roupagens articuladas em pregas largas, que se quebram em três ou quatro curvas, o ar doce das figuras femininas, de mãos com modelado sumário e cabelos corredios coroados por rosas e caindo em ondas largas pelas costas, os santos de cabelo cortado «à chamorro», à maneira da época, por vezes com as roupagens descrevendo pregas verticais, em canudos. Como característica formal de João Afonso destaca-se o oval da cabeça e as espessas pregas dos panejamentos. As obras que o autor deixou foram sobretudo na região de Coimbra, mas também Penha Garcia e Arouca. Goulão, Maria José, "Figuras do Além. A escultura e a tumulária. A escultura." in Paulo Pereira (Direção) História da Arte Portuguesa, volume II, Lisboa, Circulo de Leitores, 1995, pp. 156-179. 
O século XV ampliou a crise que já desde meados do século XIV se observava na alteração da religiosidade decorrente da laicização e vulgarização da cultura. A produção artística, apesar de estar ainda dependente da encomenda e do mecenato abriase à demanda de um público cada vez mais vasto mas também menos culto. Daí o aumento das imagens mais ingénuas ${ }^{8}$. O realismo nas atitudes nos gestos e nos rostos revela um interesse e cuidados crescentes. Na figuração ganha importância o tratamento do corpo cujos panejamentos acompanham a anatomia de modo mais natural.

No entanto estas originalidades formais não se observam na estatuária em estudo. As justificações desta ausência devem relacionar-se com as particularidades do território, tradicionalmente pouco povoado e periférico em relação aos diversos centros de poder que se foram constituindo no país. Mas, devocionalmente as esculturas de São Francisco e São Miguel Arcanjo constituem modelos iconográficos preferenciais do século XV em Portugal, não sendo este um critério suficiente para a contextualização temporal é mais um elemento de leitura, que aprofundaremos na análise iconográfica das obras.

\footnotetext{
${ }^{8} \mathrm{~A}$ alteração dos modelos iconográficos privilegiou os Calvários, a Paixão de Cristo e o sofrimento da Virgem, mas também diversas devoções taumatúrgicas reforçando o poder milagroso dos santos como intercessores junto a Deus. Os apóstolos São Pedro e São Paulo, São Bartolomeu, Santiago e São João são os mais representados, juntamente com os três diáconos-mártires São Vicente, São Lourenço e Santo Estevão, e ainda São Miguel. Goulão, Maria José, "Figuras do Além. A escultura e a tumulária. A escultura." in Paulo Pereira (Direção) História da Arte Portuguesa, volume II, Lisboa, Circulo de Leitores, 1995, pp. 156-179.
} 


\section{SÉCULO XVI}

A figuração desenvolveu-se em Portugal durante o século XVI pelos contactos cada vez mais amplos e sistematizados com outras linguagens de outros territórios. Podemos relacionar esta amplificação de influências com a imagem de Cristo Crucificado (Imagem 6 e 7) que está ainda hoje na igreja de São Francisco de Bragança.

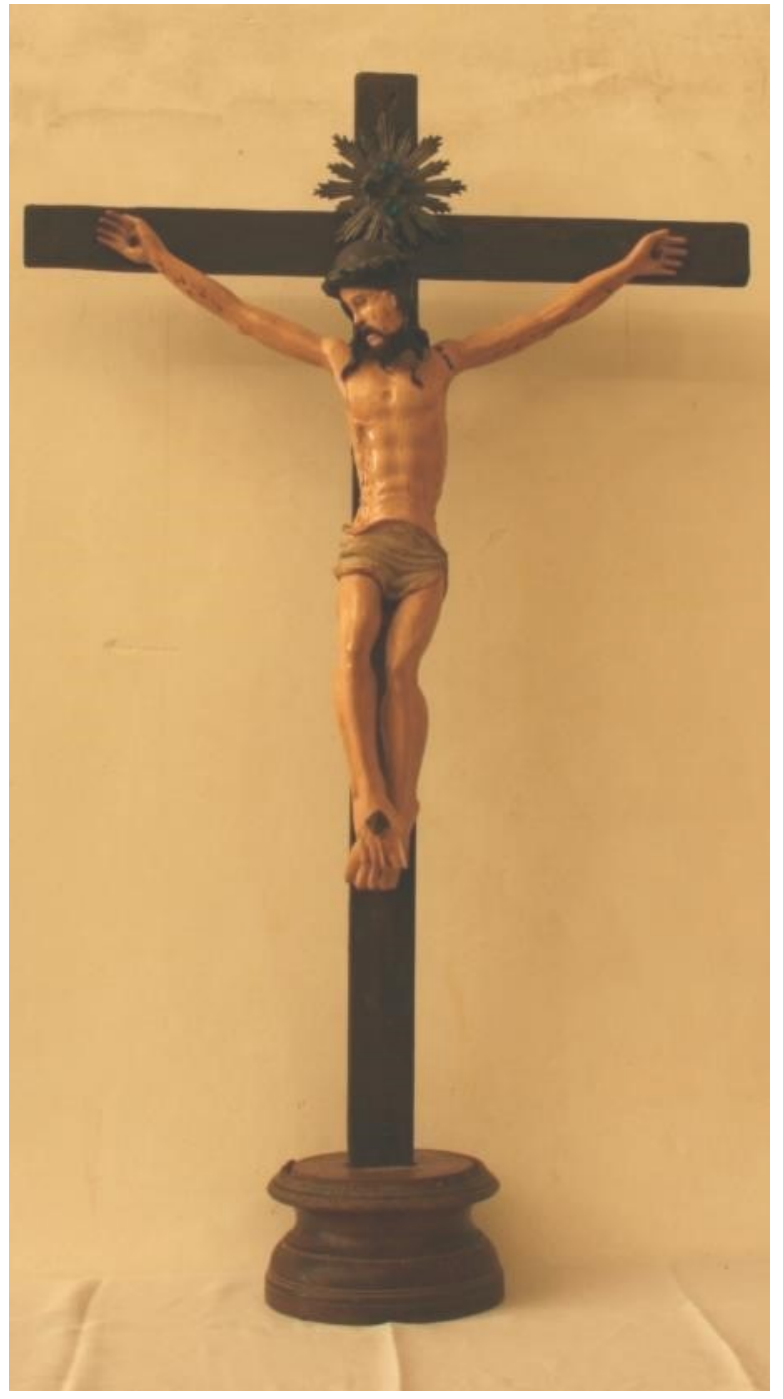

Imagem 6

Cristo Crucificado - SFB 22 Igreja de São Francisco Bragança

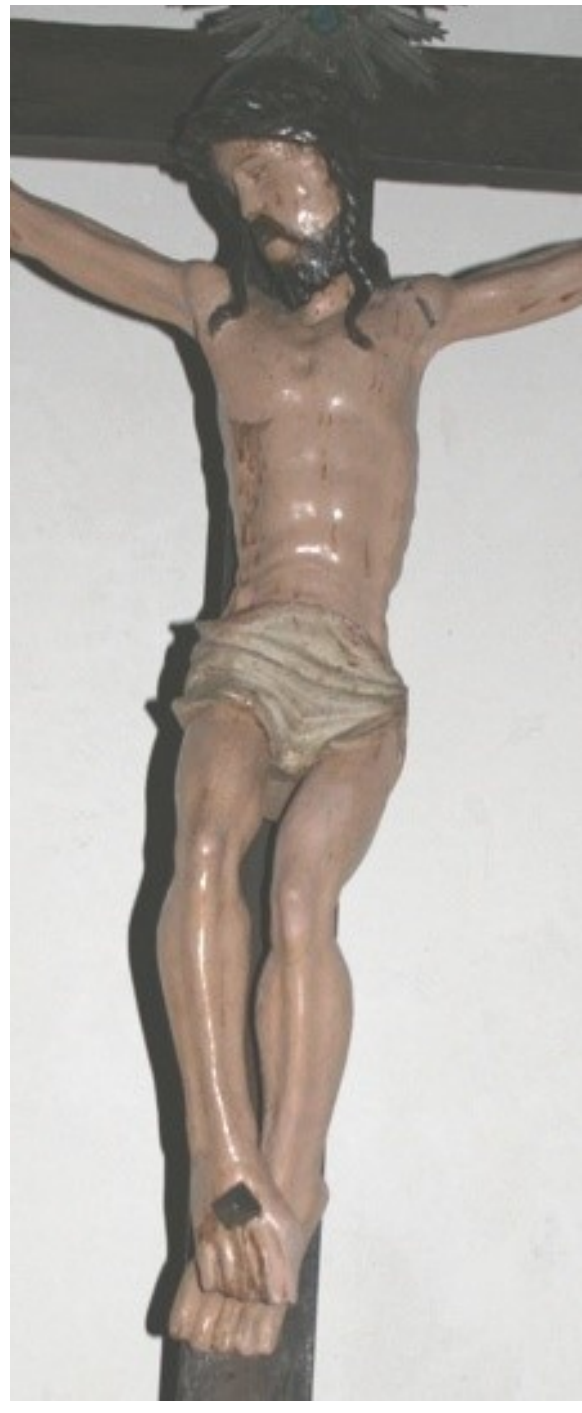

Imagem 7

Cristo Crucificado - SFB 22 Igreja de São Francisco Bragança

A figura apesar de algumas irregularidades apresenta um evidente cuidado nos pormenores anatómicos do tronco e braços muito esquálidos que contrastam com a força das pernas e sobretudo com a rudeza dos pés e mãos. A importância dada no 
tratamento do corpo sobressai pela ausência de qualquer vestígio de sangue do martírio. O cendal apresenta um tratamento sumário nas pregas e volumetria caindo de forma estática e praticamente não avultando da silhueta do corpo. A imagem pode relacionarse com o contacto com os artistas flamengos que se dava através da importação direta das imagens de madeira de Antuérpia, decorrente das relações comerciais entre ambos os países. Mas também pela presença de artistas flamengos no território português, (como foi o caso de Olivier de Gand enquanto esculpiu as imagens policromadas de grandes dimensões para a charola de Tomar entre 1508 e 1512) . $^{9}$

Poderá ser este o contexto que permitiu a presença da imagem de Cristo Crucificado na igreja do convento de São Francisco em Bragança. A posição de martírio com os braços muito abertos denota a proximidade aos modelos formalmente mais regulares do último quartel do século XVI da produção flamenga. Os pormenores anatómicos detalhadamente esculpidos revelem o gosto dos Países Baixos, assim como as irregularidades nas proporções se pode ler como consequência da fabricação seriada.

Com proximidades formais com a escultura produzida durante o século XVI é também a imagem de Nossa Senhora do Rosário da igreja de São Francisco em Bragança (Imagem 8 e 9). A figura apresenta-se com um pregueado muito plástico, em posição frontal com ligeiríssimo contraposto, que não é suficiente para quebrar a estaticidade do gesto. Estes parâmetros aproximam a obra da produção escultórica do século XVI, ou até já do século XVII. Mas o tratamento da cabeça, com os cabelos lisos a escorrer sobre os ombros e o grosso pescoço, podem sugerir o contacto com as esculturas de Coimbra do século XVI.

\footnotetext{
${ }^{9}$ Atualmente existem em diversos museus vários exemplos da importação direta da Flandres e da Renânia. O elevado número de pequenas imagens de fabricação seriada importadas por atacado devido ao baixo custo o que permitia o seu uso doméstico em oratórios privados. Constituíram, devido à sua ampla difusão, uma importante influência na produção nacional. De Inglaterra também se importavam grandes quantidades de figuras de vulto e placas relevadas em alabastro que representavam sobretudo devoções à Virgem e diversas devoções hagiológicas, segundo Goulão, referindo estudos de Jorge Dias, não tiveram especial influência na produção nacional, à exceção da iconografia dos Calvários das oficinas de Coimbra. Goulão, Maria José, "Figuras do Além. A escultura e a tumulária. A escultura." in Paulo Pereira (Direção) História da Arte Portuguesa, volume II, Lisboa, Circulo de Leitores, 1995, pp. 156-179; Carvalho, Maria João Vilhena de, "A Escultura portuguesa entre a pedra, a madeira e o barro (14501580)" in Dalila Rodrigues (Coord.), Arte Portuguesa - Da Pré-História ao Século XX, volume 7, Lisboa, Fubu Editores, 2009, pp. 11-65. As esculturas eram até ao século XV normalmente policromadas, a partir dessa data certas oficinas deixavam a madeira natural, podendo, ou não, ser posteriormente policromada. Este processo de permanente produção dificulta a identificação dos autores. Figueiredo, Maria Rosa, Escultura Europeia, Volume II, Lisboa, Fundação Calouste Gulbenkian, 1999, pp. 32-35.
} 


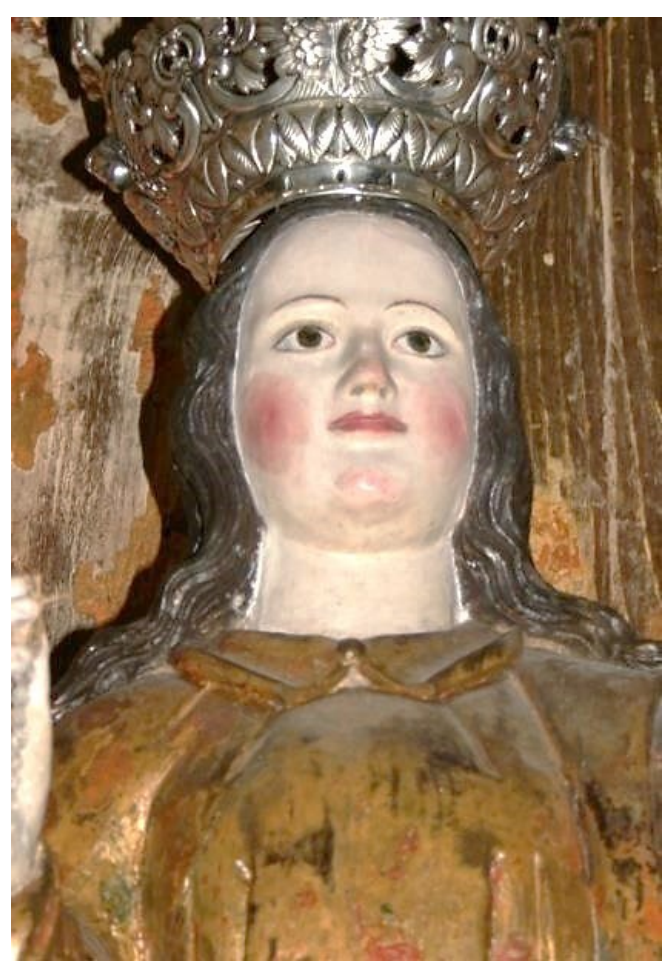

Imagem 8

Nossa Senhora do Rosário - SFB 10 (pormenor do rosto), Igreja de São Francisco Bragança

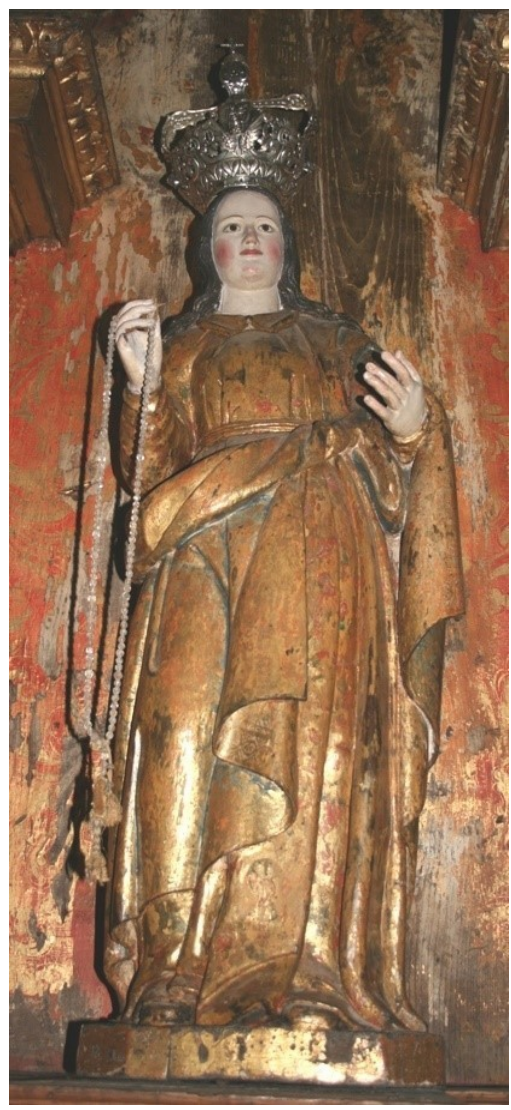

Imagem 9

Nossa Senhora do Rosário - SFB 10

Igreja de São Francisco Bragança

\section{É no plástico e ondulado grosso dos panejamentos que a figura de Nossa Senhora do}

Rosário mais se afasta da linguagem tardo gótica coimbrã, mas a cabeça e o grosso

pescoço indicam a persistência desses valores estéticos do século XVI ${ }^{10}$. A escultura

\footnotetext{
${ }^{10}$ Da linguagem tardo-gótica coimbrã destaca-se a figura de Diogo Pires-o-Velho, ativo até aos princípios do século XVI. Identifica-se pelos trabalhos apegados aos formulários góticos mas com um bom lançamento dos panejamentos finos que deixam adivinhar o corpo e um atento naturalismo assim como, pelo trabalho de composição das figuras menos convencional. Neste sentido destaca a Virgem com o Menino da igreja matriz de Leça da Palmeira, oferecida por Afonso V em 1481, em calcário de Coimbra, e que revela um forte naturalismo no tratamento da cabeça, com os cabelos lisos a escorrer sobre os ombros e o pescoço grosso, também as mangas do Menino apresentam a particularidade de estarem esculpidas com pregas transversais e angulosas a formar harmónio. Na mesma centúria e possivelmente ligado por laços de parentesco a Diogo Pires-o-Velho, Diogo Pires-o-Moço é um continuador da sua obra. Enquadrado ainda na estética medieval as suas obras destacam-se pelo gosto tardo gótico evoluindo mais tarde para uma linguagem que já se aproxima do Renascimento Transalpino. Após as primeiras produções de marcado gosto manuelino, na figura de São Miguel (Museu de Arte Antiga) o artista já apresenta a fisionomia com dignidade no tratamento correto da anatomia e a serenidade própria dos artistas renascentistas mas revela também a profunda influência dos imaginários flamengos no gosto pelo pitoresco e no tratamento minucioso dos adornos. Goulão, Maria José, "Figuras do Além. A escultura e a tumulária. A escultura." in Paulo Pereira (Direção) História da Arte Portuguesa, volume II, Lisboa, Circulo de Leitores, 1995, pp. 156-179; Carvalho, Maria João Vilhena de, "A Escultura portuguesa entre a pedra, a madeira e o barro (1450-1580)" in Dalila Rodrigues (Coord.), Arte Portuguesa - Da PréHistória ao Século XX, volume 7, Lisboa, Fubu Editores, 2009, pp. 11-65.
} 
não vem referida no inventário de 1834, mas Cardoso Borges registou o culto de Nossa Senhora do Rosário em 1721-1724, com irmandade de militares ${ }^{11}$.

O convento de São Francisco de Bragança recebeu ao longo do século XVI, sobretudo na segunda metade, algumas melhorias documentadas em relação às intervenções no edificado, que se relacionaram com a extinção do mosteiro beneditino de Castro de Avelãs e com a reutilização dos seus materiais de construção (madeiras). Do mesmo período são os frescos ${ }^{12}$ (redescobertos no final do século XX) sobre a abside do altarmor. Neste contexto de reafirmação do convento, que entretanto deixa de pertencer à linha Conventual e adota a Observância, seria expectável que novas obras fossem encomendadas de acordo com as novas orientações emergentes.

Em meados do século XVI a difusão do ornato clássico oferecia uma alternativa à linguagem gótica e à já exausta decoração manuelina. A irreprimível mutação do gosto supôs porém uma lenta e difícil passagem à prática dos novos modelos, mormente na arquitetura. Será pois na escultura, sobretudo na escultura arquitetónica que a experimentação vai encontrar campo mais amplo. Os mestres do ornato clássico aplicado aos relevos eram em Portugal quase todos mestres pedreiros oriundos da região cantábrica de Santander, os Biscainhos. A estes seguiram-se os escultores-arquitetos, dos quais se destacavam os artistas franceses oriundos da Normandia. Estas duas vagas que ocuparam a segunda e terceira décadas do século XVI provocaram a mutação plena do gosto artístico ${ }^{13}$.

O biscainho João de Castilho, com a queda em desgraça de Boitaca em 1515, torna-se mestre-de-obras do Mosteiro de Belém em 1517, que constituía o mais importante

\footnotetext{
${ }^{11}$ Borges, José Cardoso, Memórias de Bragança, Fernando de Sousa (Coord.), Bragança, CEPESE /
} Câmara Municipal de Bragança, 2012 (texto original de 1721-1724), p. 142.

${ }^{12}$ Sobre os frescos na abside da igreja de São Francisco de Bragança ver: Afonso, Luís U., "Manter a freguesia no século XVI: os frescos de S. Francisco de Bragança e a Virgem da Misericórdia" Cadernos Terras Quentes, 2, 2005, pp. 168-176; Lopes, Inês Afonso, "O papel do sujeito face à imagem. Interpretações estruturo-fenomenológicas: o estudo de caso das pinturas murais de São Francisco de Bragança", Medievalista, [Online], 11, Disponível em: http://medievalista.revues.org/834\#quotation, 2012, pp. 1 - 29.

${ }^{13}$ Importante foi também a influência decorrente da importação dos mármores de Itália, das oficinas de Génova, fundamentalmente constituídos por escultura arquitetónica, como colunas e capitéis, pormenores decorativos, portais e chaminés, apesar de não terem chegado aos nossos dias constituem uma importante referencia na transmissão dos modelos classicizantes. O imaginário dos mascarões vegetais, os putti, troféus militares, bucrâneos, aras sagradas, golfinhos e aves, tochas em chama e cornucópias, não obstante os contornos quase pagãos rapidamente foram envolvidos nas obras religiosas, aplicados muitas vezes sobre estruturas ainda góticas e manuelinas.Moreira, Rafael, "A escultura ornamental e os programas proto-renascentistas" in Paulo Pereira (direção), História da Arte Portuguesa. Volume II, Lisboa, Círculo de Leitores, 1995, pp. 321-327. 
estaleiro de obras em Portugal. Atrás dele chegou uma legião de artífices da Biscaia e muitos artistas flamencos e franceses ${ }^{14}$. Apesar de podermos ainda, no território em estudo, encontrar portais, onde é percetível a influência de João de Ruão ${ }^{15}$ (portal da igreja do convento das clarissas de Bragança) e até retábulos (retábulos do transepto da igreja de São Francisco Mogadouro), formalmente próximos ao gosto maneirista do século XVI a imaginária que chegou aos nossos dias é bastante escassa. No entanto, se ampliarmos a perspetiva percebe-se que o século XVI foi particularmente profícuo no território em estudo sobretudo na arquitetura encomendada para as novas funções e ordens que se implementam no território. A ausência de esculturas no convento de São Francisco em Bragança não pode ser dissociada das novas dinâmicas eclesiásticas que emergem nesse século. Das dinâmicas religiosas que podem ter interferido diretamente nas possibilidades de encomenda do convento de São Francisco em Bragança destacamos: a criação da Diocese de Miranda-Bragança em $1545^{16}$; a fundação do

\footnotetext{
${ }^{14}$ Nicolau de Chanterene chegou de França e integrado no ambiente culto da corte foi protegido pelo mecenas D. Álvaro da Costa, cujo sepulcro esculpiu em 1535. De França chegou ainda Filipe Hodart, que esteve fugazmente em Coimbra entre 1530 e 1535 onde modelou uma Última Ceia em barro cozido para o refeitório de Santa Cruz constituída por treze figuras de uma "vivacidade e agitação quase barrocas". Moreira, Rafael, "A escultura ornamental e os programas proto-renascentistas" in Paulo Pereira (direção), História da Arte Portuguesa. Volume II, Lisboa, Círculo de Leitores, 1995, pp. 321-327; Santos, Reynaldo dos, A escultura em Portugal II, Séculos XVI a XVIII, Lisboa, Oficinas Gráficas de Bertrand (Irmãos) Ld. ', 1950, p. 24; Dias, Pedro, A Escultura Maneirista Portuguesa, Coimbra, Minerva, 1995, p. 26; Carvalho, Maria João Vilhena de, "A Escultura portuguesa entre a pedra, a madeira e o barro (14501580)" in Dalila Rodrigues (Coord.), Arte Portuguesa - Da Pré-História ao Século XX, volume 7, Lisboa, Fubu Editores, 2009, pp. 11-65. Martín González destaca as semelhanças entre os rostos modelados por Hodart e os rostos de Juan de Juni, escultor também de origem francesa, o que poderá revelar alguma proximidade na formação de ambos os escultores. Martín González, Juan José, La huella española en la escultura portuguesa, Valladolid, Sever - Cuesta, 1961, p.15.
}

15 João de Ruão esteve ativo entre 1528-1580 e a partir de Coimbra vai irradiar a sua influência nas arquiteturas retabulares talhadas na pedra de Ançã, que só no século XVII seria substituída pela madeira. Prolonga-se a partir de Coimbra o decorativismo maneirista de raiz flamenga de que Tomé Velho, interveniente em obras de Ruão e ativo entre 1574 e 1611, será um dos artistas mais profícuos, assegurando a permanência de valores plásticos que se mantêm operantes até final do século XVII. Dias, Pedro, A Escultura Maneirista Portuguesa, Coimbra, Minerva, 1995, pp. 56-75; Soromenho, Miguel, "Classicismo, italianismo e «estilo chão». O ciclo filipino." in Paulo Pereira (direção) História da Arte Portuguesa, volume II, Lisboa, Círculo de Leitores, 1995, pp. 376-403; João de Ruão tem alguma presença documental que permite atribuir-lhe portais e pórticos bem como escultura devocional, retábulos e várias pequenas obras, faleceu em Coimbra em 1580. Moreira, Rafael, "A escultura ornamental e os programas proto-renascentistas" in Paulo Pereira (direção), História da Arte Portuguesa. Volume II, Lisboa, Círculo de Leitores, 1995, pp. 321-327; Dias, Pedro, A Escultura Maneirista Portuguesa, Coimbra, Minerva, 1995, pp. 57-72; Carvalho, Maria João Vilhena de, "A Escultura portuguesa entre a pedra, a madeira e o barro (1450-1580)" in Dalila Rodrigues (Coord.), Arte Portuguesa - Da Pré-História ao Século XX, volume 7, Lisboa, Fubu Editores, 2009, pp. 11-65.

${ }^{16}$ No Corpo Diplomático Português, Relações com a Cúria Romana encontra-se a informação de Fevereiro de 1545 para a criação do bispado de Miranda. Atendendo, pois, às pretensões de el-rei D. João III, expediu o papa Paulo III, a 22 de Maio de 1545 (...) a bula «Pro Excellenti Apostolicae Sedis», que criava a nova diocese com a sua sede em Miranda do Douro, composta das comarcas de Bragança, Vinhais, Outeiro, Monforte de Rio Livre, Vimioso, Chaves e Montalegre desmembradas da diocese de 
colégio dos Jesuítas em $1561^{17}$; e a fundação da primeira casa de monjas clarissas, no convento de Santa Clara 1569 em Bragança e em 1590 a fundação do Mosteiro de Santa Escolástica para as religiosas beneditinas ${ }^{18}$.

De todas estas alterações a mais destacável foi a constituição da Diocese de MirandaBragança em 1545, e que concentrou em Miranda do Douro, ao longo da segunda metade do século XVI e todo o século XVII, o mais importante estaleiro no território aonde afluíram vários artistas de diversas proveniências (destacamos neste fluxo a figura de Gregório Fernandez que nos inícios do século XVII fez o retábulo do altarmor da catedral de Miranda do Douro, ou mais tarde o registo relativo à pintura e douramento do retábulo data de 1637 e foi da responsabilidade do pintor zamorano Alonso Remessal $)^{19}$. O impacto da presença da corte ibérica estabelecida em Valhadolid entre 1601-1606 ${ }^{20}$ é sentido em Miranda do Douro mas também nas localidades que lhe estão mais próximas nos finais do século XVI e ao longo da primeira metade do século XVII. As relações entre a prática escultórica de ambos países ibéricos esteve mais próxima durante os 80 anos de domínio filipino. Segundo Martín González essa proximidade rompeu-se após a restauração da independência em 1640 e ao longo do século XVII ambos países definiam linguagens diferenciadas, sendo a influência espanhola já quase impercetível no século XVIII português ${ }^{21}$. No entanto, recentes

Braga. Chaves e Montalegre, que na bula da erecção vêm dadas como pertenças da diocese mirandense, não chegaram a fazer parte dela por convenção entre o seu prelado e o de Braga (...) encontramos em seu lugar mencionados os concelhos de Algoso, Penas Roias, Chacim, Nuedosa (sic), Noselos, Sofulte (Sesulfe?), Vale de Asnes, Cortiços, Torre de Dona Chama, Bemposta, Azinhoso e Mirandela. Alves, Francisco Manuel, Bragança Memórias arqueológico-históricas do distrito de Bragança (2ª edição) Tomo I, Bragança, Câmara Municipal de Bragança / Instituto Português de Museus - Museu Abade de Baçal, 2000, (original publicado em 1910-1947) p. 360.

${ }^{17}$ Alves, Francisco Manuel, Bragança Memórias arqueológico-históricas do distrito de Bragança (2a edição) Tomo II, Bragança, Câmara Municipal de Bragança / Instituto Português de Museus - Museu Abade de Baçal, 2000, (original publicado em 1910-1947), p. 329.

${ }^{18}$ Alves, Francisco Manuel, Bragança Memórias arqueológico-históricas do distrito de Bragança $\left(2^{\mathrm{a}}\right.$ edição) Tomo I, Bragança, Câmara Municipal de Bragança / Instituto Português de Museus - Museu Abade de Baçal, 2000, (original publicado em 1910-1947) p. 383.

${ }^{19}$ Alves, Francisco Manuel, Bragança Memórias arqueológico-históricas do distrito de Bragança $\left(2^{\mathrm{a}}\right.$ edição) Os Notáveis - Tomo VII, Bragança, Câmara Municipal de Bragança / Instituto Português de Museus - Museu Abade de Baçal, 2000, (original publicado em 1910-1947) p. 429; Dias, Pedro, $A$ Escultura Maneirista Portuguesa, Coimbra, Minerva, 1995, pp. 92-96; Rodrigues, Luís Alexandre, Arte da talha dourada e policromada no Distrito de Bragança. Documentos. Séculos XVII-XVIII, Mirandela, João Azevedo Editor, 2005, p. 117.

\footnotetext{
${ }^{20}$ Caetano, Joaquim Oliveira, Obras-primas da arte portuguesa: Escultura, Lisboa, Athena, 2011, p. 82.

${ }^{21}$ Martín González, Juan José, La huella española en la escultura portuguesa, Valladolid, Sever - Cuesta, 1961, p. 15 .
} 
estudos revelam não a rutura mas a relação próxima que se manteve entre ambos os países sobretudo nos territórios de fronteira ${ }^{22}$. A imagem de Santa Maria Madalena, na igreja de Santa Maria do Castelo, em Bragança, é reflexo da relação com a escultura das oficinas espanholas muito similar à imagem da mesma invocação (hoje no Museu de escultura de Valhadolid), que se supõe atualmente com proximidades às produções de Pedro de $\mathrm{Mena}^{23}$, e não de Gregório Fernández, como se repete em várias publicações.

Pouco anos após a fundação da nova diocese instalaram-se em Bragança os Jesuítas. A Fundação do Colégio veio criar algumas alterações no espaço que desde o século XIII era, no âmbito das Ordens Religiosas, exclusivamente ocupado pela Ordem dos Frades Menores. Neste mesmo sentido podemos interpretar a presença das clarissas que dependentes da câmara (apesar do vínculo à mesma Ordem dos frades menores) foram possivelmente constituído mais uma rutura no favorecimento das edilidades outrora dedicado quase exclusivamente aos franciscanos.

Parece assim provável pensar que a fraca encomenda registada ao longo do século XVI no convento de São Francisco em Bragança poderá estar dependente de factores económicos. A forte demanda de recursos que a construção da catedral de Miranda do Douro exigia, a presença da Companhia de Jesus e a fundação do convento das clarissas e das monjas de Santa Escolástica geraram seguramente uma maior repartição dos favorecimentos económicos por parte da edilidade local, forte promotora do convento desde a sua fundação.

\footnotetext{
${ }^{22}$ Folgar De La Calle, Maria Carmen, "La influencia portuguesa en los retablos barrocos de Galicia", Actas do II Congresso Internacional del Barroco, Porto, Universidade do Porto, Faculdade de Letras. Departamento de Ciências e Técnicas do Património, 2003, pag. 475-490.

${ }^{23}$ Ferreira-Alves, Natália Marinho, "Pintura, Talha e Escultura (séculos XVII e XVIII) no Norte de Portugal" in Revista da Faculdade de Letras. Ciências e Técnicas do Património vol. 2, Porto, Faculdade de Letras da Universidade do Porto, Departamento de Ciências e Técnicas do Património, 2003, pp. 735756. Registou a atribuição da escultura de Maria Madalena da igreja de santa Maria em Bragança a Pedro de Mena; Também Martín González destaca a escultura de Maria Madalena da igreja de Santa Maria de Bragança como o mais importante exemplo das influências espanholas em terras portuguesas, refere ainda que tratando-se de uma cópia supera a original que está em Valhadolid, o autor destaca a improvável autoria de Gregório Fernandez, afirmando porém que se trata de uma obra das oficinas de Valhadolid. Martín González, Juan José, La huella española en la escultura portuguesa, Valladolid, Sever - Cuesta, 1961, pp. 29, 30; A autoria da escultura de "Madalena" de Pedro de Mena, autor sevilhano e colaborador de Alonso Cano é amplamente difundida na bibliografia geral mais recente. Redondo, José Ignacio Hernández, "A escultura barroca em Espanha", in Rolf Toman (edit.), O Barroco, Lisboa, Konemann, 2004, pp. 366, 367. No entanto, em catálogos recentes, ver: Azevedo, Carlos A. Moreira de, Cristo Fonte de Esperança, Porto, Edições Asa, 2000, ainda se verifica a atribuição da escultura a Gregório Fernández, pese embora a proximidade formal da imagem de Bragança com a de Madalena penitente de Pedro de Mena, atualmente exposta no Museu Nacional de Escultura de Valhadolid, sugere essa proximidade em detrimento de Gregório Fernández.
} 


\section{SÉCULO XVII}

A arte do século XVII decorre sobre o impulso da lição tridentina a propósito do valor, significado e utilidade das imagens e tem como cenário político, cultural e social os quase trinta anos das guerras da Restauração (1640-1668). O conflito entre Portugal e Espanha foi neste território de fronteira intensamente sentido.

A guerra da Restauração e o Concílio de Tento geram no âmbito artístico a possibilidade do confronto entre a arte erudita e a arte de valores mais autóctones. Sintetizando, as duas grandes correntes sobre o belo consubstanciavam-se no sistema tridentino $^{24}$ que privilegiava a ética ou no sistema clássico que privilegiava os valores estéticos. A periferia do território nacional face às correntes estéticas vigentes na Europa vão influenciar o discurso artístico português, profundamente atingido pelo ideário pós-tridentino.

A sessão XXV do Concilio de Trento foi dedicada às artes e veio sobretudo regular e reforçar a tradição que remontava já ao Concilio de Niceia de 787 do primado do conteúdo sobre a forma. Tratava-se de retomar o primado da emanação sobre o da imitação e de regulamentar o conteúdo, vigiando-se para que a ortodoxia das imagens e o seu perfil ético tivessem prioridade sobre os valores estéticos da representação ${ }^{25}$.

\footnotetext{
${ }^{24} \mathrm{O}$ sistema tridentino gera uma noção de belo que se dissolve numa ontologia e numa ética que o fundamentam e normalizam. Decorre deste enunciado que o belo não tem autonomia, sendo antes uma recorrência. Como essência reside em Deus, não tem tempo nem espaço, está para além das contingências da matéria. Por definição é informe, embora de opulenta existência e não se oferece à contemplação mas à ascese do despojamento conseguido através de um longo e penoso caminho purificador. As formas são prisioneiras da matéria, da sua continuada e inelutável degradação. As formas belas serão sempre uma ilusão, um artificio vão e tendencialmente pecaminoso. Por isso, as imagens não têm valor em si mas apenas enquanto lembranças de essências; as imagens são sempre a representação do que não tem forma, do que não tem corpo. O seu valor traduz-se na eficácia e na estratégia que visa o convencimento e a emotiva piedade. Pereira, José Fernandes, "O barroco do século XVII: transição e mudança" in Paulo Pereira (direção), História da Arte Portuguesa, Volume III, Lisboa, Círculo de Leitores, 1995, pp. 11-49; Pereira, José Fernandes, "Estética barroca I: arquitectura e escultura", in Dalila Rodrigues (Coord.), Arte Portuguesa - Da Pré-História ao Século XX, volume 12, Lisboa, Fubu Editores, 2009, pp. 7-136; Calderón, Marica López, "El Crucificado en la escultura compostelana de mediados del siglo XVIII. José Gambino, inventor de tipos e introductor de nuevas formas", in Revista da Faculdade de Letras. Ciências e Técnicas do Património, Porto, vol. IX-XI, 2010-2012, pp. 374-399; Serrão, Vítor, "Impactos do Concílio de Trento na arte portuguesa entre o Maneirismo e o Barroco (1563-1750)" in António Camões Gouveia, David Sampaio Barbosa, José Pedro Paiva (coordenação), O Concílio de Trento em Portugal e nas suas conquistas: Olhares Novos, Centro de Estudos de História Religiosa da Universidade Católica Portuguesa, Lisboa, 2014, pp. 103-132.
}

25 José Pereira destaca das emanações do Concilio de Trento a honra e veneração que se deve prestar às imagens se justifica «não por que se creia que há nellas alguma divindade, ou virtude, pella qual se hajão de venerar, ou se lhes deva pedir alguma cousa, ou se deva por a confiança nas Imagens, como antigamente os gentios punhão a sua confiança nos ídolos; mas porque a honra, que se lhes dá se refere aos originaes que ellas representão». Pereira, José Fernandes, "O barroco do século XVII: transição e mudança" in Paulo Pereira (direção), História da Arte Portuguesa, Volume III, Lisboa, Círculo de 
As resoluções tridentinas, anti-humanistas por convicção e necessidade, foram aplicadas com mais facilidade nas regiões europeias onde foi menor a assimilação da doutrina clássica, como é o caso de Portugal. Ao mesmo tempo colocava-se a imagem ao serviço duma pedagogia da fé, procurando fazer passar a mensagem através de sinais que apelassem à emotividade e fossem de fácil descodificação, seguindo a tradição e os ensinamentos de São Gregório. Daí o rigor iconográfico que as imagens deviam possuir, de modo a serem facilmente identificadas. A função das imagens foi definida em Trento como sendo de natureza essencialmente pedagógica, devendo instruir os crentes. De todas as artes era a escultura a que por força da representação do corpo na sua tridimensionalidade oferecia maiores riscos para as regras tridentinas ${ }^{26}$. Assim se explica o afastamento dos princípios orientadores da erudição clássica na escultura em Portugal pós-Trento.

Este afastamento dos princípios clássicos pelas imposições tridentinas é sentido no território de Bragança, não só nas imposições formais, mas também no reforço de toda a produção artística.

No Museu de Arte Sacra de Vinhais está uma imagem que representa São Vicente (imagem 26). Trata-se de uma escultura que está atualmente descontextualizada ${ }^{27}$, tal como sucede com as duas imagens que julgamos terem sido produzidas no século XV (São Francisco e São Miguel Arcanjo). Existe a possibilidade de terem originalmente pertencido a outro convento porém desconhecemos qualquer documentação que o certifique. O Seminário Apostólico da Ordem de São Francisco e os seculares da Ordem III só chegaram a Vinhais na segunda metade do século XVIII o que desvincula estas imagens de terem sido encomendadas por essas duas instituições.

Leitores, 1995, pp. 11-49; Pereira, José Fernandes, "Estética barroca I: arquitectura e escultura", in Dalila Rodrigues (Coord.), Arte Portuguesa - Da Pré-História ao Século XX, volume 12, Lisboa, Fubu Editores, 2009, pp. 7-136.

${ }^{26}$ Pereira, José Fernandes, "O barroco do século XVII: transição e mudança" in Paulo Pereira (direção), História da Arte Portuguesa, Volume III, Lisboa, Círculo de Leitores, 1995, pp. 11-49; Pereira, José Fernandes, "Estética barroca I: arquitectura e escultura", in Dalila Rodrigues (Coord.), Arte Portuguesa Da Pré-História ao Século XX, volume 12, Lisboa, Fubu Editores, 2009, pp. 7-136.

${ }^{27}$ A imagem de São Vicente, em conjunto com mais duas esculturas de São Francisco e de São Miguel Arcanjo, foi encontrada na sacristia da igreja de Nossa Senhora da Encarnação do Seminário Apostólico de Vinhais conforme informação no catálogo Imagens e escultura das Comemorações Jubilares dos 450 anos da Diocese de Bragança - Miranda. Gomes, José Manuel (Coord.), Imagens e escultura. 1545-1995 Comemorações Jubilares dos 450 Anos da Diocese de Bragança - Miranda, Bragança, Departamento de Liturgia e Património Cultural da Diocese de Bragança - Miranda e Comissão de Arte Sacra, 1996, p. 14. 
Possivelmente a origem das referidas esculturas estaria noutro convento de fundação anterior, ou puderam mesmo ter chegado a Vinhais a partir das missões levadas a cabo no território antes do estabelecimento efetivo da Ordem, para qualquer uma das hipóteses carecemos de documentos que as validem.

A escultura de São Vicente, tal como ocorre nas outras duas esculturas com que partilha a origem, está atualmente alterada por vandalismo ou por descuido. Apresenta-se manchada com tinta negra sobre a cabeça cobrindo integralmente o rosto e com marcas de fogo.

Apesar da tinta negra é possível perceber 0 idealismo inerente à expressão serena do rosto. A figura apresenta-se estática, devido às vincadas pregas da túnica que o cobre sob a rígida dalmática e que caiem angulosas e sobrepostas sobre os pés. A regularidade do cercilho com madeixas uniformes que descobrem amplamente as orelhas e o cuidado nos atributos iconográficos e na indumentária que individualiza a devoção também se identificam com modelos escultóricos

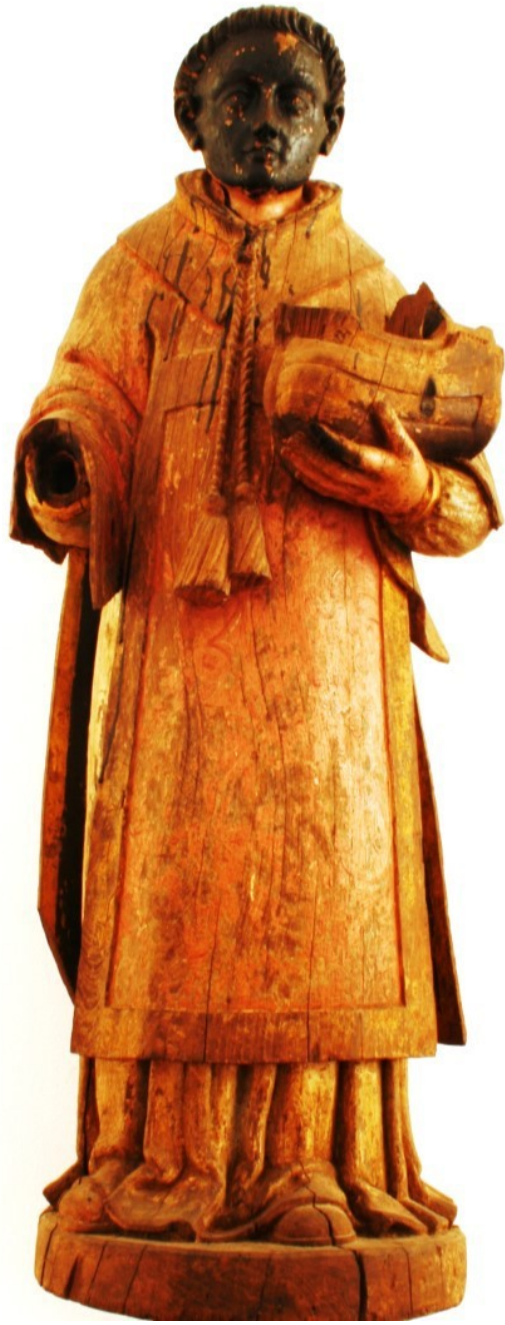

Imagem 12 SãoVicente- MASV 02 Museu de Arte Sacra, Vinhais da primeira metade do século XVII.

Com os princípios do século XVII podemos identificar a figura de Cristo Crucificado (Imagem 11) atualmente exposta no nicho central do retábulo da capela lateral do lado do Evangelho da igreja do convento de São Francisco de Bragança. 


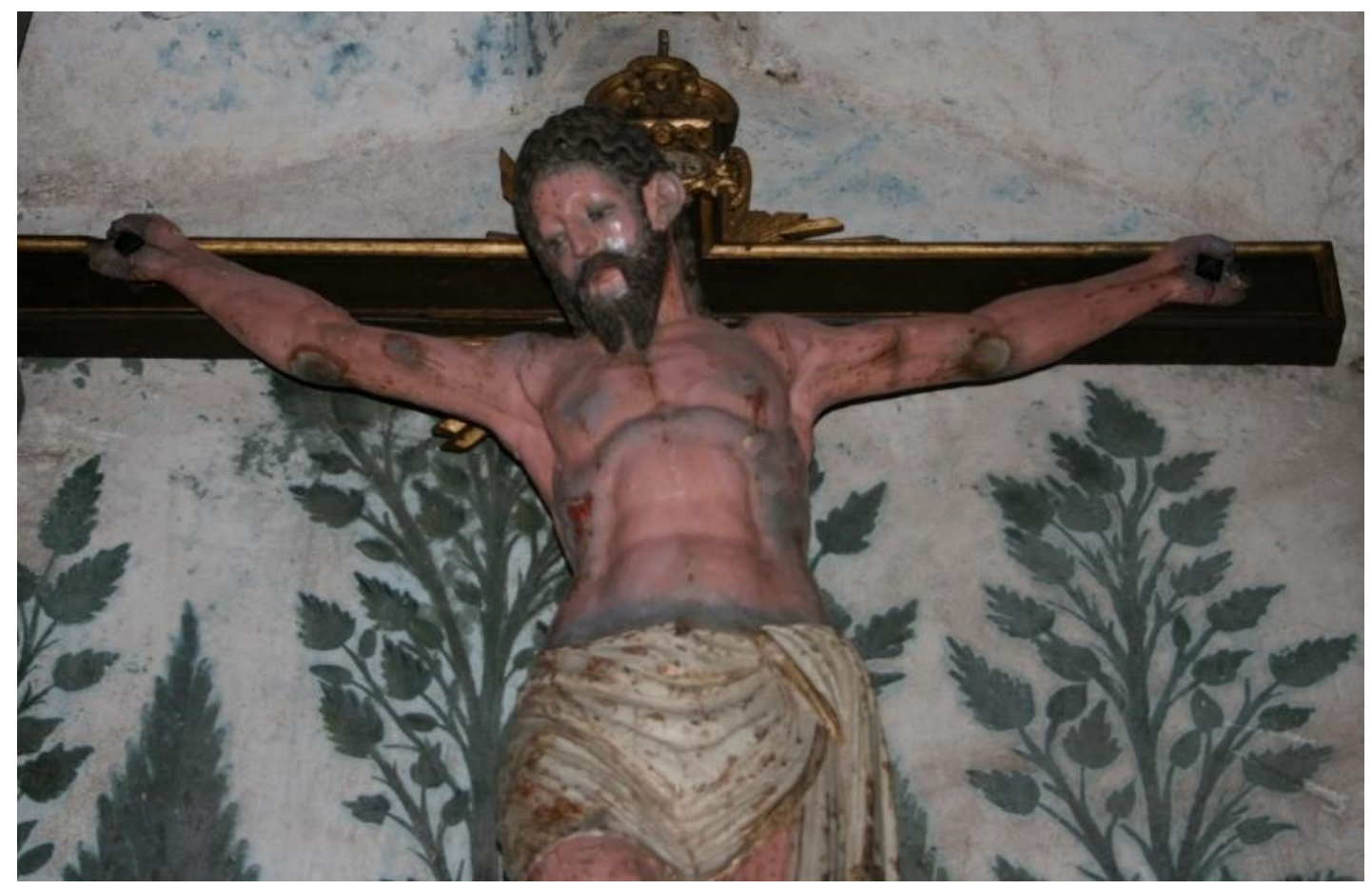

Imagem 13

Escultura de Cristo Crucificado - SFB 20 (pormenor do rosto e dorso)

Igreja de São Francisco - Bragança

Capela lateral do lado do Evangelho

A figura apresenta algum cuidado anatómico e nas proporções. Com aparente repinte posterior, a carnação é de tom róseo que contrasta com o acinzentado das chagas e do peito amplamente maçado. A expressão do rosto é de sereno sofrimento, com o olhar baixo, pálpebras semicerradas, lábios fechados. As barbas pontiagudas e bifurcadas estão decoradas com um talhe fino e ondulado, talha que também se observa sobre os longos cabelos. O cendal que o cobre está esculpido com uniforme pregueado preso sobre o lado esquerdo, acompanha a volumetria do corpo e cai de forma estática. O equilíbrio da composição com os braços muito abertos e as discretas marcas de martírio sobre a detalhada anatomia permitem identifica-lo com o gosto pós-tridentino propício a infundir piedade emotiva na contemplação das obras, mas preso a um formulário contido nas emoções. $\mathrm{O}$ aspeto atlético do corpo musculado sugere, no entanto, ainda a permanência do gosto clássico, próximo do ideal maneirista.

A capela está decorada no teto (imagem 12) com uma composição de enrolamentos que parece refletir o gosto rococó. O retábulo em pedra (imagem 13) é singular no material de suporte, na medida em que é a madeira que mais comummente é usada nas estruturas retabulares locais. Foi pintado posteriormente com marmoreados e expõe nos caixotões que o constituem diversos símbolos da paixão de Cristo também pintados. Apresenta uma estrutura regular, próxima do maneirismo, com frontão semicircular 
abatido interrompido a encimar o conjunto. $\mathrm{O}$ frontão interrompido reflete a alteração para o gosto barroco. A julgar pelas adaptações que a cruz que sustém a imagem de Cristo teve que sofrer para caber no interior do nicho central do retábulo podemos perceber que o retábulo não foi feito para expor esta imagem, ou a imagem não foi feita para aquele nicho. Possivelmente foi mudada de local no decurso das diversas intervenções que foram levadas a cabo no convento.

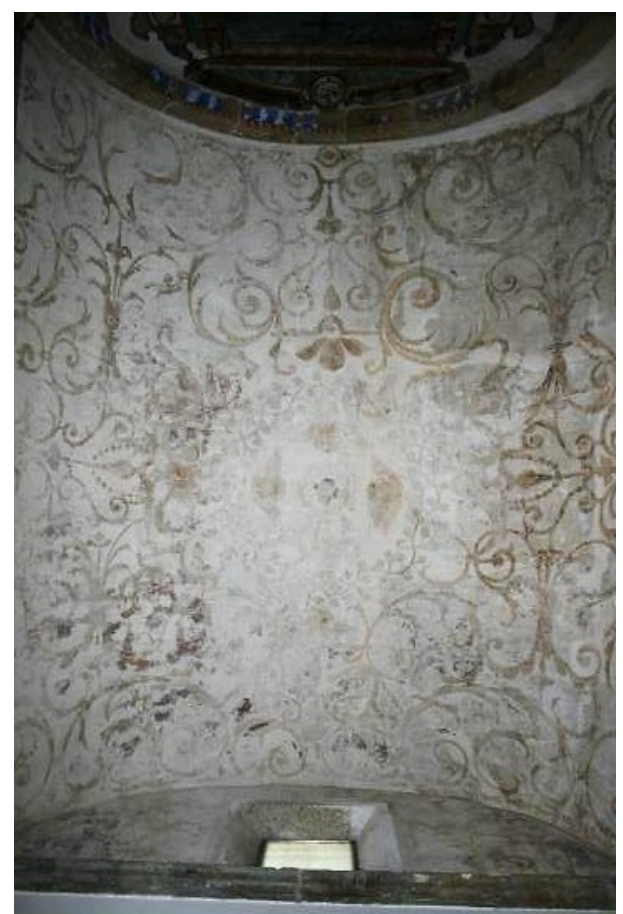

Imagem 12

Teto pintado da capela lateral do lado do Evangelho Igreja de São Francisco - Bragança

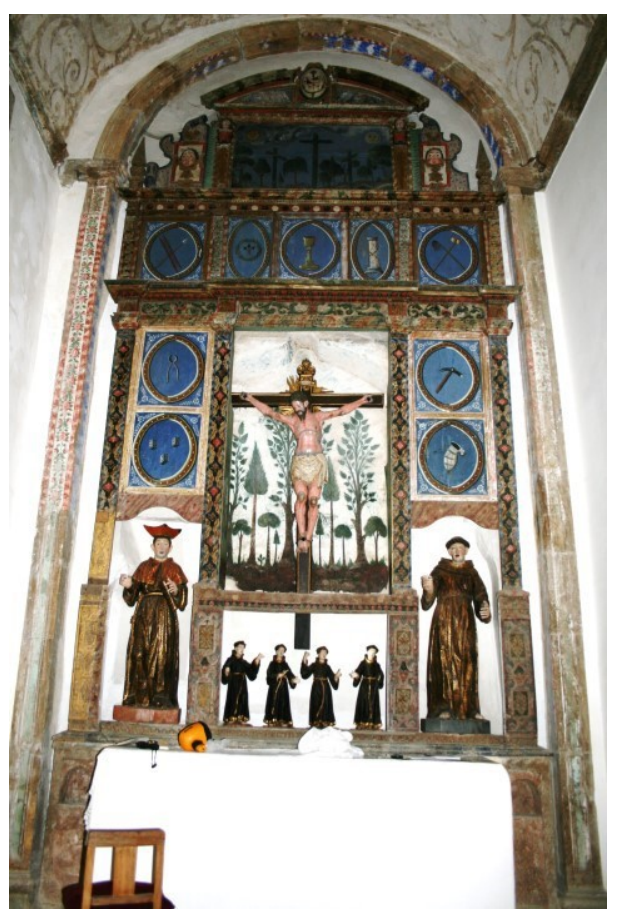

Imagem 13

Retábulo da capela lateral do lado do Evangelho Igreja de São Francisco - Bragança

No mesmo retábulo (Imagem 13) da capela lateral do lado do Evangelho, do convento de São Francisco de Bragança e ladeando a imagem central de Cristo Crucificado estão atualmente colocadas as imagens de São Boaventura (imagem 14) e Santo António (imagem 15). Tratam-se de esculturas feitas seguramente pelas mesmas mãos dadas as várias semelhanças formais. 


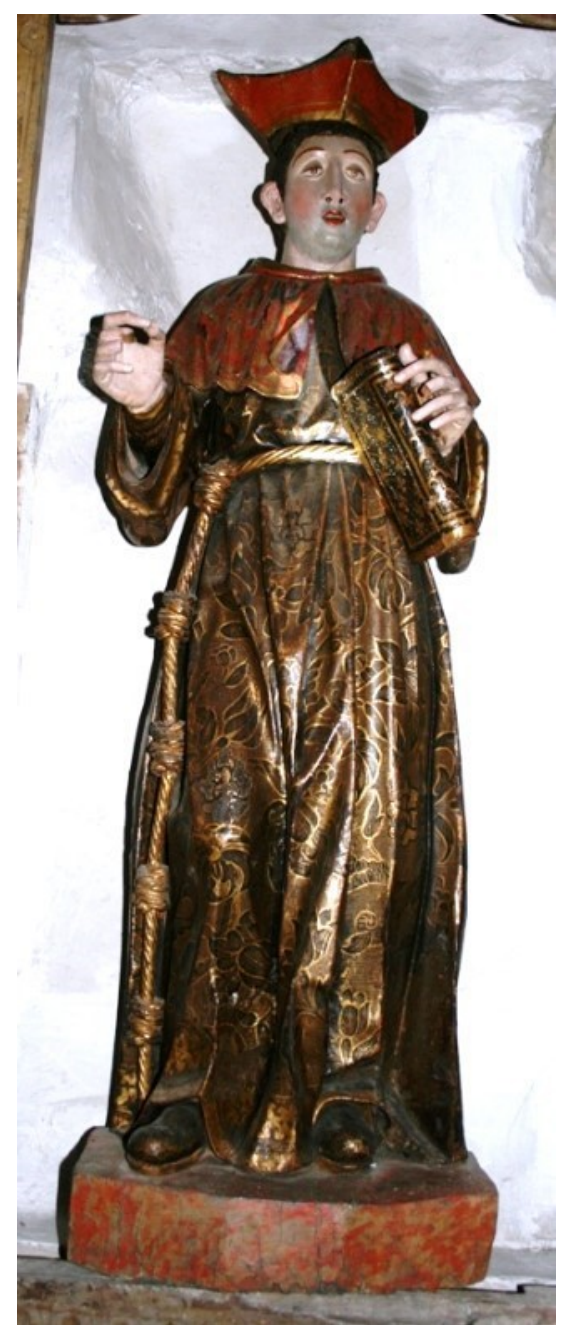

Imagem 14

Escultura de São Boaventura - SFB 15 Igreja de São Francisco - Bragança Capela lateral do lado do Evangelho

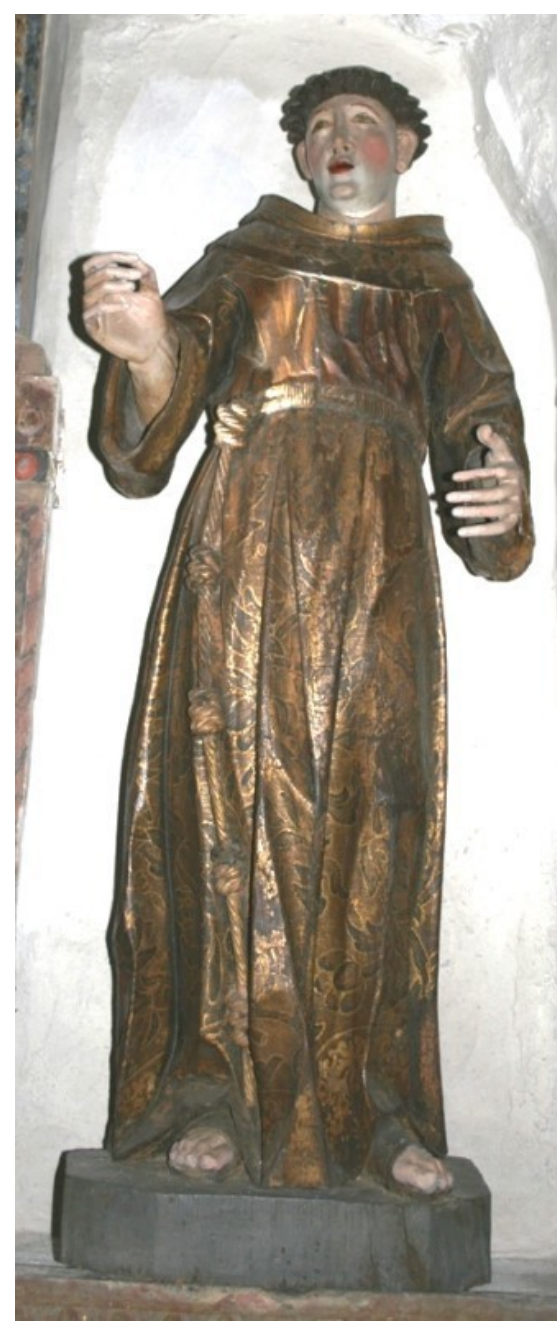

Imagem 15

Escultura de Santo António - SFB 14 Igreja de São Francisco - Bragança Capela lateral do lado do Evangelho

As pregas dos panejamentos, volumosas e vincadas, detalhadamente trabalhadas em ambas as esculturas não conseguem no entanto quebrar a estaticidade das figuras. Estão cobertas por decorativos estufados de grandes motivos vegetalistas que possivelmente foram aplicados posteriormente.

É no tratamento do rosto que melhor se percebem as semelhanças e os detalhes que apontam para uma produção vinculada ao século XVII. Os rostos imberbes, de linhas abonecadas, pueris, com o queixo arredondado, as orelhas amplas e os cabelos com as madeixas regulares e simetricamente colocadas, constituem elementos de gosto arcaizante, que no decurso da centúria se transformaram em linhas mais angulosas nos rostos mais verosímeis.

De demarcada ingenuidade no gosto é também a imagem de São Francisco que se guarda atualmente na sacristia da igreja de São Francisco em Bragança (imagem 16). 
Trata-se de uma das quatro imagens que representam o santo fundador da Ordem e que ainda podemos observar na igreja de São Francisco de Bragança. A escultura apresenta fortes sinais de drásticas intervenções de restauro o que muito empobrece a leitura que dela se pode obter. Mas pelas várias irregularidades anatómicas e pelo sumário tratamento dos panejamentos que o cobrem trata-se sem dúvida de uma produção ingénua, afastada dos princípios de proporção e equilíbrio que circulavam nos meios onde a produção artística era mais erudita. O rosto imberbe, as amplas orelhas e tonsura muito marcada, assim como, o sumário drapeado do hábito sugerem aspetos formais da escultura do século XVII. Apesar das evidentes irregularidades da figura resultantes seguramente da autoria ingénua, os inúmeros repintes e intervenções de restauro aplicados sobre a imagem evidenciam a devoção que lhe estava votada.

A partir de 1640 Lisboa retomou a

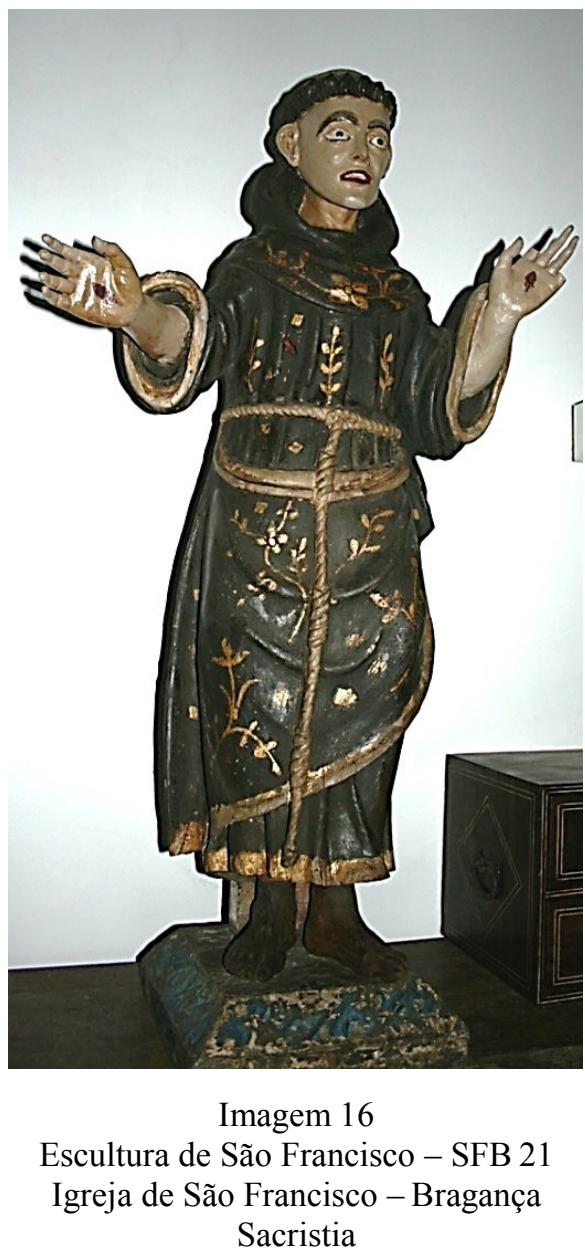
animação da centralidade face ao restante território, após os 80 anos de domínio filipino. A consequente deslocação da corte para Madrid havia provocado durante a dinastia dos Filipes a ruralização da nobreza nacional. Com este fenómeno da ruralização da nobreza pode relacionar-se a fundação do convento franciscano em Mogadouro. Mas, logo D. João IV se envolveu na urgência de fortalecer os privilégios da capital do reino, onde acorriam primeiro as novidades, onde as mais destacadas ordens religiosas tinham as suas casas, circulavam gentes e objetos oriundos dos vários continentes e as irmandades e os oficiais mecânicos proliferavam. A nobreza cuja lealdade fora recompensada construiu palácios nas zonas chave da cidade. A família real e o seu séquito protagonizavam inúmeras celebrações públicas como procissões e autos de fé, entradas régias, embaixadas, touradas e exéquias fúnebres. Todo este aparato era celebrado com arte efémera que podia distribuir-se por arcos triunfais representando os ofícios ou as cidades da Europa, esculturas em madeira ou pasta de 
papel, carros alegóricos com figurações mitológicas e religiosas. Esta produção contava com a colaboração de artistas, escultores, entalhadores, douradores e armadores. Além desta vivência pública da arte efémera os artistas contavam ainda com outra importante influência decorrente dos álbuns de gravuras ou dos tratados de arquitetura que circulavam não só entre os artistas mas também entre muitos dos encomendadores mais esclarecidos como eram as ordens religiosas ${ }^{28}$.

É possivelmente neste contexto da circulação de gravuras que melhor podemos entender alguma da produção escultórica em estudo, sobretudo a que reflete os modelos mais equilibrados e naturalistas.

Da renovação instaurada por D. João IV após a Restauração da independência destacam-se também as obras levadas a cabo no mosteiro de Alcobaça onde se constituiu uma importante oficina de imaginária. Os materiais que constituem as imagens são o barro cozido nos bustos e a madeira nas imagens de vulto, assumindo também nesta escolha o carácter simbólico, sobretudo do barro pela alusão bíblica da criação do homem, e afastando-se da erudição clássica que privilegiava a pedra ${ }^{29}$.

\footnotetext{
${ }^{28}$ Ferreira, Sílvia, A talha. Esplendores de um passado ainda presente (sécs. XVI-XIX), Lisboa, Nova Terra, 2008, pp. 23-25.

${ }^{29} \mathrm{O}$ mosteiro de Alcobaça, apoiado pelas alterações promovidas por D. João IV que permitiu que fosse de novo a comunidade a eleger os seus abades, vai promover a renovação da escultura sob forte impulso dos ideais tridentinos. O primeiro núcleo escultórico encontra-se no santuário datado entre 1669 e 1672, constituído por um recinto circular que se transformará num relicário. A talha que envolve o recinto alberga os nichos onde se colocam os bustos relicário. São imagens de uma grande serenidade cujos rostos assumem a principal atenção plástica. Todos os bustos são enquadrados por três imagens de vulto que representam, ao Centro a imagem de Nossa Senhora de feições juvenis e cabelos anelados soltos sobre os ombros e peito, à esquerda São Bernardo e à direita Santo Agostinho, de rostos verosímeis e vestes amplas com mantos largos ocultando o corpo. Sobre esta composição, um friso de anjos completa a cenografia de antevisão do céu. Pereira, José Fernandes, "O barroco do século XVII: transição e mudança" in Paulo Pereira (direção), História da Arte Portuguesa, Volume III, Lisboa, Círculo de Leitores, 1995, pp. 11-49; Santos, Reynaldo dos, A escultura em Portugal II, Séculos XVI a XVIII, Lisboa, Oficinas Gráficas de Bertrand (Irmãos) Ld. ${ }^{\text {a }, ~ 1950, ~ p p . ~ 46-57 ; ~ S m i t h, ~ R o b e r t, ~ A ~ t a l h a ~ e m ~}$ Portugal, Lisboa, Livros Horizonte, 1963, p. 56; Moura, Carlos, "A Escultura nos coutos de Alcobaça no final da Idade Média ao século XVIII", in Maria Augusta Trindade Ferreira, Mafalda Magalhães Barros, Vítor Serrão, Carlos Moura (Org.) Arte Sacra nos antigos Coutos de Alcobaça, Alcobaça, Edições Asa, 1995, pp. 65-81; Pereira, José Fernandes, "Estética barroca I: arquitectura e escultura", in Dalila Rodrigues (Coord.), Arte Portuguesa - Da Pré-História ao Século XX, volume 12, Lisboa, Fubu Editores, 2009, pp. 7-136. Relativamente ao retábulo da capela relicário de Alcobaça refere Martín González a evidente influência andaluza, nos motivos arquitetónicos e nas figuras que se aproximam das produções de Alonso Cano e de Montañes. Martín González, Juan José, La huella española en la escultura portuguesa, Valladolid, Sever - Cuesta, 1961, p. 19. No entanto, como noutros exemplos dados pelo autor, recentes estudos contrariam esta hipótese e revelam uma produção nacional de fortes valores identitários, afastando a produção espanhola das obras.
} 
A crescente valorização da madeira como material de suporte na escultura será profundamente sentida em todo o território nacional na centúria de seiscentos e setecentos e em particular no território em estudo.

Apesar da importância deste núcleo de Alcobaça, desconhecem-se os nomes dos escultores destas obras, possivelmente seriam os próprios monges do convento, mantendo assim uma prática cujas raízes estão na vida monástica medieval. Os cerca de trinta anos de sucessivos trabalhos escultóricos em Alcobaça ${ }^{30}$ criaram hábitos e técnicas de trabalho que formaram o gosto com repercussão que se amplificou para lá do mosteiro.

No Norte do país, na Ordem de São Bento, também se percebem novos compromissos com a prática escultórica. No desenvolvimento deste processo destaca-se a figura de Frei Cipriano da Cruz, de Braga, cuja obra revela uma solução plástica contida no sofrimento interiorizado e elegante no gesto e nas vestes. Natália Ferreira-Alves ${ }^{31}$

\footnotetext{
${ }^{30}$ Santos, Reynaldo dos, A escultura em Portugal II, Séculos XVI a XVIII, Lisboa, Oficinas Gráficas de Bertrand (Irmãos) Ld. ${ }^{a}$, 1950, pp. 55-57; Pereira, José Fernandes, "O barroco do século XVII: transição e mudança" in Paulo Pereira (direção), História da Arte Portuguesa, Volume III, Lisboa, Círculo de Leitores, 1995, pp. 11-49; Moura, Carlos, "A Escultura nos coutos de Alcobaça no final da Idade Média ao século XVIII", in Maria Augusta Trindade Ferreira, Mafalda Magalhães Barros, Vítor Serrão, Carlos Moura (Org.) Arte Sacra nos antigos Coutos de Alcobaça, Alcobaça, Edições Asa, 1995, pp. 65-81; Pereira, José Fernandes, "Estética barroca I: arquitectura e escultura", in Dalila Rodrigues (Coord.), Arte Portuguesa - Da Pré-História ao Século XX, volume 12, Lisboa, Fubu Editores, 2009, pp. 7-136. Desconhece-se também a autoria do segundo núcleo de esculturas o da capela do Redentor que representava Cristo a entregar as chaves da moradia celestial a Pedro que as recebia de joelhos junto dos restantes apóstolos. Originalmente estas obras estavam no transepto, quase de tamanho natural, estão atualmente dispersas na sacristia. As vestes caiem sem fulgor sobre o corpo, e mais uma vez é no rosto que se encontra maior expressividade, com expressões individualizadas captadas com verosimilhança.
}

${ }^{31}$ Frei Cipriano da Cruz ativo entre cerca de 1645 e 1717 cujas obras mais representativas do seu trabalho são a Pietá e São Miguel, atualmente expostos no Museu Machado de Castro em Coimbra. Pereira, José Fernandes, "O barroco do século XVII: transição e mudança" in Paulo Pereira (direção), História da Arte Portuguesa, Volume III, Lisboa, Círculo de Leitores, 1995, pp. 11-49; Pereira, José Fernandes, "Estética barroca I: arquitectura e escultura", in Dalila Rodrigues (Coord.), Arte Portuguesa - Da Pré-História ao Século XX, volume 12, Lisboa, Fubu Editores, 2009, pp. 7-136. Frei Cipriano da Cruz oriundo de Braga (aliás como outros mestres escultores), onde fez a sua formação artística. Referido como Manuel de Sousa bom oficial ensamblador e bom oficial de fazer santos, é admitido no Mosteiro como irmão donato (leigo), em 1676, trazendo já consigo uma sólida reputação como mestre imaginário; porém, até ao momento, não possuímos quaisquer dados que nos permitam saber como se processou a sua aprendizagem, qual a oficina que frequentou, quais as influências que sofreu. Anos depois professa (entre 1683 e 1685) e, a partir de então, já como Frei Cipriano da Cruz, a sua atividade é conhecida de forma pormenorizada. Cronologicamente, as duas primeiras obras de Frei Cipriano são as imagens em madeira de São Bernardo e de São Roberto, feitas para o anterior retábulo-mor de Tibães (concluído em 1665), hoje na igreja de São Romão do Neiva. A seguir, surge a empreitada notável da sacristia de Tibães, executada a partir do início da década de 80 de Seiscentos, e que constava de um retábulo com um painel em talha representando a Visitação (também em São Romão do Neiva, para onde foi deslocado), e doze estátuas de barro cozido, com uma forte policromia: quatro reis ligados à Ordem de São Bento, sete Virtudes - Fé, Esperança, Caridade, Prudência, Justiça, Fortaleza, Temperança - e a figura alegórica da Igreja. Ainda em Tibães, seguimos a obra de Frei Cipriano a partir da década de 90 e inícios do século XVIII, mas agora na igreja: nas duas capelas do lado da Epístola, a Visão de Santa Lutgarda (uma das suas obras mais barrocas pela emoção que transmite) e a Sagrada Família (na Capela do Desterro); nas 
destaca a conceção de uma emotividade intensa apesar da perspetiva um pouco

arcaizante na articulação do corpo com os panejamentos.

Contemporâneo de Frei Cipriano da Cruz destaca-se também a figura do escultor Manuel Pereira, nascido no Porto em 1588 e falecido em $1683^{32}$.

Em finais do século XVII ocorrerá um retorno ao método clássico da escultura, protagonizado pela presença e atividade do escultor francês, Claude Laprade, nascido em Avinhão em 1682 e falecido em Lisboa em 1738, tendo trabalhado também no Porto $^{33}$.

duas capelas do lado do Evangelho, a Assunção da Virgem e Santo Amaro. Devem-se ainda á sua autoria as figuras em barro cozido que fez para a frontaria da igreja de São Martinho de Tibães: São Bento, Santa Escolástica, e ao centro, o padroeiro São Martinho de Tours, com o mendigo. Ferreira-Alves, Natália Marinho, "Pintura, Talha e Escultura (séculos XVII e XVIII) no Norte de Portugal" in Revista da Faculdade de Letras. Ciências e Técnicas do Património vol. 2, Porto, Faculdade de Letras da Universidade do Porto, Departamento de Ciências e Técnicas do Património, 2003, pp.735-756.

Martín González refere a forte influência de Gregório Fernandez na escultura que representa a Pietá do então referido como "Primer Maestro de Coimbra" que sabemos hoje tratar-se de Frei Cipriano da Cruz. Martín González, Juan José, La huella española en la escultura portuguesa, Valladolid, Sever - Cuesta, 1961, p. 17.

${ }^{32}$ Manuel Pereira nasceu no Porto, terá no entanto desenvolvido a maior parte do seu trabalho em Madrid, Espanha. Em Portugal são-lhe atribuídas as obras da Senhora do Rosário, de rosto sereno e terno, e a imagem de Cristo Crucificado, cuja verticalidade dos braços lhe imprime maior dramatismo, ambos estão na igreja de São Domingos em Benfica, e foram feitas em 1636. Pereira, José Fernandes, "O barroco do século XVII: transição e mudança" in Paulo Pereira (direção), História da Arte Portuguesa, Volume III, Lisboa, Círculo de Leitores, 1995, pp. 11-49; Pereira, José Fernandes, "Estética barroca I: arquitectura e escultura", in Dalila Rodrigues (Coord.), Arte Portuguesa - Da Pré-História ao Século XX, volume 12, Lisboa, Fubu Editores, 2009, pp. 7-136; Redondo, José Ignacio Hernández, "A escultura barroca em Espanha", in Rolf Toman (edit.), O Barroco, Lisboa, Konemann, 2004, p. 368. Martín González destaca a evidente influência da escultura espanhola, sobretudo de Alonso Cano e de Montañes nas imagens de Cristo e de Nossa Senhora do Rosário de Manuel Pereira. Martín González, Juan José, La huella española en la escultura portuguesa, Valladolid, Sever - Cuesta, 1961, p. 19.

${ }^{33}$ Claude Laprade chega a Portugal imbuído das influências clássicas que explora sobre a pedra, em Coimbra nas figuras alegóricas que esculpe para a Universidade, bem como os relevos do pórtico da Via Latina bem como o retrato de Justiniano. Desta mesma fase é também o túmulo, de 1699, de D. Manuel de Moura Manuel, na capela da Vista Alegre em Ílhavo. Neste obra o autor encena a morte dentro do arco sólio preenchido com elementos iconográficos de grande plasticidade. Sobre a arca tumular colocou a figura do bispo despertando ante a visão da Senhora da Penha, enquanto uma figura do Tempo, representada por uma velho calvo de longas barbas lhe levanta a mortalha. Anjos, caveiras e figuras alegóricas completam a composição. Depois destas obras Claude Laprade foi progressivamente adaptando a tradição nacional, abandonando os trabalhos em pedra e marcando presença na talha de madeira onde enfatizou os valores escultóricos. Executou também trabalhos de arquitectura, na igreja das Barrocas em Aveiro, e poderá também ter colaborado no grande estaleiro de Mafra na decoração escultórica da igreja. Pereira, José Fernandes, "O barroco do século XVII: transição e mudança" in Paulo Pereira (direção), História da Arte Portuguesa, Volume III, Lisboa, Círculo de Leitores, 1995, pp. 11-49; Pereira, José Fernandes, "Estética barroca I: arquitectura e escultura", in Dalila Rodrigues (Coord.), Arte Portuguesa - Da Pré-História ao Século XX, volume 12, Lisboa, Fubu Editores, 2009, pp. 7-136. Da autoria de Claude Laprade são também as quatro imagens (São Bernardo, São Bento, São Basílio e São João Nepomuceno) do retábulo-mor da Sé do Porto (1729). Ferreira-Alves, Natália Marinho, "Pintura, Talha e Escultura (séculos XVII e XVIII) no Norte de Portugal" in Revista da Faculdade de Letras. Ciências e Técnicas do Património vol. 2, Porto, Faculdade de Letras da Universidade do Porto, Departamento de Ciências e Técnicas do Património, 2003, pp. 735-756. 
Além da importação de artistas, outro dos meios revitalizadores da escultura portuguesa foi a importação de obras. De Itália veio um conjunto de nove esculturas, na década de 60 do século XVII, encomendadas pelo bispo dominicano D. Manuel Pereira para a capela de São Gonçalo de Amarante na igreja de São Domingos de Benfica, evidenciando o caracter nacionalista da pós-Restauração e contrapondo a tradição ibérica expressa nas restantes obras do templo, com a erudição italiana ${ }^{34}$.

A igreja-casa de Deus é no século XVII um objeto arquitetónico de aparência paradoxal, opondo a singeleza exterior à máxima riqueza interna, numa metáfora entre corpo e alma, ou entre o temporal e o eterno. Assim, a simplicidade exterior contrasta com a profusa expressão interior onde a talha, o azulejo, a escultura e a pintura transformam o templo num mundo maravilhoso de luz, cromatismo e valores tácteis ao serviço da mensagem católica. Dos vários templos que espelham esta alteração, destacam-se as duas igrejas portuenses de São Francisco e Santa Clara, onde a talha que forra o interior absorve a arquitetura pré-existente ${ }^{35}$. Ambos os templos recebem obras ao longo do século XVII e XVIII. Nos interiores das igrejas, a talha assume totalmente, ou em grande parte, o espaço que com frequência não tem relevância sob o ponto de vista arquitetónico. Assim, organizam-se estruturas, por vezes de grande complexidade, onde a talha desempenha um papel fulcral. Os retábulos com as imagens, que para eles são concebidas ${ }^{36}$, púlpitos, caixas de órgãos e cadeirais, são parte da cenografia sacra.

\footnotetext{
${ }^{34}$ As esculturas de Benfica apresentam um formulário pós-berniniano, marcado pela erudição clássica, aplicado às devoções que denotam as opções pessoais do encomendante mas também o reforço dos princípios nacionalistas da pós-Restauração. A escultura de maiores dimensões representa São Gonçalo de Amarante, existe ainda outro santo português, São João de Deus, o conjunto é complementado pelas devoções de São Bento, São Domingos e São Tomás de Aquino, a Virgem do Rosário, São José e Santa Teresa de Ávila e Santa Apolónia. Todo o conjunto permitia contrapor a tradição ibérica expressa nas restantes obras do templo, com a erudição italiana cujas oficinas respondiam a um razoável comércio com encomendadores europeus ávidos do prestígio que a sua posse conferia. Pereira, José Fernandes, "O barroco do século XVII: transição e mudança" in Paulo Pereira (direção), História da Arte Portuguesa, Volume III, Lisboa, Círculo de Leitores, 1995, pp. 11-49; Pereira, José Fernandes, "Estética barroca I: arquitectura e escultura", in Dalila Rodrigues (Coord.), Arte Portuguesa - Da Pré-História ao Século XX, volume 12, Lisboa, Fubu Editores, 2009, pp. 7-136.

${ }^{35}$ Pereira, José Fernandes, "O barroco do século XVII: transição e mudança" in Paulo Pereira (direção), História da Arte Portuguesa, Volume III, Lisboa, Círculo de Leitores, 1995, pp. 11-49; Pereira, José Fernandes, "Estética barroca I: arquitectura e escultura", in Dalila Rodrigues (Coord.), Arte Portuguesa Da Pré-História ao Século XX, volume 12, Lisboa, Fubu Editores, 2009, pp. 7-136.

${ }^{36}$ Ferreira-Alves, Natália Marinho, "Pintura, Talha e Escultura (séculos XVII e XVIII) no Norte de Portugal" in Revista da Faculdade de Letras. Ciências e Técnicas do Património vol. 2, Porto, Faculdade de Letras da Universidade do Porto, Departamento de Ciências e Técnicas do Património, 2003, pp. 735756.
} 
A proximidade entre a produção retabular e a produção da imaginária registada na documentação coeva, bem como, a supremacia da primeira sobre a segunda, no que a valores se refere, condiciona significativamente as referencias documentais à escultura, que poucas ou raras vezes é mencionada.

Este facto pode sugerir que muitas vezes seriam os entalhadores dos retábulos os autores da imaginária que neles se expunha. Neste sentido, devemos destacar o dicionário de artistas e artífices de Trás-os-Montes ${ }^{37}$, focado sobretudo no distrito de Vila Real, onde se observa a discrepância entre as distintas práticas artísticas sendo os escultores ou imaginários raras vezes referidos (apenas foram registados 3), em detrimento dos carpinteiros (registados 40) que surgem inúmeras vezes referenciados. Neste registo é referido, num documento de compra de 1693 e numa procuração de 1711, o escultor de Vila Real António Lourenço. André Martins é referido como "maginario" 38 num documento de compra datado de 1711 em conjunto com um prateiro. Em 1727, Manuel Rodrigues, era identificado como "maginario" morador em Vila Real ${ }^{39}$.

Também no levantamento da capela da Ordem Terceira no Porto chama a atenção a ausência de nomes relativamente à produção das imagens, sendo sempre referidos os ensambladores dos retábulos assim como os pintores e douradores e mais raras vezes os escultores ou imaginários. A excepção surge com as imagens de Santa Isabel Rainha de Portugal, uma feita em 1644 pelo imaginário Francisco Vieira, e pintada, em 1646, pelo irmão António André, e outra imagem de pedra (1689-1690), esculpida por Manuel de Almeida um dos mais notáveis escultores portuenses ${ }^{40}$. O mesmo ocorre no convento de São Francisco em Guimarães para o qual entre 1679 e 1773 apenas se registaram os

\footnotetext{
${ }^{37}$ Ferreira-Alves, Natália Marinho e Ferreira-Alves, Joaquim Jaime, "Subsídios para um dicionário de artistas e artífices que trabalharam em Trás-os-Montes nos séculos XVII-XVIII (I)", Revista de História, vol. 5, Porto, Faculdade de Letras da Universidade do Porto, 1983-1984, pp. 159-186.

${ }^{38}$ Ferreira-Alves, Natália Marinho e Ferreira-Alves, Joaquim Jaime, "Subsídios para um dicionário de artistas e artífices que trabalharam em Trás-os-Montes nos séculos XVII-XVIII (I)", Revista de História, vol. 5, Porto, Faculdade de Letras da Universidade do Porto, 1983-1984, pp. 159-186.

${ }^{39}$ Apesar de na documentação transcrita Manuel Rodrigues ser registado como "imaginario" (tal como André Martins) os autores da transcrição optaram por identifica-lo como entalhador. Ferreira-Alves, Natália Marinho e Ferreira-Alves, Joaquim Jaime, "Subsídios para um dicionário de artistas e artífices que trabalharam em Trás-os-Montes nos séculos XVII-XVIII (I)", Revista de História, vol. 5, Porto, Faculdade de Letras da Universidade do Porto, 1983-1984, pp. 159-186.

${ }^{40}$ Ferreira-Alves, Joaquim Jaime, "Elementos para o estudo da arquitectura das duas primeiras capelas da Venerável Ordem Terceira de S. Francisco do Porto" in Revista da Faculdade de Letras, Ciências e técnicas de Património, I Série vol. 2, Porto, Faculdade de Letras da Universidade do Porto, 2003, 347364.
} 
nomes dos imaginários da escola do Porto António Gomes e Filipe da Silva ${ }^{41}$, mas mais uma vez apenas lhes é adstrita a produção retabular, não existindo qualquer referência às imagens que ocupariam o interior do retábulo.

Em 1693 foi registada em Bragança a presença de João Mendes um entalhador natural de São João das Caldas, Guimarães, que foi o responsável pela execução do retábulo de São Francisco em Viduedo assim como da imagem de São Francisco que se

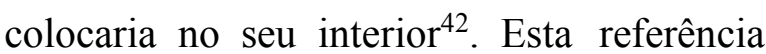
reforça a ambiguidade entre entalhador e escultor ou imaginário que se regista na produção escultórica em estudo. Constatando-se a frequência com que o executor do retábulo ou entalhador era também o executor das imagens que o retábulo exporia. A escritura que refere João

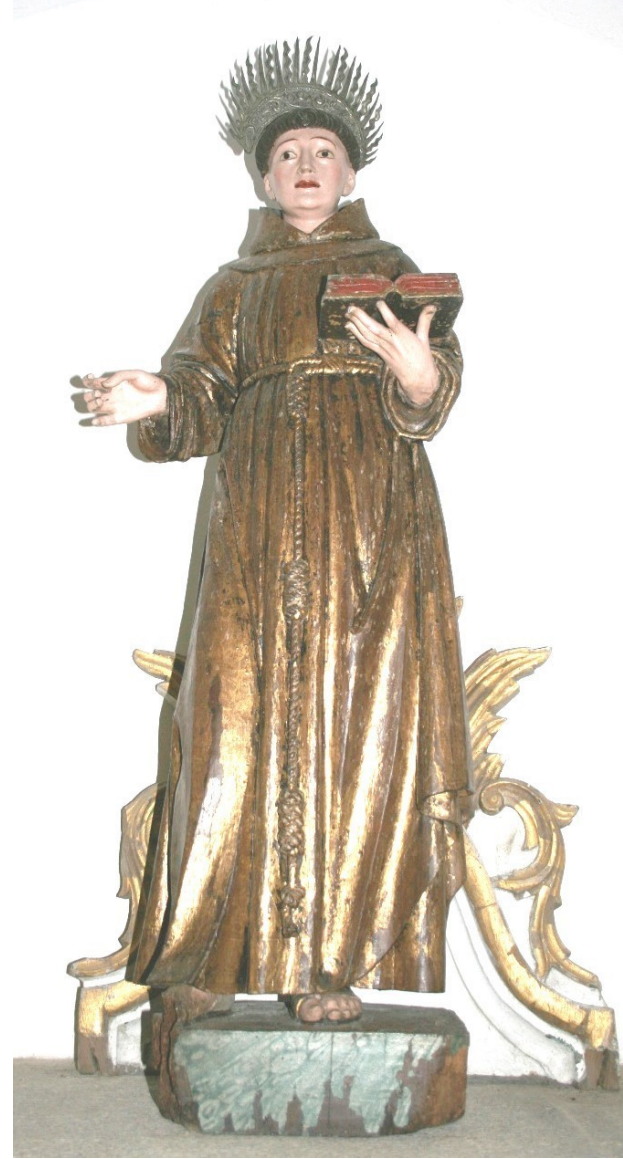

Imagem 16

Escultura de Santo António - SFB 01 Igreja de São Francisco - Bragança, colocado num nicho no lado da Epistola. Mendes permite-nos perceber também a presença de artistas oriundos de Guimarães numa pequena aldeia no território de Bragança o que denota a mobilidade destes artistas mesmo em áreas mais periféricas como pode ser Viduedo. A presença deste escultor vimaranense em Viduedo, aldeia muito próxima de Veigas, sugere que até ao segundo terço (1731 data da primeira escritura em que se registou um escultor da oficina de Veigas $^{43}$ ), não existia nenhum escultorlentalhador nesse território, forçando a vinda de um autor contratado num território mais longínquo, o que seguramente encarecia a encomenda.

\footnotetext{
${ }^{41}$ Oliveira, António José, "O Convento de São Francisco de Guimarães: artistas e obras (1679-1773)" in Natália Marinho Ferreira-Alves e (Coord.), Os Franciscanos no Mundo Português III, O Legado Franciscano, Porto, CEPESE - Centro de Estudos da População, Economia e Sociedade, 2013, pp.147175.

42 Rodrigues, Luís Alexandre, Arte da talha dourada e policromada no Distrito de Bragança. Documentos. Séculos XVII-XVIII, Mirandela, João Azevedo Editor, 2005, pp. 46, 47.

43 Rodrigues, Luís Alexandre, Arte da talha dourada e policromada no Distrito de Bragança. Documentos. Séculos XVII-XVIII, Mirandela, João Azevedo Editor, 2005, p. 48.
} 
Em Lisboa após D. João IV foi D. Pedro II que favoreceu uma importante alteração na escultura ao encomendar o programa escultórico em Itália para a fachada de São Vicente de Fora ${ }^{44}$.

Foi durante a regência e reinado de D. Pedro II que se afirmou e desenvolveu a arte da talha, mas será com o seu filho D. João V que a talha conhecerá o apogeu das grandes produções de monumentalidade e fausto que o ouro e os diamantes provenientes do Brasil possibilitaram. Apesar das encomendas feitas durante o reinado de D. João V não serem tão numerosas quanto as do reinado de D. Pedro II são no entanto mais $\operatorname{aparatosas}^{45}$.

No território de fronteira em estudo, mesmo após a restauração da independência em 1640 as influências dos autores espanhóis continuavam a fazer-se sentir conforme se percebe no acórdão de 1688 relativo à encomenda dos órgãos da Sé de Miranda que deveriam copiar os do convento de São Francisco de Zamora ${ }^{46}$.

Durante o século XVII e apesar das crises e conflitos decorrentes da guerra da Restauração, houve alguma encomenda artística nos territórios em estudo. Mesmo por vezes da mesma invocação e no mesmo templo. Tal acontece com a escultura de Santo António no convento de São Francisco de Bragança (imagem 16). Na mesma centúria, e

\footnotetext{
${ }^{44} \mathrm{Na}$ fachada de São Vicente de Fora está o único programa régio de D. Pedro II para a escultura, tratavase de retomar a prática de fazer coincidir o programa arquitetónico com o programa escultórico, circunstancia que se perdera em Portugal desde as obras no mosteiro dos Jerónimos. Sendo que a igreja de São Vicente de Fora constituía um claro sinal do domínio filipino era necessário intervir no templo com aplicação da linguagem nacionalista, processo que se continuará com D. João V. O conjunto escultórico, colocado por volta de 1704, de autor desconhecido, talvez italiano, assume importância, não pela discutível qualidade escultórica mas pela alteração iconográfica que propôs, rompendo definitivamente com a tipologia do Portal da Glória. Também a escolha dos santos é relevante; ao centro está a figura de santo Agostinho, patrono dos Cónegos Regrantes, confirmando a posse do monumento pelos frades. Ladeando a imagem de Santo Agostinho está a imagem de São Vicente, patrono da cidade de Lisboa e de São Sebastião, ambos mártires despojados do corpo pela tortura (situação que se repetirá em Mafra). Lateralmente está a imagens de Santo António, natural de Lisboa e que antes de franciscano tinha sido cónego regrante, e a imagem de São Domingos, que apesar de espanhol era natural da mesma região de D. Luísa de Gusmão mãe de D. Pedro II. Na parte superior da fachada está colocada a imagem de São Norberto, com hábito agostinho apesar de ter pouca tradição nas devoções portuguesas era alemão como a segunda esposa de D. Pedro II, e São Bruno, fundador dos Cartuchos, aproximando-se por isso da missão primordial dos frades de São Vicente de Fora. Pereira, José Fernandes, "O barroco do século XVIII" in Paulo Pereira (direção), Historia da Arte Portuguesa, Volume III, Lisboa, Círculo de leitores, 1995, pp. 50-181; Pereira, José Fernandes, "Estética barroca I: arquitectura e escultura", in Dalila Rodrigues (Coord.), Arte Portuguesa - Da Pré-História ao Século XX, volume 12, Lisboa, Fubu Editores, 2009, pp. 7-136.

${ }^{45}$ Ferreira, Sílvia, A talha. Esplendores de um passado ainda presente (sécs. XVI-XIX), Lisboa, Nova Terra, 2008, p. 18.

${ }^{46}$ Alves, Francisco Manuel, Bragança Memórias arqueológico-históricas do Distrito de Bragança (2 ${ }^{\mathrm{a}}$ edição) Tomo IV, Bragança, Câmara Municipal de Bragança / Instituto Português de Museus - Museu Abade de Baçal, 2000, (original publicado em 1910-1947), p. 530.
} 
após a produção das imagens de Santo António e de São Boaventura (imagens 14 e 15), terá sido encomendada uma nova escultura de Santo António. Neste reforço da devoção antonina está presente o compromisso iconográfico com as devoções portuguesas relativa a santos nacionais que se observa em todos os programas escultóricos pós restauração.

Talvez por saturação das linhas pueris da escultura já existente de Santo António ou talvez por necessidade de vincular o importante culto a formas mais naturalistas, talvez por doação ou depósito da imagem proveniente de outro local, ou simplesmente por possibilidade económica, o que podemos observar é que no mesmo século (mas com evidente afastamento temporal) duas imagens de Santo António foram produzidas e encontram-se ainda ambas na igreja de São Francisco de Bragança. Em relação à imagem que nos parece mais arcaica (imagem 15) podemos perceber que esta segunda imagem de Santo António obedece a um esquema formal mais erudito com gesto igualmente estático mas com rosto mais verosímil e anguloso. Os panejamentos simplificados mas volumosos e a contenção no gesto aproximam a imagem do contexto escultórico do século XVII. Mas, ao contrário do aspeto mais ingénuo que caracterizava a anterior imagem de Santo António (e possivelmente mais antiga), nesta escultura sobressaem elementos naturalistas de delicado cuidado anatómico. Nas mãos, sobretudo na mão que sustem o livro, percebe-se a talha fina e expressiva que a produziu. Também no rosto de expressão serena e linhas equilibradas é percetível o desenho ou a gravura bem executada que serviu de base à escultura. Apesar das dificuldades de leitura provocadas pelos repintes posteriores é evidente a regularidade das linhas anatómicas do rosto que refletem a prática de um artista com boa formação escultórica.

A imagem de roca que representa Deus Pai da Santíssima Trindade (imagem 17 e 18) constitui, por ser imagem de vestir, uma das esculturas que na igreja de São Francisco de Bragança podemos relacionar com as celebrações públicas levadas a cabo pelos frades do convento. 
A documentação refere a importância do convento em várias cerimónias litúrgicas ao longo do ano na cidade de Bragança durante o século XVIII ${ }^{47}$ o que nos permite intuir que a tradição da participação do convento nas celebrações públicas advinha já do

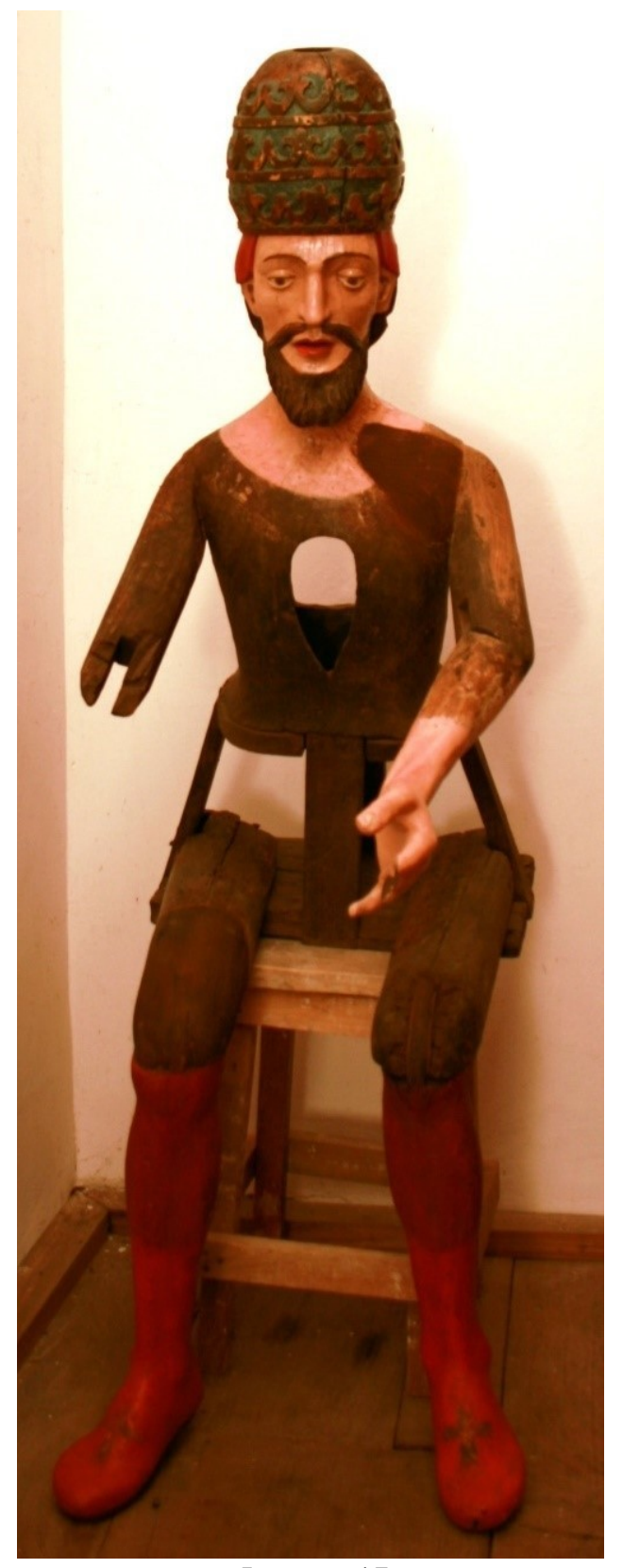

Imagem 17

Escultura de Deus Pai da Santíssima Trindade SFB 36, Igreja de São Francisco Bragança, guardada numa dependência junto ao coro alto. século XVII. Também no inventário de 1834 ficou expressa a relevância dada aos têxteis, que acompanhavam as celebrações públicas ou que vestiam e ornamentavam as imagens, pelo elevado valor monetário que lhes foi atribuído.

A escultura encontra-se desafeta ao culto, guardada numa dependência de arrumos próxima do coro alto da igreja e a sua designação estava perdida. Levanta algumas dúvidas a sua identificação, na medida em que também é comum a representação de São Pedro ostentando uma tiara Tríplice. Em comparação com outras representações na escultura quer de São Pedro quer da Santíssima Trindade percebe-se a maior proximidade da imagem estudada com a devoção da Santíssima Trindade. Desta comparação destacamos a imagem da Santíssima Trindade do Museu Nacional de Arte Antiga (figura 19).

\footnotetext{
${ }^{47}$ Borges, José Cardoso, Memórias de Bragança, Fernando de Sousa (Coord.), Bragança, CEPESE / Câmara Municipal de Bragança, 2012 (texto original de 1721-1724), p. 147; As imagens de roca foram difundidas a partir do modelo sevilhano que ao longo do século XVII e posteriormente no século XVIII se adapta à exposição cerimonial pública das imagens. Martín González, Juan José, El arte procesional del barroco (cuadernos de arte espanol), Madrid, história 16, 1993, p. 28.
} 


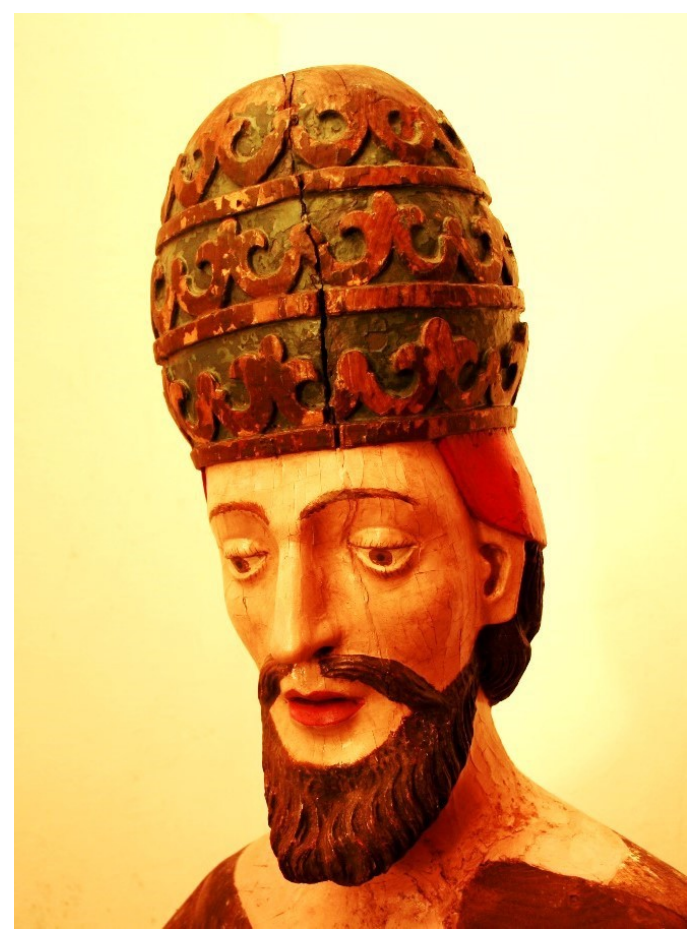

Imagem 18

Escultura de Deus Pai da Santíssima Trindade

- SFB 36 (pormenor do rosto)

Igreja de São Francisco - Bragança

Guardada numa dependência junto ao coro alto.

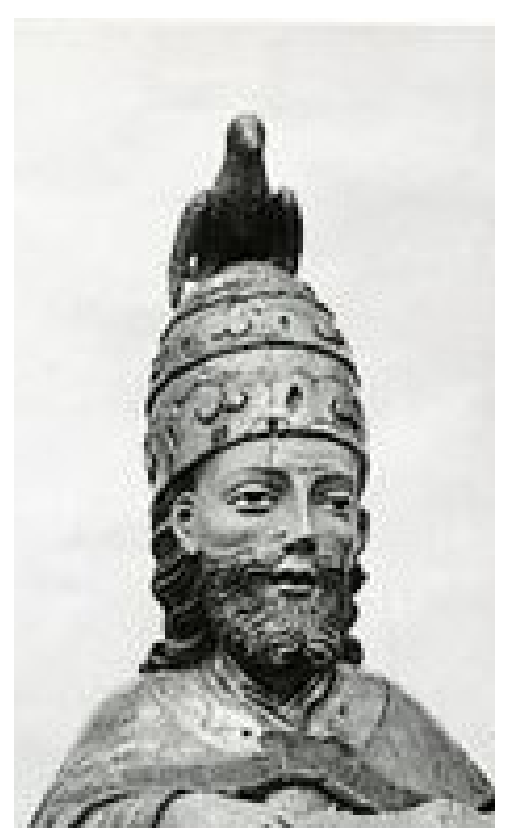

Figura 19

Pormenor do rosto da figura de Deus-Pai da escultura da Santíssima Trindade,

Museu Nacional de Arte Antiga, Lisboa Madeira, século XVII

Autor / Oficina / Fabricante: desconhecido ${ }^{48}$.

Atualmente a escultura de Deus Pai apresenta lacuna do braço direito e a ausência total das vestes que a cobriam. O rosto de expressão grave, sumariamente tratado, e olhar baixo, tem barbas e bigode castanho com ligeiras ondulações. O cabelo curto apenas visível na nuca é também castanho e ondulado. A exuberante tiara apresenta um orifício no topo que poderia permitir a colocação de um postiço para a representação do Espirito Santo, tal como se observa na escultura da Santíssima Trindade do Museu Nacional de Arte Antiga (figura 19). Também na datação estão ambas as imagens próximas, pois formalmente pensamos que a imagem de roca se trata de uma obra executada nos finais do século XVII, ou princípios do XVIII.

A representação da Santíssima Trindade do Museu Nacional de Arte Antiga é semelhante à imagem de Deus Pai de Bragança nos ornatos decorativos da tiara, mas também na composição das barbas e bigodes, apesar dos detalhes das linhas que simulam as barbas serem mais simplificados na imagem de Bragança.

\footnotetext{
${ }^{48}$ Conforme pesquisa efetuada a 12 de março de 2015 na base de dados dos Museus da DGPC, (DireçãoGeral do Património Cultural, Departamento dos Bens Culturais, Divisão do Património Imóvel, Móvel e Imaterial, Palácio Nacional da Ajuda, Lisboa - Portugal). http://www.matriznet.dgpc.pt/MatrizNet/Objectos/ObjectosConsultar.aspx?IdReg=247440
} 
Os rostos assemelham-se mas desconhece-se se a imagem de Bragança susteria a figura de Cristo Morto sobre o colo, tal como acontece com a imagem do Museu de Arte Antiga, ou se reproduziria o modelo mais comum de Deus Pai segurando entre os joelhos a figura de Cristo Crucificado. A proximidade formal das cabeças de ambas as esculturas é inegável, mas o desconhecimento da autoria e proveniência da imagem do Museu não acrescenta dados que permitam perceber a produção da imagem de Bragança, apenas possibilita a identificação da figura representada e a constatação da difusão do modelo devocional.

Aquando do inventário para o

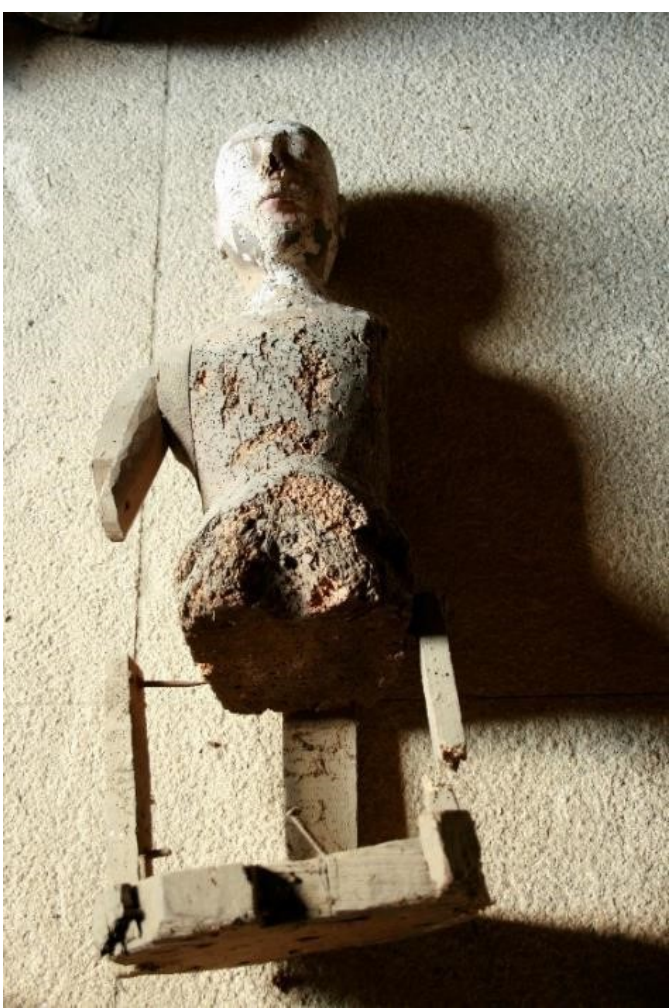

Imagem 20

Imagem de roca muito deteriorada - SFB 37 Sala do capítulo da igreja de São Francisco em Bragança presente estudo foi catalogada uma escultura (imagem 20) encontrada nos arrumos da sala do capítulo que pelo que resta da estrutura que a sustenta (atualmente fraturada em várias partes) indicia tratar-se de uma imagem de roca. $\mathrm{O}$ deteriorado estado da madeira e as várias lacunas não permitem identificar a devoção que representava, mas reforça a importância destas imagens de vestir, sobretudo para cerimoniais públicos, mesmo depois das ordenações de Trento terem limitado o seu uso.

Dos finais do século XVII parece ser também, pelas proximidades formais, a imagem que representa São Francisco de Assis ajoelhado (imagem 21). Encontra-se atualmente desafeta ao culto e guardada na sacristia da igreja de São Francisco de Bragança, já sem base que permita a sua sustentação na posição original, no entanto mantém ainda as barras nos joelhos com que estaria presa.

Os vincados drapeados verticais dos panejamentos e o talhe minucioso dos enrolamentos que decoram a barba e o cabelo (Imagem 22) aproximam a imagem dos 
modelos escultóricos do final do seculo XVII. É evidente pelo gesto de genuflexão e pelos braços abertos que se trata de uma representação de São Francisco de Assis no momento de receber os estigmas. Esta narrativa relaciona-se com a figura de Cristo Alado também existente na mesma igreja. O que não se relaciona é a disparidade formal entre ambas as imagens, parecendo a escultura de Cristo Alado ser posterior, com produção já bem dentro do século XVIII. Esta questão será desenvolvida no âmbito da análise iconográfica das imagens, no entanto houve a necessidade de referir esta desigualdade sob a perspetiva formal que supõe também a disparidade cronológica.

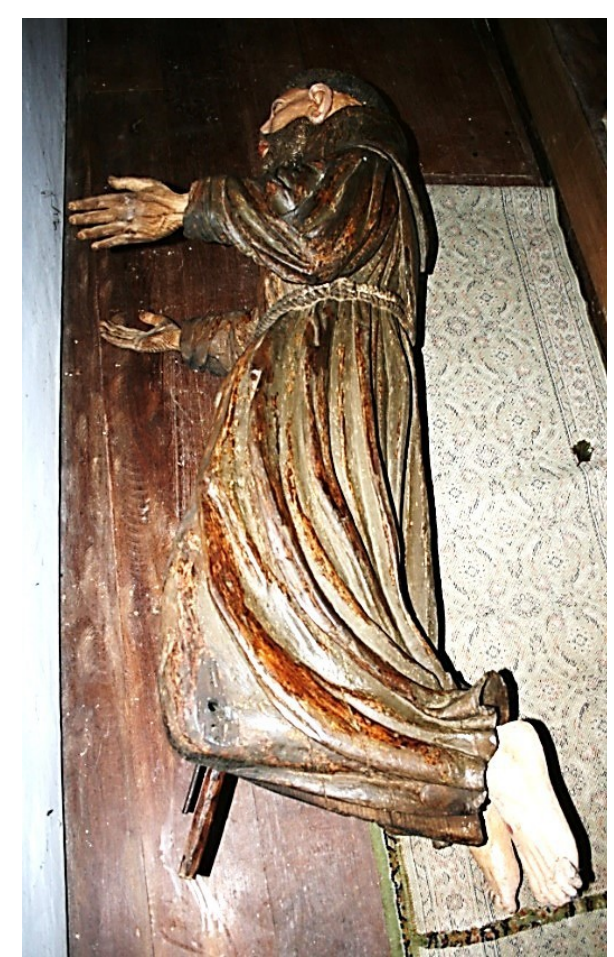

Imagem 21

São Francisco - SFB 35

Sacristia da igreja de São Francisco em Bragança

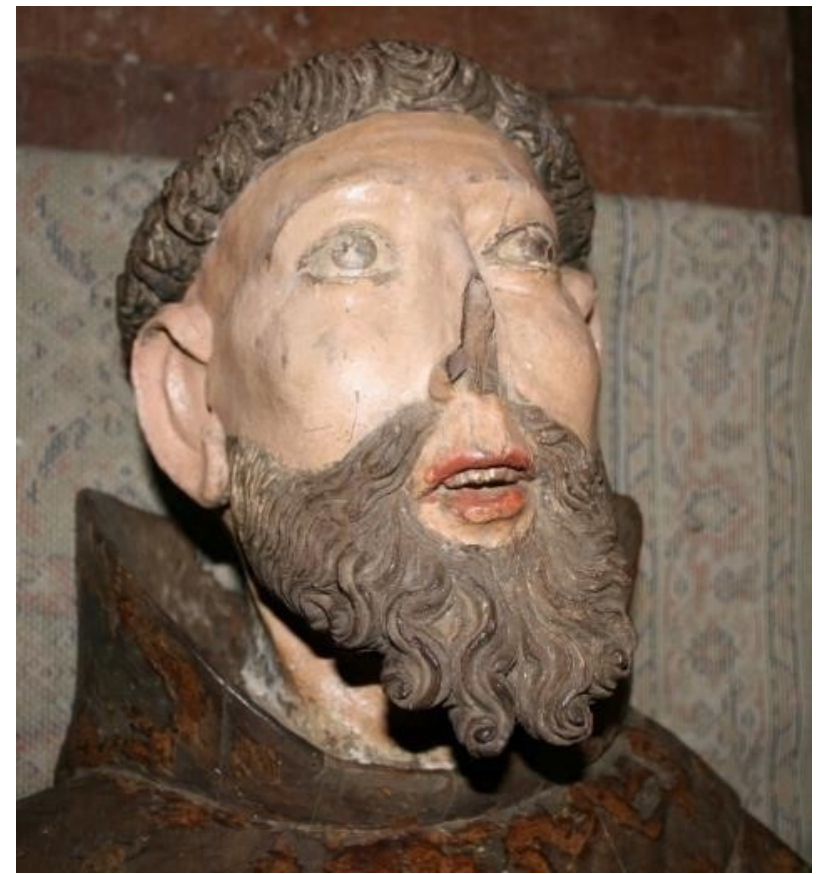

Imagem 22

São Francisco - SFB 35 (pormenor do rosto) Sacristia da igreja de São Francisco em Bragança

São Francisco originalmente teria um suporte (uma plataforma ou um andor) conforme se percebe nas duas estacas sobre os joelhos que serviriam para o fixar, pois de outro modo não se sustém. A perda desse elemento constrange de sobremaneira a sua leitura.

O seculo XVII foi no convento de São Francisco de Bragança um importante período para a produção artística e apesar da guerra da Restauração e das várias contingências económicas assistiu-se a um incremento das encomendas e das devoções que as corporalizam, processo que se desenvolveu ao longo do século XVIII. 
No mesmo século XVII o convento de Santa Clara de Bragança receberá também significativas obras.

De todos os núcleos inventariados nos espaços franciscanos do distrito de Bragança, a igreja do desaparecido convento de Santa Clara, atualmente designada por igreja de Nossa Senhora das Graças, constitui o espaço onde existem menos esculturas. Possivelmente este desequilíbrio de bens poderá ser entendido com base no próprio processo de extinção das Ordens Religiosas, que supunha nos espaços masculinos o abandono imediato dos conventos, enquanto nos femininos se permitia que as religiosas se mantivessem nos conventos até à morte da última monja. Eventualmente durante esse período as religiosas puderam salvaguardar dos inventários as imagens sagradas e demais objetos de culto e consequentemente puderam retirá-las dos seus espaços originais. As diversas adaptações que a igreja foi sofrendo já ao longo do século XX também contribuíram para a escassez de objetos anteriores a 1834. O facto é que na contemporaneidade, no âmbito do presente estudo, existe uma disparidade importante no número de bens que constam no interior dos espaços religiosos femininos comparativamente aos masculinos. O convento das clarissas foi fundado em Bragança em $1569^{49}$, mas teremos que avançar para a centúria seguinte para encontrar as esculturas que formalmente se enquadram nos modelos de produção em uso.

No interior da igreja, colocado sobre a tribuna do altar-mor, está uma figura de Cristo Crucificado (imagem 23). Está representado com algum cuidado no equilíbrio anatómico, e com detalhado pormenor nas saliências ósseas. Limpo de sangue, apenas apresenta sinais de martírio na chaga do peito e sobre os joelhos. Os pés voltados para dentro e sobrepostos estão pregados com um só cravo sobre a cruz.

\footnotetext{
${ }^{49}$ Alves, Francisco Manuel, Bragança Memórias arqueológico-históricas do distrito de Bragança $\left(2^{a}\right.$ edição) Tomo I, Bragança, Câmara Municipal de Bragança / Instituto Português de Museus - Museu Abade de Baçal, 2000, (original publicado em 1910-1947), p. 383.
} 


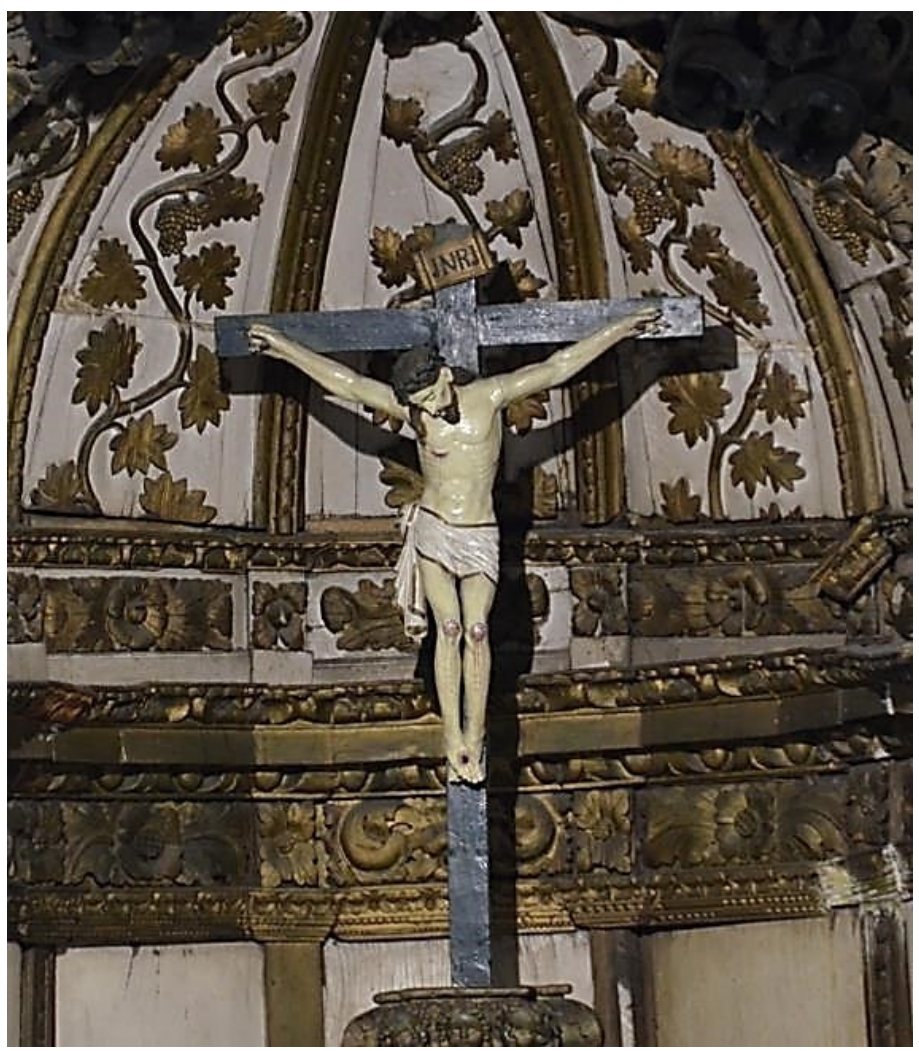

Imagem 23

Escultura de Cristo Crucificado - SCB 06

Igreja de Santa Clara (atual igreja de Nossa Senhora das Graças)

- Bragança, colocado sobre a tribuna do altar-mor

Cristo está representado morto, com rosto de linhas suaves e a boca entreaberta. Apresenta barba pontiaguda e longos cabelos castanhos com uma ampla madeixa ondulada caída sobre o ombro direito, cingida na cabeça a coroa de espinho é esculpida sobre a madeira. O corpo nu está coberto por um comprido cendal branco com bordo dourado em toda a volta. O pregueado pouco volumoso do cendal e a ampla abertura dos braços definem o gesto de contido sofrimento apenas quebrado pela ligeira genuflexão dos joelhos. Formalmente estes aspetos sugerem tratar-se de uma obra produzida nos inícios do século XVII.

Relacionadas com a mesma centúria existem mais duas esculturas ainda hoje a culto na igreja que outrora foi das clarissas em Bragança. Colocada num nicho alto, no arco triunfal que divide a nave única da igreja da capela-mor, está no lado do Evangelho um curioso conjunto formado por Santa Ana e a Virgem Maria (imagem 24). O conjunto parece ter sido reunido posteriormente à produção das duas imagens que o constituem. 
Observa-se uma evidente diferença na produção das duas imagens que constituem o conjunto. A diferença mais notória é relativa à escala das figuras. A figura maior, Santa Ana, tem ambos os braços afastados do corpo e entre eles a figura da Virgem Maria. O

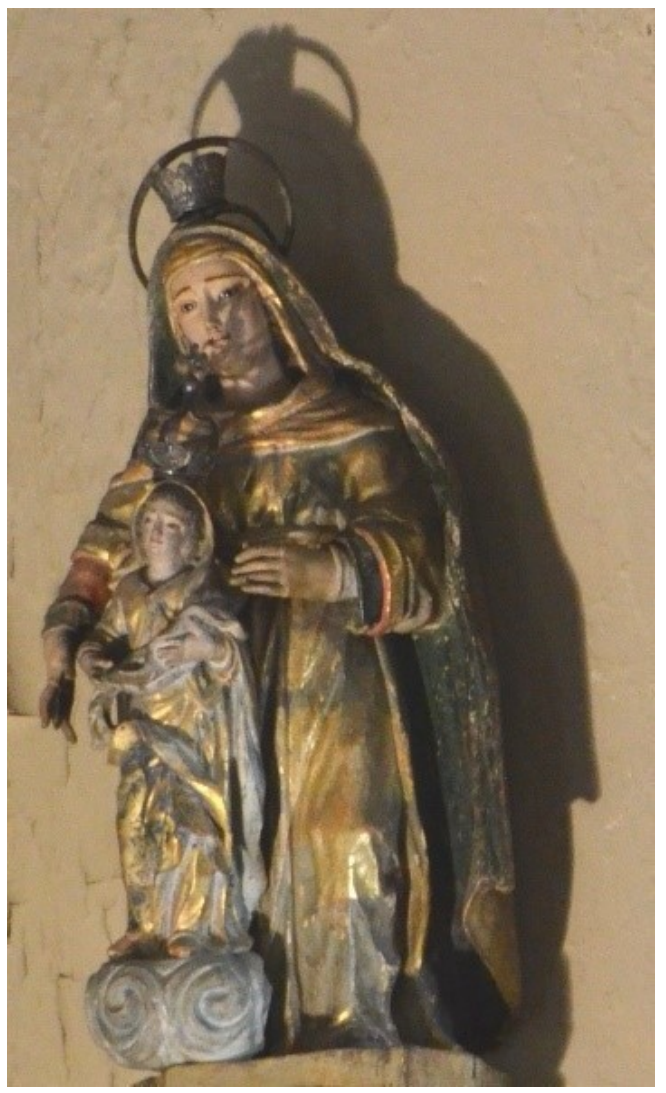

Imagem 24

Escultura de Santa Ana com a Virgem MariaSCB 08, Igreja de Santa Clara (atual igreja de Nossa Senhora das Graças) - Bragança, colocado num nicho alto no arco triunfal no lado do Evangelho vincado pregueado das vestes cobre-a sobre a cabeça até aos pés. $\mathrm{O}$ rosto fino apresenta-se cuidado, na contenção da expressão dolorosa, e, delicado nas proporções anatómicas. A contenção emocional sugere os modelos das Dolorosas espanholas, abrindo essa possibilidade de origem. $O$ véu que a cinge intensifica o natural dramatismo da expressão sugerida pelo leve arqueado nas sobrancelhas. Adossada em frente está a figura mais pequena que representa a Virgem Maria colocada sobre nuvens decoradas com simétricos enrolamentos. Representada de pé, a figura flete ambos braços sobre o peito onde assenta um panejamento (que poderia suster a figura do Menino) mas já não tem atualmente qualquer atributo.

Enverga uma túnica com dinâmico pregueado que a cobre até aos pés. O rosto inexpressivo está sumariamente tratado nos detalhes anatómicos.

É pelo contraste entre o cuidado anatómico e a expressividade do rosto de Santa Ana e o esquemático tratamento dado ao rosto da figura de Nossa Senhora que parece tratar-se de um conjunto posteriormente formado, pois não se afigura credível que ambas as esculturas tenham sido produzidas pelo mesmo autor. O facto de Nossa Senhora estar suspensa sobre uma nuvem afasta a representação da Virgem do plano da representação de Santa Ana o que torna a narrativa incongruente das imagens enquanto conjunto. 
Vinculado aos modelos seiscentistas da escultura está também a imagem de Santo António da igreja de Santa Clara (imagem 25) ${ }^{50}$. A escultura encontra-se atualmente transformada pelos diversos repintes que ao longo do tempo the foram aplicados, de tal forma alteradores da obra original que dificultam significativamente uma correta observação (Imagem 26).

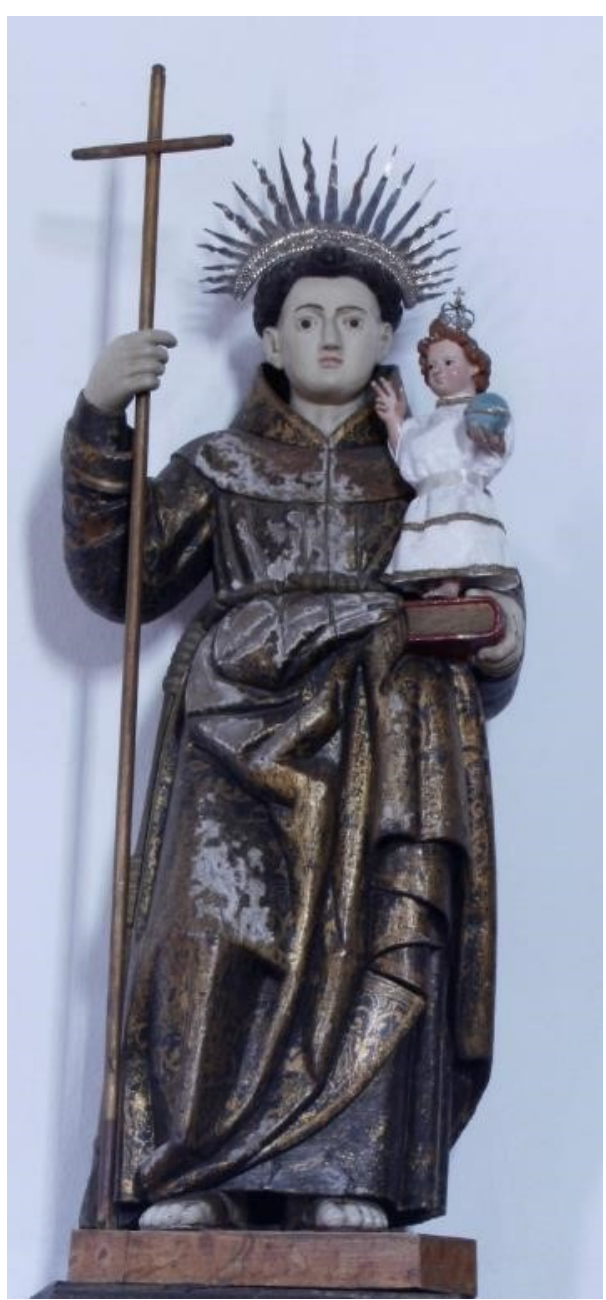

Imagem 25

Escultura de Santo António - SCB 11 Igreja de Santa Clara (atual igreja de Nossa Senhora das Graças)

- Bragança, colocado sobre uma peanha no lado do Evangelho

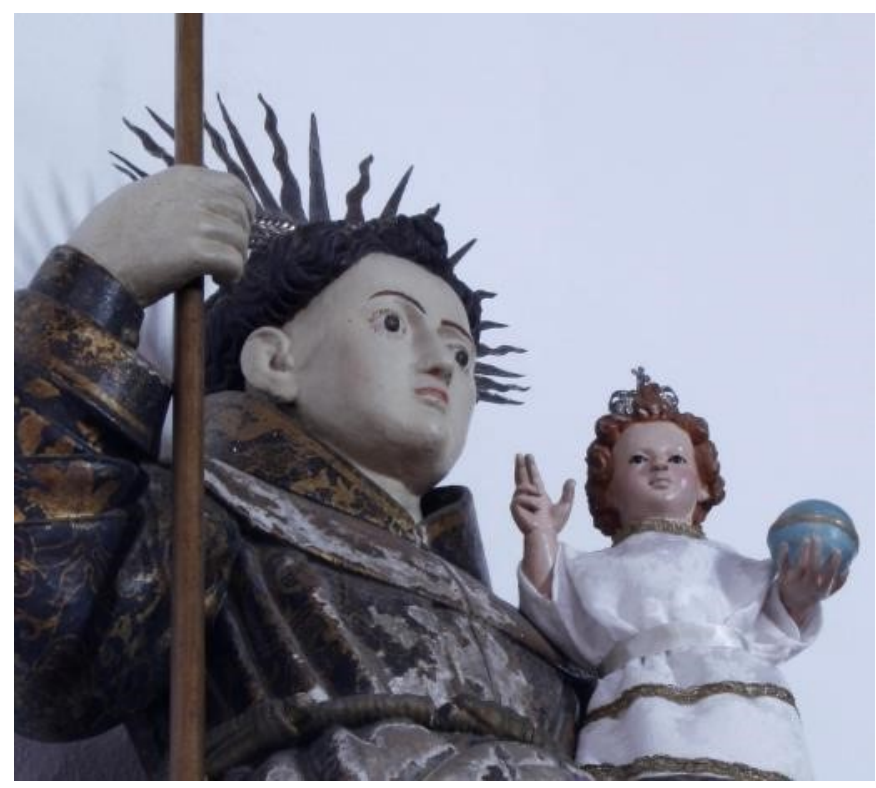

Imagem 26

Escultura de Santo António - SCB 11 (pormenor do rosto de Santo António e do menino)

Igreja de Santa Clara (atual igreja de Nossa Senhora das Graças) - Bragança

Colocado sobre uma peanha no lado do Evangelho

Os panejamentos, pesados e com volumosas pregas, desenvolvem um plástico efeito decorativo. De expressão grave, o rosto jovem, fixa o olhar em frente, com modelação

\footnotetext{
${ }^{50}$ No templo das clarissas foi registada em 1996 mais uma escultura do século XVII, a imagem de Nossa Senhora da Soledade. Gomes, José Manuel (Coord.), Imagens e escultura. 1545-1995 Comemorações Jubilares dos 450 Anos da Diocese de Bragança - Miranda, Bragança, Departamento de Liturgia e Património Cultural da Diocese de Bragança - Miranda e Comissão de Arte Sacra, 1996, p. 8. No entanto no inventário realizado para o presente estudo a escultura foi interpretada dentro dos modelos escultóricos do século XX, conforme ficha de inventário SCB 03.
} 
cuidada nos detalhes anatómicos (muito repintado). Sobre a cabeça tonsurada, o cabelo com ondas bem definidas, ostenta um resplendor semicircular raiado.

No século XVII foi fundado o convento de Mogadouro que pertencia à Ordem III Regular, segundo o Abade de Baçal em $1618^{51}$.

$\mathrm{O}$ impacto da presença da corte ibérica estabelecida em Valhadolid nos inícios do século XVII é, neste território de fronteira, mais intensamente sentido. A proximidade de Mogadouro a Miranda do Douro é também de suma importância pela presença desde 1545 da sede episcopal em Miranda do Douro e pela consequente frequência de vários artistas que trabalharam na Sé. De entre todos destacamos, pela importância que assumiu na escultura, a presença de Gregório Fernández que nos inícios do século XVII fez o retábulo do altar-mor da catedral. O retábulo terá sido concluído em $1614^{52}$. E apesar de se tratar ainda de uma obra maneirista é considerada a primeira intervenção importante que já anuncia o Barroco. A figuração em madeira a substituir a pintura, o dinamismo dos gestos e o ritmo da composição policénica de figuras inspiradas nos modelos maneiristas flamenguizantes situam o retábulo da sé de Miranda na fronteira entre o maneirismo e o Barroco ${ }^{53}$.

\footnotetext{
${ }^{51}$ Alves, Francisco Manuel, Bragança Memórias arqueológico-históricas do distrito de Bragança (2 ${ }^{a}$ edição) Tomo I, Bragança, Câmara Municipal de Bragança / Instituto Português de Museus - Museu Abade de Baçal, 2000, (original publicado em 1910-1947), p. 382.

${ }^{52}$ Correia, Maria João Pinto, "A Escultura portuguesa entre o final do século XVI e o final do século XVII" in Dalila Rodrigues (Coord.), Arte Portuguesa - Da Pré-História ao Século XX, Lisboa, Fubu Editores, 2009, pp. 75-142; Ferreira-Alves, Natália Marinho, "Pintura, Talha e Escultura (séculos XVII e XVIII) no Norte de Portugal" in Revista da Faculdade de Letras. Ciências e Técnicas do Património vol. 2, Porto, Faculdade de Letras da Universidade do Porto, Departamento de Ciências e Técnicas do Património, 2003, pp. 735-756; Mourinho (Júnior), António Rodrigues, A talha nos concelhos de Miranda do Douro, Mogadouro e Vimioso nos séculos XVII e XVIII, Braga, Associação de Municípios do Planalto Mirandês, 1984, pp. 25-28.
}

${ }^{53}$ Correia, Maria João Pinto, "A Escultura portuguesa entre o final do século XVI e o final do século XVII" in Dalila Rodrigues (Coord.), Arte Portuguesa - Da Pré-História ao Século XX, Lisboa, Fubu Editores, 2009, pp. 75-142; Ferreira-Alves identifica também os prenúncios do novo espírito que se percebem na obra de Gregório Fernández (ca. 1575-1636) do retábulo-mor da Sé de Miranda sobre uma estrutura de cariz ainda maneirista. Ferreira-Alves, Natália Marinho, "Pintura, Talha e Escultura (séculos XVII e XVIII) no Norte de Portugal" in Revista da Faculdade de Letras. Ciências e Técnicas do Património vol. 2, Porto, Faculdade de Letras da Universidade do Porto, Departamento de Ciências e Técnicas do Património, 2003, pp. 735-756. O abade de Baçal refere Juan de Moniategio como mestre do retábulo, bem como Thomaz de Velasquez. Alves, Francisco Manuel, Bragança Memórias arqueológicohistóricas do distrito de Bragança (2 ${ }^{a}$ edição) Tomo IV, Bragança, Câmara Municipal de Bragança / Instituto Português de Museus - Museu Abade de Baçal, 2000, (original publicado em 1910-1947), p. 528. Também Martín González refere que Muniátegui e Cristóbal Velásquez como ensambladores do retábulo cuja escultura que ocupa o interior denota diversos estilos de Gregório Fernandez. A figura de São João no Calvário que encima a composição denuncia a influência de Juan de Juni e as quebras no pregueado dos panejamentos que lembram a estatuária gótica e que constituirá uma das marcas identitárias de Gregório Fernandez. Martín González, Juan José, La huella española en la escultura portuguesa, Valladolid, Sever - Cuesta, 1961, pp. 48-50; Mourinho (Júnior), António Rodrigues, A talha 
Apesar da relevância do escultor para o século XVII espanhol, Martín González refere a escassa influência do retábulo de Gregório Fernández na escultura coeva portuguesa ${ }^{54}$. Mourinho, pelo contrário, refere a importante influência do retábulo-mor da Sé de Miranda em toda a região durante o século XVII e ainda no XVIII ${ }^{55}$.

Julgamos que a presença de Gregório Fernández e dos restantes autores que chegaram à fábrica da catedral de Miranda dou Douro de Valhadolid, Zamora ou Salamanca foi significativa não só em Miranda mas também nos territórios limítrofes e que se estendeu ao longo do século XVII e XVIII. No entanto as limitações provocadas pela guerra condicionaram as encomendas.

Com uma estrutura ainda maneirista e decorado com ornatos clássicos são os dois retábulos que decoram lateralmente o arco triunfal da igreja do convento de São Francisco em Mogadouro (fundado em $\left.1618^{56}\right)$, mas ocupado apenas nos finais

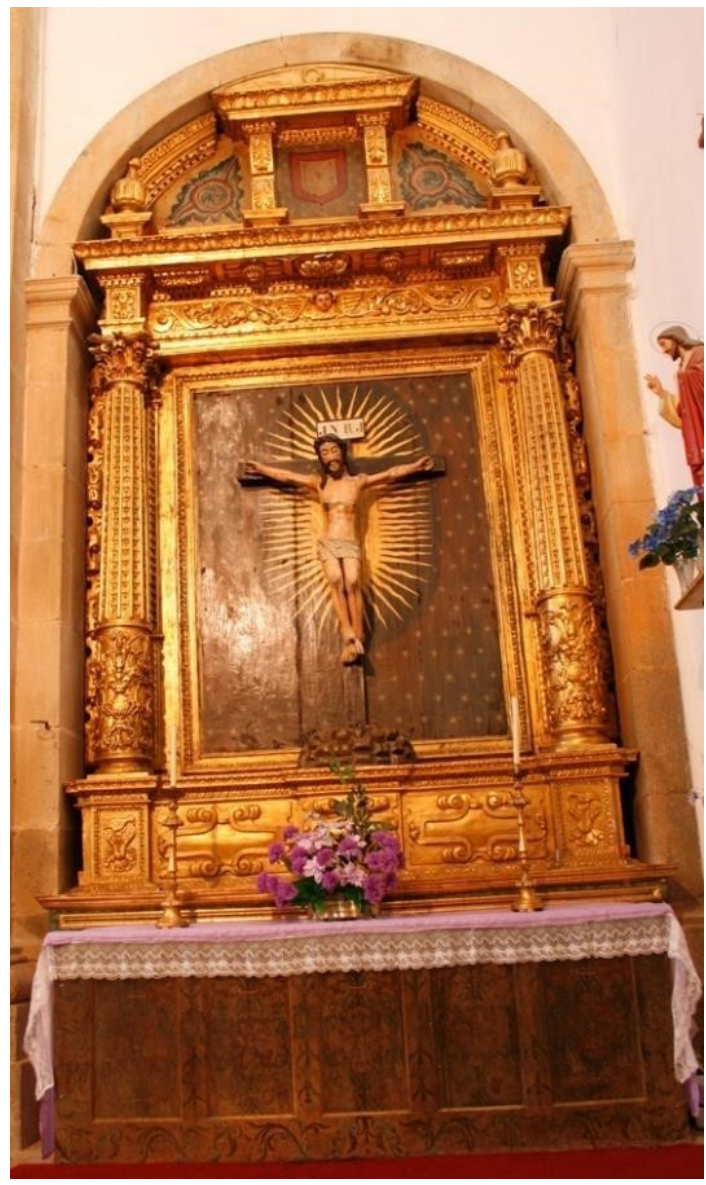

Imagem 27

Retábulo maneirista com Escultura de Cristo Crucificado - SFM 06

Igreja de São Francisco - Mogadouro Transepto do lado do Epístola

nos concelhos de Miranda do Douro, Mogadouro e Vimioso nos séculos XVII e XVIII, Braga, Associação de Municípios do Planalto Mirandês, 1984, pp. 25-28.

${ }^{54}$ Martín González, Juan José, La huella española en la escultura portuguesa, Valladolid, Sever - Cuesta, 1961, p. 17.

${ }^{55}$ A influência de Gregório Fernandez é evidente no coroamento de grande parte dos retábulos que apresentam no coroamento do ático a figura do Pai Eterno esculpida ou pintada. Mourinho (Júnior), António Rodrigues, A talha nos concelhos de Miranda do Douro, Mogadouro e Vimioso nos séculos XVII e XVIII, Braga, Associação de Municípios do Planalto Mirandês, 1984, p. 28. A proximidade entre as linguagens artísticas nos territórios de fronteira foi também identificada no território da Galiza onde a prática de escultores e entalhadores portugueses bem como a influência de Portugal se nota. Folgar De La Calle, Maria Carmen, "La influencia portuguesa en los retablos barrocos de Galicia", Actas do II Congresso Internacional del Barroco, Porto, Universidade do Porto, Faculdade de Letras. Departamento de Ciências e Técnicas do Património, 2003, pag. 475-490.

${ }^{56}$ Alves, Francisco Manuel, Bragança Memórias arqueológico-históricas do distrito de Bragança $\left(2^{a}\right.$ edição) Tomo I, Bragança, Câmara Municipal de Bragança / Instituto Português de Museus - Museu Abade de Baçal, 2000, (original publicado em 1910-1947), p. 382. 
de seiscentos. A data de 1689 gravada na cartela que se encontra sobre o nicho na fachada da igreja poderá celebrar o final da construção do atual edifício mas a igreja estaria pronta para servir ao culto, vinte anos antes ${ }^{57}$.

O templo guarda no retábulo do lado da Epistola a figura de Cristo Crucificado e no lado do Evangelho a figura da Imaculada Conceição.

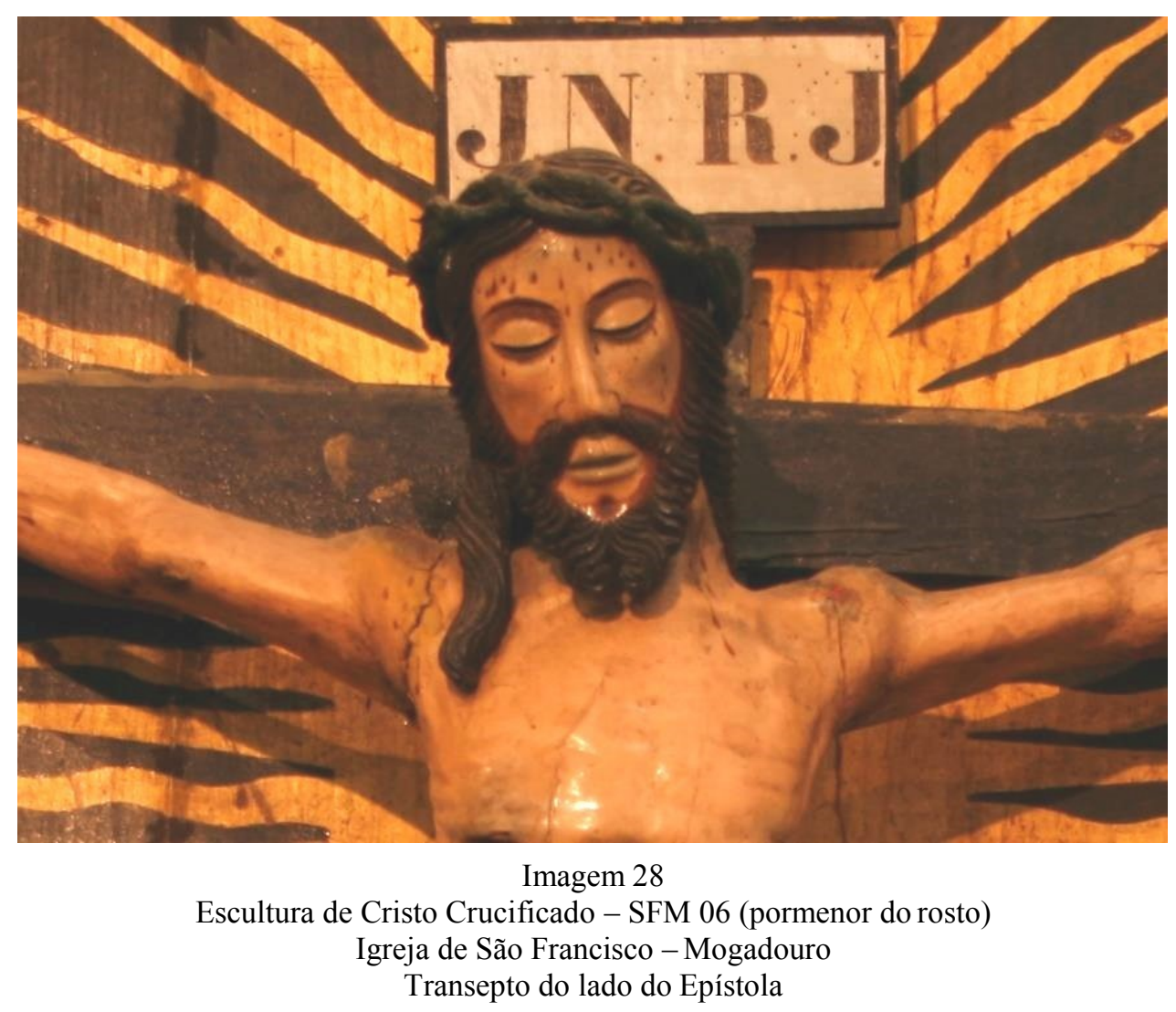

Nos modelos retabulares produzidos pela escola do Porto, Ferreira-Alves refere a existência de retábulos maneiristas e de transição até ao último terço do século XVII ${ }^{58}$. Enquadramento temporal em que se pode incluir a produção retabular do transepto (Imagem 27) na igreja de São Francisco de Mogadouro. Formalmente a figura de Cristo Crucificado parece próxima da linguagem do retábulo que a guarda, sugerindo que a produção da imagem pode ser a mesma que a do retábulo. Mourinho propõe que a escultura de Cristo, obra ingénua, pode ser do escultor António de Oliveira, que vivia em Torre de Moncorvo, autor da imagem de Cristo da igreja da Misericórdia de

\footnotetext{
${ }^{57}$ Mourinho (Júnior), António Rodrigues, Arquitectura religiosa da Diocese de Miranda do Douro Bragança, Sendim, Câmara Municipal de Miranda do Douro, 1995, p. 255.

${ }^{58}$ Ferreira-Alves, Natália Marinho, "Pintura, Talha e Escultura (séculos XVII e XVIII) no Norte de Portugal" in Revista da Faculdade de Letras. Ciências e Técnicas do Património vol. 2, Porto, Faculdade de Letras da Universidade do Porto, Departamento de Ciências e Técnicas do Património, 2003, p. 741.
} 
Miranda do Douro idêntica à imagem de Mogadouro ${ }^{59}$. O gesto regular de braços bem abertos imprime a estaticidade do corpo com algumas irregularidades anatómicas e proporções ligeiramente desequilibradas. A contenção no sofrimento e nos sinais de martírio revelam a proximidade conceptual ao gosto clássico. Mas é no cendal que o cobre, irregular com pregueado oblíquo, que nos parece residir uma linguagem mais próxima ao gosto barroco. A ausência de postiços para o cabelo e coroa de espinhos e a contenção emotiva da figura (Imagem 28) permitem-nos aproxima-la formalmente aos finais do seculo XVII, ou até, pelo ondulado nos panejamentos do cendal a princípios do XVIII. A produção não nos parece ser a mesma que a da imagem de Miranda do Douro, do escultor António de Oliveira de Moncorvo, conforme sugere Mourinho. As irregularidades formais denunciam uma produção local, ingénua, pouco influenciada pelas linguagens mais expressivas que se estendiam nos grandes centros de produção artística.

A influência da obra retabular da sé de Miranda é também percetível na adoção de linguagens que lhe estão próximas, como se observa na escultura de São Caetano ${ }^{60}$ (imagem 29) da igreja de São Francisco de Mogadouro. A figura está cuidadosamente esculpida no naturalismo do gesto. O rosto largo com contornos simétricos, bem definidos, tem o olhar elevado e expressão grave (imagem 30). Eleva ambos braços, ligeiramente assimétricos, com uma gestualidade dinâmica que reforça a torsão do corpo sugerida no contraposto. A mão direita sustem com elegância um coração, a mão esquerda reforça a teatralidade do gesto com a palma voltada para o observador. A ampla veste que o cobre tem um pesado efeito plástico conseguido com pregueados grossos e vincos profundos e ondulados com ligeiríssimas pregas. A elegante teatralidade do gesto aproxima formalmente a figura com os modelos em uso na segunda metade do século XVII, sobretudo nas oficinas espanholas. O cuidado exposto nos detalhes e expressividade do rosto, com densas e bem desenhadas barbas que se juntam com as patilhas, e olhar intenso sugerem os ecos dos trabalhos da oficina do

\footnotetext{
${ }^{59}$ Mourinho (Júnior), António Rodrigues, A talha nos concelhos de Miranda do Douro, Mogadouro e Vimioso nos séculos XVII e XVIII, Braga, Associação de Municípios do Planalto Mirandês, 1984, p. 55. No entanto, a imagem que atualmente se expõe no altar parece-nos mais cuidada na anatomia e de produção diferente que a escultura de Mogadouro que é formalmente mais arcaica, neste sentido também a imagem de Miranda do Douro nos parece posterior que a imagem de Mogadouro.

${ }^{60}$ A identificação da imagem advém do inventário de 1834 onde se registou uma imagem de São Caetano, o que nos sugere tratar-se desta escultura. Mourinho identifica a imagem como Santo Inácio de Loiola mas o registo dos bens da desamortização não refere essa devoção, Mourinho (Júnior), António Rodrigues, A talha nos concelhos de Miranda do Douro, Mogadouro e Vimioso nos séculos XVII e XVIII, Braga, Associação de Municípios do Planalto Mirandês, 1984, pp. 55, 56.
} 
escultor de Valhadolid Gregório Fernández e da sua obra mais amplamente conhecida no território - o altar-mor da sé em Miranda.

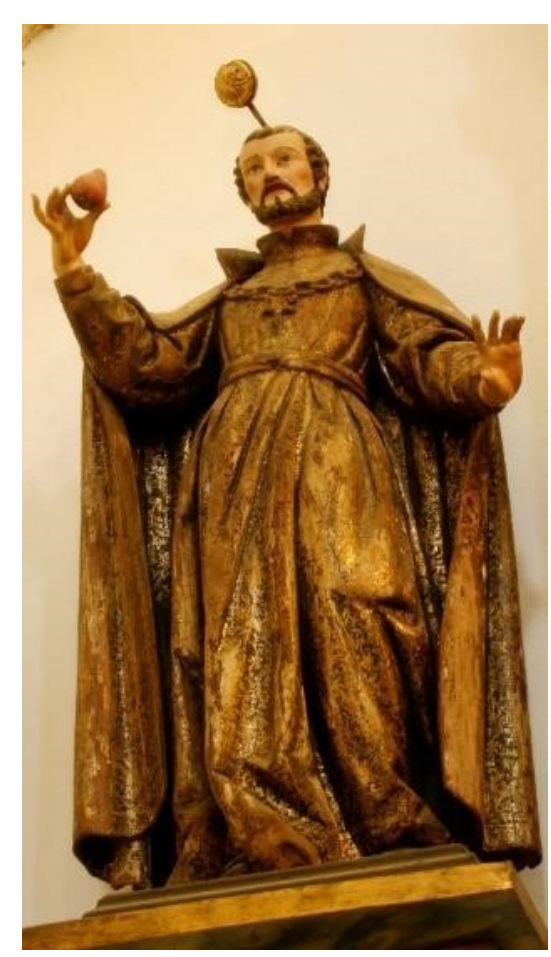

Imagem 29

Escultura de São Caetano - SFM 03 Igreja de São Francisco Mogadouro

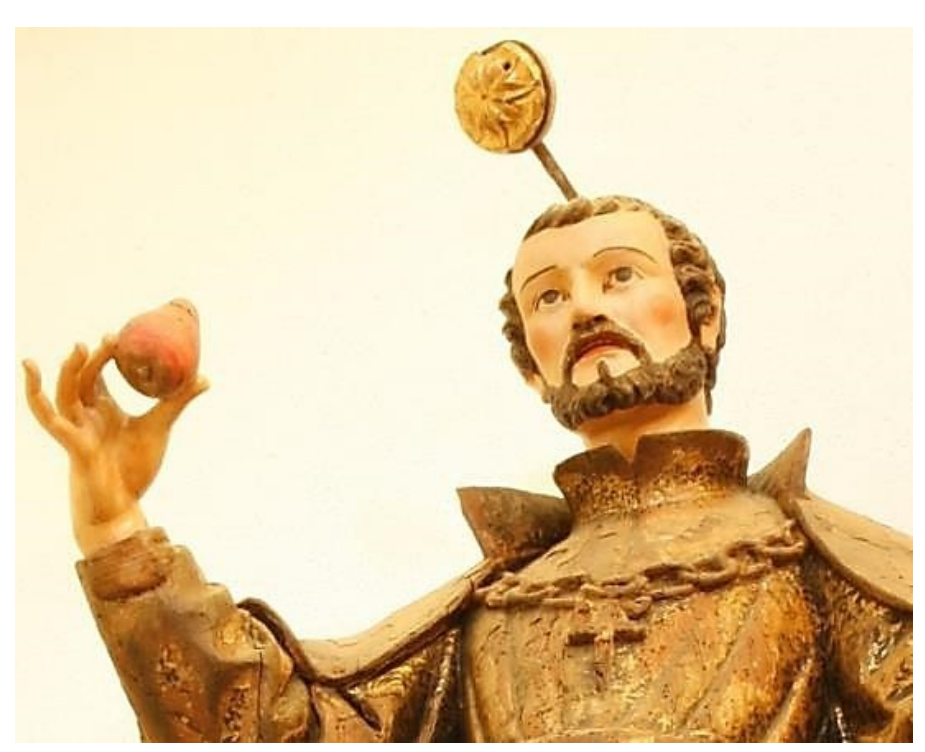

Imagem 30

Escultura de São Caetano - SFM 03 (pormenor do rosto) Igreja de São Francisco Mogadouro

No início do período barroco, a escultura no Norte segue os esquemas observados no resto do país. Mas, a elegância requintada da linguagem erudita introduzida no século XVI nos modelos escultóricos da escola de Coimbra, foi sendo esquecida ${ }^{61}$.

A guerra da Restauração (1640-1668) produziu neste território fronteiriço consequências sociais e económicas que condicionaram profundamente a produção escultórica existente desse período. Os parâmetros tridentinos e a rejeição do gosto clássico geraram formas arcaizantes mas que satisfaziam a clientela conservadora, ou com recursos limitados. Pontualmente as esculturas foram influenciadas pela efémera presença de escultores vindos de Espanha ou de obras trazidas sobretudo das oficinas de Valhadolid, mas também do Porto e Braga.

\footnotetext{
${ }^{61}$ De Nicolau Chanterene e João de Ruão. Ferreira-Alves, Natália Marinho, "Pintura, Talha e Escultura (séculos XVII e XVIII) no Norte de Portugal" in Revista da Faculdade de Letras. Ciências e Técnicas do Património vol. 2, Porto, Faculdade de Letras da Universidade do Porto, Departamento de Ciências e Técnicas do Património, 2003, pp. 735-756; Dias, Pedro, A Escultura Maneirista Portuguesa, Coimbra, Minerva, 1995, pp. 17-21; Carvalho, Maria João Vilhena de, "A Escultura portuguesa entre a pedra, a madeira e o barro (1450-1580)" in Dalila Rodrigues (Coord.), Arte Portuguesa - Da Pré-História ao Século XX, volume 7, Lisboa, Fubu Editores, 2009, pp. 11-65.
} 


\section{SÉCULO XVIII}

No reinado de D. João V assistiu-se a uma aceleração mais profunda dos programas escultóricos de formas artísticas de raiz clássica, iniciada logo com as obras da nova capela-mor da Sé de Évora com o Cristo de Manuel Dias ${ }^{62}$ e talha de João Frederico Ludovice. Na mesma obra colaborou, na representação dos Apóstolos, o escultor João António Bellini ${ }^{63}$.

A encomenda de João V para o convento, palácio, biblioteca e basílica de Mafra, conforma ao longo do século XVIII o mais importante estaleiro artístico de Portugal. A encomenda das esculturas foi feita em Itália, quer para o exterior quer para o interior do templo e começou a chegar em 1731, e pedia-se o envio faseado. Começando pelo crucifixo do altar-mor, continuando pelas Virtudes a colocar sobre a porta principal e pelo baixo-relevo para o frontispício da igreja, pelas estátuas destinadas à fachada e finalmente pelas peças a colocar no interior. Os critérios da encomenda colocavam especial ênfase na perfeição das obras e dos hábitos que identificariam as imagens. Este rigor iconográfico, principalmente nas imagens que representavam os santos fundadores de comunidades monásticas ativas em Portugal, é determinante para a visão enciclopédica do catolicismo que a estatuária de Mafra propõe.

\footnotetext{
${ }^{62}$ Manuel Dias o autor de Cristo Crucificado da sé de Évora de 1735-1736, feito a partir de um desenho de Viera Lusitano, em cedro, cujo tom claro se destaca do fundo negro dos mármores, dialoga com os anjos piedosos e com os dois Apóstolos colocados lateralmente sobre as portas. Manuel Dias, escultor lisboeta ficou celebre pelos trabalhos em madeira, executando sobretudo crucifixos, sendo por isso conhecido como "Pai dos Cristos". Pereira, José Fernandes, "O barroco do século XVIII" in Paulo Pereira (direção), Historia da Arte Portuguesa, Volume III, Lisboa, Círculo de leitores, 1995, pp. 50-181; Pereira, José Fernandes, "Estética barroca I: arquitectura e escultura", in Dalila Rodrigues (Coord.), Arte Portuguesa - Da Pré-História ao Século XX, volume 12, Lisboa, Fubu Editores, 2009, pp. 7-136.

${ }^{63}$ João António Bellini de Pádua, autor também dos dois bustos de São Pedro e São Paulo, de 1730-1733, de evocação berniniana, faz parte do crescente interesse pelas obras de artistas italianos, que encontrou em Portugal várias possibilidades de trabalho. E entre elas destaca-se o retábulo de Nossa Senhora da Boa Morte colocado em 1740 na igreja dos Jesuítas em Santarém, conforme disposição testamentária de um comerciante local. O tema da boa morte é traduzido pela narrativa mariana onde a Virgem se despede da Terra e inicia o seu trânsito para o mundo etéreo anunciado pela presença de anjinhos esvoaçantes. Executa ainda outra encomenda para a Quinta de Santa Bárbara nos arredores de Constância de resultado final mais pobre. Nos cinco retábulos da igreja do Convento do Louriçal é evidente a irregularidade do trabalho deste autor, com diversas incorreções anatómicas. O mesmo se observa nas esculturas de São Domingos e São Francisco da igreja de São Domingos em Lisboa onde trabalha com João Frederico Ludovice, assim como na imagem de São João Nepomuceno de 1742, denotando a menor qualidade das suas últimas obras. Pereira, José Fernandes, "O barroco do século XVIII" in Paulo Pereira (direção), Historia da Arte Portuguesa, Volume III, Lisboa, Círculo de leitores, 1995, pp. 50-181; Pereira, José Fernandes, "Estética barroca I: arquitectura e escultura", in Dalila Rodrigues (Coord.), Arte Portuguesa Da Pré-História ao Século XX, volume 12, Lisboa, Fubu Editores, 2009, pp. 7-136; Mangucci, Celso, "A Talha mais Moderna. O percurso artístico de Manuel Abreu e Sebastião Abreu do Ó em Évora" in António Camões Gouveia (Coord.) CENÁCULO Boletim on line do Museu de Évora $n .^{\circ} 4$, Disponível em http://museudevora.imc-ip.pt/, 2010, pp. 3-19.
} 
O mármore de Carrara e a recomendação de usar um só bloco de matéria para evitar veios e linhas de junção de partes, constituiria o imperativo de alvura e de perfeição desejada. A estas recomendações seguia-se a produção de um modelo em barro de modo a que D. João V pudesse ter uma antevisão da obra terminada. Dos vários escultores romanos que se relacionam com as encomendas de Mafra, destaca-se a figura de Carlo Monaldi (1683-1760) ${ }^{64}$ entre vários outros escultores dada a magnitude da encomenda. Em todos é evidente a influência de Camilo Rusconi, de forte marca clássica pósberniniana. Apesar das diferenças qualitativas entre os vários escultores o conjunto de Mafra apresenta uma espantosa unidade processual, compositiva e expressiva. Este equilíbrio deve ser relacionado com as imposições da encomenda de forte carga iconográfica, valorizando a tradição portuguesa na dedicação à Virgem e no culto a Santo António, bem como com a pedagogia emanada pelo monarca absoluto, D. João $\mathrm{V}^{65}$.

$\mathrm{Na}$ área de influência da corte conhece-se o nome de José de Almeida (1700-1769) que estudou em Roma onde obteve alguma notoriedade e no regresso a Portugal

${ }^{64}$ Carlo Monaldi foi o autor das imagens de maior tamanho, que representam São Vicente e São Sebastião e ainda São Felipe Néri e Santa Teresa. Mas na encomenda de Mafra colaboraram também os escultores Agostino Cornnacchini (1685-1754), Giovanni Battista Maini (1690-1752), Filippo della Valle (1698-1768) e Pietro Bracci (1690-1773), e ainda Bernardino Ludovisi (1693-1749), Giuseppe Lironi (1698-1749) e Agostino Corsini (1688-1757). Pereira, José Fernandes, "O barroco do século XVIII" in Paulo Pereira (direção), Historia da Arte Portuguesa, Volume III, Lisboa, Círculo de leitores, 1995, pp. $50-181$.

${ }^{65}$ Pereira, José Fernandes, "O barroco do século XVIII" in Paulo Pereira (direção), Historia da Arte Portuguesa, Volume III, Lisboa, Círculo de leitores, 1995, pp. 50-181; Pereira, José Fernandes, "Estética barroca I: arquitectura e escultura", in Dalila Rodrigues (Coord.), Arte Portuguesa - Da Pré-História ao Século XX, volume 12, Lisboa, Fubu Editores, 2009, pp. 7-136. Pereira, José Fernandes descreveu no frontispício de Mafra a janela das Bênçãos destinada a D. João V está ladeada pelos nichos ocupados por São Francisco e São Domingos. Santa Clara e Santa Isabel ocupam os restantes nichos da fachada. São Vicente, São Sebastião e os santos fundadores ocupam a galilé, São Bento (Beneditinos), São Bernardo (Cistercienses), São João da Mata e São Félix de Valois (Trinitários), São Bruno (Cartuxos), São Francisco de Paula (Mínimos), São Pedro Nolasco (Misericórdia), São Caetano (Teatinos), Santo Inácio de Loiola (Jesuítas), São Filipe Néri (Oratorianos), Santa Teresa (Carmelitas) e São João de Deus (Hospitalários). As restantes quarenta esculturas distribuem-se no interior do templo, totalizando as cinquenta e oito peças encomendadas em Itália, distribuindo-se por oito capelas e dois vestíbulos e agrupando-se por grupos temáticos que corporizam a história da igreja nos seus valores, dogmas e historicidade mais representativa, constituindo uma verdadeira enciclopédia do catolicismo sem paralelo na Europa. Os temas são: Os Apóstolos (São Matias, São Filipe, São Tomé, São Tiago Menor, São Tadeu, São Simão, São Bartolomeu, São Tiago Maior, Santo André, São Pedro), e Apóstolos da Gentilidade (São Barnabé e São Paulo); os Evangelistas (São Lucas, São Marcos, São João e São Mateus, os dois últimos também Apóstolos); Doutores da Igreja (São Tomás de Aquino, São Boaventura, São Gregório, Santo Agostinho, Santo Ambrósio, São Jerónimo); Sagrada Família (Santa Ana, São José, São Joaquim, São João Baptista); Anjos (anjo tutelar do Reino, São Gabriel, São Miguel e São Rafael); Eremita (São Paulo Eremita); Profeta (Santo Elias); Peregrino (São Roque); Missionário (São Francisco Xavier); Contra Reformadores (São Francisco de Bórgia e São Carlos Borromeo); Virgem (Santa Bárbara); Esposa (Rainha Santa Isabel); Mãe (Santa Maria Salomé); Beata (Rita de Cássia). A completar este erudito conjunto está na capela-mor um Cristo Crucificado, enquadrado pela Glória e por dois anjos em adoração, obra do escultor Francesco Maria Schiafino. 
trabalhou em Mafra onde executou em madeira os modelos das obras que ainda não haviam chegado de Itália. Em Lisboa no Palácio das Necessidades trabalhou ao lado de Giusti confundindo-se a obra de ambos. Executou também várias Virgens em madeira para igrejas lisboetas ${ }^{66}$.

A escultura portuguesa do século XVIII caracteriza-se por uma conceção mais erudita nos espaços da corte e por toda a restante escultura que surge nos espaços com menos acesso à informação e à cultura artística. As encomendas de Mafra coexistem em simultâneo, no resto do território, com a produção mais ingénua mas onde a influência clássica é cada vez mais evidente.

A valorização da talha que se observa desde o seculo XVII adquire no século XVIII a sua máxima expressão. Nos territórios em estudo, as influências emanadas a partir de Mafra, Lisboa e Évora chegam através do Porto e Braga que constituem localmente os principais focos disseminadores dos modelos artísticos.

$\mathrm{O}$ primeiro período barroco assistiu-se na escola do Porto à supremacia do mestre entalhador António Gomes que em parceria com Filipe da Silva, produziu a talha da capela de Nossa Senhora da Conceição ou da Árvore de Jessé na igreja do Convento de São Francisco do Porto $(1718)^{67}$. Ferreira-Alves refere que o "gosto moderno" foi introduzido na cidade do Porto e no norte do país com os trabalhos de Nasoni na Sé do Porto que terminam no ano de 1737 com uma difusão significativa durante o século XVIII $^{68}$. Além da Sé do Porto Ferreira-Alves destaca a influência do retábulo da Árvore

\footnotetext{
${ }^{66}$ Pereira, José Fernandes, "O barroco do século XVIII" in Paulo Pereira (direção), Historia da Arte Portuguesa, Volume III, Lisboa, Círculo de leitores, 1995, pp. 50-181; Pereira, José Fernandes, "Estética barroca I: arquitectura e escultura", in Dalila Rodrigues (Coord.), Arte Portuguesa - Da Pré-História ao Século $X X$, volume 12, Lisboa, Fubu Editores, 2009, pp. 7-136.
}

${ }^{67}$ António Gomes foi o responsável pela maior parte das obras de vulto que se fizeram na área de influência da cidade do Porto, para fazê-lo constituiu sociedades com outros artistas igualmente importantes. Entre muitos exemplos destaca-se a sua parceria com Domingos Nunes para os nove retábulos laterais e os dois retábulos colaterais da igreja do Mosteiro de Santa Clara de Coimbra (1692), e o retábulo e tribuna da capela-mor da igreja do Convento de Vilar de Frades (1696); com Filipe da Silva, a talha da capela de Nossa Senhora da Conceição ou da Árvore de Jessé na igreja do Convento de São Francisco do Porto (1718), e a obra de talha do cadeiral do coro do Mosteiro de Santa Maria de Arouca (1722); com Caetano da Silva Pinto, o retábulo e tribuna da capela-mor da igreja de São Pedro de Miragaia do Porto (1724); com José Correia, a obra de talha da capela-mor da igreja do Mosteiro de Jesus de Aveiro (1725). Smith, Robert, A talha em Portugal, Lisboa, Livros Horizonte, 1963, p. 79; FerreiraAlves, Natália Marinho, "Pintura, Talha e Escultura (séculos XVII e XVIII) no Norte de Portugal" in Revista da Faculdade de Letras. Ciências e Técnicas do Património vol. 2, Porto, Faculdade de Letras da Universidade do Porto, Departamento de Ciências e Técnicas do Património, 2003, p. 741.

${ }^{68}$ Ferreira-Alves, Natália Marinho, "Pintura, Talha e Escultura (séculos XVII e XVIII) no Norte de Portugal" in Revista da Faculdade de Letras. Ciências e Técnicas do Património vol. 2, Porto, Faculdade de Letras da Universidade do Porto, Departamento de Ciências e Técnicas do Património, 2003, pp. 735756. 
de Jessé da igreja do Convento de São Francisco, no Porto e refere que todas as esculturas se devem a Manuel Carneiro Adão (de Braga), que em 1719 foi o mestre imaginário escolhido, em parceria com mestres entalhadores António Gomes e Filipe da Silva ${ }^{69}$.

Sobre o retábulo da Árvore de Jessé, Flávio Gonçalves afirma que é do último quartel do seculo XVII, com exceção da imagem de pedra de Nossa Senhora da Conceição que é de origem quinhentista ${ }^{70}$. O mesmo autor refere que posteriormente, já no século XVIII, em 1718, foi acrescentada a figura de São José, de Santa Ana e São Joaquim, momento em que foi restaurado o retábulo do século XVII e acrescentados nos nichos laterais os santos franciscanos que escreveram sobre a Virgem Maria e o dogma da Imaculada Conceição ${ }^{71}$.

$\mathrm{Na}$ igreja conventual de São Francisco no Porto, a talha está maioritariamente identificada, embora ainda subsistam núcleos de autoria desconhecida, sendo também muitos os entalhadores e riscadores conhecidos; no que respeita a imaginária, comprovamos a existência de um número significativo de imagens, mas temos um quase total desconhecimento da sua disposição primitiva, já que se verificaram deslocações de invocações, sendo de igual modo escasso o nosso conhecimento sobre a sua autoria ${ }^{72}$.

\footnotetext{
${ }^{69}$ Ferreira-Alves, Natália Marinho, "Pintura, Talha e Escultura (séculos XVII e XVIII) no Norte de Portugal" in Revista da Faculdade de Letras. Ciências e Técnicas do Património vol. 2, Porto, Faculdade de Letras da Universidade do Porto, Departamento de Ciências e Técnicas do Património, 2003, p. 753. A mesma autora transcreve noutra publicação os detalhes do contrato de encomenda da árvore de Jessé onde se regista que a escultura principal do retábulo de Nossa Senhora da Conceição seria entregue a Manuel Carneiro Adão: "os quatro doutores que escreveram da Senhora, Santa Ana, São Joaquim, os quatro anjos do trono, a Santíssima Trindade, a figura da Igreja, a da Sabedoria, a da Fé, as quatro figuras dos pilares, os quatro anjos que assistem à figura da Igreja, os anjos de toda a glória, me todos os mais anjos que se vêem em todo o risco do retábulo e arco e glória, como também a reforma dos Reis", pertenceram ao mestre escultor, com quem os dois artistas portuenses António Gomes e Filipe da Silva assinaram uma escritura de contrato em 23 de Maio de 1719. Ferreira-Alves, Natália Marinho, "Entalhadores e imaginários do Núcleo Franciscano Portuense" in Natália Marinho Ferreira-Alves e (Coord.) Os Franciscanos no Mundo Português. Artistas e Obras (I), Porto, CEPESE - Centro de Estudos da População, Economia e Sociedade, 2009, pp. 195-211.
}

${ }^{70}$ Gonçalves, Flávio, "A «Árvore de Jessé» na arte portuguesa" in Revista da Faculdade de Letras História, 03, Porto, Faculdade de Letras da Universidade do Porto, 1986, pp. 213-238.

${ }^{71}$ Gonçalves, Flávio, "A «Árvore de Jessé» na arte portuguesa" in Revista da Faculdade de Letras História, 03, Porto, Faculdade de Letras da Universidade do Porto, 1986, pp. 213-238; López Calderón, Carme, "Potuit, decuit, fecit; los franciscanos y el culto a María", in Natália Marinho Ferreira-Alves (Coord.), Franciscanos no Mundo Português III, Porto, CEPESE - Centro de Estudos da População, Economia e Sociedade, 2013, pp. 225-255.

${ }^{72}$ Ferreira-Alves, Natália Marinho, "Entalhadores e imaginários do Núcleo Franciscano Portuense" in Natália Marinho Ferreira-Alves e (Coord.) Os Franciscanos no Mundo Português. Artistas e Obras (I), Porto, CEPESE - Centro de Estudos da População, Economia e Sociedade, 2009, pp. 195-211. Mas a 
O Porto, Braga e o território que envolve ambas cidades consubstancia-se como importante centro produtor de talha e imaginária ${ }^{73}$.

O desconhecimento das autorias das esculturas identificado por Ferreira-Alves no mais importante templo franciscano no norte do país é ainda mais profundo quando nos referimos a conventos periféricos, como é o caso dos espaços em estudo de Bragança, Mogadouro e Vinhais.

Genericamente os artistas portugueses encontravam-se num nível de discurso periférico mas tentavam expressar o ideário pós-tridentino de acordo com os critérios estéticos vigentes na Europa, introduzindo durante o reinado de D. João V (1706- 1750) o chamado "gosto moderno" do barroco romano ${ }^{74}$.

O Norte de Portugal, a partir de meados do século XVII e ao longo do século XVIII, se bem que em linhas gerais acompanhe o panorama artístico do país, é evidente a maior importância dada à escultura, estreitamente ligada à talha. A documentação coeva muitas vezes nem diferencia nos contratos ou pagamentos a talha retabular da imaginária o que dificulta a atribuição dos trabalhos, bem como, a identificação das autorias.

As obras multiplicam-se bem como os autores que as assinam. Ferreira Alves registou diversos nomes que associou a várias produções retabulares. No entanto, as referências estão relacionadas sempre com as estruturas retabulares, e raras vezes a imaginária que

influência das estruturas retabulares do convento de São Francisco no Porto foi amplamente sentida em todo o Norte nacional chegando também à Galiza. Folgar De La Calle, Maria Carmen, "La influencia portuguesa en los retablos barrocos de Galicia", Actas do II Congresso Internacional del Barroco, Porto, Universidade do Porto, Faculdade de Letras. Departamento de Ciências e Técnicas do Património, 2003, pag. 475-490.

${ }^{73}$ Em Matosinhos, Ambrósio Coelho em 1726 foi o autor da imagem da Verónica e dos painéis das ilhargas na igreja do Bom Jesus. Ainda no Porto surge o nome de Gabriel Rodrigues Álvares. Gabriel Rodrigues Álvares, vindo de Landim, região famosa pela qualidade dos seus artistas, aparece associado a obras importantes efetuadas na igreja de São Bento da Vitória do Porto (intervenções no retábulo-mor, caixas dos órgãos, púlpitos, talha do cadeiral do coro alto), entre as quais se destacam as duas estátuas dos dosséis dos dois púlpitos, datados de 1722: do lado da Epístola, o Zelo, e do lado do Evangelho, a Verdade. Ferreira-Alves, Natália Marinho, "Pintura, Talha e Escultura (séculos XVII e XVIII) no Norte de Portugal" in Revista da Faculdade de Letras. Ciências e Técnicas do Património vol. 2, Porto, Faculdade de Letras da Universidade do Porto, Departamento de Ciências e Técnicas do Património, 2003, pp. 735-756.

${ }^{74}$ Ferreira-Alves, Natália Marinho, "Pintura, Talha e Escultura (séculos XVII e XVIII) no Norte de Portugal" in Revista da Faculdade de Letras. Ciências e Técnicas do Património vol. 2, Porto, Faculdade de Letras da Universidade do Porto, Departamento de Ciências e Técnicas do Património, 2003, pp. 735756; O mesmo ideário se observa nos restantes território que então eram parte do reino. Carvalho, Anna Maria Fausto Monteiro de, " O complexo construtivo franciscano de Olinda no Brasil Colonial. Aspectos sócio-urbanos, arquitetônicos e artísticos" in Natália Marinho Ferreira-Alves (Coord.), Franciscanos no Mundo Português III, Porto, CEPESE - Centro de Estudos da População, Economia e Sociedade, 2013, pp.119-145. 
era exposta no seu interior é aludida. Como no caso de Luís Vieira da Cruz ${ }^{75}$, natural de Braga, mas que também fez obras no Porto, Arouca ou Aveiro; ou, Garcia Fernandes de Oliveira e Caetano da Silva Pinto ${ }^{76}$, Francisco Correia e António Pereira ${ }^{77}$.

Mas, o autor que Natália Ferreira Alves destaca, com mais influência no norte do país, na primeira metade do século XVIII, é Luís Pereira da Costa, responsável pelo retábulomor da Sé do Porto, entre 1727 e 1729, que ilustra a introdução do gosto do barroco romano na cidade. Na parceria que Luís Pereira da Costa faz com Miguel Francisco da Silva, mestre vindo da capital, vai simbolizar a permanência de uma linha conservadora no tratamento do entalhe da madeira, a par das novas interpretações características do barroco joanino $^{78}$.

\footnotetext{
${ }^{75}$ Luís Vieira da Cruz, natural de Braga, depois de trabalhar em Braga, na Sé (1709) e na igreja do Colégio de São Paulo (1710), foi o autor do retábulo-mor da igreja do Mosteiro de Santa Maria de Arouca (1723); e no Porto, do retábulo-mor da igreja de São Pedro de Miragaia (1724), e do retábulo-mor da igreja do Mosteiro de Jesus de Aveiro (1725). Ferreira-Alves, Natália Marinho, "Pintura, Talha e Escultura (séculos XVII e XVIII) no Norte de Portugal" in Revista da Faculdade de Letras. Ciências e Técnicas do Património vol. 2, Porto, Faculdade de Letras da Universidade do Porto, Departamento de Ciências e Técnicas do Património, 2003, pp. 735-756.
}

${ }^{76}$ Garcia Fernandes de Oliveira e Caetano da Silva Pinto (1726) foram os responsáveis pelos retábulos laterais da Sé do Porto. Ferreira-Alves, Natália Marinho, "Pintura, Talha e Escultura (séculos XVII e XVIII) no Norte de Portugal" in Revista da Faculdade de Letras. Ciências e Técnicas do Património vol. 2, Porto, Faculdade de Letras da Universidade do Porto, Departamento de Ciências e Técnicas do Património, 2003, p. 742.

${ }^{77}$ Francisco Correia e António Pereira foram os entalhadores do retábulo de Nossa Senhora da Purificação da igreja do Colégio de São Lourenço (1729), no Porto. Ferreira-Alves, Natália Marinho, "Pintura, Talha e Escultura (séculos XVII e XVIII) no Norte de Portugal" in Revista da Faculdade de Letras. Ciências e Técnicas do Património vol. 2, Porto, Faculdade de Letras da Universidade do Porto, Departamento de Ciências e Técnicas do Património, 2003, pp. 735-756.

${ }^{78}$ Luís Pereira da Costa foi o responsável pela feitura das caixas dos órgãos e retábulo da capela-mor da Sé do Porto. Com a construção do retábulo-mor da Sé do Porto, entre 1727 e 1729, dá-se a introdução do gosto do barroco romano no Porto, representando um dos momentos mais altos da série de transformações operadas durante a Sede Vacante (1717-1741) que visavam dar uma feição mais moderna ao edifício medieval de acordo com os novos preceitos estéticos, representa no período joanino a continuidade dos formulários utilizados anteriormente pelos grandes mestres portuenses. O retábulo-mor da Sé do Porto está esteticamente ligado a modelos lisboetas como os retábulos-mores das igrejas de Nossa Senhora da Pena e de Santa Catarina dos Paulistas, onde a inspiração da obra Perspectiva Pictorum et Architectorum de Andrea Pozzo é notória. No ano anterior, Luís Pereira da Costa tinha arrematado a execução de uma obra marcante na talha portuguesa: a capela-mor (incluindo o arco cruzeiro) da igreja do Bom Jesus de Matosinhos, em cujas ilhargas a Paixão de Cristo é narrada em painéis esculpidos que transmitem uma emoção verdadeiramente inserida no espírito barroco. Esta maneira algo arcaizante de interpretar a talha encontramo-la no cadeiral e caixas dos órgãos da igreja do Convento de São João de Tarouca (1729) e nos retábulos mor e colaterais da igreja da Santa Casa da Misericórdia de Mangualde (1729), bem como no retábulo-mor do Recolhimento de Nossa Senhora da Conceição (1733), também em Mangualde. Em Barcelos, nos retábulos laterais da igreja do Bom Jesus da Cruz (1735), Luís Pereira da Costa atinge o segundo grande momento da sua carreira ao conseguir dar às imagens, designadamente à de Cristo carregando a Cruz, um enquadramento cenográfico invulgar nos exemplares portugueses da época. Ferreira-Alves, Natália Marinho, "Pintura, Talha e Escultura (séculos XVII e XVIII) no Norte de Portugal" in Revista da Faculdade de Letras. Ciências e Técnicas do Património vol. 2, Porto, Faculdade de Letras da Universidade do Porto, Departamento de Ciências e Técnicas do Património, 2003, pp. 735- 


\section{A permanência de valores arcaizantes que Luís Pereira da Costa inscreve no retábulo}

da Sé do Porto é sentida em toda a área norte do país, na qual se inscreve o território em estudo. Apenas na segunda metade de setecentos será percetível, na imaginária dos conventos em estudo, o uso de uma linguagem mais desenvolta nos cânones clássicos.

Além de Luís Pereira da Costa, Natália Ferreira Alves destaca ainda a influência de Miguel Francisco da Silva ${ }^{79}$, não só no Porto, mas em todos os territórios que lhe estão contíguos e ainda Manuel da Costa Andrade ${ }^{80}$ autor de vários retábulos no Porto e Norte do país.

756. Luís Pereira da Costa representa em termos artísticos a feição conservadora dos grandes mestres da talha portuense da primeira fase barroca. Ferreira-Alves, Natália Marinho, "Entalhadores e imaginários do Núcleo Franciscano Portuense" in Natália Marinho Ferreira-Alves e (Coord.) Os Franciscanos no Mundo Português. Artistas e Obras (I), Porto, CEPESE - Centro de Estudos da População, Economia e Sociedade, 2009, pp. 195-211.

\footnotetext{
${ }^{79}$ Miguel Francisco da Silva que, em Lisboa, trabalhara no retábulo-mor da Pena, vinha tecnicamente preparado para interpretar os riscos que significavam na época a modernidade. A partir da intervenção na obra do retábulo-mor da Sé do Porto, Miguel Francisco da Silva deixa testemunhos da sua arte espalhados pela cidade e na área de sua influência, de forma directa ou através de outros trabalhos feitos por entalhadores de renome. Assim, em 1730 executa a talha da capela-mor da igreja do Convento de Santa Clara do Porto, que também engloba o revestimento do arco cruzeiro, sanefa e estruturas colaterais, obra importante pelas referências a talha já desaparecida (capela-mor dos Terceiros de São Domingos, retábulo-mor da Capela do Senhor Jesus do Carvalhinho), e também pela linguagem estética utilizada que serve de modelo a retábulos feitos a partir desta data. Em $1734 \mathrm{fez}$ a talha da sacristia da Sé, com risco da autoria do italiano Nicolau Nasoni. Três anos depois (1737), o cadeiral do coro alto da Sé de Braga e as sacras dos altares laterais da igreja do Senhor da Cruz, em Barcelos. Entre 1738 e 1741, no Mosteiro de Santa Maria de Arouca, foi o autor dos seis retábulos do corpo da igreja, onde segue o esquema do modelo do baldaquino berniniano, caso único na sua produção. No retábulo da capela-mor da igreja de Santo Ildefonso, no Porto, de novo sob desenho de Nasoni que anuncia o ponto da viragem do barroco joanino para o espírito rococó. A sua obra derradeira é o Candelabro das Trevas para a Sé do Porto que data de 1749. Um dos maiores contributos de Miguel Francisco da Silva para a afirmação da escola portuense de talha, e para a criação de alguns dos melhores espécimes retabulares da época joanina, passa necessariamente pelos riscos da sua autoria a que outros artistas deram forma. Nesta perspectiva se enquadram os riscos feitos para o retábulo-mor da igreja de São João da Foz, no Porto (1734), e executado pelos entalhadores Manuel da Rocha e Manuel da Costa Andrade; o retábulo-mor da igreja do Convento de São Francisco, em Guimarães (1743), executado por Manuel da Costa Andrade; o dos retábulos colaterais e frontispício do arco cruzeiro da igreja de Santo André de Canidelo, em Vila Nova de Gaia (1745), executados por Manuel Pereira da Costa Noronha; e o da tribuna do retábulo-mor da igreja de São Pedro, em Amarante (1746), executado por José da Fonseca Lima. Ferreira-Alves, Natália Marinho, "Pintura, Talha e Escultura (séculos XVII e XVIII) no Norte de Portugal" in Revista da Faculdade de Letras. Ciências e Técnicas do Património vol. 2, Porto, Faculdade de Letras da Universidade do Porto, Departamento de Ciências e Técnicas do Património, 2003, pp. 735-756; Miguel Francisco da Silva simbolizou a novidade trazida da Lisboa de D. João V, criando no Porto uma das escolas mais requintadas da época. Ferreira-Alves, Natália Marinho, "Entalhadores e imaginários do Núcleo Franciscano Portuense" in Natália Marinho Ferreira-Alves e (Coord.) Os Franciscanos no Mundo Português. Artistas e Obras (I), Porto, CEPESE - Centro de Estudos da População, Economia e Sociedade, 2009, pp. 195-211.
}

${ }^{80}$ Manuel da Costa Andrade foi o autor dos retábulos no corpo da igreja a partir dos anos 40 na igreja do Convento de São Francisco do Porto. Do lado do Evangelho, e segundo o risco de Francisco do Couto e Azevedo, erguem-se dois retábulos que enquadram o retábulo da Árvore de Jessé: o de Nossa Senhora do Rosário dos Escravos (1740), (cujas invocações posteriores foram de Nossa Senhora do Socorro e de Santa Luzia). No retábulo Nossa Senhora do Rosário dos Escravos no nicho central do primeiro registo encontrava-se a imagem de São Benedito (atualmente exposta no arco triunfal, no lado da Epistola). E o 
Em Braga, na igreja de São Paulo, destacam-se quatro magníficos Evangelistas, de autor desconhecido, em madeira, possivelmente esculpidos por um santeiro a partir de estampas. No entanto, é notável a expressão, a composição e a plasticidade do rosto e vestes $^{81}$.

Além de várias obras de autores desconhecidos existem diversos nomes que se relacionam com as oficinas de Braga. Braga assume-se como um centro ativo de produção escultórica havendo referências documentadas a vários mestres escultores no primeiro quartel de setecentos como Gabriel Rodrigues Álvares, Manuel Carneiro Adão, Marceliano de Araújo e Jacinto Vieira ${ }^{82}$, sendo o mais influente o mestre escultor Marceliano de Araújo ${ }^{83}$, cuja atividade se estende pelo segundo quartel do século, desenvolvendo uma criativa cenografia com influência que se estende a todo o norte do

de Nossa Senhora da Graça (1743) hoje com a invocação de Nossa Senhora da Rosa. Infelizmente, não possuímos quaisquer dados sobre a autoria das imagens de ambos os retábulos. Antes destes retábulos, encontramos Manuel da Costa Andrade associado à feitura do retábulo da capela dos Santos Passos da igreja de Leça da Palmeira (1737), e dos retábulos colaterais da igreja da Lavra (1738), e em seguida, aos retábulos e tribunas das capelas-mores das igrejas de São Lourenço de Pias (1741), de São Francisco de Guimarães (1743), e de Nevogilde no Porto (1750), este último considerado uma jóia da talha portuense. Smith, Robert, A talha em Portugal, Lisboa, Livros Horizonte, 1963, pp. 69-72; Ferreira-Alves, Natália Marinho, "Pintura, Talha e Escultura (séculos XVII e XVIII) no Norte de Portugal" in Revista da Faculdade de Letras. Ciências e Técnicas do Património vol. 2, Porto, Faculdade de Letras da Universidade do Porto, Departamento de Ciências e Técnicas do Património, 2003, pp. 735-756; FerreiraAlves, Natália Marinho, "Entalhadores e imaginários do Núcleo Franciscano Portuense" in Natália Marinho Ferreira-Alves e (Coord.) Os Franciscanos no Mundo Português. Artistas e Obras (I), Porto, CEPESE - Centro de Estudos da População, Economia e Sociedade, 2009, pp. 201-204.

${ }^{81}$ Pereira, José Fernandes, "O barroco do século XVIII" in Paulo Pereira (direção), Historia da Arte Portuguesa, Volume III, Lisboa, Círculo de leitores, 1995, pp. 50-181; Pereira, José Fernandes, "Estética barroca I: arquitectura e escultura", in Dalila Rodrigues (Coord.), Arte Portuguesa - Da Pré-História ao Século XX, volume 12, Lisboa, Fubu Editores, 2009, pp. 7-136.

${ }^{82}$ Jacinto Vieira é praticamente desconhecido apenas se sabe que o seu nome aparece referido como o autor das belíssimas esculturas em pedra de Ançã, datadas entre 1723 e 1725, que representam santos e santas cistercienses e beneditinos, e que se encontram no coro e no corpo da igreja do Mosteiro de Santa Maria de Arouca. Ferreira-Alves, Natália Marinho, "Pintura, Talha e Escultura (séculos XVII e XVIII) no Norte de Portugal" in Revista da Faculdade de Letras. Ciências e Técnicas do Património vol. 2, Porto, Faculdade de Letras da Universidade do Porto, Departamento de Ciências e Técnicas do Património, 2003, pp. 735-756.

${ }^{83}$ Marceliano de Araújo é escassamente referido na documentação, pressupõe-se que terá nascido na região de Braga nos finais do século XVII, tendo morrido em 1769. Para além dos magnífícos exemplares de talha que nos deixou, notabilizou-se igualmente como escultor; nessa qualidade, existem os painéis dos espaldares do cadeiral do coro alto da igreja do Mosteiro de São Bento da Vitória do Porto, de cuja feitura se ocupa entre 1716 e 1719, desenvolvendo nos trinta e seis painéis cenas relacionadas com a vida de São Bento. Em 1737, ocupar-se-ia da obra que lhe daria uma grande reputação na sua época: as caixas dos órgãos da Sé de Braga. Marceliano de Araújo provará ser um artista com uma faceta inventiva invulgar, evidenciando um estilo desenvolto caracterizado por uma grande densidade decorativa e com um raro sentido cenográfico fruto da sua prodigiosa imaginação. Ferreira-Alves, Natália Marinho, "Pintura, Talha e Escultura (séculos XVII e XVIII) no Norte de Portugal" in Revista da Faculdade de Letras. Ciências e Técnicas do Património vol. 2, Porto, Faculdade de Letras da Universidade do Porto, Departamento de Ciências e Técnicas do Património, 2003, pp. 735-756. 
país. Ferreira Alves refere ainda os nomes de Bento Alvarenga da Costa e Gabriel Rodrigues, naturais de Braga que fizeram diversas intervenções até à década de 20 no Mosteiro de São Bento da Vitória, no Porto, desde o retábulo-mor aos púlpitos.

Mas a produção retabular bracarense será sobretudo marcada pela figura de Jacinto Silva ${ }^{84}$ cujas obras se estendem de Braga até Moncorvo e Vila Real.

As cidades do Porto e Braga foram os grandes centros produtores de talha cuja marca profunda se sente numa área geográfica que se estende além do rio Douro, influenciando significativamente também todo o território do Minho e Trás-osMontes $^{85}$.

$\mathrm{O}$ aumento significativo de nomes de escultores que se conhecem desta época, sobretudo nos meios mais próximos dos centros de poder (Lisboa, Porto, Braga), denota o prestígio e importância que esta categoria artística vai absorvendo a partir do século

\begin{abstract}
${ }^{84}$ Jacinto da Silva é um dos entalhadores que vai marcar não só pelas suas obras, mas também pela influência que teve no filho (Luís Manuel da Silva), também ele entalhador. Iniciando a sua atividade artística em pleno período joanino, parte da sua produção enquadra-se numa fase de transição, mas deixando-nos os seus melhores testemunhos a partir de 1750, quando o rococó já marcava o panorama de Braga. Nesta cidade refiram-se da sua autoria antes de 1750: a talha das ilhargas da capela-mor da igreja de Nossa Senhora da Conceição (1737); o retábulo do Santo Cristo da igreja da Santa Casa da Misericórdia (1741); e o retábulo-mor da igreja de Nossa Senhora-a-Branca (1745). Na Correlhã (Ponte de Lima), no Santuário da Senhora da Boa Morte, executa os retábulos colaterais (1740) e os púlpitos (1742). A década de 50 é marcada por uma das suas mais importantes realizações: o gigantesco retábulomor da igreja matriz de Torre de Moncorvo (1752), uma das melhores criações da escola bracarense, não só pelas proporções algo desmesuradas para a região, mas também pelo esquema desenvolvido onde se inserem dois magníficos leões, cujo posicionamento (no arranque de ambos os lados), confere uma sumptuosidade única à estrutura. Em Vila Real, Jacinto da Silva foi o autor do risco do retábulo-mor da igreja de São Cristovão de Parada de Cunhos (1753). Porém, a sua afirmação como exímio entalhador do rococó bracarense surge com a execução dos riscos do mestre André Soares para a talha da igreja de Santa Maria Madalena da Falperra (Braga): o retábulo-mor (1763) e os retábulos colaterais (1766). Quanto ao filho, Luís Manuel da Silva, que trabalha em Braga com o pai no retábulo-mor da igreja de São João do Souto (1772), e que também é referido como riscador ou desenhador de talha como se verifica em 1776 relativamente à sanefa do arco cruzeiro e caixilhos da igreja de São Vicente (Braga), ficou essencialmente ligado à execução dos desenhos que o notável Frei José de Santo António Ferreira Vilaça elaborou para os retábulos do Santuário de Nossa Senhora dos Remédios, em Lamego (1766). Smith, Robert, Frei José de Santo António Ferreira Vilaça, Escultor Beneditino do século XVIII, volume II, Fundação Calouste Gulbenkian, Lisboa, 1972, pp. 400-402; Ferreira-Alves, Natália Marinho, "Pintura, Talha e Escultura (séculos XVII e XVIII) no Norte de Portugal" in Revista da Faculdade de Letras. Ciências e Técnicas do Património vol. 2, Porto, Faculdade de Letras da Universidade do Porto, Departamento de Ciências e Técnicas do Património, 2003, pp. 735-756; A presença de Jacinto Silva em terras trasmontanas foi registada em 1715 na escritura do retábulo da confraria das Almas na igreja matriz de Moncorvo em parceria com Manuel da Fonseca Coelho (de Trancoso). Um anterior retábulo do altarmor da igreja matriz de Torre de Moncorvo havia em 1653 sido pintado por Luís Álvares morador em Coimbra, o que destaca o continuado compromisso relativo à produção artística que ornamentava o templo. Rodrigues, Luís Alexandre, Arte da talha dourada e policromada no Distrito de Bragança. Documentos. Séculos XVII-XVIII, Mirandela, João Azevedo Editor, 2005, pp. 163-166.
\end{abstract}

${ }^{85}$ Ferreira-Alves, Natália Marinho, "Pintura, Talha e Escultura (séculos XVII e XVIII) no Norte de Portugal" in Revista da Faculdade de Letras. Ciências e Técnicas do Património vol. 2, Porto, Faculdade de Letras da Universidade do Porto, Departamento de Ciências e Técnicas do Património, 2003, pp. 735756. 
XVIII em Portugal. Também é de notar o aumento considerável de oficinas ${ }^{86}$ de escultura, pois além e Lisboa e Mafra, também Braga e Porto se consolidam como importantes centros oficinais de escultura e talha.

Na primeira metade do século XVIII, Bragança como cidade fronteiriça continuou a sofrer as consequências das suas obrigações militares, que foram relevantes sobretudo durante a guerra da Sucessão de Espanha (1702-1713) destabilizando o já precário equilíbrio económico local.

No entanto, e mesmo perante a instabilidade económica, emergiu um importante fluxo de produção e encomenda de obras escultóricas. Assim, surgem no distrito de Bragança mestres entalhadores, escultores e pintores, oriundos de pequenos núcleos populacionais fora dos centros urbanos.

Neste contexto é destacável a referência a Veigas (termo de Bragança) de onde eram originários ou moravam vários artistas. Entre o segundo terço e o final da centúria são registados os nomes de João Francisco ${ }^{87}$, João Duarte Pinto ${ }^{88}$, Estevão Ferreira ${ }^{89}$, Manuel Correia ${ }^{90}$, e o escultor Francisco Xavier Machado ${ }^{91}$. ${ }^{86} \mathrm{O}$ vocábulo oficina sugere apenas um espaço preparado técnica e humanamente para a produção.
Carece o território português de um levantamento que nos permita, além dos casos enunciados, identificar
e ter uma perspetiva geral dos ateliês escultóricos em uso durante o seculo XVIII.

${ }^{87}$ João Francisco entalhador em 1731 foi registado a escritura relativa à execução do retábulo de Grijó de Parada, era morador no lugar de Veigas, termo de Bragança. Rodrigues, Luís Alexandre, Arte da talha dourada e policromada no Distrito de Bragança. Documentos. Séculos XVII-XVIII, Mirandela, João Azevedo Editor, 2005, p. 48.

${ }^{88}$ João Duarte Pinto em 1753 a escritura relativa ao retábulo da capela-mor da igreja de Argozelo, Vimioso, registava-o como entalhador, morador na Quinta de Veigas. Em 1764, de novo João Duarte Pinto surge na escritura relativa ao retábulo de Montesinho, que deveria imitar na talha o retábulo de São José da Sé de Miranda. Este documento acrescenta que era morador na Quinta das Veigas, anexa do lugar de Quintela de Lampaças, bem como, regista mais dois entalhadores moradores em Quintela de Lampaças, António de Sousa e Francisco Afonso. O retábulo de Argozelo foi mais tarde, conforme recibo de 1768, dourado por Damião Rodrigues Bustamante. Rodrigues, Luís Alexandre, Arte da talha dourada e policromada no Distrito de Bragança. Documentos. Séculos XVII-XVIII, Mirandela, João Azevedo Editor, 2005, pp. 55-189.

${ }^{89}$ Estevão Ferreira, do lugar de Fermentanos, surge também como entalhador no registo de 1768 relativo ao retábulo da capela-mor da igreja de Caravelas, Mirandela. Em 1778 surge de novo referido na escritura relativa aos retábulos de São João e São José do Santuário de Santo Cristo de Outeiro. Os entalhadores e escultores das imagens eram José Fernandes Duarte (de São Martinho de Angueira) e Estevão Ferreira. Rodrigues, Luís Alexandre, Arte da talha dourada e policromada no Distrito de Bragança. Documentos. Séculos XVII-XVIII, Mirandela, João Azevedo Editor, 2005, p. 132.

${ }^{90}$ Manuel Correia entalhador que em 1770 fez sociedade com José Pires (da Quinta do Azibeiro) para a execução do retábulo da igreja de Cabanelas em Mirandela. Rodrigues, Luís Alexandre, Arte da talha dourada e policromada no Distrito de Bragança. Documentos. Séculos XVII-XVIII, Mirandela, João Azevedo Editor, 2005, p. 135. 
Os ornatos rococós que ornamentam os retábulos de Francisco Xavier Machado (em Palácios e Milhão e Dine) são próximos dos ornatos rococós que ornamentam os retábulos da igreja da Encarnação do Seminário Apostólico de Vinhais, permitindo estabelecer aproximações entre as obras da igreja do Seminário e a produção de talha de Veigas. A quantidade de autores provenientes da Veiga denuncia uma produção continuada, mantida certamente numa oficina pelos escultores e entalhadores que trabalhavam não apenas no termo de Bragança, mas também nos territórios limítrofes.

É assinalável a existência desta possível oficina de talha em Veigas, pois permite perceber o interesse crescente pela produção artística e o destaque que a talha de madeira assumia nos programas decorativos. Conforme fica exposto no contexto de uma oficina local (ou regional) confundem-se as ainda obras retabulares com a imaginária, sendo a segunda claramente menos valorizada que a primeira.

A par de intensa produção oficinal de Mafra, Lisboa, Porto e Braga que se estende ao restante território nacional, e da proliferação de pequenas oficinas locais, também a teoria sobre a prática escultórica recebeu neste período importantes reflexões das quais destacamos a obra "Artefactos" do Padre Inácio da Piedade Vasconcelos, pioneira no tratamento da escultura. Coeva da chegada das esculturas italianas a Mafra, expõe os compromissos e dilemas que se colocavam à escultura portuguesa na primeira metade do século XVIII. Vasconcelos destaca a primazia da madeira como material por excelência para a escultura. Descreve questões de métrica na representação anatómica, propondo o modelo 1:10 como sendo o mais adequado, bem como, destaca o encobrimento da ignorância anatómica com as roupagens, que sugere que devem ser finas e com cintura demarcada, exceto nas capas onde o pregueado pode ser mais solto e esvoaçante. Também a pose deve acentuar o carácter esbelto das figuras, preferencialmente com uma perna fixa e firme mas a outra deverá avançar, mostrando os contornos o joelho e o pé que desse modo simbolizavam valentia. Vasconcelos omite

\footnotetext{
${ }^{91}$ Francisco Xavier Machado, escultor e entalhador do lugar de Veigas foi responsável pelos retábulos da igreja de Milhão em 1765 e de Palácios em 1766. E, 1784 e segundo "apontamentos feitos por sua própria mão" arrematava a obra do retábulo da capela-mor da igreja de Nossa Senhora da Assunção de Dine, termo de Vinhais. Foi também o inspetor das obras e podemos perceber que aquando da inspeção dos retábulos do santuário de Santo Cristo de Outeiro, Francisco Xavier Machado era já um afamado entalhadorlescultor, cuja experiência (ou formação?) lhe permitia desenhar ele próprio os seus retábulos daí a sua presença como examinador de obras de evidente importância no contexto local como eram as do santuário de Outeiro (construído entre os anos de 1725 e 1739). Rodrigues, Luís Alexandre, Arte da talha dourada e policromada no Distrito de Bragança. Documentos. Séculos XVII-XVIII, Mirandela, João Azevedo Editor, 2005, pp. 62-200.
} 
a pedra do seu compêndio traduzindo um claro reflexo da produção escultórica portuguesa, quase exclusivamente vocacionada para a madeira ${ }^{92}$.

$\mathrm{O}$ uso da madeira em Portugal é também destacado por Ferreira ${ }^{93}$ que afirma que não só pela melhor acessibilidade e pelo seu menor custo mas também pela familiaridade dos artistas portugueses com material, bem como, o pouco hábito de trabalhar a pedra, como acontecia em Itália ou França.

Neste sentido destaca-se a preparação técnica dos artistas ligados à arte da talha nas suas diversas vertentes, desde o entalhador ao dourador, bem como a qualidade excelente das matérias-primas utilizadas ${ }^{94}$. A talha da madeira constitui no território em estudo a quase totalidade das obras inventariadas, refletindo o aumento das produções do Porto, Braga e até das oficinas regionais como Veigas, que ecoavam as influências italianizantes chegadas a Lisboa, Mafra e Évora.

Na primeira metade do século XVIII houve assim, tal como no restante território nacional, um expressivo aumento da encomenda de obras escultóricas, quer no convento de São Francisco e de Santa Clara em Bragança, quer no convento de São Francisco em Mogadouro. A diversidade de devoções ampliou-se. A pluralidade das autorias e dos

\footnotetext{
${ }^{92}$ O padre Inácio da Piedade Vasconcelos, partindo da leitura de diversas obras clássicas escreveu a sua obra Artefactos, onde dedicou o primeiro volume exclusivamente à escultura. Trata-se da primeira obra que se detém neste tema escrita em Portugal. Pereira, José Fernandes, "O barroco do século XVIII" in Paulo Pereira (direção), Historia da Arte Portuguesa, Volume III, Lisboa, Círculo de leitores, 1995, pp. 50-181; Pereira, José Fernandes, "Estética barroca I: arquitectura e escultura", in Dalila Rodrigues (Coord.), Arte Portuguesa - Da Pré-História ao Século XX, volume 12, Lisboa, Fubu Editores, 2009, pp. $7-136$.

${ }^{93}$ Ferreira, Sílvia, A talha. Esplendores de um passado ainda presente (sécs. XVI-XIX), Lisboa, Nova Terra, 2008, p. 18.

94 Os artistas fossem eles entalhadores, ensambladores, imaginários, pintores ou douradores, organizavam-se em oficinas, de acordo com os esquemas tradicionais, tendo à frente um mestre, responsável pelas empreitadas assumidas, e a quem competia distribuir as tarefas pelos oficiais mais preparados e ensinar o ofício aos aprendizes que eram iniciados na arte ainda crianças. No norte do país a aprendizagem era muito exigente, já que as oficinas reputadas rivalizavam entre si, podendo verificar-se, pelas obras que ainda hoje persistem, como o padrão de qualidade era muito elevado. A matéria-prima utilizada de modo mais recorrente é a madeira e o ouro; na maioria dos trabalhos empregava-se o castanho, logo seguido pelo carvalho, reservando-se o pinho para as armações dos retábulos ou para áreas secundárias, enquanto as madeiras exóticas eram destinadas aos espaldares dos cadeirais, gradeamentos e peças de mobiliário. A madeira a ser entalhada devia obedecer a determinados requisitos, segundo as cláusulas estipuladas em contrato assinado pelo cliente e pelo artista; assim, devia apresentar-se perfeitamente lisa, sem nós, defeitos ou rachaduras que pudessem vir futuramente a danificar a peça. Idênticas exigências se verificavam quanto ao ouro a ser aplicado na superfície entalhada, que tinha de ser "subido", bem encorpado e de boa cor, oscilando entre 20 e 24 quilates. Ferreira-Alves, Natália Marinho, "Pintura, Talha e Escultura (séculos XVII e XVIII) no Norte de Portugal" in Revista da Faculdade de Letras. Ciências e Técnicas do Património vol. 2, Porto, Faculdade de Letras da Universidade do Porto, Departamento de Ciências e Técnicas do Património, 2003, pp. 735-756.
} 
vínculos formais das obras sugere a variedade dos encomendadores e dos locais de produção.

No convento de São Francisco de Bragança, colocados dentro do retábulo da capela lateral do lado do Evangelho, estão quatro estatuetas (Imagem 31) do original conjunto que representa os Cinco Mártires de Marrocos. As esculturas destacam-se pela teatral assimetria nos gestos dos braços, pelo cuidado com a proporção das anatomias e pelos finos vincos dos amplos panejamentos. O leve ondulado das vestes e dos desencontrados cordões dos hábitos imprime movimento à composição. Os detalhes das diferentes inclinações das cabeças não é suficiente para individualizar as representações mas as diferentes orientações dos olhos de vidro ampliam as relações das figuras com o espaço envolvente. As semelhanças observadas nos detalhes escultóricos do talhe de todas as esculturas que fazem parte do conjunto tornam evidente o facto de se tratarem de obras esculpidas pelo mesmo autor $\backslash$ oficina.

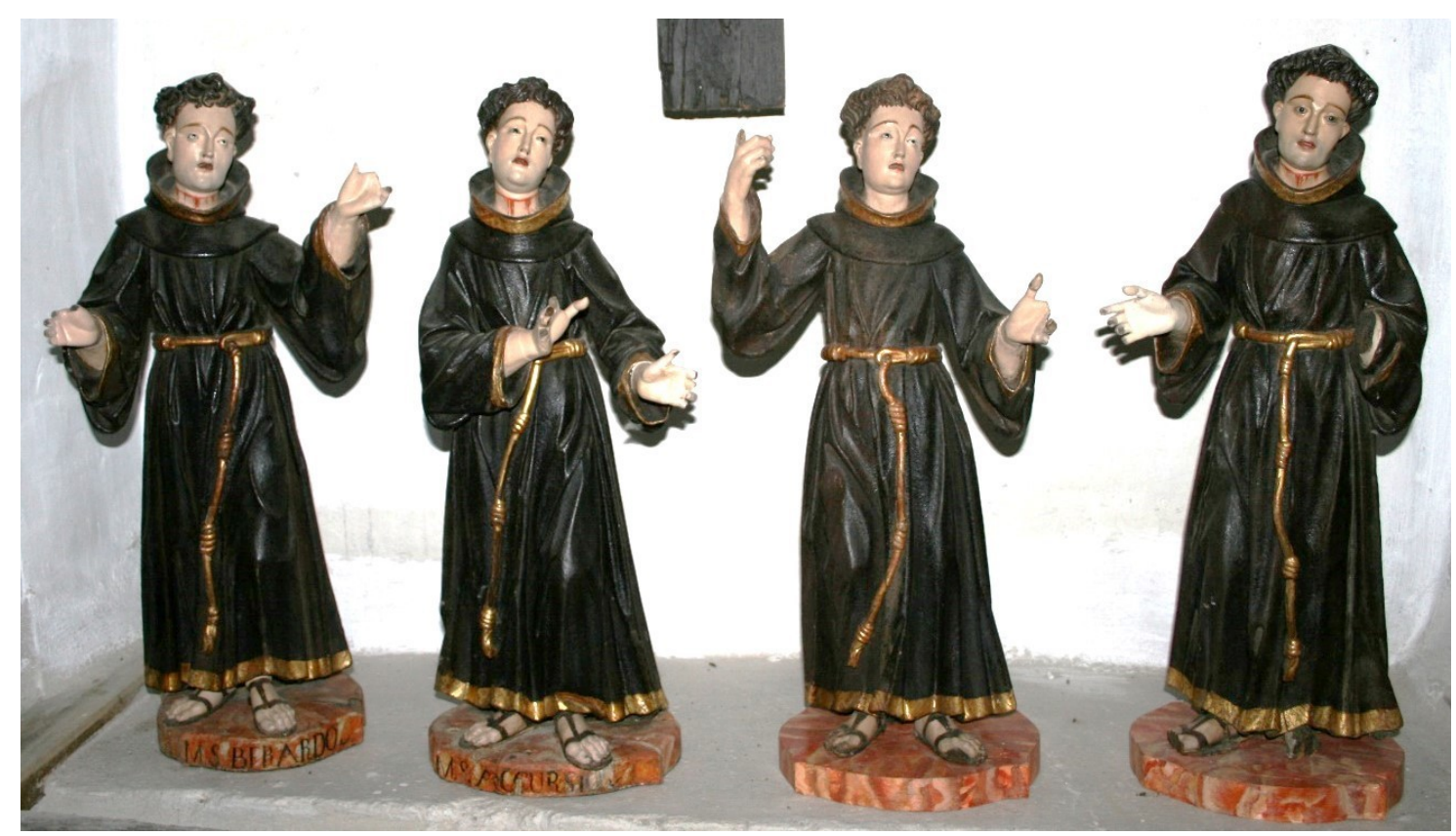

Imagem 31

Conjunto de esculturas dos Mártires de Marrocos - SFB 16; SFB 17; SFB 18; SFB 19

(Falta um dos cinco elementos originais do conjunto) Igreja de São Francisco - Bragança

Capela lateral do lado do Evangelho 


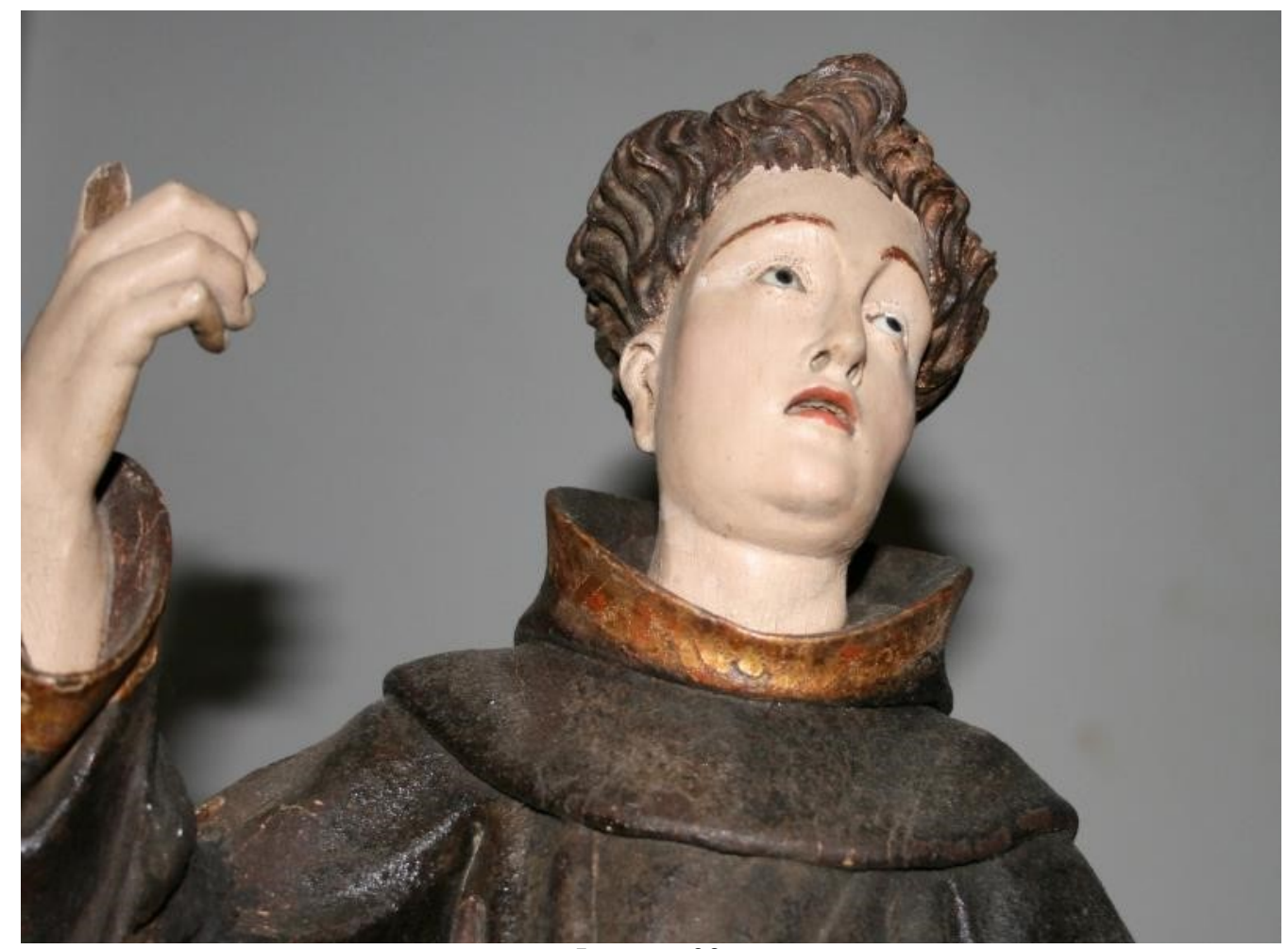

Imagem 32

Detalhe do rosto da escultura de um dos Mártires de Marrocos -SFB 18

(Falta um dos cinco elementos originais do conjunto) Igreja de São Francisco - Bragança Capela lateral do lado do Evangelho

A falta de torsão dos corpos no acompanhamento dos gestos sugeridos pelos braços e os amplos e levemente esvoaçantes panejamentos relacionam formalmente as imagens à primeira metade de setecentos. A gestualidade contida e o cuidado na representação dos rostos e no minucioso desenho das madeixas dos cabelos (Imagem 32) permitem supor que o conjunto terá sido produzido no primeiro quartel do século XVIII. Quanto à origem da produção parece-nos evidente que não se trata de uma oficina local, ou regional pois os olhos de vidro e a plasticidade dos gestos e o cuidado anatómico sugerem uma produção bem apetrechada nos meios e nos modelos.

A proximidade formal com as obras atribuídas às oficinas do Porto e Braga e a constância das relações entre as oficinas do Porto e Braga e o território de Bragança sugerem poder ser esta a proveniência do conjunto dos Santos Mártires, no entanto, a ausência documental restringe a atribuição segura da proveniência. 


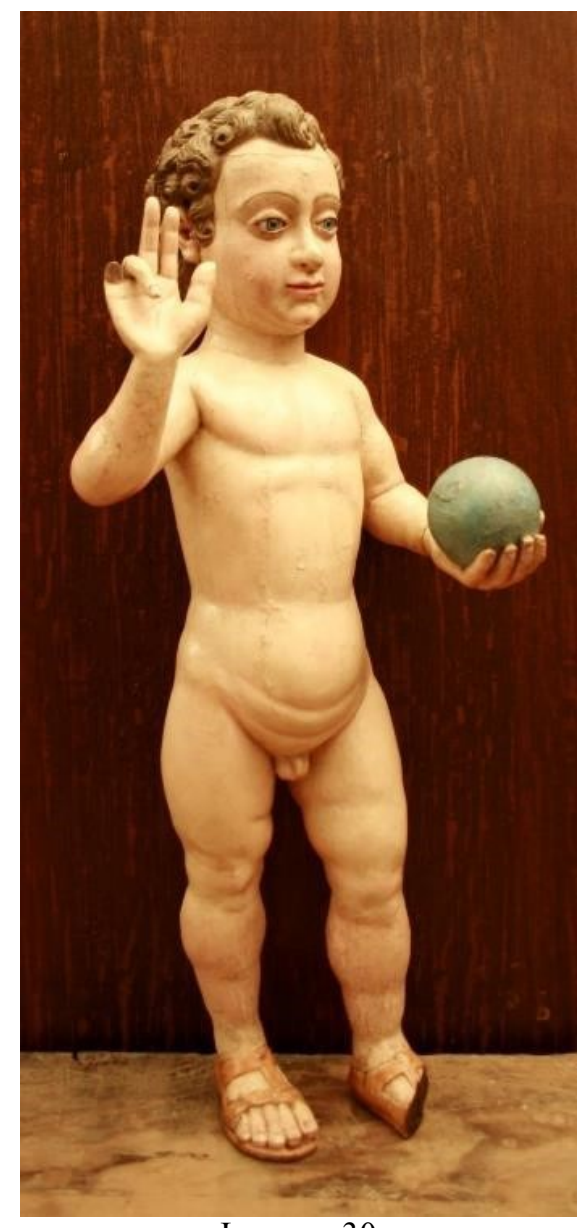

Imagem 30

Escultura de Menino Jesus Salvador do Mundo - SFB 32

Igreja de São Francisco - Bragança Sacristia

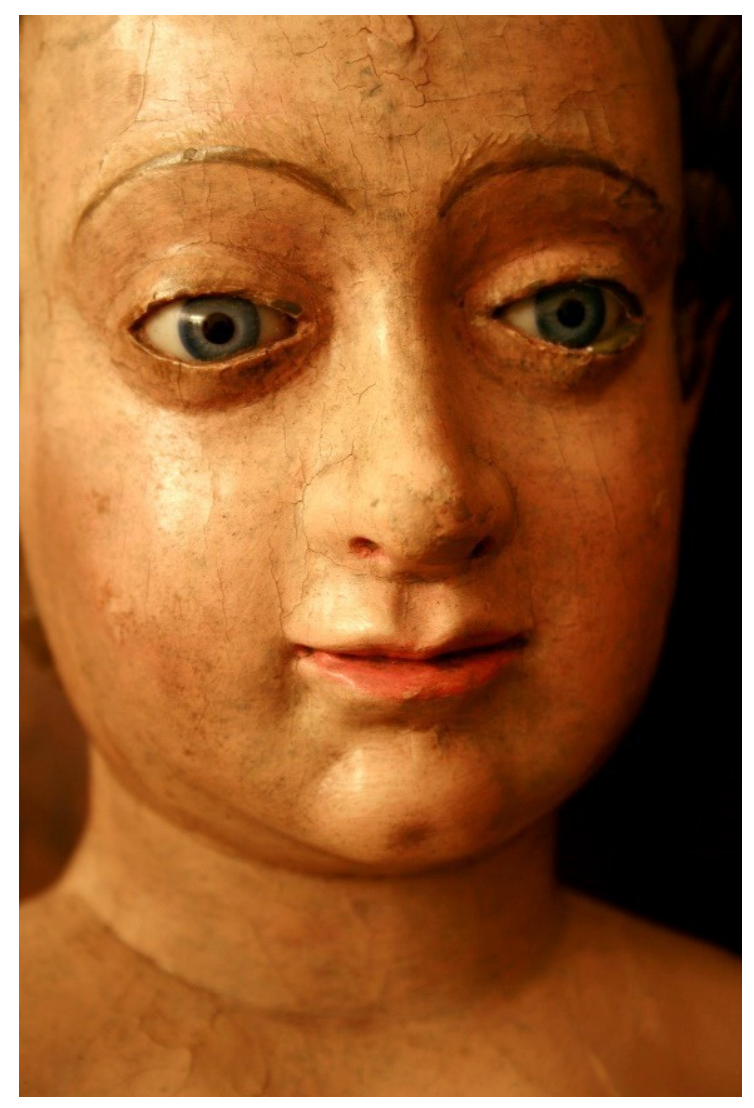

Imagem 31

Escultura de Menino Jesus Salvador do Mundo SFB 32

Igreja de São Francisco - Bragança Sacristia

No mesmo convento de São Francisco de Bragança está atualmente guardada na sacristia da igreja uma imagem que representa o Menino Jesus Salvador do Mundo (Imagem 33 e 34). Tal como no conjunto dos Santos Mártires, a estatueta apresenta os olhos de vidro e um cuidado trabalho escultórico na composição dos elementos anatómicos. Representado nu, com genitais, as linhas arredondadas sugerem algum naturalismo no difícil tratamento da anatomia infantil, apesar de se observarem algumas irregularidades. O rosto com expressão serena destaca-se pelos suaves contornos arredondados e pelas detalhadas madeixas encaracoladas. Atualmente a figura não enverga traje, porém, é percetível ao longo da cintura uma marca de desgaste sobre a policromia, sugerindo que já esteve coberto por um traje postiço, cingido ao peito. 
A escultura do Menino Salvador levanta dúvidas sobre o seu local original. Pois é rara a representação deste modelo iconográfico nos conventos masculinos, sendo todavia comum nos espaços monásticos femininos ${ }^{95}$.

Cardoso Borges em 1721-24 refere, no contiguo Mosteiro de Santa Escolástica de religiosas de São Bento, a milagrosa e formosa imagem do Menino Deus chamada de "Fosquinho" "96. Poderá após a extinção das Ordens Religiosas a escultura ter sido mudada do convento das monjas beneditinas para o vizinho convento então já expropriado aos frades franciscanos, mas ainda com a presença da Ordem Terceira. Apesar de não existir nenhuma documentação que confirme esta possibilidade não podemos deixar de fazer esta referência, pela proximidade entre ambos os espaços e pela raridade da representação infantil num convento masculino. Devemos notar também a qualidade escultórica da imagem registada em 1721-1724 no mosteiro das monjas beneditinas que suscitava o milagre tal era a sua formusura, permitindo-nos perceber que seriam raras as esculturas com tantos detalhes anatómicos e tão primorosamente representados na restante escultura coeva. Este detalhe diferenciador, bem como as formas anatómicas e os olhos de vidro postiços do expressivo rosto revelam que a escultura não provem de oficinas locais. Poderá ter sido obra de alguma oficina de Valhadolid, não só pela importância de Gregório Fernández na difusão deste modelo iconográfico, mas, porque formalmente, a obra hoje em guarda no convento de São Francisco em Bragança, se aproxima mais dos contornos castelhanos que das nacionais figuras coevas. Não obstante as irregularidades anatómicas, sobretudo na representação das mãos, e alguma estaticidade no gesto é inegável o cuidado escultórico na expressão dada ao rosto, o que vincula a escultura com uma produção oficinal cuidada.

Quer o conjunto dos Santos Mártires de Marrocos quer a figura do Menino Jesus Salvador do Mundo sugerem uma produção escultórica bem preparada. Foram seguramente feitas por um autor ou por uma oficina com acesso a técnicas e formas bem

\footnotetext{
${ }^{95}$ Réau, Louis, Iconografía del Arte Cristiano. Iconografía de la Biblia - Nuevo Testamento Tomo 1/ vol.2, Barcelona, Ediciones del Serbal, 1996, (Edição original 1955-1959), p. 269; Figueiredo, Maria Rosa, Escultura Europeia, Volume II, Lisboa, Fundação Calouste Gulbenkian, 1999, p. 70.

${ }^{96}$ Borges, José Cardoso, Memórias de Bragança, Fernando de Sousa (Coord.), Bragança, CEPESE / Câmara Municipal de Bragança, 2012 (texto original de 1721-1724), p. 158. O registo refere que o alcaide-mor Lázaro de Figueiredo Sarmento e António de Figueiredo Sarmento mandaram fazer a capela, o bispo D. Manuel de Moura Manuel mandou fazer o retábulo e o bispo D. João Franco de Oliveira o mandou dourar. Este mesmo prelado deu ordem que se registasse o princípio da capela assim como a relação de milagres do Menino Deus. A capela estava na cerca do mosteiro e atualmente já não existe.
} 
desenvolvidas, não obstante a frontalidade das poses é evidente o cuidado estético nos detalhes anatómicos e expressivos. Pelas semelhanças formais acreditamos que em ambos os casos a datação é semelhante e coincidente com os inícios do século XVIII.

Da primeira metade do século XVIII pensamos serem também mais duas imagens do convento de São Francisco em Bragança. Mas, ao contrário do que ocorre nas imagens que representam os Santos Mártires e o Menino Jesus Salvador do Mundo, pensamos que estes outros exemplos se tratam de produções locais, que refletem um acentuado gosto ingénuo, decorrente das oficinas regionais. As esculturas representam São Benedito de Palermo (Imagem 35) e um Santo franciscano (?) (Imagem 36) e estão atualmente colocadas dentro do primeiro retábulo do lado da Epístola.

Sobre a devoção a São Benedito de Palermo descreve José Cardoso Borges na terceira década do século XVIII:

“Colateral, fora do arco da capela-mor e da parte do Evangelho está o altar de S. Benedito 97 ,.

A referência à devoção a São Benedito não indica qualquer imagem, mas permite perceber existência desta invocação no momento da descrição de Borges.

É formalmente que a imagem de São Benedito nos possibilita estabelecer analogias com esculturas coevas da primeira metade do século XVIII. O mesmo ocorre com a imagem que representa São Pascoal Bailão (Imagem 36) e cuja proximidade formal nos sugere ter a mesma origem de produção que a imagem de São Benedito (Imagem 35). Os autores ou a oficina que produziram ambas as esculturas seriam locais, ou regionais, pela evidente falta de desenho, anatomia e composição dos gestos. Mas é clara em ambas as obras a valorização dada aos detalhes iconográficos.

A oficina de Veigas, no termo de Bragança, que se destaca na documentação coeva ${ }^{98}$ é sobretudo identificada com os modelos da talha retabular rococó, o que não nos sugere essa possível origem. No entanto, a mesma documentação assinala a presença de escultores em Mogadouro e Moncorvo, além dos que se deslocavam de localidades como Braga, Guimarães, Trancoso e Vila Real. São várias as possíveis origens de ambas as esculturas, mas supomos que foram feitas em oficinas portuguesas regionais do norte do território.

\footnotetext{
${ }^{97}$ Borges, José Cardoso, Memórias de Bragança, Fernando de Sousa (Coord.), Bragança, CEPESE / Câmara Municipal de Bragança, 2012 (texto original de 1721-1724), pp. 142, 143.

${ }^{98}$ Conforme os documentos publicados por Rodrigues, Luís Alexandre, Arte da talha dourada $e$ policromada no Distrito de Bragança. Documentos. Séculos XVII-XVIII, Mirandela, João Azevedo Editor, 2005.
} 


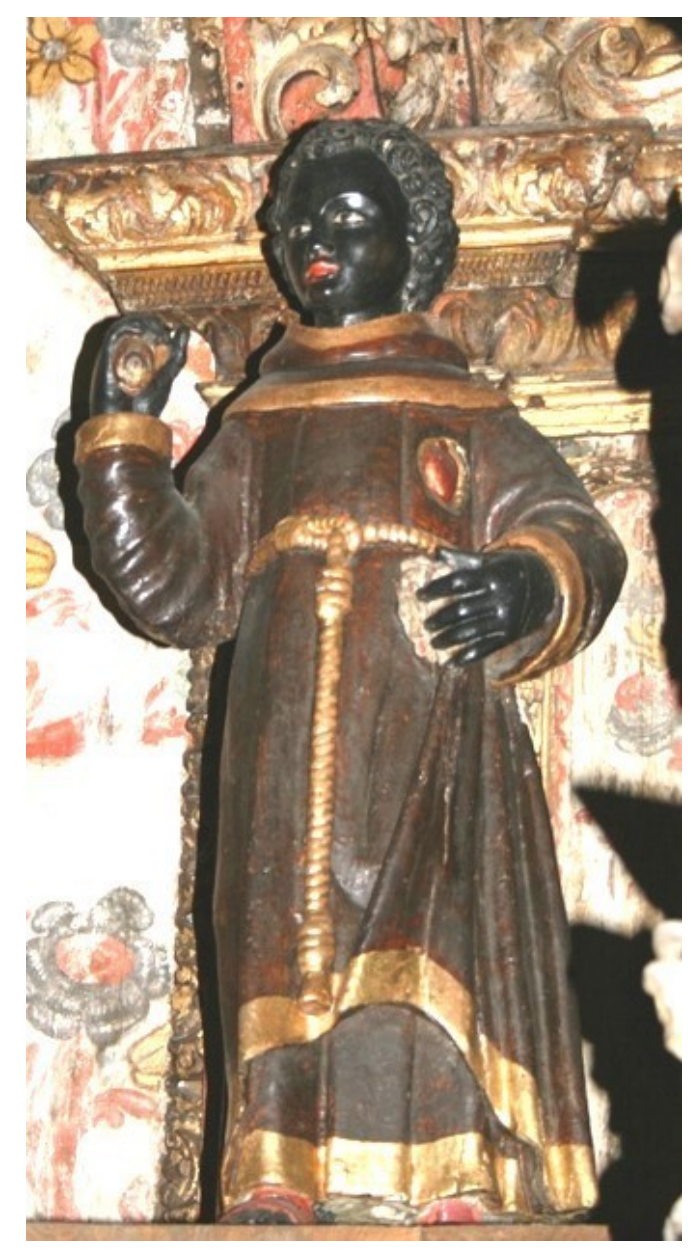

Imagem 35

Escultura de São Benedito de Palermo SFB 02

Igreja de São Francisco - Bragança Retábulo no lado da Epístola

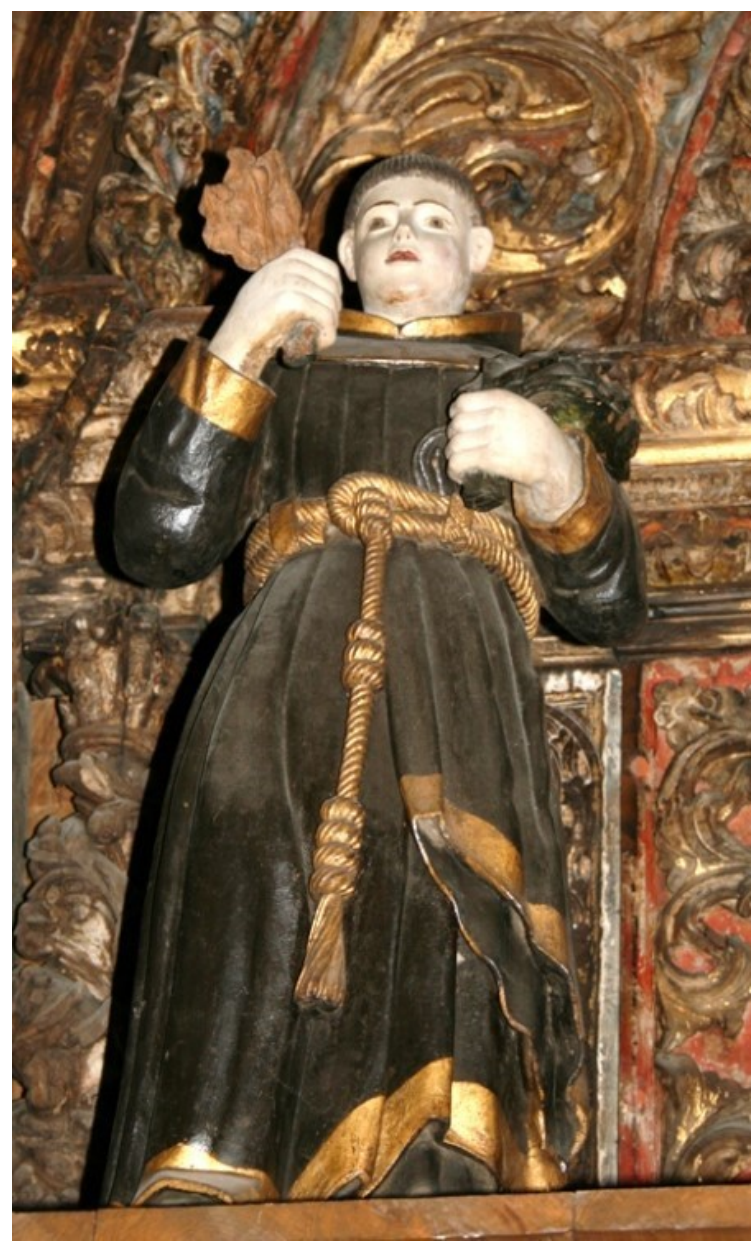

Imagem 36

Escultura de São Pascoal Bailão SFB 05

Igreja de São Francisco - Bragança Retábulo no lado da Epístola

Ambas as esculturas denunciam uma evidente rigidez formal, nos hirtos vincos dos panejamentos e na estaticidade dos gestos, que impõe ainda a valorização da iconografia e a subalternização da qualidade artística. A precária individualização dos rostos, de expressão serena e a tosca ondulação do grosso pregueado sugerem uma produção ainda vinculada com os modelos seiscentistas, mas a tentativa de simular o movimento no ligeiro contraposto, algumas assimetrias no gesto e a simplificação do hábito anunciam que possivelmente foram talhadas já nos princípios do século XVIII. 
$\mathrm{Na}$ primeira metade do século XVIII também para o convento dos terceiros regulares de Mogadouro se produziram novas esculturas.

A imagem que representa São Francisco do convento de Mogadouro (Imagem 37) tem olhos de vidro (mas já caídos no interior da cabeça) e o rosto de carnação muito brilhante com linhas simétricas e cuidado tratamento nos pormenores anatómicos. As barbas, curtas e bifurcadas estão detalhadamente onduladas. Envolve-o um amplo e dinâmico pregueado que cai sobre os pés em vincos finos evocando nesse pormenor os panejamentos tardomedievais. A assimetria e a teatralidade do gesto, os olhos de vidro postiços e a dinâmica ondulação do hábito sugerem uma produção cuidada, afeta a uma oficina com técnicas e valores

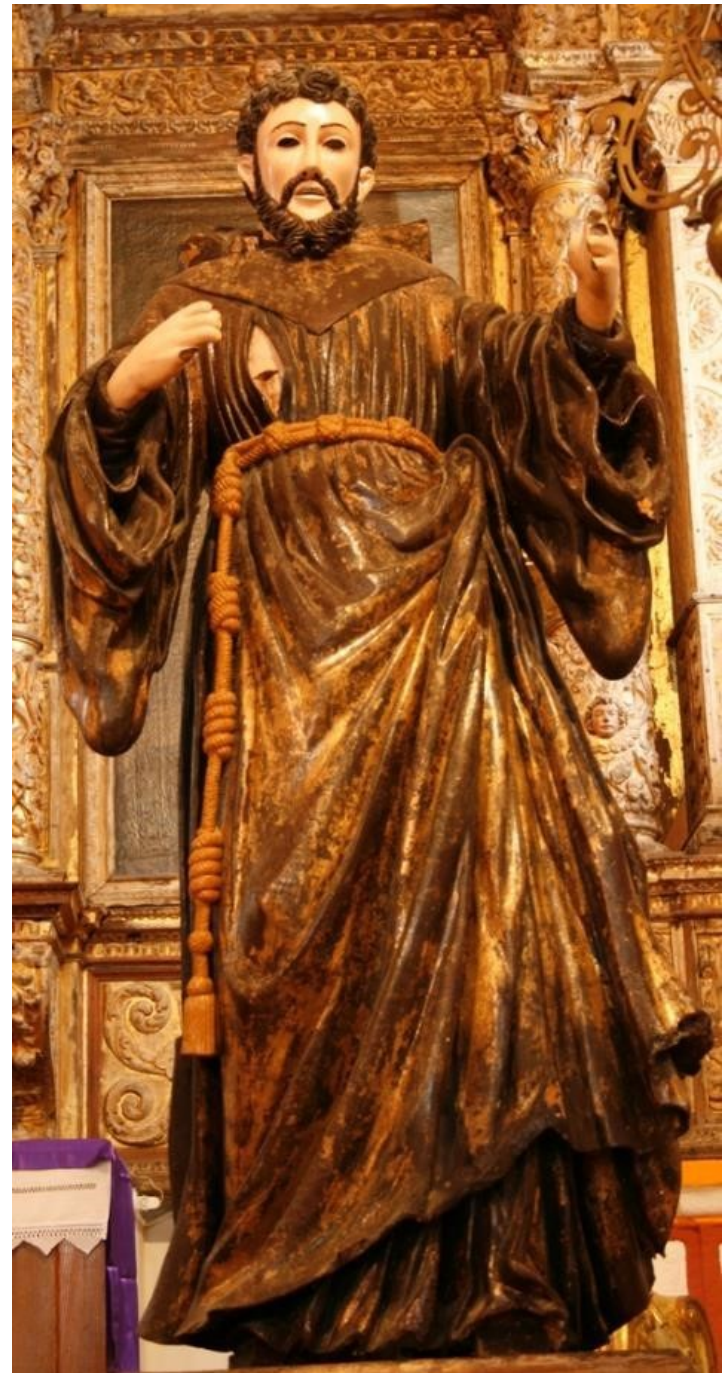

Imagem 37

Escultura de São Francisco de Assis - SFM 07 Igreja de São Francisco - Mogadouro Capela-mor no lado da Epístola estéticos bem apreendidos. O gesto de recolher o hábito é comum nas esculturas de franciscanos do Porto e Braga, o que sugere uma produção nacional, possivelmente dessa oficinas e da primeira metade do século XVIII.

O gesto de recolher o hábito sobre um dos lados raras vezes se observa nas produções espanholas do século XVIII, afastando essa provável origem, que no contexto do convento de Mogadouro, pela proximidade a Miranda do Douro, se assumiria possível. Mas, o gesto subsiste em várias das esculturas em estudo, constituindo uma singularidade recorrente no aperfeiçoamento do valor cenográfico dos panejamentos presente de forma constante nas esculturas ao longo do século XVIII, não só no território em estudo, mas também em vários outros espaços no norte de Portugal. Este gesto, (presente na escultura de São Francisco de Mogadouro, mas também nas 
esculturas de São Benedito de Palermo e de São Pascoal Bailão do convento de Bragança), permite-nos perceber analogias, com a posse repetida nas esculturas que representam os santos franciscanos doutores que ladeiam o retábulo da Árvore de Jessé na igreja de São Francisco no Porto.

A valorização do sentido catequético da figura, acompanhada pelo sentido plástico da qualidade artística da imagem de São Francisco de Mogadouro, supôs uma encomenda de valores monetários e formalidades de transporte que o convento ou algum seu beneficiário teve que cobrir, pois dificilmente em Mogadouro haveria meios técnicos e recursos humanos para efetuar os detalhes que a obra contém.

A assimetria nos pormenores formais das encomendas da primeira metade do século XVIII reforçam a pluralidade dos locais de produção sugerindo que simultaneamente se cobria o gosto mais erudito e ávido pelas novidades e o gosto mais ingénuo de raiz mais simbólica. Esta diversidade estará também relacionada com a diversidade dos encomendadores, que além dos frades do convento, podiam ser as irmandades e confrarias ou até privados individuais.

Esta pluralidade, evidente no convento de São Francisco de Bragança, também se observa no convento de São Francisco em Mogadouro. De meados do século XVIII parecem ser as duas imagens que representam São Bernardino de Siena (Imagem 38) e São Pedro de Alcântara (Imagem 39).

Existem diferenças no domínio formal das técnicas aplicadas sobre ambas as imagens, mas as mãos e os rostos são idênticos nos contornos anatómicos e na expressividade. É no tratamento dos pregueados dos hábitos que a autoria das imagens parece divergir. A imagem de São Pedro de Alcântara, apesar da assimetria do drapeado parece mais tosca no domínio do artifício da leveza. Enquanto a imagem de São Bernardino, mais estática no drapeado que cai homogeneamente, sugere porém mais verosimilhança e delicadeza nos panejamentos. 


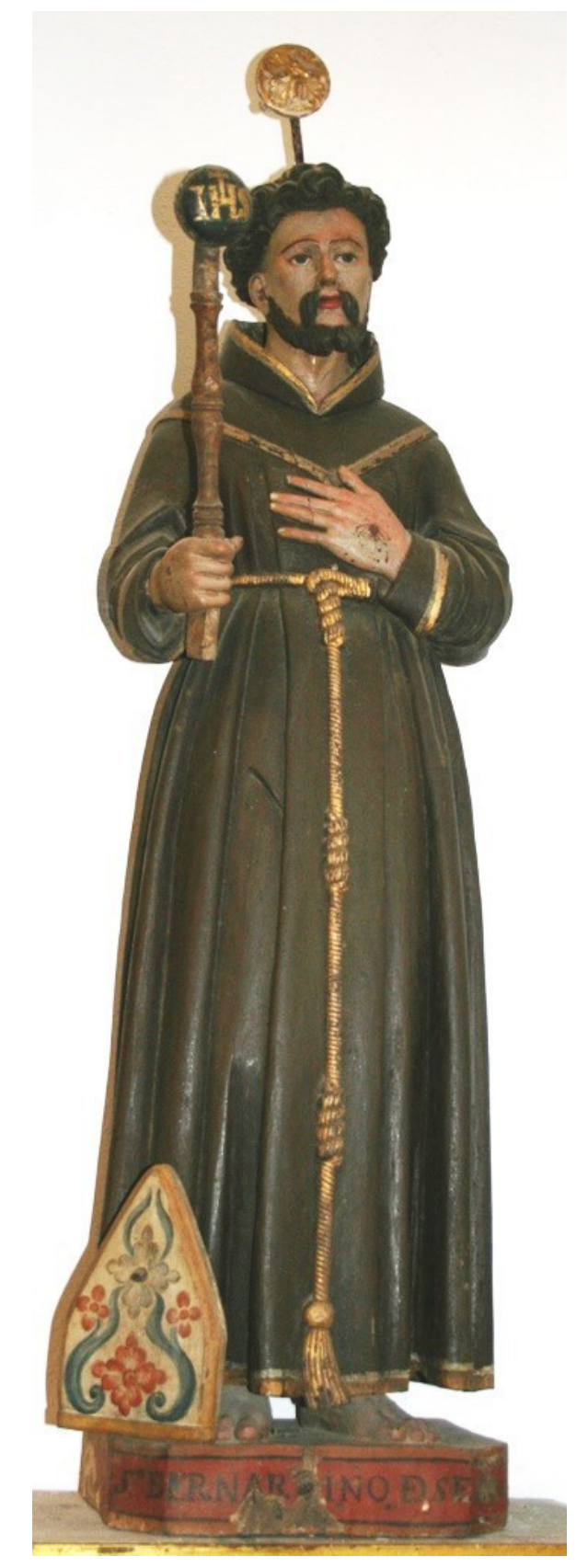

Imagem 38

Escultura de São Bernardino de Siena - SFM 13 Igreja de São Francisco - Mogadouro Retábulo no lado da Evangelho

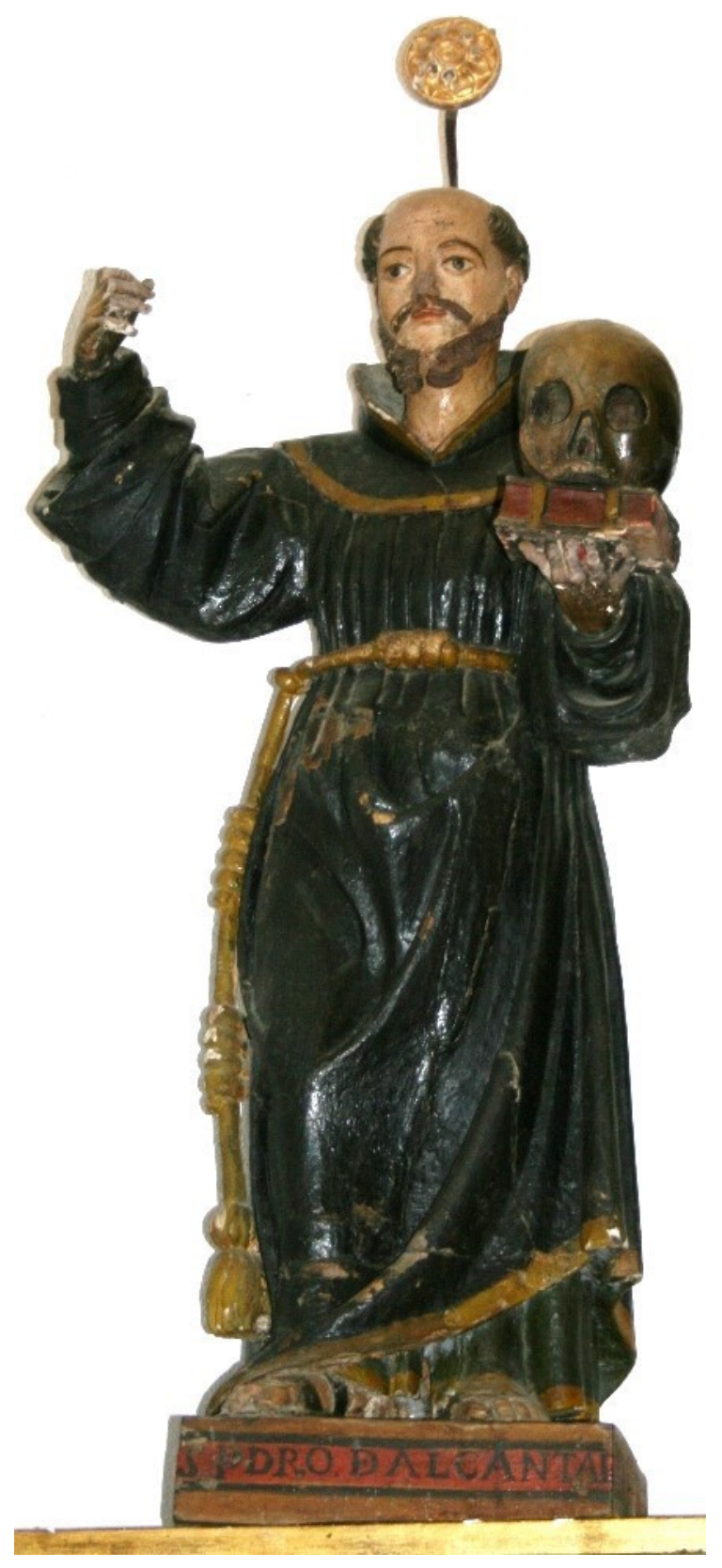

Imagem 39

Escultura de São Pedro de Alcântara - SFM 15 Igreja de São Francisco - Mogadouro Retábulo no lado da Evangelho

As imagens podem ter origem na mesma oficina, mas é evidente a maior destreza técnica do autor que talhou a imagem de São Bernardino de Siena. Se a oficina era local não temos dados documentais que no-lo permitam afirmar, mas o rigor iconográfico e a desvalorização do sentido teatral de ambas as imagens sugerem tratar-se de uma oficina local ou regional mais vinculada ao sentido ilustrativo catequético das imagens e menos ao sentido plástico. 


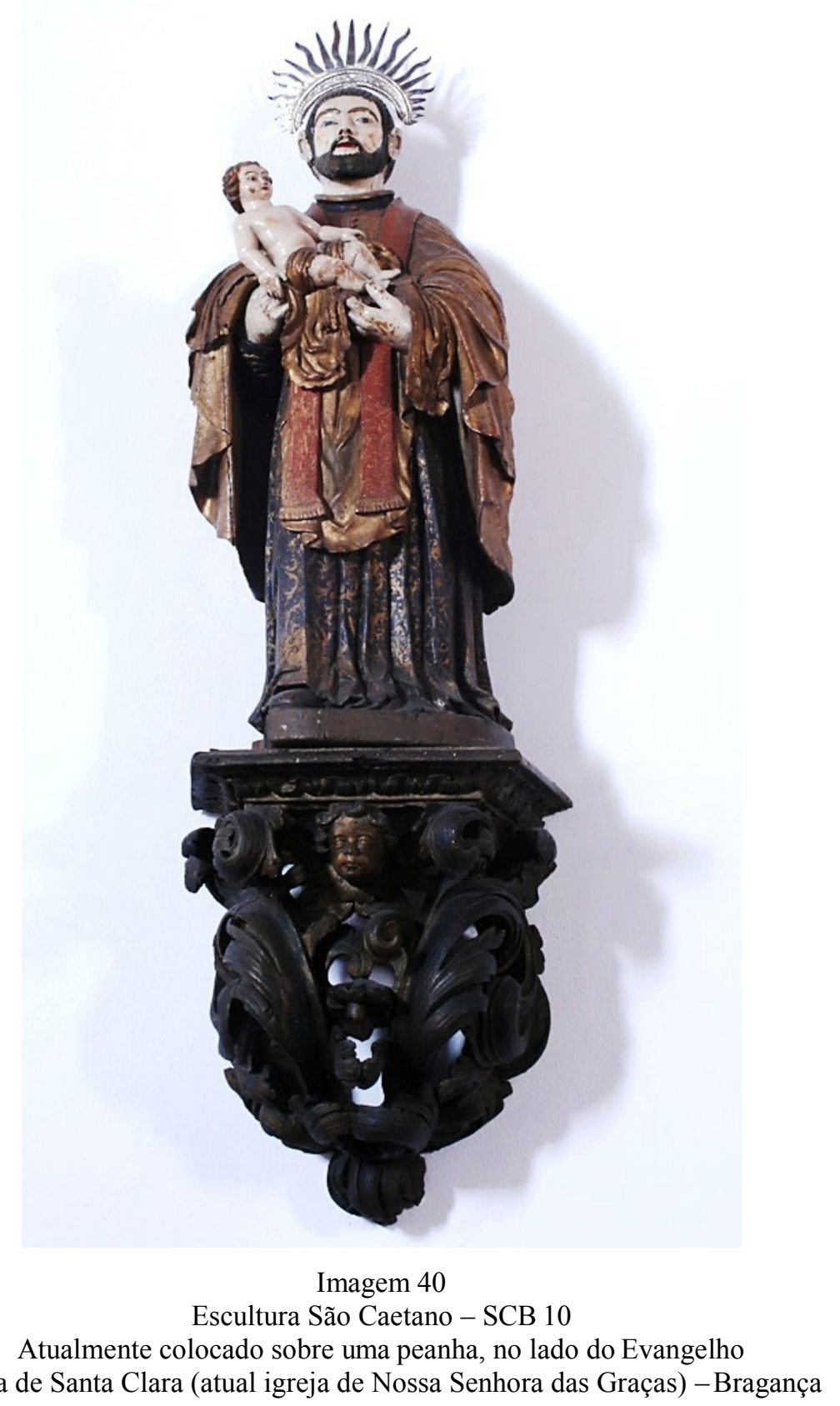

A imagem de São Caetano (Imagem 40) da igreja do convento de Santa Clara tem produção cuidada nos pregueados e nos detalhes iconográficos que identificam a devoção. No primeiro quartel do século XVIII Cardoso Borges registava a existência da capela de São Caetano (Imagem 41), com irmandade e muito frequentada de fiéis ${ }^{99}$. Se em 1721-24 Borges referia os vários fiéis da irmandade supõe que a imagem existiria já nessa data, mas supomos que seria ainda recente quando Borges a viu. Seguramente

\footnotetext{
${ }^{99}$ Borges, José Cardoso, Memórias de Bragança, Fernando de Sousa (Coord.), Bragança, CEPESE / Câmara Municipal de Bragança, 2012 (texto original de 1721-1724), p. 155.
} 
foram os irmãos confrades os encomendadores da obra. A imagem mantém o arcaísmo dos vincos angulosos e pequenos no drapeado que caí sobre os pés, mas a plasticidade dinâmica dos panejamentos com que recolhe o Menino ao colo evidenciam as formas de produção do século XVIII.

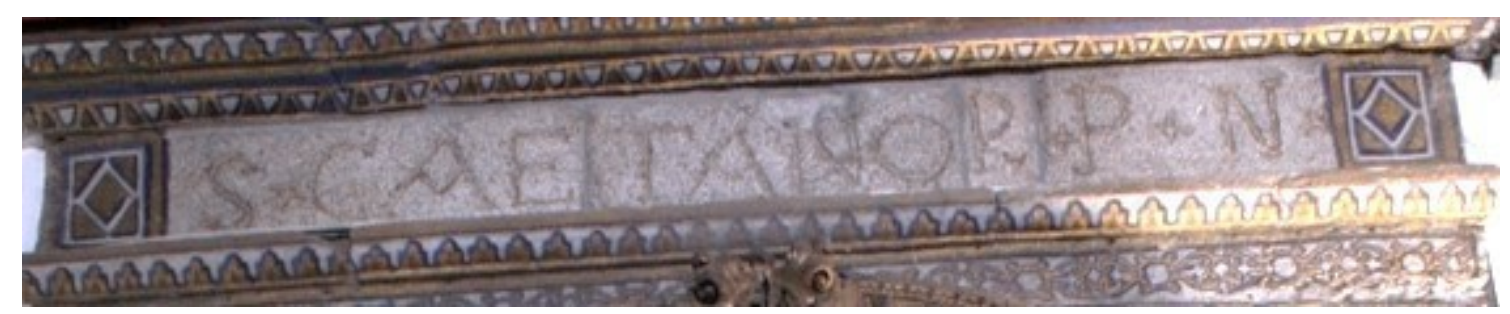

Imagem 41

Pormenor do altar de São Caetano no lado do Evangelho Atualmente o nicho central está ocupado pela imagem de Nossa Senhora das Graças, (Igreja de Nossa Senhora das Graças) - Bragança

As irregularidades anatómicas no corpo do Menino, a estaticidade da figura de São Caetano e a inexpressividade do rosto sugerem a valorização do sentido catequético da imagem em detrimento dos valores artísticos. Os repintes a que foi submetida não favorecem a leitura das formas mas parece tratar-se de uma produção regional dos princípios do século XVIII. A imagem sugere a divulgação dos modelos e dos gestos apreendidos a partir da circulação de gravuras, mas, reflete também a falta de conceitos e práticas de desenho, e o fraco domínio das proporções anatómicas e de composição.

De produção regional parecem também ambas as esculturas que atualmente se expõem na capela-mor da igreja de São Francisco em Bragança. É uma imagem de São Francisco (Imagem 42) e outra de São Vicente Ferrer (confundido com Domingos de Gusmão), (Imagem 43). As esculturas são formalmente idênticas o que sugere idêntica produção. Os panejamentos simplificados com um esquema de cinco vincos que alternam simetricamente os planos com o pregueado anguloso ${ }^{100}$, evidenciam em ambas as esculturas a pose de contraposto. Os hábitos estão cobertos, apenas na parte da frente, por estufado dourado de motivos vegetalistas também idênticos em ambas as esculturas. Mas, é no gesto contido e na simplificação dos contornos físionómicos do rosto que mais se assemelham as imagens. Os cabelos e barbas são bem definidos nos seus

\footnotetext{
${ }^{100}$ Este esquema nos vincos simétricos doa panejamentos foi introduzido por Mateo de Prado na escultura de Santiago de Compostela em meados do século XVIII. López Vázquez, José Manuel, "La imagen de san Francisco del retablo mayor del convento compostelano de Val de Dios y otras nuevas atribuciones a José Ferreiro (1738-1830): señas de identidad y estilo", in SÉMATA, Ciencias Sociais e Humanidades, vol. 26, Santiago de Compostela, Universidade de Santiago de Compostela / Facultad de Geografía e Historia / Servicio de Publicaciones e Intercambio Científico, 2014, pp. 609-632.
} 
contornos mas preenchidos por linhas pouco vincadas, dissipando as madeixas mais desenhadas da centúria anterior. A representação dos olhos muito amplos e de expressão serena e da boca entreaberta é igual nas duas obras. Tratam-se certamente de imagens produzidas pelas mesmas mãos e a partir do mesmo modelo. De forte gosto simbólico nos atributos e no rigor da representação dos detalhes devocionais refletem, nas irregularidades anatómicas, uma produção regional vinculada a uma linguagem comum nas obras de meados do século XVIII, julgamos que podem ter sido esculpidas em meados da centúria, entre 1730 e 1760.

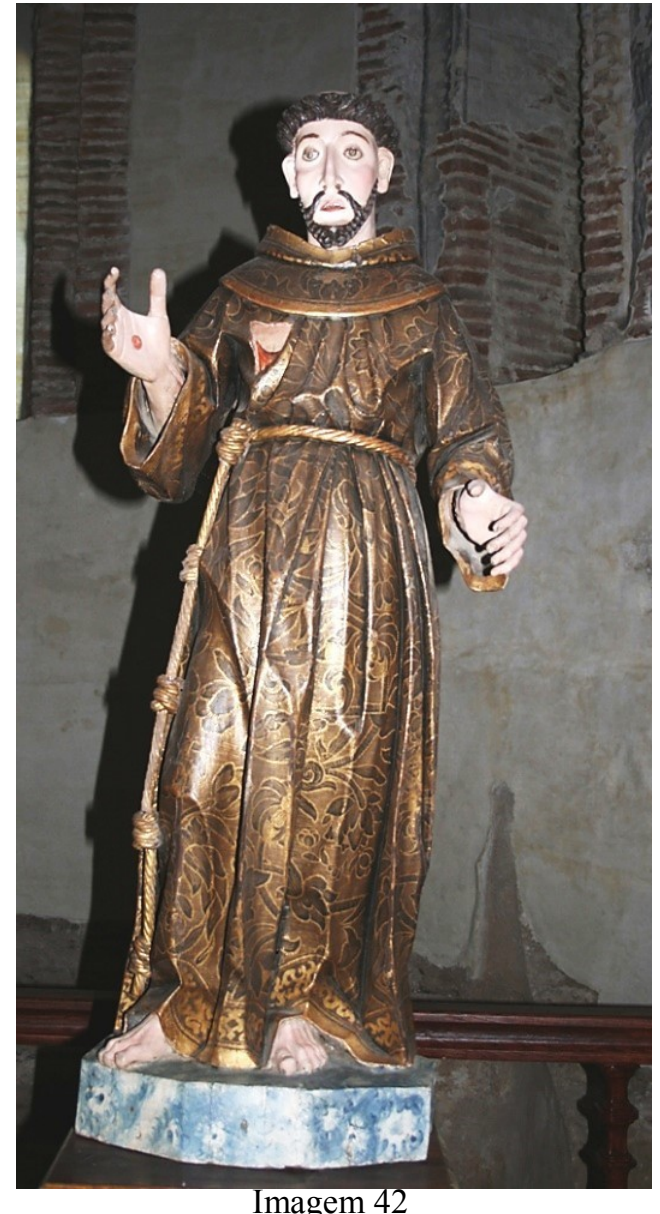

Escultura de São Francisco SFB 12

Capela-mor no lado da Epístola Igreja de São Francisco - Bragança

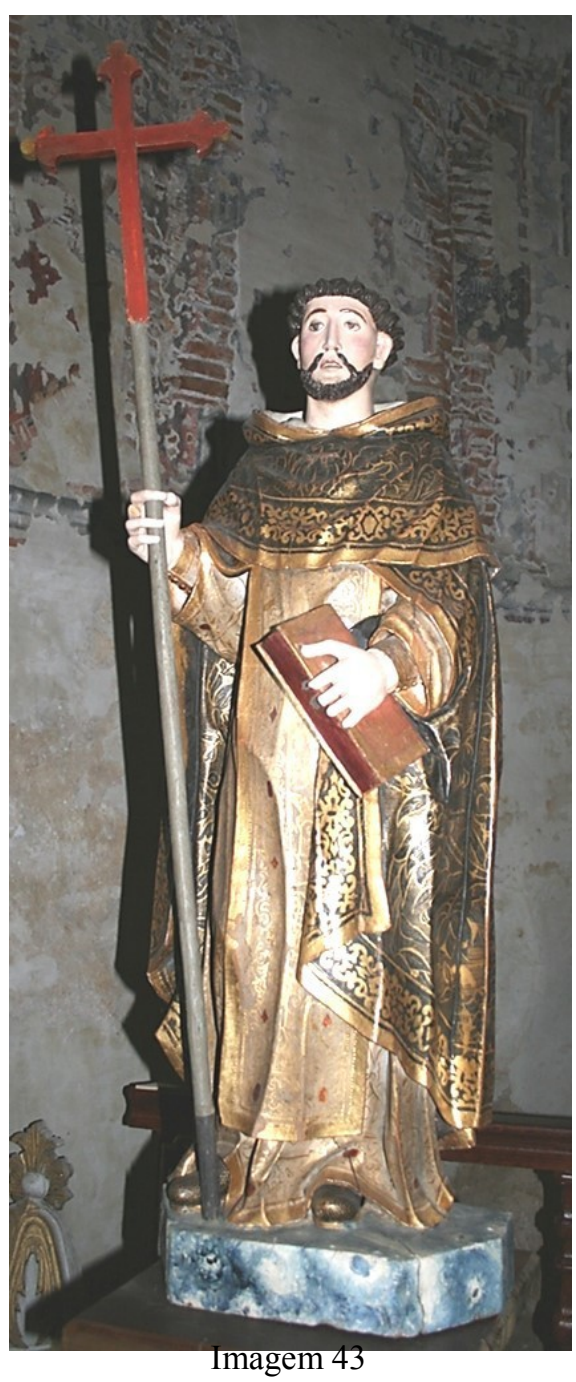

Escultura de São Vicente Ferrer SFB 13

Capela-mor no lado do Evangelho Igreja de São Francisco - Bragança

Na segunda metade do século XVIII, D. José vai prosseguir o esforço encetado por seu pai na consolidação da escultura particularmente desfavorecida em Portugal em termos culturais e de ensino. Para chefiar a equipa de trabalhos em Mafra, D. José 
recorreu a Alessandro Giusti (1715-1799) ${ }^{101}$. Giusti havia estudado pintura e escultura em Roma, de onde era natural. Depois de executar o baixo-relevo da Coroação de Nossa Senhora, Giusti terá perdido a visão pelo excesso de pó e já não terá orientado os trabalhos do retábulo de Nossa Senhora da Conceição (1771) então sob responsabilidade de Roberto Luis da Silva, manteve porém um estreito vínculo com os baixos-relevos. O Retábulo da Anunciação de 1773 foi obra dos discípulos e alunos portugueses da escola em Mafra que entretanto Giusti foi criando ${ }^{102}$. De todos os alunos de Giusti foi Machado de Castro ${ }^{103}$ o que mais se destacou. Executou encomendas

\begin{abstract}
${ }^{101}$ Alessandro Giusti (1715-1799) dirigiu a execução dos relevos dos Santos Bispos (1755), Santo Cristo (1757), Nossa Senhora do Rosário (1759), Santas Virgens (1761), Santos Mártires (1763), Santos Confessores (1765), Sagrada Família (1767), e Coroação de Nossa Senhora (1769). Giusti na maior parte dos retábulos baseou-se nos painéis pictóricos que os antecediam e que iam sendo retirados à medida que a escultura ocupava os seus lugares. Os retábulos apresentam a zona superior povoada de anjinhos que enquadram os protagonistas, no registo inferior as figuras têm um tratamento mais escultórico saindo muitas vezes do suporte. Além dos retábulos foram executadas uma série de lunetas que mantêm idênticas orientações. Os temas cristológicos, marianos e franciscanos são acrescentados pela novidade dos temas Agostinhos datando a transferência dos franciscanos para os Cónegos Regrantes em Mafra. Pereira, José Fernandes, "O barroco do século XVIII" in Paulo Pereira (direção), Historia da Arte Portuguesa, Volume III, Lisboa, Círculo de leitores, 1995, pp. 50-181; Pereira, José Fernandes, "Estética barroca I: arquitectura e escultura", in Dalila Rodrigues (Coord.), Arte Portuguesa - Da Pré-História ao Século XX, volume 12, Lisboa, Fubu Editores, 2009, pp. 7-136.
\end{abstract}

${ }^{102}$ No retábulo da Anunciação da escola em Mafra está patente a interpretação das orientações do mestre Giusti mas com uma simplificação compositiva, com diminuição das figuras em cena, convergindo numa linguagem menos romanizada e mais de acordo com as concepções de referenciais teóricos dos escultores portugueses. Há vários nomes conhecidos entre os alunos de Giusti, logo em 1753 e 1756, António Pecorato (cunhado de Giusti), José Joaquim Leitão, Alexandre Gomes, Roberto Luís da Silva, Salvador Franco e Lourenço Lopes; mais tarde entra João José Elveni, Francisco Leal Garcia, Brás Toscano de Melo, Joaquim António de Macedo, João da Silva Pevides, José Patrício, Silvério Martins e Gaspar Fróis Machado. Mas o único discípulo que se destacou de todos os alunos de Giusti dando continuidade à lição recebida foi Joaquim Machado de Castro que esteve em Mafra de 1756 até 1771. Após 1771 as obras em Mafra seguem a rotina finalizando as lunetas sob a direção de Roberto Luís da Silva, seguido por Barros Laborão e o último diretor da escultura de Mafra foi Brás Toscano de Melo. Pereira, José Fernandes, "O barroco do século XVIII" in Paulo Pereira (direção), Historia da Arte Portuguesa, Volume III, Lisboa, Círculo de leitores, 1995, pp. 50-181; Pereira, José Fernandes, "Estética barroca I: arquitectura e escultura", in Dalila Rodrigues (Coord.), Arte Portuguesa - Da Pré-História ao Século XX, volume 12, Lisboa, Fubu Editores, 2009, pp. 7-136.

${ }^{103}$ Joaquim Machado de Castro (1731-1822) nasceu em Coimbra onde recebeu lições dos jesuítas, depois foi para Lisboa onde trabalhou na oficina do santeiro Nicolau Pinto e passa mais tarde para a oficina de José de Almeida que havia estado em Roma, mas a sua formação mais destacada é na Escola de Mafra onde chega em 1756 para trabalhar com Giusti. Pereira, José Fernandes, "O barroco do século XVIII" in Paulo Pereira (direção), Historia da Arte Portuguesa, Volume III, Lisboa, Círculo de leitores, 1995, pp. 50-181; Pereira, José Fernandes, "Estética barroca I: arquitectura e escultura", in Dalila Rodrigues (Coord.), Arte Portuguesa - Da Pré-História ao Século XX, volume 12, Lisboa, Fubu Editores, 2009, pp. 7-136. No Porto, Machado de Castro fez para a venerável Ordem Terceira as duas imagens de São Francisco e de São Domingos, que se encontram na capela-mor. Ferreira-Alves, Natália Marinho, "Entalhadores e imaginários do Núcleo Franciscano Portuense" in Natália Marinho Ferreira-Alves e (Coord.) Os Franciscanos no Mundo Português. Artistas e Obras (I), Porto, CEPESE - Centro de Estudos da População, Economia e Sociedade, 2009, pp. 195-211.

Em 1775 foi Machado de Castro o escultor encarregue da estátua equestre de D. José para a praça do comércio em Lisboa, impondo algumas alterações ao desenho original do arquiteto Eugénio dos Santos. A estátua equestre de D. José constitui uma das raras obras da escultura portuguesa em que se conhece 
várias das quais se destaca a régia estátua equestre de D. José para a praça do comércio; e, mais tarde, mas com a mesma metodologia, partindo do desenho e fazendo sucessivos moldes, coordenou todo o programa escultórico da Basílica da Estrela. Machado de Castro foi gradualmente assumindo as principais encomendas régias, sendo responsável por diversos túmulos e projetos régios. Mas o âmbito teórico foi também alvo de constantes preocupações do autor, no sentido de consolidar a prática manual com a conceção teórica controlada por uma metodologia faseada. Foi o primeiro escultor português a escrever sobre escultura e fê-lo extensivamente e com forte erudição.

No Porto, os meados do século XVIII, foram marcados por uma geração de artistas com formação no joanino, mas que simultaneamente dominavam já um vocabulário decorativo rococó. Esta postura vai marcar o trabalho do mestre entalhador José Teixeira Guimarães ${ }^{104}$, assim como do entalhador Manuel Pereira da Costa Noronha ${ }^{105}$,

todo o processo criativo permitindo-nos entender a metodologia clássica inerente a toda a produção de Machado de Castro, que partindo do desenho fez sucessivos moldes para testar e controlar a obra. Na Basílica da Estrela em Lisboa oito esculturas foram colocadas na frontaria da igreja, na parte superior a Fé a Adoração, a Liberdade e a Gratidão esculpidas por Alexandre Gomes, João Elveni, José Patrício e José Joaquim Leitão. Os mesmos artistas trabalharam nas esculturas dos nichos, Santa Teresa de Ávila, Santa Maria Madalena de Piazzi, Santo Elias e São João de Deus. No átrio estão representadas a Virgem e São José e num relevo sobre a porta principal o Espirito Santo. Na Basílica da Estrela é evidente a menor complexidade iconológica relativamente ao programa de Mafra. Formalmente as esculturas acentuam o peso estético das vestes num evidente encobrimento do corpo e deliberada vontade de ampliar o valor compositivo dos atributos iconográficos. Pereira, José Fernandes, "O barroco do século XVIII" in Paulo Pereira (direção), Historia da Arte Portuguesa, Volume III, Lisboa, Círculo de leitores, 1995, pp. 50-181; Pereira, José Fernandes, "Estética barroca I: arquitectura e escultura", in Dalila Rodrigues (Coord.), Arte Portuguesa - Da Pré-História ao Século XX, volume 12, Lisboa, Fubu Editores, 2009, pp. 7-136.

${ }^{104}$ José Teixeira Guimarães foi o autor do retábulo e das sanefas da Sala das Sessões da Casa do Despacho da Venerável Ordem Terceira de São Francisco (1748-49) e da sanefa do arco cruzeiro (1750) da igreja de São Pedro de Miragaia, que remata a capela-mor. José Teixeira Guimarães é o autor do retábulo-mor da igreja de São Nicolau (1760), segundo o risco de Frei Manuel de Jesus Maria. Com Francisco Pereira Campanhã, que é também o responsável pelo desenho, executa na referida igreja, os retábulos de Santo Elói (1762-63) do lado da Epístola, e de Nossa Senhora da Conceição (1763), do lado do Evangelho. Seria, a par de Francisco Pereira Campanhã, um dos vultos mais relevantes da segunda metade de Setecentos no Porto. Ferreira-Alves, Natália Marinho, "Pintura, Talha e Escultura (séculos XVII e XVIII) no Norte de Portugal" in Revista da Faculdade de Letras. Ciências e Técnicas do Património vol. 2, Porto, Faculdade de Letras da Universidade do Porto, Departamento de Ciências e Técnicas do Património, 2003, pp. 735-756; Ferreira-Alves, Natália Marinho, "Entalhadores e imaginários do Núcleo Franciscano Portuense" in Natália Marinho Ferreira-Alves e (Coord.) Os Franciscanos no Mundo Português. Artistas e Obras (I), Porto, CEPESE - Centro de Estudos da População, Economia e Sociedade, 2009, pp. 195-211.

${ }^{105}$ Manuel Pereira da Costa Noronha, filho do mestre Luís Pereira da Costa executa, na igreja de São Francisco do Porto na nave lateral do lado da Epístola, o retábulo de Nossa Senhora da Encarnação (1750), e o retábulo dos Santos Mártires de Marrocos (1750-51). Artista da escola portuense existem dados sobre a sua atividade entre 1726 e 1752, faz a sua formação no contexto artístico joanino, e pela análise dos seus trabalhos, pode considerar-se um entalhador de transição para o rococó. Smith, Robert, $A$ talha em Portugal, Lisboa, Livros Horizonte, 1963, p. 72; Ferreira-Alves, Natália Marinho, "Pintura, Talha e Escultura (séculos XVII e XVIII) no Norte de Portugal" in Revista da Faculdade de Letras. Ciências e Técnicas do Património vol. 2, Porto, Faculdade de Letras da Universidade do Porto, Departamento de Ciências e Técnicas do Património, 2003, pp. 735-756. 
filho do mestre Luís Pereira da Costa. A adesão plena ao rococó ficou demonstrada em 1755, nos retábulos dos topos do transepto da igreja do Mosteiro de São Bento da Vitória do Porto, da autoria de José da Fonseca Lima e José Martins Tinoco ${ }^{106}$. Natália Ferreira-Alves refere que as figuras que mais marcaram a arte da talha no período rococó no Porto além de José Teixeira Guimarães, foi Francisco Pereira Campanhã ${ }^{107}$, ambos entalhadores, destacando-se Francisco Pereira Campanhã como um dos mais notáveis riscadores de talha. Os dois artistas trabalharam em conjunto em várias igrejas da cidade do Porto ${ }^{108}$.

\footnotetext{
${ }^{106}$ José Martins Tinoco em 1748, fica incumbido de executar o teto da Sala das Sessões da Casa do Despacho da Venerável Ordem Terceira de São Francisco no Porto, com seus caixilhos e florões, obra que deveria estar à altura dos outros trabalhos em talha da autoria de José Teixeira Guimarães. Tinoco, cuja atividade ainda não se encontra suficientemente estudada, por falta de dados, iria ser o autor de um dos mais notáveis retábulos em andares do período rococó: o retábulo do Desterro ou da Sagrada Família, do topo do transepto, do lado do Evangelho, da igreja do Mosteiro de São Bento da Vitória. FerreiraAlves, Natália Marinho, "Pintura, Talha e Escultura (séculos XVII e XVIII) no Norte de Portugal" in Revista da Faculdade de Letras. Ciências e Técnicas do Património vol. 2, Porto, Faculdade de Letras da Universidade do Porto, Departamento de Ciências e Técnicas do Património, 2003, pp. 735-756; FerreiraAlves, Natália Marinho, "Entalhadores e imaginários do Núcleo Franciscano Portuense" in Natália Marinho Ferreira-Alves e (Coord.) Os Franciscanos no Mundo Português. Artistas e Obras (I), Porto, CEPESE - Centro de Estudos da População, Economia e Sociedade, 2009, pp. 195-211.
}

${ }^{107}$ Francisco Pereira Campanhã, tem sua atividade como entalhador e riscador documentada entre 1755 e 1773, sendo da sua autoria alguns dos melhores desenhos de talha rococó da escola do Porto. Oriundo de uma família de artistas, era irmão dos mestres pedreiros Caetano Pereira e João Pereira, e pai do arquiteto Damião Pereira de Azevedo. Em 1764 concebe aquele que é considerado o exemplar mais requintado e elegante do rococó portuense: a Capela de Nossa Senhora da Soledade, na igreja de São Francisco do Porto. Para além da finura do entalhe e da riqueza da policromia, um dos aspetos mais relevantes deste espaço único, são as excecionais cancelas que separam o Crente da imagem da Virgem na dor da sua solidão. No ano seguinte (1765), faz o retábulo-mor da igreja de Nossa Senhora da Vitória, fazendo também os riscos de toda a talha da mesma igreja (púlpitos, sanefa e retábulos laterais) que será executada por José Teixeira Guimarães, entre 1768 e 1773. Ferreira-Alves, Natália Marinho, "Pintura, Talha e Escultura (séculos XVII e XVIII) no Norte de Portugal" in Revista da Faculdade de Letras. Ciências e Técnicas do Património vol. 2, Porto, Faculdade de Letras da Universidade do Porto, Departamento de Ciências e Técnicas do Património, 2003, pp. 735-756; Ferreira-Alves, Natália Marinho, "Entalhadores e imaginários do Núcleo Franciscano Portuense" in Natália Marinho Ferreira-Alves e (Coord.) Os Franciscanos no Mundo Português. Artistas e Obras (I), Porto, CEPESE - Centro de Estudos da População, Economia e Sociedade, 2009, pp. 195-211.

Flávio Gonçalves refere que na segunda metade de setecentos, o Porto, sem oficinas eruditas estáveis, os imaginários eram simultaneamente entalhadores. Gonçalves, Flávio, História da arte; Iconografia e Crítica., Lisboa, Imprensa Nacional Casa da Moeda, 1990, p. 181.

${ }^{108} \mathrm{Na}$ igreja dos Carmelitas e a da Venerável Ordem Terceira do Carmo, o retábulo-mor dos Carmelitas foi feito por José Teixeira Guimarães, segundo o risco do próprio filho, o Padre Joaquim Teixeira Guimarães, enquanto o retábulo-mor da igreja da Ordem Terceira do Carmo é desenhado e executado por Francisco Pereira Campanhã, em cuja estrutura permanece viva a influência tardo-barroca. Contemporâneo é também Joaquim Alves de Sousa Alão autor dos anjos e das figuras alegóricas, colocadas na igreja da venerável Ordem Terceira do Porto, bem como dos anjos que rematam superiormente os altares laterais. Na mesma igreja trabalhou o entalhador o italiano Luigi Chiari (sob as ordens de Manuel Moreira da Silva) a quem se ficaram a dever os belíssimos púlpitos, e os quatro altares laterais da igreja (Nossa Senhora da Conceição, Santa Isabel Rainha de Portugal, São Luís de França e Santa Margarida de Cortona), cuja elegante linguagem artística irá marcar os interiores contemporâneos. Ferreira-Alves, Natália Marinho, "Entalhadores e imaginários do Núcleo Franciscano Portuense" in 
Tal como acontecia na primeira metade da centúria, na segunda metade de setecentos, Braga acompanha o Porto enquanto centro oficinal de escultura. A escola de Braga atinge o seu período áureo na segunda metade de setecentos tendo como figuras cimeiras André Soares, que se distingue principalmente como desenhador, José Álvares de Araújo, um dos melhores entalhadores do rococó bracarense ${ }^{109}$, e Frei José de Santo António Ferreira Vilaça ${ }^{110}$, provavelmente o artista mais versátil na arte da talha do seu tempo, e que deixou inumeráveis testemunhos do seu talento e da sua cultura artística.

Foi na igreja do Mosteiro de São Martinho de Tibães ${ }^{111}$ onde as relações entre os dois artistas André Soares e José Álvares de Araújo e também com Frei José Vilaça, no

Natália Marinho Ferreira-Alves e (Coord.) Os Franciscanos no Mundo Português. Artistas e Obras (I), Porto, CEPESE - Centro de Estudos da População, Economia e Sociedade, 2009, p. 210.

${ }^{109}$ André Soares e José Álvares de Araújo aparecem associados a vários espécimes retabulares a partir da década de 50, sendo os riscos de Soares excelentemente executados pelo mestre entalhador, como pode ainda hoje constatar-se na talha do arco do retábulo de Nossa Senhora dos Prazeres (1756), na igreja do Colégio de São Paulo (Braga),e no retábulo de Nossa Senhora do Rosário (1761), na igreja do Convento de São Domingos, em Viana do Castelo, um dos mais significativos retábulos rococós da região do Minho. Ferreira-Alves, Natália Marinho, "Pintura, Talha e Escultura (séculos XVII e XVIII) no Norte de Portugal" in Revista da Faculdade de Letras. Ciências e Técnicas do Património vol. 2, Porto, Faculdade de Letras da Universidade do Porto, Departamento de Ciências e Técnicas do Património, 2003, pp. 735756; a influência de André Soares foi também identificada na Galiza. Folgar De La Calle, Maria Carmen, "La influencia portuguesa en los retablos barrocos de Galicia", Actas do II Congresso Internacional del Barroco, Porto, Universidade do Porto, Faculdade de Letras. Departamento de Ciências e Técnicas do Património, 2003, pag. 475-490.

${ }^{110}$ Frei José de Santo António Ferreira Vilaça, também conhecido por Frei José Vilaça (1731-1809). Acompanhando o pai, carpinteiro de profissão, que viera trabalhar nas obras da capela-mor, Vilaça trabalha em Tibães de forma contínua entre 1757 e 1764, tendo contacto com os desenhos vigorosos de André Soares e com a mestria do entalhe de José Álvares de Araújo, iniciando-se, desta forma, nas duas áreas que pautaram toda a sua vida artística. $\mathrm{Na}$ área da talha, a sua produção é muito polifacetada englobando retábulos, caixas de órgãos, púlpitos, sanefas, caixilhos, gradeamentos, credências, cadeirais, etc. Graças ao conhecimento da sua biblioteca particular, sabemos que na sua formação, para além da relação com o mundo dos entalhadores, da marca profunda dos desenhos de André Soares, e a par das referências das gravuras de Juste-Aurèle Meissonier e dos gravadores da escola alemã de Ausgsburg, existiu o contacto direto com obras importantes da tratadística europeia de autores como Andrea Pozzo, Bosse, Blondel, Briseux, e Jombert, que influenciaram decisivamente a sua obra. Os seus trabalhos encontram-se em Braga, Lamego, Refóios de Basto, Pombeiro, Paços de Sousa. Smith, Robert, Frei José de Santo António Ferreira Vilaça, Escultor Beneditino do século XVIII, volume II, Fundação Calouste Gulbenkian, Lisboa, 1972, pp. 231-401; Ferreira-Alves, Natália Marinho, "Pintura, Talha e Escultura (séculos XVII e XVIII) no Norte de Portugal" in Revista da Faculdade de Letras. Ciências e Técnicas do Património vol. 2, Porto, Faculdade de Letras da Universidade do Porto, Departamento de Ciências e Técnicas do Património, 2003, pp. 735-756; Dias, Eva Sofia Trindade, "Beneditinos e Franciscanos: convivência de invocações no espaço monástico beneditino português (Séculos XVII-XVIII)", in Natália Marinho Ferreira-Alves (Coord.), Franciscanos no Mundo Português III, Porto, CEPESE - Centro de Estudos da População, Economia e Sociedade, 2013, pp. 375-399.

${ }^{111}$ Mosteiro de São Martinho de Tibães (casa-mãe dos beneditinos em Portugal) recebeu ao longo da primeira metade do século XVIII, diversas obras de talha na igreja, devendo referir-se particularmente a Capela do Descimento da Cruz (primeira capela do lado da Epístola) cujo revestimento em talha da fase joanina, da autoria do entalhador António Fernandes Palmeira, foi realizada entre 1739 e 1740 . A partir do governo de Frei José de São Domingos (1752-1755), e com sequência dada pelos dois abades seguintes - Frei António de Santa Clara e Frei Francisco de São José - assistiu-se à execução de uma 
início da sua carreira, se manifestaram mais frutuosas, possibilitando a criação de um espaço sacro rococó de invulgar unidade.

Frei José de Santo António Ferreira Vilaça, figura prodigiosa da arte da talha, permanece associado à escola de Braga da segunda metade de Setecentos, transmitindonos, através da talha, a sua forma de acompanhar as mutações estéticas que iam ocorrendo colocando-o numa posição cimeira entre os artistas do seu tempo ${ }^{112}$.

A segunda metade do século XVIII supõe em Portugal um importante momento no desenvolvimento das técnicas, das teorias, dos conceitos que envolvem as encomendas de escultura. Permanece na documentação o destaque dado à talha dos retábulos em detrimento das esculturas que os preenchiam, o que dificulta as definiçõoes das autorias das obras escultóricas. Mas a proliferação de oficinas e de entalhadoreslimaginários ilustra a valorização da talha durante a segunda metade da centúria.

É inquestionável, também no território em estudo, o forte investimento que foi feito na escultura que encontra nos dois últimos quarteis da centúria o seu momento de máxima expressão, qualitativa e quantitativa.

A par de alguma produção local ou regional desenvolveu-se a encomenda de esculturas a oficinas mais desenvolvidas, com acesso a modelos mais criativos e sobretudo a técnicas mais apuradas, entre as quais devemos destacar as oficinas do Porto e Braga.

A preferência pelas imagens mais verosímeis acentua-se ao longo de todo o século XVIII. Mas a partir de meados do século torna-se uma imposição, conforme podemos constatar no registo da visitação do bispo D. Frei João da Cruz de 1753:

"Diz que muitas imagens de santos estão mal feitas, não infundindo por isso piedade. Manda-as reformar dentro de cinco anos, devendo ser todas de talha dourada e estofadas, podendo ser feitas na cidade de Valladolid,

empreitada gigantesca que iria transformar a igreja de Tibães num dos interiores rococós de maior unidade e magnificência do país, servindo de modelo a muitas outras casas beneditinas portuguesas. Ferreira-Alves, Natália Marinho, "Pintura, Talha e Escultura (séculos XVII e XVIII) no Norte de Portugal" in Revista da Faculdade de Letras. Ciências e Técnicas do Património vol. 2, Porto, Faculdade de Letras da Universidade do Porto, Departamento de Ciências e Técnicas do Património, 2003, pp. 735756.

${ }^{112}$ Ferreira-Alves, Natália Marinho, "Pintura, Talha e Escultura (séculos XVII e XVIII) no Norte de Portugal" in Revista da Faculdade de Letras. Ciências e Técnicas do Património vol. 2, Porto, Faculdade de Letras da Universidade do Porto, Departamento de Ciências e Técnicas do Património, 2003, pp. 735756. 
onde, nesse género, se trabalha mais perfeitamente, com olhos de cristal $^{113 "}$.

A recomendação do bispo não garante que todas as imagens fossem a partir de 1753 de produção espanhola de Valhadolid mas é significativa a preferência pelas oficinas desta cidade. $\mathrm{O}$ mesmo Bispo, dois anos mais tarde voltaria a editar uma pastoral para reforçar a qualidade e decência das imagens a culto. $\mathrm{O}$ prestígio das esculturas de Valhadolid estava bem consolidado desde as primeiras décadas do século XVII na diocese de Bragança - Miranda pela presença de várias obras de encomenda espanhola como a do retábulo da sé de Miranda do Douro ou a imagem atribuída a Pedro de Mena na igreja de Santa Maria em Bragança.

Mas, apesar do prestígio das oficinas de Valhadolid, formalmente julgamos que as encomendas decorrentes da segunda metade do seculo XVIII no território em estudo se relacionam mais com os centros de produção nacional, mais concretamente com as oficinas do Porto e Braga. Do núcleo de esculturas estudadas apenas percebemos proximidade com a escultura espanhola em obras que relacionamos com o século XVII. As obras do século XVIII na sua maioria julgamos que estão relacionadas com os modelos nacionais que partindo do grande estaleiro de Mafra irradiaram a influência internacional para as restantes oficinas, no entanto pontualmente registamos as influências espanholas, como ocorre com alguma produção de Frei Domingos em Vinhais.

No convento de São Francisco em Bragança houve um significativo aumento das devoções e consequentemente das imagens que as ilustravam. Das várias representações de São Francisco de Assis a que acompanha a figura de Cristo Crucificado com o braço pendente da cruz (Imagem 44) constitui pela sua narrativa um exemplo singular dentro dos modelos iconográficos em estudo.

Formalmente é um conjunto intenso: A dramática linha diagonal que une as figuras e as ensanguentadas marcas de martírio da figura de Cristo e o académico cuidado na representação dos detalhes anatómicos do corpo nu apenas coberto pelo esvoaçante cendal constituem importantes elementos comunicacionais. Apesar do conjunto ser autónomo nas partes que o constituem julgamos que se trata de uma narrativa compósita

\footnotetext{
${ }^{113}$ Alves, Francisco Manuel, Bragança Memórias arqueológico-históricas do distrito de Bragança $\left(2^{a}\right.$ edição) Tomo II, Bragança, Câmara Municipal de Bragança / Instituto Português de Museus - Museu Abade de Baçal, 2000, (original publicado em 1910-1947), p. 162. Também González refere este documento. Martín González, Juan José, La huella española en la escultura portuguesa, Valladolid, Sever - Cuesta, 1961, pp. 19, 20.
} 
formada pelas duas imagens, tal como ainda hoje estão expostas. As imagens assemelham-se formalmente sobretudo nos rostos, no tratamento dos cabelos e barbas, nos contornos do nariz e boca e nos olhos de vidro cuja orientação é coincidente em ambas as esculturas reforçando emocionalmente a relação formal que as une. A intensidade emocional contida no corpo martirizado da figura de Cristo é acrescida pelo gesto assimétrico do braço pendente na eminencia de envolver São Francisco no abraço místico.

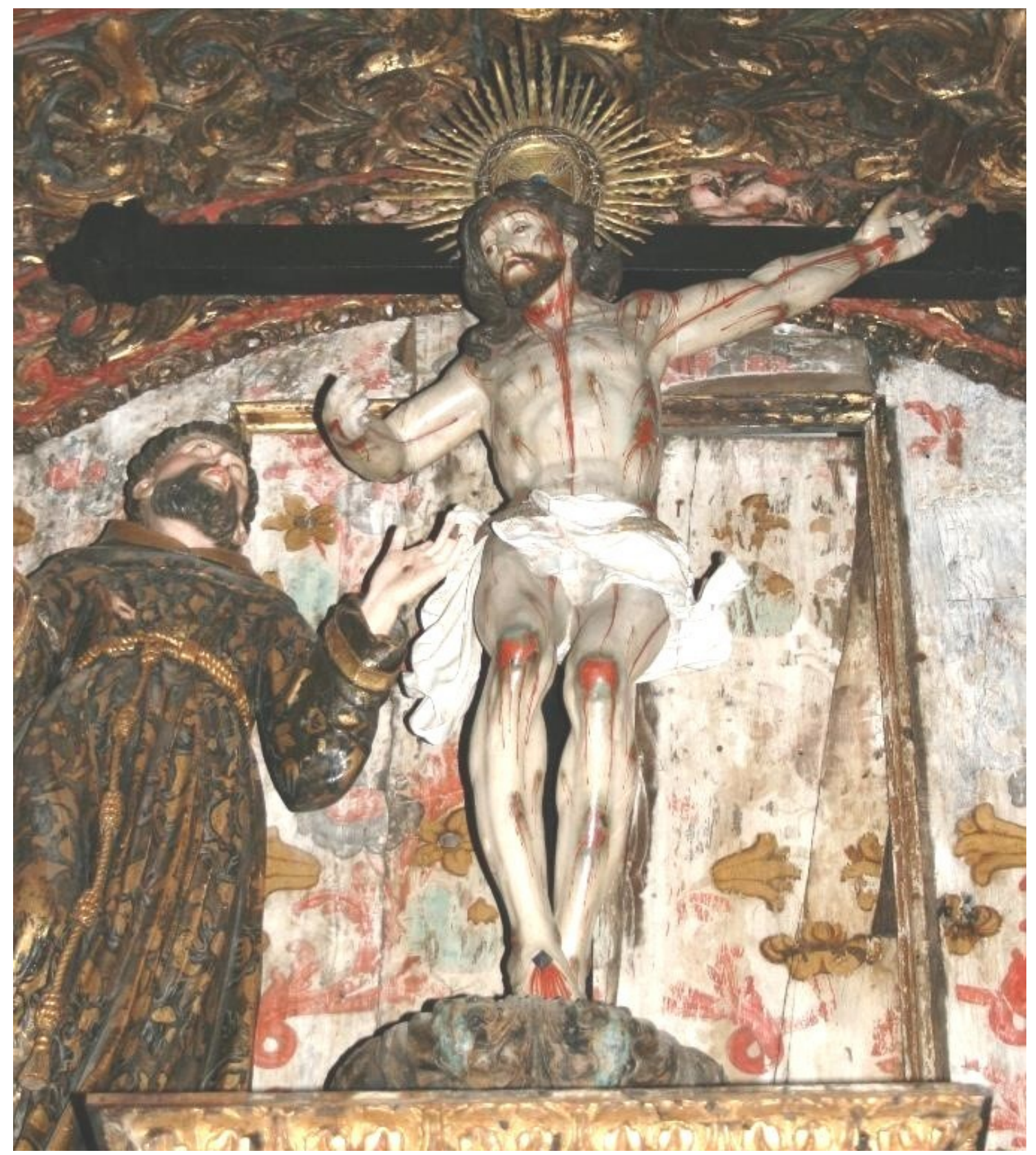

Imagem 44

Escultura de Cristo Crucificado com o braço pendente para o abraço místico a São Francisco de Assis SFB 03 e SFB 04

Retábulo lateral, lado da Epístola

Igreja de São Francisco - Bragança 
O dinamismo gerado com a linha oblíqua do braço intensifica a torsão do corpo e da tensão muscular que o movimento sugere. O gesto de São Francisco é mais contido, mas os pregueados dos panejamentos finos que se vincam entre as pernas sugerem o movimento do Santo em direção à figura de Cristo. Os braços e a cabeça elevados reforçam a relação formal entre ambas as esculturas. O sentido catequético do conjunto comove na sua pedagógica intenção narrativa. Mas é no cuidado plástico e na mestria no domínio do dinamismo dos panejamento e da emotividade das expressões que encontramos os elementos que formalmente nos permitem identificar o conjunto com a produção escultórica da segunda metade do século XVIII, de alguma oficina nacional, talvez do Porto.

No mesmo convento de São Francisco ainda se mantém a culto, num retábulo do lado do Evangelho, a imagem de Santa Clara (Imagem 45). Idêntica à imagem de São Francisco (Imagem 46), apresenta-se finamente talhada nos detalhes anatómicos e na ampla indumentária que a cobre com dinâmicos vincos finos nos panejamentos que lhe acompanham o movimento. Está representada de pé, em posição frontal com contraposto, com a cabeça ligeiramente voltado para a esquerda o que reforça a sinuosidade do gesto. $\mathrm{O}$ rosto está finamente esculpido e coberto de carnação clara e brilhante, com traços delicados que compõem uma expressão serena com olhos de vidro que se elevam. O hábito coberto por uma densa composição de aplicações estofadas de motivos vegetalistas é rico nos pormenores e ondulante no drapeado. A obra apresenta formalmente as influências que a partir do estaleiro de Mafra se ampliaram a mais territórios, também às bem apetrechadas oficinas do Porto e Braga. Desconhece-se documentação que relacione a imagem com o seu local de produção, mas os detalhes técnicos e formais que a definem são representativos de uma oficina bem preparada. $O$ pregueado do hábito, os motivos estufados que o adornam, a sinuosa gestualidade dos corpos permitem-nos perceber a possível origem comum da imagem de Santa Clara e de São Francisco. Uma vez que a imagem de São Francisco é considerada parte de um conjunto com a imagem de Cristo com o braço pendente da cruz e portanto ambas resultaram da mesma encomenda o que sugere que no mesmo período e na mesma oficina foram produzidas as três esculturas de vulto que representam Cristo, São Francisco e Santa Clara.

A qualidade técnica das três obras é evidente. A simultânea encomenda de tão significativas obras, quer pelo cuidado plástico, quer pela quantidade sugerem um 
investimento importante numa comunidade que já estava então muito consolidada no território. Desconhece-se quem foram os encomendadores, mas as devoções franciscanas escolhidas sugerem que foram elementos vinculados com a Ordem ou os próprios frades ou os irmãos da Ordem Terceira

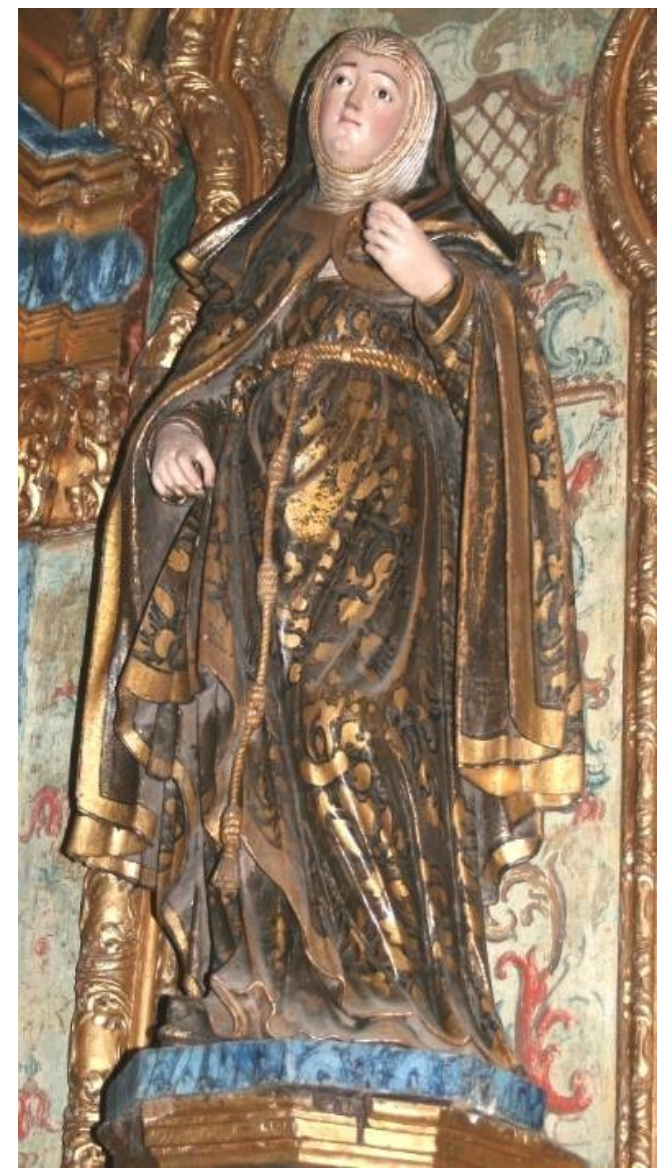

Imagem 45

Escultura de Santa Clara - SFB 23 Retábulo lateral, lado do Evangelho Igreja de São Francisco - Bragança

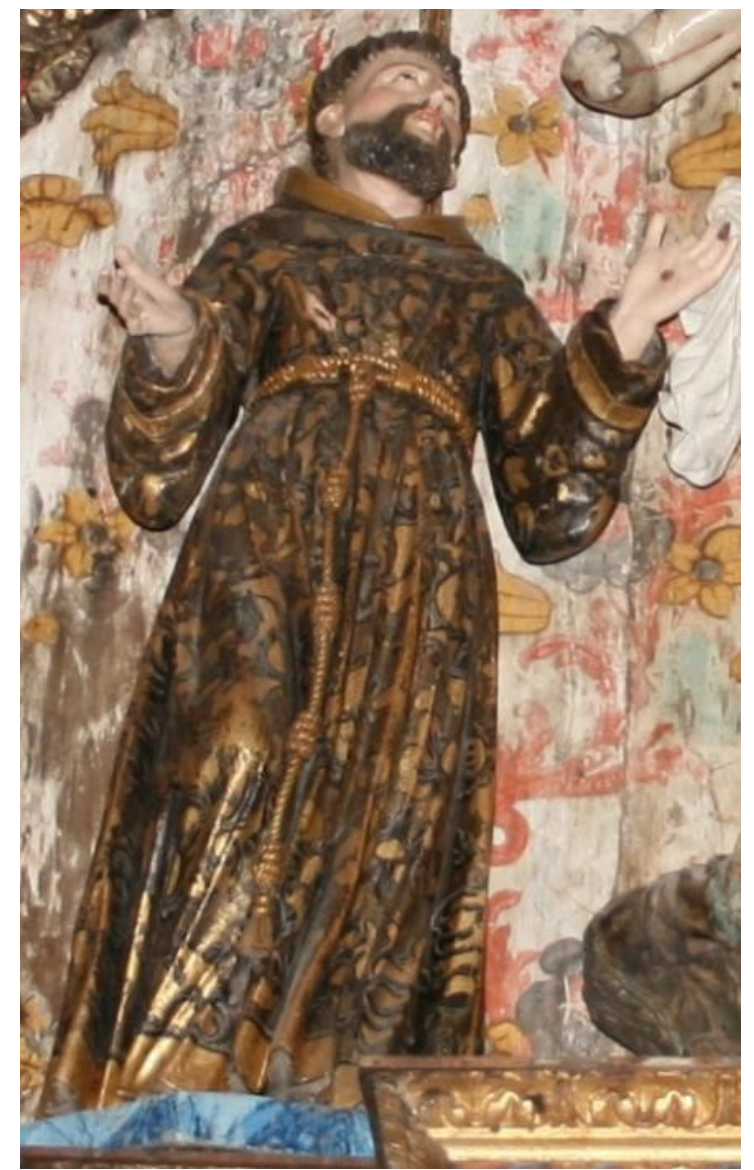

Imagem 46

Escultura de São Francisco de Assis - SFB 04 Retábulo lateral, lado da Epístola Igreja de São Francisco - Bragança

- Neste sentido devemos relacionar esta encomenda com as diversas encomendas realizadas pela Ordem Terceira de Vinhais no mesmo período e que formalmente se aproximam deste conjunto. As semelhanças com a produção de Vinhais observam-se sobretudo no tratamento da cabeça da figura de Santa Clara. Podemos comparar a cabeça da figura de Santa Clara da igreja de Bragança, com Santa Clara de Vinhais e Santa Rosa de Viterbo que se percebe o mesmo modelo de feições suaves contornos arredondados e expressão serena, e a mesma coifa e véu. As mesmas formas encontramos em alguma das estatuária atualmente exposta no núcleo museológico de São Francisco no Porto (com a escultura que representa Santa Rosa de Viterbo), permitindo-nos reforçar o vínculo destas obras com as oficinas do Porto e Braga. 
Esta proximidade formal abre a possibilidade da origem na oficina do Porto ou Braga para as obras de encomenda da igreja de São Francisco de Bragança e da Ordem Terceira de Vinhais. Porém os panejamentos das figuras de Bragança apresentam maior estaticidade e sugerem uma proximidade formal mais pegada aos meados do século que do último terço conforme se observa em Vinhais.

No mesmo período terá sido

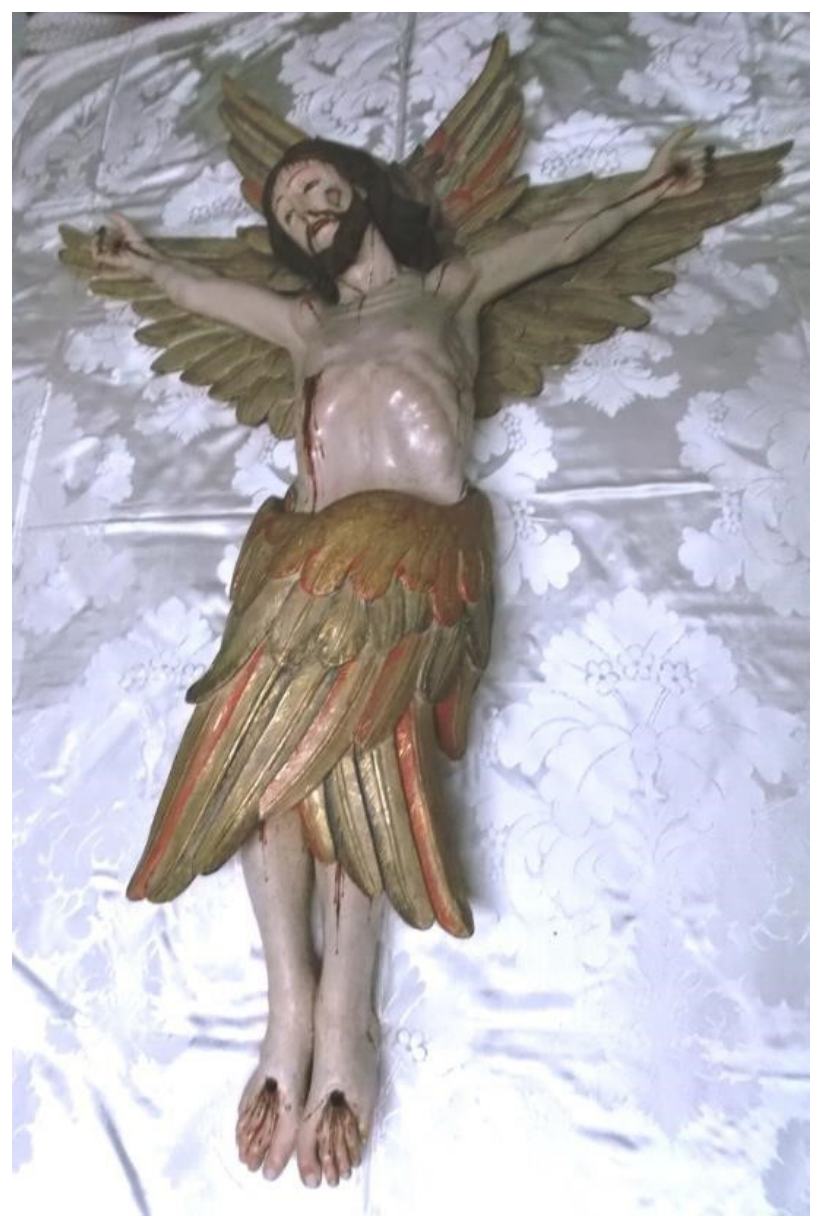

Imagem 47

Escultura de Cristo Serafim SFB 30

Não está a culto, encontra-se guardado na sacristia da Igreja de São Francisco - Bragança ainda encomendada para a igreja de São Francisco de Bragança a imagem de Cristo Serafim (Imagem 47). É uma dos raros exemplares deste modelo iconográfico presentes na escultura de vulto em Portugal. Iconograficamente pode relacionar-se a imagem de Cristo Serafim com a imagem de São Francisco ajoelhado, bem como, se pode entender na complementaridade com a anterior narrativa do Abraço Místico. No entanto, formalmente as imagens são claramente distintas, produzidas por distintas mãos e em distintos momentos. A escultura de São Francisco ajoelhado do convento franciscano de Bragança parece formalmente próxima das produções escultóricas do século XVII e não do XVIII como a escultura de Cristo Serafim.

A imagem de Cristo Serafim apresenta-se finamente talhada, na composição do corpo, no detalhe anatómico, na volumetria dos músculos e no naturalismo dos pormenores das seis asas que envolvem a figura. É no delicado trabalho de composição das plumas e das asas que melhor se percebe o compromisso formal entre o autor e a obra. $\mathrm{O}$ conhecimento anatómico e a desenvoltura na composição definem a boa formação do 
executante, assim como, a sua integração formal na segunda metade do século XVIII. Não podemos deixar de referir alguma assimetria que se observa no tratamento dado à escultura. As assas são irrepreensíveis na técnica formal da sua representação, no entanto percebem-se algumas irregularidades nas proporções do corpo o que levanta mais dúvidas sobre a possível produção da imagem. Se o naturalismo correto das assas nos sugere uma oficina bem apetrechada conceptual e tecnicamente, talvez do Porto, ou Braga, já as irregularidades das proporções anatómicas refletem uma prática mais desvinculada das normas e preceitos do desenho e das proporções então já divulgados.

A escultura de Cristo Serafim tinha originalmente uma cruz que a sustinha, hoje desaparecida ${ }^{114}$, conforme se percebe pelas argolas de suspensão que ainda mantém sobre as costas.

Mas, onde a encomenda adquire os contornos plenos da narrativa barroca aplicada na imaginária é incontestavelmente nos espaços franciscanos de Vinhais. O primeiro a ser fundado é o Seminário Franciscano de Missionários Apostólicos que integra a igreja de Nossa Senhora da Encarnação. Montes Moreira refere que os seminários autónomos de missionários apostólicos dependiam diretamente do governo central da ordem, sem laços jurídicos nem com as províncias nem sequer entre eles. O convento de Varatojo foi o primeiro seminário apostólico autónomo da ordem, autonomizado da Província dos Algarves com autorização papal de 1679, a este se seguiram outros quatro: Brancanes 1682; Vinhais em 1753; Mesão Frio em 1790 e Falperra em $1826^{115}$.

A partir de 1753, sob o patrocínio da edilidade local e também do interesse da Diocese as obras do seminário iniciam-se, e seria continuamente alvo de melhorias até à extinção das Ordens em 1834.

Tal como nos restantes espaços franciscanos, até então já fundados no território em estudo, a ausência documental envolve quer o edificado, quer o património móvel guardado no seu interior, restando-nos a comparação formal das obras para estabelecer ciclos de encomenda e analogias nas autorias.

Mais uma vez é no inventário efetuado aquando da extinção das ordens que encontramos a única referencia às obras escultóricas. Referência essa que se restringe ao seu registo como existência em 1834, não referindo nem a autoria nem o encomendador.

\footnotetext{
${ }^{114}$ A cruz de Cristo Serafim está em restauro no Porto, na oficina de restauro de Ludjero Castro, responsável pelo restauro de parte da imaginária da igreja. Segundo informação da zeladora e membro da Ordem Terceira de Bragança, D. Augusta, em dezembro de 2012. Até à data ainda não foi devolvida.

${ }^{115}$ Montes Moreira, António, "Franciscanos" in Carlos Moreira Azevedo, Dicionário de história religiosa de Portugal, Lisboa, Círculo de Leitores, 2000, pp. 273-280.
} 
Neste sentido, é notável a quantidade de obras que quase dois séculos depois do registo de 1834 ainda podemos hoje observar.

O complexo conjunto franciscano de Vinhais inclui a igreja do seminário (Igreja de Nossa Senhora da Encarnação), a capela das Dores e a sacristia, o museu de arte sacra e a igreja da Venerável Ordem III (Igreja de São Francisco) e ainda, dentro do perímetro da cerca do seminário, duas capelas com conjuntos escultóricos em terracota, já muito deteriorados. Apesar das mudanças que ocorreram na distribuição das imagens no total dos espaços pertencentes à família franciscana do território de Vinhais, foram inventariadas cerca de 60 esculturas cuja produção podemos relacionar, na sua esmagadora maioria, com a segunda metade do seculo XVIII.

O conjunto de imaginária de Vinhais sugere distintas produções e cronologias. Atualmente estão expostas, dentro de dois nichos confrontados nas paredes laterais da capela de Nossa Senhora das Dores, as duas obras que julgamos serem as primeiras deste extenso conjunto. Tratam-se de duas estatuetas que representam São Bernardino de Siena $^{116}$ (Imagem 48) e São Boaventura ${ }^{117}$ (Imagem 49).

Ambas as esculturas apresentam o rosto jovem, finamente esculpido com linhas suaves, olhos de vidro e expressão grave individualizada. Os gestos elegantes na sinuosidade sugerida pela pose do contraposto são idênticos, bem como o drapeado das vestes que acompanham o movimento do corpo. A produção cuidada nas proporções, nos gestos e nas técnicas decorativas aplicadas sobre as esculturas remete-nos para uma produção oficinal cuidada dos princípios da segunda metade do século XVIII. Possivelmente tratar-se-ão de esculturas trazidas pelos primeiros frades missionários oriundos do Seminário de Brancanes.

\footnotetext{
${ }^{116}$ A escultura de São Bernardino de Siena surge registada no catálogo de Imagens e escultura com a datação do século XVII. Gomes, José Manuel (Coord.), Imagens e escultura. 1545-1995 Comemorações Jubilares dos 450 Anos da Diocese de Bragança - Miranda, Bragança, Departamento de Liturgia e Património Cultural da Diocese de Bragança - Miranda e Comissão de Arte Sacra, 1996, p. 20. No entanto, detalhes formais como o ondulado dos panejamentos e os olhos de vidro sugerem tratar-se de uma imagem já do século XVIII.

${ }^{117}$ A escultura de São Boaventura surge registada no catálogo de Imagens e escultura com a datação do século XVII. Gomes, José Manuel (Coord.), Imagens e escultura. 1545-1995 Comemorações Jubilares dos 450 Anos da Diocese de Bragança - Miranda, Bragança, Departamento de Liturgia e Património Cultural da Diocese de Bragança - Miranda e Comissão de Arte Sacra, 1996, p. 20. No entanto, detalhes formais como o ondulado dos panejamentos e os olhos de vidro sugerem tratar-se de uma imagem já do século XVIII. Na fotografia que consta no catálogo ainda é possível observar parte da mão direita, entretanto já desaparecida.
} 


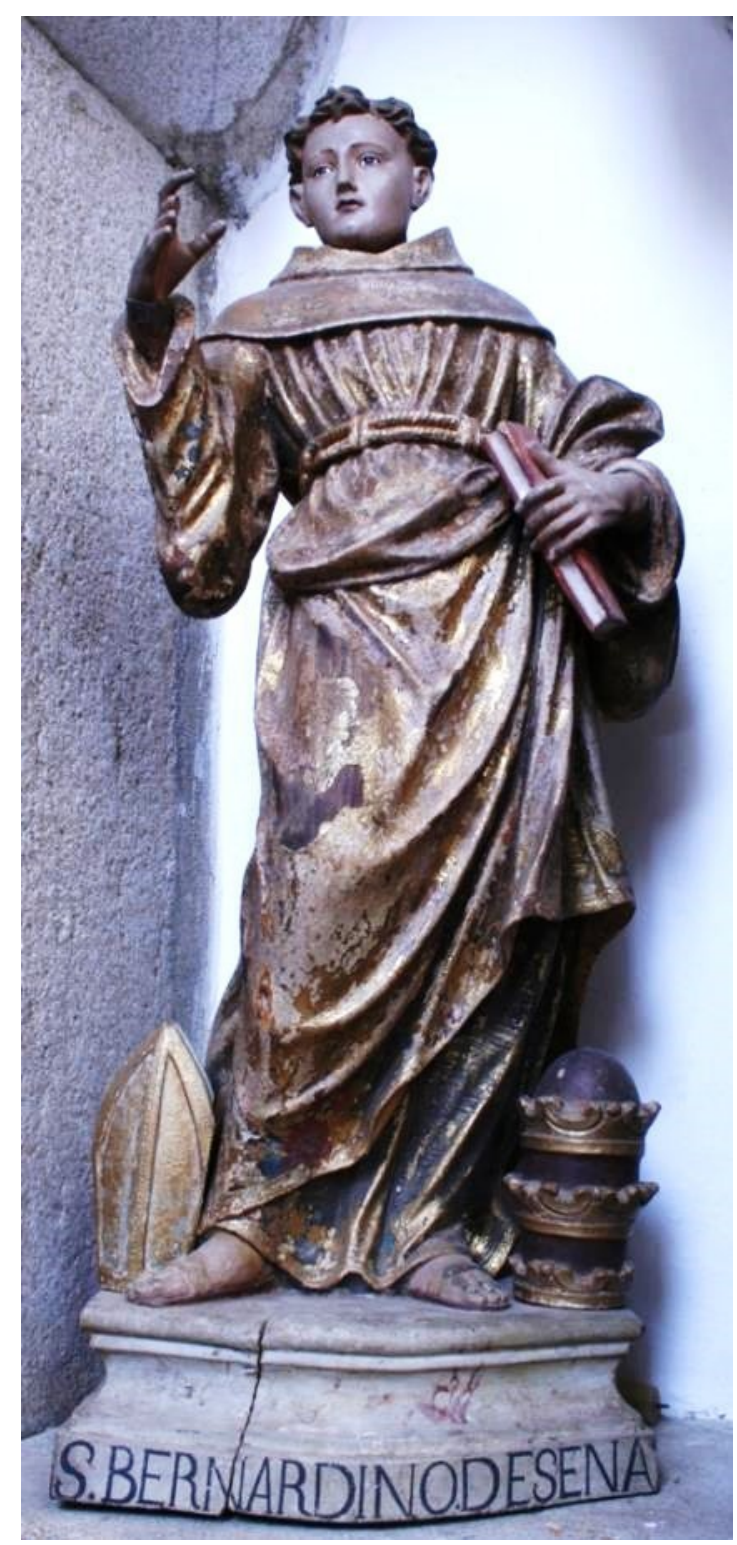

Imagem 48

Escultura de São Bernardino de SienaCSDV 01

Capela de Nossa Senhora das Dores, Igreja de Nossa Senhora da Encarnação, Vinhais

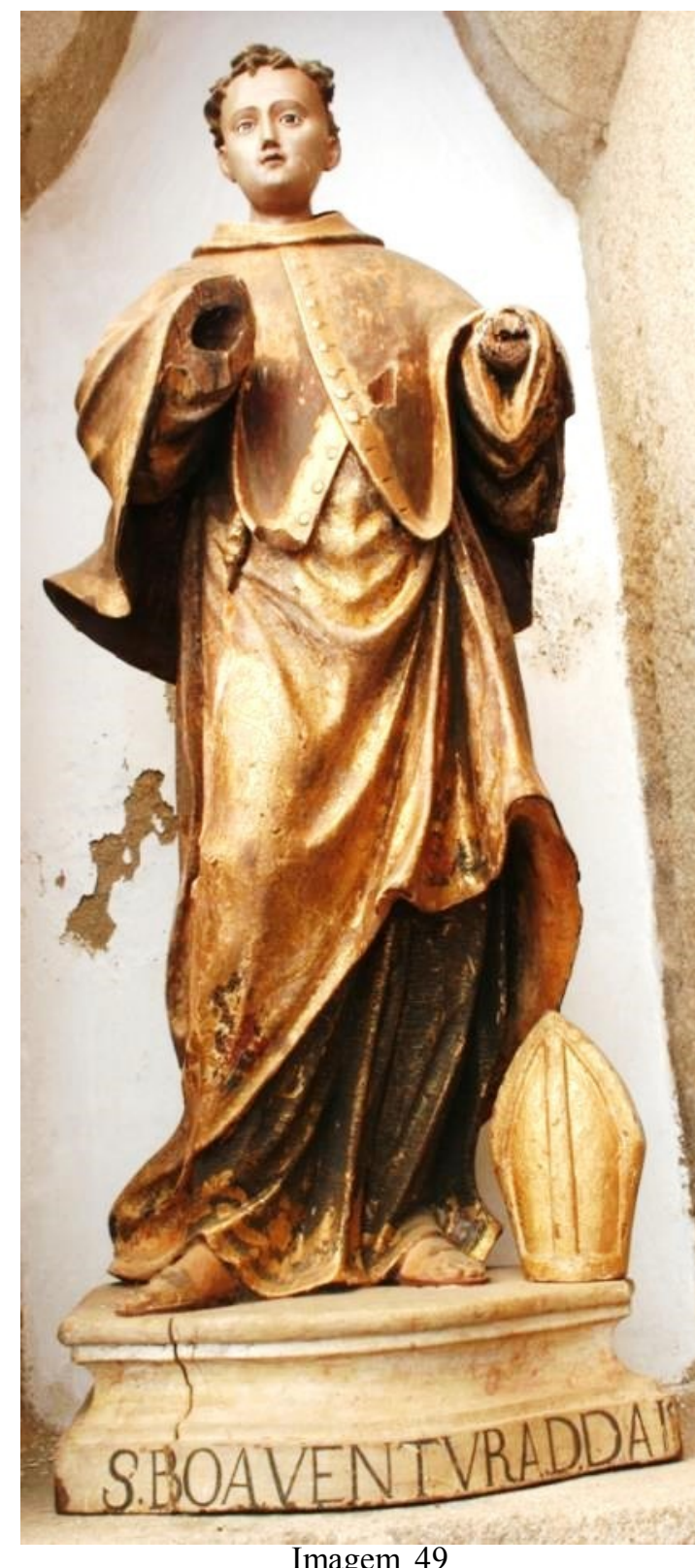

Escultura de São Boaventura CSDV 09

Capela de Nossa Senhora das Dores, Igreja de Nossa Senhora da Encarnação, Vinhais

Esta provável origem remete-nos para uma oficina de Lisboa, mais próxima da linguagem italianizante que emergia a partir do convento de Mafra.

Contemporaneamente parece-nos que existia em Vinhais, afeta ao seminário, um espaço de produção local de imaginária. Sobre esta "oficina" de escultura temos a referência de Frei Domingos que segundo Firmino Martins ${ }^{118}$ seria o escultor, entre

118 Como se percebe na imagem a escala da escultura do Senhor dos Perdidos é colossal, desproporcionada até em relação ao tamanho das restantes esculturas que atualmente o acompanham na representação do Calvário. Designada por Firmino Martins como Senhor do Côro (pela localização original da figura no coro alto da igreja) é atribuída pelo mesmo autor a Frei Domingos, frade da Ordem 
outras imagens, da figura do Cristo do Coro (Imagem 50), atualmente exposto na capela de Nossa Senhora das Dores. Acresce ainda, para consolidar esta hipótese de uma oficina de escultura no seminário de Vinhais, a referência que consta no inventário de 1834 a duas imagens em fase de produção (uma escultura sem estar encarnada e uma outra nova), ambas atualmente desaparecidas.

Huma imagem de vulto de pao preto de Nossa senhora da Conceição sem ainda estar encarnada avaliada em preço de oitocentos reis - $\$ 8000$

Huma imagem do menino Jesus nova em ponto grande com seu resplendor avaliada em preço de catorze mil reis $-14 \$ 000$

N.B. Estas imagens estavão na capela que chamavão de Noviciado $^{119}$.

As esculturas em fase de produção referidas neste registo não se encontram atualmente no interior dos espaços em culto, mas permitem perceber a efervescente e continuada pratica escultórica que decorreu no seminário ao longo dos cerca de 80 anos em que esteve em funcionamento. Não sabemos se as esculturas seriam da autoria de Frei Domingos se de algum discípulo que continuasse a sua obra. O nome de Frei Domingos surge também no registo de 1834 na referência aos 20 frades que habitavam o seminário. No entanto, não podemos afirmar tratar-se do mesmo Frei Domingos que Firmino Martins destaca como escultor do seminário. Mesmo sendo eventualmente o mesmo frade desconhecemos a sua proveniência, e mais importante ainda, a sua formação. Nos modelos que Frei Domingos criou parece influir a prática escultórica da escola de Toro, mais especificamente de António Tomé e das suas primeiras obras marcadas por um vincado arcaísmo preso ainda aos modelos do século XVII ${ }^{120}$. Mas a

Franciscana de missionários apostólicos de Vinhais. Martins, Firmino A., Subsídios para a história religiosa do distrito de Bragança: a Ordem III e a casa do Fundador do convento de S. Francisco de Vinhais, Coimbra, Imprensa da Universidade, 1929, p. 8.

A tradicional ideia, de que as obras eruditas eram sempre provenientes dos "grandes centros artísticos", e as obras das "oficinas regionalistas" eram "excessivamente populares", Serrão, Vítor M. G.V., et al. Museu de Arte Sacra de Macedo de Cavaleiros, Catálogo da Exposição, Macedo de Cavaleiros, Câmara Municipal de Macedo de Cavaleiros, 2009, pp. 17, 18, fica, perante a profícua produção que atribuímos a Frei Domingos, no âmbito das oficinas locais, num novo espaço de discussão.

119 A.N.T.T./A.H.M.F./S.N.S.E.V., Extinção das Ordens Religiosas - Seminário de Nossa Senhora da Encarnação - Vinhais, Arquivo Nacional da Torre do Tombo, Lisboa, Arquivo Histórico do Ministério das Finanças, Processos de Extinção das casas religiosas, Cx. 2265, 1834, s/fl.

${ }^{120}$ Sobre a escola de Toro e António Tomé (Toro, 1664-1730) ver: Navarro Talegón, José, Catálogo monumental de Toro y su alfoz, Zamora, Caja de Ahorros Provincial, 1980, pp. 86-199, 434-438; Navarro Talegón, José, Inventario y catálogo de bienes muebles de interés cultural propios del Excmo. Ayuntamiento de Toro, Asociación Cultural Musical Jesús López Cobos, EL CANTO DE LA MUSA, Revista Digital de Humanidades $n^{\circ} 1$, disponível em http://www.elcantodelamusa.com/num1.html, 2010, pp. 33,34 
única referência conhecida à data de Frei Domingos apenas nos permite, pelas analogias formais com a imagem do Cristo do Coro, perceber outras esculturas que se assemelham e que podem portanto compartir a mesma autoria.

Deste conjunto, que associamos à produção escultórica de Frei Domingos destacamos em primeiro lugar, a única escultura que efetivamente lhe é atribuída - a imagem do Cristo do Coro (Imagem 50, 51 e 52).

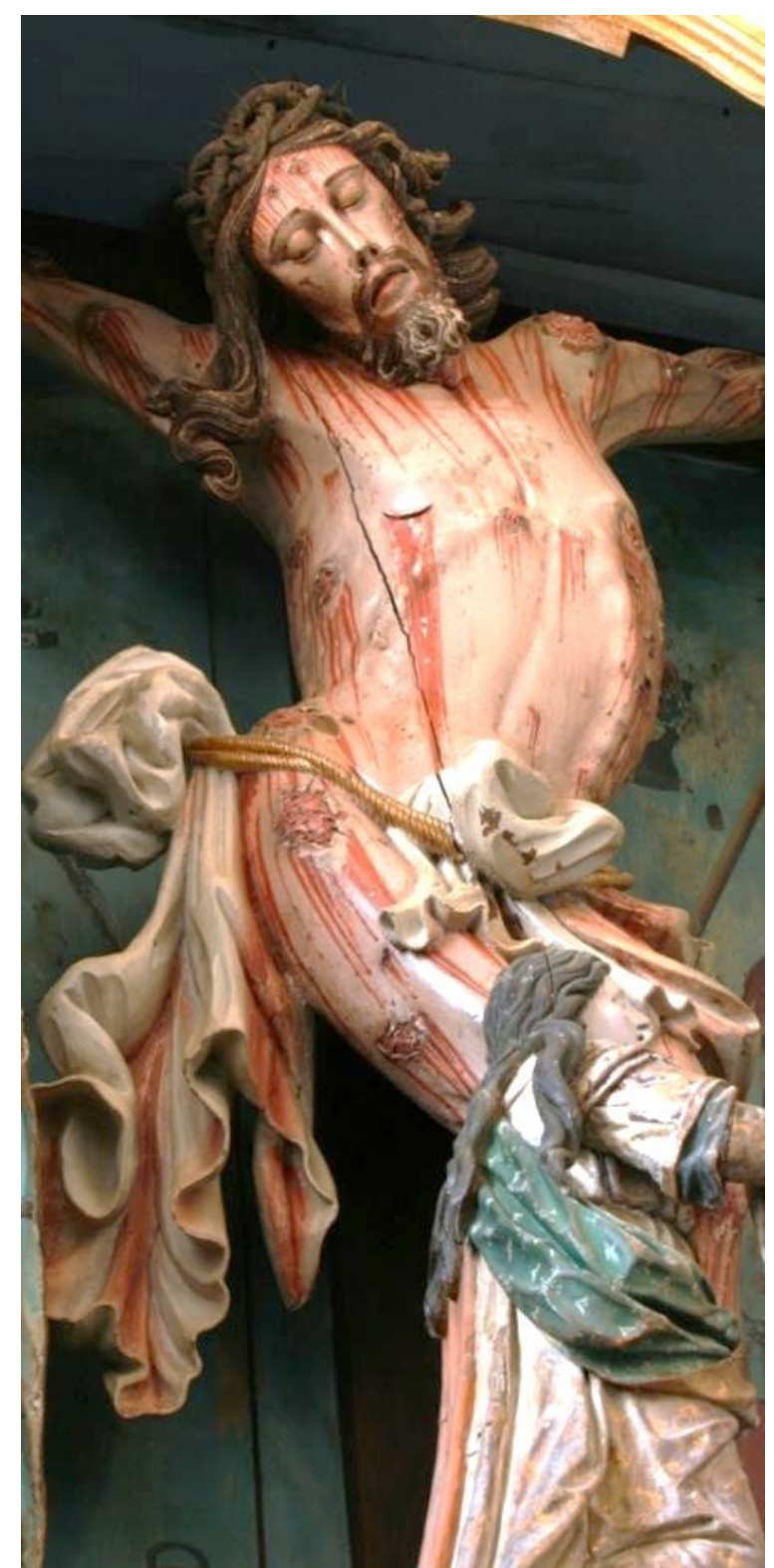

Imagem 50

Escultura de Cristo do Coro ou Bom Jesus dos Perdidos CSDV 06

Capela de Nossa Senhora das Dores, Igreja de Nossa Senhora da Encarnação, Vinhais
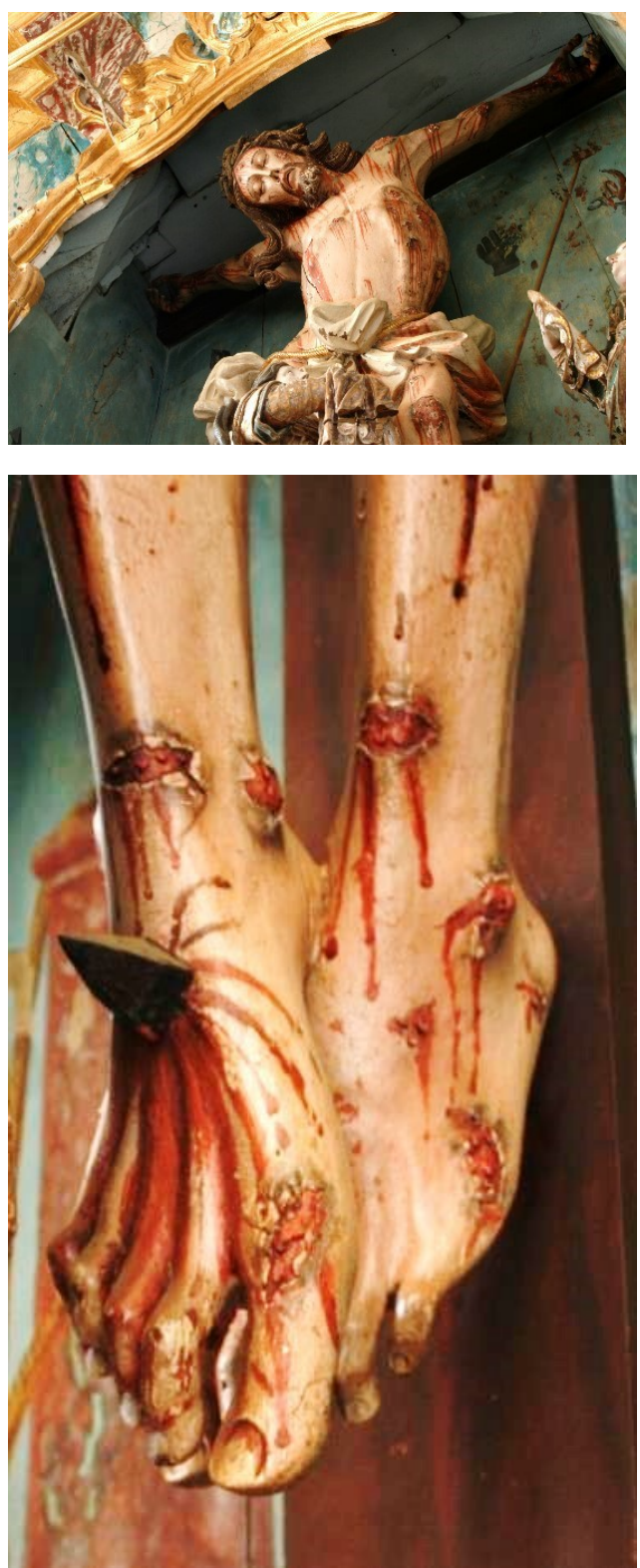

Imagem 51 e 52

Pormenor do rosto e pés da escultura de Cristo do Coro ou Bom Jesus dos Perdidos CSDV 06

Capela de Nossa Senhora das Dores, Igreja de Nossa Senhora da Encarnação, Vinhais 
É uma imagem de tamanho colossal, que pela atual exposição no retábulo da capela de Nossa senhora das Dores fica parcialmente encoberto pelas imagens que compõem o Calvário. A escultura sobressai não apenas no tamanho mas na expressividade da torção do corpo bem como na intensidade das marcas da tortura. $\mathrm{O}$ cendal que o cobre, muito ensanguentado, ondula amplamente em dinâmicas pregas. O dorso, intensamente torcido, reforça a linha curva do lado esquerdo do corpo, com evidência da estrutura óssea das costelas bem como do ombro esquerdo mais saliente. O dramático gesto do corpo é sublimado pelo peso da cabeça caída sobre o lado direito enfatizando na sinuosidade das linhas o sofrimento do corpo martirizado. A figura é detalhadamente trabalhada nos aspetos anatómicos executados com proporção e expressividade (Imagem 51 e 52). As marcas dos flagelos ultrapassam as mãos, os pés e o peito e estendem-se por todo o corpo em feridas abertas de onde escorrem abundantes gotas de sangue. O rosto magro e de linhas simétricas apresenta os olhos fechados e a boca entreaberta com os cantos dos lábios descaídos. As barbas estão talhadas em onduladas formas muito desenhadas, tal como os longos cabelos que caiem em madeixas sobre o lado direito.

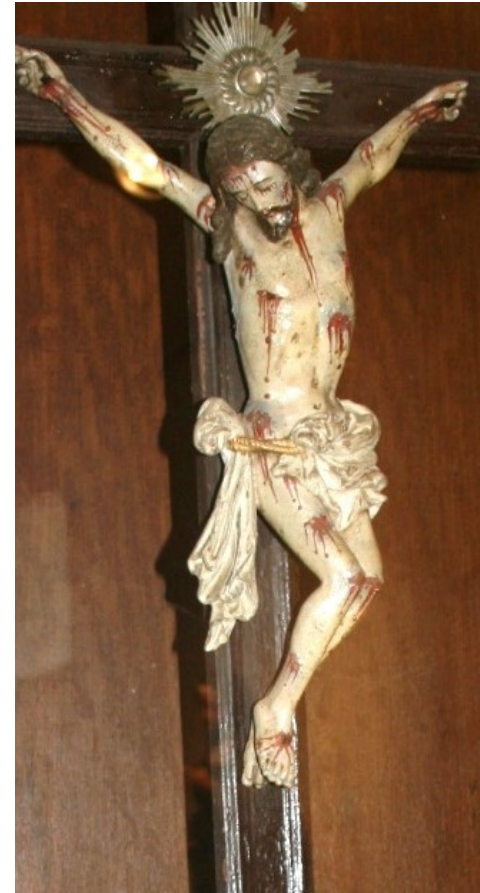

Imagem 53

Cruz de Altar que serviu de modelo para o Cristo do Coro MASV 07

Museu de Arte Sacra Vinhais

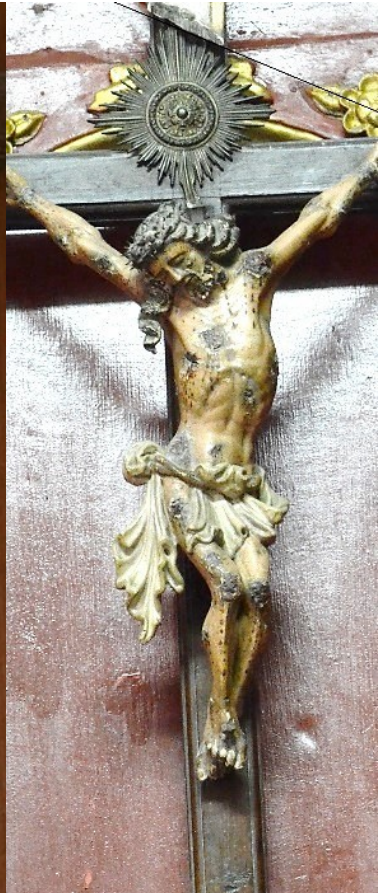

Imagem 54

Cruz de Altar que serviu de modelo para o Cristo do Coro - SIEV 05 Sacristia da Igreja de Nossa Senhora da

Encarnação, Vinhais

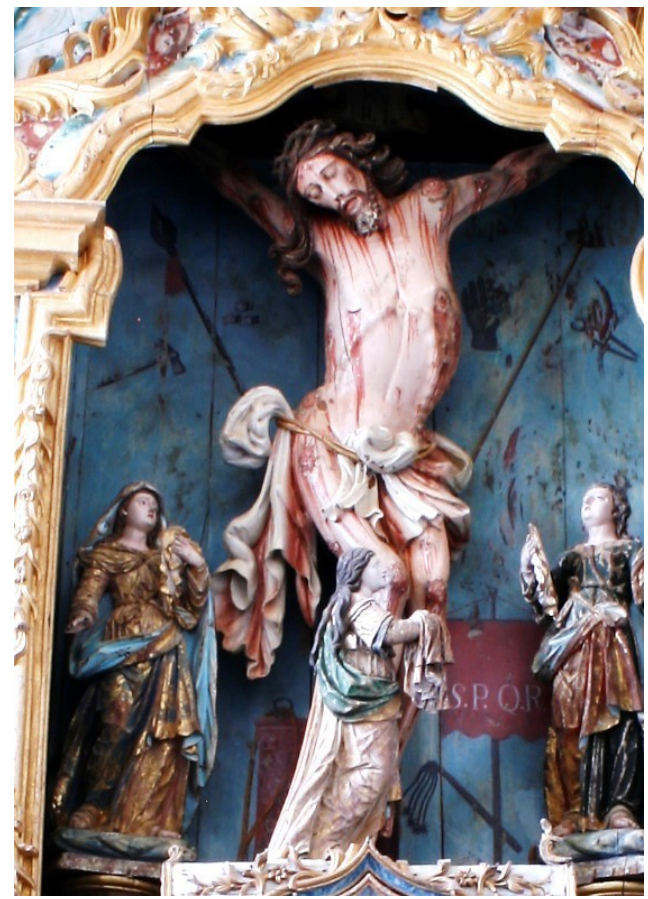

Imagem 55

Escultura de Cristo do Coro ou Bom Jesus dos Perdidos - CSDV 06

Capela de Nossa Senhora das Dores, Igreja de Nossa Senhora da Encarnação, Vinhais 
A intensidade do sentido dramático da obra não se repete em nenhuma das outras obras que supomos terem sido esculpidas por Frei Domingos, mas repetem-se detalhes escultóricos (anatomia do rosto, dos cabelos, expressão de dor). Este aspeto permite-nos pensar que a escultura de Cristo do Coro terá sido talhada numa fase já avançada do autor, talvez das suas últimas obras, dada a melhor conceção expressiva que sugere um melhor domínio das técnicas e materiais comparativamente às restantes esculturas que lhe atribuímos.

No contiguo Museu de Arte Sacra de Vinhais, estão expostas várias cruzes de altar coevas desta imagem de Cristo na Cruz, bem como no oratório da sacristia da igreja onde se expõe um outro Crucifixo. Chama a atenção as semelhanças observadas entre o Cristo do Coro e duas das cruzes de altar (Imagem 53 e 54) que julgamos que podem ter servido de modelo a Frei Domingos. Pese embora a maior expressividade do Cristo do Coro pela maior torção do corpo e exagero das marcas de martírio, é evidente, nos detalhes do cendal e do cordão que o cinge, na abertura dos braços e flexão das pernas, que os modelos que Frei Domingos superou na reprodução (Imagem 55) são a Cruz de Altar hoje exposta no Museu (Imagem 53) e a Cruz de Altar (Imagem 54) atualmente exposta no oratório da sacristia da igreja da Encarnação.

A imagem de Cristo do Coro estaria originalmente exposta sobre a balaustrada do coro alto da igreja de Nossa Senhora da Encarnação, como tema central da iconografia cristã esse era o lugar tradicional de exposição da imagem de Cristo na Cruz ${ }^{121}$. A escultura de Cristo estaria confrontada com o retábulo do altar-mor (Imagem 56) que ainda expõe a imagem de Nossa Senhora da Encarnação (Imagem 57).

${ }^{121}$ Réau, Louis, Iconografía del Arte Cristiano. Iconografia de la Biblia - Nuevo Testamento Tomo 1/ vol.2, Barcelona, Ediciones del Serbal, 1996 (Edição original 1955-1959), p. 494. Atualmente, uma outra representação de Cristo Crucificado, com produção já contemporânea atribuída ao século XX, ocupa o lugar onde outrora se expunha o Cristo do Coro. 


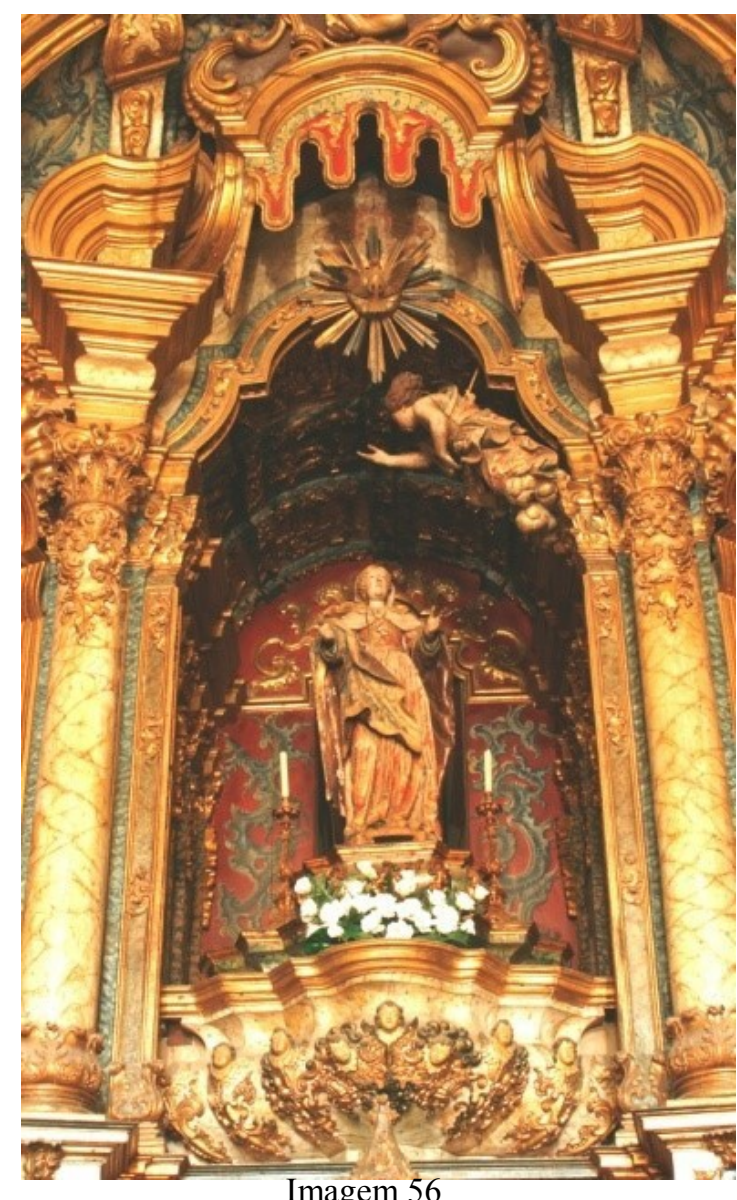

Imagem 56

Nicho central do retábulo do altar-mor com as esculturas de Nossa Senhora da Encarnação e o Anjo Gabriel

Igreja de Nossa Senhora da Encarnação, Vinhais

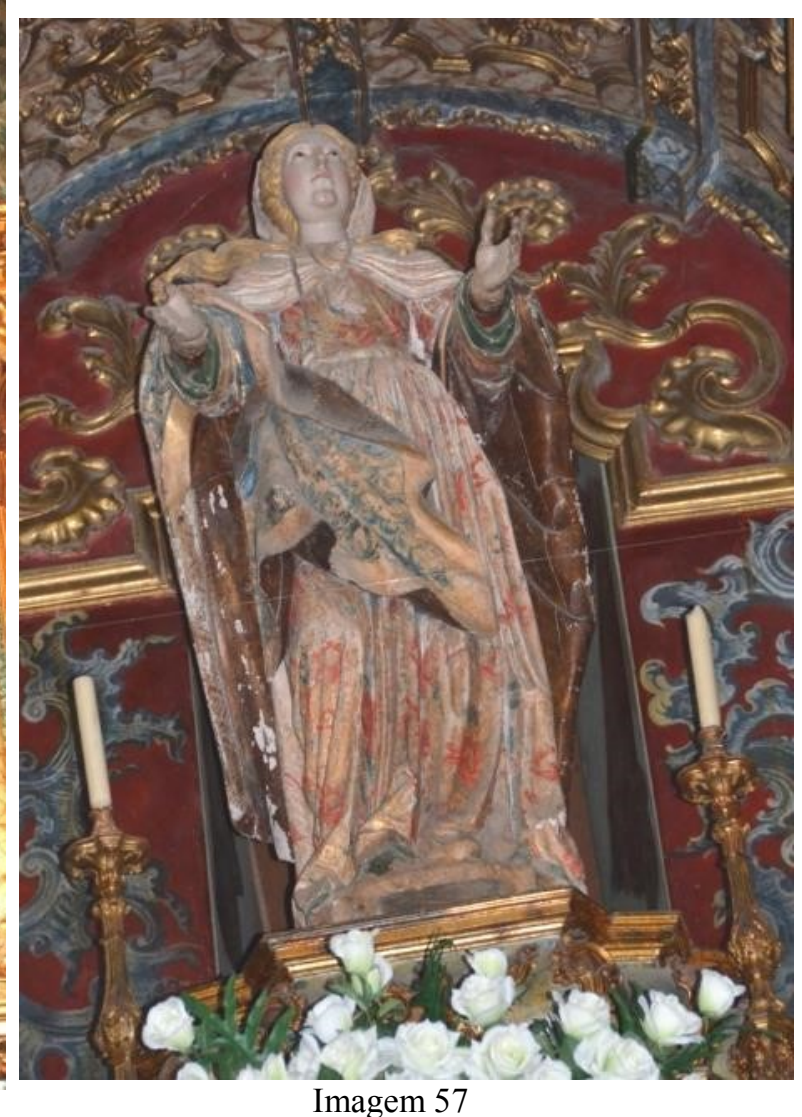

Escultura de Nossa Senhora da Encarnação IEV 06

Retábulo do altar-mor

Igreja de Nossa Senhora da Encarnação, Vinhais

A imagem também de tamanho colossal apresenta um rosto delicado nos arredondados contornos anatómicos ergue os olhos de vidro em direção ao Anjo Gabriel com uma expressão serena com a boca entreaberta num ligeiríssimo sorriso. Tem farta cabeleira loira esculpida na madeira em largas ondas que lhe envolvem o rosto e caiem dinamicamente sobre os ombros. É no tratamento das madeixas, com desenho muito vincado e ondas esvoaçantes que mais se aproxima a imagem de Nossa Senhora da Encarnação com a linguagem escultórica da figura de Cristo do Coro (Imagens $58 \mathrm{e}$ Imagem 60). Também nos contornos menos trabalhados das mãos, comparativamente a outros detalhes anatómicos, ambas as esculturas se parecem (Imagem 59 e 61). A escala é em ambas as esculturas colossal, atribuída pelo local que ocupavam no espaço devocional e apresentando um bom domínio formal da composição que assumiam perante o observador. 

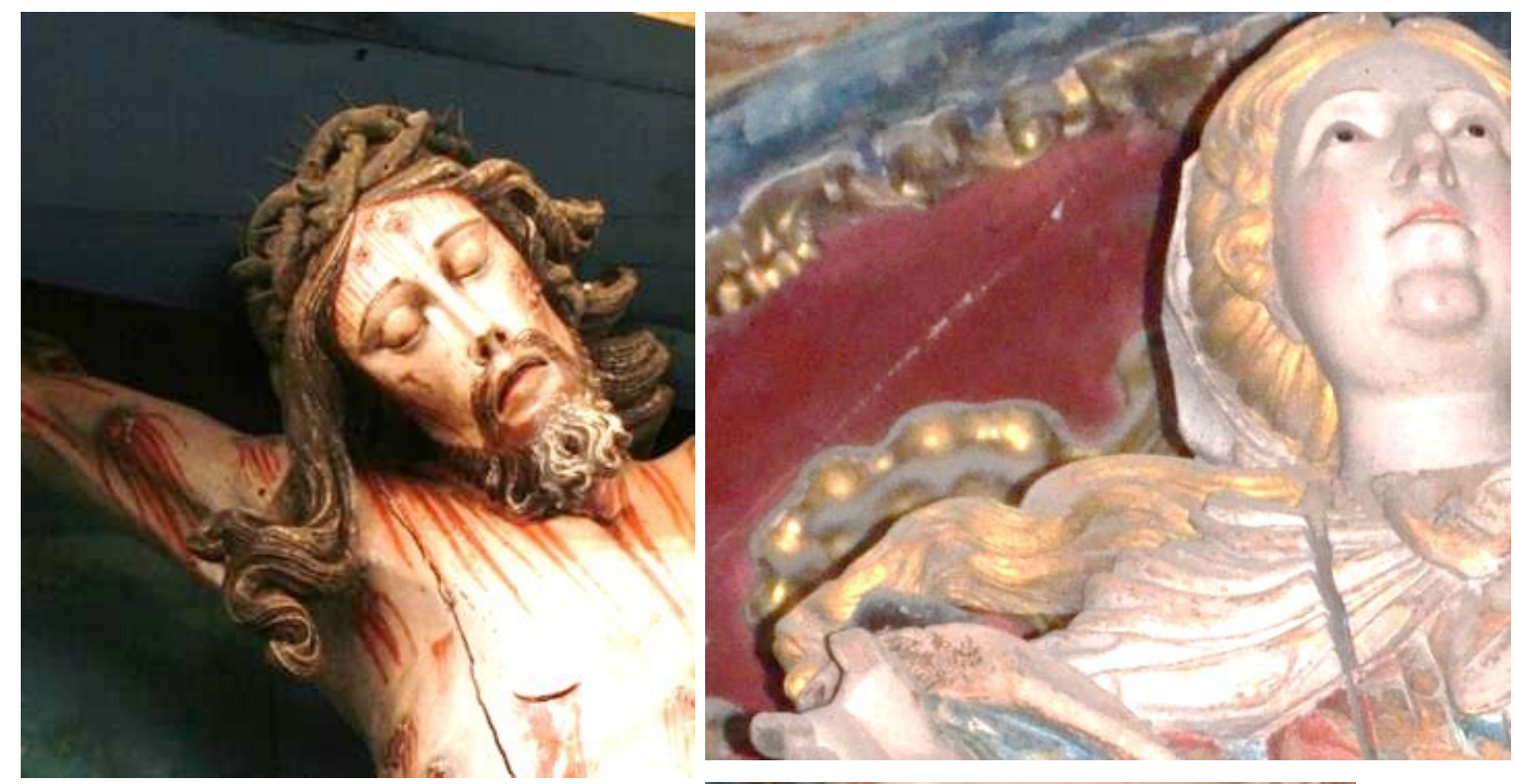

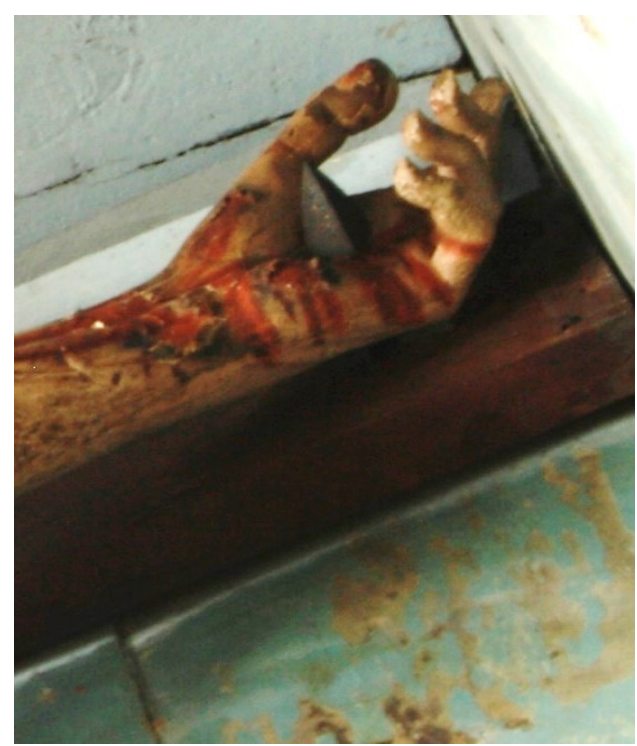

Imagem 58 e 59

Pormenor das madeixas de cabelo e das mãos da escultura de Bom Jesus dos Perdidos ou

Cristo do Coro CSDV 06

Capela de Nossa Senhora das Dores, Igreja de Nossa Senhora da Encarnação, Vinhais

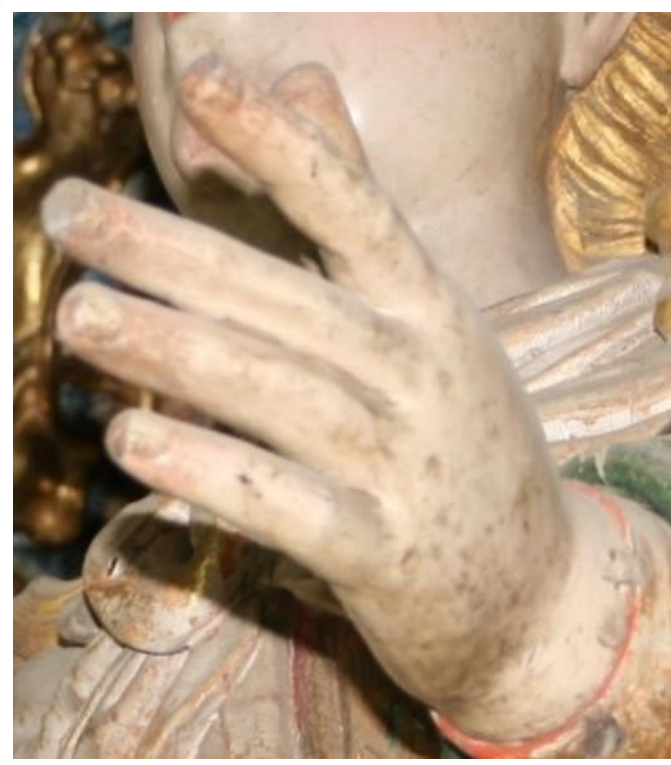

Imagem 60 e 61

Pormenor das madeixas de cabelo e das mãos da escultura de Nossa Senhora da Encarnação IEV 06

Retábulo do altar-mor

Igreja de Nossa Senhora da Encarnação, Vinhais

Do mesmo período e com analogias formais com as imagens de Cristo do Coro e de Nossa Senhora da Encarnação podemos ainda identificar as esculturas que representam São Domingos de Gusmão (Imagem 62) e São Francisco de Assis (Imagem 63). 


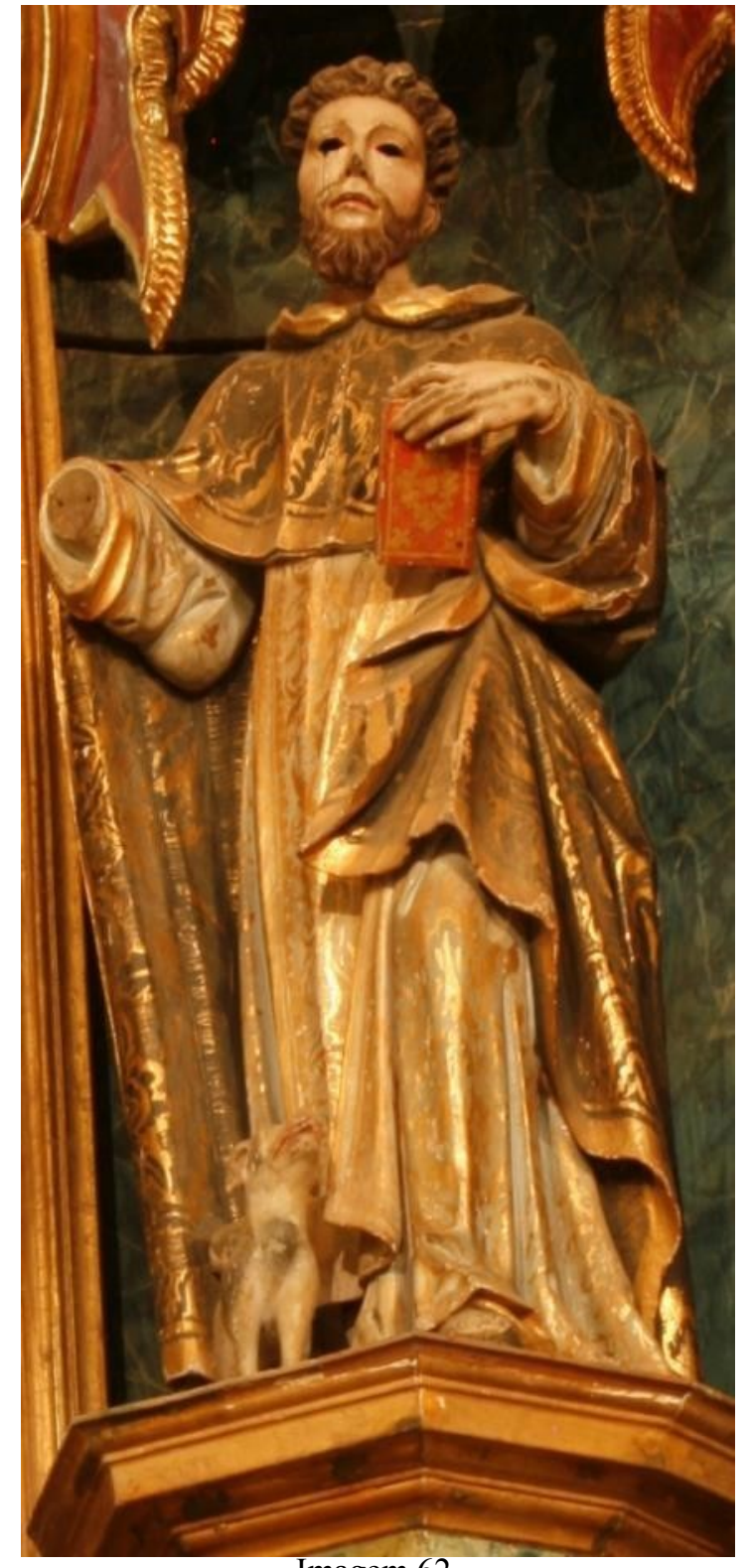

Imagem 62

Escultura de São Domingos de Gusmão IEV 05

Retábulo do altar-mor, lado da Epistola Igreja de Nossa Senhora da Encarnação, Vinhais

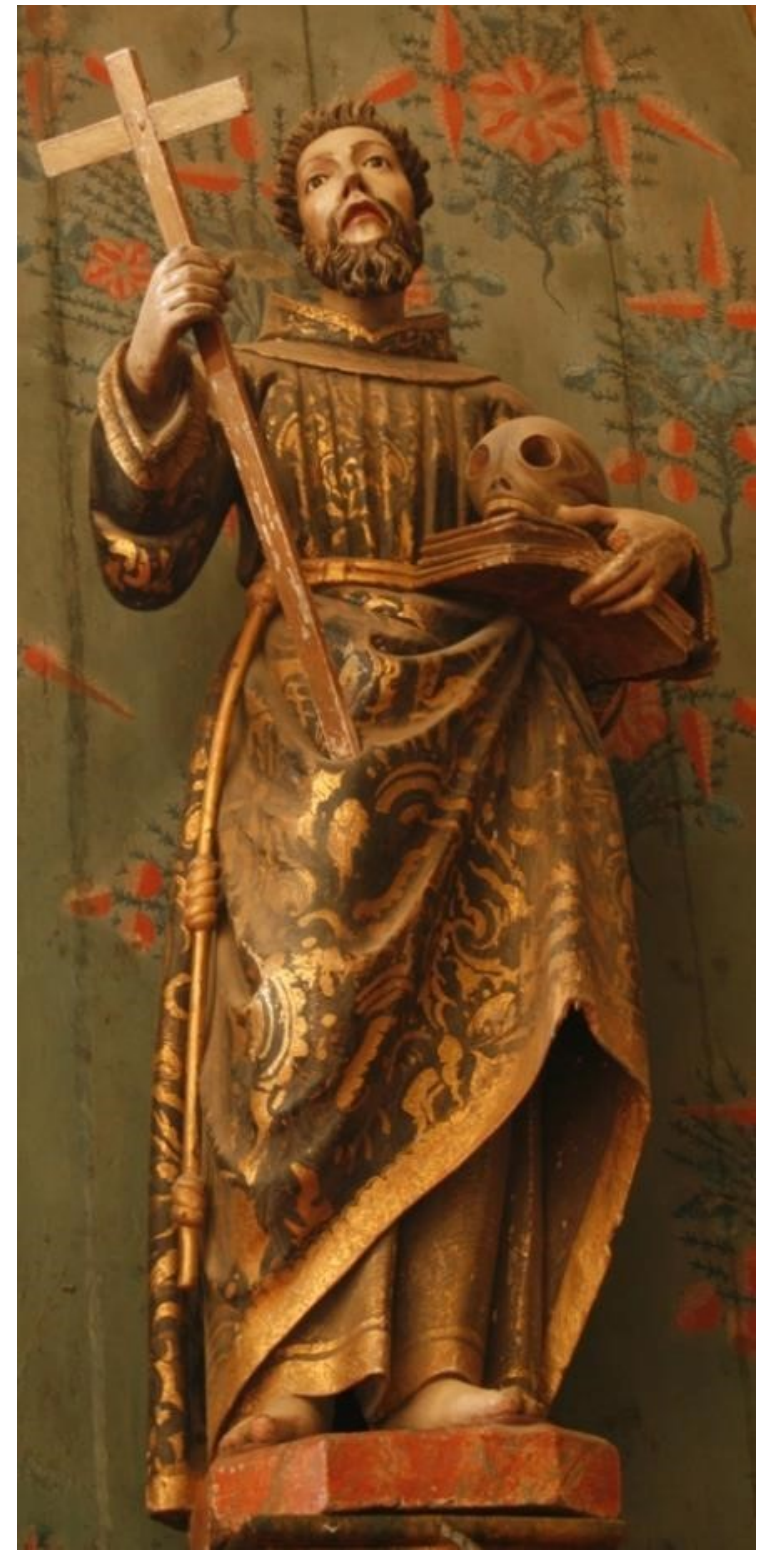

Imagem 63

Escultura de São Francisco de Assis IEV 09

Capela-mor no retábulo lateral do lado do Evangelho

Segundo o registo de 1834 estavam originalmente a ladear a imagem de Nossa Senhora da Encarnação no altar-mor.

As esculturas apresentam semelhanças nos contornos do rosto e na expressão teatral de dor com a boca entreaberta e os cantos dos lábios descaídos deixando a descoberto parte dos dentes.

O cuidado que é posto no tratamento das cabeças, dos ondulados vincos nas madeixas de cabelo e nas expressões do rosto parecem semelhantes. O desenho das 
barbas e dos cabelos, com vincos fundos e ondulação muito definida, é idêntico. A gestualidade das mãos e da postura evidenciam também a proximidade das obras. Assim como o detalhe do pregueado das mangas igual em ambas as esculturas que se apresenta mais volumoso sobre os cotovelos.

Com um trabalho escultórico muito próximo com as duas imagens de São Domingos e São Francisco é a imagem de Santo António com o Menino (Imagem 64). Porém, essa proximidade é sobretudo observável no tratamento do hábito que enverga com as pregas densas caindo em pesados vincos ondulantes e também no pormenor das mangas que se apresentam mais volumosas sobre os cotovelos. $\mathrm{Na}$ representação do Menino sustido por Santo António percebemos analogias com o Menino sustido por São José (IEV 04) bem como com os querubins que emergem na nuvem de Nossa Senhora da Imaculada Conceição (CSDV 07) aspeto que pensamos estar também relacionado com a produção de Frei Domingos ou da

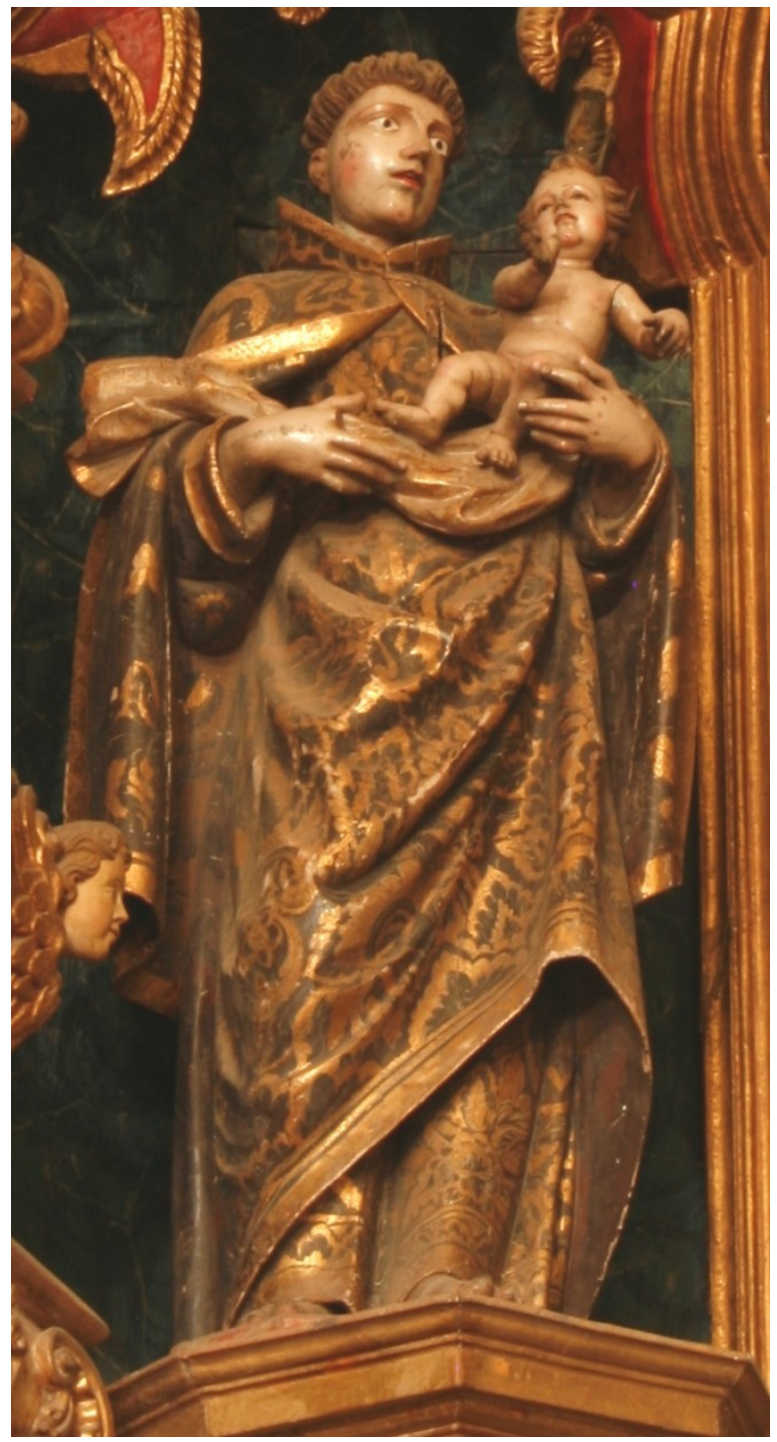

Imagem 64

Escultura de Santo António com o Menino IEV 08

Retábulo do altar-mor, lado do Evangelho Igreja de Nossa Senhora da Encarnação, Vinhais sua oficina, ou ainda com a produção retabular do templo.

O agressivo repinte do rosto de Santo António dificulta a leitura dos detalhes anatómicos, mas sugerem uma produção diversa da de São Domingos e São Francisco. Apesar das madeixas do cercilho serem semelhantes o rosto é mais oval, com contornos mais arredondados, aspetos que também se destacam nos contornos cuidados da anatomia do Menino. Esta disparidade entre o corpo e a cabeça podem denunciar distintas mãos na produção da obra. No entanto, julgamos ser coeva das esculturas de 
São Domingos e São Francisco e, se bem que, talvez apenas parcialmente, influenciada pela produção de Frei Domingos.

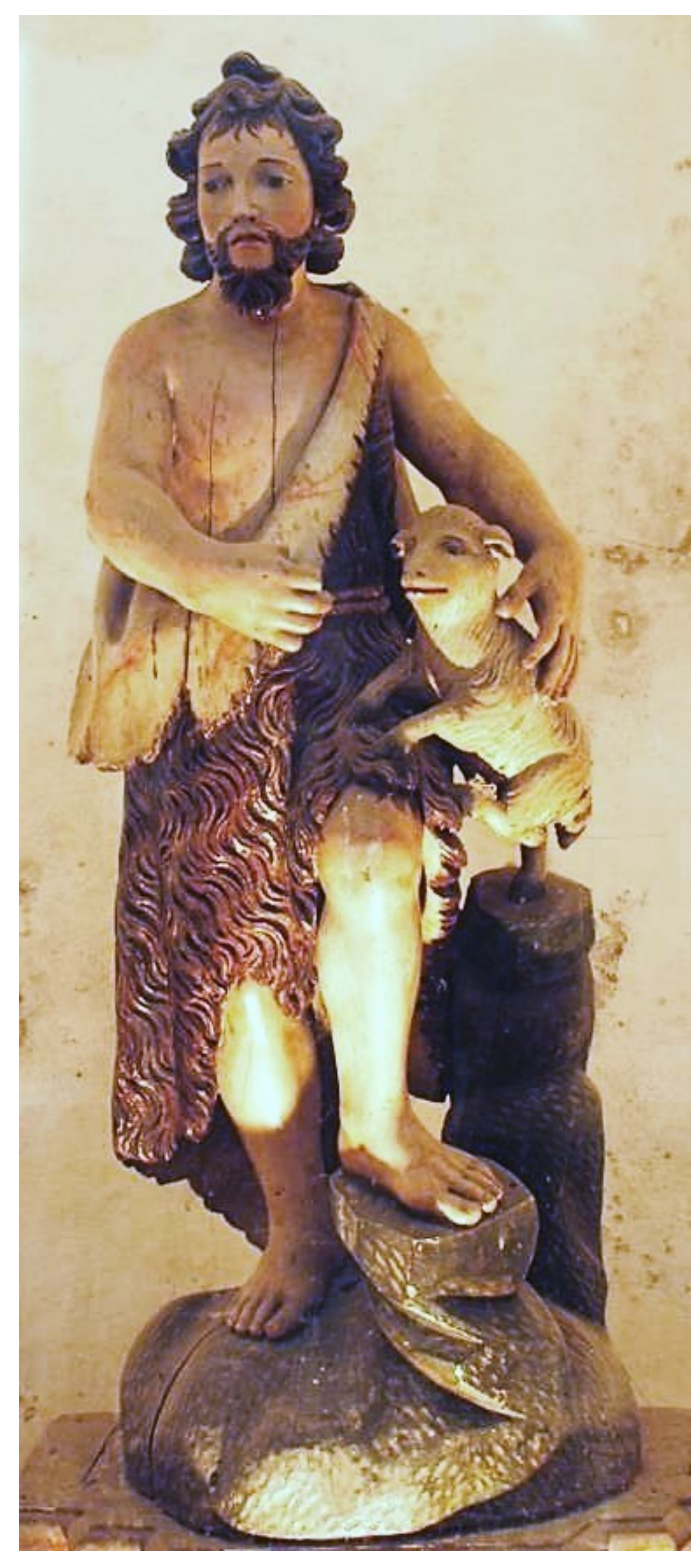

Imagem 65

Escultura de São João Batista, IEV 13

Colocada num nicho lateral do lado do Evangelho Igreja de Nossa Senhora da Encarnação, Vinhais
A possibilidade da presença do frade escultor no Seminário Apostólico de Vinhais não exclui a presença de outros escultores. Assim como as diferenças observáveis nas obras que relacionamos com a produção de Frei Domingos não excluem a alteração ou melhoria no domínio das técnicas por parte do escultor ao longo do tempo. A ausência de documentos exclui a afirmação perentória da autoria. A comparação formal apenas nos permite perceber as proximidades técnicas ou as proximidades do gosto dos encomendadores.

A correspondência formal com a produção de Frei Domingos observa-se também na imagem que representa São João Batista ${ }^{122}$ (Imagem 65). A escultura porém mostra algumas irregularidades na anatomia, decorrentes de um trabalho ainda pouco definido, muito afastado dos expressivos detalhes anatómicos observáveis na figura de Cristo do Coro.

O gesto e a pose com um pé apoiado sobre um degrau sugerem modelos menos dinâmicos que o corpo tosco e pesado

\footnotetext{
${ }^{122}$ A escultura de São João Baptista surge registada no catálogo de Imagens e escultura com a datação do século XVII. Gomes, José Manuel (Coord.), Imagens e escultura. 1545-1995 Comemorações Jubilares dos 450 Anos da Diocese de Bragança - Miranda, Bragança, Departamento de Liturgia e Património Cultural da Diocese de Bragança - Miranda e Comissão de Arte Sacra, 1996, p. 18. No entanto, apesar do arcaísmo do gesto julgamos tratar-se de uma imagem já do século XVIII.
} 
intensifica. A ausência de olhos de vidro parece também denotar um menor conforto em técnicas mais apuradas de produção escultórica. Mas são evidentes as semelhanças no desenho das barbas e no detalhe dos vincos representativo das madeixas, e das peles que o cobrem. O ondulado muito volumoso da madeixa sobre a cabeça evoca o aspeto de algumas esculturas anteriores ao século XVIII.

Estes elementos arcaizantes permitem-nos pensar que, de todo o núcleo que apresenta semelhanças com a autoria de escultura de Cristo do Coro, a imagem que representa São João Batista poderá ser das primeiras obras de Frei Domingos, na medida em que é a imagem que se apresenta formalmente mais sumária. Não se exclui a possibilidade de partilhar a autoria com a imagem de Cristo do Coro, mas possivelmente corresponde a uma fase inicial de formação do escultor, com menor domínio das técnicas e do desenho da obra.

Ainda próxima formalmente destas imagens encontramos na sacristia da igreja do Seminário de Nossa Senhora da Encarnação, esculpida numa escala mais pequena,

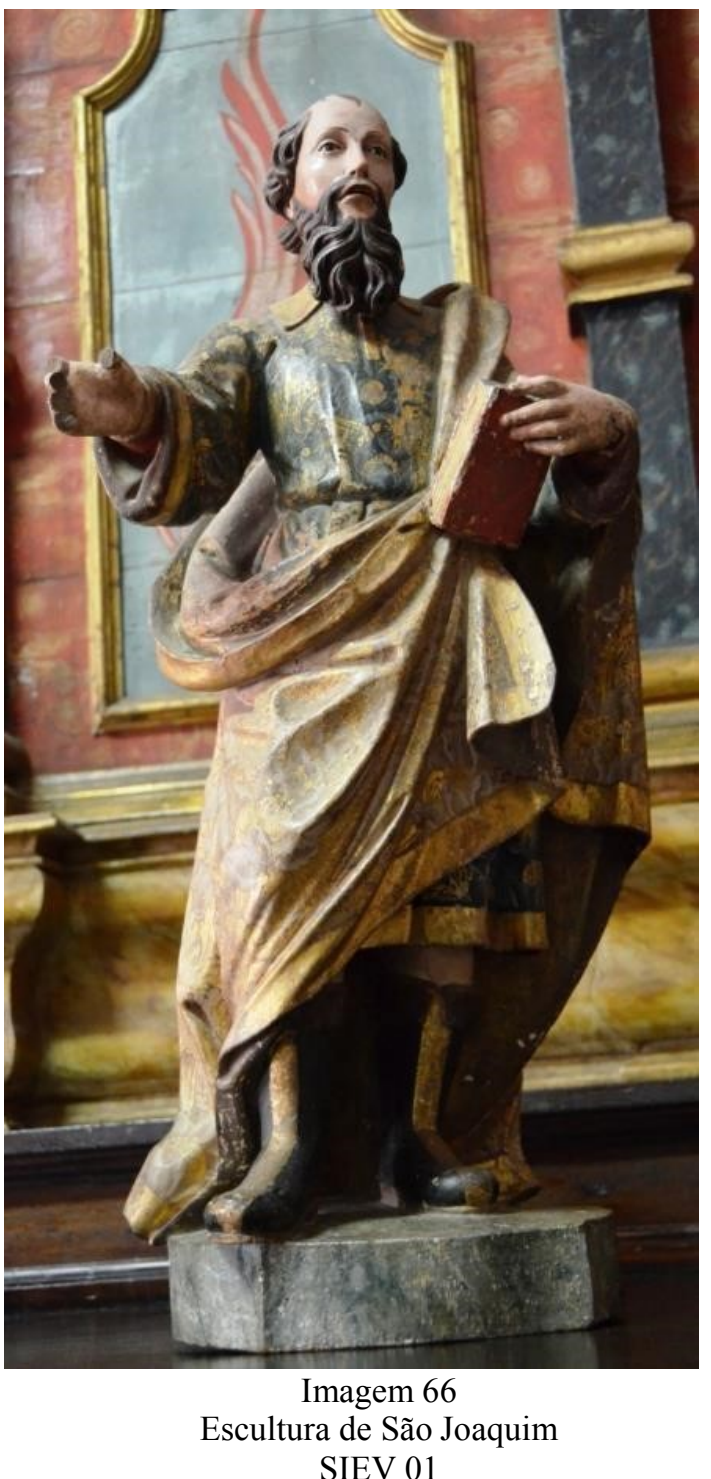

Colocada sobre o arcaz da sacristia da Igreja de Nossa Senhora da Encarnação, Vinhais

a escultura que representa São Joaquim (Imagem 66).

É nos detalhes das madeixas do cabelos e nos vincos ondulados e simétricos das barbas que a imagem de São Joaquim apresenta semelhanças com as imagens de São Francisco de Assis e de São Domingos de Gusmão. Também na expressão do rosto, nos olhos de vidro, na boca entreaberta com os cantos dos lábios descaídos, e no gesto da mão que segura o livro as esculturas são idênticas. 


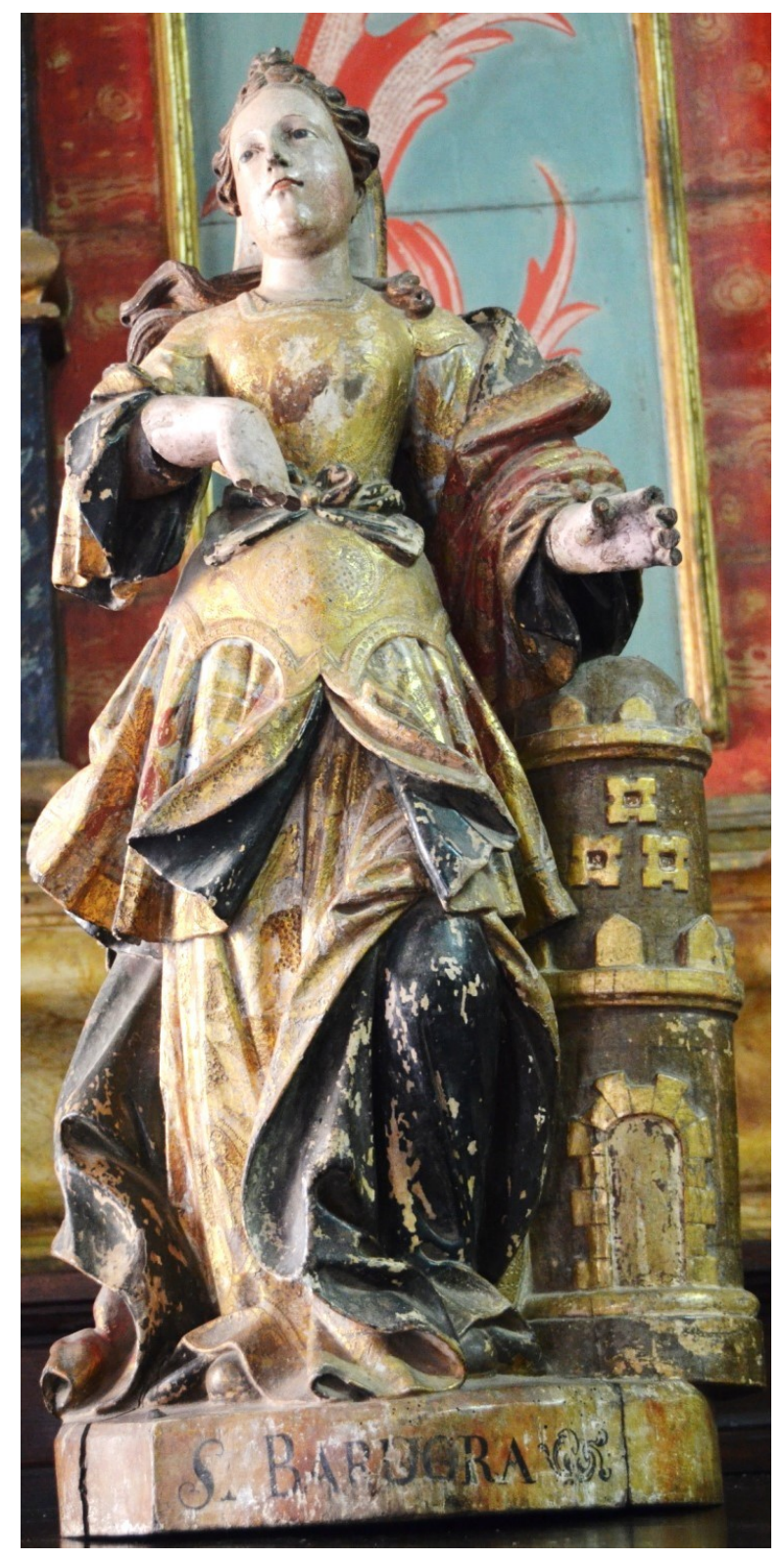

Imagem 67

Escultura de Santa Bárbara

SIEV 06

Sacristia da Igreja de Nossa Senhora da Encarnação, Vinhais

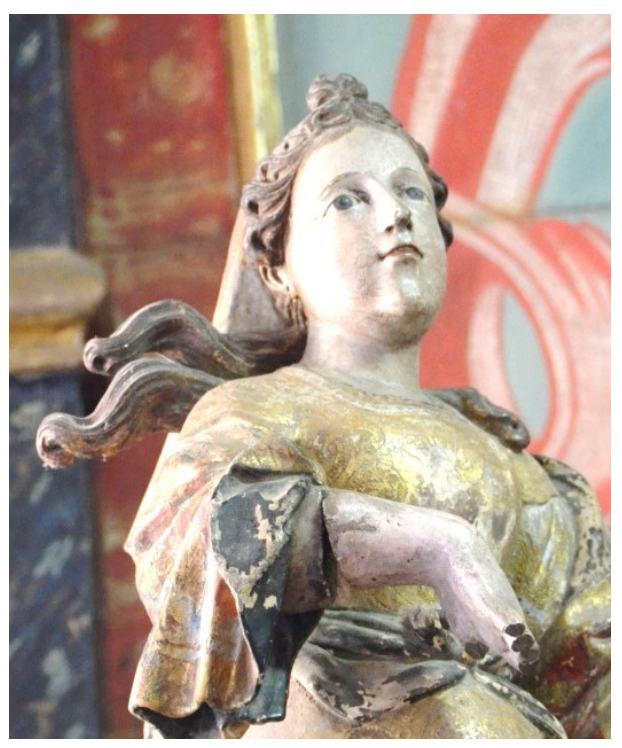

Imagem 68

Pormenor do rosto de Santa Bárbara SIEV 06,

\section{Sacristia da}

Igreja de Nossa Senhora da Encarnação, Vinhais

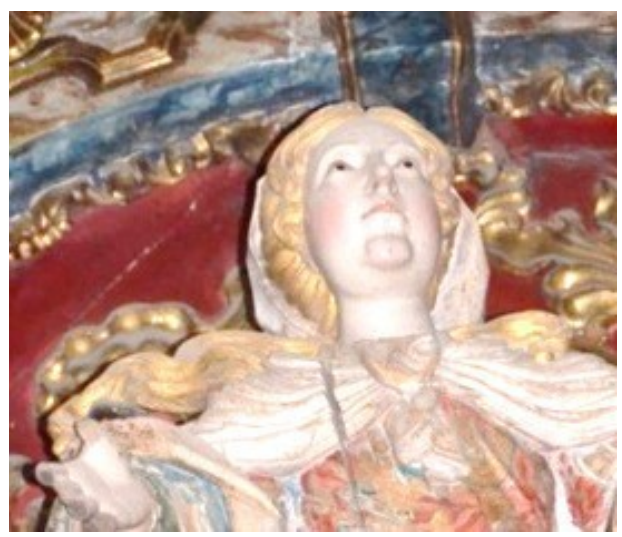

Imagem 69

Pormenor do rosto de Nossa Senhora da Encarnação - IEV 06

Igreja de Nossa Senhora da Encarnação, Vinhais

\section{Ainda na senda da produção com proximidades ao Cristo do Coro de Frei Domingos}

parece-nos a escultura de Santa Bárbara ${ }^{123}$ (Imagem 67), atualmente guardada na

${ }^{123}$ A escultura de Santa Bárbara surge registada no catálogo de Imagens e escultura com a datação do século XVII. Gomes, José Manuel (Coord.), Imagens e escultura. 1545-1995 Comemorações Jubilares dos 450 Anos da Diocese de Bragança - Miranda, Bragança, Departamento de Liturgia e Património Cultural da Diocese de Bragança - Miranda e Comissão de Arte Sacra, 1996, p. 19. No entanto, detalhes como o ondulado dos panejamentos e os olhos de vidro sugerem tratar-se de uma imagem já do século XVIII. Na fotografia que consta no catálogo ainda é possível observar a palma que a figura segurava na mão direita, entretanto já desaparecida. 
sacristia. O rosto oval feminino, de contornos arredondados, o queixo, a boca e o ondulado das madeixas de cabelo são muito semelhantes com a imagem que representa Nossa Senhora da Encarnação (conforme imagem 68 e 69).

Estas características formais ainda se repetem em mais dois espaços do Seminário Apostólico de Vinhais, mas nestes exemplos a imaginária é integralmente modelada em barro.

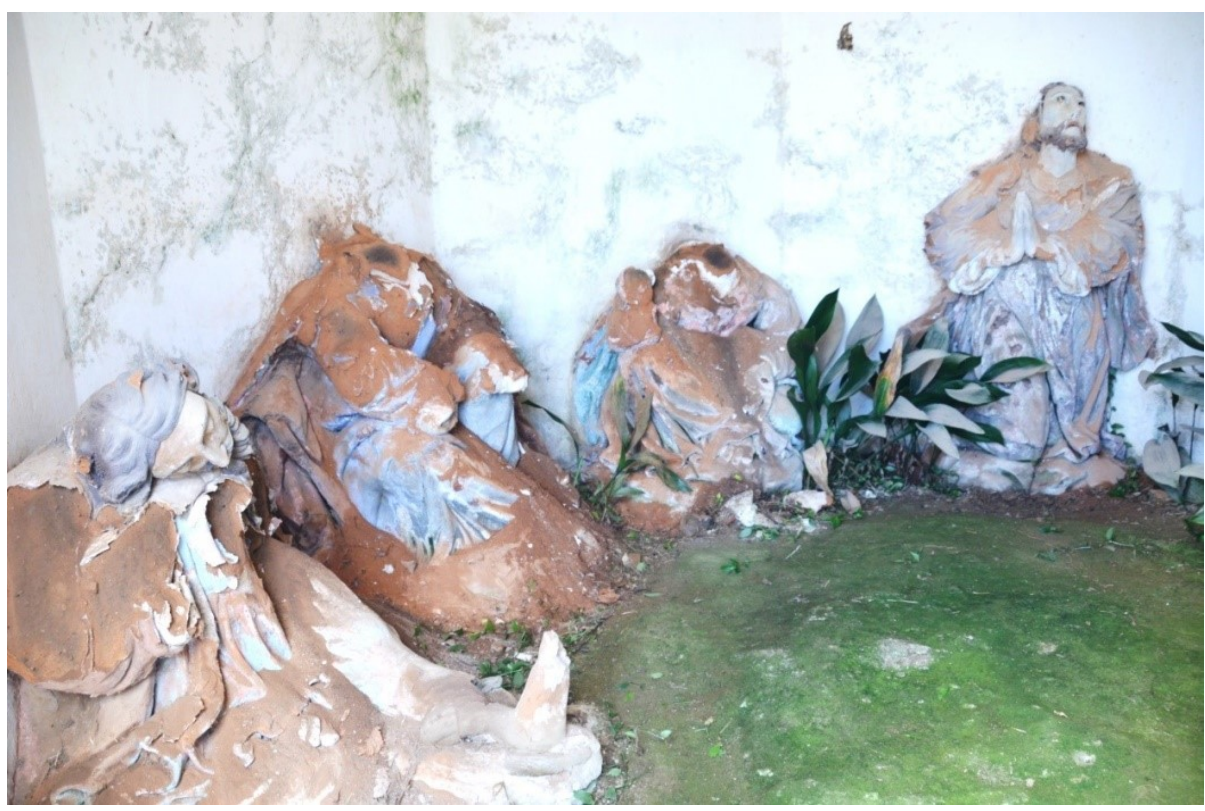

Imagem 70

Escultura de

Cristo e

Apóstolos

(Fragmentos)

COHV 02;

COHV 03;

COHV 04;

COHV 05

Capela da Oração no horto, adro da

Igreja da

Encarnação,

Vinhais

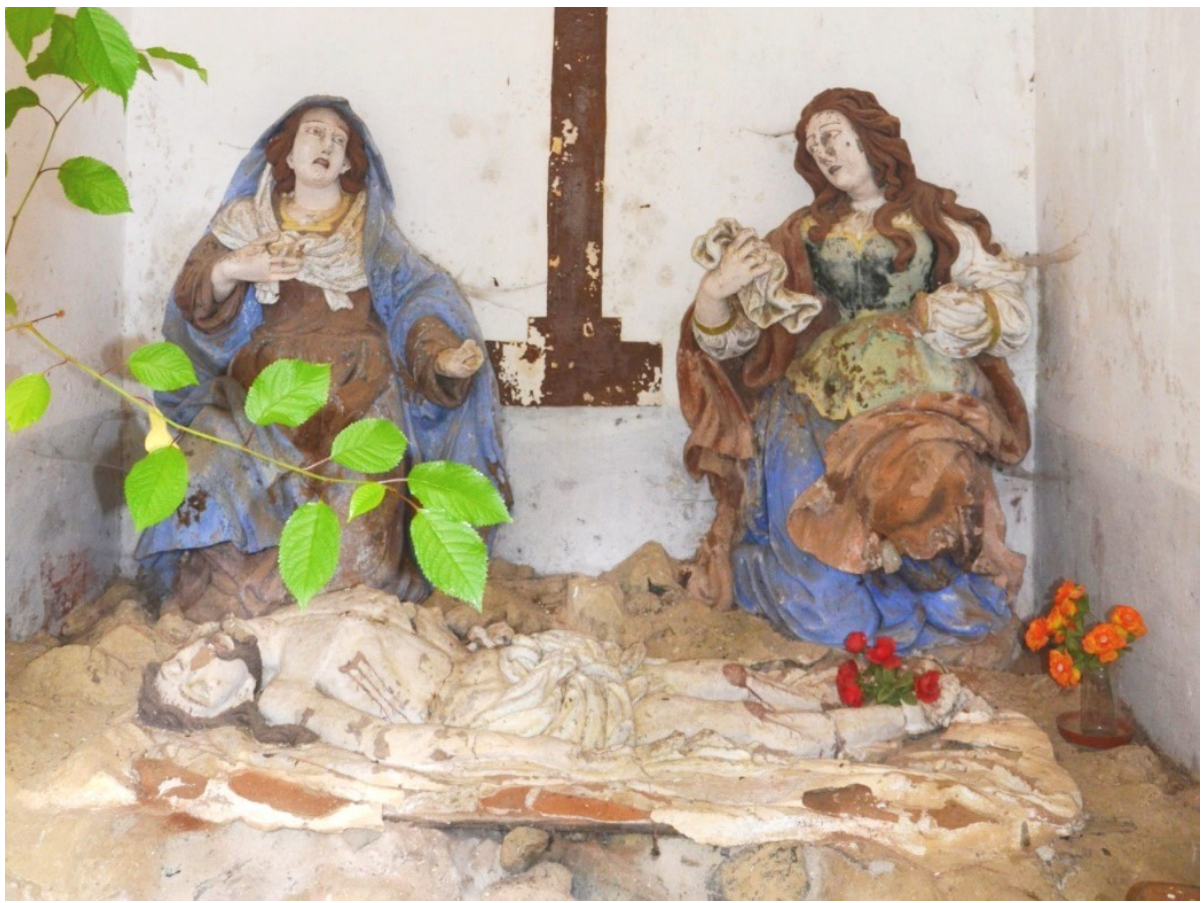

Imagem 71

Escultura de

Cristo morto com

A Virgem Maria e Maria Madalena (muito

deterioradas)

CSMV 01;

CSMV 02;

CSMV 03

Capela do Senhor do Monte, dentro da cerca do Seminário na área de pomar.

Vinhais

O barro, terracota ou mesmo a cerâmica vidrada é inusual na produção escultórica dos espaços em estudo. Igual acontece se ampliamos a observação aos restantes espaços 
religiosos do território onde são sempre escassas as esculturas de barro em detrimento da imaginária em madeira.

O barro dos dois conjuntos escultóricos está em degradação ativa, restando apenas fragmentos da maioria das figuras. Mas, ainda se mantêm os restos em duas capelas, uma em frente ao frontispício do seminário e a outra capela mais afastada do conjunto edificado dentro do pomar que ocupa a parte Sul da cerca do Seminário.

As capelas pretenderiam talvez ilustrar todos os passos da Paixão, mas apenas duas foram construídas e narram dois episódios: a Oração no Horto (Imagem 70) e Cristo Morto com Nossa Senhora e Maria Madalena (Imagem 71).

Atualmente são património da Diocese de Bragança-Miranda e mantidas pela Ordem Terceira de Vinhais. Desconhecemos a origem da encomenda da obra, podendo ter sido encomendada pela Ordem Terceira, se bem que, dadas as proximidades formais com as obras de Frei Domingos parecem tratar-se de produções dos frades missionários do Seminário em cujos terrenos estão implantadas, apesar de não terem sido registadas no inventário de 1834.

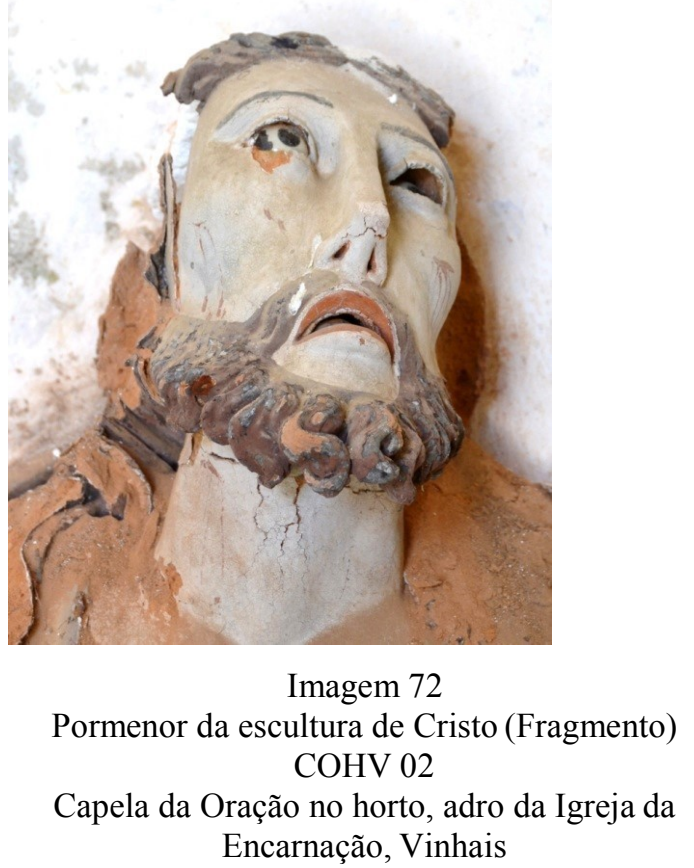

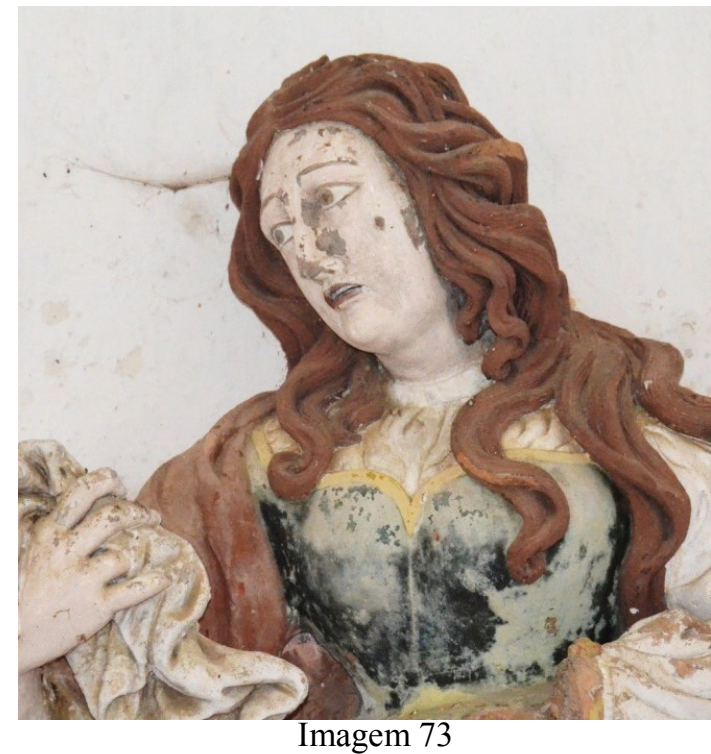

Pormenor da escultura Maria Madalena (muito deterioradas) CSMV 02

Capela do Senhor do Monte, dentro da cerca do Seminário na área de pomar. Vinhais

As esculturas estão todas apenas trabalhadas em $3 / 4$ do vulto constituindo a parte posterior o suporte que as firma nas paredes ou no solo homogeneizando-se o barro com o suporte. Este aspeto sugere que foram moldadas no local. A dificuldade de transportar 
uma obra de barro destas dimensões também aconselha a produção local. Mas é a observação dos detalhes da anatomia, dos lábios amplos com os cantos descaídos (Imagem 72) e as vincadas e onduladas madeixas esvoaçantes (Imagem 73), que vincula as obras com a produção de Frei Domingos.

A quantidade de obras que se assemelham com a única escultura para a qual existe a referência da autoria de Frei Domingos sugere que ele trabalhou durante muitos anos em Vinhais e certamente teve ajudantes ou alunos, que colaboravam elou continuaram a sua obra. Neste sentido apontam as imagens registadas em 1834 ainda em fase de produção escultórica, mas sobretudo a persistência dos mesmos modelos de anatomia, de expressão e gesto.

Além das esculturas que ainda hoje se podem contemplar no interior dos espaços do Seminário Apostólico de Vinhais, existe no catálogo de escultura das comemorações dos 450 anos da Diocese uma imagem de Cristo Ressuscitado $^{125}$ (Imagem 74), que também surge referido no inventário de 1834.

No entanto, atualmente essa imagem já não consta no interior do templo, estando em parte desconhecida. Partindo da fotografia do catálogo é possível identificar o modelo escultórico de Frei Domingos, nos panejamentos, no gesto e nos detalhes das barbas e cabelos.

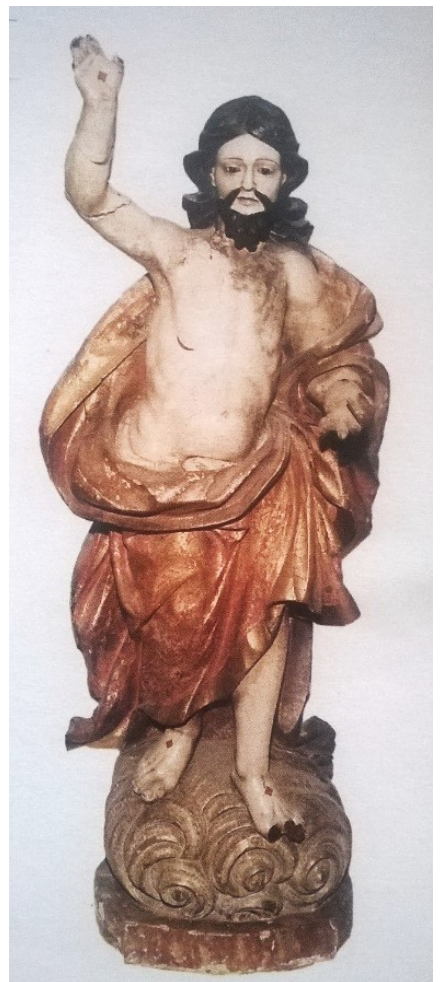

Imagem 74

Escultura de Cristo Ressuscitado (atualmente desaparecida) fotografia: Carlos Fotografo $^{124}$

\footnotetext{
${ }^{124}$ Imagem retirada do catálogo: Imagens e Esculturas - Comemorações Jubilares dos 450 anos da Diocese de Bragança - Miranda. Gomes, José Manuel (Coord.), Imagens e escultura. 1545-1995 Comemorações Jubilares dos 450 Anos da Diocese de Bragança - Miranda, Bragança, Departamento de Liturgia e Património Cultural da Diocese de Bragança - Miranda e Comissão de Arte Sacra, 1996, p. 19.

${ }^{125}$ A escultura de Cristo Ressuscitado surge registada no catálogo de Imagens e escultura com a datação do século XVII. Gomes, José Manuel (Coord.), Imagens e escultura. 1545-1995 Comemorações Jubilares dos 450 Anos da Diocese de Bragança - Miranda, Bragança, Departamento de Liturgia e Património Cultural da Diocese de Bragança - Miranda e Comissão de Arte Sacra, 1996, p. 19. No entanto, detalhes como o ondulado dos panejamentos sugerem tratar-se de uma imagem já do século XVIII.
} 
O gosto pelos panejamentos exageradamente trabalhados sempre numa sucessão de camadas que terminam numa ampla capa traçada sobre a cintura é evidente em várias esculturas que no Seminário Apostólico de Vinhais ainda podemos identificar com a produção da segunda metade do século XVIII.

Não descuramos a produção plural com diversos intervenientes para as diversas formas e técnicas aplicadas consoante os virtuosismos de cada autor. A possibilidade da existência de uma oficina insinuada pela ampla produção que relacionamos com a figura

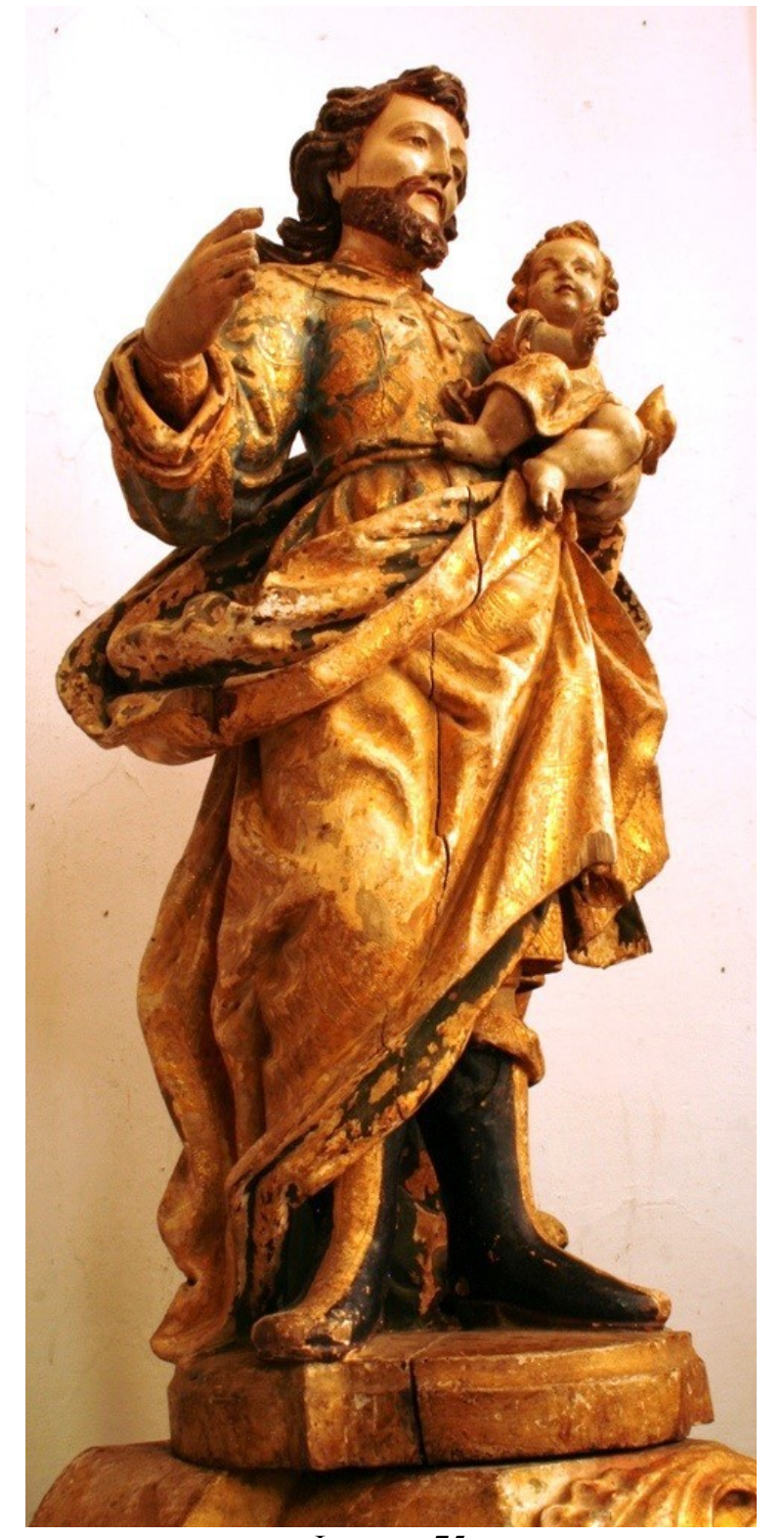

Imagem 75

Escultura de São José com o Menino IEV 04

Colocada num nicho lateral do lado da Epistola dentro da Capela-mor

Igreja de Nossa Senhora da Encarnação, Vinhais de Frei Domingos sugere precisamente essa pluralidade de autores num mesmo espaço de trabalho. Além dos possíveis discípulos e colaboradores a presença de mais autores na escultura deve também relacionarse com a produção retabular que ocupa ainda hoje importantes conjuntos no interior da igreja de Nossa Senhora da Encarnação. Os retábulos que ornamentam os diferentes altares da igreja denotam já o estilo rococó, amplamente difundido no território pela oficina de Veigas que executa vários retábulos com idêntico formulário. Esta proximidade sugere a transversalidade no novo gosto que nas últimas décadas do século XVIII ocupara desde as grandes oficinas do Porto e Braga às oficinas locais ou regionais como Veigas.

De traje rico palaciano com panejamentos muito volumosas é a 
escultura de São José com o Menino (Imagem 75). O amplo pregueado dos panejamentos é denso e pesado. A escultura de São José é particularmente detalhada na representação do Menino. A torção do corpo, a pose, o gesto de ternura e os delicados contornos da anatomia infantil demonstram um cuidadoso trabalho escultórico, idêntico ao que encontramos na imagem de Santo António com o Menino.

Com idêntico esmero na representação dos detalhes anatómicos infantis que podemos observar no Menino (Imagem 76) que São José sustem no colo são os Querubins (Imagem 77) que envolvem o globo sobre o qual está assente a imagem de Nossa Senhora da Imaculada Conceição (Imagem 78).

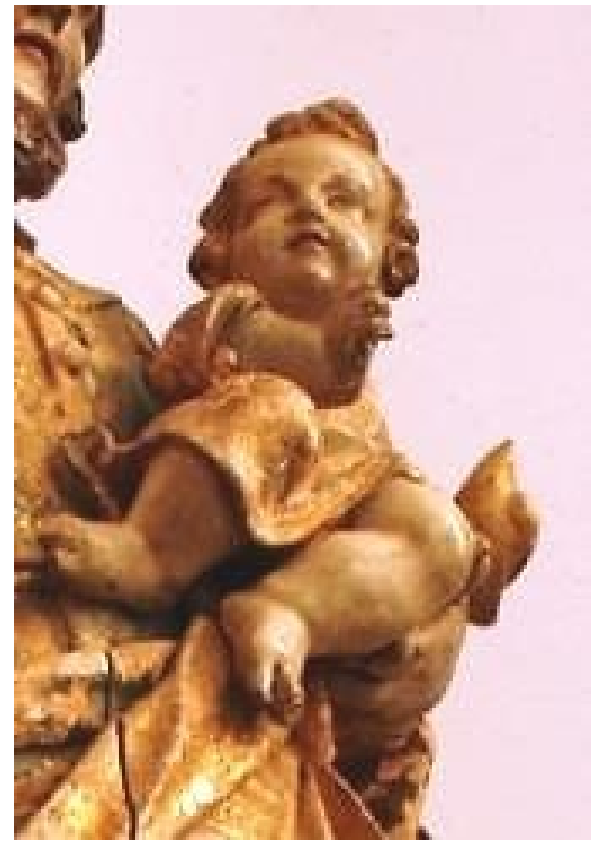

Imagem 76

Pormenor do Menino na escultura de São José com o Menino - IEV 04

Colocada num nicho do lado da Epistola dentro da Capela-mor

Igreja de Nossa Senhora da Encarnação, Vinhais

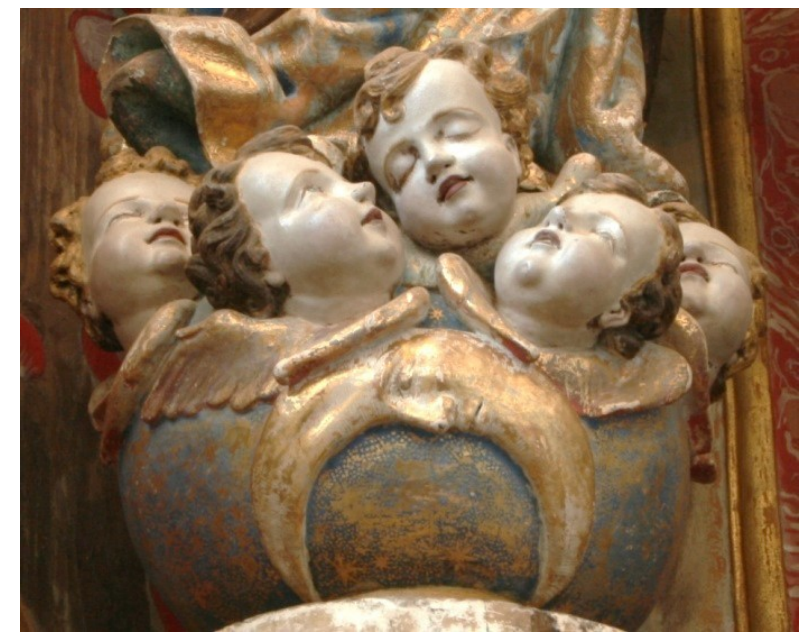

Imagem 77

Pormenor dos Querubins da escultura de Nossa Senhora da Imaculada Conceição - CSDV 07 Capela de Nossa Senhora das Dores, Igreja de Nossa Senhora da Encarnação, Vinhais

A imagem de Nossa Senhora da Imaculada Conceição denuncia alguma estaticidade no gesto, quebrada apenas pela densa volumetria dos panejamentos esvoaçantes. $\mathrm{O}$ tratamento dos pregueados e as vincadas madeixas dos cabelos ondulados demonstram ainda a persistência dos elementos que caracterizam o modelo de Frei Domingos. No entanto, a delicada graciosidade e correta anatomia dos Querubins delatam outra técnica escultórica, talvez mais vinculada com a produção retabular, pródiga na representação 
de anjos e querubins que surgem neste exemplo com evidente desenvoltura compositiva.

Não se exclui a produção de Frei Domingos, mas, tal como ocorre com a imagem do Menino na escultura de Santo António ou na de São José, julgamos que além de Frei Domingos poderá ter havido outra colaboração na talha dos Meninos e querubins.

Contemporânea do Menino de São José e dos Querubins de Nossa Senhora da Imaculada, mas, já fora dos espaços franciscanos, podemos observar os mesmos elementos formais na imagem de Nossa Senhora do Carmo (Imagem 79) na capela privada de São Caetano em Vinhais. No inventário de 1834 foi registada uma escultura de Nossa Senhora do Carmo, na desaparecida capela do claustro, poderá ser a imagem hoje exposta na capela de São Caetano.

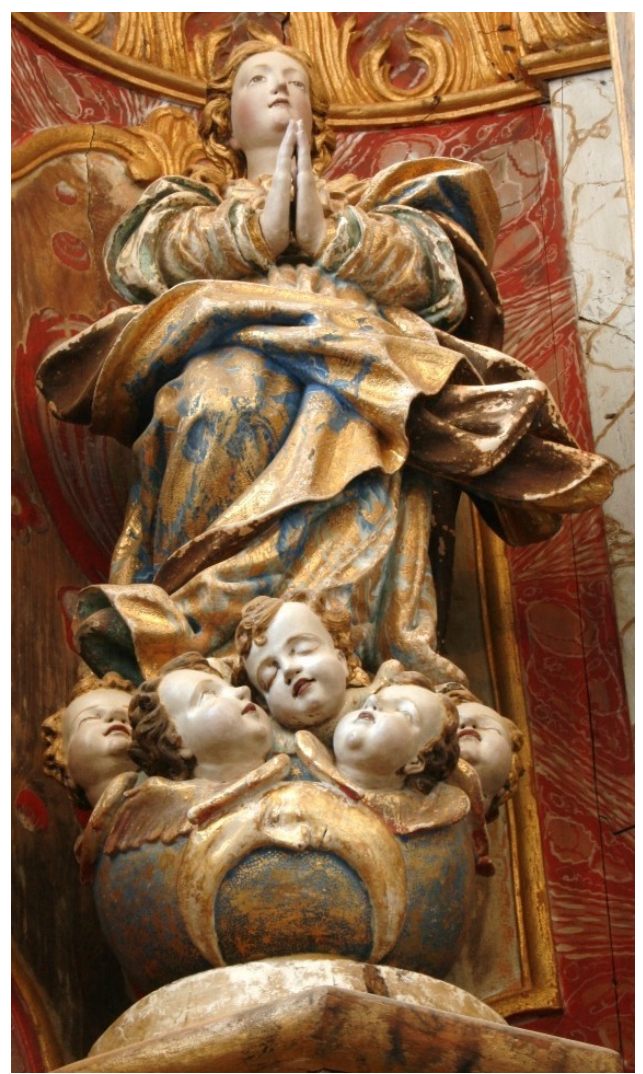

Imagem 78

Escultura de Nossa Senhora da Imaculada Conceição CSDV 07, Capela de Nossa Senhora das Dores, Igreja de Nossa Senhora da Encarnação, Vinhais

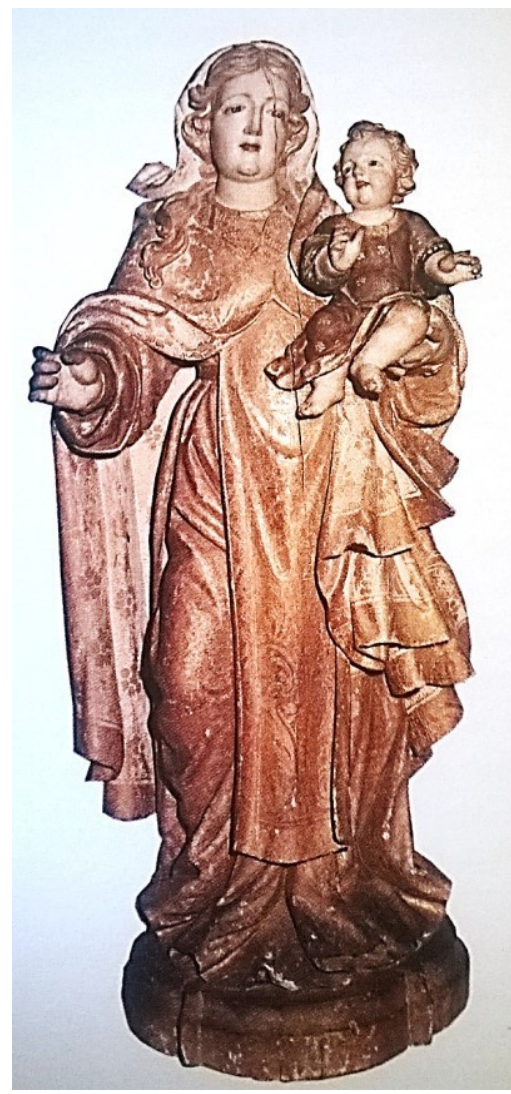

Imagem 79

Escultura de Nossa Senhora do Carmo Capela de São Caetano na casa dos Condes de Vinais, Vinhais

Fotografia: Carlos Fotografo ${ }^{126}$

\footnotetext{
${ }^{126}$ Gomes, José Manuel (Coord.), Imagens e escultura. 1545-1995 Comemorações Jubilares dos 450 Anos da Diocese de Bragança - Miranda, Bragança, Departamento de Liturgia e Património Cultural da Diocese de Bragança - Miranda e Comissão de Arte Sacra, 1996, p. 32.
} 
A imagem de Nossa Senhora do Carmo (imagem 79) é semelhante no rosto, nas madeixas de cabelo e no pregueado junto aos pés com a imagem de Nossa Senhora da Imaculada Conceição da capela de Nossa Senhora das Dores (imagem 78). O Menino que sustem é igual, no gesto e na anatomia infantil ao Menino sustido por Santo António e São José da igreja de Nossa Senhora da Encarnação. Neste sentido, permite esta terceira imagem supor que o escultor dos Meninos poderia estar em Vinhais por tempo prolongado dada a quantidade de produção registada. Desconhece-se se era um frade como Frei Domingos, se discípulo ou colaborador deste, mas julgamos que é possível tratar-se de outro autor, que terá trabalhado simultaneamente a Frei Domingos no intenso estaleiro franciscano que supôs o Seminário Apostólico e posteriormente a igreja da Ordem Terceira.

Tal como fica registado a produção artística local decorrente das encomendas do Seminário Apostólico foi profícua, deixando pouco espaço para a encomenda de obras a autores exteriores, ao contrário do que se observa na contígua igreja de São Francisco da Ordem Terceira onde é evidente a proveniência oficinal das obras escultóricas.

As semelhanças registadas não nos permitem afirmar com certeza a mesma autoria de Frei Domingos para todas as esculturas relacionadas, mas, permitem perceber a persistência do mesmo modelo que serviu para o desenho das esculturas.

O destaque dado em todas as esculturas que relacionamos com a produção de Frei Domingos aos mesmos pormenores evidencia um gosto continuado pelas mesmas formas. As formas que se identificam pela preferência das peças maciças de madeira, com exceção da imagem de Nossa Senhora da Encarnação que nos parece oca no interior; pela cuidadosa talha dos cabelos, pelo denso pregueados dos dinâmicos e amplos panejamentos e pelas expressões de dor vincadas nos cantos descaídos das bocas das figuras masculinas e na contenção expressiva dos rostos redondeados femininos.

Ainda na mesma igreja do seminário percebemos algumas encomendas exteriores à oficina de Frei Domingos como a escultura que representa Santa Ana a ensinar a Virgem Maria a ler ${ }^{127}$ (Imagem 80). Mas o gosto pelos mesmos elementos mantém-se.

\footnotetext{
${ }^{127}$ A escultura de Santa Ana e Nossa Senhora surge registada no catálogo de Imagens e escultura com a datação do século XVII. Gomes, José Manuel (Coord.), Imagens e escultura. 1545-1995 Comemorações Jubilares dos 450 Anos da Diocese de Bragança - Miranda, Bragança, Departamento de Liturgia e Património Cultural da Diocese de Bragança - Miranda e Comissão de Arte Sacra, 1996, p.9. No entanto, detalhes como o ondulado dos panejamentos e os olhos de vidro sugerem tratar-se de uma imagem já do século XVIII. Na fotografia que consta no catálogo ainda é possível observar o livro sobre o colo de Santa Ana, entretanto já desaparecido.
} 
O pregueado das vestes do manto que cobre Santa Ana desenha uma ondulação idêntica à da capa que cobre São Joaquim. O pormenorizado trabalho nas madeixas dos cabelos da Virgem, assim como, os olhos de vidro são também semelhantes às produções de Frei Domingos. Mas, as linhas mais angulosas do rosto de Santa Ana e a brilhante carnação que o cobre sugere uma produção diversa. Próxima no gosto vincado pelos elementos iconográficos e na densa composição dos panejamentos insinuando uma oficina regional, mas decorrente de outras mãos, que não as de Frei Domingos.

Na mesma segunda metade do século XVIII, mas seguramente já durante $o$ último quartel terá sido feita a encomenda por parte dos frades missionários do conjunto do Calvário exposto

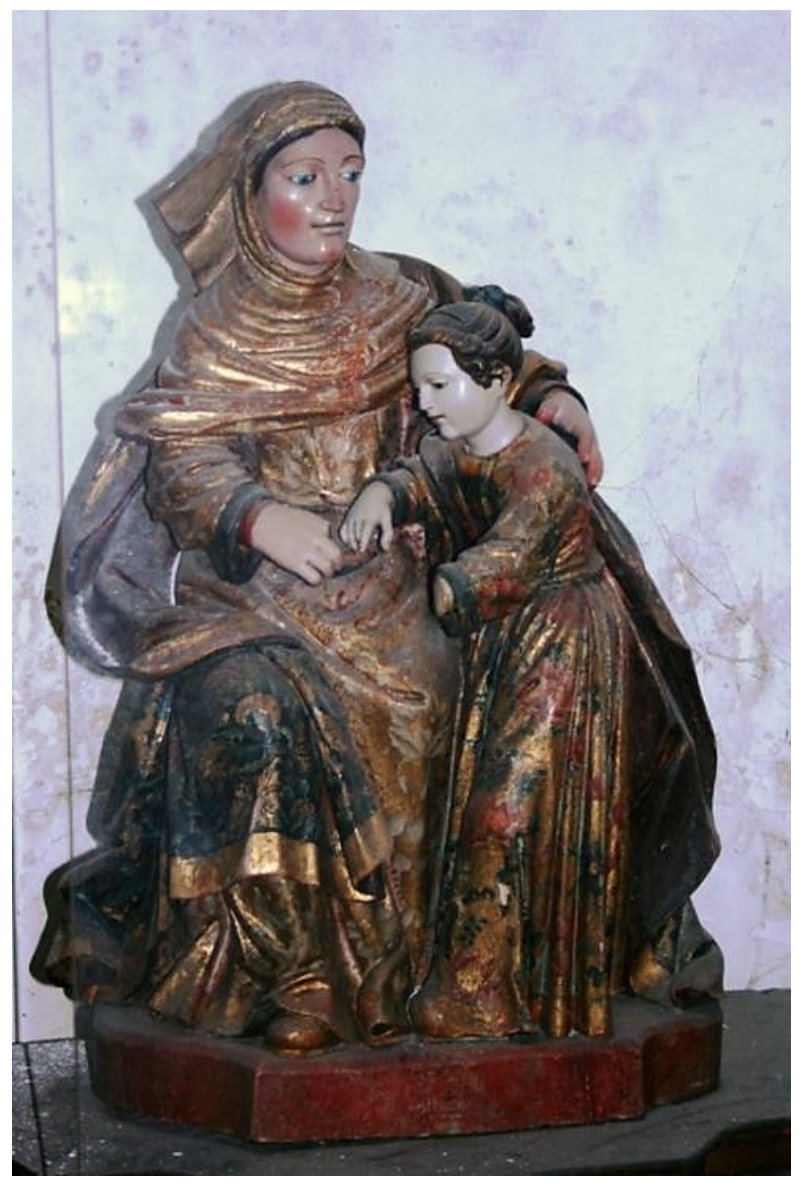

Imagem 80

Escultura de Santa Ana com a Virgem Maria IEV 12

Colocada num nicho lateral do lado do Evangelho

Igreja de Nossa Senhora da Encarnação, Vinhais

na capela lateral de Nossa Senhora das Dores. A capela para onde posteriormente a 1834 se trasladou a imagem de Cristo do Coro.

Em comparação com o conjunto de imagens que formalmente podemos associar com a figura do escultor Frei Domingos as imagens do Calvário denotam uma linguagem diferente, sobretudo no delicado trabalho dos panejamentos que todos exageradamente sustêm e em que estão envolvidos.

A figura de Cristo Crucificado que originalmente estava no centro do Calvário está atualmente desaparecida, mas constava ainda no inventário de 1834. Mantém-se no mesmo sítio as imagens de Nossa Senhora (Imagem 81), Madalena (Imagem 82) e São 
João (Imagem 83), conforme também foram registadas na capela aquando do inventário de 1834.

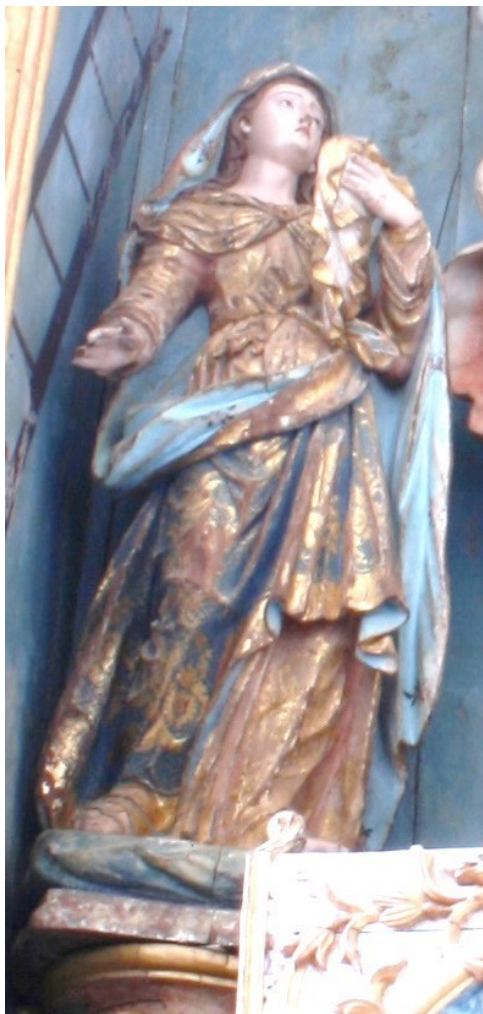

Imagem 81

Escultura de Nossa Senhora do Calvário CSDV 05

Capela de Nossa Senhora das Dores, Igreja de Nossa Senhora da Encarnação, Vinhais

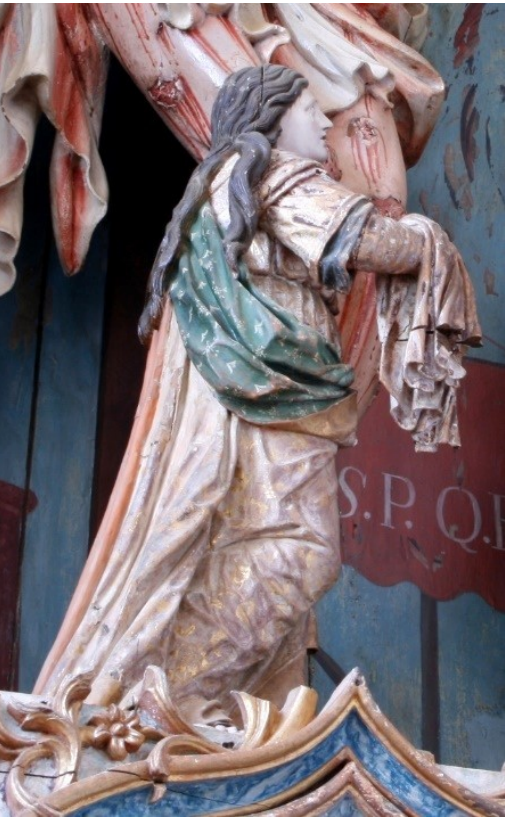

Imagem 82

Escultura de Madalena no Calvário CSDV 04

Capela de Nossa Senhora das Dores, Igreja de Nossa Senhora da Encarnação, Vinhais

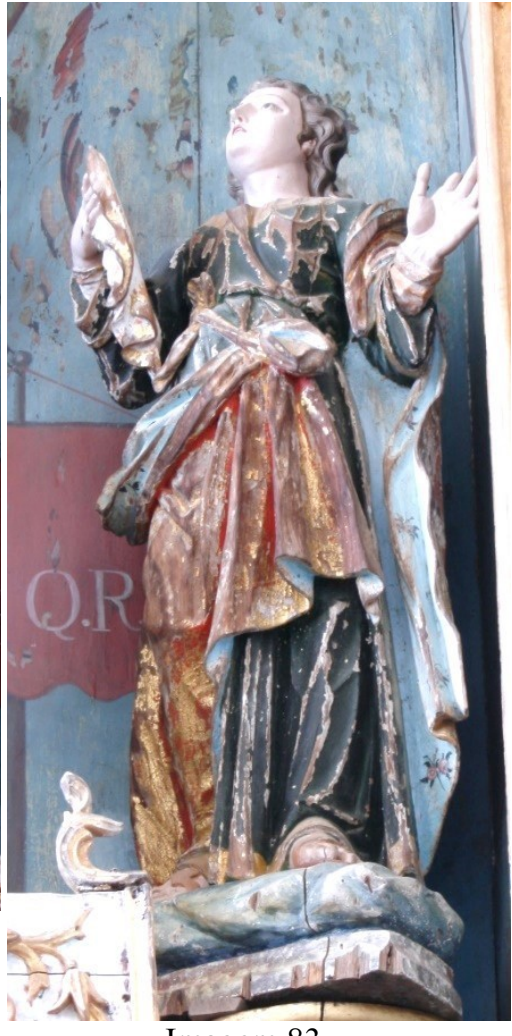

Imagem 83

Escultura de São João no Calvário CSDV 03

Capela de Nossa Senhora das Dores, Igreja de Nossa Senhora da Encarnação, Vinhais

“Tres imagens de vulto que são Nossa Senhora Sam João e a Madalena cada huma avaliada com preço de vinte mil reis somão a quantia de sessenta mil reis $60 \$ 000^{128}$

São evidentes as semelhanças formais entre as três esculturas o que permite entender o conjunto como um todo, com a mesma origem de produção e seguramente encomendadas no mesmo momento. A mudança no gosto que se observa relativamente às obras de Frei Domingos relaciona-se sobretudo com um maior efeito plástico dos panejamentos e com um refinamento da teatralidade no gesto. Os panejamentos adquirem neste conjunto um valor estético que supera as vestes, assumindo-se como

${ }^{128}$ A.N.T.T./A.H.M.F./S.N.S.E.V., Extinção das Ordens Religiosas - Seminário de Nossa Senhora da Encarnação - Vinhais, Arquivo Nacional da Torre do Tombo, Lisboa, Arquivo Histórico do Ministério das Finanças, Processos de Extinção das casas religiosas, Cx. 2265, 1834, s/f1. 
atributo dos três elementos que compõem o Calvário. As três figuras sustêm, com a mão direita, lenços dinamicamente pregueados que evocam o conforto da pena sugerida pelas expressões de dor. As vestes são complexas com distintos tipos de pregueados mais finos ou mais volumosos conforme se trata da túnica adjacente ao corpo ou da capa que o envolve traçada sobre a cintura. Os gestos e o cuidado anatómico são depurados e a expressividade das figuras individualizada mas interpretada como uma narrativa cénica de conjunto.

As três imagens do Calvário do último quartel do seculo XVIII foram certamente produzidas num contexto de oficina nacional, os complexos panejamentos e as cuidadas expressões denotam o domínio formal e técnico sobre o material esculpido.

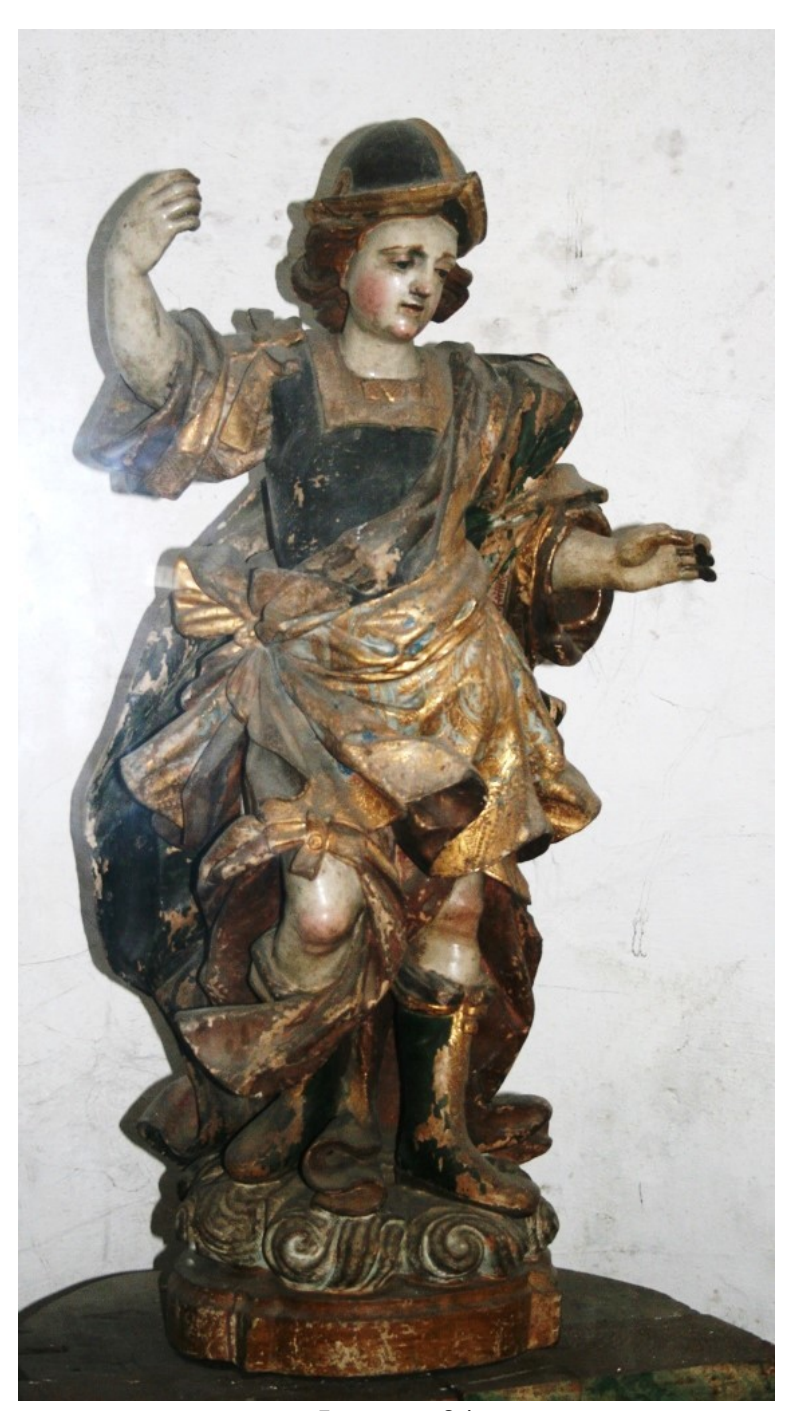

Imagem 84

Escultura de São Miguel Arcanjo - IEV 11

Colocada num nicho lateral do lado do Evangelho Igreja de Nossa Senhora da Encarnação, Vinhais

As esculturas do Seminário Apostólico que nos parecem de produção exterior ao estaleiro da obra são poucas, dada a intensa produção que se relaciona com a figura de Frei Domingos e com a sua oficina. As obras cuja técnica e composição do gesto nos sugerem uma produção oficinal exterior a Vinhais são escassas.

De rosto jovem com carnação muito brilhante, expressão grave e olhar baixo a escultura de São Miguel (Imagem 84) apresenta os cabelos com amplas ondas, muito definidas no desenho, denotando a persistência deste aspeto recorrente na maioria das esculturas que se encontram na igreja de Nossa Senhora da Encarnação. A figura destaca-se pelo dinamismo do gesto e cuidadoso trabalho do pregueado nos volumosos panejamentos que o envolvem. Também o brilho da carnação e a exuberante decoração que ornamenta o 
traje palaciano denotam uma produção nacional cuidada e apetrechada de técnicas e conhecimentos que extravasam os recursos da produção local.

A imagem de Nossa Senhora da Aparecida (Imagem 85) da capela de Nossa Senhora das Dores é formalmente identificável com os finais do século XVIII. O fino pregueado dos panejamentos aproximam a imagem do conjunto escultórico do Calvário exposto na mesma capela. Assim como a ritmada sinuosidade do gesto e os decorativos enrolamentos da nuvem que a sustem a aproximam do gosto que se evoca na escultura do Arcanjo São Miguel.

O refinamento do esvoaçar nos panejamentos constitui o efeito plástico mais valorizado na produção escultórica do último quartel do século XVIII nos espaços franciscanos de Vinhais.

A sinuosidade provocada pela torção do corpo é reforçada na assimetria do gesto criando um intenso ritmo compositivo novo e diferente das restantes obras da igreja do Seminário. A nova conceção seguramente supõe uma outra atitude artística decorrente de uma encomenda a um novo escultorloficina. A escultura cuidada na anatomia, na expressão do rosto, nos panejamentos e na gestualidade sugere uma produção oficinal nacional também cuidada.

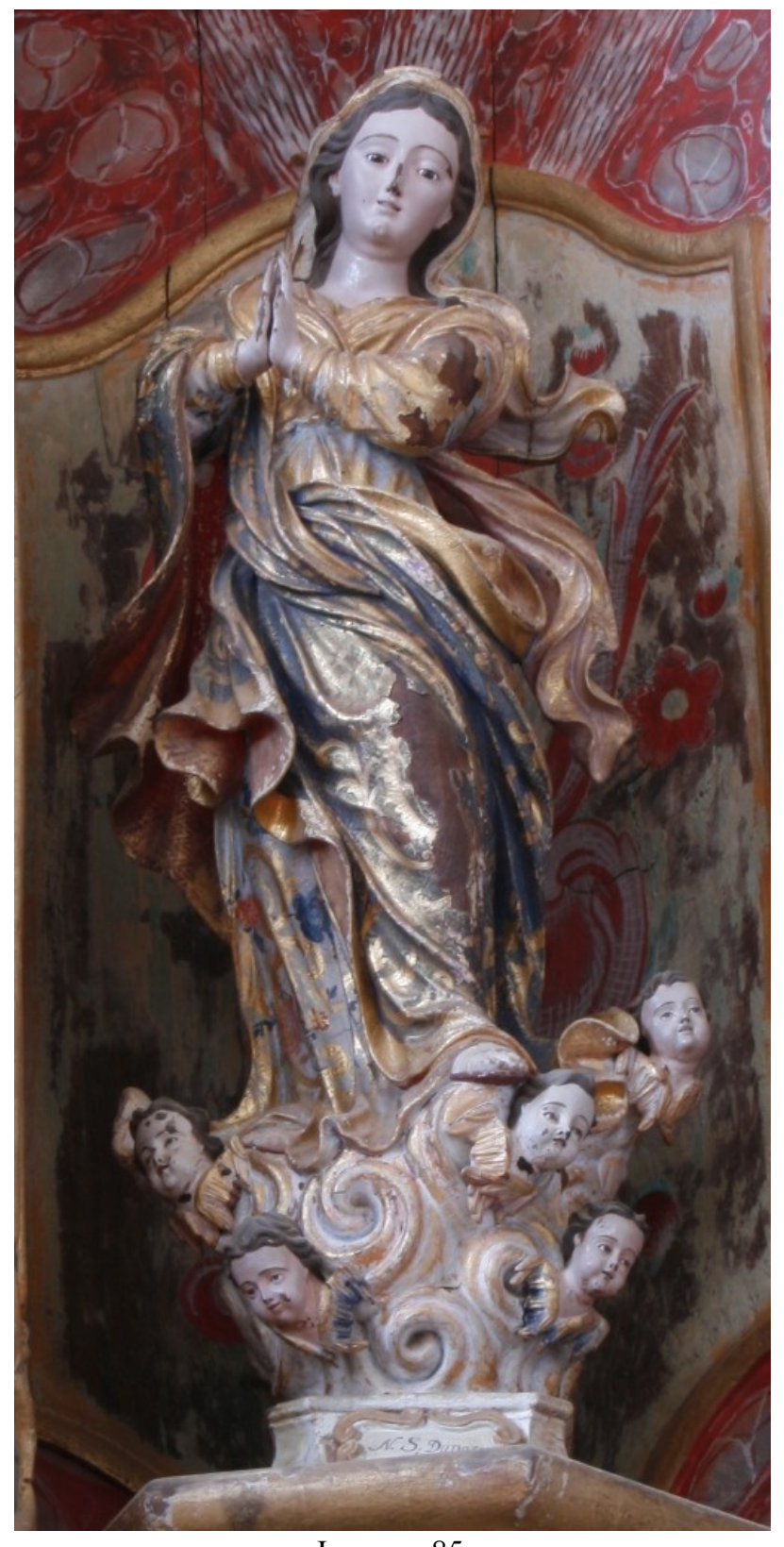

Imagem 85

Escultura de Nossa Senhora da Aparecida - CSDV 02 Capela de Nossa Senhora das Dores, Igreja de Nossa Senhora da Encarnação, Vinhais 
O catálogo de imagens e esculturas da Diocese ${ }^{129}$ identifica a imagem de Nossa Senhora da Aparecida com o século XVII. No entanto, a devoção brasileira apenas se origina em meados do século XVIII, impossibilitando a sua invocação anterior a essa data. Mas, mesmo admitindo que a devoção pudesse ter sido posteriormente alterada, parece difícil a presença da pose e dos panejamentos tão dinâmicos numa representação do seculo XVII. Parece mais verosímil uma produção de finais do seculo XVIII, e a cargo de uma oficina bem apetrechada nas técnicas e modelos. O modelo poderá ter chegado do Brasil mas parece-nos improvável que do Brasil pudesse chegar uma imagem de vulto deste tamanho, por isso julgamos que a escultura terá sido feita no Porto ou até em Braga a partir de uma estampa trazida do Brasil.

Da documentação do Seminário dos Missionários Apostólicos de Nossa Senhora dos Anjos de Brancanes, Rodrigues ${ }^{130}$ destaca, sobre as relações entre Vinhais e o Brasil a figura de Frei Constantino da Conceição, nascido em Azurara e que faleceu em Vinhais em 1767, onde chegou após ter estado no Bispado da Baía com mais dois missionários com intenção de prolongarem as missões ao território brasileiro. Frei Constantino da Conceição era carpinteiro e apesar da sua mediana suficiência terá chegado a Vinhais na condição de conselheiro técnico para a edificação da igreja e alojamentos.

Poderá a presença de Frei Constantino da Conceição chegado do Bispado da Baia para o Seminário de Vinhais explicar a devoção de Nossa Senhora da Aparecida. A sua preparação como carpinteiro pode também relacionar-se com a produção local de escultura com mais proximidade à produção retabular. No entanto, a ausência documental apenas nos permite relacionar factos e não afirmar autorias.

Na contígua igreja de São Francisco mandada fazer pela Venerável Ordem Terceira é evidente a produção de encomenda a oficinas tecnicamente bem apetrechadas reforçando a crescente importância dada à imaginária. Mas tratando-se de uma Ordem laica destaca-se também neste sentido a importância dos encomendadores, dos seus recursos económicos e das exigências formais que se observam nas esculturas.

Inicialmente a Ordem Terceira servia-se dos espaços do seminário para as suas sessões e funções religiosas, denotando a ligação estreita que unia o seminário à

${ }^{129}$ Gomes, José Manuel (Coord.), Imagens e escultura. 1545-1995 Comemorações Jubilares dos 450 Anos da Diocese de Bragança - Miranda, Bragança, Departamento de Liturgia e Património Cultural da Diocese de Bragança - Miranda e Comissão de Arte Sacra, 1996, p. 31.

${ }^{130}$ Rodrigues, Luís Alexandre, "A ação dos padres de Brancanes em Vinhais. O Seminário da Senhora da Encarnação e constituição da Venerável Ordem Terceira da Penitência" in Natália Marinho FerreiraAlves (Coord.), Os Franciscanos no Mundo Português II. As Veneráveis Ordens Terceiras de São Francisco, Porto, CEPESE - Centro de Estudos da População, Economia e Sociedade 2012, pp. 163-193. 
comunidade laica franciscana. Foi, tal como para a fundação do seminário, o empenho e as doações da família Morais Sarmento que impulsionaram o estabelecimento da ordem laica. As doações incluíam uma cortinha e o terreno onde se implantou a casa com seu "pateo curral ou despejo das mesmas" e ainda uma capela com o título das Chagas de S. Francisco. Criando assim as condições para que em 1780 surgisse a primeira notícia a referir a sessão da venerável ordem da penitência na sua casa e igreja ${ }^{131}$.

Esta data pode servir-nos de baliza para a maioria dos trabalhos, mas não descarta que possam existir atualmente esculturas no interior da igreja de São Francisco anteriores a 1780, pois, já nos outros espaços franciscanos pudemos perceber a presença de imagens cuja data antecede o edificado denotando a circulação das esculturas de espaços mais antigos para espaços de fundação mais recente.

Das várias esculturas, que ainda hoje podemos observar no interior do templo de São Francisco, apenas uma surge referida no inventário do contiguo Seminário Apostólico de 1834 confirmando a dispersão do lugar de origem que algumas imagens sofreram após a extinção das Ordens Religiosas. Identificamos essa dispersão na escultura de Nossa Senhora do Carmo atualmente exposta na capela de São Caetano na privada casa dos Condes de Vinhais e que julgamos ter originalmente pertencido a uma das capelas do Seminário. O mesmo ocorre com uma representação do Presépio (Imagem 86) numa maquineta que está hoje confrontada com uma outra maquineta que guarda uma representação da Descida da Cruz (Imagem 87), ambas adossadas ao arco triunfal da igreja de São Francisco.

As figurinhas que constituem as duas narrativas sugerem uma produção de finais do século XVIII. Mas, na representação do Presépio é evidente um menor cuidado anatómico e técnico nos pormenores dos olhos de vidro e panejamentos comparativamente à maquineta que guarda a representação da Descida da Cruz. Insinuam ambas as maquinetas evidentes vínculos com os Presépios de Machado de Castro e António Ferreira o "Ferreirinha de Chelas"132.

\footnotetext{
${ }^{131}$ Rodrigues, Luís Alexandre, "A ação dos padres de Brancanes em Vinhais. O Seminário da Senhora da Encarnação e constituição da Venerável Ordem Terceira da Penitência" in Natália Marinho FerreiraAlves (Coord.), Os Franciscanos no Mundo Português II. As Veneráveis Ordens Terceiras de São Francisco, Porto, CEPESE - Centro de Estudos da População, Economia e Sociedade 2012, pp. 163-193.

${ }^{132}$ Machado de Castro distinguiu-se, em conjunto com António Ferreira o "Ferreirinha de Chelas" na produção de Presépios. O "género pastoril", tal como Machado de Castro se referia, teve em Portugal particular devoção que possivelmente se relaciona com o franciscanismo fortemente enraizado na cultura portuguesa. Desde $\mathrm{D}$. João $\mathrm{V}$ que vários foram os presépios a adornar igrejas, mosteiros e espaços privados. Pereira, José Fernandes, "O barroco do século XVIII" in Paulo Pereira (direção), Historia da Arte Portuguesa, Volume III, Lisboa, Círculo de leitores, 1995, pp. 50-181; Pais, Alexandre, "Introdução
} 


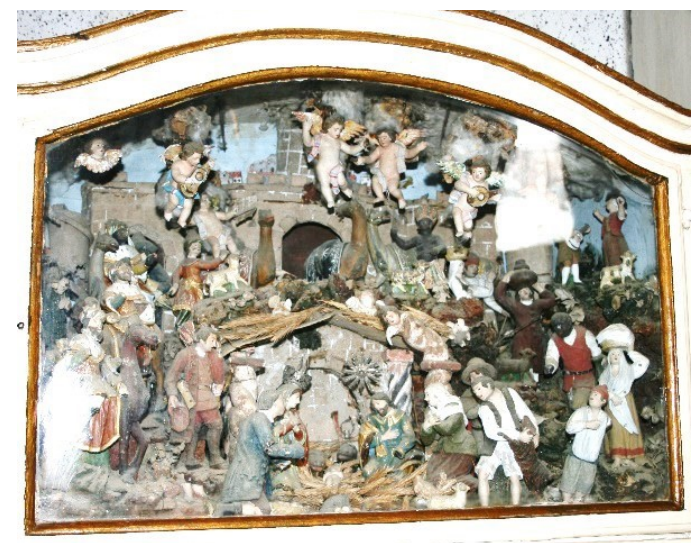

Imagem 86

Maquineta com Presépio - SFV 09 Arco triunfal no lado do Evangelho Igreja de São Francisco, Vinhais

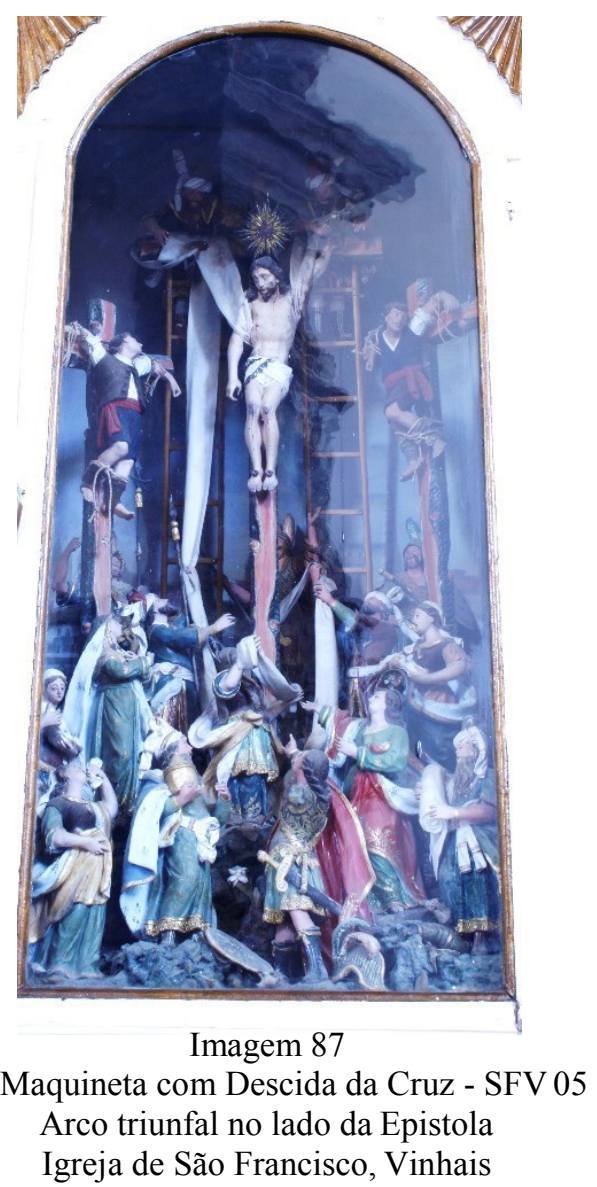

Não só nos elementos registados mas também na composição e dinâmicas da narrativa evocada. Irradiado a partir das oficinas de Lisboa o "género pastoril" terá chegado durante a segunda metade do século XVIII e inícios do século XIX a diversas igrejas, mosteiros e espaços privados.

Neste contexto da produção lisboeta ${ }^{133}$ podem ter chegado a Vinhais as maquinetas hoje ao culto na igreja da Venerável Ordem Terceira. Apesar de apenas termos

ao estudo do Presépio do Museu de Évora"n Joaquim Oliveira Caetano (Edit.) CENÁCULO Boletim on line do Museu de Évora $n^{\circ}{ }^{3}$ 3, Disponível em http://museudevora.imc-ip.pt/, 2008, pp. 3-5; Pereira, José Fernandes, "Estética barroca I: arquitectura e escultura", in Dalila Rodrigues (Coord.), Arte Portuguesa Da Pré-História ao Século XX, volume 12, Lisboa, Fubu Editores, 2009, pp. 7-136; Em Espanha os presépios eram comuns desde o século XVII, na sua produção destacou-se a oficina sevilhana da família Roldán, que assinavam as prestigiadas obras. Nas restantes oficinas não era comum assinarem e na sua maioria são de autores desconhecidos. Figueiredo, Maria Rosa, Escultura Europeia, Volume II, Lisboa, Fundação Calouste Gulbenkian, 1999, p. 72.

${ }^{133}$ Podemos associar os ambientes campestres, de grutas e montes nos presépios, às representações do Norte e Centro do país, e as arquiteturas urbanas em ruínas, como cenário dos presépios do Sul, particularmente das oficinas de Lisboa. Alcoforado, Ana, O Menino dos Meninos, Coimbra, Museu Nacional de Machado de Castro, 2007, p.15. O Presépio de Vinhais traduz ambas influências, pois o abrigo que alberga a Sagrada Família, bem como o enquadramento do fundo, sugerem arquiteturas em ruinas. Mas a paisagem remete para um ambiente campestre, com montes e natureza fingida. Mas a presença das arquiteturas sugere-nos uma maior proximidade com as oficinas de Lisboa. 
encontrado referências documentais relativamente à existência da maquineta que expõe o Presépio, julgamos poderem ser ambas do mesmo período.

O maior número de figuras do Presépio é substituído na Descida da Cruz por figuras de maior escala e de maior cuidado na modelação. A documentação de 1834 permitenos perceber que têm no entanto origens de encomenda distintas, pois o Presépio foi originalmente encomendado pelos frades missionários enquanto a Descida da Cruz terá sido encomenda dos laicos irmãos terceiros. Atualmente estão ambas dentro de caixas já de gosto neoclássico do século XIX, seguramente posteriores aos conjuntos escultóricos que guardam no interior.

Além de Machado de Castro e de António Ferreira houve outros autores a modelar conjuntos de imagens de presépios, na maioria dos casos desconhece-se o nome (Imagem 88) mas surgem mais autorias atribuídas como Silvestre Faria Lobo (Imagem 89), com o elemento comum da proveniência de Lisboa.

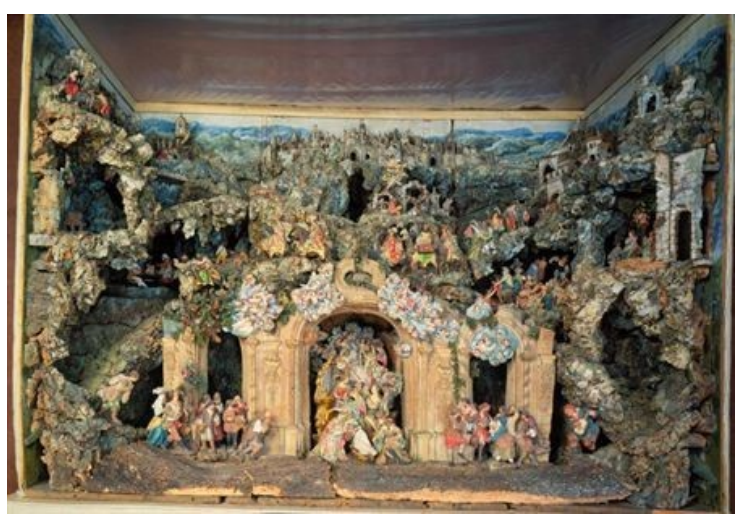

Imagem 88

Presépio das Necessidades; Autor: Desconhecido; Local de Execução: Portugal; Lisboa; Datação: 1775 d.C. - 1800 d.C.; Matéria: Barro. Cortiça. Madeira; Museu Nacional de Arte Antiga ${ }^{134}$

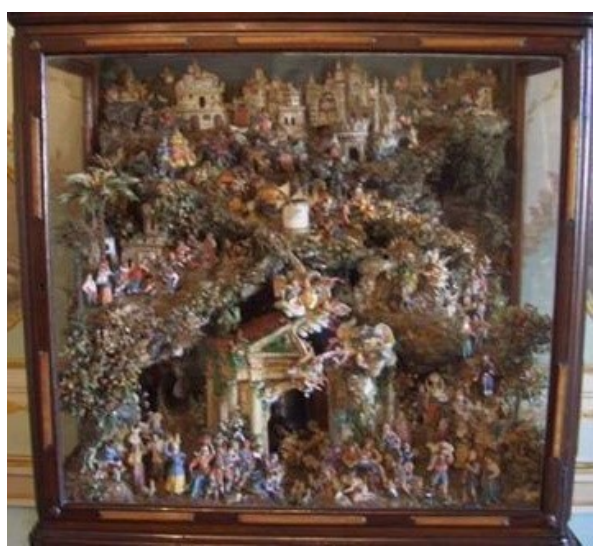

Imagem 89

Presépio; Autor: Lobo, Silvestre Faria (?); Local de Execução: Portugal; Datação: XVIII d.C. - $3^{\circ}$ quartel; Matéria: Terracota, madeira, cortiça, papel, vidro; Palácio Nacional de Queluz ${ }^{135}$

Também as oficinas de Valladolid se destacavam desde o século XVII na produção escultórica de grupos com várias figuras. Martín González, Juan José, El arte procesional del barroco (cuadernos de arte espanol), Madrid, história 16, 1993, p. 26. Se bem que, a escala dos passos processionais castelhanos seja maior, a complexidade das narrativas aproxima-as enquanto modelos, sobretudo na maquineta com a representação da "Descida da Cruz" SFV 05.

${ }^{134}$ Conforme pesquisa efetuada a 30 de março de 2015 na base de dados dos Museus da DGPC, (DireçãoGeral do Património Cultural, Departamento dos Bens Culturais, Divisão do Património Imóvel, Móvel e Imaterial, Palácio Nacional da Ajuda, Lisboa - Portugal).

http://www.matriznet.dgpc.pt/MatrizNet/Objectos/ObjectosConsultar.aspx?IdReg=260931

${ }^{135}$ Conforme pesquisa efetuada a 30 de março de 2015 na base de dados dos Museus da DGPC, (DireçãoGeral do Património Cultural, Departamento dos Bens Culturais, Divisão do Património Imóvel, Móvel e Imaterial, Palácio Nacional da Ajuda, Lisboa - Portugal).

http://www.matriznet.dgpc.pt/MatrizNet/Objectos/ObjectosConsultar.aspx?IdReg=999242 
Têm em comum, as composições de presépios que são produzidas ao longo da segunda metade do século XVIII e princípios do XIX, a estrutura escalonada com elementos arquitetónicos clássicos sobre naturezas fingidas em cortiça. No caso do Presépio de Vinhais a choupana é popular mas no último registo apresenta um portal com arco de meio ponto e toda a cena se desenvolve num cenário natural. Mostra o Presépio de Vinhais o mesmo ritmo de narrativa criada a partir de uma variada profusão de personagens que convergem, de ambos os lados e a partir dos diferentes registos, em grupos, para a cena central da Sagrada Família.

A maquineta do Presépio da igreja de São Francisco em Vinhais apresenta proximidades com as produções do final do seculo XVIII mas o sumário detalhe das figurinhas denota uma produção mais esquemática que as obras de encomenda atualmente guardadas no Palácio de Queluz ou nos Museus de Arte Antiga, Museu Azulejo e Museu Machado de Castro.

Relativamente à narrativa da Descida da Cruz trata-se de uma composição menos comum que o Presépio e formalmente devemos destacar que é um conjunto mais cuidado na produção. Possivelmente coeva do Presépio ou ligeiramente posterior, e possivelmente também da mesma oficina de Lisboa mas respondendo a diferentes critérios de encomenda.

Estas duas maquinetas sugerem tratar-se de obras de encomenda, neste caso as únicas onde registamos o barro como material de suporte.

A igreja da Ordem Terceira apresenta várias imagens de produção cuidada em vulto pleno e de tamanho grande, supõe essa produção um desafogo económico que não registamos em nenhum dos outros espaços franciscanos estudados. Supõe também um vínculo aos importantes centros de produção escultórica como eram Porto e Braga, técnica e plasticamente capazes de responder a um maior grau de exigência.

Destacamos as obras cuja origem nos perece próxima entre elas, e também próximas ao conjunto de imagens do convento de Bragança (Santa Clara, São Francisco e Cristo crucificado com o braço pendente) que relacionamos com os inícios da segunda metade do seculo XVIII. A origem de toda esta imaginária poderá estar nas oficinas do Porto e Braga, já consagradas desde o século XVII. Ainda hoje podemos observar no museu da Ordem Terceira contiguo à igreja de São Francisco uma imagem de Santa Rosa de Viterbo que traduz o mesmo figurino feminino usado na representação de Santa Clara de Bragança (Imagem 90) e Santa Rosa de Viterbo de Vinhais (Imagem 91) e Santa Clara de Vinhais (Imagem 92). 
Nas três figuras é evidente o mesmo modelo nos panejamentos do véu e detalhe da coifa. Mas as semelhanças são destacáveis sobretudo na expressão do rosto e no arredondado das linhas que o compõem.

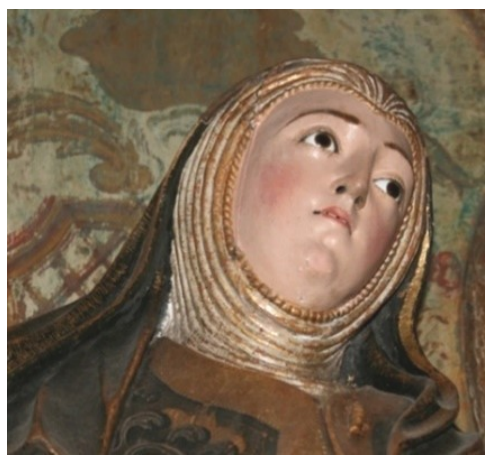

Imagem 90

Pormenor do rosto da escultura de Santa Clara - SFB 23

Retábulo no lado do Evangelho Igreja de São Francisco, Bragança

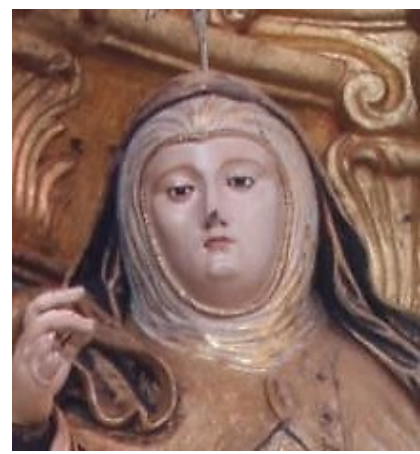

Imagem 91

Pormenor do rosto da escultura de Santa Rosa de Viterbo SFV 02

Retábulo no lado da Epistola Igreja de São Francisco, Vinhais

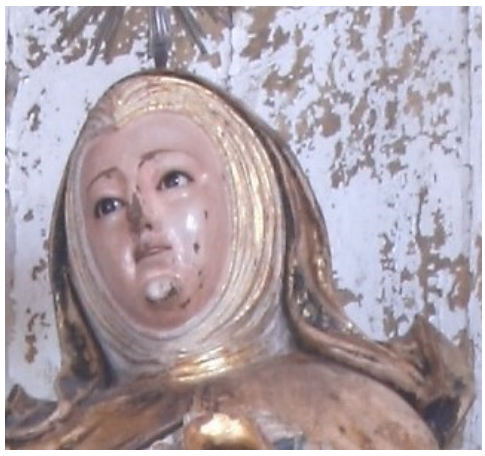

Imagem 92

Pormenor do rosto da escultura de Santa Clara - SFV 06

Retábulo mor no lado da Epistola Igreja de São Francisco, Vinhais

A escultura de Santa Clara de Bragança parece-nos anterior, pela maior contenção no gesto e no esvoaçar dos panejamentos do hábito, mas a proximidade no gosto pelos valores expressos no rosto é evidente nos três exemplos.

Se na comparação entre as imagens da igreja de São Francisco de Vinhais e da igreja de São Francisco de Bragança encontramos proximidades. Entre as imagens de Santa Rosa de Viterbo (Imagem 93) e de Santa Clara (Imagem 94) da igreja de São Francisco de Vinhais encontramos seguramente a mesma produção. Podemos afirma-lo com base nas analogias formais encontradas em ambas as imagens. $\mathrm{O}$ dinamismo no gesto e a sinuosidade da pose são idênticos. Bem como, a aderência dos panejamentos aos corpos, e o fino pregueado mais enrugado entre as penas enfatizando o movimento sugerido pelo joelho mais avançado, e as ondas que esvoaçam da capa que envergam ambas as imagens.

Da mesma oficina é também a imagem de São Francisco (Imagem 95) que está no altar-mor no lado do Evangelho, ladeando em conjunto com Santa Clara a imagem que ocupa o nicho central da Imaculada Conceição.

Nas três esculturas registadas observa-se o mesmo cuidado na anatomia, no brilho da carnação, no gesto e nos panejamentos evidenciando a mesma produção, tecnicamente desenvolvida e afastada dos modelos vinculados à produção local ou regional. 
O ritmo sinuoso evocado nas três esculturas fá-las corresponder com o último quartel do seculo XVIII. Decorrentes da influência francesa e alemã, de um rococó requintado que se sentia desde a segunda metade do século XVIII ${ }^{136}$.

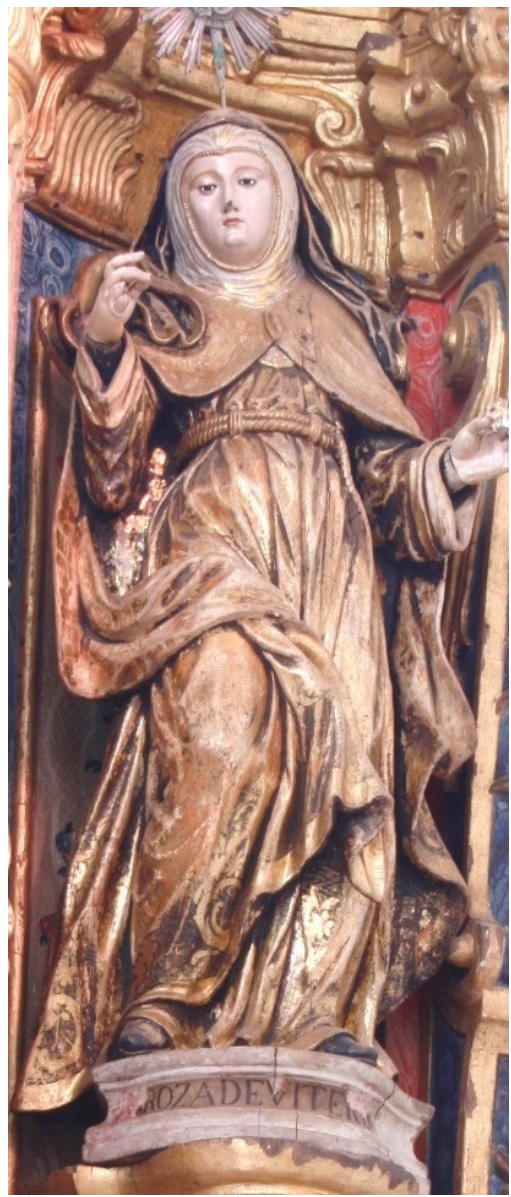

Imagem 93

Escultura de Santa Rosa de Viterbo - SFV 02

Retábulo no lado da Epistola Igreja de São Francisco, Vinhais

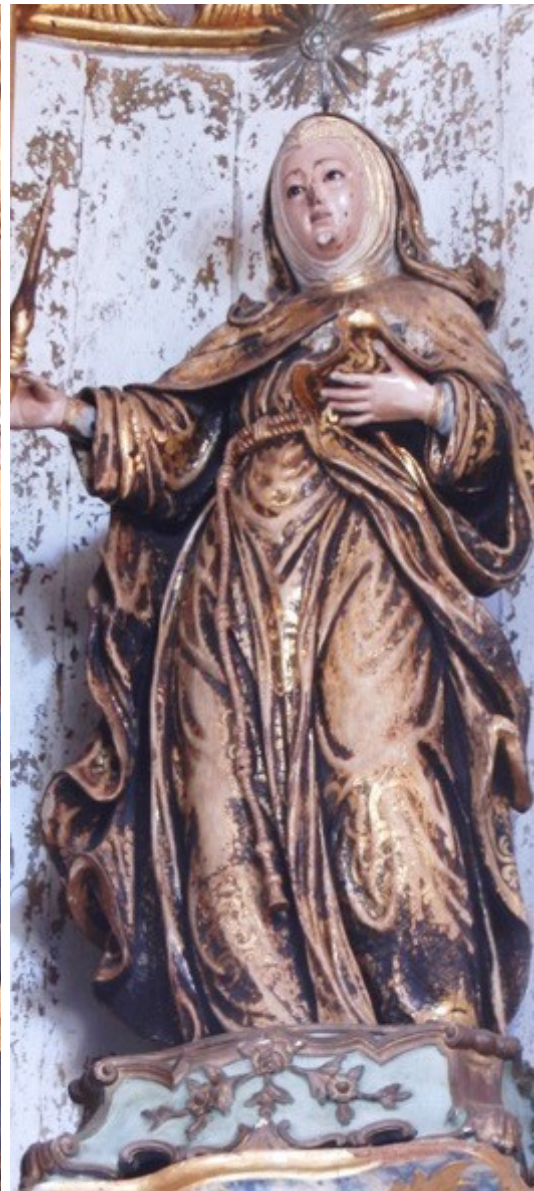

Imagem 94

Escultura de Santa Clara SFV 06

Retábulo mor no lado da Epistola Igreja de São Francisco, Vinhais

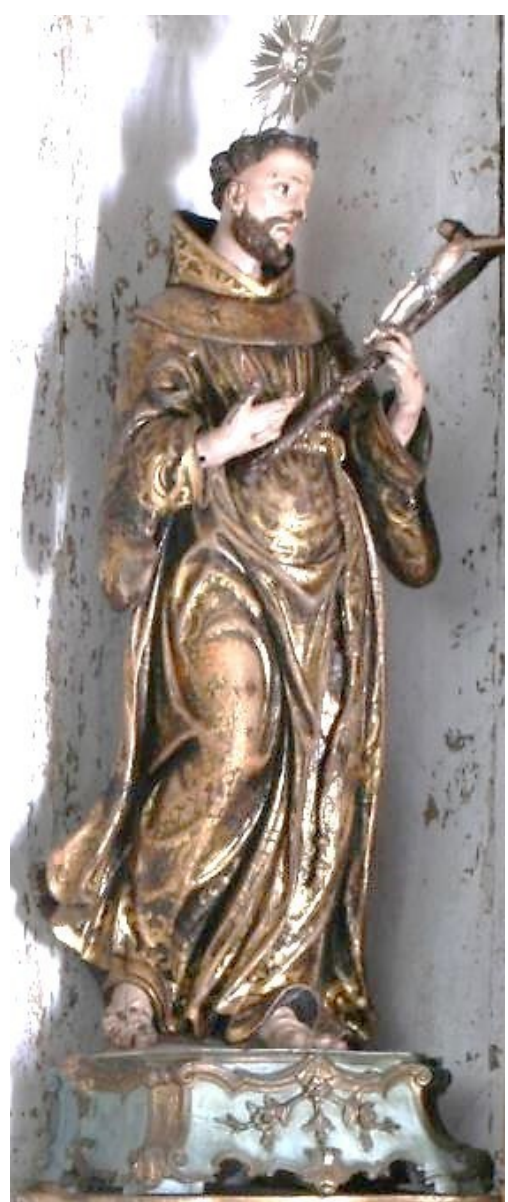

Imagem 95

Escultura de São Francisco SFV 08

Retábulo mor no lado do Evangelho Igreja de São Francisco, Vinhais

O mesmo se observa na escultura que ocupa o nicho central do retábulo do altar-mor, que representa Nossa Senhora da Imaculada Conceição (Imagem 96).

A sinuosidade na pose e o ritmo dinâmico do gesto aproximam-na dos valores formais registados das esculturas de Santa Rosa de Viterbo, Santa Clara e São Francisco. Pensamos por isso que se trata também de uma obra de encomenda a uma oficina instruída, possivelmente Porto ou Braga e produzida no último quartel do século XVIII.

\footnotetext{
${ }^{136}$ Ferreira-Alves, Natália Marinho, "Pintura, Talha e Escultura (séculos XVII e XVIII) no Norte de Portugal" in Revista da Faculdade de Letras. Ciências e Técnicas do Património vol. 2, Porto, Faculdade de Letras da Universidade do Porto, Departamento de Ciências e Técnicas do Património, 2003, pp. 735756.
} 
O gesto das mãos postas sobre o lado direito é assimetricamente equilibrado pela inclinação da cabeça para o lado esquerdo e pelo avanço do joelho no mesmo lado. No entanto os panejamentos são amplos e o pregueado exageradamente volumoso afastando-se formalmente do pregueado fino e aderente que define as vestes das esculturas de Santa Rosa de Viterbo, Santa Clara e São Francisco.

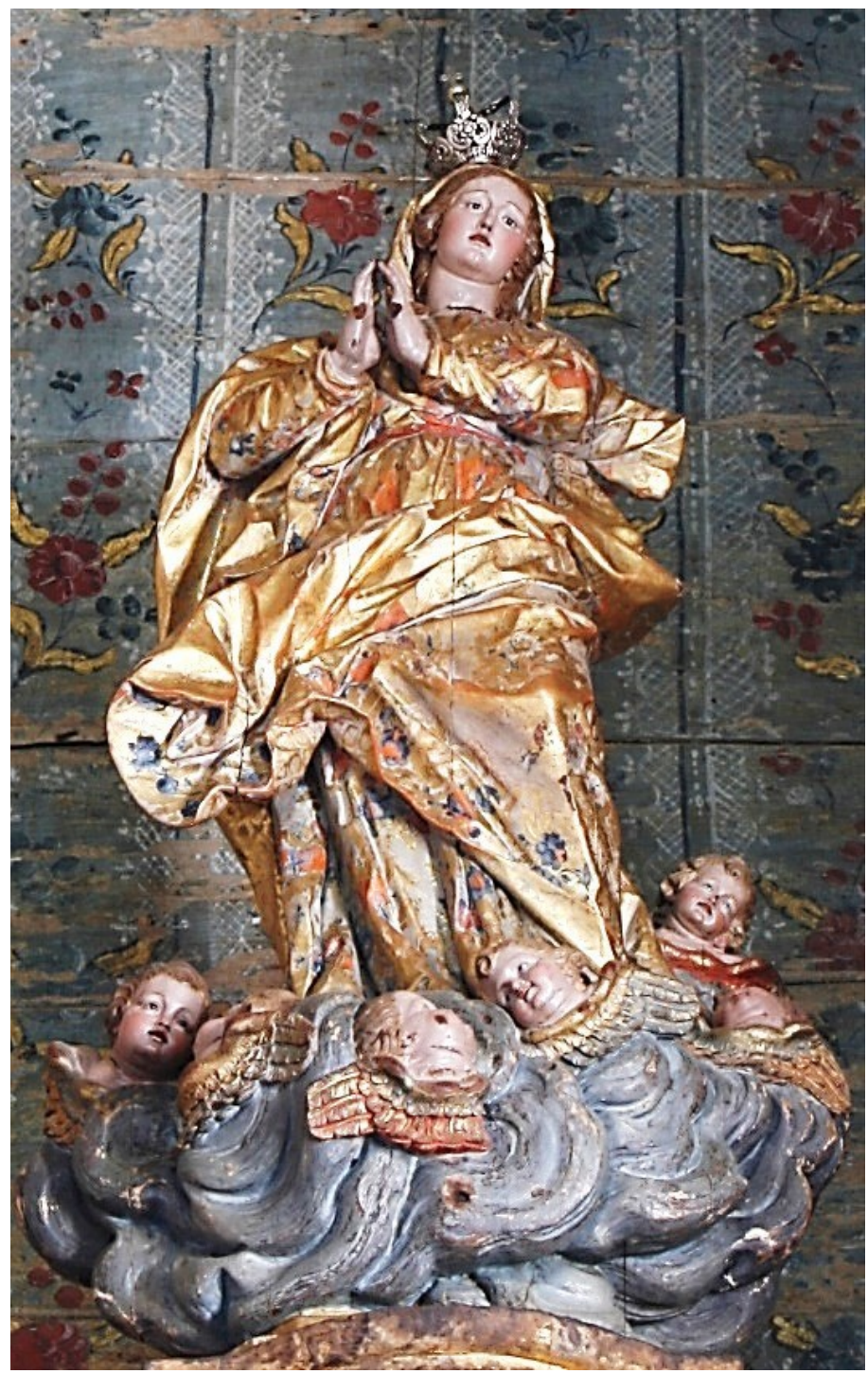

Imagem 96

Escultura de Nossa Senhora da Imaculada Conceição SFV 07

Retábulo mor no nicho central Igreja de São Francisco, Vinhais

Esta teatralidade mais densa liga a imagem a uma produção distinta mas possivelmente contemporânea. A sinuosidade do ritmo assimétrico e exagerado na volumetria assemelha-se ao que se observa na escultura de Nossa Senhora da Aparecida e ambas as esculturas da Senhora da Aparecida e da Imaculada Conceição têm mais 
correspondência com alguma da imaginária coeva de produção brasileira que com as representações da Imaculada conceição de produção portuguesa.

As ligações de Vinhais com o Brasil eram comuns como acontecia com o restante território português. Alves, no tomo dedicado aos judeus refere vários processos da Inquisição de indivíduos oriundos de Vinhais (muitos dedicados à industria das sedas) e que ao longo do seculo XVIII (até 1753) foram punidos. As penas eram muitas vezes substituídas por exílios para o então estado do Brasil. Em 1706 registava o Santo Oficio um individuo de Vinhais morador no Bispado do Rio de Janeiro ${ }^{137}$.

Neste sentido não eram apenas os frades missionários mas, a população civil estava igualmente familiarizada com o território brasileiro. Esta relação não justifica a autoria mas lança a pista para que a proximidade no gosto nos dois territórios possa ser analisada sob o ponto de vista biunívoco, na medida em que, parece que este espaço recebeu também a influência do gosto brasileiro.

De produção nacional de oficina bem preparada são também as imagens que representam Santa Margarida de Cortona ${ }^{138}$ (Imagem 97) e Santo António Menino do Coro (Imagem 98).

Ambas as esculturas apresentam proximidades no tratamento das vestes que caiem em dinâmicos vincos finos que se adensam entre as pernas. O modelo formal é semelhante com as já registadas esculturas de Santa Clara, São Francisco e Santa Rosa de Viterbo. Esta proximidade permite relaciona-las com a mesma oficina, possivelmente do Porto ou Braga, e com o mesmo período temporal do último quartel do seculo XVIII.

\footnotetext{
${ }^{137}$ Alves, Francisco Manuel, Bragança Memórias arqueológico-históricas do distrito de Bragança (2a edição) Os Judeus Tomo V, Bragança, Câmara Municipal de Bragança / Instituto Português de Museus Museu Abade de Baçal, 2000, (original publicado em 1910-1947), p. 154.

${ }^{138}$ A escultura de Santa Margarida de Cortona surge registada no catálogo de Imagens e escultura com a datação do século XVII. Gomes, José Manuel (Coord.), Imagens e escultura. 1545-1995 Comemorações Jubilares dos 450 Anos da Diocese de Bragança - Miranda, Bragança, Departamento de Liturgia e Património Cultural da Diocese de Bragança - Miranda e Comissão de Arte Sacra, 1996, p. 21. No entanto, detalhes como o ondulado dos panejamentos e os olhos de vidro sugerem tratar-se de uma imagem já do século XVIII.
} 


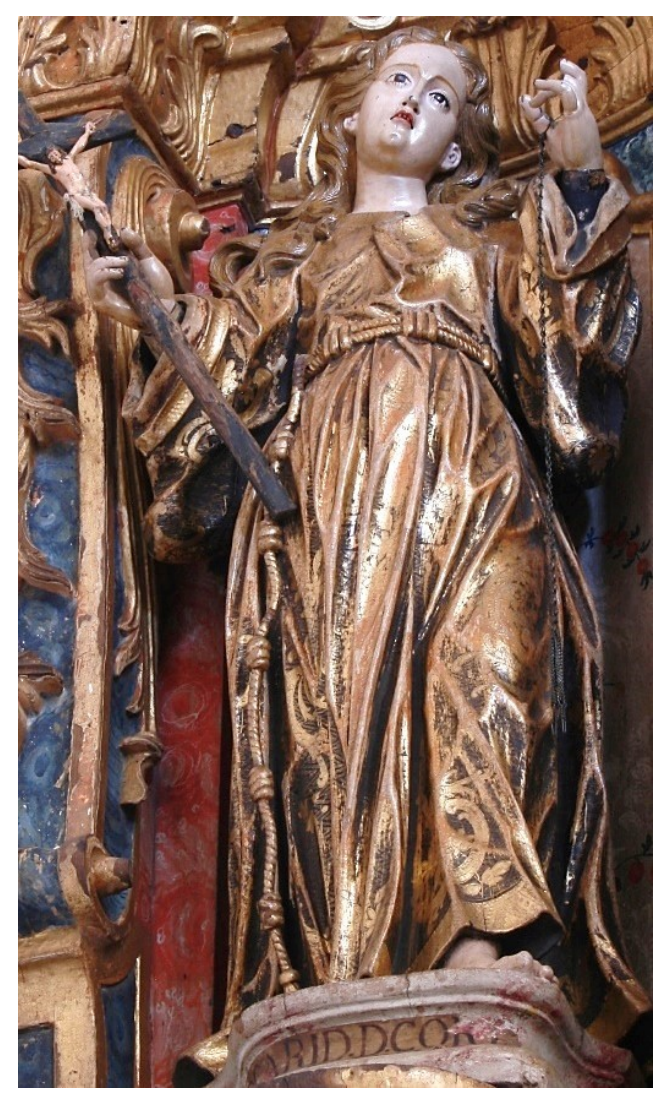

Imagem 97

Escultura de Santa Margarida de Cortona SFV 12

Retábulo no lado do Evangelho Igreja de São Francisco, Vinhais

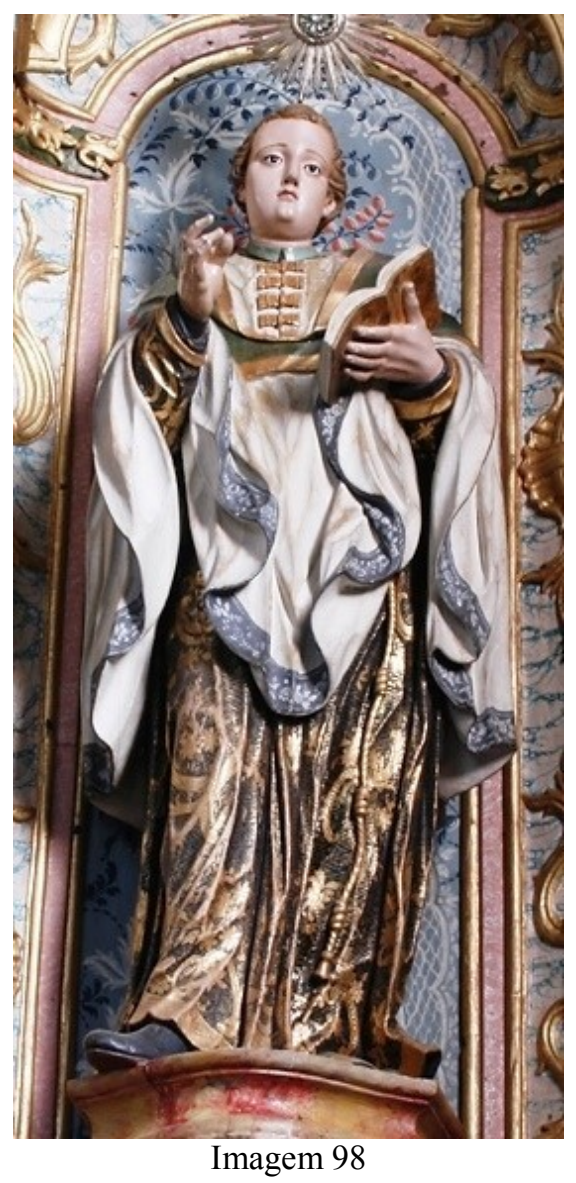

Escultura de Santo António Menino do Coro SFV 03

Retábulo no lado da Epistola Igreja de São Francisco, Vinhais

Ainda relativamente ao conjunto de imaginário de vulto da igreja da Ordem Terceira de Vinhais podemos destacar mais duas imagens cuja produção é também cuidada. Mas, nas imagens de São Roque (Imagem 99) e de São Benedito (Imagem 100) o modelo é claramente diverso do que serviu de base às produções oficinais de Santa Rosa de Viterbo, Santa Clara e São Francisco, Santa Margarida e Santo António Menino do Coro.

Não obstante as diferenças formais julgamos que igualmente se tratam de obras de produção aprumada nos detalhes técnicos e na anatomia. A estaticidade dos gestos e a frontalidade das poses que caracteriza estas duas esculturas sugere a outra origem oficinal. 


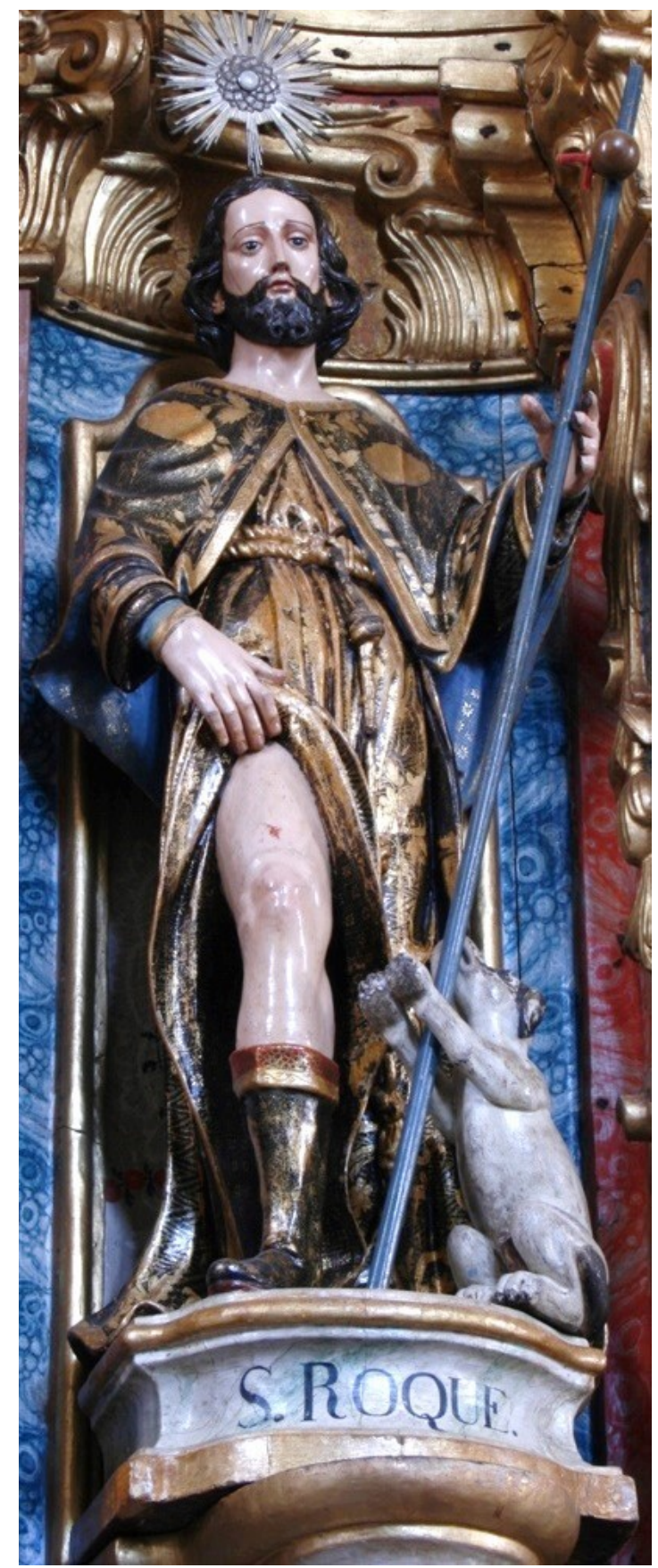

Imagem 99

Escultura de São Roque SFV 10

Retábulo no lado do Evangelho Igreja de São Francisco, Vinhais

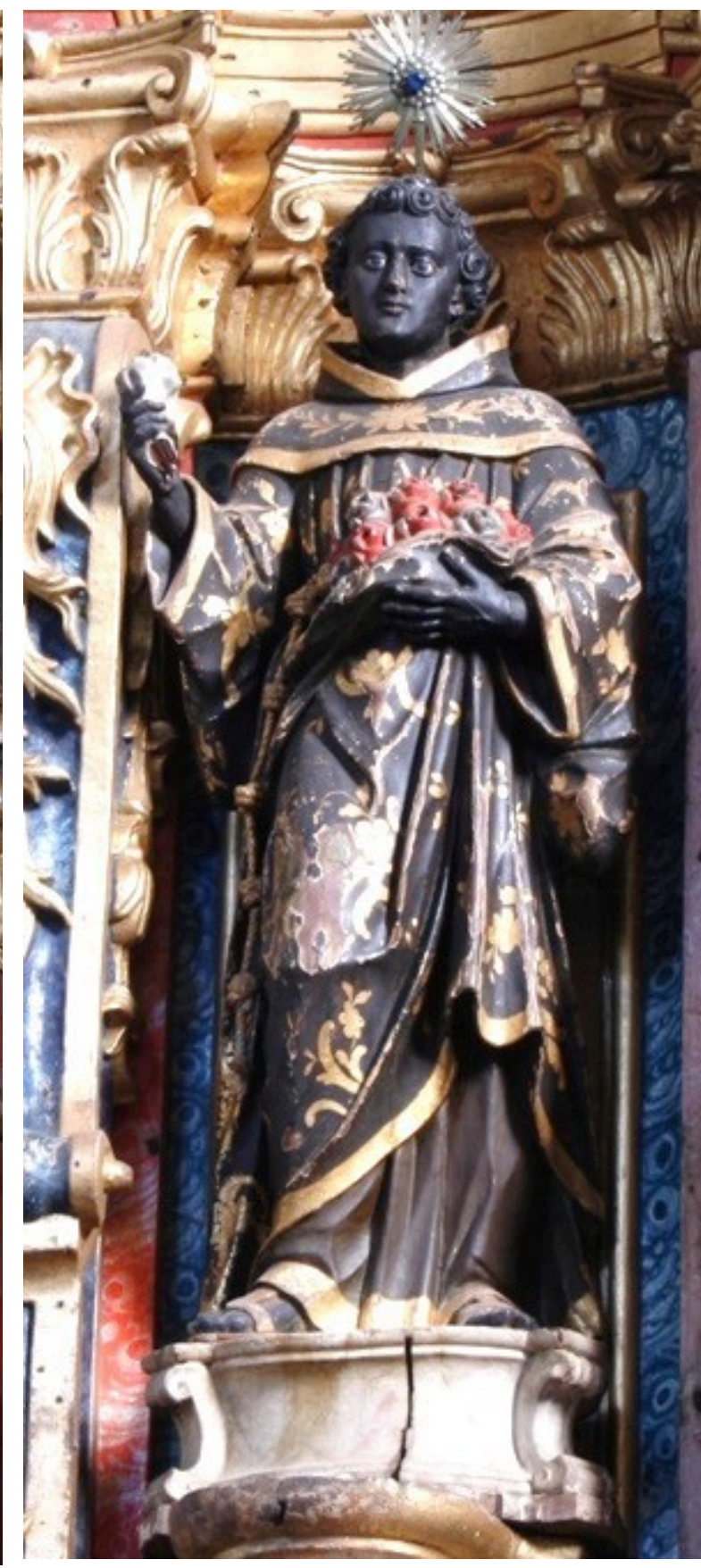

Imagem 100

Escultura de São Benedito de Palermo SFV 04

Retábulo no lado da Epistola Igreja de São Francisco, Vinhais

Ambas as esculturas denotam alguma rigidez no gesto, e os vincos regulares acentuam a estaticidade das formas, mas o cuidado anatómico e a séria expressão dos rostos denunciam uma talha cuidada decorrente de uma oficina bem apetrechada, podendo compartir procedência do Porto ou Braga, mas possivelmente de outra oficina. 
A imensa produção de encomenda que observamos na igreja de São Francisco de Vinhais expõe o poder aquisitivo da comunidade de irmãos terceiros, e sobretudo o acesso privilegiado aos mais variados modelos que na segunda metade do seculo XVIII ocuparam as oficinas nacionais.

No mesmo complexo franciscanos de Vinhais os vizinhos frades missionários também encomendavam obras a oficinas de trabalhos delicados nos panejamentos e ritmados no gesto, mas a escala da encomenda é significativamente menor. As figuras são em menor quantidade e em tamanho pequeno. Estão hoje, como em 1834 aquando do inventário após a extinção das ordens religiosas, colocadas no interior de um oratório com um Calvário ${ }^{139}$ lavrado ao centro de uma ornamentada talha na sacristia (Imagem 101) da igreja do seminário.

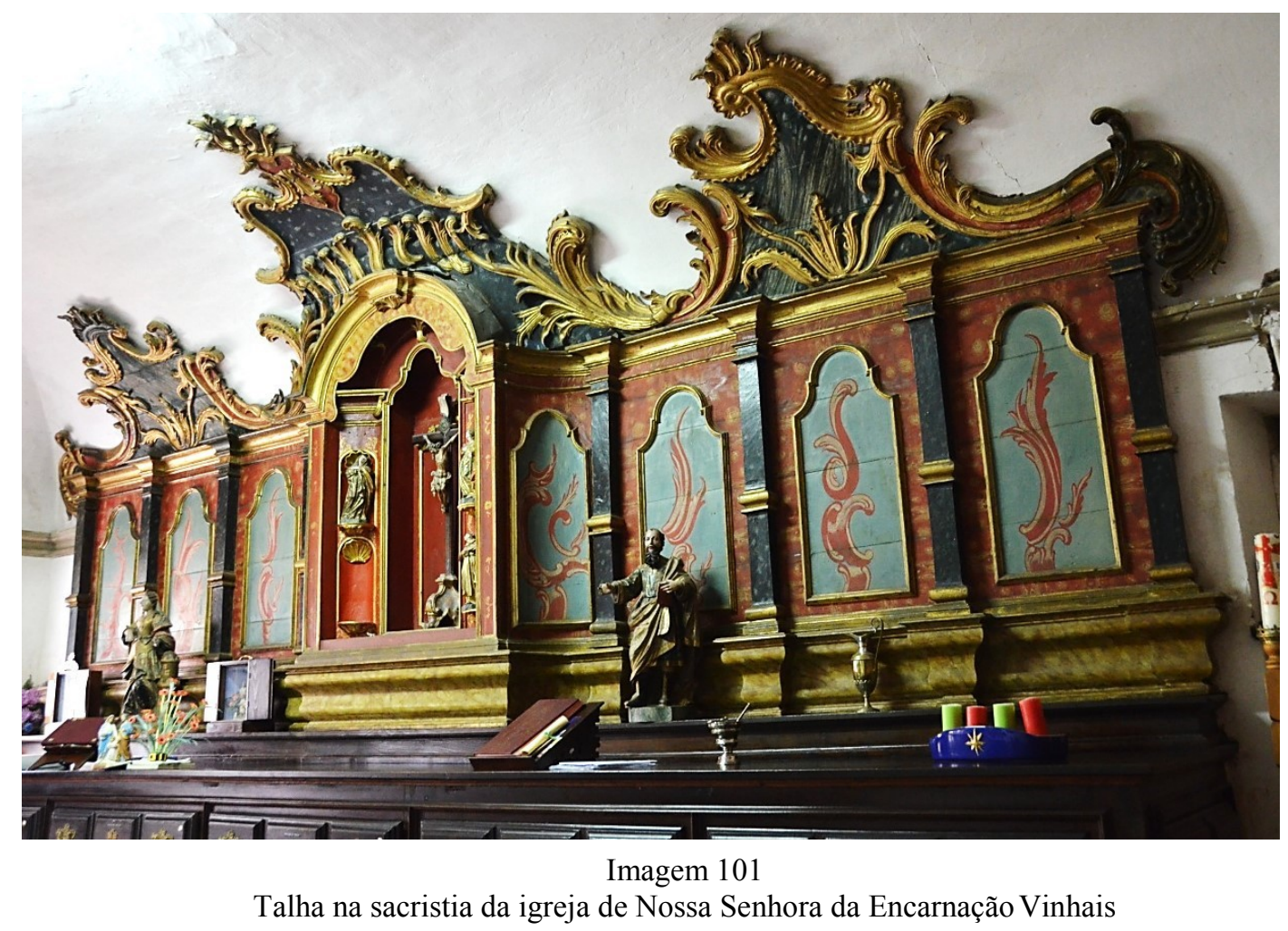

${ }^{139}$ Em 1996 o conjunto do Calvário registado no catálogo de Imagens e escultura de: Gomes, José Manuel (Coord.), Imagens e escultura. 1545-1995 Comemorações Jubilares dos 450 Anos da Diocese de Bragança - Miranda, Bragança, Departamento de Liturgia e Património Cultural da Diocese de Bragança - Miranda e Comissão de Arte Sacra, 1996, p. 34; apresentava no interior do oratório, além das figurinhas que ainda hoje se expõem, a escultura da Imaculada Conceição em Marfim MASV 05 que atualmente está exposta no Museu de Arte Sacra. 
As obras constituem um conjunto que representa o Calvário, além da imagem da Virgem Maria (Imagem 102), Cristo Crucificado ${ }^{140}$ (Imagem 103) e São João (imagem 104) existe também uma figurinha que representa São Domingos (Imagem 105). A imagem de São Domingos não constitui um elemento obrigatório na representação da cena do Calvário, mas, sabemos pelo inventário de 1834 que já então era parte do conjunto. Formalmente é evidente que as estatuetas que representam a Virgem, São João e São Domingos, se tratam de obras esculpidas na mesma oficina e no mesmo momento. Apesar dos repintes posteriores terem alterado significativamente as obras é ainda possível perceber o cuidado nos pregueados esvoaçantes e no dramatismo dos gestos.

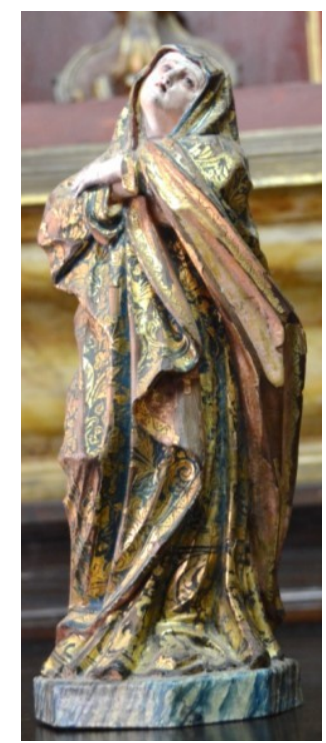

Imagem 102

Escultura de Nossa

Senhora no Calvário SIEV 04

Colocada dentro do oratório

Sacristia da

Igreja de Nossa

Senhora da

Encarnação, Vinhais

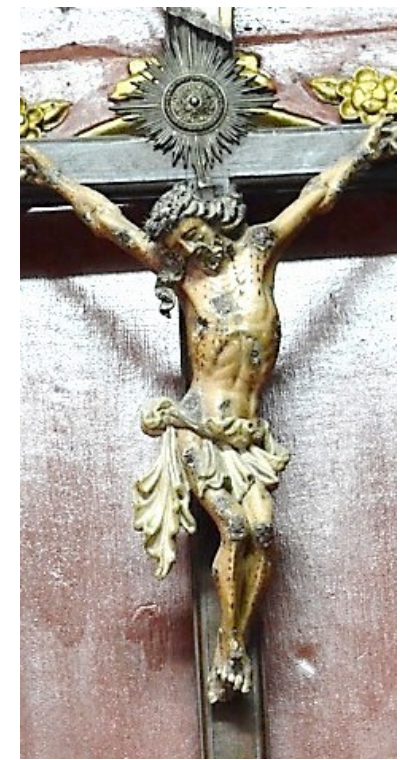

Imagem 103

Escultura de Cristo

Crucificado, Cruz de Altar

SIEV 05

Colocada dentro do oratório

Sacristia da

Igreja de Nossa Senhora

da Encarnação, Vinhais

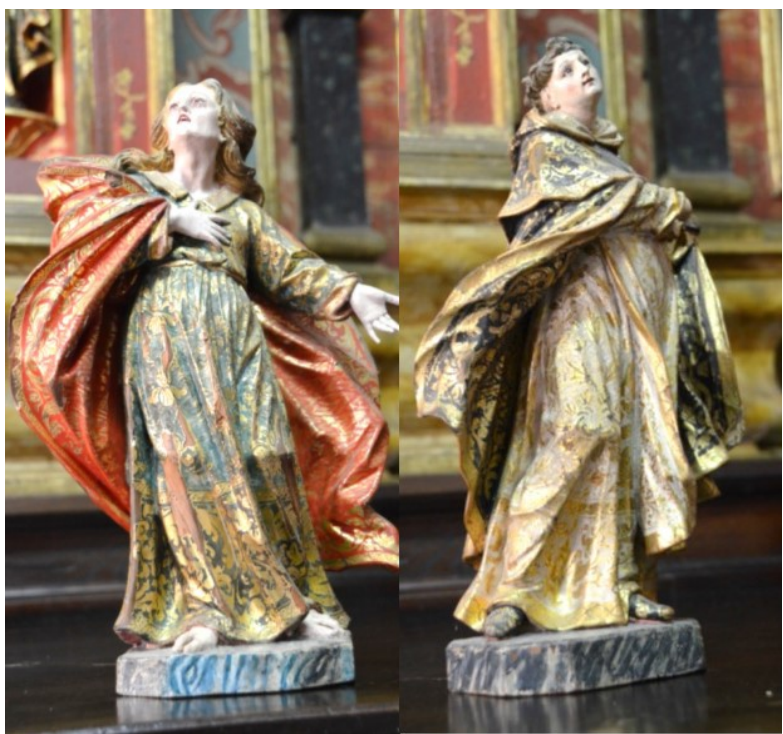

Imagem 104

Escultura de São João no Calvário SIEV 03

Colocada dentro do oratório

Sacristia da Igreja de Nossa Senhora da Encarnação, Vinhais
Imagem 105

Escultura de São

Domingos

SIEV 02

Colocada dentro do oratório

Sacristia da Igreja de Nossa Senhora da Encarnação, Vinhais

\footnotetext{
${ }^{140} \mathrm{~A}$ escultura de Cristo Crucificado surge registada no catálogo de Imagens e escultura com a datação do século XVII. Gomes, José Manuel (Coord.), Imagens e escultura. 1545-1995 Comemorações Jubilares dos 450 Anos da Diocese de Bragança - Miranda, Bragança, Departamento de Liturgia e Património Cultural da Diocese de Bragança - Miranda e Comissão de Arte Sacra, 1996, p. 11. No entanto, detalhes formais como o dinâmico pregueado do cendal e a torsão do corpo sugerem tratar-se de uma imagem já do século XVIII. No mesmo catálogo foi registado outro Crucifixo que atualmente se encontra no Museu de Arte Sacra (MASV 08) que ocupava em 1996 o nicho central do oratório com o Calvário.
} 
Relativamente à imagem que representa Cristo Crucificado temos dúvidas na filiação à mesma oficina das restantes imagens do Calvário na medida em que apresenta diferenças significativas no tratamento das vestes. Mas, a cronologia é semelhante e o gosto pelo dinamismo nas formas correspondente ao final do seculo XVIII.

O conjunto do Calvário, em escala de oratório é semelhante a outros conjuntos que se destacam no contexto da produção escultórica nacional (como o do Museu de Évora ${ }^{141}$ ). A produção é portuguesa e seriam várias as oficinas a talhar estes conjuntos. Mas o modelo foi repetido sem grandes alterações em Vinhais e Évora que apesar de separados no espaço seguiram o mesmo gosto.

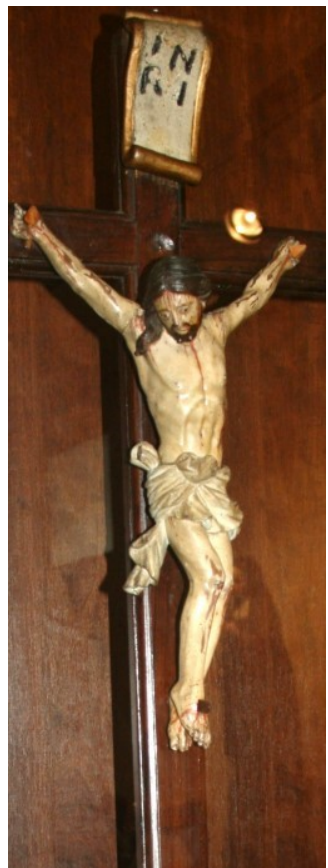

Imagem 106

Escultura de Cristo

Crucificado, Cruz de Altar MASV 06

Museu de Arte Sacra Vinhais

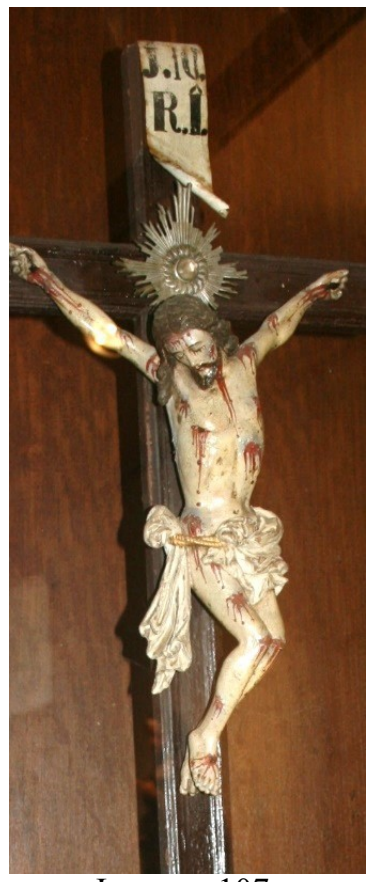

Imagem 107

Escultura de Cristo

Crucificado, Cruz de Altar MASV 07

Museu de Arte Sacra Vinhais

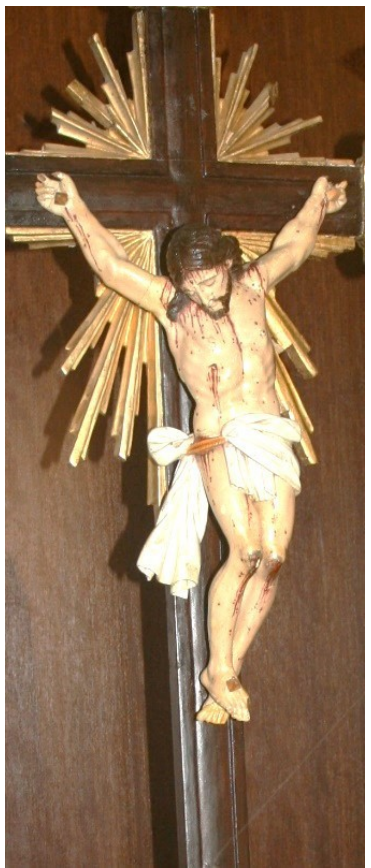

Imagem 108

Escultura de Cristo

Crucificado, Cruz de Altar

MASV 08

Museu de Arte Sacra Vinhais

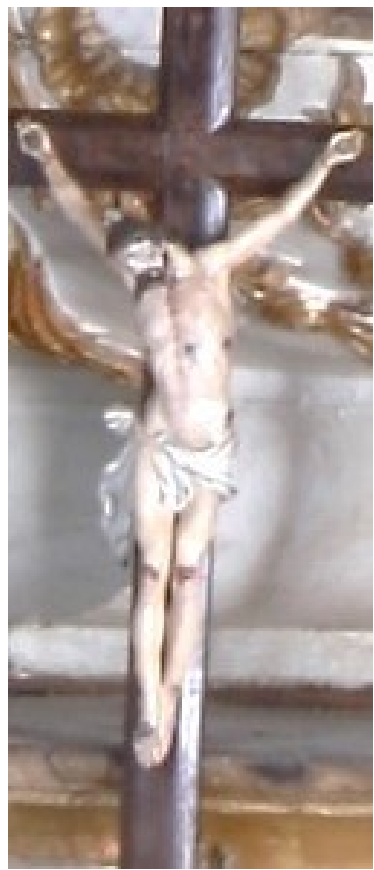

Imagem 109

Escultura de Cristo

Crucificado, Cruz de Altar SFV 13

Retábulo no altar-mor Igreja de São Francisco, Vinhais

Além da Cruz de Altar do oratório na sacristia existem mais quatro Cruzes de Altar em Vinhais que podiam ter originalmente ocupado o nicho central do oratório, pela

${ }^{141}$ Conforme pesquisa efetuada a 31 de março de 2015 na base de dados dos Museus da DGPC, (DireçãoGeral do Património Cultural, Departamento dos Bens Culturais, Divisão do Património Imóvel, Móvel e Imaterial, Palácio Nacional da Ajuda, Lisboa - Portugal).

http://www.matriznet.dgpc.pt/MatrizNet/Objectos/ObjectosConsultar.aspx?IdReg=13770 
proximidade formal e também cronológica. Três Cruzes de Altar estão contemporaneamente expostas no Museu de Arte Sacra (Imagem 106, 107 e $108^{142}$ ) e a quarta está sobre o supedâneo do retábulo do altar-mor na igreja de São Francisco da Ordem Terceira (Imagem 109).

Como se verificam várias alterações na localização das obras relativamente ao inventário de 1834 não surpreende que a Cruz do Calvário da sacristia tivesse também sido alterada. Neste sentido admitimos que outra Cruz de Altar, das que ainda chegaram aos nossos dias, poderia ter estado originalmente no oratório.

Todas as cruzes de altar apresentam um modelo semelhante, com a figura bem tratada anatomicamente e os panejamentos esvoaçantes. Os braços esticados intensamente oblíquos em relação ao corpo e apenas nas pernas se observam diversos graus de flexão, bem como de sinais de martírio. São obras bem cuidadas na talha que lhes deu forma sugerindo um trabalho oficinal de finais do seculo XVIII.

Destacamos já as imagens (MASV 07 e SIEV 05) como tendo sido os prováveis modelos para a escultura colossal de Cristo do Coro (CSDV 6) dadas as semelhanças observadas entre as esculturas, não obstante a diferença significativa da escala.

Do mesmo século e atualmente guardada no mesmo museu está uma figurinha de Nossa Senhora da Imaculada Conceição em marfim ${ }^{143}$ (Imagem 110). O material em que está esculpida remete a sua produção escultórica, desde o início da expansão marítima portuguesa, para uma produção oriental ou indo-portuguesa.

A figura não apresenta elementos da anatomia oriental. O rosto, grande e oval tem os olhos amplos e as linhas bem vincadas. A circulação de pequenas figuras em marfim era comum em Portugal desde o seculo XVII. O sumário drapeado curvilíneo da escultura do Museu de Arte Sacra de Vinhais remete a obra já para o século XVIII, as

\footnotetext{
${ }^{142}$ A escultura de Cristo Crucificado surge registada no catálogo de Imagens e escultura de Gomes, José Manuel (Coord.), Imagens e escultura. 1545-1995 Comemorações Jubilares dos 450 Anos da Diocese de Bragança - Miranda, Bragança, Departamento de Liturgia e Património Cultural da Diocese de Bragança - Miranda e Comissão de Arte Sacra, 1996, p. 34; no nicho central do Calvário da sacristia da igreja de Nossa Senhora da Encarnação, em conjunto com as imagens de Nossa Senhora, São João e São Domingos e a Imaculada Conceição em Marfim.

${ }^{143}$ A escultura de Nossa Senhora da Imaculada Conceição em marfim surge registada no catálogo de Imagens e escultura com a datação do século XVI. Gomes, José Manuel (Coord.), Imagens e escultura. 1545-1995 Comemorações Jubilares dos 450 Anos da Diocese de Bragança - Miranda, Bragança, Departamento de Liturgia e Património Cultural da Diocese de Bragança - Miranda e Comissão de Arte Sacra, 1996, p. 6. No entanto, o ondulado dos panejamentos sugerem tratar-se de uma imagem já do século XVIII.
} 
proximidades formais com a figurinha do Museu Alberto Sampaio ${ }^{144}$ de Guimarães permitem supor o mesmo modelo, apesar da escultura de Guimarães apresentar um trabalho mais cuidado

. O inventário de 1834 registava uma imagem de Nossa Senhora da Encarnação e três crucifixos em marfim na igreja de Nossa Senhora da Encarnação do Seminário Apostólico de Vinhais, mas só este exemplar chegou aos nossos dias ${ }^{145}$. A iconografia que apresenta remete-nos para o culto da Imaculada Conceição o que dificulta a correspondência com a imagem inventariada em 1834 de Nossa Senhora da Encarnação. Pode, no entanto, ter-se tratado de uma incorreta identificação por parte do inventariante de 1834 ou pode simplesmente a proximidade narrativa ter gerado confusão na designação da figurinha de marfim. A incerteza dos encomendadores e da proveniência permitem apenas comparar a imagem com outros exemplares, aproximando-a da produção oriental do seculo XVIII.

A imensa produção registada em Vinhais, (que compreende os espaços da: Igreja de

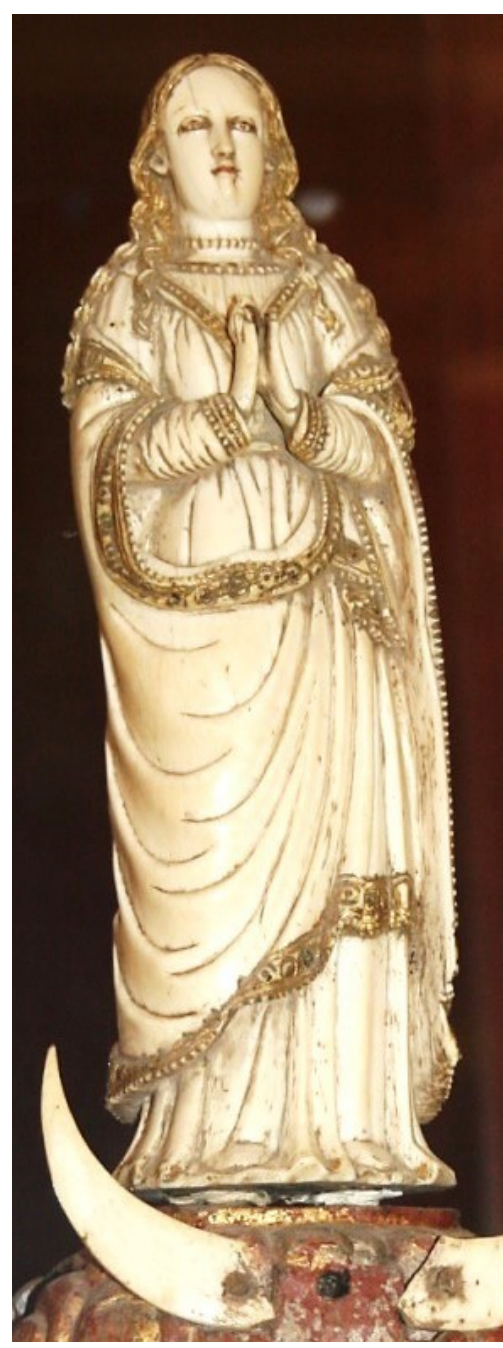

Imagem 110

Escultura de Nossa Senhora da Imaculada Conceição MASV 05

Museu de Arte Sacra Vinhais Nossa Senhora da Encarnação do seminário Apostólico; capela das Dores; capela da Oração no Horto; capela do Senhor do Monte; Igreja de São Francisco da Ordem Terceira; Museu de Arte Sacra), deixa claro o cenário

\footnotetext{
${ }^{144}$ Conforme pesquisa efetuada a 31 de março de 2015 na base de dados dos Museus da DGPC, (DireçãoGeral do Património Cultural, Departamento dos Bens Culturais, Divisão do Património Imóvel, Móvel e Imaterial, Palácio Nacional da Ajuda, Lisboa - Portugal).

http://www.matriznet.dgpc.pt/MatrizNet/Objectos/ObjectosConsultar.aspx?IdReg=6387

${ }^{145}$ Em pesquisa on-line de imagens (a 31-03-2015) destaca-se a quantidade de figuras religiosas de marfim desafetas ao culto e anunciadas para venda nas leiloeiras nacionais. Este interesse comercial não se verifica com a restante imaginária em madeira o que pode justificar a alienação quase integral das esculturas de marfim outrora existentes no Seminário Apostólico de Vinhais.
} 
de permanente estaleiro de obras e o frenesim de encomendas, sobretudo pela Ordem Terceira, que decorreu na segunda metade do seculo XVIII.

Contemporaneamente nos restantes espaços franciscanos em estudo o ímpeto artístico era bem mais contido. Por oposição destacamos o convento de São Francisco em Mogadouro. Neste templo registamos algumas obras, cuja produção se correspondia com os modelos da primeira metade do seculo XVIII, de oficinas com formação no cuidado do movimento do gesto e nos pormenores de anatomia. Mas, na segunda metade do seculo XVIII o templo de Mogadouro recebeu apenas obras de oficinas regionais ou locais. Este facto parece-nos decorrente da ruina e condena à morte de muitos dos membros da principal família de benfeitores do convento. O suplício dos Távoras imposto aos sentenciados em 1759 por exigência do Marques de Pombal ${ }^{146}$ não pode ser afastado desta realidade depauperada observada no convento de São Francisco em Mogadouro.

Houve na segunda metade do século XVIII produção de esculturas de vulto para o convento de Mogadouro mas trataram-se de encomendas de cariz mais ingénuo afetas a oficinas regionais ou locais.

A presença de Francisco António da Silva ${ }^{147}$, natural de Mogadouro e que foi o responsável em 1771 pelo retábulo da igreja de Urrós e em 1797 do retábulo da igreja matriz de Mogadouro revela que localmente existia um escultor (ou uma oficina) que dominava a linguagem ornamental do rococó e com capacidade de satisfazer a demanda local. Também o nome de José Teixeira surge numa escritura ${ }^{148}$ como mestre da vila de Mogadouro que em 1794 se comprometia a fazer os retábulos colaterais da igreja matriz de Larinho (Torre de Moncorvo), um ano após ter feito o retábulo da igreja matriz de Sendim da Ribeira em Alfandega da Fé ${ }^{149}$. Na escritura dos retábulos de Moncorvo está patente a diferenciação profissional entre entalhador e escultor na medida em que se referem trabalhos que "serão feitos o que pertence a escultor por mão destra e o que pertence a intalhador por mão de intalhador”. Não obstante a continuada omissão da

\footnotetext{
${ }^{146}$ Monteiro, Nuno Gonçalo, "Poder Senhorial, estatuto nobiliárquico e aristocracia" in José Mattoso, História de Portugal, Vol. 4, Lisboa, Círculo de Leitores, 1993, pp. 333-379.

${ }^{147}$ Rodrigues, Luís Alexandre, Arte da talha dourada e policromada no Distrito de Bragança. Documentos. Séculos XVII-XVIII, Mirandela, João Azevedo Editor, 2005, pp. 143-157.

${ }^{148}$ Rodrigues, Luís Alexandre, Arte da talha dourada e policromada no Distrito de Bragança. Documentos. Séculos XVII-XVIII, Mirandela, João Azevedo Editor, 2005, p. 176.

${ }^{149}$ Rodrigues, Luís Alexandre, Arte da talha dourada e policromada no Distrito de Bragança. Documentos. Séculos XVII-XVIII, Mirandela, João Azevedo Editor, 2005, p. 35.
} 
imaginária na documentação relativa às escrituras retabulares é evidente neste documento a crescente preocupação por parte dos encomendadores com a qualidade das obras escultóricas.

Desconhece-se a formação de Francisco António da Silva bem como de José Teixeira, sabemos apenas que eram ambos entalhadores, contemporâneos e moravam em Mogadouro. Próximo, mas já no termo de Miranda do Douro era registado o entalhador José Fernandes do lugar de São Martinho numa escritura de $1787^{150}$ relativa ao retábulo da capela-mor da igreja matriz de São Joanico. Estes dados revelam a crescente proliferação de entalhadoreslescultores decorrente do aumento significativo de encomendas em talha.

As irregularidades anatómicas e os panejamentos forçados no seu movimento vinculam as obras escultóricas da segunda metade de setecentos do convento de Mogadouro mais com a produção local que com a produção cuidada do Porto e Braga que se pode observar em produções coevas noutros espaços franciscanos do mesmo território (neste contexto destaca-se a igreja da Ordem Terceira em Vinhais).

Desta produção local é seguramente a escultura de São Domingos de Gusmão (Imagem 111). Com um grosso e

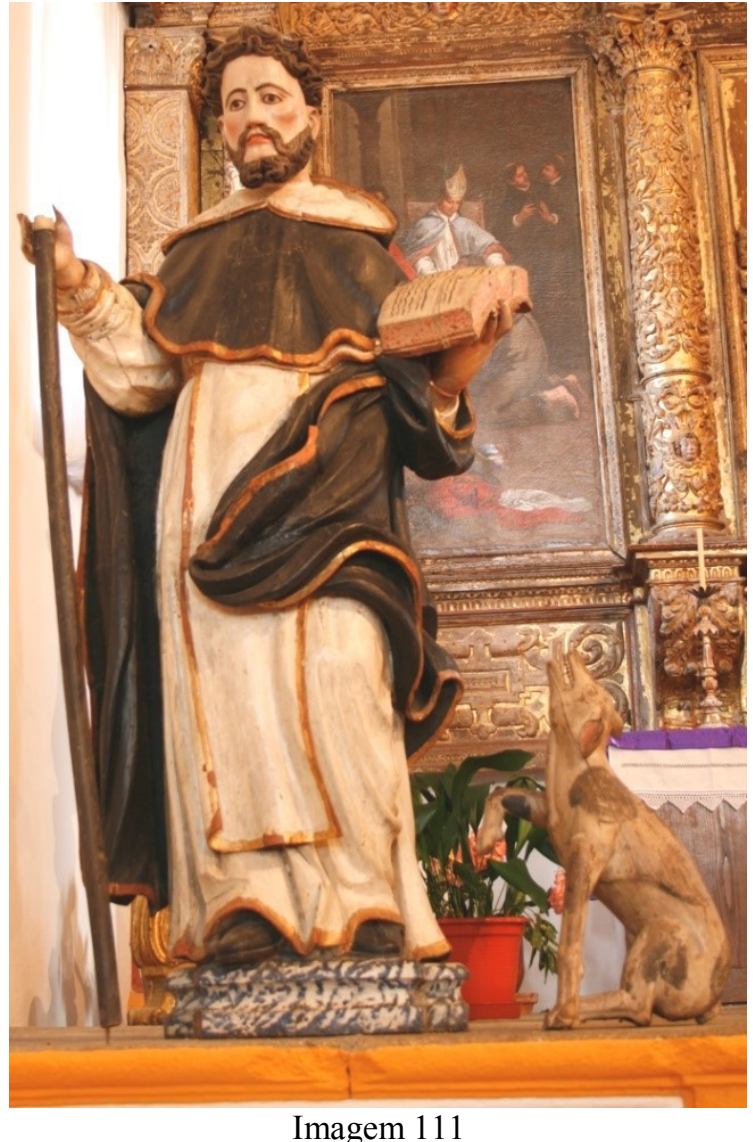

Escultura de São Domingos de Gusmão - SFM 08 Capela-mor no lado do evangelho, Igreja de São Francisco Mogadouro artificialmente dinâmico pregueado nos panejamentos, o santo tonsurado apresenta uma expressão grave com a boca entreaberta de cantos descaídos, barbas detalhadamente encaracoladas e os olhos pintados. Quer a ausência de postiços, como os olhos de vidro, quer a espessura do

150 Rodrigues, Luís Alexandre, Arte da talha dourada e policromada no Distrito de Bragança. Documentos. Séculos XVII-XVIII, Mirandela, João Azevedo Editor, 2005, p. 190. 
pregueado denotam um fraco domínio das técnicas já amplamente difundidas na segunda metade do século XVIII.

A imagem está atualmente na capela-mor no lado do Evangelho, equilibrada no lado da Epistola pela representação de São Francisco, que apesar de anterior revela um trabalho escultórico bastante mais aprumado. Ambas surgem no inventário de $1834 \mathrm{e}$ igualmente expostas dentro da capela-mor. Mas é evidente que foram esculpidas em momentos diferentes e por autores com recursos técnicos e artísticos muito desiguais.

Com um gosto ingénuo ainda mais acentuado são as esculturas de Santo António com o Menino (Imagem 112) e São Pedro (Imagem 113) que sugerem ter sido produzidas na segunda metade do século XVIII e pelas mesmas mãos.

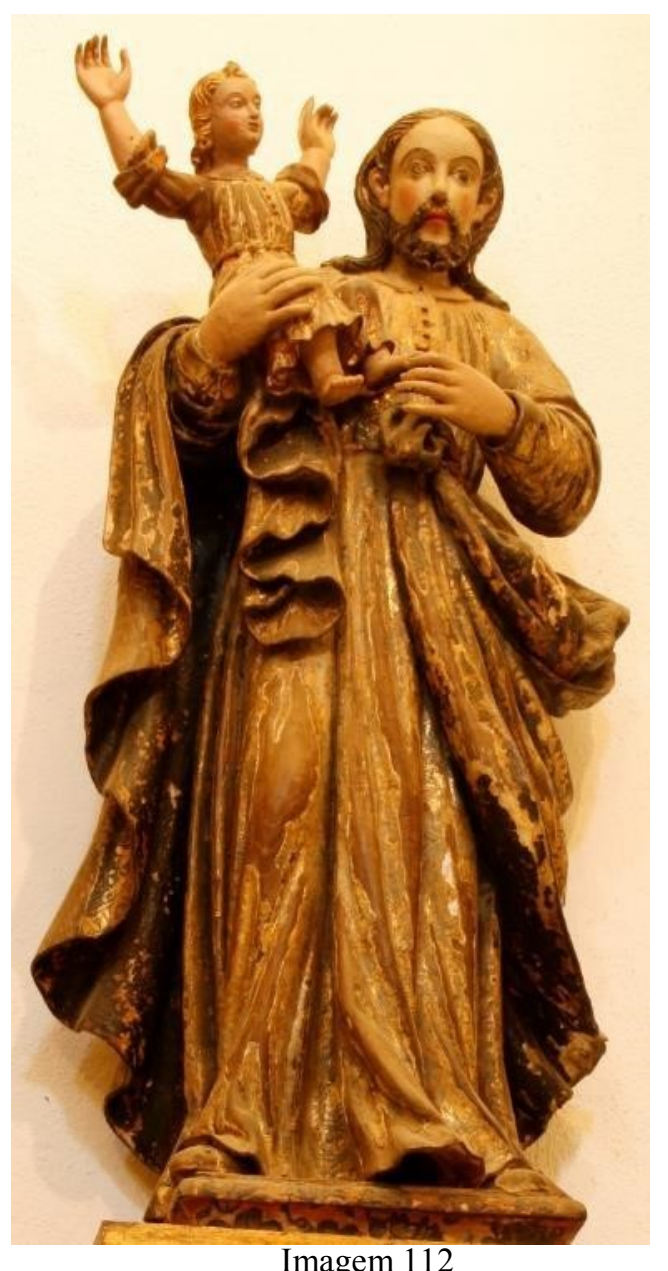

Escultura de São José - SFM 02, retábulo no lado da Epistola Igreja de São Francisco Mogadouro

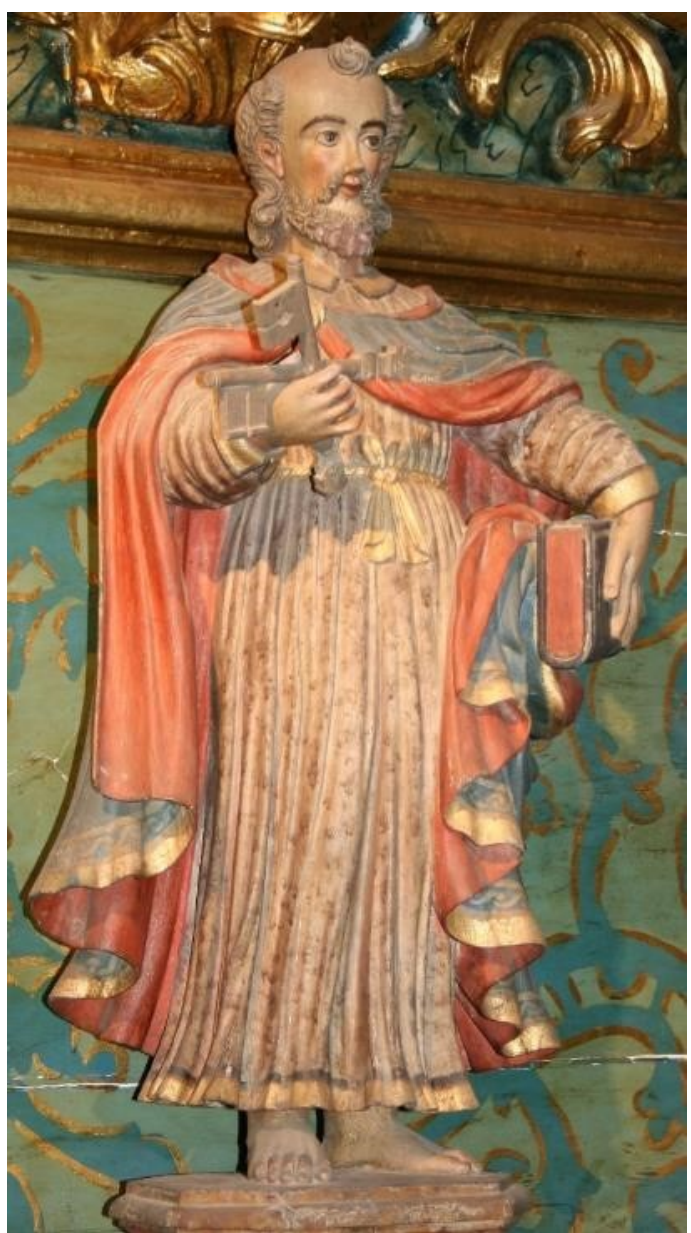

Imagem 113

Escultura de São Pedro - SFM 14, retábulo no lado do Evangelho

Igreja de São Francisco Mogadouro 
Salvo pelo dinamismo imposto no ondeado das vestes assimétricas ambas as imagens suscitam alguma ingenuidade relativamente aos modelos escultóricos então divulgados. Podemos por isso depreender a produção local, ou pelo menos a produção afastada dos meios onde o rigor do desenho mais se impunha. A anatomia das cabeças das figuras apresenta-se com diversas irregularidades, sobretudo no tratamento dos rostos. A gestualidade é forçada e frágil no naturalismo.

A figura que representa São José é de maior escala que a estatueta que representa São Pedro. Em ambas se destacam os atributos identitários dos santos bem definidos assumindo uma linguagem mais catequética que estética. As semelhanças no ondulado dos panejamentos divergentes, nas irregularidades dos contornos do rosto, nas bocas pequenas e nos minuciosos enrolamentos dos cabelos e barbas parecem ilustrar as mesmas conceções escultóricas de demarcada ingenuidade.

Também nas representações de Nossa Senhora da Imaculada Conceição (Imagem 114) e de Nossa Senhora da Lapa (Imagem 115) se percebem semelhanças formais. Os vincados pregueados regulares, a densa sobreposição dos folhos nas capas de ambas as imagens denunciam o mesmo arcaísmo técnico. Os gestos contidos e o sumário tratamento dado nos detalhes anatómicos sugerem também uma produção local ou regional, pouco cuidadosa e com pouco acesso aos materiais e técnicas decorrentes da segunda metade do seculo XVIII em que parecem ter sido produzidas.

A imagem de Nossa Senhora da Conceição é de maior tamanho e está adossada ao retábulo maneirista lateral ${ }^{151}$.

A imagem de Nossa Senhora da Lapa é de pequeno tamanho e foi movida do local onde em 1834 foi registada. As proximidades ao modelo que está hoje a culto na capela de Nossa Senhora da Lapa ${ }^{152}$ na igreja dos Clérigos do Porto são evidentes.

\footnotetext{
${ }^{151}$ Mourinho refere que se trata de uma escultura maneirista do século XVII, ver: Mourinho (Júnior), António Rodrigues, A talha nos concelhos de Miranda do Douro, Mogadouro e Vimioso nos séculos XVII e XVIII, Braga, Associação de Municípios do Planalto Mirandês, 1984, pp. 54, 55. No entanto apesar do retábulo que a expõe sugerir essa datação, a escultura parece-nos posterior, pelo gesto e pelo ondulado dos panejamentos.

${ }^{152}$ A imagem de Nossa Senhora da Lapa foi feita por mestre Custódio, custou 11\$200 reis e foi colocada num retábulo, feito por Luís Pinto, que custou 57\$600 reis, em Janeiro de 1756, conforme consta na página da Irmandade dos Clérigos, Porto. Acedida a 20 de maio de 2015 http://www.torredosclerigos.pt/pt/historia/senhora-da-lapa
} 


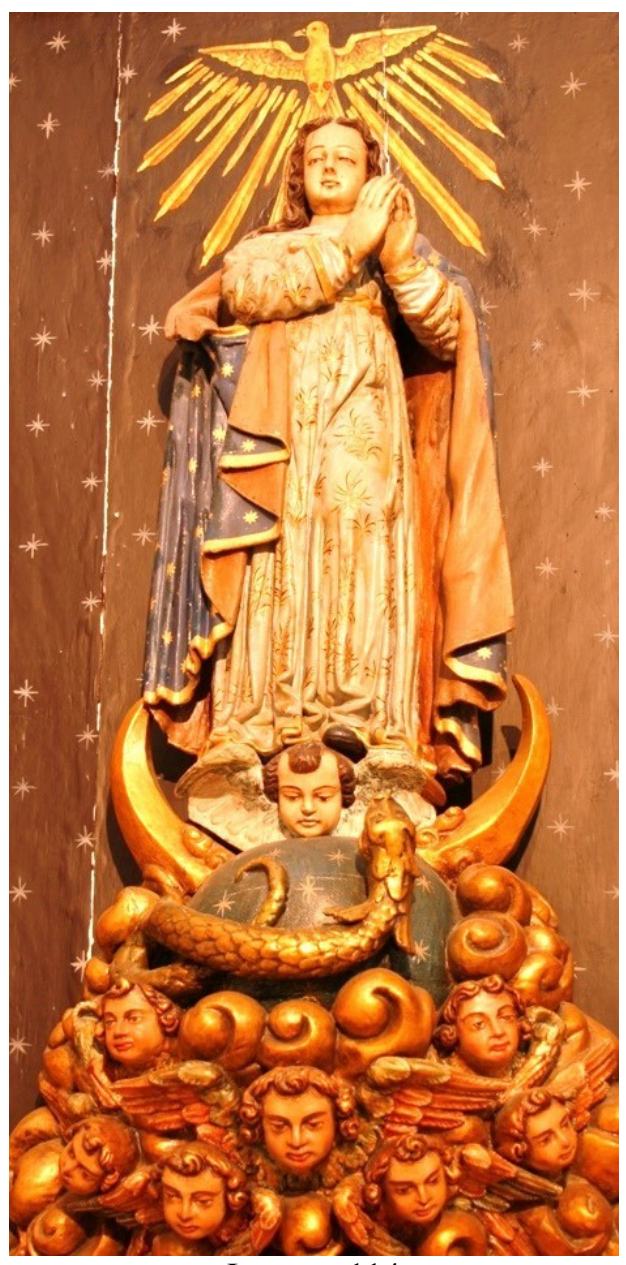

Imagem 114

Escultura de Nossa Senhora da Imaculada Conceição SFM 09, retábulo no lado do Evangelho Igreja de São Francisco Mogadouro

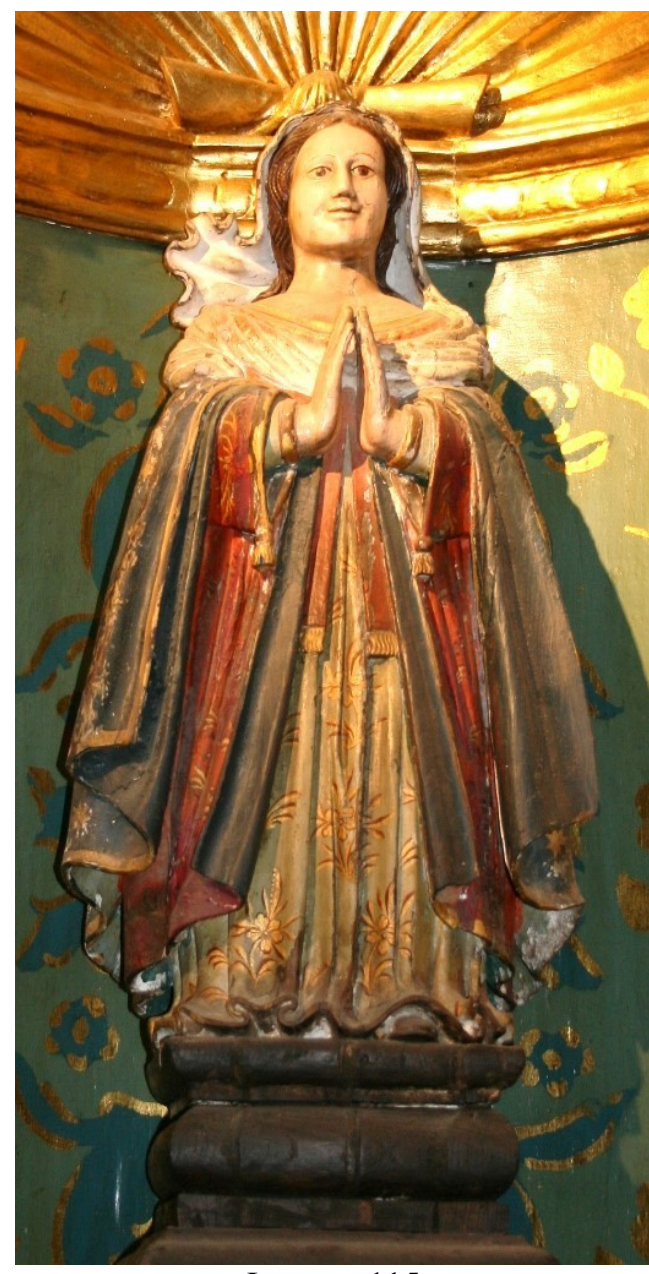

Imagem 115

Escultura de Nossa Senhora da Lapa - SFM 12, retábulo no lado do Evangelho Igreja de São Francisco Mogadouro

O gesto de oração é o elemento que individualiza as imagens cujos rostos e expressões são idênticos. A assimetria das mãos postas lateralmente na escultura de Nossa Senhora da Imaculada Conceição não é suficiente para quebrar a estaticidade da figura que se destaca sobretudo pela profusa narrativa iconográfica dos atributos que a identificam.

Também nos conventos de São Francisco e Santa Clara de Bragança se observa uma diminuição na encomenda de obras oficinais no final do século XVIII. Se no início da segunda metade do século o convento dos frades menores recebeu o importante conjunto das imagens de Cristo (com o braço pendente) no abraço místico a São Francisco e a imagem de Santa Clara bem como a singular escultura de Cristo Alado, nos finais da centúria o ímpeto por novas imagens foi travado. 
De vulto inteiro e tamanho grande apenas a imagem de Nossa Senhora da Imaculada Conceição (Imagem 116) foi encomendada. Os repintes posteriores dificultam a compreensão da obra, mas a tensão atmosférica sugerida pelos esvoaçantes panejamentos vinculam a obra com uma oficina nacional de talha cuidada dos finais da centúria de setecentos. A assimetria no gesto enfatiza o ritmo das vestes. O rosto delicadamente arredondado e cuidado na expressão tem olhos em vidro.

A imagem está colocada sobre a tribuna do nicho central do retábulo da capela com a mesma invocação. A capela apresenta no teto, de abobada de canhão, uma pintura em perspetiva, representando ao centro entre arquiteturas fingidas, Nossa Senhora da Imaculada Conceição e os diversos atributos iconográficos que consolidam o culto. A

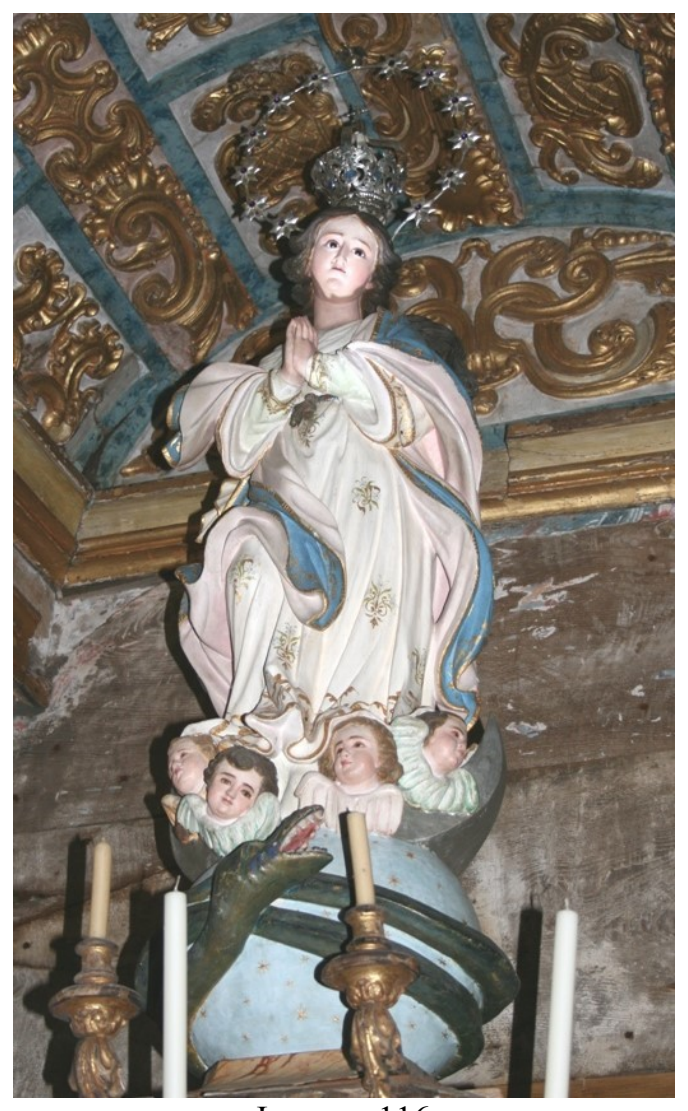

Imagem 116

Escultura de Nossa Senhora da Imaculada Conceição SFB 08 .

Sobre a tribuna do retábulo da Capela de Nossa Senhora da Imaculada Conceição, no lado do Epistola Igreja de São Francisco Bragança devoção a Nossa Senhora da Imaculada Conceição está registada no convento de Bragança desde o início do século XVIII $^{153}$. Mas a transformação integral da capela, com a pintura do teto, a talha do retábulo e da imagem de vulto que materializa a devoção, foram obra já de finais do seculo XVIII.

A obra terá coincidido sensivelmente com o momento da implementação da sede do bispado em Bragança, iniciada em 1763, e consequente abandono de Miranda do Douro onde tinha sede a diocese desde 1545 .

Este facto não justifica a intervenção artística integral observada na capela de Nossa Senhora da Imaculada Conceição, pois a relativa autonomia dos conventos desvinculava-os em parte das transições no clero secular.

\footnotetext{
${ }^{153}$ Borges, José Cardoso, Memórias de Bragança, Fernando de Sousa (Coord.), Bragança, CEPESE / Câmara Municipal de Bragança, 2012 (texto original de 1721-1724), p. 147.
} 
No entanto, a transferência da sede de bispado acarretava consigo a transferência social que lhe estava afeta, e nesse sentido poder-se-á supor que Bragança recebeu então novo alento social, mas também económico, intelectual e artístico.

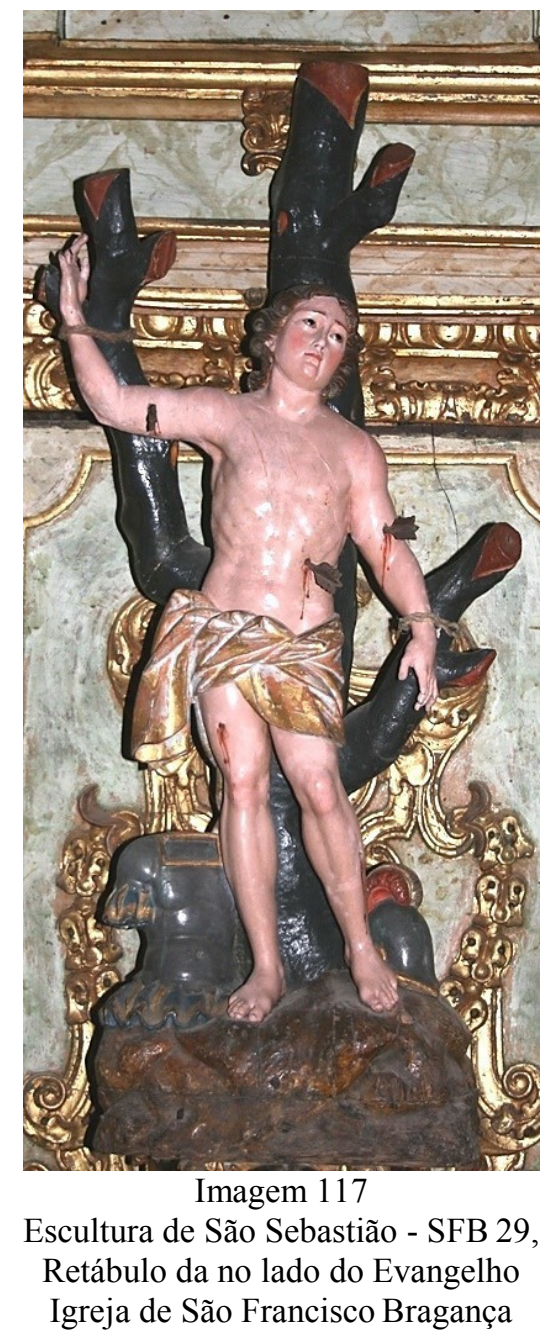

Com vários atributos iconográficos está representada a escultura de São Sebastião (Imagem 117) em tamanho pequeno. A imagem de São Sebastião com os braços assimetricamente afastados do corpo apresenta-se apenas coberta com um ligeiro panejamento cingido na cintura com vincos largos e denso drapeado.

Está martirizado com cinco flechas que lhe perfuram o corpo donde escorre sangue no torso, braços e pernas, as duas flechas das pernas já estão desaparecidas restando apenas os orifícios do martírio. O dramatismo do sofrimento é enfatizado pelo contraste com a expressão doce do rosto de delicados traços, com olhos de vidros que elevam o olhar. $\mathrm{O}$ cabelo, curto, é castanho e está esculpido com largas ondas. De forte carga dramática o corpo nu, martirizado, está representado com algum cuidado na anatomia e proporções e o ritmo assimétrico denuncia uma produção oficinal nacional também cuidada, dos finais do século XVIII. 
De tamanho pequeno, vinculada com uma produção cuidada encontramos também a imagem que representam São Roque (Imagem 118). O repinte aplicado sobre a policromia limita a compreensão da obra. Com olhos de vidro e atenção anatómica a imagem é equilibrada no gesto, apenas quebrado pela ligeira assimetria nos braços e inclinação da cabeça. A expressão serena e o gesto tranquilo aproximam a figura de valores de contenção emocional focalizando a narrativa da imagem nos atributos iconográficos, do cão que lambe a chaga.

O museu de Arte Sacra de Vinhais guarda uma estatueta (Imagem 119) cuja identificação não nos foi possível definir. De demarcado gosto ingénuo, a

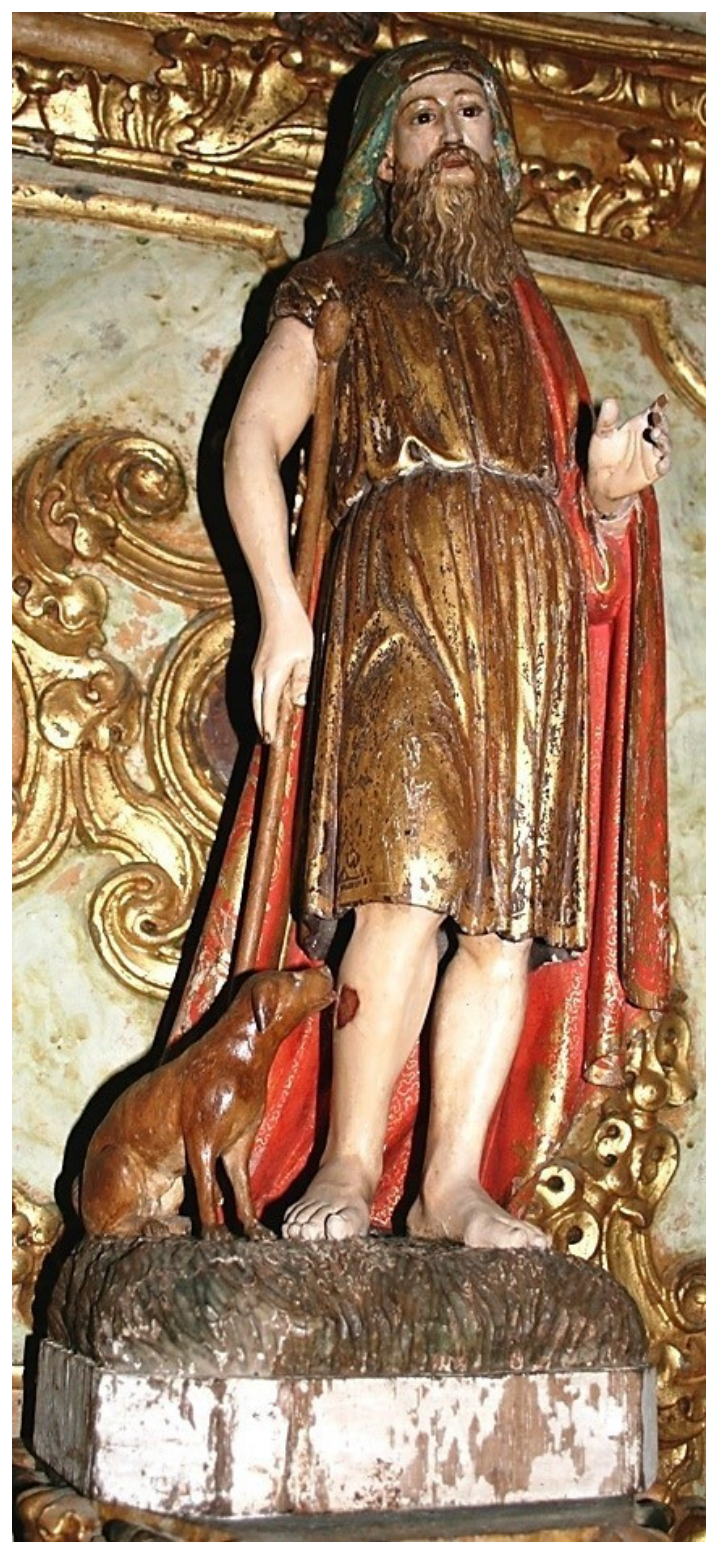

Imagem 118

Escultura de São Roque - SFB 28 Retábulo no lado do Evangelho Igreja de São Francisco Bragança escultura apresenta lacuna dos braços, e com eles dos atributos que permitiam a sua identificação. A presença da coroa e a referência no inventário de 1834 a duas imagens de Santa Bárbara sugere poder tratar-se da santa mártir, mas na dúvida mantemos a interrogação. A produção da estatueta, pela ornamentação do traje e pregueado dos panejamentos julgamos ser da segunda metade do século XVIII, o sumário tratamento anatómico e inexpressividade no rosto sugere ser uma produção local ou regional. 


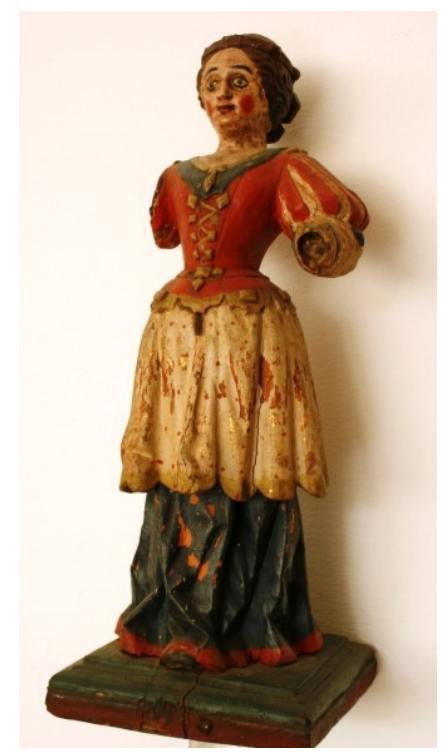

A par das várias imagens de vulto redondo talhadas em madeira ao longo da segunda metade do século XVIII, encontramos também, no convento de Bragança, no de Mogadouro e no seminário de Vinhais, várias imagens de roca ou de vestir.

A pastoral do Bispo D. Frei João da Cruz de 1755, recentemente publicada por Prada, é incisiva em relação à proibição de imagens de vestir.

"E como também achamos em varias freguezias muytas imagens de Nossa Senhora, e outras santas, e tambem de alguns santos de vestir com camizas de mangas grandes, cabelleyras postiças, e muyto infeytadas com muytas fittas, maravalhas, e outras couzas muyto alheas do verdadeyro ornato das sagradas imagens e muytas e repetidas vezes reprobadas pella Sagrada Congregação dos Rittos, e decretos ponteficios, em que se prohibe todo o vestido, e ornato postiço em que as imagens de Christo, de Maria Santissima, e dos mais santos: Mandamos que daqui por diante nenhuma pessoa mande fazer imagens de vestir, nem o parocho as admita na sua igreja, nem outra imagem alguma sem certidão de que esta benta por nos, ou pessoa da nossa comissão, cuja certidão se appresentara em visita a nos ou nossos visitadores, os quaes se acharem alguma de novo posta na igreja, e não se lhe apresentar a ditta certidão a mandarão logo tirar, o parocho será condemnado em pena de dous mil reis aplicados na forma da nossa constituição. E para que as antigas se reformem na forma dos ditos decretos lhe concedemos, e determinamos o espaço de três anos, para que com mais commodidade as possão mandar 
fazer de novo todas de talha bem dourada, e estufada, e ellas bem feytas tudo por bons mestres, e nas partes donde milhor as fazem, e com olhos de cristal para mayor formosura das ditas imagens; e para que com mais zello o promova, e os fiéis, e freguezes concorrão com suas esmolas, e deligencias para a factura das ditas imagens, lhes concedemos por cada esmola, ou deligencia, com que para isso concorrem, quarenta dias de indulgencia stando verdadeyramente contritos, e arrependidos de seos peccados ${ }^{154}$,

Parte da imposição do bispo D. Frei João da Cruz foi acatada pois observa-se, na segunda metade do século XVIII, um claro compromisso no incremento de encomenda de obras nas oficinas onde melhor se executavam, com olhos de vidro, em talha dourada e estufada.

No entanto, a presença de sete imagens de vestir nos espaços em estudo, formalmente próximas dos modelos da segunda metade do seculo XVIII, denotam mais que um simples desvio à pastoral imposta pelo bispo. A devoção cultual a que as imagens estavam expostas é certamente o fator de maior peso para a sua persistência. A relação destas imagens com as práticas processionais é também um fator relevante e de intensificação da devoção. Mas, devemos atender também ao facto de por serem talhadas apenas na cabeça e mãos suporem um valor de produção consideravelmente mais baixo que o valor de uma imagem de vulto pleno.

De todas as imagens de roca inventariadas nesta cronologia a que mais elementos retém relativos à sua devoção é a imagem de Nossa Senhora das Dores (Imagem 119). Guardada dentro de uma maquineta com portas de vidro na capela de Nossa Senhora das Dores, no lado do Evangelho, da igreja de Nossa Senhora da Encarnação do Seminário Apostólico de Vinhais.

\footnotetext{
${ }^{154}$ Além do decoro das imagens as Pastorais dos Bispos eram severas no controle das festividades e dos comportamentos dos fiéis no decurso das cerimónias religiosas. Castro, José de, Bragança e Miranda, (Bispado) Tomo II, Porto, Tipografia Porto Médico, Lda , 1947, pp. 329, 330; Castro, José de, Bragança e Miranda, (Bispado) Tomo III, Porto, Tipografia Porto Médico, Lda , 1948, p. 269; Castro, José de, Bragança e Miranda, (Bispado) Tomo IV, Porto, Tipografia Porto Médico, Lda, 1951, p. 132; Prada de Oliveira, Carlos, Pastorais dos Bispos de Miranda do Douro e Bragança, Bragança, Câmara Municipal de Bragança, 2011, pp. 123, 124.
} 


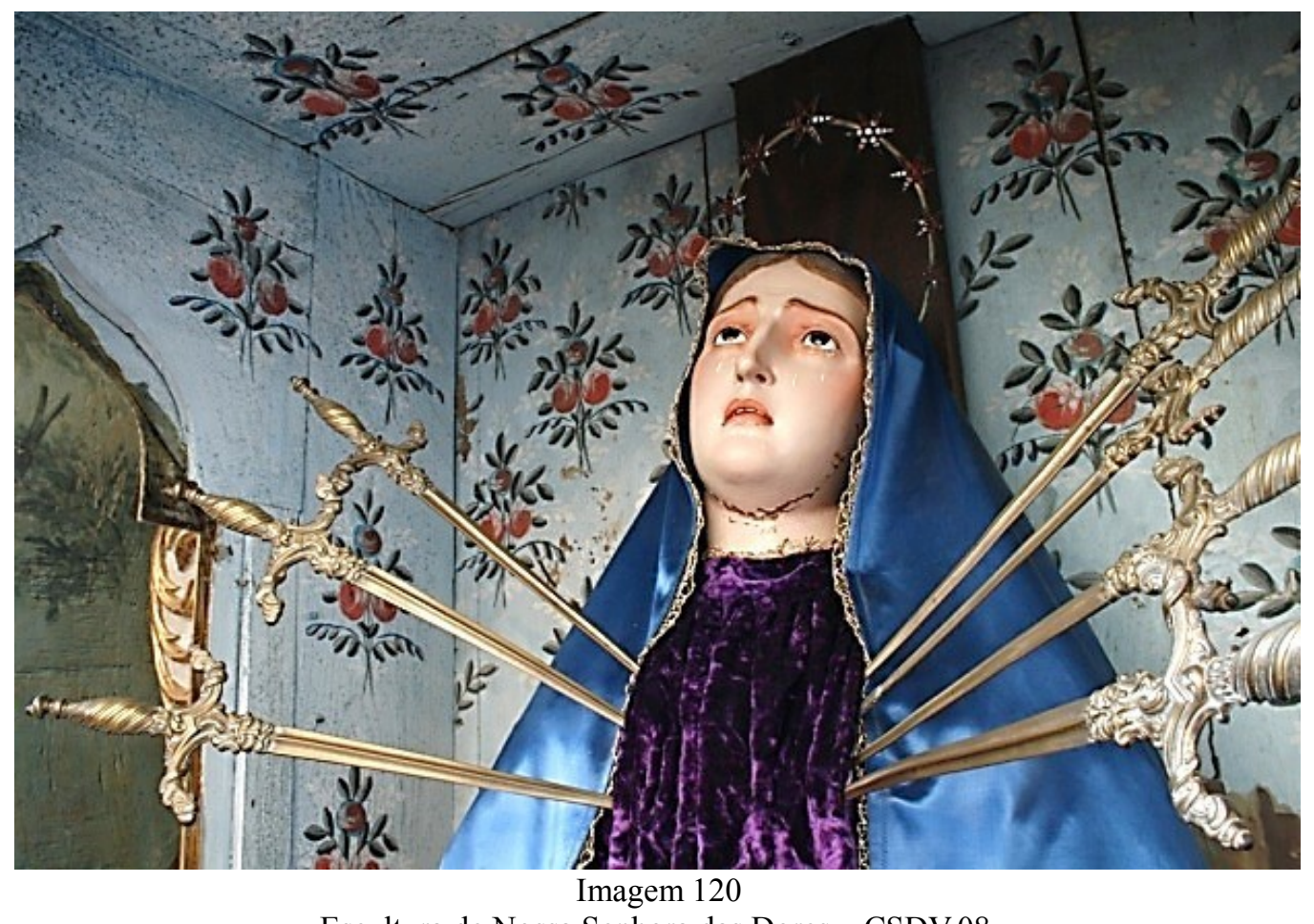

Escultura de Nossa Senhora das Dores - CSDV 08,

Dentro de uma maquineta sobre o nicho central do retábulo da Capela de Nossa Senhora das Dores Igreja de Nossa Senhora da Encarnação, Seminário Apostólico de Vinhais

Na mesma capela ainda hoje podemos ver quatro ex-votos, em pintura a óleo sobre madeira, dedicados e representando Nossa Senhora das Dores com as datas limites de 1779 e 1873. A ereção da capela e a presença dos ex-votos testemunham a importante devoção local colocada na imagem. O rosto destaca-se pelo dramatismo da expressão de dor que transmite. Com as sobrancelhas arqueadas e o olhar, com olhos de vidro, que se eleva enquanto a boca entreaberta tem os cantos dos lábios descaídos. A expressão de dor é intensificada pelas lágrimas que escorrem sobre ambas as faces evocando as processionais Virgens lacrimosas espanholas. A pungente expressividade do rosto revela uma produção cuidada de uma oficina técnica e formalmente bem preparada.

No mesmo espaço conventual, dentro da capela-mor da igreja existe outra imagem de roca que representa Nossa Senhora da Boa Morte (Imagem 121).

O culto da Senhora da Boa Morte ou da boa Viagem é comum nos espaços franciscanos $^{155}$.

\footnotetext{
${ }^{155}$ Conforme se pode observar, além de na igreja de São Francisco em Bragança e de Nossa Senhora da Encarnação em Vinhais, também na igreja do convento de São Francisco no Porto e em Guimarães, entre outras.
} 


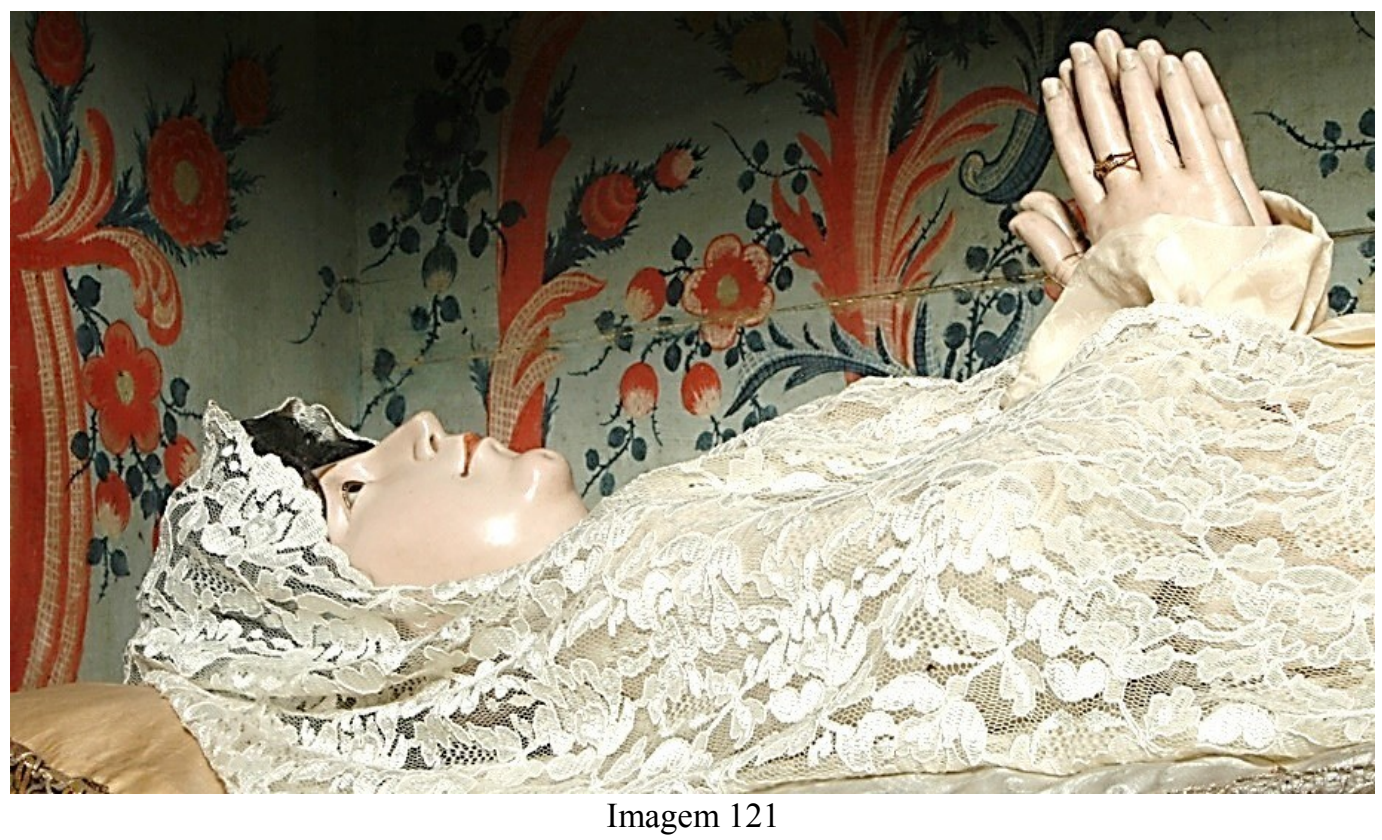

Escultura de Nossa Senhora da Boa Morte - IEV 03,

Dentro de um esquife no retábulo no lado da Epistola dentro da Capela-mor da Igreja de Nossa Senhora da Encarnação, Seminário Apostólico de Vinhais

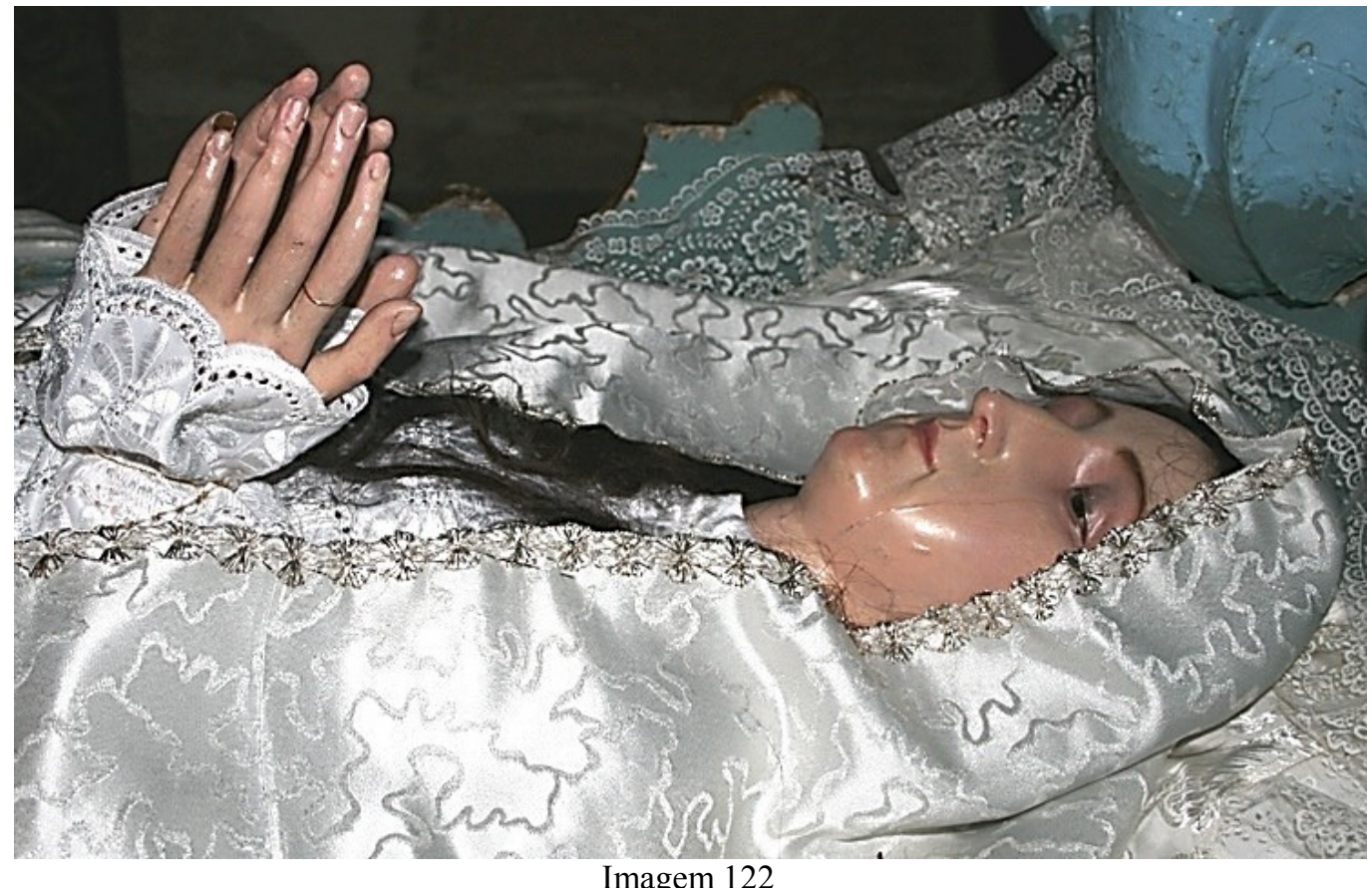

Escultura de Nossa Senhora da Boa Morte - SFB 06,

Dentro de um esquife no retábulo lateral no lado da Epistola Igreja de São Francisco de Bragança

O rosto jovem apresenta uma expressão serena, com olhos de vidro e carnação brilhante que sugere também uma produção cuidada de uma oficina bem apetrechada.

Com idêntica expressão e representando a mesma devoção existe em Bragança uma imagem de roca de Nossa Senhora da Boa Morte (Imagem 122). Menos trabalhada nos 
detalhes anatómicos que se apresentam mais simplificados que a mesma devoção em Vinhais, sugere por isso uma produção ligeiramente posterior, talvez ultrapassando os finais do século XVIII e entrando já nos inícios do século XIX. Na parede lateral da capela onde se expõe está uma indulgência dedicada à Senhora da Boa Morte, datada de 1851, editada pelo Bispo de Bragança Miranda D. Joaquim Pereira Ferraz. Expondo a persistência devocional destas imagens não obstante a sua proibição.

Com proximidades formais pela estrutura de roca que lhe constitui o corpo é a figura do Senhor dos Passos (Imagem 123 e 124) exposta atualmente dentro do nicho central de um retábulo no lado do Evangelho. Apesar da devoção do Senhor dos Passos estar registada na igreja do convento de São Francisco de Bragança desde inícios do século XVIII a imagem que encontramos hoje a culto julgamos ter sido produzida em diferentes momentos.

Formalmente parece obra dos finais do século XVIII ou inícios da centúria seguinte mas o registo que Cardoso Borges fez em 1721-1724 referia a "Capela dos Borges, que por antiga e mal administrada lhe ficou só o nome (...) os irmãos terceiros colocaram em ela a imagem do Senhor dos Passos"156. A imagem a que se referia Borges dificilmente poderá ser aquela que ainda hoje contemplamos no interior do templo. Os repintes no rosto dificultam a análise, mas, pensamos que dada a devoção a que a imagem teria sido votada poderá ter sido substituída posteriormente.

A estrutura de roca que constitui o corpo sugere uma cronologia anterior que a cabeça, e as mãos que sugerem uma produção mais recente. As barbas pontiagudas e bifurcadas estão esculpidas no mesmo suporte da cabeça, sugerindo apenas o volume sem qualquer detalhe no desenho das madeixas. A quantidade de postiços, a simplificação do desenho das barbas e a composição das linhas anatómicas do rosto sugerem formalmente as conceções neoclássicas do século XIX, ou até mais recente.

\footnotetext{
${ }^{156}$ Borges, José Cardoso, Memórias de Bragança, Fernando de Sousa (Coord.), Bragança, CEPESE / Câmara Municipal de Bragança, 2012 (texto original de 1721-1724), p. 142.
} 


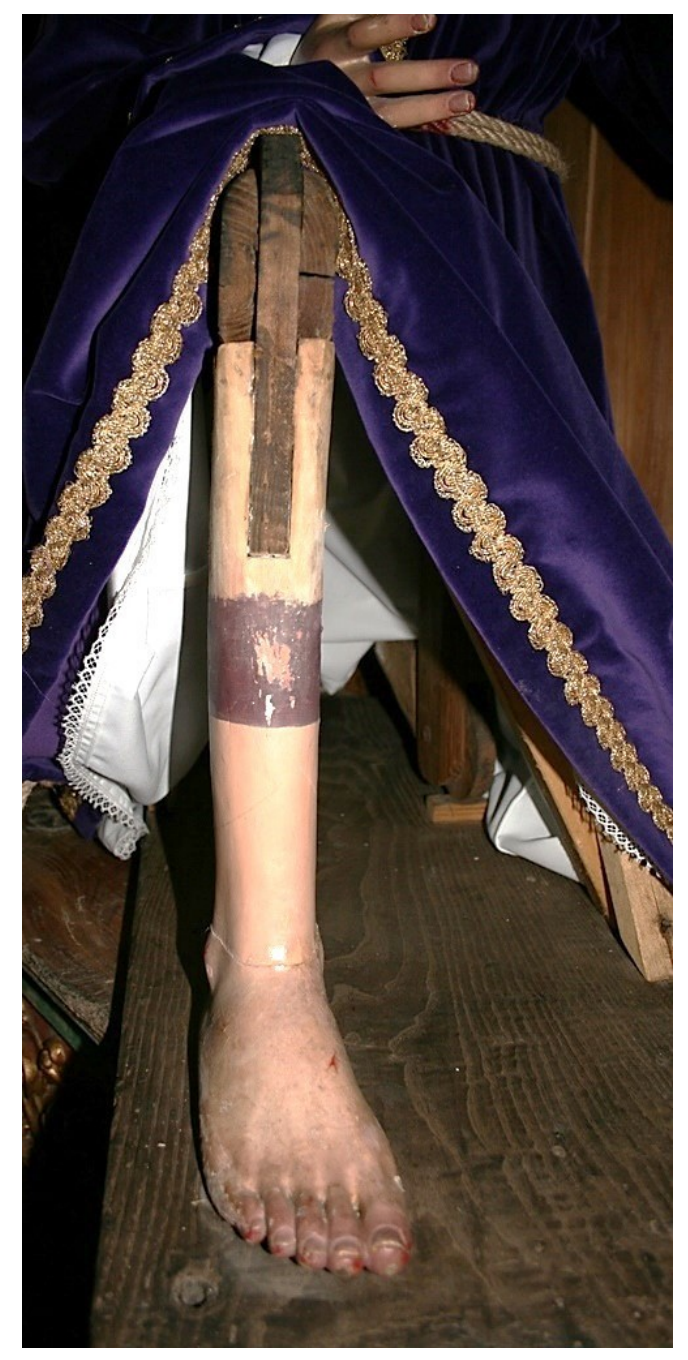

Imagem 123

Pormenor do pé e estrutura de roca do Senhor dos Passos - SFB 26

Retábulo lateral, lado do Evangelho Igreja de São Francisco de Bragança
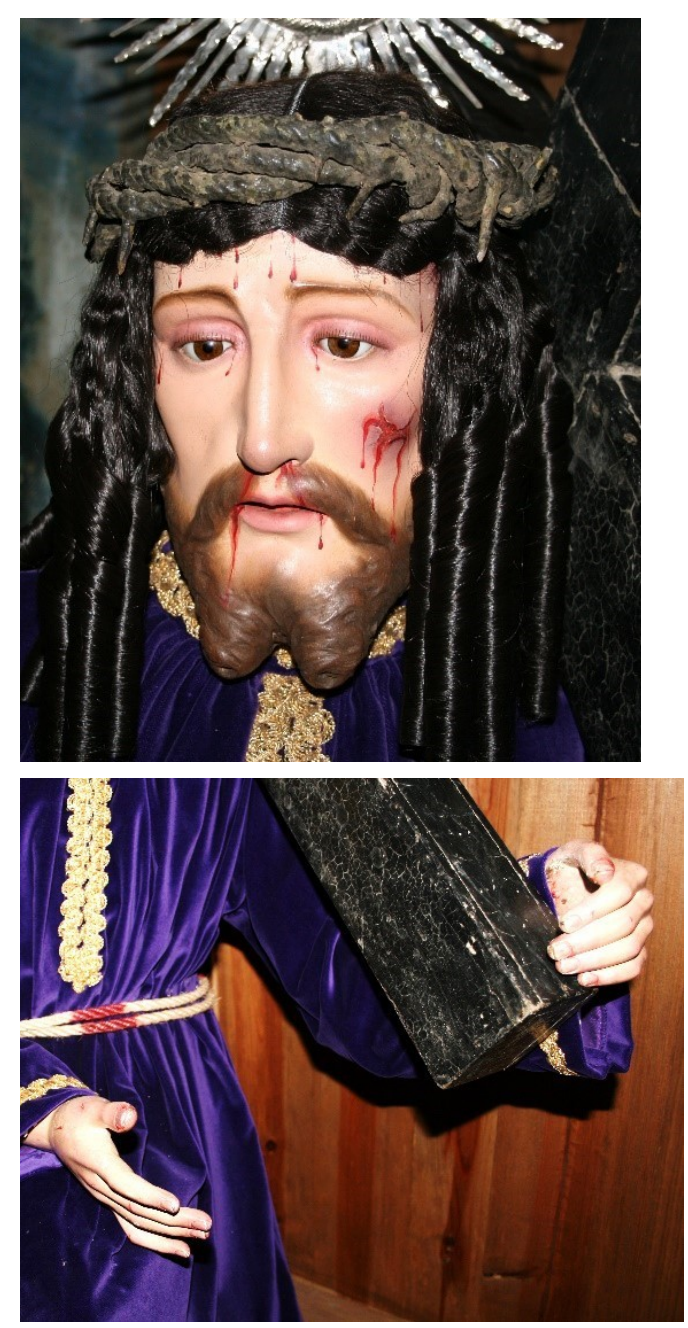

Imagem 124

Pormenores do rosto e mãos do Senhor dos Passos - SFB 26

Retábulo lateral, lado do Evangelho Igreja de São Francisco de Bragança

As restantes imagens de roca encontramo-las na igreja do convento de Mogadouro. Uma das imagens, a que representa Nossa Senhora do Caminho (Imagem 125) sabemos que não foi originalmente encomendada para o espaço dos franciscanos. É a imagem da mais importante romaria de Mogadouro, com capela própria, que a devoção contemporânea quis substituir por uma imagem nova, resguardando a imagem original dentro de um dos retábulos da igreja de São Francisco. 


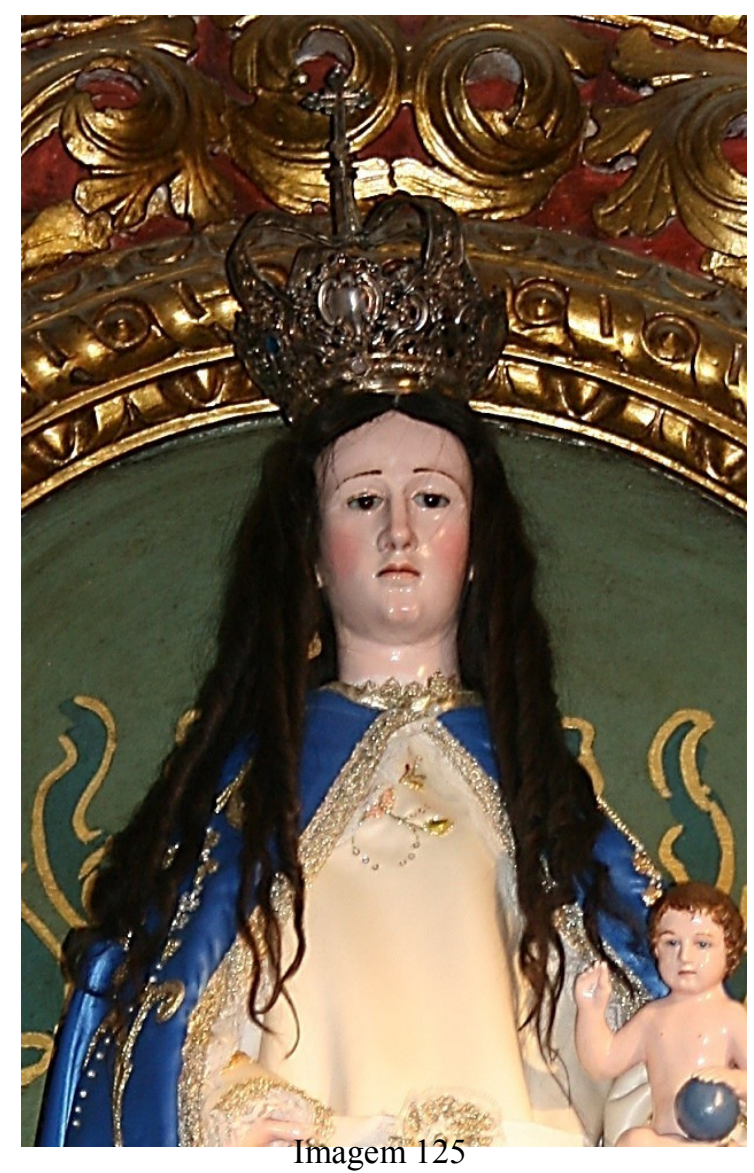

Escultura de Nossa Senhora do Caminho - SFM 01 Retábulo lateral, lado da Epistola Igreja de São Francisco de Mogadouro

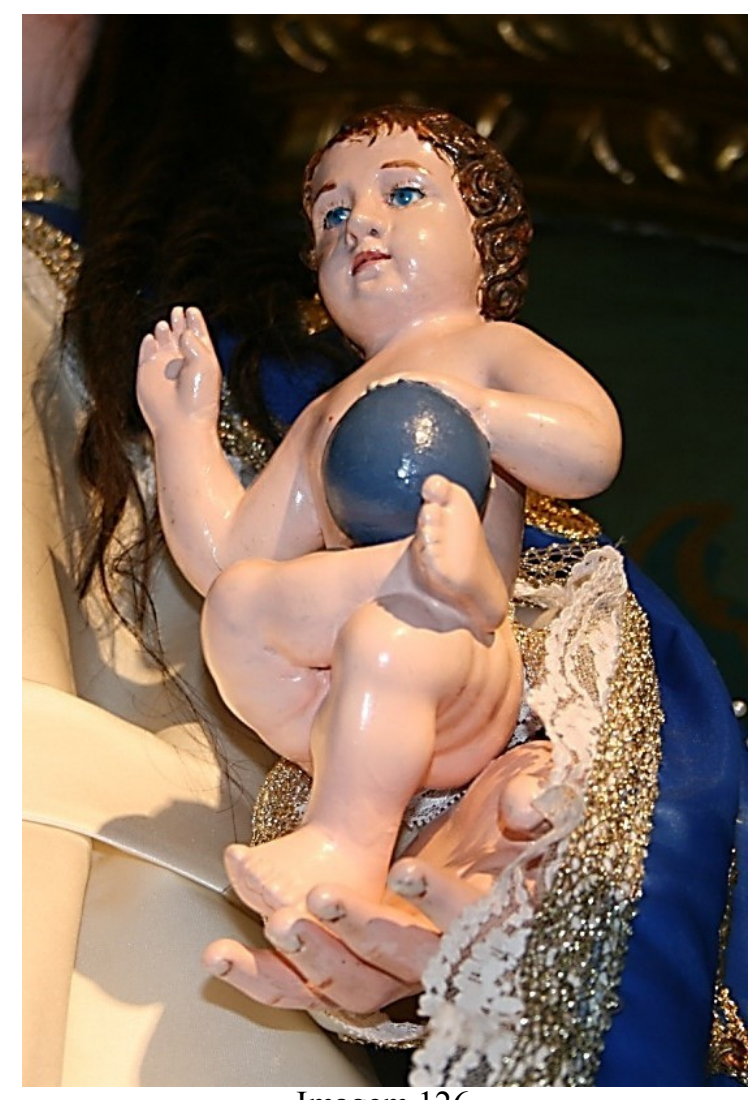

Imagem 126

Pormenor do Menino da escultura de Nossa Senhora do Caminho - SFM 01

Retábulo lateral, lado da Epistola Igreja de São Francisco de Mogadouro

Julgamos assim que não se trata de uma contaminação exterior ao núcleo de imaginária franciscana em estudo mas uma extensão às devoções limítrofes que a contemporaneidade aproximou.

A imagem de Nossa Senhora do Caminho tem o rosto detalhadamente esculpido, definido por contornos simétricos e delicados que evocam uma expressão grave acentuada pelo olhar baixo com olhos de vidro, de carnação muito brilhante está repintada num tom róseo. A mão esquerda sustem entre os dedos e o punho uma graciosa figura de um Menino Salvador do mundo (Imagem 126). O Menino, esculpido com cuidado nos contornos arredondados mas com algumas inconsistências na anatomia, está sentado sobre o punho de Nossa Senhora, com a perna direita descontraidamente cruzada sobre a esquerda, cujo pé assenta entre os dedos da mãe. Segura com a mão esquerda o globo azul, pousado sobre a perna e a mão direita em sinal de bênção. O rosto de contornos arredondados tem os olhos de vidro e o cabelo 
curto esculpido na madeira. A figura do menino apresenta-se intensamente repintada, mas a pose original denota um trabalho de talha cuidado.

Registadas no inventário de 1834 as imagens de "lan" como então as designavam, que ainda podemos observar na igreja do convento de Mogadouro representam Nossa Senhora dos Remédios (Imagem 127) e Santa Isabel (Imagem 128).

Estão ambas tão repintadas que se torna difícil compreender os elementos originais das imagens. Julgamos que ambas foram produzidas no último quartel do século XVIII, e o cuidado imposto nos contornos anatómicos do rosto e mãos sugerem uma produção cuidada.

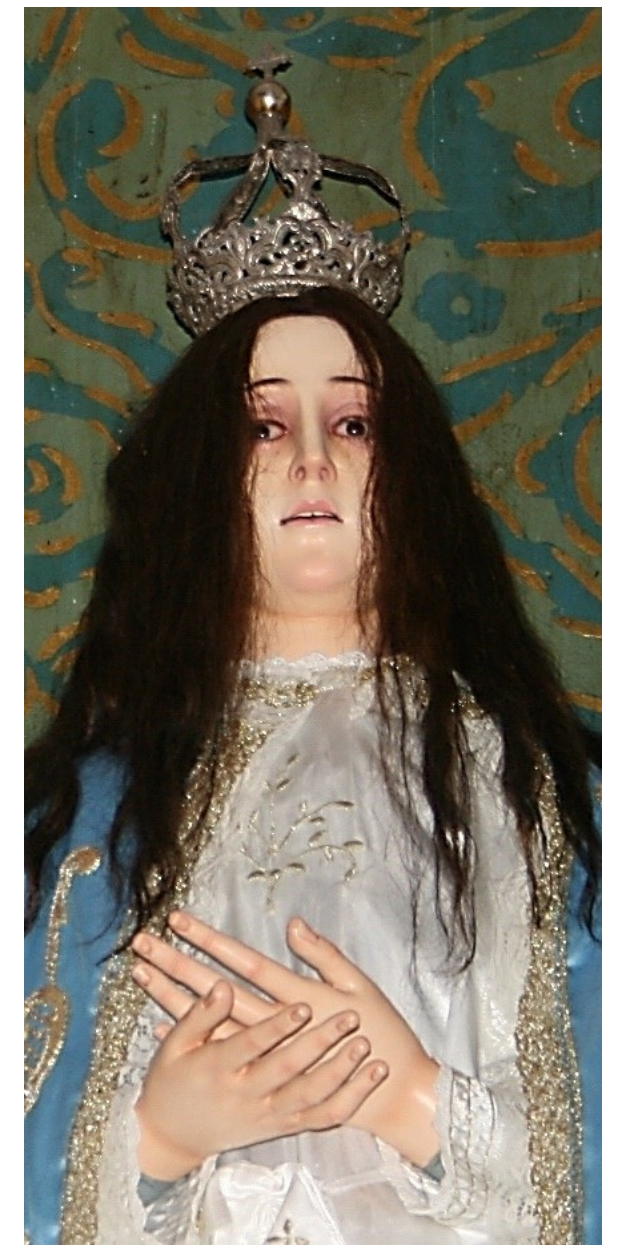

Imagem 127

Escultura de Nossa Senhora dos Remédios SFM 11, Retábulo lateral, lado do Evangelho Igreja de São Francisco de Mogadouro

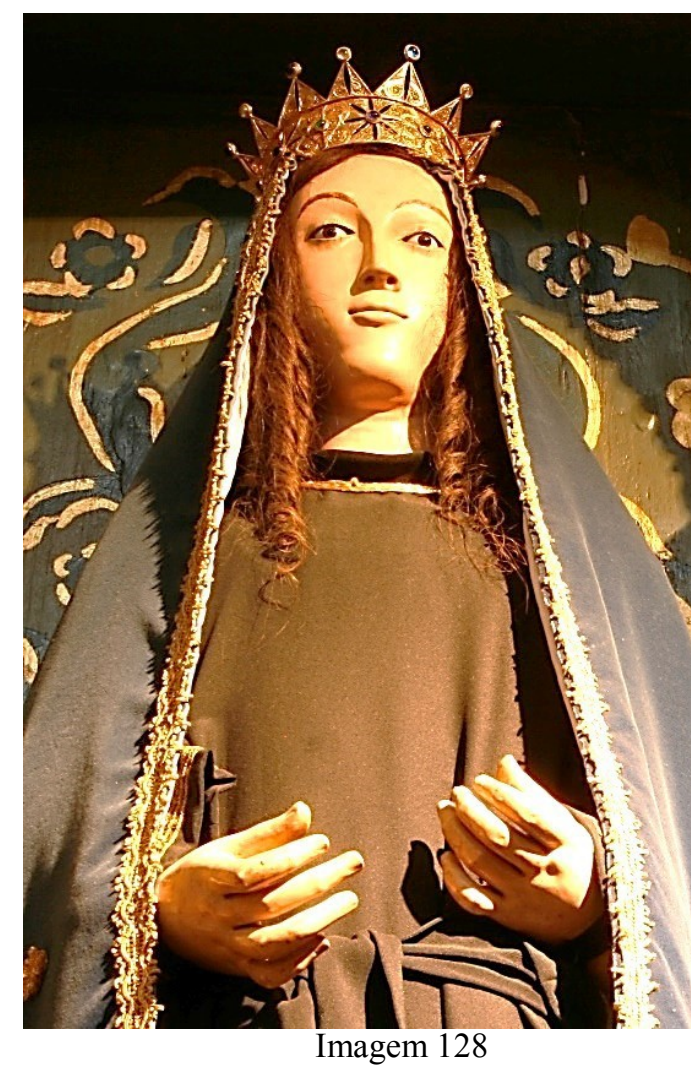

Escultura de Santa Isabel - SFM 04 Retábulo lateral, lado da Epistola Igreja de São Francisco de Mogadouro

A persistência das imagens de roca deve entender-se num contexto de forte arraigo devocional. Apesar das indulgências dadas pelo bispo a quem promovesse a sua 
substituição, o poder das esculturas era superior, dada a permanência da presença destas imagens nos locais de culto em estudo.

O que se destaca transversalmente em todos os locais de culto das três localidades estudadas é a ausência de esculturas em pedra. Trata-se de territórios de granito e xisto onde a ausência de mármores e outras rochas sedimentares mais propícias aos trabalhos escultóricos condiciona o recurso a esses suportes. A forte influência das oficinas de talha de madeira do Porto e Braga não se verifica na influência dos trabalhos pétreos.

Não só na talha da madeira se destacaram as oficinas de Braga durante o século XVIII, o granito também foi usado em importantes aplicações para o exterior, como ilustra o escadório do Bom Jesus do Monte.

A escultura do Bom Jesus do Monte, de vulto e de relevos, é esculpida no granito regional e documenta as duas grandes épocas de intervenção setecentista no grande santuário de Braga ${ }^{157}$.

Tal como no caso do Bom Jesus de Braga onde a dimensão artística é claramente subalternizada à conceção iconográfica de todo o programa, ocorre um processo idêntico na escultura dos jardins do paço Episcopal de Castelo Branco ${ }^{158}$.

\footnotetext{
${ }^{157}$ A escultura do Bom Jesus do Monte em Braga corresponde na primeira fase ao espaço entre o pórtico e o início do escadório, seguida do Escadório dos Cinco Sentidos. A linguagem mitológica romana é contraposta à linguagem do Novo Testamento com cenas da Paixão no interior das capelas. As duas primeiras capelas têm no interior imagens de pouco valor artístico onde se representa o Cenáculo e o Horto às quais se contrapõem as figuras do Sol e da Lua; à capela da Prisão a fonte de Diana; à capela das Trevas a imagem de Marte; à capela do Açoites a fonte de Mercúrio; à capela da Coroação contrapõe-se a fonte de Saturno e finalmente à capela do Pretório opõe-se a fonte de Júpiter. Após este percurso segue-se o Escadório dos Cinco Sentidos, numa alegoria do corpo humano, criando uma narrativa sobre o carácter erróneo do conhecimento sensorial, com uma fonte e respetiva bica e taça, sobre a qual está uma escultura de vulto, e sobre os muros laterais mais duas esculturas de vulto, contrapondo o Velho Testamento com a mitologia grega. Inicia-se com a fonte das Cinco Chagas, datada cerca de 1729, obra de Diogo Soares, segue-se a fonte dedicada à vista, depois a fonte do ouvido, do cheiro, do gosto e por fim do tato. Todas são acompanhadas de imagens alegóricas e animais cujas características se relacionam com os sentidos representados. O escadório dos Cinco Sentidos, obra de D. Rodrigo de Moura Teles, completa-se depois com o escadório das Virtudes. Como percurso de ascese o Escadório das Virtudes ensinava as virtudes teológicas ao crente após este estar despojado e purificado dos ensinamentos decorrentes dos Cinco Sentidos, estando portanto apto a entrar no templo. Também neste escadório é utilizado o mesmo esquema, das fontes em ligação com três esculturas que lhe complementam a informação. Figuras femininas representam alegorias da Fé, a Docilidade, a Confissão, a Esperança, a Confiança, a Glória, a Caridade, a Paz e a Benignidade. De qualidade superior às esculturas que constituem o escadório dos Cinco Sentidos, as esculturas que representam as Virtudes são obras melhor executadas e mais eruditas. As nove figuras, sem grandes distinções de atitude apenas diferem nas vestes, apresentam a gestualidade larga, apontando o infinito do espaço aberto, atitude pouco comum na escultura portuguesa. Pereira, José Fernandes, "O barroco do século XVIII" in Paulo Pereira (direção), Historia da Arte Portuguesa, Volume III, Lisboa, Círculo de leitores, 1995, pp. 50-181; Pereira, José Fernandes, "Estética barroca I: arquitectura e escultura", in Dalila Rodrigues (Coord.), Arte Portuguesa - Da Pré-História ao Século XX, volume 12, Lisboa, Fubu Editores, 2009, pp. 7-136.
}

${ }^{158}$ A escultura dos jardins do paço Episcopal de Castelo Branco é fruto da iniciativa do Bispo D. João de Mendonça, que cerca de 1725 articula em vários planos um rico programa iconográfico, que vale 
No território em estudo apenas no frontispício da igreja de São Francisco de Mogadouro (Imagem 129), no frontispício da igreja de Nossa Senhora da Encarnação de Vinhais (Imagem 130) e num fontanário no claustro (Imagem 131) do mesmo convento do Seminário Apostólico de Vinhais encontramos imaginária esculpida no granito.

Com diferentes desempenhos técnicos as imagens dos frontispícios estão colocadas em nichos sobre o portal de entrada.

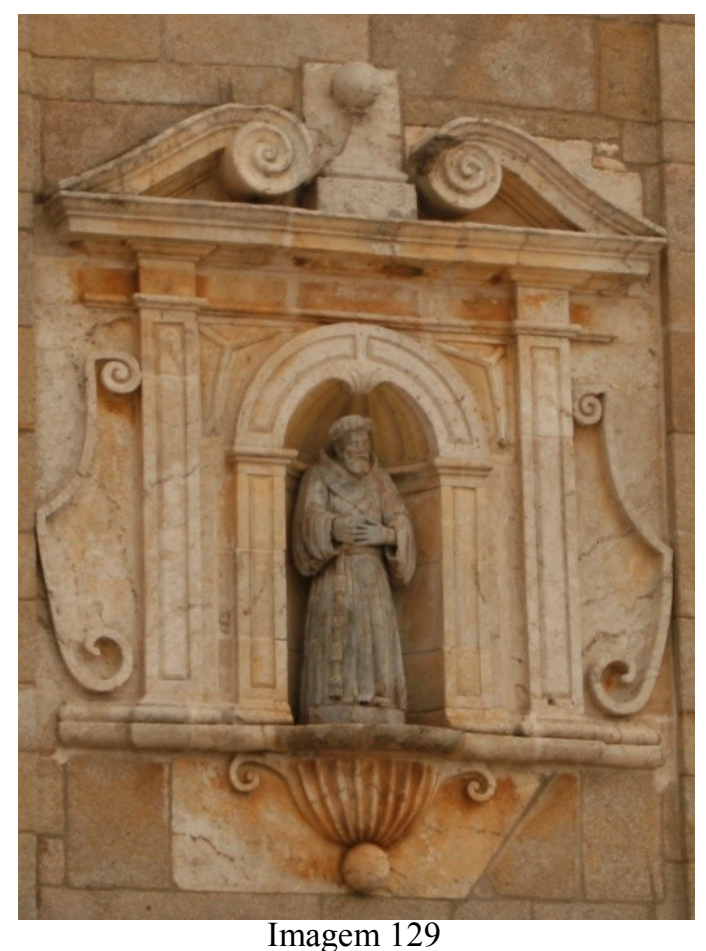

Escultura de São Francisco - SFM 16 Frontispício sobre o portal principal Igreja de São Francisco de Mogadouro

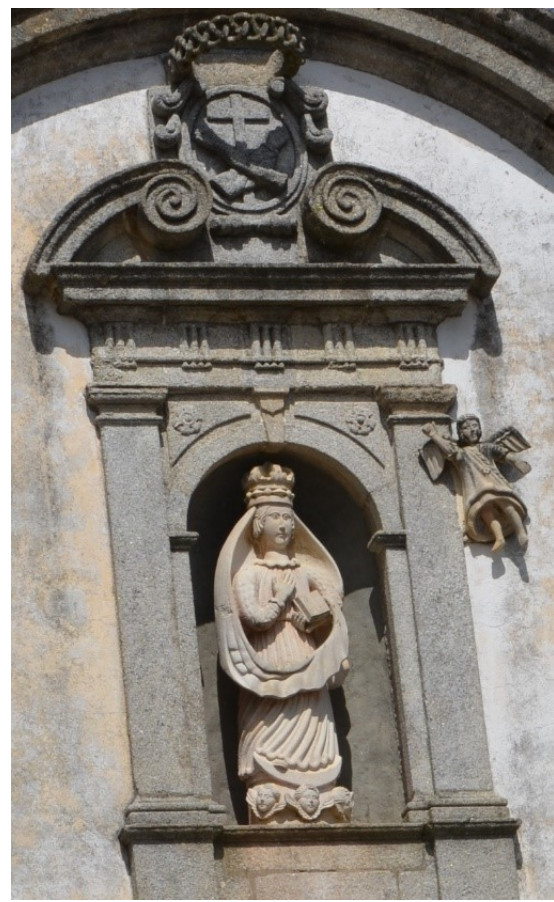

Imagem 130

Escultura de Nossa Senhora da Encarnação e anjo Gabriel - IEV 15

Frontispício sobre o portal principal Igreja de Nossa Senhora da Encarnação do Seminário Apostólico de Vinhais

A imagem de São Francisco de Mogadouro é estática e sumária no tratamento do gesto e da anatomia. A escultura arquitetónica que envolve o nicho que expõe a imagem de São Francisco denota um maior cuidado na conceção da composição e no equilíbrio

sobretudo pela variedade do conjunto, (Zodíaco; quatro estações; as quatro partes do Mundo; os quatro elementos; as Virtudes Cardeais e Teológicas; os quatro novíssimos do homem; Doutores da Igreja; Apóstolos; Reis de Portugal) não sendo porém destacável o seu valor artístico. Pereira, José Fernandes, "O barroco do século XVIII" in Paulo Pereira (direção), Historia da Arte Portuguesa, Volume III, Lisboa, Círculo de leitores, 1995, pp. 50-181; Pereira, José Fernandes, "Estética barroca I: arquitectura e escultura", in Dalila Rodrigues (Coord.), Arte Portuguesa - Da Pré-História ao Século XX, volume 12, Lisboa, Fubu Editores, 2009, pp. 7-136. 
da geometria das formas, denunciando o trabalho de um pedreiro, e não de um escultor de imagens de vulto.

A imagem de Nossa Senhora da Encarnação com o Anjo Gabriel revela o gosto ingénuo decorrente da prática de um pedreiro, conforme a lenda registou ${ }^{159}$ com pouca experiência na escultura de vulto redondo. As irregularidades na anatomia abonecada e o gesto inverosímil tornam evidente a pouca mestria no domínio dos volumes anatómicos e da expressividade. Por oposição destaca-se o trabalho equilibrado e elegante presente nos enrolamentos dos frontões que cobrem os nichos, assim como nos elementos clássicos de concheados, tríglifos e métopas que ornamentam os vãos das imagens. Esta assimetria reflete a prática de um pedreiro e não de um imaginário.

Este aspeto indica a preferência sistemática por um tratamento mais cuidado na escultura arquitetónica que na escultura de vulto redondo. A confirmar esta realidade destacamos a diferença na quantidade de registos documentais relativos a estruturas retabulares produzidos durante os séculos XVII e sobretudo XVIII, por oposição à escassez de documentos relativos a esculturas ou imaginária.

Ainda em pedra existe uma figura masculina fragmentada (Imagem 131), observável no centro do tanque do claustro do seminário de Vinhais. A lacuna da cabeça empobrece de sobremaneira a análise da obra. De claro aspeto palaciano, pelo rico e ornamentado traje que enverga, a figura apresenta semelhanças com a escultura regional que ornamenta o escadório do Bom Jesus em Braga, ou até com a escultura dos jardins do Paço episcopal de Castelo Branco. Trata-se

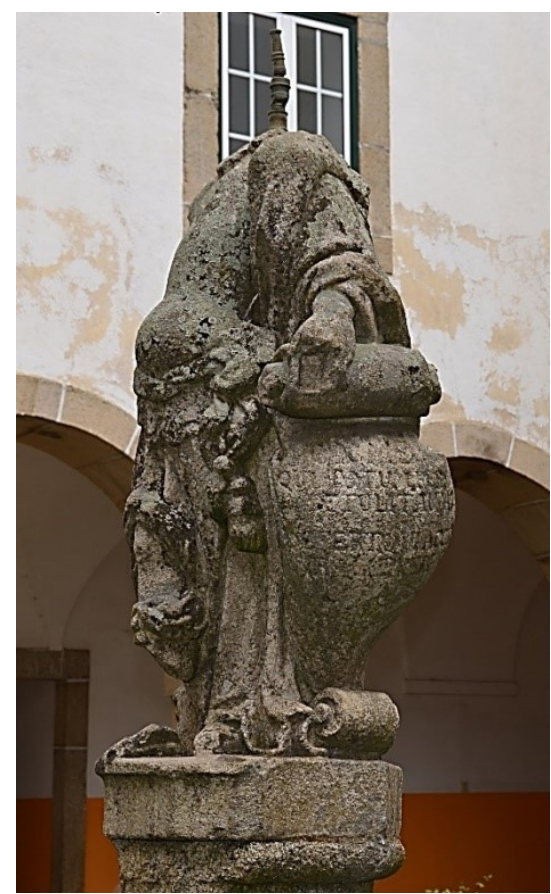

Imagem 131

Escultura fragmentada de figura masculina, SIEV 07

Ao centro do tanque do claustro da Igreja de Nossa Senhora da Encarnação do Seminário Apostólico de Vinhais por isso de uma obra de oficina que segue o modelo cortês da segunda metade do século XVIII.

\footnotetext{
${ }^{159}$ Conforme a lenda que P. Firmino Martins refere: Martins, Firmino A., Folklore do Concelho de Vinhais, Bragança, Câmara Municipal de Vinhais, 1987 (edição original 1927), p. 113, 114.
} 
A intensa produção que do século XVIII chegou aos nossos dias nos espaços outrora ocupado pelos diversos ramos da família franciscana denuncia não só a vitalidade da Ordem no território como o forte vínculo com as oficinas de produção escultórica como agentes da ilustração dos valores a catequizar. 


\section{ANÁLISE ICONOGRÁFICA}

O SENTIDO NARRATIVO DAS FORMAS

- ICONOGRAFIA DE DEUS-PAI

- ICONOGRAFIA DE JESUS CRISTO

- ICONOGRAFIA DE NOSSA SENHORA

- ICONOGRAFIA DOS SANTOS FUNDADORES

- ICONOGRAFIA DOS SANTOS DA ORDEM DE SÃO FRANCISCO

- ICONOGRAFIA DAS SANTAS DA ORDEM DE SÃO FRANCISCO

- ICONOGRAFIA DOS SANTOS DESAFETOS À ORDEM DE SÃO FRANCISCO

- ICONOGRAFIA DAS SANTAS DESAFETAS À ORDEM DE SÃO FRANCISCO 
A imagem corporaliza-se para consolar e informar, para fixar as memórias, os temores e os desejos. De modo a fazer da experiência de contemplar um exercício de crença, perante a afirmação da linguagem sobre o olhar ${ }^{1}$.

Assumindo a linguagem simbólica como uma figuração do real, viva e expressiva, as representações ganham credibilidade epistemológica ${ }^{2}{ }^{3}$

A imagem além de uma figuração do real produz uma realidade sensível, um imaginário, operante na criação de outras realidades. No contexto do período moderno, em que maioritariamente foram produzidas as esculturas em estudo, as imagens assumem-se como fenómenos pedagógicos e também de conversão.

Relativamente às imagens em estudo tentamos consubstanciar esta hermenêutica da interpretação dos objetos como representações de uma expressão de um coletivo. A

${ }^{1}$ Didi-Huberman, Georges, Lo que vemos, lo que nos mira, Argentina, Manantial, 2011, pp. 22-26.

${ }^{2}$ Pinho, Arnaldo de, "Encarnação e transcendência: o caminho das artes" in Carlos Moreira de Azevedo (Coord.), Cristo fonte de esperança Catálogo da exposição do grande jubiliu do ano 2000, Porto, Diocese do Porto, 2000, p. 20. Sobre as metodologias na interpretação iconográfica, sobretudo do período do renascimento, ver: Panofsky, Erwin, Estudos de iconologia; temas humanísticos na arte do renascimento, Lisboa, Editorial Estampa, 1995 (2 ${ }^{\mathrm{a}}$ edição), pp. 19-37, e Panofsky, Erwin, O Significado nas Artes Visuais, Lisboa, Editorial Presença, 1989, pp. 15-47. É enquanto teórico da ciência do conhecimento e reflexão sobre a iconologia que destacamos Panofsky. Uma das principais fragilidades apontadas à abordagem panofskiana é o facto de se limitar, não raras vezes, a uma análise iconográfica centrada na tradição pictórica a que uma obra de arte está ligada, convertendo-se num mero exercício de decifração. É relativamente a tais casos que Didi-Huberman assinala que a imagem corre o risco de subsumir na classificação das suas partes, perdendo expressão como um todo, assim se diluindo o que é da ordem do não-visível. Coutinho, Maria, "Panofsky e a tradição da Bildwissenschaft, para lá do cerco ao método iconológico" in Actas do IV Congresso de História da Arte Portugesa em Homenagem a JoséAugusto França, Lisboa, APHA - Associação Portuguesa de Historiadores da Arte, 2014, pp. 454-460.

Mais recentemente: Belting, Hans, Antropología de la imagen, Madrid, editorial Katz, 2007, pp. 13-71, propõe uma metodologia para o estudo da antropologia da imagem a partir da análise da complementaridade imagem-medium-corpo. O método permite uma análise ampla do objeto artístico, partindo da antropologia e da relação entre o medium (estrutura, corporalização da imagem) e o corpo (sujeito) enquanto projeção de um conjunto de associações pessoais. $\mathrm{O}$ medium ligado à imagem revela a estrutura que envolve o processo de criação e perceção da imagem material o que evidencia as dimensões estruturais e históricas envolvidas, bem como, permite a perceção do papel do sujeitolparticipante face aos fenómenos sociais. Para o contexto medieval ver: Baschet, Jerome, "Introduction: L' Image-Objet" in. Schmitt, J.-C., Baschet, J. (Coord.) L'Image. Fonctions et usages des images dans l'Occident medieval, Paris, Le Léopard D’or, pp.7-26. A ideia de imagem-objecto e a metodologia iconográfica a ela associada foi posteriormente desenvolvido na introdução do livro de: Baschet, Jérôme - L'iconographie médiévale, Paris, Gallimard, 2008. O conceito de Jerôme Baschet relativamente ao período medieval da "imagem-objeto" centrada na iconografia relacional propõe, relativamente à leitura das formas e ao aprofundamento dos conteúdos, o entendimento de ambos enquanto dimensões inter-penetrantes de uma mesma entidade que intervém na construção do real e na ativação de condutores para a sua articulação com o sagrado. No entanto, tal como ocorre com as metodologias iconográficas que antecederam Baschet trata-se de uma abordagem parcial, com fragilidades e limitações. Ramôa, Joana, "Jérôme Baschet L'iconographie médiévale", in Revista de História da Arte N. ${ }^{7}$, Lisboa, Instituto de História da Arte FCSH/UNL, 2009, pp. 196-201. 
expressão catequética traduz a Palavra, das Sagradas Escrituras, dos apócrifos, da Lenda Dourada ou Flos Sanctorum ${ }^{4}$ e das vidas e virtudes dos santos que as esculturas representam.

A par das emanações eclesiásticas gerais e as particulares da ordem de São Francisco, também a devoção popular foi definindo os atributos, os gestos e invocações taumatúrgicas que envolvem as esculturas em estudo. Muitas das identificações das figuras representadas nas esculturas estavam já esquecidas, os quase duzentos anos que nos separam da extinção das ordens religiosas criaram uma rotura na memória dos coletivos que as esculturas refletem.

A análise das obras escultóricas, enquanto narrativas, sugere, em vista da heterogeneidade de devoções e da amplitude temporal registada, uma organização temática.

Assim, agrupamos as diferentes representações escultóricas de acordo com as devoções que ilustram. A sequência das devoções mantida respeita as figuras primordiais do catolicismo romano, bem como a sequência histórica do aparecimento dos cultos.

Iniciamos a análise com a escultura de Deus-Pai, seguida pelas várias esculturas e conjuntos escultóricos que representam Jesus Cristo, nos diversos modelos iconográficos registados, e anexa a parentela, onde se inclui a escultura de São João Batista. As representações cristológicas igualam as marianas, mesmo tratando-se na sua esmagadora maioria de imagens esculpidas pós Concilio de Trento onde a valorização do culto mariano e hagiológico foi fortemente estimulada face aos ataques que os protestantes vinculavam sobre estas devoções ${ }^{5}$.

\footnotetext{
${ }^{4}$ O Flos Sactorum constitui a tradução acrescentada da obra «La leyenda de los santos» versão livre da «Leyenda aurea», Lenda Dourada de Jacobus de Voragine, importante obra de divulgação dos cultos e devoções que o catolicismo foi promovendo. O Flos Sanctorum acrescenta à narrativa dos santos os santos «Extravagantes». As narrativas e as gravuras que as ilustram consolidam as formas que as devoções foram adquirindo. A primeira edição impressa conservada do Flos Sanctorum em lingoage portugues data de 1513, feita em Lisboa, pelo alemão Hermão de Campos e por um colaborador que, até hoje, permanece desconhecido (Roberte Rabelo). A edição foi patrocinada por D. Manuel no âmbito dos interesses espirituais e culturais manifestados pelos reis do final do séc. XV e início do XVI. Sobral, Cristina, "O Flos Sanctorum de 1513 e suas adições portuguesas" in Lusitania Sacra, 2a série, 13-14, Lisboa, Universidade Católica Portuguesa, Centro de Estudos de História Religiosa, 2001-2002, pp. 531568.

${ }^{5}$ Falcão, José António, "O Mistério de Cristo na Revelação Artística" in Carlos Moreira de Azevedo (Coord.), Cristo fonte de esperança Catálogo da exposição do grande jubileu do ano 2000, Porto, Diocese do Porto, 2000, p. 36.
} 
O culto Mariano é examinado nas suas múltiplas invocações assim como nos conjuntos em que se insere, e agregamos a parentela: Santa Ana, São Joaquim e São José.

$\mathrm{Na}$ análise da iconografia dos santos mantém-se o mesmo procedimento de valorização da sequência histórica e cronológica das personagens representadas.

Inicia-se a análise com as representações do santo fundador da Ordem Franciscana São Francisco de Assis, não só porque sendo o pai espiritual de todos os templos em estudo, constitui a figura aglutinadora de todo o conjunto de esculturas, mas também porque é a personagem mais vezes representada, depois de Cristo e Nossa Senhora. Relacionado com São Francisco destacam-se ainda dois conjuntos, uma representação do Abraço Místico e uma representação da Estigmatização com Cristo Serafim.

Pela proximidade com São Francisco, enquanto reformador da igreja predicador e mendicante, destacamos posteriormente as esculturas que representam São Domingos de Gusmão que é, comummente, exposto a culto próximo da imagem de São Francisco. Seguidamente destacamos as representações de Santa Clara enquanto fundadora da vertente feminina da ordem franciscana.

Mantendo a narrativa de acordo com os espaços em estudo analisamos os restantes santos franciscanos, privilegiando a história que ilustram e criando uma sequência cronológica das suas narrativas. Iniciamos o registo com o conjunto dos Santos Mártires de Marrocos, seguidos pelas representações de Santo António, São Boaventura, São Bernardino de Siena, São Pedro de Alcântara, São Benedito de Palermo e São Pascoal Bailão. As representações femininas são mais escassas nos templos em estudo e ilustram as devoções franciscanas de Santa Isabel de Hungria, Santa Rosa de Viterbo e Santa Margarida de Cortona.

Após a análise dos santos e santas da Ordem de São Francisco, e seguindo o mesmo critério são desenvolvidas as narrativas de acordo com a cronologia das personagens representadas. Assim, principia o registo com as esculturas do Arcanjo São Miguel, seguido de São Pedro Apóstolo e depois os santos da época clássica como São Vicente e São Sebastião. Respeitando a cronologia das narrativas, depois analisamos São Roque, São Vicente Ferrer e por fim São Caetano. Nas devoções femininas apenas se regista Santa Bárbara, pois os restantes cultos femininos estão dedicados a santas franciscanas ou às diversas invocações marianas.

Os espaços em estudo apenas incluem um templo de um convento feminino, os restantes templos conventuais eram masculinos, além do templo de Vinhais da Ordem 
Terceira. Este aspeto poderá ajudar a explicar a disparidade entre as 56 esculturas que representam 18 personagens masculinas diferentes face às 25 esculturas que ilustram apenas 7 figuras devocionais femininas. 


\section{ICONOGRAFIA DE DEUS-PAI NA SANTÍSSIMA TRINDADE}

Das mais de cem esculturas esculpidas ou moldadas até 1834 nos templos em estudo, apenas uma, representa a figura de Deus-Pai, originalmente constituía parte de uma composição da Santíssima Trindade em Trono de Graça (Imagem 1).

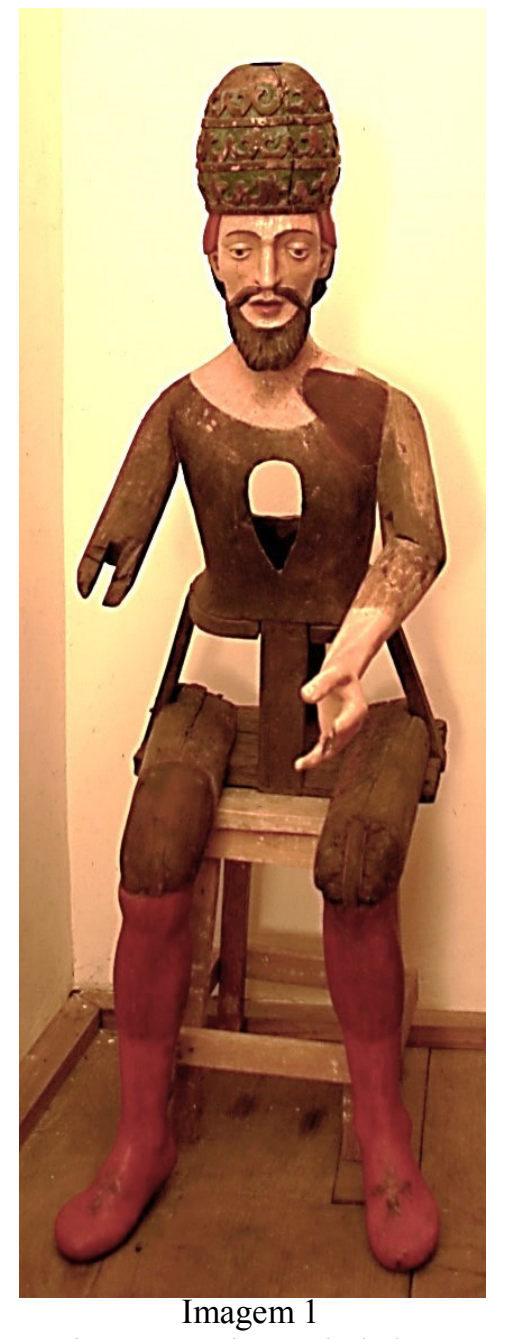

Deus-Pai na Santíssima Trindade - 36 SFB Oficina portuguesa; final do século XVII Igreja de São Francisco - Bragança Guardada numa dependência junto ao coro alto

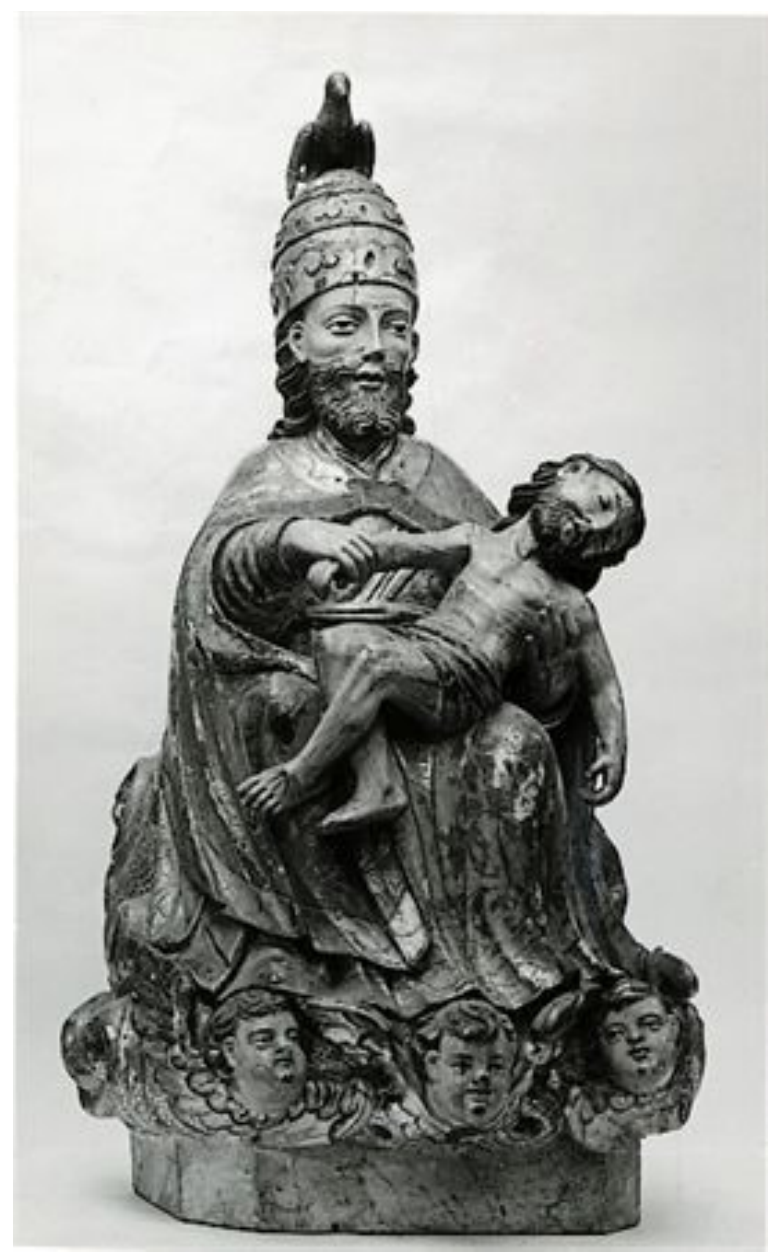

Imagem 2

Santíssima Trindade,

Museu Nacional de Arte Antiga, Lisboa Madeira, século XVII

Autor / Oficina / Fabricante: desconhecido ${ }^{6}$

\footnotetext{
${ }^{6}$ Conforme pesquisa efetuada a 12 de março de 2015 na base de dados dos Museus da DGPC, (DireçãoGeral do Património Cultural). http://www.matriznet.dgpc.pt/MatrizNet/Objectos/ObjectosConsultar.aspx?IdReg=247440.
} 
Não obstante a importância do dogma cristão a Santíssima Trindade surge poucas vezes representada pelas controvérsias e pela proximidade com a heresia que suscitaram as várias soluções que foram sendo geradas para ilustrar o mistério da Encarnação ${ }^{7}$. As Sagradas Escrituras definiram a imagem, em especial as passagens da Epístola de São Paulo ao Romanos que descreve o Pai levantando e expondo o Filho sacrificado para redenção da Humanidade «que Deus apresentou como vitima de propiciação, pelo Seu próprio sangue, mediante a fé, a fim de manifestar a Sua justiça, pela remissão dos delitos passados» (Rom 3, 24-25) e a Epistola aos Hebreus (Heb 4, 16) onde surge referido o Trono da Graça. João (Jo 3, 14-15) e o livro do Apocalipse (Ap 3, 21; 5, 1; 7, 17) também sugerem a imagem do trono para exposição do Filho, ou simbolicamente do Cordeiro. Apesar Pese da relativa abundancia de referências litúrgicas as representações de Deus-Pai na Santíssima Trindade em Trono de Graça são escassas nos espaços em estudo.

A escultura encontra-se na igreja de São Francisco do extinto convento de Bragança e já não está a culto. Trata-se de uma escultura de roca ou de vestir, incompleta e cuja identificação estava já perdida. Na análise formal comparativa com esculturas coevas conseguimos, pese embora a quase ausência de atributos, aproximar a escultura da igreja de São Francisco de Bragança com uma escultura do Museu Nacional de Arte Antiga de $\operatorname{Lisboa}^{8}$ (Imagem 2) que não só formalmente se assemelha, como, a devoção ilustrada nos parece coincidir.

\footnotetext{
${ }^{7}$ Pamplona, Germán, Iconografía de la Santísima Trinidad en el arte medieval español, Madrid, CSIC Consejo Superior de Investigaciones Científicas, 1970, p. 8; Boespflug, François; Zaluska, Yolanta "Le dogme trinitaire et l'essor de son iconographie en Occident de l'époque carolingienne au IV Concile du Latran (1215)", Cahiers de civilisation médiévale. X-XII siècles, vol. XXXVII, núm. 3, 1994, pp. 181-240; Carmona Muela, Juan, Iconografia cristiana, Madrid, Akal, 2010, pp. 173, 174.

${ }^{8}$ As dúvidas suscitadas na identificação da imagem prendiam-se com o principal atributo iconográfico que a define - a tiara tríplice. A tiara tríplice poderia identificar o Apostolo São Pedro, pois a figura de Deus Pai ostenta uma tiara de cinco coroas e não de três como a tiara papal. Réau, Louis, Iconografia del arte cristiano. Iconografia de los santos. De la P a la Z - Repertorios. Tomo 2/Volumen 5, Barcelona, Ediciones del Serbal, 2002 (primeira edição 1957), p. 554.

A base de dados dos Museus da Direção-Geral do Património Cultural de Portugal recolhe cerca de 30 imagens que representam São Pedro na escultura, mas, são na grande maioria representados de cabeça descoberta enquanto apóstolo, envergando a tiara tríplice surgem apenas 4 obras na categoria de escultura, na pintura, porém são mais frequentes. Enquanto a mesma base nacional regista apenas 14 imagens que representam a Santíssima Trindade mas a figura de Deus Pai ostenta a tiara tríplice em 7 esculturas. Conforme pesquisa na base de dados dos Museus da DGPC, (Direção-Geral do Património Cultural, Departamento dos Bens Culturais, Divisão do Património Imóvel, Móvel e Imaterial, Palácio Nacional da Ajuda, Lisboa - Portugal). http://www.matriznet.dgpc.pt/matriznet/home.aspx Acedido a 12 de Março de 2015.
} 
A imagem da igreja de São francisco de Bragança julgamos que inicialmente representaria um Trono de Graça ${ }^{9}$. Em falta está atualmente a figura de Cristo Crucificado, que Deus Pai seguraria pelos dois braços da cruz. Falta-lhe, também, a figura da pomba, representação do Espírito Santo, que ligava as duas figuras antropomórficas.

Uma observação atenta, porém, permite ver no topo da exuberante tiara um orifício que poderia permitir a colocação de um postiço para a representação do Espirito Santo, tal como se apresenta a escultura da Santíssima Trindade do Museu Nacional de Arte Antiga (imagem 2).

Atualmente a escultura apresenta lacuna do braço direito e a ausência total de vestes a cobri-la. O rosto de expressão grave, sumariamente tratado, e olhar baixo, tem barbas e bigode castanho com ligeiras ondulações. O cabelo curto apenas visível na nuca é também castanho e ondulado.

A representação da Santíssima Trindade do Museu Nacional de Arte Antiga é bastante semelhante à imagem de Deus Pai de Bragança. Sobretudo nos ornatos decorativos da tiara, mas também na composição das barbas e bigodes, apesar de nos detalhes das linhas que simulam as barbas ser mais simplificada a imagem de Bragança.

Os rostos assemelham-se mas desconhece-se se a imagem de Bragança susteria a figura de Cristo sobre o colo ou se reproduziria o modelo mais comum sustendo entre os joelhos a figura de Cristo Crucificado. Sendo uma imagem de roca não descuramos que estivesse preparada para distintas composições, não tendo forçosamente o gesto definido.

\footnotetext{
${ }^{9} \mathrm{O}$ Trono de Graça constitui a versão vertical da justaposição das figuras que compõem o tema iconográfico da Santíssima Trindade. Pamplona, Germán, Iconografia de la Santísima Trinidad en el arte medieval español, Madrid, CSIC Consejo Superior de Investigaciones Científicas, 1970, p. 65-89; Boespflug, François; Zaluska, Yolanta "Le dogme trinitaire et l'essor de son iconographie en Occident de l'époque carolingienne au IV Concile du Latran (1215)", Cahiers de civilisation médiévale. X-XII siècles, vol. XXXVII, núm. 3, 1994, pp. 181-240; Fernandes, Carla Varela, "A imagem da Santíssima Trindade da igreja de Santa Clara de Santarém", Cadernos de História Da Arte $n^{\circ}$ 2, Revista do Instituto de História da Arte - Centro de Investigação, Lisboa, Faculdade de Letras da Universidade de Lisboa, 2014, pp. 3849.
} 


\section{ICONOGRAFIA DE CRISTO}

A imagem de Jesus Cristo é forçosamente a que mais se impõe nos espaços em estudo. À inevitabilidade cultual sobre a figura central de um templo católico romano acresce o fervor do santo fundador da ordem que em imitação de Cristo definiu a sua Regra e mesmo o seu aspeto físico a partir da estigmatização que recebeu no monte Alverne.

Esta proximidade entre São Francisco e Cristo Crucificado é evidente no modelo iconográfico cristológico mais recorrente nos espaços em estudo e dentro do âmbito temporal definido pela presença da ordem nos mesmos espaços (de 1271, data da primeira referencia ao convento de Bragança até 1834, data da extinção das ordens religiosas).

A representação de Jesus na Cruz surge em sete esculturas de vulto redondo colocadas na sua maioria na área central dos retábulos que as expõem, além destas esculturas de maior tamanho a mesma representação se repete em quatro Cruzes de Altar, um Calvário e uma Descida da Cruz. O momento culminar da Paixão de Cristo é forçosamente aquele que domina as narrativas cristológicas dos espaços franciscanos estudados.

No entanto, chegaram até aos nossos dias, mas em considerável menor expressão, duas representações Cristológicas que se afastam da narrativa da Paixão e que se relacionam com os ciclos de representação da infância de Jesus. Respeitando a ordem de narrativa destacamos em primeiro lugar a maquineta que expõe o Presépio $^{10}$. Atualmente, a maquineta com o Presépio ${ }^{11}$ está adossada ao arco triunfal, do lado do

\footnotetext{
${ }^{10} \mathrm{Em} \mathrm{1223,} \mathrm{S.} \mathrm{Francisco} \mathrm{de} \mathrm{Assis} \mathrm{protagoniza} \mathrm{um} \mathrm{importante} \mathrm{acontecimento,} \mathrm{que} \mathrm{assinala} \mathrm{uma} \mathrm{grande}$ mudança no conceito associado a estas representações. Com o objetivo de tornar a liturgia do Natal mais acessível e portanto mais próxima dos fiéis, criou uma encenação invulgar, transpondo do espaço religioso para a natureza - uma gruta nos bosques montanhosos de Greccio - os festejos da noite do nascimento do Menino. Esta noite e S. Francisco marcaram, a partir de então, o início de um fenómeno extraordinário de difusão do culto da Natividade, expresso através de representações. Imitando o seu fundador, nas igrejas e conventos da Ordem espalhados por toda a Europa, os frades franciscanos foram os verdadeiros pioneiros do Presépio. A sua grande popularização, como forma de promover e valorizar o amor e a devoção ao Menino Jesus, deveu-se a S. Francisco, por isso considerado o patrono universal do Presépio. Alcoforado, Ana, O Menino dos Meninos, Coimbra, Museu Nacional de Machado de Castro, 2007, p. 11; Roque, Maria Isabel Rocha, "O Menino de Belém: da festa do Natal à iconografia da natividade e da adoração", Gaudium Sciendi $N^{\circ} 5$, Lisboa, Sociedade Científica da Universidade Católica Portuguesa, 2013, pp. 104-126. No entanto Flávio Gonçalves refere a anterioridade da representação do presépio que remonta ao século IV e se expande no Oriente a partir do século VI. Gonçalves, Flávio, História da arte; Iconografia e Crítica, Lisboa, Imprensa Nacional Casa da Moeda, 1990, pp. 14, 15.

${ }^{11}$ O "género pastoril", tal como Machado de Castro se referia, teve em Portugal particular devoção que possivelmente se relaciona com o franciscanismo fortemente enraizado na cultura portuguesa. Desde D.
} 
evangelho, na igreja de São Francisco da Venerável Ordem Terceira de Vinhais. Mas, sabemos pelo inventário de 1834 que pertencia originalmente ao contiguo Seminário Apostólico de Vinhais.

O registo bíblico de Lucas refere sobre este momento da Natividade apenas que Nossa Senhora "teve o seu filho primogénito, que envolveu em panos e recostou numa manjedoira, por não haver para eles lugar na hospedaria ${ }^{12}$ ". Este brevíssimo relato foi acrescentado pelos evangelhos apócrifos e pelo culto popular até o transformar numa encenação social com as mais diversas personagens ${ }^{13}$.

Os pastores foram também registados por Lucas (Lc 2, 15-21) ${ }^{14}$ assim como o anjo que lhes anunciou o nascimento do Salvador acompanhado por uma multidão do exército celeste. No século XVII Rubens acrescentou aos pastores as pastoras aumentando também as oferendas que cada figura aportava ${ }^{15}$.

João $\mathrm{V}$ que vários foram os presépios a adornar igrejas, mosteiros e espaços privados. Colocados dentro de maquinetas ou dentro de um camarim, o conjunto, normalmente de barro policromado era escalonado e inserido em paisagens evocadas com cortiça e musgo. A cena central da gruta era muitas vezes envolvida em elementos eruditos clássicos de colunas ou pilastras e a proporção da Sagrada Família era sempre superior aos restantes elementos que compunham o conjunto. Das restantes figuras que compunham o presépio eram os Reis Magos que dominavam o cortejo que poderia ser acrescentado por diversas personagens representando cenas de trabalho de campo diário como as lavadeiras, o moleiro, a matança do porco, ou tipos sociais como os almocreves ou o tocador de sanfona e a alcoviteira. A imaginação das cenas representadas escalonava-se em vários registos chegando a haver presépios, como o da Estrela, com cerca de quinhentas figuras. A fragilidade e pitoresco dos presépios constituem o contraponto à grandiosa retórica da estatuária barroca. Pereira, José Fernandes, "O barroco do século XVIII" in Paulo Pereira (direção), Historia da Arte Portuguesa, Volume III, Lisboa, Círculo de leitores, 1995, pp. 50-181.

${ }^{12}$ Lucas, Lc 2, 7, Bíblia Sagrada, Lisboa, Difusora bíblica (Missionários capuchinhos), 14ª edição, 1988.

${ }^{13}$ A representação do Presépio chega ao Ocidente no século V à igreja romana de Santa Maria Maior. As figuras dos animais, dos Reis Magos, os pastores e os anjos músicos foram acrescentadas desde o século IV até ao século XV. O Concilio de Trento depurou a representação da Natividade, retirando entre outras figuras as das parteiras, o banho do Menino e até os animais impondo o modelo da visão de Santa Brígida da Virgem que deu à luz sem dor, e de joelhos e mãos postas fica em adoração ao Menino acompanhada por São José. Réau, Louis, Iconografía del Arte Cristiano. Iconografía de la Biblia - Nuevo Testamento Tomo 1/ Volumen 2, Barcelona, Ediciones del Serbal, 1996, (Edição original 1955-1959), pp. 223-240; Roque, Maria Isabel Rocha, "O Menino de Belém: da festa do Natal à iconografia da natividade e da adoração", Gaudium Sciendi N 5 , Lisboa, Sociedade Científica da Universidade Católica Portuguesa, 2013, pp. 104-126.

${ }^{14}$ A ilustração da narrativa dos pastores surge numa gravura do Flos Sanctorum, depois da gravura que regista Nossa Senhora e São José em adoração ao Menino dentro da choupana com os animais. Um dos pastores sustém uma gaita-de-foles, instrumento que também encontramos no presépio de Vinhais. Campos, Hermão de e Rabelo, Roberto, Flos Sanctorum HO FLOS SANCTÕ[RUM] EM LINGOAJE[M] $P[O R] T U G U E[S]$, Lisboa, Disponível na plataforma on-line da Biblioteca Nacional de Portugual http://purl.pt/12097, 1513, fl. XV.

${ }^{15}$ Réau, Louis, Iconografía del Arte Cristiano. Iconografía de la Biblia - Nuevo Testamento Tomo 1/ Volumen 2, Barcelona, Ediciones del Serbal, 1996, (Edição original 1955-1959), p. 245. 
Os Reis Magos foram registados no Novo Testamento apenas por Mateus (Mt 2, 1$12)^{16}$ que refere que seguindo a estrela no Oriente chegaram os Magos a Jerusalém procurando o "rei dos judeus" e Herodes perturbado tentou saber através deles onde estava esse rei que acabava de nascer. Avisados em sonhos para não voltarem para junto de Herodes os Magos regressaram à sua terra por outro caminho depois de terem adorado o Menino e oferecido ouro, incenso e mirra ${ }^{17}$.

No século XV acrescentou-se um amplo cortejo a acompanhar os reis magos, usualmente a cavalo (ou, mais raras vezes, sobre camelos) e cobriram-se de faustuosas roupagens ${ }^{18}$.

A gravura que ilustra os reis magos na edição de Flos Sanctorum destaca também as decorativas vestes que identificam os magos como reis ${ }^{19}$

Em Portugal no início do século XVI, era concluído o retábulo-mor da Sé de Viseu ${ }^{20}$ onde na Adoração dos Reis Magos surge uma nova personagem - o índio, numa perspetiva idílica em que a nudez e a inocência testemunham a bondade e relacionam o

\footnotetext{
${ }^{16}$ Mateus, Mt 2, 1-12, Bíblia Sagrada, Lisboa, Difusora bíblica (Missionários capuchinhos), $14^{a}$ edição, 1988.

${ }^{17} \mathrm{O}$ silêncio dos restantes evangelistas sobre este momento permitiu ao apócrifos e ao culto popular, entre o século XI e XIII, transformar os magos em reis, definir o seu número, assim como, o seu nome e o momento do encontro entre eles e o Menino. A simbologia subjacente às etnias dos três magos relacionada com as três partes do mundo e as diferentes idades relacionadas com as idades da vida estava já assente no século XII. Réau, Louis, Iconografia del Arte Cristiano. Iconografía de la Biblia - Nuevo Testamento Tomo 1/ Volumen 2, Barcelona, Ediciones del Serbal, 1996, (Edição original 1955-1959), pp. 250-252; Roque, Maria Isabel Rocha, "O Menino de Belém: da festa do Natal à iconografia da natividade e da adoração", Gaudium Sciendi N ${ }^{\circ}$, Lisboa, Sociedade Científica da Universidade Católica Portuguesa, 2013, pp. 104-126.
}

${ }^{18}$ Réau, Louis, Iconografía del Arte Cristiano. Iconografía de la Biblia - Nuevo Testamento Tomo 1/ Volumen 2, Barcelona, Ediciones del Serbal, 1996, (Edição original 1955-1959), p. 256.

19 Campos, Hermão de e Rabelo, Roberto, Flos Sanctorum HO FLOS SANCTÕ [RUM] EM LINGOAJE[M] P[OR]TUGUE[S], Lisboa, Disponível na plataforma on-line da Biblioteca Nacional de Portugual http://purl.pt/12097, 1513, fl. XXII.

\footnotetext{
${ }^{20}$ Segundo Dalila Rodrigues o retábulo da Sé de Viseu foi obra coletiva mas com a participação do pintor português Vasco Fernandes. O rei Baltasar, tradicionalmente negro, aparece nesta obra como um índio do Brasil, um Tupinambá do subgrupo dos povos Tupi, pertencente à grande família linguística dos TupiGuarani. Certamente influenciada pelos primeiros relatos trazidos pela armada de Pedro Álvares Cabral, nos quais o índio é visto como o "bom selvagem", numa perspetiva idílica em que a nudez e a inocência testemunham a sua bondade e o relacionam com o Paraíso perdido. Rodrigues, Dalila, "A pintura no período manuelino" in Paulo Pereira e (Direção), História da Arte Portuguesa. Volume II, Lisboa, Círculo de Leitores, 1995, pp. 199-277; Goulão, Maria José, "As primeiras imagens do índio brasileiro no espaço europeu: a Adoração dos Magos de Ulrich Apt o Antigo do retábulo de Santa Cruz de Augsburgo" in Estudos de Arte e Património. População e Sociedade. Volume 20, Porto, CEPESE - Centro de Estudos de População, Economia e Sociedade e Edições Afrontamento, 2012, pp. 79-91.
} 
índio com o Paraíso perdido. Noutra obra portuguesa contemporânea ${ }^{21}$ o índio é representado como ser próximo da pura bestialidade, herético e incapaz de dominar os seus instintos mais primários.

Estes aspetos exóticos introduzidos pouco tempo após a chegada de Pedro Alvares Cabral ao Brasil tiveram forte repercussão na criatividade que a representação do Presépio iria assumir no território português ${ }^{22}$.

No século XVI, quando as figuras da Noite Santa ganham autonomia, libertando-se gradualmente das paredes dos altares e retábulos é quando a verdadeira história do Presépio se inicia ${ }^{23}$.

Exemplar nesse registo da complexidade da trama social é o Presépio de Vinhais (Imagem 3) que representa no plano central a Virgem Maria coroada e São José com resplendor, ambos ajoelhados em adoração do Menino deitado entre eles sobre as palhas. Detrás do Menino está a vaca e o jumento. Em frente da choupana, no lado direito está uma figura popular masculina, de joelhos que oferece ao Menino uma cesta cheia de ovos, que enchem também o chapéu de abas largas, já partido. Do lado oposto está uma figura feminina também ajoelhada trazendo uma galinha. Imediatamente detrás destas figuras estão dois músicos, um de cada lado da choupana, o músico do lado direito traz uma gaita-de-foles, enquanto o músico da esquerda traz uma sanfona. Ao lado do gaiteiro e acompanhando a estrutura escalonada da composição sucedem-se os três reis magos, com rica indumentária e turbantes vão todos a cavalo. Do lado esquerdo, contíguos ao músico da sanfona está um grupo de populares que se aproxima da choupana com oferendas, deste grupo destaca-se a figura de um negro africano

\footnotetext{
${ }^{21}$ Goulão refere o painel do Inferno, de oficina portuguesa e possivelmente do primeiro quartel de Quinhentos hoje no Museu Nacional de Arte Antiga, onde surge a associação índio-diabo assente no hibridismo da aparência dessas figuras cobertas de penas. Goulão, Maria José, "As primeiras imagens do índio brasileiro no espaço europeu: a Adoração dos Magos de Ulrich Apt o Antigo do retábulo de Santa Cruz de Augsburgo" in Estudos de Arte e Património. População e Sociedade. Volume 20, Porto, CEPESE - Centro de Estudos de População, Economia e Sociedade e Edições Afrontamento, 2012, pp. 79-91.

${ }^{22}$ Louis Réau refere, relativamente ao painel de Vasco Fernandes, que a repercussão da representação do índio foi inexistente no modelo iconográfico dos reis magos. Réau, Louis, Iconografía del Arte Cristiano. Iconografia de la Biblia - Nuevo Testamento Tomo 1/ Volumen 2, Barcelona, Ediciones del Serbal, 1996, (Edição original 1955-1959), p. 252. No entanto, devemos destacar a presença do índio do Brasil em várias representações do Presépio em Portugal, não como rei mago mas como participante no cortejo, tal como se observa na maquineta do Presépio de Vinhais.

${ }^{23}$ No século XVI começam a aparecer pequenos grupos de figuras de vulto, inicialmente acopladas e articuladas. Gradualmente evoluem para aquela que hoje reconhecemos como a principal característica dos presépios, a que os distingue de outras formas de representação do tema: o facto de ser modificável. Alcoforado, Ana, O Menino dos Meninos, Coimbra, Museu Nacional de Machado de Castro, 2007, p. 13.
} 
vestido com indumentária ocidental e segurando um jarro, possivelmente um escarvo. No mesmo grupo, mas num plano mais recuado destaca-se a figura de outro negro, mas este trajado com plumas sobre a cintura e na cabeça, possivelmente trata-se da representação de um índio do Brasil, acompanham-no três dromedários. A encimar a intensa composição estão suspensos os anjos com instrumentos musicais e até uma partitura de música. Em ambos os lados da maquineta estão em plano mais elevado mais figuras que se aproximam em adoração, no lado esquerdo destaca-se uma figura feminina a dançar acompanhada por um tocador de viola, no lado oposto está uma enigmática figura com longa capa negra e chapéu, podendo tratar-se da representação de um estudante, ao lado deste está um mouro com turbante e calças muito ornamentadas. Do último plano emergem ainda de ambos lados, figuras com oferendas e animais domésticos.

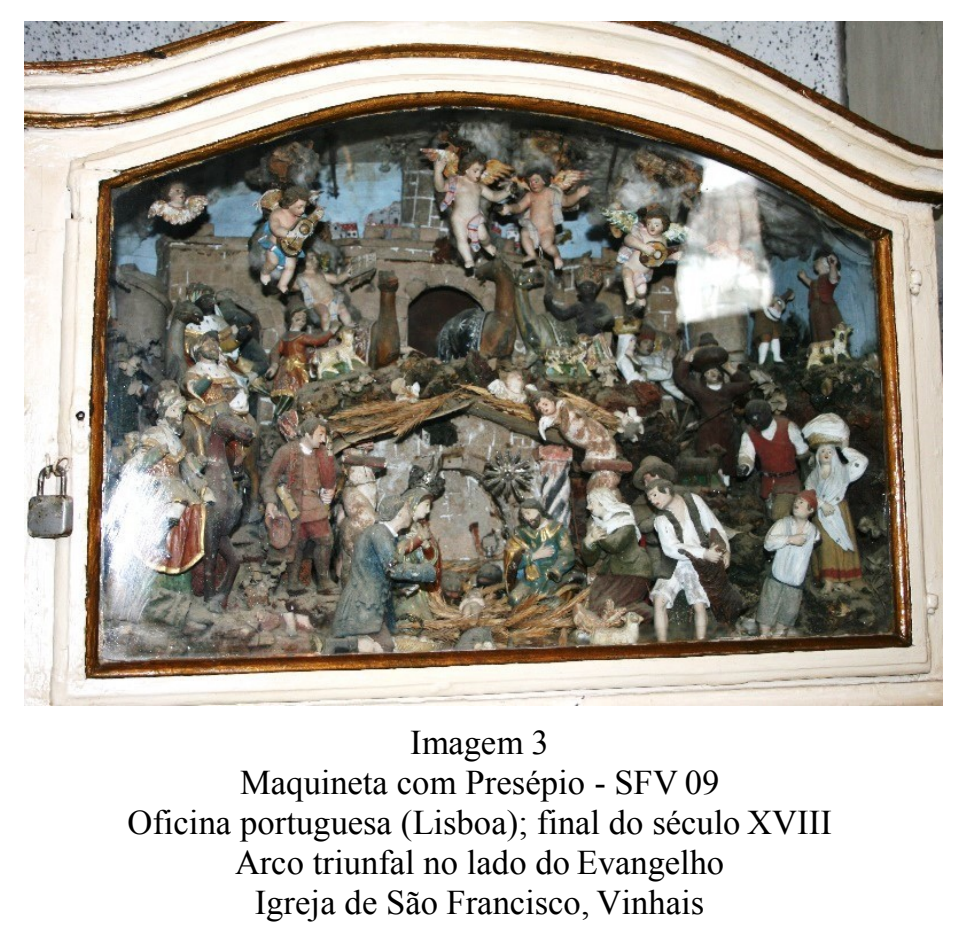

A presença dos pastores e dos reis magos é quase impercetível entre a multidão de outras figuras que na segunda metade do século XVIII ocupavam o espaço social e a representação do Presépio. Com exceção dos reis magos e do faustuoso mouro que os acompanha todas as personagens se identificam com as classes populares de trabalhadores, escravos, o exótico índio do Brasil, músicos e estudantes que definiam as classes menos favorecidas do antigo regime. Sendo a representação mormente representativa dos estratos sociais mais desfavorecidos é destacável também a ausência 
de diferenciação de escalas na proporção usada nas diferentes representações. Pereira afirma que a proporção da Sagrada Família era sempre superior aos restantes elementos que compunham o conjunto ${ }^{24}$, característica que não se observa no Presépio de Vinhais.

A influência de Machado de Castro e António Ferreira o "Ferreirinha de Chelas" no "género pastoril" 25 como Machado de Castro se referia criou em Portugal a possibilidade do então já denominado terceiro estado entrar no espaço da opulência barroca e figurar no interior dos templos junto da talha dourada e dos estufados dourados.

Pese embora a maquineta do Presépio ter sido registada em 1834 no interior da sacristia do Seminário Apostólico de Vinhais haveria seguramente algum uso cultual nas festividades da natividade que aproximasse a representação dos comuns fiéis que acorriam a esse templo.

É destacável ainda neste conjunto a variedade de instrumentos musicais que acompanham o cortejo, já sejam tocados de forma erudita pelos anjos (a partir de partituras) ou pelos diferentes músicos, as guitarras e violas, sanfona e gaita-de-foles dão conta de uma intensa relação com a música que nos permite considerar essa presença de forma transversal a toda a sociedade nos finais do século XVIII.

A lendária tradição da relação de São Francisco com o Presépio, com a primeira representação em Greccio protagonizada pelo próprio santo, faria supor uma maior presença desta representação nos espaços franciscanos em estudo. Nos cinco templos estudados apenas se registou um presépio, que originalmente estaria colocado, no espaço restrito do seminário, dentro da sacristia, o que supunha sobretudo um uso privado, ou pelo menos excecional junto da comunidade. Neste sentido é evidente que nos templos em estudo não se observa particular devoção relativamente à narrativa da Natividade, em detrimento da Paixão ou da representação de Cristo na Cruz.

A outra representação de Jesus na infância está atualmente na sacristia da igreja de São Francisco em Bragança. Trata-se de uma figura que representa o Menino Jesus

\footnotetext{
${ }^{24}$ Pereira, José Fernandes, "O barroco do século XVIII" in Paulo Pereira (direção), Historia da Arte Portuguesa, Volume III, Lisboa, Círculo de leitores, 1995, pp. 50-181

${ }^{25}$ Pereira, José Fernandes, "O barroco do século XVIII" in Paulo Pereira (direção), Historia da Arte Portuguesa, Volume III, Lisboa, Círculo de leitores, 1995, pp. 50-181.
} 
Salvador do Mundo (Imagem 4). Julgamos que esta imagem seria originalmente do vizinho mosteiro das monjas beneditinas e poder-se-á tratar de uma encomenda feita a alguma oficina castelhana. Tendo em conta o prestígio que as esculturas de Valhadolid tinham no território de Bragança poderia ser esta a origem da escultura registada em 17211724 por Cardoso Borges como o "Menino Fosquinho"26.

A infância de Jesus que corresponde ao ciclo litúrgico do Natal é escassamente referida nas Escrituras. Os temas deste ciclo podem dividir-se nos quatro episódios narrados em passagens dos evangelhos: a Natividade, a Apresentação do Menino no Templo, a Fuga para o Egito e o Menino Jesus entre os Doutores $^{27}$.

As imagens de Cristo na infância, já seja a aprender a caminhar ou a dar vida a pássaros de barro, provêm dos

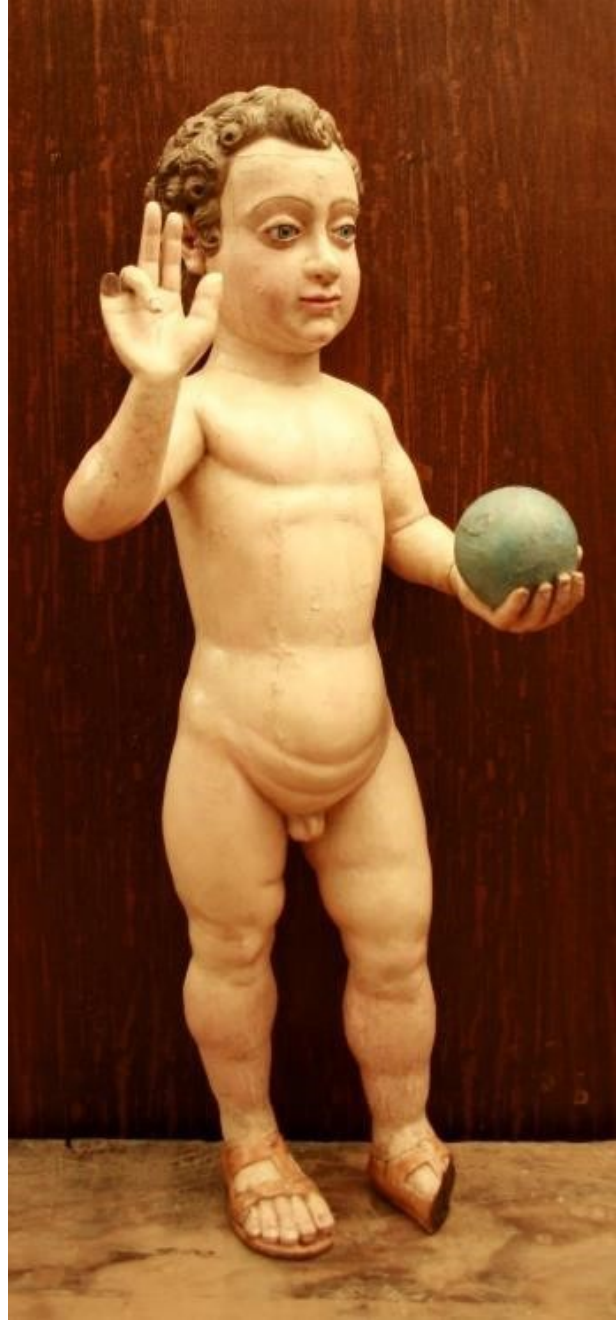

Imagem 4

Menino Jesus Salvador do Mundo, SFB 32 Oficina espanhola; finais do XVII primeiro quartel do século XVIII Sacristia da Igreja de São Francisco, Bragança evangelhos apócrifos bem como dos cultos populares e tiveram maior devoção sobretudo nos conventos de monjas ${ }^{28}$. As primeiras imagens isoladas do Menino Jesus

\footnotetext{
${ }^{26}$ Borges, José Cardoso, Memórias de Bragança, Fernando de Sousa (Coord.), Bragança, CEPESE / Câmara Municipal de Bragança, 2012 (texto original de 1721-1724), p. 158. O registo refere que o primeiro milagre se operou com a mesma imagem do Menino Deus, que "sendo de escultura tosca e andava pelas mãos das meninas com o nome de fosquinho, se fez tão formoso que rouba os corações a sua vista". Borges refere ainda a cura milagrosa que o Menino operou na sua filha enquanto educanda no mosteiro. A capela do Menino Jesus estava na cerca do mosteiro de Santa Escolástica e atualmente já não existe.
}

${ }^{27}$ Réau, Louis, Iconografía del Arte Cristiano. Iconografía de la Biblia - Nuevo Testamento Tomo 1/ Volumen 2, Barcelona, Ediciones del Serbal, 1996, (Edição original 1955-1959), p. 301.

${ }^{28}$ Réau, Louis, Iconografía del Arte Cristiano. Iconografía de la Biblia - Nuevo Testamento Tomo 1/ Volumen 2, Barcelona, Ediciones del Serbal, 1996, (Edição original 1955-1959), pp. 296, 297. Réau refere ainda que estes temas da infância de Jesus eram desconhecidos na idade média, mas tornam-se 


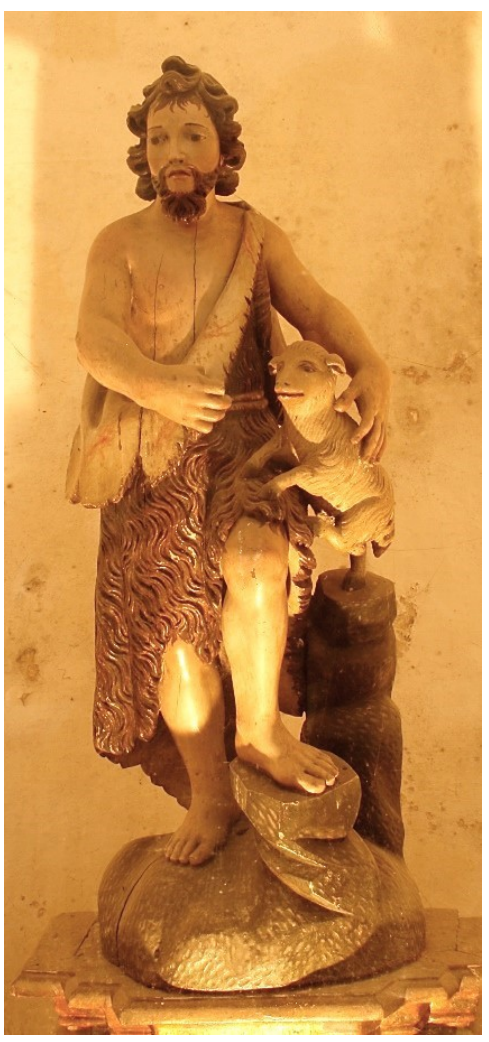

Imagem 5

São João Batista - IEV 13

Oficina local (Frei Domingos); Ultimo quartel do século XVIII

Colocada num nicho do lado do Evangelho, Igreja de Nossa Senhora da Encarnação, Vinhais surgem nos conventos femininos, durante $\mathrm{o}$ século XIV. A partir do século XV-XVI, destacam-se as figuras do Menino com cerca de 4 ou 5 anos, despido. Amplificam-se as imagens de Jesus Bom Pastor bem como de Jesus Salvador do Mundo a abençoar e posteriormente surge a imagem do Menino acompanhado por símbolos da Paixão ${ }^{29}$.

O modelo iconográfico do Menino Salvador apresenta a mão direita levantada, em gesto de pregar, comummente entendido como a abençoar $^{30}$, com o dedo médio e o indicador juntos, segura na mão esquerda ora os Evangelhos, ora uma ave ou pomba, ora ainda um cacho de uvas, ou, mais frequentemente, um globo ou esfera do mundo, símbolo da sua soberania no Universo ${ }^{31}$.

Com este contexto de crescente valorização da santa infância desenvolve-se o grande movimento de interesse pela infância que

frequentes a partir do século XVII. Este detalhe reflete sem dúvida a alteração que se verifica relativamente à perspetiva social sobre a infância e a criança no decurso da época moderna. No século XVII a atitude pedagógica perante a criança funda-se na ideia da criança como testemunha da inocência batismal, próxima de Cristo. Ariès, Philippe, História Social da Criança e da Família. Rio de Janeiro, LTC- Livros Técnicos e Científicos Editora S.A, 1981, p. 120.

${ }^{29}$ Alcoforado, Ana, O Menino dos Meninos, Coimbra, Museu Nacional de Machado de Castro, 2007, p. 19.

${ }^{30} \mathrm{O}$ gesto da mão direita alçada, já seja apenas com o indicador e o dedo médio estendidos ou com o polegar também estendido e sempre com os dedos menores fechados sobre a palma da mão, tem origem nos gestos clássicos da oratória e argumentação. Os gestos de fala assimilam-se com os gestos de transmissão da Palavra e portanto da predicação. Na baixa idade média o gesto transforma-se em bendição. Nas cenas taumatúrgicas o gesto assume a palavra que antecede o milagre. O milagre sela a predicação e os sacramentos ministrados pelos presbíteros consubstanciam essa função. Fraga Sampedro, Maria Dolores, "Predicación e imágenes en los siglos finales de la edad media hispana" in Plenitudo Veritatis homenaje a Mons. Romero Pose, Santiago de Compostela, Instituto Teológico Compostelano, 2008, pp. 829-847.

${ }^{31}$ A representação do Menino com o globo tornou-se muito popular no século XVII, por influência das irmãs carmelitas, que criaram a "Associação do Menino Jesus". Alcoforado, Ana, O Menino dos Meninos, Coimbra, Museu Nacional de Machado de Castro, 2007, p. 22. 
caracteriza a Europa a partir do século XVII ${ }^{32}$ e que revela nesta escultura conventual de Bragança essa mesma inquietação.

A escultura do Menino Salvador da sacristia da igreja de São Francisco em Bragança, julgamos ser já dos inícios do século XVIII, e pensamos que originalmente estaria a culto na capela da cerca do vizinho mosteiro feminino de Santa Escolástica. A mão direita em gesto de bênção e a esquerda sustendo o globo identificam a figura que poderia, conforme denunciam as marcas de desgaste da policromia em volta da cintura, ter estado ornamentada com um traje cingido na cintura. As práticas cultuais em volta da imaginária isolada da infância de Jesus relacionam-se com os espaços femininos e de modo subjacente parece implícito um sentido lúdico no uso da imagem. Conforme registou Borges em 1721-1724 esta imagem seria alvo de brincadeiras pois "andava pelas mãos das meninas" 33 , bem como, as marcas de desgaste sobre a policromia denotam as roupagens que o ornavam, seguramente ricas e variadas. Estes aspetos afastam o objeto cultual dos espaços dos frades menores, mas, a devoção que lhe estaria afeta tê-lo-á protegido. Supomos, pela proximidade geográfica entre ambos os conventos, que terá ficado responsável pela salvaguarda da imagem a Ordem Terceira de Bragança. A ausência documental não permite afirmar com certeza esta proveniência, mas, a inexistência de outras esculturas do Menino Jesus (do século XVIII) nos templos da cidade de Bragança assim o sugere.

Relacionado com a parentela de Cristo e sobretudo com o seu batismo registamos em Vinhais uma representação de São João Batista (Imagem 5). Dada a devoção popular que em Portugal se lhe presta surpreende a raridade da sua representação escultórica no interior dos templos. Originalmente a imagem partilhava o altar com Santa Bárbara e Santo António ${ }^{34}$, no entanto, não constituíam uma narrativa conjunta, simplesmente dividiam o mesmo espaço retabular. A escultura de Vinhais representa São João de pé,

\footnotetext{
${ }^{32}$ Ariès, Philippe, História Social da Criança e da Família. Rio de Janeiro, LTC- Livros Técnicos e Científicos Editora S.A, 1981, p. 127.

${ }^{33}$ Borges, José Cardoso, Memórias de Bragança, Fernando de Sousa (Coord.), Bragança, CEPESE / Câmara Municipal de Bragança, 2012 (texto original de 1721-1724), p.158.

${ }^{34}$ Conforme consta no inventário dos bens de raiz do Seminário Franciscano de missionários apostólicos em Vinhais. A.N.T.T./A.H.M.F./S.N.S.E.V., Extinção das Ordens Religiosas - Seminário de Nossa Senhora da Encarnação - Vinhais, Arquivo Nacional da Torre do Tombo, Lisboa, Arquivo Histórico do Ministério das Finanças, Processos de Extinção das casas religiosas, Cx. 2265, 1834, s/fl.
} 
descalço, acompanhado pelo cordeiro e vestido com peles. O cordeiro ${ }^{35}$, símbolo primitivo de Cristo, Agnus Dei vincula a mensagem de São João Baptista como o profeta que anuncia a vinda de Cristo. Essa mensagem consubstancia-se no momento do batismo em que São João se encontra com Jesus, momento que é referido nos quatro evangelhos canónicos.

Pese embora o aspeto bucólico sugerido pela terna presença do cordeiro, pela pose descontraída de São João com o pé apoiado sobre o solo natural e a mão acariciando o pequeno animal, a expressão do rosto do santo é grave reforçada pelo olhar baixo que quebra a aparente tranquilidade da situação antecipando a tragédia que o cobrirá a ele e a Jesus.

Das narrativas Cristológicas registadas nos espaços franciscanos em estudo são os ciclos da Paixão os que desenvolveram maior número de representações escultóricas.

Como elemento isolado ou como elemento de um conjunto, a Paixão de Jesus, constitui o culto mais representativo. De novo, respeitando a ordem histórica da narrativa destacamos primeiro a representação da Oração no Horto da capela da cerca do Seminário Apostólico de Vinhais (Imagens 6, 7 e 8). Trata-se de um conjunto já muito deteriorado e parcialmente destruído. Mas, a escassez de capelas com cenografias complexas e imagens de terracota de finais do século XVIII no território em estudo, impõem a este conjunto uma singularidade que importa destacar.

Conforme fica exposto no capítulo relativo à análise formal, julgamos que este conjunto terá sido produzido em Vinhais e pelas mãos de Frei Domingos.

A narrativa exposta representa o momento que antecede a prisão de Jesus. O episódio da oração no Monte das Oliveiras é narrado por três dos quatro evangelistas: Mateus, Marcos e Lucas. A agonia do momento é expressa pelos três evangelistas, a cena decorre após a última ceia quando Jesus se afasta para o monte Getsémani acompanhado por três discípulos a quem segundo Mateus 26: 38 diz «A Minha alma está numa tristeza de morte; ficai aqui e vigiai Comigo» e afastando-se dos discípulos para rezar por três vezes encontrou-os no regresso sempre adormecidos. Mateus 26: 39

\footnotetext{
${ }^{35} \mathrm{O}$ cordeiro, como representação do Agnus Dei ilustra a relação de São João Baptista como o profeta que anuncia a vinda de Cristo. Carmona Muela, Juan, Iconografia cristiana, Madrid, Akal, 2010, p. 57. A narrativa do santo envergando peles e descalço, na representação do batismo de Cristo no rio Jordão, constitui a representação mais comum de São João Batista. Kaftal, George, Iconography of the saints in central and south Italian schools of painting, Firenze, Casa Editrice Le Lettere, 1986, pp. 609-614.

No Flos Sanctorum é também envolto em peles e descalço que se representa em gravura São João Batista, que segura o livro sobre o qual está colocado o agnus dei. Campos, Hermão de e Rabelo, Roberto, Flos Sanctorum HO FLOS SANCTÕ[RUM] EM LINGOAJE[M] P[OR]TUGUE[S], Lisboa, Disponível na plataforma on-line da Biblioteca Nacional de Portugual http://purl.pt/12097, 1513, fl. CXXXI v.
} 
refere a oração «Meu Pai, se é possível passe de Mim este cálice; todavia, não seja como Eu quero, mas, como Tu queres», que Marcos e Lucas também referem. Marcos 14, 32-42 coincide na descrição do momento com Mateus e acrescenta os nomes dos três discípulos Pedro, Tiago e João que acompanham Jesus no Monte das Oliveiras. A descrição de Lucas 22, 39-46, idêntica às anteriores, foi no entanto a que mais influenciou as representações artísticas da Agonia no Getsémani. Refere Jesus de joelhos a orar, e não caído ou prostrado em terra como referiam Mateus e Marcos, e perante Ele "Então vindo do Céu, apareceu-lhe um anjo que O confortava". Lucas é o único evangelista que refere o anjo que conforta Jesus na sua agonia.

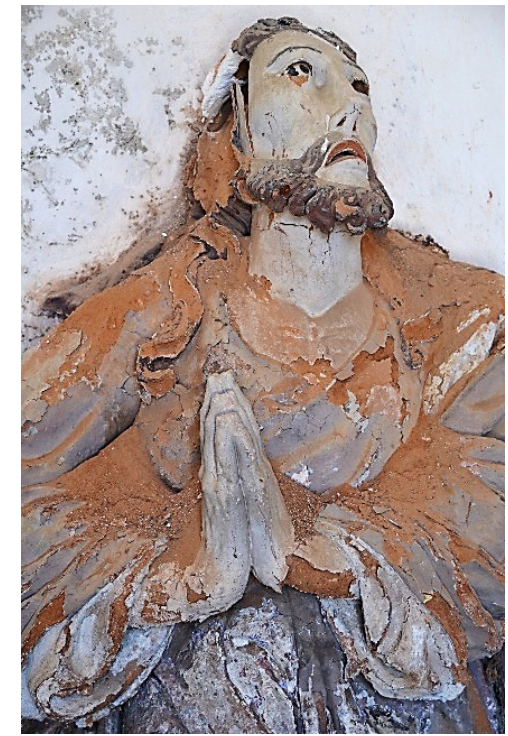

Imagem 6

Cristo em oração no horto COHV 2

Oficina local (Frei Domingos); Ultimo quartel do século XVIII Capela da Oração no Horto Vinhais

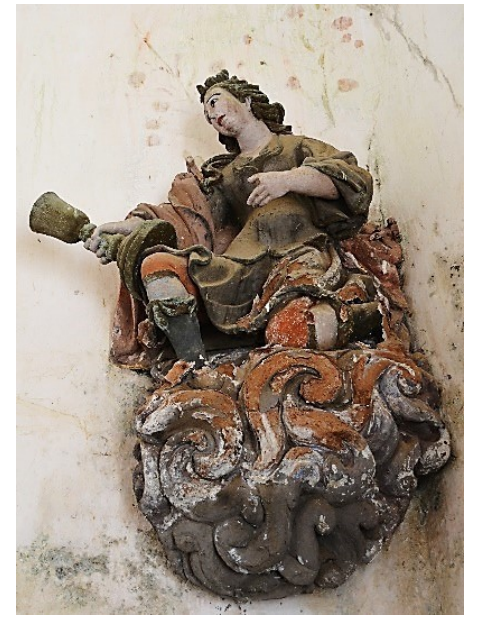

Imagem 7

Anjo com cálice - COHV 1 Oficina local (Frei Domingos); Ultimo quartel do século XVIII Capela da Oração no Horto Vinhais

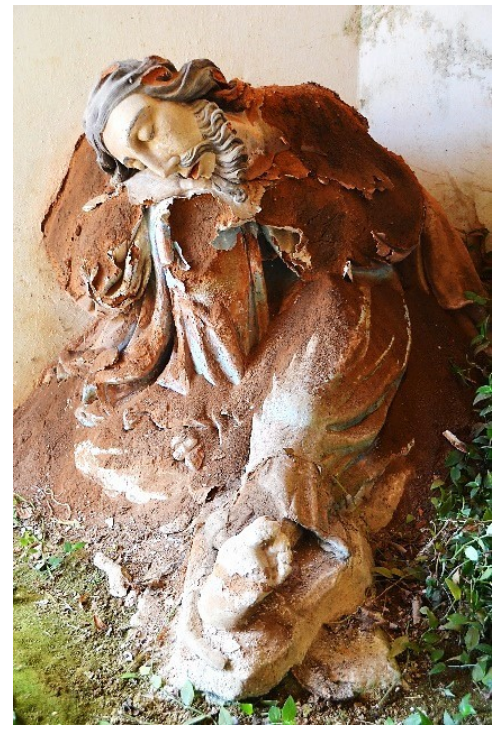

Imagem 8

Apóstolo adormecido - COHV 5 Oficina local (Frei Domingos); Ultimo quartel do século XVIII

Capela da Oração no Horto Vinhais

A partir do século XVI o anjo passou a ser representado com um cálice como metáfora da Paixão, não sendo no entanto um atributo iconográfico indispensável ${ }^{36}$.

É pois o evangelho de Lucas que vemos representado na Oração do Horto da capela da cerca do Seminário Apostólico. Neste conjunto, Jesus de joelhos e mãos postos eleva o rosto para o anjo que o conforta. A expressão de angústia, mesmo com o rosto já parcialmente destruído pelo tempo, é percetível nos olhos e na boca (Imagem 6). Bem

\footnotetext{
${ }^{36}$ Réau, Louis, Iconografía del Arte Cristiano. Iconografia de la Biblia - Nuevo Testamento Tomo 1/ Volumen 2, Barcelona, Ediciones del Serbal, 1996, (Edição original 1955-1959), p. 445; Carmona Muela, Juan, Iconografia cristiana, Madrid, Akal, 2010, pp. 156, 157.
} 
como a compaixão do anjo se percebe na expressão do rosto (Imagem 7). O expressivo sofrimento de angústia e compaixão de ambas as figuras contrasta com a serena placidez do apóstolo adormecido. Apenas um dos apóstolos chegou aos nossos dias (Imagem 8), os restantes dois encontram-se em ruinoso estado de conservação, reduzidos a fragmentos do corpo já sem cabeças. A intensa expressividade da cena é acompanhada pela dinâmica cenografia da composição em círculo, onde abunda a cor e se destaca a riqueza da indumentária palaciana do anjo.

Este conjunto seria parte de um amplo programa que representaria toda a Paixão, mas apenas a capela da Oração do Horto e a capela do Cristo Morto chegaram a ser construídas. Esta representação escultórica da Via Crucis, se bem que incompleta, é única na imaginária dos espaços em estudo, não só no material de suporte das esculturas, a terracota, mas nas compósitas narrativas propostas. As capelas da Via Sacra foram encomendados pelos frades missionários tal como as gravuras ${ }^{37}$ da Via Crucis atualmente expostas no Museu de Arte Sacra de Vinhais.

Réau afirma que a origem do Caminho do Calvário se deve aos franciscanos que no final da idade média custodiavam os Lugares Santos de Jerusalém entre os quais, e inspirados pelos místicos como o Pseudo Boaventura e Santa Brígida, se estabeleceu um percurso. No século XVII, o franciscano Leonardo de Porto Maurizio instituiu o número de catorze estações, consolidando assim uma das devoções mais populares da ordem franciscana ${ }^{38}$.

Luís Alexandre Rodrigues, contraria esta origem afirmando que a prática da Via Crucis, tal como se configurou no Ocidente nos últimos séculos, não foi influenciada por Jerusalém, onde chegou apenas no século XVII. A prática ocidental resultou da difusão das práticas devocionais que tinham a sua fundamentação na possibilidade de se evocar espiritualmente a caminhada de Cristo com a cruz até ao Gólgota. Uma lógica processional em que o itinerário se convertia num percurso simbólico de redenção dos

\footnotetext{
${ }^{37}$ As gravuras que representam a Via Crucis atualmente expostas no Museu de Arte Sacra de Vinhais foram registadas no inventário de 1834 como parte dos bens do Seminário Apostólico, não sendo por isso de crer que o conjunto tivesse sido encomendado pela Ordem Terceira conforme afirma Rodrigues, mas antes sim pelos frades missionários. As gravuras italianas da via-sacra do museu da Ordem Terceira de $\mathrm{S}$. Francisco, em Vinhais, fazem parte de uma série que foi produzida em Roma poucos anos depois da Via Crucis ter sido oficialmente sistematizada em catorze episódios. Rodrigues, Luís Alexandre, "Caminho Doloroso: as gravuras italianas da Ordem Terceira de Vinhais" in Natália Marinho Ferreira-Alves (Coord.), Franciscanos no Mundo Português III, Porto, CEPESE - Centro de Estudos da População, Economia e Sociedade 2013, pp. 491-527.

${ }^{38}$ Réau, Louis, Iconografía del Arte Cristiano. Iconografía de la Biblia - Nuevo Testamento Tomo 1/ Volumen 2, Barcelona, Ediciones del Serbal, 1996, (Edição original 1955-1959), pp. 484, 485.
} 
homens através da dor e da humilhação. O domínio que Espanha exercia nos PaísesBaixos justificou uma ampla difusão do Caminho Doloroso em Espanha, país donde, irradiou para outras paragens ${ }^{39}$.

As representações que se relacionam com esta devoção nos espaços em estudo são do século XVIII, período em que o culto estava já amplamente difundido. Para esta ampliação é forçoso relacionar as capelas da Oração no Horto e de Cristo Morto com as gravuras vindas de Roma para o Seminário Apostólico de Vinhais. Não apenas pelos vínculos devocionais formais, mas pela insistência, por diferentes meios, no culto que os frades missionários tentaram impor no território. O Seminário dispunha, ou pretendia vir a dispor, não apenas de uma representação do Caminho Doloroso para o interior do templo, ilustrado nas gravuras, mas também para o exterior com a representação da narrativa nas capelas. Dada a considerável distancia entre as duas capelas é compreensível que o caminho doloroso viesse a estender-se pela extensa propriedade que então os frades detinham, encenando os vários episódios da Paixão.

Com exceção destas capelas a narrativa da Via Crucis não constitui um motivo devocional comum nos espaços franciscanos estudados. Mais uma vez, tal como acontece com a devoção do Presépio, chama a atenção a escassez de representações iconográficas que se relacionam com o Caminho Doloroso nos espaços franciscanos estudados, dada a tradicional relação entre a Ordem e os cultos referidos.

No contexto do Caminho Doloroso apenas na igreja de São Francisco em Bragança voltamos a encontrar uma representação que se lhe relaciona. Trata-se de uma imagem de roca de Cristo transportando a Cruz. O Senhor do Passos, (Imagem 9), representado isoladamente e não em narrativa de conjunto conforme acontece na capela de Vinhais apresenta algumas singularidades que merecem menção. Conforme se expõe na análise formal julgamos que a escultura que representa o Senhor dos Passos é constituída por partes de diferentes cronologias. Enquanto a estrutura interior sugere proximidades com os inícios do século XVIII, a cabeça e as mãos parecem ser posteriores, do século XIX

\footnotetext{
${ }^{39}$ A devoção da Via Crucis foi difundida na maioria dos países europeus pelo franciscano anónimo de Saint-Trond, por Jean Van Paschen e por Adrichomius e só a partir do século XVII seria introduzida em Jerusalém. Rodrigues, Luís Alexandre, "Caminho Doloroso: as gravuras italianas da Ordem Terceira de Vinhais" in Natália Marinho Ferreira-Alves (Coord.), Franciscanos no Mundo Português III, Porto, CEPESE - Centro de Estudos da População, Economia e Sociedade 2013, pp. 491-527.
} 
ou até mais recentes. A devoção está registada no interior do templo desde 1721-1724 sob a responsabilidade da Ordem Terceira $^{40}$.

Os evangelhos não coincidem na descrição do momento, Mateus Mt 27, 31, Marcos Mc 15, 21 e Lucas Lc 23,26 , referem que Jesus foi ajudado a carregar a cruz por Simão de Cirene, enquanto João Jo 19, 16, refere que Jesus transportou a cruz todo o caminho sozinho.

A representação do Senhor dos Passos representa Jesus sozinho, seguindo a narrativa de João evangelista. A imagem a culto na igreja de São Francisco em Bragança, pelo facto de ser de roca, sugere que

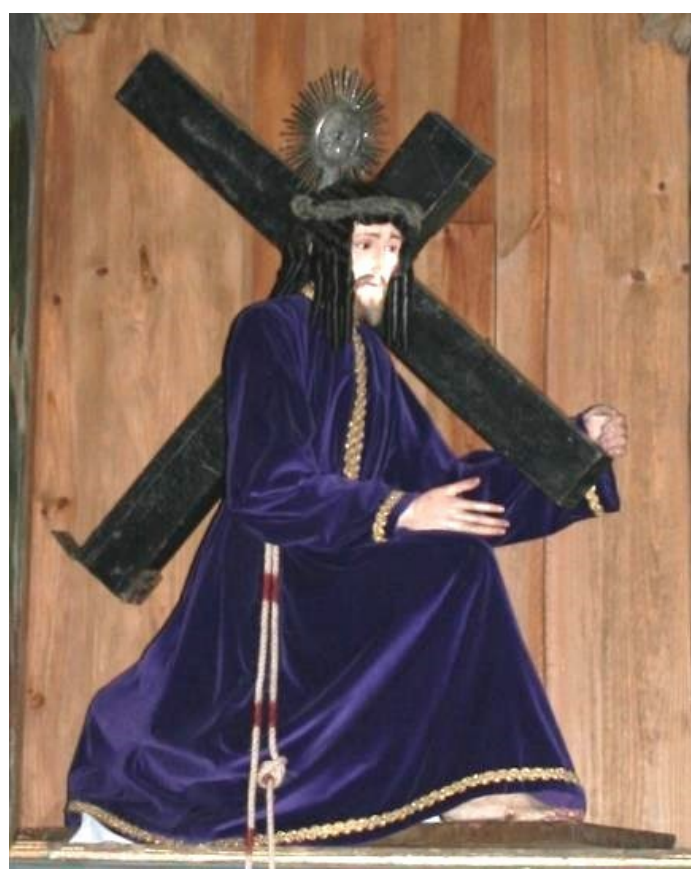

Imagem 9

Senhor dos Passos - SFB 26

Oficina portuguesa (Porto\Braga); século XVIII $\backslash$ XIX Retábulo lateral, lado do Evangelho Igreja de São Francisco, Bragança poderia ser usada em distintas posições, pois tanto os braços como as pernas são articulados permitindo ser alterados. A imagem está caída de joelhos, com o joelho esquerdo no chão, enquanto o joelho direito fletido sugere o movimento de se elevar. O peso da cruz enorme, apenas parcialmente exposta no retábulo por condicionalismos físicos, impossibilita o movimento e obriga à genuflexão.

O tamanho e o peso da cruz aumentaram durante o renascimento e barroco assim como os elementos, alegóricos ou simbólicos, que acompanhavam e ajudavam Jesus a suportar a condena ${ }^{41}$.

Seguramente que esta escultura se relacionaria através da Ordem Terceira com as celebrações da Semana Santa, nas quais o convento franciscano tinha especial destaque junto da comunidade local ${ }^{42}$.

\footnotetext{
${ }^{40}$ Borges, José Cardoso, Memórias de Bragança, Fernando de Sousa (Coord.), Bragança, CEPESE / Câmara Municipal de Bragança, 2012 (texto original de 1721-1724), p. 142.

${ }^{41}$ Réau, Louis, Iconografía del Arte Cristiano. Iconografia de la Biblia - Nuevo Testamento Tomo 1/ Volumen 2, Barcelona, Ediciones del Serbal, 1996, (Edição original 1955-1959), p. 483.
} 
O final do Caminho Doloroso é o Gólgota onde Jesus foi crucificado. A narrativa da crucificação é a maior devoção nos espaços em estudo e a que originou mais representações.

De entre os diferentes templos em estudo aquele onde se regista maior complexidade e variedade dentro da figura de Cristo Crucificado é a igreja do convento de São Francisco de Bragança. Esta variedade é facilmente compreensível tendo em conta a amplitude temporal do convento. Sendo o mais antigo da região é também aquele onde os consequentes processos de adaptações e melhorias do espaço foram mais

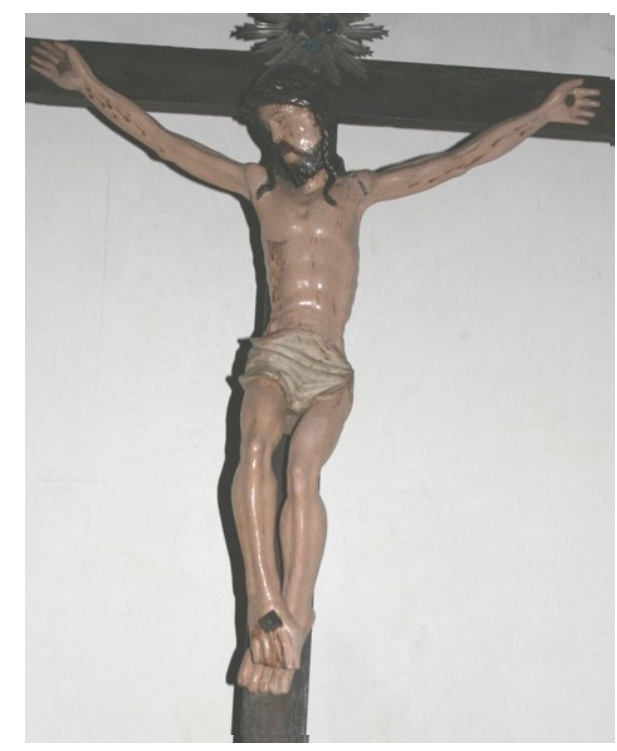

Imagem 10

Cristo Crucificado - SFB 22

Oficina: Países Baixos; século XVI Igreja de São Francisco, Bragança significativos.

No conjunto de esculturas que representam Cristo Crucificado registadas na igreja do convento de São Francisco em Bragança consta a imagem cuja cronologia é mais recuada (Imagem 10). Assumimos integrar a escultura de Cristo Crucificado (número de inventário SFB 22) no século XVI e pensamos que a sua origem pode estar relacionada com o fluxo de imagens provenientes das oficinas dos Países-Baixos que se regista em todo o território nacional no decurso dessa centúria.

Destaca-se desta primeira representação de Jesus na Cruz a quase total ausência de sinais de martírio. A figura de Cristo está representada morta, conforme passou a ser usual a partir do século $\mathrm{XI}^{43}$. A alteração da representação de Cristo vivo e triunfante na cruz para o Cristo morto, com a cabeça

\footnotetext{
$42 \mathrm{O}$ Convento franciscano de Bragança além ter a responsabilidade dos sermões do Advento e da Quaresma, Borges refere que em 1721-24 que no dia de Páscoa por "estilo antiquíssimo vem a procissão a esta igreja". Borges, José Cardoso, Memórias de Bragança, Fernando de Sousa (Coord.), Bragança, CEPESE / Câmara Municipal de Bragança, 2012 (texto original de 1721-1724), p. 147.
}

43 A representação de Cristo na Cruz foi, durante os primeiros séculos do cristianismo, evitada e substituída pela representação do cordeiro místico. A partir do século VI surge a representação de Cristo de forma humana cravado na cruz, que se desenvolverá posteriormente em dois modelos distintos, coberto apenas pelo perisónio nas representações carolíngias, ou envergando uma longa túnica sem mangas nas representações sírias, mas sempre vivo e até triunfal. O Concilio de 692 em Constantinopla recomendou a representação de Cristo com sua forma humana em detrimento do símbolo do cordeiro. Réau, Louis, Iconografía del Arte Cristiano. Iconografía de la Biblia - Nuevo Testamento Tomo 1/ Volumen 2, Barcelona, Ediciones del Serbal, 1996, (Edição original 1955-1959), pp. 494-496. 
caída sobre o lado direito, os olhos fechados e o corpo fletido, decorre do misticismo sentimental, que a partir do século XIII, e por influência de São Francisco de Assis, ou dos Exercícios de Johannes Tauler, as Meditações da vida de Cristo de Pseudo Boaventura ou as Revelações de Santa Brígida, exaltavam o atroz sofrimento da paixão de Cristo e, em particular, o lento martírio da sua morte, que se traduz na intenção de provocar a comoção pelos padecimentos de Cristo junto dos fiéis ${ }^{44}$.

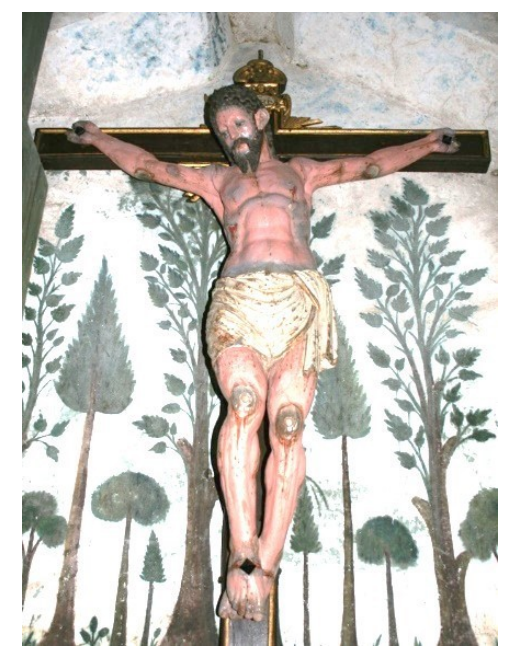

Imagem 11

Escultura de Cristo Crucificado - SFB 20

Oficina portuguesa; início do século XVII

Capela lateral do lado do Evangelho

Igreja de São Francisco, Bragança

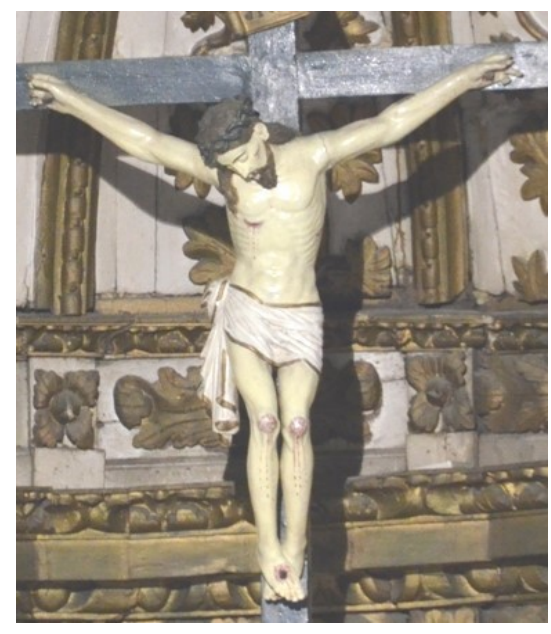

Imagem 12

Escultura de Cristo Crucificado SCB 06

Oficina portuguesa; início do século XVII

Tribuna do altar-mor Igreja do convento de Santa Clara (atual igreja de Nossa Senhora das Graças) Bragança

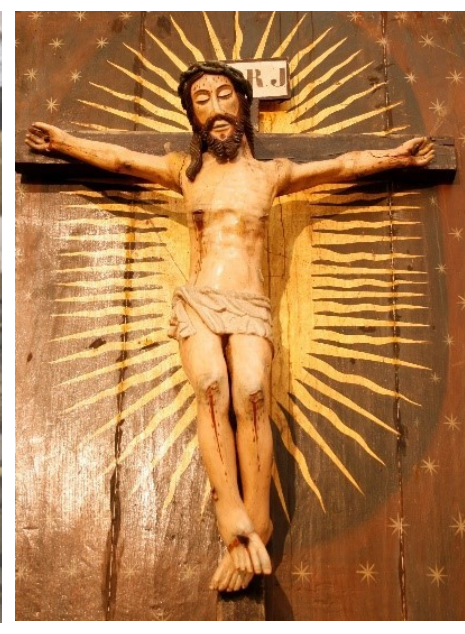

Imagem 13

Cristo Crucificado - SFM 06 Oficina portuguesa; final do século XVII $\backslash$ início do XVIII Transepto do lado do Epístola Igreja de São Francisco, Mogadouro

Maria Isabel Roque refere o Concílio de Calcedónia, reunido em 451, instaurou o dogma da Encarnação como união hipostática: "o Senhor nosso Jesus Cristo, perfeito na sua divindade e perfeito na sua humanidade, verdadeiro Deus e verdadeiro homem" (Concílio da Calcedónia, 4. ${ }^{\circ}$ ecuménico, 5. ${ }^{\text {a }}$ sessão. In Denzinger, 2007: 113). Foi neste contexto que, ainda no século V, surgiram as primeiras figurações humanas de Cristo crucificado, com os olhos abertos e a cabeça erguida, com um diadema real em substituição da coroa de espinhos, firmando a tradição bizantina da representação de Christus triumphans, vivo e triunfante sobre a morte. O corpo, com os braços abertos horizontalmente sobre a trave da cruz e os pés apoiados no supedâneo, aparenta estar de pé. Estendendo-se a todo o mundo cristão, este modelo dominou a iconografia medieval até ao século XI. Roque, Maria Isabel Rocha, "Imagens esculpidas de cristo na dor", Lumen Veritatis: boletim da Sociedade Científica da Universidade Católica Portuguesa, Lisboa, Universidade Católica Portuguesa, 2012, pp. 8-10.

${ }^{44}$ Réau, Louis, Iconografía del Arte Cristiano. Iconografía de la Biblia - Nuevo Testamento Tomo 1/ Volumen 2, Barcelona, Ediciones del Serbal, 1996, (Edição original 1955-1959), pp. 497, 498; Roque, Maria Isabel Rocha, "Imagens esculpidas de cristo na dor", Lumen Veritatis: boletim da Sociedade Cientifica da Universidade Católica Portuguesa, Lisboa, Universidade Católica Portuguesa, 2012, pp. 810. 
O cendal ou perisónio é de origem helénica, pois a tradição romana obrigava a que o condenado à crucificação estivesse nu. Porém, as representações artísticas raras vezes se detiveram neste detalhe histórico. No renascimento instituiu-se o perisónio em detrimento da túnica, até se transformar num elemento decorativo ${ }^{45}$.

Todas as representações de Cristo na Cruz incluídas no presente estudo se apresentam com perisónio, mais ou menos esvoaçante, consoante a cronologia de produção da escultura.

As figuras de Cristo na Cruz do século XVII (Imagem 11, 12 e 13) ocupam o espaço central dos retábulos que as acolhem.

A imagem de Cristo Crucificado da Igreja de São Francisco de Bragança (Imagem 11) apresenta dramáticos sinais de martírio. No entanto, Cristo está figurado vivo, de olhos abertos com olhar baixo e com expressão de serena compaixão, que contrasta com a intensa coloração do corpo ensanguentado e escurecido como se estivesse já em decomposição. A forte anatomia, quase atlética, intensifica o conflito com o sofrimento resignado da serena expressão do rosto.

A figura está acompanhada por diversas representações pictóricas dos elementos da Paixão que se distribuem nas edículas do retábulo maneirista que o expõe na capela lateral que ocupa.

De anatomia mais frágil e sofrimento menos ensanguentado o Cristo da igreja do convento de Santa Clara (atual igreja de Nossa Senhora das Graças) em Bragança (Imagem 12), está colocado sobre a tribuna do altar-mor, constituindo, nos templos em estudo, o único exemplar desta devoção que ocupa atualmente o espaço central da capela-mor. Neste sentido, convém referir que tratando-se de um templo de um convento feminino a desamortização dos bens foi posterior aos conventos masculinos e denota significativas alterações dos cultos, por isso é questionável a posição central da figura de Cristo, sendo o templo dedicado pelas clarissas a Nossa Senhora da Conceição.

Esta representação mostra Cristo morto, de olhos fechados e boca entreaberta. O corpo magro e a cabeça caída enfatizam a fragilidade do cadáver que inspira compaixão. Coevo do Cristo Crucificado dos conterrâneos frades menores, expõe os preceitos de Trento com mais rigorosa observância.

\footnotetext{
${ }^{45}$ Réau, Louis, Iconografia del Arte Cristiano. Iconografia de la Biblia - Nuevo Testamento Tomo 1/ Volumen 2, Barcelona, Ediciones del Serbal, 1996, (Edição original 1955-1959), p. 499; Carmona Muela, Juan, Iconografia cristiana, Madrid, Akal, 2010, pp. 129, 130.
} 
Privilegiando o sentido catequético, tal como o Concilio de Trento impunha, e desvalorizando até a verosimilhança e a harmonia formas, o Cristo Crucificado da igreja de São Francisco de Mogadouro (Imagem 13) traduz, a subjugação da imagem ao conteúdo que comunica. Dentro do formulário tardo-maneirista do retábulo que o expõe, a figura de Cristo revela já, pelo ondulado perisónio, a introdução do gosto barroco.

Nas três representações de Cristo Crucificado que foram esculpidas ao longo do século XVII nos templos em estudo, é evidente a crescente pressão do Concilio de Trento. A pressão é manifesta na configuração de obras onde o propósito do significado e utilidade das imagens se impunha sobre a forma que assumiam. Indissociável desta contenção formal é o contexto económico e político decorrente da Guerra da Restauração que preencheu quase trinta anos da centúria.

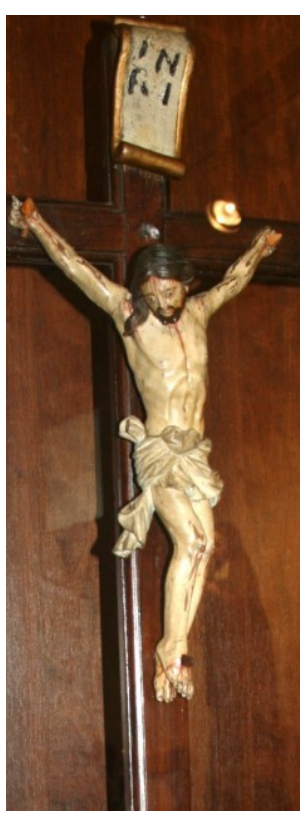

Imagem 14

Cruz de Altar MASV 06

Oficina nacional; meados do século XVIII

Museu de Arte Sacra Vinhais

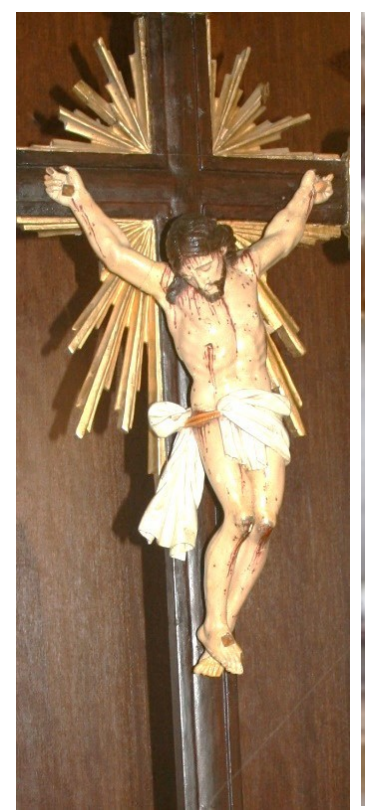

Imagem 15

Cruz de Altar MASV 08

Oficina nacional; segunda metade do século XVIII Museu de Arte Sacra Vinhais

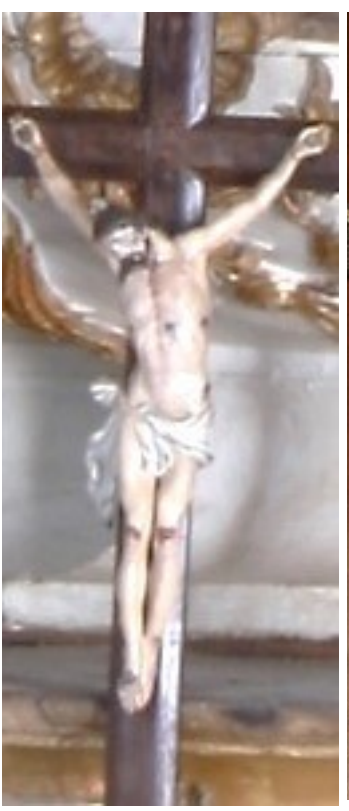

Imagem 16

Cruz de Altar SFV 13

Oficina nacional; segunda metade do século XVIII

Retábulo no altar-mor Igreja de São

Francisco, Vinhais

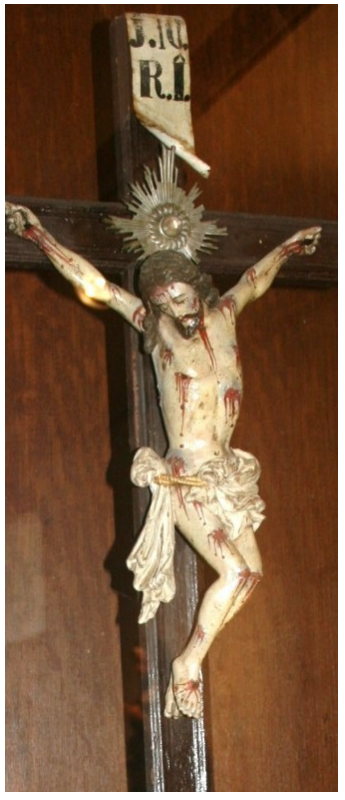

Imagem 17

Cruz de Altar MASV 07

Oficina nacional; segunda metade do século XVIII

Museu de Arte Sacra Vinhais

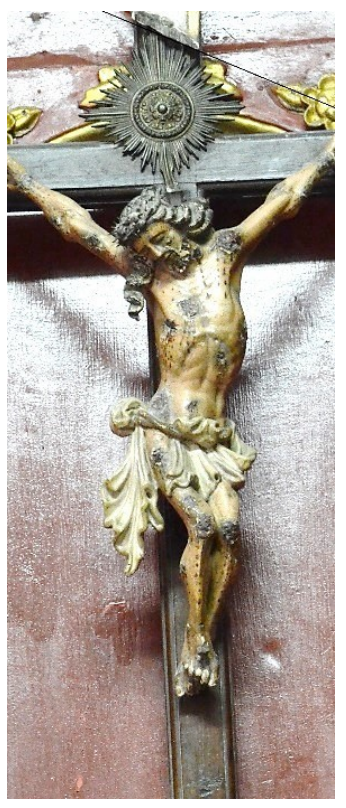

Imagem 18

Cruz de Altar SIEV 05

Oficina nacional; segunda metade do século XVIII Sacristia da Igreja de Nossa Senhora da Encarnação, Vinhais 
Mas, o século XVIII foi pródigo em representações de Crucificações. Neste século além da representação de Cristo na Cruz, sozinho, surgem várias representações de narrativas em que Cristo na Cruz é acompanhado por outras figuras.

Das representações de Cristo isolado devemos destacar a numerosa quantidade de Cruzes de altar atualmente expostas em Vinhais (Imagem 14, 15, 17 e 17, 18). Deste conjunto de cinco cruzes apenas uma está a culto no interior da igreja (Imagem 15), as restantes estão expostas no Museu de Arte Sacra de Vinhais e escultura com o número de inventário SIEV 03 está na sacristia da igreja de Nossa Senhora da Encarnação. Julgamos que terão possivelmente pertencido ao Seminário Apostólico, podendo estar relacionadas com as missões que os frades comummente faziam no exterior.

Apenas uma das estatuetas representa Cristo vivo, (Imagem 14), coberto por um perisónio particularmente decorativo. A torção do corpo e os sinais de martírio denunciam a teatralidade que esta representação vai assumindo ao longo do século XVIII.

As semelhanças iconográficas entre as quatro representações são evidentes, sugerindo a ligeira alteração do modelo apenas no efeito cénico do perisónio. O cordão que o cinge (Imagem 15, 16, 17, 18) permite em conjunto com o cendal enfatizar a dinâmica e tumultuosa atmosfera que envolve a figura de Cristo. A valorização do equilíbrio anatómico é acrescentada pela intensidade do gesto. A maior genuflexão das pernas e o estreitamento da abertura nos braços criam formas emocionalmente mais pungentes. A comunicação do sofrimento insuportável adquire nestas formas de Cristo a intenção da profunda comoção piedosa.

Conforme ficou exposto na análise formal, julgamos que a escultura MASV 07 e a SIEV 03 terão servido de modelo à escultura colossal de Cristo do Coro (Imagem 19 e Imagem 20). Hoje, a escultura de Cristo do Coro, atribuída a Frei Domingos, está colocada dentro do retábulo da capela de Nossa Senhora das Dores, ajustado de modo a comportar a exposição da escultura de tamanho colossal. A referência como "Senhor do Côro" permite entender a escala colossal desajustada da imagem face ao retábulo que a expõe, bem como percebê-la no espaço original, sob a balaustrada do coro alto da Igreja da Encarnação. No coro alto está atualmente exposto um Cristo Crucificado mas de produção atribuída à segunda metade do século XX. A imagem de Cristo do Coro ou Senhor dos Perdidos, como é designada hoje em dia, estaria, originalmente confrontada com a também colossal escultura de Nossa Senhora da Encarnação colocada, ainda atualmente, no nicho central do altar-mor da igreja da Encarnação. 
De todas as representações da Crucificação o Cristo do Coro é a que expressa o exagero do sofrimento de forma mais dilacerante. A torção do dorso e as marcas de martírio no corpo de Cristo já morto configuram a linguagem emocional propícia à comoção que originalmente seria equilibrada pela representação suave da Encarnação da Virgem Maria que lhe estaria oposta no altar-mor.

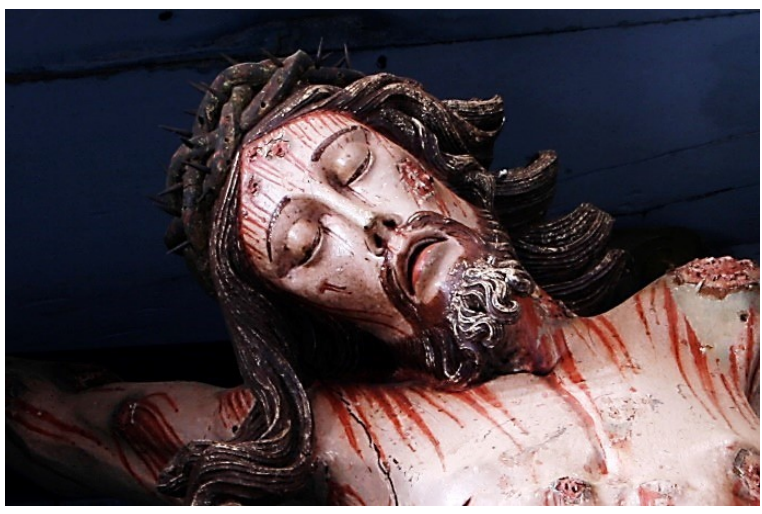

Imagem 19

Pormenor do rosto da escultura de Bom Jesus dos Perdidos ou Cristo do Coro - CSDV 06 Oficina local (Frei Domingos); Século XVIII (finais) Capela de Nossa Senhora das Dores, Igreja de Nossa Senhora da Encarnação, Vinhais

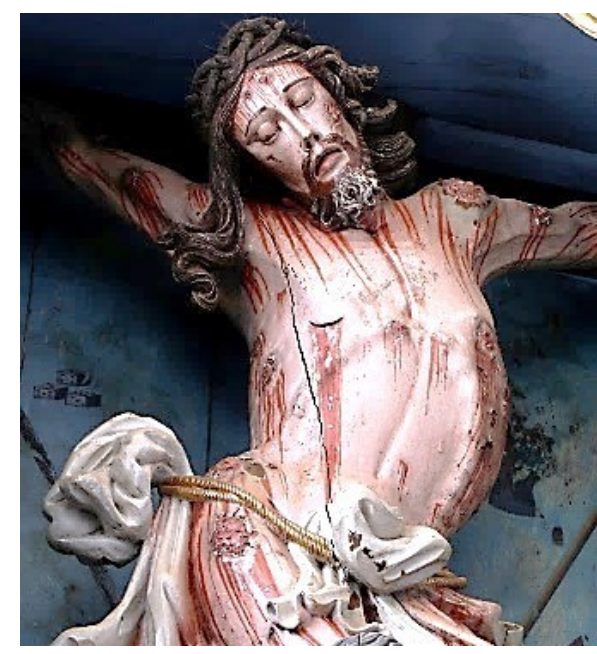

Imagem 20

Pormenor do dorso da escultura de Bom Jesus dos Perdidos ou Cristo do Coro - CSDV 06 Oficina local (Frei Domingos); Século XVIII (finais)

Capela de Nossa Senhora das Dores, Igreja de Nossa Senhora da Encarnação, Vinhais

Atualmente a escultura de Cristo do Coro está acompanhada por três figuras de Calvário, porém sabemos que originalmente não constituíam uma narrativa conjunta.

A representação do Calvário da capela de Nossa Senhora das Dores teria seguramente um outro Cristo esculpido, ou pintado, hoje já desaparecido, mas que existia ainda aquando do inventário de 1834.

O conjunto de figuras do Calvário da capela de Nossa Senhora das Dores representam Nossa Senhora, São João e Maria Madalena.

Mateus 27, 56 refere as mulheres que observavam de longe o momento da crucificação "Maria de Magdala, Maria, mãe de Tiago e de José, e a mãe dos filhos de Zebedeu". Marcos 15, 40 acrescenta à narrativa Salomé junto de Maria de Magdala e Maria, mãe de Tiago e José. Lucas 23, 49 refere apenas os conhecidos e as mulheres que acompanhavam Jesus desde a Galileia que se mantinham à distância. É no evangelho de João 19, 25-27 que o momento é descrito com mais detalhe "junto da cruz de Jesus estavam Sua mãe, Maria, mulher de Cléofas e Maria de Magdala. Ao ver Sua 
mãe e junto dela, o discípulo que Ele amava, Jesus disse a Sua mãe: «Mulher, eis aí o teu filho». Depois disse ao discípulo: «Eis aí a tua mãe». E, desde aquela hora, o discípulo recebeu-A em sua casa.

A narrativa que é ilustrada na representação da capela de Nossa Senhora das Dores de Vinhais (Imagem 21) é retirada do Evangelho de João pois é o único que refere João, testemunho ocular do momento, bem como, é o único que refere Nossa Senhora junto a Madalena.

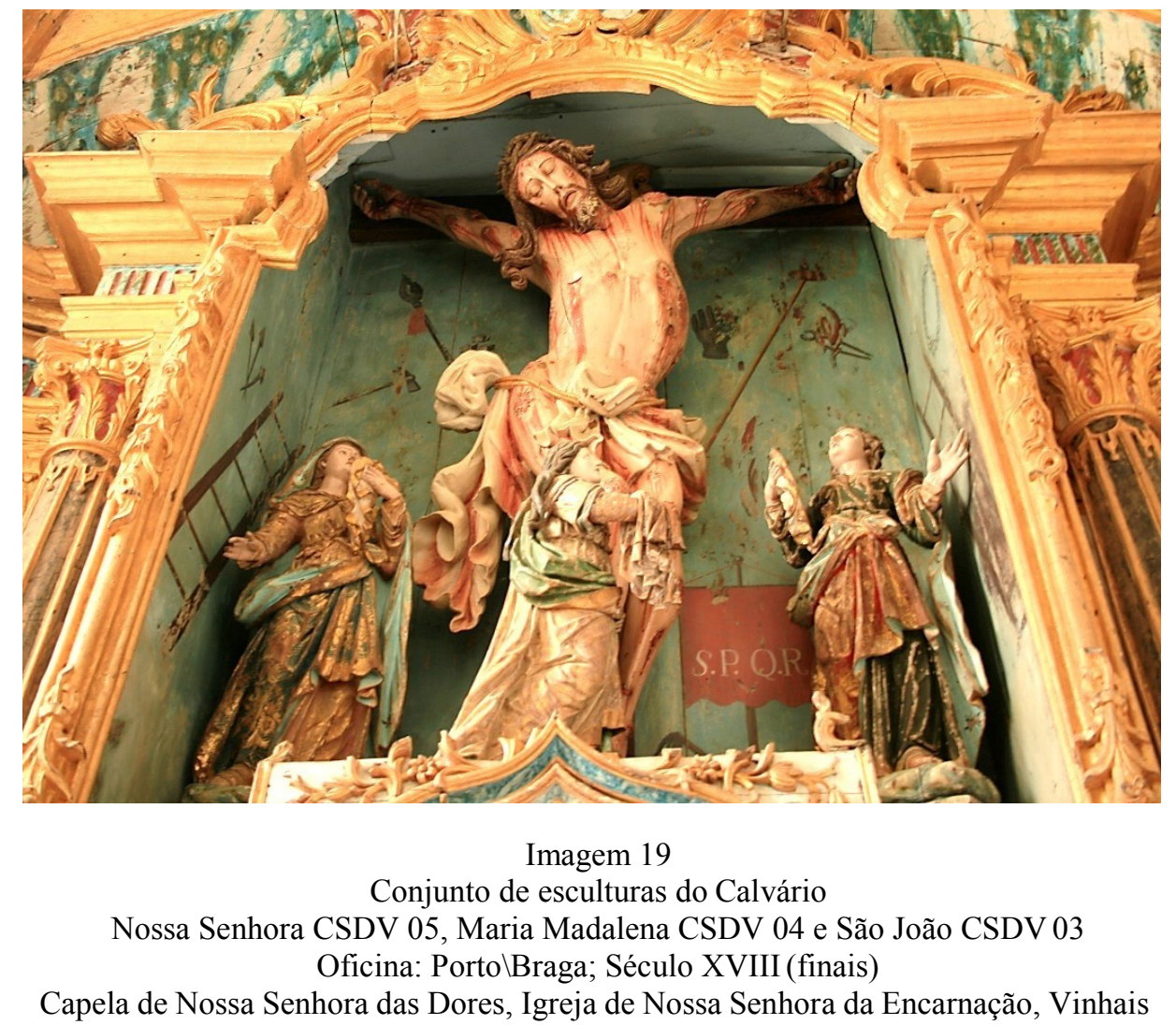

Conforme foi descrito na análise formal a imagem de Cristo que atualmente se expõe na capela foi posteriormente acrescentada ao conjunto. O Calvário representa Nossa Senhora à direita de Cristo crucificado e São João à esquerda, seguindo a organização tradicional da narrativa ${ }^{46}$. Madalena está em frente e aos pés do crucifixo em acentuado contraposto, quase genuflexão ${ }^{47}$. Os restantes elementos estão de pé sem desfalecerem

\footnotetext{
${ }^{46}$ Réau, Louis, Iconografia del Arte Cristiano. Iconografia de la Biblia - Nuevo Testamento Tomo 1/ Volumen 2, Barcelona, Ediciones del Serbal, 1996, (Edição original 1955-1959), p. 518; Carmona Muela, Juan, Iconografia cristiana, Madrid, Akal, 2010, pp. 118, 119.

${ }^{47}$ Em frente da cruz de joelhos constitui o gesto mais recorrente nas narrativas de Madalena. Kaftal, George, Iconography of the saints in central and south Italian schools of painting, Firenze, Casa Editrice Le Lettere, 1986, p. 763.
} 
assumindo assim a resistência ao sofrimento. A Virgem eleva a mão esquerda ao rosto denunciando nesse gesto a influência da tradição oriental da representação da dor ${ }^{48}$.

O conjunto quebra o estoicismo da resistência ao sofrimento apenas com os panejamentos que as três figuras sustêm, sugerindo nesse gesto de amparo do lenço a resiliência perante a dor. A emotividade contida das personagens contrasta com a cénica utilização dos panejamentos que evocam a turbulência atmosférica do momento.

Imagem 22

Calvário com as imagens de São Domingos SIEV 02, São João SIEV 03, Nossa Senhora SIEV 04 e Cristo Crucificado SIEV 05 Oficina: Portuguesa; Século XVIII (finais) Oratório na sacristia da Igreja de Nossa Senhora da Encarnação, Vinhais

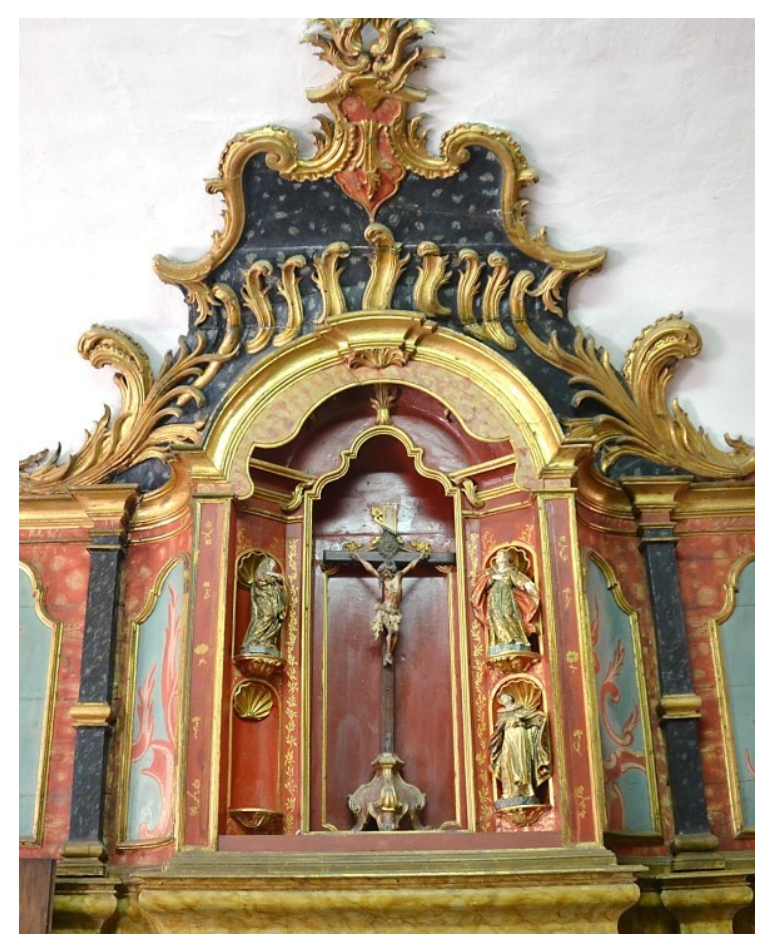

Após o Concilio de Trento, de modo a dignificar a representação que deveria ser comovedora, a cenografia da crucificação estabelece-se de acordo com os evangelhos, excluindo muitas das personagens que se haviam até então incorporando na cena ${ }^{49}$. $\mathrm{O}$ Calvário da capela de Nossa Senhora das Dores de Vinhais segue as recomendações tridentinas registando apenas três personagens.

Ainda em Vinhais, e igualmente encomendada pelos missionários apostólicos encontramos outro Calvário (Imagem 22).

Este conjunto, de pequeno tamanho está colocado no oratório da sacristia e encontrase atualmente incompleto, pois um dos nichos vazio assim o denuncia. Nesta representação, além de Nossa Senhora e de São João a cena é acompanhada por São

\footnotetext{
${ }^{48}$ Réau, Louis, Iconografía del Arte Cristiano. Iconografía de la Biblia - Nuevo Testamento Tomo 1/ Volumen 2, Barcelona, Ediciones del Serbal, 1996, (Edição original 1955-1959), p. 520.

${ }^{49}$ Réau, Louis, Iconografia del Arte Cristiano. Iconografía de la Biblia - Nuevo Testamento Tomo 1/ Volumen 2, Barcelona, Ediciones del Serbal, 1996, (Edição original 1955-1959), p. 521; Carmona Muela, Juan, Iconografia cristiana, Madrid, Akal, 2010, p. 119.
} 
Domingos de Gusmão. Julgamos pela presença de São Domingos que a narrativa deste Calvário se relacionaria com a visão de Cristo que teve São Domingos em Roma, segundo a qual perante a cólera de Cristo com os vícios da humanidade do orgulho, a avareza e a luxuria, Nossa Senhora tê-lo-ia acalmado com a visão dos monges ajoelhados a seus pés, São Domingos e São Francisco que fariam reinar no mundo as virtudes da obediência, pobreza e castidade ${ }^{50}$. Neste sentido a imagem em falta atualmente no oratório pensamos que deveria ser São Francisco de modo a completar a narrativa. A incerteza perante a falta da imagem e de documentação não nos permite assegurar esta relação e destacamos assim apenas as figuras do Calvário, deixando a figura de São Domingos para a análise desta devoção isolada.

Acompanham Cristo no momento da crucificação Nossa Senhora e São João. Ambas as figuras se destacam pelo sofrimento exposto não apenas na comoção do rosto mas também na gestualidade dos corpos. As mãos cruzadas sobre o peito na figura da Virgem (Imagem 23) e o gesto pungente da mão direita sobre o peito na figura de São João (Imagem 24) evidenciam a emotividade dramática do momento.

A dor das expressões dos rostos é acrescida pelos gestos mas também pelo intenso esvoaçar dos panejamentos que os envolvem no padecimento. Trata-se de uma narrativa pungente e propicia à comoção. A emotividade das figuras é assumida na dignidade dos corpos que se mantêm de pé, mas o gesto das mãos sobre o peito revelam o limite da contenção da dor. A teatralidade, nas poses com intenso movimento e torção dos corpos e nos olhares, sugere a tradicional disposição da Virgem à direita e São João à esquerda da cruz.

Ao contrário da representação do Calvário da capela das Dores em que se destaca o estoicismo emocional das figuras, neste conjunto destaca-se a intensa emotividade e fragilidade das figuras.

É também em Vinhais que se encontra a narrativa que historicamente se segue à crucificação. Trata-se de uma representação da Descida da Cruz $^{51}$ (Imagem 25), colocada no interior de uma maquineta envidraçada e que tal como a representação do Presépio está adossada ao arco triunfal da igreja de São Francisco da Venerável Ordem

\footnotetext{
${ }^{50}$ Réau, Louis, Iconografia del arte cristiano - Iconografia de los santos, de la A a la F. Tomo 2 / Volumen 3, Barcelona, Ediciones del Serbal, 1997 (edição original 1955-1959), pp. 399,400.

${ }^{51}$ A representação da Descida da Cruz é pouco comum na escultura, a sua representação provavelmente foi influenciada pelo misticismo franciscano e pela sequência das cenas do teatro religioso medieval. Roque, Maria Isabel Rocha, "Imagens esculpidas de cristo na dor", Lumen Veritatis: boletim da Sociedade Científica da Universidade Católica Portuguesa, Lisboa, Universidade Católica Portuguesa, 2012, pp. 8-10.
} 
Terceira. O conjunto é amplo e diverso nas personagens que representa afastando-se do decoro histórico promovido a partir do Concílio de Trento.

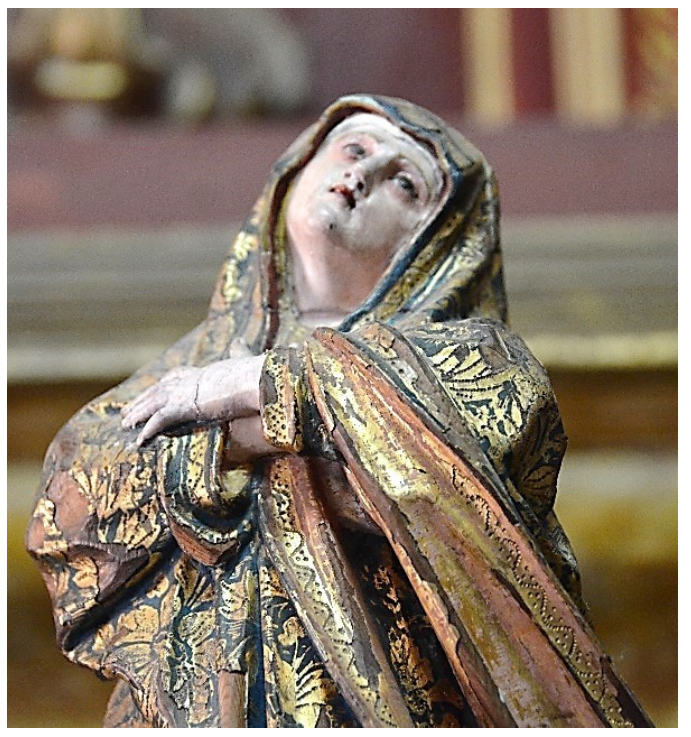

Imagem 23

Calvário; Nossa Senhora SIEV 04

Oficina: Portuguesa; Século XVIII (finais) Oratório na sacristia da

Igreja de Nossa Senhora da Encarnação, Vinhais

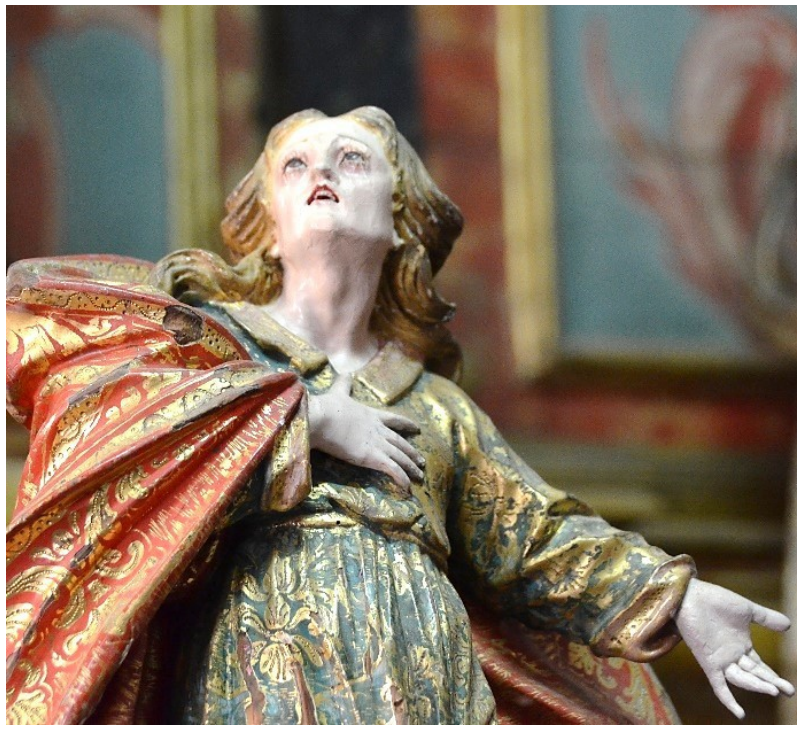

Imagem 24

Calvário; São João SIEV 03

Oficina: Portuguesa; Século XVIII (finais)

Oratório na sacristia da

Igreja de Nossa Senhora da Encarnação, Vinhais

A representação das figuras que as escrituras, sobretudo o evangelho de João e Lucas, registam no Gólgota de Nossa Senhora, Maria Madalena e demais mulheres que desde a Galileia seguiam Jesus, os dois ladrões (Gestas e Dimas) que junto de Cristo foram crucificados, os soldados romanos responsáveis pelo martírio, e José de Arimateia e Nicodemos, foi acrescentada neste conjunto por uma turba de homens e mulheres que acompanham a cena.

No primeiro plano e com sumptuosas vestes José de Arimateia segura o rolo de ligaduras com que iria envolver o corpo de Jesus. Oposto a José de Arimateia, está Nicodemos que sustém num rico vasilhame a mirra e o aloés com que iria perfumar o corpo. Aos pés da cruz Madalena, com a cabeça descoberta, prepara-se para segurar os pés de Cristo. Curiosamente os pés de Cristo estão cravados com dois pregos e não com um prego apenas como era usual já desde o seculo XIII ${ }^{52}$.

\footnotetext{
${ }^{52}$ Réau, Louis, Iconografia del Arte Cristiano. Iconografia de la Biblia - Nuevo Testamento Tomo 1/ Volumen 2, Barcelona, Ediciones del Serbal, 1996, (Edição original 1955-1959), p. 449; Carmona Muela, Juan, Iconografia cristiana, Madrid, Akal, 2010, pp. 128, 129.
} 


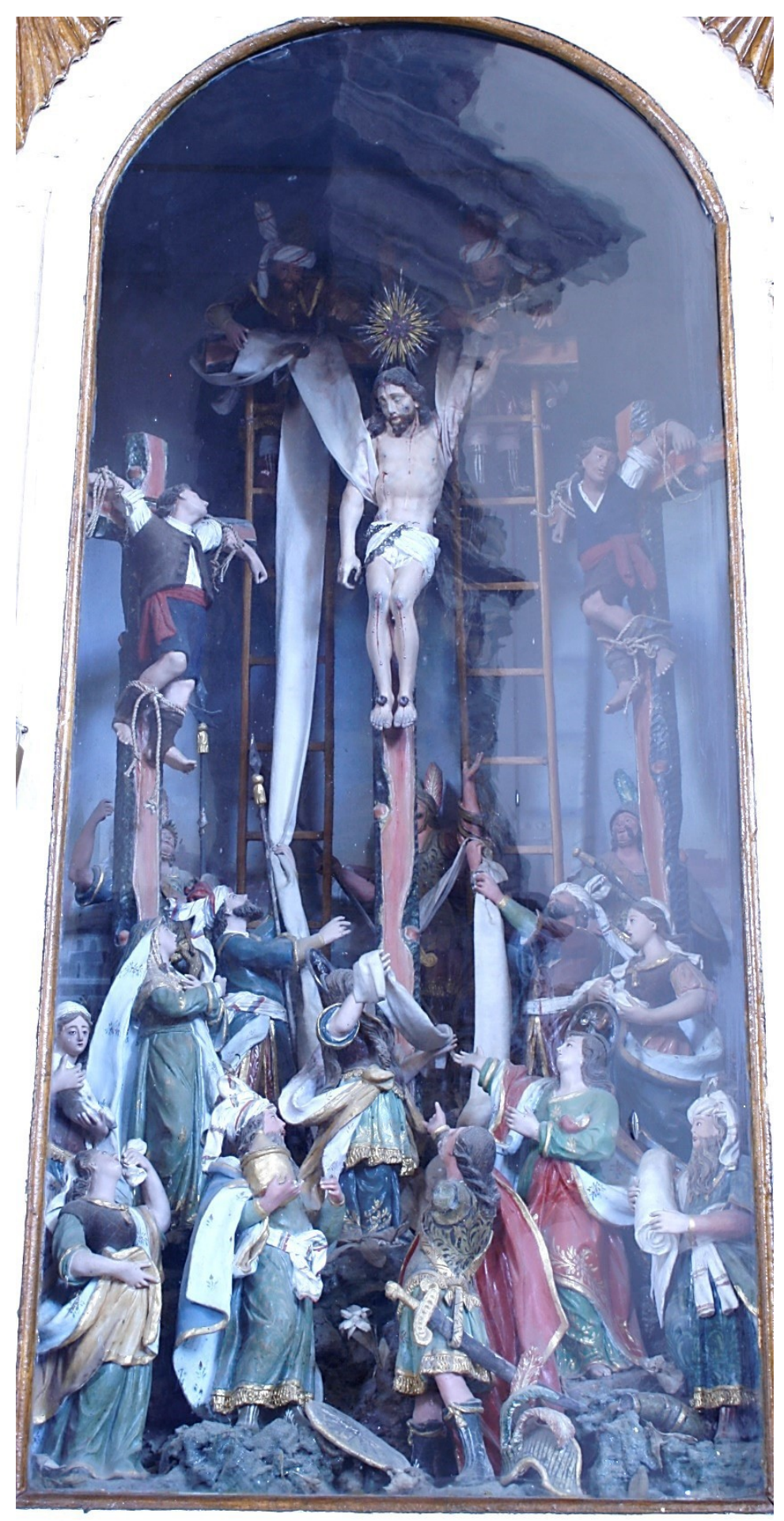

Imagem 22

Maquineta com Descida da Cruz SFV 05

Oficina portuguesa; último quartel do século XVIII

Arco triunfal no lado da Epistola

Igreja de São Francisco, Vinhais

A dinâmica teatralidade que envolve todas as figuras contrasta enormemente com a estaticidade do corpo de Jesus morto mas ainda com o braço esquerdo pregado sobre a cruz. Usando panos para suster o corpo os ajudantes de José de Arimateia e de 
Nicodemos estão subidos nas escadas por trás da cruz enquanto os soldados romanos escarnecem da situação. Ao centro da complexa composição um soldado com as armas depositadas no chão aponta para a figura de Cristo, representando possivelmente o centurião romano que após a morte de Jesus Mateus (Mt 27, 54) regista dizendo «Este era verdadeiramente o Filho de Deus!».

Toda a composição é pródiga nas narrativas sugeridas e na complexa trama que envolve as diversas personagens. Ao carácter didático da iconografia registada acresce a devoção popular que se ilustra nas maquinetas expostas em templos e espaços privados do século XVIII.

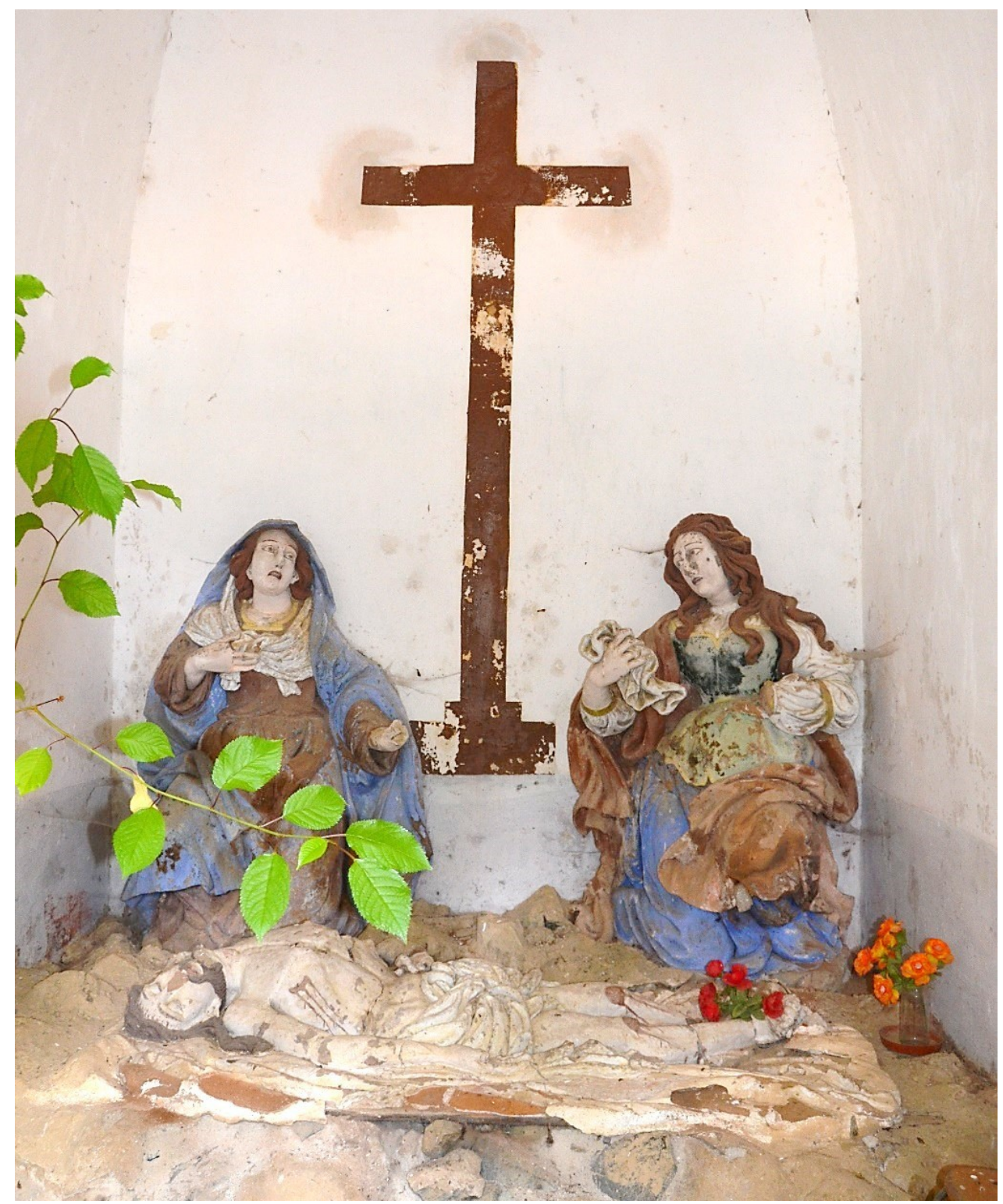

Imagem 26

Cristo deposto ao pé da cruz com a Virgem Maria e Maria Madalena CSMV 01; CSMV 02; CSMV 03 Oficina local (Frei Domingos); último quartel do século XVIII

Capela do Senhor do Monte, cerca do Seminário Apostólico, Vinhais 
A iconografia de Cristo termina nos espaços franciscanos em estudo com a deposição de Cristo morto, pois a única representação da Ressurreição de Cristo (registada em Vinhais $^{53}$ ) está hoje desaparecida.

É também em Vinhais que registamos a narrativa de Cristo Morto (Imagem 26). A cena está representada em terracota no interior de uma capela levantada dentro da propriedade agrícola outrora dos frades missionários, sob a designação atual de capela do Senhor do Monte. Seria parte da Via Crucis que se iniciava na capela da Oração no Horto e tal como nessa primeira capela, julgamos que se trata de obra de Frei Domingos. A cena apresenta Cristo jacente em primeiro plano, seguida da imagem da Virgem à direita e de Maria Madalena à esquerda, entre ambas está pintada a cruz. Destaca-se a ausência de São João na cena exclusivamente velada por mulheres. Ambas estão de joelhos e com desgarrada expressão de dor, acrescida pelo gesto da mão sobre o peito na escultura da Virgem e do lenço sustido pela mão na escultura que representa Madalena.

A cena não está registada em nenhum dos evangelhos e desenvolve-se como narrativa apenas a partir do século XII, tendo como influência os autos sacramentais a arte bizantina e as meditações dos místicos medievais.

Nossa Senhora está próxima da cabeça, enquanto Madalena está junto aos pés em analogia com o episódio da unção dos pés de Cristo que lhe é atribuída na casa de Simão ${ }^{54}$.

A Virgem de cabeça coberta por um véu eleva o olhar com veemente expressão de dor intensificada pelo gesto da mão sobre o peito, onde o coração está assoberbado de sofrimento perante o seu filho morto. Madalena, jovem ${ }^{55}$, de cabelos soltos, observa a mãe de Jesus, com sofrimento mais contido eleva na mão o lenço que lhe irá confortar

\footnotetext{
${ }^{53}$ No catálogo Imagens e Esculturas - Comemorações Jubilares dos 450 anos da Diocese de Bragança Miranda. Gomes, José Manuel (Coord.), Imagens e escultura. 1545-1995 Comemorações Jubilares dos 450 Anos da Diocese de Bragança - Miranda, Bragança, Departamento de Liturgia e Património Cultural da Diocese de Bragança - Miranda e Comissão de Arte Sacra, 1996, p. 19, está registada uma escultura que representa Cristo Ressuscitado que pertencia à igreja de Nossa Senhora da Encarnação de Vinhais, mas está atualmente em parte desconhecida.

${ }^{54}$ Réau, Louis, Iconografía del Arte Cristiano. Iconografía de la Biblia - Nuevo Testamento Tomo 1/ Volumen 2, Barcelona, Ediciones del Serbal, 1996, (Edição original 1955-1959), pp. 538, 539.

${ }^{55}$ A jovem mulher de joelhos perante Cristo morto é uma das representações mais frequentes de Madalena. Quando representada isolada é acompanhada pelos atributos do vaso ou a caixa dos balsamos ou como penitente. Kaftal, George, Iconography of the saints in central and south Italian schools of painting, Firenze, Casa Editrice Le Lettere, 1986, pp. 763-766.
} 
as lágrimas. Cristo frágil martirizado e nu está depositado sobre o lençol providenciado por José de Arimateia, mas mais ninguém vela o seu corpo exceto as duas mulheres. O dramatismo da narrativa é sublimado pela solidão das figuras femininas que velam o cadáver jacente e cujos olhares desencontrados as isola ainda mais.

Existem mais representações onde consta a figura de Cristo, porém estão afetas a narrativas do culto a São Francisco e não a episódios descritos nos evangelhos, por isso serão analisadas em conjunto com o santo e a sua iconografia. 


\section{ICONOGRAFIA DE NOSSA SENHORA}

O número de representações da Virgem Maria quase iguala em número as representações de Cristo nos espaços franciscanos em estudo. $\mathrm{Na}$ análise iconográfica que nos propomos fazer trataremos apenas das devoções marianas onde a figura central da imagem é representada por Nossa Senhora. Assim, o Presépio, os Calvários e as demais narrativas da Paixão de Cristo em que também surge a figura da Virgem foram registados já na análise iconográfica de Jesus.

Seguindo a narrativa dos evangelhos e as influências dos relatos apócrifos e das devoções populares tentaremos estruturar as distintas representações de Nossa Senhora respeitando a ordem histórica relativa à figura feminina que compete no culto cristão com a figura de Cristo.

Neste sentido, destacamos primeiro o modelo iconográfico da Imaculada Conceição, seguido das representações de Nossa Senhora da Encarnação, depois a Virgem Maria com Santa Ana, na narrativa da Paixão Nossa Senhora das Dores, e por fim as devoções tutelares de Nossa Senhora do Rosário, Nossa Senhora da Lapa, Nossa Senhora dos Remédios, Nossa Senhora da Boa Morte, Nossa Senhora da Aparecida e Nossa Senhora do Caminho.

A escassez de referências à mãe de Jesus nos evangelhos é compensada pela pródiga devoção popular que lhe é dedicada e que espelha na Virgem a imitação de Cristo. A ausência de martírio, milagres e relíquias, que constituem os três fundamentos para o culto dos santos é compensada pelas lendas e paralelismos entre a Virgem e Cristo. Assim, definiu-se que sofreu o martírio de Jesus na alma e postumamente lhe forma atribuídos diversos milagres e relíquias deixadas. Em 431 no Concilio de Éfeso era proclamada Santa Mãe de Deus, expandindo-se a partir desse momento o seu culto a toda a cristandade, e simultaneamente converteu-se no símbolo da igreja ${ }^{56}$.

A misoginia herdada do cristianismo primitivo e do ascetismo oriental foi compensada pela influência popular das religiões pagãs anteriores ao cristianismo onde a mulher constituía parte do culto do divino. Na europa foi o amor cortês e o ideal de cavalaria que amplificou o culto da Virgem. As ordens religiosas, quer masculinas quer

\footnotetext{
${ }^{56}$ Réau, Louis, Iconografia del Arte Cristiano. Iconografia de la Biblia - Nuevo Testamento Tomo 1/ Volumen 2, Barcelona, Ediciones del Serbal, 1996, (Edição original 1955-1959), p. 62; Carmona Muela, Juan, Iconografia cristiana, Madrid, Akal, 2010, p. 118.
} 
femininas, foram-se assumindo sob a proteção de Nossa Senhora, a primeira a fazê-lo foi a Ordem de Cister, e já no século XIII dominicanos e franciscanos competiram pela devoção de Nossa Senhora do Rosário e da Imaculada Conceição, respetivamente. O culto mariano, não obstante algumas limitações resultantes do renascimento e da contrarreforma foi ascendente em devoção, até à contemporaneidade, chegando por vezes a competir com a devoção cristológica ${ }^{57}$.

A Imaculada Conceição supõe o privilégio exclusivo de Maria que a exclui do pecado original de Adão e Eva sendo a única dos seus descendentes a ser concebida sem pecado no ventre de Santa Ana e antes ainda no pensamento de Deus. Como dogma foi tardio o seu reconhecimento e como modelo iconográfico apenas surge na época moderna, estando totalmente ausente nas representações medievais. A discussão teológica foi intensa durante toda a idade média. Defendida por franciscanos e mais tarde pelos jesuítas o dogma da Imaculada Conceição foi finalmente publicado pelo Papa Pio IX em 1854, mas a devoção estava amplamente difundida desde o último quartel do século $\mathrm{XV}^{58}$.

A iconografia da Imaculada Conceição desenvolveu-se em distintos modelos, primeiro simbolicamente a partir do Abraço entre Santa Ana e São Joaquim ${ }^{59}$ e mais tarde com base no Cântico dos Cânticos do Antigo Testamento e no Apocalipse de São João ${ }^{60}$.

\footnotetext{
${ }^{57}$ Réau, Louis, Iconografia del Arte Cristiano. Iconografía de la Biblia - Nuevo Testamento Tomo 1/ Volumen 2, Barcelona, Ediciones del Serbal, 1996, (Edição original 1955-1959), pp. 64-65.

${ }^{58}$ Réau, Louis, Iconografia del Arte Cristiano. Iconografia de la Biblia - Nuevo Testamento Tomo 1/ Volumen 2, Barcelona, Ediciones del Serbal, 1996, (Edição original 1955-1959), pp. 82-88; Strattom, Suzanne, "La Inmaculada Concepción en el arte español" in Cuadernos De Arte E Iconografia / Tomo I2., disponível em http://www.fuesp.com/publicaciones_revistas_numeros_articulos.asp?cdnumero=2, Madrid, 1988, pp.1-88; Carmona Muela, Juan, Iconografia cristiana, Madrid, Akal, 2010, p. 146; López Calderón, Carme, "Potuit, decuit, fecit; los franciscanos y el culto a María", in Natália Marinho FerreiraAlves (Coord.), Franciscanos no Mundo Português III, Porto, CEPESE - Centro de Estudos da População, Economia e Sociedade, 2013, pp. 225-255.
}

${ }^{59} \mathrm{O}$ encontro entre Santa Ana e São Joaquim bem como a Árvore de Jessé simbolizavam a Imaculada Conceição até que no século XVI quando se fixou o modelo da Imaculada. Réau, Louis, Iconografía del Arte Cristiano. Iconografia de la Biblia - Nuevo Testamento Tomo 1/ Volumen 2, Barcelona, Ediciones del Serbal, 1996, (Edição original 1955-1959), pp. 86, 87; Gonçalves, Flávio, "A «Árvore de Jessé» na arte portuguesa", in Revista da Faculdade de Letras História, 03, Porto, Faculdade de Letras da Universidade do Porto, 1986, pp. 213-238; Strattom, Suzanne, "La Inmaculada Concepción en el arte español" in Cuadernos De Arte E Iconografia / Tomo I- 2., disponível em http://www.fuesp.com/publicaciones_revistas_numeros_articulos.asp?cdnumero=2, Madrid, 1988, pp.188; Carmona Muela, Juan, Iconografia cristiana, Madrid, Akal, 2010, p. 155.

${ }^{60}$ Muela refere que quase todas as representações da Imaculada Conceição se fixam a partir do século XV
e seguem os textos do Apocalipse elementos do Antigo Testamento e as recomendações de Pacheco na
sua obra El Arte de la Pintura, onde descrevia a imagem segundo a visão de D. Beatriz da Silva, 
A Virgem Maria na representação da Imaculada foi compreendida como a noiva, esposa, amante do Cântico dos Cânticos «Toda és formosa, ó amiga minha, e não há mancha em ti » ${ }^{61}$ e as metáforas do poema foram acrescentados como símbolos na sua representação.

O texto do Apocalipse 12:1 descreve «Depois, apareceu um grande sinal no Céu: uma mulher revestida de Sol, tendo a Lua debaixo dos seus pés e uma coroa de doze estrelas sobre a cabeça ${ }^{62} \gg$ consubstanciando a imagem que identifica o modelo mais difundido desta devoção.

Em Portugal o culto da Imaculada foi desde o século XVII assumido como a invocação protetora do reino. A tradição dizia que se reconhecia a Imaculada Conceição de Maria desde o momento que Ela deu à luz o Redentor e foi milagrosamente anunciada a sua inocência por uma venturosa filha da cidade de Lisboa. Essa ligação propiciou que Portugal se tornasse o "theatro das glórias" de Nossa Senhora e no hagiológio lusitano a Imaculada Conceição da Virgem Maria é referida como padroeira do reino ${ }^{63}$.

Sendo particularmente defendido o dogma da Imaculada Conceição pelos franciscanos é a devoção mariana com mais exemplares nos espaços em estudo, ao todo registamos cinco esculturas de vulto que representam este culto. Todas foram esculpidas no século XVIII e reproduzem não apenas as influências do Antigo e Novo Testamento mas também as célebres representações que o barroco espanhol difundiu.

portuguesa que se recolheu em São Domingos de Toledo a fundar a religião da Conceição Puríssima Carmona Muela, Juan, Iconografia cristiana, Madrid, Akal, 2010, p. 146; Carme López Calderón refere, além dos místicos e doutores seráficos, a importância no discurso apologético do dogma da Imaculada expresso no retábulo da árvore de Jessé no convento de São Francisco no Porto, da figura de Soror Maria de Jesús Agreda, mística espanhola, que desenvolveu nos seus textos um dos modelos mais utilizados para expressar o triunfo de Maria sobre o pecado original - a mulher Apocalíptica. López Calderón, Carme, "Potuit, decuit, fecit; los franciscanos y el culto a María", in Natália Marinho Ferreira-Alves (Coord.), Franciscanos no Mundo Português III, Porto, CEPESE - Centro de Estudos da População, Economia e Sociedade, 2013, pp. 225-255.

${ }^{61}$ Cântico dos Cânticos, Cant 4, 7, Bíblia Sagrada, Lisboa, Difusora bíblica (Missionários capuchinhos), $14^{\mathrm{a}}$ edição, 1988.

${ }^{62}$ Apocalipse, Ap 12, 1, Bíblia Sagrada, Lisboa, Difusora bíblica (Missionários capuchinhos), $14^{\mathrm{a}}$ edição, 1988.

${ }^{63}$ Cardoso, Jorge, Agiologio lusitano dos sanctos, e varoens illustres em virtude do Reino de Portugal, e suas conquistas : consagrado aos gloriosos $S$. Vicente, e S. Antonio, insigns patronos desta inclyta cidade Lisboa e a seu illustre Cabido Sede Vacante. Tomo IV, Lisboa, Officina Craesbeekiana, Disponível na plataforma on-line da Biblioteca Nacional de Portugal http://purl.pt/12169, 1652. 
Imagem 27

Nossa Senhora da Imaculada Conceição - MASV 05 em

marfim

Oficina: Oriental; Primeira metade do século XVIII

Museu de Arte Sacra Vinhais

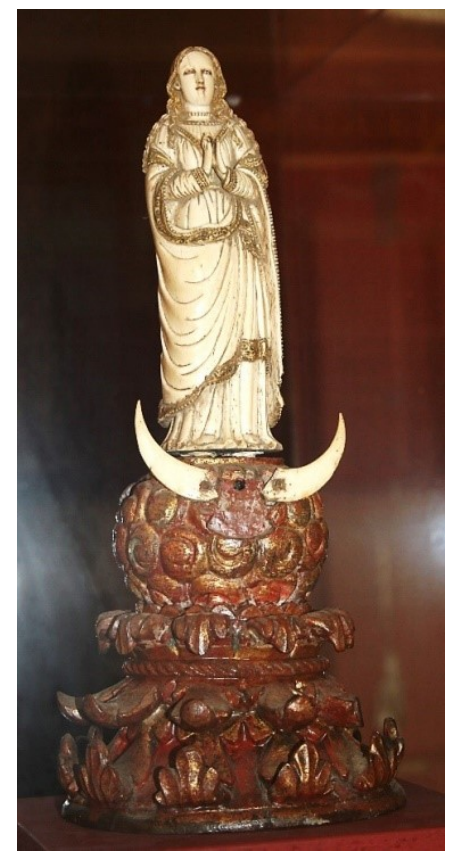

Do conjunto de cinco imagens que representam Nossa Senhora da Imaculada Conceição a que nos parece ter sido esculpida primeiro é o exemplar que se encontra atualmente exposto no museu de arte sacra de Vinhais (Imagem 27). Sendo de marfim julgamos que poderá proceder da India, de onde a maioria da produção de figurinhas deste material era proveniente. Trata-se de uma representação estática da Virgem de mãos postas sobre o peito, olhar baixo e longos cabelos soltos sobre as costas.

A lua crescente aos pés da Virgem colocada sobre as nuvens ilustra o modelo iconográfico que se vulgariza a partir do século XVII.

Mas, são as obras em talha de madeira policromada que expressam maior variedade nos atributos iconográficos que definem o modelo.

O gesto das mãos postas sobre o peito é comum a todas as representações registadas, apesar de se observar uma crescente teatralidade na assimetria sinuosa do corpo. Também é comum em todas as esculturas de madeira de Nossa Senhora da Imaculada Conceição a nuvem que a sustém de onde emergem os querubins e a lua em quarto crescente. Mas, a serpente tentadora, como símbolo do pecado original apenas aparece na escultura de Mogadouro (Imagem 28) e na escultura de Bragança (Imagem 31). Bem como, o globo, como alusão à universalidade do pecado original que a Imaculada Conceição superou é comum às esculturas de Mogadouro (Imagem 28), Vinhais, (Imagem 29) e Bragança (Imagem 31). A pomba, símbolo do Espirito Santo ${ }^{64}$, que se

\footnotetext{
${ }^{64}$ Réau, Louis, Iconografía del Arte Cristiano. Iconografia de la Biblia - Nuevo Testamento Tomo 1/ Volumen 2, Barcelona, Ediciones del Serbal, 1996, (Edição original 1955-1959), p. 186.
} 
observa sobre a cabeça da Virgem pintada no retábulo de Mogadouro é pouco frequente na representação da Imaculada Conceição nos espaços em estudo, bem como as estrelas, que são recolhidas do Cântico dos Cânticos e ornamentam o restante painel que the serve de fundo.

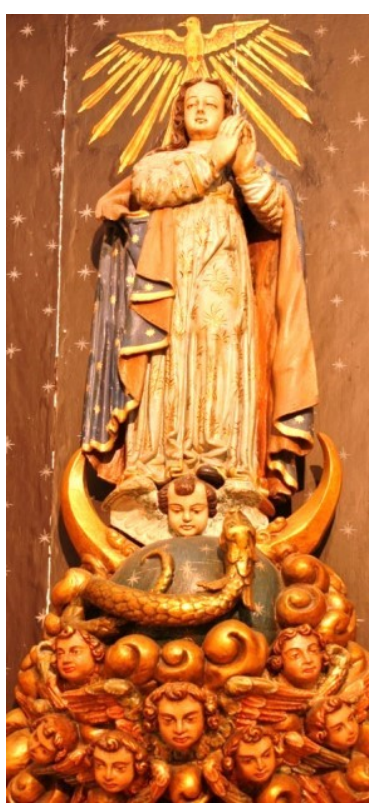

Imagem 28

Nossa Senhora da Imaculada Conceição SFM 09,

Oficina: local; segunda metade do século XVIII

Retábulo no lado do Evangelho Igreja de São Francisco Mogadouro

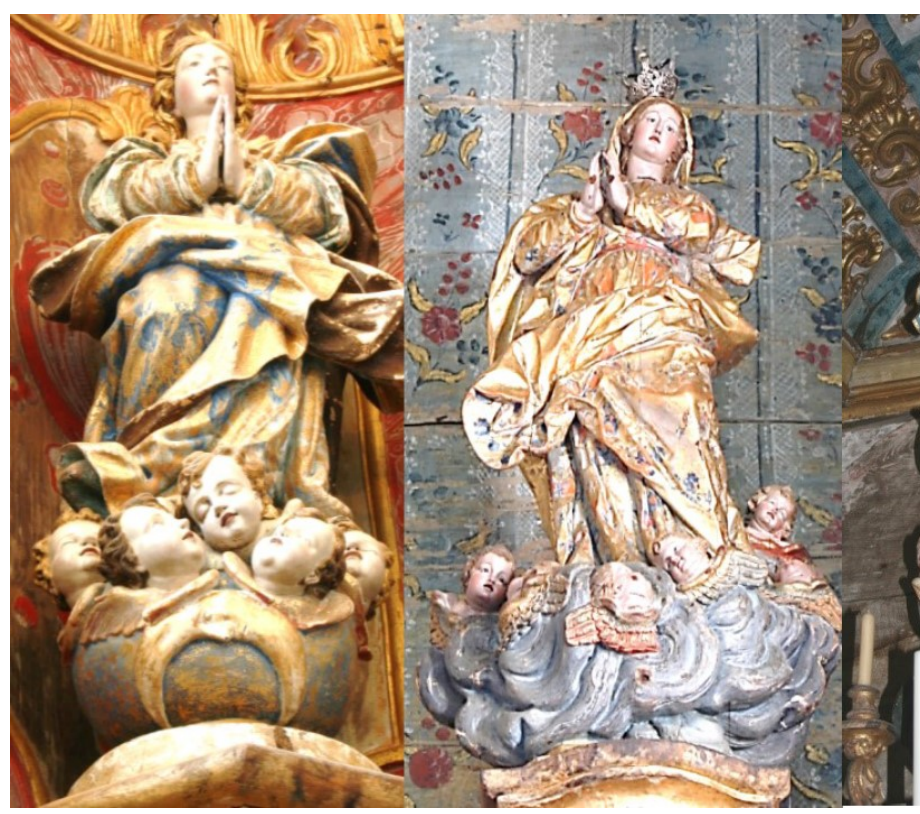

Imagem 29

Escultura de Nossa

Senhora da Imaculada Conceição - CSDV 07

Oficina: local; segunda metade do século XVIII Capela de Nossa Senhora das Dores,

Igreja de Nossa Senhora da Encarnação, Vinhais

\section{Imagem 30 \\ Escultura de Nossa Senhora da Imaculada Conceição SFV 07 \\ Oficina portuguesa (PortoไBraga); último quartel do século XVIII Retábulo mor Igreja de São Francisco,} Vinhais

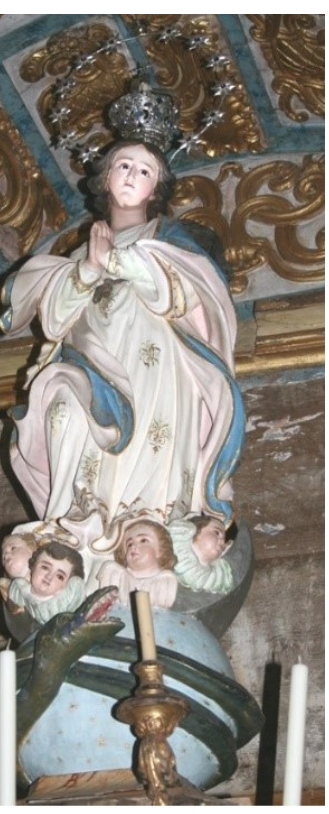

Imagem 31

Escultura de Nossa Senhora da Imaculada Conceição - SFB 08, Oficina portuguesa (Porto\Braga); último quartel do século XVIII Capela no lado do Epistola Igreja de São Francisco Bragança

Todas as imagens consubstanciam a importância da sua devoção dentro dos templos que as guardam pelo espaço que ocupam, a Imaculada Conceição da igreja da Ordem Terceira de São Francisco de Vinhais (Imagem 30) ocupa a tribuna central do altar-mor. A imagem de Bragança (Imagem 31) tem capela própria e confraria registada desde o início do século XVIII, mas a devoção existia já no convento de São francisco em Bragança em 1334-1342 quando o Papa Bento XII lhe deu a graça de altar privilegiado $^{65}$. Também em Mogadouro a escultura da Imaculada Conceição preenche $\mathrm{o}$ nicho central do retábulo que ocupa no lado do evangelho. Os espaços privilegiados que

\footnotetext{
${ }^{65}$ Borges, José Cardoso, Memórias de Bragança, Fernando de Sousa (Coord.), Bragança, CEPESE / Câmara Municipal de Bragança, 2012 (texto original de 1721-1724), p. 147; Castro, José de, Bragança e Miranda, (Bispado) Tomo II, Porto, Tipografia Porto Médico, Lda , 1947, p. 306.
} 
na sua maioria ocupam no interior dos templos denota a importância da devoção que lhes era dedicada.

Em todas as esculturas que representam a Imaculada Conceição se observa o olhar baixo, dirigidos à terra, onde descende enviada por Deus que a elegeu para a redenção dos descendentes de Eva ${ }^{66}$. A juventude da figura é exposta na ausência de véu a cobrir os cabelos, quase todas os apresentam soltos sobre os ombros, apenas se tapam com véu, e parcialmente, as esculturas de Mogadouro e Vinhais (Imagens 28 e 30) respetivamente.

O único templo que não mantém nenhuma escultura de Nossa Senhora da Imaculada Conceição, dentro das balizas cronológicas em estudo, é a igreja do convento de Santa Clara, hoje designada por igreja de Nossa Senhora das Graças. Durante a presença das clarissas no convento a igreja estava sob a invocação da Imaculada Conceição, o que sugere que forçosamente existia alguma escultura anterior a 1834 com esta invocação. Atualmente ainda se presta culto a uma imagem da Imaculada Conceição mas com uma escultura contemporânea que julgamos ter sido produzida já no século XX.

Depois de eleita por Deus para vir a conceber o seu filho, a infância de Nossa Senhora decorre em episódios que se decalcam dos episódios da infância de Cristo, dos evangelhos apócrifos e da Lenda Dourada e da devoção popular ${ }^{67}$. A descrição da vida de Nossa Senhora antes do nascimento de Jesus não é nunca referida nos evangelhos canónicos. A infância da Virgem é raras vezes representada nos espaços em estudo, surge apenas em duas esculturas em que se apresenta em conjunto com Santa Ana ${ }^{68}$ (Imagem 32 e Imagem 33).

\footnotetext{
${ }^{66}$ Enquanto Nossa Senhora da Assunção apresenta o olhar dirigido ao céu onde a espera Cristo. Réau, Louis, Iconografia del Arte Cristiano. Iconografia de la Biblia - Nuevo Testamento Tomo 1/ Volumen 2, Barcelona, Ediciones del Serbal, 1996, (Edição original 1955-1959), p. 86.

${ }^{67}$ Réau, Louis, Iconografia del Arte Cristiano. Iconografia de la Biblia - Nuevo Testamento Tomo 1/ Volumen 2, Barcelona, Ediciones del Serbal, 1996, (Edição original 1955-1959), p. 172; Carmona Muela, Juan, Iconografia cristiana, Madrid, Akal, 2010, p. 143.

${ }^{68} \mathrm{O}$ culto a Santa Ana expandiu-se no final da idade média, o Humanismo colocou-a ensinando a Virgem a ler, contrariando os apócrifos e a Lenda Dourada, o modelo teve muita popularidade mesmo após a Reforma Católica mantendo-se pelo século XVII e XVIII. Gonçalves, Flávio, História da arte; Iconografia e Crítica, Lisboa, Imprensa Nacional Casa da Moeda, 1990, p. 77; Carmona Muela, Juan, Iconografía de los santos, Madrid, Akal, 2008, pp. 23-26.
} 


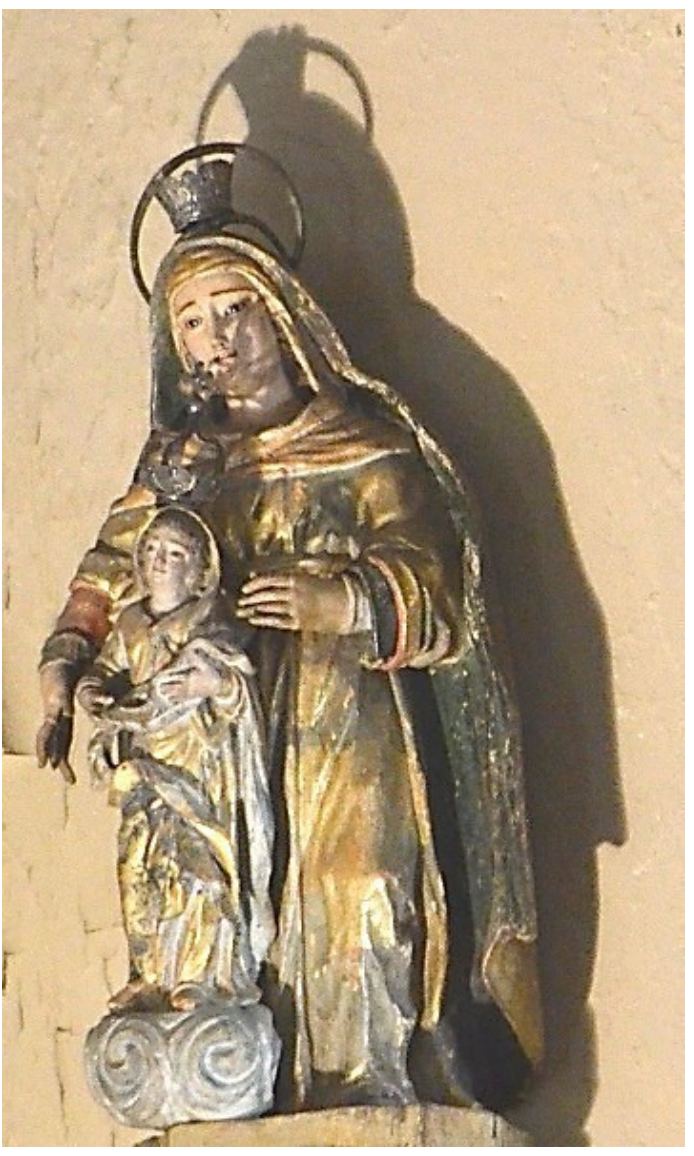

Imagem 32

Escultura de Santa Ana com a Virgem MariaSCB 08

Santa Ana - Oficina espanhola (?);Virgem Maria - Oficina portuguesa; Século XVII Arco triunfal no lado do Evangelho colocadas num nicho alto Igreja das Clarissas (atual igreja de Nossa Senhora das Graças), Bragança,

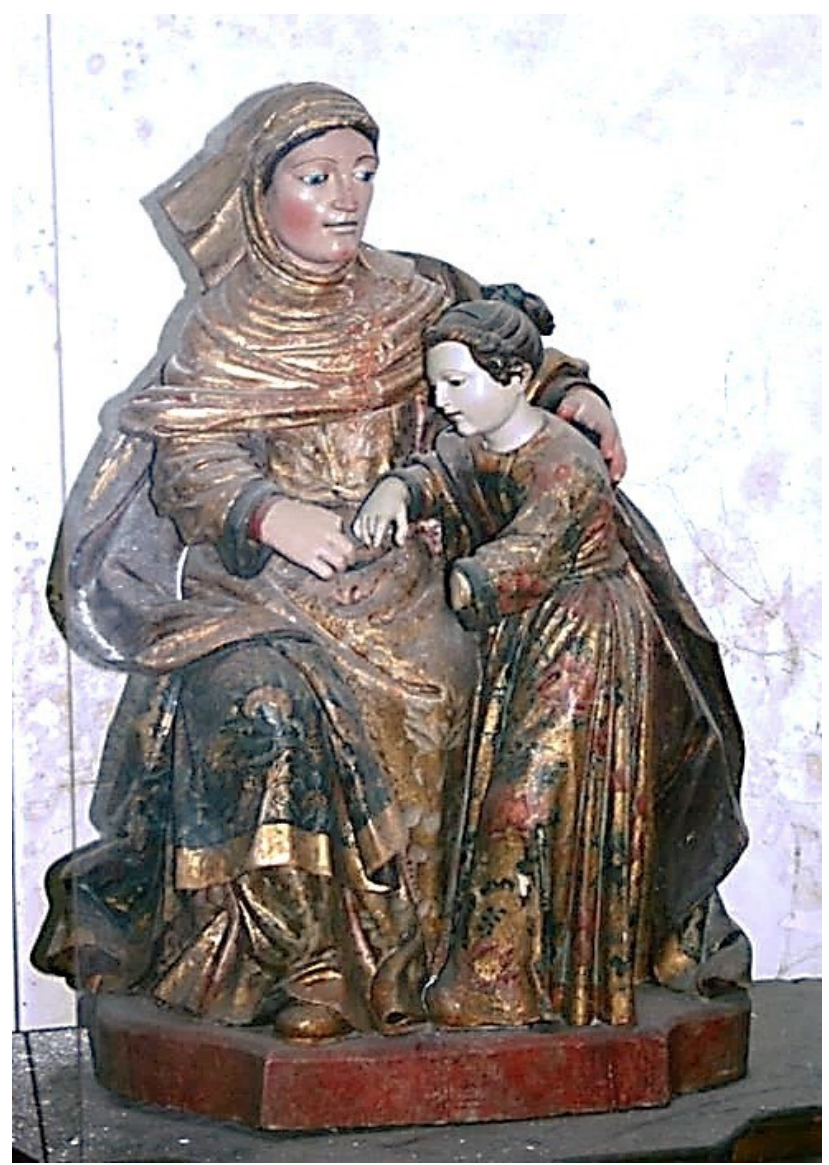

Imagem 33

Escultura de Santa Ana com a Virgem Maria IEV 12

Oficina local $\backslash$ Frei Domingos (?): último quartel do século XVIII

Colocada num nicho lateral do lado do Evangelho Igreja de Nossa Senhora da Encarnação, Vinhais

O conjunto que julgamos ter sido esculpido primeiro, e cuja datação assumimos no século XVII está atualmente colocado no arco triunfal da igreja do desaparecido convento das clarissas em Bragança (Imagem 32). A sua localização, no nicho mais alto, dificulta a correta observação dos seus elementos. No entanto, é evidente que se trata de um conjunto posteriormente assemblado. A figura de Santa Ana, jovem e de linhas suaves no rosto evocam o modelo das Virgens Dolorosas proveniente de Espanha. Enquanto a pequena figura da Virgem que posteriormente lhe foi anexada é claramente de produção mais fraca no domínio das técnicas escultóricas. No entanto, o facto de se encontrarem reunidas sugere hoje uma leitura de conjunto. O gesto de proteção das mãos de Santa Ana que envolvem a Virgem Maria sugerem a relação entre ambas as figuras, que pese embora se tratem de esculturas autónomas, estaria 
originalmente pensada, a suposta figura de Santa Ana, em relação com uma outra figura. A nuvem que sustém a figura da Virgem reforça a inverosimilhança do conjunto, e remete a figura de Nossa Senhora para um original culto autónomo da Virgem. A possibilidade de ela suster ao colo o Menino, entre os panejamentos que segura sobre o peito sugere que poderia tratar-se de um conjunto das Santas Mães. As dúvidas formais que o conjunto suscita permitem apenas levantar hipóteses sobre a sua leitura iconográfica. O que nos parece mais destacável, tratando-se de um templo de um convento feminino é a presença de duas mulheres que em gesto de proteção se relacionam.

Mais clara é a leitura do outro conjunto de Nossa Senhora com Santa Ana (Imagem 33) registado nos espaços franciscanos em estudo.

Exposto na igreja dos missionários apostólicos de Vinhais representa um modelo amplamente difundido desde o século XVI. A educação de Maria, segundo os apócrifos e a Lenda Dourada, teria sido feita desde os três anos de idade num convento de clausura. No entanto, o crescente culto popular a Santa Ana, que ao longo da época medieval se desenvolve, outorga à mãe de Maria essa responsabilidade ${ }^{69}$.

$\mathrm{Na}$ representação de Vinhais está já em falta o livro sobre o qual ambas se debruçavam. Santa Ana sentada ensinaria a Virgem a ler, com a bíblia aberta sobre o colo. Num período em que a alfabetização das mulheres era ainda descurada é destacável a representação de Santa Ana como professora e da Virgem enquanto aluna atenta. $\mathrm{O}$ aspeto feminino do penteado elaborado de Maria e o traje sumptuoso que ambas envergam afastam ainda mais o conjunto da verosimilhança histórica, no entanto, aproximam-no do quotidiano social que o século XVIII e o iluminismo transformaram.

Relacionada com a escultura de Santa Ana a ensinar a Virgem a ler estaria originalmente $^{70}$, no mesmo altar, uma escultura de São Joaquim (Imagem 34) e a escultura de São José (Imagem 35). Ficava assim mais amplo o registo familiar da Virgem Maria.

\footnotetext{
${ }^{69}$ Réau, Louis, Iconografia del Arte Cristiano. Iconografía de la Biblia - Nuevo Testamento Tomo 1/ Volumen 2, Barcelona, Ediciones del Serbal, 1996, (Edição original 1955-1959), p. 177.

${ }^{70}$ Conforme consta no inventário dos bens de raiz do Seminário Franciscano de missionários apostólicos em Vinhais. A.N.T.T./A.H.M.F./S.N.S.E.V., Extinção das Ordens Religiosas - Seminário de Nossa Senhora da Encarnação - Vinhais, Arquivo Nacional da Torre do Tombo, Lisboa, Arquivo Histórico do Ministério das Finanças, Processos de Extinção das casas religiosas, Cx. 2265, 1834, s/fl.
} 
A identificação de São Joaquim suscitanos dúvidas pela ausência do seu atributo mais comum - o cesto com duas pombas para a oferenda ritual no templo ${ }^{71}$. Mas o facto de se representar calvo, de provecta idade sugere-nos essa possível identificação. O livro que sustém poder-se-ia relacionar com a cena central de Santa Ana a ensinar a Virgem a ler. Noutras esculturas portuguesas que representam São Joaquim Santo é comum a representação do livro como atributo (escultura do século XVII no Museu Machado de Castro e do XVIII no Museu Gão Vasco, entre outras).

A escultura de São José da igreja dos missionários de Vinhais (Imagem 35), apesar de ser autónoma no seu culto optamos por inseri-la dentro na análise iconográfica

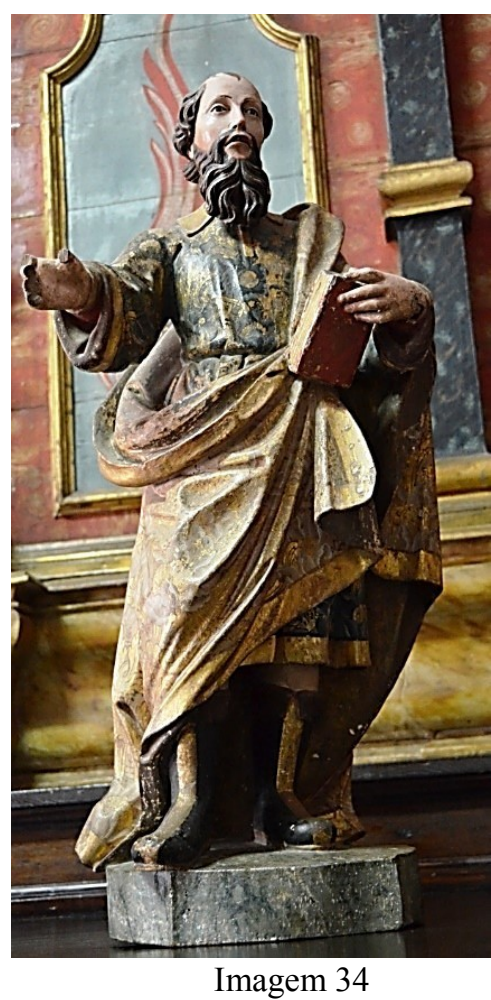

Escultura de São Joaquim, SIEV 01 Oficina local $\backslash$ Frei Domingos: último quartel do século XVIII

Colocada sobre o arcaz da sacristia da Igreja de Nossa Senhora da Encarnação, Vinhais do culto mariano pois na sua localização original completava a narrativa familiar em conjunto com Santa Ana e a Virgem (Imagem 33) e São Joaquim (Imagem 34). Acrescentamos nesta análise a outra representação de São José que registamos nos espaços em estudo, concretamente em Mogadouro (Imagem 36).

Nos evangelhos canónicos São José é escassamente referido, é a partir dos evangelhos apócrifos que a sua devoção se divulga. Associado com a figura de Maria e de Jesus transforma-se a partir do seculo XVII num dos mais importantes cultos da igreja católica espelhando na sua devoção os episódios de Cristo (descritos nos evangelhos canónicos e apócrifos) que, por crença popular, haviam reverberado naturalmente na vida de São José. Depois dos Jesuítas terem popularizado a Trindade (Jesus, Maria e José), São Francisco de Sales ter considerado São José o maior dos santos, e a reformadora da Ordem dos Carmelitas, Santa Teresa, pela cura milagrosa que havia

\footnotetext{
${ }^{71}$ Réau, Louis, Iconografía del arte cristiano; Iconografia de los santos De la G a la O; Tomo 2 / Volumen 4, Barcelona, Ediciones del Serbal, 1997 (Edição original 1955-1959), p. 153.
} 
recebido, ter dedicado o seu primeiro convento em Ávila ao culto a São José a devoção espalhou-se amplamente por todo o mundo católico ${ }^{72}$.

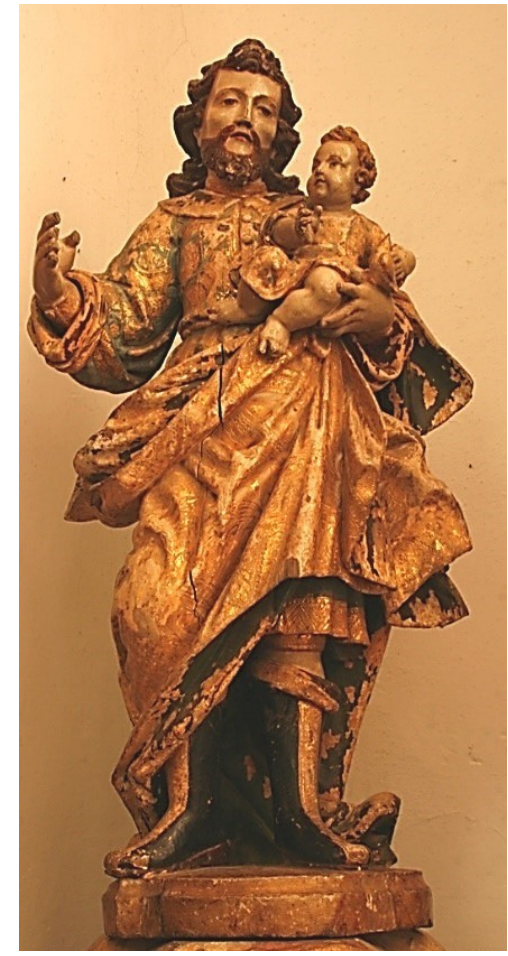

Imagem 35

Escultura de São José com o Menino IEV 04

Oficina local $\backslash$ Frei Domingos (?): último quartel do século XVIII Colocada num nicho do lado da Epistola na Capela-mor Igreja de Nossa Senhora da Encarnação, Vinhais

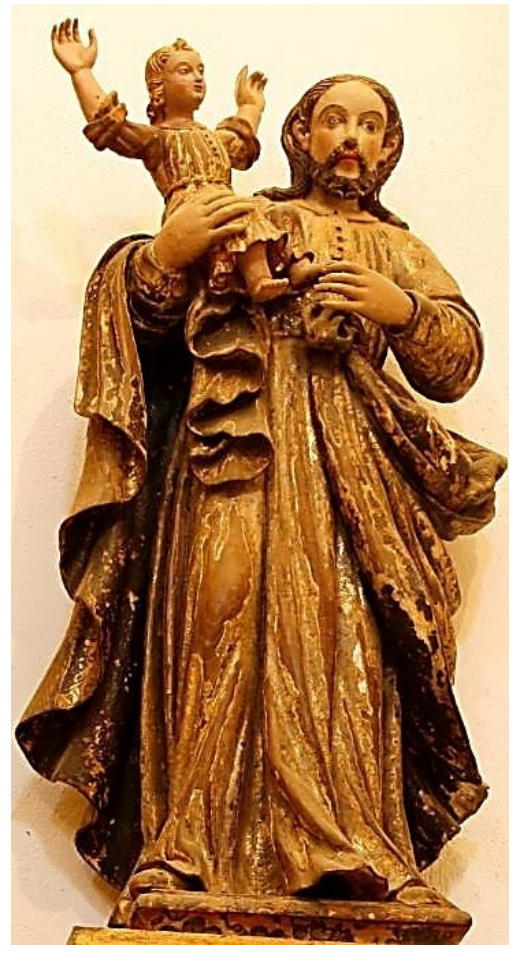

Imagem 36

Escultura de São José - SFM 02,

Oficina regional $\backslash$ local: segunda metade do século XVIII

Retábulo no lado da Epistola Igreja de São Francisco Mogadouro

Quer a escultura de São José de Vinhais (Imagem 35) quer a escultura de São José de Mogadouro (Imagem 36) representam ambas o mesmo modelo iconográfico. Pese embora as diferenças no traje, com alusões ao traje militar na figura de Vinhais é evidente, pelo Menino que sustêm ao colo, que ambas se relacionam com a narrativa de José protetor acompanhando Jesus na infância. Nas duas esculturas São José é representado como homem jovem, com o aspeto que se desenvolve a partir do século $\mathrm{XVI}^{73}$ ao contrário das representações mais arcaica que privilegiavam a representação

\footnotetext{
72 Réau, Louis, Iconografia del arte cristiano; Iconografía de los santos De la G a la O; Tomo 2 / Volumen 4, Barcelona, Ediciones del Serbal, 1997 (Edição original 1955-1959), p. 166.

${ }^{73}$ Réau, Louis, Iconografia del arte cristiano; Iconografía de los santos De la G a la O; Tomo 2 / Volumen 4, Barcelona, Ediciones del Serbal, 1997 (Edição original 1955-1959), p. 167; Carmona Muela, Juan, Iconografia cristiana, Madrid, Akal, 2010, p. 58; López Vázquez, José Manuel, "A propósito de
} 
de José de provecta idade. A representação de São José isolado apenas se fortalece na arte da contrarreforma. Apesar de atualmente as esculturas em estudo apenas apresentarem como atributo iconográfico o Menino ao colo, julgamos que no caso da escultura de Vinhais (Imagem 35) poderia possivelmente ostentar na mão direita o bastão florido ou o talo do lírio, hoje já desaparecido, mas que surge comummente como atributo.

Curiosamente em nenhuma das duas esculturas de São José dos espaços franciscanos estudados, se observam os objetos de trabalho de carpintaria que tradicionalmente acompanham a representação do santo. As obras estudadas privilegiam a narrativa que relaciona São José com o âmbito familiar nas responsabilidades que lhe estão inerentes em detrimento das insígnias profissionais.

Este aspeto é revelador das alterações que se operam nas estruturas familiares ao longo do Antigo Regime. A crescente valorização da infância é acompanhada pela exaltação da família onde São José surge como chefe ${ }^{74}$. Quer a escultura de Vinhais, quer a escultura de Mogadouro ilustram esta conceção e a consequente catequização dos valores que lhe estão intrínsecos junto das populações onde intervinham.

A preocupação com os infanticídios e com a exposição de crianças estaria seguramente nas alterações de comportamento que a Ordem de São Francisco e as restantes dinâmicas católicas queriam suscitar. A imagem serena de São José com o Menino, mesmo que representado com botas militares é uma apologia ao reforço dos vínculos familiares onde a paternidade e a infância se articulam entre as malhas emocionais e sociais da ternura e da responsabilidade.

A narrativa mais complexa do culto mariano que registamos nos espaços em estudo é, pelo número de intervenientes, Nossa Senhora da Encarnação, que apenas existe em Vinhais em dois conjuntos escultóricos. Exposta no retábulo do altar-mor em talha (Imagem 37, 38 e 39) e numa curiosa obra popular em pedra sobre a fachada (Imagem

una imagen del monasterio de Celanova: tipología de san José y estilo en el taller de Gambino-Ferreiro (Jose Gambino y José Ferreiro Suárez)", in Enrique Fernández Castiñeiras y Juan M. Monterroso Montero (ed.), Arte Beneditina nos camiños de Santiago. Opus Monasticorum II, A Coruña, Xunta de Galicia. Consellería de Innovación e Industria, 2006, pp. 439-462.

${ }^{74}$ Sobre este tema ver a coleção História da Vida privada dirigida por Philippe Ariès e Georges Duby (1990) Vol. III e Ariès, Philippe, História Social da Criança e da Família. Rio de Janeiro, LTC- Livros Técnicos e Científicos Editora S.A, 1981. 
4o). A iconografia da Encarnação está próxima da iconografia da Anunciação ${ }^{75}$. A narrativa tece-se entre a Virgem e o Arcanjo Gabriel.

O conjunto em talha que mantém o sue lugar original dentro do templo representa a invocação principal da ainda hoje designada igreja de Nossa Senhora da Encarnação. A narrativa estaria oposta ao dramático Cristo do Coro enfatizando o contraste entre a esperança da jovem Mãe e o cruel martírio do seu filho Jesus.

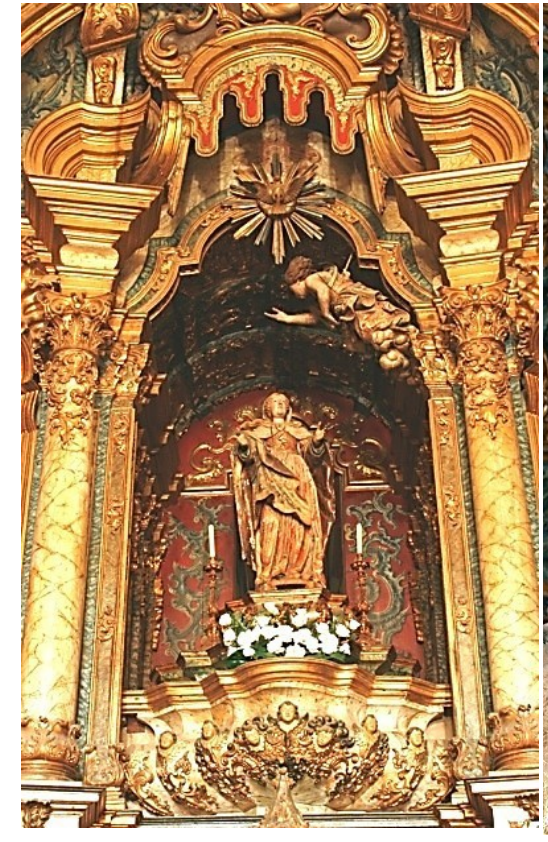

Imagem 37

Nicho central do retábulo do altarmor com as esculturas de Nossa Senhora da Encarnação e o Anjo Gabriel

Igreja de Nossa Senhora da Encarnação, Vinhais

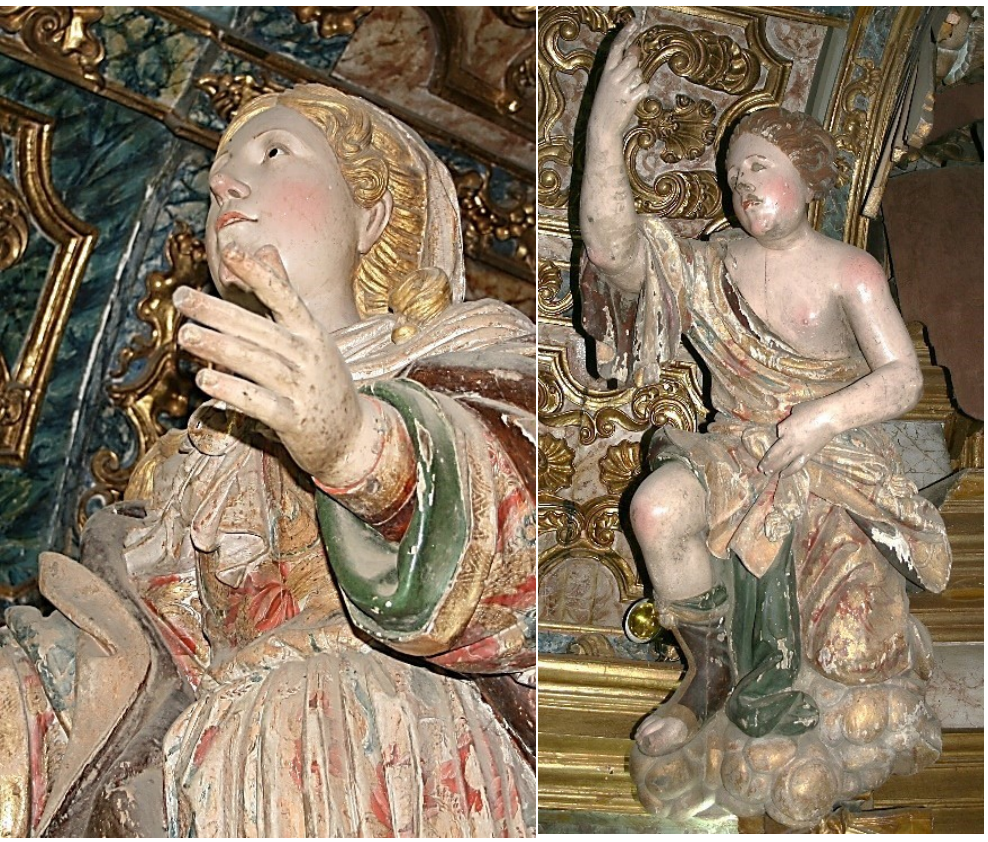

Imagem 38

Pormenor da escultura de Nossa

Senhora da Encarnação IEV 06

Oficina local $\backslash$ Frei Domingos: último quartel do século XVIII Retábulo do altar-mor Igreja de Nossa Senhora da Encarnação, Vinhais
Imagem 39

Pormenor da escultura do Anjo Gabriel IEV 07

Oficina local $\backslash$ Frei

Domingos: último quartel do século XVIII

Retábulo do altar-mor Igreja de Nossa Senhora da Encarnação, Vinhais

Não se trata se uma simples representação da vida de Nossa Senhora mas é a representação da origem da vida humana de Cristo e é portanto o prelúdio da Obra da Redenção $^{76}$. Neste sentido, a narrativa da Redenção estaria completa com a

\footnotetext{
${ }^{75} \mathrm{~A}$ imagem divulgada no Flos Sanctorum é constituída pela Virgem sentada a ler interrompida pelo anjo Gabriel. Campos, Hermão de e Rabelo, Roberto, Flos Sanctorum HO FLOS SANCTÕ [RUM] EM LINGOAJE[M] P[OR]TUGUE[S], Lisboa, Disponível na plataforma on-line da Biblioteca Nacional de Portugual http://purl.pt/12097, 1513, fl. LIII v.

${ }^{76}$ Sobre a Anunciação Gonçalves refere a proximidade do modelo iconográfico com a representação da Árvore de Jessé, (como acontecia originalmente no portal da igreja de Nossa Senhora da Oliveira em Guimarães) enquanto elemento prefigurativo da conceção de Jesus.
} 
representação da Crucificação que se lhe opunha sobre o coro alto, como momento final da vida humana de Cristo.

A composição da cena privilegia a figura da Virgem, de pé em escala colossal com gesto amplo e pose sinuosa ocupa o espaço central do nicho. O Anjo, mais pequeno, ajoelhado, sem asas, suspenso sobre a nuvem ${ }^{77}$, ergue o braço em direção à Virgem, e é nesse gesto de orador, com o dedo esticado ${ }^{78}$ que a linha obliqua que o seu corpo desenha, termina. $\mathrm{O}$ anjo ilustra a transmissão da mensagem no gesto de orador, mas está de joelhos perante a Mãe de Deus. Com traje de inspiração militar e sem asas pareceria um servo perante a sua senhora se não fosse a nuvem e o plano superior em que está colocado e o separa da narrativa terrestre (Imagem 39). Portanto a escala das figuras e a posição que ocupam define a relação entre ambas. O evangelho de Lucas (Lc 1, 26-38) descreve a cena representada, no entanto, o receio e a perturbação da Virgem com a aparição do Anjo parecem ausentes nesta representação (Imagem 38). A figura da Virgem é segura e majestosa na sua gestualidade apenas quebrada pela tensão atmosférica que traduzem os panejamentos que a envolvem. Enverga um traje rico sobre o qual sobrepõe um véu ${ }^{79}$ que lhe cobre a cabeça. Esboça um ligeiro sorriso e olha frontalmente o Arcanjo que a interrompe. A encarnação que designa esta devoção

\footnotetext{
No século XVII o tema da Árvore de Jessé popularizou-se em Portugal, enquanto no resto da Europa caía em desuso, este facto pode definir um aspeto característico da arte da contrarreforma portuguesa. Gonçalves, Flávio, "A «Árvore de Jessé» na arte portuguesa" in Revista da Faculdade de Letras História, 03, Porto, Faculdade de Letras da Universidade do Porto, 1986, pp. 213-238; Ruiz Maldonado, Margarita, "Libro de Horas (Oficio de la Virgen)" in Inmaculada, catálogo da exposição Las Edades del Hombre, Madrid, 2005, pp. 94-96.
}

${ }^{77}$ A partir do Concilio de Trento estabeleceu-se como preferencial a representação do Anjo sobre a nuvem de modo a enevoar o interior do espaço onde costumava ser representada a cena. Réau, Louis, Iconografia del Arte Cristiano. Iconografía de la Biblia - Nuevo Testamento Tomo 1/Volumen 2, Barcelona, Ediciones del Serbal, 1996, (Edição original 1955-1959), p. 201.

${ }^{78} \mathrm{O}$ gesto de dicção e bendição aproximam-se e ambos têm origem nos gestos clássicos de oratória. Fraga Sampedro, Maria Dolores, "Predicación e imágenes en los siglos finales de la edad media hispana" in Plenitudo Veritatis homenaje a Mons. Romero Pose, Santiago de Compostela, Instituto Teológico Compostelano, 2008, pp. 829-847.

${ }^{79}$ Uma vez consagradas a Deus as virgens deveriam cobrir a cabeça com um véu ou com o próprio manto. A Virgem Maria com a cabeça coberta pelo manto ou com o véu poderá ser uma alusão ao voto de virgindade que a jovem teria feito segundo a tradição transmitida desde a Patrística. O costume das mulheres cobrirem a cabeça quando se encontram em oração, independentemente do seu estado civil, tem uma expressão escrita desde o século primeiro, pois, São Paulo ao escrever aos Coríntios refere que as mulheres devem cobrir a cabeça quando estiverem na sinagoga devido à presença dos anjos. Casimiro, Luís Alberto Esteves, "Iconografia da Anunciação: símbolos e atributos", Revista da Faculdade de Letras, Ciências e Técnicas de Património, Vol. 07-08, Porto, Faculdade de Letras da Universidade do Porto, 2008-2009, pp. 151-174. 
Mariana é a partir do Concilio de Trento assumida na continuidade da Anunciação, resultando ambas na mesma cena representada ${ }^{80}$.

A mesma cena da anunciação do anjo Gabriel se repete em granito sobre o portal do templo do seminário apostólico. Trata-se de uma produção popular ${ }^{81}$ cujo interesse se vinculada sobretudo à quantidade de atributos iconográficos que acompanham a figura da Virgem. O paralelismo com o conjunto de talha no interior do templo estabelece-se com a diferente escala das figuras e o maior protagonismo espacial dado à representação de Nossa Senhora. Mas, a expressão de espanto, mesmo que com linhas sumarias, do rosto da Virgem difere enormemente da serena curiosidade que majestosamente surpreende a imagem da Virgem da Encarnação do altar-mor.

Imagem 40

Escultura de Nossa Senhora da Encarnação e Arcanjo Gabriel -

IEV 15

Produção local (pedreiro): último quartel do século XVIII

Frontispício sobre o portal principal

Igreja de Nossa Senhora da

Encarnação do Seminário Apostólico de Vinhais

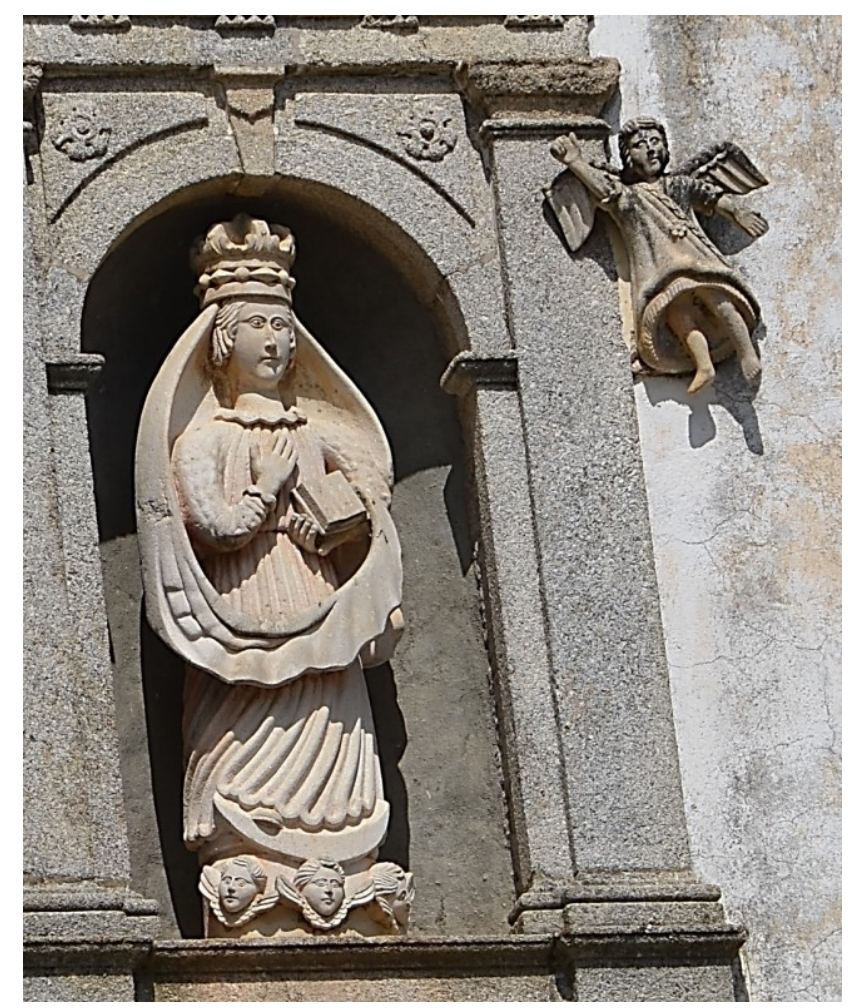

${ }^{80} \mathrm{O}$ tema da Encarnação foi, nos finais da Idade Média, entendido com a representação da "Imersão do Menino Jesus no ventre da Virgem" quer pelo canal uterino quer pela orelha ou com a representação da “Caça ao Unicórnio"|"Caça Mística". Mas, ambos os modelos foram abandonados pós Trento e assumida apenas a representação da Anunciação do Anjo à Virgem. Réau, Louis, Iconografía del Arte Cristiano. Iconografía de la Biblia - Nuevo Testamento Tomo 1/ Volumen 2, Barcelona, Ediciones del Serbal, 1996, (Edição original 1955-1959), pp. 198-201.

${ }^{81}$ Conta a lenda que, quando o pedreiro que andava a assentar as cantarias da cornija escorregou e caiu ficando incólume da queda. Em prova do reconhecimento do milagre esculpiu a imagem de Nossa Senhora e o arcanjo São Gabriel. Martins, Firmino A., Folklore do Concelho de Vinhais, Bragança, Câmara Municipal de Vinhais, 1987 (edição original 1927), pp. 113, 114. A lenda pode sugerir a verdade relativamente à produção da escultura, cujas formas arcaicas e a iconografia livre evidenciam a prática de um pedreiro. Mas a lenda apenas refere um pedreiro, de que não sabemos o nome ou a proveniência. 
No portal a figura de Nossa Senhora ostenta uma sumptuosa coroa e segura um livro $^{82}$. O corpo da Virgem já não está representado num espaço terrestre mas sobre uma nuvem com querubins, onde está suspensa pisando com o pé a Lua crescente. Esta sobreposição de elementos característicos da representação da Imaculada Conceição é decorrente da criatividade do autor que não obedeceu a nenhum modelo iconográfíco estabelecido, nem formalmente se deteve em primores. Mas esforçou-se por enaltecer com o vocabulário iconográfico as virtudes do símbolo representado, acrescentando atributos facilmente reconhecíveis para reforçar catequeticamente o poder da imagem.

O facto da Senhora da Encarnação ser a invocação principal do templo e o destacável número de imagens de devoção mariana dão conta da forte intenção mariana dos frades missionários junto do território onde intervinham.

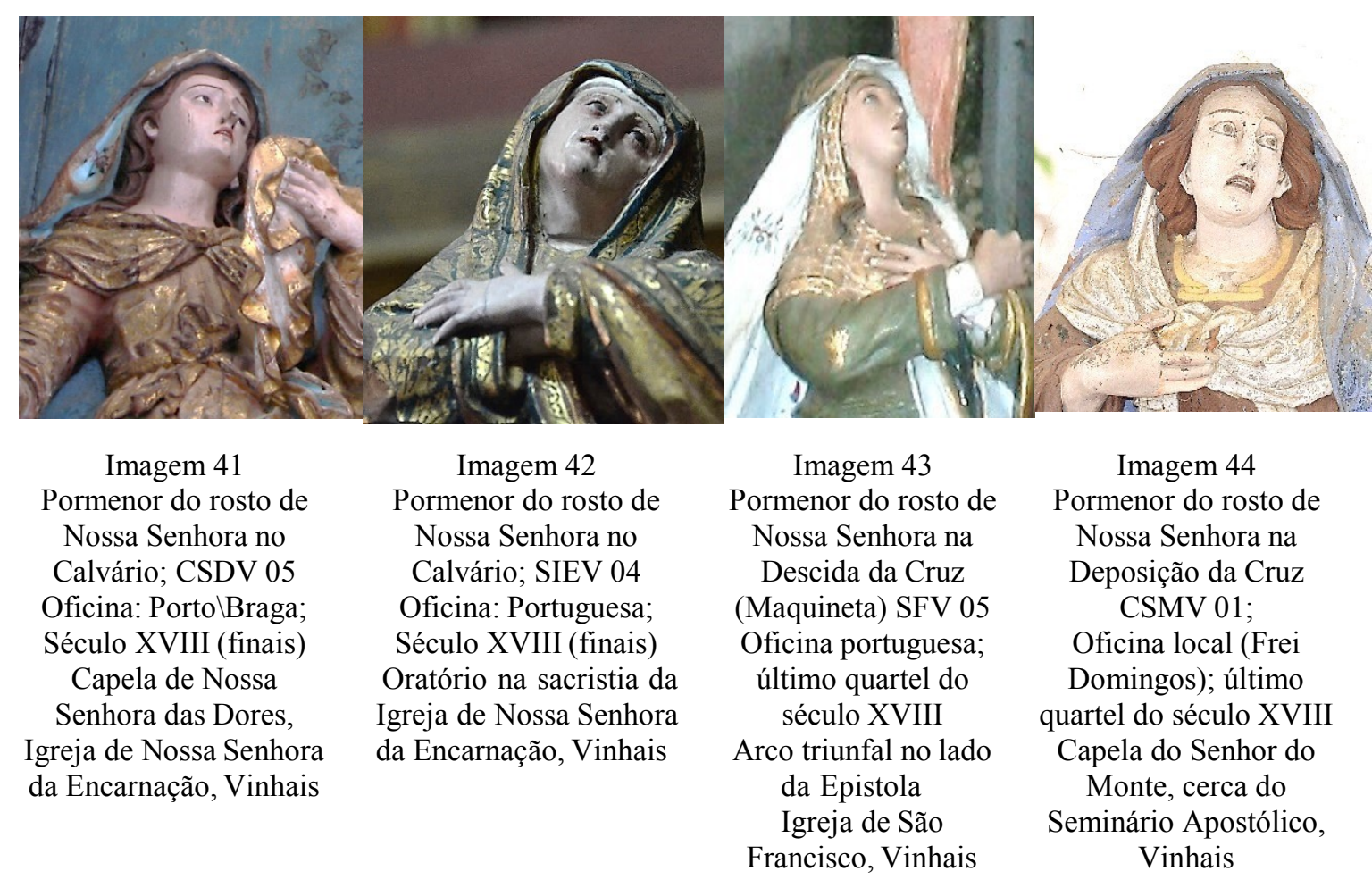

\footnotetext{
${ }^{82} \mathrm{O}$ livro fechado nas mãos de Maria pode ser interpretado como uma indicação da vida de oração e meditação que a jovem levava, ou que a Virgem acabara de ler uma determinada passagem ou oração e se encontrava meditando sobre o seu conteúdo. Casimiro, Luís Alberto Esteves, "Iconografia da Anunciação: símbolos e atributos", Revista da Faculdade de Letras, Ciências e Técnicas de Património, Vol. 07-08, Porto, Faculdade de Letras da Universidade do Porto, 2008-2009, pp. 151-174.

O livro é o atributo que distingue a representação da Anunciação no Ocidente desde a Idade Média, por oposição a Bizâncio onde se representava a Virgem interrompida pelo Anjo em afazeres domésticos ou em trabalhos manuais. Réau, Louis, Iconografía del Arte Cristiano. Iconografía de la Biblia - Nuevo Testamento Tomo 1/ Volumen 2, Barcelona, Ediciones del Serbal, 1996, (Edição original 1955-1959), p. 188.
} 
Na sequência histórica dos episódios bíblicos que se relacionam com a Virgem Maria existe, também em Vinhais, a representação de um Presépio (Imagem 3). Além desta representação da sagrada família em Belém não existe mais nenhuma figuração escultórica de Nossa Senhora com o Menino Jesus. É assinalável nas representações familiares que existem nos espaços franciscanos em estudos a existência de duas representações de São José com o Menino, no entanto não existe nenhuma representação da Mãe com o Menino.

A narrativa seguinte que envolve a figura Virgem está já relacionada com a Paixão de Cristo (Imagens 41, 42, 43 e 44) e são no conjunto que constituem inseparáveis.

Todas estas narrativas, duas de Calvário (Imagens 41 e 42), uma Descida da Cruz (Imagem 43) a Deposição de Cristo Morto (Imagem 44), se encontram em Vinhais. Em todas é Cristo que assume a centralidade da narrativa, e constam no capítulo relativo a análise iconográfica de Jesus Cristo. Mas, todas as representações destacadas favorecem a narrativa de conjunto onde a Virgem Maria tem destaque entre as diversas personagens conforme se configura nos detalhes expressivos do rosto e na gestualidade de todas as figuras. É observável um distinto controlo emocional dos distintos discursos do dramatismo da representação. A imagem da Descida da Cruz (Imagem 43) revela um gosto próximo ao neoclássico, com a gestualidade segura da emoção mais contida. Por oposição a produção local de Frei Domingos (Imagem 44) transmite um sentimentalismo desgarrado na expressividade da dor. Também nos Calvários as duas Virgens assumem atitudes diferentes. Frágil e desamparada nos requebros do corpo a Nossa Senhora do oratório da sacristia (Imagem 42) parece estar na eminência do desmaio. A Virgem do Calvário da capela de Nossa Senhora das Dores (Imagem 41) em posição frontal e de cabeça erguida sugere a resistência estoica no drama que representa. A pluralidade emocional que envolve as diferentes representações de Nossa Senhora na Paixão é rica e ampla favorecendo a comunicação a resiliência ao sofrimento por meio de diversos modelos.

O amplo conjunto franciscano de Vinhais constitui o espaço mais rico em narrativas escultóricas compostas por vários elementos, onde o culto mariano, apesar de secundário assume espacial e iconograficamente uma linguagem densa.

Nossa Senhora surge ainda noutra narrativa da Paixão, também em Vinhais, mas numa escultura isolada em que está representada sozinha. Trata-se de uma imagem de roca ou de vestir que representa Nossa Senhora das Dores (Imagem 45) 


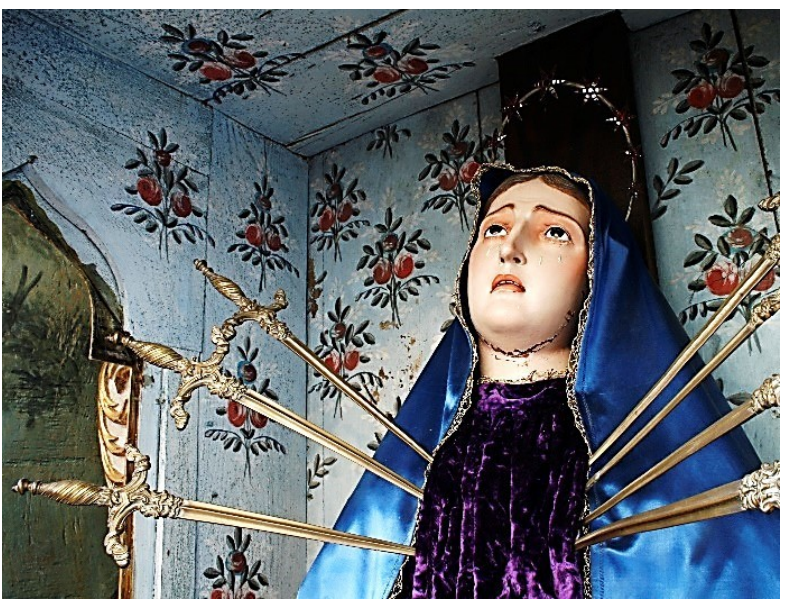

Imagem 45

Pormenor do rosto de Nossa Senhora das Dores CSDV 08,

Oficina: Espanhola; Segunda metade do século XVIII Dentro de uma maquineta sobre o nicho central do retábulo da Capela de Nossa Senhora das Dores Igreja de Nossa Senhora da Encarnação, Seminário Apostólico de Vinhais

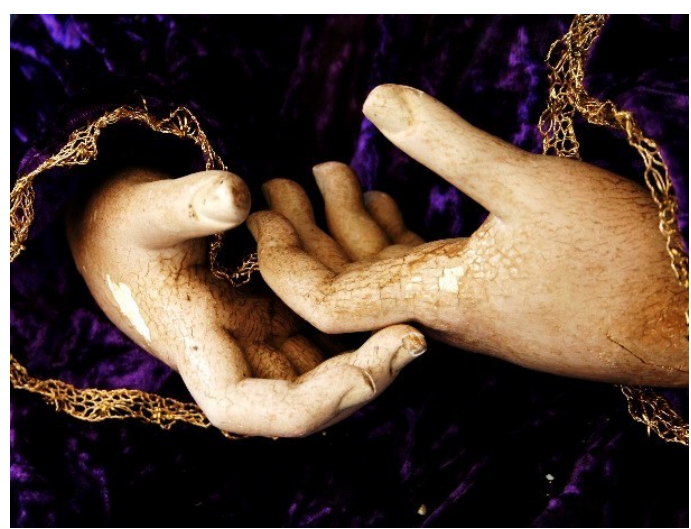

Imagem 46

Pormenor das mãos de Nossa Senhora das Dores CSDV 08,

Oficina: Espanhola; Segunda metade do século XVIII

Dentro de uma maquineta sobre o nicho central do retábulo da Capela de Nossa Senhora das Dores Igreja de Nossa Senhora da Encarnação, Seminário Apostólico de Vinhais

. Tem capela própria, à entrada do templo no lado do evangelho e quatro ex-votos em pintura sobre madeira e pele que testemunham a devoção popular e o poder taumatúrgico da imagem ${ }^{83}$. A imagem está trespassada no peito com sete espadas de prata decoradas nos punhos, três do lado direito e quatro espadas no lado esquerdo ${ }^{84}$. Tem analogia no número com as sete caídas de Cristo no Calvário, mas as sete espadas referem-se a três dores sofridas pela Virgem durante a infância de Cristo e quatro relativas à Paixão. O culto é tardio, desenvolve-se a partir dos Países-Baixos apenas a partir do século XVI. Apesar de ligeiras diferenças o modelo que se definiu e expandiu mais amplamente desta invocação é idêntico ao que ainda hoje podemos observar na

\footnotetext{
${ }^{83}$ Dois dos ex-votos são relativos a curas milagrosas que Nossa Senhora das Dores operou sobre frades franciscanos do seminário, sendo um ainda noviço. Afonso, Belarmino, Ex-votos e religiosidade popular no Distrito de Bragança, Bragança, Região de Turismo do Nordeste Transmontano, 1995, pp. 108, 109. $\mathrm{O}$ mesmo autor refere a importância das missões franciscanas na proliferação da religiosidade popular que os ex-votos ilustram, p.11.

${ }^{84}$ A origem afirma Réau, desta devoção está na Flandres nos finais do século XV onde se fundou a primeira confraria sob invocação da Virgem das Sete Dores. Nos inícios do século XVI em Antuérpia numa gravura dedicada a Carlos V foi gravada a primeira representação de Nossa Senhora com sete espadas cravadas em volta do peito. Réau, Louis, Iconografía del Arte Cristiano. Iconografía de la Biblia - Nuevo Testamento Tomo 1/ Volumen 2, Barcelona, Ediciones del Serbal, 1996, (Edição original 19551959), pp. 117-118.
} 
capela de Vinhais e que se destaca pelas mãos juntas (Imagem 46) e pelas grossas lagrimas sobre o rosto ${ }^{85}$.

A expressão do rosto denota o desamparo da figura representada sozinha no momento de maior dor, as mãos inertes sobre o colo reforçam essa impotência perante o sofrimento.

$\mathrm{O}$ arquear das sobrancelhas, o olhar elevado e as grossas lágrimas sugerem a proximidade formal com a linguagem processional espanhola. A escultura por ser de roca permitia o seu uso em celebrações públicas de procissões ou cortejos dado o menor peso que tem relativamente às imagens de vulto pleno. Não temos documentação que nos permita perceber esse uso cultual, mas os ex-votos dão conta dos milagres e devoção que a imagem suscitava. Atualmente a imagem de roca de Nossa Senhora das Dores está colocada dentro de uma maquineta já de gosto neoclássico, mas mantem-se na mesma capela que originalmente the foi dedicada.

As restantes esculturas de devoção mariana representam Nossa Senhora isoladamente e relacionada a cultos cuja origem se afasta da narrativa histórica dos evangelhos canónicos.

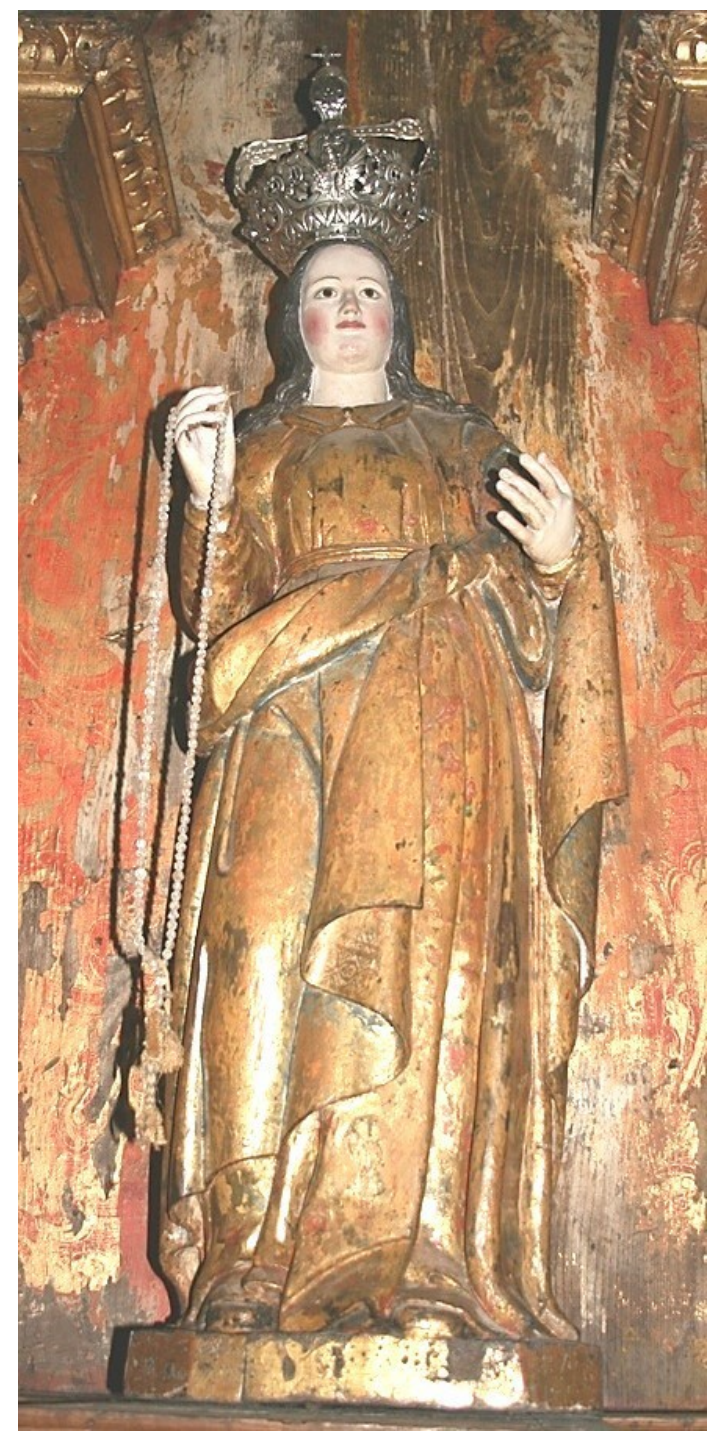

Imagem 47

Nossa Senhora do Rosário; SFB 10 Oficina: Coimbra; Segunda metade do século XVI Igreja de São Francisco Bragança

Destacamos neste contexto das Virgens tutelares uma imagem que representa Nossa Senhora do Rosário, ao culto na igreja de São Francisco em Bragança (Imagem 47).

\footnotetext{
${ }^{85}$ Réau, Louis, Iconografía del Arte Cristiano. Iconografía de la Biblia - Nuevo Testamento Tomo 1/ Volumen 2, Barcelona, Ediciones del Serbal, 1996, (Edição original 1955-1959), p. 116.
} 
A confraria responsável pela sua devoção era a confraria dos militares. A imagem não vem referida no inventário de 1834, mas Cardoso Borges expunha o culto de Nossa Senhora do Rosário em 1721-1724. No interior do templo destacou a capela de "Nossa Senhora do Rosário que tem irmandade de todos os militares" $" 86$.

Bragança como cidade fronteiriça teve sempre obrigações militares que foram relevantes desde o início da nacionalidade e mais tarde durante a guerra da Restauração (1640-1668) e também durante a guerra da Sucessão de Espanha (1702-1713). Dessas centúrias (século XVII ou XVIII) serão seguramente os fragmentos (Imagem 48; Imagem 49) que ganham valor pela curiosidade das formas que representam e seguramente pelas festividades públicas em que seriam usadas.

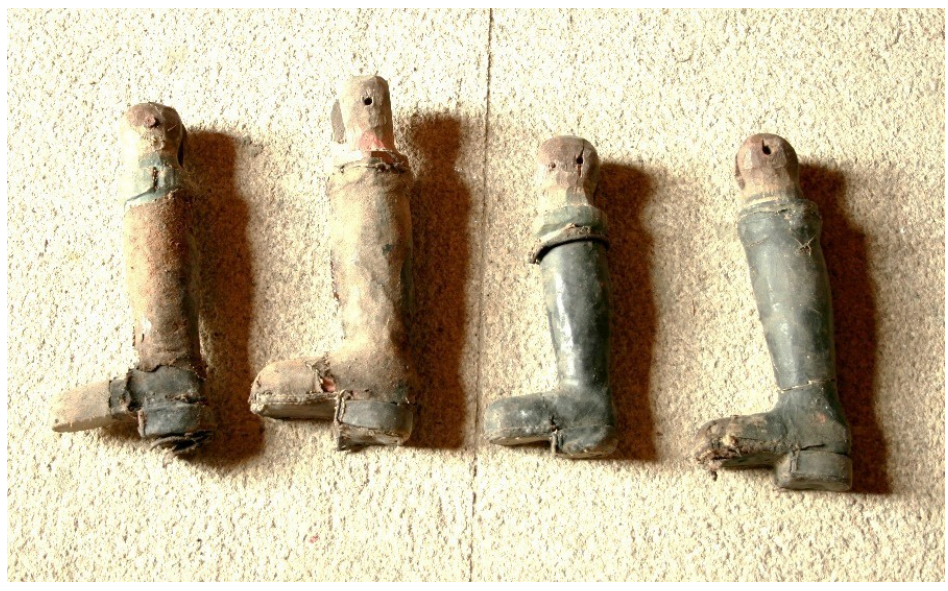

Imagem 48

Fragmentos (conjunto de dois pares de pernas com botas de cano alto) SFB 52

Produção local; Século XVIII

Sala do Despacho da Ordem Terceira da igreja de São Francisco em Bragança

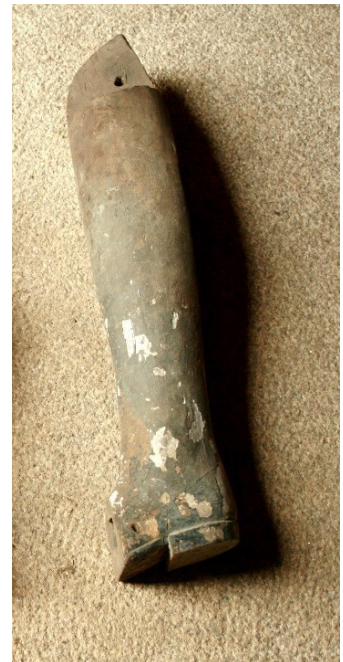

Imagem 49 Fragmento (perna com bota de cano alto) SFB 54

Produção local; Século XVIII

Sala do Despacho da Ordem Terceira da igreja de São Francisco em Bragança

Ao peculiar conjunto de pequenas pernas em madeira cobertas de cabedal simulando botas de militares acresce um fragmento isolado, de maior tamanho que o conjunto de botinhas, mas representando também uma bota de cano alto. A inquestionável referência militar destes fragmentos pode ser relacionada com as festividades religiosas em que o convento franciscano tomava parte, em especial a irmandade dos militares que dentro

\footnotetext{
${ }^{86}$ Borges, José Cardoso, Memórias de Bragança, Fernando de Sousa (Coord.), Bragança, CEPESE / Câmara Municipal de Bragança, 2012 (texto original de 1721-1724), p. 142.
} 
do templo franciscano tinha a sua capela. Mais uma vez é Cardoso Borges que nos dá detalhes sobre a participação da comunidade nestes festejos, em especial nas celebrações do culto a São Jorge e Santiago onde eram comuns as danças e festejos representando práticas militares, contando também com a participação dos meninos que acompanhando o Santo com ladainhas iam depois "pelo campo com militar impulso em desformada tropa". A nobreza empenhava-se também nos festejos a simular combates e "festas de cavalaria, comédias e outros espetáculos que divertiam o povo por seis a oito dias" $\$$.

A escultura de Nossa Senhora do Rosário do convento de São Francisco de Bragança não pode ser dissociada da devoção popular que lhe estava afeta, constituindo quer para a nobreza local quer para a restante comunidade um importante elemento em celebrações conjuntas.

A invocação do Rosário relaciona-se tradicionalmente com a figura do santo fundador da Ordem Dominicana. São Domingos teria recebido da Virgem, em cerca de 1210, o sagrado talismã da coroa de rosas de Nossa Senhora, que o ajudou a combater a heresia dos albigenses. Mas a representação da devoção expande-se tardiamente pela europa. Apenas surgirá figurada numa obra do último quartel do século XV. A partir da Alemanha, onde em 1478 se institui a primeira Confraria do Rosário, os dominicanos patrocinaram a nova devoção que se espalhou rápida e amplamente ${ }^{88}$.

Ferreira de Almeida afirma que a devoção a Nossa Senhora do Rosário, próxima com a de Nossa Senhora do Carmo bem como de Nossa Senhora da Boa Morte se expande tanto na época moderna por gradual substituição do culto medieval ao Arcanjo São Miguel enquanto guia das almas, psicopompo junto de Deus. Este aspeto relaciona-se com a crescente crença no juízo particular, que se afirma no final da idade média, onde Nossa Senhora intercede, ao contrário de São Miguel cuja balança remetia para um juízo do coletivo através da confissão pública. Santa Maria, que se designa a partir dos

\footnotetext{
${ }^{87}$ Borges, José Cardoso, Memórias de Bragança, Fernando de Sousa (Coord.), Bragança, CEPESE / Câmara Municipal de Bragança, 2012 (texto original de 1721-1724), pp. 126, 127.

${ }^{88}$ Réau, Louis, Iconografía del Arte Cristiano. Iconografía de la Biblia - Nuevo Testamento Tomo 1/ Volumen 2, Barcelona, Ediciones del Serbal, 1996, (Edição original 1955-1959), pp. 129-130. O promotor da primeira Confraria do Rosário foi, o prior dos dominicanos de Colónia, Sprenger, autor da célebre obra de combate às bruxas e heresias Malleus Maleficarum. O mesmo autor refere que a devoção de Nossa Senhora do Rosário foi inventada e difundida nos finais do século XV pelo dominicano bretão Alain de la Roche. O culto apenas de divulgou já no contexto moderno a partir da Alemanha ou de França. Réau, Louis, Iconografía del arte cristiano - Iconografia de los santos, de la A a la F. Tomo 2 / Volumen 3, Barcelona, Ediciones del Serbal, 1997 (edição original 1955-1959), p. 394.
} 
finais da época medieval como Nossa Senhora não só reflete as diversas invocações de Cristo mas muitas vezes substitui o culto de outros santos ${ }^{89}$.

A iconografia da imagem de Nossa Senhora do Rosário do convento franciscano de Bragança centra-se no rosário de cem contas de vidro, que ostenta pendente na mão direita. Filiada nos modelos de representação da mãe de Jesus como auxiliadora ou moderadora entre Deus e os homens a expressão do rosto é serena, a pose frontal e majestática é acrescentada, já em período posterior, pela ornamentada coroa de prata.

$\mathrm{Na}$ igreja do convento da Ordem Terceira Regular de Mogadouro estão a culto duas devoções marianas distintas, ambas com origem na Diocese de Lamego. Nossa Senhora da Lapa (Imagem 48), Nossa Senhora dos Remédios (Imagem 49), que figuram no inventário de 1834.

Iconograficamente estas devoções estão vinculadas com a vida no campo e a agricultura com origem remota nas festividades relacionadas com a fertilidade e a abundância ${ }^{90}$.

A imagem de Nossa Senhora da Lapa representa um culto português, que se desenvolveu segundo a lenda em finais do século XV a partir do achado milagroso numa gruta rochosa, a "Lapa", da imagem sagrada por parte de uma pastorinha. A imagem terá milagrosamente devolvido a fala à pastorinha que era muda, depois desse, muitos foram os milagres que favoreceu, ampliando a devoção não só em Portugal mas também ao Brasil. As celebrações da romaria em Sernancelhe, Lamego, decorrem no primeiro Domingo de Setembro e a imagem venerada nos diversos templos onde em Portugal se lhe presta culto é semelhante à de Mogadouro.

Com as mãos postas em oração sobre o peito a figura está de pé e envolvida por duas capas, e véu sobre a cabeça. $O$ rosto, de expressão serena esboça um ligeiro sorriso.

Com origem próxima geograficamente ao aparecimento de Nossa Senhora da Lapa, surge Nossa Senhora dos Remédios no século XVI em Lamego, com remota origem na lenda da bolsa com dinheiro que serve de remédio para a libertação de cativos.

\footnotetext{
${ }^{89}$ Almeida, Carlos Alberto Ferreira de, "O culto a Nossa Senhora, no Porto, na época moderna: perspectiva antropológica", Revista de História, vol. 2, Porto, Faculdade de Letras da Universidade do Porto, 1979, pp. 159-173. Também Réau referia esta substituição que se operou nos alvores da época moderna nas devoções de santos por novas devoções marianas. Réau, Louis, Iconografía del Arte Cristiano. Iconografia de la Biblia - Nuevo Testamento Tomo 1/ Volumen 2, Barcelona, Ediciones del Serbal, 1996, (Edição original 1955-1959), p. 124.

${ }^{90}$ Almeida, Carlos Alberto Ferreira de, "O culto a Nossa Senhora, no Porto, na época moderna: perspectiva antropológica", Revista de História, vol. 2, Porto, Faculdade de Letras da Universidade do Porto, 1979, pp. 159-173.
} 
A igreja de São Francisco de Mogadouro é assim o único templo da família franciscana em estudo onde se prestava culto uma devoção nacional, prática nacionalista que se intensifica no período pós guerra da Restauração e que perdurará muito além do século XVII. Julgamos que este aspeto deve ser também associado com proximidade da fronteira com Espanha. Critério que é também comum aos territórios de Bragança e Vinhais, mas nos finais do século XVIII é no espaço de fronteira de Miranda do Douro (Concelhos vizinho de Mogadouro) onde os conflitos entre Portugal e Espanha geram repercussões mais profundas.

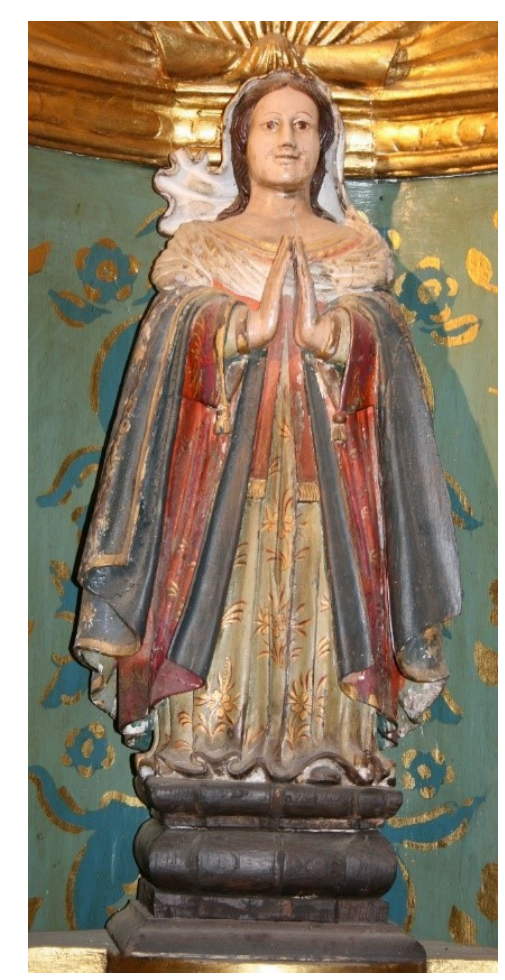

Imagem 48

Nossa Senhora da Lapa - SFM 12, Oficina: Local; Segunda metade do século XVIII Retábulo no lado do Evangelho Igreja de São Francisco Mogadouro

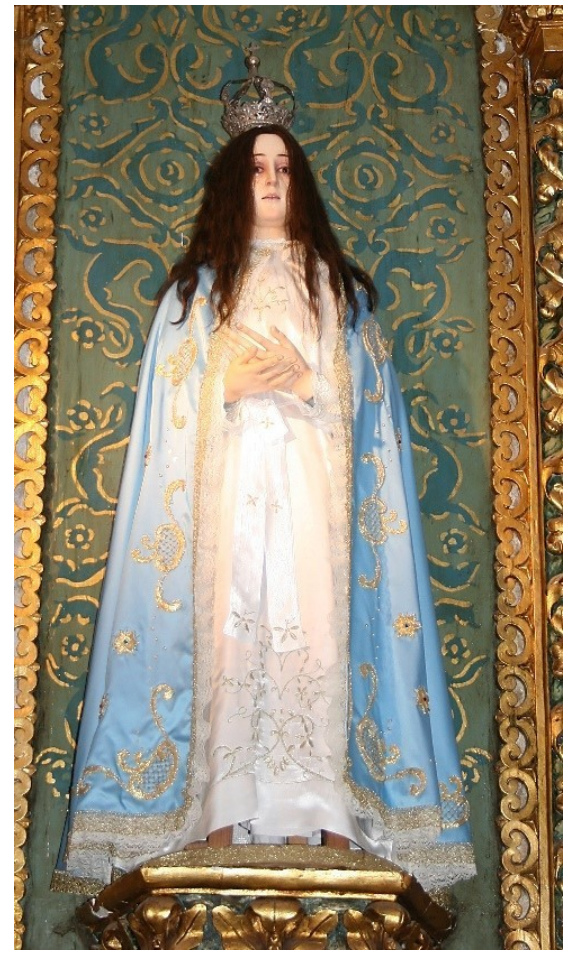

Imagem 49

Nossa Senhora dos Remédios - SFM 11 Oficina: Local; Segunda metade do século XVIII Retábulo lateral, lado do Evangelho Igreja de São Francisco de Mogadouro

A amplificação das devoções da diocese de Lamego nos territórios limítrofes seria espectável, curioso é o facto de apenas se observarem em Mogadouro.

A Imagem de Nossa Senhora dos Remédios da igreja de São Francisco de Mogadouro está representada numa imagem de roca, cuja invocação estava perdida. A sua 
identificação advém do inventário dos bens de 1834, mas em 2013, aquando do inventário das esculturas perdurava ainda em Mogadouro uma lenda sobre a imagem ${ }^{91}$.

A origem do culto em Portugal, cujo principal templo se encontra em Lamego remonta ao século XVI. A sua difusão foi ampla e iconograficamente é representada com o Menino ao colo e sustendo na mão uma bolsa. A imagem de Mogadouro, dada a escassez de elementos que a compõem, sendo de roca tem apenas a cabeça e mãos esculpidas em vulto, o que permitia a transformação da imagem numa vasta variedade de invocações, bastaria acrescentar o atributo, da bolsa dos Remédios, do Rosário, Menino ou até a Custódia como refere a lenda de Mogadouro.

Trata-se de uma representação relacionada com a proteção, como é evidente na expressão serena do rosto e no olhar baixo para os fiéis por quem intercede. As mãos, móveis, poderiam dirigir-se aos fiéis em sinal de entrega (da bolsa).

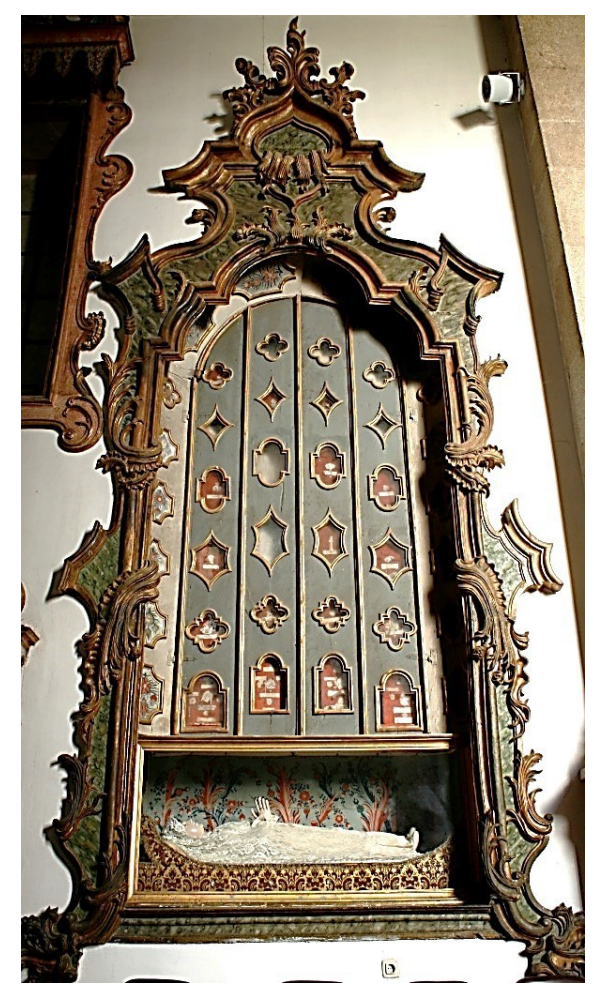

Imagem 50

Retábulo de Nossa Senhora da Boa MorteIEV 03, com a imagem dentro do esquife e sobrepostas as relíquias

Oficina: Porto; ultimo quartel do século XVIII

Capela-mor no lado da Epistola da Igreja de Nossa Senhora da Encarnação, Seminário Apostólico de Vinhais

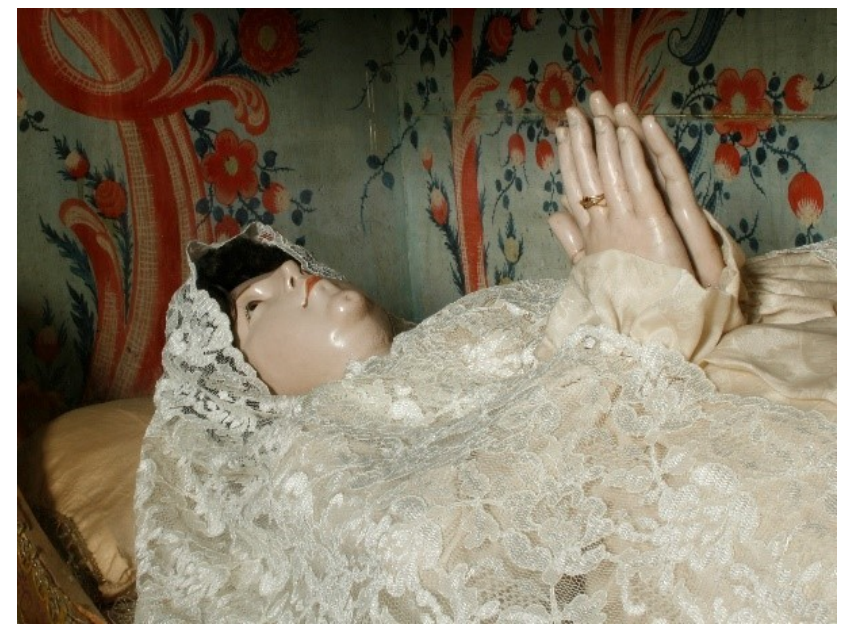

Imagem 51

Pormenor do rosto de Nossa Senhora da Boa Morte - IEV 03, com a imagem dentro do esquife e sobrepostas as relíquias

Oficina: Porto; ultimo quartel do século XVIII Capela-mor no lado da Epistola da Igreja de Nossa Senhora da Encarnação, Seminário Apostólico de Vinhais

${ }^{91}$ O pároco da igreja, Cónego Dino Parra em Dezembro de 2013 referiu a lenda sobre a imagem de Nossa Senhora que teria milagrosamente sustido, sem qualquer apoio, a custódia num dia em que saiu em procissão ostentando a Sagrada Forma. No entanto poderia em vez da custódia tratar-se da lendária bolsa com dinheiro, o remédio para libertar os cativos. 
Relacionadas com a proteção surgem mais duas esculturas de invocação mariana, em Vinhais (Imagem 50 e Imagem 51) e Bragança (Imagem 52 e Imagem 53). A Senhora da Boa Morte constituiu em ambos os templos importante devoção conforme atestam os ex-votos em Bragança e as relíquias que em Vinhais ${ }^{92}$ lhe estão associadas (Imagem $50)$.

A morte da Virgem é, como outros episódios, inexistente nos registos dos evangelhos. É nos evangelhos apócrifos, na Lenda Dourada e na religiosidade popular que tem origem da representação de Nossa Senhora da Boa Morte ${ }^{93}$.

A Boa Morte ou Boa Viagem é invocação mariana tradicional dos povoados costeiros, dos mareantes, dada a sua relação com o mar e com as viagens ${ }^{94}$. Esta invocação está representada em ambos os modelos dentro de um esquife em forma de nau ou galeão (Imagem 50 e 52), não deixa de ser curiosa a presença de um elemento marítimo em dois concelhos do interior do país.

\footnotetext{
${ }^{92}$ A propósito do culto das relíquias em Vinhais Rodrigues refere a devoção popular que envolveu a morte de Frei Francisco da Ascensão, que terá morrido em Vinhais em casa de José de Morais Sarmento, em 1746. O próprio José de Morais Sarmento foi quem notificou o guardião de Brancanes dos milagrosos sucessos que circundaram a morte do frade, sucesso que era útil ao acrescento da fama dos padres de Brancanes bem como aos notáveis de Vinhais que persistiam na fundação do seminário. Segundo o mesmo autor: o relato é também importante por deixar ver algumas semelhanças entre o sentimento religioso e a respetiva compreensão numa região periférica de Portugal e práticas multiculturais correntes nas zonas que os portugueses tentavam colonizar enquanto se manifestam as vivências associadas ao culto das relíquias e algumas das metodologias que os religiosos incrementavam para favorecer o estreitamento de laços com a generalidade da população. Rodrigues, Luís Alexandre, "A ação dos padres de Brancanes em Vinhais. O Seminário da Senhora da Encarnação e constituição da Venerável Ordem Terceira da Penitência" in Natália Marinho Ferreira-Alves (Coord.), Os Franciscanos no Mundo Português II. As Veneráveis Ordens Terceiras de São Francisco, Porto, CEPESE - Centro de Estudos da População, Economia e Sociedade 2012, pp. 163-193.
}

A identificação das relíquias perdeu-se na maioria dos casos, bem como grande parte das relíquias guardadas sobre as portas da Senhora da Boa Morte mas a quantidade de recetáculos atesta a importância do culto.

${ }_{93} \mathrm{O}$ ciclo narrativo dos últimos momentos da vida de Nossa Senhora engloba distintos episódios populares na arte bizantina como na europa medieval. Réau afirma que esta devoção desaparece no final do século XVI, e que no barroco já não se representa a morte Nossa Senhora. Réau, Louis, Iconografía del Arte Cristiano. Iconografia de la Biblia - Nuevo Testamento Tomo 1/ Volumen 2, Barcelona, Ediciones del Serbal, 1996, (Edição original 1955-1959), pp. 620-636. A recolha iconográfica de Louis Réau raras vezes inclui exemplos de Portugal o que denota o escasso conhecimento da arte portuguesa, pois ao longo do século XVIII e XIX são frequentes as representações de Nossa Senhora da Boa Morte.

94 Almeida, Carlos Alberto Ferreira de, "O culto a Nossa Senhora, no Porto, na época moderna: perspectiva antropológica", Revista de História, vol. 2, Porto, Faculdade de Letras da Universidade do Porto, 1979, pp. 159-173. 


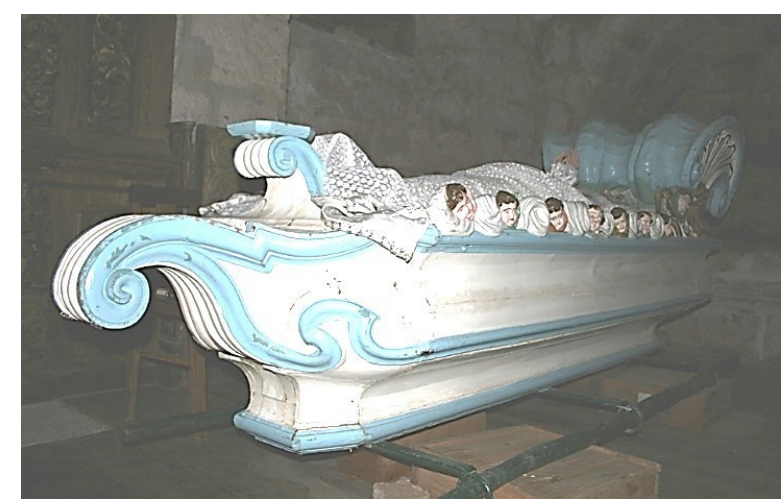

Imagem 52

Esquife de Nossa Senhora da Boa Morte - SFB 06, Oficina: Porto; ultimo quartel do século XVIII ou princípios do século XIX

Dentro do retábulo lateral no lado da Epistola Igreja de São Francisco de Bragança

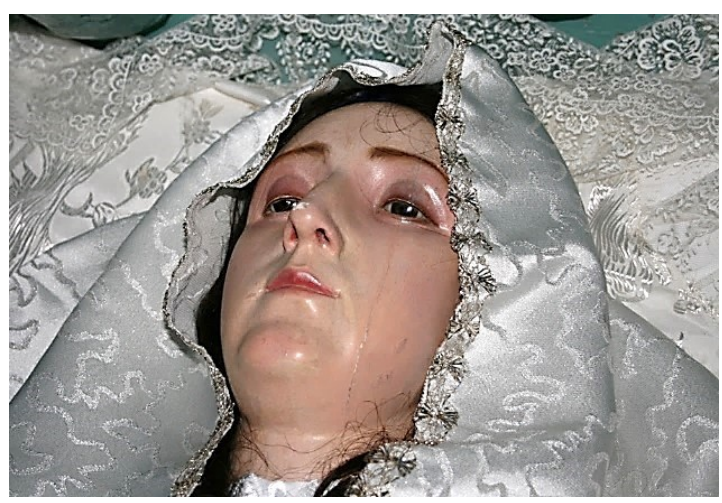

Imagem 53

Pormenor do rosto de Nossa Senhora da Boa Morte - SFB 06,

Oficina: Porto; ultimo quartel do século XVIII ou princípios do século XIX

Dentro do retábulo lateral no lado da Epistola Igreja de São Francisco de Bragança

Esta amplitude do modelo revela a devoção a Maria enquanto mediadora de viagens mas sobretudo como mediadora perante o trânsito da vida terrestre para a vida celestial.

As duas esculturas são de roca, apenas as mãos, cabeça e pés estão trabalhados em vulto pleno. As vestes que a envolvem dissipam-se na mortalha constituindo apenas o volume que sugere o corpo jacente. Ambas têm os olhos abertos, assumindo a representação da Virgem viva, em oração de mãos postas sobre o peito (Imagem 51 e $53)$.

A representação da Virgem viva dentro do esquife remete para a devoção que se impõe a Nossa Senhora como mediadora, facilitadora do temido transito e do mais temido ainda juízo final.

Nos territórios em estudo apenas encontramos esta devoção nos espaços franciscanos, estando ausente de outros templos conventuais e também paroquiais. Na igreja de São Francisco no Porto, bem como em Guimarães existe também esta representação da Virgem dentro do esquife.

A relação que existia no convento de Bragança com as procissões ao longo do ano, em especial a procissão de Cinzas, e com as exéquias fúnebres está documentalmente confirmada. A imagem de Nossa Senhora da Boa Morte constituía uma parte relevante da encenação processional de Cinzas ${ }^{95}$. Era dever da Ordem terceira fazer anualmente e

\footnotetext{
95 Entre outras figuras simbólicas acompanhava a procissão da Cinza a figura da morte que, após vários conflitos gerados, foi proibida de sair em 1876. O argumento do bispo Dom José Maria da Silva Ferrão de Carvalho Martens para proibir a figura da morte foi por "se ter introduzido o inadmissível abuso de, na quarta-feira de cinzas, haver quem tome vestido e máscara de esqueleto representando o espectro da morte”. Castro, José de, Bragança e Miranda, (Bispado) Tomo II, Porto, Tipografia Porto Médico, Ld",
} 
com a máxima solenidade a procissão da Cinza, com muitas figuras simbólicas, entre elas a figura da morte, e de pessoas e episódios bíblicos, saiam em andores todos os santos da igreja franciscana sendo o ultimo andor o de Nossa Senhora da Boa Morte. A última vez que saiu a procissão da Cinza, após muitos anos sem se fazer, foi em 1898.

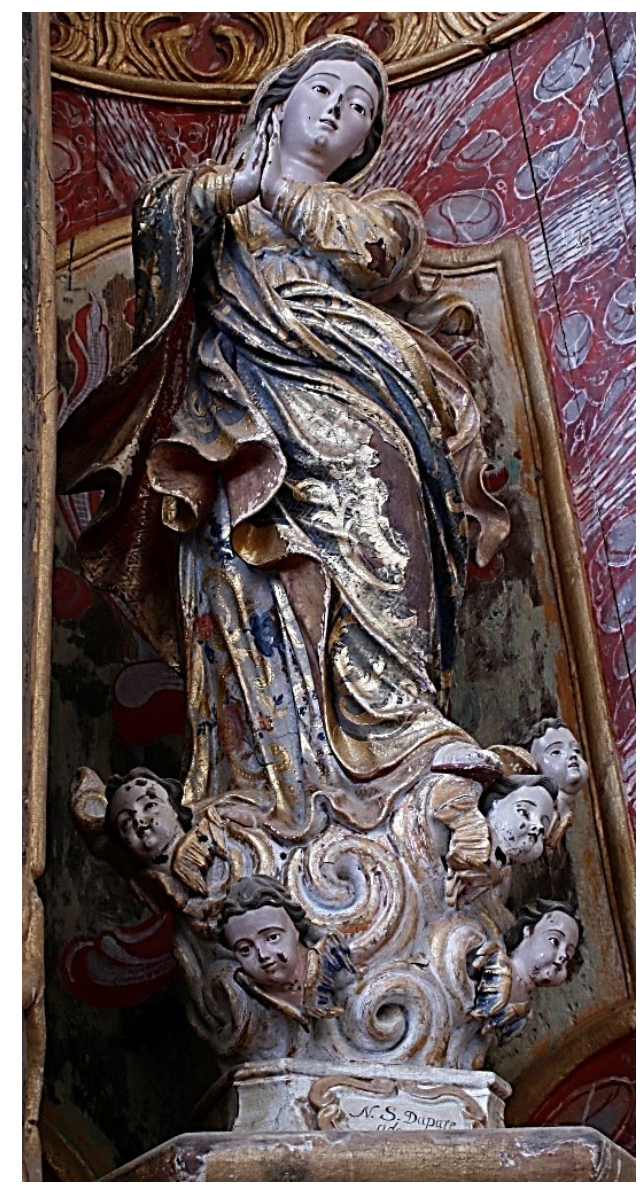

Imagem 54

Escultura de Nossa Senhora da Aparecida - CSDV 02

Oficina: Porto; ultimo quartel do século XVIII Capela de Nossa Senhora das Dores,

Igreja de Nossa Senhora da Encarnação, Vinhais

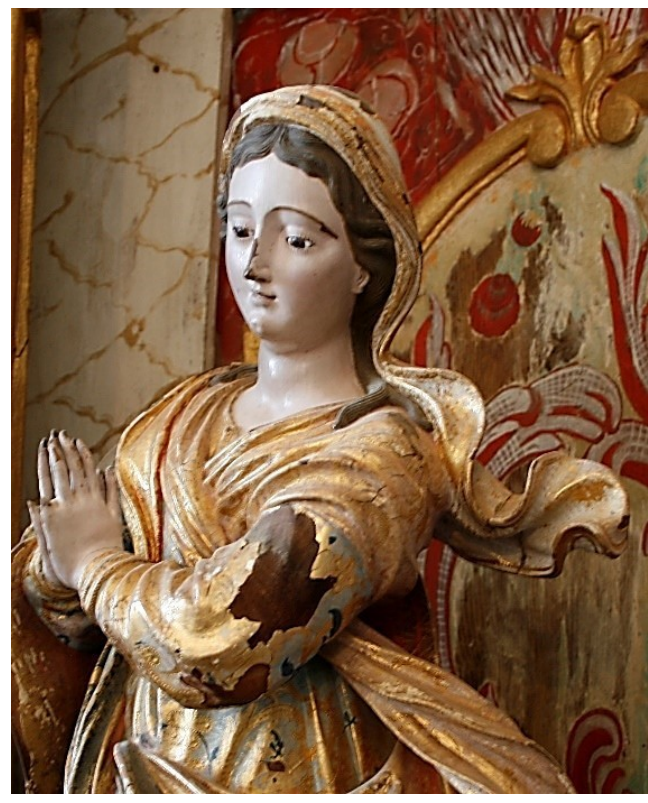

Imagem 55

Pormenor do rosto de Nossa Senhora da Aparecida - CSDV 02

Oficina: Porto; ultimo quartel do século XVIII Capela de Nossa Senhora das Dores, Igreja de Nossa Senhora da Encarnação, Vinhais

Em Vinhais encontramos a devoção mariana de Nossa Senhora da Aparecida ${ }^{96}$

(Imagem 54). Relacionada seguramente com a devoção privada trazida por algum frade

1947, pp. 313-316. Esta prática da saída pelas ruas da cidade de Bragança da figura da morte na quartafeira de cinzas manteve-se como cerimónia profana até há poucas décadas. Entretanto foram acrescentadas as figuras da censura e do diabo. Atualmente existe a vontade de alguns particulares em reabilitar os festejos reintroduzindo as figuras dos três mascarados em arruadas no centro histórico durante o dia de quarta-feira de cinzas.

${ }^{96}$ A história de Nossa Senhora Aparecida foi registrada pelo Pe. José Alves Vilela em 1743, e confirmada pelo Pe. João de Morais e Aguiar, em 1757. Em meados de 1717, durante passagem do Conde de Assumar, D. Pedro de Almeida e Portugal, governador da Capitania de São Paulo e Minas de Ouro, pela 
missionário ${ }^{97}$ ou algum benemérito do convento que teria recebido esse culto no Brasil. A imagem, sorridente e cheia de requebros graciosos no gesto afasta-se dos coevos modelos nacionais e ilustra por isso o fluxo de influências que ocorria não só de Portugal para o Brasil, mas também do Brasil para Portugal. A imagem encontrada nas águas do rio brasileiro seria uma representação da Imaculada Conceição o que permite perceber as analogias com este modelo iconográfico no gesto das mãos postas em oração bem como na nuvem com querubins sobre a qual está suspensa Nossa Senhora e no olhar baixo em direção aos fiéis (Imagem 55). Se bem que a devoção terá chegado do Brasil supomos que a imagem terá sido esculpida numa oficina do Porto. Poucas décadas depois da aparição brasileira o seu culto havia já chegado ao interior de Trásos-Montes incrementando a pluralidade de cultos marianos difundidos pelos frades missionários, bem como a pluralidade de fluxos estabelecidos entre territórios tão distantes. No entanto, trata-se de uma invocação mariana pouco comum nos templos portugueses $^{98}$.

A última representação mariana que encontramos nos espaços franciscanos em estudo sabemos que originalmente não pertencia às devoções franciscanas. Trata-se de uma Nossa Senhora do Caminho (Imagem 56) que foi posteriormente guardada no interior do templo, não constitui assim parte dos cultos difundidos pelos franciscanos, pois a imagem representa a padroeira da vila, substituída no século XX por outra imagem nova.

povoação de Guaratinguetá, a caminho de Vila Rica (atual Ouro Preto). Os pescadores Domingos Garcia, Felipe Pedroso e João Alves foram convocados a providenciar um bom pescado para a receção do Conde, e partiram a lançar as suas redes no rio Paraíba do Sul. Tentaram muitas vezes, sem conseguir nenhum peixe, já sem esperança, João Alves lançou mais uma vez a sua rede às águas e, ao recolhê-la, percebeu algo insólito: junto à rede viera uma imagem de Nossa Senhora da Conceição, sem a cabeça. Guardaramna e tornaram a lançar as redes, numa nova tentativa de apanhar peixes, mas o que ocorreu a seguir foi ainda mais extraordinário: a rede retornou com a cabeça da imagem. Boing, Mafalda Pereira, Nossa Senhora Aparecida - A Padroeira do Brasil, São Paulo, Edições Loyola, 2007, p. 20.

${ }^{97}$ Rodrigues destaca, a figura de Frei Constantino da Conceição, carpinteiro, nascido em Azurara e que faleceu em Vinhais em 1767, onde chegou após ter estado no Bispado da Baía. Veio para Vinhais como conselheiro técnico para a edificação da igreja e alojamentos. Rodrigues, Luís Alexandre, "A ação dos padres de Brancanes em Vinhais. O Seminário da Senhora da Encarnação e constituição da Venerável Ordem Terceira da Penitência" in Natália Marinho Ferreira-Alves (Coord.), Os Franciscanos no Mundo Português II. As Veneráveis Ordens Terceiras de São Francisco, Porto, CEPESE - Centro de Estudos da População, Economia e Sociedade 2012, pp. 163-193.

${ }^{98} \mathrm{Na}$ base de dados do inventário on-line dos bens culturais da igreja do secretariado nacional apenas duas esculturas surgem registadas sob a invocação de Nossa Senhora da Aparecida, ambas na Diocese de Viana do Castelo, território com profundas ligações ao Brasil por diversos fluxos migratórios. Tratam-se no entanto de imagens iconograficamente próximas da representação da Imaculada Conceição, e de Nossa Senhora das Graças, sugerindo tratar-se de uma invocação posteriormente assumida na imagem. https://www.bensculturais.com/areas-de-actuacao/inventario, acedido a 08 de junho de 2015. 
A imagem de roca apresenta um rosto idêntico com o da imagem da Senhora da Boa Morte de Vinhais. Os olhos baixos a expressão grave é anemizada pela familiar pose do Menino de pernas cruzadas. O conjunto é o único que representa Nossa Senhora com o Menino em todos os espaços franciscanos estudados. $\mathrm{O}$ facto de ter sido posteriormente integrado no espaço franciscano ilustra a exceção do modelo que é inexistente nos restantes espaços franciscanos estudados.

O culto mariano constitui nos espaços em estudo uma intensa devoção, que se amplia sobretudo ao longo do século XVIII, comparável no número de representações que a ilustram com as representações de Cristo.

O modelo iconográfico mais vezes reproduzido é o da Imaculada Conceição, dogma defendido tradicionalmente pela Ordem. Mas também se destaca o culto das narrativas da Paixão e de diversas devoções tutelares, de Virgens

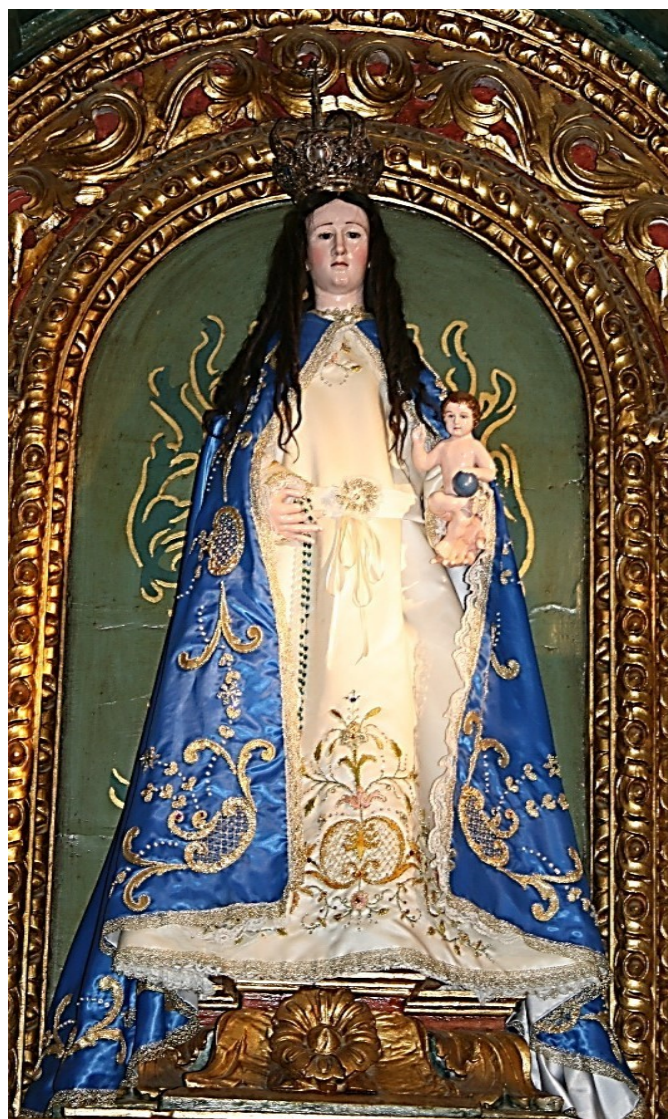

Imagem 56

Escultura de Nossa Senhora do Caminho - SFM 01; Oficina: Local; Segunda metade do século XVIII; Retábulo lateral, lado da Epistola Igreja de São Francisco de Mogadouro protetoras e mediadoras. Pese embora neste âmbito a total ausência de representações da Virgem com o Menino.

Os frades missionários apostólicos de Vinhais foram, incontestavelmente, os maiores divulgadores das devoções marianas no território em estudo. 


\section{ICONOGRAFIA DOS SANTOS FUNDADORES:}

\section{SÃO FRANCISCO DE ASSIS}

Depois da figura de Cristo e da Virgem Maria é a representação de São Francisco de Assis que mais vezes se repete. Os espaços em estudo, vinculados todos à família franciscana nas suas diversas variantes, revelam plasticamente a importância do santo pregador medieval e fundador da Ordem ${ }^{99}$.

Imbuído pela espiritualidade penitente e espirito de pregação São Francisco partiu, segundo a tradição em viagens da Península Ibérica até à Síria, depois de ter renunciado aos bens patrimoniais. São Francisco permitia o acesso à Ordem de todos aqueles que se demonstravam fiéis seguidores do espírito de pobreza, de oração e de pregação do Evangelho. Fundou diversos ramos destinados a religiosos e a leigos, a homens e a mulheres. Foi canonizado dois anos após a sua morte. Rapidamente a ordem se estendeu em toda a europa através dos conventos de frades menores e clarissas e pela intervenção leiga da Ordem Terceira.

Apesar do convento de Bragança constituir o único cuja fundação é medieval, do século XIII, atualmente não se encontra na igreja nenhuma representação do santo anterior ao século XVII. É no Museu de Arte Sacra de Vinhais que encontramos a representação mais arcaica de São Francisco (Imagem 57) formalmente próxima às esculturas dos finais do século XV e inícios do XVI, denotando ainda a linguagem medieval. O modelo que representa é o que mais amplamente foi reproduzido nos templos em estudo e que se mantém com poucas alterações até à segunda metade do século XVIII. São Francisco enverga o hábito franciscano e está representado de pé, com os braços elevados e a palma das mãos voltadas para a frente de modo a mostrar os estigmas, bem como a chaga sobre o peito.

\footnotetext{
${ }^{99}$ Le Goff afirma que Francisco propõe um modelo único - Cristo e um único programa "seguir nu o Cristo nu". Le Goff, Jacques, S. Francisco de Assis. Lisboa, Teorema, 2000, p. 27.

Francisco destacava-se sobretudo pela sua conduta, pois não propôs nenhum programa religioso nem reforma social, como pregador da penitência o seu maior sermão foi a sua própria vida, Francisco sempre pregou mais pelo exemplo do que pelas palavras, como refere: Thompson, Augustine, São Francisco de Assis, uma nova biografia. Alfragide, Casa das letras, 2012, p. 83.
} 


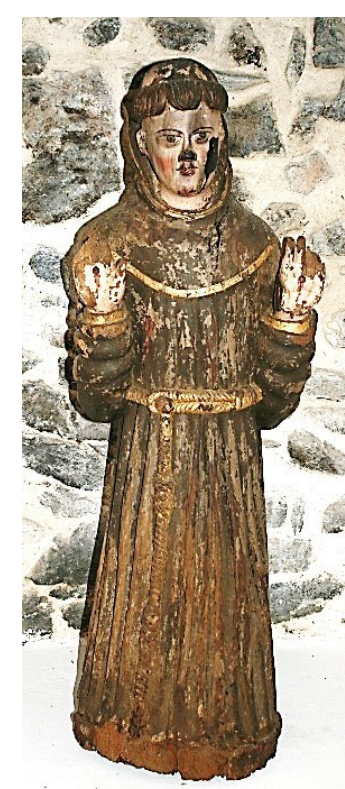

Imagem 57

São Francisco de Assis MASV 01

Oficina nacional; finais do século XV início do século XVI Museu de Arte Sacra, Vinhais

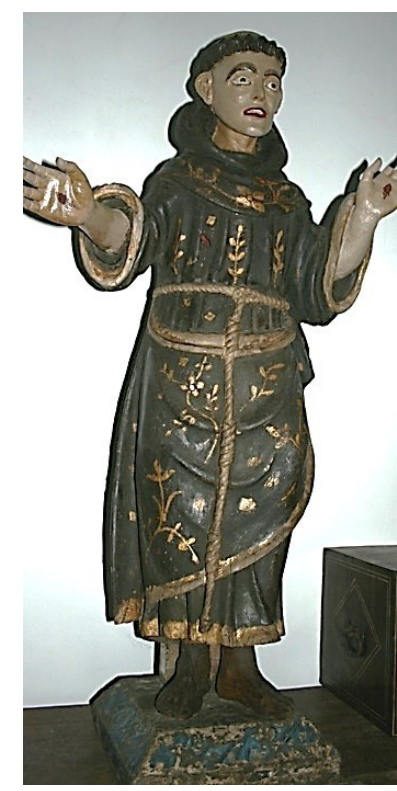

Imagem 58

São Francisco de Assis SFB 21

Oficina regional; Século XVII

Sacristia da Igreja de São Francisco, Bragança

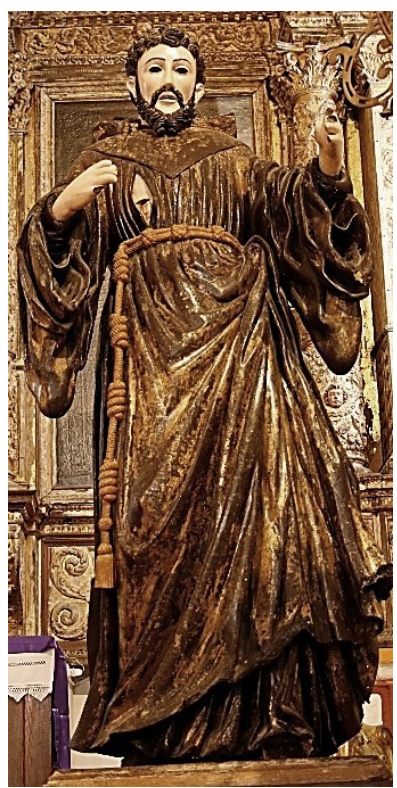

Imagem 59

São Francisco de Assis SFM 07

Oficina (Porto $\backslash$ Braga); primeira metade do Século XVIII

Capela-mor no lado da Epístola

Igreja de São Francisco, Mogadouro

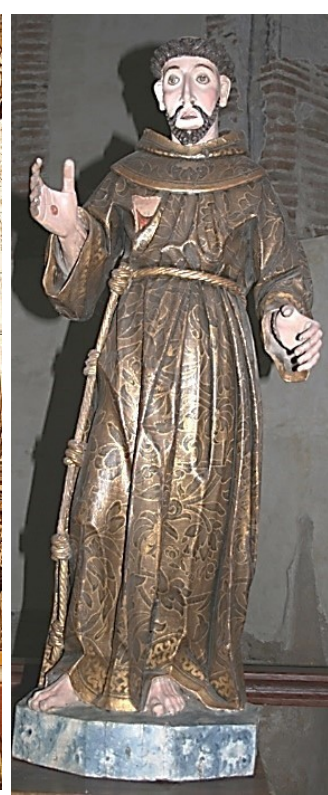

Imagem 60

São Francisco de Assis SFB 12

Oficina portuguesa; meados do Século XVIII

Capela-mor no lado da Epístola Igreja de São Francisco, Bragança

No entanto, apesar das semelhanças entre as quatro esculturas, são percetíveis ligeiras alterações no modelo. Se nas representações mais arcaicas o santo surge imberbe (Imagem 57 e 58), já nas esculturas do século XVIII se apresenta com barba ${ }^{100}$ (Imagem 59 e 60$)$.

A gestualidade é idêntica em todas as esculturas, apenas se percebem alterações na assimetria na elevação dos braços. A narrativa imposta no gesto remete para o momento da estigmatização do santo, com as mãos abertas e as palmas voltadas para a frente. $\mathrm{O}$ rasgo no hábito sobre a chaga é mais valorizado nas representações do século XVIII (Imagem 59 e 60) se bem que também consta nas representações do santo do século XV\XVI e XVII (Imagem 57 e 58). Ambas as esculturas apresentam o hábito aberto sobre a chaga do peito, mas claramente menos evidenciada. Esta alteração na

\footnotetext{
${ }^{100} \mathrm{O}$ aspeto físico de São Francisco nunca foi totalmente definido. O seu primeiro biógrafo, Tomás de Celano, descreve-o com barbas ralas, baixo e com olhos macilentos. A primeira representação, do século XIII assim o apresenta com escasso cabelo e barbas curtas, que mais tarde desaparecem. Kaftal, George, Iconography of the saints in central and south Italian schools of painting, Firenze, Casa Editrice Le Lettere, 1986, pp. 471, 472; Giotto foi quem idealizou a figura do santo imberbe. As barbas surgem na escola veneziana a partir do século XVI. Réau, Louis, Iconografía del arte cristiano - Iconografia de los santos, de la A a la F. Tomo 2 / Volumen 3, Barcelona, Ediciones del Serbal, 1997 (edição original 19551959), p. 548; A representação que mais comumente se impõe é do santo jovem com pequena barba pontiaguda. Carmona Muela, Juan, Iconografia cristiana, Madrid, Akal, 2010, p. 90.
} 
valorização dos sinais de martírio pode relacionar-se com o episódio da visita do Papa Nicolau V que em 1449 entrou na cripta de Assis e teve uma visão de São Francisco. O santo, de cujo corpo incorrupto ainda fluía o sangue dos estigmas apareceu ao Papa olhando para o céu e de mãos postas, depois levantou o hábito para mostrar os estigmas nos pés ${ }^{101}$.

Esta nova visão do santo influenciou as esculturas de Mogadouro e Bragança, onde o sangue é mais intensamente representado. O gesto de recolher o hábito deixando os pés a descoberto como se observa na escultura de Mogadouro (Imagem 59) pode também estar relacionado com o episódio do Papa Nicolau V com o momento em que São Francisco destapa os pés. O gesto é recorrente ainda noutras representações de santos franciscanos.

A correspondência de São Francisco com Cristo, assumida na vida penitente do santo, é na estigmatização que atinge o seu maior valor plástico e ilustrativo. Depois da visão de Cristo Serafim, São Francisco recebe os estigmas e, segundo os seus cronistas, a partir de então ficou marcado com os sinais da crucificação de Jesus ${ }^{102}$. Antes do Concílio de Trento é este o aspeto mais valorizado nas representações do santo ${ }^{103}$.

\footnotetext{
${ }^{101}$ Réau, Louis, Iconografía del arte cristiano - Iconografia de los santos, de la A a la F. Tomo $2 /$ Volumen 3, Barcelona, Ediciones del Serbal, 1997 (edição original 1955-1959), p. 563.
}

${ }^{102}$ A aparição teve lugar em 1224 próximo da ermida do monte Alverne. São Francisco viu um homem com seis asas, como um serafim, com os braços estendidos, os pés juntos e fixo à cruz, com duas asas elevadas sobre a cabeça, outras duas abertas para voar e as outras duas velavam todo o corpo, depois da visão nas suas mãos e pés começaram a aparecer as marcas do martírio da cruz. A lenda reproduz a visão de Serafins de Isaías (Is, 6:1-14) que permite reforçar a correspondência entre Cristo e São Francisco. A estigmatização de São Francisco celebra-se a 17 de Setembro. Réau, Louis, Iconografía del arte cristiano - Iconografia de los santos, de la A a la F. Tomo 2 / Volumen 3, Barcelona, Ediciones del Serbal, 1997 (edição original 1955-1959), p. 556; Kaftal, George, Iconography of the saints in central and south Italian schools of painting, Firenze, Casa Editrice Le Lettere, 1986, pp. 481, 482; Fraga Sampedro, Maria Dolores, "San Francisco de Betanzos: nuevas aportaciones a su programa iconográfico", in separata do anuário Brigantino $\mathrm{n}^{\circ}$ 18, Betanzos, 1995, pp. 207-226; influíram neste modelo iconográfico sobretudo a biografia de Tomás de Celano e de São Boaventura, Giotto representou-o desenvolvendo a figura de Cristo em detrimento da representação do Serafim, reforçando assim a imagem oficial de São Francisco como "alter Christus". Fraga Sampedro, Maria Dolores, "San Francisco y sus frailes: arte y devoción en el gótico galaico-portugués", separata da obra II Congresso Internacional de História de Arte -2001, Actas, Coimbra, Almedina, 2005, pp. 617-634. Sobre a estigmatização de São Francisco ver: Frugoni, Chiara, Francesco e l'invenzione delle stimmate: Una storia per parole e immagini fino a Bonaventura e Giotto, Turim, Einaudi edições, 1993.

Também no Anno Christão é este o milagre representado na gravura de São Francisco, designado São Francisco das Chagas. O santo de joelhos recebe de Cristo Serafim as marcas de martírio, sobre um rochedo está pousada uma caveira e uma cruz. Croiset, João, Anno Christão ou exercicios devotos para todos os dias do anno. Tomo IIII, Porto, Editor - Antonio Dourado, 1888, pp. 18-24.

${ }^{103}$ Réau, Louis, Iconografía del arte cristiano - Iconografia de los santos, de la A a la F. Tomo $2 /$ Volumen 3, Barcelona, Ediciones del Serbal, 1997 (edição original 1955-1959), pp. 556-560. 
$\mathrm{Na}$ análise das esculturas em estudo percebemos que a representação da estigmatização perdura muito além do Concílio de Trento constituindo a narrativa preferencial sobre São Francisco ${ }^{104}$.

Relativo a este episódio encontra-se na igreja do convento de São Francisco em Bragança um singular conjunto que apesar das diferenças cronológicas e estilísticas julgamos que estaria relacionado. Trata-se de uma representação de São Francisco ajoelhado (Imagem 60) que posteriormente poderá ter sido completada com a figura de Cristo Serafim (Imagem 59). Carecemos de documentação que permita estabelecer esta narrativa, mas, pelo gesto da genuflexão e pela representação de Cristo Serafim, que não se completa sem ser com a imagem de São Francisco, julgamos que poderão, em algum momento, ter constituído uma narrativa conjunta.

O episódio da Estigmatização de São Francisco ajoelhado perante o Cristo Serafim, apesar das evidentes diferenças cronológicas entre ambas as esculturas, constitui na representação tridimensional um raro exemplo. Nenhuma das duas esculturas se encontra atualmente a culto.

A representação de Cristo Serafim tem lacuna da cruz que ainda se encontra em restauro. O corpo de Cristo sobressai da composição de serafim com três pares de asas, como desde a representação de Giotto se havia divulgado. Apresenta intensas marcas de martírio e a singularidade da pose com os pés juntos conforme a descrição da visão de São Francisco, e não sobrepostos como comummente se representa na crucificação. $O$ delicado naturalismo das asas (Imagem 61) segue também a composição descrita pelos cronistas na visão do Monte Alverne que aproxima a imagem dos Serafins da visão de Isaías.

São Francisco ajoelhado constitui a única representação do santo nesta postura nos espaços em estudo. A atitude de São Francisco é semelhante, no gesto de elevar ambas as mãos, com as restantes representações de São Francisco estigmatizado, apenas difere na genuflexão. Originalmente teria um suporte conforme se percebe nas duas estacas

\footnotetext{
${ }^{104}$ A propósito das representações iniciais de São Francisco na Península Ibérica Fraga Sampedro cita Lucía Lahoz (2006) na obra editada por Eduardo Azofra A catedral de Ciudad Rodrigo a través de los siglos onde se refere a imagem de São Francisco num dos arranques a abobada da catedral de Cuidad Rodrigo das primeiras décadas do século XIV. O santo de Assis apresenta-se com a mão direita em gesto de predicação, do qual deriva a Benedictio latina. Fraga Sampedro, Maria Dolores, "Predicación e imágenes en los siglos finales de la edad media hispana" in Plenitudo Veritatis homenaje a Mons. Romero Pose, Santiago de Compostela, Instituto Teológico Compostelano, 2008, pp. 829-847.

Nos templos em estudo nenhuma das nove esculturas apresenta o santo na narrativa da pregação com a Benedictio latina, apenas se regista o gesto de expor ou receber os estigmas, e o gesto pungente da mão sobre o peito ou segurando o crucifixo na narrativa da ascese mística dosanto.
} 
sobre os joelhos que serviriam para o fixar, pois de outra forma não se sustém. Mas, atualmente não se conhece nenhuma plataforma ou andor que pudesse fixar a escultura na posição correta o que limita a sua leitura. A posição de joelhos e com os braços elevados e sobretudo o olhar muito aberto e elevado em expressão de espanto define o episódio narrado. São Francisco com barbas reflete o gosto que se instaura a partir de Itália no século $\mathrm{XVI}^{105}$.

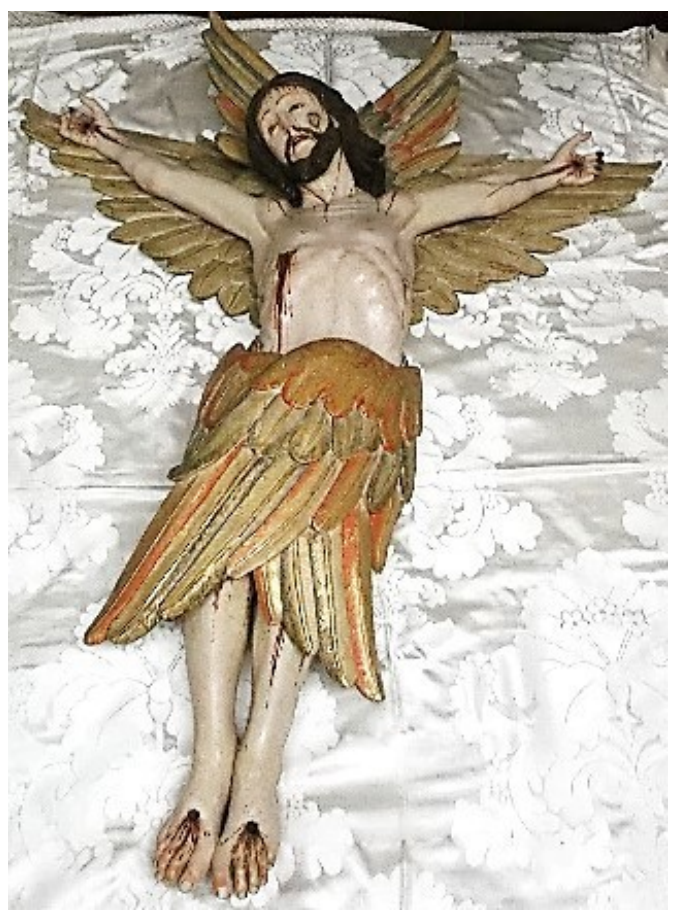

Imagem 61

Cristo Serafim - SFB 30

Oficina: Porto\Braga; segunda metade do Século XVIII

Sacristia da Igreja de São Francisco, Bragança

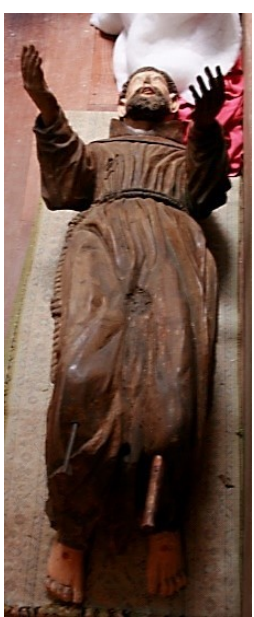

Imagem 62 São Francisco de Assis - SFB 35 Oficina: nacional; segunda metade do Século XVII Sacristia da igreja de São Francisco em Bragança

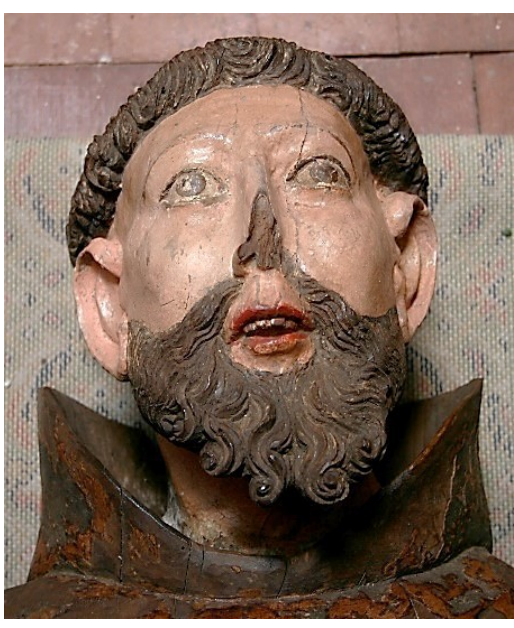

Imagem 63

Pormenor do rosto de

São Francisco de Assis - SFB 35

Oficina: nacional; segunda metade do Século XVII

Sacristia da igreja de São Francisco em Bragança

Apesar de formalmente julgarmos que ambas as esculturas estão separadas por cerca de 100 anos não pudemos deixar de as associar à mesma narrativa, sugerindo por isso $\mathrm{o}$ seu conjunto. Poderá originalmente a escultura de São Francisco ter estado relacionada com outra obra (escultórica ou pictórica) entretanto substituída pelo Cristo Serafim, ou constituída por partes dispersas ensambladas posteriormente. Pese embora a ausência de

\footnotetext{
${ }^{105}$ Réau, Louis, Iconografia del arte cristiano - Iconografia de los santos, de la A a la F. Tomo 2 / Volumen 3, Barcelona, Ediciones del Serbal, 1997 (edição original 1955-1959), p. 548; Carmona Muela, Juan, Iconografia cristiana, Madrid, Akal, 2010, p. 90.
} 
documentação empobreça de sobremaneira a leitura do conjunto, iconograficamente percebemo-lo enquanto narrativa integrada.

É ainda na igreja do convento de São Francisco em Bragança que encontramos outra narrativa alusiva a São Francisco com a figura de Cristo (Imagem 64). Mas, neste caso, o conjunto não sugere qualquer dúvida. As analogias formais permitem afirmar que se trata de um conjunto, encomendado na mesma oficina, feito pelas mesmas mãos para serem expostas as duas esculturas juntas.

O episódio de Cristo a abraçar São Francisco é uma transferência da visão protagonizada por São Bernardo ${ }^{106}$. Análoga imitação se observa também na visão de Santa Lutgarda, obra de Frei Cipriano da Cruz no mosteiro de Tibães, sublinhando a contaminação narrativa que se opera entre a devoção popular e a função catequética das imagens que sistematicamente reforçam as mesmas mensagens.

Maria Isabel Roque refere a escassez deste tema na escultura em Portugal. No entanto destaca a sua proliferação no Brasil onde é designado como Divino Amor ${ }^{107}$.

A figura de Cristo despregou a mão direita para tocar no santo, esse dinâmico movimento contrasta com o olhar suave que Cristo dirige a São Francisco. A atitude de São Francisco é semelhante, no gesto de elevar ambas as mãos, com as restantes representações de São Francisco estigmatizado. Mas, a intensa inclinação da cabeça sugere a comunicação que se estabelece com a figura de Cristo que o sobrepõe, afastando-se da postura mais hierática de exposição dos estigmas. De rosto descarnado com os pómulos salientes e com barbas a figura do santo aproxima-se do modelo mais divulgado após o Concílio de Trento e que se aproxima da representação do ardor místico do santo em meditação.

\footnotetext{
${ }^{106}$ A representação de Cristo na cruz a abraçar São Francisco surge de um sonho em que o santo vê a figura de Cristo crucificado no gólgota e ao aproximar-se para abraçar o corpo de Cristo, Jesus desprega a mão direita da cruz para assim o tocar no ombro enquanto o observa. Ilustra o sacrifício de Cristo na cruz como didática para o despojamento dos bens terrenos. Análogo episódio é referido relativamente a São Bernardo. Réau, Louis, Iconografia del arte cristiano - Iconografia de los santos, de la A a la F. Tomo 2 / Volumen 3, Barcelona, Ediciones del Serbal, 1997 (edição original 1955-1959), p. 561; Roque, Maria Isabel Rocha, "Imagens esculpidas de cristo na dor", Lumen Veritatis: boletim da Sociedade Científica da Universidade Católica Portuguesa, Lisboa, Universidade Católica Portuguesa, 2012, pp. 8-10.

Além desta narrativa do sonho, Kaftal destaca o episódio entre as alegorias que São Francisco protagonizou, como o encontro com São Domingos ou os esposórios com a Pobreza, a entrega da Regra a Santo António, São Bernardino de Siena, São Luis de Toulouse, Santa Clara e Santa Isabel, entre outras narrativas. Kaftal, George, Iconography of the saints in central and south Italian schools of painting, Firenze, Casa Editrice Le Lettere, 1986, pp. 487-492.

${ }^{107}$ Roque, Maria Isabel Rocha, "Imagens esculpidas de cristo na dor", Lumen Veritatis: boletim da Sociedade Científica da Universidade Católica Portuguesa, Lisboa, Universidade Católica Portuguesa, 2012, pp. 8-10.
} 


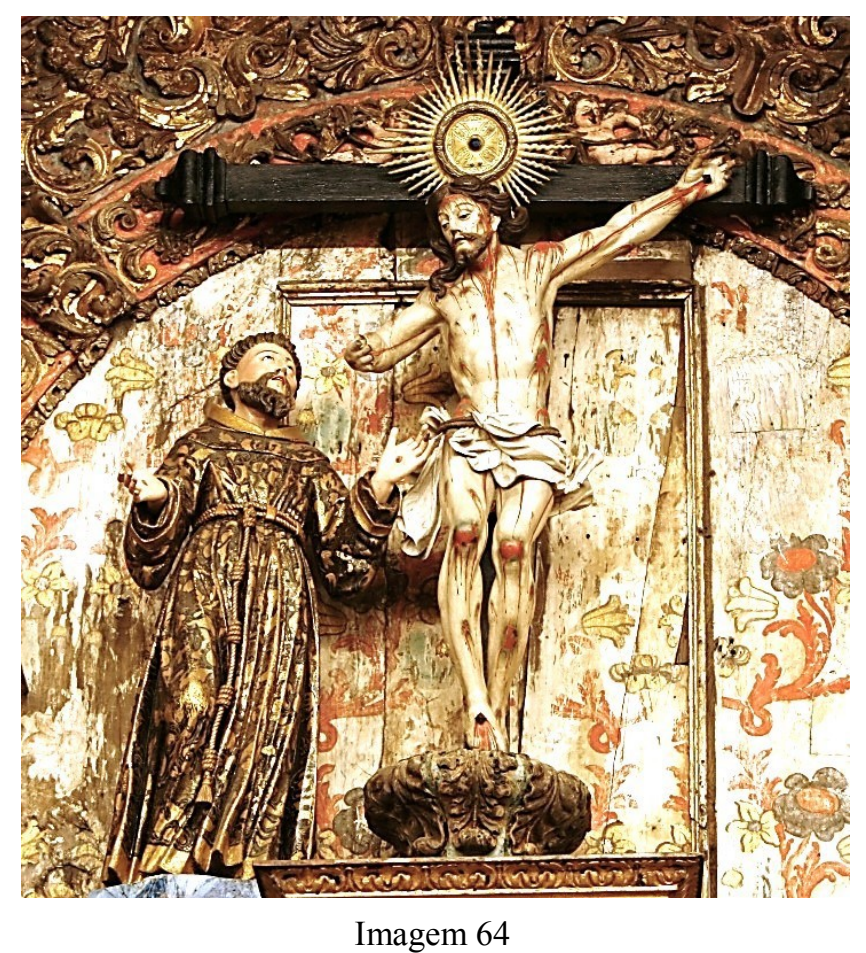

Cristo com o braço despregado da cruz para abraçar São Francisco - SFB 03 e SFB 04

Oficina: Porto; Segunda metade do século XVIII

Retábulo lateral, lado da Epístola

Igreja de São Francisco - Bragança

O intenso dramatismo nos gestos, nos olhares e no sangue que abundantemente cobre a figura de Cristo vinculam a narrativa a uma exacerbada linguagem emocional, querida aos princípios catequéticos do barroco a que este conjunto plasticamente responde.

Esta singular representação permite ampliar o culto da Paixão de Cristo como de São Francisco, enquanto imitador de Cristo.

A possibilidade dos encomendadores do conjunto é plural, poderão ter sido os frades ou a Ordem Terceira ou alguma Irmandade. Com base nas proximidades formais com outras esculturas julgamos ser mais credível a encomenda por parte da Ordem Terceira $^{108}$.

A encomenda de dois modelos, de devoção simultaneamente franciscana e cristológica, tão incomuns (Cristo Serafim e Cristo abraçando São Francisco) poderá estar relacionada com a importância da participação do convento franciscano de Bragança nas celebrações religiosas públicas.

\footnotetext{
${ }^{108}$ No capítulo da análise formal destacamos as proximidades deste conjunto (ao qual acresce a imagem de Santa Clara de Bragança) com obras atualmente expostas na sala da Ordem Terceira no convento de São Francisco no Porto.
} 
Cardoso Borges em 1721-1724 referia que no dia de Páscoa, "por estilo antiquíssimo" 109 chegava a procissão até à igreja de São Francisco. Referia também a Irmandade das Chagas que festejavam no próprio dia, a 17 de Setembro, mas sem altar particular. O facto de Borges registar a inexistência de altar da Irmandade das Chagas mas referir o seu culto pode indiciar que o culto se tenha desenvolvido posteriormente com a materialização da devoção das Chagas na encomenda por parte da Irmandade da escultura de Cristo Alado da visão do Monte Alverne.

O inventário de 1834 dos bens do convento de São Francisco de Bragança refere ainda "quatro mangas da cruz processional das quatro cores, preto, roxo, branco e encarnado" 110 o facto de serem da uma cruz processional reforça a importância da presença da comunidade franciscana nas solenidades públicas de Bragança. A referência às quatro cores do calendário litúrgico insinua que a cruz processional seria exposta diversas vezes ao longo do ano constituindo uma presença continuada perante a comunidade.

Mas, não se conhece documentalmente o cerimonial que na segunda metade do século XVIII a comunidade franciscana de Bragança organizaria nas festividades religiosas, nem podemos afirmar a presença dos conjuntos de Cristo Serafim com São Francisco ajoelhado, ou de Cristo abraçando São Francisco nas mesmas. Mas, é destacável, pela singularidade e pela abrangência de narrativas franciscanas, a presença destes dois conjuntos encomendados no século XVIII momento em que tradicionalmente a ordem já estaria em declínio.

Nos finais da centúria foram feitas as duas representações que ainda estão a culto em Vinhais. Ilustram ambas o mesmo modelo divulgado pós Concílio de Trento em que São Francisco é representado como místico, asceta, descarnado e de expressão torturada segurando um crucifixo ou uma caveira ${ }^{111}$.

\footnotetext{
${ }^{109}$ Borges, José Cardoso, Memórias de Bragança, Fernando de Sousa (Coord.), Bragança, CEPESE / Câmara Municipal de Bragança, 2012 (texto original de 1721-1724), p. 147.

110 A.N.T.T./A.H.M.F./S.F.B., Extinção das Ordens Religiosas - Convento de São Francisco em Bragança, Arquivo Nacional da Torre do Tombo, Lisboa, Arquivo Histórico do Ministério das Finanças Processos de Extinção das casas religiosas, M.F. 7580 (cota antiga Cx. 2202), 1834, fl. 47, 47 v.

${ }^{111}$ Réau, Louis, Iconografía del arte cristiano - Iconografia de los santos, de la A a la F. Tomo $2 /$ Volumen 3, Barcelona, Ediciones del Serbal, 1997 (edição original 1955-1959), p. 559. Réau refere que na difusão deste novo modelo destacam-se no século XVII os trabalhos de El Greco e mais tarde Zurbarán e Pedro de Mena. No entanto, já o Flos Sanctorum na primeira edição impressa portuguesa dos inícios do século XVI divulgava a gravura de São Francisco sustendo na mão direita um crucifixo e na mão esquerda o livro divulgando este modelo antes do Concilio de Trento. Campos, Hermão de e Rabelo, Roberto, Flos Sanctorum HO FLOS SANCTÕ[RUM] EM LINGOAJE[M] P[OR]TUGUE[S], Lisboa,
} 


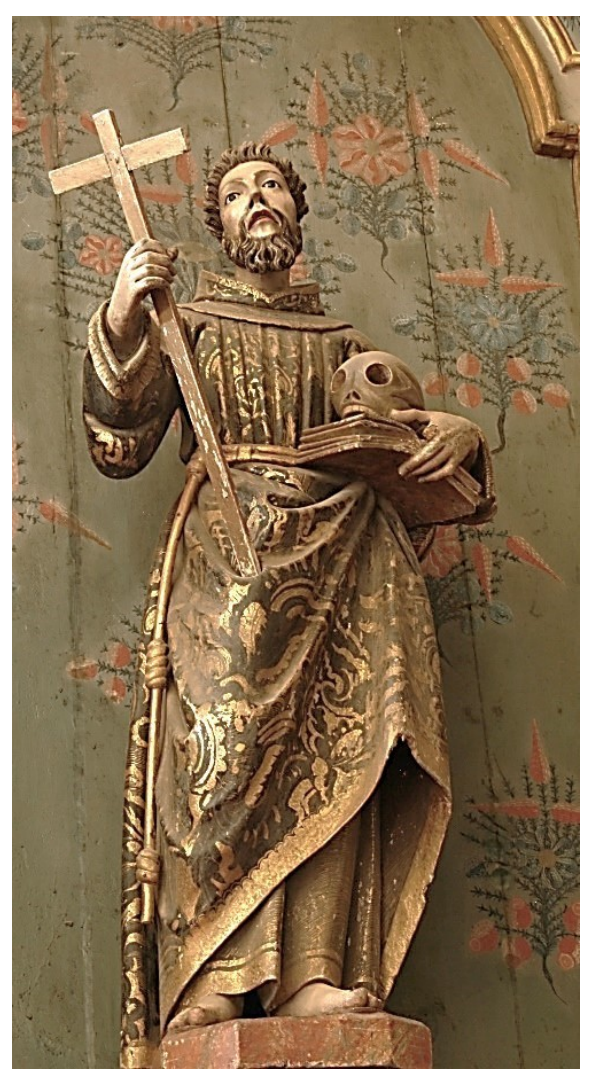

Imagem 65

São Francisco de Assis - IEV 09

Oficina local $\backslash$ Frei Domingos: último quartel do século XVIII

Capela-mor no lado do Evangelho Igreja de Nossa Senhora da Encarnação, Vinhais

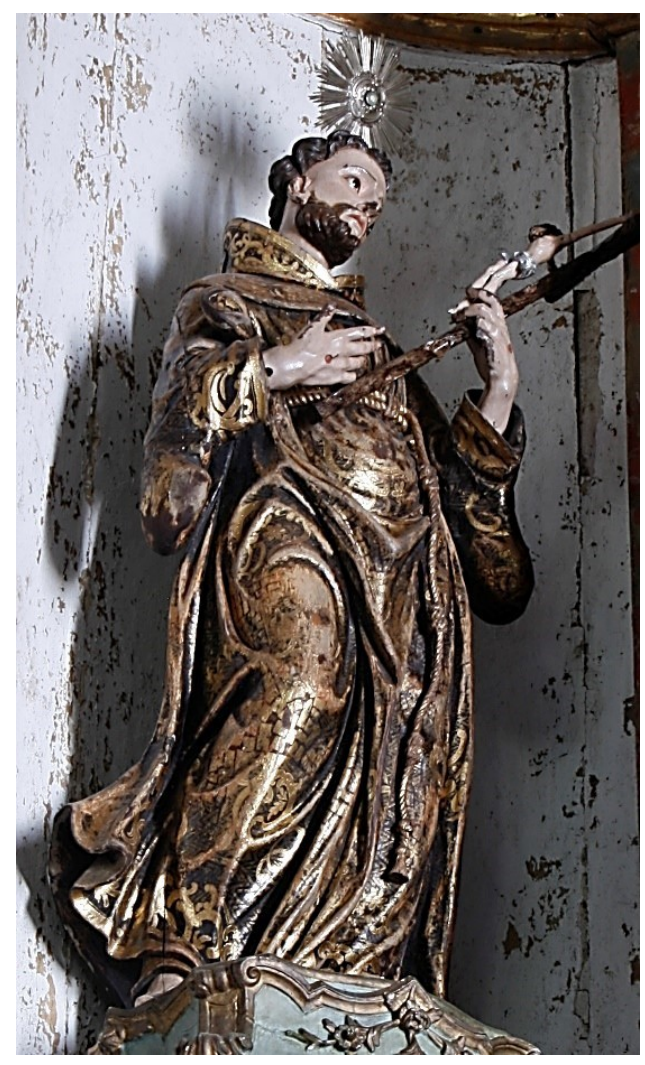

Imagem 66

São Francisco de Assis - SFV 08

Oficina: Porto\Braga: último quartel do século XVIII

Retábulo mor no lado do Evangelho Igreja de São Francisco, Vinhais

A escultura de São Francisco que atribuímos a Frei Domingos (Imagem 65) e que está a culto na igreja do seminário apostólico constitui um modelo rico em atributos iconográficos, além do crucifixo o santo segura a caveira colocada sobre um livro, constituindo uma composição da "Vanitas" que contrasta com a pobreza, a humildade e a obediência simbolizadas nos três nós do cíngulo. O hábito levantado para mostrar os estigmas dos pés, segundo a visão do Papa Nicolau V, reforça no sinal que o marca a imitação de Cristo. A expressão do rosto, descarnado e com barbas, é intensificada com o olhar elevado e perdido que enfatiza o êxtase místico.

Disponível na plataforma on-line da Biblioteca Nacional de Portugual http://purl.pt/12097, 1513 , fl. CXLVI v.; López Vázquez, José Manuel, "La imagen de san Francisco del retablo mayor del convento compostelano de Val de Dios y otras nuevas atribuciones a José Ferreiro (1738-1830): señas de identidad y estilo", in SÉMATA, Ciencias Sociais e Humanidades, vol. 26, Santiago de Compostela, Universidade de Santiago de Compostela / Facultad de Geografía e Historia / Servicio de Publicaciones e Intercambio Científico, 2014, pp. 609-632. 
Enquanto a escultura encomendada pela Ordem Terceira de Vinhais (Imagem 66) que revela melhor domínio técnico, nos atributos é menos simbólica que a dos vizinhos frades missionários. A expressividade da dinâmica assimetria do gesto opõe-se à tensão do olhar do santo sobre o crucifixo que sustem com a mão. De rosto descarnado com pómulos salientes e com barbas representa o santo em meditação.

Mas, o intenso movimento sugere mais a pregação que o ardor místico. Esta valorização do gesto de caminhar seguramente que se relaciona com a intensa prática da pregação assumida não apenas pelo santo fundador mas por todos os que na família franciscana seguiram o seu exemplo e que em Vinhais, na segunda metade do século XVIII, constituíam uma importante e poderosa força de intervenção social.

Imagem 67

Escultura de São Francisco - SFM 16

Oficina local $\backslash$ regional: século XVIII

Frontispício sobre o portal principal Igreja de São Francisco de Mogadouro

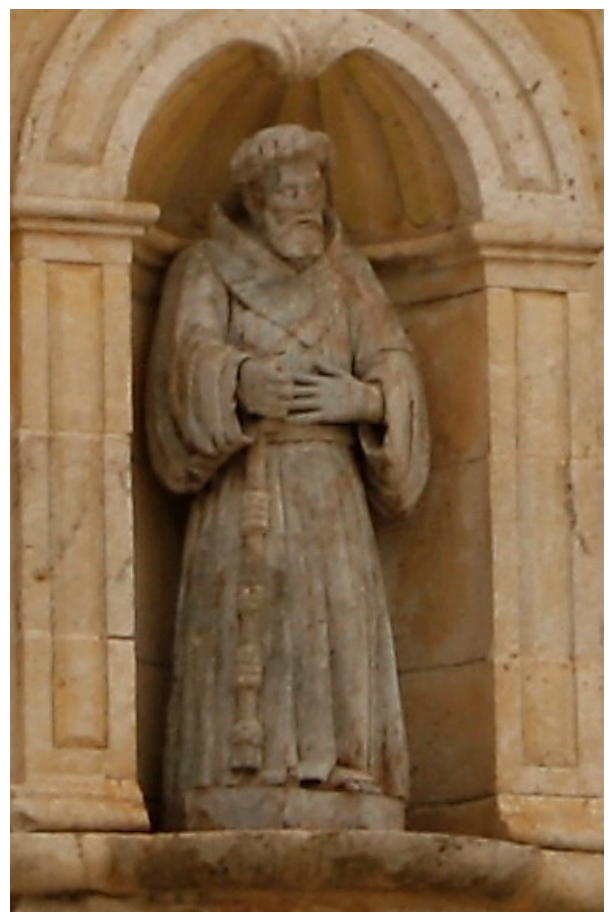

Em Mogadouro, sobre o frontispício da igreja está dentro de um nicho uma escultura em pedra que representa São Francisco (Imagem 67). A representação é sumária nos elementos expressivos. Julgamos que originalmente susteria na mão direita o crucifixo, no entanto o atributo está atualmente desaparecido. Mas pela atitude e gestualidade seguiria o modelo pós Trento do santo místico com a cruz ou a caveira. A substituição do modelo da estigmatização pelo modelo do santo em meditação observa-se em Vinhais (com a obra dos frades missionário e com a obra dos Terceiros Seculares) e em Mogadouro apenas no exterior do convento dos Terceiros Regulares. 


\section{SÃO DOMINGOS DE GUSMÃO}

São Domingos de Gusmão ${ }^{112}$ surge em diversas representações associado com a imagem de São Francisco de Assis ${ }^{113}$. Por se tratarem dos dois fundadores das ordens pregadoras mendicantes medievais partilham episódios, milagres e visões o que estimulou várias narrativas conjuntas.

Ainda hoje encontramos, nos templos em estudo, as duas figuras dos santos fundadores juntas a ocuparem a capela-mor. Assim acontece ainda na igreja de São Francisco em Mogadouro, conforme constava já em $1834^{114}$. Na igreja do seminário de Vinhais também estavam originalmente São Francisco e São Domingos a ladear o nicho central do altar-mor de Nossa Senhora da Encarnação, conforme o registo dos bens em $1834^{115}$. Porém, atualmente apenas se mantém no altar-mor a escultura de São Domingos.

Na capela-mor da igreja de São Francisco de Bragança, também estão atualmente colocadas as esculturas de São Francisco de Assis e de um santo dominicano identificado como São Domingos de Gusmão, mas carecemos de elementos relativos à disposição original das duas imagens. A identificação de São Domingos de Gusmão parece-nos deslocada, pois no único registo dos altares e dos seus cultos ${ }^{116}$ apenas se refere um santo dominicano que é São Vicente Ferrer. Como dominicano e pregador partilha alguns dos elementos iconográficos que identificam São Domingos, assim

\footnotetext{
${ }^{112}$ Fundou a Ordem dos Dominicanos ou Irmãos Predicadores confirmada em 1216, e participou na perseguição da heresia dos albigenses. A sua lenda mistura-se com a de São Francisco de Assis em inumeráveis sonhos, visões e milagres, que em vários casos copiam ambos a lenda de São Bernardo. Réau, Louis, Iconografía del arte cristiano - Iconografia de los santos, de la A a la F. Tomo 2 / Volumen 3, Barcelona, Ediciones del Serbal, 1997 (edição original 1955-1959), p. 394; Carmona Muela, Juan, Iconografia de los santos, Madrid, Akal, 2008, pp. 98-103; Carmona Muela, Juan, Iconografia cristiana, Madrid, Akal, 2010, p. 92.
}

${ }^{113}$ Carmona Muela, Juan, Iconografia cristiana, Madrid, Akal, 2010, p. 92. O Papa Honório III confiou aos dominicanos o Santo Oficio da Inquisição.

114 A.N.T.T./A.H.M.F./S.F.M., Extinção das Ordens Religiosas - Convento de São Francisco em Mogadouro, Arquivo Nacional da Torre do Tombo, Lisboa, Arquivo Histórico do Ministério das Finanças, Processos de Extinção das casas religiosas, Cx. 2238, 1834, fl. 4.

115 A.N.T.T./A.H.M.F./S.N.S.E.V., Extinção das Ordens Religiosas - Seminário de Nossa Senhora da Encarnação - Vinhais, Arquivo Nacional da Torre do Tombo, Lisboa, Arquivo Histórico do Ministério das Finanças, Processos de Extinção das casas religiosas, Cx. 2265, 1834, s/f1.

${ }^{116}$ Borges apenas refere as devoções, não especifica se existia alguma escultura, pintura ou a imagem sobre qualquer outro suporte. Borges, José Cardoso, Memórias de Bragança, Fernando de Sousa (Coord.), Bragança, CEPESE / Câmara Municipal de Bragança, 2012 (texto original de 1721-1724), p. 142 . 
apesar de estar a devoção atualmente identificada como São Domingos julgamos, com base nas referências aos cultos existentes na documentação, que se trata de São Vicente Ferrer.

Em nenhum dos casos são conjuntos, pois as esculturas são autónomas, mas assumem no templo Mogadouro e no de Vinhas uma relação estabelecida entre as duas figuras.

Todas as esculturas que representam São Domingos de Gusmão foram produzidas durante o século XVIII e revelam muitas proximidades no modelo iconográfico que ilustram.

O santo está representado com o hábito bicolor, branco como símbolo de pureza e negro de austeridade. Segura na mão esquerda um livro, de capas vermelhas, a Bíblia, com a qual combateu a heresia dos albigenses, na mão direita um báculo ou um talo de um lírio, e aos pés o cão branco e negro ${ }^{117}$.

As esculturas de São Domingos de Gusmão (Imagem 68 e 69) apesentam-se com idêntica gestualidade. O hábito é semelhante apenas diferindo nos estofados dourados que cobrem a imagem de Vinhais (Imagem 68) e que estão ausentes na policromia mais simples da escultura de Mogadouro (Imagem 69).

As duas figuras sustêm na mão esquerda o livro de capas vermelhas, fechado na escultura de Vinhais (Imagem 68) e aberto na escultura de Mogadouro (Imagem 69).

Em termos genéricos, o livro «fechado» significa a matéria virgem enquanto o livro «aberto» a matéria fecundada, mas o livro é, também, símbolo da cultura, da ciência e da sabedoria ${ }^{118}$.

\footnotetext{
${ }^{117}$ Os atributos de São Domingos derivam de diversas fontes. O cão branco e negro surgiu num sonho premonitório da mãe antes do nascimento que anunciava São Domingos como o defensor da fé contra a heresia. O lírio, partilhado com outras figuras é símbolo de castidade. O báculo recebeu-o de São Pedro e o livro de São Paulo quando foi a Roma pedir autorização ao Papa para fundar uma nova ordem. Nessa mesma estadia teve uma visão de Cristo que ia disparar três flechas para combater três vícios: orgulho; avareza e luxuria, Nossa Senhora interveio e mostrou a Jesus São Domingos em conjunto com São Francisco a combater os vícios com a obediência; pobreza e castidade. Numa outra aparição, mas esta em França, Nossa Senhora ter-lhe-ia entregue um rosário dando origem a essa devoção. Réau, Louis, Iconografía del arte cristiano - Iconografia de los santos, de la A a la F. Tomo 2 / Volumen 3, Barcelona, Ediciones del Serbal, 1997 (edição original 1955-1959), pp. 395-401; Kaftal, George, Iconography of the saints in central and south Italian schools of painting, Firenze, Casa Editrice Le Lettere, 1986, pp. 353363; Carmona Muela, Juan, Iconografia cristiana, Madrid, Akal, 2010, p. 92.

No Flos Sanctorum está representado com o hábito, segurando um ramo florido na mão esquerda e um bordão de pregador na direita. Campos, Hermão de e Rabelo, Roberto, Flos Sanctorum HO FLOS SANCTÕ[RUM] EM LINGOAJE[M] P[OR]TUGUE[S], Lisboa, Disponível na plataforma on-line da Biblioteca Nacional de Portugual http://purl.pt/12097, 1513, fl. CXIIIIv.
}

118 Casimiro, Luís Alberto Esteves, "Iconografia da Anunciação: símbolos e atributos", Revista da Faculdade de Letras, Ciências e Técnicas de Património, Vol. 07-08, Porto, Faculdade de Letras da 


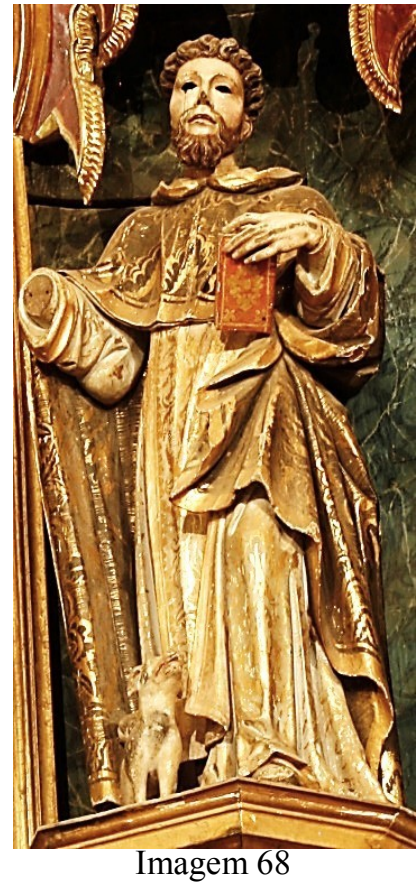

São Domingos de Gusmão - IEV 05

Oficina local $\backslash$ Frei Domingos: último quartel do século XVIII

Retábulo do altar-mor, lado da Epistola Igreja de Nossa Senhora da Encarnação, Vinhais

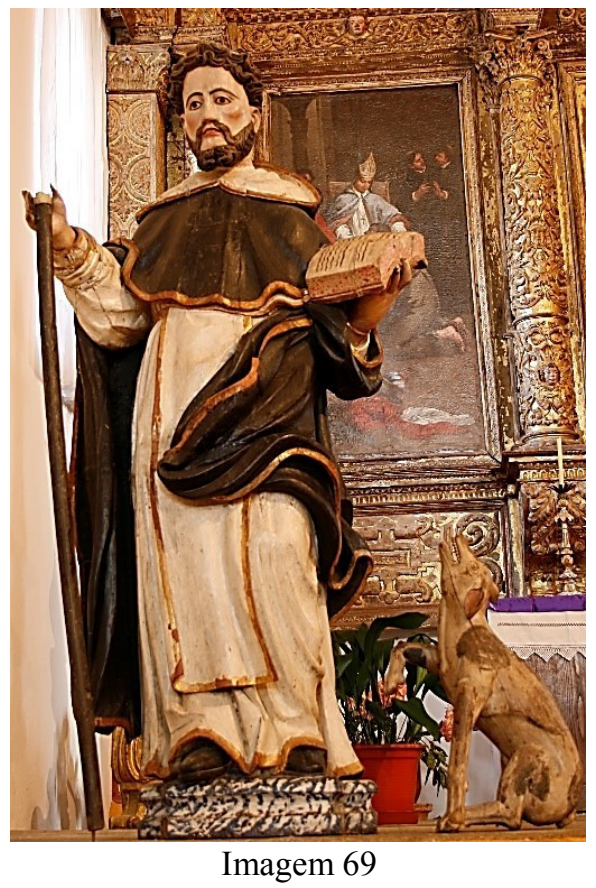

São Domingos de Gusmão - SFM 08

Oficina local $\backslash$ regional; segunda metade do século XVIII

Capela-mor no lado do evangelho, Igreja de São Francisco Mogadouro

Tratando-se da representação de São Domingos é forçoso relacionar a presença do livro com a predicação a que se dedicava o santo, bem como, com os milagres que tradicionalmente se lhe atribuem como o da prova de fogo que salva o livro sagrado e reduz a cinzas o herético.

Quer a escultura de Vinhais quer a de Mogadouro estão acompanhadas pelo cão branco e negro. Está representado sentado, voltado para São Domingos como fiel e bom cão de guarda.

O báculo, ou lírio seria atributo das duas esculturas, mas o de Vinhais (Imagem 68) já se perdeu, junto com a mão que o sustinha, o de Mogadouro (Imagem 69) está fraturado não permitindo por isso perceber a sua configuração. 
O báculo ou bastão ilustram a pregação a que o santo e a sua ordem se dedicaram, reforçando neste elemento a proximidade com São Francisco, bem como com a ordem franciscana.

As duas representações de São Domingos da igreja de Nossa Senhora da Encarnação de Vinhais, e da igreja de São Francisco em Mogadouro, (Imagem 68, 69), apresentam o santo tonsurado, com barba e expressão grave.

A outra representação de São Domingos de Gusmão está identificada com base no inventário dos bens do seminário de 1834, onde, também então na sacristia, dentro do

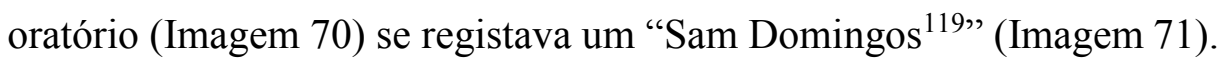

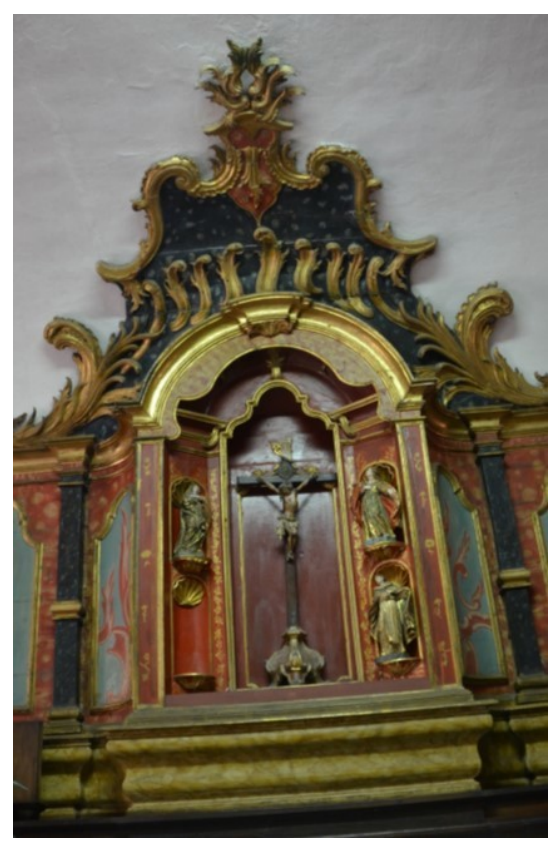

Imagem 70

Colocada dentro do oratório Sacristia da Igreja de Nossa Senhora da Encarnação, Vinhais

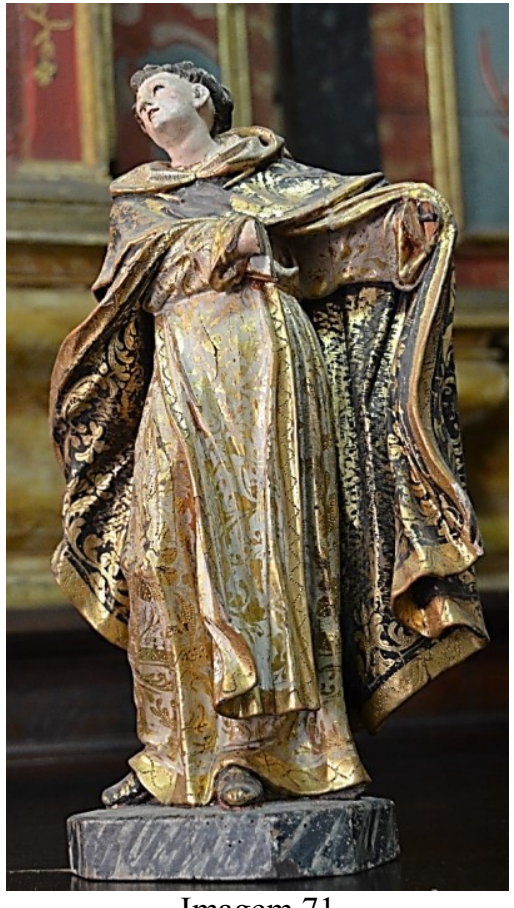

Imagem 71

São Domingos de Gusmão - SIEV 02 Oficina portuguesa; finais do século XVIII Colocada dentro do oratório

Sacristia da Igreja de Nossa Senhora da Encarnação, Vinhais

A lacuna das mãos e com elas dos atributos que acompanhavam a figurinha empobrece a leitura iconográfica do modelo. Apenas o hábito bicolor, com refinados estufados, e a intensa perturbação atmosférica que o envolve assistem a dinâmica gestualidade rodopiante da figura. De rosto imberbe e olhar elevado ilustra uma

\footnotetext{
119 A.N.T.T./A.H.M.F./S.N.S.E.V., Extinção das Ordens Religiosas - Seminário de Nossa Senhora da Encarnação - Vinhais, Arquivo Nacional da Torre do Tombo, Lisboa, Arquivo Histórico do Ministério das Finanças, Processos de Extinção das casas religiosas, Cx. 2265, 1834, s/fl. É de realçar o facto que no mesmo inventário não se verifica mais nenhuma devoção a um santo dominicano, apenas São Domingos é referido, excluindo dessa forma outras possíveis identidades da escultura.
} 
expressão suave onde se esboça um ligeiro sorriso. Diferindo substancialmente das representações mais hieráticas e graves de Vinhais e Mogadouro.

Como pregador mendicante e reformador da igreja, em conjunto com São Francisco, a devoção a São Domingos de Gusmão regista-se em dois dos cinco templos franciscanos estudados, consubstanciando assim a sua devoção em conjunto com São Francisco. Está ausente no templo do convento dos frades menores e das clarissas em Bragança e no templo da Ordem Terceira Secular de Vinhais. 


\section{SANTA CLARA DE ASSIS}

Santa Clara, seguidora de São Francisco e fundadora da variante feminina da ordem, as clarissas, nasceu em Assis em $1193^{120}$. A vida de clausura e os milagres que operou divulgaram a devoção pela Europa ainda durante o período medieval. Santa Clara, contemporânea e filha espiritual de São Francisco, surge por vezes representada próxima da imagem de São Francisco.

Na capela-mor da igreja da ordem terceira de Vinhais é, ainda hoje, a escultura de Santa Clara, em conjunto com a escultura de São Francisco, que ladeia o nicho central do altar-mor. Na igreja do convento de São Francisco de Bragança, dadas as proximidades formais não descuramos que a escultura de Santa Clara pudesse originalmente estar exposta em conjunto com a narrativa do Abraço entre São Francisco e Cristo com o braço despregado da cruz. Pensamos por isso, que ambas as esculturas que representam Santa Clara, e que nos espaços em estudo chegaram aos nossos dias, estavam primitivamente relacionadas com esculturas de São Francisco.

A escultura do templo do convento dos frades menores de Bragança (Imagem 72) já perdeu os atributos que mais facilmente identificavam a narrativa representada. Também a escultura do templo da ordem terceira de Vinhais (Imagem 73) apresenta o único atributo que sustém na mão direita fraturado (parte de um bastão?). A ausência dos possíveis atributos que tradicionalmente acompanham a representação de Santa Clara como a custódia, com que milagrosamente teria posto fim à invasão de sarracenos no seu convento, a cruz ou o talo de lírio, não permite perceber a iconografia que originalmente definia a narrativa das obras. Apenas o hábito que enverga e a gestualidade da atitude nos possibilita supor a mensagem inerente à escultura.

\footnotetext{
${ }^{120}$ Clara de Assis abandonou a casa familiar e distribuiu todos os seus bens pelos pobres, foi recebida na capela de Porciúncula por São Francisco que lhe cortou o cabelo e a cingiu na cintura com o cíngulo da ordem. Viveu em clausura fiel aos preceitos de São Francisco. Estão-lhe associados diversos milagres, de curas e bênçãos, iconograficamente o elemento mais comum que a acompanha é a custódia pela sua devoção à Eucaristia e pelo milagre da sua exposição que pôs em fuga os sarracenos que em 1241 tentaram entrar no convento, foi canonizada em 1255 pelo Papa Alexandre IV. Réau, Louis, Iconografía del arte cristiano - Iconografia de los santos, de la A a la F. Tomo 2 / Volumen 3, Barcelona, Ediciones del Serbal, 1997 (edição original 1955-1959), pp. 309, 310; Carmona Muela, Juan, Iconografia de los santos, Madrid, Akal, 2008, pp. 83-86. A custódia constitui o atributo mais comum nas representações portuguesas de Santa Clara. No entanto, na pintura italiana é mais vezes representada com o livro, a cruz, e até a palma. Kaftal, George, Iconography of the saints in central and south Italian schools of painting, Firenze, Casa Editrice Le Lettere, 1986, pp. 290-296.

No Flos Sanctorum Santa Clara foi acrescentada na narrativa nos santos extravagantes e além do hábito é identificada pela custódia e pelo talo florido. Campos, Hermão de e Rabelo, Roberto, Flos Sanctorum HO FLOS SANCTÕ [RUM] EM LINGOAJE[M] P[OR]TUGUE[S], Lisboa, Disponível na plataforma on-line da Biblioteca Nacional de Portugual http://purl.pt/12097, 1513, fl.CCXLVIII.
} 
Ambas as imagens apresentam semelhanças nos detalhes do hábito, do véu que lhe cinge a cabeça e na capa que a cobre sobre os ombros.

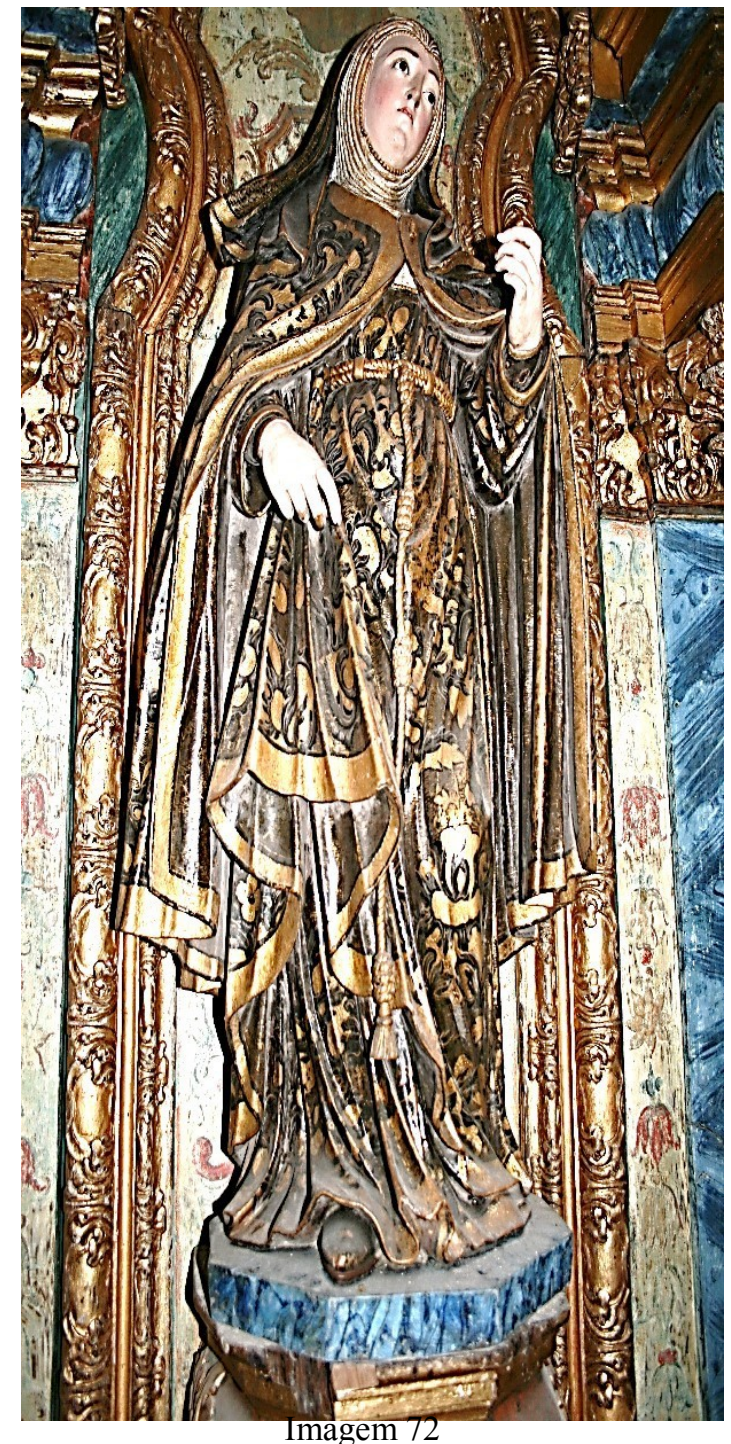

Santa Clara de Assis - SFB 23

Oficina: Porto; Segunda metade do século XVIII Retábulo lateral, lado do Evangelho Igreja de São Francisco, Bragança

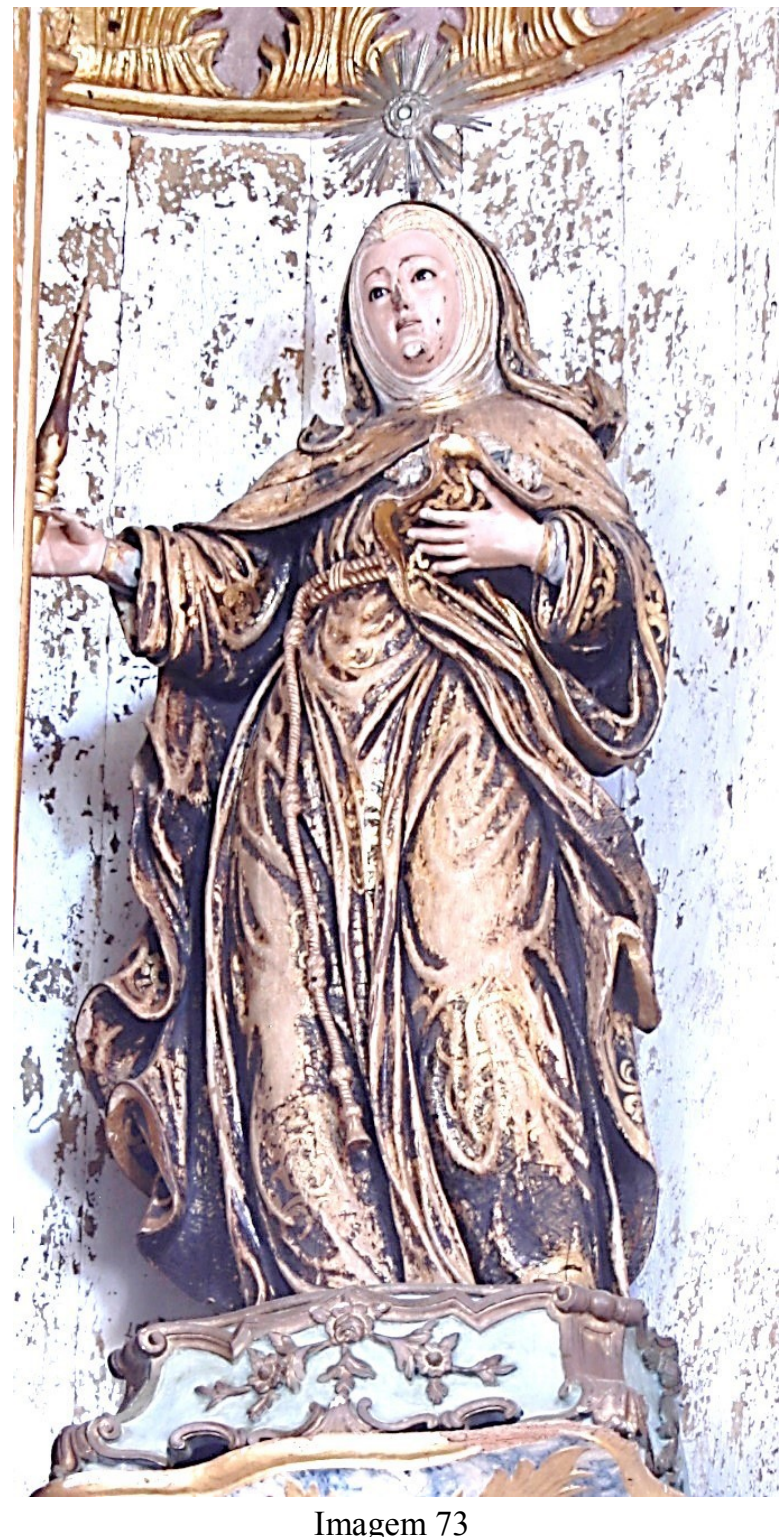

Santa Clara de Assis - SFV 06

Oficina: PortoไBraga: último quartel do século XVIII Retábulo mor no lado da Epistola Igreja de São Francisco, Vinhais

Mas a forma como os panejamentos acompanham o movimento do corpo difere substancialmente nas duas esculturas. Se na imagem da igreja de São Francisco de Bragança (Imagem 72) o hábito é constituído por pesados drapeados que reforçam a majestade da clausura, na escultura de Vinhais (Imagem 73) a tensão atmosférica provoca a aderência ao corpo dos finos panejamentos que dinamicamente acompanham o movimento da figura. 
O gesto, apesar de próximo nas duas representações é também ligeiramente mais amplo mas sobretudo mais intenso, pela tensão na mão esquerda sobre o peito, na imagem de Santa Clara da igreja dos terceiros de Vinhais.

Ambas as esculturas apresentam um rosto jovem, de linhas suaves e arredondados, com a cabeça ligeiramente inclinada denotando a meditação ou a oração que lhe preenche o pensamento. A expressão, de olhos elevados e sobrancelhas tensas é mais pungente na escultura de Bragança, enquanto a escultura de Vinhais, que olha em frente, apresenta uma expressão mais serena.

A ausência de esculturas a representar Santa Clara no único templo de clarissas que na Diocese chegou aos nossos dias é de sobremaneira destacável. No entanto, conforme referimos relativamente a outras devoções que seriam igualmente espectáveis de encontrar em representações plásticas no interior da igreja, a atual igreja de Nossa Senhora das Graças, constitui, no âmbito dos templos em estudo aquele que mais alterações sofreu com consequentes perdas na imaginária.

Apenas em dois dos cinco templos em estudo se encontram representações de Santa Clara, em ambos casos julgamos que as esculturas terão sido encomendadas pela Ordem Terceira, e a boas oficinas do Porto ou Braga. O empenho na devoção, com encomenda de obras de boa execução por parte dos privados, contrasta com a total ausência da devoção no Seminário Apostólico de Vinhais ou no convento da Ordem Terceira regular de Mogadouro.

Tratando-se da fundadora da segunda ordem franciscana surpreende a escassez de imagens que representam Santa Clara, que parece supor, nos templos franciscanos em estudo, uma insipiente devoção a esta impar figura feminina medieval. 


\section{SANTOS DA ORDEM DE SÃO FRANCISCO}

\section{SANTOS MÁRTIRES DE MARROCOS}

Apenas na igreja de São Francisco de Bragança encontramos uma representação do conjunto de frades que em 1220 foram martirizados em Marrocos ${ }^{121}$.

A invocação dos Santos Mártires de Marrocos tutela ainda atualmente a província franciscana de Portugal e são vários os conjuntos que os representam nos templos franciscanos nacionais, ligados à lenda que descreve a sua estadia em terras lusitanas.

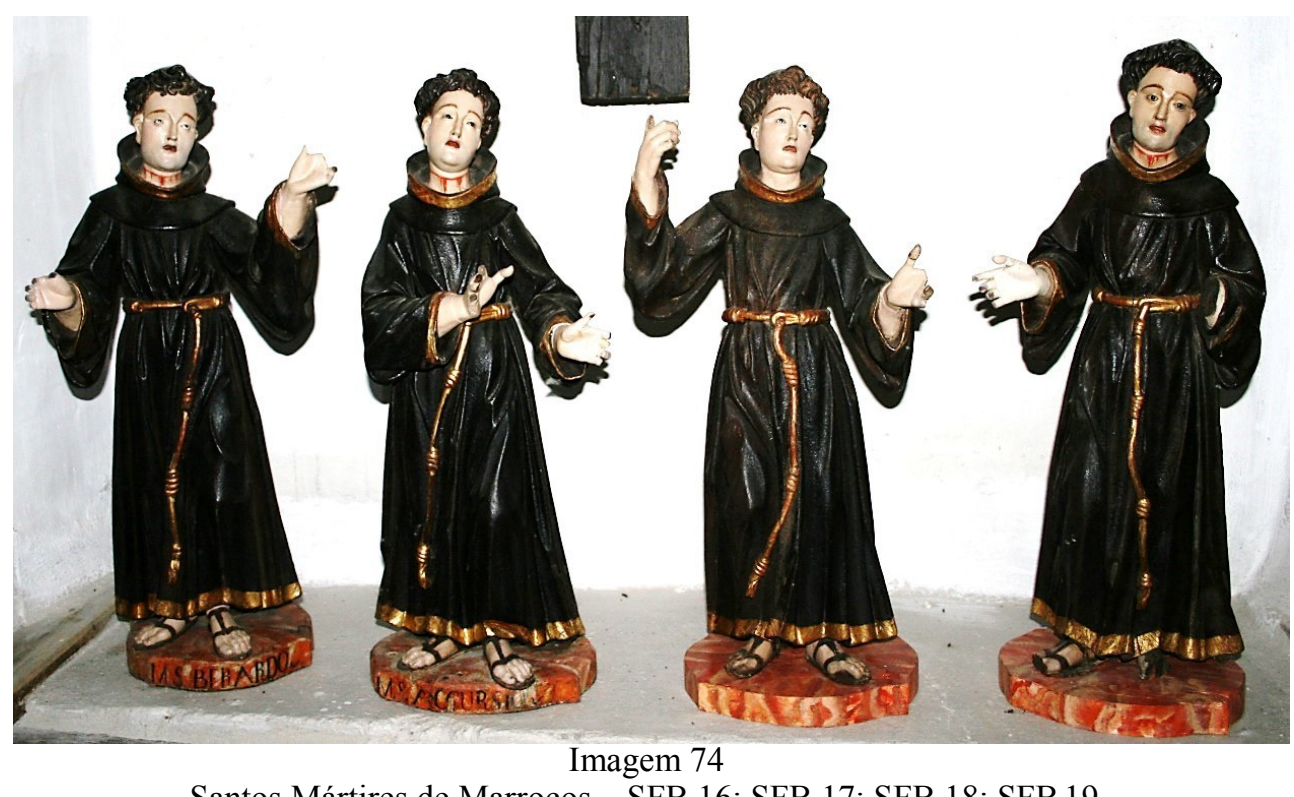

Santos Mártires de Marrocos - SFB 16; SFB 17; SFB 18; SFB 19

(Falta um dos cinco elementos originais do conjunto)

Oficina portuguesa: primeiro quartel do século XVIII

Igreja de São Francisco - Bragança

Capela lateral do lado do Evangelho

Terá sido, segundo a tradição, o próprio São Francisco que após a conclusão do capítulo geral da Ordem, reunido durante a festa do Pentecostes, decidiu enviar para o

\footnotetext{
${ }^{121}$ Ainda em 1220 os Cónegos Regrantes do Mosteiro de Santa Cruz de Coimbra, da Regra de Santo Agostinho, como fiéis depositários dos despojos sagrados, implementaram o fervoroso culto dos ProtoMártires de Marrocos. Além de divulgarem as primeiras formas devocionais iriam acompanhar todo o processo de canonização, concluído em 1481. Foi ainda por intercessão da comunidade crúzia, que, no século XVIII todas as dioceses de Portugal obteriam de Bento XIV a permissão para a celebração da solenidade litúrgica no dia da sua festa. Outro foco religioso, localizado na circunscrição diocesana de Coimbra e de grande importância para a implementação e continuidade do culto dos Santos Mártires, foi o Mosteiro de São Paio e São Mamede de Lorvão, contemplado também com algumas das suas relíquias. Pacheco, Milton Pedro Dias, "Os proto-mártires de Marrocos da Ordem de São Francisco - muy suave odor de sancto martyrio", Universidade Lusófona de Humanidades e Tecnologias. Revista Lusófona de Ciência das Religiões $n^{\circ} 15$ - Martírios e Massacres - fazer da morte uma vitória, Lisboa, Edições universitárias Lusófonas, 2009, pp. 85-108.
} 
Norte de África seis dos seus irmãos em evangelização. O grupo de seis homens, de nacionalidade italiana, foi liderado, inicialmente, por Frei Vital, sacerdote, pregador da Primeira Ordem franciscana (que não prosseguiu viagem pois ficou doente em Aragão), assumiu a liderança do grupo Frei Berardo de Carbio, presbítero famoso pelos dons de pregação, eram os dois únicos conhecedores da língua árabe, acompanhava o grupo na viagem até Marrocos ${ }^{122}$ também Frei Oto, igualmente sacerdote, Frei Pedro de Santo Geminiano, diácono, e Frei Adjuto e Frei Acúrsio, ambos irmãos professos ${ }^{123}$.

Na representação escultórica do episódio da igreja de São Francisco de Bragança a individualização dos cinco mártires é pouco evidente. Se tinham atributos, atualmente já não existem, nem são percetíveis marcas de desgaste ou partes fragmentadas. Jovens ${ }^{124}$, todos envergam o mesmo hábito franciscano, mas só os dois sacerdotes (Bernardo e

${ }^{122} \mathrm{Na}$ viagem até Marrocos, depois de Espanha, passaram vários dias em Portugal. Em Coimbra ficaram no hospício do Mosteiro de Santa Cruz, onde teriam contactado com Santo António que era monge crúzio. Esta estadia envolveria depois os Cónegos Regrantes de Santa Cruz na divulgação do culto. Foram também recebidos pela nobreza e pela família real do reino. Seguiram para Sevilha, ainda islâmica, onde começaram a pregação e o consequente martírio. Já em Marrocos foi na casa de Dom Pedro, príncipe português, irmão do rei Dom Afonso II e das devotas princesas Teresa, Mafalda e Sancha que os pregadores foram recebidos. Após diversas prisões e martírios os pregadores não renunciaram a sua intenção e foi o próprio califa almóada Yusuf al-Mustansir, conhecido por Miramolim de Marrocos, que lhes cortou as cabeças "polo meo da testa" e depois os degolou, enraivecido pelos ataques a Maomé. Depois de várias disputas os restos dos corpos dos santos martirizados, as relíquias foram, por interferência de Dom Pedro, trazidos para Portugal, para a igreja de Santa Cruz em Coimbra. Pacheco, Milton Pedro Dias, "Os proto-mártires de Marrocos da Ordem de São Francisco - muy suave odor de sancto martyrio", Universidade Lusófona de Humanidades e Tecnologias. Revista Lusófona de Ciência das Religiões $n^{\circ} 15$ - Martírios e Massacres - fazer da morte uma vitória, Lisboa, Edições universitárias Lusófonas, 2009, pp. 85-108, citando Tratado da vida \& martyrio dos cinco Martires de Marrocos, fol. CXXXIX, r, col.b; Gonçalves, Flávio, História da arte; Iconografia e Crítica, Lisboa, Imprensa Nacional Casa da Moeda, 1990, pp. 83-85; Fraga Sampedro, Maria Dolores, "San Francisco y sus frailes: arte y devoción en el gótico galaico-portugués", separata da obra II Congresso Internacional de História de Arte -2001, Actas, Coimbra, Almedina, 2005, pp. 617-634.

${ }^{123}$ Esperança, Manuel da, Frei, Historia Seráfica Da ordem Dos Frades Menores de S. Francisco Na Província de Portugal, Tomo I, Lisboa, Officina Craesbeeckiana; disponível na Biblioteca Nacional online http://purl.pt/20706/4/, 1656, p. 287, acerca da presença dos três estados da Ordem Franciscana, escreveu que "como Deos pretendia consagrar como seu sangue os fundamentos primeiros da nossa Ordem serafica, tambe nelles ajuntou os três estados, de que ella se compõem: sacerdotes, \& coristas [...] \& frades leigos"; Pacheco, Milton Pedro Dias, "Os proto-mártires de Marrocos da Ordem de São Francisco - muy suave odor de sancto martyrio", Universidade Lusófona de Humanidades e Tecnologias. Revista Lusófona de Ciência das Religiões $n^{\circ} 15$ - Martírios e Massacres - fazer da morte uma vitória, Lisboa, Edições universitárias Lusófonas, 2009, pp. 85-108, onde cita o Tratado da vida \& martyrio dos cinco Martires de Marrocos [...] 1568, fol. III, v; Livro primeiro [...], 1566, fol. CXXXII, r, col.b e Cornejo, Damian, Chronica Seraphica [...] 1727, p. 276.

${ }^{124}$ Kaftal refere que os jovens franciscanos são comumente representados com palmas, ou com os instrumentos de martírio: Bernardo com uma espada sobre o peito; Oto com a espada sobre o pescoço; Pedro com três varas rasgando o pescoço e peito e segurando três varas, ou trespassado por três adagas; Adjuto, jovem ou de meia-idade com uma serra ou uma adaga a trespassar a cabeça; Acúrsio, jovem ou de meia-idade com uma serra a trespassar a cabeça, a visão do crucifixo ou breviário dentro de uma bolsa sustida no cíngulo. Kaftal, George, Iconography of the saints in central and south Italian schools of painting, Firenze, Casa Editrice Le Lettere, 1986, p. 762. 
Otto), e o diácono (Pedro) apresentam tonsura, ausente nos dois irmãos professos (Adjuto e Acúrsio). O conjunto dos Santos Mártires de Marrocos está atualmente incompleto. A imagem em falta corresponde à representação de Adjuto, um dos irmãos professos, pois apenas uma das quatro imagens se apresenta sem tonsura e está identificada na base como Acúrsio. Frei Bernardo também está identificado na base e expõe a marca de martírio sobre o pescoço, pois conhecendo o idioma teria sido o primeiro a sofrer os golpes do sacrifício. As outras duas figuras não estão identificadas mas representam ambas frades com tonsura, sugerindo poder trata-se de Frei Oto ou do Diácono Pedro. Apenas diferem no facto de uma das figuras não apresentar qualquer marca de martírio. As marcas de martírio, tendo em conta a crueldade das cronicas, seria espectável serem mais evidentes, sangrentas e denunciadoras dos flagelos a que foram submetidos os pregadores franciscanos. $\mathrm{O}$ momento representado é o do decurso do martírio, pois a presença de um dos frades sem qualquer marca de tortura evidencia que ainda decorre o suplício que matou todos os elementos do grupo. Apesar da brutalidade do momento narrado a composição dos jovens franciscanos expõe sobretudo o profundo misticismo na gestualidade das figuras, que com os braços abertos aceitam o martírio na convicção plena da obediência aos planos de Deus. O conjunto ainda a culto no templo de Bragança não pode ser dissociado da intercessão da comunidade crúzia, que, no século XVIII obteriam de Bento XIV a permissão para a celebração da solenidade litúrgica em todas as dioceses de Portugal ${ }^{125}$. Datado dessa mesma centúria, a qualidade escultórica do conjunto supõe a encomenda a uma boa oficina e por tanto o compromisso local de também neste templo franciscano se prestar culto aos santos mártires.

A permanência de vários dias dos Santos Mártires em Portugal e as privilegiadas relações que estabeleceram com o clero e com a nobreza local implementaram o culto e a influência do episódio em terras lusas. Neste fluxo devocional destaca-se a figura Santo António que inspirado pelos mártires franciscanos tentou ir pregar para Marrocos e abandonou a ordem dos cónegos regrantes para ingressar na ordem dos frades menores.

${ }^{125}$ Pacheco, Milton Pedro Dias, "Os proto-mártires de Marrocos da Ordem de São Francisco - muy suave odor de sancto martyrio", Universidade Lusófona de Humanidades e Tecnologias. Revista Lusófona de Ciência das Religiões $n^{\circ} 15$ - Martírios e Massacres - fazer da morte uma vitória, Lisboa, Edições universitárias Lusófonas, 2009, pp. 85-108. 


\section{SANTO ANTÓNIO DE LISBOA OU DE PÁDUA}

Santo António ${ }^{126}$ nasceu em Lisboa e foi canonizado apenas um ano após a sua morte em $1232^{127}$. O santo popular português é o santo franciscano, depois de São Francisco, mais vezes representado nos templos em estudo. Mas o seu culto demorou dois séculos a consolidar-se nas representações portuguesas ${ }^{128}$.

As três esculturas de Santo António, a culto nas igrejas de Bragança, julgamos terem sido produzidas ao longo do século XVII. Com o século XVIII relacionamos as esculturas de Vinhais, da igreja do seminário dos missionários apostólicos e da igreja da Ordem Terceira.

A devoção antoniana não existe atualmente no templo de Mogadouro, no entanto, em 1834 era registado: "No terceiro altar que esta unido ao retablo que tem varias imagens debuxadas achou a imagem de Santo António ${ }^{129 ",}$

\footnotetext{
${ }^{126}$ Santo António é um dos santos de maior devoção em Portugal, enquanto taumatúrgico executou em vida quantidade de prodígios. Os milagres de Santo António situam-se em diferentes vertentes: exorcismos, curas várias, ressurreições, levar uma criança a tomar a defesa da mãe, o Sermão aos peixes, o milagre eucarístico ou da mula, ou o episódio de Santo António a livrar o pai da forca. Os milagres realizados depois da morte, sobre os quais há um inquérito rigoroso do bispo de Pádua, promovido a pedido do Papa Gregório IX, referem dezanove curas: cinco de paralíticos, sete de cegos, três de surdos, dois epiléticos, três de corcundas, dois de altas febres, duas ressurreições. Azevedo, Carlos A. Moreira de, "Variantes iconográficas nas representações antonianas" in. Cultura. Revista de história e teoria das ideias. Vol. 27, Lisboa, Centro de História da Cultura. Faculdade de Ciências Sociais e Humanas, Universidade Nova de Lisboa, 2010, pp. 41-55.

Sobre a representação dos episódios taumatúrgicos ver: Kaftal, George, Iconography of the saints in central and south Italian schools of painting, Firenze, Casa Editrice Le Lettere, 1986, pp. 106-112.
}

127 Santo António depois da sua malograda viagem a Marrocos já como frade franciscano desembarcou em Itália onde terá participado em 1227 no Capitulo Geral de Assis, morreu em Pádua em 1231. Até ao século XV o seu culto centrava-se no território de Pádua. Réau, Louis, Iconografía del arte cristiano Iconografia de los santos, de la A a la F. Tomo 2 / Volumen 3, Barcelona, Ediciones del Serbal, 1997 (edição original 1955-1959), pp. 124-126; Carmona Muela, Juan, Iconografía de los santos, Madrid, Akal, 2008, pp. 34-37.

${ }^{128}$ As primeiras representações antonianas portuguesas datam do século XV. Azevedo, Carlos A. Moreira de, "Variantes iconográficas nas representações antonianas" in. Cultura. Revista de história e teoria das ideias. Vol. 27, Lisboa, Centro de História da Cultura. Faculdade de Ciências Sociais e Humanas, Universidade Nova de Lisboa, 2010, pp. 41-55; Santo António, mesmo fora dos espaços franciscanos, constitui a invocação franciscana mais comum, como se percebe nos espaços beneditinos do Minho. Dias, Eva Sofia Trindade, "Beneditinos e Franciscanos: convivência de invocações no espaço monástico beneditino português (Séculos XVII-XVIII)", in Natália Marinho Ferreira-Alves (Coord.), Franciscanos no Mundo Português III, Porto, CEPESE - Centro de Estudos da População, Economia e Sociedade, 2013, pp. 375-399.

129 A.N.T.T./A.H.M.F./S.F.M., Extinção das Ordens Religiosas - Convento de São Francisco em Mogadouro, Arquivo Nacional da Torre do Tombo, Lisboa, Arquivo Histórico do Ministério das Finanças, Processos de Extinção das casas religiosas, Cx. 2238, 1834, fl. 5. 
O altar com pinturas "debuxadas" mantém-se no templo mas a escultura de Santo António está hoje desaparecida.

O século XVII constitui um período fortemente marcado pela longa guerra da Restauração que condicionou a frágil dinâmica de encomenda de obras escultóricas. A existência de três esculturas dedicadas ao culto antoniano revela a valorização da devoção que ao longo de seiscentos se consolidou na fronteiriça cidade de Bragança.

A clara intenção nacionalista na divulgação do culto relaciona-se com os coevos programas escultóricos régios que se desenvolvem após a Restauração e onde Santo António, enquanto santo português, é comummente representado ${ }^{130}$.

No Officio menor dos sanctos de Portugal Jorge Cardoso referia-se a "Santo António de Lisboa, esclarecido filho seu, vulgarmente chamado de Pádua, sol refulgente entre os santos de Portugal" 131 . Valorizando a nacionalidade do santo em conjunto com as virtudes e poderes taumatúrgicos que lhe estavam afetos.

Borges $^{132}$, no início do século XVIII, destaca, no interior do templo de São Francisco de Bragança, a capela de Santo António, porém não refere qualquer escultura.

Mas, é neste convento que encontramos a escultura que julgamos ter sido a primeira a ser produzida nos templos em estudo a representar Santo António (Imagem 75). Já não exibe nenhum atributo, o que dificulta a sua leitura iconográfica. Mas, os gestos das mãos sugerem que poderia segurar algum dos seus atributos iniciais mais comuns. De rosto imberbe e abonecado é no hábito franciscano, na tonsura, e pose estática que nos baseamos para a sua identificação.

Na mesma centúria e no mesmo templo foi encomendada nova escultura de Santo António (Imagem 76) de rosto mais verosímil sustém na mão esquerda um livro ${ }^{133}$

\footnotetext{
${ }^{130}$ Pereira, José Fernandes, "O barroco do século XVII: transição e mudança" in Paulo Pereira (direção), História da Arte Portuguesa, Volume III, Lisboa, Círculo de Leitores, 1995, pp. 11-49.

${ }^{131}$ Cardoso, Jorge, Officio menor dos sanctos de Portugal: tirado de breviarios, \& memorias deste reino, Lisboa, Pedro Crasbeeck, Disponível na plataforma on-line da Biblioteca Nacional de Portugal, http://purl.pt/14148, 1629, p. 20.
}

${ }^{132}$ A capela de Santo António de que era padroeiro o alcaide-mor Lázaro de Figueiredo Sarmento e que tinha um túmulo metido na parede. Borges, José Cardoso, Memórias de Bragança, Fernando de Sousa (Coord.), Bragança, CEPESE / Câmara Municipal de Bragança, 2012 (texto original de 1721-1724), p. 142.

${ }^{133} \mathrm{O}$ livro é atributo antigo e mais usado. Aparece geralmente na mão esquerda, ora aberto, ora fechado. O livro usado habitualmente nas representações dos Apóstolos, dos Doutores e dos Bispos, como depositários da doutrina evangélica, sublinha, em Santo António, a qualidade de apóstolo da Boa Nova e de "Arca do Testamento". Patenteava o escritor, o sábio. Quem viveu o Evangelho como "regra e forma de vida" e o anunciou fielmente é natural que segure o livro no átrio das suas mãos. Junto se coloca, frequentemente, o Evangelho vivo: o Menino Deus em pessoa nos braços do Santo. A imagem de Jesus, 
aberto. Na mão direita julgamos que susteria um bastão com cruz consolidando a sua devoção enquanto pregador. A pose estática e a valorização iconográfica de clara influência tridentina é também evidente nesta escultura do século XVII.

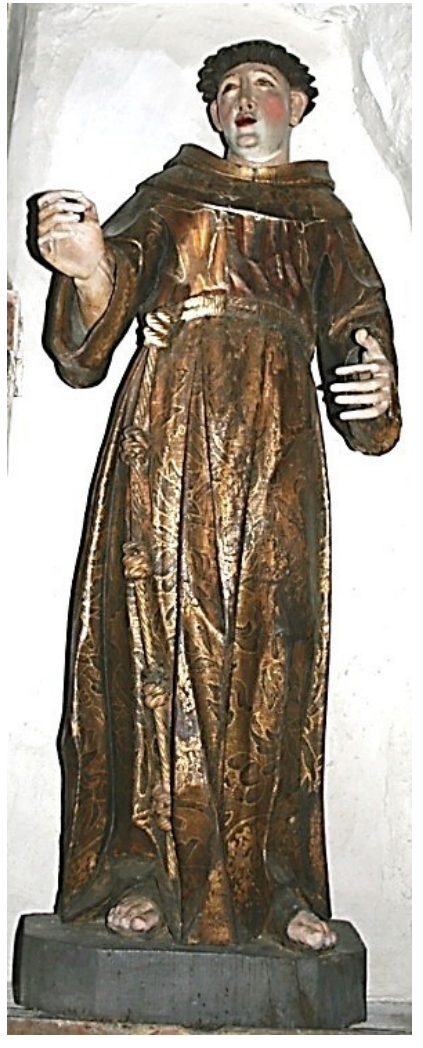

Imagem 75

Santo António - SFB 14

Oficina portuguesa; primeira metade do século XVII

Capela lateral do lado do Evangelho, igreja de São Francisco, Bragança

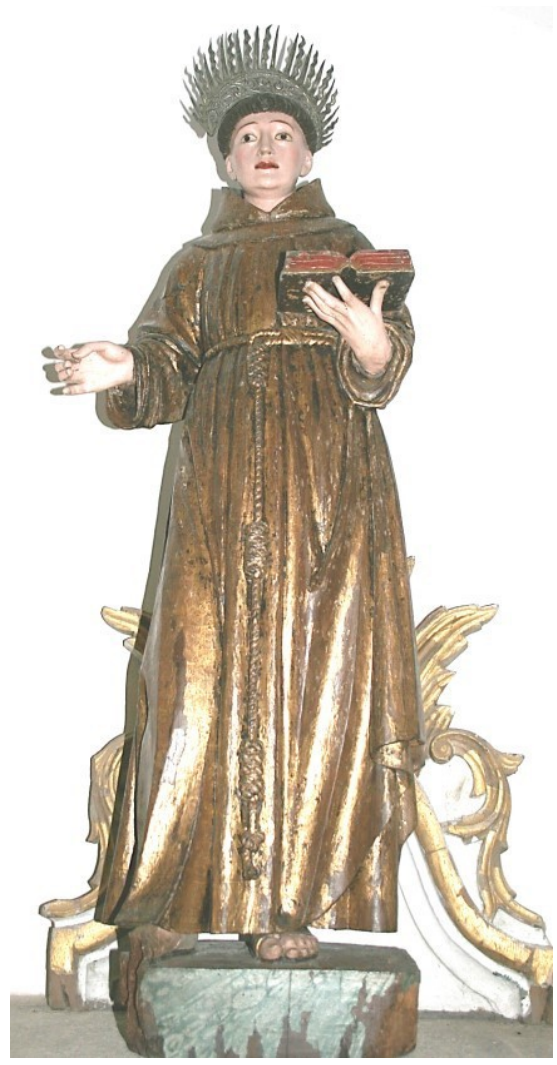

Imagem 76

Santo António - SFB 01

Oficina portuguesa; segunda metade do século XVII

Colocada num nicho no lado da Epistola, igreja de São Francisco, Bragança

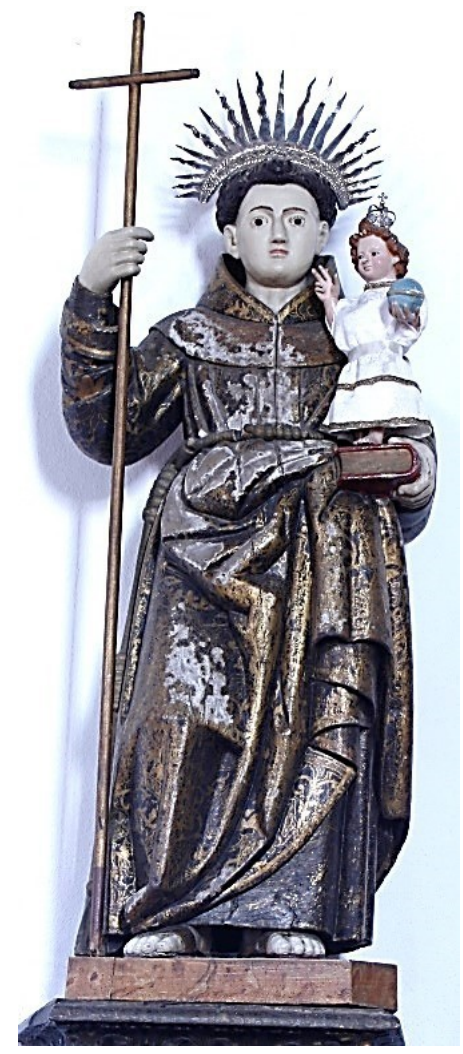

Imagem 77

Santo António - SCB 11

Oficina portuguesa; segunda metade do século XVII

Colocada sobre uma peanha no lado do Evangelho Igreja das Clarissas (atual igreja de Nossa Senhora das Graças), Bragança

No Flos Sanctorum, Santo António surge no acrescento que é feito de santos extravagantes, e a gravura que ilustra a sua narrativa é a mesma que ilustra São

grande amor da vida de António de Lisboa, não decaiu nos seus lábios e não caiu dos seus braços. Azevedo, Carlos A. Moreira de, "Variantes iconográficas nas representações antonianas" in. Cultura. Revista de história e teoria das ideias. Vol. 27, Lisboa, Centro de História da Cultura. Faculdade de Ciências Sociais e Humanas, Universidade Nova de Lisboa, 2010, pp. 41-55, citando Matos, Manuel Cadafaz de - Ideologia e práticas de representação antonianas na cultura ocidental do Renascimento: a imagem de Santo António na iconografia e na história do livro quinhentista. In congresso internacional "pensamento e testemunho", vol. 2, pp. 1233-1276. 
Francisco de Assis. Representado com hábito franciscano sustendo um crucifixo e o livro, mantendo igualmente o estigma na mão ${ }^{134}$.

Esta contaminação iconográfica, fruto do ainda então recente culto, poderá também ter contribuído para explicar a presença do livro e do crucifixo nas primeiras representações antonianas.

$\mathrm{Na}$ igreja das clarissas encontramos a escultura seiscentista mais completa nos atributos que ainda a acompanham. Com resplendor idêntico à coeva imagem da igreja de São Francisco (Imagem 76), mas que possivelmente se trata de um postiço acrescentado posteriormente, já no século XVIII. A imagem de Santo António do convento de Santa Clara (Imagem 77) sustém sobre o livro o Menino Jesus ${ }^{135}$. Destacamos neste modelo o facto de se tratar de um espaço feminino onde eram mais comuns as representações da infância de Cristo. Nesta representação o Menino surge como Salvador do Mundo, com o globo na mão esquerda e a mão direita em gesto de bênção ${ }^{136}$, o Menino está colocado sobre o livro fechado.

A espiritualidade veiculada na associação do Menino Jesus, reflete a humanidade de Jesus, valorizada também na promoção do presépio. O atributo antoniano harmonizavase com esta linha espiritual franciscana e servia a causa da sua difusão, motivando a visualização de um amor ao Menino, ensinado na pregação popular ${ }^{137}$.

134 Campos, Hermão de e Rabelo, Roberto, Flos Sanctorum HO FLOS SANCTÕ[RUM] EM LINGOAJE[M] P[OR]TUGUE[S], Lisboa, Disponível na plataforma on-line da Biblioteca Nacional de Portugual http://purl.pt/12097, 1513, fl. CCXLIII.

$135 \mathrm{O}$ Menino Jesus é desde o século XV o atributo preferido da iconografia antoniana. A fonte hagiográfica que serviu de base à sua representação é o Liber miraculorum, escrito por Arnaldo de Serrano entre 1369 e 1374. A lenda refere um benfazejo hospedeiro, numa das suas viagens por França ou Itália, recebeu o Santo que viu, numa certa noite, a receber a visita de belíssimo infante. Tratava-se do Menino Jesus que descia do céu sobre um livro e passava aos braços do Santo. Tudo isto viu o burguês, por uma porta entreaberta. Prometeu guardar segredo. Assim fez até que António morreu. Em virtude deste "milagre", entra o Menino Jesus na iconografia. Azevedo, Carlos A. Moreira de, "Variantes iconográficas nas representações antonianas" in. Cultura. Revista de história e teoria das ideias. Vol. 27, Lisboa, Centro de História da Cultura. Faculdade de Ciências Sociais e Humanas, Universidade Nova de Lisboa, 2010, pp. 41-55; Réau, Louis, Iconografía del arte cristiano - Iconografia de los santos, de la A a la F. Tomo 2 / Volumen 3, Barcelona, Ediciones del Serbal, 1997 (edição original 1955-1959), pp. 130, 131.

${ }^{136}$ Fraga Sampedro, Maria Dolores, "Predicación e imágenes en los siglos finales de la edad media hispana" in Plenitudo Veritatis homenaje a Mons. Romero Pose, Santiago de Compostela, Instituto Teológico Compostelano, 2008, pp. 829-847.

${ }^{137}$ Azevedo, Carlos A. Moreira de, "Variantes iconográficas nas representações antonianas" in. Cultura. Revista de história e teoria das ideias. Vol. 27, Lisboa, Centro de História da Cultura. Faculdade de Ciências Sociais e Humanas, Universidade Nova de Lisboa, 2010, pp. 41-55. 
$\mathrm{Na}$ outra mão a escultura de Santo António (Imagem 77) segura um bastão em cruz $^{138}$ como símbolo da pregação, e, enquanto símbolo da Paixão com que o Menino irá redimir a humanidade.

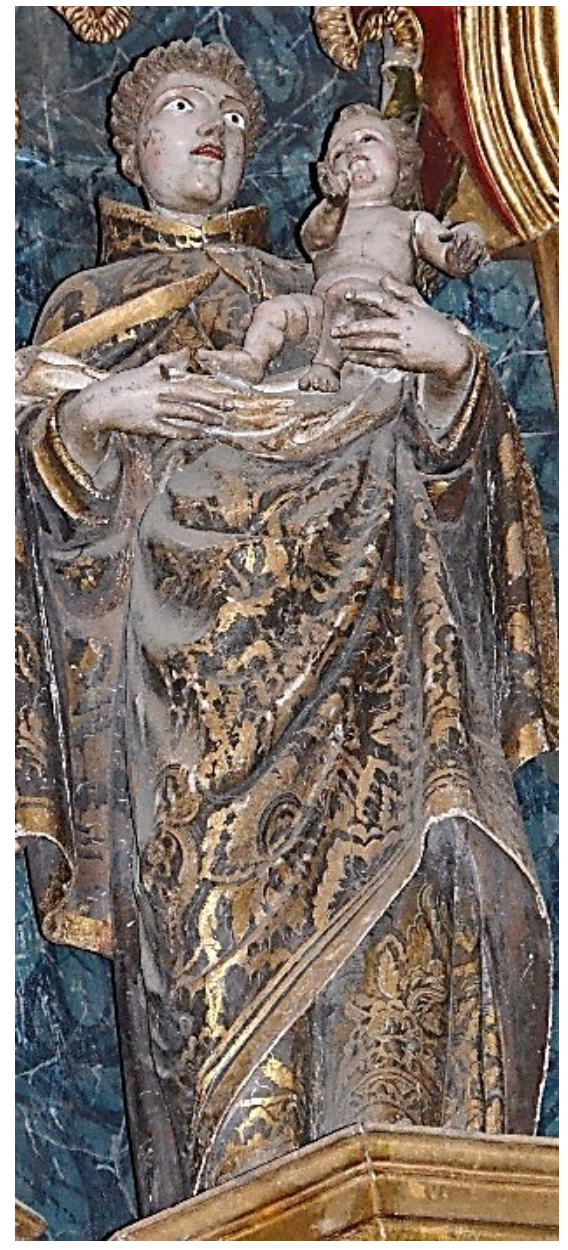

Imagem 78

Santo António com o Menino - IEV 08

Oficina local $\backslash$ Frei Domingos (?): último quartel do século XVIII

Retábulo do altar-mor, lado do Evangelho Igreja de Nossa Senhora da Encarnação, Vinhais

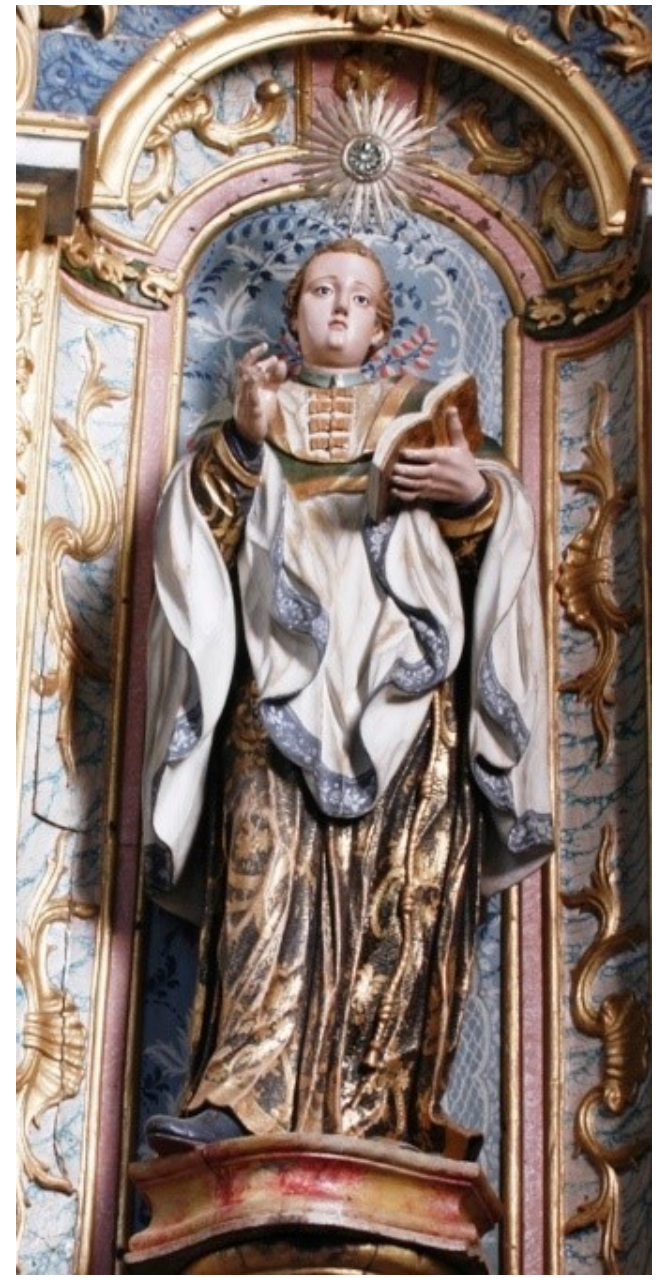

Imagem 79

Santo António Menino do Coro - SFV 03

Oficina: PortoไBraga: último quartel do século XVIII

Retábulo no lado da Epistola Igreja de São Francisco, Vinhais

\footnotetext{
${ }^{138}$ As primeiras representações antonianas portuguesas mostram António com a cruz. A cruz refere-se à Paixão e Morte e sublinha a salvação do mundo, operada pela sua vida entregue. A cruz nas mãos de António alude à vontade de querer seguir Cristo pobre e crucificado. Azevedo, Carlos A. Moreira de, "Variantes iconográficas nas representações antonianas" in. Cultura. Revista de história e teoria das ideias. Vol. 27, Lisboa, Centro de História da Cultura. Faculdade de Ciências Sociais e Humanas, Universidade Nova de Lisboa, 2010, pp. 41-55.

A presença da cruz constitui também o elemento de contaminação com a representação de São Francisco de Assis, conforme é possível observar nas gravuras que representam ambos santos no Flos Sanctorum. Campos, Hermão de e Rabelo, Roberto, Flos Sanctorum HO FLOS SANCTÕ [RUM] EM LINGOAJE[M] $P[O R] T U G U E[S]$, Lisboa, Disponível na plataforma on-line da Biblioteca Nacional de Portugual http://purl.pt/12097, 1513, fl. CCXLIII.
} 
A presença do Menino reflete igualmente a transformação do culto do santo popular taumatúrgico que, face a novos milagres e maravilhas que foi operando, foi acrescentada na sua representação os elementos que os ilustravam.

De uma réplica de São Francisco de Assis na gravura do Flos Sanctorum, com a cruz e o livro, as esculturas de Santo António consubstanciam uma crescente individualização motivada pela crescente devoção nacional.

As duas representações antonianas do século XVIII estão em Vinhais. A escultura do seminário apostólico (Imagem 78) surge na documentação relativa aos inventários de 1834 onde se registou "Huma imagem de vulto de Santo Antonio com seu menino"139.

O santo sustém com a mão esquerda a figura do Menino. Mas nesta representação o Menino brinca rodopiando num gesto de natural irrequietação infantil, afastando-se da linguagem mais simbólica seiscentista, e o livro bem como a cruz estão já ausentes na narrativa.

Esta alteração iconográfica poder-se-á relacionar não apenas com a espiritualidade franciscana mas também com a alteração social do valor da infância que caracteriza a Europa a partir do século XVII ${ }^{140}$.

O santo pregador medieval é em todas as esculturas, já sejam seiscentistas ou setecentistas, representado jovem, com expressão grave e gesto contido, e com o hábito franciscano ${ }^{141}$.

A escultura da igreja da Ordem Terceira de Vinhais reflete o modelo menos usual de Santo António Menino do Coro $^{142}$ (Imagem 79). Representado muito jovem, enverga o hábito franciscano e sobreposto o sobrepeliz, segura o livro na mão esquerda, ao contrário das restantes representações em que o santo é representado com as sandálias franciscanas, no modelo do Menino do Coro a imagem ostenta sapatos e cobre os loiros cabelos com solidéu. A narrativa da escultura relaciona-se com o Milagre da Cruz, que

\footnotetext{
139 A.N.T.T./A.H.M.F./S.N.S.E.V., Extinção das Ordens Religiosas - Seminário de Nossa Senhora da Encarnação - Vinhais, Arquivo Nacional da Torre do Tombo, Lisboa, Arquivo Histórico do Ministério das Finanças, Processos de Extinção das casas religiosas, Cx. 2265, 1834, s/fl.

${ }^{140}$ Ariès, Philippe, História Social da Criança e da Família. Rio de Janeiro, LTC- Livros Técnicos e Científicos Editora S.A, 1981, p. 127.

${ }^{141}$ Kaftal refere a representação do santo jovem, sem braba e com hábito franciscano como a mais comum. Kaftal, George, Iconography of the saints in central and south Italian schools of painting, Firenze, Casa Editrice Le Lettere, 1986, pp. 105-114.

${ }^{142}$ Azevedo, Carlos A. Moreira de, "Variantes iconográficas nas representações antonianas" in. Cultura. Revista de história e teoria das ideias. Vol. 27, Lisboa, Centro de História da Cultura. Faculdade de Ciências Sociais e Humanas, Universidade Nova de Lisboa, 2010, pp. 41-55. Santo António Menino de Coro aparece vestido com túnica vermelha e roquete ou sobrepeliz, numa alusão clara ao passo hagiográfico do milagre da cruz, nas escadas do coro da Sé de Lisboa.
} 
ainda hoje é contado na escadaria de acesso ao Tesouro da Sé de Lisboa. A lenda refere que ao ser tentado pelos fulgores da adolescência, o jovem santo benzeu-se e a marca da cruz ficou gravada na pedra.

A refinada linguagem formal, reiteradamente preferida na encomenda das esculturas da igreja dos terceiros de Vinhais, é acrescida nesta escultura pela raridade iconográfica do modelo do santo popular português que representa.

A pluralidade de milagres enquanto invocação taumatúrgica e a relevância do santo enquanto místico e pregador franciscano é ilustrada nas cinco esculturas dos templos em estudo que sublinham a importância do culto nos espaços franciscanos bem como no território da fronteira transmontana. 


\section{SÃO BOAVENTURA}

O Doutor Seráfico, nascido em 1221 e canonizado em 1482, é o mais influente teólogo franciscano, escreveu, entre outras, as Memorias de São Francisco e foi professor na Sorbonne. Designado Geral da Ordem dos Franciscanos, recebeu também a dignidade cardinalícia. Contemporâneo do dominicano Tomás de Aquino é por vezes representado em conjunto com este outro Doutor da Igreja, em analogia com a representação de São Francisco com São Domingos.

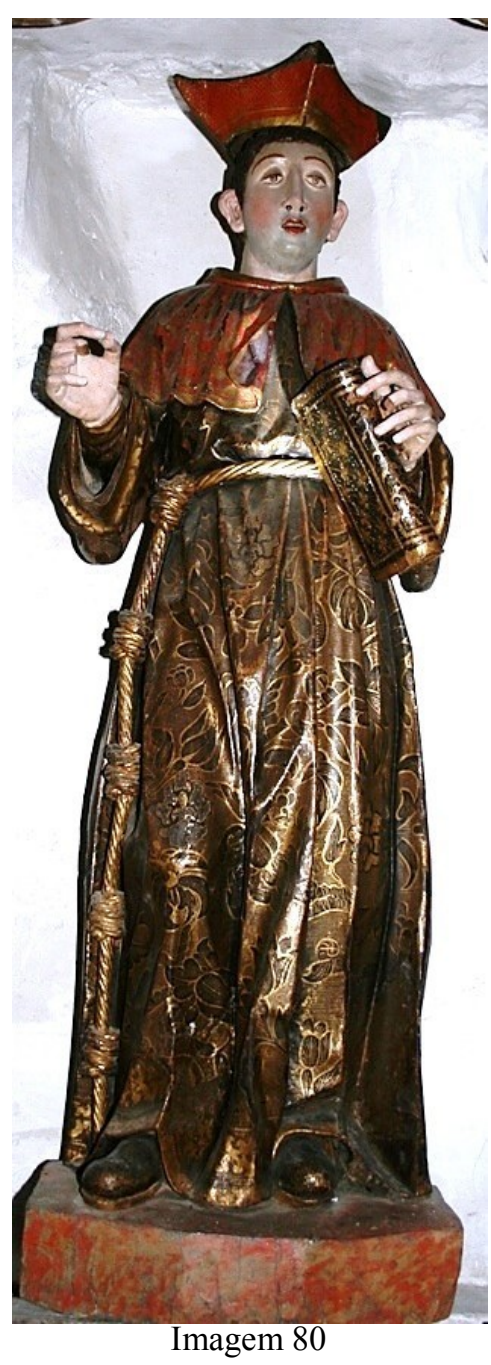

São Boaventura - SFB 15

Oficina portuguesa; primeira metade do século XVII, capela lateral do lado do Evangelho, Igreja de São Francisco, Bragança

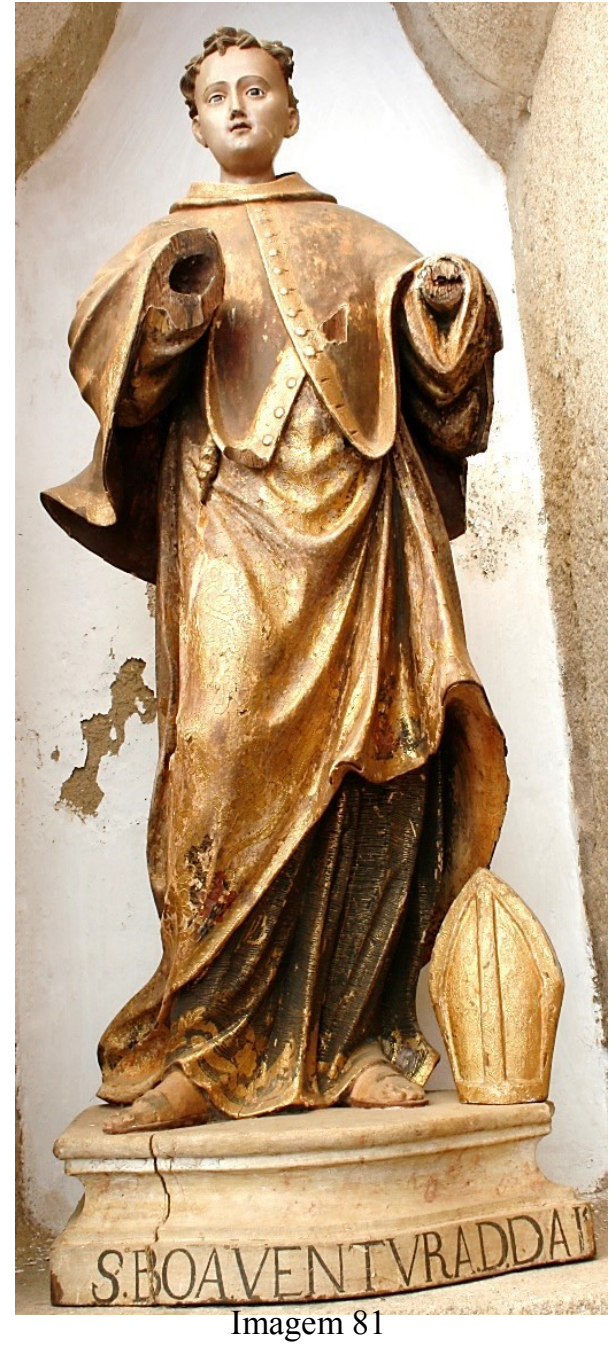

São Boaventura - CSDV 09

Oficina portuguesa (Lisboa); terceiro quartel do século XVIII, capela de Nossa Senhora das Dores, Igreja de Nossa Senhora da Encarnação, Vinhais 
Representado comumente com o hábito franciscano, sobre o qual enverga a capa e mitra $^{143}$.

Nos espaços em estudo encontramos duas representações de São Boaventura. Em Bragança, no convento dos frades menores (Imagem 80) e na capela de Nossa Senhora das Dores da igreja do seminário apostólico de Vinhais (Imagem 81)

A escultura de São Boaventura de Bragança de rosto imberbe e abonecado perdeu já o atributo que seguraria na mão direita. Na esquerda segura o livro, que o identifica enquanto doutor da igreja. O hábito franciscano, posteriormente decorado com ornamentados estufados, está preso com um cíngulo com cinco nós. Sobreposto ao hábito enverga a capa magna cardinalícia e sobre a cabeça o barrete cardinalício, ambos decorados a dourado sobre um brilhante tom vermelho.

De técnica escultórica mais aprumada, a estatueta de São Boaventura de Vinhais terá sido das primeiras imagens que os frades missionários trouxeram, possivelmente da casa mãe de Brancanes. O gesto elegante e a refinada ondulação das vestes sugerem o movimento do corpo que a expressão serena atenua. Ambas as mãos se perderam e com elas os atributos que possivelmente seguravam. Enverga o hábito franciscano com a dalmática sobreposta e sobre esta a capa cardinalícia. Aos pés, está colocada a mitra.

Não obstante as diferenças formais, ambas as esculturas seguem a mesma narrativa, evocando o santo no seu mais alto estatuto eclesiástico. Tratando-se também de um teólogo e Doutor da Igreja a presença da sua devoção, nos dois espaços franciscanos de maior compromisso com a pregação e o ensino, não poderá ser dissociada desta função pedagógica que o convento dos frades menores tinha perante a comunidade de Bragança e os frades missionários perante a comunidade de Vinhais.

\footnotetext{
${ }^{143}$ Réau, Louis, Iconografía del arte cristiano - Iconografia de los santos, de la A a la F. Tomo $2 /$ Volumen 3, Barcelona, Ediciones del Serbal, 1997 (edição original 1955-1959), p. 252; Kaftal, George, Iconography of the saints in central and south Italian schools of painting, Firenze, Casa Editrice Le Lettere, 1986, pp. 227-230; Carmona Muela, Juan, Iconografia de los santos, Madrid, Akal, 2008, pp. 6367 ; Carmona Muela, Juan, Iconografia cristiana, Madrid, Akal, 2010, p. 91.
} 


\section{SÃO BERNARDINO DE SIENA}

Bernardino nasceu em 1380 perto de Siena e foi canonizado em 1450. Assíduo predicador foi também o promotor da observância que iniciaria um novo ramo na família franciscana na intenção de seguir em estreita fidelidade a regra primitiva de São Francisco. A sua representação mais comum destaca o brasão com a inscrição do anagrama J.H.S. com uma cruz sobreposta na letra $\mathrm{H}^{144}$ que por devoção ao nome de Jesus o acompanhava nas suas predicações. Ou o episódio em que São Bernardino rejeitou a dignidade episcopal, que ocorreu com as dioceses de Siena, Ferrara e Urbino $^{145}$.

As duas esculturas que do convento de Mogadouro e do seminário de Vinhais chegaram aos nossos dias ambas mantêm o elemento iconográfico da mitra pousada aos pés do santo em alusão à recusa do cargo eclesiástico.

A escultura de Mogadouro (Imagem 82) é formalmente mais arcaica, apresenta aspetos decorrentes das imposições reformistas pós Concílio de Trento. São Bernardino é representado com barbas e rosto magro de asceta envergando o simples hábito franciscano. O olhar elevado e a mão sobre o peito intensificam a tensão mística do santo pregador. A mão direita segura o bastão com o brasão onde se inscreve o trigrama do nome de Jesus. Em ambas as mãos apresenta estigmas, tal como São Francisco, esta contaminação iconográfica ${ }^{146}$, talvez decorrente da devoção popular, é incomum na representação de São Bernardino.

\footnotetext{
${ }^{144} \mathrm{O}$ culto ao nome de Jesus foi primeiro difundido por São Bernardo de Clairvaux que dizia que o "Nome de Jesus é mel na boca, musica nos ouvidos e alegria no coração". Depois foi São Francisco que reanimou a devoção inserindo-a na sua espiritualidade cristológica com repercussão em vários membros da ordem como Santo António, Santa Margarida de Cortona e São Ubertino de Casale e São Bernardino que foi o grande divulgador do trigrama antes de Santo Inácio de Loiola, por influência franciscana, o ter assumido como símbolo dos Jesuítas. Teixeira, Victor Gomes, "Entre a Devoção e o Sentimento, a Iconografia Franciscana Barroca. Algumas notas sobre S. Bernardino de Siena" in Fausto Sanches Martins (Coord.), Actas do II Congresso Internacional do Barroco, Porto, Faculdade de Letras da Universidade do Porto, 2003, pp. 691-700.
}

${ }^{145}$ Réau, Louis, Iconografia del arte cristiano - Iconografia de los santos, de la A a la F. Tomo 2 / Volumen 3, Barcelona, Ediciones del Serbal, 1997 (edição original 1955-1959), pp. 208-210. Muitas vezes foi representado idoso, sem barbas e como frade asceta segurando um disco com o anagrama ou segurando um livro, ou uma caveira. Carmona Muela, Juan, Iconografia de los santos, Madrid, Akal, 2008, pp. 50, 51. Sobre a representação dos episódios taumatúrgicos do santo ver: Kaftal, George, Iconography of the saints in central and south Italian schools of painting, Firenze, Casa Editrice Le Lettere, 1986, pp. 195-218. Kaftal não refere qualquer representação do episódio da renúncia dos cargos eclesiásticos.

${ }^{146}$ Além de São Francisco de Assis, também Santa Brígida da Suécia e Santa Catarina de Siena apresentam estigmas. Réau, Louis, Iconografia del arte cristiano. Iconografia de los santos. De la P a la 


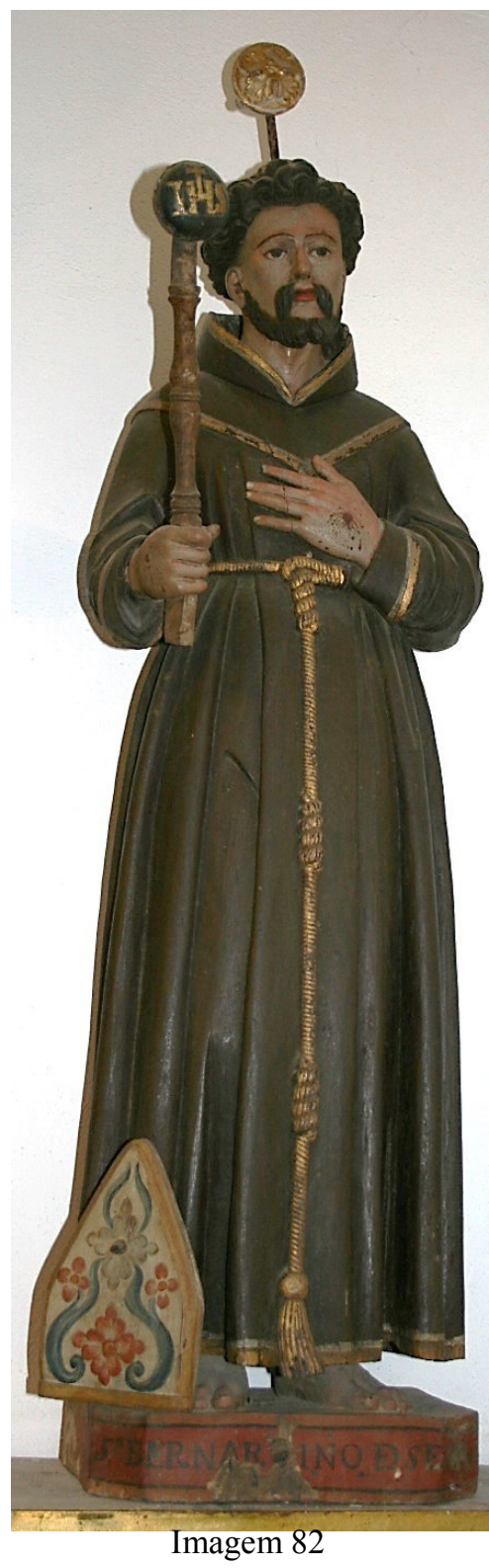

São Bernardino de Siena - SFM 13

Oficina local $\backslash$ regional; segundo quartel do século XVIII

Retábulo no lado da Evangelho Igreja de São Francisco, Mogadouro

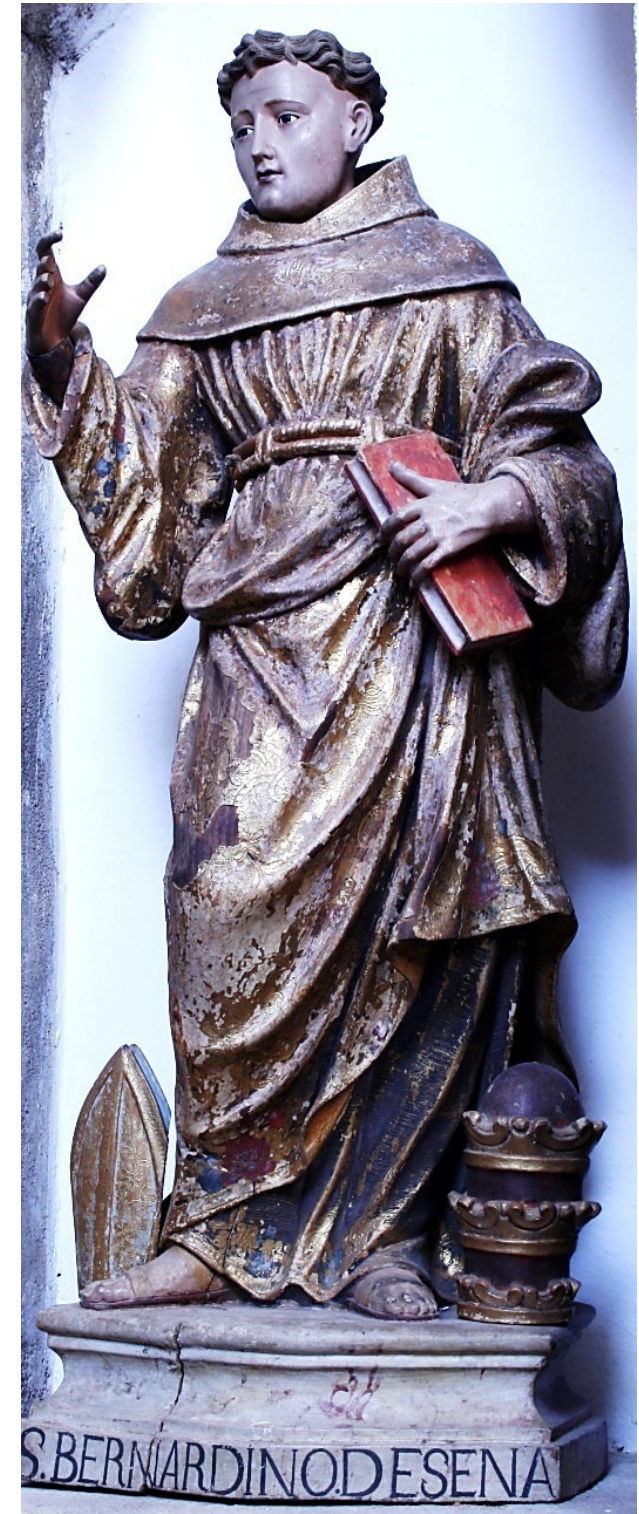

Imagem 83

São Bernardino de Siena - CSDV 01

Oficina portuguesa (Lisboa); terceiro quartel do século XVIII

Capela de Nossa Senhora das Dores, Igreja de Nossa Senhora da Encarnação, Vinhais

Julgamos que se pretende comunicar, com os sinais de martírio da Paixão de Cristo, a imitação com a vida e o sofrimento do Redentor na observância de São Bernardino.

Z - Repertorios. Tomo 2/ Volumen 5, Barcelona, Ediciones del Serbal, 2002 (primeira edição 1957), p. 538. Mas, São Bernardino, em nenhuma representação, exceto a que se encontra na igreja de Mogadouro, apresenta os estigmas. Poder-se-á tratar de uma transferência do atributo iconográfico de São Francisco com quem partilhava o ardor místico cristológico. Parece menos credível que se trate de uma escultura cuja invocação inicial tenha sido alterada de São Francisco de Assis para São Bernardino de Siena, no entanto a proximidade do gesto com o modelo iconográfico de São Francisco asceta e místico sugere também esta possibilidade. 
Junto aos pés descalços de predicador está, com sumario tratamento escultórico, a mitra como símbolo da dignidade eclesiástica rejeitada.

A estatueta de São Bernardino de Siena de Vinhais (Imagem 83) de técnica escultórica mais aprumada terá sido das primeiras imagens que os frades missionários trouxeram, possivelmente da casa mãe de Brancanes, tal como acontece com a escultura de São Boaventura (Imagem 81), colocada oposta a esta na capela das Dores do seminário de Vinhais.

A imagem tem lacuna de parte da mão direita, o que pode supor a lacuna do atributo iconográfico que sustinha. Mas tratando-se do afamado predicador e a culto no templo dos frades missionários, que valorizavam especialmente a predicação, julgamos que poderia estar apenas com a mão direita elevada privilegiando o gesto de pregação ${ }^{147}$. Em conjunto com o livro a Palavra dita, através da atrativa comunicação que São Bernardino, detém o poder de suscitar uma maior devoção a Cristo. Na mão esquerda segura um livro fechado, que tal como nas representações de Santo António sublinha a predicação do evangelho a que se dedicava São Bernardino. Aos pés tem colocado no lado direito a mitra e no esquerdo a tiara tríplice. A lenda da rejeição da dignidade episcopal chega a referir três dioceses, mas nada refere que justifique a tiara tríplice papal, também aqui se poderá tratar de uma contaminação, mas sendo uma obra de oficina terá sido antes por orientação do encomendador da escultura, para valorizar e amplificar o ato de rejeição de dignidades eclesiásticas de São Bernardino.

De rosto delicado e expressão suave o santo é jovem e está representado imberbe com gesto elegante e a refinado pregueado nas vestes que sustem sobre o lado esquerdo. Não é apenas o livro que evoca o santo como pregador, as aparatosas insígnias eclesiásticas valorizam os estatutos que São Bernardino rejeitou para se poder dedicar inteiramente à pregação evangélica. No seminário apostólico dos frades missionários a presença da escultura de São Bernardino de Siena, em conjunto com a se São Boaventura, ilustraria as devoções dos frades mas também as intenções do seminário, perante a comunidade, de pregar e ensinar.

\footnotetext{
${ }^{147}$ Fraga Sampedro, Maria Dolores, "Predicación e imágenes en los siglos finales de la edad media hispana" in Plenitudo Veritatis homenaje a Mons. Romero Pose, Santiago de Compostela, Instituto Teológico Compostelano, 2008, pp. 829-847.
} 


\section{SÃO PEDRO DE ALCÂNTARA}

Nasceu em Alcântara, Espanha em 1499, franciscano descalço reformou a ordem e foi diretor espiritual de Santa Teresa de Ávila, foi canonizado em 1669. A sua representação mais comum privilegia o hábito, a cruz, a caveira e a pomba inspiradora do seu dom profético e a disciplina que usava para se flagelar ${ }^{148}$.

Viveu em Portugal, onde, entre outros conventos, se estabeleceu na Serra da Arrábida e aí ajudou a fundar várias casas para os Arrábidos (ou Capuchos). Iniciou a reforma da Ordem dos Frades Menores Capuchinhos mediante as regras "alcantarinas", hoje conhecidas como de "Estrita Observância".

A única representação de São Pedro de Alcântara registada nos espaços franciscanos em estudo encontra-se na igreja do convento da ordem terceira regular de Mogadouro (Imagem 84). Tratando-se de um reformador da ordem de tanta significância dentro da família franciscana é diminuta a sua devoção nos templos da fronteira transmontana, estando ausente nas igrejas de Bragança e Vinhais $^{149}$.

A figura, formalmente com alguns

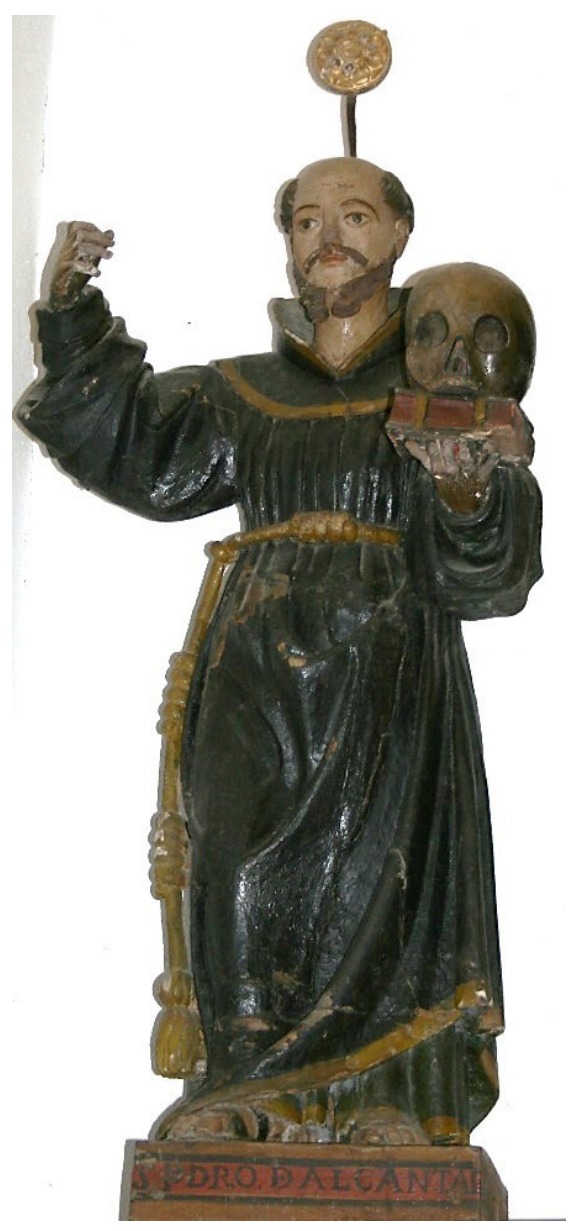

Imagem 84

São Pedro de Alcântara - SFM 15 Oficina local $\backslash$ regional; segundo quartel do século XVIII

Retábulo no lado da Evangelho Igreja de São Francisco - Mogadouro arcaísmos, tem lacuna do atributo que seguraria na mão direita. Na mão esquerda segura um livro, sobre o qual está pousada uma caveira ilustrando as virtudes do santo enquanto teólogo místico e pregador.

\footnotetext{
${ }^{148}$ Réau, Louis, Iconografia del arte cristiano. Iconografia de los santos. De la P a la Z - Repertorios. Tomo 2/ Volumen 5, Barcelona, Ediciones del Serbal, 2002 (primeira edição 1957), p. 74.

${ }^{149} \mathrm{Na}$ base de dados dos Bens Culturais da Igreja do secretariado nacional apenas estão registadas duas esculturas, ambas na arquidiocese de Évora e apenas uma apresenta o atributo da cruz. https://www.bensculturais.com/areas-de-actuacao/inventario acedida e 11 de junho de 2015
} 
Enverga o simples hábito franciscano e está representado em provecta idade, calvo com barbas e expressão grave.

A ausência de qualquer dos reformadores da ordem (São Bernardino de Siena e São Pedro de Alcântara) no templo dos frades menores de Bragança é notória face à presença de São Bernardino de Siena no convento da Ordem Terceira Regular de Mogadouro, e no Seminário Apostólico de Vinhais e de São Pedro de Alcântara em Mogadouro. Esta diversidade de devoções que se regista na imaginária dos reformadores reflete a diversidade de ramos e reformas na ordem que os conventos em estudo ilustram. 


\section{SÃO BENEDITO DE PALERMO}

São Benedito de Palermo, o "Mouro", franciscano, morreu em 1589, é representado com a pele negra e o cabelo ondulado, o seu atributo iconográfico mais comum é o coração de onde brotam sete gotas se sangue como símbolo das sete virtudes. Além do coração, posteriormente associou-se à imagem o atributo das rosas como representação do milagre da misericórdia. Numa releitura popular articulam a esperança de receber cuidado divino apesar de fazer parte de um grupo social privado do direito de poder sonhar $^{150}$.

O santo africano foi beatificado oficialmente em 1763 e canonizado no início do século XIX, em $1807^{151}$.

Apesar da tardia canonização já no século XVI se registava a sua devoção em Portugal, onde a primeira irmandade dedicada a São Benedito foi instituída no ano de 1609 na igreja de Santa Ana, em Lisboa ${ }^{152}$.

As confrarias a partir dos seus elos confraternais eram um excelente meio de aculturação para uma população a princípio desenraizada. Esta ideia de aculturação evangelizadora leva ao crescimento em todos os sentidos da devoção a Santos Negros. Por um lado, estes eram signo e sinal do domínio do cristianismo face aos gentios negros, por outro é antropologicamente percetível que a ideia de um santo a eles igual na cor criava nos negros uma empatia pela religião que os tinha acolhido. Assim, a imagem de um santo negro servia como agente e recetor de uma política de

\footnotetext{
${ }^{150}$ Réau, Louis, Iconografía del arte cristiano - Iconografia de los santos, de la A a la F. Tomo 2 / Volumen 3, Barcelona, Ediciones del Serbal, 1997 (edição original 1955-1959), p. 195; Renders, Helmut, "O coração como atributo hagiográfico de São Benedito do Rosário: hipótese sobre a sua origem e seu modelo subjacente da vida cristã", Horizonte. Dossiê Religiões Afro-brasileiras. vol. 13, n. 29, Belo Horizonte, Minas Gerais, Universidade Metodista de São Paulo, 2013, pp. 109-132.

${ }^{151}$ Reginaldo, Lucilene, “ "África em Portugal»: devoções, irmandades e escravidão no Reino de Portugal, século XVIII", História vol.28 no.1, São Paulo, Faculdade de Ciências Humanas e Sociais, 2009, pp. 289-319, citando (Butler, Alban “A vida dos santos". Petrópolis, Vozes, 1984, pp. 48-50.)

${ }^{152}$ Lahon refere que em 1620, uma escultura de São Benedito exposta no convento franciscano de Leiria originou diversos milagres, e outros se operaram no mesmo ano no convento de São Francisco de Porto, e o Geral da ordem remeteu uma relíquia de São Benedito para o convento de S. António de Trancoso. Lahon, Didier, "Esclavage, confréries noires, sainteté noire et pureté de sang au Portugal (XVIe--XVIIIe siècles)", Revista Lusitania Sacra, Lisboa, Centro de Estudos de História Religiosa - Universidade Católica Portuguesa, 2003, pp. 119-162; Renders, Helmut, "O coração como atributo hagiográfico de São Benedito do Rosário: hipótese sobre a sua origem e seu modelo subjacente da vida cristã", Horizonte. Dossiê Religiões Afro-brasileiras. vol. 13, n. 29, Belo Horizonte, Minas Gerais, Universidade Metodista de São Paulo, 2013, pp. 109-132.
} 
evangelização por parte do Império em crescente expansão numa comunidade multiétnica ${ }^{153}$.

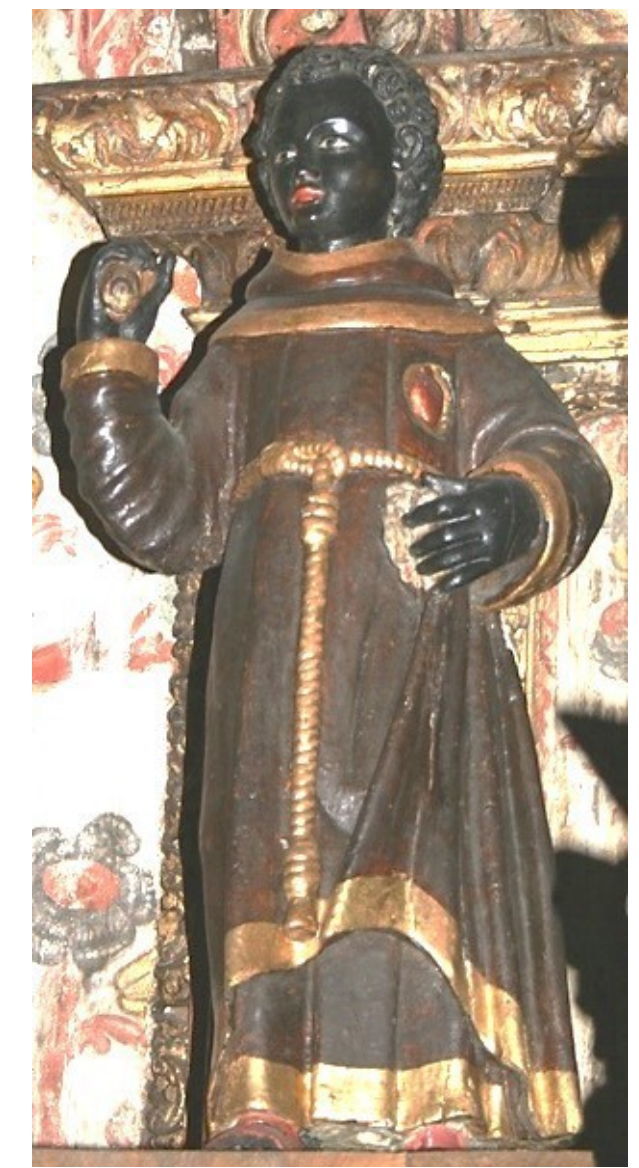

Imagem 85

São Benedito de Palermo - SFB 02

Oficina local $\backslash$ regional; primeira metade do século XVIII

Retábulo no lado da Epístola Igreja de São Francisco, Bragança

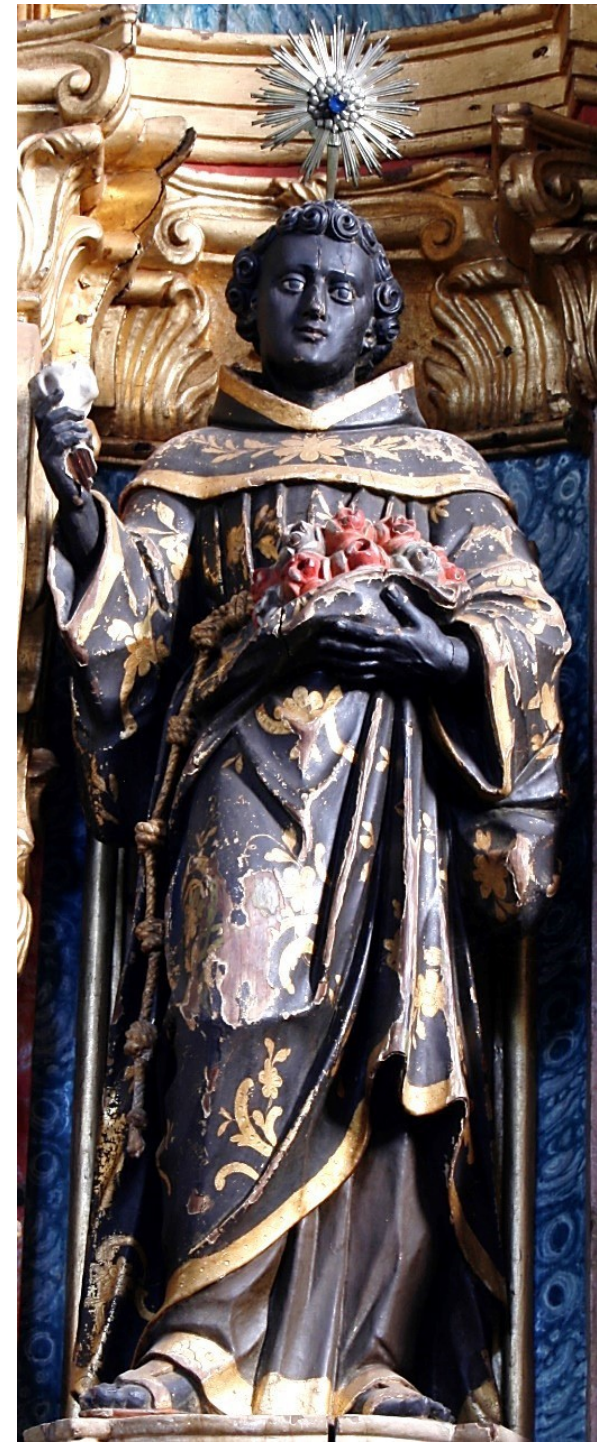

Imagem 86

São Benedito de Palermo - SFV 04

Oficina: Porto $\backslash$ Braga: último quartel do século XVIII

Retábulo no lado da Epistola Igreja de São Francisco, Vinhais

A devoção ao santo negro em Portugal advém da divulgação que a ordem franciscana lhe promove mas, não poderá ser dissociado da presença africana e crioula que se estende fora dos limites de Lisboa desde o início da época moderna.

\footnotetext{
${ }^{153}$ Lopes, Inês Afonso, "A Memória das Imagens: Os Santos Negros da Igreja de Santa Clara", Revista da Faculdade de Letras. Ciências e Técnicas do Património, vol. IX-XI, Porto, Faculdade de Letra da Universidade do Porto, 2010-2012, pp. 206-222.
} 
O culto a São Benedito de Palermo regista-se em Bragança e Vinhais pela presença de duas esculturas (Imagem 85 e 86).

A escultura de Bragança (Imagem 85) é formalmente mais arcaica ${ }^{154}$, tem fraturado o atributo que segurava na mão direita o que limita a leitura iconográfica do modelo. $\mathrm{Na}$ mão esquerda segura junto ao corpo um conjunto de rosas, também já parcialmente fraturado. Com simples hábito franciscano, o santo expõe sobre o peito o rubro coração $^{155}$ que saliente se destaca sobre o fundo escuro do hábito. De pele negra e desenhados caracóis apresenta uma expressão grave que os sucessivos repintes alteraram.

A escultura de Vinhais (Imagem 86), de rosto delicado, denota uma cuidada produção oficinal, com o hábito franciscano decorado com estufados dourados. Lamentavelmente também a escultura de Vinhais apresenta o atributo sustido na mão direita partido, e impercetível na sua forma. E já não expõe o rubro coração como símbolo das suas virtudes. Mas, tal como na imagem de Bragança segura junto ao corpo com a mão esquerda um conjunto de rosas. Este gesto em ambas as esculturas provoca um pregueado repuxado que deixa a descoberto a túnica que envergam sob o hábito.

As rosas terão seguramente origem na lenda que confere a virtude ao santo uma tão ampla generosidade que lhe obrigava a esconder (ou transformar em rosas) as suas esmolas. Igual narrativa se associa à medieval Rainha Santa Isabel de Portugal, sublinhando a catequização da caridade imposta em ambos os episódios.

A comum presença da representação de São Benedito de Palermo nos templos franciscanos (Porto, Guimarães, Ourense ${ }^{156}$ até Santiago de Compostela, citando alguns) denota o empenho da ordem na divulgação do culto ${ }^{157}$.

\footnotetext{
${ }^{154}$ Em 1721-24 era registado o altar de São Benedito mas sem qualquer referência a confrarias ou mesmo à escultura da devoção. Borges, José Cardoso, Memórias de Bragança, Fernando de Sousa (Coord.), Bragança, CEPESE / Câmara Municipal de Bragança, 2012 (texto original de 1721-1724), pp. 142, 143.

${ }^{155} \mathrm{Na}$ base de dados dos bens culturais da igreja estão registadas na arquidiocese de Évora, três esculturas a representar São Benedito, em duas das imagens o santo expõe o coração rubro. Na mesma base de dados surge ainda outra escultura de São Benedito, na diocese de Lamego, formalmente próxima da escultura de Vinhais, mas, já sem nenhum atributo.

Conforme pesquisa em https://www.bensculturais.com/areas-de-actuacao/inventario acedida a 11 de junho de 2015

${ }^{156}$ Fraga Sampedro refere, com base na documentação da desamortização, na igreja do convento de Ourense, entre outros, o culto a São Benedito de Palermo. Fraga Sampedro, Maria Dolores, San Francisco de Ourense. Análisis historico-artístico de la iglesia y convento . Ourense : Museo Arqueolóxico Provincial de Ourense-Grupo Marcelo Macías, 2002.

${ }^{157}$ Outros santos negros foram divulgados pela ordem franciscana. Na igreja de Santa Clara no Porto duas esculturas ilustram os cultos aos Santos Negros Carmelitas - Santo Elesbão e Santa Ifigénia.
} 
Observando em comparação as duas esculturas de Bragança e Vinhais percebe-se a alteração iconográfica que o modelo sofreu ao longo do seculo XVIII. O coração vermelho como símbolo das virtudes foi desaparecendo para dar lugar à narrativa do milagre das rosas valorizando a caridade do santo e o atributo que se reconhecia facilmente por acompanhar também as representações da rainha Santa Isabel.

Sobre estas duas obras leia-se A Memória das Imagens: Os Santos Negros da Igreja de Santa Clara do Porto, de Lopes, Inês Afonso na Revista da Faculdade de Letras. Ciências e Técnicas do Património. Porto, vol. IX-XI, 2010-2012, pp. 206-222.

Também Santo António de Noto é negro e franciscano. O seu culto foi sobretudo divulgado no Brasil. Lahon, Didier, "Esclavage, confréries noires, sainteté noire et pureté de sang au Portugal (XVIe--XVIIIe siècles)", Revista Lusitania Sacra, Lisboa, Centro de Estudos de História Religiosa - Universidade Católica Portuguesa, 2003, pp. 119-162. 


\section{SÃO PASCOAL BAILÃO}

Na igreja de São Francisco de Bragança está ainda hoje a culto uma imagem de São Pascoal Bailão. A devoção foi custosa de definir pois já estava perdida a sua identificação e trata-se de um santo franciscano, com pouca devoção nacional. Foi na documentação que encontramos os elementos que nos permitiram identificar a figura, que iconograficamente não segue os modelos mais comuns. A referência à "custódia com a relíquia de São Pascoal Baillão" ${ }^{158}$ permite-nos saber da devoção a São Pascoal Bailão, na capela de Nossa Senhora da Conceição da igreja de São Francisco de Bragança, que estará na origem da encomenda posterior da escultura para ilustrar o culto.

A figura enverga o hábito franciscano com o cíngulo, no entanto não se apresenta com tonsura. $\mathrm{O}$ atributo colocado na mão direita é impercetível na sua forma e parece tratarse de um postiço de recente acrescento. Na mão esquerda, segura junto ao corpo, um conjunto de ramas com folhas (Imagem 87). Este elemento poderá relacionar-se com a humilde função de hortelão que o santo assumiu ao entrar no convento, pese embora a sua ausência enquanto elemento iconográfico na maioria das representações. São Pascoal, nasceu em 1540 em Aragão e morreu em 1592. Era pastor e aprendeu a ler enquanto tomava conta dos rebanhos. O culto que o santo devotou à eucaristia é narrado na custódia como o seu elemento iconográfico mais comum. Foi beatificado em 1618 e canonizado em $1690^{159}$.

\footnotetext{
${ }^{158}$ No processo de reconhecimento dos administradores da capela de Nossa Senhora da Conceição A.N.T.T., C.S.F.B. Titollo de medição, e demarcação da capella, e inventatio dos paramentos della Cx. 1, Mç. 7, s sflo inventário descreve os diversos quadros vindos de roma que preenchiam o retábulo e as paredes cobertas de azulejo e o altar de pedra. Entre os objectos inventariados consta também uma custódia de Agnus Dei, outra custódia com a relíquia de São Pascoal Baillão, um cofre fechado com a relíquia de Santa Luzia, uma cruz de ébano em fragmentos, mas que o registo refere que ainda se podia concertar. Rodrigues, Luís Alexandre, Bragança no século XVIII. Urbanismo. Arquitectura, Volume I, Bragança, Junta de Freguesia da Sé, 1997, p. 425.

${ }^{159}$ Réau, Louis, Iconografia del arte cristiano. Iconografia de los santos. De la P a la Z - Repertorios. Tomo 2/ Volumen 5, Barcelona, Ediciones del Serbal, 2002 (primeira edição 1957), pp. 36, 36.

Francisco Manuel Alves, o Abade de Baçal e Monsenhor José de Castro referem, com fama de santidade, João Hortelão, natural de Valverde, Alfandega da Fé, pastor de gado que terá professado no convento de Santa Marina e depois em Salamanca onde morreu em 1499. Alves, Francisco Manuel, Bragança Memórias arqueológico-históricas do distrito de Bragança (2 ${ }^{a}$ edição) Os Notáveis -Tomo VII, Bragança, Câmara Municipal de Bragança / Instituto Português de Museus - Museu Abade de Baçal, 2000, (original publicado em 1910-1947), pp. 242, 243; Castro, José de, Bragança e Miranda, (Bispado) Tomo II, Porto, Tipografia Porto Médico, Ld ${ }^{\mathrm{a}}$, 1947, p. 301. No entanto não se verifica na documentação qualquer devoção a João Hortelão, pese embora as possíveis proximidades iconográficas estabelecidas pela rama com folhas descartamos esta possível identificação da figura.
} 


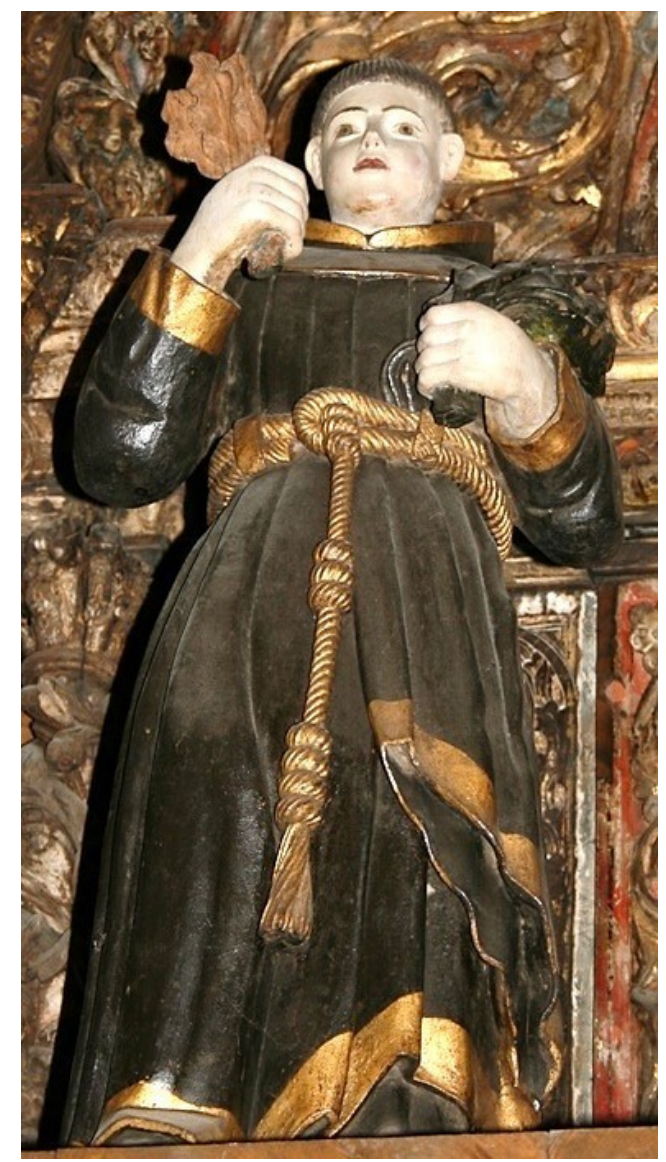

Imagem 87

São Pascoal Bailão, SFB 05

Oficina local $\backslash$ regional; Primeira metade do século XVIII

Retábulo no lado da Epístola Igreja de São Francisco - Bragança
A recente substituição do atributo da mão direita não nos permite saber se acaso o santo sustinha originalmente uma custódia ou um cálice como é usual na representação de São Pascoal Bailão.

A devoção é comum em Espanha, mas quase inexistente no território nacional. Tal como se percebe na devoção a São Vicente Ferrer, entre outras $^{160}$, a proximidade com a fronteira supôs alguma influência formal mas também devocional.

\footnotetext{
${ }^{160}$ Borges refere na igreja próxima de São Bento do convento das monjas beneditinas a devoção a Nossa Senhora dos Desamparados que "trouxeram os soldados, que militaram em Valença no nosso exército, que governava o marquês das Minas, a devoção de Nossa Senhora dos Desamparados, muito venerada naquela cidade por milagrosa. E trazendo a sua novena e uma estampa, por esta se mandou fazer a imagem e se lhe levantou altar". Borges, José Cardoso, Memórias de Bragança, Fernando de Sousa (Coord.), Bragança, CEPESE / Câmara Municipal de Bragança, 2012 (texto original de 1721-1724), p. 158.
} 


\section{SANTAS DA ORDEM DE SÃO FRANCISCO}

\section{SANTA ISABEL DA HUNGRIA OU DE PORTUGAL}

A representação das duas mulheres franciscanas é idêntica, não só por serem ambas do século XIII, mas por serem ambas da família real e partilharem até os mesmos milagres.

A Rainha Santa Isabel da Hungria era filha do rei André II da Hungria nasceu em 1207, casou na Turíngia e depois de enviuvar tomou o hábito da ordem terceira franciscana dedicando-se à vida ascética consagrada aos pobres e aos enfermos, foi canonizada apenas quatro anos após a sua morte em 1235. O seu culto, divulgado não só pelos franciscanos mas também pelos cavaleiros da ordem teutónica, logo no século XIII lhe acrescentou episódios e milagres. Dos diversos elementos iconográficos que a acompanham o mais recorrente na representação é o milagre das rosas, mas também a coroa e o livro ou o milagre do leproso que se converte em Jesus crucificado ${ }^{161}$.

A Rainha Santa Isabel de Portugal nasceu em Aragão em 1271, era sobrinha de Santa Isabel de Hungria e depois de enviuvar de D. Dinis deu entrada no convento das clarissas em Coimbra. A devoção à Rainha Santa foi amplamente divulgada em Portugal ${ }^{162}$, e entre outros milagres também se lhe relaciona o milagre das rosas, pela sua continuada caridade e atenção aos pobres e enfermos. Não só as clarissas mas

\footnotetext{
${ }^{161}$ Réau, Louis, Iconografia del arte cristiano; Iconografia de los santos De la G a la O; Tomo 2 / Volumen 4, Barcelona, Ediciones del Serbal, 1997 (Edição original 1955-1959), pp. 122-126; Ruiz Maldonado, Margarita, "San Luis de Tolosa a la luz de obras «trecentistas»" in SÉMATA, Ciencias Sociais e Humanidades, vol. 26, Santiago de Compostela, Universidade de Santiago de Compostela / Facultad de Geografía e Historia / Servicio de Publicaciones e Intercambio Científico, 2014, pp. 633-654; No Flos Sanctorum Santa Isabel de Hungria é registada nos santos extravagantes, acrescentada posteriormente à Lenda Dourada e a gravura que ilustra a sua narrativa privilegia a coroa. Usa uma coroa que lhe cinge a cabeça e outra coroa que sustem sobre as mãos. Campos, Hermão de e Rabelo, Roberto, Flos Sanctorum HO FLOS SANCTÕ[RUM] EM LINGOAJE[M] P[OR]TUGUE[S], Lisboa, Disponível na plataforma on-line da Biblioteca Nacional de Portugual http://purl.pt/12097, 1513, fl. CCXXII.
}

${ }^{162}$ Foi canonizada por Urbano VIII em 1626. Cardoso, Jorge, Officio menor dos sanctos de Portugal: tirado de breviarios, \& memorias deste reino, Lisboa, Pedro Crasbeeck, Disponível na plataforma on-line da Biblioteca Nacional de Portugal, http://purl.pt/14148, 1629, pp. 27, 27 v.; Ferreira-Alves, Joaquim Jaime, "Elementos para o estudo da arquitectura das duas primeiras capelas da Venerável Ordem Terceira de S. Francisco do Porto" in Revista da Faculdade de Letras, Ciências e técnicas de Património, I Série vol. 2., Porto, Faculdade de Letras da Universidade do Porto, 2003, pp. 347-364.

Tradicionalmente se refere que na viagem de Santa Isabel de Aragão para Portugal se incluiu uma estadia em Bragança tendo como pousada o convento de São Francisco. Finda a estadia a futura rainha teria agraciado com esmolas e mercês o convento. No entanto não existe, atualmente, nenhuma escultura da Rainha Santa no convento de São Francisco em Bragança a ilustrar esta devoção. Borges, José Cardoso, Memórias de Bragança, Fernando de Sousa (Coord.), Bragança, CEPESE / Câmara Municipal de Bragança, 2012 (texto original de 1721-1724), p. 142. 
também a ordem terceira a reivindicavam e a sua imagem é por vezes colocada próxima da imagem de Santa Clara de Assis.
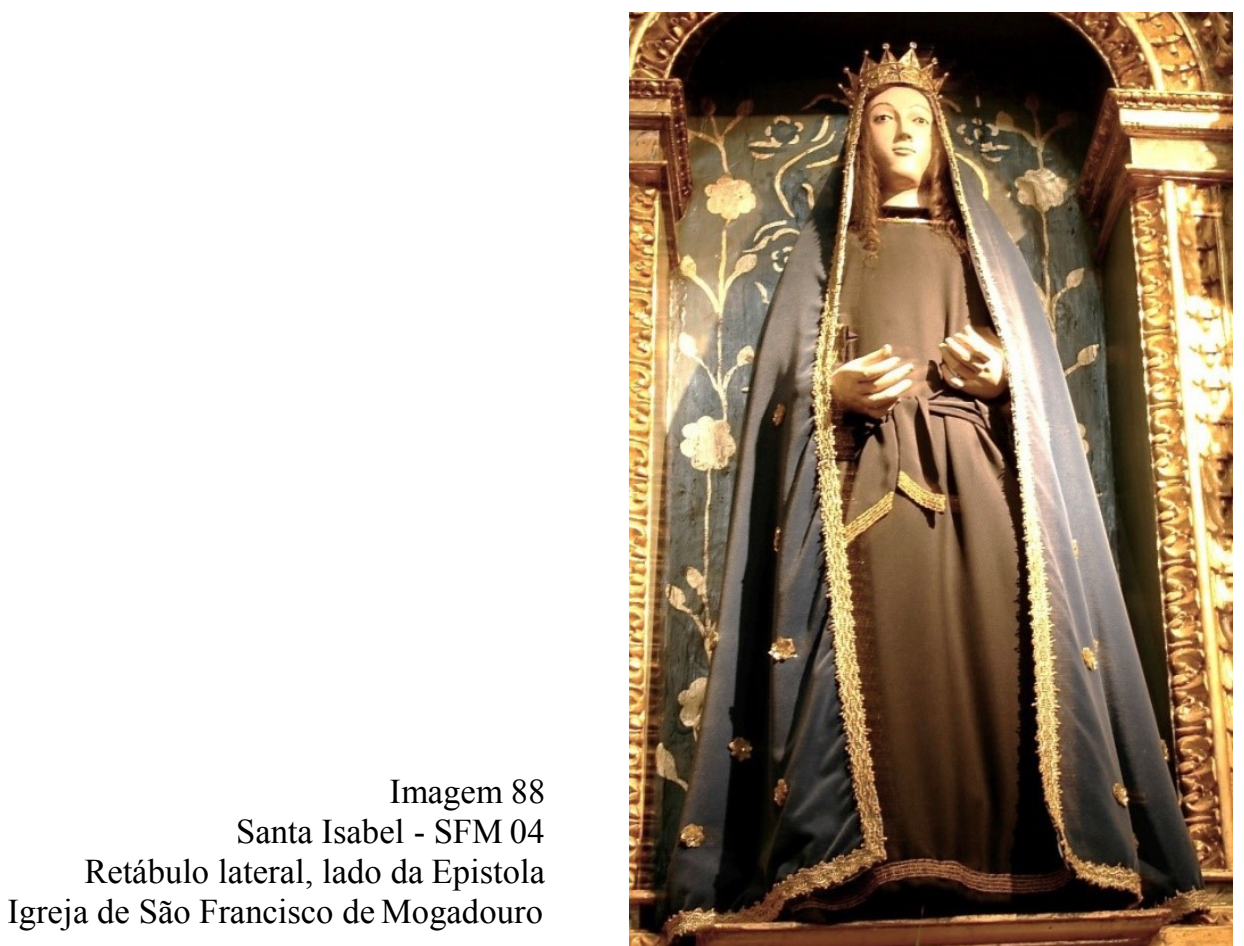

A escultura de Santa Isabel está ainda a culto na igreja de São Francisco em Mogadouro (Imagem 88). É uma imagem de roca e a sua identificação estava perdida. O reconhecimento da devoção advém do inventário de 1834 onde refere o segundo altar no lado da epístola com "três Imagens, Santa Izabel, São Bernardino, e São Pedro d'Alcantara"163. O registo não especifica se é Santa Isabel de Hungria ou Santa Isabel de Portugal, no entanto a designação mais comum de Santa Isabel de Portugal é simplesmente Rainha Santa, o que nos impele pensar que se a designação a refere apenas com Santa Isabel deverá ser a da Hungria. A imagem de Santa Isabel permanece no mesmo retábulo que ocupava em 1834, o mesmo já não ocorre com as restantes esculturas que a acompanhavam.

As proximidades entre a representação de Santa Isabel de Hungria e de Portugal não nos permitem assegurar qual das devoções a escultura representa. Ambos os cultos são comuns aos espaços franciscanos e o único atributo que a escultura ainda mantém, a coroa, é também comum a ambas as figuras.

163 A.N.T.T./A.H.M.F./S.F.M., Extinção das Ordens Religiosas - Convento de São Francisco em Mogadouro, Arquivo Nacional da Torre do Tombo, Lisboa, Arquivo Histórico do Ministério das Finanças, Processos de Extinção das casas religiosas, Cx. 2238, 1834, fl. 5. 
A imagem já não sustém nas mãos nenhum atributo, mas o gesto sugere que poderia suster as rosas do milagre com que mais comumente se representa Santa Isabel (quer a da Hungria quer a de Portugal). A presença da coroa sobre a cabeça é hoje o único elemento iconográfico que acompanha a escultura, que sendo de roca apenas apresenta a cabeça e as mãos trabalhadas. O traje negro que enverga e o manto azul que a cobre são recentes.

A devoção representada na imagem sugere ainda duvidas na sua identificação, o claro valor nacionalista que reveste muitos dos programas escultóricos desenvolvidos pós guerra da restauração enfatizam os santos nacionais, neste sentido seria provável tratarse de Santa Isabel de Portugal. Porém, o convento de Mogadouro era da ordem terceira o que vincularia mais facilmente a escultura com a devoção a Santa Isabel da Hungria pois foi irmã terceira.

A devoção representada na escultura de roca de Mogadouro é incerta mas as virtudes que ilustra são próximas, quer se trate da monarca da Hungria ou da monarca portuguesa, expressam a caridade, a atenção e o cuidado aos necessitados que ambas as virtuosas rainhas medievais prodigaram. A importância, sobretudo da Ordem Terceira, na divulgação dos modelos de virtude dos mendicantes foi amplamente acolhida por diversos membros das famílias reais europeias, conforme se expressa desde a escultura funerária medieval ${ }^{164}$.

\footnotetext{
${ }^{164}$ Não só o modelo de virtude da Ordem Franciscana mas também da dominicana granjeou especial devoção. O carácter apotropaico que envolve os santos fundadores das respetivas ordens provocou múltiplos exemplos de proximidade das ordens no âmbito dos rituais fúnebres desde a idade média. Ruiz Maldonado, Margarita, "El sepulcro de doña Beatriz de Portugal en Sancti Spiritus (Toro)", in Goya, no. 237, 1993, pp. 142-148; Ruiz Maldonado, Margarita, "Consideraciones iconográficas en torno al sepulcro de la Reina Santa. Santa Clara (Coimbra)", in VII Simposio Hispano-Portugués de Historia del Arte, Cáceres, 1995, pp. 17-24; Fraga Sampedro, Maria Dolores, "El arte gótico mindoniense (siglos XII-XV): mendicantes, parroquiales y capillas", in Anuário de estudos histórico-teológicos de la diócesis de Mondoñedo-Ferrol n ${ }^{\circ} 15$, Fundación Caixa Galicia, 1999, pp. 411-457.
} 


\section{SANTA ROSA DE VITERBO}

Rosa de Viterbo nasceu em 1235 e morreu muito jovem, apenas com 18 anos, foi canonizada em 1457. Taumaturga desde a infância quando milagrosamente terá ressuscitado uma familiar, também se lhe atribui o milagre das rosas e difíceis conversões, foi franciscana da ordem terceira. Desterrada por Frederico Barba roxa da sua cidade de Viterbo, por constantemente se opor às ordens do imperador, pode voltar após a morte do imperador que ela predissera. O seu principal atributo são as rosas em que teria transformado o pão para as esmolas ${ }^{165}$.

A única imagem de Santa Rosa de Viterbo a culto, nos espaços franciscanos da fronteira transmontana, encontra-se na única igreja da ordem terceira secular construída neste território, a igreja de São Francisco de Vinhais (Imagem 89).

A figura enverga o hábito franciscano intensamente decorado com estufados dourados. Ambos os atributos que seguraria nas mãos estão fraturados e perdidos, limitando assim a narrativa iconográfica que ilustraria. No entanto, pelo gesto não parece representar o milagre das rosas conforme tradicionalmente é exposta. O mesmo milagre está também relacionado com a devoção a São Benedito de Palermo (Imagem 86). A escultura de São Benedito partilha atualmente o retábulo com a escultura de Santa Rosa de Viterbo, o que poderá ter definido a narrativa iconográfica da jovem santa.

A escultura detalhadamente trabalhada representa a jovem com expressão grave e olhar baixo contrastando com a intensidade atmosférica que lhe envolve os panejamentos.

\footnotetext{
${ }^{165}$ Croiset, João, Anno Christão ou exercicios devotos para todos os dias do anno. Tomo III, Porto, Editor - Antonio Dourado, 1887, pp. 450-451; Réau, Louis, Iconografia del arte cristiano. Iconografia de los santos. De la P a la Z - Repertorios. Tomo 2/ Volumen 5, Barcelona, Ediciones del Serbal, 2002 (primeira edição 1957), p. 156.

Kaftal refere não só as rosas no regaço mas também em coroa sobre a cabeça, e o crucifixo na mão esquerda, descreve Rosa de Viterbo como jovem fidalga medieval. Kaftal, George, Iconography of the saints in central and south Italian schools of painting, Firenze, Casa Editrice Le Lettere, 1986, p. 975.
} 


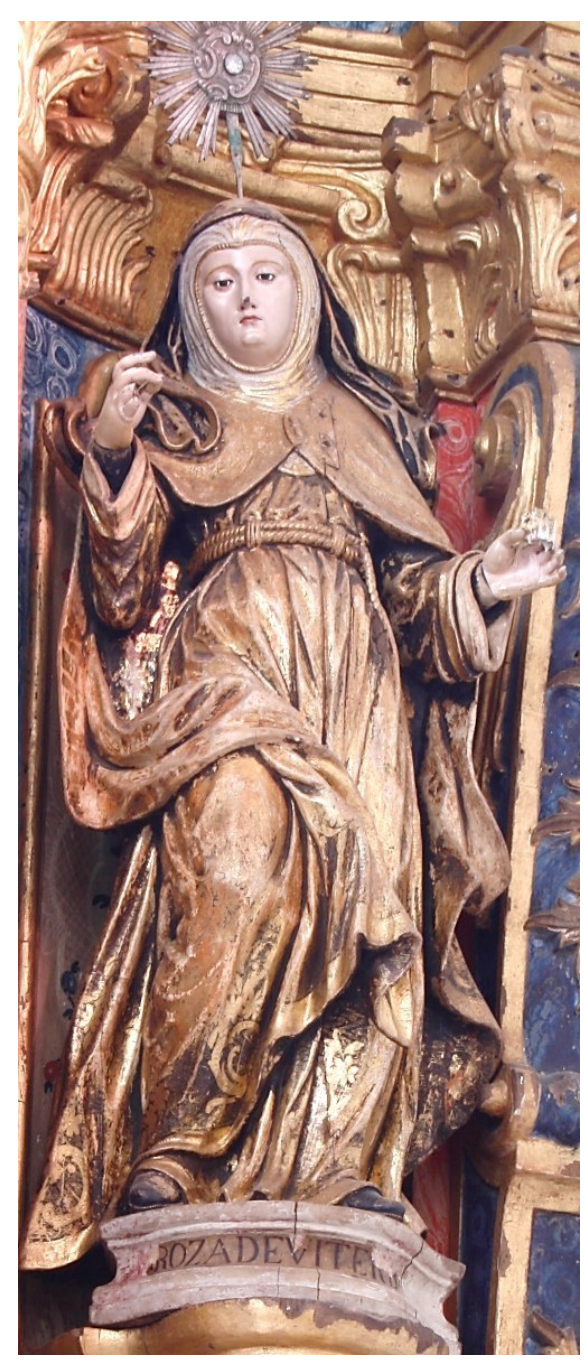

Imagem 89

Santa Rosa de Viterbo - SFV 02

Oficina: Porto\Braga: último quartel do século XVIII

Retábulo no lado da Epistola

Igreja de São Francisco, Vinhais

A igreja da ordem terceira secular de Vinhais é de todos os templos franciscanos aquele onde se observa maior número de representações femininas além do culto mariano, divulgaram também as devoções femininas franciscanas. $\mathrm{O}$ facto de estas esculturas se tratarem de encomendas privadas, dos membros leigos da ordem, poderá justificar esta alteração ao padrão, claramente mais masculino e escassamente representativo da família franciscana feminina nos restantes templos em estudo. 


\section{SANTA MARGARIDA DE CORTONA}

Margarida nasceu na Toscana, depois da morte do amante e de uma vida mundana a bela jovem ingressou na ordem terceira franciscana dedicando-se à oração em extrema austeridade e sacrifício. Representada como jovem terceira franciscana, os seus atributos mais comuns são os símbolos de penitência, a caveira, o cilício e as varas que aludem também à penitência. Beatificada em 1623 foi canonizada em $1728^{166}$.

É também no templo da ordem terceira de Vinhais que se encontra a culto a única representação de Santa Margarida de Cortona (Imagem 90).

Imagem 90

Santa Margarida de Cortona - SFV 12

Oficina: Porto\Braga: último quartel do século

XVIII

Retábulo no lado do Evangelho Igreja de São Francisco, Vinhais

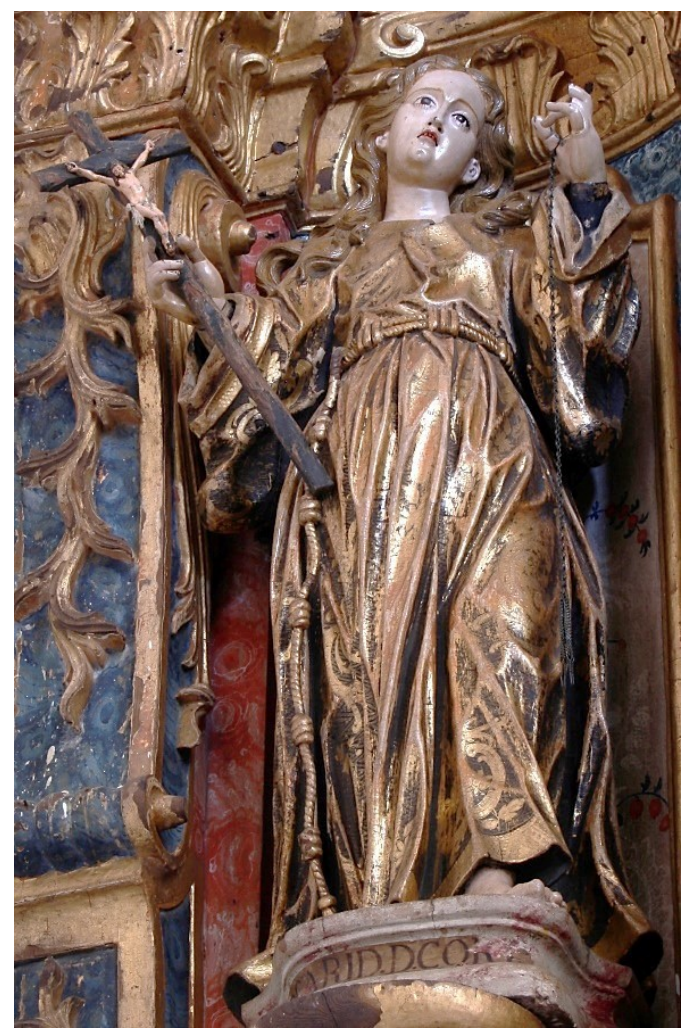

\footnotetext{
${ }^{166} \mathrm{O}$ rosário, ou um conjunto de contas e uma pedra são também referidos como atributos de Santa Margarida. Morreu a 22 de fevereiro de 1297. Kaftal, George, Iconography of the saints in central and south Italian schools of painting, Firenze, Casa Editrice Le Lettere, 1986, p. 738; Réau afirma que nasceu em 1247: Réau, Louis, Iconografia del arte cristiano. Iconografia de los santos. De la $P$ a la Z Repertorios. Tomo 2/ Volumen 5, Barcelona, Ediciones del Serbal, 2002 (primeira edição 1957), p. 497. No Anno Christão a data de nascimento referida é 1249. Croiset, João, Anno Christão ou exercicios devotos para todos os dias do anno. Tomo I, Porto, Empreza d'obras populares illustradas, 1885, pp. 347349 .

No final da vida recolheu-se numa cela entre êxtases e orações onde dava conselhos, orientações e conforto, entre os devotos que acorreram a Cortona ouvir a santa esteve Dante Alighiéri. Ferrini, Giuliano e Ramírez, José Guillermo, Santos franciscanos para cada dia, I Volume, Braga, Editorial franciscana, 2001, p. 188.
} 
A escultura representa Santa Margarida jovem, de cabelos loiros, soltos sobre os ombros. Enverga a túnica do hábito franciscano, profusamente decorada com estufados dourados e cingida por cíngulo com cinco nós.

Ao contrário das representações mais comuns ${ }^{167}$ que a cobrem com coifa e véu sobre a cabeça, a escultura de Vinhais valoriza a afamada beleza física da santa. De rosto delicado e farta cabeleira solta é na tensão do olhar elevado que o êxtase penitente da figura é realçado. Descalça, segura na mão direita o crucifixo e na esquerda o cilício para mortificar o corpo. O contraste entre a beleza física e a penitência que sacrifica o corpo é ilustrada nesta figura feminina cuja santidade lhe advém após uma vida mundana.

Não só o modelo iconográfico da representação de Santa Margarida de Cortona é invulgar como a sua devoção é escassa nos templos em estudo. O templo da ordem terceira de Vinhais é singular nas devoções, mas sobretudo nos modelos iconográficos eleitos para as representar. Tal como na representação de Santa Rosa de Viterbo, a escultura de Santa Margarida de Cortona destaca o reforço nas devoções femininas franciscanas, apesar de ambas as figuras representarem percursos de vida quase antagónicos o caminho de penitência e oração que elegeram aproxima-as. A pluralidade de exemplos, de virtuosismo feminino é mais forte na igreja dos terceiros seculares de Vinhais que em qualquer dos outros templos em estudo, este acréscimo nas devoções é forçoso relaciona-lo com a ação apostólica dos leigos em detrimento dos religiosos, cujos templos expõem escassas representações femininas franciscanas.

\footnotetext{
${ }^{167}$ As esculturas que representam Santa Margarida de Cortona são escassas em Portugal (conforme pesquisa nas bases de dados nos museus nacionais: http://www.matriznet.dgpc.pt/MatrizNet/Home.aspx, e no bens culturais da igreja http://bensculturais.inwebonline.net/e;) e o modelo mais comum ilustra a santa com hábito franciscano completo, com a cabeça coberta pela coifa, véu e capa sobre os ombros (esculturas do Museu Gão Vasco)
} 


\section{SANTOS DESAFETOS À ORDEM DE SÃO FRANCISCO}

\section{SÃO MIGUEL ARCANJO}

A devoção a São Miguel Arcanjo apenas se regista em Vinhais. Uma das esculturas está exposta no museu de Arte Sacra (Imagem 91) a outra escultura está ainda a culto na igreja do seminário apostólico (Imagem 92).

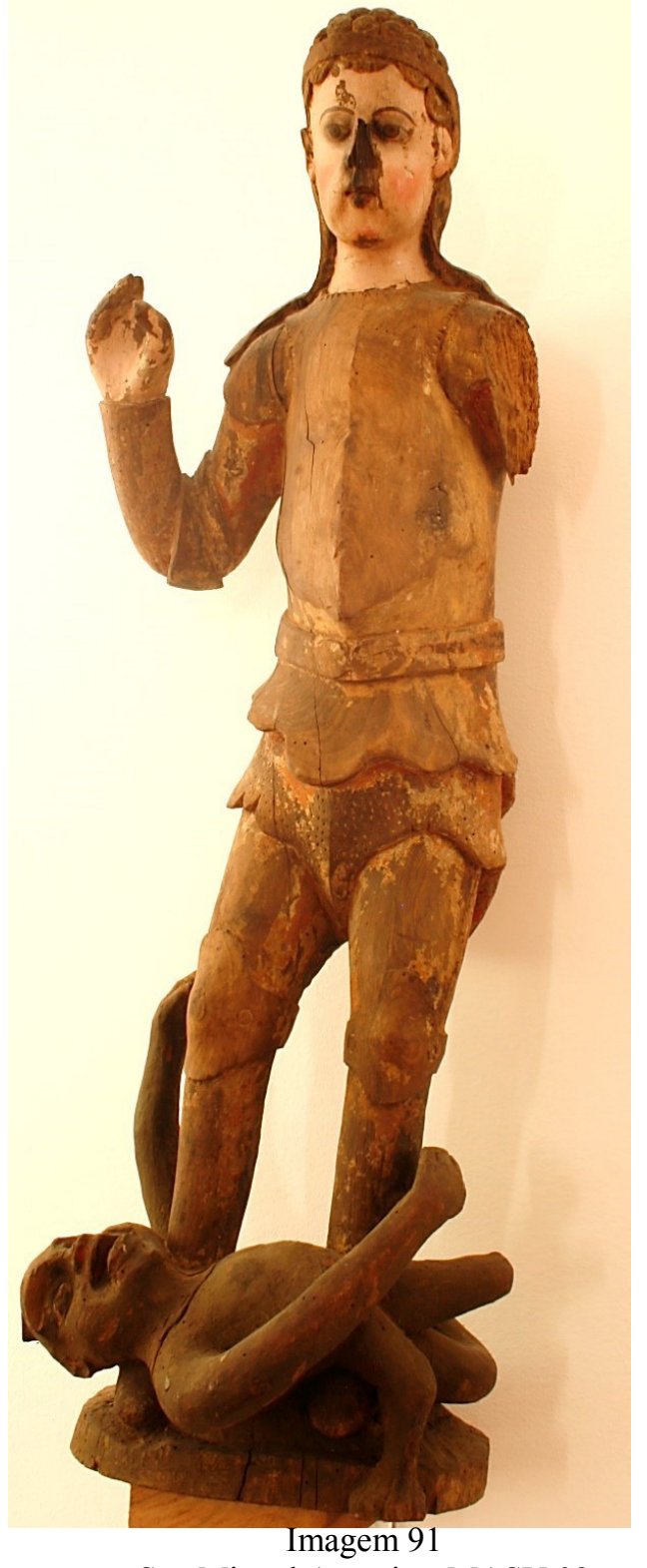

São Miguel Arcanjo - MASV 03

Oficina nacional; finais do século XV início do século XVI

Museu de Arte Sacra, Vinhais

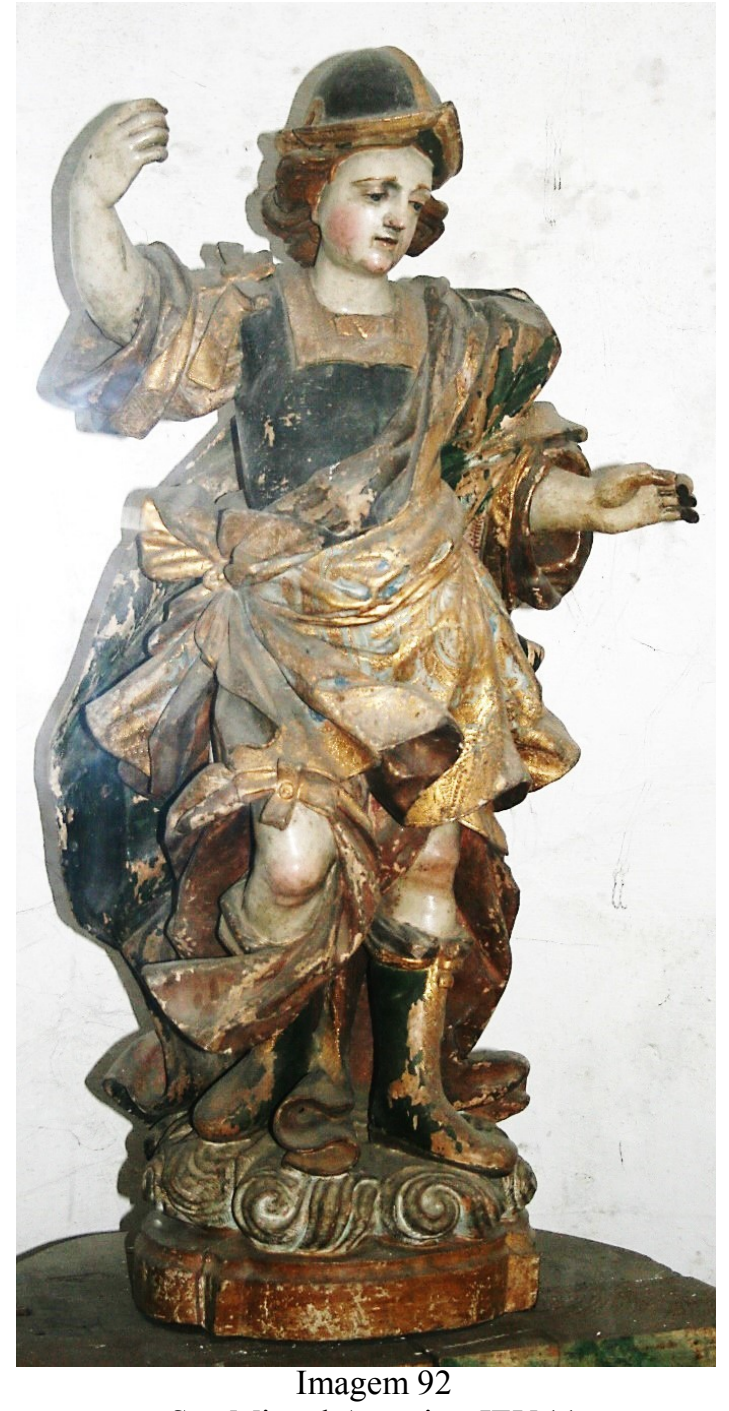

São Miguel Arcanjo - IEV 11

Oficina nacional; segunda metade do século XVIII No lado do Evangelho

Igreja de Nossa Senhora da Encarnação, Vinhais 
Os arcanjos pertencem à terceira hierarquia angélica e caracterizam-se por levar a cabo missões ou mensagens concretas e definidas aos homens. São Miguel Arcanjo venceu e expulsou Lucifer e tem como função pesar as almas no dia do Juízo Final, realizou vários milagres e aparições que se ilustram em diversos episódios. Os atributos iconográficos mais comuns são a armadura e a espada, a balança e o demónio encadeado. É representado como jovem e belo cavaleiro ${ }^{168}$.

As várias referências onde São Miguel surge citado na Bíblia privilegiam a sua capacidade de defender e guiar o povo bem como a luta que venceu em que expulsou o demónio e os seus anjos do céu.

Já nenhuma das esculturas apresenta as asas, atributo comum na representação do arcanjo, nem os restantes atributos que acompanham a representação.

É desconhecido o lugar em que originalmente estaria a culto a escultura exposta no museu (Imagem 91). Na medida em que os franciscanos apenas se estabelecerem em meados do século XVIII, e a produção da escultura terá sido realizada em finais do XV ou inícios do XVI julgamos que terá sido trazida para o seminário de outro local de culto $^{169}$. A escultura de marcado arcaísmo no gosto medieval que ilustra apresenta o arcanjo vestido com armadura completa, com couraçado, e proteção nos joelhos e cotovelos. A cabeça, descoberta e com os longos cabelos sobre os ombros cingida sobre a frente com uma decorativa fita. O gesto é contido e a expressão grave contrastando com o retorcido corpo do demónio aos seus pés. A ausência dos atributos que seguraria nas mãos empobrece a leitura da narrativa, mas a vitoria do jovem arcanjo sobre Lucifer ilustrava a devoção a São Miguel enquanto psicopompo. A figura retorcida do demónio caracteriza-se pelo aspeto grotesco. Tem a boca amplamente rasgada e ainda se observa parte dos chifres e da coloração vermelha que o cobria. A cor vermelha, comum nas

\footnotetext{
${ }^{168}$ Kaftal, George, Iconography of the saints in central and south Italian schools of painting, Firenze, Casa Editrice Le Lettere, 1986, pp. 787-791; Carmona Muela, Juan, Iconografia cristiana, Madrid, Akal, 2010, p. 68.

Também no Flos Sanctorum se privilegia esta narrativa, o Arcanjo enverga armadura e empunha a espada e a balança enquanto pisa uma figura de demónio. Campos, Hermão de e Rabelo, Roberto, Flos Sanctorum HO FLOS SANCTÕ[RUM] EM LINGOAJE[M] P[OR]TUGUE[S], Lisboa, Disponível na plataforma on-line da Biblioteca Nacional de Portugual http://purl.pt/12097, 1513, fl. CXLIII.

${ }^{169}$ A imagem foi encontrada na sacristia da igreja de Nossa Senhora da Encarnação do Seminário Apostólico de Vinhais, conforme: Gomes, José Manuel (Coord.), Imagens e escultura. 1545-1995 Comemorações Jubilares dos 450 Anos da Diocese de Bragança - Miranda, Bragança, Departamento de Liturgia e Património Cultural da Diocese de Bragança - Miranda e Comissão de Arte Sacra, 1996, pp. 14,15 .
} 
representações do demónio, evoca o dragão apocalíptico, mas também o sangue dos mártires e o fogo que abrasa ${ }^{170}$.

O culto medieval ao Arcanjo São Miguel enquanto guia das almas junto de Deus no Juízo Final relacionava-se com o juízo do coletivo através da confissão pública. Devoção que no final da idade média foi gradualmente substituída por diferentes invocações marianas acompanhando a alteração da confissão pública para a confissão individual $^{171}$.

Esta alteração não significou porém o desaparecimento da devoção a São Miguel. A escultura ainda a culto no interior do templo de Nossa Senhora da Encarnação terá sido encomendada a uma oficina já na segunda metade do século XVIII, e seguramente a pedido dos frades missionários, pois o inventário de 1834 registava a escultura de São Miguel na desaparecida capela do claustro do seminário ${ }^{172}$.

Apesar do distanciamento temporal que separa a produção das duas esculturas, a narrativa que evocam é semelhante.

A escultura do Arcanjo São Miguel ainda a culto (Imagem 92) enverga também um traje militar, menos operacional pois o amplo manto traçado sobre a cintura e que lhe envolve o corpo define um aspeto mais palaciano que bélico, mas o elmo e as botas altas identificam a figura apetrechada para combate. A ausência de atributos é, mais uma vez, fortemente limitadora da leitura iconográfica da escultura. A espada e a balança seguramente seriam sustidas nas mãos evocando a função de pesar as almas no dia do Juízo Final que lhe é atribuída. O jovem arcanjo apresenta os cabelos curtos e expressão grave com olhar baixo.

Ambas as esculturas destacam a mestria combativa do arcanjo que venceu Lucifer e simultaneamente a sua função enquanto guia dos homens perante a morte e o Juízo Final.

\footnotetext{
${ }^{170}$ López Vázquez, José Manuel, "Hablemos de ángeles calvos, demonios pelones y figur,s grotescas en la escultura barroca gallega" in IMAGO Revista de Emblemática y Cultura Visual, Núm. 6, disponível em: https://ojs.uv.es/index.php/IMAGO/article/view/3925, 2014, pp. 39-64.

171 Almeida, Carlos Alberto Ferreira de, "O culto a Nossa Senhora, no Porto, na época moderna: perspectiva antropológica", Revista de História, vol. 2, Porto, Faculdade de Letras da Universidade do Porto, 1979, pp. 159-173.

Também Réau referia esta substituição que se opera nos alvores da época moderna nas devoções de santos por novas devoções marianas Réau, Louis, Iconografía del Arte Cristiano. Iconografía de la Biblia - Nuevo Testamento Tomo 1/ Volumen 2, Barcelona, Ediciones del Serbal, 1996, (Edição original 19551959), p. 124.

172 A.N.T.T./A.H.M.F./S.N.S.E.V., Extinção das Ordens Religiosas - Seminário de Nossa Senhora da Encarnação - Vinhais, Arquivo Nacional da Torre do Tombo, Lisboa, Arquivo Histórico do Ministério das Finanças, Processos de Extinção das casas religiosas, Cx. 2265, 1834, s/fl.
} 


\section{SÃO PEDRO APÓSTOLO}

A única representação que se encontra nos espaços franciscanos em estudo de São Pedro Apóstolo está na igreja de São francisco de Mogadouro (Imagem 93). Tratandose de uma das figuras basilares da igreja católica surpreende a escassez de esculturas a ilustrar a sua devoção.

Simão, que recebeu de Jesus o nome de Pedro, como símbolo da pedra angular que seria para a igreja, foi em conjunto com o seu irmão André, o primeiro apóstolo recrutado por Cristo. Acompanhou Jesus durante a Sua vida e depois da morte de Jesus foi preso em Jerusalém, daí teria viajado a Roma onde foi o primeiro bispo da cidade, e de novo prisioneiro foi crucificado por ordem do imperador Nero. O culto a São Pedro foi imediato e propagou-se enquanto fundador do papado e enquanto porteiro do Paraíso vinculando as devoções oficiais com as mais populares. A representação mais comum de São Pedro caracteriza-se por uma figura de meia-idade, calva, apenas com uma madeixa sobre a frente, destacando a tonsura que recorda o primeiro sacerdote. $\mathrm{O}$ cercilho evoca a coroa de espinhos de Jesus Cristo. A barba encaracolada é sempre curta. Os atributos que o acompanham são múltiplos, ilustrando as diversas narrativas que lhe estão relacionadas ${ }^{173}$. A indumentária era, segundo Réau, inicialmente constituída pela túnica dos apóstolos, mas a partir da idade média, a representação papal com os ornamentos pontifícios vai gradualmente sendo a eleita, convertendo-se em regra a partir do século $\mathrm{XV}^{174}$. Contrariamente ao que afirma Réau, em Portugal são mais comuns as imagens que representam São Pedro com as vestes de Apóstolo, mesmo depois do século $\mathrm{XV}$, que as que representam São Pedro com os atributos pontifícios.

\footnotetext{
${ }^{173}$ Kaftal refere que o aspeto físico de São Pedro se manteve com poucas alterações, no entanto os atributos e indumentárias variaram significativamente dada a profusão de episódios que se lhe associam. Kaftal, George, Iconography of the saints in central and south Italian schools of painting, Firenze, Casa Editrice Le Lettere, 1986, p. 875.

${ }^{174}$ Réau, Louis, Iconografia del arte cristiano. Iconografia de los santos. De la P a la Z - Repertorios. Tomo 2/ Volumen 5, Barcelona, Ediciones del Serbal, 2002 (primeira edição 1957), pp. 43-51.

As três gravuras que representam São Pedro no Flos Sanctorum privilegiam também as vestes humildes de apóstolo e o par de chaves na mão esquerda. Campos, Hermão de e Rabelo, Roberto, Flos Sanctorum HO FLOS SANCTÕ [RUM] EM LINGOAJE[M] P[OR]TUGUE[S], Lisboa, Disponível na plataforma online da Biblioteca Nacional de Portugual http://purl.pt/12097, 1513, fl. XLVIII.
} 


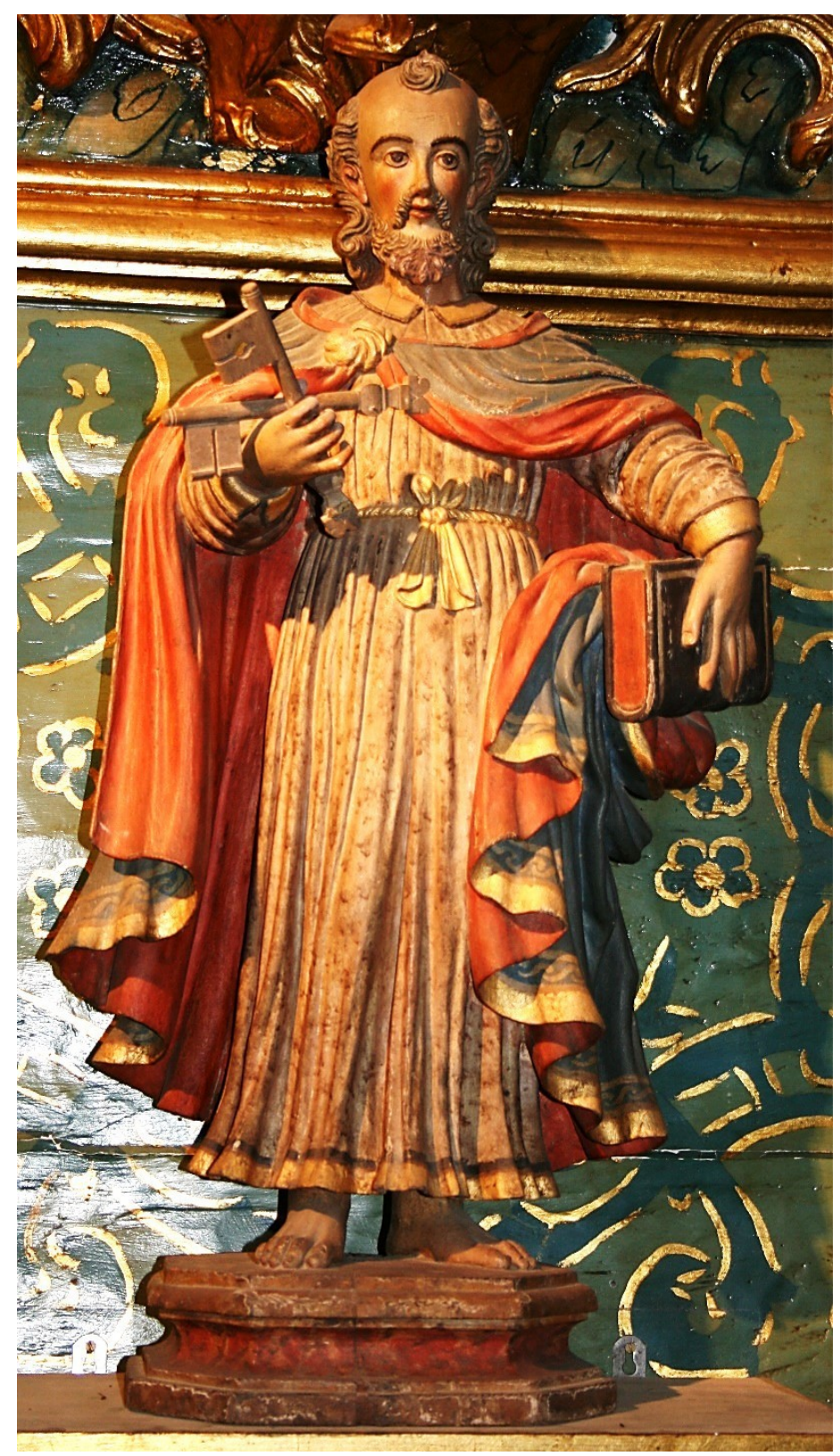

Imagem 93

São Pedro Apóstolo - SFM 14, retábulo no lado do Evangelho Oficina regional $\backslash$ local: segunda metade do século XVIII Igreja de São Francisco Mogadouro

A escultura de São Pedro da igreja de São Francisco de Mogadouro privilegia a narrativa de Pedro apóstolo e pregador. De claro perfil popular, valorizando a iconografia mais que a forma, apresenta-se calvo, envergando túnica e descalço, segura na mão direita um par de chaves. Este elemento iconográfico é o mais recorrente nas representações escultóricas, bem como, o mais popular. As chaves evocam a passagem de Mateus ${ }^{175}$ em que Jesus após ser reconhecido por Pedro como o Filho de Deus Vivo

${ }^{175}$ Mateus, Mt 16, 18, Bíblia Sagrada, Lisboa, Difusora bíblica (Missionários capuchinhos), $14^{\mathrm{a}}$ edição, 1988. 
lhe responde «Tu és Pedro, e sobre esta Pedra edificarei a Minha Igreja e as portas do inferno nada poderão contra ela. Dar-te-ei as chaves do reino dos céus, e tudo quanto ligares na terra ficará ligado nos céus, e tudo quanto desligares na terra será desligado nos céus.»

As duas chaves que Pedro ostenta na mão direita constituem o atributo bíblico que lhe confere o poder de, através da Igreja, ligar, ou desligar, o céu e a terra. Mas as chaves são também a insígnia que popularmente o identifica como porteiro do Paraíso. Na mão esquerda segura o livro fechado, a palavra sagrada das escrituras que identifica Pedro enquanto pregador.

Em 1834 a escultura de São pedro tinha altar próprio e estava colocada no retábulo do lado da epístola imediatamente depois do altar das almas privilegiando nessa aproximação o poder de mediar a entrada das almas nos céus.

No terceiro, hum retablo, com seu painel das almas, e hum crucifixo.

No quarto e ultimo; Imagem de São Pedro, e hum crucifixo ${ }^{176}$.

176 A.N.T.T./A.H.M.F./S.F.M., Extinção das Ordens Religiosas - Convento de São Francisco em Mogadouro, Arquivo Nacional da Torre do Tombo, Lisboa, Arquivo Histórico do Ministério das Finanças, Processos de Extinção das casas religiosas, Cx. 2238, 1834, fl. 5. 


\section{SÃO VICENTE}

São Vicente de Huesca foi diácono e mártir. A chegada milagrosa dos seus restos mortais à cidade de Lisboa transformaram-no numa importante figura nas devoções portuguesas.

Nascido em Aragão foi martirizado em 304 durante a perseguição que Diocleciano e Maximiliano moveram nas Espanhas. O seu martírio foi popularizado por Santo Agostinho e pelo poeta espanhol Prudêncio que registou os diversos suplícios e torturas que o santo sofreu em vida até à fogueira onde sucumbiu, e as várias privações a que submeteram o cadáver sem sepultura, que milagrosamente se salvou de ser devorado pelos animais. O seu corpo teria em 1173 sido trasladado para o proteger das invasões islâmicas. $\mathrm{O}$ navio que o transportava quase não resistia à viagem, e depois de um incidente na costa algarvia, próximo ao Cabo de São Vicente, um par de corvos grasnando acompanharam a embarcação até chegar ao porto seguro de Lisboa, sendo os restos do Santo Mártir depositado na catedral sempre acompanhados pelos $\operatorname{corvos}^{177}$.

O santo representado com vestes de diácono comummente apresenta a palma, como símbolo do martírio ${ }^{178}$. As representações de São Vicente em Portugal privilegiam a narrativa do seu traslado milagroso até Lisboa, com os corvos sobre a embarcação.

A escultura atualmente exposta no Museu de Arte Sacra de Vinhais ${ }^{179}$ (Imagem 94) evoca o santo mártir na sua relação com Portugal e mais concretamente com Lisboa.

\footnotetext{
${ }^{177}$ Réau refere três igrejas que reclamam ter o corpo de São Vicente, além de Lisboa, também Gaeta em Itália e Saint Benoit de Castres em França. Réau, Louis, Iconografia del arte cristiano. Iconografia de los santos. De la P a la Z - Repertorios. Tomo 2/ Volumen 5, Barcelona, Ediciones del Serbal, 2002 (primeira edição 1957), pp. 322-328.

O santo mártir é representado na gravura do Anno Christão apenas coberto por um cendal durante o martírio que o descarnou. Croiset, João, Anno Christão ou exercicios devotos para todos os dias do anno. Tomo I, Porto, Empreza d'obras populares illustradas, 1885, pp. 123, 124. Esta representação é incomum no território português onde o santo surge sempre como diácono e comummente acompanhado pela barca com os corvos; Kaftal refere o episódio em que o santo é lançado ao mar em Valencia preso a uma pedra e os vários modelos iconográficos do jovem diácono destacando também, além do livro e da cruz, os atributos do barco com os corvos que o relacionam com o episódio de Lisboa. Kaftal, George, Iconography of the saints in central and south Italian schools of painting, Firenze, Casa Editrice Le Lettere, 1986, pp. 1130-1132.
}

${ }^{178}$ A gravura no Flos Sanctorum representa o santo diácono com dalmática, palma e segurando um livro aberto. Campos, Hermão de e Rabelo, Roberto, Flos Sanctorum HO FLOS SANCTÕ[RUM] EM LINGOAJE[M] P[OR]TUGUE[S], Lisboa, Disponível na plataforma on-line da Biblioteca Nacional de Portugual http://purl.pt/12097, 1513, fl. XXXII.

${ }^{179}$ A imagem foi encontrada na sacristia da igreja de Nossa Senhora da Encarnação do Seminário Apostólico de Vinhais, conforme: Gomes, José Manuel (Coord.), Imagens e escultura. 1545-1995 Comemorações Jubilares dos 450 Anos da Diocese de Bragança - Miranda, Bragança, Departamento de 
Enverga túnica e sobre esta a dalmática, sustem na mão esquerda a maqueta da embarcação que transportou o seu corpo até Lisboa. Apresenta-se tonsurado e com expressão grave.

Imagem 94

SãoVicente - MASV 02

Oficina nacional; primeira metade do século XVII

Museu de Arte Sacra, Vinhais

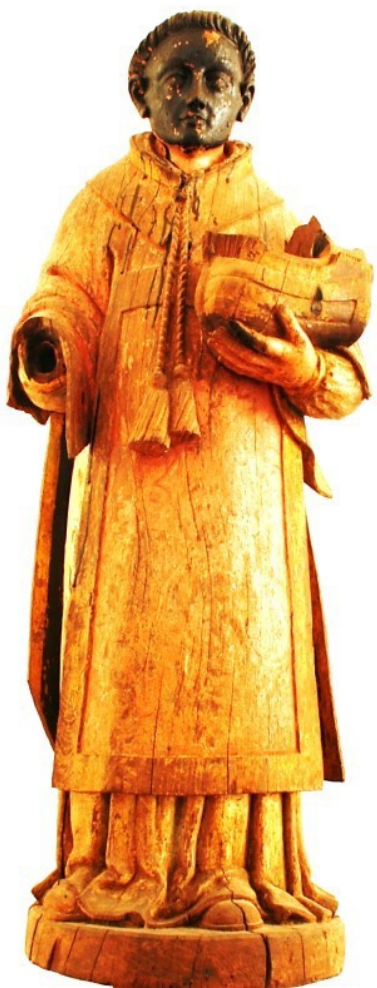

Apesar dos danos físicos que a escultura patenteia, (tinta negra sobre o rosto, diversas marcas de fogo e várias lacunas) é percetível o cuidado trabalho oficinal que a produziu na primeira metade do século XVII. Nessa centúria os princípios tridentinos preconizavam a valorização da mensagem imposta na imagem e os princípios nacionalistas valorizavam as devoções que se relacionavam com o território português face à ocupação dos Filipes e posterior guerra da Restauração.

É evidente o cuidado iconográfico, facilitador da apreensão da devoção, no único atributo que ainda sustém. A bojuda nau apresenta sobre o casco parte de uma das aves que acompanharam o corpo do santo na viagem até Lisboa.

Desconhece-se a proveniência do local de culto original da imagem, as várias igrejas e altares que lhe estavam dedicadas ilustram a amplificação da devoção mas dificultam a compreensão do percurso da escultura.

Liturgia e Património Cultural da Diocese de Bragança - Miranda e Comissão de Arte Sacra, 1996, pp. $14,15$. 


\section{SÃO SEBASTIÃO}

Nascido nas Gálias foi centurião durante o período de Diocleciano. Por exultar os amigos Marcos e Marcelino a permanecer fiéis na sua fé foi condenado por Diocleciano a ser atado a um poste no centro do Campo de Marte. Aí foi atingido pelas setas dos arqueiros que o deixaram quase sem vida. Salvo pela esposa Irene que o cuidou foi de nova preso e morto a varadas. Mais tarde surge a Santa Lucina para lhe ensinar o local onde estavam os restos mortais de modo a que lhe pudessem dar sepultura nas catacumbas, próximo dos restos dos apóstolos. O culto a São Sebastião difundiu-se amplamente, referidas as suas maravilhas por Santo Ambrósio estava considerado depois de Pedro e Paulo o terceiro patrono de Roma. A idade média acresceu à devoção o poder contra a peste ${ }^{180}$ que difundiu o culto por todo o território Europeu. O aparecimento posterior de outros santos que tinham curado a peste ou sofrido a enfermidade (São Roque ou São Carlos Borromeu) foram dissipando a invocação a São Sebastião para a proteção ou cura das pestes. Réau refere que, após ter sido extremamente popular, o culto a São Sebastião apenas mantém a invocação de protetor dos homossexuais, pela sua nudez de efebo apolíneo. A difusão e antiguidade do culto criou diferentes modelos iconográficos, com base nas diferentes narrativas do flagelo ou de centurião. A partir do século XV define-se o modelo jovem, e o renascimento italiano divulgará o aspeto de Apolo nu que caracterizará a iconografia de São Sebastião, de pé, atado a uma árvore (ou a uma coluna ou poste) atravessado pelas setas do martírio ${ }^{181}$.

\footnotetext{
${ }^{180}$ Também na pintura da Itália central e do sul a representação mais comum de São Sebastião privilegia o santo jovem, sem barba, trespassados por setas. Kaftal, George, Iconography of the saints in central and south Italian schools of painting, Firenze, Casa Editrice Le Lettere, 1986, pp. 995-996; Croiset, João, Anno Christão ou exercicios devotos para todos os dias do anno. Tomo I, Porto, Empreza d'obras populares illustradas, 1885, pp. 107, 108. Réau, que sobre a origem da invocação de São Sebastião contra a peste, refere a explicação proposta por Émile Mâle e também pelo Padre Cahier que tem por base a antiga crença da representação da peste como uma chuva de setes lançadas por um deus irado. A sobrevivência ao flagelo das setas daria a São Sebastião o poder de sobreviver ao flagelo da peste. No entanto, Réau refuta esta proposta afirmando a origem do culto no ano 680 pela boa intervenção do santo face à epidemia que grassava em Roma. Réau, Louis, Iconografia del arte cristiano. Iconografia de los santos. De la P a la Z - Repertorios. Tomo 2/ Volumen 5, Barcelona, Ediciones del Serbal, 2002 (primeira edição 1957), pp. 193-196; Cendón Fernández, Marta, "San Sebastian", Santiago, punto de encuentro. Obras Maestras de la Catedral y Caixa Galicia, Fundación Caixa Galicia, 2010, pp.310-315.
}

${ }^{181}$ No Flos Sanctorum a gravura que ilustra a narrativa escrita representa São Sebastião apenas coberto pelo cendal, atado à coluna e martirizado com setas. Campos, Hermão de e Rabelo, Roberto, Flos Sanctorum HO FLOS SANCTÕ[RUM] EM LINGOAJE[M] P[OR]TUGUE[S], Lisboa, Disponível na plataforma on-line da Biblioteca Nacional de Portugual http://purl.pt/12097, 1513, fl. XXX; Réau, Louis, Iconografia del arte cristiano. Iconografia de los santos. De la P a la Z - Repertorios. Tomo 2/Volumen 5, Barcelona, Ediciones del Serbal, 2002 (primeira edição 1957), pp. 197-200. 
A invocação do santo contra a peste manter-se-á em Portugal muito além da idade média. É recorrente a presença de uma capela com a sua invocação próxima aos povoados, de modo a protege-los da entrada da peste. Tal como ainda hoje se mantém em Bragança a capela de São Sebastião mandada fazer em 1569 quando o "Reino se via agonizar entre os horrores de uma terrível peste" ${ }^{\text {"182 }}$, construída na então zona periférica da cidade, bem próxima do convento dos frades menores franciscanos.

Imagem 95

São Sebastião - SFB 29

Oficina nacional; segunda metade do século XVIII

Retábulo da no lado do Evangelho

Igreja de São Francisco Bragança

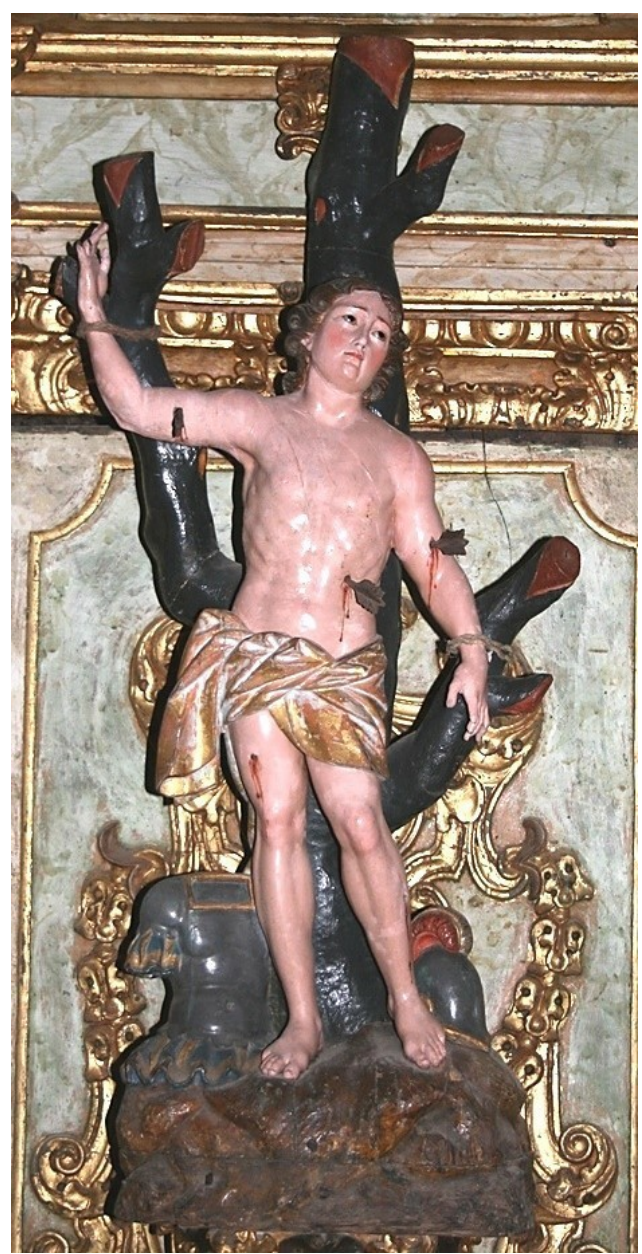

Não obstante a popularidade do culto apenas na igreja de São Francisco de Bragança encontramos a devoção ilustrada em escultura (Imagem 95). Talvez pela proximidade com a capela com a mesma invocação, ou pela continuada frequência de pestes e epidemias que o convento era convocado a apaziguar.

A estatueta representa o santo nu, martirizado por cinco setas atado a uma árvore e com o couraçado e o elmo da armadora depositados aos pés. A pluralidade de atributos identitários é reveladora do sentido catequético da obra. A cuidada anatomia e a expressividade do gesto apelam à emotividade na sua contemplação.

\footnotetext{
182 Borges, José Cardoso, Memórias de Bragança, Fernando de Sousa (Coord.), Bragança, CEPESE / Câmara Municipal de Bragança, 2012 (texto original de 1721-1724), p. 163.
} 
Poder-se-á tratar de uma obra de encomenda da ordem terceira ou de outra das irmandades que na igreja do convento dos frades menores de Bragança, tinha altar. Não só pela raridade da devoção nos espaços franciscanos, mas sobretudo pelos escassos recursos económicos que durante o final da centúria assolam o convento.

De forte carga dramática o corpo nu, martirizado, está representado com algum cuidado na anatomia e proporções e o ritmo assimétrico denuncia uma produção oficinal também cuidada, dos finais do século XVIII. A expressão de resignação face ao sofrimento e o cendal que o cobre aproximam o martírio do santo com o martírio de Cristo. 


\section{SÃO ROQUE}

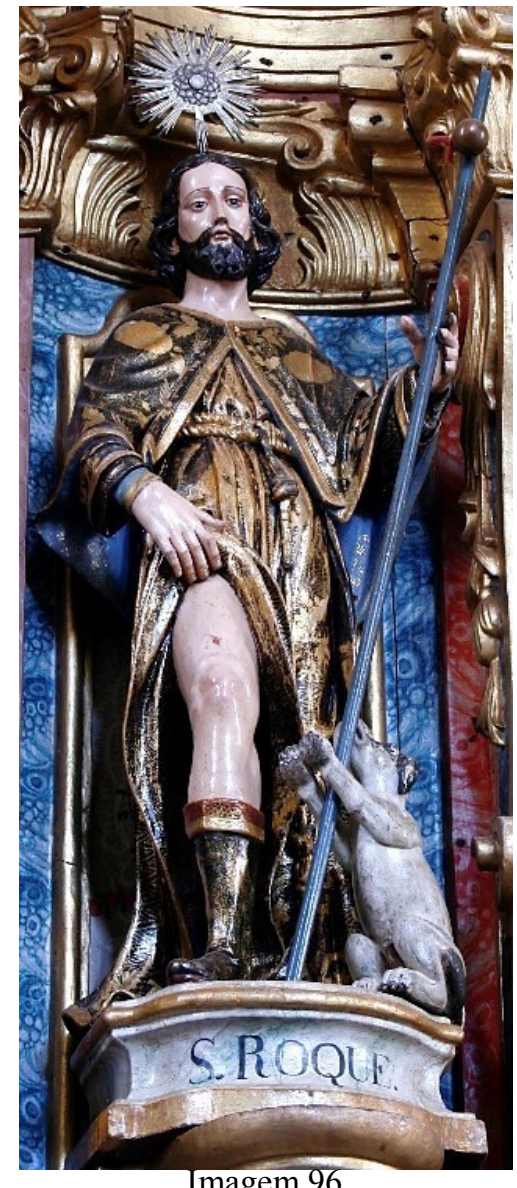

Imagem 96

São Roque - SFV 10

Oficina: Porto $\backslash$ Braga: último quartel do século XVIII

Retábulo no lado do Evangelho Igreja de São Francisco, Vinhais

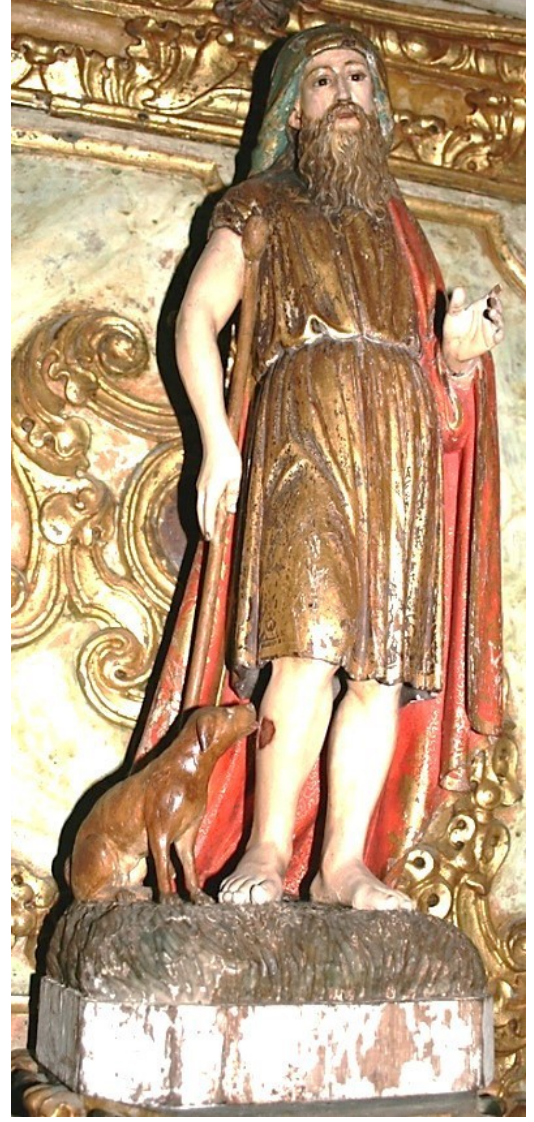

Imagem 97

São Roque - SFB 28

Oficina nacional; segunda metade do século XVIII Retábulo no lado do Evangelho Igreja de São Francisco Bragança

São Roque nasceu em Montpellier, depois de ficar órfão terá distribuído o património familiar para se dirigir a Roma como peregrino. No caminho encontrou uma cidade nos alpes devastada pela peste onde assistiu e curou milagrosamente os enfermos. No regresso contraiu a peste e em vez de se lamentar retirou-se para morrer num bosque isolado sem contagiar ninguém. A solidão foi anemizada por um anjo enviado por Deus com um bálsamo curativo e que fez também brotar uma fonte. Um cão, de um senhor da região todos os dias lhe levava um pão roubado da farta mesa para amenizar a fome do santo. Chegado a Montpellier ninguém reconheceu São Roque que foi preso, morreu no carcere irradiando uma luz sobrenatural. O seu culto foi tardio, pois contra a peste existiam já várias invocações (como São Miguel ou São Sebastião), só no século XV se desenvolve em França e Itália a partir de onde se espalha em toda a europa. 
Representado como peregrino, com uma chaga pestilente na perna, a partir do século XVI o cão, torna-se inseparável de São Roque na imaginária e nas bandeiras de peregrinação. Por contaminação com a iconografia de São Lázaro o cão por vezes lambe a chaga, mas na representação mais comum está sentado com um pão nas fauces ou mais raramente ergue-se sobre as patas ${ }^{183}$.

Nos espaços em estudo encontram-se duas representações de São Roque. São ambas do século XVIII porém apresentam significativas diferenças na narrativa que evocam.

A escultura de Vinhais (Imagem 96) representa o modelo mais comum na imaginária setecentista portuguesa. O santo, jovem e atlético, enverga o traje de peregrino com túnica roçagante e botas altas. Segura na mão esquerda o bordão com a cabaça e com a mão direita sustém a túnica para expor a chaga sobre a perna. Com as patas erguidas o cão sentado volta-se para o santo. Com barbas e cabelos curtos, sobre a cabeça ostenta um resplendor. O traje de peregrino que enverga cingido por um cíngulo evoca o hábito franciscano, reforçando a crença popular da pertença do santo à ordem terceira secular.

A estatueta de Bragança (Imagem 97) apresenta o santo debilitado, apoiado no bordão, descalço, com longas barbas e cabelos. Enverga uma túnica curta que deixa a descoberto a chaga aberta na perna, que é lambida pelo cão. Sobre a cabeça cobre-o um manto que lhe cai sobre as costas. $\mathrm{O}$ atributo que seguraria na mão esquerda está já omisso e com a mão direita apoia o bordão que o ampara sob o ombro. A narrativa evoca o poder curativo sobre a peste que o santo abatido, peregrino e penitente ilustra.

A chaga na perna é consideravelmente mais fácil de expor com a túnica curta, o que poderá justificar a alteração no traje, evitando o levantar da túnica. Igual alteração no decoro se observa nas representações da chaga pestilente que nas esculturas mais recuadas do santo se expunha na virilha (como escultura de calcário de Coimbra de meados do século XVI, no Museu de Arte Antiga em Lisboa, entre outras) mas gradualmente passou para a zona do joelho e finalmente para a perna.

A tradição que relaciona o santo francês com a ordem terceira secular é recorrente e poderá ser nesse âmbito que encontramos a imagem em Vinhais no templo da ordem terceira e em Bragança no templo dos frades menores mas onde a ordem terceira tinha também altar.

\footnotetext{
${ }^{183}$ Croiset, João, Anno Christão ou exercicios devotos para todos os dias do anno. Tomo III, Porto, Editor - Antonio Dourado, 1887, pp. 318-321, refere que São Roque nasceu em 1284 e Réau refere que nasceu cerca de 1350: Réau, Louis, Iconografia del arte cristiano. Iconografia de los santos. De la P a la Z Repertorios. Tomo 2/ Volumen 5, Barcelona, Ediciones del Serbal, 2002 (primeira edição 1957), pp. 147151. Nenhuma das obras bibliográficas citadas regista que São Roque tenha sido irmão da ordem terceira secular, no entanto a tradição popular recolhe este facto.
} 
A resiliência evocada na escultura de Vinhais é substituída pela piedade na escultura de Bragança enquanto valor catequético, e em ambas é valorizado o poder taumatúrgico atribuído ao santo. Este poder estendeu-se além da peste a várias outras enfermidades, não só humanas mas também animais e vegetais. Esta amplificação do culto poderá explicar a presença das duas esculturas nos templos franciscanos de Bragança e Vinhais enquanto territórios vincadamente rurais, bem como, significativamente afastados dos principais centros hospitalares. Neste sentido, os precários cuidados de saúde disponibilizados nos conventos franciscanos estarão também relacionados com a frequência desta devoção.

A suposta pertença do santo à ordem terceira, bem como a intervenção dos leigos seculares no apoio social assumido perante a comunidade constituem relações possíveis para a consolidação do culto nos espaços em estudo. 


\section{SÃO VICENTE FERRER}

Vicente nasceu em Valencia em 1350 e morreu na Bretanha em 1419, foi assessor espiritual de D. João I de Aragão e mais tarde foi Penitenciário Maior. Em Avinhão foi o responsável por persuadir o anti papa a renunciar à tiara pontifícia. Mas a devoção a São Vicente Ferrer advém sobretudo das suas práticas enquanto pregador. Como pregador foi responsável pela conversão de muitos judeus, mouros, valdenses e cátaros. Esta propensão permitiu que popularmente lhe fosse devotada fé como taumaturgo ${ }^{184}$.

Imagem 98

São Vicente Ferrer - SFB 13

Oficina portuguesa; meados do século XVIII

Capela-mor no lado do Evangelho

Igreja de São Francisco - Bragança

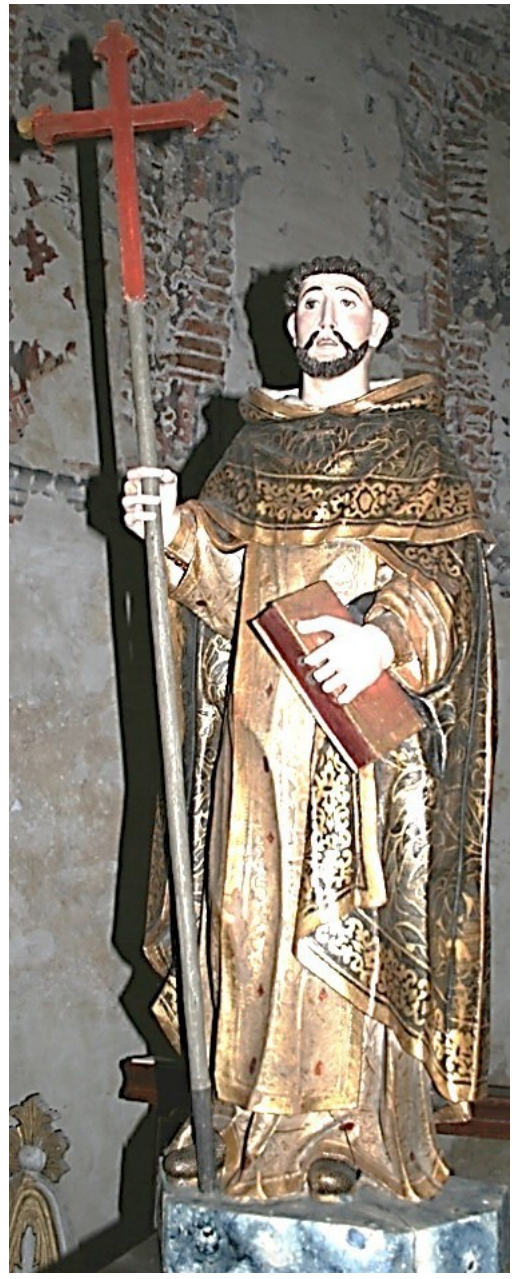

A devoção a São Vicente Ferrer apenas se regista na igreja de São Francisco em Bragança (Imagem 98). A obra de meados do século XVIII terá vindo ilustrar o culto

\footnotetext{
${ }^{184}$ Réau, Louis, Iconografia del arte cristiano. Iconografia de los santos. De la P a la Z - Repertorios. Tomo 2/ Volumen 5, Barcelona, Ediciones del Serbal, 2002 (primeira edição 1957), pp. 328-331.
} 
que nas primeiras décadas do XVIII já Borges identificava com "alguns devotos (...) festejam a S. Vicente Ferrer com novena e práticas ${ }^{185 "}$.

A referência em 1721-1724 da devoção foi o que nos suscitou a identificação da imagem, já que atualmente está colocada em conjunto com São Francisco de Assis no altar-mor, como se se tratasse de São Domingos de Gusmão.

A iconografia de ambos frades dominicanos é muito semelhante. Tal como São Domingos, São Vicente Ferrer é também representado com o hábito dominicano. Como foram ambos pregadores, ambos estão frequentemente segurando um livro. Pela prática de conversão a partir da pregação São Vicente Ferrer é representado com o báculo cruciforme $^{186}$.

A devoção a São Vicente Ferrer é pouco comum em Portugal ${ }^{187}$. Mas a proximidade com a fronteira castelhana poderá justificar a ampliação do culto para Bragança.

\footnotetext{
${ }^{185}$ Borges, José Cardoso, Memórias de Bragança, Fernando de Sousa (Coord.), Bragança, CEPESE / Câmara Municipal de Bragança, 2012 (texto original de 1721-1724), p. 142

A obra de Borges constitui o mais completo repositório das devoções em culto nas igrejas de Bragança. Relativamente à igreja de São Francisco, Borges não refere o culto de São Domingos de Gusmão. Igual ausência se percebe na restante documentação consultada, reforçando a possibilidade de se tratar de São Vicente Ferrer e não São Domingos.

${ }^{186} \mathrm{O}$ báculo cruciforme ou abacial relaciona-se com a pregação do santo contra as heresias Carmona Muela, Juan, Iconografia cristiana, Madrid, Akal, 2010, pp. 92. Muela destaca o atributo relativamente a São Domingos de Gusmão, mas que transita para a iconografia de São Vicente Ferrer, seguramente pela analogia das práticas evangélicas entre ambos os santos

$187 \mathrm{Na}$ base de dados dos museus nacionais da Direção Geral do Património Cultural; http://www.matriznet.dgpc.pt/; (acedido a 18 de junho de 2015) apenas se regista uma escultura de São Vicente Ferrer, no Museu de Aveiro e está representado com asas, que o identificam como enviado por Deus para converter os pecadores; Na base de dados do Secretariado Nacional dos bens culturais da Igreja: https://www.bensculturais.com/areas-de-actuacao/inventario; (acedido a 18 de junho de 2015) estão registadas duas esculturas de São Vicente Ferrer, ambas na Diocese de Lamego, com o livro como atributo.
} 


\section{SÃO CAETANO}

Caetano nasceu em Itália em 1480, ordenou-se sacerdote e foi nomeado cardeal por Leão X, representou o papado na Alemanha durante a época da reforma. Associou-se com Pedro Caraffa, bispo de Chieti (na época designada por Theate) para fundar em 1521 a congregação de clérigos regulares conhecida por Teatinos que foi aprovada em 1524.

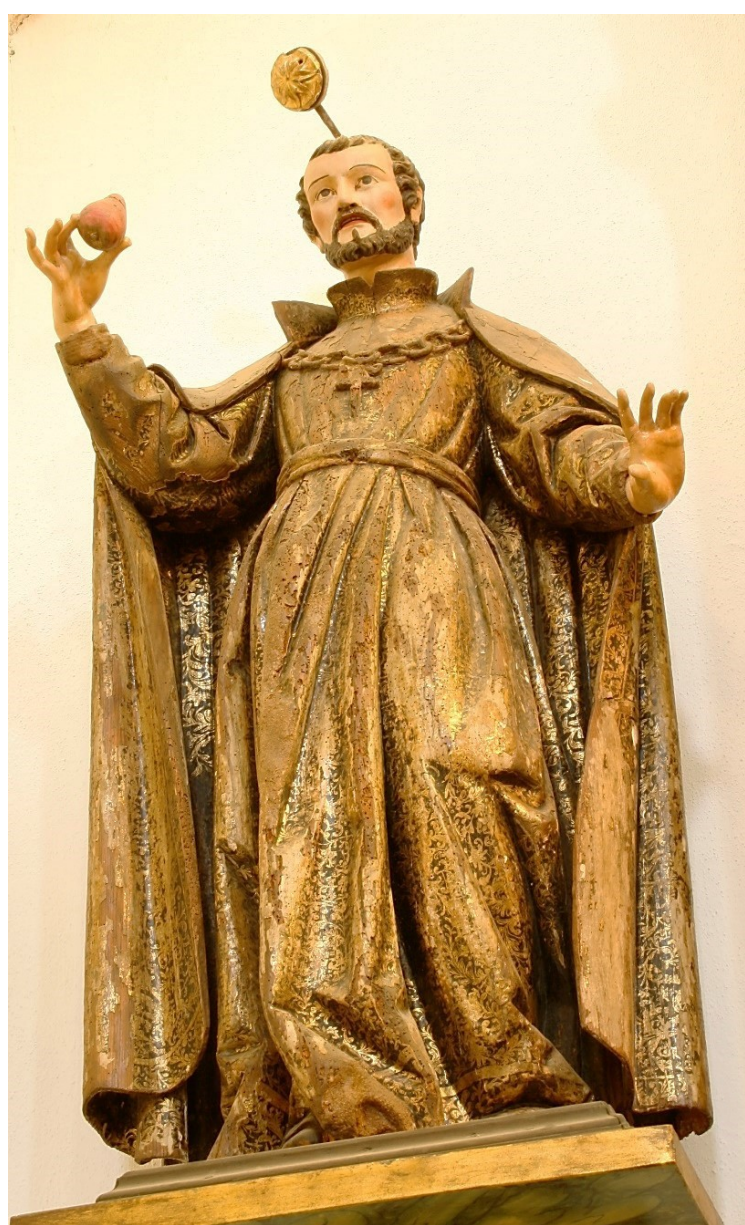

Imagem 99

São Caetano - SFM 03

Oficina espanhola; ultimo quartel do XVII Altar no lado da Epistola Igreja de São Francisco, Mogadouro

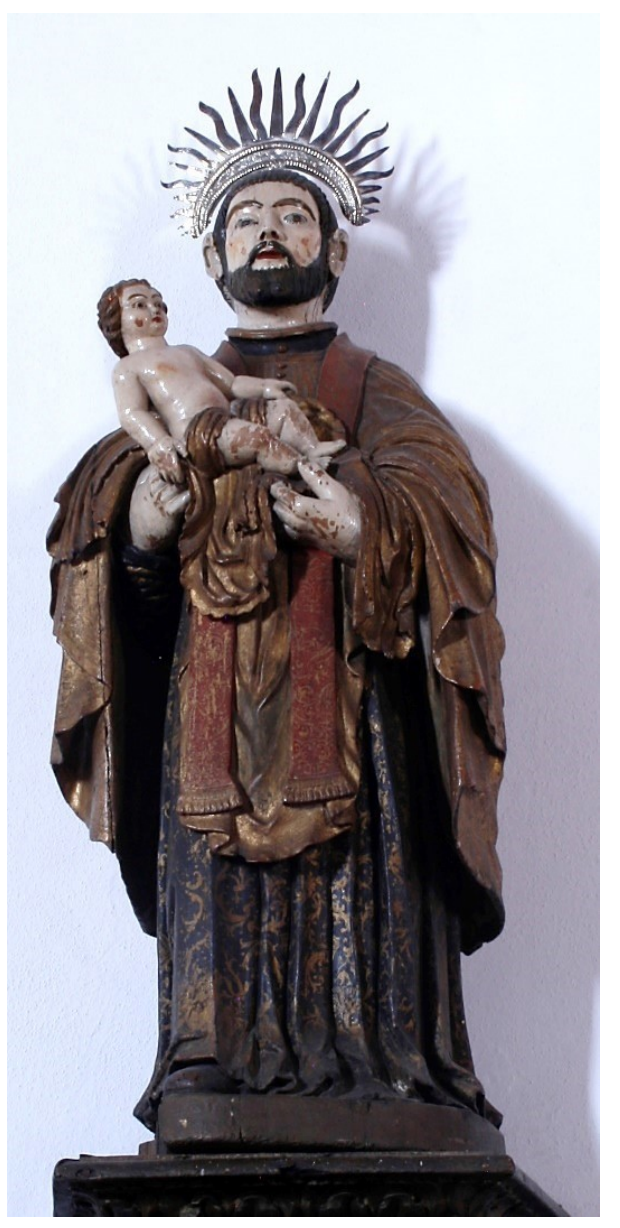

Imagem 100

São Caetano - SCB 10

Produção regional $\backslash$ local; primeira metade do século XVIII

Sobre uma peanha no lado do Evangelho, Igreja do convento das clarissas (atual igreja de Nossa Senhora das Graças), Bragança

A sua representação mais comum valoriza o hábito teatino negro com veste inferior branca, como atributo costuma suster um lírio, um coração alado ou o Menino Jesus que 
a Virgem ou São José lhe confiam nos braços ${ }^{188}$.A presença da devoção ao fundador do teatinos nos espaços franciscanos em estudo regista-se na igreja do convento das clarissas em Bragança e na da terceira ordem regular de Mogadouro.

A escultura de São Caetano ${ }^{189}$ de Mogadouro (Imagem 99) é densa nas amplas vestes mas elegante no gesto teatral com que sustém o coração na mão direita, este aspeto denota a influência castelhana, face à contenção expressiva da escultura coeva registada no território. A figura enverga um hábito negro, densamente decorado, ao qual sobrepõe uma capa igualmente ornamentada. De rosto expressivo com cabelos e barbas curtas, eleva o olhar antecipando a emotividade mística.

A escultura do convento das clarissas (Imagem 100) é ligeiramente posterior, mas a expressividade é ainda substituída pela catequização iconográfica, valorizando o milagre da entrega do Menino. O santo enverga o hábito negro com hirtos vincos até aos pés, ao qual sobrepõe uma sobrepeliz e um escapulário. O Menino, de corpo anatomicamente irregular e pose pouco naturalista, está pousado entre as mãos de São Caetano. Com o rosto muito repintado a figura do santo apresenta um sumário tratamento anatómico, com barbas e cabelos curtos.

A devoção popular a São Caetano em Bragança era registada no início do século XVIII com uma irmandade muito frequentada de fiéis ${ }^{190}$.

A presença da devoção a São Caetano não é frequente nos espaços franciscanos, no entanto a existência de esculturas em dois dos cinco templos estudados denota uma difusão significativa do culto no território em estudo.

\footnotetext{
${ }^{188}$ Réau, Louis, Iconografía del arte cristiano - Iconografia de los santos, de la A a la F. Tomo $2 /$ Volumen 3, Barcelona, Ediciones del Serbal, 1997 (edição original 1955-1959), pp. 289, 290; Carmona Muela destaca como atributos mais comuns o livro, o lírio e o Menino Jesus em braços. Carmona Muela, Juan, Iconografía de los santos, Madrid, Akal, 2008, pp. 79-81

189 A identificação da imagem advém do inventário de 1834 onde se registou uma imagem de São Caetano, o que nos sugere tratar-se desta escultura. "No sigundo altar do mesmo lado achou a Imagem de Nossa Senhora dos Remédios adornada com seu manto de seda matizada, e hua coroa de prata. Mais duas imagens, hua de São José, e outra de São Caetano; mais hum Crucifixo, e quatro castiçais de madeira, três sacras, hua pedra ara. A.N.T.T./A.H.M.F./S.F.M., Extinção das Ordens Religiosas - Convento de São Francisco em Mogadouro, Arquivo Nacional da Torre do Tombo, Lisboa, Arquivo Histórico do Ministério das Finanças, Processos de Extinção das casas religiosas, Cx. 2238, 1834, fl. 4 v., 5. Mas, Mourinho (Júnior), identifica a imagem como Santo Inácio de Loiola, o que apesar das proximidades iconográficas e de indumentária não julgamos corresponder à identificação da devoção. Mourinho (Júnior), António Rodrigues, A talha nos concelhos de Miranda do Douro, Mogadouro e Vimioso nos séculos XVII e XVIII, Braga, Associação de Municípios do Planalto Mirandês, 1984, pp. 55, 56.
}

${ }^{190}$ Borges, José Cardoso, Memórias de Bragança, Fernando de Sousa (Coord.), Bragança, CEPESE / Câmara Municipal de Bragança, 2012 (texto original de 1721-1724), p. 155. 


\section{SANTAS DESAFETAS À ORDEM DE SÃO FRANCISCO}

\section{SANTA BÁRBARA}

O culto da santa mártir oriental foi divulgado no ocidente a partir da Lenda Dourada de Jacopo de Vorágine no século XIII. A lenda refere o suplício de Bárbara filha de Dióscuro e nascida em Nicomedia ou Heliopolis. No século XV o culto estava já amplamente difundido em toda a europa, invocada contra os trovões, os raios e a morte fulminante, é também patrona de vários coletivos, entre eles os artilheiros, os militares, os mineiros e os arquitetos. Os atributos mais comuns que acompanham a representação de Santa Bárbara são a torre com três janelas, a palma que a identifica enquanto mártir e a coroa $^{191}$. O modelo iconográfico está registado em gravura na edição de 1513 de Flos Sanctorum, com a torre, a coroa e a palma ${ }^{192}$.

$\mathrm{O}$ culto à jovem virgem santa está ilustrado numa escultura de Santa Bárbara (Imagem 101), atualmente guardada na sacristia da igreja de Nossa Senhora da Encarnação de Vinhais, era registada no inventário de 1834 no altar em conjunto com a escultura de Santo António e São João Batista:

Hua imagem de Santa Barbara com resplendor de prata avaliada em preço de seis mil reis $-6 \$ 000^{193}$

No mesmo inventário foi registada uma outra imagem de Santa Bárbara dentro de

Hum oratório com vidraças e dentro hum crucifixo sem resplendor e set

[sic] santos de vulto a saber; Sam João, Nossa Senhora, Sam Sebastião, Santa Bárbara, Sam Domingos, todos com resplendores de prata

\footnotetext{
${ }^{191}$ Bárbara por ser cristã foi presa numa torre pelo pai com apenas duas janelas, por devoção à Santíssima Trindade Bárbara abriu uma terceira janela. Consegui fugir e refugiar-se milagrosamente num penhasco que se abriu para a resguardar. Denunciada por um pastor foi martirizada, com diversos tormentos e decapitada pelo pai que de imediato foi fulminado por um raio. Réau, Louis, Iconografia del arte cristiano - Iconografia de los santos, de la A a la F. Tomo 2 / Volumen 3, Barcelona, Ediciones del Serbal, 1997 (edição original 1955-1959), pp. 169-178; Kaftal, George, Iconography of the saints in central and south Italian schools of painting, Firenze, Casa Editrice Le Lettere, 1986, pp. 150-152; Carmona Muela, Juan, Iconografía de los santos, Madrid, Akal, 2008, pp. 38-40.

192 Campos, Hermão de e Rabelo, Roberto, Flos Sanctorum HO FLOS SANCTÕ[RUM] EM LINGOAJE[M] P[OR]TUGUE[S], Lisboa, Disponível na plataforma on-line da Biblioteca Nacional de Portugual http://purl.pt/12097, 1513, fl. VII v.

${ }^{193}$ A.N.T.T./A.H.M.F./S.N.S.E.V., Extinção das Ordens Religiosas - Seminário de Nossa Senhora da Encarnação - Vinhais, Arquivo Nacional da Torre do Tombo, Lisboa, Arquivo Histórico do Ministério das Finanças, Processos de Extinção das casas religiosas, Cx. 2265, 1834, s/fl.
} 
avaluado tudo pelos louvados em preço e quantia de trinta mil reis $30 \$ 000^{194}$.

Pela presença da tiara julgamos que a imagem registada em 1834 poderá ser a que está hoje exposta, sem identificação, no museu de Arte Sacra de Vinhais (Imagem 102).

A escultura de Santa Bárbara (Imagem 101) está identificada na base e ostenta a torre com três janelas. As mãos estão já parcialmente fraturadas, mas aquando da exposição em 1996 a imagem segurava ainda a palma de mártir com a mão direita ${ }^{195}$.

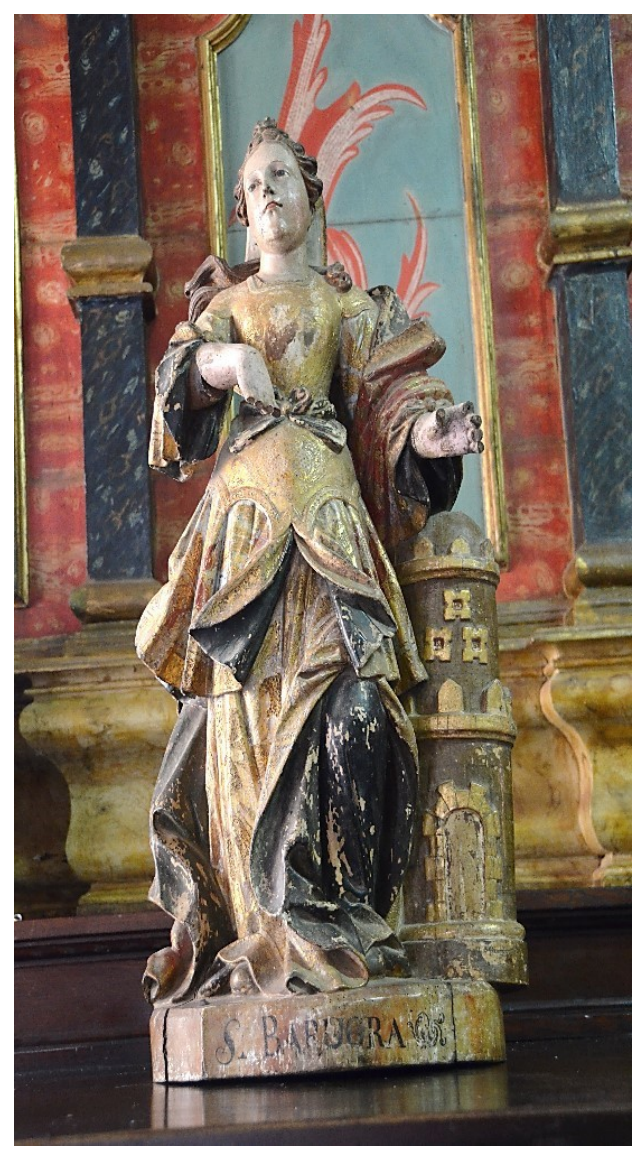

Imagem 101

Santa Bárbara - SIEV 06

Oficina local $\backslash$ Frei Domingos (?): último quartel do século XVIII

Sacristia da Igreja de Nossa Senhora da Encarnação, Vinhais

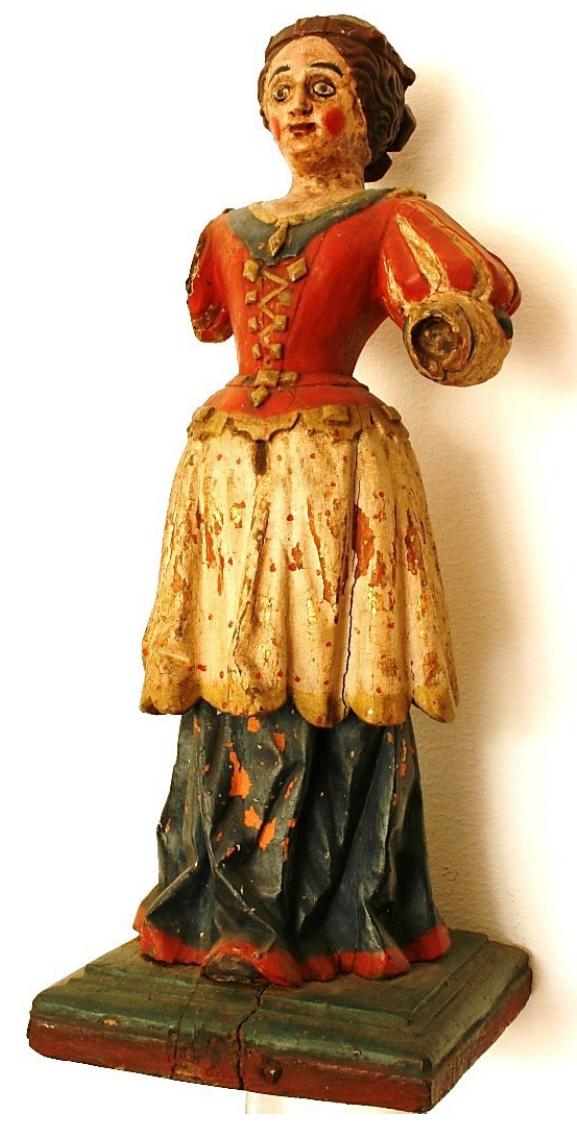

Imagem 102

Santa Bárbara (?) - MASV 04

Produção local $\backslash$ regional: segunda metade do século XVIII

Museu de Arte Sacra, Vinhais

194 A.N.T.T./A.H.M.F./S.N.S.E.V., Extinção das Ordens Religiosas - Seminário de Nossa Senhora da Encarnação - Vinhais, Arquivo Nacional da Torre do Tombo, Lisboa, Arquivo Histórico do Ministério das Finanças, Processos de Extinção das casas religiosas, Cx. 2265, 1834, s/fl.

195 Conforme é possível observar na imagem que consta no catálogo coordenado por: Gomes, José Manuel (Coord.), Imagens e escultura. 1545-1995 Comemorações Jubilares dos 450 Anos da Diocese de Bragança - Miranda, Bragança, Departamento de Liturgia e Património Cultural da Diocese de Bragança - Miranda e Comissão de Arte Sacra, 1996, pp. 19. 
A imagem exposta no museu (Imagem 102) pela perda de ambos os braços já não apresenta qualquer atributo. Apenas a tiara sobre a cabeça e o registo de uma outra estatueta a representar Santa Bárbara no inventário do seminário de 1834 nos sugerem essa identificação, que por falta de elementos mantemos com a interrogação. A proximidade formal, (no gesto e na indumentária) que observamos com outras representações contemporâneas de Santa Bárbara reforçam esta identificação ${ }^{196}$.

A importância da praça militar de Vinhais, enquanto território de fronteira pode justificar o fervor do culto a Santa Bárbara por patrona de militares e artilheiros. A presença de minas e o tradicional culto que lhe é prestado em ermidas e capelas nos altos dos promontórios onde a queda de raios é mais comum pode igualmente ter sido motivador da presença de duas obras a celebrar a devoção.

Ambas as esculturas são coevas mas denotam uma significativa disparidade autoral. $\mathrm{O}$ cuidado com o gesto, a expressão e os panejamentos é evidente na imagem hoje guardada na sacristia (Imagem 101), enquanto o sumário tratamento anatómico e a estaticidade da escultura do museu evidenciam uma produção popular, menos cuidada (Imagem 102).

Nos templos franciscanos estudados apenas em Vinhais se regista o culto a Santa Bárbara, que estaria, pela presença das duas esculturas, já consolidado popularmente mesmo antes da chegada dos frades missionários.

Poucas são as invocações a santas que não foram franciscanas, registadas na documentação relativa às devoções dos altares (como Santa Luzia no convento dos frades menores de Bragança $\left.{ }^{197}\right)$.

Atualmente na imaginária anterior à extinção dos conventos em 1834 não se regista mais nenhuma escultura a ilustrar o culto a figuras femininas não franciscanas, com a exceção de Santa Bárbara em Vinhais.

\footnotetext{
196 Neste âmbito destacamos, uma estatueta em barro no Museu Grão Vasco de Viseu, na base de dados dos Museus da DGPC, (Direção-Geral do Património Cultural, Departamento dos Bens Culturais, Divisão do Património Imóvel, Móvel e Imaterial, Palácio Nacional da Ajuda, Lisboa - Portugal), http://www.matriznet.dgpc.pt/MatrizNet/Objectos/ObjectosConsultar.aspx?IdReg=207894, acedido a 05 de junho de 2015 .

${ }^{197}$ Borges, José Cardoso, Memórias de Bragança, Fernando de Sousa (Coord.), Bragança, CEPESE / Câmara Municipal de Bragança, 2012 (texto original de 1721-1724), p. 142; A.N.T.T./A.H.M.F./S.F.B., Extinção das Ordens Religiosas - Convento de São Francisco em Bragança, Arquivo Nacional da Torre do Tombo, Lisboa, Arquivo Histórico do Ministério das Finanças Processos de Extinção das casas religiosas, M.F. 7580 (cota antiga Cx. 2202), 1834, fl. 10 v.
} 


\section{A ESCULTURA NOS ESPAÇOS FRANCISCANOS DEPOIS DA EXTINÇÃO DAS ORDENS RELIGIOSAS}


Após o decreto de extinção das Ordens Religiosas todos os bens das ordens foram incorporados na fazenda nacional, exceto paramentos e vasos sagrados que foram "postos à disposição dos Ordinários respetivos para serem distribuídos pelas igrejas mais necessitadas da Dioceses"1.

Os espaços conventuais do território da Diocese de Bragança-Miranda foram todos adaptados a novos usos. Alguns dos conventos desapareceram, (convento Franciscano de Torre de Moncorvo, convento da Terceira Ordem Regular de Sezulfe, o convento das Clarissas de Vinhais e o convento das clarissas de Bragança de que apenas resta a igreja). No entanto, as igrejas dos conventos de São Francisco e das clarissas em Bragança, de São Francisco de Mogadouro e as igrejas de Nossa Senhora da Encarnação e de São Francisco em Vinhais estão todas ainda ao culto.

A continuidade do culto, agora paroquial, no interior dos templos propiciou novas encomendas de esculturas e a atualização das devoções.

Apesar da época contemporânea extravasar o âmbito do presente estudo, optamos por incluir as esculturas no inventário que o precedeu. Na medida em que o território carece ainda de um inventário geral dos bens móveis da igreja, julgamos oportuno registar toda a escultura que se encontra a culto e em guarda nas igrejas supra citadas.

No conjunto de obras escultóricas a culto nas igrejas, cuja produção julgamos posterior à extinção das ordens religiosas de 1834, destacamos a presença continuada e preferencial do talhe da madeira, policromada e também estufada como técnica e suporte para as esculturas. Existem algumas peças moldadas em cerâmicas, mas em menor número que as de madeira e são na sua maioria estatuetas de pequeno tamanho.

Destacamos também a preferência pelas oficinas e pelos santeiros dos territórios do Porto e $\mathrm{Braga}^{2}$, privilegiando as relações que se haviam já consolidado no decurso do século XVII e XVIII.

\footnotetext{
${ }^{1}$ Em 1834 D. Pedro IV em nome da Rainha determinou a extinção imediata de "todos os conventos, mosteiros, colégios, hospícios e quaisquer casas de religiosos de todas as ordens regulares, seja qual for a sua denominação, instituto ou regra", e a incorporação dos seus bens na fazenda nacional. Almeida, Fortunato de, História da Igreja em Portugal. Ed. pre. e dir. por Damião Peres, Porto, Lisboa, Livraria Civilização, 1967-1971, p. 146.

${ }^{2}$ Estão identificadas nas próprias esculturas as oficinas da Casa Fânzeres em Braga, Casa Sagrado Coração de Jesus no Porto e a oficina de Guilherme Thedim em Matosinhos, Porto.

A oficina Thedim estava originalmente sediada em São Mamede do Coronado, tal como Olot, na província de Girona, Catalunha ou Vendeuvre-sur-Barse e Vaucouleurs em Aube e Meuse, França, São Mamede de
} 
A alteração da linguagem formal nas esculturas contemporâneas é evidente na contenção dos gestos e na acalmia da turbulência atmosférica que envolvia os panejamentos das obras da segunda metade do XVIII.

No século XIX raras foram as encomendas de novas esculturas para as igrejas. As esculturas posteriores a 1834 são na sua esmagadora maioria já do segundo quartel século $\mathrm{XX}$, o que denuncia a quebra com o compromisso religioso que o anticlericalismo liberal e mais tarde a República preconizaram.

Foi no período do Estado Novo, em que se estreitam os laços entre o poder politico e a igreja, que as igrejas em estudo receberam as novas esculturas que estão ainda a culto.

Além da diminuição acentuada de encomendas que se observa na passagem do Antigo Regime para a Contemporaneidade é notória sobretudo a alteração das devoções.

Assim, relativamente ao culto a Cristo, nas igrejas enquanto estavam ocupadas pelos franciscanos evidenciamos a preferência pela representação da crucificação, e de forma mais ampla pela Paixão de Cristo, que constituía a principal narrativa das esculturas que representavam Jesus Cristo. Posteriormente a 1834 apenas encontramos uma representação da crucificação (Imagem 1).

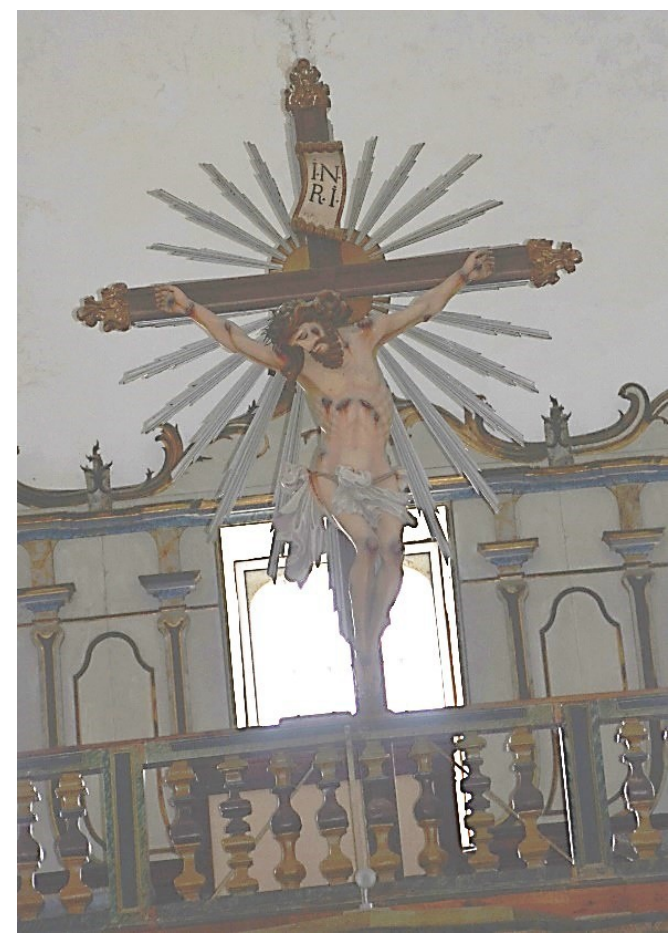

Imagem 1

Cristo Crucificado - IEV 14

Oficina do Porto $\backslash$ Braga; século XX

Colocada na balaustrada do coro alto

Igreja de Nossa Senhora da Encarnação,

Vinhais

Coronado, em conjunto com os concelhos de Santo Tirso e Maia, constituía a terra de santeiros que provia grande parte do território nacional. Atualmente a maioria das oficinas encerraram, mas as que ainda trabalham mantêm a produção de santos em madeira em detrimento das resinas e fibras de vidro usadas atualmente em Olot. Dinis da Silva, Laura Sofia e Ribeiro, Napoleão Gonçalves, "A imaginária em São Mamede de Coronado: a produção de um santo" catálogo da exposição Ide a José, Bragança, Seminário Diocesana de São José e Museu Abade de Baçal, 2013, pp. 19-23. 
A escultura de Cristo Crucificado está hoje exposta sobre o coro alto da igreja de Nossa Senhora da Encarnação de Vinhais. Trata-se da figura que substituiu o "Cristo do Coro" atribuída a Frei Domingos, atualmente exposta na capela de Nossa Senhora das Dores.

A narrativa ilustrada na maioria das representações de Cristo contemporâneas é o Sagrado Coração de Jesus. Apesar de se tratar de uma devoção recente suprimiu as outras representações cristológicas ${ }^{3}$. Todas as igrejas em estudo expõem uma escultura do Sagrado Coração de Jesus o que evidencia a relevância do culto (Imagem 2, 3, 4, 5, 6).

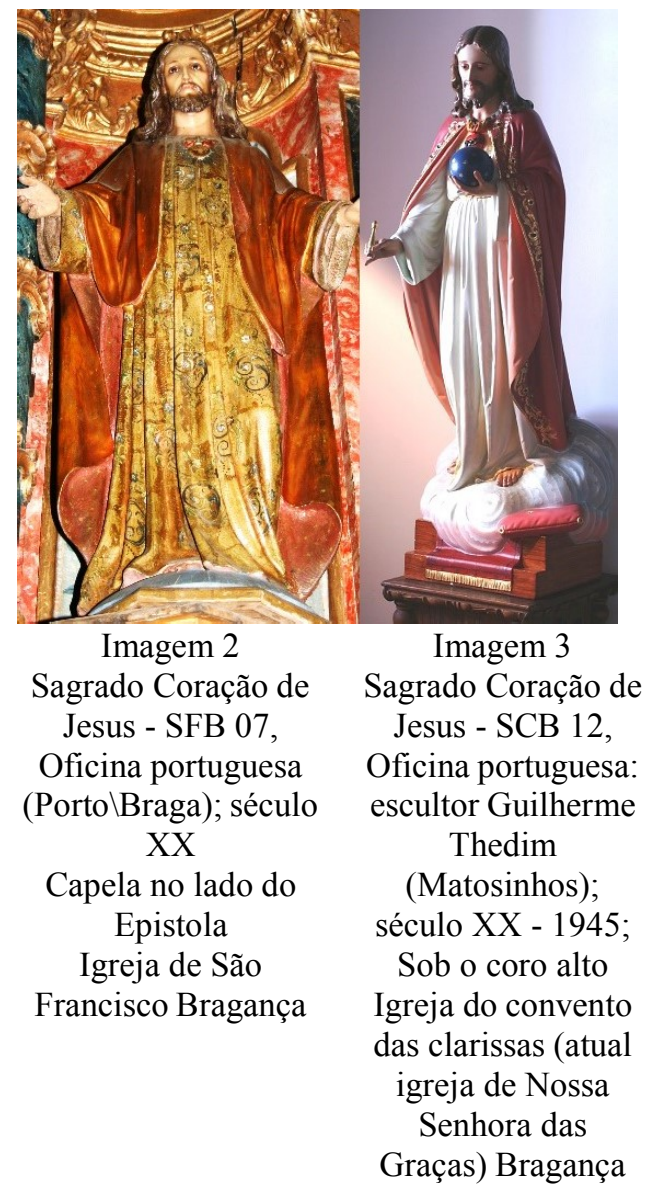

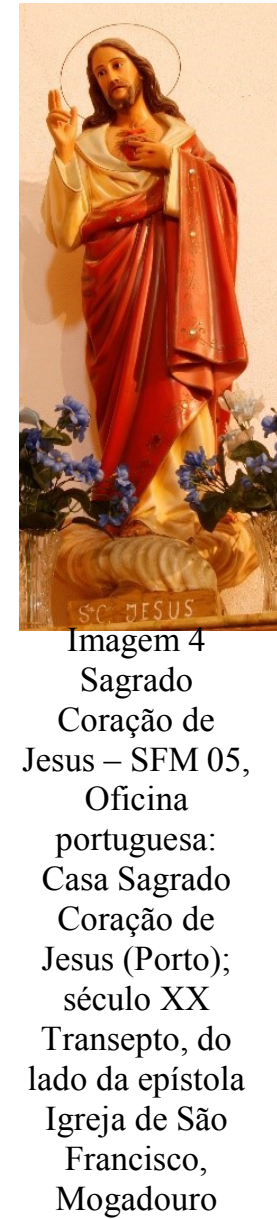

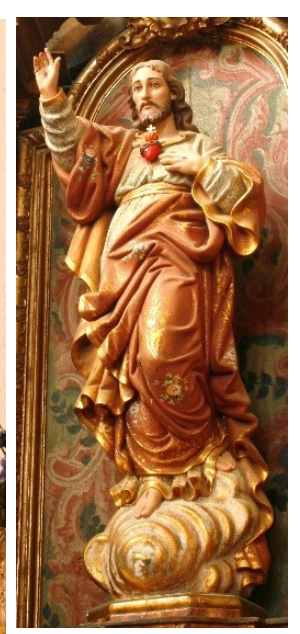

Imagem 5

Sagrado Coração de Jesus - IEV 10,

Oficina portuguesa: escultor Guilherme

F. Thedim

(Matosinhos); século XX - 1964;

Nicho central do retábulo do lado do Evangelho Igreja de Nossa

Senhora da

Encarnação, Vinhais

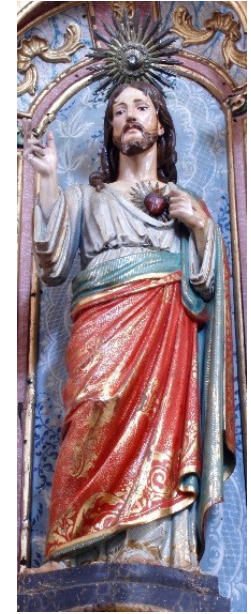

Imagem 6

Sagrado

Coração de Jesus - SFV 11, Oficina portuguesa (Porto\Braga); século XX

Nicho central do retábulo do lado do Evangelho Igreja de São Francisco, Vinhais

A devoção mariana espelha um processo idêntico ao ocorrido com a devoção a Cristo. Assiste-se a uma diminuição significativa das narrativas evocadas na estatuária. $\mathrm{O}$ culto

\footnotetext{
${ }^{3} \mathrm{O}$ culto do Sagrado Coração de Jesus foi sobretudo divulgado por D. Maria II que encomendou a imagem ao italiano Pompeo Batoni em 1780. A pintura representava Cristo com o coração em chamas na mão esquerda encimado por uma pequena cruz e rodeado pela coroa de espinhos. Este modelo foi posteriormente recusado em favor do coração em chamas colocado sobre o peito ou com raios de luz que emanam de uma incisão sobre o peito. Réau, Louis, Iconografía del Arte Cristiano. Iconografía de la Biblia - Nuevo Testamento Tomo 1/ Volumen 2, Barcelona, Ediciones del Serbal, 1996 (Edição original 1955-1959), pp. $52-54$.
} 
mais divulgado é o de Nossa Senhora de Fátima. Trata-se de uma devoção recente que quase suprimiu as anteriores invocações. O arraigo popular da devoção a Nossa Senhora de Fátima mantém-se até aos dias de hoje e encontramos a imagem em todos os templos com exceção da igreja de Nossa Senhora das Graças.

A igreja de Nossa Senhora das Graças é o único templo que tem outras invocações marianas representadas em esculturas contemporâneas.

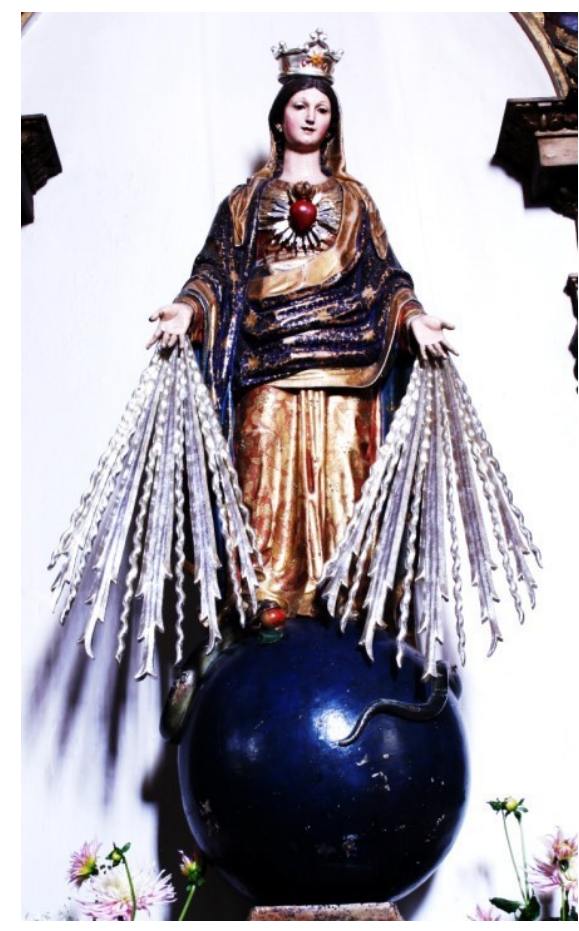

Imagem 7

Nossa Senhora das Graças, SCB 09 Oficina portuguesa (Porto $\backslash$ Braga); século XIX

lado do evangelho igreja do extinto convento das clarissas (atual igreja de Nossa Senhora das Graças) Bragança

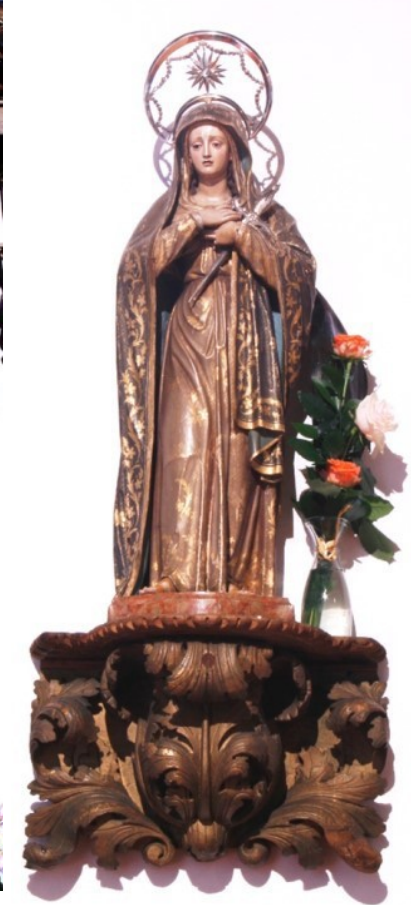

Imagem 8

Nossa Senhora das Dores, SCB 03

Oficina portuguesa

(Porto\Braga); século XX lado da epístola

igreja do extinto convento das clarissas (atual igreja de Nossa Senhora das Graças) Bragança

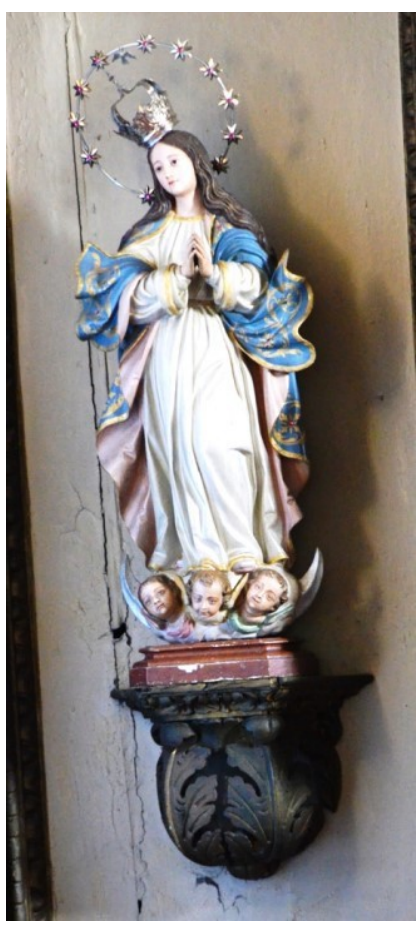

Imagem 9

Nossa Senhora da Imaculada

Conceição, SCB 07

Oficina portuguesa (Porto \Braga); século XX lado da epístola igreja do extinto convento das clarissas (atual igreja de Nossa Senhora das Graças)

Bragança

O templo outrora das clarissas expõe atualmente a imagem da padroeira da Cidade, Nossa Senhora das Graças ${ }^{4}$ (Imagem 7). É das escassas esculturas encomendadas durante o século XIX e ocupa, nos dias comuns, o altar outrora da irmandade de São Caetano com a respetiva escultura.

\footnotetext{
${ }^{4}$ A imagem de Nossa Senhora das Graças foi adquirida em 1862. Jacob, João Manuel Neto, Bragança, Lisboa, Presença, 1997, p. 100, citando Francisco Felgueiras na revista Amigos de Bragança, 1964.
} 
Além desta invocação encontramos outras duas esculturas que representam Nossa Senhora, são ambas esculturas do século XX. Trata-se de uma Virgem Dolorosa ${ }^{5}$ (Imagem 8) e uma Nossa Senhora da Imaculada Conceição (Imagem 9). As duas devoções terão tido esculturas que as representassem anteriores à extinção das ordens religiosas. A documentação relativa aos bens da igreja após a extinção das ordens religiosas refere

"Uma pequena alampada de prata que allumia o altar da $\mathrm{Sr}^{\mathrm{a}}$ das Dores que se diz ser propriedade particular destinada àquele uso com a clausula de reverter ao poder dos seus proprietários no caso da extinção do convento ${ }^{6}$ ",

Podemos supor que após a extinção do convento os particulares tenham reclamado a imagem de Nossa Senhora das Dores em conjunto com a lâmpada de prata.

A devoção da Imaculada Conceição suporia seguramente a presença de uma escultura no interior do templo das clarissas. Além de se tratar de uma invocação mariana particularmente relacionada com a ordem franciscana, o convento estava sob a sua designação. Neste sentido, supomos que já na segunda metade do século XX as esculturas que ilustravam as devoções originais do convento poderão ter sido substituídas por imagens novas. Esta dinâmica de substituição de esculturas mais antigas por esculturas recentes foi prática recorrente em diversos templos até à contemporaneidade.

Nos restantes templos apenas Nossa Senhora de Fátima ${ }^{7}$ (Imagem 10, 11, 12, 13)foi acrescentada ao conjunto da imaginária mariana. Não se verifica em mais nenhuma igreja

\footnotetext{
${ }^{5}$ Gomes, José Manuel (Coord.), Imagens e escultura. 1545-1995 Comemorações Jubilares dos 450 Anos da Diocese de Bragança - Miranda, Bragança, Departamento de Liturgia e Património Cultural da Diocese de Bragança - Miranda e Comissão de Arte Sacra, 1996, p. 8. A imagem de "Nossa Senhora da Soledade" está atribuída à produção do século XVII, no entanto, formalmente julgamos tratar-se de uma obra das oficinas de santeiros do Porto e Braga, possivelmente já da segunda metade do século XX.
}

${ }^{6}$ A.N.T.T./A.H.M.F./C.S.C.B., Extinção das Ordens Religiosas - Convento de Santa Clara - Bragança, Arquivo Nacional da Torre do Tombo, Lisboa, Arquivo Histórico do Ministério das Finanças, Processos de Extinção das casas religiosas, Cx. 1891, 1870, s/fl.

\begin{abstract}
${ }^{7}$ A iconografia de Nossa Senhora de Fátima teve como primeiro modelo uma Imaculada Conceição, de finais de Setecentos ou inícios da centúria seguinte, da catedral de Leiria. A primeira escultura é de José Ferreira Thedim feita para a Casa Fânzeres de Braga, 1920, terá tido como modelo, além da descrição da vidente, uma estampa de Nossa Senhora da Lapa. A popularidade da imagem de Nossa Senhora de Fátima, da Virgem Peregrina e do Imaculado Coração de Maria de Fátima criadas por José Ferreira Thedim propiciou que os modelos fossem amplamente reproduzidos na maioria das oficinas da região (São Mamede de Coronado). Mas logo outras representações se seguirão acrescentando elementos iconográficos e valores expressivos com destaque para a escultura de António Teixeira Lopes que foi a primeira imagem feita após o reconhecimento oficial das aparições. Duarte, Marco Daniel, "A iconografia da Senhora de Fátima: da criação ex nihilo às composições plásticas dos artistas", Cultura, Revista de História e Teoria das Ideias. Vol. 27 Iconografia religiosa das invocações nacionais, Lisboa, Universidade Nova de Lisboa, 2010, pp. 235-270.
\end{abstract}


a persistência das devoções franciscanas marianas anteriores à extinção das ordens religiosas.

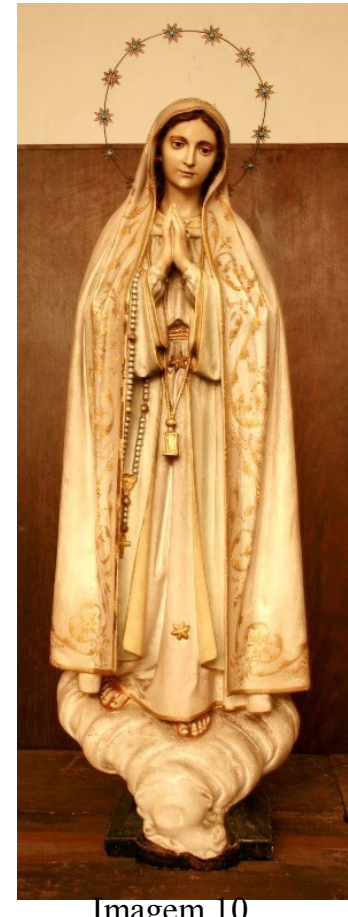

Imagem 10

Nossa Senhora de Fátima, SFB 31

Oficina portuguesa (Porto\Braga); século XX

Sacristia da Igreja de São Francisco, Bragança

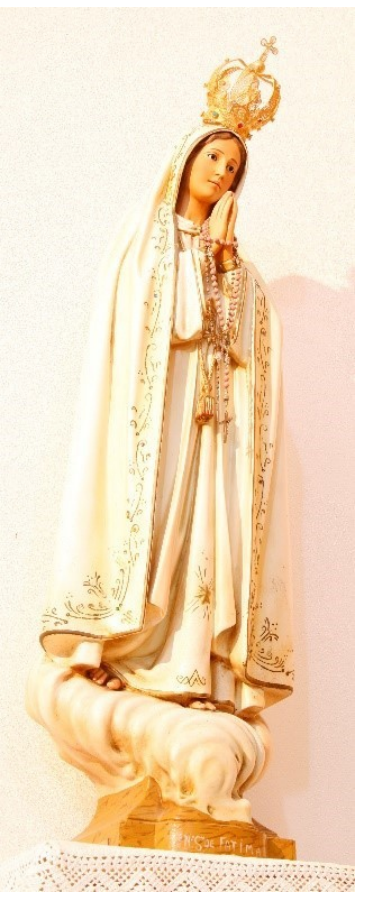

Imagem 11

Nossa Senhora de Fátima, SFM 10

Oficina portuguesa:

Casa Sagrado Coração de Jesus (Porto); século $\mathrm{XX}$

Lado do evangelho da Igreja de São Francisco, Mogadouro

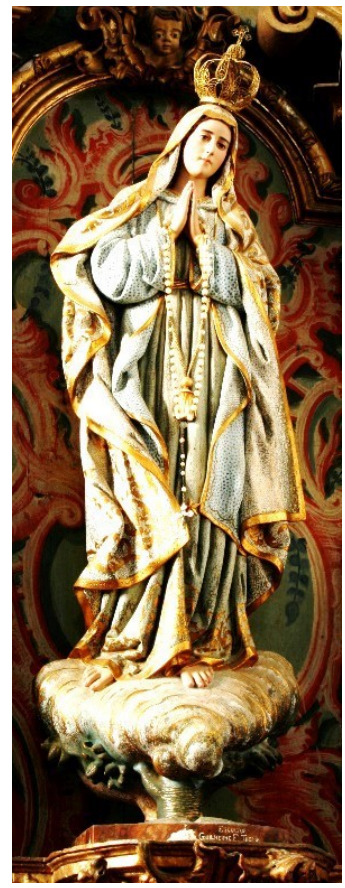

Imagem 12

Nossa Senhora de Fátima, IEV 02

Oficina portuguesa:

escultor Guilherme F.

Thedim (Matosinhos); século XX - 1964 Sacristia da

Igreja de Nossa Senhora da Encarnação, Vinhais

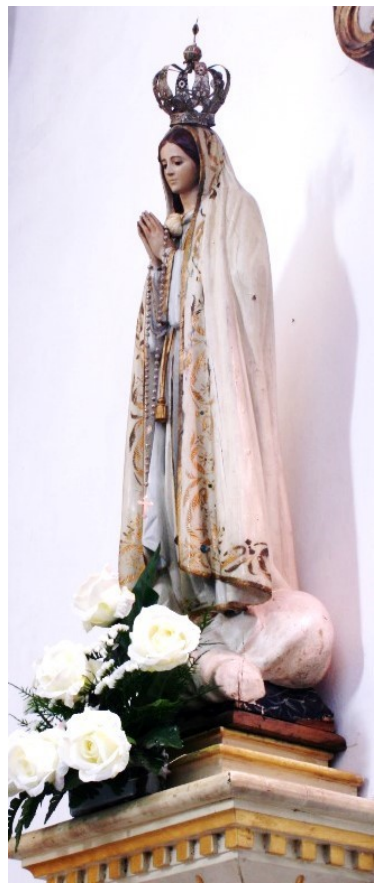

Imagem 13

Nossa Senhora de Fátima, SFV 01

Oficina portuguesa

(Porto\Braga); século XX

Lado da epistola da Igreja de São

Francisco, Vinhais

Relacionado com a parentela de Nossa Senhora mantém-se ainda nos templos em estudo o culto a São José (Imagens 14, 15). Observam-se poucas alterações relativamente à devoção por São José. As esculturas que o representam anteriores à extinção das ordens privilegiavam também a representação de São José com o Menino. O santo, representado como homem jovem enfatiza a relação paterna com o Menino. Não podemos deixar de notar que tal como ocorre nas representações do Antigo Regime, também na contemporaneidade estão ausentes, nas igrejas em estudo, as representações da Virgem com o Menino. 


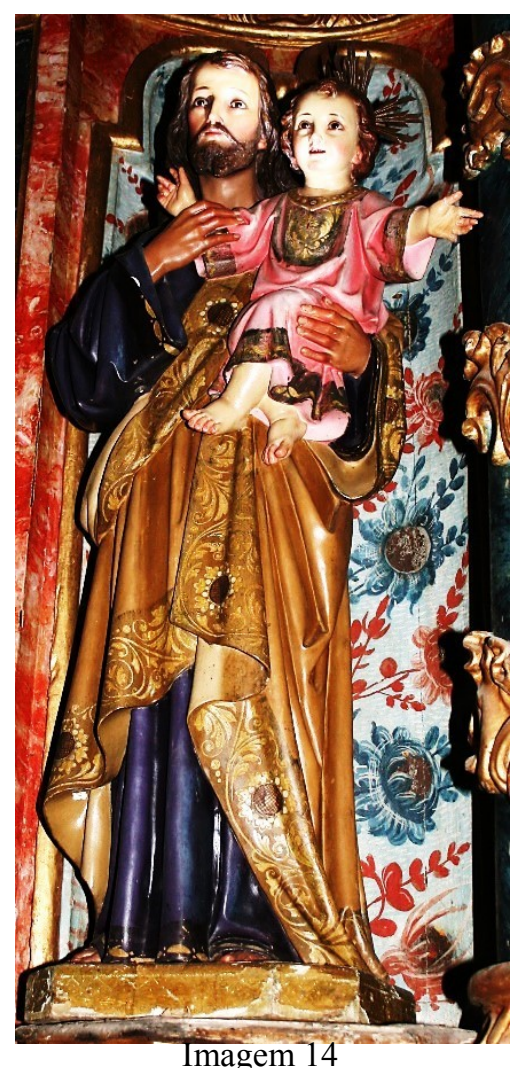

São José com o Menino, SFB 09

Oficina portuguesa (PortoไBraga); século XX Capela da Imaculada Conceição, do lado da epistola da

Igreja de São Francisco, Bragança

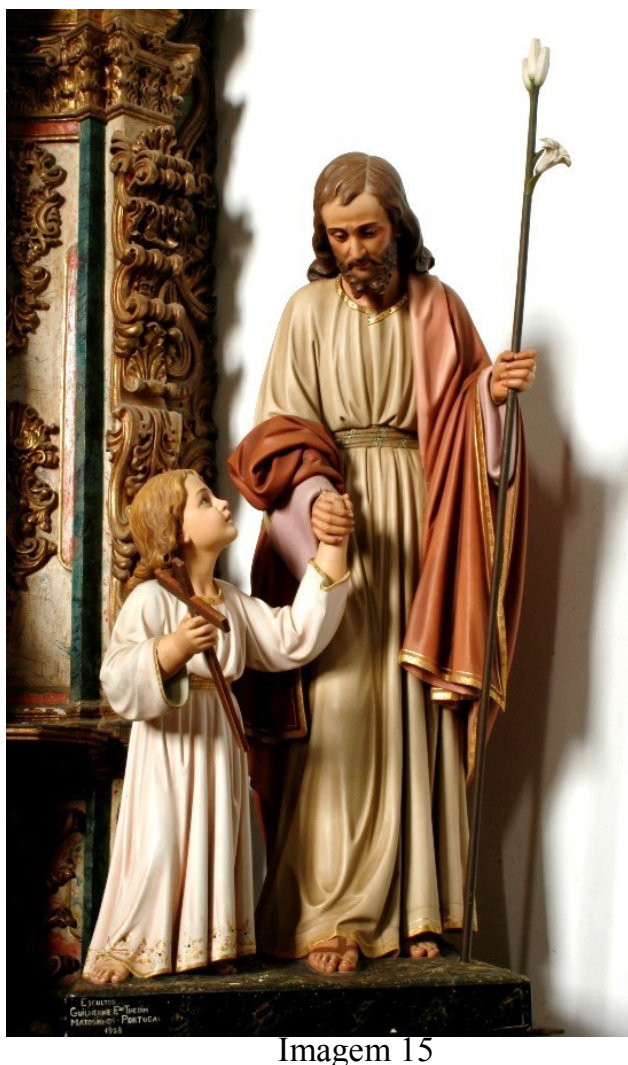

São José com o Menino, IEV 01

Oficina portuguesa: escultor Guilherme F.ra

Thedim (Matosinhos); século XX - 1958

do lado da epistola da

Igreja de Nossa Senhora da Encarnação, Vinhais

Relativamente ao culto dos santos observa-se um claro afastamento dos santos franciscanos. Enquanto os templos se mantiveram sob orientação franciscana a presença de devoções a santos e santas da ordem era significativa na escultura.

$\mathrm{Na}$ contemporaneidade apenas na igreja de Santa Clara se observa a persistência das principais devoções franciscanas (Imagem 16, 17, 18). Este facto reforça mais uma vez a possível substituição, já na segunda metade do século XX, de esculturas anteriores a 1834 por esculturas recentes, dada a continuidade das devoções, observável na igreja de Santa Clara e inexistente nos restantes templos franciscanos em estudo. O inventário efetuado em 1870 após a extinção do convento regista "várias imagens" sem no entanto as identificar. Mas, esta referência permite supor a existência de um considerável número de esculturas que se perderam ou foram substituídas, pois anteriores a 1834 apenas identificamos três esculturas no templo das clarissas.

\footnotetext{
8 "Várias Imagens existentes na Igreja e coro do Convento". A.N.T.T./A.H.M.F./C.S.C.B., Extinção das Ordens Religiosas - Convento de Santa Clara - Bragança, Arquivo Nacional da Torre do Tombo, Lisboa, Arquivo Histórico do Ministério das Finanças, Processos de Extinção das casas religiosas, Cx. 1891, 1870, s/fl.
} 


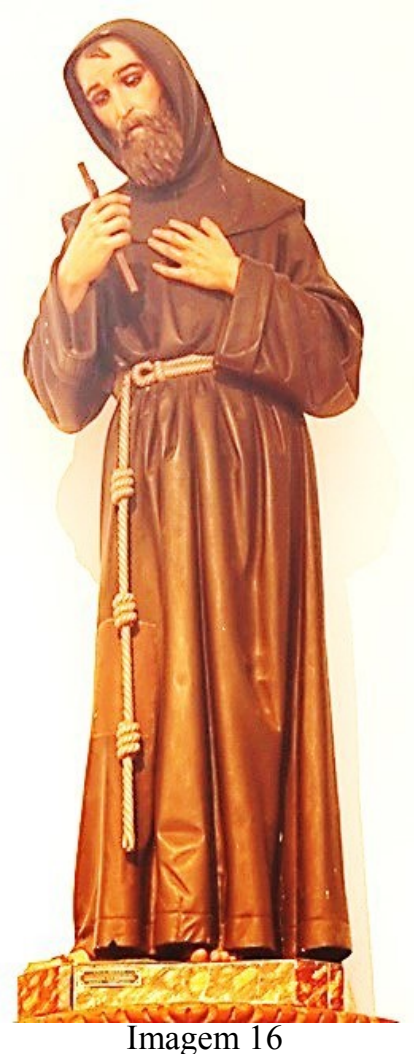

São Francisco de Assis, SCB 01

Oficina portuguesa: Casa

Fânzeres (Braga); século XX lado da epístola

igreja do extinto convento das clarissas (actual igreja de Nossa Senhora das Graças) Bragança

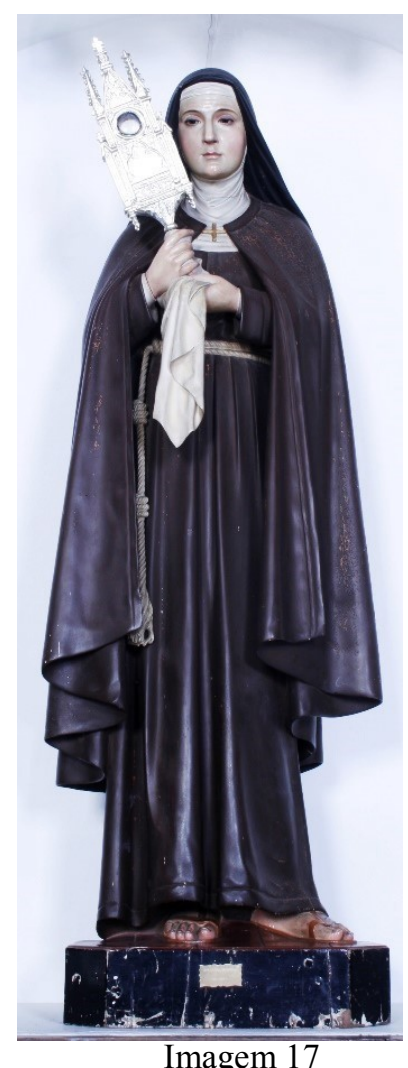

Santa Clara de Assis, SCB 15 Oficina portuguesa: Casa Fânzeres (Braga); século XX lado do evangelho no coro alto da igreja do extinto convento das clarissas (actual igreja de Nossa Senhora das Graças) Bragança

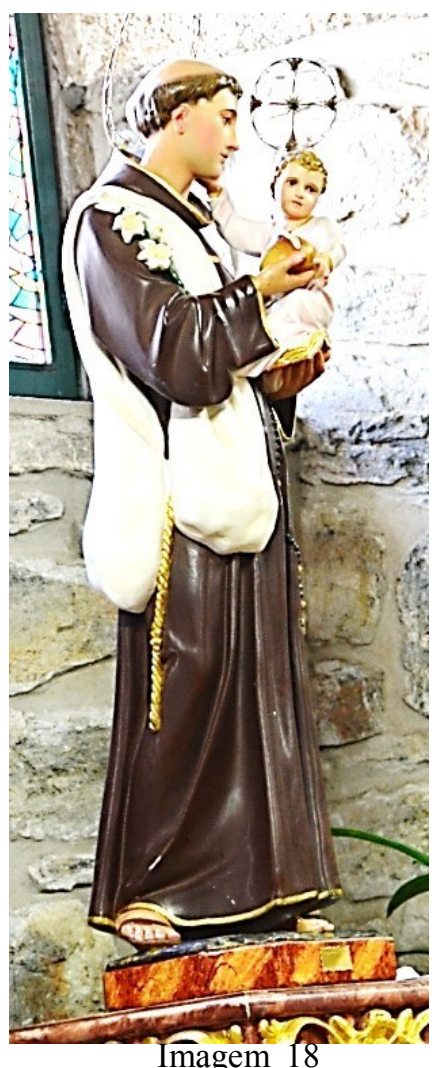

Santo António, SCB 14

Oficina portuguesa:

(Porto\Braga); século XX lado da epístola sob o coro alto da igreja do extinto convento das clarissas (actual igreja de Nossa Senhora das Graças) Bragança

Sobre a escultura de Santa Clara que estaria originalmente a culto na igreja das clarissas temos o registo dos bens de 1870 onde consta um báculo e um relicário de prata da imagem de Santa Clara ${ }^{9}$. A imagem que o registo refere e que como atributos expunha o báculo e a custódia em prata está atualmente desaparecida. A imagem que está hoje a culto, tal como ocorre com a escultura de São Francisco foi produzida na segunda metade do século XX na Casa Fânzeres de Braga.

Relativamente aos restantes cultos ilustrados na escultura contemporânea observa-se a permanência da devoção a Santa Luzia na igreja de São Francisco de Bragança.

\footnotetext{
9 "Um báculo de prata da imagem de Santa Clara que peza duzentas e dez gramas, a vinte e cinco reis cada uma, cinco mil duzentos e cincoenta $\mathrm{R}-5.250 \backslash$ Um relicário da mesma imagem, de prata que peza duzentas e cincoenta e uma gramas a vinte e cinco reis cada uma seis mil duzentos e setenta e cinco R- 6.275" A.N.T.T./A.H.M.F./C.S.C.B., Extinção das Ordens Religiosas - Convento de Santa Clara - Bragança, Arquivo Nacional da Torre do Tombo, Lisboa, Arquivo Histórico do Ministério das Finanças, Processos de Extinção das casas religiosas, Cx. 1891, 1870, s/fl.
} 
No interior do templo existia um altar dedicado a Santa Luzia desde o século XVII "com relíquia e, no seu dia, venerada com grande concurso" ${ }^{10}$. No decurso do inventário registamos um fragmento de uma figura feminina, jovem que poderia tratar-se da original imagem de Santa Luzia (Imagem 19), pois não se regista na documentação mais nenhum culto feminino (além das devoções marianas).

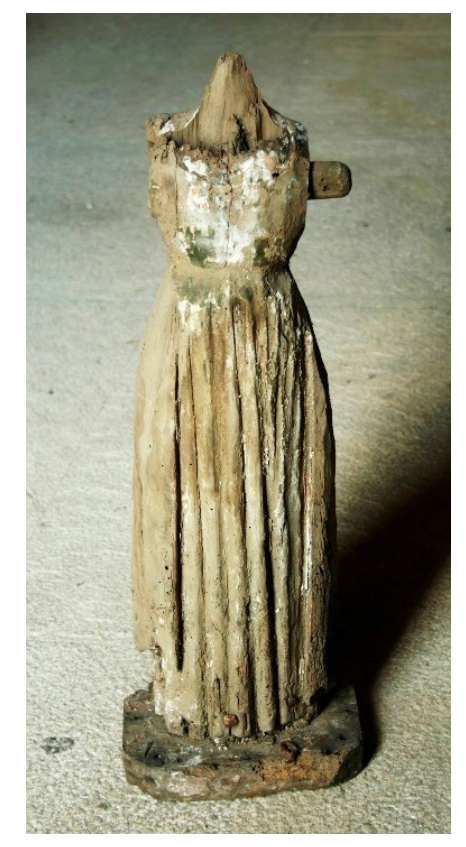

Imagem 19

Fragmento de uma figura feminina Santa Luzia (?), SCB 38

Oficina regional\local: século XVII (?) Sala das sessões

Igreja de São Francisco, Bragança

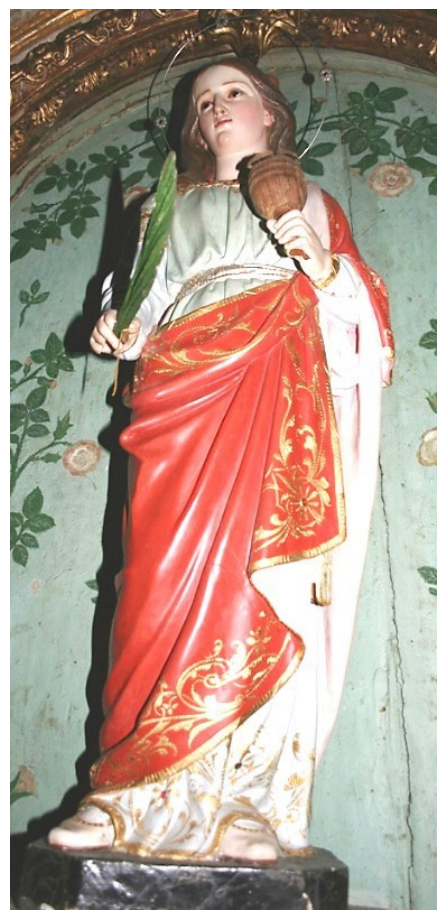

Imagem 20

Santo António, SCB 14

Oficina portuguesa: (Porto\Braga); século XX

Retábulo, lado do evangelho Igreja de São Francisco, Bragança

A escultura que ainda está a culto é do século XX (Imagem 20) e mantém-se a celebração da religiosa em honra da jovem mártir no dia 13 de Dezembro.

A ampliação de devoções contemporâneas regista nos templos em estudo uma clara intensificação das figuras femininas.

\footnotetext{
${ }^{10}$ Borges, José Cardoso, Memórias de Bragança, Fernando de Sousa (Coord.), Bragança, CEPESE / Câmara Municipal de Bragança, 2012 (texto original de 1721-1724), p. 142.
} 


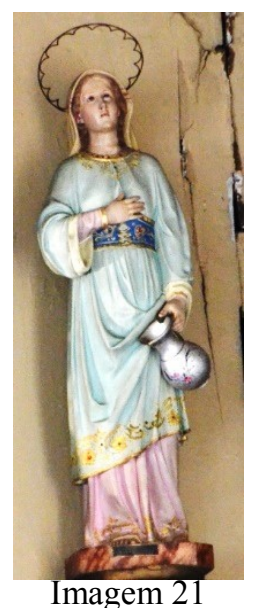

Santa Zita, SCB 05

Oficina portuguesa:

(Porto\Braga); século XX

Arco triunfal no lado da epístola igreja do extinto convento das clarissas (atual igreja de Nossa Senhora das Graças) Bragança

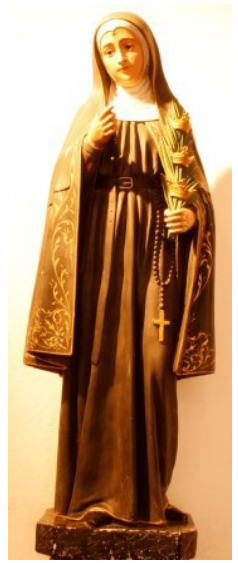

Imagem 22

Santa Rita,

MASV 09

Oficina

portuguesa:

(PortolBraga);

século XX

Museu de Arte

Sacra Vinhais

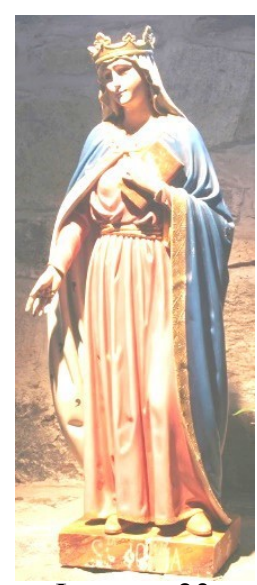

Imagem 23

Santa Joana, SCB 13

Oficina portuguesa:

(PortolBraga); século XX

lado da epístola sob o coro alto da igreja do extinto convento das clarissas (atual igreja de Nossa Senhora das Graças) Bragança

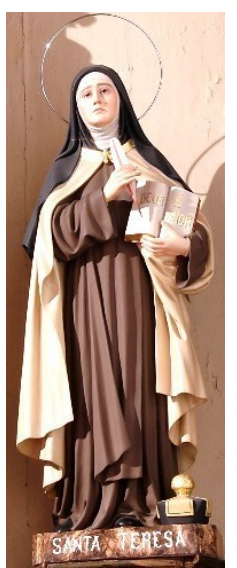

Imagem 24

Santa Teresa de

Ávila, SCB 04

Oficina

portuguesa:

(Porto\Braga); século XX

Arco triunfal no lado da epístola igreja do extinto convento das clarissas (atual igreja de Nossa

Senhora das Graças) Bragança

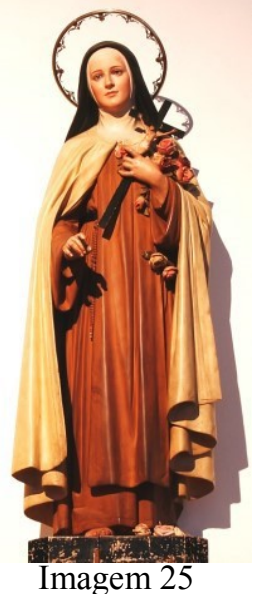

Santa Teresinha, SCB 02

Oficina portuguesa: Casa Fânzeres (Braga); século $X X$

Arco triunfal no lado da epístola igreja do extinto convento das clarissas (atual igreja de Nossa Senhora das Graças) Bragança

A rede de mulheres virtuosas torna-se mais variada. As devoções são relativas a três mulheres da época medieval, Santa Zita, Santa Rita e Santa Joana (Imagem 21, 22, 23), Santa Teresa de Ávila, doutora da Igreja da época Moderna (Imagem 24) e Santa Teresinha do Menino Jesus, da época contemporânea com forte devoção popular (Imagem 25). Além das três santas religiosas, Santa Rita, Santa Teresa de Ávila, e Santa Teresinha do Menino Jesus, regista-se a devoção a Santa Joana princesa, e Santa Zita, humilde trabalhadora doméstica. Comparativamente às devoções franciscanas há um acréscimo significativo nas devoções femininas durante o período contemporâneo, sobretudo na segunda metade do século XX. É na igreja de Nossa Senhora das Graças de Bragança (do convento das clarissas) que se percebe a maior presença de estatuária contemporânea, bem como, a menor existência de esculturas anteriores a 1834. 


\section{CONCLUSÕES}


Os caminhos que as esculturas dos Franciscanos na Diocese de Bragança-Miranda nos sugeriram possibilitaram-nos algumas reflexões conclusivas.

A Ordem fundada nos inícios do século XIII por São Francisco de Assis foi a ordem religiosa com mais presença na Diocese de Bragança-Miranda.

Num território periférico, pouco povoado e com uma economia frágil, a Ordem Franciscana constituiu, através das suas várias casas, importantes centros irradiadores de doutrina cristã que definiram os comportamentos sociais.

Durante a primeira dinastia portuguesa, a Dinastia Afonsina, no período medieval, apenas Bragança, com funções de centralidade urbana face ao restante território, reunia as condições propícias à instalação da Ordem dos Frades Menores que chegaram durante o século XIII.

No período Moderno, em plena época de Expansão Ultramarina, amplifica-se a presença da família franciscana na cidade de Bragança. A chegada das Clarissas (Segunda Ordem) ocorre durante os últimos anos de reinado da Dinastia de Avis, em 1569.

No século XVII, durante o domínio filipino, Mogadouro recebeu a Terceira Ordem Regular. A vila fora favorecida pela ruralização da nobreza nacional decorrente da deslocação da corte de Lisboa para Madrid, aproximando a família dos Távoras, normalmente na corte, ao seu território rural. Mogadouro, pela proximidade geográfica, beneficiou também dos ecos artísticos emanados a partir do estaleiro da catedral de Miranda do Douro. Não obstante a depauperada conjuntura nacional, marcada a partir de 1640 por 30 anos de Guerras da Restauração da Independência, as obras do edificado conventual estavam terminadas em 1689.

$\mathrm{Na}$ segunda metade do século XVIII, reinava D. José da dinastia dos Braganças, quando Vinhais recebeu os Missionários Franciscanos do Seminário Apostólico. Foram acompanhados, pouco tempo depois, pela organização da Ordem Terceira Secular, difundido o ideal franciscano para a zona mais ocidental da Diocese.

Esta densa malha institucional que se intensifica nos finais do Antigo Regime reflete a história da Ordem de São Francisco em Portugal, com as reformas e os novos ramos que foram formando a ampla família franciscana. Reflete, também, o forte sentido evangélico da Ordem que, a partir dos Descobrimentos e até à chegada dos Jesuítas, é responsável pela praxis doutrinária junto dos leigos. Assim, fosse no Brasil ou em Trásos-Montes, a missionação era causa franciscana, privilegiando a continuada relação com os leigos. Este vínculo promovia a integração da população local, enquanto membros 
ativos nas fraternidades terceiras ou noutras irmandades que se instalaram nos conventos. Os leigos, amplo e desconhecido grupo social, eram também o público-alvo das pregações. Dentro destas dinâmicas sociais, plurais e heterogéneas, não podemos esquecer a forte presença das comunidades de cristãos-novos, ou de judeus conversos que se instalarem em Bragança, Mogadouro e Vinhais e um pouco por todo o periférico território de fronteira. A emergência em dissipar a Lei-Velha, numa sociedade que se pretendia totalitariamente católica, constitui uma das linhas de ação dos religiosos, regulares e seculares. Desde o início do século XVI e até meados do século XVIII, quando o Marques de Pombal diluiu o sectarismo entre cristão-velho e cristão-novo, a necessidade de integração dos judeus conversos e a necessidade de evangelização por parte das entidades religiosas constituiu uma dinâmica social inegável no território em estudo. Não submetemos a realidade da instalação das diferentes casas franciscanas a este fenómeno, pois a ausência documental não permite entender a relação entre ambos grupos sociais: franciscanos e cristãos-novos. No entanto, não podemos deixar de referir a intensa presença local, essa sim documentada com inúmeros processos no tribunal da Inquisição, de judeus conversos. De igual modo, notamos a intensa presença franciscana.

A edilidade local não se excluiu dos processos de fundação e posterior engrandecimento das casas franciscanas para as quais contribuíram, de forma continuada, as famílias economicamente mais poderosas dos territórios em estudo.

$\mathrm{Na}$ época medieval, a família Morais beneficiava com propriedades o convento dos Frades Menores, em Bragança, no século XIII. É também no convento de Bragança que se percebe a importância social das capelas privadas com as dinâmicas geradas pelos diversos titulares. Nestas capelas verifica-se a instituição de novas devoções, desafetas aos cultos mais divulgados pela ordem franciscana.

Em pleno domínio da Dinastia dos Filipes, a poderosa família Távora protegeu o convento dos frades da Ordem Terceira Regular, em Mogadouro.

Na segunda metade do século XVIII, a família Morais Sarmento (com ligações familiares à família Morais de Bragança) favoreceu o estabelecimento do Seminário Apostólico e, posteriormente, da Ordem Terceira Secular, em Vinhais.

Além da edilidade local, foram inúmeras as vezes em que o clero secular apoiou os conventos, estipulando esmolas, divulgadas nas Pastorais dos Bispos, para cobrir as necessidades mais emergentes das diferentes casas. Os benefícios reais também foram constantes, vinculando a presença local dos religiosos e das religiosas franciscanas à 
figura do Rei através de esmolas, rendas e benefícios. Mas, além dos membros da família franciscana foi a própria comunidade, reunida em fraternidades e irmandades leigas, a responsável por muitas das esculturas que ainda podemos observar no interior dos templos.

Perante estas dinâmicas sociais, julgamos que as esculturas desempenhavam um importante papel, dentro do conjunto edificado que as expunha e mesmo no espaço público, durante as cerimónias religiosas e nas missões evangélicas. Enquanto representações da expressão doutrinária franciscana, as esculturas ilustravam tridimensionalmente os valores e o ideário a difundir.

Entre as diversas categorias artísticas, a escultura constitui claramente a categoria mais valorizada quantitativamente, face à pintura e até à talha retabular que cobre a maioria dos altares no interior dos templos. Nos cinco templos em estudo foram inventariadas 109 esculturas de vulto completo. Além das esculturas registamos também em inventário 11 fichas de relativas a fragmentos escultóricos.

Relativamente ao ritmo de produção das esculturas, percebemos que, também neste âmbito, se reflete a conjuntura nacional. A produção escultórica medieval é, no território português, marcada pelas obras pétreas de calcário brando dos estaleiros da Batalha e de Coimbra. Ao único convento franciscano medieval da Diocese de Bragança-Miranda, o convento de São Francisco de Bragança, não chegou essa produção. Mas, é no convento de São Francisco de Bragança que está a maioria das imagens cujas formas podemos identificar com as cronologias mais recuadas. Como também é no convento de São Francisco de Bragança que se regista maior constância diacrónica na encomenda das esculturas.

Inesperadamente, é em Vinhais, na casa franciscana de fundação mais recente (segunda metade do século XVIII), que encontramos as esculturas que ecoam de modo mais claro o gosto medieval. Trata-se de uma representação de São Francisco de Assis (MASV 01) e de uma representação de São Miguel Arcanjo (MASV 03), atualmente expostas no Museu de Arte Sacra de Vinhais. São ambas em madeira e, formalmente, próximas às produções escultóricas do século XV, inícios do XVI, o que lança a questão sobre a itinerância das obras entre as casas mais antigas, de onde, forçosamente, eram originárias as esculturas de São Francisco de Assis e de São Miguel Arcanjo, e as novas fundações religiosas que, numa primeira fase, careciam de imagens de culto. Esta itinerância ajuda a entender a permanência de valores arcaizantes no gosto, mas, sobretudo sugere a supremacia dos valores simbólicos das representações sobre o aspeto 
plástico que as corporaliza. A escultura do século XV em Portugal ficou marcada pelo vigor do estaleiro de Coimbra e do Mosteiro de Santa Maria da Vitória na Batalha nos trabalhos de pedra calcária branda. Desconhece-se a produção escultórica de vulto em pedra no território de Bragança durante o século XV e a estatuária de Gil Eanes e Afonso Martins e João Afonso apenas chegou em ecos longínquos evocados no oval dos rostos de volumes amenos e arredondados e na falta de naturalismo dos gestos muito presos ao volume dos corpos das imagens de São Francisco e São Miguel expostos atualmente no Museu de Arte Sacra de Vinhais.

No início do século XVI Coimbra mantinha-se ainda como centro produtor de esculturas de linguagem tardo-gótica marcado pela forte influência de Diogo Pires-oVelho. No naturalismo no tratamento da cabeça, no grosso pescoço e nos cabelos lisos a escorrer sobre os ombros da escultura de Nossa Senhora do Rosário (SFB 10) da igreja de São Francisco em Bragança podemos perceber a persistência desses valores arcaizantes. Os valores do renascimento chegaram à escultura portuguesa pela crescente encomenda de escultura arquitetónica em mármores de Itália, mas sobretudo pela importação direta de imagens em madeira dos Países Baixos e pelo fluxo de escultores chegados de França e da Flandres. A testemunhar esta ligação, no convento dos Frades Menores de Bragança, encontramos uma representação de Cristo Crucificado (SFB 22) de evidente produção flamenga no tratamento minucioso da anatomia. Mas as refinadas linguagens de Nicolau de Chanterene, Filipe Hodart ou de João de Ruão são impercetíveis na imaginária dos espaços franciscanos da diocese de Bragança-Miranda.

No século XVII, amplia-se a dinâmica franciscana no território. Além dos Frades Menores de Bragança, acresce a já consolidada presença, também em Bragança, das Clarissas (que se haviam instalado em 1598). Na segunda metade da centúria, os Terceiros Regulares fixam-se em Mogadouro, fortalecendo uma força doutrinária significativa na região, à qual corresponde uma crescente necessidade de recursos didáticos que lhes favorecessem uma eficiente aproximação às populações. Assim, e não obstante a constância das crises motivadas pelos conflitos bélicos que ocupam parte considerável da centúria, é inquestionável o incremento dados às artes plásticas, em particular, à escultura. Este aumento da produção artística beneficiou da influência que o estaleiro da catedral de Miranda do Douro irradiou para o território de Trás-osMontes. Mas a importante presença das obras de Gregório Fernández no retábulo-mor da catedral de Miranda do Douro, entre outros mestres castelhanos, deixou apenas ligeiríssimas marcas que pudemos identificar em detalhes das figurações do século 
XVII. Destacamos neste âmbito a escultura de São Caetano da igreja de São Francisco em Mogadouro (SFM03) cuja gestualidade e detalhes nas representação volumétrica do rosto evocam as influências de Gregório Fernández. A imagem de Santa Ana na igreja das clarissas de Bragança (SCB 08) reproduz no detalhe das sobrancelhas arqueadas as Dolorosas de Juan de Juni. Timidamente, surgiu também a influência mais clássica na idealização anatómica que se observa numa das representações de Cristo Crucificado da igreja de São Francisco em Bragança (SFB 13). Mas a expressividade barroca de Manuel Pereira ou de Frei Cipriano da Cruz bem como de Gregório Fernández foi pouco copiada nas esculturas seiscentistas que ainda existem nos espaços franciscanos em estudo. A esmagadora maioria das esculturas do século XVII, foi influenciada pelas oficinas nacionais de Alcobaça cujos autores desconhecidos impunham os valores tridentinos de subjugação da forma à mensagem, posteriormente esta linguagem foi ampliada pelas oficinas do Porto e Braga. A magna importância dada à iconografia de base teológica e ética subalternizou a qualidade artística considerada supérflua na sua materialidade. As oficinas nacionais espelhavam as resoluções dos programas régios do pós-guerra da Restauração. Os conjuntos escultóricos, pensados já como cenografias, estavam inspirados no fortalecimento dos princípios e valores nacionais que, após os 80 anos de domínio filipino, se impunha reforçar. Simultaneamente, a ênfase dada à aplicação das orientações tridentinas gerou, em Portugal, uma expressão artística profundamente simbólica. A valorização do conteúdo sobre a forma, cuja natureza era essencialmente pedagógica, teve como consequência uma figuração muitas vezes pouco verosímil, com escassa expressividade, mas com forte carga narrativa e doutrinária. Esta tendência ocupou parte significativa da produção escultórica do século XVII e prolongou-se, nos espaços em estudo, ainda no século XVIII.

O século XVIII constitui, no território nacional, o momento de maior valorização da escultura. O estaleiro de Mafra, com as iniciais encomendas escultóricas a Itália e posterior criação da oficina de escultura em Mafra, estabeleceu em Portugal os valores italianos pós-berninianos. Em Évora destacam se as obras de Manuel Dias. Mas para o território em estudo foram as cidades do Porto e Braga que imprimiram uma marca mais profunda. A cidade do Porto e a frutífera prática artística de Nicolau Nasoni bem como de um significativo número de entalhadores e imaginários, entre eles António Gomes e Filipe Silva, Luís Pereira da Costa, Miguel Francisco da Silva e Manuel da Costa Andrade. De Braga foram as influências de Manuel Carneiro Adão e Marceliano de Araújo que maior impacto tiveram no território. As oficinas do Porto e de Braga 
divulgaram um crescente cuidado plástico. A expressividade afirmou-se, definitivamente, como valor estético. Percebemos esta alteração do gosto na gestualidade e no dinâmico pregueado dos panejamentos do conjunto dos Santos Mártires de Marrocos, (SFB 16; SFB 17; SFB 18; SFB 19) ao culto na igreja de São Francisco em Bragança.

A correspondência com este cenário nacional é notória também nos templos franciscanos da Diocese de Bragança-Miranda. Durante o século XVIII, atinge-se o apogeu da produção escultórica, não apenas em número de esculturas, mas, sobretudo, no cuidado anatómico e expressivo das figuras e na ampliação das devoções que representavam. A par das esculturas de encomenda a oficinais mais desenvolvidas multiplicam-se as oficinas regionais que copiam os modelos emanados sobretudo a partir do Porto e Braga

Na segunda metade da centúria, a família franciscana seria ampliada com a fundação do Seminário Apostólico e, posteriormente, com a construção do templo da Ordem Terceira Secular, ambos em Vinhais. Mas, mesmo nos templos que estavam já instalados no território, se percebe uma clara valorização da encomenda de esculturas. A origem desta vasta produção escultórica é plural. Observa-se o recurso a oficinas locais e regionais de valores plásticos ingénuos, e onde prevalecia a talha mais artesanal, executada com maior ou menor mestria técnica, na reprodução dos modelos mais divulgados.

Relativamente às oficinas locais e regionais, destacamos a proficiente figura do escultor Frei Domingos, do Seminário Apostólico de Vinhais. O escultor Frei Domingos foi o responsável por um número significativo de esculturas que ainda estão ao culto no Seminário Apostólico das quais destacamos pela intensidade dramática e valor expressivo a escultura de Cristo do Coro (CSDV 06), hoje exposta na capela de Nossa Senhora das Dores da igreja de Nossa Senhora da Encarnação. As esculturas são em madeira, mas também em terracota e denotam uma cuidada prática, cuja formação nos merecerá posteriores estudos.

Mas, simultaneamente, eram crescentes as encomendas a oficinas bem apetrechadas, técnica e teoricamente. Relativamente às oficinas mais bem preparadas destacamos, nos espaços em estudo, a relação preferencial com as oficinas do Porto e Braga que, maioritariamente, satisfaziam a clientela do Norte do País. As oficinas do Porto foram marcadas pelas figuras de José Teixeira Guimarães e Francisco Pereira Campanhã. As oficinas de Braga foram influídas pelas figuras de André Soares, José Alvares de Araújo 
e sobretudo por Frei José de Santo António Ferreira Vilaça. Ambas as oficinas traduziam na segunda metade do século XVIII o gosto rocaille. Percebemos esta alteração nos requebros dos gestos e nos cingidos e esvoaçantes panejamentos da escultura de Santa Clara (SFV 06) ou da Imaculada Conceição (SFV 07) e São Francisco de Assis (SFV 08) na igreja de São Francisco em Vinhais, mas também na escultura de Nossa Senhora da Aparecida (CSDV 02) na capela de Nossa Senhora das Dores da igreja de Nossa Senhora da Encarnação em Vinhais.

Mais excecionalmente percebemos a presença de oficinas de Lisboa, traduzida nas influências italianas emanadas a partir de Mafra e da figura de Alessandro Giusti cujos ecos são percetíveis nas estatuetas de São Bernardino de Siena (CSDV 01) e São Boaventura (CSDV 09) atualmente a culto na capela de Nossa Senhora das Dores da igreja de Nossa Senhora da Encarnação em Vinhais. De Machado de Castro e de António Ferreira o "Ferreirinha de Chelas" e do gosto pelo pitoresco e pela poética do quotidiano por eles divulgado chegaram aos nossos dias duas maquinetas, ambas ao culto na igreja de São Francisco em Vinhais, onde se expõe um Presépio (SFV 09) e uma Descida da Cruz (SFV 05).

A par da produção escultórica intensifica-se também a produção retabular e a pintura em perspetiva sobre os tetos de madeira, assim como a ornamentação dos púlpitos, cadeirais e dos arcos triunfais.

Todos estes elementos visuais concorriam para um aparato cenográfico propiciador à comoção dos fiéis. Os fiéis, através dos sentidos, ilustravam as Sagradas Escrituras e as palavras dos sermões, das pregações e cerimoniais religiosos que pautavam o ano litúrgico, que marcava o quotidiano de toda a comunidade. Neste cenário a escultura, enquanto mimese formal do observador, constituía o centro de interesse de atenção visual e portanto também o cerne devocional.

Os registos documentais referem-se mais comummente à produção de estruturas retabulares do que à produção de esculturas, com muitas mais referências a entalhadores que a escultores. Este facto denuncia não apenas o desmerecimento profissional do imaginário, mas também a superior valorização do cenário retabular em detrimento da imagem que expunha, e para a qual era construído. Apesar do silêncio das fontes sobre as autorias das esculturas, a pesquisa documental permitiu-nos, muitas vezes partindo apenas do registo de uma devoção ou de uma relíquia, identificar a totalidade das figuras representadas nas esculturas em estudo. 
Relativamente às estruturas retabulares, apenas em Mogadouro se observa o gosto maneirista que na talha portuguesa se mantém até aos finais do século XVII. Residualmente percebemos a constância de elementos de gosto maneirista no retábulo em pedra da igreja de São Francisco em Bragança da capela que hoje expõe a figura de Cristo e dos Santos Mártires de Marrocos, e nos detalhes de pedra que ainda subsistem do retábulo de São Caetano na igreja das clarissas na mesma cidade. Há, nos espaços em estudo, uma clara preferência pela talha barroca nacional, cuja produção se baliza normalmente entre 1680-1720. Podemos observar a talha barroca nacional em alguns retábulos da igreja do convento dos Frades Menores de Bragança, na igreja das Clarissas na mesma cidade e também, mas em menor quantidade, em Mogadouro. Nos espaços franciscanos mais recentes, construídos em Vinhais observa-se apenas a talha rocaille. No templo do Seminário Apostólico, a talha rocaille denuncia ainda a persistência de alguns elementos joaninos. A cobrir os altares do templo da Ordem Terceira Secular, a talha rocaille apresenta já indícios neoclássicos. Também na igreja do convento dos Frades Menores de Bragança, a talha rocaille está presente na original capela da Ordem Terceira, ocupada a partir de 1780 com a devoção da Imaculada Conceição e intervencionada então no retábulo e teto com cenografia mariana a cobrir todo o espaço. Em nenhum dos templos em estudo existe, porém, talha joanina, com a totalidade dos elementos que a identificam, apenas se observam detalhes joaninos, misturados com outros modelos. Não descuramos que tenha existido algum retábulo joanino no interior dos espaços franciscanos em estudo, contudo não chegou aos nossos dias. Apesar de documentalmente não nos ser possível relacionar os entalhadores dos retábulos com os escultores das imagens ou imaginários, julgamos que os trabalhos de ambos estariam próximos e respondiam perante os mesmos fluxos de encomendas.

A partir do século XVIII, sobretudo da segunda metade, as encomendas artísticas já não se restringiam ao objeto cultual, mas expandiram-se para o espaço envolvente, transformando a arquitetura interior dos espaços numa cenografia emocional em que todos os elementos convergiam para a pedagogia doutrinal.

Neste sentido, e entendidas enquanto expressão de um coletivo, as esculturas adquirem valor principalmente pelo seu carácter narrativo.

A análise iconográfica das esculturas permitiu-nos perceber as figuras concretas e as narrativas específicas que preenchiam os imaginários expressos nas obras. Pudemos, também, identificar e quantificar as devoções. Numa perspetiva quantitativa contemporânea, é forçoso refletir sobre a quase paridade entre as representações de 
Cristo e de Nossa Senhora. Esta proximidade numérica é tanto mais surpreendente pela disparidade de género dos ocupantes dos conventos, pois apenas o convento de Santa Clara de Bragança era feminino, e comparativamente aos restantes espaços é o que mantém menos esculturas anteriores à extinção das Ordens Religiosas. Os restantes espaços eram masculinos, com exceção do templo dos Terceiros de Vinhais que reunia homens e mulheres leigos.

O culto a Cristo era transmitido sobretudo a partir da narrativa da Paixão. Como comummente ocorre sobressaem as esculturas com a representação de Cristo na Cruz (SFB 22; SFB 20; SCB 06; SFM 06; CSDV 06), além de diversas cruzes de altar. Existem também dois originais conjuntos que reúnem a figura de Cristo com São Francisco de Assis, o Abraço Místico ou Amor Divino (SFB 03 e SFB 04) e a representação de Cristo Serafim conforme a visão de São Francisco no Monte Alverne (SFB 30), perante São Francisco ajoelhado (SFB 35).

O culto mariano foi expresso, principalmente, pela devoção a Nossa Senhora da Imaculada Conceição (SFM 09; CSDV 07; SFV 07; SFB 08). A histórica defesa do dogma da Imaculada Conceição por parte dos franciscanos não limitou a expansão escultórica mariana a outras invocações. Destacam-se as esculturas de Nossa Senhora relacionada com a Paixão de Cristo, mas, sobretudo, destacam-se as representações das Nossas Senhoras tutelares, Nossa Senhora da Boa Morte (SFB 06) e (IEV 03); Nossa Senhora do Rosário (SFB 10); Nossa Senhora dos Remédios (SFM 11); Nossa Senhora da Lapa (SFM 11); Nossa Senhora da Aparecida (CSDV 02). Relativamente ao culto mariano é manifesta a ausência de imagens de Nossa Senhora com o Menino. Apenas existe uma representação de Nossa Senhora com o Menino ao colo (SFM 01), em Mogadouro, e sabemos que era proveniente da Capela de Nossa Senhora do Caminho, também em Mogadouro e por isso seria exterior às devoções disseminadas pelos franciscanos. A ausência de imagens de maternidade, nos templos em estudo, contrasta com a presença de imagens de paternidade. A figura de São José, incluída na análise da parentela da Virgem, é representada duas vezes com o Menino ao colo (IEV 04 e SFM 02). Ambas as esculturas estão em espaços franciscanos masculinos, no Seminário Apostólico de Vinhais e no convento dos Regulares Terceiros de Mogadouro. O valor catequético imposto na representação da paternidade de São José parece-nos exemplificativo das alterações sociais que, ao longo do século XVIII e centúrias seguintes, foram reestruturando os comportamentos e os papéis dos indivíduos no 
âmbito familiar, com evidente empenho no incremento da proteção à infância, e em consequência na responsabilização parental.

A presença da representação de São Francisco de Assis nas esculturas é definida sobretudo pelo modelo do santo a expor os estigmas (MASV 01; SFB 21; SFM 07; SFB 12), nas obras mais recente percebemos a preferência pela figura do santo como asceta e penitente (IEV 09 e SFV 08). Apesar das escassas variações dos gestos da figura de São Francisco houve a ampliação das narrativas de conjunto. Nesta perspetiva de conjunto, identificamos a figura de Cristo Alado, ou de Cristo Serafim, presente apenas nas narrativas franciscanas, e que julgamos que constituiria um conjunto com a escultura de São Francisco ajoelhado, formando a narrativa do momento da estigmatização do Santo. Bem como a cena do Abraço Místico, que ainda hoje está exposta, e representa a lenda da visão que teve São Francisco em que Cristo desprendia o braço da Cruz para o abraçar. Ambas as narrativas se encontram no templo, outrora dos Frades Menores de Bragança, e testemunham a vitalidade e originalidade dos modelos iconográficos encomendados durante o século XVIII. A par da figura de São Francisco de Assis, que depois dos cultos a Cristo e a Nossa Senhora constitui a figura mais vezes representada, outros fundadores que com ele se relacionaram foram esculpidos para os templos franciscanos, entre eles, São Domingos de Gusmão e Santa Clara de Assis. Ambas as figuras surgem associadas a São Francisco expostas em conjunto. Ainda hoje, em Mogadouro sobre o altar-mor estão colocadas as esculturas de São Francisco e São Domingos, e o mesmo ocorria originalmente na igreja do Seminário de Vinhais. Em conjunto com Santa Clara ainda hoje se expõe a imagem de São Francisco na igreja da Ordem Terceira de Vinhais.

As restantes devoções incidem sobretudo nos santos franciscanos, com destaque pela quantidade de esculturas, para Santo António de Pádua ou de Lisboa (SFB 14; SFB 01; SCB 11; IEV 08). Santo António reflete, desde o século XVII, a intensificação dos cultos nacionais que, a partir dos programas régios, influenciaram toda a imaginária portuguesa. As representações antoninas partiram de um reflexo do próprio Santo fundador da Ordem, São Francisco de Assis. Mas, a devoção popular, bem como as orientações nacionalistas ampliaram os modelos iconográficos do Santo, sendo um dos mais incomuns o Santo António, Menino do Coro (SFV 03) que ainda se mantém a culto na igreja dos terceiros de Vinhais.

A singularidade de alguns modelos iconográficos das esculturas da igreja de São Francisco da Ordem Terceira de Vinhais é representativa da diferenciação relativamente 
às imagens a culto no contíguo Seminário Apostólico. Nem uma imagem esculpida por Frei Domingos está a culto na vizinha igreja dos Terceiros Seculares, não obstante partilharem a mesma família de beneméritos para a fundação de ambas as casas. Esta demarcação estética, com recurso a oficinas claramente melhor apetrechadas, por parte dos leigos da Ordem Terceira de Vinhais supõe um evidente conforto material que permitiu à Ordem Terceira preencher o templo com esculturas de boas oficinas do Porto e Braga e ao mesmo tempo que nas estruturas retabulares e nos tetos a cenografia ocupava preenchia todo o espaço. O programa escultórico do templo dos terceiros de Vinhais revela o prestígio social que a fraternidade de leigos representou no território, que reflete a crescente intervenção social assumida pelos coletivos leigos. $\mathrm{Na}$ mesma igreja encontramos outro singular modelo iconográfico da representação de Santa Margarida de Cortona (SFV 12). A Santa é regularmente representada em Portugal como monja, quase integralmente coberta pelo hábito. No entanto, a escultura da igreja dos Terceiros de Vinhais privilegiou a representação de Santa Margarida enquanto jovem e intensamente bela com os longos cabelos loiros sobre as costas. A narrativa da mulher mundana arrependida, a representação da sujeição da vontade própria à vida de oração, penitência e contemplação fortalecia o culto da contrição como processo ascético. Já antes a figura de Santa Maria Madalena ilustrava um caminho semelhante, mas, nos templos em estudo, Maria Madalena está presente apenas como elemento periférico na representação do Calvário e de Cristo Morto. É também no templo dos terceiros de Vinhais que encontramos a escultura de Santa Rosa de Viterbo (SFV 02), ampliando, além de Santa Clara, e Santa Margarida de Cortona a presença feminina nos espaços franciscanos. Na igreja da Ordem Terceira Regular de Mogadouro existe uma representação de Santa Isabel de Hungria (SFM 04). Mas, esta ligeira presença de figuras femininas apenas na segunda metade do século XVIII se expande nos templos em estudo. A maioria das esculturas representam figuras masculinas. A maioria das figuras masculinas representam santos da Ordem Franciscana. Dentro do conjunto de Franciscanos canonizados destacamos, ainda, a presença em Bragança e Vinhais de São Benedito de Palermo (SFB02 e SFV 04). O Santo, de pele negra, constitui uma importante devoção dos coletivos socialmente mais fragilizados, de entre os quais os escravos. Além da presença de São Benedito destacamos também a presença do escravo negro e do índio brasileiro no Presépio que está hoje exposto dentro de uma maquineta na igreja dos terceiros em Vinhais, mas que, originalmente, pertencia ao contíguo Seminário Apostólico. A crescente presença feminina e multiétnica nas representações 
religiosas anunciava as transformações sociais que a contemporaneidade operaria sob os coletivos então ainda destituídos de valor social? Seguramente que não, pelo menos nos termos radicais e anticlericais em que a contemporaneidade se instalou, com a imediata extinção das Ordens Religiosas, em 1834. Mas, como espaços de doutrina, os templos franciscanos expandiam modelos de comportamento contribuindo, a partir da sua representação, para a dignificação e para a emancipação dos coletivos mais subjugados.

As devoções, nos espaços em estudo, surgiram por diversas vias. A principal via era constituída pelas emanações gerais da Igreja, seguidas das emanações da Ordem de São Francisco. Mas as devoções que estão representados nas esculturas dos franciscanos na diocese, não se circunscreveram apenas às emanações da Ordem Franciscana. A partilha dos templos com outras fraternidades e irmandades leigas promoveu a ampliação de cultos. Nesse contexto destacamos, na igreja de São Francisco em Bragança, a presença da devoção a São Vicente Ferrer (SFB 13) e a São Pascoal Bailão (SFB 05). Ambos os santos, de origem espanhola, têm pouca devoção no território português e foram instituídos por privados que trouxeram a devoção doutros locais. Igual procedimento se conhece para a devoção de Nossa Senhora dos Desamparados, na igreja do extinto mosteiro das monjas beneditinas em Bragança, trazida de Espanha pelos militares, no último quartel do século XVIII.

Assim, enquanto a influência formal da arte espanhola nos parece quase residual nas obras escultóricas em estudo, é notória relativamente à influência sobre as devoções. Também nesta atitude prevalece a sistemática valorização do conteúdo sobre a forma que identificamos na escultura pós-Trento e que, em Portugal, se fincou longamente. Nas devoções expressas nas esculturas julgamos também identificar a influência do Brasil. A influência brasileira consubstancia-se na rápida transmissão do culto de Nossa Senhora da Aparecida, presente em Vinhais no último quartel do século XVIII. Mas, também identificamos a influência brasileira na representação do abraço entre Cristo e São Francisco, frequente como representação escultórica no Brasil onde é denominado de "Amor Divino" ao contrário do que ocorre em Portugal onde raras vezes foi representado na escultura. Também a escultura de Cristo Serafim, com os três pares de asas, é mais comum no Brasil que em Portugal. Esta proximidade devocional não significa que se trate de obras produzidas no Brasil, mas a frequência de fluxos migratórios entre Trás-os-Montes e o Brasil poderá ter contribuído para a fluência de cultos entre ambos os territórios. 
Se nas formas das esculturas apenas pudemos identificar escassas ligações entre as obras dos vários espaços franciscanos em estudo, prevalecendo a ideia de que cada comunidade teria a sua preferência oficinal, raras vezes coincidindo nas oficinas ou nos autores das esculturas, no sentido narrativo das formas, as proximidades são múltiplas e repetem-se, com raras exceções, as devoções entre os diferentes templos.

A heterogeneidade nas autorias das esculturas e nas oficinas de encomenda desvanece-se completamente quando observamos a produção escultórica contemporânea. Após a extinção das Ordens Religiosas em 1834, todas as igrejas em estudo mantiveram funções cultuais o que motivou a introdução de novas esculturas. A quase total ausência de novas aportações durante o século XIX é transversal a todos os templos. Os conflitos bélicos e a depauperação económica acrescida da intensa mobilização anticlerical limitou o empenho religioso (secular) e leigo na introdução de novas obras artísticas. Mas, o século XX, mormente o período do Estado Novo, foi profícuo na produção de imagens religiosas. A representação de Nossa Senhora de Fátima e do Sagrado Coração de Jesus, das oficinas da Casa Fanzeres, em Braga, ou dos Thedim, em Matosinhos, estão em praticamente todas as igrejas. Trata-se de produções em série, talhadas sobre madeira, e que, apesar de ligeiríssimas diferenças, espelham uma normalização criativa que, funcionalmente, se adapta aos modelos de consumo contemporâneos.

Relativamente ao número de esculturas que chegou aos nossos dias, devemos referir a disparidade da presença de esculturas nos diferentes espaços em estudo. É notória a escassez de esculturas, anteriores ao processo de extinção das ordens religiosas, no templo das clarissas comparativamente aos restantes templos. Sabemos que muitas esculturas foram deslocadas do seu lugar de origem. O movimento imposto às obras é evidente na disparidade observada em muitos dos retábulos que estão atualmente ocupados por novas devoções, e exporiam, originalmente, obras que hoje estão sobre peanhas ou mesmo deslocalizadas dos templos. As alterações no interior dos templos não cessaram, desde a extinção das ordens religiosas, provocando irreparáveis perdas e inumeráveis repintes sobre as esculturas. Não só identificamos obras atualmente desaparecidas do seu lugar de culto original, como também percebemos lacunas sofridas nas esculturas, desde as últimas intervenções de restauro. Neste sentido, destacamos a perda de vários atributos iconográficos nas esculturas de Vinhais, que constavam ainda nas respetivas imagens, aquando do único inventário que as registou, recentemente, no 
catálogo de Escultura das Comemorações Jubilares dos 450 anos da Diocese de Bragança-Miranda de 1996.

A técnica escultórica mais comum é a talha sobre madeira, que posteriormente era policromada e estufada. Muitas vezes percebemos os diferentes ritmos de imposição das técnicas sobre as esculturas, não apenas porque as podiam incumbir a diferentes profissionais, mas porque o repinte sobre esculturas consideradas já impróprias para estar ao culto, constituía, não raras vezes, a maneira de prolongar a vida devocional da imagem. As recomendações das pastorais dos Bispos são claras na exigência do decoro das imagens. Mas a permanência, em quase todos os templos, de imagens de roca ou de vestir denota que as recomendações episcopais nem sempre eram acatadas. A referência à proibição de imagens de vestir repete-se em dois documentos episcopais, no entanto, as imagens de vestir mantiveram-se ao culto. Possivelmente, enquanto acessórios das imagens de vestir ou como complementos aos cerimoniais públicos, a presença dos elementos têxteis é de sobremaneira evidente na documentação pesquisada. O elevado valor que é atribuído aos dosséis, umbelas, pálios e mantos, na sua maioria de seda, sugere também o prestígio da indústria sericícola local, mas denota, sobretudo, a valorização das técnicas têxteis e das suas matérias-primas na encenação cerimonial no interior das igrejas.

Apesar da pobreza franciscana, mais ou menos transversal a todos os espaços franciscanos em estudo, não podemos deixar de referir que o templo dos Frades Menores de Bragança, o templo dos Regulares Terceiros de Mogadouro e o dos Missionários Apostólicos de Vinhais constituem, nos três núcleos urbanos onde se localizam, os maiores templos existentes. Esta projeção exterior dos espaços de poder apenas é superada pela intrincada teia de narrativas que se tecem a partir das esculturas no interior. Perante uma sociedade de contrastes e fortes oposições, o controle social era também feito pela Igreja e pelos poderes locais. No território em estudo, a ordem Franciscana desempenhava, diligentemente, a missionação como prática doutrinária dos comportamentos perante comunidades periféricas e tradicionalmente relacionadas com persistências da Lei Velha.

O estudo da arte portuguesa reflete, ainda hoje, o desequilíbrio entre a cultura rural e a cultura urbana. No entanto, as duas matrizes são constantes e, mesmo em territórios afastados dos centros de poder, constatamos análogos caminhos estéticos.

Após a extinção das Ordens Religiosas, todos os espaços conventuais foram adstritos a novos usos. O convento das Clarissas de Bragança foi totalmente destruído, resistindo 
apenas a igreja. O convento dos Frades Menores de Bragança, depois de múltiplas funções, foi adaptado para receber o Arquivo Distrital, função que ainda mantém. O convento de Mogadouro está hoje ocupado com os serviços da autarquia. O espaço conventual de Vinhais aguarda ainda uma ocupação continuada.

Todos os espaços conventuais que chegaram aos nossos dias têm em comum o facto de terem sofrido readaptações, obras e até demolições. As reocupações laicas beneficiaram do aparato de poder que o edificado arquitetónico projeta no espaço, mas não superam o investimento conceptual e artístico que os franciscanos, ao longo de seis séculos, impuseram no território.

Julgamos que a aproximação às imagens esculpidas dos templos franciscanos da Diocese de Bragança-Miranda nos permitiu o confronto com a linguagem simbólica como uma figuração do real, viva e expressiva. A imagem, corporalizada nas esculturas, consola e informa, fixa as memórias, os temores e os desejos, através da sua materialidade e continuada preservação, as esculturas comunicam-nos o esforço e a comunhão coletiva que ecoam até nós. 
BIBLIOGRAFIA 


\section{Fontes Documentais:}

A.N.T.T./A.H.M.F./C.S.C.B., Extinção das Ordens Religiosas - Convento de Santa Clara - Bragança, Arquivo Nacional da Torre do Tombo, Lisboa, Arquivo Histórico do Ministério das Finanças, Processos de Extinção das casas religiosas, Cx. 1891, 1870.

A.N.T.T./A.H.M.F./C.S.C.V., Extinção das Ordens Religiosas - Convento de Santa Clara - Vinhais, Arquivo Nacional da Torre do Tombo, Lisboa, Arquivo Histórico do Ministério das Finanças, Processos de Extinção das casas religiosas, Cx. 1892, 1897.

A.N.T.T./A.H.M.F./S.F.B., Extinção das Ordens Religiosas - Convento de São Francisco em Bragança, Arquivo Nacional da Torre do Tombo, Lisboa, Arquivo Histórico do Ministério das Finanças Processos de Extinção das casas religiosas, M.F. 7580 (cota antiga Cx. 2202), 1834.

A.N.T.T./A.H.M.F./S.F.M., Extinção das Ordens Religiosas - Convento de São Francisco em Mogadouro, Arquivo Nacional da Torre do Tombo, Lisboa, Arquivo Histórico do Ministério das Finanças, Processos de Extinção das casas religiosas, Cx. 2238, 1834.

A.N.T.T./A.H.M.F./S.N.S.E.V., Extinção das Ordens Religiosas Seminário de Nossa Senhora da Encarnação - Vinhais, Arquivo Nacional da Torre do Tombo, Lisboa, Arquivo Histórico do Ministério das Finanças, Processos de Extinção das casas religiosas, Cx. 2265, 1834. 


\section{Bibliografia (livros e artigos):}

Afonso, Belarmino, Ex-votos e religiosidade popular no Distrito de Bragança, Bragança, Região de Turismo do Nordeste Transmontano, 1995.

Afonso, Belarmino, "Os Franciscanos no Distrito de Bragança" in Boletim do Arquivo Distrital de Vila Real - Revista de Cultura, Estudos Transmontanos e Durienses $n^{\circ}$, Vila Real, Arquivo Distrital de Vila Real, 1995, pp. 333-351.

Afonso, Luís U., "Manter a freguesia no século XVI: os frescos de S. Francisco de Bragança e a Virgem da Misericórdia" Cadernos Terras Quentes, 2, 2005, pp. 169 - 176.

Alcoforado, Ana, O Menino dos Meninos, Coimbra, Museu Nacional de Machado de Castro, 2007.

Almeida, Carlos Alberto Ferreira de, "O culto a Nossa Senhora, no Porto, na época moderna: perspectiva antropológica", Revista de História, vol. 2, Porto, Faculdade de Letras da Universidade do Porto, 1979, pp. 159-173

Almeida, Fortunato de, História da Igreja em Portugal. Ed. pre. e dir.por Damião Peres, Porto, Lisboa, Livraria Civilização, 1967-1971.

Alves Batista, Maria Isabel, "O Convento de S. Francisco: Contributos para a sua história" in A construção de uma identidade - Trás-os-Montes e Alto-Douro, Bragança, Arquivo Distrital de Bragança, 2002, pp. 83-87.

Alves, Francisco Manuel, Bragança Memórias arqueológico-históricas do distrito de Bragança (2 ${ }^{a}$ edição) Tomo I, Bragança, Câmara Municipal de Bragança / Instituto Português de Museus - Museu Abade de Baçal, 2000, (original publicado em 1910-1947). 
Alves, Francisco Manuel, Bragança Memórias arqueológico-históricas do distrito de Bragança (2 ${ }^{a}$ edição) Tomo II, Bragança, Câmara Municipal de Bragança / Instituto Português de Museus - Museu Abade de Baçal, 2000, (original publicado em 1910-1947).

Alves, Francisco Manuel, Bragança Memórias arqueológico-históricas do distrito de Bragança (2a edição) Tomo III, Bragança, Câmara Municipal de Bragança / Instituto Português de Museus - Museu Abade de Baçal, 2000, (original publicado em 1910-1947).

Alves, Francisco Manuel, Bragança Memórias arqueológico-históricas do distrito de Bragança (2 ${ }^{a}$ edição) Tomo IV, Bragança, Câmara Municipal de Bragança / Instituto Português de Museus - Museu Abade de Baçal, 2000, (original publicado em 1910-1947).

Alves, Francisco Manuel, Bragança Memórias arqueológico-históricas do distrito de Bragança (2 ${ }^{a}$ edição) Os Judeus - Tomo V, Bragança, Câmara Municipal de Bragança / Instituto Português de Museus - Museu Abade de Baçal, 2000, (original publicado em 1910-1947).

Alves, Francisco Manuel, Bragança Memórias arqueológico-históricas do distrito de Bragança (2a edição) Os Notáveis -Tomo VII, Bragança, Câmara Municipal de Bragança / Instituto Português de Museus - Museu Abade de Baçal, 2000, (original publicado em 1910-1947).

Andrade, Maria Filomena Pimentel de Carvalho, "Franciscanos" in José Augusto Mourão e Ana Cristina da Costa Gomes, José Eduardo Franco (dir.), Dicionário Histórico das Ordens e Instituições Afins em Portugal, Lisboa, Gradiva Publicações, 2010, pp.158-169.

Araújo, António de Sousa, "Ordens Terceiras" in Carlos Moreira (Dir.) Azevedo, Diccionário de História religiosa de Portugal, Lisboa, Círculo de Leitores, 2000, pp. 348-355. 
Ariès, Philippe, História Social da Criança e da Família. Rio de Janeiro, LTC- Livros Técnicos e Científicos Editora S.A, 1981.

Azevedo, Carlos A. Moreira de, Cristo - Fonte de Esperança, Porto, Edições Asa, 2000.

Azevedo, Carlos A. Moreira de, "Variantes iconográficas nas representações antonianas" in. Cultura. Revista de história e teoria das ideias. Vol. 27 , Lisboa, Centro de História da Cultura. Faculdade de Ciências Sociais e Humanas, Universidade Nova de Lisboa, 2010, pp. 41-55.

Bailão, Ana, "Terminologia associada à conservação e restauro de pintura", in Conservar Património $n^{\circ}$ 18, Lisboa, ARP (Associação Profissional de Conservadores-Restauradores de Portugal), 2013, pp. 55-61.

Baschet, Jerôme, "Introduction: L' Image-Objet" in. Schmitt, J.-C., Baschet, J. (Coord.) L'Image. Fonctions et usages des images dans l'Occident medieval, Paris, Le Léopard D’or, pp.7-26.

Baschet, Jérôme, L'iconographie médiévale, Paris, Gallimard, 2008.

Belting, Hans, Antropología de la imagen, Madrid, editorial katz, 2007.

Bíblia Sagrada, Lisboa, Difusora bíblica (Missionários capuchinhos), 14 edição, 1988.

Boing, Mafalda Pereira, Nossa Senhora Aparecida - A Padroeira do Brasil, São Paulo, Edições Loyola, 2007. 
Bonazzi Da Costa, Mozart Alberto, "A Igreja Conventual Franciscana de Salvador: História, talha e arquitetura" in Natália Marinho Ferreira-Alves (Coord.), Franciscanos no mundo português. III, Porto, CEPESE - Centro de Estudos da População, Economia e Sociedade, 2013.

Borges, José Cardoso, Memórias de Bragança, Fernando de Sousa (Coord.), Bragança, CEPESE / Câmara Municipal de Bragança, 2012 (texto original de 1721-1724).

Boespflug, François; Zaluska, Yolanta "Le dogme trinitaire et l'essor de son iconographie en Occident de l'époque carolingienne au IV Concile du Latran (1215)",Cahiers de civilisation médiévale, X-XII siècles, vol. XXXVII, núm. 3, 1994, pp. 181-240.

Caetano, Joaquim Oliveira, Obras-primas da arte portuguesa: Escultura, Lisboa, Athena, 2011.

Calderón, Marica López, "El Crucificado en la escultura compostelana de mediados del siglo XVIII. José Gambino, inventor de tipos e introductor de nuevas formas", in Revista da Faculdade de Letras. Ciências e Técnicas do Património, Porto, vol. IX-XI, 2010-2012, pp.374-399.

Campos, Hermão de e Rabelo, Roberto, Flos Sanctorum HO FLOS SANCTÕ[RUM] EM LINGOAJE[M] P[OR]TUGUE[S], Lisboa, Disponível na plataforma on-line da Biblioteca Nacional de Portugual http://purl.pt/12097, 1513.

Capela, José Viriato, et al., As freguesias do distrito de Bragança nas memórias paroquiais de 1758, Braga, Edição José Viriato Capela / Rogério Borralheiro, 2007.

Cardoso, Jorge, Agiologio lusitano dos sanctos, e varoens illustres em virtude do Reino de Portugal, e suas conquistas : consagrado aos gloriosos S. Vicente, e S. Antonio, insigns patronos desta inclyta cidade Lisboa e a seu illustre Cabido Sede Vacante. Tomo IV, Lisboa, Officina Craesbeekiana, 
Disponível na plataforma on-line da Biblioteca Nacional de Portugal http://purl.pt/12169, 1652.

Cardoso, Jorge, Officio menor dos sanctos de Portugal: tirado de breviarios, \& memorias deste reino, Lisboa, Pedro Crasbeeck, Disponível na plataforma on-line da Biblioteca Nacional de Portugal, http://purl.pt/14148, 1629.

Carmona Muela, Juan, Iconografia de los santos, Madrid, Akal, 2008.

Carmona Muela, Juan, Iconografia cristiana, Madrid, Akal,2010.

Carvalho, Anna Maria Fausto Monteiro de, " O complexo construtivo franciscano de Olinda no Brasil Colonial. Aspectos sócio-urbanos, arquitetônicos e artísticos" in Natália Marinho Ferreira-Alves (Coord.), Franciscanos no Mundo Português III, Porto, CEPESE - Centro de Estudos da População, Economia e Sociedade, 2013, pp.119-145.

Carvalho, Maria João Vilhena de, Normas de Inventário - Artes Plásticas e Artes Decorativas - Escultura, Lisboa, I.P.M. (Instituto Português de Museus), 2004.

Carvalho, Maria João Vilhena de, "A Escultura portuguesa entre a pedra, a madeira e o barro (1450-1580)" in Dalila Rodrigues (Coord.), Arte Portuguesa - Da Pré-História ao Século XX, volume 7, Lisboa, Fubu Editores, 2009, pp. 11-65.

Casimiro, Luís Alberto Esteves, "Pintura e escultura do Renascimento no Norte de Portugal", Revista da Faculdade de Letras, Ciências e Técnicas do Património, vol. 05-06, Porto, Faculdade de Letras da Universidade do Porto,2006-2007, p. 87-114 
Casimiro, Luís Alberto Esteves, "Iconografia da Anunciação: símbolos e atributos", Revista da Faculdade de Letras, Ciências e Técnicas de Património, Vol. 07-08, Porto, Faculdade de Letras da Universidade do Porto, 2008-2009, pp. 151-174

Castro, José de, Bragança e Miranda, (Bispado) Tomo I, Porto, Tipografia Porto Médico, Ld $\mathrm{Ld}^{\mathrm{a}}, 1946$.

Castro, José de, Bragança e Miranda, (Bispado) Tomo II, Porto, Tipografia Porto Médico, Ld a, 1947.

Castro, José de, Bragança e Miranda, (Bispado) Tomo III, Porto, Tipografia Porto Médico, Ld a $_{1948 .}$

Castro, José de, Bragança e Miranda, (Bispado) Tomo IV, Porto, Tipografia Porto Médico, Ld $\mathrm{Ld}^{\mathrm{a}} 1951$.

Cendón Fernández, Marta, "San Sebastian", Santiago, punto de encuentro. Obras Maestras de la Catedral y Caixa Galicia, Fundación Caixa Galicia, 2010, pp.310-315.

Cendón Fernández, Marta, "Yacentes de obispos franciscanos en época de los Trastámara", Graña Cid, MaMar (ed.), El franciscanismo en la Península Ibérica. Balance y perspectivas, I Congreso Internacional, Asociación Hispánica de Estudios Franciscanos en Barcelona, 2005, pp.917-934.

Cendón Fernández, Marta, "Los santos de su devoción. Aspectos de religiosidad popular en los sepulcros episcopales de Castilla a fines de la Edad Media", Religiosidad popular en España, Actas del Simposium celebrado en San Lorenzo del Escorial, 1/4-IX-1997, Instituto Escurialense de Investigaciones Históricas y Artísticas, Estudios Superiores del Escorial, R.C.U. Escorial-Ma Cristina, tomo II, pp.779-797. 
César, Aldilene Marinho, "Transformações na cultura religiosa: os ciclos pictóricos da vida de Francisco de Assis na Itália dos séculos XIII ao XVI" in, Anais do XXV Simpósio Nacional de História - História e Ética, Fortaleza, ANPUH, 2009, pp. 1-9.

César, Aldilene Marinho, "Francisco de Assis e Antônio de Lisboa: questões acerca da iconografia dos santos franciscanos na igreja de Santo Antônio de Belém-PA", In: XXVII Simpósio Nacional de História Conhecimento histórico e diálogo social, Anais do XXVII Simpósio Nacional de História - Conhecimento histórico e diálogo social, Natal - RN, 2013, pp.1-14.

Correia, Maria João Pinto, "A Escultura portuguesa entre o final do século XVI e o final do século XVII" in Dalila Rodrigues (Coord.), Arte Portuguesa - Da Pré-História ao Século XX, volume 7, Lisboa, Fubu Editores, 2009, pp. 75-142.

Coutinho, Maria, "Panofsky e a tradição da Bildwissenschaft, para lá do cerco ao método iconológico" in Actas do IV Congresso de História da Arte Portugesa em Homenagem a José-Augusto França, Lisboa, APHA Associação Portuguesa de Historiadores da Arte, 2014, pp. 454-461.

Croiset, João, Anno Christão ou exercicios devotos para todos os dias do anno. Tomo I, Porto, Empreza d'obras populares illustradas, 1885.

Croiset, João, Anno Christão ou exercicios devotos para todos os dias do anno. Tomo III, Porto, Editor - Antonio Dourado, 1887.

Croiset, João, Anno Christão ou exercicios devotos para todos os dias do anno. Tomo IIII, Porto, Editor - Antonio Dourado, 1888.

de Sousa, Ernesto, Para o estudo da escultura portuguesa, Lisboa, Livros Horizonte, 1973 (2 edição). 
Dias, Pedro, A escultura maneirista portuguesa, Coimbra, Minerva, 1995.

Dias, Eva Sofia Trindade, "Beneditinos e Franciscanos: convivência de invocações no espaço monástico beneditino português (Séculos XVIIXVIII)", in Natália Marinho Ferreira-Alves (Coord.), Franciscanos no Mundo Português III, Porto, CEPESE - Centro de Estudos da População, Economia e Sociedade, 2013, pp. 375-399.

Didi-Huberman, Georges, Lo que vemos, lo que nos mira, Argentina, Manantial, 2011.

Dinis da Silva, Laura Sofia e Ribeiro, Napoleão Gonçalves, "A imaginária em São Mamede de Coronado: a produção de um santo" catálogo da exposição Ide a José, Bragança, Seminário Diocesana de São José e Museu Abade de Baçal, 2013, pp. 19-23.

Duarte, Marco Daniel, "A iconografia da Senhora de Fátima: da criação ex nihilo às composições plásticas dos artistas", Cultura, Revista de História e Teoria das Ideias. Vol. 27 Iconografia religiosa das invocações nacionais, Lisboa, Universidade Nova de Lisboa, 2010, pp. 235-270.

Duby, Georges e Ariés, Philippe, História da Vida Privada - Vol. I- vol. IV, Lisboa, Edições Afrontamento, 2009.

Esperança, Manuel da, Frei, Historia Seráfica Da ordem Dos Frades Menores de S. Francisco Na Província de Portugal, Tomo I, Lisboa, Officina Craesbeeckiana; disponível na Biblioteca Nacional on-line http://purl.pt/20706/4/, 1656.

Falcão, José António, "O Mistério de Cristo na Revelação Artística" in Carlos Moreira de Azevedo (Coord.), Cristo fonte de esperança Catálogo da exposição do grande jubileu do ano 2000, Porto, Diocese do Porto, 2000. 
Félix Lopes, Frei Fernando, Colectânea de estudos de história e literatura, Volume I, Lisboa, Academia Portuguesa de História, 1997.

Ferrando Roig, Juan, Iconografía de los Santos, Madrid, Ediciones Omega, 1950.

Fernandes, Carla Varela, "A imagem da Santíssima Trindade da igreja de Santa Clara de Santarém", CADERNOS DE HISTÓRIA DA ARTE $n^{\circ} 2$, Revista do Instituto de História da Arte - Centro de Investigação, Lisboa, Faculdade de Letras da Universidade de Lisboa, 2014, pp. 38-49.

Ferreira, Sílvia, A talha. Esplendores de um passado ainda presente (sécs. XVI-XIX), Lisboa, Nova Terra, 2008.

Ferreira-Alves, Joaquim Jaime, "Elementos para o estudo da arquitectura das duas primeiras capelas da Venerável Ordem Terceira de S. Francisco do Porto" in Revista da Faculdade de Letras, Ciências e técnicas de Património, I Série vol. 2., Porto, Faculdade de Letras da Universidade do Porto, 2003, pp. 347-364.

Ferreira-Alves, Natália Marinho e Ferreira-Alves, Joaquim Jaime, "Subsídios para um dicionário de artistas e artífices que trabalharam em Trás-os-Montes nos séculos XVII-XVIII (I)". Revista de História, vol. 5. Porto, Faculdade de Letras da Universidade do Porto, 1983-1984, pp. 159186.

Ferreira-Alves, Natália Marinho, "Entalhadores e imaginários do Núcleo Franciscano Portuense" in Natália Marinho Ferreira-Alves e (Coord.) Os Franciscanos no Mundo Português. Artistas e Obras (I), Porto, CEPESE Centro de Estudos da População, Economia e Sociedade, 2009, pp. 195-211. 
Ferreira-Alves, Natália Marinho, "Pintura, Talha e Escultura (séculos XVII e XVIII) no Norte de Portugal" in Revista da Faculdade de Letras. Ciências e Técnicas do Património vol. 2, Porto, Faculdade de Letras da Universidade do Porto Departamento de Ciências e Técnicas do Património, 2003, pp. 735-756.

Ferrini, Giuliano e Ramírez, José Guillermo, Santos franciscanos para cada dia, I Volume, Braga, Editorial franciscana, 2001.

Figueiredo, Maria Rosa, Escultura Europeia, Volume II, Lisboa, Fundação Calouste Gulbenkian, 1999.

Ferri Chulio, Andrés de Sales, Iconografía popular de San Pascual Baylón, Ed. Caja Rural, Coop. Católico Agraria, Vila-real, 1992.

Filha, Maria Berthilde Moura e Filho, Ivan Cavalcanti, "Ordens Terceiras Franciscanas Setecentistas: três casos de emancipação espacial na arquitetura brasileira" in Natália Marinho Ferreira-Alves (Coord.), Franciscanos no Mundo Português III, Porto, CEPESE - Centro de Estudos da População, Economia e Sociedade, 2013, pp. 649-672.

Folgar De La Calle, Maria Carmen, "La influencia portuguesa en los retablos barrocos de Galicia", Actas do II Congresso Internacional del Barroco, Porto, Universidade do Porto, Faculdade de Letras. Departamento de Ciências e Técnicas do Património, 2003, pag. 475-490.

Fraga Sampedro, Maria Dolores, "San Francisco de Betanzos: nuevas aportaciones a su programa iconográfico", in separata do anuário Brigantino $\mathrm{n}^{\mathrm{0}}$ 18, Betanzos, 1995, pp. 207-226.

Fraga Sampedro, Maria Dolores, San Francisco de Ourense. Análisis historico-artístico de la iglesia y convento, Ourense, Museo Arqueolóxico Provincial de Ourense-Grupo Marcelo Macías, 2002. 
Fraga Sampedro, Maria Dolores, "San Francisco y sus frailes: arte y devoción en el gótico galaico-portugués", separata da obra II Congresso Internacional de História de Arte -2001, Actas, Coimbra, Almedina, 2005, pp. 617-634.

Fraga Sampedro, Maria Dolores, "Predicación e imágenes en los siglos finales de la edad media hispana" in Plenitudo Veritatis homenaje a Mons. Romero Pose, Santiago de Compostela, Instituto Teológico Compostelano, 2008, pp. 829-847.

Fraga Sampedro, Maria Dolores, "El arte gótico mindoniense (siglos XIIXV): mendicantes, parroquiales y capillas", in Anuário de estudos históricoteológicos de la diócesis de Mondoñedo-Ferrol $n^{\circ} 15$, Fundación Caixa Galicia, 1999, pp. 411-457.

Freedberg, David, El poder de las imagenes, Madrid, Cátedra, ( $4^{\mathrm{a}}$ edición, primera em 1992), 2011

Frugoni, Chiara, Francesco e l'invenzione delle stimmate: Una storia per parole e immagini fino a Bonaventura e Giotto, Turim, Einaudi edições, 1993.

Gomes, José Manuel (Coord.), Imagens e escultura. 1545-1995 Comemorações Jubilares dos 450 Anos da Diocese de Bragança - Miranda, Bragança, Departamento de Liturgia e Património Cultural da Diocese de Bragança - Miranda e Comissão de Arte Sacra, 1996.

Gonçalves, Flávio, "A «Árvore de Jessé» na arte portuguesa" in Revista da Faculdade de Letras História, 03, Porto, Faculdade de Letras da Universidade do Porto, 1986, pp. 213-238. 
Gonçalves, Flávio, História da arte; Iconografia e Crítica, Lisboa, Imprensa Nacional Casa da Moeda, 1990.

Goulão, Maria José, "Figuras do Além. A escultura e a tumulária. A escultura." in Paulo Pereira (Direção) História da Arte Portuguesa, volume II, Lisboa, Circulo de Leitores, 1995, pp. 156-179.

Goulão, Maria José, "As primeiras imagens do índio brasileiro no espaço europeu: a Adoração dos Magos de Ulrich Apt o Antigo do retábulo de Santa Cruz de Augsburgo" in Estudos de Arte e Património. População e Sociedade. Volume 20, Porto, CEPESE - Centro de Estudos de População, Economia e Sociedade e Edições Afrontamento, 2012, pp. 79-91.

Jacob, João Manuel Neto, Bragança, Lisboa, Presença, 1997.

Kaftal, George, Iconography of the saints in central and south Italian schools of painting, Firenze, Casa Editrice Le Lettere, 1986.

Lahon, Didier, "Esclavage, confréries noires, sainteté noire et pureté de sang au Portugal (XVIe--XVIIIe siècles)", Revista Lusitania Sacra, Lisboa, Centro de Estudos de História Religiosa - Universidade Católica Portuguesa, 2003, pp. 119-162.

Lalanda, Maria Margarida, "Clarissas (Ordem de Santa Clara)", in Carlos Moreira Azevedo, Dicionário de história religiosa de Portugal, Lisboa, Circulo de Leitores, 2000, pp. 353-355.

Le Goff, Jacques, S. Francisco de Assis. Lisboa, Teorema, 2000.

Lei-Quadro dos museus portugueses. Direç̧ão Geral do Património Cultural. [Online] http://www.patrimoniocultural.pt/pt/museus-emonumentos/rede-portuguesa/lei-quadro-dos-museus-portugueses/. 
Lopes, Inês Afonso, "A Memória das Imagens: Os Santos Negros da Igreja de Santa Clara", Revista da Faculdade de Letras. Ciências e Técnicas do Património, vol. IX-XI, Porto, Faculdade de Letra da Universidade do Porto, 2010-2012, pp. 206-222.

Lopes, Inês Afonso, "O papel do sujeito face à imagem. Interpretações estruturo-fenomenológicas: o estudo de caso das pinturas murais de São Francisco de Bragança", Medievalista, [Online], 11, Disponível em: http://medievalista.revues.org/834\#quotation, 2012, pp. 1 -29.

López Calderón, Carme, "Potuit, decuit, fecit; los franciscanos y el culto a María", in Natália Marinho Ferreira-Alves (Coord.), Franciscanos no Mundo Português III, Porto, CEPESE - Centro de Estudos da População, Economia e Sociedade, 2013, pp. 225-255.

López Calderón, Carme, "La emblemática como instrumento devocional: la Capilla de Nossa Senhora da Esperança en Abrunhosa (Viseu, Portugal)" in Ana Martínez Pereira, Inmaculada Osuna, Víctor Infantes (Eds.) Palabras, Símbolos, Emblemas. Las Estructuras Gráficas De La Representación, Madrid, Sociedad Española de Emblemática, Turpin Editores, 2013, pp. 299-311.

López Vázquez, José Manuel, "A propósito de una imagen del monasterio de Celanova: tipología de san José y estilo en el taller de Gambino-Ferreiro (Jose Gambino y José Ferreiro Suárez)", in Enrique Fernández Castiñeiras y Juan M. Monterroso Montero (ed.), Arte Beneditina nos camiños de Santiago. Opus Monasticorum II, A Coruña, Xunta de Galicia. Consellería de Innovación e Industria, 2006, pp. 439-462.

López Vázquez, José Manuel, "A propósito del retablo mayor de la Magdalena de Montemaior (1773): Algunas esculturas inéditas de José Ferreiro Suárez" in Compostellanum, LIV, Santiago de Compostela, 2009, pp. 487-506. 
López Vázquez, José Manuel, "Mentalidad barroca y Plástica Monástica: El conjunto retablístico de San Martín Pinario como síntesis de la ideología postrentina", in en Kazimir Sabik y Karolina Kumor (eds.) La cultura del barroco español e iberoamericano y su contexto europeo, Varsovia, Instytut Studiów Iberyjskich I Iberoamerykańskich, Uniwersytet Warszawskiu, 2010, pp. 423-432.

López Vázquez, José Manuel, "Hablemos de ángeles calvos, demonios pelones y figur,s grotescas en la escultura barroca gallega" in IMAGO Revista de Emblemática y Cultura Visual, Núm. 6, disponível em: https://ojs.uv.es/index.php/IMAGO/article/view/3925, 2014, pp.39-64.

López Vázquez, José Manuel, "La imagen de san Francisco del retablo mayor del convento compostelano de Val de Dios y otras nuevas atribuciones a José Ferreiro (1738-1830): señas de identidad y estilo", in SÉMATA, Ciencias Sociais e Humanidades, vol. 26, Santiago de Compostela, Universidade de Santiago de Compostela / Facultad de Geografía e Historia / Servicio de Publicaciones e Intercambio Científico, 2014, pp. 609-632.

Magalhães, Joaquim Romero, "A sociedade" in José Mattoso, História de Portugal volume 3, Lisboa, Círculo de Leitores, 1993, pp. 469-509

Magalhães, Joaquim Romero, "O pano de fundo" in José Mattoso, História de Portugal volume 3, Lisboa, Círculo de Leitores, 1993, pp. 575-607.

Mâle, Emile, "El arte religioso de la contrarreforma (1932), Madrid, Ediciones Encuentro, 2001

Mangucci, Celso, "A Talha mais Moderna. O percurso artístico de Manuel Abreu e Sebastião Abreu do Ó em Évora" in António Camões Gouveia (Coord.) CENÁCULO Boletim on line do Museu de Évora n. ${ }^{\circ}$ 4, Disponível em http://museudevora.imc-ip.pt/, 2010, pp.3-19. 
Martín González, Juan José, El arte procesional del barroco (cuadernos de arte espanol), Madrid, história 16, 1993.

Martín González, Juan José, La huella española en la escultura portuguesa, Valladolid, Sever - Cuesta, 1961.

Martín González, Juan José, Escultura barroca en España: 1600-1770, Madrid, Cátedra, 1998.

Marques, José, "Os franciscanos no norte de Portugal nos finais da Idade Média", Porto, Boletim do Arquivo Distrital do Porto, 1982, pp. 149-189.

Martins, Firmino A., Folklore do Concelho de Vinhais, Bragança, Câmara Municipal de Vinhais, 1987 (edição original 1927).

Martins, Firmino A., Subsídios para a história religiosa do distrito de Bragança: a Ordem III e a casa do Fundador do convento de S. Francisco de Vinhais, Coimbra, Imprensa da Universidade, 1929.

Mattoso, José e Armindo de Sousa in José Mattoso (Dir.), História de Portugal, volume 2, Lisboa, Círculo de Leitores, 1993.

Mattoso, José, "O enquadramento social e económico das primeiras fundações franciscanas", Portugal medieval: novas interpretações, Volume 8, Lisboa, Circulo de Leitores, 2002.

Moreira, Rafael, "A escultura ornamental e os programas protorenascentistas" in Paulo Pereira (direcção), História da Arte Portuguesa. Volume II, Lisboa, Círculo de Leitores, 1995, pp. 321-327 
Monteiro, Nuno Gonçalo, "Poder Senhorial, estatuto nobiliárquico e aristocracia", in José Mattoso, História de Portugal, Vol. 4, Lisboa, Círculo de Leitores, 1993, pp. 333-379.

Montes Moreira, António, "Franciscanos" in Carlos Moreira Azevedo (Dir.), Dicionário de história religiosa de Portugal, Lisboa, Círculo de Leitores, 2000, pp. 273-280.

Montes Moreira, António, "Documentação Inédita de fins do século XVII sobre os Franciscanos em Portugal" separata de Itinerarium, Ano LI-N ${ }^{\circ} 181$ 183, Lisboa, 2005, pp. 297-315

Moura, Carlos, "A Escultura nos coutos de Alcobaça no final da Idade Média ao século XVIII", in Maria Augusta Trindade Ferreira, Mafalda Magalhães Barros, Vítor Serrão, Carlos Moura (Org.) Arte Sacra nos antigos Coutos de Alcobaça, Alcobaça, Edições Asa, 1995, pp. 65-81.

Mourinho (Júnior), António Rodrigues, A talha nos concelhos de Miranda do Douro, Mogadouro e Vimioso nos séculos XVII e XVIII, Braga, Associação de Municípios do Planalto Mirandês, 1984.

Mourinho (Júnior), António Rodrigues, Arquitectura religiosa da Diocese de Miranda do Douro - Bragança, Sendim, Câmara Municipal de Miranda do Douro, 1995.

Navarro Talegón, José, Catálogo monumental de Toro y su alfoz, Zamora, Caja de Ahorros Provincial, 1980.

Navarro Talegón, José, "Virgen del Transparente" in Remembranza, catálogo da exposição Las Edades del Hombre, Zamora, 2001, pp. 583, 583

Navarro Talegón, José, "Santa Teresa de Jesus" in Remembranza, catálogo da exposição Las Edades del Hombre, Zamora, 2001, pp. 221, 222. 
Navarro Talegón, José, "Crucificado" in Remembranza, catálogo da exposição Las Edades del Hombre, Zamora, 2001, pp. 222-224.

Navarro Talegón, José, Inventario y catálogo de bienes muebles de interés cultural propios del Excmo. Ayuntamiento de Toro, Asociación Cultural Musical Jesús López Cobos, EL CANTO DE LA MUSA, Revista Digital de Humanidades $n^{\circ} 1$, disponível em: http://www.elcantodelamusa.com/numl.html, 2010, pp. 33, 34

Nogueiro, Maria Emília, Práticas museologicas. Museu Militar de Bragança: Fundação; Práticas Museologicas, Dissertação de Mestrado em Museologia apresentado à Faculdade de Letras da Universidade do Porto, Porto, (texto policopiado), 2009.

Oliveira, António José, "O Convento de São Francisco de Guimarães: artistas e obras (1679-1773)" in Natália Marinho Ferreira-Alves e (Coord.), Os Franciscanos no Mundo Português III, O Legado Franciscano, Porto, CEPESE - Centro de Estudos da População, Economia e Sociedade, 2013, pp.147-175.

Pacheco, Milton Pedro Dias, "Os proto-mártires de Marrocos da Ordem de São Francisco - muy suave odor de sancto martyrio", Universidade Lusófona de Humanidades e Tecnologias. Revista Lusófona de Ciência das Religiões $n^{\circ} 15$ - Martírios e Massacres - fazer da morte uma vitória, Lisboa, Edições universitárias Lusófonas, 2009, pp. 85-108.

Pais da Silva, Jorge Henrique e Calado, Margarida, Dicionário de termos de arte e arquitectura, Lisboa, Presença, 2005.

Pais, Alexandre, "Introdução ao estudo do Presépio do Museu de Évora"n Joaquim Oliveira Caetano (Edit.) CENÁCULO Boletim on line do Museu de Évora n. ${ }^{\circ}$ 3, Disponível em http://museudevora.imc-ip.pt/, 2008, pp.3-5. 
Paiva, José Pedro, "Os mentores" in Carlos Moreira Azevedo, História Religiosa de Portugal, volume 2, Lisboa, Círculo de Leitores, 2000, pp. 201237.

Paiva, José Pedro, "As missões internas" in Carlos Moreira Azevedo, História Religiosa de Portugal, volume 2, Lisboa, Círculo de Leitores, 2000, pp. 239-250.

Panofsky, Erwin, Estudos de iconologia; temas humanísticos na arte do renascimento, Lisboa, Editorial Estampa, 1995 (2ª edição).

Panofsky, Erwin, O Significado nas Artes Visuais, Lisboa, Editorial Presença, 1989.

Pamplona, Germán, Iconografía de la Santísima Trinidad en el arte medieval español, Madrid, CSIC Consejo Superior de Investigaciones Científicas, 1970.

Pereira, José Fernandes, "O barroco do século XVII: transição e mudança" in Paulo Pereira (direção), História da Arte Portuguesa, Volume III, Lisboa, Círculo de Leitores, 1995, pp. 11-49.

Pereira, José Fernandes, "O barroco do século XVIII" in Paulo Pereira (direção), Historia da Arte Portuguesa, Volume III, Lisboa, Círculo de leitores, 1995, pp. 50-181.

Pereira, José Fernandes, "Estética barroca I: arquitectura e escultura", in Dalila Rodrigues (Coord.), Arte Portuguesa - Da Pré-História ao Século XX, volume 12, Lisboa, Fubu Editores, 2009, pp. 7-136. 
Pinho, Arnaldo de, "Encarnação e transcendência: o caminho das artes" in Carlos Moreira de Azevedo (Coord.), Cristo fonte de esperança Catálogo da exposição do grande jubiliu do ano 2000, Porto, Diocese do Porto, 2000.

Pinho, Elsa Garrett e Freitas, Inês da Cunha, Normas de Inventário Normas Gerais Artes Plásticas e Decorativas, Lisboa, I.P.M. (Instituto Português de Museus), 2000.

Prada de Oliveira, Carlos, A Diocese de Miranda do Douro em meados do século XVIII, segundo as Memórias Paroquiais de 1758, Universidade do Minho, Instituto de Ciências Sociais, Braga, texto policopiado, 2006.

Prada de Oliveira, Carlos, Pastorais dos Bispos de Miranda do Douro e Bragança, Bragança, Câmara Municipal de Bragança, 2011.

Ramôa, Joana, "Jérôme Baschet - L'iconographie médiévale", in Revista de História da Arte N. ${ }^{\circ}$, Lisboa, Instituto de História da Arte - FCSH/UNL, 2009, pp. 196-201.

Réau, Louis, Iconografía del Arte Cristiano. Iconografia de la Biblia Nuevo Testamento Tomo 1/ Volumen 2, Barcelona, Ediciones del Serbal, 1996 (Edição original 1955-1959).

Réau, Louis, Iconografía del arte cristiano - Iconografia de los santos, de la A a la F. Tomo 2 / Volumen 3, Barcelona, Ediciones del Serbal, 1997 (edição original 1955-1959).

Réau, Louis, Iconografía del arte cristiano; Iconografia de los santos De la G a la O; Tomo 2 / Volumen 4, Barcelona, Ediciones del Serbal, 1997 (Edição original 1955-1959). 
Réau, Louis, Iconografia del arte cristiano. Iconografia de los santos. De la P a la Z - Repertorios. Tomo 2/ Volumen 5, Barcelona, Ediciones del Serbal, 2002 (primeira edição 1957).

Redondo, José Ignacio Hernández, "A escultura barroca em Espanha", in Rolf Toman (edit.), O Barroco, Lisboa, Konemann, 2004, pp. 354-371.

Reginaldo, Lucilene, "África em Portugal": devoções, irmandades e escravidão no Reino de Portugal, século XVIII. História vol.28 no.1. Franca - São Paulo - Brasil : Faculdade de Ciências Humanas e Sociais, 2009, pp. 289-319.

Rema, Henrique (Frei), "A Ordem Franciscana em Tras-os-Montes" in Boletim do Arquivo Distrital de Vila Real - Revista de Cultura, Estudos Transmontanos e Durienses $n^{\circ}$, Vila Real, Arquivo Distrital de Vila Real, 1995, pp. 299-332.

Renders, Helmut, "O coração como atributo hagiográfico de São Benedito do Rosário: hipótese sobre a sua origem e seu modelo subjacente da vida cristã", Horizonte. Dossiê Religiões Afro-brasileiras. vol. 13, n. 29, Belo Horizonte, Minas Gerais, Universidade Metodista de São Paulo, 2013, pp. 109-132.

Ribeiro, P. Bartolomeu, Os terceiros franciscanos portugueses; sete séculos da sua história. Braga, Tip. Missões Franciscanas, 1952.

Rodrigues, Dalila, "A pintura no período manuelino" in Paulo Pereira e (Direção), História da Arte Portuguesa. Volume II, Lisboa, Círculo de Leitores, 1995, pp. 199-277.

Rodrigues, Luís Alexandre, Bragança no século XVIII. Urbanismo. Arquitectura, Volume I, Bragança, Junta de Freguesia da Sé, 1997. 
Rodrigues, Luís Alexandre, De Miranda a Bragança: arquitectura religiosa de função paroquial na época moderna, Bragança, Faculdade de Letras da Universidade do Porto (Tese de Doutoramento), texto policopiado, 2001.

Rodrigues, Luís Alexandre, Arte da talha dourada e policromada no Distrito de Bragança. Documentos. Séculos XVII-XVIII, Mirandela, João Azevedo Editor, 2005.

Rodrigues, Luís Alexandre, "A ação dos padres de Brancanes em Vinhais. O Seminário da Senhora da Encarnação e constituição da Venerável Ordem Terceira da Penitência" in Natália Marinho Ferreira-Alves (Coord.), Os Franciscanos no Mundo Português II. As Veneráveis Ordens Terceiras de São Francisco, Porto, CEPESE - Centro de Estudos da População, Economia e Sociedade 2012, pp. 163-193.

Rodrigues, Luís Alexandre, "Caminho Doloroso: as gravuras italianas da Ordem Terceira de Vinhais" in Natália Marinho Ferreira-Alves (Coord.), Franciscanos no Mundo Português III, Porto, CEPESE - Centro de Estudos da População, Economia e Sociedade 2013, pp. 491-527.

Roque, Maria Isabel Rocha, "Imagens esculpidas de cristo na dor", Lumen Veritatis: boletim da Sociedade Científica da Universidade Católica Portuguesa, Lisboa, Universidade Católica Portuguesa, 2012, pp. 8-10.

Roque, Maria Isabel Rocha, "O Menino de Belém: da festa do Natal à iconografia da natividade e da adoração", Gaudium Sciendi $N^{\circ} 5$, Lisboa, Sociedade Científica da Universidade Católica Portuguesa, 2013, pp. 104126.

Ruiz Maldonado, Margarita, "La escultura trecentista de la Seo de Evora”, Bol. Museo e Instituto Camón Aznar, vol. XLV, Zaragoza, 1991, pp. 29-70. 
Ruiz Maldonado, Margarita, "El sepulcro de doña Beatriz de Portugal en Sancti Spiritus (Toro)", in Goya, $\mathrm{n}^{\circ} .237,1993$, pp. 142-148.

Ruiz Maldonado, Margarita, "Consideraciones iconográficas en torno al sepulcro de la Reina Santa. Santa Clara (Coimbra)", in VII Simposio Hispano-Portugués de Historia del Arte, Cáceres, 1995, pp. 17-24

Ruiz Maldonado, Margarita, "Fernando Gallego y coloboradores" in Remembranza, catálogo da exposição Las Edades del Hombre, Zamora, 2001, pp. 513-526.

Ruiz Maldonado, Margarita, "Virgen com Niño" in Remembranza, catálogo da exposição Las Edades del Hombre, Zamora, 2001, pp. 578, 579

Ruiz Maldonado, Margarita, "Llanto sobre Cristo muerto" in Remembranza, catálogo da exposição Las Edades del Hombre, Zamora, 2001, pp.617, 618

Ruiz Maldonado, Margarita, "Libro de Horas (Oficio de la Virgen)" in Inmaculada, catálogo da exposição Las Edades del Hombre, Madrid, 2005, pp. 94-96.

Ruiz Maldonado, Margarita, "San Luis de Tolosa a la luz de obras «trecentistas»" in SÉMATA, Ciencias Sociais e Humanidades, vol. 26, Santiago de Compostela, Universidade de Santiago de Compostela Facultad de Geografía e Historia / Servicio de Publicaciones e Intercambio Científico, 2014, pp. 633-654.

Santos, Reynaldo dos, A escultura em Portugal II, Séculos XVI a XVIII, Lisboa, Oficinas Gráficas de Bertrand (Irmãos) Ld. ${ }^{a}$, 1950. pp. 24-57 
Santos, Rui Afonso e Soromenho, Miguel, "Escultura" in Anabela Carvalho, Isabel Cordeiro, Instituto Portugês de Museus, catálogo do Museu Abade de Baçal, Bragança, Lisboa, Instituto Português de Museus, 1994, pp. 82-92.

Serrão, Vítor, A Trans-Memória das Imagens, Estudos Iconológicos de Pintura Portuguesa (Séculos XVI - XVIII), Lisboa, Edições Cosmos, 2008.

Serrão, Vítor M. G.V., et al. Museu de Arte Sacra de Macedo de Cavaleiros, Catálogo da Exposição, Macedo de Cavaleiros, Câmara Municipal de Macedo de Cavaleiros, 2009.

Serrão, Vítor, "Impactos do Concílio de Trento na arte portuguesa entre o Maneirismo e o Barroco (1563-1750)" in António Camões Gouveia, David Sampaio Barbosa, José Pedro Paiva (coordenação), O Concílio de Trento em Portugal e nas suas conquistas: Olhares Novos, Centro de Estudos de História Religiosa da Universidade Católica Portuguesa, Lisboa, 2014, pp. 103-132.

Smith, Robert, A talha em Portugal, Lisboa, Livros Horizonte, 1963.

Smith, Robert, Frei José de Santo António Ferreira Vilaça, Escultor Beneditino do século XVIII, volume II, Fundação Calouste Gulbenkian, Lisboa, 1972, p. 231- 401

Sobral, Cristina, O FLOS SANCTORUM DE 1513 E SUAS ADIÇÕES PORTUGUESAS. LUSITANIA SACRA, $2^{a}$ série, 13-14, Lisboa, Universidade Católica Portuguesa, Centro de Estudos de História Religiosa, 2001-2002, pp. 531-568.

Soromenho, Miguel, "A Arquitectura do ciclo filipino" in Dalila Rodrigues (Coord.) Arte Portuguesa Arte Portuguesa - Da Pré-História ao Século XX, volume 10, Lisboa, Fubu Editores, 2009, pp. 7-125 
Soromenho, Miguel, "Classicismo, italianismo e «estilo chão». O ciclo filipino." in Paulo Pereira (direção) História da Arte Portuguesa, volume II, Lisboa, Círculo de Leitores, 1995, pp. 376-403

Stierlin, Henry \& Anne, El Arte Barroco en España y Portugal, Barcelona, Moleiro Editor, 1994.

Strattom, Suzanne, "La Inmaculada Concepción en el arte español" in Cuadernos De Arte E Iconografia / Tomo I- 2., disponível em $\mathrm{http} / / / \mathrm{www}$. fuesp.com/publicaciones_revistas_numeros_articulos.asp?cdnu mero=2, Madrid, 1988, pp.1-88.

Teixeira, Vitor Rui Gomes, "A presença franciscana na região de Bragança-Miranda até ao séc. XV" in Comissão de Arte Sacra de BragançaMiranda, Páginas da História da Diocese de Bragança-Miranda, Actas do Congresso histórico 450 anos da fundação, Bragança, Comissão Executiva das Comemorações, 1997, pp. 671-683.

Teixeira, Vitor Gomes, O maravilhoso no mundo franciscano português da baixa idade média, Porto, Granito editores e livreiros, 1999.

Teixeira, Victor Gomes, "Entre a Devoção e o Sentimento, a Iconografia Franciscana Barroca. Algumas notas sobre S. Bernardino de Siena" in Fausto Sanches Martins (Coord.), Actas do II Congresso Internacional do Barroco, Porto, Faculdade de Letras da Universidade do Porto, 2003, pp. 691-700.

Thompson, Augustine, São Francisco de Assis, uma nova biografia. Alfragide, Casa das letras, 2012.

Vasconcelos e Sousa, Bernardo (Dir.)., Ordens religiosas em Portugal: das origens a Trento. Guia Histórico. Lisboa : Livros Horizonte, 2005. 
Vila Jato, María Dolores, "El Retablo Renacentista en Galicia" IMAFRONTE. N.Os 3-4-5, 1987-88-89, pp. 33-49

WEB (dados disponíveis on-line)

Biblioteca Nacional de Portugal,http://purl.pt/index/geral/PT/index.html, 2015

Direcção Geral do Património Cultural, Base de dados dos museus nacionais, MatrizNet, http://www.matriznet.dgpc.pt/., 2015.

Enciclopédia das Localidades Portuguesas, http://www.mapadeportugal.net., 2014.

Secretariado Nacional dos bens culturais da Igreja, Inventário on-line Bens culturais da Igreja, https://www.bensculturais.com/areas-deactuacao/inventario, 2015.

Plataforma digital SIPA (Sistema de Informação para o Património Arquitetónico) da Direção Geral dos Edifícios e Monumentos Nacionais do Instituto da Habitação e Reabilitação Urbana \Ministério da Agricultura, do Mar, do Ambiente e do Ordenamento do Território, http://www.monumentos.pt/

Câmara Municipal de Vinhais, http://cm-vinhais.pai.pt/ms/ms/camaramunicipal-de-vinhais-turismo-5320-331-vinhais/ms-90043268-p-2/, 2015. 


\section{ANEXOS}

CONSENTIMENTOS INFORMADOS E COMPROVATIVO DE IDONEIDADE DA DIOCESE DE BRAGANÇA-MIRANDA 


\title{
COMPROVATIVO DE IDONEIDADE
}

\author{
Encontrando-se a Excelentissima Dra MARIA EMILIA PIRES
} NOGUEIRO, natural de Bragança e titular do BI n 10526952, a elaborar a Tese de Doutoramento em História de Arte, na Universidade de Salamanca, sob o tema: FRANCISCANOS EM TRÁS OS-MONTES: Inventário de Escultura afecta ao culto em guarda nas igrejas da Ordem Terceira Franciscana, na Diocese de Bragança-Miranda, atestamos tratar-se de uma pessoa que goza de competência, idoneidade, honestidade e reconhecida rectidăo, pelo que recomendamos, à autoridade competente, que the seja facultado o estudo nas igrejas da Ordem existentes da Diocese de Bragança-Miranda, que ficará culturalmente mais enriquecida com o estudo em elaboração.

Bragança, 19 de Setembro de 2012

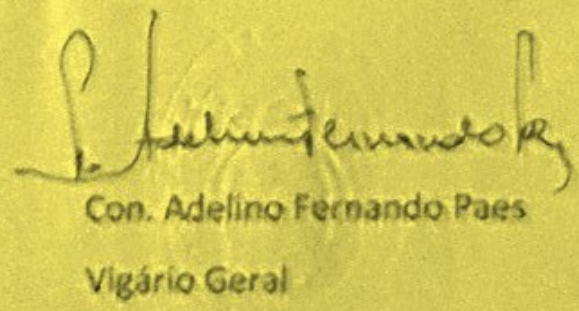




\section{Investigação no âmbito de Doutoramento em Historia de Arte na} Universidade de Salamanca

Autora: Maria Emília Pires Nogueiro - docente na Escola Superior de Educação do Instituto Politécnico de Bragança

Maria Emília Pires Nogueiro, natural de Santa Maria - Bragança, titular do bilhete de identidade $n^{\circ}$ 10526952, licenciada em História e mestre em Museologia actualmente a exercer funções de docência na Escola Superior de Educação do Instituto Politécnico de Bragança. Pretendendo prosseguir a investigação sob o tema: Franciscanos em Trás-os-Montes: inventário da escultura afecta ao culto e em guarda nas igrejas dos conventos da Ordem Franciscana na Diocese de Bragança Miranda vem por este meio rogar a V.Ex. ${ }^{a}$ se digne a autorizar dito estudo dentro dos espaços por si tutelados. A tese é orientada pela Professora Doutora Margarita Maldonado (USAL).

Este estudo não lhe trará nenhuma despesa ou risco. As informações serão recolhidas através da observação directa das esculturas não intervindo sobre quaisquer objectos

Depois de saber as informações acima referidas,

Eu, Roberto de Morais Afonso, vereador da Cultura da Câmara Municipal de Vinhais, declaro que consinto que seja feita esta investigação.

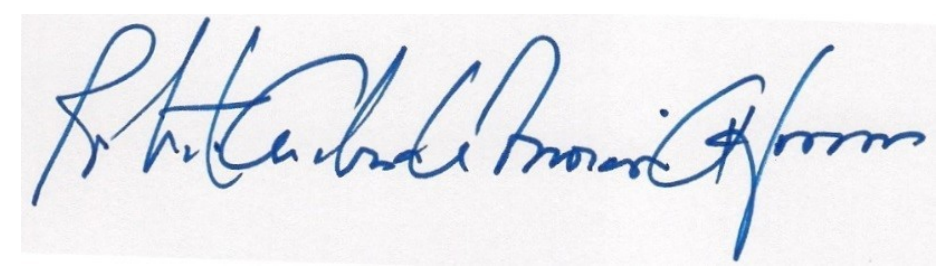

Data: 25 de Julho de 2013 Local: Vinhais 
Investigação no âmbito de Doutoramento em Historia de Arte na Universidade de Salamanca

Autora: Maria Emilia Pires Nogueiro - docente na Escola Superior de Educaça do Instituto Politécnico de Bragança

Maria Emilia Pires Nogueiro, natural de Santa Maria - Braganca, titular do bithete de identidade $n^{\circ} 10526952$, ficenciada em História e mestre em Museologia, actualmente a exercer funçóes de docéncia na Escola Superior de Educaçáo do Instituto Politécnico de Bragança.

Pretendendo prosseguir a investigação sob o tema Franciscanos em Trás-os-Montes inventário da escultura afecta ao culto e em quarda nas igreias dos conventos da Ordem Franciscana na Diocese de Braganca Miranda vem por este melo rogar a V.Ex a se digne a autorizar o dito estudo dentro dos espaços por si tutelados. A tese é orientada pela Professora Doutora Marganta Maldonado (USAL) e co-orientada pelo Professor Doutor Alexandre Rodrigues (FLUP).

Este estudo nāo the trara nenhurna despesa ou risco. As informaçdes seráo recolhidas através da observaçāo directa das esculturas nāo intervindo sobre quaisquer objectos
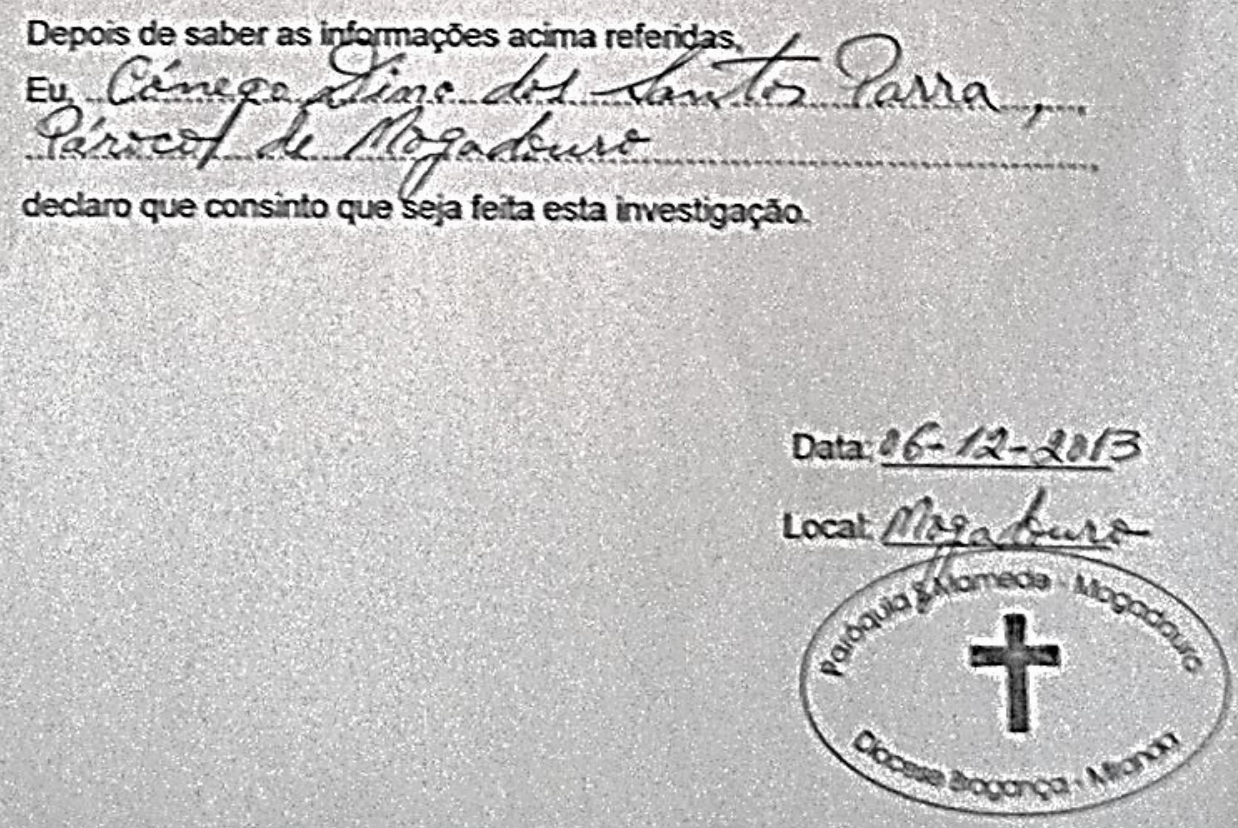
